
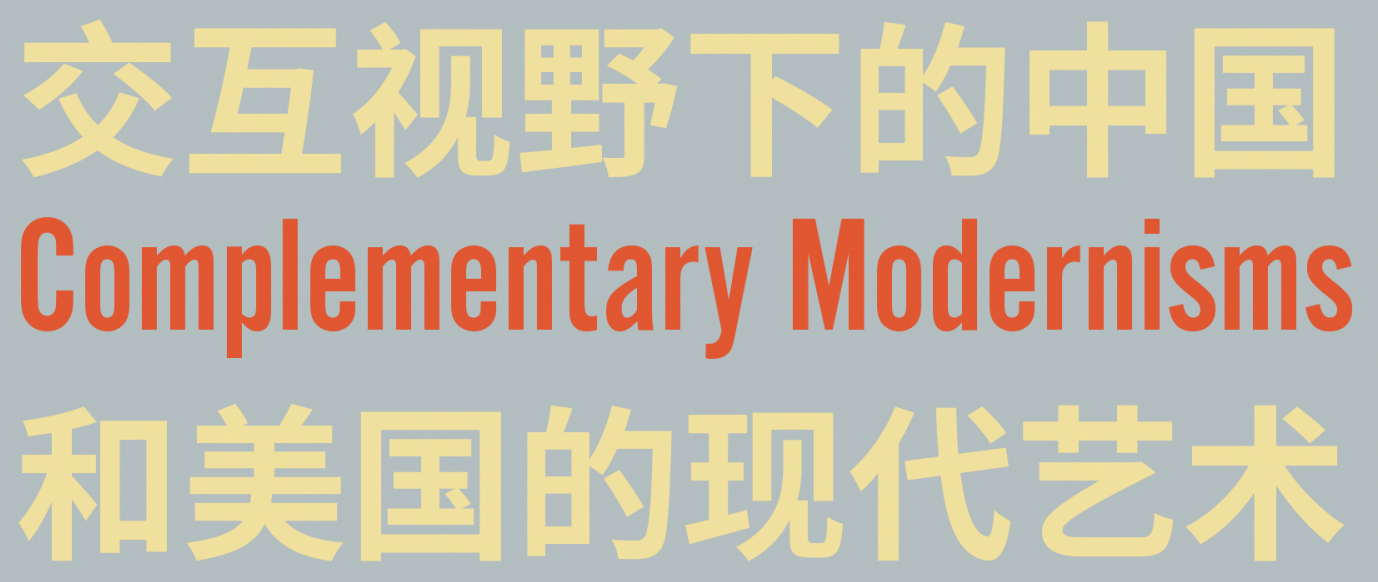

\title{
in China and the United States
}

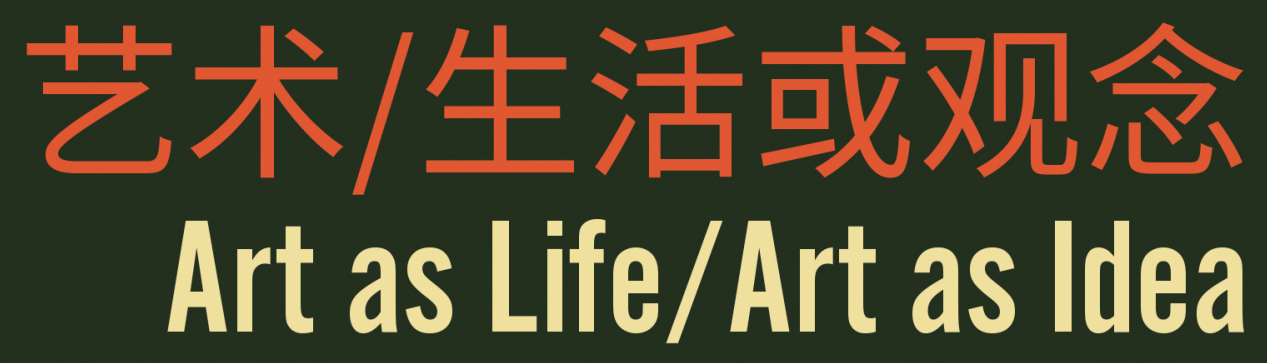

张坚 布鲁斯・罗伯森 主编 Zhang Jian and Bruce Robertson (eds.)

p. 
COMPLEMENTARY MODERNISMS IN CHINA AND THE UNITED STATES 

BEFORE YOU START TO READ THIS BOOK, take this moment to think about making a donation to punctum books, an independent non-profit press,

$$
\text { @ https://punctumbooks.com/support/ }
$$

If you're reading the e-book, you can click on the image below to go directly to our donations site. Any amount, no matter the size, is appreciated and will help us to keep our ship of fools afloat. Contributions from dedicated readers will also help us to keep our commons open and to cultivate new work that can't find a welcoming port elsewhere. Our adventure is not possible without your support.

Vive la Open Access.

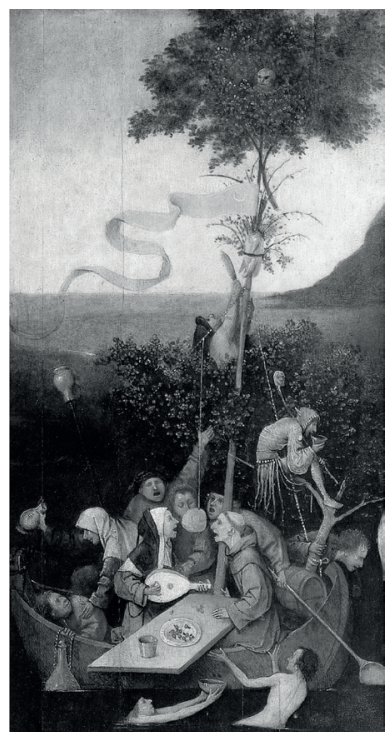

Fig. I. Hieronymus Bosch, Ship of Fools (I490-I500) 
Complementary Modernisms in China and the United States: Art as Life/Art as Idea. Copyright @ 2020 by the editors and authors. This work carries a Creative Commons BY-NC-SA 4.o International license, which means that you are free to copy and redistribute the material in any medium or format, and you may also remix, transform and build upon the material, as long as you clearly attribute the work to the authors (but not in a way that suggests the authors or punctum books endorses you and your work), you do not use this work for commercial gain in any form whatsoever, and that for any remixing and transformation, you distribute your rebuild under the same license. http:// creativecommons.org/licenses/by-nc-sa/4.o/

First published in 2020 by punctum books, Earth, Milky Way.

https://punctumbooks.com

ISBN-I3: 978-I-950192-57-I (print)

ISBN-I3: 978-I-950192-58-8 (ePDF)

DOI: 10.21983/P3.0269.I.00

LCCN: 2020940865

Library of Congress Cataloging Data is available from the Library of Congress

This project is made possible through support from the

Terra Foundation for American Art.

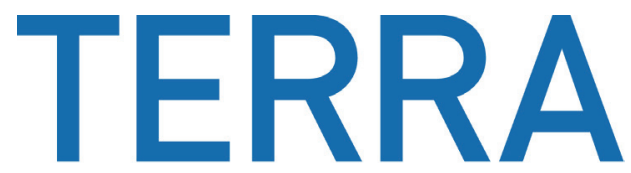

FOUNDATION FOR AMERICAN ART 


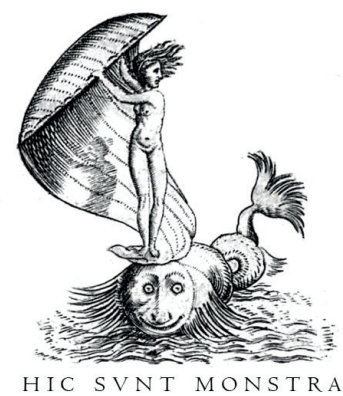





\title{
交互视野下的中国 Complementary Modernisms 和美国的现代艺术 in China and the United States
}

\author{
艺术/生活或观念 \\ Art as Life/Art as Idea
}

张坚 布鲁斯・罗伯森 主编 Zhang Jian and Bruce Robertson (eds.) 



\section{Contents}

\section{Preface}

Parallel/Complementary:

Thinking through American and Chinese Modernisms

Bruce Robertson

平行/互补:对美国和中国的现代主义的思考 布鲁斯·罗伯森

\section{Introductions}

多元的现代主义“探索交互视野下的中美现代艺术”的实验” 张坚

Multi-Modernisms: Exploring "Complementary Modernisms in China and the United States" Zhang Jian

Cosmic Jokes and Tangerine Flake: Translating Andy Warhol's POPism 82 Reva Wolf and Kou Huaiyu

宇宙的玩笑与橙色亮片漆: 译介安迪·沃霍尔的《波普主义》 列娃·沃尔夫、寇淮禹

中西现代主义绘画的会通之路:论塞尚与黄宾虹 沈语冰

The Converging Way of Modern Art between China and the West: Cézanne and Huang Binhong Shen Yubing

\section{0s-1920s: Modernism's Beginnings}

Whose Metropolis, Whose Mental Life? Rethinking Space and the Local in Urban Imagery

Rebecca Zurier

谁的大都市? 谁的精神生活? 城市图像中的空间与本地居民 158 瑞贝卡·泽瑞尔 
The Urban Spectacle:

New York City, Impressionist Painting, and the Ashcan School

Chen Yao

进化抑或革命:沃尔特·帕克与1913年美国军械库艺术展 206 陆豪

Evolution or Revolution: Walter Pach and the Armory Show in I9I3

刘晨

After the École des Beaux-Arts and Bauhaus: Liang Sicheng and the Utopia of Modernism in Chinese Architecture of the Twentieth Century

Liu Chen

\section{0s-1950s: Modernism's Redefinitions}

决澜社艺术研究——作为国际艺术资源的中国现代美术 李超

A Study of "the Storm Society":

Chinese Modernism as a Resource of International Modern Art

Li Chao

Joseph Cornell at the Museum of Modern Art

Marci Kwon

通俗现代主义:约瑟夫·康奈尔与民粹主义文化

权玛西

Picturing the Good Earth:

Modernism's Rural Roots in China and the United States

Jason Weems

描绘大地: 中美现代主义的乡土渊源

詹森·维姆斯

Peggy's "War Babies":

Pollock, Motherwell, and Baziotes at Art of This Century 
佩吉的“战争之子”:“本世纪艺术展”上的波洛克、

马瑟韦尔和巴齐奥特

艾伦· $G$ ·兰道

纽约画派与意识形态

毛秋月

The New York School and Ideology

Mao Qiuyue

转义和建树: 中美艺术交互影响的若干个案

丁宁

Artistic Tropes: Some Cases of Mutual Chinese-American Influence

400

Ding Ning

塑造人民形象与认识自我:

20世纪60年代的蔡亮和其他历史画家

张坚

Modeling People and Identifying the Self in History Painting:

Cai Liang and Others in the Early I960s

424

ZhangJian

\section{0s-1970s: Modernism in Ferment}

Rethinking the I960s: The History of Art History

Bruce Robertson

反思60年代: 艺术史的历史

布鲁斯·罗伯森

Louise Nevelson's Modernisms

462

Julia Bryan-Wilson

路易斯·尼维尔森的现代主义延帯性

482

朱丽·布莱恩一威尔逊

Because Night Time Is the Right Time:

Tactics, Popular Resistance and the Formation of the Black Arts Council

492

John Vincent Decemvirale

夜晚好时光:策略、公众抗拒与黑人艺术委员会的形成

约翰·文森特·德赛穆维拉 
劳伦斯·林德

\section{0s to the Present: Modernism and/or Post-modernism}

建构Vs.解构：一旅美中国当代艺术家作品中的“传统”困局 章锐

Construction vs. Deconstruction:

Different "Chineseness" in Chinese Diaspora Artists' Works

Zhang Rui

现代美术的再发现：回溯与借鉴一从吴冠中到“新潮美术”运动 张坚

Rediscovering Modern Art in the I980s:

Diachronic Enquiring and Synchronic Borrowing from Wu Guanzhong to the 1985 New Wave Movement

Zhang Jian

无尽的社会风景

576

邵亦杨

An Imagined Utopia:

Chinese Contemporary Art through the Perspective of Globalization

Shao Yiyang

对中国概念艺术的几点认识

朱青生

Some Remarks on Conceptual Art in China

Zhu Qingsheng

替罪的肉身一中国行为艺术的意义

王端廷

Redemption of Sins through the Human Body:

Meanings of Action Art in China

Wang Duanting

艺术史: 趣味、图像与身份一从何多苓VS怀斯到王广义VS

沃霍尔两对个案看艺术的出发点与针对性对艺术史书写的作用 622 吕澎 
Taste, Image, and Identity: He Duoling and Andrew Wyeth;

Wang Guangyi and Andy Warhol. A Comparative Analysis of the

Role of Artistic Approaches and Directions in Art History

Lu Peng

抽象或视觉逼真:历史画创作的新趋向

“国家重大历史题材美术创作工程”中的视觉表达问题

张坚

Abstract or Optical Fidelity:

New Trends in History Painting after the I980s

696

Zhang Jian

Author Biographies 


\section{Acknowledgments}

Our first thanks are to the Terra Foundation for American Art, especially Elizabeth Glassman, Amy Gunderson, and the always supportive Carrie Haslett. They have guided this project from the start and have patiently awaited the publication of this book.

We also thank the authors, who so generously gave their time and intellectual energies to the project, from the initial conference in 2016 through its completion: Julia Bryan-Wilson, UC Berkeley; Chen Yao, Hefei University of Technology; J.V. Decemvirale, UC Santa Barbara; Ding Ning, Peking University; Kou Huaiyu, independent scholar; Marci Kwon, Stanford University; Ellen Landau, CWRU; Lao Zhu, Peking University; Li Chao, Shanghai Academy of Fine Arts; Liu Chen, Tsinghua University; Lu Peng, CAA Hangzhou; Lu Hao, Guangzhou Academy of Fine Arts; Mao Quiyue, Tongji University; Lawrence Rinder, UC Berkeley; Shao Yiyang, CAFA; Shen Yubing, Zhejiang University; Wang Duangting, China Art Research Institute; Jason Weems, UC Riverside; Reva Wolf, SUNY New Paltz; Zhang Rui, Tsinghua University; and Rebecca Zurier, University of Michigan

A bilingual publication is always enormously complicated to execute, and we have been supported by a team of translators and editors. In Hangzhou, as translators, Dr. Nie Haoxue, Ms. Chen Han, Mr. Wang Shanlu, Ms. Li Xinlei, and especially Prof. Zhang Jian. As editors, Dr. Zhang Fanying, Ms. Zhutian, Ms. Liu Lianlian, and Ms. Gu Jingxing. At the Santa Barbara end: Charlene Garfinkle, Elizabeth Hsinyin Lee, Lu Yu-Chen, Wang Yinan, Wang Shihua, Jing Cao. Susan Tai at the Santa Barbara Museum of Art and Daisy Wang at the Peabody-Essex Museum reviewed some of the translations, and Kou Huaiyu continued to apply his linguistic skills to the project.

For assistance with photographs: Paula Conde-Porto, Emily Corb and Edith De La Cruz. Tara Wang in Beijing, Prof. Julia Andrews, Ohio State University, and David Borgonjon at Columbia University, guided us to specific artists. We also thank the rights holders, galleries and museums who assisted us, and the very helpful staff at Artists Rights Society and Art Resources.

Also, Mr. Shi Guoxiang and Mr. Sun Jinsong acted as photographers of the conference; and J.V. Decemvirale and Wencheng Yan assisted at UCSB. Professor Peter Sturman at UCSB provided crucial support throughout. 
Preface

Parallel/Complementary: Thinking through American and Chinese Modernisms

\author{
Bruce Robertson
}

Contrapuntal juxtapositions [...] diminish orthodox judgment and elevate appreciative sympathy.

—Edward Said, $1990^{1}$

The problem of nationalism in art history seems insoluble and toxic, the issue of modernism no less so. Both are so deeply implicated in the rise of Western imperialism, technology and the devastation of cultures, peoples and the environment globally. So why put both together?

The Terra Foundation's mission is to create and sustain interest in American art around the world. Five years ago the Foundation asked me for my thoughts on how to develop a collaboration in China. ${ }^{2}$ I proposed an exchange of seminars and a joint conference and publication, with four fundamental premises. Both partners had to be as equal as possible: despite the fact that Terra's monies were driving the project, the American side of the partnership could not be in the driver's seat. Also, the differences were real but of equal substance: we were not engaged in a project of "teaching" American art. Rather, we were in a situation of learning from each other. We needed to begin by juxtaposition, because otherwise we would get into a situation of influence or a hierarchy of importance. Finally, I asked that Terra include as part of the project a colleague who taught Chinese art, to act as "interpreter" and bridge-builder. A year later, I was asked to submit a proposal to implement these ideas. My American partner was Peter Sturman, my colleague who teaches Chinese art at the University of California, Santa Barbara; and my Chinese co-organizer was Prof. Zhang Jian, from the China Academy of Art in Hangzhou, an already very-experienced collaborator on Terra projects. I knew I would need Sturman's guidance in China, and that Zhang Jian, my Chinese colleague, would welcome his presence in Santa Barbara. Moreover, it would make it even clearer that I was the one who

I Quoted in Anna Malik, "Conceptualizing 'Black' British Art through the Lens of Exile," in Exiles, Diasporas \& Strangers, ed. Kobena Mercer (Cambridge: MIT Press, 2008), 167.

2 See an earlier symposium funded by the Terra Foundation, East-West Interchanges in American Art: A Long and Tumultuous Relationship, eds. Cynthia Mills, Lee Glazer, and Amelia Goerlitz (Washington, DC: Smithsonian Institution Scholarly Press, 2009). The mandate for this gathering was broader (all of Asia) and included far fewer Asian scholars. 
needed help and guidance, more than Zhang, who was more than adept in both Western art history and Western institutions.

The process and activities of the three-year project are laid out by Prof. Zhang in his Introduction. In this preface, I want to address some of the questions we faced and the solutions we arrived at, and then reflect on both their larger meanings and the outcome, as embodied in this volume. First, I had proposed a seminar and conference that explored the whole development of modernism in both countries, from the Stieglitz Circle (on the American side) to the I950s, while Zhang was much more interested in the second half of the twentieth century. This reflected a Chinese reality, which only became clear to me later (discussed below). I had been enthralled by Julia Andrews and Kuiyi Shen's The Art of Modern China: their account of how Chinese artists reacted to Western art in the late igth- and early 2oth-century was a revelation. ${ }^{3}$ But Zhang was much more interested, as were his students and colleagues, in the American art whose reception in China they had lived through and which continued to be of interest to contemporary artists. For my seminars I was encouraged to teach post-War art only; I smuggled in pre-War art by devoting a lecture to the development of government funding for the arts (e.g., art developed in the US in the late 1920 s through the I930s during the time of the Works Project Administration and the Great Depression).

Second, the question of the title for the project was an unsettled one. In my mind we were always talking about "parallel modernisms," but Zhang was interested in "complementary modernisms." In my mind, we were simply juxtaposing two modernist developments, in order to say something about the meaning and limits of modernism. In Zhang's view, we were looking at modernisms that, although distinct, had a relationship to each other, something that the Chinese scholars were consistently interested in, while I had deliberately chosen Americanists who did not research American-Chinese collaborations (such as the visits of Andy Warhol and Robert Rauschenberg to China in the 1970s). Zhang makes the point clearly when he notes in his introduction the two meanings of "complementary": "supplemental" and "reciprocal." Second, Zhang proposed the thematic title "Art as Life/Art as Idea." For me, this evoked idealist overtones but at the same time I had to acknowledge the phrases' very specific relevance to the history of American art, through the voice of Robert Henri's slogan, "The art that is life." And, as I gradually realized, it summoned up a notion of social responsibility and social commentary that resonated particularly in China. But, even after three years of living with the title, I instinctively call the project "parallel modernisms." So it seems worthwhile to keep both terms in mind, and Zhang's title in play, as an indication both of the ultimate state of irresolution in the project's outcomes and the element of opacity that lies in the translation between two cultures (see the brilliant interplay of Kou Huaiyu and Reva Wolf, in this volume, which for me reveals the heart of the project). Kobena Mercer comof California Press, 2012). 
ments, that "where the laws of geometry hold that parallel lines never intersect, it is precisely the mutual entanglement of western and non-western practices" that studies of global modernism need to address. ${ }^{4}$ The impossible geometries of cultural production are what interest us.

China and the United States seem incomparable entities, at least until this century. One is densely populous, and imbued with ancient traditions; the other is resource-rich in relation to population, technologically advanced and historically shallow. It must be a shock to every American visitor to visit China now-as it was for me-and realize that in comparison, the United States seems backward in its infrastructure and small, even provincial. And so, however we juxtapose them, we must also realize that the character of the comparison changes over time.

There are obvious ways to proceed when placing bodies of art production next to each other. The models of influence and diffusion, from center to periphery, are not necessarily either bad or falsifying. On its own terms, however, China has always been the center of the world, and certainly the center of Asia, while the United States has been taken by most to be a cultural adjunct to Europe-the western addition of the West. Putting the two together might appear to flip the relationship, at least technologically, where for the twentieth century the United States was the most technologically advanced country in the world. As Duchamp said in 1917: "The only works of art America has given are her plumbing and her bridges."s According to Virginia Woolf, in her 1924 essay "Mr. Bennett and Mrs. Brown," written under the influence of an exhibition of Manet and other Post-Impressionists, I9IO was when the world became modern, a truth observed in any history of art that invokes that flash-point of modernity as the invention of cubism. By that calculation, then, modernism in the United States is only a few years closer to that birthdate and place than China: with the Armory Show of I9I3 in New York and Chinese painters producing recognizably "modern" work by the early I920s. On the other hand, how we account for the huge gap between the modernity of America itself around 1900- the most modern of countries, techno-culturally, for most of the twentieth century-and the peripheral nature of its art-making has occupied the attention of Americanists for decades. The solution, ultimately, is to ignore the problem and move on to more interesting issues, like thinking about modernisms (plural) as a world-wide phenomenon rather than simply emanating out of Paris.

Kobena Mercer's program of studying global modernism, produced in the last fifteen years, is still the most productive and useful I have encountered; the work of such scholars as Sonal Khullar, Sylvester Ogbechie, and Chike Okeke-Agula

4 Mercer, "Introduction," in Exiles, Diasporas \& Strangers, 8.

5 Marcel Duchamp, quoted in Theories and Documents of Contemporary Art: A Source-book of Artist's Writings, eds. Kristine Stiles and Peter Selz (Berkeley: University of California Press, 1996), 817. 
expand upon this work. ${ }^{6}$ Mercer argues for starting from specificities of time and place, and recognizing that modernism wears many different guises. He and his colleagues argue that all modernisms are located in specific communities and instances and are subject to the effects of actors, events, and resources, not abstract forces, but still shaped by the conditions of human psychology and sociology, cause and effect, economics and so on.

China itself offers a spectacular example of its own specific history of and with modernism. After suffering the destruction of so much contemporary art and the disruption of art communities from the early I930s onwards (beginning with the invasion of Japanese armies), and then the isolation from the West into the I970s, the opening up of China in the I980s meant that every American artist from Jackson Pollock to Andy Warhol to Cindy Sherman arrived simultaneously. Whereas, in the United States, we have these artists separated in our consciousness into carefully and firmly distinguishable historical strata, for Chinese artists and audiences, all three are more or less equivalent. Where we distinguish between Pollock and Warhol as modernist and post-modernist, in China they are all cheerfully accepted as modernist. Or post-modernist. It doesn't matter in China. This "confusion" of modernism and post-modernism—a border which is constantly patrolled and fought over in the United States-is productively ignored in China, which has significant implications for understanding a longer history of modernism, and its continuing relevance, than we are now used to giving that history. ${ }^{7}$

But having said that, of course, no wall is impermeable (the uses of the Great Wall as a metaphor for joining as well as separating are useful here). ${ }^{8}$ After coming across an interesting Bulgarian abstract artist, Detchko Uzunov, James Elkins, one of the more interesting scholars thinking about global art history, is finally convinced that he arrived at abstraction anew, apart from the history of abstraction that preceded him, because of the impermeability of the Iron Curtain. ${ }^{9}$ This is naive. First, and most obviously, because there is a history of abstraction in Sophia and other eastern European capitals in the $1920 .^{\text {.0 }}$ Second,

6 See, for example, Elizabeth Miller's review essay in The Comparatist: Journal of the Society for Comparative Literature and the Arts 40 (2016): 348-46.

7 See, for example, the discussions in Ellen Johnston Laing, "Is there Post-Modern Art in the People's Republic of China?" in Modernity in Asian Art, ed. John Clark (Sydney: Wild Peony Ltd., 1993), 207-2I, and Arif Dirlik, "Postmodernism and Chinese History," in Turning Points in Historiography, eds. Q. Edward Wang and Georg G. Iggers (Rochester: University of Rochester Press, 2002), 287-324.

8 See Carlos Rojas, Great Wall: A Cultural History (Cambridge: Harvard University Press, 20I0).

9 James Elkins, Chinese Landscape Painting as Western Art History (Hong Kong: Hong Kong University Press, 2010), 7-8.

Io Timothy O. Benson, Central European Avant-Gardes: Exchange and Transformation, 1910-1930 (Los Angeles and Cambridge: Los Angeles County Museum of Art and MIT Press, 2002). 
because it misunderstands the nature of communication channels. When we have the world at our fingertips through the internet, we assume a poverty of information dominating earlier generations. But I will never forget seeing the movie Cabaret in 1972, in Saskatoon, Saskatchewan, when it first came out, with my mother - a woman who had been born in New Zealand and lived there until the r96os. She remarked: "Berlin was just like that." I was both amused and stunned, and asked how she could possibly know, and she said with great satisfaction: "We listened to the radio and imagined." Indeed, a word may be sufficient to create the full flowering of an idea and practice: simply the knowledge that abstraction is possible is sufficient; that Uzunov's work reminded Elkins of CoBrA (a post-World War II European group of avant-garde artists) may be coincidental or an example of convergence. Thus, an artist in China in 1920 knows European modernism as well as he or she needs to, to do the work she or he wants to do: a Chinese modernist is not peripheral or marginal, but is at the center of his or her place of experience. And that is not a marginal position, but a productive one. Americanists know the fundamental story of colonialist art production as the history of American art: the paintings of John Singleton Copley, immensely compelling work produced on the basis of the knowledge of bad copies and marginally-talented mentors, far transcends its sources (what Copley felt about being stuck in Boston is another matter, but the work speaks for itself). Or consider the equally important story of American colonial furniture, which has been validated by more than a century of collecting and study as an independent and significant cultural and artistic production, not a provincial copy of English Georgian style. And of course, market validation helps as well: an excellent piece of American colonial furniture is worth as much or more as its more sophisticated English model.

The problem of writing about modernism without discussing influence is one that Americanists are also very familiar with, and one of the major reasons for staging the original conference that led to this volume. Having emerged from a long period of "European influence" studies, where one of the jobs of an Americanist was to name the European artist responsible for the American artist's style, by contrast, for the last generation or two, Americanists have been perfectly happy to ignore, for example, the world of British illustration and European academic realist painting from which Winslow Homer's work emerged, or the European abstraction against which Georgia O'Keeffe deliberately worked. ${ }^{\text {II }}$ By attending to what the work does in relation to itself and its immediate national context, it is easy enough to ignore the issue of influence.

Indeed, the history of American art, since the I970s, has been largely produced within the orbit of American studies. As Jason Weems and Joshua Shannon have pointed out, in clarifying the difference between an Americanist approach to modern art and a Modernist's, Americanists tend to pay attention to

II See Bruce Robertson, "Usable Form: Materials, Methods and Motifs," in Georgia O'Keeffe: Abstraction, ed. Barbara Haskell (New Haven: Yale University Press, 2009), I25-33. 
subject matter and social context, while for Modernists, form and formal concerns remain the overwhelming center of attention: the beginning and end of any analysis. ${ }^{12}$ From an Americanist perspective, European modernists still seem trapped within a formalist and qualitative canon; a Modernist cannot imagine writing seriously about the European equivalent of a Norman Rockwell, for example (whomever that might be), or about the cartoonist Ronald Searle's influence on the painter Lucien Freud. Elkins has bemoaned the inability of modernists to enlarge the canon to include Uzunov and others. Nothing similar stops Americanists, where it's possible to write significant art historical monographs on dioramas and camouflage. ${ }^{13}$

This larger Americanist focus, in the face of Modernist indifference to the same sort of material, occurs because there are resources available in terms of scholars, positions, and support, as well as cognate fields of American history and literature, and because the issue against which some of this work is done-that of identity and civil rights - is one of the central issues of American history and culture. But one could well imagine that within the changing European Union, Uzunov's identity and art become compelling elements of a richer European story (rather than one of just Paris, and sometimes Berlin). When it does so, and resources are turned in that direction, that is when we will see monographs of artists like the Romanian artist Geta Batescu taken seriously. Kobena Mercer remarks on "cultural differences, not as an arbitrary irrelevance that detracts from the 'essence' of art, nor as a social problem to be managed by compensatory policies, but as a distinctive feature of modern art and modernity that was always there and which is not going away." "I4 Since the I970s, Americanists have been busily deconstructing a sense of a unified American identity through the analysis and validation of multiple American identities, arising from racial and gender differences as well as regional ones. Within the last presidential election cycle, indeed, the sense of the centripetal spin of identity difference has only intensified. In contrast, European Modernists have taken much longer to open up a largely class-based analysis of identity into something more complex and sophisticated.

Having said that, the simple binaries of center and periphery, within the canonical narratives of modernism, have been the subject of attack and critique for a quarter century or more, but Americanists have largely stood at the sidelines, which turns out to have been a productive position. In a 2005 interview with Partha Mitter, one of the founders of global art history, the dialogue between

I2 Joshua Shannon and Jason Weems, "A Conversation Missed: Towards an Historical Understanding of the Americanist Modernist Divide," in Companion to American Art, eds. John Davis, Jennifer Greenhill, and Jason Lafountain (Oxford: Blackwell, 2015), 17-33.

I3 See Renee Ater, Remaking Race and History: The Sculpture of Meta Warwick Fuller (Berkeley: University of California Press, 20II), and Alexander Nemerov, "Vanishing Americans: Abbott Thayer, Theodore Roosevelt, and the Attraction of Camouflage," American Art II (Summer 1997): 50-8I. 
canonical and global modernism is entirely construed as between mainstream European modernists (such as Braque/Picasso, Kandinsky/Malevich, and so on) and the Indian painters Mitter is interested in. But this binary leaves out two very important elements. First, there is the force of what might be called vulgar modernism: already by the early I920s, modernist imagery and motifs had been appropriated by mass media, morphing into Art Deco. The avant-garde was always immediately appropriated for commercial ends as the new and the fashionable, and thus available to any artist in the world in a debased, vulgar, and creative fashion. ${ }^{15}$ Second, and perhaps just as important, there are other plenty of other modernists out there: I cannot imagine, for example, that Indian painters were not well aware of British figures like Wyndham-Day Lewis, just as much as they would have been of Malevich, and probably more so.

This more complex conversation among multiple centers, and through various media and means, informs this collection of essays, which shows what happens when you consider the United States and China in relation to France, so that one compares not France and the Other, but all three players, or four. The history of colonialism complicates the picture further: France had a powerful presence is Southeast Asia, but less so in China. At the same time, China and Europe have been in cultural dialogue for millennia, but the Americas were not part of that conversation until the sixteenth century. Yet, as recent scholarship has demonstrated, the route of much Asian art into Europe is through Mexico, as the Spanish trade routes came from China and Japan, through the Philippines to Mexico, and thence to Europe.

These triangular, or multivalent, relationships are the norm, not the exception. For example, the classic analysis of Orientalism posits it as a two-sided relationship of European artists appropriating "Oriental" subjects. But in fact, the visual intermediary was often as not photographs of Middle Eastern subjects produced for the European tourists by Armenian photographers, who occupied a middle-position, neither ethnically nor religiously the same as the subjects of their cameras. ${ }^{16}$ Just so, one can explore the role of Japanese artists as intermediaries between European modernism and Chinese modernist artists. There are enough spectacular examples of Japanese Orientalist works, as well as the aggressive history of Japanese imperialist activity throughout Asia, to suggest that the situation of Chinese modernists was no simple matter. ${ }^{17}$

Is See for example, the Hollywood photographer Ruth Harriet Louise's use of Brancusi's Blanche et Negre, published in Vanity Fair: Robert Dance and Bruce Robertson, Ruth Harriet Louise and Hollywood Glamor (Berkeley: University of California Press, 1999).

I6 I am grateful to Abelina Galustian, $\mathrm{PhD}$ candidate at the University of California, Santa Barbara, for pointing this out to me, in her soon-to-be-completed dissertation on the subject.

I7 See the astonishing reworking of Manet's Olympia with a Japanese subject as Olympia and an Indonesian as her black servant, Nude in Black Lace, by an unknown artist, reproduced in Kendall H. Brown, ed., Deco Japan: Shaping Art 
The construction of the initial conditions of modernist art is complex in different ways in both the United States and China. In China, there is both direct knowledge acquired in Paris and knowledge gained by intercessors, such as in Japan for the most part, but also in the United States. In the United States, it is both Europe (mostly Paris), as well as nativist ideas (derived from technology but also African- and Native American peoples), as well as a strong component of Asian sources. In other words there is, in neither instance, a direct, "pure" transmission of modernism. It is interesting to think of Ikem Stanley Okoye's specifically African example of an independent development of modernism in Nigeria - the architecture of James Onwudinjo-in contrast to any Chinese examples, where the weight of indigenous tradition may be comparable but the kind of tradition is very different, both in kind and scale. ${ }^{\mathrm{I}}$ So much of global art history concerns itself with post-colonial societies, and while China was terrorized by the West, it was a unified territory of millions of square miles and people, a text-based and sociologically very different society, compared to Nigeria or any African country. In China, the technology of social organization is on an industrial scale. We might call it a technology of social organization in order to position China sociologically in mirror-relation to the West's scale of industrial technology. And I use the term "industrial scale" because I want to put the immense scale of Chinese society and culture in opposition to the immense scale of Western technological industry, as comparably weighty entities. Of course, having said that, so far there is nothing comparable to Okoye's example of modernism (although why it should be called modern except for the rhetorical value largely escapes me) that we know of in China, and perhaps there never will be found such an example, given the nature of tradition in China. ${ }^{19}$ But even were such an example to be found, it would be fundamentally different in its particularities of time and place.

Each country has a specific history of modernism, and indeed, each community within that country, which does not "flow" from a single origin point; modernism is never a river. We never know when a community or nation's art production becomes "modern" except in retrospect. Rather, modernism is the frog in water that slowly reaches a boiling point, and which does not realize the

and Culture, 1920-1945 (Seattle: University of Washington Press, 2013), I86.

I8 See Ikem Stanley Okoye, "Unmapped Trajectories: Early Sculpture and Architecture of a 'Nigerian' Modernity," in Exiles, Diasporas \& Strangers, 3I-35.

I9 Okoye wonders why there is a burst of such activity in Africa around I9I0, which then goes dormant until the 1960s. But this is surely the effect of global depression and a succession of two world wars. Okoye's characterization of the situation as determined by "local current eddies and dangerous rapids" (40) should be taken with a grain of salt. On the other hand, one could simply do as Ian McLean argues, taking a sociological approach, that if the art was produced within the contemporary modern era, it is then modern and modernist. See Eric Michaels, "Aboriginal Modernism in Central Australia," in Exiles, Diasporas \& Strangers, 72-95. 
water is boiling until it is too hot. Or perhaps modernism is like a boat on the sandbar, to use a more graceful image, that rises at some point when the incoming tide finally lifts it and it floats away. While the water might move, it does so as the ocean, not as a river that flows like the Seine from Paris; rhizomes and networks are equally useful analogies.

What then is the value of putting these two histories beside each other? It is only of value if it illuminates the politics of the relationship, the history of empire, and suggests a productive framework for future questions.

Inevitably, however, we engage in comparison. Are such comparisons inherently inadequate or pointless? Comparison is a beginning point, perfectly suitable for initiating a conversation. As every educational study demonstrates, any student or audience needs a point of entry, a move from the familiar to the unfamiliar. In his deliberately provocative book, Chinese Landscape Painting in Western Art History, James Elkins uses the tool of comparison to demonstrate the continued imposition of Western values and terms in commentary on Chinese painting by art historians. Elkins argues that art history itself is a western discipline, and that the imposition of art history on non-Western art is part of the deep structure of art history, whether one likes it or not. As he points out, any attempt to map the historical development of Chinese painting against Western models (Baroque scroll paintings?) is ultimately ludicrous and pointless: what could we learn that would be of any value? It would be like comparing chocolate cake and beef stew - at the point one finds common ground, the exercise has become pointless. But this changes when one enters the twentieth century, with two societies in close, challenging contact (yes, there has been two-way contact between East and West for millennia but the winding road is not the same thing as adjacent avenues). The size and nature of the contacts, enhanced by technological developments, are overwhelming.

But Elkins has not thought of art history as a discipline that is shaped by social conditions as well as intellectual concerns; that is to say, he has not considered art history in terms of its functioning as a discipline within the field of other disciplines. Is there an art history or are there art histories? he asks. ${ }^{20}$ With a knowledge of the history of academic disciplines, the answer is "yes." Disciplines are communities of followers, and at a certain point, when the community grows large enough, they fissure. The more complex the nature of the community, the sooner it splits; that is to say, the greater number of rules and internal structures (of thought or hierarchy), the less flat the organization is. The "community" of ice-cream lovers is a very large one, but a relatively stable one; the community of ice cream lovers for whom ice cream is part of a religious ideology (and I assume there must be such a community out there) is one that would surely split into dogmatic factions before it reached a millionth of the size of the former. As art history has grown, it must inevitably become art histories. 
Disciplines are sets of tools wielded by trained professionals on a class of evidence and materials for agreed upon purposes. In other words, they are social enterprises in addition to their other aspects. Thus, if you are not doing what is agreed upon as art history, then you are not an art historian and what you produce is not art history. ${ }^{2 \mathrm{I}}$ It is something else (this is a dilemma faced by many Americanist art historians). On the one hand, when Elkins says "Chinese landscape painting" is Western art history, whether practiced in Beijing or New York, he is right, in the same way that physics practiced in China is Western physics. On the other hand, as an Americanist I remember well when I started graduate school at the end of the I970s the general art historical prejudice against the study of American art as second-rate, not quite "real" art history, a prejudice still felt in some quarters.

But, of course, change will occur. A generation or two of Chinese art historians writing about Chinese art or modern art or Western art, will produce their own art history, adapted and evolved to suit local circumstances and histories. There is nothing wrong with such hybridization or naturalization: imagine Italian cuisine without tomato paste, a contribution from Mexico! Something new and interesting will emerge, and it will be taken as inevitable and natural, as the number of practitioners and their institutions grow. And it is patronizing in the extreme to assume otherwise. To worry about the post-colonialism of Western art history is ultimately to deny agency and self-direction and innovation to other cultures and nationalities. To insist on the centrality of the Other as an organizing principle of discourse is to say that others have no ability to see us as the Other. Give it fifty years (within the lifetimes of our students) and these debates will seem absurdly provincial. Just as the fierce patrolling of the borders of the discipline of art history, as connoisseurship and iconography began to crumble and social art history began to rise in the I970s when I started graduate school, now seems absurd.

The way to proceed, as Mercer makes clear, is through specificity, and a respect for and interest in differences. The anxiety expressed by art historians like Elkins, or Thomas DaCosta Kaufman and David Summers a few years ago, about the nature of the results produced by other art histories is exactly comparable to the anxieties felt a generation or two ago about questioning the canon of modernism. ${ }^{22}$ The idea that there were different narratives and different canons, different starting points and ending points, that the juggernaut launched in Paris around I9IO was neither entirely determinative nor especially interesting-this was all heretical, and the anger directed at those who wasted their and our time

2I See David Carrier's illuminating essay, "Deep Innovation and Mere Eccentricity: Six Case Studies of Innovation in Art History," in Art History and Its Institutions: Foundations of a Discipline, ed. Elizabeth Mansfield (London: Routledge, 2002), II5-3I.

22 See Thomas DaCosta Kaufmann, Towards a Geography of Art (Chicago: University of Chicago Press, 2004), and David Summers, Real Spaces: World Art History and the Rise of Western Modernism (London: Phaidon, 2003). 
writing about abstraction, for example, outside the core defined by Alfred Barr and MoMA in the I930s, was palpable. But then we all got over it, aside from a few die-hard October formalists. ${ }^{23}$

Elkins laments the role of the university in disseminating an overly uniform art history, but fails to understand the point of "university" — which is to create a shared community of scholars across national boundaries (this was the purpose of the first universities) — which is hardly possible without the arbitrary choice of a universal language. ${ }^{24}$ Initially this was Latin, which served some 500 years as a means for all European university scholars to communicate-Latin being, of course, the heavy hand of dead imperializing power. Adrian Piper has argued that one of the side effects of post-modernism is that the Enlightenment tool of rationality is taken away from women of color. ${ }^{25}$ One could add the university and the museum as two other universalizing tools of (at least semi-) rationality that have their value. Here it is worth pointing out that markets are not rational, and if there is an enemy, it is they. Tools for communication across borders, however, are always useful.

As Elkins reminds us, there really hasn't been much change in the way art history is taught, and in the artists who make up the marketplace and canon. ${ }^{26}$ There are certainly exceptions, and the dynamic of such exceptions is the same as it has been in every other sphere of life-one per country per niche, two or three at most. Changing this dynamic only comes through explicit, concerted and self-conscious effort over time. The big exception is China currently, where contemporary artists get a fairly rich treatment in general art surveys produced in the West, particularly Chinese artists who live and work mostly in China as opposed to those other non-Western artists (usually African) whose careers are almost entirely built in the West. This Chinese exceptionalism becomes more interesting when it is read back into China itself, as opposed to being read simply as an extension of Western contemporary art, which is the way most international markets treat artists from outside the Euro-American sphere. In most surveys, and most Western collections, such artists appear only after we have been thoroughly indoctrinated into the post-I960s explosion of "isms," primarily in New

23 Regarding Barr, see "Cubism and Abstract Art," Museum of Modern Art, https:// www.moma.org/calendar/exhibitions/2748. On the October formalists, see Shannon and Weems, "A Conversation Missed," cited in note I2 above, as well as Peter Osborne, "October and the Problem of Formalism," Quadern Portàtils, Museum of Contemporary Art Barcelona (MACBA), 2012: https://www.macba.cat/ uploads/20130503/QP_28_PeterOsborne.pdf

24 James Elkins, "Why Art History is Global," in Globalism and Contemporary Art, ed. Jonathan Harris (Oxford: Wiley-Blackwell, 20II), 380. For a short history of the university, see Glenys Patterson, The University from Ancient Greece to the 20th-Century (Palmerston North: Dunmore Press, 1997).

25 Kobena Mercer, "Adrian Piper, 1970-1975: Exiled on Main Street," in Exiles, Diasporas \& Strangers, I48.

26 See Elkins's essay cited above in note 22. 
York. We hit the I980s and we're prepared to acknowledge the rest of the world, just as the Cold War ends.

But China is different. China had modern art in the I920s and I930s. It had a massive, state-sponsored art tradition to draw upon, or to read against. There is not a village in China without its public art (an inspiring worker or fanciful animal, with an encouraging calligraphic text next to it). Art and art making rest in China on monumental foundations. But China's relationship to its own history, and to the history of the rest of the world, is dramatically fractured in ways that complicate any comparisons. The era of Communist isolation and the cultural terrorism of the Red Brigades still affect the production of art. Meanwhile there are valid, state-supported academies of traditional art and calligraphy, for which there are active markets, schools, critics, and all the other apparatus of the art world.

All this is to say that while American modernism and Chinese modernism are incommensurate in many ways, to view an aspect of global modernism from both an Americanist and Chinese perspective provides a productive counterpoint to the usual (and by now almost canonical) story of global modernism, dominated by post-colonialism.

As a starting point, the first group of essays, including this introduction, lay out the premises for the conference, and give a greater background to the project. Zhang's introduction summarizes the contributions in an exemplary fashion, and need not be repeated here. What emerges from the papers are both the differences in methodology and the interests between the American and the Chinese scholars, as well as some fundamental similarities: parallel and complementary. All of the American scholars argue for the need to reexamine assumptions about modernist art vis-à-vis the specifics of context, time, and place. All have the goal of overturning the deadening effect of the canon, terminology, schools - the categorizing language of art history. All seek to recover a sense of the original reception, rather than the codified knowledge that accrues when we use terms like "urban," or "Abstract Expressionism." The American scholars are engaged in a project of recovery, one dominated today by the hope of recovering marginalized voices (as seen most clearly in Decemvirale's chapter). Many of the Chinese scholars' papers are also engaged in similar recovery operations (such as the chapters by Liu Chen and Li Chao), but more were concerned with examining critically the reception of modernism in China, and the tension with Chinese cultural and artistic traditions. Here, too, though, the meaning and usefulness of terminology came into question: "conceptual" and "performance," even "consumerism," for example, are critiqued in the chapters by Zhu Qingsheng, Wang Duangting, and Kou Huaiyu. The value of misreading (from an American perspective) such artists as Andy Warhol or Andrew Wyeth, as analyzed by Ding Ning and Lu Peng, is another aspect of this critique. Further, the very specificity of the American scholars' papers may be seen in contrast to the willingness of Chinese scholars to write about much bigger issues and generalities, such as the nature of modernism or conceptual art itself. We have been encouraged to be cautious in a way our Chinese counterparts have not been. 
The two other chapters in the introductory section highlight these differences. The interchange between Reva Wolf and Kou Huaiyu vividly enacts the problem of translation: Kou had reached out to Wolf for assistance with his translation of Warhol's POPism. There was the usual problem of how to deal with idiomatic speech and metaphors, but even more enlightening was the question and answer period (during the conference that initiated this volume), when Kou reminded Wolf that he already had a sense of what a "babushka" was because he had Googled it, while Wolf felt that one needed to know a fuller context to fully understand the weight of "Babushkaville." For both, specific context counts for something, and recovering that specific context shapes the translation. Shen Yubing's chapter, on the other hand, reminds us of the very different disciplinary contexts, where a transhistorical discussion of visual form in China still carries real significance and weight, and provides a necessary foundation for any discussion of modernism.

In the Chinese edition of the conference proceedings, the order of the papers reflected the order of their presentation. ${ }^{27}$ In this volume, the papers have been arranged in broad historical periods. In the first section, the papers build out from Zurier's examination of the city and the first impact of modernism in American and Chinese art and architecture. The second section looks at the next generation, and bridges the great divide of the Depression and World War II, experienced so much more catastrophically in China than in the United States, and leading to two very different outcomes in the I950s, as Zhang mentions in his introduction. The third section concentrates on the I96os and early I970s, the period from which most contemporary art today seems to be derived. For Americanists, this period marks a divide as well between modernism and post-modernism. And it is not surprising that, given the overarching theme of "modernism," I chose scholars working up to 1970 as the participants from the American side. In contrast, Zhang chose as many scholars working in contemporary, or what we would think of as "post-modern" art, and that the last section, from the 1980 os to the present, is dominated entirely by Chinese scholars. This reflects both the institutional realities of the Chinese art world - the primary concern with Western art comes with the opening up of China after 1980-and a different understanding of what is mean by "modern" and "modernism." This volume, then, visibly reflects the complementary nature of both American and Chinese experiences with modernism and modernity, but also the methodological, historiographic, and institutional differences between the two art histories. As noted earlier, however, this is a difference that will change radically in the next few decades. For now, this volume stands as a record of a specific moment of intellectual exchange, but also as a significant contribution to these changes.

27 Zhang Jian and E. Bruce Robertson, eds., 艺术: 生活或观念交互视野下的 中国和美国的现代艺术 [Art as LifelArt as Idea: Complementary Modernisms in China and the United States], conference proceedings (Hangzhou, China: China Academy of Art, 2017). 


\section{导言}

\section{平行 / 互补：对美国和中国的现代主义的思考}

布鲁斯・罗伯森

两者并置……将削弱广为接受的正统判断而增进同情的理解。

—爱德华·萨义德，1990 年

艺术史中的民族主义问题似乎是不可解的, 而且极易引起敌对情绪; 而现代主义问题绝不比民族主义问题简单。这种不可解和不简单在 于，民族主义和现代主义都与西方帝国主义的兴起、技术的发展以 及各地文化、人民和环境的倍遭摧残有着极深的牵连。既然如此, 为什么要把两者放到一起加以讨论呢?

泰拉基金会的使命是在全球范围内唤起并维系人们对美国艺术 的兴趣。五年前，基金会就应当如何与中国展开合作一事来征询我 的意见。我提议以研讨班（seminars）和学术会议的形式在中美间 展开学术交流，此外当然还有相关图书的出版。但我认为这些工作 必须在几个前提下进行。首先，中美双方应尽可能地平等一一虽说 是泰拉基金会出资，但美国方面在这一合作关系中不应居于主导地 位。由此也就是要明确，尽管双方存在不同之处，但这些差异是同 等重要的, 美方不是做一个项目来 “教授” 美国艺术 ; 与此相反, 这将是双方彼此学习、互补短长的一次合作。为此, 我们需要并置 中美双方，将二者等量齐观，否则难免畸轻畸重，让一方过分影响 了另一方。最后，我提议将一位教中国艺术的美国同事纳入到项目 中来，以利双方的沟通与合作。

1 在本文的翻译过程中, 我与罗伯森教授有过几番邮件往来, 就翻译中遇 到的问题逐一加以探讨。罗伯森教授在 2019 年 5 月 31 日的邮件中提到, 作为写作者，他有一个不良的倾向 : 有时会把复杂的论证压缩过甚，以 致文意难明。他主动提议我在翻译时, 可以在感觉有必要的地方, 将我 们邮件往来中他所做的解释直接补入行文之中，以便使文章明晰易读。 目前的译文有两三处地方我做了这样性质的增补。此外, 本文所有注释 为译者所加, 原文注释按照全书体例未加翻译，也未保留。 
过了一年，基金会请我以上述想法为基，提交一份正式的方案。 我的美方搭档是我的同事彼得 - 斯特曼（Peter Sturman），他在加 州大学圣塔芭芭拉分校教中国艺术 ; 而与我共同组织会议的是中国 美术学院的张坚教授，他此前曾多次参与过泰拉基金会的项目，很 有经验。我知道我将需要斯特曼的指点，而有他在圣塔芭芭拉，张 坚也会感到便利。不过事后看来，我比张坚更为需要斯特曼的帮助 和指点一一张坚对于西方极为了解，无论是西方艺术史，还是西方 学术机构的运作。

这个为期三年的项目的具体情况，张教授在第二章他的导言部 分交代得很清楚。在本文中, 我想谈谈张教授和我在整个项目中遇 到的问题和最后采取的解决办法。之后我想探究一下，这些问题及 其解决有何意味，而当前的这册书作为项目的成果又取得了哪些成 就。

我想谈的第一点，是有关研讨班和学术会议的主题的。我起初 的想法是梳理一下现代主义在中美两国的发展情况，从施蒂格利茨 的圈子 ${ }^{2}$ (作为美方的起点) 到 20 世纪 50 年代，而张兄则对 20 世 纪后半期更为感兴趣。这涉及到中国的一个现实情况，而关于这一 点我是后来才明白的（具体请参看下文）。我以前读过安雅兰 (Julia Andrews）和沈揆一（Kuiyi Shen）所著《现代中国的艺术》（The Art of Modern China）一书，他们对 19 世纪末、20 世纪初的中国 艺术家是怎样回应西方艺术的有极为出彩的论述，我读之入迷，印 象很深。但张兄与他的学生和同事, 都对他们亲历过的美国艺术有 更大的兴趣，而且这些美国艺术至今仍让中国当代艺术家感到兴味。 他们都希望我在研讨班上只讲战后艺术，我则想方设法将战前艺术 夹带了进去：我拿出研讨班中的一节，在演讲时追述了政府对艺术 的资助是如何变化的，这样我就能谈及 20 世纪 20 年代晚期到 30 年代，这一大萧条和应运而生的公共事业振兴署主事时期，艺术所 取得的发展。

我想谈的第二点，是关于这一项目的名称的，直到最后我们 也不能说达成了一致意见。在我看来，我们谈的是 “彼此平行的

2 指在艾尔弗雷德・施蒂格利茨（I864-I946）身边形成的艺术家、作家 和文化人群体。 
现代主义” (parallel modernisms), 而张兄则以为要讲 “彼此互 补的现代主义” (complementary modernisms) 才对。我认为我 们只是将中美两国现代主义的发展并置, 而当两者摆在彼此旁边 之时，也就可以较为方便地谈谈现代主义的意涵和局限。而在张 兄看来，尽管中美两国的现代主义彼此不同，二者却并非没有关 联; 这一问题也是中国学者全都感兴趣的, 而我在选择美方与会 人员时, 有意只选了那些并不研究中美互通 (比如安迪 - 沃霍尔和 罗伯特. 劳申伯格访华) 的学者。张兄在他的导言里谈到 “互补” (complementary) 时说, “互补” 意为 “互动的” (reciprocal) 和 “补 足的” (supplemental), 由此表明了他对两国现代主义关系的认识。 ${ }^{3}$ 此外, 张兄提议, 会议的主题以 “作为生活的艺术 / 作为观念的艺 术” 为标题。对我来说, 这一题目颇有观念论 (idealism) 的味道, 让人觉得仿佛是要把艺术在历史当中的复杂状况简化为抽象的 “观 念”（idea）; 但与此同时, 我也必须承认它与美国艺术的历史有着 极为具体的关联一一罗伯特-亨利（Robert Henri）曾提出过 “能 捕捉住生活的，方为艺术” 的口号。而且我也渐渐意识到，这一标 题可以让人们想到艺术承载着社会责任, 艺术家被期待以艺术来进 行社会批评，这样的想法在中国尤能引起共鸣。

但即使与张兄提出的这一标题一起生活了三年, 我还是本能地 叫这个项目为 “平行的现代主义”。所以也许我们应该在脑海里保 留两个标题, 而在实际中采用张兄的那个, 这一状况也颇可表明本 项目的最终结果乃一未完成的状态, 并非所有的问题都得到了解决, 而文化间的交流与沟通总是有模糊和难解的成分的（参看本册中收 录的寇淮禹和瑞娃 - 沃尔夫间的精彩互动, 在我看来这一互动揭示 了本项目的核心和关键)。科贝纳 - 梅塞 (Kobena Mercer) 曾说, 依照几何学公理, 平行线永不相交, 但西方和非西方的实践的交缠 却正是研究全球现代主义 (global modernism) 时所要处理的问题。 在文化生产之中，几何学的不可能成为了可能，而这正是我们感兴

3 张坚在他的中文行文中使用的是 “交互” 这个词来对应 complementary, 但罗伯森读的是张坚文章的英译, 他对张坚意思的理解也是以英译文为 基础, 所以此处我对罗伯森转述的张坚的论说按照罗伯森转述时所用的 英文表达来译，而不求与张坚的中文行文一致。 
趣的。

中国和美国似乎是不可进行比较的两个实体，至少本世纪以前是如 此。中国人口稠密，有着古老的传统; 而美国呢，资源以人均水平 而论是丰富的，技术是先进的，但历史则不免有些 “短浅”。不过 美国人要是现在去一趟中国, 一定会大吃一惊一一至少我是大吃了 一惊一一美相较，美国似乎在基础设施方面是落后的，这里那里 都是小模小样的，甚至有些村里村气。所以无论我们如何将中美两 国并置，我们都必须意识到这一比较的性质是会随着时间的改变而 改变的。

显然，将中美两国的艺术摆在一起进行比较可以采取多种方式。 从中心到边缘的影响 - 传播模式并不一定就不好，也不一定就会给 读者以误导。然而，就中国自身的观点来看，中国始终是世界的中 心，而且当然是亚洲的中心 ; 而美国在大多数人看来只不过是欧洲 的文化附庸一一是在更西一点儿的地方对西方进行的补充。将中美 放到一起也许会翻转两者的关系，让美国成为了中心一一至少从技 术水平的角度来看是这样的，美国在二十世纪是全世界技术最为先 进的国家。杜尚 1917 年时不是说过吗：“美国拿得出手的艺术只有 她的自来水管道系统和桥梁。”而维吉尼亚・伍尔夫在 1924 年的文 章《贝内先生和布朗女士》(Mr. Bennett and Mrs. Brown) 中曾表 达过这样的看法：1910 年是世界变得现代起来的年份。她这篇文章 的写作受到彼时她看过的一场名为 “马奈和后印象派” 的展览的影 响；而她文中关于 “现代” 诞生年份的观点，在任何将立体主义的 发明视为现代（modernity）的引爆点的艺术史看来，都是正确的。 这样算起来的话，美国在时空维度上同现代主义的诞生的距离，只 比中国早上一点儿, 也只比中国近上一点儿: 纽约军械库展览会是 在 1913 年，而在 20 世纪 20 年代早期，中国画家已经在画相当 “现 代” 的作品了。另一方面，如何对美国自身在 1900 年左右就已经 进入现代一一在 20 世纪的大多数时期都是技术上和文化上最为现 代的国家一一而它的艺术却居于次要而边缘的地位这一现象进行解 释，几十年来都颇为研究美国艺术的学者所关注。而解决这一问题 的办法, 最终是要将它抛开, 转而关注更为有趣的问题, 比如考虑 一下在世界各地出现的现代主义，我是说各式各样的、复数的现代 
主义，而非仅仅将它们视为从巴黎传播出去的东西。

科贝纳 ·梅塞在过去的十五年间对全球现代主义的研究，是我所 知道的最为有益、也最为有用的; 而桑诺 - 库拉 (Sonal Khullar)、 西尔维斯特 - 奥格别契 (Sylvester Ogbechie) 和奇科 - 奥可可 - 阿 古拉（Chike Okeke-Agula）等学者在他的基础上又有所扩充。梅 塞主张对现代主义的研究要从具体的时间和地点着手, 要充分意识 到现代主义有许多不同的面貌。依照他和他的同事的论证，所有的 现代主义都是存在于具体的社群和事例之中的，受制于特定的行动 者、事件和相关资源，而诸如人类心理、人类社会的运行、经济规 律和事件之间的因果机制等抽象的力量，对于现代主义的面貌亦有 塑造作用。

中国是一个绝佳的例子，可供我们从它的现代主义的历史以及 它与现代主义的历史两方面加以考察。从 20 世纪 30 年代早期起, 中国的艺术创作和艺术社群就不断受到严重的破坏（日本的侵略是 这一过程的开端）；而之后一直到 70 年代，中国都与西方相隔绝； 这样 80 年代的改革开放意味着从杰克逊. 波洛克到安迪 - 沃霍尔 再到辛迪・舍曼等大批美国艺术家都是同一时间进入地中国。

在美国，我们在仔细考量之后，把这些艺术家归入严加区分的 不同时期，而对中国艺术家和中国大众来说，这三位艺术家大体上 是可以同等看待的。我们将波洛克归入现代而沃霍尔归入后现代， 而在中国，他们都被作为现代主义艺术家而欣然接纳，又或者作为 后现代艺术家一一在中国，这都不是问题。现代主义和后现代主义 的分界线在美国是被严加巡视的一一而且一直争论不休; 而在中国, 这一现代主义和后现代主义的 “淆乱” 却被无视，而且中国的艺术 创作反倒因此受益。这一情况对于理解现代主义的历史及其和当下 的关联是有重大意义的 : 在美国, 现代主义结束于后现代的到来 ; 而在中国，对现代和后现代的不加区分，意味着现代主义依旧是活 跃着的力量。

但说过了这些，我们还得说 : 没有墙是穿不透的（让我们想一 下万里长城, 它固然是一种分隔，但也可视为一种连接）。在偶然 发现一位保加利亚抽象画家德切柯 - 乌祖诺夫（Detchko Uzunov） 后，詹姆斯 · 埃尔金斯 (James Elkins) 一一他是那些一心想着写 作全球艺术史的学者中较为有趣的一位一认定乌祖诺夫必然是独 
立达成的抽象，他一定没有受到在他之前已经存在的抽象艺术的影 响，因为没有什么能穿透苏联的铁幕。这想法未免幼稚。

首先，也是最为明显的是，在 20 世纪 20 年代的保加利亚的首 都索菲亚以及其他东欧首府，都曾有过抽象艺术。其次，埃尔金斯 误解了信息传播渠道的性质。我们现今透过互联网可以将世界尽数 收入掌中，所以我们就假定以前的人们一定是信息闭塞的。但我 永远难以忘却 1972 年在加拿大萨斯克彻温省的萨斯卡通市和我母 亲一起看刚上映的新片《歌厅》(Cabaret) 的经历。我母亲在新西 兰出生，直到 60 年代都还住在那儿。她看了片子，对我说 : “柏 林确实是这样的。” ${ }^{4}$ 我感到很好笑，同时也很吃惊，我问她她怎么 会知道柏林是这个样子的呢?她很是得意地对我说 : “我们那会儿 听收音机嘛，然后就开始幻想啊。”确实，一个词也许就足以生发 出一个新的想法，足以创造出一个新的实践：只是知晓抽象是可能 的，就足以创造出抽象了。乌祖诺夫的作品让埃尔金斯想起眼镜蛇 （CoBrA）-一个二战后的欧洲先锋艺术家团体，这也许是巧合， 但也可能是乌祖诺夫和眼镜蛇的创作为我们提供了一个趋同的例子 (an example of convergence) ${ }^{5}$ 。

因此，在 1920 年的中国，一位艺术家可以就其所需要的程度、 就其所想要创作的作品，对欧洲现代主义进行了解：一个中国的现 代主义艺术家并不处在外围，他 / 她在其经验的中心。他 / 她所在 的绝非边缘位置, 反倒是一个大有可为的处所。研究美国艺术的学 者应该对于美国艺术史在谈到殖民主义艺术时会讲的以下这个故事 并不陌生 : 约翰·辛格尔顿・科普利 (John Singleton Copley) 的 老师只是略具才能，他参考得到的也只是些拙劣的仿制品，然而他 的画作却极为憾人，远超他所承袭的和所凭依的（他感到自己被困 在波士顿是另一回事，因为无论如何，他的作品的成就是摆在那儿 的）。又或者想一下美国殖民地时期的家具的情况，这些家具迄今 已在一个多世纪的时期里被视为独立的、意义重大的文化和艺术创 作而被研究和收藏, 没人把它们看作英国乔治时期风格的乡下翻版。

4 《歌厅》的故事发生在 20 世纪 30 年代的柏林。

5 这里是用了演化生物学上的概念。在演化生物学中, 趋同指不同物种独 立演化出了相近的生物特征。 
看一下它们在市场上的表现也对我们的讨论有所助益 : 一件出色的 美国殖民地时期的家具和它更为繁复的英国原型相比, 具有同等的、 乃至更高的市场价值。

在处理现代主义时不谈及影响也是研究美国艺术的学者所熟悉 的, 这一情况也是我们之所以要举办那场促成了当前这本书的学术 会议的重要原因之一。对美国艺术的研究曾长期以“追索欧洲影响” 的方式来进行。研究美国艺术的学者的诸多工作中的一项就是指明 某一美国艺术家的风格来自于哪位欧洲艺术家。与此不同，过去这 一两代的研究美国艺术的学者 ${ }^{6}$ 对于欧洲影响绝口不提而丝毫不觉 有何不妥, 比如他们在处理温斯洛 - 霍默 (Winslow Homer) 的 作品时, 就不谈其所从出的英国插画和欧洲学院派现实主义绘画, 又如在讲乔治娅 - 奥基夫 (Georgia O' Keeffe) 时, 并不论述作 为其创作背景的欧洲抽象绘画。要做到无视欧洲影响并不难, 只要 将注意力放在作品和它自身的关系以及作品和它最为直接的国家情 境（national context）的关系之上就可以了。

实际上，美国艺术史自上世纪 70 年代起，就基本上是在美国 研究 (American studies) 的轨范内进行的。贾森 - 威姆斯 (Jason Weems) 和乔舒亚·香农（Joshua Shannon）曾指出，对于现代 艺术的研究, 美国研究的路数（Americanist approach）和现代主 义的路数 (Modernist's) 的区别在于前者倾向于关注艺术的主 题（subject matter）和社会情境（social context），而对后者来说， 艺术作品的形式 (form) 和艺术家对于形式的考量是他们关注的重 点, 是他们分析的起点和指归。

在研究美国艺术的学者看来, 研究欧洲现代主义艺术的学者似 乎仍被困在由形式主义所确立的典范（canon）之中，这一典范依 艺术家在形式上所作探索的成就而将他们分出高下。 ${ }^{7}$ 比如说一个

6 下文马上会谈及, 研究美国艺术的学者 (Americanists) 现今通常遵循 美国研究（American studies）的路数，而与现代主义路数有别。之后 的讨论中, 凡谈到研究美国艺术的学者, 即暗含了他们遵循美国研究路 数这样一层意思在。

7 上一段区分了艺术史研究中的两种路数, 美国研究的路数和现代主义的 路数, 并且提到对美国艺术的研究从上世纪 70 年代起, 就基本是在美 
遵循现代主义路数的研究者，就不能想像自己会去研究一个欧洲版 本的诺曼·罗克韦尔（Norman Rockwell）（我们且不管谁是诺曼· 罗克韦尔的欧洲版本), 也无法想像自己会研究漫画家罗纳德·瑟尔 （Ronald Searle）对于画家卢西安·弗洛伊德（Lucian Freud）的 影响。埃尔金斯为遵循现代主义路数的研究者不能将乌祖诺夫或其 他一些艺术家纳入到典范（canon）之中并对其加以研究而倍感惋 惜; 而研究美国艺术的学者却不会受到类似的束缚或限制，他们可 以对自然博物馆中常见的那种模型展示（dioramas）进行艺术史研 究，或者以迷彩（camouflage）为题写作艺术史专著。

艺术史中的美国研究路数所以能有更为广阔的视野，将现代主 义路数置之不理的材料拿来加以研究, 乃是由于相关学者、相应的 工作机会和各方支持的存在，另外还要考虑到美国历史和美国文学 这两个美国研究的相关领域的存在。此外，这类对美国艺术所做的 研究中的一些，涉及到美国历史和文化的核心问题，我指的是身份 认同问题和公民权问题。我们当然可以想像，在不断变化的欧盟之 中，有一天乌祖诺夫的身份和艺术变得引人入胜，构成更为丰富的 欧洲故事的一部分（现在一讲欧洲故事就只是关于巴黎，或者偶尔 再加上柏林）。当这一天来临，相关资源被引导到这一方向上去的 时候，我们也就会看到严肃地对待诸如罗马尼亚艺术家格塔·贝慈 库（Geta Batescu）这类主题的艺术史专著的出版。

科贝纳 - 梅塞在谈到文化差异时说，“文化差异并非有损于艺 术 “本质” 的随便而无关紧要之事，也非需要政府的补贴政策来应 对的社会问题，文化差异是现代艺术和现代状况（modernity）所

国研究的路数下进行。我曾邮件询问罗伯森教授是否有采取美国研究的 路数对欧洲现代主义艺术进行研究的学者，罗伯森教授答复说，据他所 知没有。也就是说，美国研究路数只在对美国艺术的研究中采用，而对 欧洲现代主义艺术所进行的研究完全是在现代主义路数下进行的，这些 遵从现代主义路数的研究者, 关心艺术家在形式（form）上所做的考量, 关心他们的艺术作品对于形式（form）的贡献，并依照其贡献大小，将 其分出高下，由此确立了一批可以称作典范（canon）的艺术家; 位于 典范之外的艺术家及其作品，既不在他们的研究视野之中，也很难纳入 到他们的研究框架之内。 
具有的特点，文化差异会一直存在而不会消逝。” 自上世纪 70 年 代以来，研究美国艺术的学者一直忙于解构统一的美国身份认同 (American identity)，这一工作是通过对基于种族、性别和地域 差异而生的不同的身份认同（identities）的分析和确认来达成的。 从特朗普的当选中，我们可以切实看到美国民众对于彼此身份认同 的差异的感受更其强烈了。与此形成对照的是, 研究欧洲现代主义 艺术的学者花了更长的时间来打破一个大体上是基于阶级来分析身 份认同的模式, 现在对欧洲身份认同的研究采取了更为精细而繁复 的方法。

对现代主义的正统叙事中所运用的中心 - 边缘这一简单的二分 法进行攻击和批评, 至今已有四分之一个世纪或更长时间了。 ${ }^{8}$ 在 这一过程中, 研究美国艺术的学者大体上是置身事外的, 而回过头 来看，这是有益的。在一个 2005 年对帕萨 · 米特（Partha Mitter） 这位全球艺术史的创建者之一所作的访谈中，正统的现代主义和全 球现代主义之间的对话完全被他讲成是在主流的欧洲现代主义艺术 家（如布拉克 / 毕加索, 康定斯基 / 马列维奇等等）和他所感兴趣 的印度画家之间展开的。

但这一二元分析没有考虑到两点非常重要的因素。首先, 有一 股可称为通俗现代主义的力量。在 20 世纪 20 年代早期，现代主 义的图像和主题已然被大众媒体所挪用, 衍生出装饰艺术 (Art Deco）。先锋艺术总是很快被商业力量当作新潮事物来挪用, 商业 挪用为全球各地的艺术家接触到先锋艺术提供了便利, 这一挪用可 能是通俗的，但也常常是创意十足的。另外也许同等重要的是，在 主流的欧洲现代主义艺术家之外，还有许许多多现代主义艺术家。 我觉得印度画家对温德姆 - 刘易斯（Wyndham Lewis）这类英国 艺术家和对马列维奇会是同样地熟悉，也许更为熟悉也说不定。

这一在多中心之间、通过不同的媒介和手段展开的更为复杂的 对话, 在本书的论文中是有所体现的, 它们展现了当你不仅是在法

8 依循现代主义的路数对现代主义艺术所做的研究, 构成了对现代主义 的正统叙事（canonical narratives）。在这些叙事中，有一批被目为构 成了现代主义典范（canon）的艺术家及其作品。本文在翻译中，对于 canon 一词及其形容词形式，有时译为正统，有时译为典范。 
国和另一国度间，而是在美国、中国和法国三国间一一甚至四国 间一一考虑问题的时候，所能取得的成果。殖民的历史让情况更为 复杂：法国在东南亚曾经极有影响，但对中国的影响就不那么大。 与此同时，中国和欧洲之间的文化对话有上千年历史，但美洲直到 十六世纪才参与到对话中来。然而，根据最近的学术研究所揭示的 情况，我们可以知道亚洲艺术进入欧洲的路线是经过墨西哥的，因 为西班牙的贸易航线是从中国和日本出发，通过菲律宾，穿过墨西 哥，最后抵达欧洲的。

这些三边或多边的关系是常态，而非例外。比如说，经典的对 于东方主义的分析将其视为一个欧洲艺术家挪用 “东方” 主题的双 边关系。但实际上，欧洲艺术家的创作所凭依的那些中东题材的照 片经常是由亚美尼亚摄影师拍摄的，而这些作为中介发挥作用的亚 美尼亚摄影师和他们所拍摄的对象在种族上和宗教上都是不相同 的。与此类似，我们可以探究日本艺术家作为中间人在欧洲现代主 义和中国现代主义艺术家间发挥的作用。如果将许多日本的东方主 义的作品和日本帝国主义在整个亚洲的侵略活动纳入考量，就会发 现中国现代主义艺术家的情况绝不是简单能说清的。

最初促成现代主义艺术的条件是复杂的，也是不同的，在中美 两国都是如此。在中国，既有从巴黎直接获得的知识，也有通过中 介获取的知识，日本当然是主要的中介，但美国也是中介之一。在 美国，促成了现代主义艺术兴起的既有欧洲因素（主要是巴黎）， 也有本地因素（美国自身的技术，以及非裔美国人和美洲原住民）, 但我们也可以明显看到来自亚洲的成分。

换句话说，中美两国的事例展现的都并非是现代主义的直接而 “纯粹的” 传播。伊肯·斯坦利 - 奥古亚 (Ikem Stanley Okoya) 曾专门探讨过詹姆斯 - 昂丁右（James Onwudinjo）的建筑实践, 这是一个在尼日利亚独立发展出来的现代主义的事例。中国传统无 论是在类别上还是在规模上都与非洲大不相同，如果挑选一个同样 强烈地受到了本土传统影响的中国事例与詹姆斯 - 昂丁右的建筑相 比较，将是有意思的。全球艺术史中的一大关注点是后殖民社会。 而中国尽管曾经受到西方的威胁，但如果将之与尼日利亚或任何非 洲国家相较，那么很明显，中国有着统一而广大的疆域，有自己的 文字，在社会学意义上也是非常不同的社会。在中国，社会组织技 
术一一我是说它的官僚制度一一完全达到了工业时代的规模。

我们以社会组织 “技术” 名之, 以便将中国在社会学意义上和 拥有发达的工业技术的西方相比照。而我用 “工业时代的规模” 这 样的说法，是因为我想将中国社会和中国文化的宏大体量同西方由 科技铸就的工业的宏大体量相比较。当然，尽管如此，必须要说的 是现在在中国还没有发现可以和奥古亚举出的现代主义的事例相 仿佛的事例（尽管奥古亚给出的例子为什么应该被称为是 “现代 的” ——除了修辞上的需要——我没有太深究), 而且也可能永远 不会在中国找到相仿佛的事例, 因为中国有着太过不一样的传统了。 但即使找到了可相比照的事例, 也会是一个在时间上和地点上非常 不同的例子。

每个国家的现代主义都有它独特的历史，而且一国之内的不同 社群，其现代主义的历史也彼此不同。现代主义不是从一个单一起 点 “流向” 各处的, 现代主义从来不是一条河流。我们只有在回顾 中才能知晓，某个国家或社群的艺术是在何时变得 “现代” 的。现 代主义是缓慢加热至沸点的水中的青蛙，这青蛙对水沸并无觉察。 又或者, 用个更为优雅的画面来打比方, 现代主义像静躺在沙洲之 上的一条船，当涨潮的海水终于托起了它，它才浮起来，飘走了。 即使将现代主义比作水, 那也是如大洋一般运动着, 而非像塞纳河 水一般从巴黎流出; 将现代主义想像为根状茎或网络, 对我们的理 解也是有帮助的。

那么, 将中美两国现代主义的历史放在彼此旁边又有什么价值 呢? 应该说，只有当这样做可以让我们更好地理解两国关系的政治 维度以及理解 “帝国” 这一概念的历史的时候, 只有当这样做可以 为我们未来的思考提供一个有价值的框架的时候, 这样的并置才是 有价值的。

然而我们总是不可避免地进行比较。这样的比较注定是不妥的或是 无意义的吗? 比较是起点, 非常适合开启一个对话。正如教育学的 研究所揭示的，学生或受众需要一个入口，从熟悉的进入陌生的。 在他刻意以会激起争议的方式写作的《西方艺术史中的中国风景画》 (Chinese Landscape Painting in Western Art History) 一书中，詹 姆斯 - 埃尔金斯使用比较的方式，展示了艺术史学者是怎样将西方 
的价值和术语加于中国画之上，来对其进行审视和评判的。

埃尔金斯认为，艺术史本身是一个西方学科 ; 喜欢也好，不喜 欢也罢，将艺术史加于非西方的艺术之上的做法构成了艺术史的深 层结构的一部分。他指出，任何试图将中国画的历史发展以西方模 型（巴洛克卷轴画?）为参照来进行测绘和描画的尝试，都是可笑 而无意义的，我们能指望从中得到什么有价值的认识呢?这样的做 法无异于将巧克力蛋糕和炖牛肉作比较, 从中得出的关于二者共通 之处的认识（比如，都能提供卡路里)，能有什么价值呢? 但是到了 二十世纪，情况变得不同了，中国和美国开始了密切的接触，彼此 都是对方需要应对的挑战（东方和西方之间，在上千年的时间里确 实都存在着双向的接触，但是蜿蜒小道和通鹳大道是不同的）。技 术进步使东西方间的交往在性质上和范围上都有了巨大而惊人的改 变。

埃尔金斯将艺术史视作一个受到探求知识的智性活动的塑造和 影响的学科, 但未能对社会条件对艺术史学科的塑造和影响加以考 量。也就是说, 艺术史作为学科是处在其他诸多学科的场域内的, 而对此他却没有加以考量。是有一种艺术史，还是有多种艺术史？ 他问道。如果我们知晓学科的发展史的话, 我们就可以回答他这个 提问。一个学科是从事这一学科的人构成的社群, 而在某一时刻, 当这一社群生长得足够大的时候，它就会分裂。

一个社群的体量越大，性质越复杂，它的分裂就会来得越快 ; 而性质的复杂程度, 则是看组织中规则的多寡以及组织内部结构 (思 想差异或权力等级）的情况。冰激凌爱好者群体的规模是非常庞大 的，但同时是非常稳定的 ; 然而将冰激凌视为构成了他们宗教意识 形态的一部分的冰激凌爱好者群体 (我想世界上一定有这样的群体) 则一定会分裂为自以为是、各自为政的多个派系，尽管当其分裂之 时，它的规模甚至可能还不及简单的冰激凌爱好者群体的百万分之 一。同理，当艺术史这一学科不断生长之时，一定会由一种艺术史 (art history) 变为多种艺术史 (art histories)。

学科是一组工具，被专业人士为了共同的目的所使用，来处理 相关材料。换句话说，尽管可以从其他方面来定义学科，但学科无 疑是一项社会事业。因此，如果你做的不是公认的艺术史，那么你 也就不是艺术史学者，你的成果也就不是艺术史。它们是别的什 
么（这是以美国研究的路数做美国艺术史研究的学者所处的尴尬境 地)。一方面，当埃尔金斯说 “中国风景画” 是西方艺术史一一不 管研究是在北京做的还是在纽约做的一之时，他是对的，正如在 中国所进行的物理学研究是西方的物理学。另一方面, 作为一个研 究美国艺术史的学者, 我还记得当我在上世纪 70 年代末开始读研 的时候，在艺术史界普遍存在的将对美国艺术的研究视为二等品的 偏见一一对美国艺术的研究不被视为 “真正的” 艺术史, 而这一偏 见今天在一些地方仍能感觉到。

但是当然，改变会发生。一两代中国艺术史学者，就中国艺术、 现代艺术或西方艺术进行研究和写作, 就会产生出他们自己的艺术 史。那一艺术史将是为了适应他们的具体情况和特定历史而进行了 相应的调整和改变的。这样的改变和终将继之而来的自然化的过 程一一视改变后的艺术史为理所当然一一并没有什么错。没有了西 红柿酱的意大利料理在今天似乎是难以想像的, 然而西红柿来自墨 西哥! 随着艺术史从业者和相关机构的增加，新的、有趣的情况会 出现, 而且会被视为不可避免的和自然而然的。如果有人不认为艺 术史会有这样的发展的话，那么未免过于妄自尊大了。

对西方艺术史作后殖民式的读解，担心其中弥漫的殖民者视角 和立场，说到底相当于否认了其他文化和民族也有其能动性，他们 可以自出心裁，有化用一切的能力。他者（the Other）固然是当 前艺术史论述（discourse）的主要编织原则，通过将他人他者化的 过程, 我们将其置于更为次要的、失去了自主的解释权的地位之上。 但过分强调和担忧这一点, 也就等于是说别人没有能力将我们视为 他者。再过五十年 (也就是经过我们学生辈那代人), 这些争论会 显得荒谬而过时，正如上世纪七十年代末人们对艺术史的学科边界 的极力捍卫, 在今天看起来也是荒谬而过时的一样。上世纪七十年 代末，我才刚刚开始读研，鉴赏家式的艺术史研究方法和图像志在 瓦解，而艺术社会史方兴未艾。

前行的路, 梅塞指点得很明白: 要具体问题具体分析, 要尊重 差异，要对差异有兴趣。埃尔金斯或者几年前像托马斯 - 达科斯塔 ·考夫曼（Thomas DaCosta Kaufman）和大卫・萨默斯（David Summers) 这类艺术史学者对于别种艺术史 (other art histories) 的 研究成果所感到的焦虑, 和一两代人之前在质疑何为现代主义的典 
范（canon）时所引发的焦虑是大有其可相比照之处的。那时，若 是有谁觉得艺术史可以有其他的叙事或者其他的典范，可以有不同 的起点和不同的终点，觉得在 1910 年前后的巴黎发生的大事既非 具有重大的决定性意义也非特别有趣的话，那么谁就会被目为旁门 左道 ; 而那些浪费他们的时间还有我们的时间去写由阿尔弗雷德 . 巴尔（Alfred Barr）和纽约现代艺术博物馆（MoMA）认定的核 心作品之外的抽象艺术的人，可以明白无误地感受到来自他人的愤 怒。但之后我们都过了这一关，除了一些死硬的十月派 ${ }^{9}$ 的形式主 义者。

埃尔金斯哀叹大学在传播过于清一色的艺术史，他没能明白 “大 学”（university）的意义所在一一创造一个跨越国界的学术共同体 （这是早期大学的宗旨），而若是没有一个通用语言的话一一随便 什么语言都行，这样的共同体将是不可能的。起初这一通用语言是 拉丁语，在大约 500 年的时间里，它作为全欧洲大学学者沟通交流 的媒介一一当然，拉丁语是已经死去的帝国所强加的遗产。阿德里 安·派珀（Adrian Piper）认为，后现代主义的一个副作用是从有 色妇女那里拿走了理性这一启蒙运动的工具，这些女人固然借由后 现代而挣得了更为显耀的地位，但在理性的修为上，却不得不有所 欠缺了。我们也许还可以附带说说大学和博物馆，两者都常被视为 欧洲将一己的标准强加于人的工具，但是在传布理性（至少是相当 程度的理性）上，它们也发挥了重要的作用。同样值得指出的是， 市场不是理性的，如果说理性有敌人，那就是市场了。然而可以跨 越国界进行沟通的工具总是有用的。

埃尔金斯提醒我们，教授艺术史的方式没有太大的改变，构成 艺术市场和艺术典范（canon）的艺术家阵容也没有太大改变。当 然例外也是有的，艺术领域的例外和生活其他领域的例外的出现机 制没什么不同：在每个艺术分支中，每个国家都能有一个艺术家成 为例外，或者最多有两三个。这一状况的改变，只有在同心协力的 情况下，凭借长期而自觉的努力才有可能实现。

目前，中国的情况是非常特殊的：中国当代艺术家在西方写作

9 原文为 a few die-hard October formalists, 仿语丝派和现代评论派等团 体的得名译作十月派。 
的艺术概览中得到了相当篇幅的讨论, 特别是和其他主要在西方开 展他们的事业的非西方艺术家（通常是非洲艺术家）相较，主要生 活和工作在中国的艺术家尤其受到瞩目。中国艺术家在西方著作中 得到的这一特殊待遇是很有意思的, 特别是如果我们将中国的当代 艺术放置在中国自身的历史中加以考察的话，会发现中国艺术的发 展有着其内在的逻辑; 而绝大多数时候, 国际艺术市场在对待欧美 之外的艺术家时, 都是将他们的作品简单视为西方当代艺术的延展。 在大多数艺术概览里和大多数西方收藏中, 一直都见不到这些非欧 美艺术家的身影, 直到作者们在以纽约为中心, 对 1960 年代起勃 兴的诸多艺术运动和艺术流派大讲特讲了一番之后，才让其他艺术 家出场。我们来到 1980 年代, 我们准备好承认世界的其他部分了, 而冷战的结束也刚好是在那个时候。

但中国是不同的。中国在二十世纪二三十年代就有现代艺术了。 它还有一个广泛存在的、由国家对艺术进行赞助的传统可资利用, 此外这一传统还可以为我们对当下状况的理解提供一个参照。在中 国，没有一个村子是没有公共艺术的（鼓舞人心的工人，异想天开 的神兽, 旁边配以励志的标语)。在中国, 艺术和艺术创作是建立 在伟大而悠久的传统之上的。但中国和它自身历史的关系, 以及它 和世界其他地区的历史的关系，都是极为割裂的，而这给任何形式 的比较增添了困难和麻烦。与世界相隔离的共产主义时期，红卫兵 运动造成的文化破坏, 所有这些都仍在影响今日的艺术创作。与此 同时, 中国有重要的、由国家资助的学院在教授传统的艺术和书法, 此外中国还有有效运转着的市场、学校、批评家和其他所有艺术世 界的标配。

所有这些不外是说，尽管美国现代主义和中国现代主义在很多方面 都无法加以比较, 但是从中国和美国的视角出发, 来考察一下全球 现代主义的一个方面，对于常见的（到如今已经几乎成为了典范式 的）、为后殖民主义所主导的全球现代主义叙事而言，是有益的。

作为开始的，是一组包括这篇导言在内的文章，它们阐明了会 议的前提和基础, 对整个项目更宏大的背景进行了介绍。张坚在导 言中对各与会者的贡献给出了堪称典范式的总结，对于这篇导言， 在这里没有重复的必要。本书所收论文显示了中美两国学者方法论 
的差异和兴趣的不同，以及一些更为基本的相似之处: 平行和互补。 所有美国方面的学者都认为，我们需要参照具体的情境、时间 和地点来重新检讨关于现代主义艺术的诸多假定。所有人的目标都 是打破典范（canon）、术语和流派这些艺术史习用的分类所产生的 窒息效应。当我们使用诸如 “都市” 或 “抽象表现主义” 这类术语 时，体系化的知识就会进一步增加 ; 但所有美国学者都试图多少复 原在最初的时刻，艺术是如何被接纳的，而非增加已经体系化的知 识。美国学者所从事的是一项复原工程，希望恢复被边缘化的声音 (这一点在德赛姆维拉勒的那章尤其明显)。

许多中国学者的论文也在从事相似的复原工作（比如刘晨和 李超的章节)，但更多人的关注点则是放在了批判性地检视现代 主义在中国是被如何接受的，以及在这一接受过程中，现代主义 与中国的文化传统和艺术传统间的张力。然而在这里，术语的意 涵和有效性再次受到质疑，比如 “观念的” (conceptual)、“表演” （performance）, 甚至 “消费主义”（consumerism）就分别在朱青生、 王端廷和寇淮禹的章节中被加以批评或检讨。而丁宁和吕澎在他们 的分析中，对于像安迪·沃霍尔或安德鲁·怀斯这样的艺术家的误读 (至少从美国视角来看是误读), 也有价值一一它们构成了这一批 评和检讨的另一面。此外, 美国学者对于具体的、特殊的问题的关注, 和中国学者喜欢探讨远为宏大的问题、探讨一般情形构成了鲜明的 对比，比如他们会论述现代主义的性质或是观念艺术本身。我们被 劝导要具有某种的小心和谨慎, 而我们的中国同仁尚未被如此规劝。

导论章节中的另两篇文章尤其可以视作观察中美间差异的例子。 瑞娃·沃尔夫和寇淮禹间通过电邮往来所作的探讨，生动地展现了 翻译的问题。寇淮禹为解决翻译安迪 - 沃霍尔的《波普主义》时遇 到的问题联系到沃尔夫，他们的探讨涉及翻译中常会碰到的如何处 理习语和比喻的问题，但更具启发意义的，是他们在会议期间的现 场问答环节所作的对话。寇淮禹提醒沃尔夫他对于何为“babushka” （一种为东欧和俄罗斯的妇人所惯常佩戴的头巾）已经有所了解了, 因为他在谷歌上检索过了，而沃尔夫觉得他需要对相关情境有更为 全面的了解才能完全明白 “babushkaville” 这个词的分量。对他们 二人来说，特定的情境（context）是重要的，而恢复相关的情境 塑造了翻译。另一方面，沈语冰的章节提醒我们中国学界有着非常 
不同的情况, 对于视觉形式进行超历史（transhistorical）的讨论 仍然是有真正的意义和分量的，而且为所有关于现代主义的讨论提 供了一个必需的基础。

在本书的中文版中，文章的顺序是依照会议期间的发言顺序来 排列的。在本册中，文章则按照涉及的历史时期来排。第一部分以 泽瑞尔探讨城市的文章开篇, 此部分的论文主要探讨的是现代主义 最初在中国和美国的艺术和建筑中的影响。第二部分考察了之后的 几十年, 涉及大萧条和二战一一这一时期中国遭受的创伤远比美国 为甚，而也就由此导向了 1950 年代两国非常不同的情况，正像张 坚在他的导言中提及的那样。

第三部分集中关注 1960 年代和 1970 年代早期，当代艺术中的 大多数似乎都可溯源自这一时期。对研究美国艺术的学者来说, 这 还是一个区分了现代主义和后现代主义的时期。而由于 “现代主义” 是会议的最为主要的议题, 所以毫不奇怪的是, 我从美国方面选取 的参会学者的研究上限是 1970 年。与此有别的是, 张坚选取的学 者中, 研究现代艺术的和研究当代一一或者在我们看来是 “后现 代”一一艺术的一样多。所以本书最后的部分, 从 1980 年代至今 的章节, 全部都是中国学者的文章。这一情况既反映了中国艺术世 界的特殊历史一一对于西方艺术的大力关注是伴随着 1980 年代中 国的对外开放而来的，也反映了中国对于什么是 “现代” 和 “现代 主义” 的不同的理解。

因而本书以可见的形式反映了中美两国对现代主义和现代 （modernity）的经历和体验，是具有互补的性质的; 同时，本书 也反映了两国的艺术史在方法论、历史编纂学和学术体制方面的差 异。然而正像前文所指出的，这一差异将在接下来的几十年间发生 巨大的改变。以当下而论, 本书是对一个特定时刻的知识交流的记 录; 放眼未来，则本书同时也为即将发生的巨大改变做出了重大贡 献。

( 寇淮禹译) 


\section{介绍}

\section{多元的现代主义}

\section{“探索交互视野下的中美现代艺术” 的实验 张坚}

2016 年 3 月 24-26日，“艺术 : 生活或观念一交互视野下中美现 代艺术国际学术研讨会” 在杭州中国美术学院南山校区举行。参加 会议的 II 位中方学者分别是来自北京大学的朱青生教授、丁宁教 授，浙江大学的沈语冰教授，清华大学的章锐教授、刘晨教授，上 海大学的李超教授，中央美术学院的邵亦杨教授和中国美术学院 的张坚教授、吕澎教授，以及独立学者寇淮禹先生。IO 位美方学 者是来自加州大学圣塔芭芭拉分校的布鲁斯 · 罗伯森教授（Bruce Robertson）、石慢教授，伯克利分校的朱丽·布莱恩·威尔逊教 授 (Julia Bryan-Wilson)，河滨分校的詹森·维姆斯教授（Jason Weems)，密歇根大学瑞贝卡·泽瑞尔教授（Rebecca Zurier），纽 约州立大学列娃 · 沃尔夫教授 (Reva Wolf)，凯斯西储大学艾伦· 兰道教授（Ellen Landau），以及加州大学伯克利分校艺术博物馆 与太平洋电影档案馆馆长劳伦斯 - 林德博士（Lawrence Rinder）。 同时，会议还设立了一个青年学者论坛，来自中国美术学院、北京 大学、浙江大学、加州大学圣塔芭芭拉分校、纽约大学等 5 位青年 学者和博士候选人分别做了专题发言 ${ }^{1}$ 。石慢、朱青生、丁宁以及布 鲁斯·罗伯森和张坚教授分别担任单元主持和评议人。这次会议是

1 三位中方青年学者分别是来自北京大学博士陈瑶, 她的报告《城市景观: 印象主义和垃圾箱画派绘画中的纽约形象》, 中国美术学院博士研究生 陆豪，他的报告是《进化还是革命?沃尔特 - 科内尔和民粹主义》，浙江 大学博士研究生毛秋月，她的报告是《纽约画派与意识形态》; 美方青 年学者来自加州大学圣塔芭芭拉分校的博士研究生 J.V. Decemvirale, 他的报告是 “Because Night Time is the Right Time: The Black Arts Council's Foundational Action as an Intermedial Space of Popular Resistance”，纽约大学博士研究生 Marci Kwon 的报告是 “Vernacular Modernism: Joseph Cornell and the Culture of Populism”. 
2013 年 IO 月启动的 “探索交互视野下的中美现代艺术” 项目的第 三阶段, 前两个阶段分别是 2014 年 IO 月在中国美术学院举行的 “中 美现代主义艺术青年学者研讨班” 和 2015 年 2 月在加州大学圣塔 芭芭拉分校举行的以中国现当代历史画为主题的研讨班, 该项目获 得 “泰拉美国艺术基金会” (Terra Foundation for American Art) 资助, 由中国美术学院和加州大学圣塔芭芭拉分校合作主办, 圣塔 芭芭拉分校艺术博物馆执行馆长、艺术史系教授布鲁斯. 罗伯森和 中国美术学院图书馆馆长、艺术人文学院教授、博士生导师张坚共 同组织策划（图 I）。

改革开放以来，现当代艺术在中国重新崛起，并逐渐发展壮大 成为一支在国际上具有重要艺术、学术和市场影响力的创作力量, 出现了一批具有国际知名度的现当代艺术家, 在这个过程中, 美国 对于中国现当代艺术的发展产生了重要影响, 尽管对这种影响的评 估在国内学界存在着某些争议。事实上, 中国和美国, 都属于现代 艺术的后来者, 在各自国家现代艺术的早期阶段, 都经历了一个接 受和回应来自欧洲大陆前卫艺术影响, 并确立自身的文化身份的过 程, 只是在上个世纪 40-50 年代后, 两个国家的现代艺术才走上 不同道路。在中国, 社会主义现实主义成为主导艺术语言, 而在美 国, 抽象表现主义和波普艺术盛行一时。上个世纪 70 年代晚期和 80 年代初期在中国兴起的思想解放和新潮美术运动, 使得中断的 现代主义线索得以重新接续, 并发展出较之半个世纪前早期现代美 术更为复杂的创作观念和表达形态，期间，中美两国现当代艺术间 的丰富复杂的互动关系也成为艺术全球化语境下的一个重要话题。

事实上，近 6 年来，中美艺术史学者业已开展了一系列艺术史 的学术研究和教学交流活动, 包括 2010 年 7 月由亨利 - 鲁斯基金 会 (Henry Luce Foundation) 资助, 香港大学承办的 “第一届 西方艺术与艺术史高级工作坊”，20II 年 5 月和 2012 年 7 月分别 在中国美术学院和纽约亚洲文化协会举办第二、第三届西方艺术 与艺术史高级工作坊，以及 2013 - 2015 年由盖蒂基金会 (Getty Foundation）支持, 哈佛大学意大利文艺复兴研究中心举办的连续 三届的 “意大利文艺复兴艺术” 研讨班。受邀主持这些项目活动的 学者多为欧美著名大学或艺术机构的现职教授, 以短期系列讲座、 研讨班及博物馆、美术馆和历史文化遗址实地考察等方式开展教学 
和研讨活动，过程中，他们也尝试让讲授主题尽可能切入国内学界 语境，中方学者以英语为工作语言，与欧美学者面对面讨论问题， 增强了这类项目活动对参与双方的实际收益。

“探索交互视野下的中美现代艺术” 项目的设想是在 2012 年 7 月 “第三届西方艺术与艺术史工作坊 (纽约 )” 期间酝酿的 ; 在泰 拉基金会学术与展览项目部主任凯瑞（Dr. Carrie Hasslet）博士 的大力促成下，基金会于 2013 年下半年批准该项目。除布鲁斯 · 罗伯森和我本人外，圣塔芭芭拉分校中国美术史教授石慢（Peter Sturman）和洛杉矶分校李慧漱教授也参与了这个项目一些相关工 作。

作为项目主题的 “现代主义” 和 “交互视野” 的界定，首先， 我们认为，“现代主义” 是一个涵盖广泛、指向复杂的概念，其基 本意义应理解为社会现代化进进程导致的人的心理、思想和精神层 面诸种变化，以及由这些变化引发的多样艺术与文化表达形态，也 包括对这些变化的反思成果。现代艺术, 无论在欧美国家还是中国, 都不是单纯美学或形式变革，而更多地与一种对艺术的新认识，以 及艺术介入乃至改造生活行动联系在一起。现代主义因此也被视为 一种文化，以及与这种文化相关的观念、信仰、价值和感知方式构 架。现代主义部分源于对现代化反动, 特别是对理性和效率的反动, 但这种反动也包含不确定性，现代主义者赞赏速度、动力和各类技 术进步，又反对非人性的、机械的或数字化的冷漠。在欧洲，现代 艺术往往表现为一种对品味和格调的追求，以此来保持艺术的内在 个体性，反抗社会的既成体制，而在美国，现代主义更多地指向一 种艺术在晚期资本主义时代创造自身的现实性的策略构架。至于中 国情况，要更为复杂，多重的时间、地域、文化、历史和政治的关 涉，使得现代主义充满由各种相互冲突的情感、思想、意识形态和 价值观引发的张力, 由此，我们并不认为有一种普遍的现代主义 存在，不同文化语境下，现代主义有着多样表现形态和发展道途， 现代主义是一个复数概念，这个复数的现代主义只有在 “交互的” (complementary) 视野下才可能得到呈现。

“Complementary” 英文中的原意指 “互补” “相互补充”，把这 个词译成 “交互”, 是因为只有在交互视野下，复数的现代主义才 能形成互补关系，才能赋予我们更为完整的现代主义的答案。事实 
上，在中美双方对于对方的现代艺术的叙述中，存在着各种遮蔽和 误区，也常有那种为论证自己的既定观点，而人为地把对象设置为 自己的对立面做法，这种情况特别反映在艺术与政治的关系上面。

\section{美国艺术的现代与后现代 : 杭州秋季研讨班}

2014 年 IO 月 28 日至 II 月 4 日，“探索交互视野的历史，中美现代 主义艺术青年学者研讨班” 在中国美术学院南山校区图书馆举行。 参加研讨班的 22 位青年学者分别来自北京大学、南京大学、浙江 大学、广州美术学院、中国美术学院、中央美术学院、清华大学美 术学院、温州大学、安顺学院等国内高校 ${ }^{2}$ (图 2)。跟文金书经研讨 班由罗伯特森教授和石慢教授主持, 系列讲座主题包括 “美国现代 主义的历史” “美国艺术及其体制背景” “20 世纪 60 年代至今的美 国艺术” 以及 “现代主义与中国海外移民现代艺术家”等。

对于 20 世纪美国现当代艺术与艺术史, 罗伯森认为, 首先需要 从方法论上进行反思, 关注当下艺术史家是如何认识和理解这段历 史的。作为美国艺术研究的三个主要学科来源 : 艺术史、美国研究 和批判理论, 前两者是在 1945 年前得到广泛运用, 而对于之后的 艺术，传统风格分析和图像学，以及一般意义上的文化史视角，已 不再受到青睐, 取而代之的是批判理论, 诸如法国的拉康、德里 达、波德里亚等本质上属于马克思主义和心理分析的理论; 福柯的 权力关系分析，女性主义、酷儿理论，后殖民理论等。这些思想和 学说的流行与 $60 、 70$ 年代美国民权运动、越战危机等政治和文化 事件联系在一起, 改变了传统艺术史的叙事方式, 即那种把美国艺 术从欧洲独立出来，论证美国文化统一性和独特性的做法，其间， 也牵涉到所谓 “欧洲主义者” 和 “美国主义者” 的文化和政治思 想态度差别。按照罗伯特森的说法: “就方法论差异而言, 艺术史 中的 “美国主义者”（Americanist）强调的是情境，“欧洲主义者”

2 参加研讨班的青年学者分别是北京大学陈瑶、初金铭、冯晗、万永婷, 浙江大学蒋苇、金影村、毛秋月、吴毅强，中央美术学院姜宛君，南京 大学温婷, 清华大学美术学院徐达艳, 广州美术学院廖呢喃, 温州大学 张晓剑, 安顺学院黄斌, 中国美术学院洪潇婷、李浪浪、陆豪、谭贞寅、 顾景行、季方、张帆影、吴雪婧。 
（Europeanist）注重形式和品质。美国主义者认为，欧洲主义者 并不理解美国的核心问题，即民权问题，诸如种族平等、性别权力 等，这些都是一种下意识的政治态度。”

“美国主义者” 的这种对社会与文化情境的关注，是与艺术在美 国社会生活中的地位及其变化相关的。罗伯特森指出, 在这一点上, 中美之间存在很大不同，中国有着悠久的历史文化传统，艺术的文 化地位明确; 而美国是一个年轻国家，艺术，特别是美国自身艺 术, 一直处于边缘状态, 学术形象不清晰, 在大学系统中, 无法与 传统的欧洲艺术相提并论。早期美国艺术研究，与美国社会和文化 史研究联系在一起，这也成为美国艺术史的学术史的一个特点。他 的系列讲座中，美国艺术的社会支持系统是一项重要内容，包括联 邦和地方政府、基金会、博物馆、大学、展览、教育和学术研究机 构, 以及艺术经纪人、画廊等市场要素等; 在论及 20 世纪中期以来, 美国艺术的重大变化时，他强调要联系 30-40 年代经济大萧条后, 美国从生产型向消费型社会转换的背景。他引用 1944 年美国社会 学家利奥·洛文塔（Leo Lowenthal）观点，大萧条前，美国人看 待个人成功的态度普遍与生产及生产者的道德相关, 在文学作品中, 都是些勤劳致富的模范 ; 之后，则是转向了消费和消费者概念，对 于消费偶像, 重点不再是他们如何走向成功, 而是成功后做了什么, 如何消费这种成功，成功带给他们的私生活的效应是什么，他们的 消费模式如何等（图 3)。

上个世纪 60 年代前后，美国艺术家开始更多地寻求在商业、政 治和文化活动中来实现其艺术影响力, 诸如 “身份与身体” (identity and the body)、“媒介地位” (status of the medium)、消费模式以 及当代艺术市场等成了热点话题。在晚期资本主义时代，媒介决定 了艺术家类型，而诸如 “挪用”（appropriation）之类的表达方式， 成了当代艺术家的重要创作手段，他们创造性地让大众媒介形象重 获 “文化相关性”（referenced again），同时，又实现了对体制和权 力的批判。杰夫 ·昆斯 (Jeff Koons) 的目标是控制市场，而不是 反对市场。此外，他也提到，60 年代以后，美国西海岸，特别是 洛杉矶地区的当代艺术变得越来越重要。

石慢讲座以 20 世纪 50 到 80 年代寓居中国香港、中国台湾及欧 美国家的中国艺术家曾佑和、刘国松、楚戈、王无邪等为主线，这 
些移民艺术家表现出对欧美现当代艺术潮流的持续回应，同时又保 持 “中国身份”。王无邪山水意象来自传统，但没有邀请观者走进 他的画中，其内部是一个有机、自足的整体空间，与西方绘画更接 近。石慢也谈到当下美国艺术史界有关中国现当代艺术的一些热点 话题, 诸如如何运用现代媒介让自身的艺术传统视觉化; 如何在传 统与外来影响结合中，发现新的表现形式与概念等。

中美现代美术的话题，自然包含多重视角，既涉及到如何看待 自己，也与如何看待对方有关，还有诸如如何理解对方对于自己传 统的看法, 如何评价自己艺术中的他者的影响等问题，这个过程中， “误读” (misreading) 或 “重读” (rereading) 是持续发生的，而 无论是误读还是重读, 都未尝不是一种激发创作新思路的方式。两 位教授的演讲和研讨班成员间的交流切磋，一方面强化了大家对美 国现当代艺术的多元表达形态背后的社会政治、经济和文化情境的 了解; 另一方面, 也促使大家反思中国现当代艺术的历史场域, 它 不应简单地理解为是一种对来自西方影响的被动接受和移植, 西方 刺激引发的语境内省, 可以激发艺术创新和发展的成果。石慢将中 国现当代绘画中的西方影响称为 “中国艺术的漂泊”之旅，而在我 看来, 这种 “漂泊” 同时也是一种自觉的探索, 一种在外部刺激下 的传统内在力量的迸发。而美国现当代艺术也有相似情况, 无论如 何, 中美双方都不应忽略一种源于自身传统的身份认同的诉求, 这 种诉求也只有在现当代美术的全球视域之下，才会是切实的，而非 虚妄的。

\section{历史画中的艺术世界 : 圣塔芭芭拉的春季研讨班}

2015 年 2 月 9 日一 13 日, 我赴加州大学圣塔芭芭拉分校主持一个 题为 “历史瞬间与永恒: 当代中国历史画中的现代性问题” (Historical Moment and Its Eternity: A Problem of Modernity in the History Painting of Contemporary China）的青年学者研讨班，20 位来自 芭芭拉分校艺术史系的博士研究生、青年学者和部分教师参加了 这个研讨班。期间, 我做了 “塑造人民形象与认识自我：60 年代 的蔡亮和其他历史画家” (Modeling People and Identifying Self in History Painting: Cai Liang and Others in the Early I960s) 和 “抽 象或视觉逼真：1980 年代后历史画创作的新趋向” (Abstracting or 
Optical Fidelity: New Trends of History Painting after the I980s) 两 个主题演讲（见论文集附录）（图 4）。

选择社会主义现实主义历史画作为研讨班课程的内容, 主要基 于视觉文化的视野。事实上，在现实主义艺术方面，中美两国是存 在共同点的。约翰 - 戴维斯（John Davis）曾用 “内容艺术”（art of content）的说法，来指称二战前美国垃圾箱画派及政治卡通画 家和政府资助壁画家的社会现实主义作品，只不过，在美国，这类 作品被后来崛起的抽象表现主义遮蔽 ${ }^{3}$; 而在中国，情况正好相反， 50 年代后，社会主义现实主义遮蔽了现代派艺术。中美间的这种 艺术语境的差别和错位非常有趣，在我看来，美方学者可以透过这 样一种有趣的错位现象, 更切实地认识和理解新中国成立后, 艺术 创作与政治、文化及艺术家个人命运的复杂关系。

我把上个世纪 $50 、 60$ 年代的一位著名历史画家蔡亮作为案例, 他早年就读于中央美术学院, 素描功底深受徐悲鸿青睐, 毕业时, 因牵扯到文艺小团体 “二流堂” 的活动而被下放到陕西省，在那 里工作了 20 多年。他的油画名作《延安火炬》曾作为新中国历史 画代表作之一，参加 1998 年由中国国家文物局和纽约古根海姆艺 术博物馆联合举办的 《20 世纪中国艺术中的传统和现代性 : 世纪 危机》(A Century in Crisis: Modernity and Tradition in the Art of Twentieth-Century China) 展览。

蔡亮画作，虽以政治、军事为题材，属于政府定件，承担了宣 传功能，但同时也是一个时代生活和理想的记录和表达。画作中的 人物形象源于他在陕北农村交往和熟悉的那些身处社会底层的农 民, 寄予了他个人对这些农民的深切理解和同情 ${ }^{4}$ 。他笔下的农民形 象，那种乐观和吃苦耐劳精神以及对于土地的信赖与承诺，那种坚 韧、顽强的生命力以及略带狡黠的智慧，让我想起美国作家赛珍珠 (PearlS.Buck) 在《大地》（The Good Earth）中描绘的活灵活现

3 John Davis, "Current Scholarship on the Art of the United States", Art Bulletin (2003).

4 参见作者论文《古典写实中的写意和表现精神: 蔡亮历史画的一点认识》 《历史与追怀 : 蔡亮艺术文献》《历史与追怀 : 蔡亮艺术回顾》, 吉林美 术出版社, 2010 年 9 月。 
的人物。当然, 蔡亮农民形象显然要比赛珍珠的更加正面和理想化 一些。我尝试的是一种结合艺术家传记资料、他的素描习作和作品 的创作语境、相关地域风俗和人情等多维视角, 来解读和讲述他的 历史画名作背后的故事。比如, 《延安火炬》的主题, 虽是 1945 年 延安地区庆祝抗战胜利游行, 但根据画家本人回忆, 构思这幅画时, 引用的却是大跃进热火朝天的大炼钢铁运动的意境 ${ }^{5}$; 同时, 我也提 供了一些上个世纪 $50 、 60$ 年代延安地区的黑白照片, 包括蔡亮本 人拍摄的照片, 来说明这幅画作包含的多重现实, 美方学者在具体 可感的社会文化条件下来理解它的人文内涵，了解这个时期中国社 会的特殊氛围, 而不是将画作与社会政治意识形态做简单并列和等 同。

对改革开放后的历史画，我选择 2009 年国家重大历史题材美术 创作工程为案例。相对于 50、60 年代的历史画，这个时期的创作 多借鉴现代艺术的形式构成和拼贴手法, 整合历史图像与符号资源; 有的则是用大尺幅和全景包围式构图, 以逼真的照相写实手法刻画 和描摹细节, 创造作品的临场感和视觉震撼力, 反映了近半个世纪 以来视觉艺术中的观看模式的变化。传统历史画的那种注重人物性 格表现及情感和精神统一性的方式, 被媒体与视觉文化时代的景观 营造或抽象形式感的追求取代。我列举了一些事例来说明这种变 化。比如在以《地道战》为主题的画作中, 50 年代有罗工柳的版本, 一个在狭小马厩内展开的瞬间场景, 相对集中统一的人物组合和情 态刻画，让观者与画中人物休戚与共 ; 2009 年的同题材作品，展 现的是一个宽银幕的场景, 一个地道战的视觉奇观, 这个奇观期许 的是一种在心理和情感上都与事件保持距离的凝视。

参加研讨班的美方学者表现出对这些历史画作的浓厚兴趣, 他 们从各自角度提出一些有趣问题。（图 5) 有学者注意到, 蔡亮前后 两个版本《延安火炬》 ${ }^{6}$ 中, 都有 “抱孩子妇女” 形象, 后一个版本中,

5 蔡亮: 《“延安火炬” 创作琐记》《《革命历史画创作经验谈》, 人民美术 出版社，1963。他当时在陕南参加炼铁，留下一张记忆画，画的是老乡 到山上运矿石，打着火把行进。

6 蔡亮《延安火炬》有两个版本，第 $\mathrm{I}$ 个版本创作于 1960 年，现藏于中 国国家博物馆; 另一个版本是 1972 年的变体画, 为延安革命纪念馆创作, 
她的位置从前排退到右端下方角落，他想知道，这种改变是否是定 件单位的要求，蔡亮本人反对这种位置的改变吗?罗伯森则谈到他 对形式分析的看法。他说，形式分析在当下美国大学里已不像过去 那么普遍，他在耶鲁时受过这样的训练，只是现在大家都热衷于艺 术的社会与政治语境。他觉得描述性鉴赏术语，指向微妙和复杂的 视觉感受，在谈论蔡亮的素描作品时是有效的。不过，习惯上，他 们是不把这些带有政治内容的写实绘画当成严肃艺术来看待，但他 也同意我的看法，即我们应该认真对待这些画作，毕竟它们是现实 的存在，是中国现代美术的很重要的一个方面。我是在想，他们对 中国现代美术的了解和认识，大概都与改革开放后的那些先锋派艺 术家联系在一起。我只是想要提醒他们，在中国，社会主义现实主 义艺术始终是一支主导的视觉艺术力量。当然，总体上，他们还是 认为，这样的艺术是过去式的，至于如何评估和判断政治题材的艺 术作品的艺术价值，那属于另外一个问题了。

\section{艺术 : 生活或观念, 现代主义的多元性一杭州国际学术研讨会}

“作为生活的艺术” 还是 “作为观念的艺术” 是一个关涉当下艺术 概念的界定的问题。在中国, “为生活而艺术”, 还是 “为艺术而艺术”, 是一个近似于哈姆雷特式的难题, 经常与政治立场联系在一起 ; 在 美国，像罗伯特. 亨利这样的艺术家，把艺术视为所有人的事业的， 视之为生活本身，最终指向了创造生活的理念。事实上，无论在美 国还是中国，都存在把复杂的现当代艺术现象，纳入标准化艺术史 叙事的情况，艺术史成了约定俗成的话语游戏，惯性思维和术语遮 蔽了艺术的多元性。杭州的研讨会所确定的这个主题，意在把前两 个阶段讲座和研讨涉及的诸多话题，还原到一个更为基础的观念的 层面，为中美双方学者创造一个深度交流和对话的语境。此外，中 国的与会学者大都以英语发表演讲，也增强了会议沟通效果。

对于研讨会的主旨和学术理路，罗伯森和张坚分别在《反思 60 年代，艺术史造就的历史》《现代美术的再发现 : 溯源与借鉴一从 吴冠中到 “新潮美术”》的主题报告中, 从不同角度做了说明 (图 6)。 
罗伯森以艺术史术语及其关涉的创作现象为着眼点, 致力于重构罗 伯特·莫里斯（Robert Morris） I96I-I962 年的极少主义作品《柱 子》(Column) 的原初语境 ${ }^{7}$ 。在他看来, 这件作品有点像杜尚 “泉”, 曾作为现成品出现在不同环境中。罗萨林德・克劳斯对它的阐释, 使之成了艺术史的一个标准件，此后，它的最初语境就被忘却，人 们不断地根据照片谈论它，早期极少主义雕塑的达达般的幽默感被 抽干。他想要说明的是, 艺术史家所应做的不是去证明莫里斯的这 件作品是极少主义标准件, 而是要解构对它的习惯认知, 重新创造 这件作品成为极少主义之前的创作和接受语境。

当下中国的现代艺术史，也存在话语混杂所致的对历史本相的 遮蔽。我的报告尝试重述改革开放之初现代美术再发现的语境，特 别是艺术家的作用。吴冠中倡导形式美, 他对那些几乎被完全遗忘 的中国早期现代美术家的重新发掘，对那些他熟悉的西方现代美术 名家名作的鉴赏和评析，促进国内学界和体制对现代艺术的正面接 纳，创构了形式主义的话语。而新潮美术运动中的艺术家对西方现 代艺术诸多风格流派的横向移植, 表现出超越形式和美学, 注重语 境和观念的倾向, 一些旅美艺术家对西方现代艺术认识更是与他 们个人经历的文化与历史 “错位” 体验联系在一起, 成为他们在 艺术全球化语境下在国际上崭露头角的创作资源，这种由 “形式” (formalism) 到 “语境” (contextualism) 的转换, 应是认识新时 期中国现代艺术的学术史的一条重要思路（图 7)。

中美双方学者对各自国家的现代艺术有着不同的叙史角度, 美 国学者报告中, 现当代艺术更多地表现出一种多面性, 远非我们通 常了解的标准化的从军械库展、抽象表现主义到波普艺术的历史。 密歇根大学的瑞贝卡. 泽瑞尔以 $1890-1940$ 年期间的纽约为蓝本, 指出这个时期艺术品中的纽约形象并非是那种普泛化的大都市的体

7 这件作品最初并非是一件雕塑, 而是当时一位舞蹈家雷纳（Yvonne Rainer）演出时的道具，由雕塑家叙格曼（George Sugarman）制作, 涂成浅黄色，这件舞蹈道具，后来被挪用到莫里斯的演示艺术中，他进 入到柱子内部，以身体而把这个道具转换为一个活动雕塑，表达身体的 在场性。 
验的表达, 而是与特定的地域意识纠缠在一起 ${ }^{8}$ 。如果说存在某种都 市生活一般条件的话, 那也需要一个更为复杂的 “地域性” (locality) 的在场作为范型，地域性是人在都市中活动的方式，是基于阶级、 种族和代际等因素形成的，它是现代艺术的都市体验的重要组成部 分。

类似这样对现代生活的矛盾性的认识也反映在加州大学伯克利 分校艺术博物馆馆长林德的报告 ${ }^{9}$ 中。他以去年在明尼苏达沃克艺 术中心（Walker Art Centre）的一个展览为论题，把嬉皮士和现 代主义两种对立元素放在一起讨论。他提出了威廉 - 莫里斯时期的 工艺美术运动、包豪斯和美国黑山学院之间的历史线索，认为早期 包豪斯，特别是伊顿影响下的包豪斯更像嬉皮士团体，神秘象征主 义、宗教热情，以及浪漫的向后看风格，成了黑山学院的范型，黑 山学院又对嬉皮士运动产生影响。在他看来，美国现代主义包罗万 象，充满内在矛盾，其中也包含嬉皮士成分，比如对新技术的怀疑、 反抗固化的社会阶层、对思想的内在机制的探索，回归自然和简朴 生活以及艺术融入日常生活的实践等。为此，他特别提到这个时期 的一位反文化人物布兰德（Stewart Brand）与计算机科学家合作， 参与创办第一个开放的线上共同体 “全球电子连接” (The Well), 并出版《全球目录》(The Whole Earth Catalog), 预示了后来搜索 引擎和社交网络，是新技术和嬉皮士文化结合产生的硕果。

加州大学河滨分校的维姆斯的论题是格兰特 - 沃德 (Grant Wood）农村主题画作中的现代体验 ${ }^{10}$ 。他发现, 沃德画作中的俯瞰 取景方式，与美国政府的农业土地调查联系在一起，当时采用航空 摄影技术，用网格划分农田，农民也被鼓励从俯视而非水平视角 观看自己的土地，把它当作生产空间，而不是田园牧歌的文化风 景, 这改变了农村的视觉体验条件。他认为, 沃德“空中俯瞰主义” （aerialism）既是航空技术成果，也是美国农村现代化的视觉和观

8 Rebecca Zurier, "Whose Metropolis, Whose Mental Life? Space and the Local in Urban Images".

9 Lawrence Rinder, "Hippie Modernism”.

10 Jason Weems, “Picturing the Good Earth: Modernism’s Rural Roots in China and the United States". 
念框架。空中俯视所致的陌生化, 在他的作品中也隐喻了一种现代 化的危险。被简化为抽象起伏如枕头状的农田, 发表在《生活》杂 志上之后，成了美国农村现代化体验的流行图像，那种观者和土地 的距离感, 既是身体的, 也是心理的, 沃德的这类画作所要求的凝 视是非人性化的，由此，他把过去和现在艺术地结合在了一起。

在以媒介为主导的美国现代艺术史的话语系统中，尼维尔森术 与经典的抽象雕塑家, 不过, 加州大学伯克利分校的朱丽·布莱恩 - 威尔逊看来, 这位雕塑家是在对这种媒介的主导理论提出挑战 ${ }^{11}$ 。 实际上，这位艺术家在创作中力图让自己从纯粹抽象中脱离出来, 转而追求一种包含女性社会意识的 “身体形式主义” (embodied formalism)。她的 “梦想之屋” (Dream House， 1972）使用各种 现成的建筑构件，诸如檐口、床柱、门把手，栏杆，插销和纺锤等 元素，重新构架空间，这个空间，包括它的单色调，都不能仅从形 式层面理解，而需要辨析其中的性别、阶级、种族意识。

凯斯西储大学艾伦 - 兰道是一位资深抽象表现主义学者，她以 I942 年 IO 月古根海姆艺术博物馆的 “本世纪艺术展” 为案例, 对 二战期间，佩吉 . 古根海姆与三位抽象表现主义艺术家，也被称为 “战争之子” 的马瑟韦尔、波洛克和巴泽特斯（William Baziotes） 的复杂关系进行深度解读 ${ }^{12}$ 。她指出, “本世纪艺术展” 意在建构一个 “艺术创新” 实验室，为躲避纳粹而移居美国的欧洲超现实主义和 抽象艺术家提供一个自由的艺术创造场所，同时，佩吉也把她资助 的三位美国艺术家纳入到这个展览系统中。兰道认为, 超现实主义 和抽象是表达战争时期人们普遍不安情绪和心理状态的方式, 不过, 三位美国艺术家拒绝欧洲具象超现实主义，而是把心理自动主义当 作纯粹形式创新工具, 力图协调抽象和具象关系, 在一种不受限制 的个体生命活力的表达过程中，满足自身的对于人性的渴望，担负 起为自由和生命而战的责任和勇气。这个时期的波洛克和马瑟韦尔 作品, 包含了战争元素, 比如构图模仿或取材于军方的照片和地图, 与戈雅、毕加索类似主题画作也存在关联。兰道的观点是, 抽象表

11 Julia Bryan-Wilson, "Louise Nevelson's Modernist Drag”.

12 Ellen Landau, “Peggy's War Babies: Motherwell, Pollock and Baziotes at 
现主义对艺术的原创性的追求，是基于二战这个危机四伏的年代， 三位艺术家信奉的是真实和自由的生命创造，尽管这样的创造充满 危险和不确定性，战后，他们的这种在战争时期形成的艺术理想成 了新的个人主义美学，也被当作不断扩张的美国力量的表征。

纽约州立大学列娃・沃尔夫和国内学者寇淮禹围绕翻译安迪・沃 霍尔《波普主义》 ${ }^{13}$ 问题, 提供了一个交互视野中美现代艺术阐释研 究的范本 ${ }^{14}$ 。显然, 两人对安迪 - 沃霍尔有着各自认识经历和语境。 对寇淮禹来讲，沃霍尔给了他解决当下生活矛盾的思路，这个矛盾 来自于他所受教育中的物质享乐的道德限制与改革开放以来兴起的 消费文化。沃霍尔让他了解如何成为消费者，如何在消费时代学会 舒适地生活，这也是一种自我解放。沃尔夫早在 1980 年就购买了 这本书，之后阅读过多次，但是，她也承认，寇淮禹的问题让她对 沃霍尔这本书的含义的多重性有了新认识。她还概括书中涉及的那 些比较难以翻译的俗语和词汇类型, 比如, 谈到 60 年代流行词汇“上 帝玩笑” (cosmic joke) 的意义。她认为，寇淮禹把这个词包含的 悲观生活态度译出来，而沃尔夫在准备会议演讲时发现，这个词在 19 世纪晚期和 20 世纪初期文学作品中就相当流行，那时，生活可 以是 “上帝玩笑”，但到了 60 年代，因为迷幻药 LSD，这个词获 得新的含义，旧用法被完全忘却。

相对于美方学者对自己国家现代美术的跨学科和多元话语的讨 论，中方学者更多表现出对全球化语境下中国现当代艺术的历史、 观念、语言形态、文化身份及社会批判触角的探索和思考。

中国现代艺术史的传统标杆人物，诸如黄宾虹、梁思成、林风眠、 吴冠中等仍是会议发言的重点，这些艺术家在回应西方影响时，表 现出对中国文化主体性的强烈意识和表达。浙江大学沈语冰《中西 现代主义汇通之路 : 塞尚与黄宾虹》的报告，是从传统内向变革角 度对比塞尚和黄宾虹的艺术创作理路和实践，以阐明中西两位现代 艺术大师创作中的某种汇通性。清华大学刘晨着眼于 “现代主义”

13 Andy Warhol, Pat Hackett, POPism: The Warhol' '6os, 初版于 1980 年, 中译本《波普主义》由河南大学出版社于 2014 年出版，寇淮禹译

14 Reva Wolf/Kou Huaiyu, "Cosmic Jokes and Tangerine Flake: Translating Andy Warhol's POPism." 
学术话语在中国建筑界的归认，即 “现代主义” 如何在中国语境下 被移栽，构成为中国建筑 “现代运动”。她的题为《巴黎美院之往， 包豪斯之后：梁思成与 “现代主义” 的镜花缘》的报告，指出梁思 成对于过度引进西方现代主义建筑的批评，而试图从中国传统建筑 样式以及意大利文艺复兴古典建筑中，开辟出另一条通向现代建筑 的道路，这种思想对当下中国建筑界反思如何借鉴现当代建筑语言 和风格也具有启示意义。上海大学李超教授《决澜社艺术研究一中 国现代主义美术作为优质的国际艺术资源》以 “决澜社” 为例，回 溯了以庞薰琹、倪贻德为代表的中国早期前卫艺术家的 “纯造型艺 术” 创作实践，即通过研究西方现代艺术，提炼创作精髓，并赋之 以本土性 ; 同时也对 “决澜社” 倡导的现代艺术赖以生存的环境, 上海都市文化进行了周详讨论。

在中国，概念艺术涉及一种不同于传统的对艺术的认识。北京 大学朱青生在《对中国的概念艺术的几点认识》中，从他同时作为 艺术家与艺术史家的创作体验和学术理路出发, 阐述他个人对概念 艺术的理解和认识。他认为, 概念艺术内涵的悖论是它题中之义: 即它的可被理解的意义与它在形式上可以指涉的意义是此消彼长的 关系, 概念艺术本身应是一个搅动人心的感觉，可以激发人的创造 性的遭遇。这种当时当刻的感受极端私人化, 具有排他性, 是每次 重返艺术创作现场都会有新的感悟的、不断衍义的艺术形态。

事实上，概念艺术内涵对艺术是作为社会和文化批判的思想形 式的指向的, 中央美术学院邵亦杨教授《想象的乌托邦 : 全球化语 境下的中国当代艺术》把当代艺术视为一种创造性地解构各种形式 的乌托邦的观念实践活动，解构方式既有艾未未的激进式的，也有 徐冰的和谐类型，解构对象包括文革时期的极左意识形态，市场经 济条件下的全球化工业生产和消费文化，各种名义的权威以及有关 中国传统文化的神话等。中国艺术研究院王端廷教授《替罪的肉身: 中国行为艺术的意义》以 80 年代以降若干以身体为媒介的行为艺 术家为样本, 分析和阐释他们的创作背景、意图、过程、批判指向 以及遭遇的种种困境，也对行为艺术后继无人的状况表达了忧郁。

上个世纪 80 年代以来，中国现当代艺术是在对西方的接受与 回应中发展起来的, 期间, 美国艺术具有重要的影响。北京大学 丁宁报告《转义和建树 : 中美艺术交互影响的若干个案》, 借用诺 
曼 - 布列逊 “转义”（tropes）概念，一种既非模仿，也非转换的状 态，来阐释中美艺术间的复杂关系。他钩沉了 20 世纪上半叶中国 艺术对美国抽象艺术家马克·托比 (Mark Tobey)，野口勇（Isamu Noguchi）和菲利普·古斯顿（Philip Guston）的影响，也谈到 $80 、 90$ 年代美国艺术家怀斯对何多苓、艾轩和王沂东的影响，认 为中美艺术间的这种交互影响是基于艺术家个人的视角，不同于一 般意义的文化和艺术史的叙事，艾轩至今仍旧认为怀斯是美国艺术 史中最伟大的艺术家。

改革开放以来美国艺术对中国的影响，中国美术学院吕澎的报告 《艺术史: 趣味、图像和身份》, 提供了两个分析案例, 一是何多 苓和怀斯，二是王广义和沃霍尔。他认为，虽然这两对艺术家表面 上有一定的相似性，但他们各自的出发点和意图存在根本差别。怀 斯《克里斯蒂娜的世界》中的草地只是何多苓早年记忆的诱因，他 是在怀斯的作品中找到了自己；王广义的波普表达也非基于沃霍尔 的对消费文化的逻辑的认识，而是包含了对中国社会的一种特殊政 治文化生态的思考，在这个意义上，很难将他说成沃霍尔在中国的 翻版。

清华大学美术学院章锐《建构 VS 解构 : 旅美中国当代艺术家 作品中的 “传统” 困局》关注的是旅美艺术家艾未未和徐冰在艺术 全球化语境下的文化错位，及其催生的一种对于传统象征物的创造 性拆解。她认为, 两位艺术家的作品取材于寻常生活之物, 却寻求 在当下中国安放悠久历史文化传统的方式，用艾未未的话说，就是 “你必须了解，才能摧毁”，这也在一定程度上反映出中国当代艺 术的某种身份迷失或分裂。

\section{几点感想}

2013 年 10 月底, 在规划这个项目的活动和内容框架时，我们希望 它不仅仅是系列讲座，还要创造交互性，这种交互性既是中美学者 之间的，也包括不同年龄层次和教育学术机构学者间的交流和对 话 ${ }^{15}$, 研讨班、学术研讨会和出版项目应尽可能把中美学者引入到一

152013 年 IO 月 26 日，本文作者与罗伯森教授在普林斯顿第一次见面，共 同讨论确定的项目实施方案。当时，作者正在普林斯顿大学艺术史与考 
个共同的学术平台上，与此同时，我们也决定以英语作为这个项目 活动的工作语言 ; 其次, 我们把在两地举办青年学者研讨班作为项 目的落脚点。我们认为, 研讨班成员应以在读研究生为主, 讲座和 研讨活动, 应致力于帮助和促进这些研究生的课题研究和学位论文 写作。事实上，在研讨班期间，主持教授与成员就课题研究、资料 收集及论文写作等方面问题展开了深入的讨论, 有的就此建立了学 术联系; 其三, 对于项目的国际研讨会, 旨在建构一个多元的现代 主义的讨论框架和语境, 而不只是把视点局限在风格、形式或图像 的影响或被影响层面, 以发掘和发现中美现代艺术叙事中的那些被 遮蔽的真实; 其四, 我们尽可能地让双方博士研究生作为助手, 参 与到项目的联络、组织、协调和文宣出版等工作, 并设想了在最后 阶段的国际研讨会中, 设立青年学者论坛, 发言人拟从参加两地研 讨班的成员中选拔。

应该说，这个项目最初设定的目标基本都已实现，虽然这个项 目本身的规模并不大, 但先后参与活动的美方学者和研究生人数超 过 40 人, 他们分别来自美国 II 所综合性大学 ${ }^{16}$, 中方学者和研究生 人数总计也在 40 人以上, 来自于国内 IO 所专业美术院校和综合 性大学。作为一个注重小范围的深度研讨、直接用英语交流的国际 学术交流项目, 它给参加活动学者和研究生带来挑战, 也带来了实 际收益。这些收益包括更切实地了解和熟悉了彼此教学、研究和学 术资源的情况, 学者、研究生个人之间、机构与机构之间的专业联 系, 以及一些具体成果, 比如促成了双方人员的往来、中方博士研 究生学位论文赴美短期调研、学者论文和学术报告在对方学术平台 上发表, 双方学者互相引用对方的研究成果等, 此外, 杭州国际学 术研讨会的论文集将分别在中国和美国以纸质和网络版的形式正式 出版。自上个世纪 80 年代以来, 国内西方艺术史教学和研究是比 较注重以文本读解、经典翻译和学术史梳理的, 以此强化专业艺术 史的学理基础, 而近年来, 类似这样的中外艺术史学者面对面的研 讨和教学交流合作, 让国内学者进入到了一个更加鲜活和复杂、同

古系访学。

16 斯坦福大学和南加州大学的两位美方学者临时因个人原因没有能赴杭参 加研讨会。 
时也更具可能性的当下的学术世界中。毕竟，人与人之间的交流与 合作是其他的单向度的形式所无法取代的。

当然，项目的活动也存在可以改进和完善的空间。归结起来， 找到合适的人参加合适的活动是成功的重要条件，此外，让项目如 何更好地与国内高校西方艺术史教学和研究现状的对接, 特别是针 对国内艺术院校与综合性大学的艺术史存在的既交集，又有所分离 的情况，如何恰当处理是颇具挑战性 ; 专题研讨会的组织应考虑设 置专门的青年学者论坛或学位论文选题的展示区，是否也可尝试开 展中美艺术史学者在教学、翻译、研究、展览和艺术社会服务等项 目上合作，是否能在一些艺术史的基础教学和研究资源建设上进行 合作，使得中美间的这种艺术史交流惠泽更多群体，并产生重要的 学术成果。

2016 年 5 月 3 日 


\section{Introduction \\ Multi-Modernisms: Exploring "Complementary \\ Modernisms in China and the United States"}

Zhang Jian

\section{Preamble/Acknowledgments}

On March 24-26, 2016, Hangzhou's China Academy of Art, Nanshan hosted "Art as Life/Art as Idea: Complementary Modernisms in China and the United States," an international academic conference. The eleven participating Chinese scholars included: Professors Zhu Qingsheng [Lao Zhu] and Ding Ning from Peking University; Professor Shen Yubing from Zhejiang University; Professors Zhang Rui and Liu Chen from Tsinghua University; Professor Shao Yiyang from the Central Academy of Fine Arts (CAFA); Professors Zhang Jian and Lu Peng from the China Academy of Art, and Mr. Kou Huaiyu, an independent scholar. The ten participating American scholars were: Professors Bruce Robertson and Peter Sturman of the University of California, Santa Barbara (UCSB); Professor Julia Bryan-Wilson from the University of California, Berkeley; Professor Jason Weems from the University of California, Riverside; Professor Rebecca Zurier from the University of Michigan, Ann Arbor; Professor Reva Wolf from State University of New York at New Paltz; Professor Ellen Landau from Case Western Reserve University; and Dr. Lawrence Rinder, Director of the University of California, Berkeley Art Museum and Pacific Film Archive. ${ }^{1}$

In addition, the conference included an emerging scholars forum, where five doctoral candidates from the China Academy of Art, Peking University, Zhejiang University, UCSB, and New York University presented their scholarship. ${ }^{2}$ Peter Sturman, Zhu Qingsheng, Ding Ning, Bruce Robertson, and Zhang Jian all served as panel chairs and/or discussants.

I Early career scholars who participated in the seminar were Chen Yao, Chu Xinming, Feng Wei, and Wan Yongting from Peking University; Jiang Wei, Jin Yingcun, Mao Qiuyue, and Wu Yiqiang from Zhejiang University; Jiang Wanjun from the Central Academy of Fine Arts; Wen Ting from Nanjing University; Xu Dayan from Tsinghua University's Academy of Fine Arts; Liao Linan from Guangzhou Academy of Fine Arts; Zhang Xiaojian from Wenzhou University; Huang Bin from Anshun University; and Hong Yuting, Li Langlang, Lu Hao, Tan Wei, Gu Jingxing, Ji Fang, Zhang Fanying, and Wu Xueyu from the China Academy of Art.

2 The three Chinese doctoral scholars were Dr. Chen Yao from Peking University, who presented "Urban Landscapes: Images of New York in Impressionism and Ashcan Painting"; Lu Hao, a doctoral student from the China Academy of Art, who presented "Evolution or Revolution? Walter Pach and Populism"; and Mao 
This conference was the third part of a program series launched in October 2013 called "Exploring Complementary Modernisms in China and the United States." The first two parts were separate seminars- "Chinese and U.S. Modernisms: Young Scholars Seminar," held at the China Academy of Art in October 20I4, and another on contemporary Chinese history painting held at UCSB in February 2015. This program received funding from the Terra Foundation for American Art and was co-hosted by the China Academy of Art and UCSB. It was jointly organized by Bruce Robertson, Professor in the Department of the History of Art and Architecture and Director of the Art, Design \& Architecture Museum (UCSB), and Zhang Jian, Director of the China Academy of Art Library, Professor of Arts and Humanities

After the social and economic reforms of the r970s and 1980s, modern and contemporary art emerged in China with renewed vigor in the late I980s. Over time, it has grown into a generative force with significant influence on the interconnected worlds of art, higher education, and the market. The group of contemporary Chinese artists that emerged at this moment received international recognition. Amid this process, art from the United States greatly influenced the development of Chinese contemporary art, although the extent of this influence is still debated by the scholarly community in China.

China and the United States were both later arrivals to the modern art scene. Early in the development of each country's modern art, there was first an intense period of reception and response to the arts of the European avant-garde. Furthermore, both countries only really came to establish an independent cultural identity in the second half of the twentieth century. Only after the I940s and I950s did modern art in each country take a new, more culturally distinctive path. In China, Socialist Realism became the dominant artistic language, while in the United States, Abstract Expressionism and then Pop Art came into vogue. ${ }^{3}$ The ideological liberalism and new artistic directions in China in the late I970s and early I980s connected to an earlier thread of mid-twentieth-century modernism; however, the result was more visually and conceptually complex than the modernism from half a century earlier. Over this period, the rich and complex relationship between modern and contemporary art in China and the United States become an important topic within the context of the contemporary globalization of the art world.

Qiuyue, a doctoral student from Zhejiang University, who presented "Ideology and the New York School of Painting." The emerging American scholars were J.V. Decemvirale, a doctoral student at UCSB, who presented "Because Night Time is the Right Time: The Black Arts Council's Foundational Act as an Inter-medial Space of Popular Resistance," and Marci Kwon, a doctoral student from the Institute of Fine Arts, New York University, who presented "Vernacular Modernism: Joseph Cornell and the Culture of Populism."

3 See John Davis, "The End of the American Century: Current Scholarship on the Art of the United States," The Art Bulletin 85, no. 3 (2003): 544-80. 


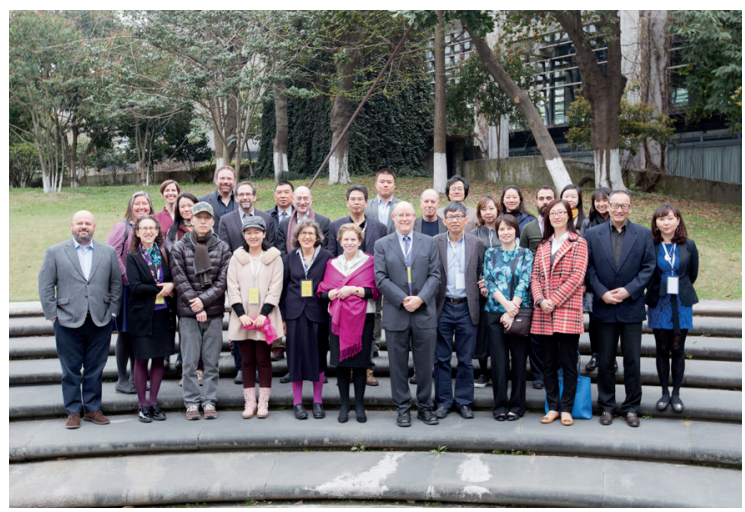

Fig. I. Participants of 2016 Hangzhou conference with Terra Foundation representatives.

In recent years, art historians in the United States and China have collaborated on a number of research and professional exchanges, including the First Annual Advanced Workshop in Western Art and Art History, funded by the Henry Luce Foundation and held at Hong Kong University (July 20IO), the Second and Third Annual Advanced Workshops on Western Art and Art History at the China Academy of Art (May 20II) held at the Asia Society, New York (July 20I2), and conferences at the Harvard University Center for Italian Renaissance Studies at Villa I Tatti in 2013, 20I4, and 2015, which received support from the Getty Foundation. Scholars invited to host these activities included many professors from well-known universities and arts organizations in the United States and Europe. A series of short-term lectures, seminars, and visits to local museums and cultural and historical sites became the means for collaborative teaching, learning, and research. With each initiative, organizers chose topics that resonated with Chinese academic discourse. Using English as the working language, the Chinese scholars were able to engage in face-to-face discussions with European and United States-based scholars, which made these programs meaningful to participants on both sides.

The idea for our own collaborative, multiyear project, "Exploring Complementary Modernisms in China and the United States," was conceived in July 2012 during the Third Annual Advanced Workshop on Western Art and Art History in New York. It was approved in the second half of 2013, under the tireless direction of Dr. Carrie Haslett, Program Director of Exhibition and Academic Grants at the Terra Foundation. I, along with Dr. Bruce Robertson and Dr. Peter Sturman (UCSB), as well as Professor Hui-Shu Lee (UCLA), contributed to organizing the culminating "Art as Life/Art as Idea: Complementary Modernisms in China and the United States" in 2016 at Hangzhou's China Academy of Art, Nanshan (Fig. I).

\section{“Complementary" Modernisms}

Two major themes and lines of inquiry for the 2016 Hangzhou conference were: How do we define "Modernism?" And how might the art of China and the United States offer "complementary perspectives" to this historical development? First of all, we believe "Modernism" is a broad concept with complex implications. Modernism encompasses the emotional, cognitive, and spiritual changes brought on by the processes of modernization, the diverse forms of ar64 tistic and cultural expression sparked by these changes, and the ensuing critical 
Fig. 2. Class members of the Autumn Workshop in Hangzhou, China Academy of Art, Nanshan Library, October 2014.

and scholarly analyses of the social and cultural impact of these changes. The introduction of modern art, regardless of whether it was created in Europe, the United States, or in China, does not merely

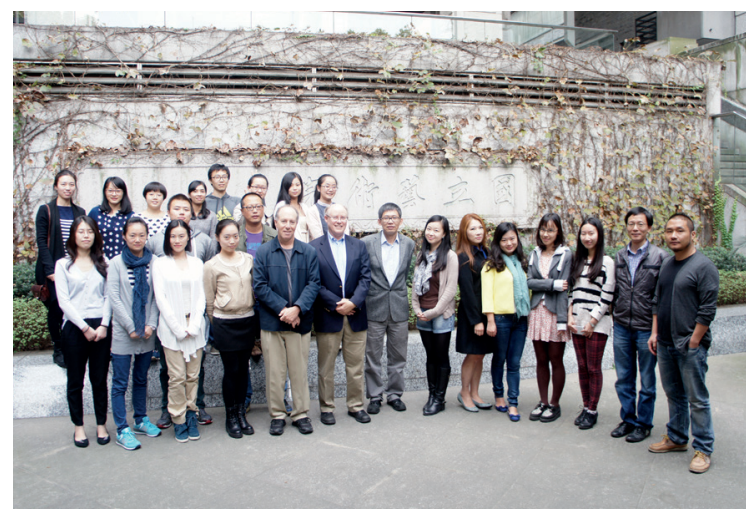
indicate an aesthetic or formal change, but a fundamental shift in society's understanding of what art is and what art can be. Modernism is, in some respects, the process of art entering and even changing life_-art and life in union as one. Therefore, Modernism has been seen both as a culture and as a framework of ideas, beliefs, values, and perceptions associated with that culture. Modernism, in art, is partially a reaction to historical modernity, especially to modernity's fetishization of rationality and efficiency; yet, this reaction also contains ambivalence. Modernists celebrated speed, power, and technological progress, but opposed the coldness of dehumanization, mechanization, and digitization. European Modern art often emphasized the formalist elements of taste and style, using these ideals to preserve the essential nature of art while also opposing existing social structures. In the United States, Modernism has been defined as an artistic category that can generate its own strategic framework within late capitalism. Within a Chinese context, these concepts are even more complicated. Compared to Europe and the United States, Chinese Modernism was stratigraphically distilled over a much shorter timeline and under very different social, cultural, and economic circumstances. Because multiple eras, locations, cultures, histories, and political systems were involved, Chinese Modernism is replete with tensions caused by confrontations between different emotions, concepts, ideologies, and values. As a result, scholars of Chinese Modernism do not believe there is one universal "Modernism." Within distinct cultural contexts, "Modernism" developed into many styles and extended itself in diverse directions. Modernism is a pluralistic concept, and this Pluralistic Modernism can only be understood through the context of "complementary" perspectives.

The English word "complementary" has two meanings: "supplementary" and "reciprocal." Our word choice is intentional: only through complementary perspectives can multiple modernisms enter into dialogue and give us a more complete picture of Modernism. China and the United States have areas of misunderstanding and gaps in their knowledge of each other's histories of modern art. Both have the tendency to turn the other into an artificial opposite in order to reinforce their own point of view. This type of discourse is especially pervasive in discussions of both art and politics. 


\section{American Modernism and Post-Modernism: An Autumn Workshop in Hangzhou}

From October 28 to November 4, 20I4, the China Academy of Art, Nanshan Library, hosted the seminar "Exploring the History: Complementary Perspectives, Chinese and US Modernisms." The lecture series brought together 22 young scholars from Peking University, Nanjing University, Zhejiang University, the Guangzhou Academy of Fine Arts, China Academy of Art, the Central Academy of Fine Arts, the Academy of Fine Arts at Tsinghua University, Wenzhou University, Anshun College, and several other Chinese universities (Fig. 2). The lectures were led by Professors Robertson and Sturman from UCSB, and topics for the series of lectures included: "The History of American Modernism," "American Art and Its Institutional Background," "Twentieth-century American Art: 1960 s to the Present," and "Modernism and Modern Artists of the Chinese Diaspora."

To understand twentieth-century American modern and contemporary art and art history through the lens of Pluralistic Modernisms, Robertson argued to start first with methodology. Then he suggested considering how current art historians approach and interrogate a particular historical period. He explained to the seminar participants that there are three primary methods for researching American art: art history, American studies, and critical theory. The first two tactics were popular prior to 1975. After 1975, stylistic analysis, iconography, and even cultural history were no longer in vogue. These methodologies were displaced by critical theorists such as Lacan, Derrida, and Baudrillard as well as by psychoanalytic theory, Foucault's analysis of power relations, feminism, queer theory, and postcolonial theory. Contemporary events, including the American civil rights movement and the Vietnam War crisis, influenced the growing popularity and influence of these ideas in the r960s and I970s. Coming of age during this period, a new generation of scholars challenged nationalistic approaches to art of the United States that reinforced notions of American culture as singular, unique, and exceptional. Informed by critical theory, new methodologies for interpreting art produced in the United States challenged traditional narratives of art history, especially the version that represented American art as a colonial art form, which emerged and gained independence from a European progenitor. Robertson also discussed the different cultural and political attitudes of "Europeanists" and "Americanists," arguing that within modern art history, Americanists place a greater emphasis on context, while Europeanists focused more on quality and form. This differing value system manifests itself in scholarship and has led scholars of American art to be more amicable to Pluralistic Modernism (and its implications) than their European counterparts. Moreover, it allows Americanists to engage with critical themes in the history of the United States, such as civil rights, racial inequality, and gender politics, which are all political ideologies.

For Americanists, the focus on context is a result of the changing status of art in American society. As Robertson pointed out, there is a significant difference here between China and the United States. Throughout China's long 
history, the high status and cultural value of art is clear. In contrast, the United States is a comparatively young country, and art made in the United States has been traditionally marginalized. Within American universities, the discipline of American art history was somewhat amorphous when it emerged in the I950s and I960s: what exactly is "American" art and what should or could the discipline surrounding it be? The study of American art could not be compared with traditional European art. In the early years, American art history was studied alongside American cultural studies, which became an important feature of the historiography of the discipline. In his lectures, Robertson emphasized the system of institutional support for American art, including federal and local governments, foundations, museums, universities, exhibitions, educational and academic research institutions, as well as art dealers, galleries, and other market influences. When discussing art since the mid-twentieth century-a period of monumental change in American art and culture-he emphasized the impact of transitioning from an industrial society to a consumer society in the wake of the Great Depression. Robertson also mentioned Leo Löwenthal, a German-American sociologist and member of the Frankfurt School. Before the Great Depression, Löwenthal argued that American attitudes towards individual success typically focused on production and the morality of the producer. In literature, hard work and success through the accumulation of wealth were frequently occurring themes. After the Depression, narratives shifted to focus on consumerism and individual consumption. For these American hero-consumers, the focus was not on how they became successful, but what they did afterwards: how did they perform their success? What effect did success have on their lives? How did their personal habits of consumerism change?

Contemporaneous to these developments, American artists increasingly pursued commercial, political, and cultural activities to project the power and influence of their artistic production and personal voice. Themes such as "identity and the body," the "status of the medium," consumer habits, and the contemporary art market became popular. In late capitalism, the media helped to determine the artist's genre, and genres such as "appropriation" became important tools and creative strategies for contemporary artists. While claiming to critique institutions and power, artists enabled the imagery of mass media to regain cultural relevance. The well-known American artist Jeff Koons's goal, from one perspective, is to control the market, not to oppose or resist commercialism. Robertson also mentioned that after the I96os, the West Coast, especially Los Angeles, became increasingly important to contemporary art.

Professor Sturman lectured on twentieth-century diasporic Chinese artists from Hong Kong, Taiwan, Europe, and America working from the I950s to the I980s, such as Zeng Youhe (b. 1924), Liu Guosong (b. 1932), Chu Ge (b. 1931/32-d. 2013), and Wang Wuxie (b. 1936). These emigrant artists showed they could engage with ongoing trends in American and European modern and contemporary art, while maintaining their "Chinese identity." For example, the motifs in Wang Wuxie's landscapes are drawn from traditional Chinese landscape painting. Yet, in contrast to traditional paintings, the landscape is less welcoming visually; there is no longer a clear entry point for the viewer to 


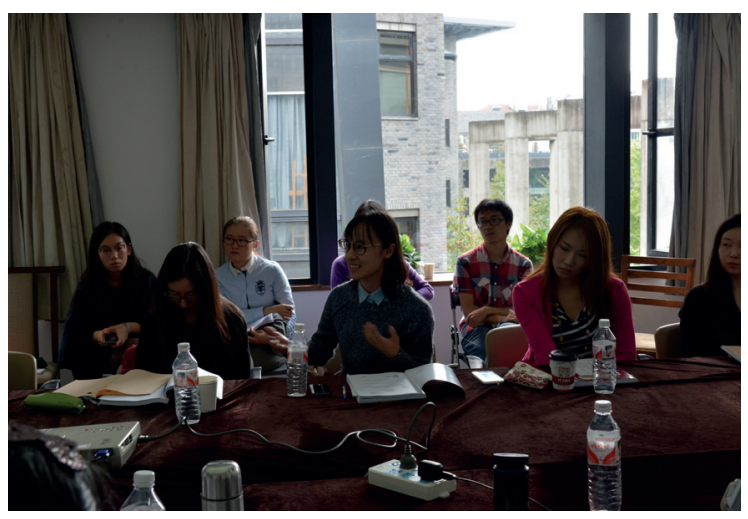

Fig. 3. Discussion among members of the

Hangzhou Autumn Seminar in October 2014.

navigate the painterly terrain.

The interior is an organic, self-contained, and unified space, which bears similarities to Western painting. Sturman also mentioned modern and contemporary Chinese art topics currently being discussed among American art historians: how can contemporary media be used to pay homage to artistic traditions? How do artists develop new styles and concepts at the intersection of divergent influences of the past, present, and future?

Chinese and American modern art reveal multiple perspectives and nodes of influence. Modern art from both countries confronts issues of selfhood, or individuality, and relationships, such as how one regards oneself, how one regards the other, how one understands the others' attitudes towards cultural traditions, and how one evaluates influence in one's work. Within artistic contexts, there is constant reading, misreading, and re-reading. Regardless of whether the artist engages in either misreading or re-reading, both ways of reading are critical acts and can stimulate new ideas.

Discussions following the American professors' lectures reinforced our understanding of the forces driving American art and of the approaches taken by Chinese artists within a transnational context (Fig. 3).

The opportunity for discourse further strengthened seminar participants' knowledge of the social, political, economic, and cultural conditions driving patterns of expression in American contemporary art. On the other hand, these exchanges in the 2014 seminar enabled everyone to better consider the rich historical context for modern and contemporary Chinese art, which is far more complex than a passive acceptance and adaptation of Western influences. For example, Chinese artists' brush with Western influence(s) could precede artistic innovation and development within their own cultural tradition. Professor Sturman referred to Western influence in Chinese modern and contemporary painting as the "drift of Chinese art." In my opinion, this "drift" is also a kind of self-conscious exploration and a bursting forth of the power of tradition as provoked by an outside stimulus. Modern and contemporary art created in the United States are in a similar historical position. In either case, China and the United States must both not forget their own artistic and cultural identities, which spring from their specific traditions. The value and power of these traditions can only be recognized and analyzed by looking at modern and contemporary art from a global perspective. 
Fig. 4. Profs. Zhang and Robertson at 2015 Spring Workshop in Santa Barbara.

The Artistic World within History Painting: A Spring Workshop in Santa Barbara

From February 9 to 13, 2015, I went to the University of California, Santa Barbara

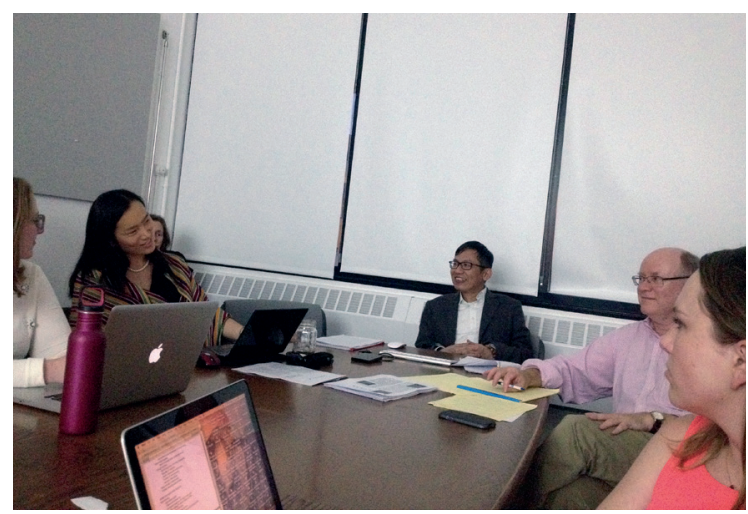
(UCSB) to host a young scholars' seminar entitled "The Historical Moment and Its Eternity: A Problem of Modernity in the History Painting of Contemporary China” (Fig. 4). Twenty doctoral students, young scholars, and professors from the Department of History of Art \& Architecture at UCSB participated in this seminar. While in Santa Barbara, I gave two lectures: "Modeling People and Identifying Self in History Painting: Cai Liang and Others in the Early 1960s" and "Abstracting or Optical Fidelity: New Trends of History Painting after the I980s" (both reprinted in this volume).

I chose to focus the seminar on Socialist Realist historical paintings with an eye towards visual culture. When it comes to realism, China and the United States share some common ground. American art historian John Davis used the phrase "art of content" to refer to the pre-war American Social Realist works of the "Ashcan" circle, political cartoonists, and government-funded muralists. In the United States, Social Realism was quickly overshadowed by the arrival of Abstract Expressionism. Meanwhile in China, the opposite was true: after the I950s, Socialist Realism overshadowed modernist art. This difference and reversal between the artistic contexts in China and the United States is very interesting. In my opinion, American scholars can use this comparison to more conscientiously approach and understand the complex relationships between creative works, politics, culture, and artists' individual inclinations in the period after the founding of New China.

I cited the example of Cai Liang, a famous history painter from the I950s and 1960s. ${ }^{4}$ In his early years, he studied at the Central Academy of Fine Arts (CAFA), where he was influenced by the sketching skills favored by celebrated Chinese painter and CAFA instructor Xu Beihong. When Liang graduated, and because of his involvement in the activities of the Layabouts Lodge (Erliu Tang), a small group of left-leaning writers and artists who were still critical

4 See my own assessments of Cai Ling: "The Spirit of Impressionism and Expressionism in Classical Realism: A Brief Discussion of Cai Liang's Historical Paintings," History and Memory: Cai Liang's Art Documents," and History and Memory: Cai Liang's Art Reflections (Changchun: Jilin Fine Arts Publishing House, 20I0). 
of the Chinese Communist Party, he was assigned to work in Shanxi. He remained in this remote and underdeveloped area of China for over twenty years. His famous oil painting The Torchlight Parade in Yan'an (1959) became an exemplar of history painting in the New China.5 In 1998 he was among the artists included in A Century in Crisis: Modernity and Tradition in the Art of the Twentieth-Century China, an exhibition jointly organized by the State Administration of Cultural Heritage in China and the Guggenheim Museum of Art in New York.

Cai Liang's paintings often drew upon political and military themes. As a result, he received a number of government commissions and his paintings served as propaganda. However, they were also a record of daily life and ideals of the time. The figures in his paintings are based on the farmers who occupied the lowest rungs of society, and whom he met and grew to know in the countryside in northern Shanxi. Liang's paintings reveal his deep understanding of and sympathy for these people. With his brush, Liang depicted farmers who, despite their circumstances, maintained a spirit of optimism and perseverance; of trust in and commitment to the land; of tenacity, vitality, and folk wisdom. A literary corollary might be the characters that American author Pearl S. Buck so vividly portrayed in her book The Good Earth (193I). Of course, compared to Buck, Cai Liang's portraits of farmers are more positive and idealized.

My lecture on The Torchlight Parade in Yan'an combined details from Liang's life, the creative influences on his sketches and artworks, and the historical context, including popular sentiments and local customs, to describe and interpret narratives behind his famous historical paintings. For example, the subject of The Torchlight Parade in Yan'an is the 1945 parade in Yan'an to celebrate China's victory in the Anti-Japanese War (i.e., World War II). According to the artist's recollections, when he conceptualized this painting he was actually inspired by the exuberant energy of the Great Leap Forward's Backyard Furnace Campaign. ${ }^{6}$ To further contextualize the painting, I included historical documentary photographs of Yan'an from the I950s and I960s, including some taken by Cai Liang himself, to illustrate the multiple realities contained in the painting - concrete and environmental, as well as social and cultural. Providing American scholars with a broad background helped them to better understand the painting's humanistic content and its specific context within a complex

5 Cai Liang's The Torchlight Parade in Yan'an is available in two versions. The first version was created in 1960 and is now in the National Museum of China. The other version is a 1972 variant created for the Yan'an Revolutionary Memorial Hall. It is now in the National Art Museum of China (NAMOC).

6 See Cai Liang, "The Story of Yan'an Torch" and "The Experience of Creating Historical Paintings" (Shanghai: People’s Fine Arts Publishing House, 1963). Liang was involved in ironmaking in southern Shaanxi, leaving a memory painting. The paintings were of the villagers transporting the ore to the mountains 
period of Chinese history, instead of simplistically grouping the painting with Socialist political ideology and risking a false equivalency.

For post-reform era history painting, I chose several paintings from the National Art Museum of China's 2009 National History Painting Exhibition. Compared to the historical paintings of the I950s and I960s, these paintings embrace formal structure and assemblage techniques of modernist art. They integrate historical images, which resonate with symbolic meaning. Some artists even use large-scale panoramic compositions and photorealistic techniques to depict and describe specific historical details, in order to create a sense of presence and enhance the visual impact of the work of art. This reflects changes in the perception and role of visual art over the last fifty years. An emphasis on portraying virtuous figures and an overall unison of feeling and spirit in traditional history painting has been replaced by a desire to construct scenes or the feeling of abstract form in a new era of media and visual culture.

I presented several examples to illustrate this point to seminar participants. A painting by Luo Gongliu from the I950s is among the works included in the 2009 National History Painting Exhibition to address the subject of tunnel warfare. Gongliu’s Tunnel Warfare captures a moment from an intimate scene unfolding in a narrow stable. The compositional unity between the characters and the mood of the painting aims to solicit an emotional response from the audience, as if they too are sharing the joys and sorrows of the painted figures. In contrast, a work from 2009 by Shun Zhixi on the same topic presents a widescreen scene of a visual spectacle of tunnel warfare. This spectacle assumes a detached gaze, one psychologically and emotionally distanced from the historical event and context.

The American students and scholars participating in the seminar expressed a deep interest in these history paintings. They raised a number of interesting questions from various perspectives. One scholar noticed that two versions of Cai Liang's The Torchlight Parade in Yan'an include a woman holding a child; in the later version, the woman's placement shifted from the front of the parade to the lower right-hand corner of the canvas. He asked about the circumstances surrounding this change: did it result from a request from Cai's work unit? And, if so, how did the artist feel about this change? While I was unable to provide a definitive answer, the question sparked a vibrant discussion around artistic intentions, external influences, and the nature of propaganda.

Robertson discussed the role of formal analysis in the training of historians of American art within the United States. He said formal analysis is not as common now in American universities as it was in the past. As a graduate student at Yale University in the I970s and 1980s, Robertson received training in a formalist methodology. The current trend is to study the social and political context of artworks. He felt the detailed, descriptive language of connoisseurship, which can highlight a work's subtle and complex visual effects, was an effective means through which to discuss Cai Liang's sketches and finished paintings. Robertson pointed out American scholars are not accustomed to looking at politically-driven realist paintings as "high" art. However, he agreed with me that these paintings should be taken seriously and should be subject 


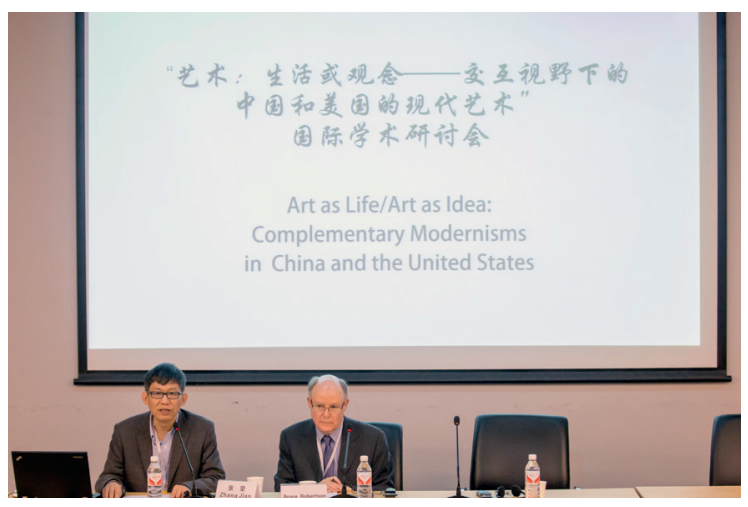

Fig. 5. Opening of the international conference,

"Art as Life/Art as Idea," Hangzhou, March 2016.

to thoughtful analysis; they speak to a moment in Chinese art history and illustrate an important aspect of modern art in China. I suspected the extent of many American scholars' prior knowledge of modern Chinese art included avant-garde artists from the post-reform era like Ai Weiwei, and Cai Guoqiang. In my lectures, I emphasized that Socialist Realism was and continues to be the mainstream form of visual art in China. Because abstract art and then conceptual art are the predominant artistic movements for the twentieth and twenty-first centuries within the United States, seminar members in Santa Barbara still considered Social Realism to be anachronistic and, at the very least, out of sync with American artistic production. As for how to evaluate this kind of political artwork's artistic value in the present moment, that is a question for another time.

\section{Art as Life/Art as Idea: Complementary Modernisms in China and the United States (Hangzhou, 2016)}

"Art as life" or "art as idea": these phrases touch upon contemporary questions of the conceptualization and definition of art. In China, the question of "art for art's sake" or "art for life's sake" is as difficult to answer as Hamlet's "to be or not to be": this refers to the socialist idea that art should be a means of life In the United States, artists like Robert Henri saw life experience as an inspiration for everything. There was little distinction between art and life; they reinforced each other and were ultimately both creative or generative forces. Regardless of whether we are talking about modern and contemporary art in the United States or China, to take a complex, transnational phenomena and constrict it to a standard art historical narrative is to turn art history into a game of conventional rhetoric. Well-trod lines of inquiry and a desire to categorize art historical developments obscure the overwhelming diversity found in artistic expression.

"Art as life or art as idea" was chosen as a theme for the 2016 conference in Hangzhou to return to a number of questions and fundamental concepts raised in the earlier seminars. This provided an environment for scholars from both countries to equally participate in a rich dialogue. Many of the Chinese scholars participating in the Hangzhou lecture series mostly used English to deliver their conference papers, which further enhanced the impact of these scholarly exchanges.

Robertson and I presented two keynote addresses on "Rethinking the '6os: 
Lessons from Wu Guanzhong to New Wave Art," respectively (Fig. 5). These topics reflected two varied yet informed perspectives on the conference's main topic and academic direction (Fig. 5). Robertson attempted to reconstruct the original context of Robert Morris's minimalist work Columns (I96I-I973) by focusing on the art historical discourse and potential sources of inspiration. ${ }^{7}$ To me, this work shared a ready-made quality with Marcel Duchamp's notorious Fountain (1917), although Columns and Fountain were created and displayed in very different environments. Rosalind Krauss's interpretation of Columns made it a standard work within art history. ${ }^{8}$ After that, its original context was forgotten, and everyone talked about it on the basis of photographs. In short, early minimalist sculptures were drained of their Dadaist roots and sense of humor. Robertson worked to show that the work of the art historian is not to prove that Morris's work is the standard for minimalism; instead, the art historian's job is to deconstruct our conventional understanding of it and to reconstruct the context of this work's creation and reception from before it was labeled as "minimalist" art.

Current scholarship on Chinese modern art history also has this problem. My keynote address attempted to recount the rediscovery of modern art at the beginning of the reform era (I970s-1980s), with a focus on the role played by artists. For example, I discussed Wu Guanzhong's promotion of formal beauty and his rediscovery of the early Chinese modern artists, who had been almost completely forgotten, as well as his appreciation (jinshang) for and evaluation (pinxi) of them. The famous artists and artworks of Western modernism that Guanzhong was familiar with pushed domestic academic circles and institutions towards an acceptance of modern art and created a formalist discourse. Simultaneously, the artists in the New Wave Movement ('85 New Wave) transplanted Western modern art's various styles and schools and thus demonstrated a tendency to move beyond form and aesthetics towards an emphasis on context and concept. Artists who went abroad to the United States combined their understanding of Western modern art with their personal experiences of cultural and historical "dislocation," and they used this as the material with which they would make a name for themselves in a globalizing art world. This turn from formalism to contextualism is an important framework for understanding the history of this new era of Chinese art.

7 Morris's Column was originally not a sculpture, but a prop that the sculptor George Sugarman created for the dancer Yvonne Rainer. Painted a light yellow, this dance prop was later used in Morris's performance art. He entered the interior of the pillar and used his body to convert the prop into a living sculpture, expressing the presence of the body.

8 See, for example, Rosalind E. Krauss, Passages in Modern Sculpture (New York: Viking, 1977), "Sculpture in the Expanded Field," October 8 (Spring 1979): 30-44, and "The Mind/Body Problem: Robert Morris in Series," in Robert Morris: The Mind/Body Problem [exhibition catalogue] (New York: Solomon R. Guggenheim Museum, 1994), 2-17. 
Chinese and American scholars had different narrative perspectives of their respective countries' modern art. The American scholars' presentations demonstrated the diversity within modern and contemporary art from the United States and also emphasized a history far from the traditional narrative of the Armory Show, Abstract Expressionism, and Pop Art. Rebecca Zurier of the University of Michigan looked at New York from the period between I890 to I940. She pointed out that images of New York from this period were not generalized expressions of a metropolis, but were entangled with a specific local consciousness. If there is a general condition of urban life, then a more complex understanding of the specifics of any "locality" is needed Locality is the way people experience life within a metropolis; it is heavily influenced by factors such as class, race, and age. The specificity of the local and its environment is an important component of the urban experience in modern art.

A similar approach to the problematic nature of modern life was reflected in the presentation of Lawrence Rinder, Director of the University of California, Berkeley Art Museum. He discussed two visually opposing movementshippie culture and modernism-that brought together William Morris's Arts and Crafts movement, the Bauhaus school, and Black Mountain College in the United States. ${ }^{9}$ He suggested that early Bauhaus, especially Bauhaus under the influence of Johannes Itten, resembled a hippie commune. He argued that mystical symbolism, religious enthusiasm, and romantic nostalgia became characteristics of Black Mountain College, and that Black Mountain College in turn influenced the hippie movement. American Modernism contains multitudes and is full of contradictions. It includes hippie elements, such as expressing skepticism towards new technologies, opposing social ossification, exploring the inner mechanisms of thought, returning to nature, living simply, and integrating art into everyday life. To this end, Rinder raised the example of counter-culture figure Stewart Brand, who collaborated with computer scientists, co-founded the first open online community The Well (Whole Earth 'Lectronic Link), and published The Whole Earth Catalog, which foreshadowed later search engines and social networks. In Rinder's view, these were the results of combining new technology and hippie culture.

Jason Weems from the University of California, Riverside presented on the modern experience in Grant Wood's pastoral paintings. ${ }^{\text {.0 }}$ The overhead perspective used in Wood's paintings, Weems stated, can be connected to the use of aerial photography in the U.S. government's agricultural land surveys, an emerging and relatively new technology which used grids to divide the countryside. Farmers were encouraged to look at their own land from an aerial rather than

9 Rinder curated an exhibit, "Hippie Modernism: The Struggle for Utopia," at BAMPFA (UC Berkeley Art Museum and Pacific Film Archive) that ran from February 8 to May 2I, 20I7: https://bampfa.org/program/hippie-modernism-struggle-utopia.

Io See Jason Weems, Brainstorming the Prairies: How Aerial Vision Shaped the Midwest (Minneapolis: University of Minnesota Press, 2015). 
horizontal perspective, and to also think of agriculture as the fruitful production of space, not an idyllic pastoral landscape. This changed the conditions for visual experience in the American countryside. Weems argued that Wood's "aerialism" was both a product of aviation technology and a visual and conceptual framework for modernization in rural America. Wood's aerial perspective led to a sense of alienation in his works that served as a metaphor for the dangers of modernization. Wood's depictions of a simplified, abstract, undulating, pillow-like countryside were published in Life magazine, and they became a popular representation of the experience of modernization in rural America. The sense of distance between the viewer and the land is both physical and psychological, and the gaze demanded by Wood's paintings is a dehumanizing one.

Within the media-driven discourse of American modern art history, Louise Nevelson is considered an abstract sculptor, but as Julia Bryan-Wilson from the University of California, Berkeley discussed, Nevelson challenged the dominant theory that the medium should lead in analytical considerations of art. Nevelson tried to depart from pure abstraction in her work and instead pursue an "embodied formalism" that contained a feminine social consciousness and distinctly female perspective. Her Dream House (1972) uses a variety of readymade architectural components, such as cornices, bedposts, door handles, railings, bolts, and spindles to reframe space. This space, with its monochrome palette, cannot be understood from a purely formal level, but must be interpreted through the prisms of gender, class, and ethnicity.

Ellan Landau of Case Western Reserve University, a respected scholar of Abstract Expressionism, used the Guggenheim Museum's "Art of This Century" exhibition from October 1942 to interrogate the complex relationship between Peggy Guggenheim and three abstract expressionist artists known as the "war babies" - Robert Motherwell, Jackson Pollock and William Baziotes—during World War II. She pointed out that the exhibition was intended to establish a laboratory for "artistic innovation." It was meant to provide a place of artistic freedom and expression for European surrealist and abstract artists who immigrated to the United States to avoid the Nazis. Guggenheim also used the exhibition as an opportunity to promote three American artists with whom she had established relationships. Surrealism and abstraction, Landau noted, were ways to express a general mood of anxiety and psychological unease during the war. The American artists in the exhibition rejected European figurative surrealism, using instead psychic automatism as a tool for formal innovation. They tried to strike a balance between abstraction and figuration by looking within an unrestricted creative process of individualism and vitality. This served to satisfy their own longing for humanity and to help them shoulder the responsibility and find courage to fight for freedom and life. Pollock's and Motherwell's works from this period were full of references to the war, such as their use of materials such as military photographs and maps; they shared a certain similarity to Goya's and Picasso's works on a similar theme. Landau argued that Abstract Expressionism's pursuit of originality is rooted in the crisis of World War II. Each of the American artists believed in authentic, free, and vital creation, even though such creation was full of danger and uncertainty. After the war, the ar- 
tistic ideals that they formulated during the conflict became a new aesthetics of individualism and were appropriated as a symbols for the expansion of American power and influence globally.

Kou Huaiyu, Peking University, and Reva Wolf, State University of New York, New Paltz discussed their collaborative project to translate Andy Warhol's I980 memoir into Mandarin. ${ }^{\text {II }}$ Their experience provides a case-study for interpreting modern art from China and the United States through complementary perspectives. Wolf and Kou shared the personal contexts and experiences that led them to their individual interpretations of Warhol. For Kou, Warhol offered a path towards resolving a contradiction in contemporary Chinese life. This tension rose from the ethical restrictions on material pleasure enforced during Kou's youth, coupled with the rise of consumer culture in the post-reform era. Warhol provided a model for Chinese consumers: how to be a consumer and to live comfortably in a consumer era, a self-liberation of sorts for Kou and his generation. Based in the United States, Wolf bought POPism shortly after it was published in 1980 and read it many times. ${ }^{12}$ Despite her deep familiarity with the artist and this book, she confessed the issues raised by Kou gave her a new understanding of the multiplicity of the meanings of Warhol's writings. In her presentation, Wolf also summarized difficult-to-translate words and phrases found throughout POPism, such as the phrase "cosmic joke," which was used frequently in United States throughout the I96os. She felt Kou effectively translated the pessimistic attitude towards life contained within the mid-twentieth-century American phrase. However, as Wolf was preparing her presentation for the Hangzhou conference, she discovered this phrase was popularized even earlier, in late nineteenth and early twentieth-century literature. At that time, life (shenghuo) could have been a "cosmic joke," but with the rise of LSD in the I96os, the phrase took on a new meaning, and the old usage was forgotten.

Compared to American scholars' interdisciplinary discussions and diverse discourses on the modern art of their country, Chinese scholars expressed greater interest in and engagement with the influences of history, concepts, linguistic forms, cultural identity, and social criticism relative to Chinese modern and contemporary art within the context of globalization. The traditional major figures of Chinese modern art history, such as Huang Binhong, Liang Sicheng, Lin Fengmian, and Wu Guanzhong, were the central focus of many papers presented by the Chinese scholars at the Hangzhou conference. While these wellknown artists responded to Western influences, they also demonstrated a strong subjective awareness of and expression of Chinese culture.

Shen Yubing, Zhejiang University, presented a paper, "The Converging Way of Modern Art Between China and the West: Cézanne and Huang Binhong,"

II Andy Warhol and Pat Hackett, POPism: The Warhol 'bos (New York: Harcourt Brace Jovanovich, 1980).

I2 The first edition of Warhol and Hackett's POPism: The Warhol '6os was printed in 1980. The Chinese translation popu zhuyi was published in 2014 by Henan 
that used social and cultural developments to compare the creative paths and artistic practices of Paul Cézanne and Huang Binhong. Yubing's transnational approach brought to light similarities between two masters of modern art from China and the West. Liu Chen, Tsinghua University, focused on the academic discourse around the term "Modernism" in Chinese architecture, and how this idea was translated and reconstituted as the "modernist movement." After Chinese architect Liang Sicheng was criticized for using Western modernist architecture, Chen argued that Sicheng carved another path for Chinese modernist architecture by drawing on classical architectural styles from China and the Italian Renaissance. Chen's presentation, titled "After École des Beaux-Arts and Bauhaus, Liang Sicheng and the Utopia of Modernism in Chinese Architecture of the Twentieth Century," illustrates a line of inquiry about modern and contemporary architecture's language and style which could be a source of inspiration for the contemporary Chinese architectural community. Professor Li Chao of the Shanghai Academy of Fine Arts used the example of the Storm Society to revisit the "pure art" practices of early Chinese avant-garde artists. In his paper, "A Study of the 'Storm Society': Chinese Modernism as a Resource of International Modern Art," Chao discussed Chinese artists Pang Xunqin and Ni Yide, who through their study of Western modern art, refined the essence of creativity and gave it a local character. He also discussed the cosmopolitan culture of Shanghai celebrated by the Storm Society as the ideal environment within and from which modern art might thrive. ${ }^{13}$

In China, conceptual art requires a non-traditional and more fluid understanding of art. Peking University's Zhu Qingsheng [Lao Zhu] spoke from his experience as an artist and an art historian, in order to explain his understanding of conceptual art in his paper, "Some Remarks on Conceptual Art in China." He believes that the paradox of conceptual art is evident within its name: that is, its cognitive significance and its formal significance should go hand in hand. Conceptual art has the power to both move viewers emotionally and to provoke creative encounters. This immediacy of feeling is intensely personal and self-contained, and as a result, the viewer's response is extraordinarily specific. In other words, conceptual art evokes a different emotional response with every viewing, and the meaning the work is constantly changing. Lao Zhu explained that conceptual art points to art as a form of social and cultural critique. In "An Imagined Utopia: Chinese Contemporary Art under the Perspective of Globalization," Professor Shao Yiyang of the Central Academy of Fine Arts framed contemporary art as a utopian activity: the conceptual practice of

13 The Storm Society (Juelanshe) was founded in $193 \mathrm{I}$ and represented "a shortlived movement in China informed by Post-Impressionism. The group, based in Shanghai, emerged following drastic changes to the education system implemented by the Qing Dynasty": Belinda Piggott, "Juelanshe [Storm Society]," Routledge Encyclopedia of Modernism, September 5, 2016, https://www.rem. routledge.com/articles/juelanshe. See also Pang Xunqin, "Juelanshe xiao shi” ["A Small History of the Storm Society"], Yishu xunkan [L'Art] I, no. 5 (1932): 9. 
creatively deconstructing every kind of form. Its methods of deconstruction include the radicalism of $\mathrm{Ai}$ Weiwei and the harmonious approach of Xu Bing; its objects of deconstruction include the extreme left-wing ideology of the Cultural Revolution, the conditions of global industrial production, and consumer culture within the market economy, and every form of power, authority, and mythology surrounding Chinese culture and tradition. Professor Wang Duanting of the Chinese Art Research Institute discussed action artists in the I980s, who used their bodies as artistic media. In Duanting's paper, "Redemption for Sins through the Human Body: Meanings of Action Art in China," he analyzed and interpreted the artists' creative backgrounds, intention, process, critical orientation, and the obstacles they encountered. Duanting also expressed regret over the human absence in the works that followed in the wake of performance art.

Since the 1980s, developments in Chinese modern and contemporary art have included an acceptance of and response to the West, with American art playing an important role. In "Artistic Tropes: Some Cases of Mutual Chinese-American Influence," Ding Ning of Peking University used Norman Bryson's concept of "tropes," a state of being neither imitated nor transformed, to describe the complex relationship between Chinese and American art. ${ }^{\mathrm{I}} \mathrm{He}$ used Mark Tobey, Isamu Noguchi, and Philip Guston to illustrate the influence of Chinese art on American abstract artists in the first half of the twentieth century. He also talked about the influence of the American artist Andrew Wyeth on He Duoling, Ai Xuan and Wang Yidong in the I980s and I990s. Ding believes the nature of the interaction between Chinese and American art is based on artists' individual perspectives and experience. Despite his hyper-realistic style, which cuts against the hegemonic narrative of modernist abstraction in the United States, Ai Xuan is still thought of as the greatest artist from an American perspective of Chinese art history. Ning argued that this type of mutual influence between China and the United States was grounded in artists' individual perspectives and not merely part of a broader cultural and art historical narrative. Ai Xuan, for examples, continues to regard Wyeth as the greatest artist in the history of American art.

Lu Peng, professor of art history at the China Academy of Arts, explored the influence of American art in post-reform era China in his paper entitled, "Art History: Taste, Image, and Identity." He presented two transnational case studies: the first on He Duoling and Andrew Wyeth, and the second on Wang Guangyi and Andy Warhol. He argued that although these paired artists share superficial resemblances, there are fundamental differences in their respective starting points and intentions. The grassy field in Wyeth's Christina's World is a seed planted in He Duoling's early memories; yet by studying Wyeth's works, Duoling found himself. Wang Guangyi's expression of Pop is not derived from

I4 See, for example, Norman Bryson, Word and Image: French Painting of the Ancien Régime (Cambridge: Cambridge University Press, 198I) and Tradition and Desire: From David to Delacroix (Cambridge: Cambridge University Press, 1984). 
Fig. 6. Audience and participants, 2016 Hangzhou Conference.

Warhol's understanding of consumer culture; instead, it is grounded in Guangyi's interpretation of the political and cultural ecology of Chinese society. Considering the very different contexts and influences on the two artists,

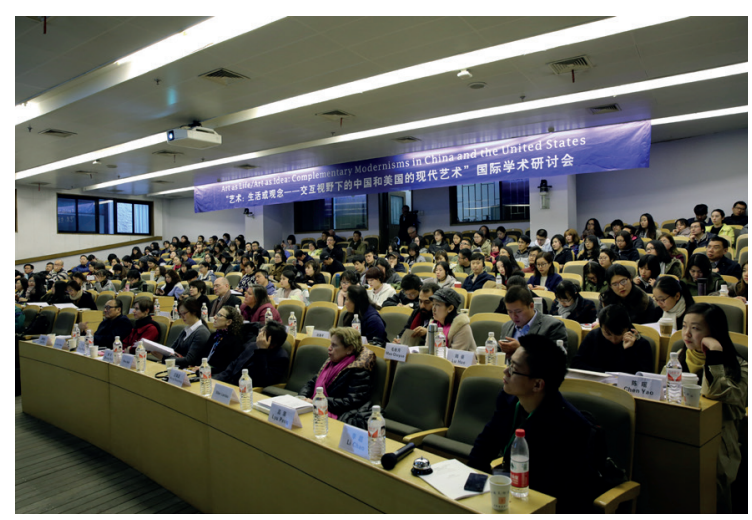
it becomes impossible to call Wang the Chinese equivalent of Warhol.

In "Construction vs. Deconstruction: Different 'Chinese-nesses' in Chinese Diaspora Artists' Works," Zhang Rui, Academy of Fine Arts, Tsinghua University, focused on the theme of cultural dislocation in work by Ai Weiwei and $\mathrm{Xu}$ Bing. As diasporic artists working in the United States during a period of intense art-world globalization, Zhang discussed Ai Weiwei's and Xu Bing's creative dismantling of traditional symbols of globalization. She argued the artists' work draws upon mundane objects of contemporary life, but also utilizes methods from ancient Chinese cultural and historical traditions. In the words of Ai Weiwei, "You must understand before you can destroy." Ai Weiwei's comments further speak to the loss or splitting of identity within diasporic Chinese contemporary art (Fig. 6).

\section{Conclusion}

As we began discussing and laying the foundations for this project in late October 20I3, we hoped it would be not only a series of transnational lectures, but also an opportunity for intellectual exchange and fellowship between Chinese and American scholars of different career stages and from a variety of educational institutions. We wanted these workshops, academic seminars, and publishing projects to help Chinese and American scholars gain access to a shared academic platform and collegial experience, and at that time, we decided to use English as the working language. We also chose to make young scholars' seminars in China and in the United States the main points of entry for the project. We strongly believed that the seminar participants should primarily be graduate students, and that lectures and seminar activities should, when possible, support and promote students' dissertation research and writing. The lead professor and students used the seminar to spark in-depth discussions, research questions, and scholarship. Given the relevance of the topics to many students' research, some participants established important academic contacts. For the international symposium at Hangzhou in 2016, we wanted Pluralistic Modernisms to serve as a framework and context for discussion, rather than style, form, or image. The breadth of this methodology allowed us to more effectively excavate and discover truths obscured in traditional narratives of modern art in 
China and the United States. Finally, we tried as much as possible to let doctoral students from both countries act as administrative assistants and participate in the planning and orchestration of the conference through outreach, organization, coordination, and publication; we ultimately envisioned the establishment of an emerging scholars' forum in the final stage of the international seminar, with speakers selected from among the participants of the two earlier seminars in 2014 (Hangzhou) and 2015 (Santa Barbara).

The goals we initially set at the beginning of this project have all, in some form or another, been accomplished. Although the scope of the project itself was not large, more than forty American scholars and graduate students representing eleven research universities across the United States participated in the seminar series. The Chinese delegation was represented in equal numbers: over forty Chinese scholars and graduate students from ten domestic specialized fine arts colleges and comprehensive research universities. With its focus on smallscale, in-depth seminars conducted in English, this international academic exchange project brought participating scholars and graduate students a number of challenges as well as benefits. These benefits included a more realistic understanding of and familiarity with each other's approach to teaching and research and of the availability of academic resources. Professional links were forged between established scholars and graduate students at both individual and institutional levels, and the project also facilitated communication and mutual cultural understanding. Participating Chinese graduate students also had an opportunity to conduct short-term dissertation research in the United States. The scholarship resulting from the project was shared across academic platforms, and scholars from both countries cited each other's research findings. The publication of this volume-the proceedings of the 2016 Hangzhou International Symposium-marks an important bookend for the project. In addition to being published in print in both China and the United States, an open-access e-book of the proceedings will make the project and its resulting scholarship available online to an even wider international audience.

Since the 1980 os, teaching and research on Western art history in China has focused on textual interpretation, historiography, and the translation of canonical works, in order to strengthen the academic foundations of the profession of art history. However, in recent years, international exchange programs like this one, with face-to-face instruction and discussion between art historians, have enabled domestic scholars to enter a more dynamic, complex, and likely more current academic world. After all, there is no substitute for person-to-person communication, collaboration, and fellowship. As with any endeavor, particularly ones of an experimental nature, there is always room for refinement and growth. One critical component of our success was identifying and recruiting the right group of scholars, both those early in their careers and those well-established, for the project's varied activities. Within the Chinese university system, the cloistering of art and the history of art presents a challenge for engaging a broader range of humanistic perspectives. To further increase the program's impact in China, we might have considered how to better integrate the seminars into the university system, especially for domestic art colleges 
and comprehensive universities. One solution to this is to establish an ongoing interdisciplinary forum or symposium for young scholars from China and the United States. There are many productive lines of inquiry to explore when art historical narratives are examined through an informed transnational perspective. We hope this initiative-especially the scholarship and camaraderie it produced-will encourage further collaboration between Chinese and American art historians in teaching, in assembling basic pedagogical and research resources, in translating key texts, in comparative or transnational art historical research, as well as in exhibition planning and community outreach, so that the benefits of this kind of art historical exchange can reach more people and generate additional important results. 


\title{
Cosmic Jokes and Tangerine Flake: Translating Andy Warhol's POPism
}

\author{
Reva Wolf and Kou Huaiyu
}

The advantages of a sociosemiotic approach to translating are to be found in...recognizing the plasticity of language, the fuzzy boundaries of usage, and the ultimate indeterminacy of meaning, which makes language such a frustrating and subtly elegant vehicle for dialogue....

\section{Introduction (Wolf)}

It is self-evident that translation involves comprehending both the meanings of words and the culture that produced these words. The complexity of the act of translation is brought into high relief when the words in question are colloquialisms or terms otherwise specific to a particular time and place. The publications of Andy Warhol and his collaborators are filled with this kind of language, which at times is deployed to evoke the hip, modern world of the I96os. These writings offer unique challenges to any translator. The challenges multiply when there seem to be enormous cultural gaps due to the distinct circumstances of the originating and receiving countries of the works in question. A case in point is the 2014 translation from English into Mandarin of Warhol and Pat Hackett's 1980 book, POPism. ${ }^{2}$ How can Warhol's life and art in the 1960s, as explained twenty years later in terms that draw heavily upon the "modern" language of "pop," be translated by and for readers in twenty-first-century China? Is any translation doomed to be a form of "displacement," as the poet Kenneth Goldsmith suggests?3 One way forward is through a process of discussion and collaboration. Collaboration, if not always smooth and easy, can be especially rewarding and illuminating.

I Eugene A. Nida, "Theories of Translation," TTR: Traduction, terminologie, redaction 4, no. I (199I): 27-28.

2 Andy Warhol and Pat Hackett, POPism: The Warhol '6os (New York: Harcourt Brace Jovanovich, I980).

3 Kenneth Goldsmith, "Displacement Is the New Translation," Rhizome, June 9, 20I4, http://rhizome.org/editorial/20I4/jun/og/displacement-new-translation/. Goldsmith's essay has been republished in book form as Against Translation: Displacement Is the New Translation (Paris: Jean Boîte Éditions, 20I6), now accompanied (to ironic effect) by translations of it into French, Spanish, German, Chinese, Japanese, Russian, and Arabic. 


\section{Reading Warhol: What I Learned from Warhol's Concept of Pop (Kou) ${ }^{4}$}

At the end of POPism, when talking about the situation in 1969 America, Warhol writes: "All the morality and restrictions that the early superstars had rebelled against seemed so far away-as unreal as the Victorian era seems to everybody today. Pop wasn't an issue or an option for this new wave: it was all they'd ever known." Born in China in the I980s, by the time I reached my twenties, "morality and restrictions" of a different kind were in place, and they troubled me a lot. When I was a child, I was taught not to pay attention to material enjoyment or to one's appearance, but to one's spiritual world and inner qualities. However, with the growing success of China's reform-and-opening-up policies, my country enjoyed a remarkable economic boom. By 2004, when I entered the university, I found myself in an awkward situation: on the one hand, I wanted to go to fancy restaurants and wear fashionable clothes; on the other hand, I felt that indulging in these pleasures was to a certain degree morally incorrect. So I really needed a reason to move on. But for many years, I didn't find it.

In 2009 I came across the Chinese translation of The Philosophy of Andy Warhol. ${ }^{6}$ It vaguely seemed to me the reason I had been looking for was there in this book. So I read two other books by Warhol: America and POPism. ${ }^{7}$ From his books and his works of art, I finally saw the significance of consumerism and successfully persuaded myself that consumption beyond a basic level is not morally incorrect.

To explain why Warhol's work had such an effect on me, we have to have an understanding of Warhol's own experience of being poor when he was a kid and how that to a large degree shaped his own sensibility. This is a sensibility reflected in his works of art and later in his books. I've selected several passages from his books as examples:

I confront the problem of how to look at a maid only when I'm staying at a European hotel or when I'm a guest at somebody else's house. It's so awkward when you come face to face with a maid. I've never been able to pull it off. Some people I know are very comfortable looking at maids and even telling them what they'd like done, but I can't handle it. When I go to a hotel, I find myself trying to stay there all day so the maid can't come in. I make a point of it. Because I just don't know where to put my eyes, where to look, what to

4 The full story of my translation of Warhol was not told at the 2016 Hangzhou conference on "Complementary Modernisms" due to time limits, but you may read it here: https://www.douban.com/note/589442074/.

5 Warhol and Hackett, POPism, 298.

6 Andy Warhol, The Philosophy of Andy Warhol (From A to B and Back Again) (New York: Harcourt Brace Jovanovich, 1975).

7 Andy Warhol, America (New York: Harper \& Row, I985). 
be doing while they're cleaning. It's actually a lot of work, avoiding the maid, when I think about it. ${ }^{8}$

My favorite simultaneous action is talking while eating. I think it's a sign of class. The rich have many advantages over the poor, but the most important one, as far as I'm concerned, is knowing how to talk and eat at the same time.... The rich somehow manage to work it out but I just can't do it. They are never caught with an open mouth full of food but that's what happens to me. ${ }^{9}$

Looking at store windows is great entertainment because you can see all these things and be really glad it's not home filling up your closets and drawers.

And if you don't have much money and it makes you depressed to see all the stuff you think you want, just go to the wholesale districts where the signs say "No Retail" and try to buy something and have the stores kick you out. ${ }^{\text {IO }}$

America was published in 1985 , when Warhol was 57. What kind of man would make a joke like this when he was already 57 ? I would say a man once troubled by the fact that there were many things he wanted but could not afford. It seems that even after so many years of being rich and famous, he still felt compelled to make a joke as a way to clear up those unpleasant experiences he had had.

As the son of a working-class immigrant family from Eastern Europe, he couldn't even have enough candy when he was small." So when he grew up, he really saw the beauty of mass production, which provides commodities of good quality at an affordable price. Thus even the common people can have the material enjoyment that the very rich have. As he puts it, using Coke as an example:

What's great about this country is that America started the tradition where the richest consumers buy essentially the same things as the poorest. You can be watching TV and see Coca-Cola, and you can know that the President drinks Coke, Liz Taylor drinks Coke, and just think, you can drink Coke, too. A Coke is a Coke and no amount of money can get you a better Coke than the one the bum on the corner is drinking. All the Cokes are the same and all the Cokes are good. Liz Taylor knows it, the President knows it, the bum knows it, and you know it. ${ }^{12}$

Another familiar image Warhol used was the one of Marilyn Monroe. To me, the message is more or less the same as his Coke bottles- that you can enjoy the beauty of Marilyn Monroe with very few or even no expenses. You just buy

8 Warhol, The Philosophy of Andy Warhol, IO2.

9 Ibid., I99-200.

Io Warhol, America, 2I.

II Warhol, The Philosophy of Andy Warhol, IO3.

84 I2 Ibid., IOO-IOI. 
a movie ticket or turn on the TV, and there you see and enjoy the beauty of Monroe:

Rich people can't see a sillier version of Truth or Consequences, or a scarier version of The Exorcist. You can get just as revolted as they can-you can have the same nightmares. ${ }^{\mathrm{I3}}$

Through his works of art, Warhol was saying: consciously enjoy in your daily life the beauty of those things made possible by modernization, such as mass-manufactured commodities and the movies and TV programs of the culture industry. Look at them and realize you are in a new era. This is an era of equality. Not only is it political equality, but now you buy the same products and watch the same movies as everyone else, so it is economic and cultural equality as well. You are not restrained any more, so go out there and try new things you are interested in.

The main focus of Henry's life was still art, and the main focus of mine was Pop-Pop anything. ${ }^{14}$

The Pop idea, after all, was that anybody could do anything, so naturally we were all trying to do it all. Nobody wanted to stay in one category; we all wanted to branch out into every creative thing we could - that's why when we met the Velvet Underground at the end of ' 65 , we were all for getting into the music scene, too. ${ }^{\text {Is }}$

As I understand it, Warhol's concept of Pop consists of two layers. The first consists of a movement from life to art. You perceive the beauty of this era of equality embodied in mass-produced commodities and stars made by the cultural industry. And you express your enjoyment of this beauty in your works of art. The second layer consists of conscious actions in this era of equality, in enjoying life, trying out new things, and figuring out your own way of living, thus in effect making a contribution to the beauty of this era. It was this concept of Pop that finally made me feel that I had a tenable reason to learn to become a consumer, so I learned to do just that. What sorts of difficulties I encountered during the process of becoming a consumer, the complexities of each sort of difficulty, and how the shopping experience is different in China than it is in America are all related, interesting topics I don't have the space to go into now.

\section{Reading Together: Translation as Collaboration (Wolf)}

Kou Huaiyu first contacted me in August 2013, as he was finishing his translation of POPism, seeking advice on how to translate several words, phrases, and

I3 Ibid., IOI.

I4 Warhol and Hackett, POPism, I93.

I5 Ibid., I34. 
colloquialisms about which he was uncertain. In an e-mail exchange extending over several months, we worked together to make sense of the language in Warhol and Hackett's book. In the process, I was startled to discover that there were passages in the book that I did not understand, despite having read POPism a number of times. Kou's questions led me to a new appreciation of the book's richness and complexity and to see that the book's words-and perhaps above all, the words hardest to translate-play an important role in creating an image of being "modern" in the United States of the I96os. Four types of language featured in this book caused some of the most fascinating translation difficulties and will be the focus of my discussion: (a) time-bound terms; (b) inventive uses of colloquialisms; (c) unusual names of places and people; and (d) historically specific descriptions and allusions.

Before turning to examples within each of these four categories, I will say a little about my own first encounter with POPism. Though Kou did not know it when he contacted me, Warhol and Hackett's book occupies a special place in my life. I acquired my copy of the book in 1980, the year it was published, as a young graduate student, and without imagining that one day I would write about Warhol—not to mention, specifically about the role of words and language in his life. ${ }^{16} \mathrm{~A}$ bookstore a few blocks away from my graduate school in New York City, Books and Company on Madison Avenue and 74th Street, located next door to the Whitney Museum of American Art, had a stack of signed copies and I knew that I had to have one. Since then, I have read POPism for distinct purposes at different points in my life. But only Kou's questions about the meanings of particular words and phrases in the book allowed me to appreciate Warhol and Hackett's multi-layered and sometimes oblique use of language.

An important component of the language in POPism is that it weaves together many voices, having been based partly on interviews that Hackett conducted with Warhol's friends and colleagues of the 1960s. ${ }^{17}$ Their stories become part of the fabric of POPism through the recurrence of rhetorical terms used to indicate dialogue. Here is a handful of examples (others are sprinkled throughout this study):

De told me once

Henry said to me

David Bourdon complained to me once

Taylor confessed to me a couple of years later

I6 This work includes: Andy Warhol, Poetry, and Gossip in the I96os (Chicago: University of Chicago Press, 1997); "Introduction: Through the Looking-Glass," in I'll Be Your Mirror: The Collected Andy Warhol Interviews, ed. Kenneth Goldsmith (New York: Carroll \& Graf, 2004), xi-xxxi and 403-9; and "I'm OK-You're OK': Andy Warhol, Transactional Analysis, and Books," in Reading Andy Warhol: Author, Illustrator, Publisher, ed. Nina Schleif (Munich: Brandhorst Museum, in association with Hatje Cantz Publishers, 20I3), 258-7I.

I7 David Bourdon, Warhol (New York: Harry N. Abrams, 1989), 386. 
Stanley once reflected

Nicky told me

Henry told me years later

Danny said

Mel told me later

Nico told us

Danny remembers

Paul reflected

Larry Rivers once said to $\mathrm{me}^{\mathrm{18}}$

In one of the few reviews of POPism that commented at all on its use of language (however minimally), the novelist Joyce Carol Oates, picking up on this "so-andso said" language, characterized Warhol as presenting himself "chattily, informally," though she strongly disliked both Warhol's art and his book, describing his "delivery" in POPism as "less deadpan than simply dead." ${ }^{19}$ Another review, more positive, by the New Yorker art chronicler Calvin Tomkins, viewed POPism as something "like a novel" — no doubt on account of this same "so-and-so said" terminology—adding that the "dialogue is terrific." ${ }^{20}$ It would be reasonable to assume that a book written with such qualities would be easy to translate. I recently ran into a poet friend who is a Warhol aficionado and he doubted whether POPism would be hard to translate. The analysis that follows shows why one might make this assumption, but most especially, why this assumption is false. I hope the analysis also will show why we read something in our own language more carefully-better, that is—when we read it alongside a translator.

\section{(a) Time-Bound Terms}

I begin this examination with terms specific to I960s U.S. sub-cultures. A term commonly employed in the r96os is "cosmic joke." In POPism, the term is used in a discussion of the hallucinogenic drug LSD. Warhol observed that his film collaborator Paul Morrissey blamed LSD for the decline of humor in the sixties. He said, "the only person on LSD who had a sense of humor left was Timothy Leary. [...] Everybody seemed to be taking the Cosmic Joke so seriously they didn't want to make little uncosmic jokes." ${ }^{21}$

I8 Warhol and Hackett, POPism, 4, I8, I9, 38, 53, 58-59, 77, 97, I24, I45, I54, I70, and 186 , respectively.

I9 Joyce Carol Oates, "POPism: The Warhol '6os, by Andy Warhol and Pat Hackett," The New Republic, February 2, 1980, 32.

20 Calvin Tomkins, "The Art World: The Art Incarnate," The New Yorker, May 5, I980, II4. Tomkins even proposed that POPism was "arguably the best piece of work that Warhol has yet given us, in any medium."

2I Warhol and Hackett, POPism, I69. 
Fig. I. Tom Wolfe, The Kandy-Kolored Tangerine-Flake Streamline

Baby, cover. New York: Farrar, Straus and Giroux, 1965.

The statement that the cosmic joke was being taken "seriously" is a good example of Warhol's love of irony and paradox. ${ }^{22}$ But this point is no help with the question of how to translate "cosmic joke." ${ }^{23}$ The term was, like LSD, especially popular in the I96os. However, I was startled to discover that "cosmic joke" already had been in circulation and had become popular at an earlier time, in the late nineteenth century, when several examples appeared in English-language literature. ${ }^{24}$ Life already could be a "cosmic joke" in the nineteenth century, but, assisted by LSD in the I960s, the phrase acquired a new and modern significance, with the old usage all but forgotten.

Another term of the I960s, no less easy to un-

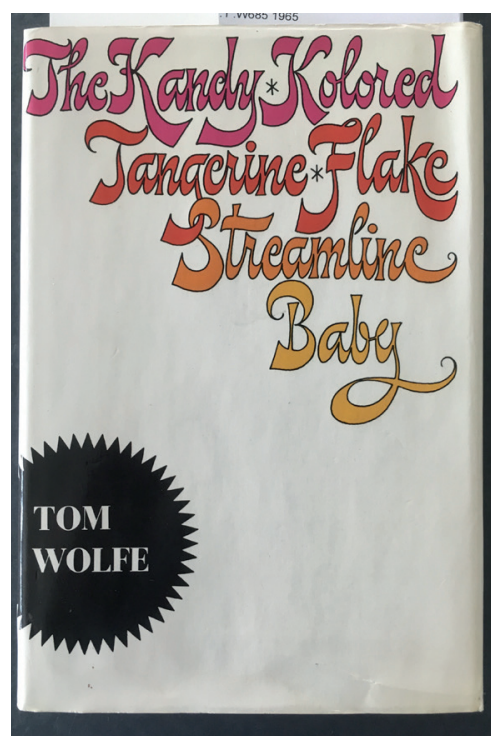
derstand, if more concrete and narrow in its meaning and usage, is "tangerine flake." ${ }^{25}$ This term was popularized by the writer Tom Wolfe in the cover story of his 1965 collection of essays, The Kandy-Kolored Tangerine-Flake Streamline Baby (Fig. I). The story is about the micro-world of custom cars that flourished at the time in California, featuring the "biggest name in customizing," George Barris. Barris painted a favorite of his custom cars in a metallic automobile paint color that he called "tangerine flake." But without knowing that "tangerine flake" is a highly specialized color name, we are left with two words that together are nonsensical: a citrus fruit and a small thin object.

Wolfe viewed Barris's custom cars as both modern and pop; he even likened them to art, observing that upon entering Barris's body shop, "pretty soon you realize you're in a gallery," adding that Barris and other custom-car makers, like Picasso, have "made a lot of money" through the reproductions of their cre-

22 This is in contrast to Joyce Carol Oates' claim, in her review of POPism, that the book is an "absolutely uninflected unironic 'memoir" (32).

23 Kou Huaiyu established through his own research that "cosmic joke" connotes a pessimistic view of life (God's cosmic joke): Kou Huaiyu, e-mail queries to Reva Wolf, August 24 and 29, 2013; e-mail responses from Wolf to Kou, August 27 and 29, 2013.

24 For an example from 1885, see under "energize, v.," Oxford English Dictionary Online. "Cosmic joke" does not appear in the $O E D$ as a term on its own. For an overview of the "cosmic joke" vision in late nineteenth- and early twentieth-century literature, see Alexander Welsh, "Realism as a Practical and Cosmic Joke," NOVEL: A Forum on Fiction 9, no. I (Autumn 1975): 23-39.

25 Kou Huaiyu, e-mail query to Reva Wolf, August 24, 2013; e-mail response from Wolf to Kou, August 27, 2013. 


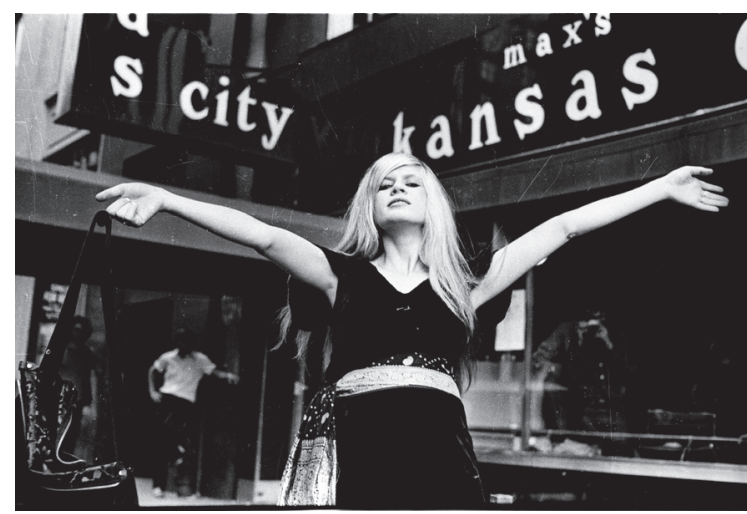

Fig. 2. Anton Perich, Andrea Feldman, Max's Kansas City, 1972. Courtesy of Anton Perich.

ations - in Barris's case, in the form of to-scale model toy cars. ${ }^{26}$ Embedded, then, in the term "tangerine flake," is an equation of modern art and popular culture-a perfect match for Warhol's sensibility. ${ }^{27}$

\section{(b) Inventive Uses of Colloquialisms}

POPism contains several instances of colloquialisms employed with a twist: either used in unexpected contexts or changed by one word so that the original is recognizable even as a new meaning has been attached, which is itself dependent upon and in dialogue with the meaning of the original. ${ }^{28}$ An example of an idiom used in an atypical context is "heading for the big time." Ordinarily, this expression would refer to an ambitious person's quest for fame and success: an actor might wish to "make it big" or "head for the big time." Andrea Feldman (Fig. 2), a troubled young woman who acted in some of Warhol's films, used this expression, instead, to suggest redemption after death-eternal success, that is - according to reports that appeared following her 1972 suicide. In an obituary published in the New York weekly paper, The Village Voice, Feldman's friend

26 Tom Wolfe, "The Kandy-Kolored Tangerine-Flake Streamline Baby," in The Kandy-Kolored Tangerine-Flake Streamline Baby (New York: Farrar, Straus and Giroux, 1965), 83, 94. Wolfe's article was originally published as "There Goes (VAROOM! VAROOM!) that Kandy-Kolored (THPHHHHHH!) Tangerine-Flake Streamline Baby (RAHGHHHH!) Around the Bend (BRUMMMМMMMMMMMMMM......)," Esquire 60, no. 5 (November 1963): II4-2I.

27 However relevant this confluence of modernity and pop is to the spirit of the book POPism and to the challenges it poses to any translator, the term "tangerine flake" has nothing directly to do with why the title of Tom Wolfe's book is mentioned in POPism. The reason Warhol and Hackett mention Wolfe's book is that it contains an essay about Warhol's associate Jane Holzer: "The Girl of the Year," in The Kandy-Kolored Tangerine-Flake Streamline Baby, 204-20, originally published in New York (the New York Herald Tribune Sunday supplement), December 6, I964, 8-II. For Warhol and Hackett's reference to Wolfe's book, see POPism, 133 .

28 Chi Ren and Hao Yu have proposed that idioms are societal and not individualized, in "Translation of English Idioms from the Perspective of Cultural Context," Cross-Cultural Communication 9, no. 5 (2013): 79. However, the examples in POPism of altered idioms show that they can become individualized, if still in dialogue with the societally understood originals, through the act of creative alteration. 
Geraldine Smith explained that Feldman had "jumped to her death [...] from a I4th-floor window...taking with her a crucifix and Bible she found in a church a few days before." Smith reported that "Andrea left a note [...] saying [...] 'I'm going for the bigtime. I hit the jackpot!'”29 In POPism, selected information and terminology from this obituary is repeated: "She said she was "heading for the Big Time' and then jumped out the fourteenth-floor window, clutching a Bible and a crucifix." 30 The challenge for the translator comes with Feldman's uncommon - and poignant — application of the expression.

Equally challenging and evocative are the cases in which one word of a familiar expression is changed. Warhol and Hackett quote the rock musician Lou Reed as stating in 1966 to music impresario Danny Fields, who had just been made an editor of a teen magazine, "And to think you launched your career... getting out the wrong side of a limousine." ${ }^{\mathrm{I}}$ What might this phrase mean? To be born on the "wrong side of the tracks" means to be born in the wrong neighborhood, or into poverty. To "wake up on the wrong side of the bed" means to wake up grumpy. What would it mean, then, to get out on the "wrong side of a limousine"? Perhaps to have everything going for you — as connoted by the limousine as a luxury car - and to not take advantage of it? ${ }^{22} \mathrm{Or}$, maybe to be grumpy, even though given every advantage? Or, might the skewed idiom be an indirect way to reveal that Danny Fields is gay? Or, yet again, might it just signify that Fields did not know proper manners?

29 Geraldine Smith, "Andy Feldman, 1948-72," The Village Voice, August 17, 1972.

30 Warhol and Hackett, POPism, 299.

3I Ibid., I54.

32 Kou Huaiyu, e-mail queries to Reva Wolf, August 24 and 29, 2013; e-mail responses from Wolf to Kou, August 27 and 29, 2013. (Kou: "Does Lou Reed mean that he doesn't think Danny's settling down with a career is a good decision?" Wolf: "I don't think so. But the expression 'wrong side of a limousine' is unusual. Here's my best guess: it is a play on the expression, 'wrong side of the tracks.' If you are born on the 'wrong side of the tracks,' it means you are born in a poor and bad neighborhood. With that idea in mind, if you get out of the 'wrong side of a limousine,' you are born into privilege but make a bad choice. But Reed says this was at the beginning of his career, not the present, as referred to in the passage you quote, I think." Kou: "I think when Reed says that, it refers to the present, as 'At Ann Arbor, we met up with Danny Fields, who'd just been made the editor of a teenage magazine, Datebook.' Danny Fields had just got this job and started his career. So 'the present' was 'the beginning of his career'." Wolf: "I see what you mean. Perhaps Reed means that this particular career is not good [not a career, generally]. I would need to dig deeper into things to fully understand the passage. Perhaps you can look into what else Warhol says about Fields in POPism, to better contextualize the passage in question. If you still have trouble, I can do some additional research when I have a little more time.") 
An idiomatic expression can have multiple meanings, as well may the altered idiom "wrong side of the limousine." ${ }_{33}$ To translate an idiom is hard; to translate one that has been transformed, as this one has, is that much more difficult. Translation theorists have proposed three principles for translating idioms: (I) do not treat idioms too literally; (2) look for equivalencies in the target language that will convey the meaning to your audience; and (3) maintain the "artistic" or "original rhetorical effect" as much as possible. ${ }^{34}$ In the case of "wrong side of a limousine," a key question is how to translate the phrase so that its character as a transfigured idiom is retained, as this detail is central to its art and rhetoric.

Another example in POPism of an idiom altered by swapping one word concerns the U.S. film industry. In contrast to the "underground" films Warhol made in the 1960s, those made in Hollywood were rated to comply with the Production Administration Code. According to Warhol and Hackett, in order to avoid the censorship and work around the image-making needs of the film industry, the major film companies established sub-companies in different names for their "dirty" films. The companies could thereby "moralize all the way to the bank." ${ }_{5}$ To "moralize all the way to the bank" is an amusing modification of the idiom "to laugh all the way to the bank" - to make a lot of money easily, perhaps at the expense of others. To "moralize all the way to the bank" implies that hypocrisy was involved in the profit. ${ }^{36}$

\section{(c) Names of Places and People}

Names can pose puzzles for the translator as much as idioms, although in the case of names, the puzzles usually — though not always — are easier to solve. To translate the name Gramercy Arts Theatre, where Warhol's film Sleep was shown in 1964, requires the knowledge that Gramercy is the name of the neighborhood in Manhattan where the theater was located ( 138 East 27th Street). Without this information, a literal translation from the French "gran merci" becomes an option, but in this instance perhaps a phonetic translation would be suitable. ${ }^{37}$ It is noteworthy that in China, there is a long and interesting history of transliteration, or what is called "not-translation" (bùfän), going back to sixth- and seventh-century translations of Buddhist scriptures. ${ }^{38}$

33 On the difficulties of translating idioms containing multiple meanings, see Lanchun Wang and Shuo Wang, "A Study of Idiom Translation Strategies between English and Chinese," Theory and Practice in Language Studies 3 (September 2013): 1691.

34 Ibid., I695-96.

35 Warhol and Hackett, POPism, 204.

36 Kou Huaiyu, e-mail query to Reva Wolf, August 29, 20I3; e-mail response from Wolf to Kou, August 29, 2013. (Kou: "Does 'to the bank' mean making a lot of money?")

37 Kou Huaiyu, e-mail query to Reva Wolf, October 17, 2013; e-mail response from Wolf to Kou, October 29, 2013.

38 On this history, see Martha P. Y. Cheung, "Translation as Intercultural Commu- 
Another difficult to translate word in POPism designating a place in Manhat$\tan$ is "Babushkaville." "39 "Babushkaville" is a made-up word connoting something less than fashionable..$^{\circ}$ The nuances of this connotation reside in the association of the babushka—a scarf worn around the head and tied under the chin—with Eastern Europe, and particularly Poland, Russia, and the Ukraine, where the babushka traditionally was worn by the peasant class. The neighborhood of the East Village in Manhattan that Warhol and Hackett called "Babushkaville" had been populated by immigrants from these countries and in the 1960s, it was also a "cool" neighborhood of the in-crowd - a main location in this neighborhood where Warhol's band, the Velvet Underground, performed, in fact, had been the Polski Dom Narodowy, or, Polish National Home, known popularly as The Dom. In POPism, the irony of a hip Babushkaville is fully exploited. Not only is the old world fused with the new, and the unfashionable with the cool, but also Warhol's past with his present, since his parents were from Eastern Europe. ${ }^{41}$ In fact, there are photographs of his mother wearing a babushka.

A related kind of name difficulty results from the aim to capture non-native speakers within POPism through the phonetic spelling of heavily-accented speech. Warhol and Hackett used this approach when quoting the words of Nico, the deep-voiced German singer who performed with the Velvet Underground. According to Warhol and Hackett, Nico lamented that on the first Velvet Underground album she did not sound sufficiently like "Bawwwhhhb Deee-lahhn," referring to the famous folk-rock musician, Bob Dylan. ${ }^{42}$ Without knowing the particulars of music culture of 1966 in the United States, it can be difficult to decode "Bawwwhhhb Deeelahhn." ${ }^{33}$ Warhol and Hackett used such phonetic spelling in order to represent spoken language. In this regard, it functions like the already-noted recurring use of "he said," "she told me," and

nication: Views from the Chinese Discourse on Translation," in A Companion to Translation Studies, eds. Sandra Bermann and Catherine Porter (Chichester: Wiley-Blackwell, 20I4), I85-87, I90niı.

39 Warhol and Hackett, POPism, 157.

40 Kou Huaiyu, e-mail query to Reva Wolf, October I7, 2013; e-mail response from Wolf to Kou, October 29, 20I3. (Kou: "Is Babushkaville a coined up word? Babushka is 'A woman's head scarf, folded triangularly and worn tied under the chin' and 'ville' is to represent the quality of the scarf, so together it means something unfashionable, unhip, far from trends.")

4I E-mail from Reva Wolf to Kou Huaiyu, October 29, 2013.

42 Warhol and Hackett, POPism, 166.

43 Kou Huaiyu, e-mail queries to Reva Wolf, August 24 and 29, 2013; e-mail responses from Wolf to Kou, August 27 and 29, 2013. In his August 29th e-mail, Kou observed that other passages within POPism in which Nico's speech is similarly written phonetically in order to convey her drawn-out pronunciation of English had been easy for him to decode since the spellings only repeated certain letters (and did not involve other changes): "fooood that flooooats in the wiiine" (I45) and "the Red Seeeea...paaaaarting" (I62). On Nico's "very strange way of speaking," see POPism, I45. 
other similar phrases. Indeed, the conversational tone of POPism is one reason it is so very readable. Yet the speech sounds that bring POPism to life can pose a special problem for the translator. Translation scholar Sunny Tien observes in a study of a Mandarin rendition of George Bernard Shaw's play Pygmalion (1913) that Shaw's transcriptions of Cockney dialect and conversational sounds, such as "ah-ah-ah-ow-ow-ow-oo" and "nah-ow" are so difficult to translate that they are omitted, despite their importance for character development and tone. ${ }^{44}$

Still more confusing for any translator of POPism are the instances in which a person goes by more than one name, and the real and fictional names are then used interchangeably. So it is with Warhol's close friend Brigid Berlin, who sometimes goes by the name "Brigid Polk," and other times, "The Duchess." The Duchess is both the name of a person Warhol had met at the San Remo Coffee Shop in Greenwich Village, and also that of Brigid Berlin's character in the movie The Chelsea Girls (1966). However, the stars of Warhol's film largely play themselves, with fiction and reality turning into a tangled mess, impossible to unravel, and quite deliberately on Warhol's part. ${ }^{45}$

\section{(d) Historically Specific Descriptions and Allusions}

A calculated confusion of fiction and reality again may be at play in a story within POPism concerning the June 5, 1968 assassination of Robert F. Kennedy, at the time a presidential candidate, and the shooting of Warhol just a few days earlier, on June 3rd. According to this story, on the day of the Kennedy assassination, Brigid Berlin ran into the artist Robert Rauschenberg and told him the news, to which he responded, weeping, "Is this the medium?" She reported his words to Warhol, who wondered, "What was that supposed to mean?" Berlin then explained, "First you, then Bobby Kennedy....Guns." ${ }^{46}$ Alas, her explanation of "the medium" hardly clarifies what Rauschenberg meant. But it provides some clues, allowing us to at least make a guess. Might the statement somehow refer to the media theorist Marshall McLuhan's famous statement, "the medium is the message," from his 1964 book, Understanding Media? Alternately, could "the medium" refer to some kind of supernatural power or spirit, or even allude to a science fiction movie then showing? ${ }^{28}$

44 Sunny Tien, "Pygmalion, Humor, and the Translation of Dialect," Translation Quarterly 75 (March 2015): 5, 7, I2.

45 Gary Comenas notes, "Brigid played the part of The Duchess in The Chelsea Girls and was sometimes referred to by that name in real life." See warholstars. org, page II: http://www.warholstars.org/warholfilm/warholır.html. As Kou puts it, "Warhol wrote in a way that the Duchess and Brigid Berlin are two people, but it seems Brigid Berlin IS the Duchess instead of just playing as the Duchess in Chelsea Girls": e-mail query to Reva Wolf, August 24, 2013.

46 Warhol and Hackett, POPism, 276.

47 Kou Huaiyu, e-mail query to Reva Wolf, October 3I, 20I3; e-mail response from Wolf to Kou, November I, 20I3.

48 Kou Huaiyu, e-mail query to Reva Wolf, October 17, 2013; e-mail response from 
Fig. 3. The Medium, 1951, a film by Gian Carlo Menotti, produced by Walter Lowendahl, Radiotelevisione italiana, Orchestra sinfonica di Roma.

In fact, there is a film called The Medium, directed by the Italian composer Gian Carlo Menotti, and made in I95I based on Menotti's own opera of the same title, which was first performed in 1946 (Fig. 3). In The Medium, often described as

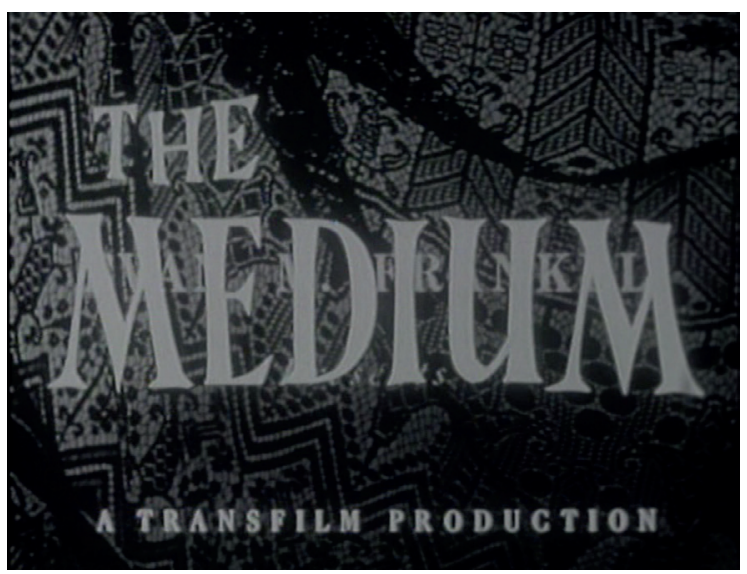
a "film noir opera," a scam fortune teller, Madame Flora, holds séances to prey on parents who have lost a child. Madame Flora, however, through a sequence of events, goes mad, and at the end of the story she shoots and kills a mute servant boy, Toby. Given this storyline, is it possible, then, that Rauschenberg had Menotti's work in mind when he asked, "Is this the medium?" Rauschenberg likely knew Menotti, and certainly knew of him. ${ }^{49}$ Furthermore, although The Medium predates the I96os, the film aired on TV several times during this decade, while the opera was performed in New York City in 1961, 1963, and 1967..$^{\circ}$ Moreover, in the late 1970s, while Warhol and Hackett were composing POPism, the first English-language biography of Menotti, by John Gruen, was published. ${ }^{\text {.I }}$ (Gruen also wrote about art, and he was a photographer, portraying both Rauschenberg and Warhol on more than one occasion, writing about them, and operating within the same social networks.) $)^{52}$ A reviewer of Gruen's book praised The Medium as a work that still

Wolf to Kou, October 29, 2013.

49 Menotti had established what became a famous art festival in Italy, the Spoleto Festival of the Two Worlds, and in 1958, at the first Festival, Rauschenberg's famous 1955 "combine painting," Bed, was to have been included in an exhibition of work by young artists from the U.S. and Italy (these being the "Two Worlds" in the Festival's name); however, in an often-told story, Festival officials refused to show Bed and placed it in a storage room. See https://www.rauschenbergfoundation.org/artist/chronology-new. Rauschenberg also contributed to the brief "Album Leaves" that Menotti devised for the Festival: see John Gruen, Menotti: A Biography (New York: Macmillan, 1978), 138.

50 New York Times TV listings for The Medium include: April II, 1960; April 8, 1962; November 20, 1963; and May 18, 1965. Listings or reviews of live performances of the opera in New York appeared in The New York Times on March 25, 1961, May 6, 1963, and May 6, 1967. Menotti's The Medium even showed up as a clue in a crossword puzzle in the February 6, 1966 New York Times.

5I See note 49 above.

52 For example, see John Gruen, The New Bohemia, with Photographs by Fred W. McDarrah (1966; rpt. Chicago: a cappella books, 1990), 147-48 (on Rauschenberg) and 93-96 (on Warhol). 
held audiences and singled out something else about the opera that would have resonated with Warhol: in New York, it was first performed not in a concert hall but on Broadway. ${ }^{53}$ In other words, Menotti, like Warhol after him, created work that fused high art and popular culture.

In the fiction of Menotti's opera, Madame Flora becomes increasingly paranoid and psychologically unhinged, an occurrence that echoes the reality of the woman who shot Andy Warhol, Valerie Solanas. Warhol's description of Solanas's physical appearance on the day she visited his studio, the Factory, and shot him, contains some revealing if encoded details. For example, Warhol noted that she "was wearing pants, more like trousers (I'd never seen her in a dress)." 54 The distinction between "pants" and "trousers" served to communicate, to an audience of 1980 - still less open about sexual preference than we are today-that Solanas was a lesbian. 55

A more tricky translation issue in POPism concerns guns and the particularities of United States social and legal history regarding the Black Panthers, a group established in 1967 to seek equality for African Americans. In POPism, readers are told how the Black Panthers wielded guns as a means of self-defense, making use of a then-in-place California law stipulating that, as Warhol and Hackett put it, "it wasn't against the law to carry guns openly, just to conceal them." ${ }^{6}$ It may be surprising even for U.S. citizens to discover the existence of this law (which was repealed shortly after the Black Panthers exercised it). ${ }^{77}$ On top of that, the phrasing in POPism — "just to conceal them" — can easily be taken to mean the opposite of what was intended..$^{8}$ Understandably, a translator might be hard-pressed to conclude that the California law permitted citizens to carry guns unconcealed. As an aside, it is worth noting that Warhol is often perceived as out of tune with the political upheaval of the 1960s, of which this

53 John Yohalem, "Successful Heretic," New York Times Book Review, June I8, 1978, I5, 35 .

54 Warhol and Hackett, POPism, 272. (Warhol and Hackett spell Solanas, "Solanis," throughout POPism.)

55 Kou Huaiyu, e-mail queries to Reva Wolf, August 29 and September 2, 2013; e-mail responses from Wolf to Kou, August 29 and September 9, 2013.

56 Warhol and Hackett, POPism, 233.

57 The Mulford Act instated the repeal, under then Governor Ronald Reagan. In 1968, the federal government followed suit with the Gun Control Act.

58 Kou Huaiyu, e-mail queries to Reva Wolf, August 24 and 29, and September 2, 20I3; e-mail responses from Wolf to Kou, August 27 and 29, and September 9, 2013. (Kou: "Thank you. Now I can see the question rose up from my inability in English.... To make sure, the sentence it wasn't against the law to carry guns openly, just to conceal them, if we make it a complete sentence, it would be: it wasn't against the law to carry guns openly, just [which means 'only'] to conceal them would be against the law. Is that correct?" Wolf: "Yes, that is correct. The sentence is phrased in such a way that it would be difficult to understand if you are not a native speaker of English": Kou Huaiyu, e-mail query to Reva Wolf, September 2, 20I3; e-mail response from Wolf to Kou, September 9, 2013.) 
story is just one manifestation. In a recent study, for example, it is claimed that in POPism, Warhol and Hackett mention "black power only as an instance of newly fashionable natural hairstyles." 59 A reading of POPism alongside a translator might prompt a more nuanced description of how the 1960 is portrayed in the book.

\section{Conclusion (Wolf)}

Interacting with a translator from a different culture is enriching as an activity that is not so much "cross-cultural" as "intercultural," to borrow the terms of the translation studies scholar Martha P.Y. Cheung. As Cheung persuasively explains it, in a discussion worth quoting at length:

"Cross" suggests movement, but not necessarily contact; the prefix "inter-," on the other hand, denotes not just movement but also contact and, more importantly, interaction. This means that "cross-cultural communication" and "intercultural communication" stand as separate and independent concepts.... To take translation/interpretation as a form of cross-cultural communication is, in my view, to stress the notion of translation as transfer, as a carrying-across of meaning. The assumption is that meaning can be transferred, in a fairly intact manner, from one language to another.... To take translation/interpretation as a form of intercultural communication, however, is to highlight the very special kind of complex communication that translation is. Translation is not automatically envisaged as a bridge or a conduit providing smooth and unproblematic traffic of ideas between peoples and cultures. Rather, the emphasis is on the interactions that occur when cultures come into contact or conflict with one another, through translation and/or interpreting. ${ }^{60}$

The discussions Kou Huaiyu and I had about translating words and phrases in POPism were exactly this kind of "intercultural" activity, affecting both sides of the dialogue. The cultural gulfs that we confronted through our discussions of Warhol's words were sometimes large.

Translations of Warhol's writings appeared at an earlier date in countries where, due to historical circumstances, the cultural gaps with the U.S. are smaller than in China, and the language less radically distinct. The Philosophy of Andy Warhol is the first of Warhol's books that was translated. A French edition was published in 1977, only two years after the English edition, while the Chinese version-which Kou mentioned as the inspiration for his translation of POPism-came out only in 2006, in Taiwan, and 2008, in mainland China. ${ }^{61}$ This

59 Gustavus Stadler, “'My Wife': The Tape Recorder and Warhol's Queer Ways of Listening," Criticism 56, no. 3 (Summer 2014): 450.

60 Cheung, "Translation as Intercultural Communication," 179-8I. 
thirty-year gap is reflected in the circulation of Warhol's art as well. In France, Warhol, and pop art generally, was embraced from the outset, and notably in exhibitions held at the Sonnabend Gallery in Paris in 1963, 1964, and $1965 .{ }^{62}$ The first high profile exhibitions of Warhol's work in mainland China were, on the other hand, quite recent: in $2013 \cdot{ }^{63}$ But it is interesting that the first French edition of POPism seems to have been published only in 2007, not long before Kou's translation. The reason for this unexpected chronology is worth investigating, and may well be due to the unique translation difficulties posed by Hackett and Warhol's book, even for those whose language is rooted in Latin.

Cheung wrote that translation, as an "intercultural" activity, is an "ideal site for the analysis of cultures in contact, conflict, contest or collision." ${ }^{64}$ I would add another term to this list: collaboration. I consider my discussions with Kou, in which he aimed for the best possible translation of a word or phrase, to be an act of collaboration. It is most curious - strange, too- that one can collaborate on parts of a translation without being able to read a single word of the target language. I do not know a word of Mandarin. In a 1999 article about the history of translation in modern China, Shouyi Fan offered some fascinating examples of the role of similar types of collaboration in late nineteenth- and early twentieth-century renditions of literary works from English into Mandarin by Lin Shu (1852-1924), who became a renowned translator. In Lin Shu's case, he "did not speak any foreign languages" (unlike Kou, who has an excellent knowledge of English), but "he penned elegant classic Chinese translations of Occidental texts with collaborators who could speak foreign tongues with varying degrees of fluency, but could not translate the works they read into the appropriate Chinese."6s Fan pointed out that similar kinds of translation collaborations were later encouraged in China, during a moment of cultural flourishing in the mid-r950s, and concluded by looking ahead, from his vantage point in the late I990s, to a renewed flourishing of translation practices in the coming years. ${ }^{66}$ Fan argued that "collective work should be encouraged, so that collaborators could pool their skills for better quality translations." ${ }^{67}$ Such collaboration is the approach

January 20, 2016.

62 The works by Warhol in the 1963 exhibit, "Pop Art Américain," included Twenty Marilyns, Marilyn in Black and White, and Big Torn Campbell's Soup Can (Black Bean). See Georg Frei and Neil Printz, The Andy Warhol Catalogue Raisonne: Paintings and Sculpture 196I-I963, vol. I (London: Phaidon, 2002), 248 (cat. no. 266), 237 (installation photograph).

63 "Andy Warhol: 15 Minutes Eternal," Beijing and Shanghai, 2013.

64 Cheung, "Translation as Intercultural Communication," I8I (see also I84).

65 Shouyi Fan, "Highlights of Translation Studies in China since the Mid-Nineteenth Century," Meta: journal des traducteurs 44, no. I (1999): 3I. On Lin Shu, see also Michael Gibbs Hill, Lin Shu, Inc.: Translation and the Making of Modern Chinese Culture (Oxford: Oxford University Press, 2013).

66 Fan, "Highlights of Translation Studies in China since the Mid-Nineteenth Century," $4 \mathrm{I}-42$.

67 Ibid., 4I. 
that Kou took when he contacted me with his queries about translating parts of POPism. Perhaps it is not a coincidence that such collaboration also is in the spirit of Warhol's version of modernity: POPism, co-authored with Pat Hackett, and based on interviews with figures in Warhol's i96os life, was itself a grand collaboration. 
认识到语言的可塑性、模糊的使用界限以及终极意义的不确定 时，可以发现社会符号学翻译方法的诸多优点，塑造了语言这 一令人困惑又曼妙优雅的对话媒介。1

\section{序言（列娃・沃尔夫）}

翻译包含理解词语的含义和产生这些词语背后的文化，这是不言而 喻的。每当产生疑惑的词语是口语，或者是特定时间、空间中的特 定术语时，翻译复杂性就大大增加了。1960 年代的现代社会，安 迪·沃霍尔与其合作者的出版物中，大量使用了这类语言，有时是 为了唤起时髦。这些文章对任何翻译者来说，都是巨大挑战。尤其 是最初产生这些令人疑惑的文字和接受它们的国家存在明显文化差 异时，翻译的挑战就更大了。2014 年，将沃霍尔与帕特 - 哈克特写 于 1980 年的《波普主义》从英文译成中文, 就是一个恰当的案例。 如何把 1960 年代沃霍尔的生活和艺术在二十年后用 “波普” 的 “现

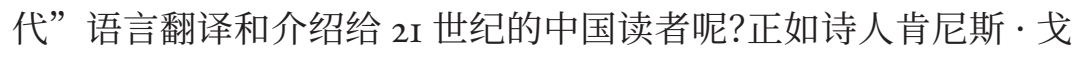
德史密斯所说的, 任何翻译都注定是一种 “替换” 形式吗 ${ }^{2}$ 有一种 方法是通过讨论与合作的过程。合作，如果说并不总是简单和顺利 的，但无疑是很有回报，且富于启发的。

1 Eugene A. Nida, "Theories of Translation," in TTR: Traduction, Terminologie, Rédaction 4, no. I (1991): 27-28.

2 Kenneth Goldsmith, "Displacement Is the New Translation," Rhizome, June 9, 20I4. http://rhizome.org/editorial/20I4/jun/og/displacementnew-translation/ 其论文 “Against Translation: Displacement Is the New Translation”已经以书籍的形式重新出版（2016 年巴黎出版社），(讽刺 的是）如今他的论文正在被翻译成法语、西班牙语、德语、中文、日语、 俄罗斯语和阿拉伯语。 


\section{第一部分安迪・沃霍尔的波普概念（寇淮禹）}

I. 波普艺术的字面含义

“波普艺术”（pop art）这个词在中文中难免让人觉得无从索解，但 在英文中却并不那么困难。Pop 一词本有 “流行的、大众的、通俗 的”之意，譬如 pop culture，意为流行文化、大众文化、通俗文化， pop music，意为流行音乐。 ${ }^{4}$ 所以 pop art 也就是流行艺术。在中 文中，“流行艺术” 可以被理解为 “流行的艺术”一虽然说起来， 波普艺术确实是一个非常流行的艺术风格，而且很可能是现代艺术 诸运动中，在一般民众的范围里波及最广、影响最大的一个艺术运

3 此文写于 2013 年《波普主义》中文译稿完成后，本拟用作《波普主 义》译者序。后来河南大学出版社通知我说外方要求中译本除了译文, 不加任何东西，所以文章就没能面世。本次杭州会议我按照大会主题, 从 complementary modernism 的角度出发，以此文为基础，加以精简 和重写，在会上用英文作了题为 Reading Warhol: What I Learned from Warhol's Concept of Pop 的发言。现在会议论文集出版, 英文部分存留会 议所用英文发言稿, 中文部分则使用 2013 年写就的原稿, 二者各有侧重, 读者可分别加以参看。

4 本文不拟深入探讨流行文化、大众文化、通俗文化这三者的语义是否有 别以及若有分别的话有何分别。一般读者可按自己的喜好拿流行文化、 大众文化、通俗文化去对应 pop culture。在本文中使用的流行文化、大 众文化、通俗文化，可以互换。不做深入探讨的原因，在于英文学术中 本就有不同理论家在不同意义上使用 pop culture 和 mass culture，而这 两个术语在译为中文时, 后者通常作 “大众文化”, 但前者则有流行文化、 大众文化、通俗文化三种常见译法 ; 此外，在中文里，不同的人也在各 自不同的理解下运用流行文化 / 大众文化 / 通俗文化。比如，我小学时 有一本杂志叫做《通俗歌曲》, 我没读过, 但那会儿觉得怪异来着一 我不明白为什么拿个贬义词来做杂志名。现在想来, 以那本杂志的立场 而言, “通俗” 自然毫无贬义, 无非是 pop 的中文对译而已, 虽然今日 “通 俗音乐”、“通俗歌曲”这类讲法相较于 “流行音乐”、“流行歌曲”而言 已经远为不常见了。流行文化 / 大众文化 / 通俗文化三者语义的复杂情 况，对于理解本文主旨并无太大关系，所以不做深入探讨。我们不妨以 列举法来了解流行文化 / 大众文化 / 通俗文化的所指:流行乐、商业电影、 电视、通俗小说、杂志、漫画、时尚等等。 
动——为免歧义，约定俗成音译为 “波普艺术”。就 pop art 这个词 原初所要表达的含义而言，无非是说 “这些艺术家用流行文化中的 形象作画” 而已 ${ }^{5}$, 如安迪·沃霍尔的创作中最广为人知的 《玛丽莲》 系列, 即是以玛丽莲 - 梦露的头像这一流行文化中的形象为题材进 行的创作。画抽象，就叫作抽象艺术，画流行文化中的形象，就叫 作流行艺术，两者的命名原则是一样的。Pop art 音译为波普艺术， 固然避免了歧义，但是一般读者，不了解波普艺术的，难免要觉得 无从索解了。

上面将波普艺术简单解释为 “用流行文化中的形象作画”，留下 了一个困难。波普艺术家的创作主题，另有一重大构成部分，即 商品。如安迪・沃霍尔的《金宝浓汤罐头》系列，以金宝浓汤罐头 形象进行丝网印刷，即为使用商品形象进行波普艺术创作的一个例 子。我们恐怕难以将汤罐头纳入到 “流行文化” 这一概念里去，汤 罐头的形象当然也就不能算是 “流行文化中的形象”，所以像《艺 术术语词典》 (Dictionary of Art Terms) 和《简明牛津艺术和艺术 家词典》(Oxford Concise Dictionary of Art and Artists) 的相关词 条下，都将波普艺术定义为利用消费主义和流行文化中的形象进行 创作的艺术 ${ }^{6}$ 。也就是说，将消费主义与流行文化并置，同时将二者 作为波普艺术创作的形象来源。与此有别的是，有学者将消费主义 视为构成流行文化的一个部分或者促成流行文化的一股力量，这样 自然也就可以将消费主义纳入到流行文化这一概念里，进而把商品 形象囊括到 “流行文化中的形象” 中去 ${ }^{7}$, 从而消解 “流行文化中的

5 关于 Pop art 这一术语的起源和原初用法的更详细的情况, 可以参看《牛 津现当代艺术词典》(Oxford Dictionary of Modern and Contemporary Art) 的 Pop art 词条。Oxford Dictionary of Modern and Contemporary $\operatorname{Art}$ (Oxford: Oxford University Press, 2009), 第 565 页。

6 Dictionary of Art Terms (London: Thames \& Hudson Ltd, 2003), 第 172 页。Oxford Concise Dictionary of Art and Artists (Oxford: Oxford University Press, 1996), 第 415 页。

7 我们恐怕会同意，在今日中国，苹果手机（iPhone）大概要算是流行文 化的一个部分，如果以iPhone 的形象来做波普艺术的创作，而说这是 在以 “流行文化中的形象” 进行创作, 大概并无不妥。不过一个麻烦是, iPhone 作为商品固然流行，却不够大众。这提示我们注意波普艺术家 
形象” 无法涵盖商品形象这一困难。《企鹅艺术和艺术家词典》(The Penguin Dictionary of Art and Artists）说波普艺术是 “对人工制品、 大众广告和传媒、现代生活的产品（亦即流行文化）作为有效的艺 术形式的接受和使用” 8 , 或者可以视为接受上述看法而对波普艺术 加以定义的一个例证。

当然，我们也可不必在辨析流行文化 / 大众文化与消费主义的 关系上大费周章。安迪 ·沃霍尔在一次访谈中，这样回答 “什么是 “波普艺术”” : “波普…艺术” …是…使用…随处可见的（popular） …形象。” 9 商品如可口可乐是随处可见的形象，电影明星如梦露是 随处可见的形象，摇滚歌手如猫王是随处可见的形象，他们都可以 成为波普艺术创作的题材。沃霍尔在谈到他于一九六三年十月乘车 横穿美国大陆的旅行时说：“我们越往西开，高速路两旁的景象就 越波普。……尽管波普到处都是一一正因如此才称得上波普......”, 也是同样的意思。现在我们再来看 “波普” 这两个字，就能体会 这不仅是简单地对 pop 的音译，还有 “波及普遍” 这样的意思在，

拿来进行创作的商品，几乎都是大众轻易可以负担得起的商品。

8 The Penguin Dictionary of Art and Artists (London: Penguin Books Ltd, I99I), 第 330 页。

9 I'll Be Your Mirror: The Selected Andy Warhol Interviews (New York: Carroll \& Graf Publishers，2004)，第 23 页。此书有中译本，但错误颇 多, 我在豆瓣网有一篇翻译批评, 可参看 : https://book.douban.com/ review/7676225/。另外，中译本未作任何交待，删去了原书两个访谈。 本文所有引自此书的字句，均由我自行翻译。中译本 : 《我将是你的镜 子一安迪·沃霍尔访谈精选》, 肯尼思·戈德史密斯编，任云莛译，三 联书店，2007。 popular一词有民间的、通俗的、流行的、大众的、普 通人可以企及的等等含义, 我这里取 “流行”义。如果这样定义波普艺术, 也就避开了分析消费主义与流行文化二者关系的麻烦。沃霍尔在《波普 主义》一书开篇说 : “波普艺术家采用的形象是随便谁沿着百老汇大街 前行都能在 0.01 秒就注意到的形象: 漫画、露天餐桌、男装长裤、名人、 浴帘、冰箱、可口可乐瓶—所有这些了不起的摩登事物。” “摩登事 物” (摩登， modern，亦即现代）来定义波普艺术的形象来源同样是一 个简便的办法。波普艺术，说到底，是对现代生活的爱。 
也就是说把 “流行的”、“大众的” 这样的意思涵盖其中了。10

2. 波普艺术是经济民主化 ${ }^{11}$ 时代的美学

为什么要拿商品形象入画? 为什么要拿它们来作创作主题? 以沃霍尔 常用主题可口可乐为例，这个工业流水线上生产的无个性商品，这 个很多人眼中无足轻重的廉价饮料，在沃霍尔眼里却是民主美国的 象征。

他说：“美国了不起的地方在于它开创了一个传统：最富有的消 费者和最贫穷的消费者基本上买的是同样的东西。你看电视，看到 可口可乐，你知道总统喝可乐，伊丽莎白·泰勒喝可乐，而你想上 一想，你也可以喝可乐。可乐就是可乐，花多少钱也买不到比街角 的流浪汉正在喝着的可乐更好的可乐。所有的可乐都一样，所有的 可乐都很好喝。伊丽莎白 - 泰勒知道，总统知道，流浪汉知道，你 也知道。” 12

他说：“美国这个概念好极了，一样东西越是平等，它就越是美 国。”13

沃霍尔的另一个创作主题，金宝浓汤罐头也是一样 : 批量生产、 标准化、售价低廉，人人皆可享用。在一九六二年的一次访谈中, 当被问及他成排的金宝浓汤罐头作品有何意味时，沃霍尔答道: “它

10 台湾将 pop art 译为普普艺术，似乎在 “普及”、“普遍” 这类意思之外, 把“通俗”一普普通通一这层意思也放进去了, 是个不错的译法。另外, “普普” 读音颇为俏皮, 与 pop art 的风格很贴切。

11 这里，民主化的意思也就是平等化。经济民主化的进程并不一定就是 收入差距缩小的过程，而更可能一如下文将提及的沃霍尔的描述 是消费差距缩小的过程，即有钱人虽然还是可以买很多穷人买不到、买 不起的东西，但是在日常生活层面，在一般生活消费品上，大家买的基 本是同样的东西。

12 The Philosophy of Andy Warhol (London: Penguin Books Ltd，2007)，第 IOO 至 IOI 页。此书有中译本，偶有小错，但整体译得不错; 本文引用 此书的部分为我自己翻译。中译本: 《安迪·沃霍尔的哲学》, 安迪·沃 霍尔著, 卢慈颖译, 广西师范大学出版社, 2008。

13 The Philosophy of Andy Warhol，第 IоI 页。 
们是我小时候有的东西。” ${ }^{14}$ 在一九六三年的一个访谈中, 当被问到 为什么要画金宝浓汤罐头时，沃霍尔回答说：“因为我过去喝它。 我过去每天都吃一样的午餐, 有二十年吧, 我想。” ${ }^{15}$ 在同年另一个 访谈中，在被问及为什么挑选金宝浓汤罐头而非其它的人工制品作 画时，沃霍尔答道: “为什么，我喝金宝汤，嗯，有二十年时间我 都是一个三明治一罐汤。” 16

沃霍尔是斯洛伐克工人阶级移民的孩子，家境并不富裕。这使 得他尤其能体会到批量生产的工业制成品的好，体会到这个经济民 主化时代的好。所以他要拿商品入画，而且并不改换它们的形象。 他希望你在画布上看到的，就是一直以来都环绕在你身边而你却习 以为常、视而不见的商品形象。在这个意义上，波普艺术无所创造， 沃霍尔说： “波普艺术拿了里面的放到外面, 又拿了外面的放到里 面。”波普艺术家做的，不过是把超市里的商品放到画布上面去了。 然而当你在画布上遭遇过这些商品形象之后，你再去超市时就无法 再以过去的眼光看待它们。波普艺术提供了一副新眼光, 当你从美 术馆离开，你身边所有的商品都改换了它们的模样。“一朝波普， 你就无法再以从前的眼光来看一块儿招牌。一旦波普, 你就无法再 以从前的眼光来看美国。” 17

3. 波普艺术欢呼文化民主化时代的到来

与工业流水线上生产的商品一样, 流行文化 / 大众文化也意味着平 等。所有人都听着同样的流行音乐，去影院观看同样的热门电影， 每晚坐在电视前收看同样的节目。“有钱人也看不到更为俊里俊气的 《问答或后果》, 或者更为恐怖的《驱魔人》。你可以像他们一样被

14 I'll Be Your Mirror: The Selected Andy Warhol Interviews，第 5 页。

15 同上, 第 18 页。

16 同上，第35 页。关于沃霍尔喝金宝浓汤一事，国内相关人士的言论往 往不确。他们或者说沃霍尔是晚饭喝汤，或者说他总是餐前一罐汤，乃 至于说他强迫自己二十年每天都要喝一罐汤。这些专家应该好好看看英 文第一手材料再说话。

17 《波普主义》, 安迪·沃霍尔和帕特·哈克特著, 寇淮禹译, 河南大学出 版社, 20I4, 第59页。 
恶心到——你们会做同样的咞梦。” ${ }^{18}$ 过去莫扎特为贵族作曲、弹琴, 今天猫王为每个人作曲、唱歌。过去贵族请画师为自己的美人儿作 画，然后挂在自家墙上，现在文化工业从全国遴选了美人儿演电影、 拍照片供你赏玩。文化成了众人享用之物。这样的文化也许肤浅, 但沃霍尔拥抱这种肤浅。

“我想到美国不再有两个分离的社会了一一个官方的、重大的、 “有意义的”，另一个肤浅的、波普的。人们过去假装孩子们每年 买的数百万张摇滚唱片无足轻重，是可以不算数的，但哈佛或者类 似哪儿的一个经济学家说，算数。所以这次的美国展就像是来自官 方的承认：比起别的什么来，人们更愿意在媒体上看名人。” 19

“每个人现在都是同一个文化的一部分了。这种拿流行文化来比 照的做法让人们意识到文化是正在发生的事情，他们不必读一本书 来成为文化的一部分一一他们需要做的仅只是把它买下来（或是把 一张唱片、一台电视、一张电影票买下来)。”20

在一九六三年的一次访谈中，当被问及波普艺术离开了公关人 士还能不能存续时, 沃霍尔回答说当然可以, “因为我觉得那些来 看展览的人明白得更多。他们不非得思考。他们基本上就是看到它 们, 然后喜欢它们, 他们明白起它们来更容易。我觉得人们正在变 得不愿思考，而这样事情就要简单得多了。”访谈者紧跟着确认道： “我想你在这样的趋势里看到了某种正面的东西。” 沃霍尔说：“对， 没错。” 21

“如果你想要知道安迪·沃霍尔的一切, 那么只看表面就好了： 我的画和电影还有我，那就是我了。没有什么在表面的后面。”22

“我觉得我很大程度上是我的时代的一部分，是我的文化的一部 分，就像火箭和电视是这时代和文化的一部分一样。我最喜欢美国 电影, 我觉得它们棒极了, 它们是那样地清楚明白, 是那样地真实,

18 The Philosophy of Andy Warhol，第 IOI 页。

19 《波普主义》, 安迪·沃霍尔和帕特·哈克特著, 寇淮禹译, 河南大学出 版社，2014，第 325 页。

20 同上，第 326 页。

21 I'll Be Your Mirror: The Selected Andy Warhol Interviews，第 32 页 22 同上，第 90 页。 
它们的表面非常美。我喜欢美国电影想要表达的：它们基本上没什 么想要表达的，而这也就是为什么它们是如此地美好。我觉得一件 事物越是没什么要表达的，它就越是完美。欧洲电影里则有着更多 需要思考的东西。” 23

流行文化里没有深刻和复杂，沃霍尔也不需要深刻和复杂，表 面的美好就挺好了，干嘛那么沉重呢? “至于说用那么强烈的颜色 画梦露是否有什么象征意味, 我的回答是 : 那样很美, 而梦露她人 美，如果说有什么是美的，那就是亮丽的颜色了，就是这样。”24

《百变星君》里有句台词，“男人中的男人，三重刘德华”，沃霍 尔的梦露大概也要比梦露还梦露。波普艺术摄取了流行文化的特质, 把它更其夸张化了。时代流转, 沃霍尔的朋友, 艺评人大卫. 鲍登 曾以 “浮夸、尖利、近于粗俗” 来形容的彩色《玛丽莲》 25 , 在我们 今天看来刚刚好，我们觉得那就是梦露，那才是梦露，反倒是梦露 的那些电影剧照，看起来像顽皮女孩儿多过性感偶像。

\section{4. 波普 : 从生活到艺术，从艺术到生活}

波普艺术是艺术家对于民主化进程在艺术上的确认、表达、拥抱和 赞颂。波普艺术引导你观看你身处期间的生活，发现其中的美。波 普艺术主动摄取这一民主时代的文化特质，加以夸张扩大，用以进 行艺术创作。

大众厌恶深沉、躲避崇高、追欢逐乐、钟情俗艳，波普艺术提 供欢乐、俗艳而不要求观众深沉、崇高。这里当然有着对于传统的 审美倾向的叛离, 乃至潜藏着对于传统行为导向、价值规范的拒斥。 然而沃霍尔在其间看到的是解放的力量。这是富足社会的民众心态： 有吃有喝有玩儿有乐, 干吗还要想那么多? 等级社会已经被推翻了, 社会壁垒已然不存在了，轻松点儿，去做你想要做的随便什么事， 去做你想要做的所有的事。

“亨利生活的主要关注点仍然是艺术，而我生活的主要关注点是 
波普一波普任何事情。”26

教皇保罗六世造访纽约，在一日的行程结束后，登机时记者问 他最喜欢纽约的什么，他回答道：“一切都好。” 沃霍尔说：“这正 是波普哲学。”27

“波普的想法，归根结底，是随便谁都可以做任何事，所以很自 然我们尝试去做所有的事。没人想呆在一个领域里，我们都想尽其 所能地伸入到每一个有创造性的领域里去一这就是为什么当我们 在六五年底遇到地下丝线时，我们也全都乐意踏足音乐圈。” 28

沃霍尔也许是最早有意识地以波普的态度生活的人之一，但是 当本书的叙述来到结尾，面对着新生的一代青年，沃霍尔如此说道: “波普对于这新的一代人来说不再是个问题或是选项 : 它是他们所 仅知的东西。”29

\section{第二部分（列娃・沃尔夫）}

2013 年 8 月, 寇淮禹第一次联系我，那时，他正要完成《波普主义》 的翻译，询问如何翻译那些他不确定的字词、短语和术语。在长达 几个月的电子邮件交流中，我们共同理解了沃霍尔与哈克特书中的 语言。在这个过程中, 我惊奇地发现, 书中还有些段落是没有理解的, 即使《波普主义》已经读过很多遍了。寇淮禹的问题让我对这本书 的丰富性和复杂性有了新的理解，让我认识到书中的词语，尤其是 那些最难翻译的词语，在 1960 年代创造美国 “现代” 图景中扮演 了重要的角色。这本书中，有四类语言造成了引人关注的翻译的困 难，也将是我谈论的重点：(I）时效性术语；(2）创造性使用的口语;

（3）不常见的地名和人名；（4）历史性的特殊描述以及典故。

在举例讨论这四类语言之前, 我要先说说自己第一次接触《波 普主义》的情况。寇淮禹联系我的时候，他并不知道沃霍尔和哈 克特的这本书在我生命中占据特殊的位置。1 980 年这本书出版了,

26《波普主义》, 安迪·沃霍尔和帕特·哈克特著，寇淮禹译，河南大学出 版社，2014，第 285-286 页。

27 同上，第 198 页。

28 同上，第 197 页。

29 同上，第 435 页。 
我便拥有了一本。作为一名年青的研究生, 我从没想过会写作沃霍 尔的文章, 更别说是有关他人生中的文字和语言了。 ${ }^{30}$ 在纽约距离 我的研究生院几个街区远的地方有家书店, 就是麦迪逊大道和第 74 街的 “图书与伙伴” 的前身，位于惠特尼美国艺术博物馆旁边， 那里有一些签名本, 我觉得我要有一本。此后, 出于明确的目的和 生命中不同出发点, 我读了《波普主义》好多遍。但是, 只有寇淮 禹的有关书中的特殊词汇和短语含义问题，让我领会了沃霍尔和哈 克特语言多层性以及有时是间接的运用。

《波普主义》语言的一个重要组成部分是它将很多声音交织在一 起，部分来自 20 世纪 60 年代帕特-哈克特对沃霍尔朋友和同事的 采访。 ${ }^{31}$ 通过那些用来表明对话的修辞性的术语, 他们的故事就成了 《波普主义》结构的组成部分。这里有些随手可得的例子（其他的 也在这书中随处可见）:

德有次和我说亨利和我讲

过大卫.布东有次向我抱

怨几年后泰勒对我承认

斯丹利有次表示尼基告诉

我几年后亨利告诉我

丹尼说之后梅尔

告诉我妮可告诉

我们丹尼回忆说

保罗回应

30 这些研究包括 : Andy Warhol, Poetry, and Gossip in the Ig6os (Chicago:

University of Chicago Press, 1997); “Through the Looking-Glass," introduction to I'll Be Your Mirror: The Collected Andy Warhol Interviews, ed. Kenneth Goldsmith (New York: Carroll \& Graf, 2004), xi-xxxi and 403-9; and " 'I'm OK-You're OK' : Andy Warhol, Transactional Analysis, and Books," in Reading Andy Warhol: Author Illustrator Publisher, ed. Nina Schleif (Munich: Brandhorst Museum, in association with Hatje Cantz Publishers, 2013), 258-7I. 
在为数不多的完全是对《波普主义》语言运用的评论中（然而是最 低程度的), 其中一条来自小说家乔伊斯·卡罗尔・欧茨, 她谈论了 “某 某说过” 这类语言，表现了沃霍尔将自己塑造为 “饶舌地，非正式 地”, 即使她对沃霍尔的艺术和著作非常厌恶, 描述他在《波普主义》 中的 “说话方式” 是 “比死掉更加面无表情”。33 另外一条乐观一点 的评论来自《纽约客》的艺术大事记编者卡尔文·汤姆金斯, 他觉得, 阅读《波普主义》好像在 “读一本小说”, 毫无疑问, 同样因为这 “某 某说过” 的术语，还补充了 “对话非常棒”， ${ }^{34}$ 我们有理由认为，用 这样的方式写成的书籍应该很容易翻译。下面部分分析了为什么可 以这样来设想，但最特别的是，为什么这样的设想是错误的。我希 望以下分析能说明为什么我们用自己的语言阅读时更加细心，而与 翻译者共同阅读时则效果更好。

\section{I. 时效性术语}

我对这类术语的考察开始于有关 1960 年美国的亚文化。“宇宙的玩 笑”（cosmic joke）是在 1960 年代广泛使用的一个术语。在《波 普主义》中，这个术语被用在了致幻药物摇头丸的讨论中。沃霍尔 察觉到他的电影合伙人保罗. 莫里西 “......指责 60 年代摇头丸造 成了幽默的衰退。他表示在摇头丸的影响下，唯一还有幽默感的人 就剩下蒂莫西·利里了。……每个人好像都拿 “宇宙的玩笑” 非常 当真，他们不想制造那些不宇宙的小小的玩笑。”35

“严肃” 对待 “宇宙的玩笑” 这一陈述是沃霍尔钟爱反语和悖论

32 Warhol and Hackett, POPism: The Warhol Sixties (New York: Harcourt

Brace Jovanovich, I980), 4, I8, I9, 38, 53, 58-59, 77, 97, I24, I45, I54, I70, and I86, respectively.

33 Joyce Carol Oates, "Review of POPism," The New Republic, February 2, I980, 32.

34 Calvin Tomkins, “The Art World: The Art Incarnate," The New Yorker, May 5, I980, II4.

35 Warhol and Hackett, POPism, I69. 
的绝佳例证。 ${ }^{36}$ 但这一点对如何翻译 “cosmic joke” 毫无帮助。 ${ }^{37}$ 如同摇头丸 (LSD), 这一术语在 1960 年代特别流行。然而，我惊 奇地发现，“宇宙的玩笑” 早就流通使用了，并且在 19 世纪晚期就 已开始，英语文学中有许多例证。 ${ }^{38} 19$ 世纪的生活已成为 “宇宙的 玩笑” 了，但在 1960 年代摇头丸的推动下，它获得了全新的现代 意义，老的用法完全被遗忘。

1960 年代的另一个术语是 “橙色亮片漆” (tangerine flake), 就 算这个词的意思和用法再具体精确一些，也依然很难理解。 ${ }^{39}$ 这一 术语是通过汤姆·沃尔夫 1965 年文集的封面故事《糖果色橙色亮片 漆流线型宝贝儿》 (The Kandy-Kolored Tangerine-Flake Streamline Baby)（图 I）流行起来的。这个故事是关于当时加利福尼亚高级 轿车的微缩世界, 塑造了定制界的大腕 : 乔治-巴里斯。巴里斯把 他最喜欢的一辆高级轿车涂上了金属色的汽车颜色，他称之为 “橙 色亮片漆”。但是，如果不知道 “tangerine flake” 是一种高度专业 化的颜色名称，我们就只会有两个毫无关联的词：一种相橘类水果 和细小薄片。

沃尔夫将巴里斯的高级轿车看作既现代又波普 ; 他甚至把它们 比作艺术，发觉走进巴里斯的汽车修理厂时，“很快就会发现自己 身处一家美术馆里”, 又补充到，巴里斯和其他高级汽车制作者如 同毕加索一样，通过复制他们的创作 “赚了很多钱”，巴里斯的案

36 这与乔伊斯 · 卡罗尔 · 奥茨（Joyce Carol Oates）在评述《波普主义》 中所宣称的相悖, 称这是一本 “完全单调直白的 “回忆录” ” (absolutely uninflected unironic "memoir") (32)。

37 昰淮禹通过研究指出 “宇宙的玩笑” 是一种悲观的人生观（上帝的宇 宙的玩笑）; 寇淮禹，2013 年 8 月 $24 、 29$ 日邮件询问作者，2013 年 8 月 27、29日邮件回复。

38 如 1885 年的例子, “energize, v.,” OED Online, http://www.oed.com/ view/Entry/62083? rskey=dqjPqF\&result=I. "Cosmic joke" does not appear in the $O E D$ as a term on its own. For an overview of the "cosmic joke" vision in late nineteenth and early twentieth-century literature, see Alexander Welsh, "Realism as a Practical and Cosmic Joke," NOVEL: A Forum on Fiction 9, no. I (Autumn 1975): 23-39. 
例中, 是采取了按比例制作玩具汽车模型的方式 ${ }^{40}$ 。在 “橙色亮片漆” 这一术语中，融入的是一种现代艺术和流行文化的等式，与沃霍尔 的敏锐是完美地匹配的。 ${ }^{41}$

2. 创造性使用的口语

《波普主义》包含了一些变化使用口语的例子 : 不管是在让人料想 不到的语境中使用，还是改变了其中一个词，都能让人发现是原初 的用法被附加了新的含义，这取决于它本身以及在对话中所具有的 原初含义。42 “迈向辉煌” (heading for the big time) 就是一个在非 典型语境中使用习语的例子。通常，这一表达是指一个雄心勃勃的 人追求名声和成功：一个演员可能希望 “成名”（make it big）或者 “走向成功” (head for the big time)。安德里亚·费尔德曼（图 2) 是个充满困惑的年轻女子，她出演了一些沃霍尔的电影。相反，根

40 Tom Wolfe, "The Kandy-Kolored Tangerine-Flake Streamline Baby," in The Kandy-Kolored Tangerine-Flake Streamline Baby (New York: Ferrar, Straus and Giroux, 1965), 76-107, at 83, 94. 沃尔夫的标题原先为 “There Goes (VAROOM! VAROOM!) that Kandy-Kolored (THPHHHHHH!) Tangerine-Flake Streamline Baby (RAHGHHHH!) Around the Bend (BRUMMMMMMMMMMMMMM...)," Esquire 60, no. 5

(November 1963): II4-2I.

41 然而，现代艺术和波普的融合被视为是《波普主义》一书的内核，也是 对所有译者的挑战, “橙色亮片溙”一词与《波普主义》书中为什么提 到沃尔夫的书名没有什么直接关系。沃霍尔和哈克特提到沃尔夫的书 是因为书中有一篇关于沃霍尔合伙人简 - 霍泽尔 (Jane Holzer) 的文章 "The Girl of the Year," in The Kandy-Kolored Tangerine-Flake Streamline Baby, 204-20 (originally published in New York Herald Tribune Sunday supplement, December 6, 1964), 8-II, 67. 沃霍尔和哈克特对沃尔夫书 的提及见 Warhol and Hackett, POPism, 133 .

42 Chi Ren and Hao Yu have proposed that idioms are societal and not individualized, in "Translation of English Idioms from the Perspective of Cultural Context," Cross-Cultural Communication 9, no. 5 (2013), 79. 然 而，《波普主义》中关于改变惯用表达的例子表明，如果通过创造性改 变的行为, 与原初的理解对话, 语言能变得个性化。 
据 1972 年她自杀后的报道得知，她以这样一种表达而追求死后的 救赎，永久的成功。在纽约的一份周报《乡村之声》的计告里，费 尔德曼的朋友杰拉尔丁 · 史密斯解释了费尔德曼 “拿着她的十字架 和几天前在教堂捡到的 《圣经》……从 I 4 楼的窗户……跳了下去”。 史密斯还说“安德烈亚留了张纸条……说道……我正 “走向辉煌时刻” (the big time)。我中了头奖!” 43 在《波普主义》中, 重复出现这份 计告的信息和用词：“她说她正 “迈向辉煌” (heading for the big time), 然后, 就紧握着一本 《圣经》和一个十字架跳出了 I4 楼的 窗户。” 44 费尔德曼不寻常又生动地运用这一表述, 给翻译者带来了 挑战。

同样具有挑战且引人思考的例子是替换掉惯用表达中的一个词。 沃霍尔和哈克特引用摇滚音乐家卢. 里德在 1966 年对刚刚成为青 少年杂志编辑的音乐经理人丹尼·菲尔兹说的话 “那么, 想想你开 始了你的职业生涯……豪华轿车错的一边下车 (getting out the wrong side of a limousine)” 45 这个短语是什么意思? 出生在 “道路 的错误的一边” (wrong side of the tracks) 的意思是出生在了错误 的街区，或者出身贫穷。“在床的错误的一边醒来” (wake up on the wrong side of the bed) 的意思是一觉醒来就脾气很差。那么, “从 豪华轿车错的一边下车” 会是什么意思呢?也许你已经拥有了一切, 例如奢侈品牌的豪华轿车, 却没从中获益? ${ }^{46}$ 或者, 即使获得了所有

43 Geraldine Smith, “Andy Feldman, 1948-72," The Village Voice, August I7, 1972.

44 Warhol and Hackett, POPism, 299.

45 Ibid., I54.

46 寇淮禹， 2013 年 8 月 24、29 日邮件询问作者，2013 年 8 月 27、29日 邮件回复。[寇 : “卢. 里德认为丹尼设定职业生涯不是一个好决定?” 沃尔夫 : “我不这么认为。但是 “豪华轿车错的一边” 的表达并不寻常。 我的猜想是, 这是一种表达的剧本, “轨道错误的一边”。如果你出生在 “轨 道错误的一边” 意味着你出生在贫穷的街区。带着这样的想法, 如果你 摆脱 “豪华轿车错误的一边”, 那么你生来有特权但是会做出错误的选择。 但是我想，正如你在文章中引用的那样，里德认为这只是在职业生涯的 开始, 不是现在。” 寇 : “我认为里德指的是现在, 正如 “在安娜堡, 我 
好处，却还是脾气暴躁?或者，这歪曲的习语可能在间接地揭示丹 尼・菲尔兹是个同性恋?再者，这也许只意味着菲尔兹不懂得适当 的表达方式?

一个惯用的表述可以有多重含义，这一被改变了的习语也可能 如此。 ${ }^{47}$ 翻译习语很难 ; 翻译一个被转换了意义的习语更难, 例如 刚才提到的这个词。翻译理论家提出了翻译习语的三个原则：(I) 对待习语不要太表面化; (2) 在译入语中寻找近义词, 以此向你的 读者表达含义; 以及（3）尽可能多地保留 “艺术的” 或者 “原始 的修辞效果”。在 “wrong side of a limousine” 的例子中，一个关 键问题是如何在翻译中, 保留变形习语的特征, 又体现出这一细节 对艺术和修辞的重要性。

《波普主义》中的另外一个调换习语的例子是关于美国电影工业 的。与沃霍尔在 1960 年代制作的 “地下” 电影形成对比的是那些 好莱坞制作的严格遵守生产管理准则的电影。根据沃霍尔和哈克特 的说法, 为避免审查, 并且要围绕电影工业的图像制作需要进行工 作，那些主要的电影公司为他们的 “黄色” 电影建立了不同名字的 子公司。这些公司就可以因此 “大发其财” (moralize all the way to the bank)。4 “moralize all the way to the bank” 是对 “to laugh all the way to the bank” 这个习语有趣的改变，意思是很容易赚到 大量金钱，也可能是同等价值的其他东西。“moralize all the way to the bank” 意味着利益中包含了虚伪。 ${ }^{49}$

刚得到这份工作展开他的职业生涯，因此 “现在” 就是他 ‘职业生涯的 开始”。” 沃尔夫：“我懂你的意思了，也许是因为里德认为这份特殊的 职业不够好 (不能算是一份职业)。我需要深度挖掘来理解这段话。或 许你可以看看沃霍尔在《波普主义》里谈到菲尔兹的部分，它能更好地 提供一个理解这一问题的语境。如果你还有问题, 我可以在有空的时候 做一些额外的研究。”]

47 翻译惯用语法多重含义的难点，见 Lanchun Wang and Shuo Wang, “A Study of Idiom Translation Strategies between English and Chinese," Theory and Practice in Language Studies 3 (September 2013), I69r.

48 Warhol and Hackett, POPism, 204.

49 寇淮禹, 2013 年 8 月 29 日邮件询问作者, 2013 年 8 月 29 日邮件回复。(寇:

““去银行”意味着“赚很多钱吗?”’) 


\section{3. 地名和人名}

名字也和习语一样给翻译者造成困扰, 这些有关名字的案例中，困 惑时常出现，而不是频繁出现，还是相对容易解决的。Gramercy Arts Theatre 是沃霍尔电影《睡眠》1964 年上映的地方, 翻译这个 名字需要了解 Gramercy 是这家位于曼哈顿的电影院所在街区的名 字（I38 东第 27 街）。如果没有这一信息的话，就可能从字面的法 语翻译成 “非常感谢”, 但是, 在这个例子中, 也许音译法更合适。50 值得注意的是，在 6、7 世纪佛经的翻译中，可以发现音译法或者 不翻在中国有着悠久且有趣的历史。 ${ }^{51}$

《波普主义》中另一个很难翻译的用来命名曼哈顿地方的词是 “巴 布什卡村” (Babushkaville)。52 “Babushkaville” 是被创造出来的词, 它意味着一些不时尚的事物。 ${ }^{53}$ 这一含义的细微之处存在于巴布什卡

（Babushka 是一款穿戴在头上并系在下巴下面的围巾）与东欧的 关联，特别是波兰、俄罗斯和乌克兰，这些地方的农民从前有穿戴 巴布什卡的传统。沃霍尔和哈克特称曼哈顿的东村街区为 “巴布什 卡村”，这里曾聚集着来自这些国家的移民，19 世纪 60 年代，这 里也是时髦人群很 “酷” 的街区 ; 事实上，沃霍尔的地下丝线乐队 在这一街区表演的主要地点就是在一个波兰人的家里, 叫作 Polski Dom Narodowy, 或者 Polish National Home, 如同大教堂（The Dom）一样流行（图 3)。在《波普主义》中，充分运用了时髦的 巴布什卡村的反语。不仅仅是新旧世界的融合, 过时与时髦的混合, 还有沃霍尔的从前与他的当下的融合，因为他的父母来自东欧。 ${ }^{54}$

50 寇淮禹, 2013 年 10 月 17 日邮件询问作者, 2013 年 IO 月 29 日回复邮件。

51 Martha P.Y. Cheung, "Translation as Intercultural Communication:

Views from the Chinese Discourse on Translation," in A Companion to Translation Studies, eds. Sandra Bermann and Catherine Porter

(Chichester: Wiley-Blackwell, 20I4), I85-87 and I90, note II.

52 Warhol and Hackett, POPism, I57.

53 寇淮禹, 2013 年 10 月 17 日询问作者的邮件, 2013 年 IO 月 29 日邮件回复。

（寇：“Babushkaville 是被创造出来的词吗?” “'Babushka”是一块女

人的头巾，折成三角形，系在下巴底下，'ville' 代表围巾的质量，组

合在一起意味着不时尚的、远离流行。”

54 来自 2013 年 10 月 29 日作者和寇淮禹的邮件。 
事实上，这些照片就是他的母亲佩带着巴布什卡。

《波普主义》中的一个对非本土语言者来说涉及名字的难题是口 音浓重的语音拼写。妮可是在地下丝线乐队表演的声音低沉的德 国歌手, 沃霍尔和哈克特在引述她的话时就用这样的方法（图 4)。 通过沃霍尔和哈克特的描述，妮可痛惜在地下丝线的第一张专辑中 没能完全听清著名民谣摇滚音乐家鲍勃 ·迪伦类似 “博……滴…… 啦…… (Baww-whhhb Deeelahhn) 的发音。 ${ }^{55}$ 要是不了解 1966 年美国音乐文化的特性，想要破译 “Bawwwhhhb Deee-lahhn” 就 非常难。 ${ }^{56}$ 沃霍尔和哈克特运用这种语音拼写来再现口语。在这点上, 它的效果类似于前面说过的对 “他说过” “她告诉我” 和其他类似 短语的重复运用。事实上，《波普主义》的对话语气是它可读性的 原因之一。然而, 这样的语音在把《波普主义》带入生活时, 给翻 译者制造了特别的困难。翻译学者 Sunny Tien 在乔治·萧伯纳的 剧作《窈灭淑女》（I9I3）的中国话表演的研究中，观察到萧改变 了伦敦方言和对话声音，例如 “ah-ah-ah-ow-ow-ow-oo” 和 “nahow” 都是由于非常难翻译而被省略，尽管它们对角色发展和音调很 重要。57

更让人困惑的例子是用多个名字指代一个人，并且真实名字与 虚构名字交替使用。沃霍尔的好朋友布里姬・伯林有时候以“布里 姬·波尔卡” 出现，其他时候却是 “公爵夫人”。公爵夫人是沃霍 尔曾在格林尼治村的圣雷莫咖啡馆遇见的一个人的名字，也是布里 姬·伯林在《切尔西女孩》（1966）这部电影中所扮演角色的名字。

55 Warhol and Hackett, POPism, 166.

56 寇淮禹，2013 年 8 月 24、29 日邮件询问作者，2013 年 8 月 27、29日， 邮件回复。在寇淮禹 2013 年 8 月 29 日的邮件中, 他观察到在《波普主义》 的另外一些段落中，妮可以类似语音的方式书写，从而传达她低沉的英 语发音，这使得他很容易解码她的话语因为只有重复的字母（并没有 涉及其他改变）: “漂……浮在葡萄酒……上的食……物”（I45）“红海 ……的部……分”（I62）. 参见 Nico' s “very strange way of speaking” (POPism, I45).

57 Sunny Tien, "Pygmalion, Humor, and the Translation of Dialect," Translation Quarterly 75 (March 2015): 5, 7, and I2. 
然而, 沃霍尔的电影明星们大多数时候是表演他们自身, 虚构与真 实相互纠缠, 这很难分辨, 而且, 很大程度上沃霍尔也是刻意为之。 58

\section{4. 历史性的特殊描述以及典故}

《波普主义》中的一个故意混淆虚构与真实的故事是关于 1968 年 6 月 5 日罗伯特· F. 肯尼迪身为一名总统候选人被刺杀的事情，在 这件事情发生的几天前, 也即 6 月 3 日, 沃霍尔刚遭遇了枪击（图 5)。通过这一故事, 在肯尼迪被刺杀那天, 布里姬 - 伯林跑去了艺 术家罗伯特. 劳申伯格那里, 告诉了他这件新闻, 劳申伯格哭泣着 回应 “这就是媒介吗? (Is this the medium)” 她把他的话告诉了 沃霍尔, 沃霍尔疑惑地说 “这会是什么意思?” 于是, 伯林解释说, “先 是你，然后是博比·肯尼迪……枪。” 59 唉，她对 “the medium” 的 解释, 几乎不能说明劳申伯格的意思。但是, 这至少为我们做出猜 测提供了一些线索。也许, 这一陈述一定程度上与媒介理论家马歇 尔·麦克卢汉 1964 年著作《理解媒介》中的著名论述 “媒介即讯息” 相关? ${ }^{60}$ 或者, “the medium” 可能涉及一些超自然力量或者灵魂? ${ }^{61}$

事实上，有一部叫作《The Medium》的电影，由意大利作曲家 吉安. 卡洛·梅诺蒂 I95I 年执导, 基于梅诺蒂 1946 年首演的同名 歌剧（图 6)。在这部经常被描述为黑色电影的作品中，一位叫作 佛罗达夫人的玫财的出纳员凭借降神会, 剥削那些失去孩子的父母。 然而, 佛罗达夫人在经历了一连串的事情后发疯了, 并在故事的结 尾枪杀了一名叫托比的哑巴服务生。基于这一故事情节，那么，我 们猜想当劳申伯格问到 “Is this the medium” 的时候，他脑中可

58 Gary Comenas 指出 “布里姬在切尔西女孩中扮演的公爵夫人有时也 被在现实生活中提及”, 见 http://www.warholstars.org/warholfilm/ warholir.html. 正如寇淮禹在 2013 年 8 月 24 日询问作者的邮件中提出 “沃霍尔写的公爵夫人和布里姬·伯林斯两个人，但看起来布里姬·伯 林就是公爵夫人，而不是在电影切尔西女孩中扮演的公爵夫人”。

59 Warhol and Hackett, POPism, 276.

60 寇淮禹， 2013 年 IO 月 $3 \mathrm{I}$ 日邮件询问作者，20I3 年 II 月 I 日邮件回复。 61 寇淮禹, 2013 年 10 月 17 日邮件询问作者, 2013 年 IO 月 29 日邮件回复。 
能呈现梅诺蒂的作品。劳申伯格大概了解梅诺蒂, 当然听说过他。6 62 此外，即使《The Medium》早于 1960 年代，但是，这部电影那 十年间在电视上放映过许多次，同时，这部同名歌剧曾于 I96I 年、 1963 年和 1967 年在纽约市上演。 ${ }^{63}$ 此外， 20 世纪 70 年代末，当 沃霍尔和哈克特在写作《波普主义》的时候，梅诺蒂的第一部英语 传记由约翰 - 格伦写作出版了。（格伦也有关于艺术的写作，并且 他是一名摄影师，在不止一个场景中为劳申伯格和梅诺蒂摄像，写 作关于他们的文字，而且，在相同的社交网络工作） ${ }^{64}$ 一名格伦著作 的评论家称赞《TThe Medium》是一部可以抓住观众，并且选出一 些能引起沃霍尔共鸣的歌剧的其他东西 : 在纽约，它的首演不在音 乐厅而在百老汇。 ${ }^{65}$ 换句话说，梅诺蒂如同在他之后的沃霍尔，创 造的作品把高雅艺术与流行文化融合了起来。

在梅诺蒂歌剧的虚构情节中，佛罗达夫人逐渐变成妄想狂并心 理精神错乱，现实中一个类似事件是一位名叫瓦莱丽·索拉纳斯 的女人枪击了安迪 · 沃霍尔。沃霍尔描述了索拉纳斯那天来到工

62 梅诺蒂创办了著名的艺术节，两个世界的斯波莱托节（the Spoleto Festival of the Two Worlds)。1958 年，劳申伯格 I955 年著名的 “联 合绘画” 作品《床》, 被列入美国和意大利年轻艺术家作品展览（即 艺术节名字中所说的两个世界)。然而在很多故事中，艺术节官方 拒绝展出《床》这件作品并将之放在储藏室中。参见 http://www. rauschenbergfoundation.org/artist/chronology/ 劳申伯格帮助梅诺蒂为 艺术节设计 “叶子专辑” (Album Leaves)。见 John Gruen, Menotti: A Biography (New York: Macmillan, I978), I38.

63 《纽约时报》列出的电视播放 The Medium 包括：1960 年 4 月 $\mathrm{II}$ 日, 1962 年 4 月 8 日，1963 年 II 月 20 日和 1965 年 5 月 18 日，《纽约时报》 在 196 年 3 月 25 日，1963 年 5 月 6 日和 1967 年 5 月 6 日刊登了歌剧在 纽约的表演和评论。梅诺蒂的 The Medium 甚至出现在 1966 年 2 月 6 日 《纽约时报》的填字游戏中。

64 例如，参见 John Gruen, The New Bohemia, with Photographs by Fred W. McDarrah (1966; rpt. Chicago: a cappella books, 1990), I47-48 (on Rauschenberg) and 93-96 (on Warhol).

65 John Yohalem, “Successful Heretic,” New York Times Book Review, June I8, $1978, \mathrm{I} 5,35$. 
作室 “工厂” 时候的穿着打扮，揭示了一些隐含细节。比如，沃 霍尔提到她 “穿着长裤，更像是西裤（我从来没看她穿过连衣裙） ......” 66 “长裤” 和 “西裤” 之间的差别是向 1980 年的观众传递了索 拉纳斯是女同性恋者，当时，人们对性别取向的态度远没有我们今 天开放。 ${ }^{67}$

《波普主义》中更难的一个翻译问题是有关枪支和美国社会和法 律的历史特殊性，这涉及到黑豹组织，一个 1967 年建立的寻求非 裔美国人平等权利的组织。《波普主义》中，读者被告知黑豹组织 是如何运用加利福尼亚即时就地的法律规定，以持枪作为正当防卫 的一种方式, 正如沃霍尔和哈克特描述的 “公开携带枪支并不违法, 但隐藏它们是违法的。” 68 对于一些美国公民来说, 发现这一法律的 存在也许会让他们非常惊讶（在黑豹组织行使了这一法律后就立刻 被废除了)。 ${ }^{69}$ 更重要的是, 《波普主义》中的短语 “just to conceal them”（去隐藏它们）会很容易被理解为要做什么的相反含义。70 这就不难理解，一个翻译者可能在推断加利福尼亚的法律允许公民 公开携带枪支时很有压力。顺便提一下，有一点值得注意的是，沃 霍尔常被视为是与 20 世纪 60 年代的政局格格不入, 这个故事便 是例证。例如，一项最近的研究声称，《波普主义》中，沃霍尔与

66 Warhol and Hackett, POPism, 272. (Warhol and Hackett spell Solanas, "Solanis," throughout POPism.)

67 Ibid., 233.

68 寇淮禹, 2013 年 8 月 29 日和 9 月 2 日邮件询问作者, 2013 年 8 月 29 日和 9 月 9 日邮件回复。

69 在当时州长罗纳尔多. 里根执政下, 《马尔福德法案》 (The Mulford Act) 被废除。1968 年，联邦政府效仿了《枪支控制法案》（The Gun Control $A c t)$ 。

70 寇淮禹，2013 年 8 月 24、29日，9月 2 日向作者发送邮件; 2013 年 8 月 $27 、 29$ 日，9月 9 日回复邮件。（寇：“谢谢，现在因为我无助的英 语而出现问题……不是反对公开携带枪支的法案, 而是藏匿枪支, 完整 来说就是公开携带枪支并不违法，只是（意味着 “只有”）藏匿枪支才 是违反法例，对吗?” 沃尔夫: “是这样没错，如果不是英语为母语的人， 这句话就很难理解。” 寇淮禹, 2013 年 9 月 2 日邮件询问作者, 2013 年 9 月 9 日, 邮件回复。 
哈克特提到 “黑人权利仅仅被当作是最新流行的自然发型.....” 71 与 翻译者一起阅读《波普主义》可以更加细致深入地了解这本书中如 何刻画 20 世纪 60 年代。

\section{结语}

与来自不同文化的翻译者交流互动是一种不断丰富的活动，借用翻 译学专家玛莎·P·Y 张的术语来说, 这项活动不是那么 “跨文化”, 而是 “交互文化的”。张极具说服力的讨论解释值得详细引用 :

“Cross” 暗示着活动，但没有必要的联系 ; 另一方面，前缀 “inter-, “表示不只是活动，还有联系，以及更重要的交流互动。 这意味着 “跨文化交流” 和 “不同文化间的交流” 代表了分开 的和独立的概念……在我看来，把翻译或译介看成一种跨文化 交流的形式，是强调了翻译作为转换的概念，作为一种含义的 承载跨越。假设含义可以相当完整地由一种语言转换为另一种 语言……然而，把翻译或译介视为一种不同文化间的交流形式， 便突出了翻译中交流的特殊复杂性。翻译不是像提供不同人和 文化之间顺畅无问题的思想交通的桥梁或管道，不是机械地面 对。而是，在翻译 / 或译介的过程中，当不同的文化发生联系 或冲突时，交流互动得以强化。 ${ }^{72}$

寇淮禹和我对翻译《波普主义》中的词汇和短语的讨论正是这种 “不 同文化间的” 活动，对话双方都深受影响。有时，我们在讨论沃霍 尔文字时面对着巨大的文化鸿沟。

沃霍尔著作的译本在其他国家较早出现是因为在历史环境、与 美国的文化间隔以及语言的根本差异上要小于中国。《安迪·沃霍 尔的哲学》是沃霍尔著作中第一部被翻译出来的。在英语版本出版 仅仅两年后，法语版本就于 1977 年出版了，但是，正如寇淮禹提 到的，中文译本是激发他翻译《波普主义》的灵感来源，即 2006

71 Gustavus Stadler, “'My Wife' : The Tape Recorder and Warhol' $s$

Queer Ways of Listening," Criticism 56, no. 3 (Summer 2014): 450.

72 Cheung, “Translation as Intercultural Communication,” I79-8I. 
年台湾版本，以及 2008 年左右的中国大陆版本。 ${ }^{73}$ 这三十年的间 隔也同样反映在沃霍尔艺术的传播上。在法国，沃霍尔以及波普艺 术从一开始就被接受，特别是 1963 年、1964 年和 1965 年索纳本德 画廊在巴黎举办了相关展览。 ${ }^{74}$ 另一方面, 沃霍尔作品在中国大陆 第一场大型展览是在距今很近的 2013 年。 ${ }^{75}$ 但是, 有趣的是《波普 主义》的第一个法语版本是在 2007 年出版的, 并没比寇淮禹的译 本早多久。这一意料之外的年表背后的原因值得研究, 这也许是由 于哈克特与沃霍尔在书中制造了独特的翻译困难, 还有可能是因为 他们的语言是扎根于拉丁语的。

玛莎 $\cdot \mathrm{P} \cdot \mathrm{Y} \cdot$ 张在文章中表明，翻译作为一种 “不同文化间的” 活动, 是一个 “文化间的联系 (contact)、冲突 (conflict)、竞争 (contest)、碰撞（collision）等方面得以分析的理想场所。” ${ }^{76}$ 我想 要给这个条目再加上一个词: 合作 (collaboration)。我认为, 与 寇淮禹的讨论就是一种合作活动, 他力求把每个词和短语都翻译到 最佳。一个对译入语丝毫不懂的人能参与合作翻译，这简直太奇特 了，也同样奇怪。我对中文一䛎不通。1999年，㚞守义在一篇关 于现代中国翻译史的文章中，举了一些类似的吸引人的翻译合作的 例子，是 19 世纪末期和 20 世纪初期著名翻译家林纾（I852-I924） 将英文的文学作品翻译成中文的案例。林纾 “不会讲任何外语” (与 掌握了很棒的英语知识的寇淮禹不同), 但是, “他与那些可以用不 同流畅度说外语，但不能把所读作品翻译成合适中文的人合作，将 西方文本翻译成了优美经典的中文本。”77 范守义在 20 世纪 90 年代

73 感谢寇淮禹在 2016 年 I 月 20 日邮件时给予的出版年表的帮助。

74 沃霍尔在 1964 年美国波普艺术展览上的作品包括玛丽莲、黑白玛丽

莲、金宝汤罐头（黑豆）。参见 Georg Frei and Neil Printz, The Andy

Warhol Catalogue Raisonne or: Paintings and Sculpture 196I-I963 (London:

Phaidon, 2002), 248 (cat. 266) and 237 (installation photograph).

752013 年，北京和上海 “安迪·沃霍尔：十五分钟的永恒” 展览。

76 Cheung, “Translation as Intercultural Communication,” I8I ( 参见 I84).

77 Shouyi Fan, "Highlights of Translation Studies in China since the MidNineteenth Century," Meta: journal des traducteurs / Meta: Translators' Journal 44, no. I (1999): 3I. 参见 Michael Gibbs Hill, Lin Shu, Inc.: 
末指出，在 20 世纪 50 年代中期的文化繁荣期间，类似的翻译合作 在中国得到了鼓励和倡导，他也展望未来，期待接下来更新的翻译 活动的繁荣...... 78 当寇淮禹带着对《波普主义》的部分翻译问题联 系我的时候，他用的就是这样的合作方式。也许这并不是巧合，这 样的合作同样出现在沃霍尔的现代性的观点中: 与帕特. 哈克特合 著《波普主义》, 并且是基于对 20 世纪 60 年代沃霍尔生活中的人 的采访，这本身就是一场出色的合作。

( 李馨蕾译，张坚校)

Translation and the Making of Modern Chinese Culture (Oxford: Oxford University Press, 20I3).

78 Fan, "Highlights of Translation Studies in China since the Mid-

Nineteenth Century," 4I-42. 


\section{中西现代主义绘画的会通之路：论塞尚与黄宾虹}

沈语冰

20 世纪初，英国著名艺术史家、批评家和美学家罗杰·弗莱（Roger Fry）在阐明其形式主义 - 现代主义理论时，援用了大量东方艺术 思想资源，特别是中国的美学资源。弗莱本人是一位优秀的画家和 极其敏锐的评论家，同时又是当时欧洲数一数二的艺术鉴定家与博 物馆专家。在他的朋友、汉学家劳伦斯 ·宾雍（Lawrence Binyon） 的指点下，弗莱迅速发现了中国书法和绘画的鬼力，对于绘画质地、 笔触、书写与线条在艺术表达中的作用，很快就有了超人的见识。 而这些恰恰都是经过现代主义理论的阐发后才被凸现出来的艺术要 素。弗莱很自然地抓住了东方资源，来为他激赏的西方现代派绘画 艺术辩护。

这里，为了谈论的方便，我想先对三个概念做一简单的区分（而 不是定义)。笔触是指画笔(或毛笔)触及画布 (或画纸) 留下的痕迹。 最简单的笔触当然是一个点。但笔触还可以是一个面，当留下的笔 迹较为扁平而且有一定的面积之时。而当笔触伴随着画家的运笔姿 势连续行进, 形成一定的规律性运动时, 我们就称这样的运作为 “书 写”。而这样的书写在画布或画纸上形成的轨迹, 则是线条。在下 文里，我多多少少是在相当宽泛的意义上交替使用这三个词，只是 根据上下文不同而有所侧重。请读者留意。

我们还可以补充以第四个概念，既是弗莱喜欢使用的，也是我 们中国人最为熟悉的，那就是书法（Calligraphy）。什么是书法? 弗莱下过一个简明易懂的定义（当然比中国传统中的书法概念毛 䊁、简单得多）: 我们称这样的线条为书法，当这种线条想要达到 的目标是在绝对确信的状态下作出的时候。弗莱的意思是，普通线 条并不一定就是书法，只有当这种线条是在画家或书家的确信中画 下的时候，才称得上书法。换言之，书法就是拥有内在确定性的 线条。板滞刻厉，或犹豫不定，都不可能产生 “优美的线条”，即 Calligraphy（来自希腊语，字面的意思就是 “优美的书写”)。

现在来谈弗莱对笔触与书写问题的看法。在《塞尚及其画风的 发展》一个讨论笔触问题的上下文里，弗莱写道 : 
没有哪个绘画问题像物质质地那样让公众百般挑剔。这种挑剔 有强大的偏好, 有时可以凌驾于艺术家之上。因此, 杜奥（Dou） 和凡·得·维尔夫 (Van der Werff) 的画那种光溜溜的表面，是 为了适应一种蒙昧的鉴定学的需要而加以绘制的。一般而言, 荷兰画家被局限在一种最后加工完成的虚伪表面上，而不敢使 用更有表现力的方法。正是这一点使得伦勃朗成为出类拔萃的 典范。因为正是伦勃朗，在其晚年揭示了物质材料的充分表现 潜力。对他来说，没有什么东西是惰性的，相反，材料为观念 所渗透，并仿佛为观念所极化，因而画面上的每一颗粒子都变 得灵动起来。 ${ }^{1}$

笔触与书写，是让西方油画家感到很头疼的问题，因为公众对此很 挑剔。古典绘画中如果暴露了笔触, 观众就会认为此画 “尚未完成”, 因为古典绘画强调的是再现物象，而不是让人们去欣赏笔触、质地 等绘画本身的媒介特性。因此人们认为一幅画只有被修饰得光溜溜 的样子，才算完成。正是在这种要求下，伦勃朗才显示出其与众不 同的一面。他在晚年反其道而行之，不顾公众的喜好，坚持笔触在 其艺术表达中的地位，坚持物质的表现潜力。

在这幅《熟睡的女子》（图 I）里，他用了毛笔和墨水，这是最 接近中国绘画的材料和工具。伦勃朗用了胗翏数笔就刻画了一位熟 睡的女子。如果用传统的西方古典绘画来衡量，我们会认为这只是 一个速写，或者习作。但是如果接受过东方的艺术观念，观众就会 认为这幅画已经完成了，因为中国古代的艺术从来不要求作者将笔 触掩盖起来，修饰得光溜溜的。中国古代艺术一直强调表达对象与 表达本身的和谐统一, 所以判断绘画的第一个标准就是 “气韵生动”, 而非形象精确。其次是骨法用笔，又一次强调用笔的重要性。再后 才是应物象形、随类赋彩等等属于描绘形象的层次。罗杰・弗莱虽 然没有直接运用 “气韵生动”, 但是他的很多概念, 比如 “粒子的灵动” 等等，足见他受到东方美学影响之深。

1 罗杰·弗莱: 《塞尚及其画风的发展》, 沈语冰译, 广西师范大学出版社, 2009 , 第 89 页。 
对于这样一幅画, 传统的欧洲人是不太能欣赏的, 可是中国观 众却很容易接受，因为我们传统的人物画，尤其是南宋以后，都 采用这种简笔画法。直到 19 世纪下半叶, 西方世界才逐渐认识 伦勃朗这类作品的伟大之处。而要等到 2I 世纪，西方的眼睛才能 发现它与东方书法的契合之处。哈佛大学艺术史系的司立辅教授 (Seymour Slive), 在 2009 年出版的《伦勃朗素描新探》里, 用 了很大的篇幅来分析这幅画。他说 :

这幅藏于大英博物馆的《熟睡的年轻女子》, 被公认为是这位大 师最精美的素描之一。伦勃朗以强有力的笔触和无与伦比的简 洁，用灵活的手腕，暗示出了模特的整个形式以及包围她的大 气氛围。这幅素描完全是用毛笔画的，这种技术对于伦勃朗来 说也非常罕见。看看这张画的下面部分，那些宽阔的、饱含墨 水的笔触, 用 $2 \mathrm{I}$ 世纪西方人的眼光来看, 很难不让人联想到中 国和日本的书法家, 或是杰出的抽象表现主义者们最优秀的作 品; 它们予人这样的印象: 它们完全是自发的, 与此同时, 它 们又都处于绝对的掌控之中。 ${ }^{2}$

在伦勃朗《熟睡的年轻女子》里，那些笔触，以及毛笔的运行所产 生的线条, 是如此抽象而富有表现力, 完全不是战战兢硯地去捕捉 一个形象, 而是自由的挥酒。伦勃朗晚年很大胆地发挥了大师的掌 控能力 ; 他完全可以自如地表现自己。这些作品, 很难不让人联想 到中国、日本的书法, 或是抽象表现主义的杰作。它们给人一种绝 对自发的印象, 又是完全掌控的。自发与掌控一般被认为是一对矛 盾。因为绝对自发就很容易流于任意, 失去控制, 所以不可能绝对 掌控; 而要绝对掌控, 又容易陷入形象塑造的艰难工作，不可能做 到自发。而这个矛盾, 只有到了伦勃朗那样的大师手里, 才得到了 很好的统一。然而, 我们都知道, 在中国的绘画传统里, 画家从小 就接受书法训练和形体造型方面的训练, 所以在创作的时候必须胸 有成竹，一气呵成，也就是说要完全自发; 但这种自发，又处于因

2 Seymour Slive, The Drawings of Rembrandt: A New Study (London: 
长期训练而获得的自信和确定性之中。

弗莱没有说笔触、媒介特质、质地本身就是现代主义绘画的本质， 虽然其中隐含了一些这样的结论。美国大批评家格林伯格 (Clement Greenberg）在弗莱的基础上做了进一步的推进。他干脆将现代主 义绘画与老大师的作品做了对比。他认为老大师们的再现性绘画作 品是要掩饰媒介的，用艺术来掩盖艺术，而现代主义则用艺术来关 注艺术本身，这是格林伯格对现代主义绘画的一个重要论述。格林 伯格说：

写实主义、错觉主义艺术掩饰了媒介，运用艺术来掩盖艺术 ……而现代主义却运用艺术来关注艺术本身。 ${ }^{3}$

老大师们总在考虑表面与错觉，媒介的物理事实与其所刻画的内容 之间的张力，不过，在他们用艺术来掩盖艺术的要求中，他们最不 愿意做的就是明确指出这一张力。 ${ }^{4}$

“表面” 是一个二维的世界，一块画布，一些颜料 ; “错觉” 则 是一个三维的虚拟空间，以及有立体感的物象。表面与错觉之间的 矛盾构成了张力。而绘画既是一个二维平面，又是一个三维的错觉 空间，其最大的特征就在于这种矛盾。古典画家用艺术掩盖艺术， 即用完美的错觉空间，来掩盖绘画是一个平面这一事实。格林伯格 认为现代主义绘画则相反，刻画的事物本身已经无关紧要，而材料 的媒介本身的特性则无限放大，成为绘画最主要的特征。格林伯格 的现代主义绘画理论，显然是进一步推进了罗杰·弗莱的思想，使 其观点更集中，也更极端化了。

罗杰·弗莱在《塞尚》一书中，对塞尚的《高脚果盘》(图 2) 一画中的笔触做了大量的集中分析，构成了整本书的一个高潮。这 件作品本身非常伟大，是现代艺术史上的标志性作品。它曾经为高 更所有（高更将其挂在自己的工作室里，在他一幅自画像的背景中 就出现过此画)，现在收藏于美国纽约现代艺术博物馆（MoMA）。

3 Clement Greenberg, "Modernist Painting," in The New Art, ed. Gregory Battcock (New York: E.P. Dutton, 1966), I02.

4 弗莱: 《塞尚及其画风的发展》，第 90 页。 
弗莱说：

这个物质质地的问题当然在很大程度上取决于艺术家的 “笔迹” 或 “书写）（handwriting），取决于其笔触所划出的习惯性曲线。 在这件静物画中，手法恢复了某些古老的精神，但它变得更有 节制，也更加质朴。他已经采用了我们不妨称之为他自己独特 的和个人的方法。他已经完全放弃了大笔直扫的做法, 而是通 过不间断的深思熟虑的小笔触来建立起他的体块。这些小笔触 严格平行，几乎完全是直线条，并从右向左逐步倾斜下降。这 些方向的笔触与对象的轮廓并无关系。这与巴洛克画法正好相 反。 ${ }^{5}$

此画在刻画事物本身之外，最大特征就在于从左下方向右上方的平 行小笔触, 它们几乎完全是直线, 贯穿整个画面, 形成强烈的秩序 感。这些笔触并不与所刻画对象的轮廓相吻合，它们之间没有必然 的关系，所以是塞尚别有用心的考虑。塞尚把古典绘画中通过光影 处理物体的手法, 转化为通过小笔触的色彩叠加来表达。这是一种 全新的理念。习惯用光影考虑问题的人会对色彩视而不见，会大大 削减色彩的表现力，而印象派则用色彩对比取代光影对比。

《高脚果盘》一画，包含了现代主义绘画中用表达本身取代表达 对象的理念，但此时的塞尚，其表达本身与表达对象之间还处于平 衡状态，并没有完全抛开表达对象。到了晚年，他越来越强调单纯 颜料的马赛克效果。我们以《圣维克多山》(图 3) 一画为例。

塞尚在此画中完全使用了小块面的马赛克效果来建立其空间和 对象。观众走近看, 只能看到笔触, 看到马赛克的块面效果, 只有 远看才能发现绘画内容，前面是树丛、房屋，中间是一大片原野， 远处是圣维克多山。人的视觉会通过一些暗示, 想象性地补全图 案的缺漏, 帮助自己形成图像, 这也就是所谓的 “格式塔”（德语 gestalt, 意为 “完成为形式”)。因为人类有这样的心理功能, 所以 塞尚觉得绘画不需要刻画得非常精细; 过于清楚的画面反而会使观 
众的想象力没有着落。中国古代的绘画大师，例如吴道子，就被唐 代最伟大的美术史家张彦远赞为 “点画离披，时有缺落”。说吴道 子的点画与对象是分离的，某些地方没有被画到，从而形成缺落， 但我们通过想象却会填满这些空白。西方古典绘画却总想将绘画全 部填满，而塞尚的作品却几乎都是马赛克构成的小平面，只是隐约 地觉得能够构成一个画面，而且出现了空白。

塞尚晚年有一些未完成的作品，画了一半就放弃了，但是未完 成的作品恰恰使我们能更清楚地看到塞尚是如何构思的。他首先也 是将画面分为近景、中景、远景三部分，再通过色彩小平面暗示空 间中的物体。这幅画后来可能由于天气改变而无法继续画下去，却 给了我们一个最好的机会来欣赏塞尚作画的过程。毕加索曾经评论 过古典油画, 认为他们要将画面中的每一个角落都填满才算是画完, 但是当塞尚在画布上画下第一笔的时候，整幅作品就已经完成了。 毕加索的这个说法很具有启发性。从这些作品中我们可以看出，笔 触在现代绘画中的作用越来越高，画家们有意识地去暴露笔触，而 非掩盖它，公众也意识到从这些笔触中能传达出很多艺术家的信息。 笔触和材料本身成为了审美的对象，绘画不再被苛求要满足诗意或 叙事之类的要求，只需关注绘画本身足矣。

塞尚的《圣维克多山》（图 4）表现近、中、远景的对象时，用 了色彩笔触的叠加, 完成了对象与空间的建构。黄宾虹的《栖霞岭》 （图 5）与此类似，前景中是屋子、树木，中间用空白形成一个过渡， 表示前景与后景的变化。中国人很聪明，觉得不需要完全画出画面 中间的过渡，只需要一些留白即可。我们看了画题就知道那空白处 就是 “栖霞岭下的桃花溪”。我们发现这两幅画在布局上有很多相 似的地方。从局部来看，黄宾虹作品中的山体部分与树木，局部来 看就是一些墨线与色块的叠加。

黄宾虹吃透了中国的传统艺术，又受到一些西方现代艺术观念 的影响。这个观点并不是我们的猜测，黄宾虹与傅雷曾数次探讨过 西方印象派绘画，并且认为西方现代派绘画摆脱写实之后，已经走 上变形、半抽象等写意艺术的过程。因此黄宾虹曾大胆预测不出一、 两年，中西绘画就会走到一条路上。这幅《栖霞岭》局部（图 6) 来看, 就是一些墨线与色块的叠加。如果不加说明, 我们几乎无法 认出是黄宾虹的画作，还会以为是一件抽象表现主义作品。而这种 
墨线与色块叠加的手法，在塞尚的作品中并不鲜见（图 7)。虽然 东西方画家所使用的颜料不同（中国画的颜料比较稀薄，而油画的 质感却很粘稠)，但是，他们在使用颜料的手法上已经非常相似， 都是采用黑色的墨线, 与色块相叠加, 来营造物象及空间感。通过 这些比较，我们会发现中西绘画并非截然不同，尤其是塞尚晚年， 以及一些现代派作品，与东方或中国绘画有很多共通之处。有的学 者讨论黄宾虹是否一定受到西方现代派的实质性影响（指的是技法 而不是一般的观念)。我觉得在某种意义上黄宾虹并没有受到现代 派的影响, 而是从中国画的历史渊源中探索出一条道路, 并且非常 巧妙地与西方印象派之后的现代派艺术不期而遇。

但这只是事情的一面，相同或类似的一面。事情还有另一面， 即差异的一面。如果说黄宾虹在强调笔墨, 隐退物像方面, 与西方 现代绘画有异曲同工之妙，那么，他对笔墨的理解，显然与西 方 现代的笔触理论并不完全相同, 而是有着极其重要的差别。这一点 源于中国独特的绘画美学。前面已经提到, 唐朝的张彦远已经认识 到吴道子 “离披点画” 的可能性。而最晚到明代的董其昌那里，笔 墨已经获得了堪与图像本身同等重要的意义, 其价值不再完全取决 于它们所再现的物象。那么, 黄宾虹的创造性贡献又在哪里呢?

本文认为, 黄宾虹最了不起的贡献在于实现了两个转向 : 一、 书法式的笔触更加突出; 用笔从帖学的细淢向碑学的雄浑转向。二、 点、线、面更加突出，几乎成为独立的表达要素。

黄宾虹的第一个创新在他的笔法, 从细淢、温婉、优雅的帖学 书法笔法, 向雄浑、刚健、豪放的碑学书法笔法的发展。如果不能 辨别帖学书法（其代表人物如王羲之与董其昌）的风格与碑学书法 的风格 (其代表人物如康有为与吴昌硕), 要理解黄宾虹在水墨上 的发展将是困难的。甚至在同属碑学书法的范畴里, 黄宾虹也是独 树一帜的。与吴昌硕大气磅礴、放笔直扫和阳刚率直、富有装饰性 的风格相比, 黄宾虹追求的是 “含刚健于婀娜” 的笔墨理想, 显得 更加内敛而蕴藉。

黄宾虹的出新之二:点、线、面更加突出, 几乎成为独立的表 达要素，但与波洛克最典型的纯抽象作品仍然不同。在这方面，黄 宾虹的追求, 与塞尚更为接近。在塞尚的晚年作品, 特别是在其速 写性的水彩作品里, 笔触几乎达到了抽象的程度, 但是, 与康定斯 
沈语冰

基、蒙德里安，乃至波洛克的纯粹抽象作品仍然不同。黄宾虹的晚 年作品, 特别是在其速写或实验性的小品里, 笔触几乎达到了抽象, 但仍然维系着与大自然的最后联系。 


\title{
The Converging Way of Modern Art between China and the West: Cézanne and Huang Binhong
}

\author{
Shen Yubing
}

In the beginning of the 2oth century, when he was formulating the formalism of Modernist art theory, the renowned British art historian, critic, and aesthetician Roger Fry evoked a great deal of Eastern aesthetic resources, particularly Chinese aestheticism. Fry himself is an outstanding painter and extraordinarily sensitive critic; at the same time he was one of the very few art authenticators as well as museum experts in Europe of that time. With the aid of his friend, sinologist Lawrence Binyon, Fry quickly discovered the charm of Chinese calligraphy and paintings; very soon he demonstrated his unusual understanding of the ways in which the texture of painting, brush strokes, writing, and lines work in Chinese artistic expression. And these are precisely the artistic elements discovered after modernist theorization. Fry quickly grasped the Eastern artistic sources, which became his defense for his appreciation of Western modernist arts.

Here, for the sake of argument, I would like to make a rough distinction between three concepts (not definitions). Brush stroke means the tip of the calligraphy brush and the trace it leaves on the canvas (or paper). The simplest kind of brush stroke, of course, is a point. But brush strokes can also mean a surface when remaining traces are flat and cover a certain surface. When the brush strokes move along with the painter's painting movements and form some regular movements, we call this kind of movement "writing." This kind of writing thereby creates traces on the canvas or painting paper and these traces are "lines." So the readers might take note that in the following text I will more or less use these three terms interchangeably in their general meanings while emphasizing different aspects according to the context.

We can further supplement a fourth concept, which is Fry's favorite one and also the most familiar one to us Chinese: that is, "calligraphy." What is calligraphy? Fry gives a simple and easy to understand definition (of course, his definition is a lot more simplified and rough around the edges than the traditional Chinese concept of calligraphy): When a line is created in the condition of absolute certainty and reaches its goal, we call this kind of line "calligraphy." What Fry means is not every simple line is calligraphy; a line can only be called "calligraphy" when it's drawn by a painter or a calligrapher with absolute certainty. In other words, calligraphy is lines with internal certainty. Dullness, harshness, or hesitancy can produce no "beautiful lines," which is the literal meaning of calligraphy Greek etymology.

Now let's talk about Fry's view on the issues of brush strokes and writing. In Cézanne: A Study of His Development, there is a passage in which Fry discusses the issue of brush strokes: 


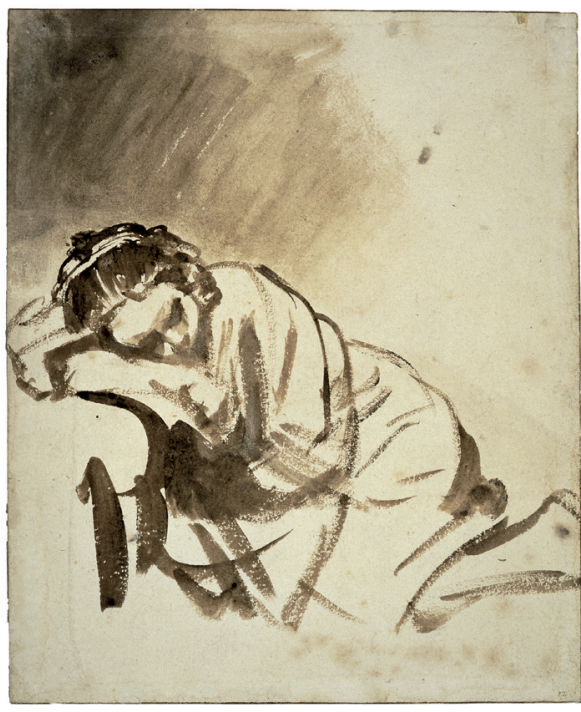

Fig. I. Rembrandt Van Rijn, Young Woman Sleeping, c. 1654. (O) The Trustees of the British Museum/Art Resource, NY.

There is no pictorial issue about which the public is so exacting as that of material quality. It has its strong preferences which it can sometimes impose on the artist. It is thus that the licked and polished surfaces of a Dou and a Van der Werff were created in response to a particularly unenlightened connoisseurship, and, in general, the Dutch painters were constrained to a fictitious appearance of finish and dared not use a more frankly expressive handling. It is this that renders Rembrandt's case so extraordinary. Because it was Rembrandt, in his later years, who revealed the full expressive possibilities of matter. With him nothing is inert, the material is permeated and, as it were, polarized by the idea, so that every particle becomes resonant. ${ }^{1}$

"Calligraphy" and "writing" are two thorny issues for Western oil painters because the public are particular on this issue. If traces of brush strokes are seen in Classical paintings, the painting would be deemed "unfinished" because classical paintings emphasize "representation," not the unique materiality of brush strokes and the texture of the medium. Therefore, the public deem a painting "finished" only when its surface is worked to be smooth. Seen in the light of such public demand of the artists, Rembrandt's insistence appeared unique. In his late years, he went the opposite of the public's taste, insisting on the status brush strokes have as an artistic expression and on the expressive potentials of materiality.

In his Young Woman Sleeping (Fig. I), Rembrandt applies brush work and ink, a tool and material that show the closest affinity to Chinese painting. $\mathrm{He}$ has painted a sleeping woman with only a few strokes. This piece would be regarded only as a sketch or an exercise if viewed as a classical Western painting. However, if one has been exposed to Eastern esthetics, the viewer would think this painting finished because ancient Chinese arts never ask the creator to cover up the brush strokes and make the surface smooth. The ancient Chinese arts have always stressed the unifying coherence between the object and its expression. So the highest standard for evaluating the quality of a painting has to do with the painting being "spirit resonance" (vivid in spirit and vibrant in allure, qi yun sen dong), not its "faithful delineation of appearance." The second one is

I Roger Fry, Cézanne: A Study of His Development (London: L. and V. Woolf, I927), 43. 
the "bone method" (or, the way of using the brush), which again emphasized the importance of writing. And the last ones are "correspondence to the object" (or, the depiction of form), "suitability to type" (the application of color, including layers, value and tone). Although he didn't directly refer to the concept of "spirit resonance," many of Fry's concepts, such as "the rhythm of particles" can be proof of how deeply he had been influenced by Eastern esthetics.

Traditionally Europeans have problems appreciating a painting like Rembrandt's Young Woman Sleeping. But the painting would be met with a positive reception by Chinese viewers because the Chinese portraiture tradition, particularly since the Southern Song dynasty, has adapted this sketchy brush work in painting. It is not until the second half of the I9th century that the West started to grasp the greatness of this type of works by Rembrandt. Moreover, it is not until the 2Ist century that the West opens its eyes to the correspondence between the West and the East. In his 2009 Rembrandt's Drawings, Seymour Slive, a Harvard professor of fine arts, has written at length on Rembrandt:

The painting, A Woman Sleeping, housed in the British Museum, is regarded as one of the master's finest drawings. Rembrandt gives a hint of the model's entire form and the surrounding atmosphere with strong and powerful brushstrokes, unparalleled simplicity and flexible technique. If we look at the lower part of this drawing, with a 2Ist century Western perspective, it is hard not to associate those broad brushstrokes that are full of ink with Chinese and Japanese calligraphists or the best works by the outstanding abstract expressionists; they give people this kind of impression: they are completely spontaneous; at the same time, they are in absolute control. ${ }^{2}$

In Rembrandt's Young Woman Sleeping, those brushstrokes and the lines created by the brush's trancing are so abstract and full of expressivity. They don't set out to capture a meticulous lookalike image, but express freely. In his late years, Rembrandt could boldly be in masterly control of his arts; he could thoroughly express himself at ease. These works inevitably make people think of Chinese and Japanese calligraphy or Expressionist masterpieces. They give out an impression of absolute spontaneity and being in total control. Being spontaneous and being in control at the same time tend to be seen as paradoxical. Being absolutely spontaneous can be easily turned into being willful and thereby losing control, which bars being in control. To be in absolute control tends to be trapped by the difficult work of creating a lookalike, thereby being the opposite of spontaneity. And this kind of paradox can only be unified in a masterly hand like Rembrandt's. However, we all know that in the tradition of Chinese paintings, painters are trained from a young age on in calligraphy and image-creation. So, Chinese painters paint with a clear sense of knowledge and the work has to be completed in one go, meaning created out of spontaneity. But this kind of spon- 


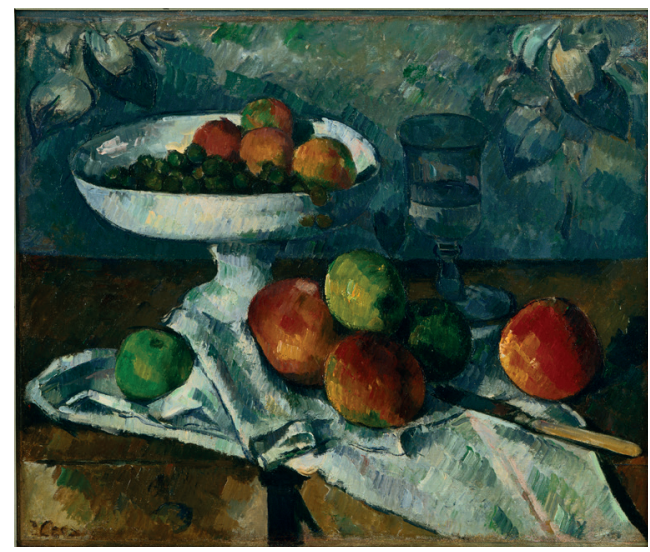

Fig. 2. Paul Cézanne, Still life with Fruit Dish, I879-80. Museum of Modern Art, New York. Image (C) The Museum of Modern Art/Licensed by SALA/ Art Resource, NY.

taneity is placed inside self-confidence and certainty gained through long-term training.

Fry never says that brushstrokes, medium characteristics, and texture themselves are the essence of modernist paintings. Another critic, Clement Greenberg, makes further comments on the basis of Fry's observations. Greenberg draws a comparison between modernist paintings with the master's works. He believes that the representation in old masters' works functions to conceal the medium, deploying art to conceal art, while modernism uses art to talk about art itself. And that is Greenberg's seminal discourse on modernist paintings. Greenberg says:

Realistic, naturalistic art had dissembled the medium, using art to conceal art. Modernism used art to call attention to art. ${ }^{3}$

The old masters always consider the surface and illusion, the tension between the physical reality of the medium and the content it depicts. However, in their requirement to dissemble art with art, they are reluctant to point out this tension.

The "surface" is a two-dimensional world: a piece of canvas and some paint; while "illusion" is like a virtual three-dimensional space with a physical sense of reality. The paradox between the surface and illusion creates tension. And this paradox is the most prominent feature of the illusionary space on canvas, which is two-dimensional and three-dimensional at once. The classical painters employ such perfect illusionary space to dissemble art with art, concealing the fact that a painting is a surface. Greenberg thinks that modernism is the opposite of such practice. The things painted are irrelevant to modernism. Instead, the material properties of the medium have been infinitely stressed and become the main features of paintings. Greenberg's theorization of modernist painting is a more focused and militant perspective developed out of Roger Fry's ideas.

In Cézanne, Roger Fry analyzes extensively Cézanne's use of brushstroke with a focused study on Still Life with Fruit Dish (Fig. 2) and this part is the highlight of the book. This piece itself is monumental, a landmark piece in the history of modern art history. It was once owned by Gauguin and is now part of the collection at Museum of Modern Art in the United States (MoMA). (Gauguin hung

3 Clement Greenberg, "Modernist Painting," in The New Art, ed. Gregory Battcock (New York: E.P. Dutton, 1966), I02. 
the painting in his studio. It makes an appearance in one of his self-portraits.) Fry writes:

This question of material quality depends, of course, to a great extent on the artist's "handwriting," on the habitual curves which his brush strokes describe. [...] In this still-life the handling has recovered something of its older spirit, but it remained far more restrained and austere. He has adopted what we may regard as his own peculiar and personal method. He has abandoned altogether the sweep of a broad brush, and builds up his masses by a succession of hatched strokes with a small brush. These strokes are strictly parallel, almost entirely rectilinear, and slant from right to left as they descend. And this direction of the brush strokes is carried through without regard to the contours of objects. This is the exact opposite of Baroque handling. ${ }^{4}$

Apart from the painted object itself, the most prominent characteristic of this painting lies in the small brushstrokes in parallel which move from lower lefthand side towards upper right hand. These brushstrokes are almost straight lines, coursing through the entire canvas and forming a strong sense of order. These brushstrokes do not match the outline of the painted object; there is no necessary corresponding relationship between them. So they must be Cézanne's deliberate consideration. Cézanne transforms the classical technique of chiaroscuro of treating objects through light and shadow into a new expression of layering colors with small brushstrokes in parallel. This is a brand new kind of conception. Those who habitually see the depth of paintings in light and shadow tend to disregard colors. Such inattention would diminish the colors' expressivity. But the expressionists replace the contrast between light and shadow with colors.

In Still Life with Fruit Dish, we can see a hint of the modernist idea of replacing represented objects with expressivity. However, Cézanne's artistic expression at this point still strikes the balance between representation and expressivity; he hasn't abandoned the represented objects completely. In his late years, he stresses more and more the mosaic effects with simple paint. We will illustrate this point with his Mont Sainte-Victoire (Fig. 3).

In Mont Sainte-Victoire, Cézanne constructs the space and the phenomenon with only small blocks of mosaic effects. If one sees the painting up-close, one can only see brushstrokes, the blocking effects of mosaic. Only when one sees the painting from a certain distance can one see its content: groups of trees and houses at the foreground, wilderness in the middle and Mont Sainte-Victoire at the back. Human vision tends to make up for, with some hints, what has been missing in the big picture with imagination; this is what is called "gestalt." (In German, Gestalt means "an organized whole.”) Because of such human psychology, Cézanne believes that paintings do not need to be subtly refined. Too exquisitely drawn a canvas would instead leave no space for viewers' imagination. The master painters in ancient China, such as Wu Daozi, are praised by the greatest art 


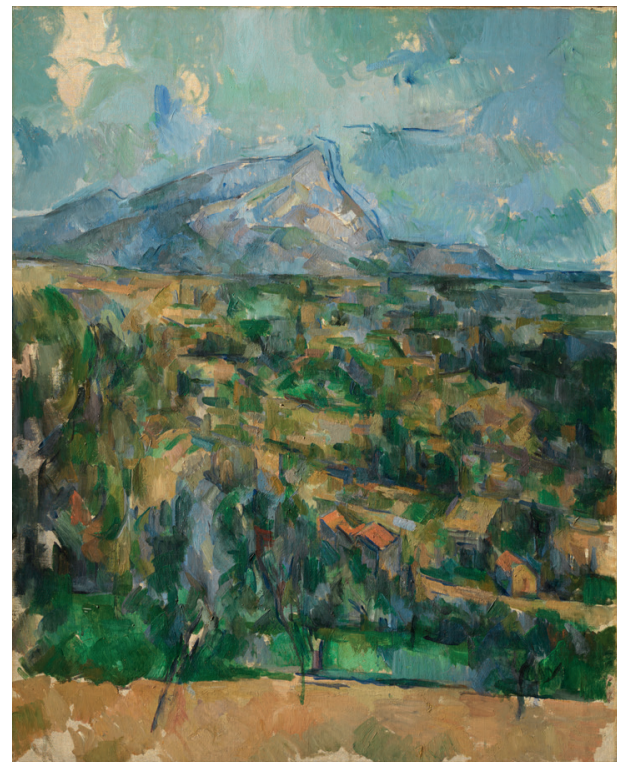

Fig. 3. Paul Cézanne, Mont Sainte-Victoire, c. 1904-6. The Henry and Rose Pearlman Foundation on longterm loan to the Princeton University Art Museum. Photo Bruce M. White. Image courtesy of The Princeton University Art Museum/ Art Resource, NY.

historian in Tang dynasty Zhang Yanyuan as "dots and lines of link are sharp; elliptical space is left between dots and lines." What Zhang means is that in Wu Daozi's paintings, the employment of dots and lines are not for representing the painted object; on his canvas, some space is left without paint and forms an omission. But we will fill up this empty space with our imagination. In the Western classical paintings, the paintings are filled up completely. But Cézanne's works are mostly small surfaces composed with mosaic and we can only sense a painted space roughly. Therefore there is empty space on his canvas.

In his late years, Cézanne produced some unfinished works. He abandoned them half way through. However, these abandoned works can allow us to see clearly the ways in which Cézanne composes his works. He usually divides his canvas into foreground, middle ground and background and hints at an object within a space through small blocks of colors. The painting might have to be abandoned because of the changed weather condition but it gives us the best opportunity to appreciate Cézanne's work in progress. Picasso once criticized that classical oil painters do not consider a painting finished unless every corner of the canvas is filled up; but when Cézanne paints the first brushstroke on his canvas the entire work is completed. Picasso's comment is very inspiring. In these paintings, we can see that the use of brushstrokes is playing a more significant role in modernist paintings. Painters intentionally reveal brushstrokes, instead of concealing them. And the public are conscious of the artists' intended messages conveyed through these brushstrokes. Brushstrokes and materiality themselves have become the object of aestheticism and paintings are not asked to meet poetic or narrative needs. The focus on the canvas itself is enough.

Cézanne's Mont Sainte-Victoire uses repeated brushstrokes to layer colors on top of another to establish objects in the foreground, middle ground and background and thereby structuring the relationship between the objects and the space. Huang Binhong's Qi Xia Ling (Qi Xia Ridge) (Fig. 4) adopts a similar approach: in the foreground there are a house and trees; the middle ground is left an empty space, indicating the transition between the foreground and background. The Chinese wisdom dictates that the middle ground transition can simply be left blank instead of being filled up with paint. We know instinctively that the blank space indicates the "Taohua stream beneath Qi Xia Ridge." We can see that there are many similarities in composition between the two paint- 
Fig. 4. Huang Binhong, Landscape in the Style of Dong Qichang, late I940s. The Metropolitan Museum of Art, Gift of Robert Hatfield Ellsworth, in memory La Ferne Hatfield Ellsworth. Image (C) The Metropolitan Museum of Art/ Art Resource, NY (compaable image).

ings. From a local perspective, the trees in the mountains in Huang Binhong's work are the layering of ink lines and color blocks.

Huang knows the traditional Chinese art inside out while being influenced by some Western modernist arts. Such view on Huang's knowledge is not based on speculation. Huang Binghong

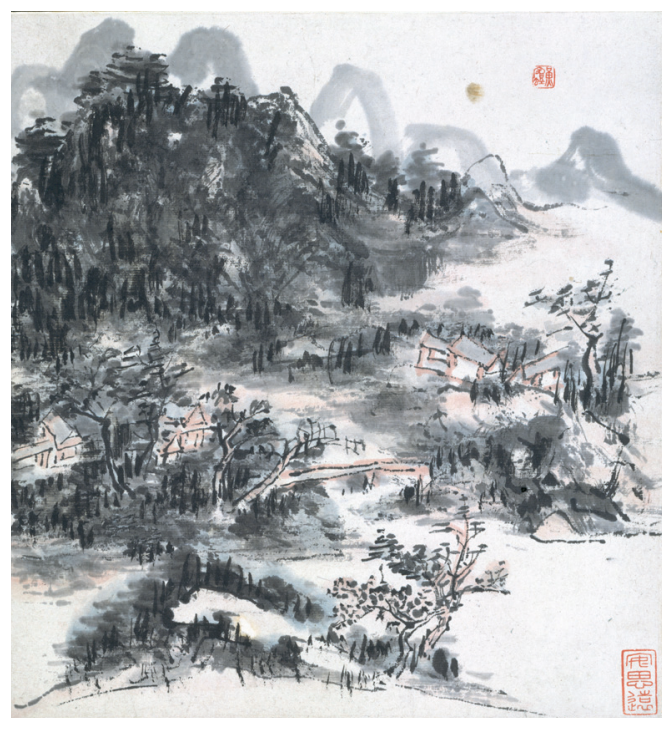
had discussed with Fu Lay Western Impressionist paintings on several occasions and believed that the Western modernist art is on the path to transformation, becoming half abstract and imaginary when it got rid of realism. Therefore, Huang boldly predicted that the Western and Eastern paintings would soon cross path in a year or two. And the local analysis of the painting Qi Xia Ling reveals the painting to be composed of layering of ink lines and color blocks. Without further explanation, we would be hard-pressed to recognize this painting to be Huang Binhong's work and might mistake it for a work of abstract expressionism. Such technique of layering ink lines and color blocks is not uncommon in Cézanne's works. Although the paint used by Western and Eastern artists differ widely (the Chinese paint tends to be on the thin side while the texture of oil paintings tends to be on the thick side), the techniques to apply paints are similar: both impose black ink lines on color blocks to delineate objects and a sense of space. Through such comparison, we come to realize that the paintings by Western and Eastern artists do not differ fundamentally. Particularly Cézanne's late works and some modernist works have many affinities to Eastern or Chinese paintings. Some scholars have argued that Huang must have been influenced by Western modernism in real terms (meaning, in terms of Huang's painting techniques instead of his general ideas about art). I feel that Huang in a sense was not affected by modernism; instead, he has found a way from the history of Chinese painting. And he craftily made the unexpected encounter with the Western modernist art after the impressionism.

But that is only one side of the coin, the side that looks the same or similar to Western art. Now we look at the side where the East and the West part company. If we say that Huang Binhong's emphasis on brushstrokes and retreated objects has affinities with the sentiments of Western modernist paintings, there is a clear distinction between his understanding of brushstrokes and the Western modernist theory of brushstrokes. And the distinction is a significant one. This is derived 136 from the unique aestheticism of Chinese painting. We have mentioned earlier 
that Zhang Yenyuan of the Tang dynasty was aware of the possibility of realizing the "elliptical lines and dots" theory proposed by Wu Daozi in painting. As late as Dong Qichang of the Ming dynasty, brushstrokes had gained similar value to images themselves. The value of a painting did not rely on the physical phenomenon it represents. Then, where does Huang Binhong's creative contribution lie?

This article takes the view that the most significant contributions Huang Binhong has made lie in two turning points: I) He brings the calligraphic brushworks into more prominent relief by changing his brushwork styles from the school of copying scripts (teixue) which boasts an exquisite style to the more majestically-styled engraving calligraphy (the school of beixue, imitating calligraphic from memorial stones; 2) Points, lines and planes have become so conspicuous that they are almost independent elements of expression.

Huang Binhong's first innovation lies in his brushworks: he has changed track from the school of copying scripts, which is known for its exquisite, soft, and graceful style, to the majestic, strong, powerful, and liberating school of engraving calligraphy. If one cannot distinguish the style of copying scripts school (the school's representative figures are Wang Xizhi and Dong Qichang) from that of engraving school (whose representatives are Kang Youwei and Wu Changshuo), it would be difficult to understand Huang Binhong's development in ink-and-wash painting. Even within the school of engraving calligraphy, Huang's style stands out. As opposed to Wu Changshuo's grand, authentic, and imposing brushworks by leashing out the masculine energy straightforwardly, Huang is searching for an ideal brush work that would "be strong, powerful and sinewy at once," which appears to be more restrained and subdued.

The second innovation of Huang's emphasis on making "points, lines, and planes" near independent expressive elements, which is at variance from Pollock's typical pure abstract works. In this regard, Huang's pursuit comes closer to Cézanne's. In Cézanne's late works, particularly in his sketchy watercolor pieces, his brushstrokes are almost abstract but Cézanne's kind of abstraction again is dissimilar from pure abstract works by Kandinsky, Mondrian and Pollock. The brush works in Huang's late works, particularly his sketches or experimental works of smaller scale, are almost abstract. Yet there still remains the last connection with nature. 


\title{
Whose Metropolis, Whose Mental Life? Rethinking Space and the Local in Urban Imagery
}

\author{
Rebecca Zurier
}

If modernism is said to have grown up in the city, then modern art and urban-

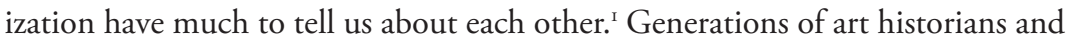
urban theorists have cited the same works of sociology and works of avant-garde art as examples of both modernity and modern urban consciousness, thus coming to mutually reinforcing conclusions. ${ }^{2}$ This essay seeks an alternative reading of urban modernity through art that imagines a more supple understanding of place and the local neighborhood in relation to urban space. My aim is to use urban art and theory to complicate each other and enhance our understanding of both cities and art in the past 150 years. The icons of the skyscraper and the street, threaded through by urban transit, play their roles but are re-mixed with perspectives from the bottom up as well as the top down. The focus will be New York City in the first half of the twentieth century, but will range into paradigms that could apply to modernizing cities today. These examples help us understand the processes through which modern urbanites have made space, not always within structures of their own choosing.

How did the powerful narrative linking artistic modernism and urban modernity come about? One version begins in Paris, sometimes considered the birthplace of both the modern city and the artistic avant-garde, with Manet's painting The Bar at the Folies Bergère (1882, Courtauld Gallery) and a series of iconic fragments familiar to art historians and urban theorists alike. These statements describing space, time, and consciousness in a modern city have also been used to explain both the appearance of, and the sense of disjointedness within the painting. Note how they combine social analysis with the language of artistic experiment. First, Baudelaire describes a new, transient sensation that inspired the painter of modern life: "for the passionate spectator, it is an immense joy to set up house in the heart of the multitude, amid the ebb and flow of movement, in the midst of the fugitive and infinite." ${ }^{3}$ Next, the German sociologist Georg

I See Scott MacCracken, "Imagining the Modernist City," in The Oxford Handbook of Modernisms, eds. Peter Brooker, Andrzej Gąsiorek, Deborah Longworth, and Andrew Thacker (Oxford: Oxford Univ. Press, 2010), 638-55. See also Raymond Williams, The Politics of Modernism: Against the New Conformists (London: Verso, 2007)

2 Robert Herbert, Impressionism: Art, Leisure, and Parisian Society (New Haven: Yale University Press, 1988), 50-57, 80. T.J. Clark, The Painting of Modern Life: Paris in the Art of Manet and his Followers (New York: Alfred A. Knopf, 1984), 238-39. David Harvey, Paris: Capital of Modernity (London: Routledge, 2003), 59.

1383 Charles Baudelaire, "The Painter of Modern Life" (I863), in The Painter of 
Simmel writes in 1903 , in "The Metropolis and Mental Life," that the "psychological foundation, upon which the metropolitan individuality is erected, is the intensification of emotional life due to the swift and continuous shift of external and internal stimuli." Simmel contrasted the "essentially intellectualistic character of the mental life of the metropolis" to that of "the small town which rests more on feelings and emotional relationships." In the city, he argued, "Money economy and the domination of the intellect stand in the closest relationship to one another. They have in common a purely matter-of-fact attitude in the treatment of persons and things" — an attitude that has been discerned in the barmaid's face in The Bar at the Folies Bergère. ${ }^{4}$ The historian Marshall Berman explained a modern urban attitude more hopefully: "There is a mode of vital experience-experience of space and time, of the self and others, of life's possibilities and perils - that is shared by men and women all over the world today. I will call this body of experience 'modernity'... it pours us all into a maelstrom of perpetual disintegration and renewal.... To be modern is to be part of a universe in which, as Marx said, 'All that is solid melts into air."'s Looking back to Paris, the sociologist Richard Sennett expanded on Baudelaire: "To accept this constantly shifting scene, rather than look for someplace fixed, stable, and whole, was to become involved in the life of the city. [Fernand] Léger painted that involvement." ${ }^{6}$ Léger himself, creator of cubist interpretations of a city of juxtaposed fragments, told an interviewer in 19I4: "If pictorial expression has changed, it is because modern life has necessitated it. The existence of modern creative people is much more intense and more complex than that of people in earlier centuries....Innumerable examples of rupture and change crop up unexpectedly in our visual awareness.... The advertising billboard, dictated by modern commercial needs, brutally cuts across a landscape...posters on the walls, flashing advertising signs_-both are the same order of ideas."7 Léger's painting The City (1919, Philadelphia Museum of Art) celebrates that modern commercial environment of visual bombardment, flashing neon and moving traffic in which figures are reduced to part of the machinery that makes the city function. Finally, an anecdote about Léger: The American artist George L.K. Morris visited Léger for lunch on the terrace at his home in Paris in the I930s "The house was located

Modern Life and Other Essays, ed. and trans. Jonathan Mayne (London: Phaidon, 1964), 9 .

4 Georg Simmel, "The Metropolis and Mental Life" (1903), in On Individuality and Social Forms, ed. Donald N. Levine (Chicago: University of Chicago Press, 1971), 325. On Simmel and Manet, see Herbert, Impressionism, 80.

5 Marshall Berman, All That Is Solid Melts into Air: The Experience of Modernity (New York: Simon and Schuster, 1982), is.

6 Richard Sennett, The Conscience of the Eye: Design and the Social Life of Cities (New York: W.W. Norton, 1990), I75.

7 Fernand Léger, "Contemporary Achievements in Painting," in Fernand Léger: Functions of Painting, ed. Edward F. Fry, trans. Alexandra Anderson (New York: Viking, I973), II-I3 passim; Morris, "Preface" (I97I) in Functions of Painting, xii. 
on a boulevard where the Metro became an elevated instead of a subway; there was a considerable roar from each passing train, and sparks would almost land in the soup. Léger said he loved this sensation of being immersed in the mechanical world and pushed his chair back in contentment."

As Léger did at lunch in Paris, modern artists and writers have invoked urban transit- subways, trams, or the elevated trains rushing above "roaring pavements where the sun shines through the Elevated striping the blue street with warm seething yellow stripes" (to quote John Dos Passos ${ }^{9}$ )— to convey free-floating mobility through a landscape of continual change and novel visual sensation. The Italian Futurist Carlo Carràs painting What the Tram Told Me (I9II, Museum of Modern and Contemporary Art of Trento and Rovereto, Italy) explores a modern, shifting mental state amidst the onrushing sensations of a tram ride amidst multiple, partial glimpses of the metropolis. Its cubo-futurist vocabulary presents simultaneously the inner perceptions of the rider and an external view of the street through which the tramcar passes. Theories of postmodernity adapt many of these assumptions about the fragmentary nature of urban space and time as symptomatic of a condition of "placelessness." ${ }^{\circ}$ The Italian futurists" innovations in fusing space and time with inner consciousness in turn inspired the American artist Joseph Stella to create his artistic homages to the modern metropolis. Stella's own trajectory had taken him from his youth in a small city in southern Italy to New York as an immigrant in the early I900s. His polyptych Voice of the City of New York Interpreted (1920-22, Newark Museum) imagines that journey from the port of entry in the leftmost pane, continuing through visual leaps upward, scanning skycrapers, and downward into the city's subways, and concludes looking across the Brooklyn Bridge, all of it tied together with Futurist force-lines. Were, or are, these visions of rupture, speeding movement, and infinite freedom truly representative of modern urban life, then or now?

Consider a few more accounts of spatial experience in early twentieth century New York, in oral history and memoir by people who grew up there in the various ethnic enclaves in which immigrants settled. First, there is Betty Chen, born in New York's half-mile-square Chinatown in 1908: "In those days Chinatown was Mott [Street], Pell, and Doyers. That was it. I didn't know there were other streets. My world was very small. I just went from home to school and back. I had a Jewish friend, Eva, who was the first person who took me out of the neigh-

8 George L.K. Morris, "Preface," in Léger, Functions of Painting, xii.

9 John Dos Passos, Manhattan Transfer (New York: Harper and Brothers, 1925), 17.

Io See Fredric Jameson's discussion of modern and postmodern space, and cognitive mapping, in Postmodernism: The Cultural Logic of Late Capital (Durham: Duke University Press, 1992), 156, 162, and 415. See also the discussions of urban space in David Harvey, Consciousness and the Urban Experience (Baltimore: Johns Hopkins University Press, 1985) and The Condition of Postmodernity: An Enquiry into the Origins of Cultural Change (Oxford: Blackwell, 1990), as well as Edward Soja, Postmodern Geographies: The Reassertion of Space in Critical Social Theory

140 (London: Verso, 1989). 
borhood-to Henry Street, and I thought I was in another part of the world." Next is Mike Gold, from his autobiographical novel Jews without Money, describing his boyhood a few blocks away in the mainly Jewish neighborhood of the Lower East Side: "The East Side, for children, was a world plunged in eternal war. It was suicide to walk into the next block. Each block was a separate nation, and when a strange boy appeared, the patriots swarmed. 'What streeter?' was demanded, furiously. 'Chrystie Street,' was the trembling reply. BANG! This was the signal for a mass assault on the unlucky foreigner, with sticks, stones, fists and feet." ${ }^{12}$ Finally, here is the reminiscence of Dorothy Greenwald who grew up in the fashionable "Gilded Ghetto" of the Upper West Side: "Our neighborhood was constant and secure in the sense that we were all the same.... Not until I was much older did I venture downtown. You were not encouraged to leave the neighborhood, because then you would meet people who were not commensurate with your background." ${ }^{13}$ The discrepancies between these descriptions of restricted urban space and the accounts of "the fugitive and the infinite" quoted earlier offer ways to reconsider the equation between modernist form and modern urban consciousness. Abstracted visions of the metropolis, like Simmel's analysis, might be not definitive, but are rather idealized and partial—shaped by class, age, race, generation, and circumstance-and need not serve as a universal measure of urban experience or mental life. The polemics that ushered in and celebrated the concept of modernity overstated its difference from older forms of thought and spatial experience. If there is one modern condition-a questionable proposition in itself - we need a more complex model for it that acknowledges the presence of both the neighborhood—what Arjun Appadurai terms "life-worlds constituted by relatively stable associates, by relatively known and shared histories, and by collectively traversed and legible spaces and places"- and the larger economic as well as spatial systems within which neighborhoods are imagined or maintained. ${ }^{\mathrm{I}}$ Appadurai describes this process as "the

II Betty Chen, quoted in Jeff Kisseloff, You Must Remember This: An Oral History of Manhattan from the I89os to World War II (San Diego: Harcourt Brace, 1989), I8.

I2 Mike Gold, Jews without Money (New York: Horace Liveright, 1930), 42-43.

I3 Dorothy Greenwald, quoted in Kisseloff, You Must Remember This, I58. See also the writer Claudia Stearns describing the Upper East Side in 1929: "we couldn't live on the West Side. People didn't. Our crowd was on the East Side. I never thought about it, and my husband never thought about it" (quoted in Kisseloff, You Must Remember This, 136). For debates over the idea of the urban enclave as voluntary or involuntary, see John Logan and Harvey Molotch, Urban Fortunes: The Political Economy of Place, 2nd edn. (Berkeley: University of California Press 2007), I24-27.

I4 Arjun Appadurai, Modernity at Large: Cultural Dimensions of Globalization (Minneapolis: University of Minnesota Press, 1996), 178-99. The urban sociologists John Logan and Harvey Molotch frame the relationship in an economic context: "People's feelings about their daily round, their psychological attachment to place, and their neighborhood ethnic solidarities are very real to them, but these feelings are bound up with forces originating outside residents' imme- 
Fig. I. Albert Gleizes, On Brooklyn Bridge, 1917. Solomon R. Guggenheim Museum, New York. Solomon R. Guggenheim Founding Collection. (C) 20I9 Artists Rights Society (ARS), NY/ADAGP, Paris.

production of locality" through which people have moved and dreamed within the metropolis. ${ }^{15}$ We can explore these differences in viewpoint through representations made during American modernism's heyday. Between 1890 and the I940s, New York City emblematized the future to Americans but even more so to observers from overseas who regarded it as a pure expression of forces of modernity glimpsed only partially in European cities. These were years of enormous technological development that trans-

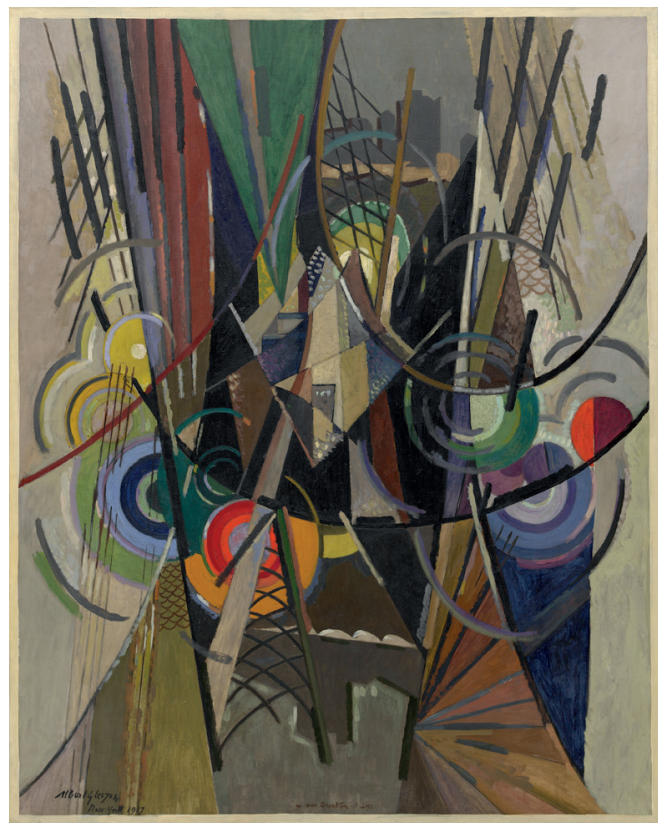
formed the skyline of American cities, but also of peak immigration-first from Europe, Asia, and the Middle East, and then the "Great Migration" of blacks from the rural South-which wrought great social transformations. As a magnet for adventurous artists and writers, as well as for millions of other migrants, New York inspired imagery nearly as diverse as its population, which now allows us to compare a variety of accounts. Many described leaving the small town for the metropolis, experienced as both loss and gain.

For members of the European avant-garde, New York served a peculiar function as a dream city, a symbol of displaced longing and dread. To outsiders who felt trapped in a civilization bound by tradition, America could be seen as a place with no history, dedicated to progress, commerce, and greed. The dadaists Georg Grosz and Paul Citroen are but two of the European artists who created dystopian visions of New York City without having been there. Splintered skyscrapers,

diate milieus, far beyond the social and geographic boundaries of their routines....The city is the setting for the achievement of both exchange values and use values, and the neighborhood is the meeting place of the two forces, where each resident faces the challenge of making a life on a real estate commodity" (Logan and Molotch, Urban Fortunes, 99).

I5 See also the discussion of "locality and community" in David Byrne, Understanding the Urban (Hampshire: Palgrave, 200I), 68-85, and Doreen Massey, "The Political Place of Locality Studies," in Space, Place, and Gender (Minneapolis: University of Minnesota Press, 1994), I25-45. All of these studies emphasize the fragility of neighborhoods, as well as the tendency to romanticize them. The authors also maintain the importance of neighborhoods in relation to larger 
advertisements, crowds, and traffic dominate their work. ${ }^{16}$ For Francis Picabia and Albert Gleizes, two French artists who actually made the journey, the place nonetheless seemed unreal in comparison to Europe: "Your New York is the cubist, the futurist city," declared Picabia in I9I3. "It expresses in its architecture, its life, its spirit, the modern thought. You.... are futurists in word and deed and thought." ${ }^{17}$ Gleizes's homage On Brooklyn Bridge (Fig. I) conveys less about architecture than about a dazzlingly multivision sensation that merges the bridge, the city, light, and movement. Marcel Duchamp found New York "a complete work of art," while Léger, visiting in I93I, pronounced "I adore this overloaded spectacle, all that unrestrained vitality, the virulence that is there, even in mistakes. It's very young." ${ }^{18}$

Not only European visitors but also American modernists repeated the trope of New York as a futuristic abstraction. Some of these artists had left provincial towns to seek their fortune in the metropolis and celebrated New York's difference: Max Weber (who moved to New York from Białystock at age Io) described "this great city of cubic form-New York," while the poet William Carlos Williams praised John Marin's busy paintings of a "skyscraper soup" of a city. ${ }^{19}$ Such images contributed to an iconography of Manhattan as modernity

I6 For European modernist fantasies of the United States, see the stimulating account of Grosz and his Weimar contemporaries in Beeke Sell Tower et al., eds., Envisioning America: Prints, Drawings and Photographs by George Grosz and His Contemporaries, I9I5-1933 [exhibition catalog] (Cambridge: Busch-Reisinger Museum, Harvard University, 1990), and Wanda Corn, The Great American Thing: Modern Art and National Identity (Berkeley: University of California Press, 1999), 47-72.

I7 Francis Picabia, "How New York Looks to Me," New York American [magazine section], March 30, 1913, II. Albert Gleizes, discussing "a cubist impression of Broadway" in 1915 , remarked: "Walking through the streets of this great city, I have, not infrequently, a feeling of being hemmed in and even crushed. This is perhaps partly due to the height of the buildings, but also to the movement of humanity, streaming so steadily, so fixed of purpose, knowing so exactly where the goal lies. In Paris there is a maze of little streets. Life goes with starts and stops. It is much more devious and complex. But New York is a very thrilling place. It stimulates me ": quoted in "French Artists Spur on American Life," New York Tribune, October 24, 1915, sec. 4, 2-3.

I8 Duchamp went on to repeat the trope of New York as a city without history in contrast to European tradition: "I believe that your idea of demolishing old buildings, old souvenirs, is fine.... We must learn to forget the past, to live our own lives in our own time": quoted in "A Complete Reversal of Art Opinions by Marcel Duchamp, Iconoclast," Arts and Decoration 5, no. II (Sep. 1915): 427-28. Fernand Léger, quoted in "New York," Cahiers d'Art, 1931, reprinted in Léger, Functions of Painting, 84-90 passim.

I9 Max Weber, "Oh Sun," in Cubist Poems (London: Elkin Matthews, I9I4), 2 I. Note that Weber, who grew up in New York, credited his friend, the visiting English photographer Alvin Langdon Coburn, with opening his eyes to the possibilities of the city as a subject for modern art. Williams described Marin's 
while equating the modern with the future. How could these ecstatic, all-encompassing visions coexist with the Chinatown memories of Betty Chen? Was it simply a matter of adult artists maturing from the spatial, social, and imaginative boundaries of childhood as described in New York-based bildungsromans, by both Mike Gold and Henry Roth, in which the protagonists eventually leave the old neighborhood for the freedoms of Manhattan? ${ }^{20}$ Or was the situation due less to age than to structural prejudice, similar to what Janet Wolff analyzed in her study of women and the literature of modernity in I9th-century Paris, which concludes, "The literature of modernity describes the experiences of men"? ${ }^{21}$ Not exactly: in New York memoirs, neither spatial restriction nor freedom of movement are consistently gender-specific. Recall the boys' battles over delimiting gang turf described by Mike Gold, or-conversely-the vivid accounts of female bohemians and journalists, such as Mary Heaton Vorse, Dorothy Day, and Djuna Barnes, who made roaming the city their particular beat in the I9IOs. In less literary realms countless women traversed New York City each day on the journey from home to work, while fashionable types conducted rounds of shopping, theater, charity work, and family business. ${ }^{22}$

work in the poem "Young Love": The Collected Poem of William Carlos Williams, Volume I: 1909-1939, eds. A. Walton Litz and Christopher MacGowan (New York: New Directions, 1986), 389-9I. Marin himself characterized his urban images this way: "I try to express graphically what a great city is doing. Within the frames there must be a balance, a controlling of these warring, pushing, pulling forces": The Selected Writings of John Marin, ed. Dorothy Norman (New York: Pellegrini \& Cudahy, 1949), 5. Their contemporary, the critic Paul Rosenfeld, praised Marin for capturing "New York with its frantic life...the street a noisome cavern under an elevated railroad; the place where men toiled only a jumble of misshapen buildings": "American Painting," The Dial 7I (December I92I): 649-70.

20 Gold, Jews without Money; Henry Roth, Call It Sleep (New York: Robert O. Ballou, 1935). See also Sara Blair, "Against Trauma: Documentary and Modern Times on the Lower East Side," in Trauma and Documentary Photography, eds. Sara Blair and Eric Rosenberg (Berkeley: University of California Press, 20I2), IO-50.

2I Janet Wolf, “The Invisible Flâneuse: Women and the Literature of Modernity," Theory, Culture \& Society 2, no. 3 (1985): 46.

22 On women and urban space, see Janet Wolff, Feminine Sentences: Essays on Women and Culture (Berkeley: University California Press, 1990), 34, as well as Christine Stansell, City of Women: Sex and Class in New York, 1789-I860 (Ann Arbor: University of Michigan Press, 1986) and American Moderns: Bohemian New York and the Creation of a New Century (Princeton: Princeton University Press, 2009). See also Tom McDonough, An Eye for Others: Dorothy Day, Journalist, I9I6-I9I7 (Washington, DC: Clemency Press, 2016). Elaine S. Abelson, When Ladies Go A-Thieving: Middle-Class Shoplifters in the Victorian Department Store (New York: Oxford University Press, 1992), cites diaries of upper middle-class women in the late nineteenth century to detail itineraries that took them throughout New 144 York City. 
In the last fifty years, social sciences have devised studies that examine the differentiation of mobility and experience within cities, making concrete the idea, once proposed by Henri Lefebvre, that space is a social production. ${ }^{23}$ Studies of American cities reveal some of the constrains within which that production operates. One resulting concept is the "mental map" through which urban residents create a functional "image of the city" characterized by "nodes" — the landmarks significant to each subject— - "edges," or boundaries, and "paths" linking place to place. Urban geographers use their own forms of abstract visual language-diagrams and maps - to chart the ways that people experience the city day to day, on the ground. For example, in Los Angeles in the I970s, a team of researchers asked adult residents to map their own images of the city. Los Angeles is a city rarely experienced as an entity; before GPS, the street map that residents used most often was not an overview but rather an inch-thick book which divided the place into hundreds of navigable zones. When the geographers compared composites based on maps drawn by residents of three different neighborhoods, enormous discrepancies emerged. Residents in the prosperous area of Westwood produced the most extensive image of the city, with nodes strung along the horizontal lines of the Ventura and Santa Monica freeways. In images drawn from the predominantly working-class, African-American, downtown area known as Avalon, the central spine was the vertical route of the public bus. Boyle Heights, a Latino neighborhood, produced the smallest map: a walking city only a few blocks square, about the size of New York's Chinatown in Betty Chen's recollection. More recent work documents the inequality perpetuated by a "spatial mismatch" in US cities between job opportunities and African-American men's ownership of automobiles. ${ }^{24}$ Such studies suggest that concepts of the layout and physical extent of a city depend largely on the observer's race or social and economic circumstance, cultural traditions, and access to transit. They bear the traces of U.S. urban history, especially as industrializing cities segregated in response to the influx of newcomers in the twentieth century, and the discriminatory housing policies—legal, financial, and social—by which certain racial and ethnic groups were threatened or channeled into undesirable sections of cities and denied access to other neighborhoods. The "images" of the city in these studies are hardly

23 Henri Lefebvre, The Production of Space, trans. Donald Nicolson-Smith (Oxford: Blackwell, 1994).

24 See Kevin Lynch, Image of the City (Cambridge: MIT Press, 1960), and also The Visual Environment of Los Angeles (Los Angeles: Department of City Planning, I97I), as discussed in Harold Carter, "Images of the City: The Citizen's View," in The Study of Urban Geography, 3rd edn. (London: Edward Arnold, 198I), 343-47. The impact and criticism of Lynch's work is discussed in James S. Duncanson, "Progress Report: Review of Urban Imagery: Cognitive Mapping," Urban Geography 8, no. 3 (1987): 264-72. See also Kenya L. Covington, "Overcoming Spatial Mismatch: The Opportunities and Limits of Transit Mode in Addressing the Black-White Unemployment Gap," City and Community 17, no. 2 (Feb. 20I8): 2II-35. 
universal, and many can exist simultaneously. ${ }^{25}$ The urban theorist Peter Marcuse goes beyond the Los Angeles study's discrete maps to propose a "layered city" in which different groups enact their overlapping routes simultaneously: neighborhoods that elites call home could be where domestic workers travel for labor. Another useful concept of the multiple metropolis comes from urban anthropologists and psychologists who track individuals as they move through a city. They describe patterns and routes but also a strong sense of "place attachment" associated with ethnic neighborhoods, even after former residents relocate. ${ }^{26}$

Art, designs, and novels can also function as "images of the city" to suggest different experiences or concepts of urban space. When we ask what mental maps might underlie certain representations of New York from the first half of the twentieth century, surprising parallels and alliances emerge. In some ways they correspond to Michel de Certeau's conceptual distinction between the tourist's all-powerful view from the skyscraper and the resident's "readable" city seen from the sidewalk. ${ }^{27}$ Many of these images assume an elevated viewpoint in order to contain the entire city within one comprehensive scene. We can see comparable attempts to map the whole city in works as dissimilar as Gleizes's cubist paintings of city lights and the panoramic view from the top of the 22-story Flatiron building, published as a magazine illustration in $1905 .{ }^{28}$ Whether they de-

25 In moving beyond the documentable variables of social class and economic position to the more subjective realm of consciousness, less tangible factors come into play, including individual predilection and history. Mike Gold implied as much in his description of three female characters from the same socio-economic background in his novel Jews without Money. The protagonist's mother refuses to leave her neighborhood, displaying the "peasant's aversion to travel...the East Side was her village now" (I48). Her younger sister, born in the same village, arrives in New York and spends weeks exploring the city (propriety dictates that she be accompanied by her nephew, but the impulse to roam is her own). The hero's sister is more limited in her journeys, but leaves the neighborhood periodically to deliver garments from the family workshop to a swank haberdasher on Fifth Avenue.

26 See Peter Marcuse, "The Layered City," in The Urban Lifeworld: Formation, Perception, Representation, eds. Peter Madsen and Richard Plunz (London: Routledge, 200I), 94-II4. See also Maria Lewicka, "Place Attachment: How Far Have We Come in the Last 40 Years?" Journal of Environmental Psychology 3I, no. 3 (20II) 207-30. Citing network theory, the historian Kenneth Scherzer makes the case for "aspatial communities" in his study of New York in the years before peak migration: The Unbounded Community: Neighborhood Life and Social Structure in New York City, 1830-I875 (Durham: Duke University Press, 1992), I4.

27 Michel de Certeau, The Practice of Everyday Life (Berkeley: University of California Press, 1984), 9I-95. Douglas Tallack has defied Certeau's conventional wisdom by arguing that early twentieth-century bird's-eye views actually render visible the workings of the city in a way that the more appealing street-level image does not: New York Sights: Visualizing Old and New New York (Oxford: Berg, 2005), I29. 
pict a whirlwind of fragments or a neatly ordered expanse, such images conceive "Manhattan" as an organic entity encompassed by the artist's gaze. Clean-lined works by the British visitor C.R.W. Nevinson and the American Charles Sheeler (both inspired by photographs, and both working in the early I920s) present panoramic views of the city, now from the windows of skyscrapers, showing a city of soaring geometries and sheer canyons, devoid of people. ${ }^{29}$

This stark, extensive vision appealed greatly to the precisionist Georgia O'Keeffe, one of the first artists to enjoy a skyscraper home and studio. Her painting New York Night (1928-29, Sheldon Museum of Art, Nebraska) assumes a vertiginous dual perspective to look both up and down on a skyscraper and then far out into the distance. O'Keeffe and her husband Alfred Stieglitz found their eyrie on the thirtieth floor of the Shelton hotel to be the perfect urban living space because it detached them from a particular locale in the city, as well as from its people. Stieglitz rejoiced: "Georgia and I somehow don't seem to be of New York — nor of anywhere. We live high up in the Shelton Hotel....We feel as if we were out at midocean." For O'Keeffe, working "way up near the roof of a big hotel" offered unprecedented possibilities for a new urban art: "I think that's just what the artist of today needs for stimulus. He has to have a place where he can behold the city as a unit before his eyes." ${ }^{\circ}$ In the Los Angeles study, as in de Certeau's schema, such extensive views of the "city as a unit" indicated a position of privilege. In these paintings, too, implied mental maps that render all parts of a city visible suggest certain kinds of privileged viewers: the tourist, the government official, the fascinated visitor from abroad, the adventurous spirit in search of new experience (and so on). In their very reach and scope, these comprehensive views ignore the intensely local experiences of the urban neighborhood: the walking city of nodes and edges mapped in the New York City memoirs cited earlier, and analyzed in studies of neighborhood place attachment. As Gwendolyn Wright has argued, modernism seems to lack a concept of home,

the Flatiron," Munsey's Magazine 33 (July 1905): 382-83, and compare to the sweeping City Beautiful projects for New York City discussed in Michelle Bogart, Public Sculpture and the Civic Ideal in New York City (Chicago: University Chicago Press, 1989), and William Taylor, In Pursuit of Gotham: Culture and Commerce in New York (New York: Oxford University Press, 1992), chapters 2-4.

29 See, for example, C.R.W. Nevinson, Looking Down on Downtown (1920, private collection) and Charles Sheeler, Skyscrapers (1922, Phillips Collection). The British photographer Alvin Langdon Coburn had used this technique earlier in a series of images of Manhattan architecture inspired by a trip with Max Weber to the Grand Canyon in 1911. In 1913, Coburn exhibited them in London as "New York from Its Pinnacles," which included the well-known photograph The Octopus (1912), a view of Madison Square Park taken from the top of the Metropolitan Life tower, and the "cubist fantasy" The House of the Thousand Windows (I9I2).

30 Georgia O'Keeffe and Alfred Stieglitz, quoted in Anna Chave, "Who Will Paint New York?” American Art 5, nos. I-2 (Winter/Spring 199I): 96 (Stieglitz), 98 (O’Keeffe). 
Fig. 2. Max Weber, Chinese Restaurant, I915. Whitney Museum of American Art/New York, NY/USA. Image (C) Whitney Museum of Art/Licensed by Scala/Art Resource, NY. Courtesy Gerald Peters Gallery.

or of meaningful contact among people. ${ }^{3 \mathrm{I}}$ But rather than deny the idea of locality within the city, or (conversely) the urbanity of the local or neighborhood view, could modernist concepts of the city have encompassed both of these perspectives?

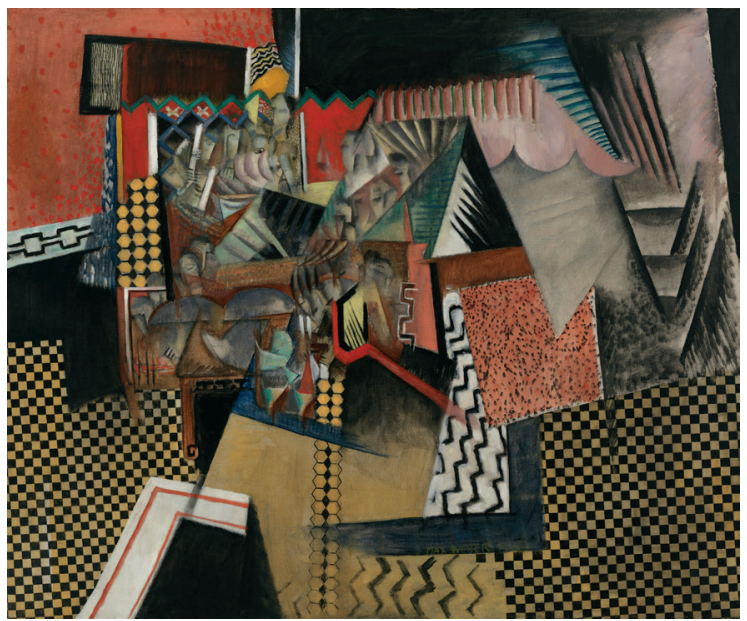

Such tensions are at work in the opposing urban visions presented in two scenes made in New York within a few years of each other, both painted by American artists who had moved to Manhattan from smaller cities and both now titled Chinese Restaurant (Figs. 2, 3). Both images make use of the characteristic red-painted trim typically found in Chinese-American restaurants at the time. The subject attracted artists in these years with its inexpensive food, fanciful decor, and diverse clientele in low-rent neighborhoods that both artists and prostitutes frequented. Max Weber deployed familiar modernist references to fragmentation and transience in describing the inspiration for his painting: "On entering a Chinese Restaurant from the darkness of the night outside, a maze and blaze of light seemed to split into fragments the interior and its contents, the human and inanimate. For the time being the static became transient and fugitive-oblique planes and contours took vertical and horizontal positions, and the horizontal and vertical became oblique, the light so piercing and so luminous, the color so liquid and the life and movement so enchanting! To express this, kaleidoscopic means had to be chosen." ${ }^{2}$ Deploying Weber's interest in the fourth dimension, the paint-

3I Gwendolyn Wright, "Permeable Boundaries: Domesticity in Post-war New York," in Madsden and Plunz, The Urban Lifeworld, 207-17.

32 Weber's comments are from annotations he wrote on the checklist for a retrospective exhibition at the Museum of Modern Art, as cited in Alfred Barr, Jr., Max Weber: Retrospective Exhibition, 1907-1930 (New York: The Museum of Modern Art, 1930), 17. Weber painted Chinese Restaurant in response to a letter from Coburn suggesting that he make a "Memory Picture of the essence of Chinatown" to commemorate the "many nights that we spent there" - the idea of painting as an "essence" or "memory" might lead to a more generalized abstract image than Sloan's discussed below, though note that Sloan, too, painted from memory: letter from Alvin Langdon Coburn to Weber, 6 April I9I5, quoted 148 (Atlanta: High Museum of Art, 199I), 37. 


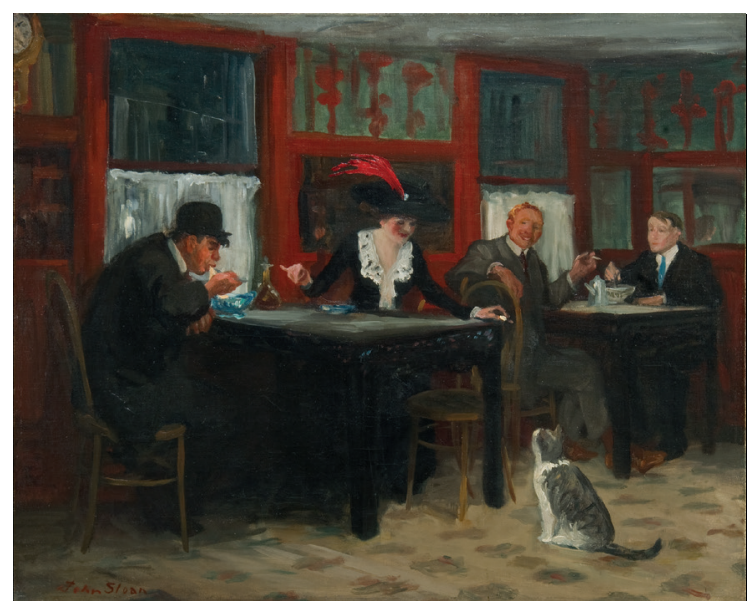

Fig. 3. John Sloan, Chinese Restaurant, 1909. Memorial Art Gallery of the University of Rochester. Marion Stratton Gould Fund. (C) 2019 Delaware Art Museum/Artists Rights Society (ARS), New York.

ing_originally titled Memory of a Chinese Restaurant - tips up the room's tiled floor and juxtaposes multiple viewpoints as they take place over time, with lines that vibrate in movement; human forms are indicated only as repeating partial profiles, near center right.

Weber's contemporary, John French Sloan, instead used architectural elements to frame and group his characters in temporary interactions. He recounted the making of his painting in diary entries for 1909 that began with a walk on Sixth Avenue: "Felt restless so went to the Chinese restaurant and was glad I did for I saw a strikingly gotten up girl with red feathers in her hat playing with the restaurant's fat cat. It would be a good thing to paint." A few weeks later he wrote: "Painted on my 'Chinese Restaurant' picture, girl with red feather-and went to the restaurant for my dinner to refresh my memory of the place. Just in time, for tomorrow they move to the corner below (29th St.)." Where Weber sought to synthesize a universal experience in memory, Sloan's paintingoriginally titled "Chinese Restaurant, Sixth Avenue" — was so dependent on its specific place that he would have lost his bearing when the restaurant moved a block south. Like many works by the Ashcan School, Sloan's seemingly traditional painting is anchored by its title to a particular address. ${ }^{33}$ Yet in its own way it too participates in modern urban dislocation and relocation. It explores the mingling of ethnic groups, as Chinese restaurants moved uptown to Sloan's neighborhood near Sixth avenue and 2Ist Street and thus into a hybrid culture.

33 On Ashcan art as "picturesque" see Corn, The Great American Thing, I6I. Several bodies of theoretical writing address the presence of the urban neighborhood within the metropolis. In Marxism and the City (London: Clarendon Press), 203-56, Ira Katznelson invokes the concept of "uneven development" to account for working-class attachment to the neighborhoods of igth-century London. The Chicago sociologists devoted considerable attention to urban "communities": see Robert E. Park and Ernest W. Burgess, The City: Suggestions for Investigation of Human Behavior in the Urban Environment (1925; rpt. Chicago: University of Chicago Press, 1967), as well as Jane Jacobs, The Death and Life of Great American Cities (New York: Random House, 196I). Yi-Fu Tuan defines "place" as a location with known associations, while "space" is an open arena when he writes, "place is security, space is freedom; we are attached to one and long for another": Space and Place: The Perspective of Experience (Minneapolis: University Minnesota Press, 1977), 3. 
Fig. 4. Morris Engel, Street Scene, Harlem, 1935. George Eastman House, Gift of Aaron Siskind. Courtesy Ruth Orkin Photo Archive.

We see the nature of temporary, cash-based transactions between strangers akin to what Simmel had described. On close observation we find that Sloan's painting might not simply depict a cozy meeting among regular customers at a neighborhood gathering place. The woman in the plumed hat is likely

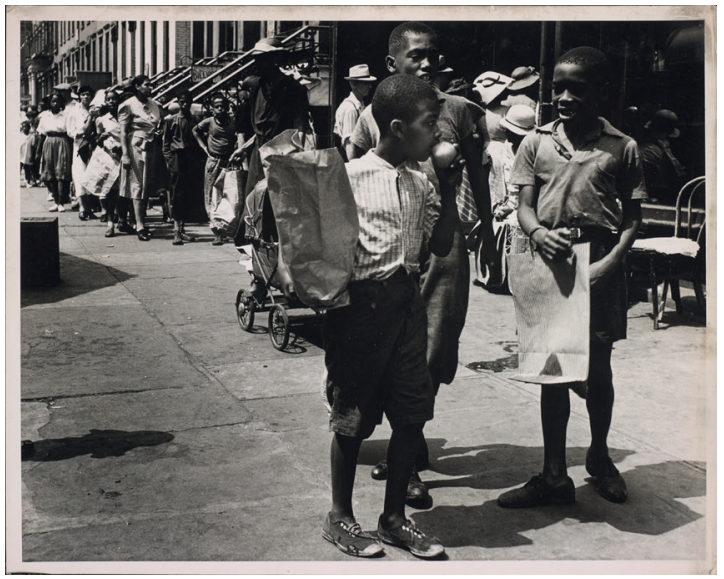
a prostitute who depends for her livelihood on attracting the attention of strangers in public. At the same time the painting assumes a kind of familiarity by placing viewers in the thick of the scene, here seated at an adjacent table in the restaurant.

Works such as Sloan's, or Morris Engel's 1935 photograph (Fig. 4) of a busy Harlem street where a group of children pursue purposive activity (i.e., chat) in an urban setting, are sometimes described as stylistically retrograde and romantic, or as nostalgic refusals to acknowledge the chaotic randomness, poverty, and inhuman scale of modern urban conditions. Yet in their emphases on the particular, on stopping a moment in time, on depicting a certain locale, these works convey valid examples of other aspects of modern urban experience. They remind us that to many city dwellers, local attachments - the need to maintain place amidst space-continue to loom larger on the mental map than the universalizing abstraction of the metropolis. These attachments are not entirely determined by ethnicity or economic circumstance-as Dorothy Greenwald's memoir recounts, New Yorkers' horizons could be shaped by tradition, fashion, propriety, nostalgia, or personal sensibility. Even as adults, a middle-class Manhattanite could feel the need to escape from the borough of Queens or return to the old neighborhood on the Lower East Side. ${ }^{34}$ These comparisons suggest alternatives to pairing the local and the general, place and space, the homogeneity of the ethnic enclave and the heterogeneity of the metropolis, or the particular and the kaleidoscopic, in a simple gemeinschaft-gesellschaftlich binary. A more complex relationship emerges in Helen Levitt's photograph New York (c. 1945) (Fig. 5), which depicts men on an urban block. Although the figures stand and sit together, as Levitt composes the image, they gaze away in separate directions

34 For histories that explore the generations who left New York neighborhoods for the suburbs but maintained identification with their old neighborhoods, see Robert A. Orsi, The Madonna of IIsth Street: Faith and Community in Italian Harlem, I880-1950 (New Haven: Yale University Press, 20I0), and Hasia R. Diner, Lower East Side Memories: A Jewish Place in America, rev. edn. (Princeton: Princeton University Press, 2002). 


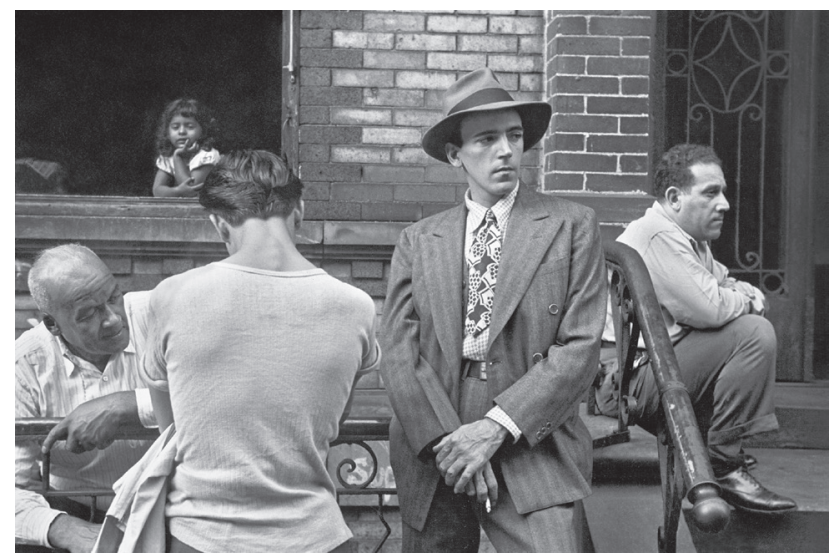

Fig. 5. Helen Levitt, Untitled, 1945. (C) Helen Levitt Film Documents LLC. All rights reserved. Courtesy of Thomas Zander Gallery.

and seem to confront the camera as if it were an intruder, and only the girl looking through the window seems to greet the photographer with interest. Such images remind us that there is a dark side to place attachment: it can create communities but also defenses of territory. The political theorist Susan Fainstein has analyzed the ugly politics of "enclave clustering" that arise in gated communities and other American neighborhoods when residents exclude newcomers. ${ }^{35}$ The way that Levitt's photographs combine centripetal and centrifugal forces also reminds us that immigrant neighborhoods were transient places, often divided within themselves or between ethnic subgroups. ${ }^{36}$ The affective bonds of neighborhoods have not always delimited their residents' horizons. The nodes on most city-dwellers' mental maps may be scattered yet connected by familiar paths, as when one travels from home to work, or leaves the neighborhood on weekends for leisure. Again, social science has a word for the phenomenon of a "multi-local" experience of the city with known places linked along transit routes. To live in such a place is not to abandon the idea of the neighborhood but rather ---for some--to experience it in counterpoint to greater movement in time and place. All of these ideas, like Sloan's paintings, or Engel's and Levitt's photographs, suggest not an escape from the overload of the metropolis. Rather, we can see in their work the tension of maintaining islands of coherence and recognizability within the maelstrom. This may be the more typical, truly modern, state of mind which neither abandons itself to the urban onslaught nor shuns it.

35 Susan Fainstein, The Just City (Ithaca: Cornell University Press, 2010), 76.

36 The process by which residents of U.S. ethnic enclaves suburbanized within a few decades while African-Americans remained trapped in urban neighborhoods that restricted their opportunities is discussed below. See Douglas S. Massey and Nancy A. Denton, American Apartheid: Segregation and the Making of the Underclass (Cambridge: Harvard University Press, 1990), and Peter Marcuse, "The Shifting Meaning of the Black Ghetto in the United States," in Of States and Cities: The Partitioning of Urban Space, eds. Peter Marcuse and Ronald van Kempen (Oxford: Oxford University Press, 2002), III. See also John Bodnar, The Transplanted: A History of Immigrants in Urban America (Bloomington: Indiana University Press, 1985). 
Fig. 6. Faith Ringgold, Woman on a Bridge \#I of 5: Tar Beach, 1988. Solomon R. Guggenheim Museum. Photo credit: The Solomon R. Guggenheim Foundation/Art Resource, NY. (C2019 Artists Rights Society (ARS), NY/ADAGP, Paris.

As an example of some of the ways that near and far, bounded place and infinite space, can be combined in a city dweller's experience, consider the role of the rooftop. In a crowded modern city, roofs can function as liminal space, an intermediate zone between cramped and spacious, close (home) and distant (horizon). Modernist

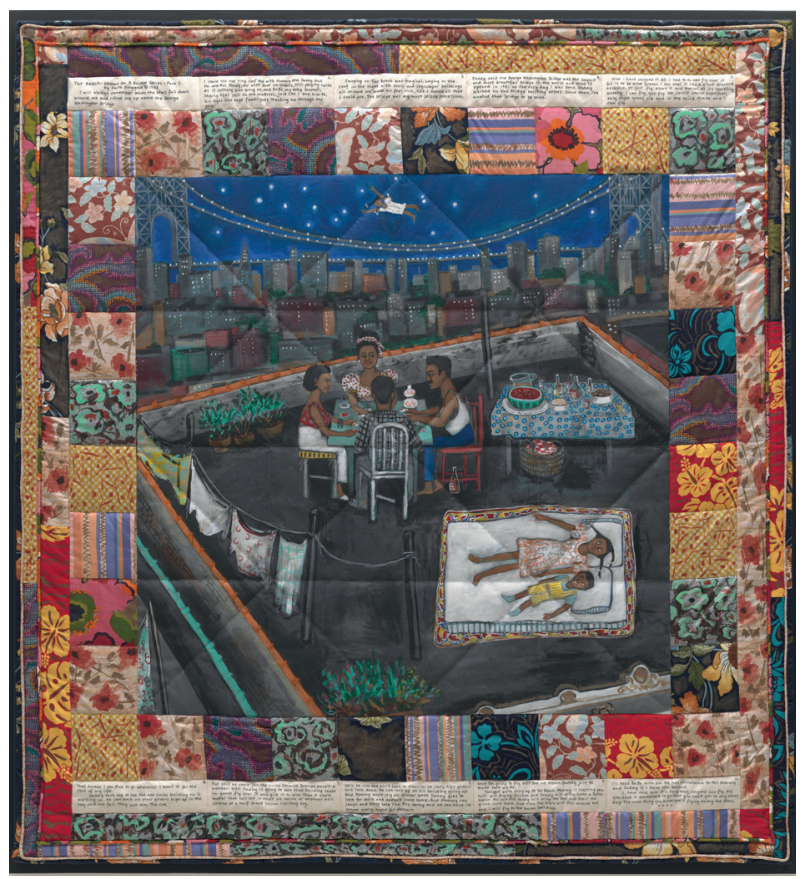
artists ascended to the roof to look down on a city abstracted into distant geometries that were either frenetic (as for Marin) or eerily stilled (for Sheeler). However, Sloan depicted rooftop views in terms of human activity and subjectivity. His small etching, Roofs, Summer Night (1906), nearly eliminates the horizon by filling the frame with the bodies of people who have brought blankets up to the roof to sleep edge-to-edge in the open air, thus bringing the viewer close to the level of his neighbors' space by representing the rooftop as a crowded extension of the sweltering tenements below. Amid the scene of sleepers, we discern one man awake and looking outward. Far from the splendid isolation of O'Keeffe's apartment at the Shelton, this claustrophobic image of massed bodies is a trenchant reminder of a sociological fact of urban space: in a crowded city, both privacy and unrestricted room are precious commodities of which the poor enjoy little.

Yet ironically, the very dispossession that drives the tenement dweller to the roof also affords access to some of the most powerful experiences of spacious urban vistas. Sloan's contemporary Mary Antin recalled her experience as a teenager in a crowded Boston slum, where the roof offered refuge from the overbearing physical presence of neighbors. In purplish but panoramic prose, she described the view at dawn: "It is one flight up to the roof; it is a leap of the soul to the sunrise. The morning mist rests lightly on chimneys and roofs and walls, wreathes the lampposts, and floats in gauzy streamers down the streets. Distant buildings are massed like palace walls, with turrets and spires lost in rosy clouds. I love my beautiful city spreading out all about me." ${ }^{37}$ This expansive evocation of infinite professional journalist, is describing the South End of Boston in the I89os. 
space, and seeing as a form of possession ("my city"), seems to counter the geographer Yi-Fu Tuan's assertion, in Space and Place, that "the rich and powerful not only own more real estate than the less privileged, they also command more visual space...from their residence the rich are reassured every time they look out the window and see the world at their feet. ${ }^{38}$

Austin's vision recalls instead the simultaneous sensations of constriction and freedom in the midst of poverty captured in Faith Ringgold's story quilt Tar Beach (Fig. 6). Created in 1988, it is based on the artist's memories of Harlem in the I930s, in about the same period that Morris Engel made his photographs there. In these years, Harlem's population had shifted rapidly from a mix of ethnicities, incomes, and races in 1900 to $70 \%$ "colored" in the 1930 census. Unofficial violence that drove African-American residents from other areas, official agreements between banks and landlords to prevent them from accessing housing elsewhere, and the eventual relocation of white residents to New York's outer boroughs contributed to a process by which an enclave became a ghetto that generated high rents for landlords from tenants who had few other options. As tens of thousands of African-Americans migrated from the south, Harlem's population swelled. Remembered as a center of black culture and community that included an entrepreneurial middle class, it was also incredibly overcrowded, its buildings often poorly maintained by absentee landlords. ${ }^{39}$

These conditions inform but do not delimit Ringgold's retrospective depiction of a rooftop as an intimate gathering place ringed by a broad horizon. An accompanying text describes the view from the vantage point of the young girl seen at right: "Lying on the roof in the night, with stars and skyscraper buildings all around me, made me feel rich, like I owned all I could see. The [George Washington] bridge was my most prized possession." ${ }^{40}$ In the distance, she imagines herself flying about the cityscape and "claiming" each landmark she looks at. Trapped by circumstance, a child envisions boundless scopic dominion over a map that extends indefinitely. These images suggest that rather than contrasting de Certeau's conception of the view from the former World Trade Center to the walk on the street, one could conceive of urban experience that encompasses both of these viewpoints and then returns home.

In light of these varied versions of the way art could imagine the experience of urban space in the first half of the twentieth century, the mental maps of an unlikely pair of modern metropolites further muddy the distinction between elite or cosmopolitan modernism and the traditions of the local urban neighborhood. The Italian artist Fortunato Depero created a vivid artistic legacy inspired by New York. One of the younger members of the futurist movement, he lived for a time in Rome and Paris, then left his home in the small northern Italian city of Rovereto to sojourn in Manhattan from 1928 to 1930. From New York, in

38 Tuan, Space and Place, 38.

39 See Gilbert Osofsky, Harlem: The Making of a Ghetto: Negro New York, I890-1930 (New York: Harper and Row, 1966), I05-I2, 127-36.

40 Faith Ringgold, Tar Beach (New York: Crown Publishers, I99I), n.p. 
bilingual poems, paintings, published interviews, and letters written in Italian to his Futurist colleagues, he extolled the city in characteristically modernist language. Americans "don't have to encounter ancient monuments at every step" and instead see "powerful skyscrapers, fabulous bridges, the speediest elevated and underground trains, forests of ships that are impressive shows of modernity." He described New York as a metropolis of "millions of lighted windows disguising millions of tiny, busy humanoids. There're millions of parties. Millions of loves....Millions of sleeping and dancing people that make this cubist metropolis alive, this new and Boundless Babel that looks like a madhouse and a laboratory at once." ${ }^{41}$ Like many modernists before him, Depero created a vision of the city as an entity while speeding through it on public transit. He took in views from the elevated trains but was even more impressed with the descent into the hurtling cars of the subway. New York's subways inspired him to create a series of ecstatic parole in libertà (words-in-freedom) manuscripts that used letters to create both forms and sounds that collapsed diverse fragments of urban sensation into a concentrated journey. Outsized letters sound out the rumble of the underground.

As did Depero, Notte Zurier also made the voyage from Europe to New York, but he came a generation earlier, landing at the immigration station at Castle Garden in I888 and eventually making his way North. By the time Depero was singing Manhattan, my great-grandfather had lived in Providence, Rhode Island for forty years within the confines of an orthodox Jewish community. Bound by tradition and language to the old-world village, his urban life seems a far cry from the expansive visions that Depero experienced in New York. Yet Zurier, like Depero, was an afficionado of urban transit. Each week he purchased a trolley pass that allowed unlimited rides, and he used it extensively to travel throughout the city. His itinerary was shaped by dislocation as well as by ritual.

Three times a day the trolley took my great-grandfather from his daughter's house-in a new part of Providence-back to the synagogue in the old Jewish neighborhood for prayer and study. And here Notte's daily commutes go beyond the "multilocal" to something approximating Depero's delight in movement and mobility: between his visits to the synagogue, he seems to have used the pass for

4I Quotations are from Fortunato Depero, "Futurism According to New Yorkers," unpublished manuscript, Filipppo Tomasso Marinetti papers, Beinecke Library, Yale University (my translation), and also from an article on New York City published in La Sera (Milan newspaper), July 3, I93I, as cited in Maurizio Scudiero and David Leiber, Depero Futurista and New York (Trento: Longo, 1986). This book reproduces the manuscripts of Depero's parole in libertà (a genre of experimental Italian Futurist poetry: “words-in-freedom”). It also explains that, on returning to Italy in 1930, Depero prepared several manuscripts and a project for a "verbal-visual-sonorous" book titled New York_Film Vissuto [New York: A Movie Lived]. The finished parole in libertà, including "Subway," were part of this project. It was going to include two disks with sound recordings of Depero

154 reading passages from his poetry. 
joyriding, for hours at a time. There are stories of people sighting the old man with the long white beard in nearly every corner of the city. His urban mental map could thus have encompassed the entire transit system. It would be difficult to say whether he rode the trams to explore new territory, to visit known destinations, simply to experience the sensation of being in motion, or for some other reason. He left no record and no one would have dared to speculate on his mental life. Relatives recall a formidable patriarch, steeped in tradition and smelling of mothballs, yet modern enough to admire Eleanor Roosevelt. I would hesitate to claim that his example, John Sloan's, Dorothy Chen's, or Faith Ringgold's defines modern consciousness any more than Depero's might have done.

Cities and living patterns in the United States have changed since I950 due in part to the attractions of the suburban ideal enabled by an automobile-based culture. These developments have been unequal. Subsidized mortgages, high union wages, and massive suburban construction made the dream of owning a single-family house available to white working class Americans in the 1950s-70s. However, in a process that has come to be termed "American Apartheid," banks continued to perpetuate "redlining" by denying mortgage loans to most people of color, while white residents threatened newcomers they deemed undesirable. In these years, highways slashed through working-class urban neighborhoods and the demographic shift, originally known as "white flight," but later including middle-class Americans of more races and ethnicities, sent families away from what became pejoratively termed the "inner city." Increasingly, the cultural concept of "urban" came to be associated with African-American neighborhoods - a trend changing only recently as young professionals, attracted by the convenience and excitement of the city, return to now-gentrifying downtowns. In the meantime, within an increasingly globalized economy, traditional industry left the metropolis in the quest for cheaper, non-unionized labor or automated production. In the aftermath, both local activists and a new generation of planners have redoubled the call for a "just city." 42

Inspired by these changes and new technologies of vision, contemporary artists now imagine both absence and presence within the city. In Detroit, a city drastically affected by rapid and deliberate deindustrialization, the controversial photographer Julia Reyes Taubman ascended beyond the skyscraper to an even loftier aerial view from a private helicopter. Photographs from her book Detroit: I38 Square Miles ${ }^{43}$ depict the grid of an expansive city, once filled with large and

42 Thomas J. Sugrue describes these changes in The Origins of the Urban Crisis: Race and Inequality in Postwar Detroit (Princeton: Princeton University Press, 1998), see also Massey and Denton, American Apartheid, and Fainstein, The Just City. Robert W. Snyder presents a more hopeful example of a working-class, New York City neighborhood organizing across racial lines in Crossing Broadway: Washington Heights and the Promise of a New America (Ithaca: Cornell University Press, 20I4).

43 Julia Reyes Taubman, Detroit: 138 Square Miles (Detroit: Museum of Contemporary Art, 20II). 
small manufacturing plants and neighborhoods of modest single-family houses, in which entire blocks now appear vacated. The dominant color in some of Taubman's photographs is green, as swaths of city blocks seem to be overtaken with prairie. Missing, from this height, is the sidewalk-level activity that continues in pockets of what has become one of the nation's largest majority-black cities. In contrast to this distanced view, large-scale paintings by Kerry James Marshall pay tribute to urban life in the black communities of Los Angeles and Chicago. De Style (1993, Los Angeles County Museum of Art), whose title and rhythmic arrangement of primary colors offer a winking nod to the early twentieth-century Dutch avant-garde movement, shows men gathered in a barbershop. The stately scene viewed from close quarters is intimate, yet heroic.

Today's biggest metropolises grow outside the United States and Europe, and artists are devising new forms to convey their experiences of urban space. Some of their work retains surprising ties to the relationships, traced in this essay, among the view from on high, the view from the sidewalk, and the sensations of urban transit. On the African continent, according to Mike Davis, global finance, desertification, and the aggressions of warlords have contributed to "the exodus of rural labor to urban slums." 44 Julie Mehretu, an artist whose family fled Ethiopia when she was a child, is reinventing the modernist vision of the city of fragments to tell a more extensive story that involves people and money in motion across continents and through time. Her twelve-foot-wide painting Dispersion (2002, Private Collection) concerns processes of migration and exile. To make this and related pieces, Mehretu begins by collecting drawings, photographs, topographic maps, historic illustrations, and diagrams that chart demographic change. Her working process moves back into time as she researches the developments in a site's urban plan, but extends outward into space as well. Her paintings relate to her father's work as a geographer who uses diagrams to give form to the kinds of structural trends that exist beyond human sight - for example, the developments in income distribution within a population. ${ }^{45}$ The artist layers concepts from these forms of visual information and many others, from close-up outline drawings of architectural detail to what seems to be marks of human groupings as viewed from a great height. She combines these with sweeping arcs similar to the force lines imagined by the Futurists one hundred years ago. The resulting images convey the dynamism of global forces that connect cities and send people into flight around the world, or what Berman termed the "perpetual disintegration and renewal" of cities imploding or decaying over time.

While Mehretu's work sometimes leaves the viewer looking in vain for human stories and human bodies, the Johannesburg-based artist Kay Hassan's work

44 Mike Davis, Planet of Slums (London: Verso, 2006), I3-17.

45 See Siemon Allen, Kinsey Katchka, and Rebecca Hart, Julie Mehretu: City Sitings (Detroit: Detroit Institute of Arts, 2007); Joan Young and Brian Dillon, Julie Mehretu: Grey Area (New York: Guggenheim Museum, 20Io); and Assefa Mehretu, Regional Disparity in Sub-saharan Africa: Structural Readjustment of Uneven Development (Boulder: Westview Press, 1989). 
is dedicated to what he calls "everyday people" within the moments and detritus of the "highly charged urban landscape" of post-apartheid South Africa. His installations and monumental collages made from torn pieces of billboards express, in his words, lives "torn apart and put together." ${ }^{66}$ In doing so, he brings the commercial environment into the daily lives of people, in a way similar to what the Ashcan School artists had once done. The locations Hassan depicts, on the outskirts of South African cities, carry within them a profound history involving the experience of urban space and places. The artist grew up in a township under the apartheid system's strict rules governing access to space and citizenship that placed severe limits on mobility within the city. From that vantage point, the metropolis was understood by means of distance and relocation: blacks and "coloreds" were permitted to work in cities during the day but not permitted to stay there at night. At 5 o'clock each day, an alarm sounded, signaling the mandatory return to the townships, often as far as 40 miles away. With the fall of apartheid, many people were forcibly relocated from townships to areas called "homelands" that were not familiar neighborhoods at all. Hassan's installation Shebeen (1997) is inspired by the after-hours speakeasies "where good conversation mingles with desperation." The recurring modern motif of urban transit carries special meaning in Hassan's work. Bus Ride (1996, High Museum, Atlanta) imagines not the lone traveller's shifting view out onto the urban landscape depicted by Carlo Carrà. Rather, it sits inside the bus to depict temporary communities of people in motion, here riding the improvised, informal transport that carries workers from metropolis to living space.

From Paris to Johannesburg, from the sidewalks of New York's Chinatown to a helicopter over Detroit, this essay has explored a multiplicity of urban viewpoints and the experience of modern metropolites over a long twentieth century. The commanding view from the skyscraper provides only some of them; the imagination of the neighborhood retains its presence in the story. ${ }^{47}$ The city's freedoms, celebrated by the first generation of modernists and urban writers, may always have been unequal or hard-won. We have considered the role of movement, whether of transit through a city or migration across the globe, which has altered but not always eliminated the pull of the local. With more than half the world's population now living in cities, the coexistence of these varied mental maps suggests that many more varieties of modern urban experience await their modern artists, and perhaps their urban theorists as well.

46 On Kay Hassan's work, see Rory Bester, "Kay Hassan: Borders and Borderlands" Nka: Journal of Contemporary African Art io (Spring/Summer 1999): I8-23. Quotations of Hassan are from Sue Williamson, "Kay Hassan," Artthrob 38 (October 2000): http://artthrob.co.za/oooct/artbio.html. For context, see Lindsay Bremmer, "Mobile Johannesburg," in The Life of Cities, ed. Mohsen Mostafavi (Zurich: Lars Muller Publishers, 20I2), 210.

47 In many twenty-first century cities, the view from the skyscraper is presently obscured by air pollution. Perhaps our colleagues in China will analyze that next chapter in the image of the city! 


\section{谁的大都市?谁的精神生活?城市图像中的空间与 \\ 本地居民}

瑞贝卡・泽瑞尔

如果现代主义成长于城市，那么，现代艺术与都市化之间就存在许 多可开掘之处。1

一代代的艺术史家与城市理论家援引相同的社会学著作与现代 艺术作品作为现代性与现代城市意识的例子, 由此，相互强化了各 自的结论。本文希望通过对艺术中城市现代性的另类解读，来想象 一种与城市空间相关的对地域与相邻街区的更为灵活的理解。我的 目标在于采用城市艺术与理论来扩充与加强过去 150 年来对城市与 艺术的理解。摩天大楼、街道以及穿梭其中的城市交通的图像扮演 着角色，但其中也不断混合着仰视和俯瞰的视角。文章的重点会放 在 20 世纪上半叶的纽约，同时也涉猎那些适用于当今城市现代化 的范型。

那么，这种连结艺术的现代主义与都市现代性的强大叙事是如 何产生的呢? 让我们从巴黎开始，它有时被认为是现代城市与艺术 的先锋主义的诞生地，马奈《女神游乐厅的吧台》以及一系列艺术 史家与城市理论家熟悉的图像片段，这些在现代城市中描述空间、 时间和意识的表达，也被用来解释绘画中的表象和脱节感。需要注 意的是，他们是如何把艺术的实验语言和社会分析结合起来。首 先, 波德莱尔描述了一种新的启迪现代生活画家的转瞬即逝的感受: “对热情的观察者来说，在人群中心，在运动潮流兴衰之中去建立 一个安身之所，是一种巨大快乐。” 1900 年左右，社会学家格奥尔 格·齐美尔 (Georg Simmel) 在《大都会与精神生活》 (Metropolis and Mental Life) 中写道: “大都会的个体性得以建立的心理基础,

1 Scott McCracken, "Imagining the Modernist City," in The Oxford Handbook of Modernisms, ed.s Peter Brooker, Andrzej Gasiorek, Deborah Longworth, and Andrew Thacker (Oxford: Oxford Univ. Press, 20Io), 638-55; Raymond Williams, The Politics of Modernism: Against the New Conformists (London: Verso, 2007). 
就是在内在与外在刺激之下的突发事件与持续转换带来的情感生活 的激烈化。” 齐美尔将 “大都会精神生活的基本智力特征” 与 “更 多地依靠感觉与情感关联的乡镇” 进行对比。他写道 : “在城市中, 金钱、经济与智力的主导地位构成人与人之间最紧密关系，他们在 对待人与事时有一种共同的务实态度（这一点，我们在马奈作品中 的酒吧女招待的脸上看得很清楚)。”2

历史学家马歇尔 ·伯曼（Marshall Berman）的解释则更加抱有 希望：“存在一种至关重要的经验模式一对时间与空间的体验，对 自我与他人的体验，对生活的可能性与冒险的体验，如今，这种体 验在世界范围的男女中都普遍存在。我将这种人类的体验形态称 为 “现代性”，它让我们被观念裂变与更新的暴风骤雨所裹挟…… 如马克思所说，变得现代就意味着让自己成为一个 “一切坚固东西 都已烟消云散”（All that is solid melts into air）的世界的一部分。 社会学家理查德・西奈特（Richard Sennett）进一步扩展了波德莱 尔的说法：“应当接受持续变化的场景，而不是去寻找变动不居的、 稳固的和整体的东西，这种态度已融入城市生活。费尔南德 - 莱热 描绘了这种介入的状况。” 莱热本人，作为一个将城市各种碎片并 置在一起的立体主义创造者，I9I4 年，他告诉来访者：“如果说绘 画表达发生变化，那是因为现代生活让它这样。现代的富于创造性 的人类的存在比过去几个世纪的人类表现得更激烈与复杂。数不清 的破裂与变化的例子不期而至地呈现在我们眼前。穿过路边风景的 广告招贴的出现, 是由于现代商业的需要。墙上海报、闪炼广告标识, 都是相同观念的传达。” 莱热绘画《城市》是在歌颂视觉轰炸下的 现代商业环境，耀眼的霓虹灯和流动的交通，还原为让整个城市运 作的机器装置的形象。最后，有一个关于莱热的轶事：20世纪 30 年代，美国艺术家乔治·莫里斯（George L.K. Morris）在某天的 午餐时间来到莱热的巴黎寓所的阳台，“这个房间坐落于林荫大道，

2 Charles Baudelaire, "The Painter of Modern Life" (I863), in The Painter of Modern Life and Other Essays, ed. and trans. Jonathan Mayne (London: Phaidon, 1964), 9; Georg Simmel, "The Metropolis and Mental Life" (1903), in On Individuality and Social Forms, ed. Donald N. Levine (Chicago: University of Chicago Press, 197I), 325. 
在这里，大都市成了高架公路，而不是地下通道 ; 每辆过往的列车 都会发出巨大轰鸣声，火光几乎要迸进浓雾中。莱热说，他十分喜 欢这种沉浸在机械世界中的快感，心满意足地拉回了椅子”。3

从波德莱尔到齐美尔再到本雅明，以及马奈、莱热和其他人， 这个强有力的阐释线索已经证明了现代主义艺术的定义或代表了一 种现代都市意识。社会理论学者转向艺术与文学来寻找其他资源中 无法找到的现代的主观性。 ${ }^{4}$ 立体 - 未来主义的语汇, 有着破碎的形 式与不规则的空间形象, 常常是在齐美尔分析去人性化与快速变化 的疏离时, 作为一种视觉的对等物而被引用的。二十世纪的艺术家, 以新的形式手段来表达碎片化城市, 来自人群与摩天大楼的速度与 超负荷的感觉、震颤和断裂，与资本主义商业交易的去人性化相平 行的疏离感。马列维奇（Kazimir Malevich）对《一个英国人在莫 斯科》(Georg Grosz, An Englishman in Moscow, 19I4, Stedelijk Museum）中的错位概念的歌颂，以及德国人乔治·格鲁兹战时创 作的错位的作品《大都会》(Metropolis, I916-17, Museo ThyssenBornemisza), 那些破碎片段都在努力表达多重城市刺激下的共时之 感。

就像莱热在巴黎午餐时所做的那样, 现代艺术家与作家也激活 了城市交通系统一地铁、有轨电车、或者在头顶轰鸣疾驶的高架列车: “喧华人行道上，阳光通透，酒在高架列车上，温暖火热的黄色光 束穿透了高架铁路下的蓝色街道” (约翰 - 帕索斯语)。借助于持续 变化的风景与鲜活的视觉感知来传达自由漂浮的流动性。 ${ }^{5}$ 意大利

3 Marshall Berman, All That Is Solid Melts into Air: The Experience of Modernity (New York: Simon and Schuster, 1982), 15; Richard Sennett, The Conscience of the Eye: Design and the Social Life of Cities (New York: Norton, 1990), 175; Fernand Léger, "Contemporary Achievements in Painting," Soirees de Paris 19I4, in Functions of Painting (New York: Viking, I973), II-I3 passim; Morris, "Preface" (I97I) in Functions of Painting, xii.

4 这些联系构成了社会学家大卫.哈维和艺术史学家 T.J. 克拉克对 19 世 纪巴黎的讨论主题。

5 John Dos Passos, Manhattan Transfer (New York: Harper and Brothers, I925), chap. II. 
未来主义者卡洛·卡拉 (Carlo Carra) 的绘画《有轨电车告诉我的事》 (What the Tram Told Me, I9II, MART Rovereto) 是在探索大都会 杂乱和片段的掠影中，搭乘有轨电车的那种突进感，以及一种不断 变换的现代心理状态。后现代理论采纳了许多城市空间、“无地域 归属”（Placelessness）以及时间的碎片化的假设。 ${ }^{6}$ 相应地，意大 利未来主义者在透过内在意识融合时间和空间的创新方面是启发了 美国的约瑟夫 ·斯特拉（Joseph Stella）创作他向现代都会致敬的 作品。斯特拉的人生轨迹在于他从儿时居住的南部意大利小城移民 到 20 世纪初的纽约。他的三联画《阐释纽约的声音》 (Voice of the City of New York Interpreted 1920-22, Newark Museum）构想了一 个从左边的入境口岸, 到眼花缭乱的摩天大楼, 转入城市地铁, 然 后以眺望布鲁克林桥为终结的旅程，所有一切又都与未来主义者的 动力线结合在一起。

那么，在过去与现在，这些断裂的视角、高速的运动以及无限 自由是否可以真正代表城市生活呢?我们可以根据一些本地居民的 口述历史与回忆录，来考察 20 世纪早期纽约空间经验的更详尽描 述。首先是陈贝蒂, 1908 年出生于纽约 0.5 平方英里见方的中国城: “那时的中国城，就是蒙特、配尔与多耶斯街区。我并不知道还有 其他街道。我的世界很狭窄。我只是在学校与家之间来往……我的 犹太朋友伊娃是第一个带我走出这个狭隘范围的人，她带我来到亨 利街，我觉得自己好像进入了另一个世界。”另外一个经验来自于 一本自传小说《贫穷的犹太人》(Jews without Money)，描述的是 麦克·古德 (Mike Gold) 在下东区的童年生活：对孩子来说，东 边是一个陷入无休止纷争的世界，走到另一个街区无异于自杀。每 个街区都是一个独立国家，当一个陌生男孩出现，爱国者就会蜂拥 而至。人们会愤怒质问：“来自哪个街道?”他颤抖地回答：“克里 斯蒂街道。”BANG” 的一声，这就是对这位不幸的异域人士进行

6 参见詹明信对现代和后现代空间以及后现代主义认知地图的讨论，见 Fredric Jameson, Postmodernism: The Cultural Logic of Late Capital (Duke University Press, 1992), 156, 162, 415 以及大卫·哈维的城市空间讨论, 见 Consciousness and the Urban Experience and The Postmodern Condition; Edward Soja, Postmodern Geographies (London: Verso, 1989). 
殴打与围攻的信号，他们持有棍棒等凶器，开始拳打脚踢。最后， 是成长在时尚的上西区 “金色住宅区” 的桃乐西·格林伍德 (Dorothy Greenwald）的回忆。“我们居住的街区一如往常, 这种安全感和 稳定感来源于我们认为, 邻居与我们是同一类人……直到年长一些, 我才开始在市中心区冒险。人们不会鼓励你离开这个街区，因为你 会遇到一些和你的成长背景不相称的人”。7

这种被限定的城市空间的描述与上文引述的 “短暂与无限” 的 描述之间的不一致，让我们重新思考现代主义的形式与城市意识的 对等关系。如齐美尔分析的那样, 大都会的抽象景象可能部分地由 阶级、年龄、世代以及环境等理念塑造的，而不是清晰明确的，并 不需要成为一种城市经验或者精神生活的普遍准则。随之而来的争 论, 以及对现代性概念的推崇, 夸大了它与之前思想形式和空间经 验的区别。如果存在一种现代境况, 这本身就是一个可以质疑的命 题, 为此, 我们需要更复杂的范本, 以便于确认人们在大都市活动 方式中的 “地域性” 的存在。 ${ }^{8}$

我们可以通过对美国现代主义全盛之时造就的不同视角的论述 来探讨这些区别。在 19 世纪 90 年代到 20 世纪 40 年代, 纽约标 志了美国的未来，而对于那些来自异域的，仅在欧洲的一些城市瞥 见了部分现代性的人来说, 他们更是将纽约视为一种现代性力量的 纯粹表达。在这些年里, 大力发展的技术工业改变了纽约曼哈顿的 天际线，同时，也遭遇了移民潮的巅峰，首先是欧洲、亚洲、中东 地区，之后是来自南部乡村的黑人 “大移民”，移民大潮也带来了 巨大社会变革。吸引了有冒险精神的艺术家和画家，他们中间也有 大量移民，纽约启发了如它拥有之人种的多样性一样繁多的意象，

7 陈和格林伍德引自 Jeff Kisseloff, You Must Remember This: An Oral History of Manhattan from the I8gos to World War II (San Diego: Harcourt Brace, 1989)，18，158. 另见作家 Claudia Steams 形容 1929 年 的上东区: “......我们不能住在西边, 人们也不会, 我们一伙人过去住 在东边。我从来没想过，我丈夫也从未想过。”（Kisseloff, I36）Mike Gold, Jews Without Money (New York: 1930), 42-43.

8 “地方与社区” (locality and community) 的讨论, 见 David Byrne, 
使得我们可以进行一系列比较。很多人都描述了离开家乡小镇来到 大都会的得失体验。

对欧洲现代派成员来说, 纽约承载着一个梦之城的特殊功能, 是一个经过转换的渴望与畏惧的象征。对那些感到自己直于一种传 统文明的局外人来说，美国可以被看作是一个没有历史的地方，致 力于进步、商业与贪婪。达达主义者格鲁兹和比利时人保罗 ·希特 鲁恩（Paul Citroen）是这些欧洲艺术家中的例外，他们创造了纽 约的反乌托邦景观, 却未曾到访此地。分化为碎片的摩天大楼、广 告画、人群以及交通，构成了他们作品的主要题材。 ${ }^{9}$ 但是，对弗 朗西斯 · 皮卡比亚和阿尔伯特 - 格雷兹这两位真正到访过纽约的人 来说，此地与欧洲相比显得不真实 : “你们纽约是立体主义者和未 来主义者的世界。”皮卡比亚（Francis Picabia）1913 年如是说。这 表现在它的建筑、生活、精神以及现代思想中。“你们……是语词、 行为和思维意义上的未来主义者。” 相对于建筑的表现, 格雷兹《布 鲁克林大桥》表现出的敬意, 更多是对融入桥梁、城市、灯光与运 动中的耀眼的多视角的感知。杜尚认为，纽约是 “一件彻头彻尾的 艺术品”，而 193 I 年到访的莱热则宣称，“我十分仰慕这个超负荷 的景观，所有这些无拘无束的蓬勃生命力，这正是其中的要害，即 便是在错误当中，它如此年轻”。10

不仅是来自欧洲的访客，美国本土现代主义者也一再将纽约视

9 对欧洲的现代主义者来说, 对美国的幻想可以从格雷兹和魏玛时期同 代人那些令人兴奋的描述中看出，Beeke Sell Tower et al., Envisioning America ex. cat., Busch-Reisinger Museum and Wanda Corn, The Great American Thing: Modern Art and National Identity (Berkeley: University of California Press, 1999), 47-72.

10 Picabia, “How New York Looks to Me,” New York American (1913), II. 阿尔伯特・格雷兹在 1915 年讨论 “百老汇的立体主义印象” (a cubist impression of Broadway）时说到：“走在这座大都市街道上时，我常有 一种被卷入甚至是压碎的感觉。这可能是因为部分建筑物的高度，也有 可能是因为人的移动, 如此稳定地流动, 如此坚定的目的, 非常准确地 了解目标在哪里。在巴黎街道如同迷宫。生活时走时停。它曲折且复 杂。但是纽约却让人兴奋, 它刺激我......” 引自 “French Artists Spur on American Life," NY Tribune October 24, I9I5, sec. 4, 2-3. 
为抽象的未来主义的隐喻。部分艺术家因为政治避难离开欧洲, 来 到美国大都会寻找机会, 他们颂扬纽约的差异性: 马克斯·韦伯 (Max Weber）（他 Io 岁时，从比亚委斯托克移民纽约）描述道，“纽约 是一个伟大的立方体的城市”。诗人威廉·卡洛斯・威廉姆斯 (William Carlos Williams) 盛赞约翰·马林（John Marin）的那些拥塞着 “摩 天大楼群” 的城市绘画。 ${ }^{11}$ 这些形象有助于提升作为现代性标志的 曼哈顿，是等同于未来的，贡献了一种作为现代性的呈现的曼哈顿 图像。

那么, 这些让人迷且包罗万象的景观如何与陈贝蒂的中国城记 忆共存呢? 它是否仅仅是一个成年艺术家从孩提时代的空间、社 会和想象界域中获得成熟的问题? 正如小说家麦克 - 古德 (Mike Gould）与亨利 - 罗斯（Henry Roth）在他们的教育与文化类小说 描述的那样, 最终是为了曼哈顿的自由而离开了之前的街区? ${ }^{12}$ 或者

11 与欧洲传统相比, 杜尚坚持认为纽约是一个没有历史的城市：“我相信 拆除旧建筑、旧纪念物的想法很好……我们必须学习忘记过去，在我 们的时代过自己的生活。” “A Complete Reversal of Art Opinions by Marcel Duchamp, Iconoclast," Arts and Decoration 5 (Sept. 1915), 427-28. "New York," in Cahiers d'Art (193I reprinted in Functions), 8490 passim. Max Weber, “OH Sun," Cubist Poems (1914)（纽约长大的 韦伯，在他的朋友摄影师阿尔文·兰登·科伯恩影响下将目光投向了城 市作为现代艺术主题的可能)。威廉姆斯用《年轻的爱》(Young Love, I923）形容马林的作品。马林描绘了他认为的城市形象：“我试着以图 形的方式表现一个大城市的样子。在框架内必须有平衡，来控制这些拉 力、推力的交战。” (画廊目录介绍第 29I 页, 1913) 评论家保罗·罗森 菲尔德 (Paul Rosenfeld) 称赞马林捕捉了 “纽约的狂热生活……高架 铁路下是令人厌恶的街道洞穴, 人们辛苦劳作的地方只有杂乱无章的 建筑。” Rosenfeld, “American Painting,” The Dial 7I (December 192I), 649-70.

12 Gold, Jews Without Money; Henry Roth, Call It Sleep (New York:

Robert O. Ballou, 1935). Sara Blair, "Against Trauma: Documentary and Modern Times on the Lower East Side," in Trauma and Documentary Photography of the FSA, eds. Sara Blair and Eric Rosenberg (Berkeley: University of California Press, 20I2). 
这种情况是不是与詹尼特 - 沃尔夫（Janet Wolf）的描述类似，“现 代性的文学描述往往是男性经验” ?情况也并非如此：在有关纽约 的回忆录中，空间的限定与活动的自由都并不总是与性别相关 : 比 如小说家麦克·古德描写的男孩帮的势力范围，或者相反，如女记 者玛丽 ·哈顿 ·佛斯（Mary Heaton Vorse）, 多罗西 ·代（Dorothy Day）以及德居娜·巴尔斯（Djuna Barnes）的生动描述，她们在 1910 年代是以特殊节奏而在城市中漫步的。在更为现实的领域里, 无数女性每天穿过纽约，从家里到达工作场所，与此同时，各种流 行时尚引导了一系列购物、观剧、慈善及家庭事务。13

为描述城市中的这种经验的差异性，让我们从现代主义批评理 论领域转到基于美国城市居民行为的社会研究的概念。一个是 “精 神地图”（mental map）的概念，也就是城市居民创造了一个由不 同 “节点” 定义的功能性的 “城市形象”，对 “边缘” 或 “边界”, 以及连接不同地方的 “道路” 等主题来说，地标是十分重要。社会 科学家使用抽象的视觉语言形式 : 诸如表格或地图来表示人们日常 的城市生活经验。比如，居住在洛杉矶的地理学家，让成年居民勾 画自己城市的图像。洛杉矶是一个很难感受到整体性的城市 : 在全 球定位系统出现之前，居民最常使用的街道地图并不是全景，而是 一本一英寸厚的书，把这个地区分为几百个可检索的区域。研究者 对比了三个不同街区居民所绘地图的集成, 巨大差异就显示出来了。 居住在怀斯特伍德繁华区域的居民绘制出了最为广衰的城市图像, 这条线贯穿在文图拉与圣塔莫妮卡快速路的各个节点上。非裔美国 工薪阶层聚居区的人描绘的地图，阿瓦隆中心城区，其主干是垂直

13 关于女性及城市空间，见 Janet Wolff, Feminine Sentences: Essays on Women and Culture (Berkeley: University of California Press, 1990), 34; Christine Stansell, City of Women: Sex and Class in New York, I789I860. 另见 Dorothy Day, An Eye For Others: Dorothy Day, Journalist: I9I6-I9I7, ed. Tom McDonough (Washington, D.C.: Clemency Press, 2016). Elaine Abelson, When Ladies Go A-Thieving: MiddleClass Shoplifters in the Victorian Department Store (New York: Oxford University Press,1992). 引用了 I9 世纪晚期中产阶级女性的日记详细记 录了她们每天在纽约的城市漫步。 
走向的公交车路线。拉丁裔聚居区的波义耳高地的地图是最小的： 仅有几个街区的步行城市，相当于陈贝蒂回忆中的纽约中国城的大 小。14

这样的研究说明, 城市布局的概念以及物理范围主要取决于观 察者的社会与经济状况，文化传统，交通的便利性，可能还有性别 因素。他们承载了美国都市化的历史痕迹, 特别是在 20 世纪, 同时, 也承载了那些把特定种族群体区分或隔离开来，并形成城市相邻区 域隔绝的法律、金融和社会方式。因此, 这些研究中的城市 “形象” 几乎没有什么普遍性，很多东西是同时存在的。 ${ }^{15}$ 城市理论家皮特 ·马尔库斯 (Peter Marcuse) 超越了洛杉矶的这种分隔式的地图研究, 而提出了 “分层的城市”, 其中, 不同族群让他们相互交叠的路径 同时发生作用，那些精英住家所在的街区是工人劳动的地方。另一 个实用的多重都会概念来自于城市人类学家，他们对个人在城市的 活动进行追踪。描述他们活动的路径和模式, 以及一种强烈的对族 群聚居区的地域依恋倾向，即便这些居民离开后也是如此。16

14 Kevin Lynch, Image of the City (Cambridge: MIT Press, I960); Harold Carter, "Images of the City: The Citizen's View," in The Study of Urban Geography, 3rd edn. (London: Edward Arnold, 198I), 343-47. 对林奇的 研究工作的影响与批判讨论见 James S. Duncanson, “Review of Urban Imagery: Cognitive Mapping,” Urban Geography 8 (1987): 264-72.

15 在超越可被记录在案的社会阶层和经济地位, 进入更主观的意识领域 时，更多无形的因素开始发挥作用，包括个人偏好和个人史。麦克·戈 尔德（Mike Gold）在小说《没钱的犹太人》(Jews without Money) 中 描述的三个在同一社会经济背景下的女性人物有所暗示。主角的母亲拒 绝离开她所居住的街区，表现出 “农民对旅行的厌恶……过去的东边是 她现在的村庄。”(第 I 48 页) 出生在村庄的妹妹, 来到纽约, 花了数周 游历这座城市（出于礼节她由侄子陪伴，但是她更想要自己到处走走）。 英雄的姐姐出行更受限制, 但她需要定期离开街区, 将家庭作坊制作的 衣服送到第五大道的一家时髦的服饰经销店。

16 Peter Marcuse, "The Layered City," in The Urban Lifeworld: Formation, Perception, Representation, eds. Peter Madsen and Richard Plunz (London: Routledge 200I), 207-30; Maria Lewicka, "Place Attachment: How Far Have We Come in the Last 40 Years? Journal of Environmental 
艺术、设计和小说都有 “城市形象” 功能，以说明城市空间 的不同经验与概念。当我们追问 20 世纪上半叶的一些纽约再现 中隐含的精神地图是什么时，让人惊讶的平行与联系的情况就出 现了。在某些方面，它们回应了米歇尔·德·塞尔托（Michel de Certeau）对游客的那种来自摩天大楼的全能视角与城市居民街边 看到的 “更为亲切的” 城市之间概念差别。在这些图像中，有许多 采用高视点，以便在全景中涵盖整座城市。1905 年作为杂志插图出 版的格雷兹的立体主义绘画，描绘了城市灯光与从 22 层慰斗大厦 顶端观看到的城市全景，其中，我们可以领略艺术家在作品中想要 展现城市整体的企图。17

不论是描绘片段的急速变化，还是整洁有序的广阔区域，这样 的图像是以艺术家的眼光而将 “曼哈顿” 构想为一个有机整体。这 些静止视角的总体视野，是在现代主义的那些穿越城市无限扩展 空间的公共交通图像中被激活，通过现代绘画，正如多斯·帕索 斯展现的图像，“茧火虫般的火车经过蜘蛛网般桥梁，穿梭于薄暮 中”，首尾相接，把这个岛屿联系起来。整个城市相似的精神地 图同时也以一种非常不同的现代主义者语汇而凸显这些图像的特 征 : 那是静态而完美的理性秩序, 构成了理想化柯布西耶式的城 市。勒 ·柯布西耶认为，纽约是 “第一个在现代尺度上建立起来的 城市”（尽管很遗憾，建筑师并未实现创造一个完美 “伏瓦生计划”

Psychology 31(201I): 207-30.

17 Michel de Certeau, The Practice of Everyday Life, trans. Steven F. Rendall (Berkeley: University of California Press, 1984), 9I-95. 道格拉斯 - 泰莱 克（Douglas Tallack）不认同塞尔托的常规研究，他指出 20 世纪早期 的鸟瞰图视角在一定程度上可以看到整座城市的运作，而那些更为亲切 的街边视角则做不到。见 Douglas Tallack, New York Sights: Visualizing Old and New New York (Oxford: Berg, 2005), I29. 插图见 Edgar Saltus, "New York from the Flatiron," Everybody's Magazine (July 1905); Michelle Bogart, Public Sculpture and the Civic Ideal in New York City (Chicago: University of Chicago Press, 1989); and William Taylor (with Thomas Bender), In Pursuit of Gotham: Culture and Commerce in New York (New York: Oxford University Press, 1992), chap. 2-4. 
$\left(\right.$ Plan Voisin ${ }^{18}$ ) 的可能性。由英国旅居者 C.R.W. 尼文森 (C.R.W. Nevinson) 和美国人查尔斯 - 席勒 (Charles Sheeler) 这样的现代主 义者（两人都活跃在 20 世纪初期）创作的那些边界清晰的作品, 展现了城市全景视角, 现在, 从摩天大楼的窗户，就显示了一个充 满高䇤的几何形体与陡峭峡谷的城市，里面却是没有人烟。19

这种荒凉而延展的视野吸引了精确主义者乔治娅 - 奥基弗 (Georgia Keeffe), 她是最早的那些乐于把家与工作室安置在摩天 大楼中的艺术家之一。她的作品《纽约之夜》构想了一个让人晕眩 的双重视角，在塔楼上，同时向上与往下观看，然后眺望远方。奥 基弗和她的丈夫阿尔弗雷德・斯蒂格利茨（Alfred Stieglitz）发现, 他们在喜来登酒店十三层楼的住所是完美的城市生活空间, 因为这 个住所把他们与城市的特定区域和居民分离开来。斯蒂格利茨高兴 地说: 乔治娅和我在某种程度上并不属于纽约，也不属于任何地方。 我们居住在喜来登酒店的高层……觉得自己是外在于此地而处于一 片汪洋之中。对于奥基弗来说，“在大酒店的高楼层创作，为一种 新的城市艺术提供了前所未有的可能性, 我想, 这就是今天艺术家 需要的一种刺激。他必须拥有一个处所, 可以让他整体观察这座城 市”。20

在对洛杉矶的研究中，就像塞尔托的图表一样，“作为整体城市”

18 参见 Richard Sennett, The Conscience of the Eye。柯布西耶对纽约拥挤且 不规则的街景失望, 称其为 “美丽的灾难” (fairy catastrophe), 见 Le Corbusier, When the Cathedrals Were White: A Journey to the Country of Timid People (London: Reynal \& Hitchcoke, 1947), viii.

19 参见尼文森的作品《俯视市中心 I920》 (Looking Down on Downtown 1920) 和席勒的《摩天大楼 I922》(Skyscrapers 1922)。摄影师阿尔文 · 科伯恩（Alvin Langdon Coburn）在 I9II 年和韦伯的科罗拉多大峡谷 之旅中受到启发，在拍摄一系列曼哈顿建筑时就运用了这一摄影技术。 1913 年，科伯恩在伦敦展出了这些作品，展览名为 “New York from Its Pinnacles”，其中包括著名的摄影作品 The Octopus（I9I2），在大都会 人寿保险大楼顶拍摄的麦迪逊广场一景，以及充满立体感的作品 House of the Thousand Windows。

20 Anna Chave, "Who Will Paint New York?” American Art 5 (Winter/ Spring I99I): 87-I07. 
的延展视角表明了一个优越的观察位置。这些绘画中，也同样隐含 了那些表达可见城市的所有部分的精神地图，表明了某些特定类型 的保持心理优势的旁观者: 旅行家、政府官员还有来自海外的游客， 探寻新经验时的那种冒险精神。在他们所及的范围内，这些包罗万 象的视野是无视城市邻里的那种强烈的地域体验: 前文引用的纽约 回忆中勾画的那些步行城市及其边界和节点，还有对街区归属的研 究和分析。正如格温多琳·怀特（Gwendolyn Wright）所说，现 代主义似乎缺乏一种家园的概念，以及人与人之间有意义联系的概 念。 ${ }^{21}$ 但是，现代主义的城市概念是否可以不再无视城市内的地域 观念或者区域和邻里的都市性而涵盖这两种观点?

我们可以考察两幅对立的城市景观，它们都创作于纽约，且年 份相近, 两幅作品都是由从小城市迁至曼哈顿的美国艺术家创作的, 而且, 都题名为《中国餐馆》。两幅图像使用了当时美国的中国餐 厅随处可见的红色涂装作为典型特征。近年来，这个主题是以廉价 食物、异域装饰以及廉租街区中的杂色斑斓客户（艺术家与妓女们 常常光顾的地方)，吸引艺术家的到来。马克斯・韦伯在描述他的 绘画灵感时, 参考了现代主义者所熟悉的破碎与短暂: “漆黑的暗夜, 进入一家中餐馆，光线的迷离与闪耀将室内及其陈设、将人与单调 事物分解为碎片。一时之间，静止变得捉摸不定，稍纵即逝，倾斜 的面和轮廓占据了垂直和水平位置，水平或垂直变得倾斜了。光如 此地洞透和明亮，色彩如此地流动，生命和运动如此地迷人!为表 达这些, 你必须懂得从万花筒中撷取。” 22 利用韦伯对第四维的兴趣,

21 Gwendolyn Wright, "Permeable Boundaries: Domesticity in Post-war New York," in Urban Lifeworld, eds. Peter Madsen and Richard Plunz (London: Routledge, 2002), 207-I7.

22 韦伯的评论来自他在 MoMA 回顾展清单上写的注释, Alfred H. Barr, Jr., Max Weber (New York: MoMA, 1930), 17. 《中国餐馆》这幅画原先 叫做《中餐馆的记忆》，韦伯作此画为了回应科伯恩的来信，建议他创 作一幅带有 “唐人街特质的记忆的画” 来记念 “我们一起在那儿度过的 许多个夜晚”一—要画出 “特质” (essence) 或是 “记忆”（memory） 的想法或许使得他的作品要比下文讨论的斯洛恩有着更为全面的抽象形 象，尽管斯洛恩也从记忆中汲取相关元素进行创作。 $[1915$ 年 4 月 6 日 科伯恩写给韦伯的信，引自 Percy North, Max Weber: The Cubist Decade 
那幅本来命名为 “中餐馆的记忆” 画作翻倒在房间的砖地上，不同 视点并置在一起, 就好像它们是在时间流逝中发生的, 颤动的线条; 人的形状仅仅是作为不断重复的局部的剪影而呈现出来，它靠近了 画面的中右侧。

与韦伯同时代的约翰 - 斯洛恩（John Sloan）则是使用了建筑元 素来框定与组合他的那些处在即时互动中的人物。1 909 年日记中, 他重述了这幅画的制作，那是从第六大道的漫步开始的：“我感到 筋疲力尽, 所以就来到一个中餐馆休息, 我兴奋地看到了一个奇特 打扮的女孩子，她的帽子上面有红色羽毛，在和餐馆里的小猫嬉戏。 这个场景适合入画……”几个星期之后, 他写道: “正在画 “中国餐馆” 作品中戴红羽毛帽子的女孩儿, 为唤醒记忆, 我再次来到这个餐馆 午餐, 必须及时去, 因为明天他们就会搬到下面的街角（29街）了。” 韦伯试图在记忆中综合一种包罗万象的经验, 斯洛恩的绘画, 原名 是《第六大道的中国餐馆》(Chinese Restaurant, Sixth Avenue), 如此这般地依赖它所在的处所，乃至于这个餐厅搬到南面街区时， 他就丧失了方位感。正如许多 “垃圾箱画派” 作品, 斯洛恩的那种 显然属于传统的绘画，因其主题而归属于一个特定地点。但是，这 幅绘画也是以自己的方式, 而参与到了现代城市错位与再定位的进 程中。他探索了族群融合（当中国餐馆搬到上城，斯洛恩所在的临 近第六大道和 $2 \mathrm{I}$ 街的街区时, 也就进入一种杂合文化)。如同齐美 尔所描述的，我们看到了陌生人之间基于金钱的临时性关系的本质。 在近距离观察之下, 我们发现, 斯洛恩绘画可能不仅仅是描绘了一 个街区社交场所里熟客们的温馨聚会。戴羽毛帽子的女人看起来像 是一个妓女, 她赖以生活的基础就是在公共场所吸引别人的注意力。 与此同时，画作也通过将观众置于密集场景，即从毗邻桌子角度， 构想了一种熟悉的气息。

类似于斯洛恩的作品或莫里斯 - 恩格尔 (Morris Engel) 1935 年 拍摄的繁忙的哈莱姆街道的摄影, 其中, 一群孩童在城市场景中追 逐玩要, 它们都曾被排除在一些现代艺术史之外，仅仅是因为它们 太过特殊，太过一致，专注于某个特定区域。在城市中，那些交互 
的影响和事件的形象，总是被当作风格上倒退的、浪漫的和乡愁式 的对现代都市生活的无序和不近人情的拒绝。但是，在它们对特殊 性、时间节点的停滞以及地域性的描绘中，是传达了现代城市经验 的其他方面的有效范例的。它们提醒我们，对很多城市居民来说， 地域归属，在空间中维系一个落脚之地的需要，会持续在精神地图 上产生重大影响，而不是在那种都市的包罗万象的抽象当中。 ${ }^{23}$ 这 种归属感并非全然是桃乐西・格林伍德回忆中的所指，全由族群或 经济状况决定，纽约人的视野也可以被传统、时尚、礼仪或乡愁的 世界所塑造。一个曼哈顿的中产阶级是会有想要逃离皇后区或回到 下东区老街坊的想法的。

这些比较也提醒我们，不要在简单的礼俗 - 法理社会的二元结 构中，将地域与一般、处所与空间，族群领地的同质性与大都会的 异质性，或特殊与万花筒般的景象匹配在一起。我们在海伦·莱维 特（Helen Levitt） 1940 年城市街区中的人的摄影中是可以看到这 种张力的。尽管这些人物成群站立或坐在那里，他们的目光却投向 不同方向，而且，他们面对照相机的目光就好像它是一个入侵者。 这样的图像提醒我们，地域归属也存在阴暗面：它可以创造群体, 也可以守卫领地。政治理论家苏珊 ·法恩斯坦因（Susan Fainstein） 分析过，当本地居民驱逐新的外来者时，美国街区中 “领土聚居” 的黑暗政治便产生了。莱维特照片中的向心力与离心力的结合也提 醒我们，移民街区是转瞬即逝的地方，常常在他们各自内部或者种

23 一些理论著作强调大都会城市社区的存在。在《马克思主义和城市》 [Marxism and the City (London: Clarendon Press), 203-56)] 一书中， Ira Katznelson 引用了 “不平等的发展”（uneven development）概念来 解释 I9 世纪伦敦工人阶级对社区的依附。芝加哥社会学家非常关注城市 “共同体” (communities) (见 Robert E. Park et al, The City [Chicago: Unversity of Chicago Press, 1967]）如 Jane Jacobs 的《美国大城市的生 与死》 [The Death and Life of Great American Cities (New York: Random House, 196I)]。段义孚定义 “地方” (place) 为已知的位置, 将 “空间” （space）定义为一个开放的场所：“地方是安全，空间是自由；我们依 附于一个空间和地方，渴望另一个。” Yi-Fu Tuan, Space and Place: The Perspective of Experience (Minneapolis: University of Minnesota Press, 1977), 3 . 
族的子族群中分裂。

街区中的有效联系并不总是限制此间居民的视野。大多数城市 居民的精神地图的节点也许是散开的，但也是由相似道路连结在一 起。当一个人从家里出发到工作场所, 或者是周末离开居住区去度 假。再次申明，社会科学中有一个词来解释这种现象 : 我们可以想 象一种将公共交通线路与知名地点连结起来的 “多重的本地居民” (multilocal) 的城市经验。居住在这样的地方, 并不意味要舍弃 街区理念, 而只是存在于一种时间和空间的更大规模位移的对应物 中。就如斯洛恩的绘画, 或恩格尔与莱维特的摄影, 并不意味着是 对大都会的超负荷的逃避。我们在他们的作品中看到, 冉宁是那种 力图在漩浴中维系街区孤岛的统一性和辨识度的张力。这也许是更 为典型和真实的思想的现代状态, 面对城市的冲击, 既不放弃, 也 不回避。24

在城市居民的经验中，作为一个以某种方式把近和远、有边界 的地域和无限空间结合在一起的例子，屋顶的角色值得思量。在一 个拥挤的现代城市中，屋顶可以起到跨界作用，是一个介于狭险与 广阔、邻近（家园）与遥远（地平线）的中间地带。现代主义艺术 家走上屋顶，俯瞰一个被抽象为遥远的几何形体的城市，它要么狂 热如马林画作，要么像谢勒笔下的神秘与宁静。然而，斯洛恩是依 据人的活动和主观性来描绘屋顶的。他的小幅蚀刻版画《屋顶: 夏 日之夜》(Roofs, Summer Night, 1906)，描绘的是人们带着自己的 建炎子来到屋顶, 在露天靠在一起睡觉的场景, 让观者的视域靠近他 的这些街坊邻居所在的空间。画作把这个屋顶描绘成为下面问热而 拥挤的房屋的延伸。在这个拥挤着熟睡者的场景中，我们注意到， 有一个人是醒着的，并在向外瞭望。与奥基夫在喜来登酒店上的那 个颇为壮观的独立领地不同, 这个充满杂乱人体的幽闭恐惧的图像, 清晰有力地表达了一个城市空间的社会学事实: 在一个拥挤城市中, 兼具私密性与无限空间视野的房间是奢侈商品, 穷人很难享受到。

但具有讽刺意味的是, 这种驱使住户占据屋顶的行动, 也让他

24 Susan Fainstein, The Just City (Ithaca: Cornell University Press, 20Io), 76; John Bodnar, The Transplanted: A History of Immigrants in Urban America (Bloomington: Indiana University Press, 1985). 
们强烈感受到了城市广阔的景象。斯洛恩的同代人玛丽·安婷 (Mary Antin）回忆她青少年时期在拥挤的波士顿贫民窟的经验，屋顶成 了逃离过于拥挤的街坊邻居的避难所。在紫色调的和全景式的描述 中，她是这样来述说拂晓时看到的景象的：“飞升到屋顶之上，这 是灵魂向着旭日的飞跃。晨间的薄雾索绕在烟图、屋顶与墙壁之上， 索绕在路灯杆之上，轻纱一般的帷幔漂浮在街道上。远处建筑物团 聚在一起，就像宫殿的高墙，那些塔楼和尖顶消失在玫瑰色的云端。 我喜欢在我周围扩展的美丽城市。” ${ }^{25}$ 这种不断增强的对无限空间感 悟, 视之为财产形式 (“我的城市”), 似乎是与地理学家段义孚 (Yi-Fu Tuan）的观点对立的：“掌握财富与权力的人，不仅比其他普通人 拥有更多地产, 还掌控了更多的视觉空间……富人从寓所眺望窗外, 看到的是他们脚下的世界。”

奥斯丁的视角则让人想起费斯 - 林谷德（Faith Ringgold）的故 事拼布《塔尔·宾奇》（Tar Beach）中表达的那种在贫困中感到的 既束缚又自由的状况。这件作品创作于 1988 年，是基于艺术家 20 世纪 30 年代的哈莱姆记忆，大约同时，莫里斯·恩格尔也在此处 拍摄他的照片。这个场景是把屋顶当作一个私密活动场所来描绘的, 周边则是宽广的地平线。附随的文本描述了这个年轻女孩从右边的 位置看到的景象: “夜晚躺在屋顶上, 摩天大楼和星辰就在我的周围, 让我感到很充实，好像目之所及都归我所有。这座桥（乔治·华盛 顿桥）是我拥有的最珍贵的财富。” 在远处，她想象自己飞翔在城 市上空，去 “辨认” 每一个她看到的地标。圈于自己的境况，一个 孩子可以在无限延展的地图上想象那无边无际的领地。这些图像说 明，人们可以构想一个包罗了这两种视点的城市体验，然后回家， 而不是去对比德·塞尔托的从世贸中心视点到街区行走的视域概念。

根据 20 世纪上半叶艺术家构想城市空间体验的这些不同方式, 我们需要重新反思一些显然并不匹配的现代大都会的精神地图, 它 们进一步模糊了精英或大都会的现代主义与地域性的街区传统之间 的界限。来自意大利的佛图纳托·德佩罗（Fortunato Depero）因 纽约的而创造了如此生动的艺术遗产。作为未来主义中的年轻一员, 
他在罗马和巴黎住过一段时间，之后离开意大利北部小城韦雷托， 从 1928 到 1930 年，居住在曼哈顿。在纽约，他的双语诗歌、绘画 作品、出版的访谈以及用意大利语写给他的未来主义同道的信，是 以特点鲜明的现代主义语言来颂扬这座城市。美国人 “不必步步紧 跟古代纪念碑的步伐”，他们看到的是 “强悍的摩天大楼、绝美的 桥梁、急速的高架列车与地铁, 还有桅杆如林的船只, 这些都是现 代性的有力证明”。他将纽约描述为 “一个万家灯火的都市，里面 隐藏着蝼蚁般忙碌的劳动者。那里有无数的聚会、无数的爱情…… 无数的沉睡与舞动的人群, 让这个立体主义的都会生机勃勃，这种 新䓉和无界的巴别塔, 看起来像一个疯人院与实验室”。正如在他 之前的许多现代主义者一样, 德佩罗是在公共交通工具的疾驰中创 造了城市的景象。他的视角是在高架列车上, 但是, 进入到地铁疾 驰车厢，却让人印象更加深刻。纽约地铁激励了他创造一系列迷幺𠃌 的 “自由语词” (parole in libertà) 手稿, 使用字母同时造就形式 和声音，它们让城市体验的不同片断转化为一个浓缩的旅程。 ${ }^{26}$ 在 这个例子中，大号字母好像来自地下轰鸣。

像德佩罗一样，诺特·泽瑞尔（Notte Zurier）也由欧洲游历到 纽约，但是，他比诺特早了一代，他于 I888 年抵达嘉顿城堡的移 民接待站，最终一路向北。德佩罗歌颂曼哈顿之时，我的曾祖父已 在罗德岛的普罗维登斯的一个正统的犹太人社区内居住了四十年之 久。因为受限于旧世界乡村的传统和语言, 他的城市生活与德佩罗 在纽约体验到的扩张的视野有着天壤之别。但与德佩罗一样，泽瑞 尔也是城市交通的狂热爱好者。每周，他都会购买一张电车通票游

26 引文来自 Depero “Futurism according to New Yorkers," unpublished manuscript in the Filippo Tommasso Marinetti papers (Beinecke Library, Yale University) (作者译)； I93I 年 7 月 3 日，La Sera（米兰报 纸）发表了德佩罗的文章，引自 Maurizio Scudiero and David Leiber， Depero Futurista and New York (Trento: Lonngo, 1986). 这本书再现了德 佩罗的自由语词手稿。同时也解释了德佩罗 1930 年回到意大利后，准 备的一些手稿和一个名叫 “New-York: film vissuto” 的视听说一体书的 项目。在已完成的自由语词中，包括 “地铁”（Subway）也是项目的一 部分。同时也包括两卷德佩罗记录读自己诗歌段落的录音磁带。 
历这座城市。他的跨越多个街区的旅程是由错位和仪式塑造的。

一天三次，他离开位于普罗维登斯新区的女儿家，回到古老的 犹太街区教堂做祷告和研究。在这里，诺特的例子是超越 “多重地 域性”, 接近德佩罗对运动与流动的喜爱：在他到访教堂的过程中, 他似乎对用通票乘车兒风乐在其中, 往往一次就有数个小时。于是, 就有了人们看到白胡子老人几乎走遍这个城市每个角落的故事。他 的城市精神地图可能就包括了整个城市的交通系统。很难说诺德是 否乘坐有轨电车去探索新的地方，访问那些知名的地点，或者仅仅 是去体验运动中的存在感，或者是因为某些其他的原因。他并没有 留下记录，也没有人敢于揣测他的精神生活。亲戚们回忆起这个让 人敬畏的老人，他浸润在传统中，有一股樟脑丸的味道，但同时又 足够现代，推崇艾莉诺·罗斯福（Eleanor Roosevelt）。我无法肯 定地得出结论，他的例子，约翰·斯洛恩的，桃乐西·陈的或者海 伦·莱维特的例子，比德佩罗可能做的一切更能定义现代意识。

1950 年以来，美国城市与生活模式已发生变化，部分是因为汽 车文化所致的城郊生活理念的吸引力。 20 世纪 50-70 年代的美 国，抵押贷款、高工资以及大量的城郊建设，使得每个家庭拥有一 栋独立住房的梦想对工人阶级来说变得是可以负担的。这些年里, 快速路大刀阔斧地穿越工薪阶层所在的城镇街区，人口统计的结果 也有所变化，最初被称为 “白人逃离” (White flight), 之后也包 括了所有族群的美国中产阶级, 将各自家庭从被轻藿地称为 “内城” （inner city）的地方搬离。“城镇” 的文化概念日益紧密地与非裔 美国街区联系在一起，这个趋势仅仅在最近才发生改变，年轻的专 业人员，因为城市生活的便利与鲜活的吸引，而回到现在已经中产 阶级化的下城。与此同时，日益增强的全球化经济，传统工业因为 寻求低廉和非工会的劳动力或者采用自动化生产，而离开了传统都 市。其后果是，本地激进分子与新一代的规划者增强了对于 “正义 城市” 的要求。 27

27 Thomas Sugrue 在《城市危机的起源》[The Origins of the Urban Crisis (Princeton: Princeton University Press) ] 一书中描述了这些改变 ; Robert W. Snyder 举了一个工人阶级，纽约社区跨越种族界限的例 子, 见 Crossing Broadway: Washington Heights and the Promise of a New 
受到这些变化与新科技视角启发，当代艺术家在日趋扩展的尺 度来构想城市中的缺席与在场。底特律, 这座受疾速的去工业化 理念影响的城市, 颇受争议的摄影师朱利亚・陶伯曼 (Julia Reyes Taubman）借助私人直升飞机, 将拍摄视角提升到了超越摩天大楼 的更为高等的鸟瞰视域。她的著作《底特律: 138 平方英里》 (Detroit: I38 Square Miles, 20II）中的照片, 展现了一个扩张城市的网格, 它曾被大大小小的制造厂与朴素的住宅街区填满，而现在，整个街 区都已腾空。陶伯曼一些照片中的主色调是绿色，就好像城市的街 区被大草原所裹挟。从这个高度看, 一直延续到这个国家最大黑 人城市的那些小区域里的街边活动是消失了的。与这种远眺相比, 凯瑞 - 马歇尔 (Kerry James Marshall) 大尺幅的油画则是颂扬了 洛杉矶与芝加哥黑人社群中的城市生活。《风格》(De Style, I993, Museum of Contemporary Art, Chicago）的标题与原色的富有韵 律的安排, 是对 20 世纪先锋艺术运动的赞许, 画作展现了五个人 在理发店里聚会。这个有点正式的场景是从临近单元看到的，有点 私密，却又具有英雄气概。

现在，最大的都会都在美国之外了，艺术家也在运用新的形式 传达城市空间的体验。其中一些人保持了与我们刚才论及的俯瞰以 及人行道视角的话语的令人惊讶联系, 同时, 他们也与城市交通保 持联系。朱丽叶・莫莱图 (Julie Mehretu), 这位艺术家在童年时 期举家逃离埃塞俄比亚, 致力于重建现代主义的碎片城市理念, 以 讲述一个更为广阔的故事，这个故事牵涉人群和金钱在大陆之间、 在时间进程中的流动。她的 12 英尺宽的绘画《驱散》(Dispersion, 2002 , 私人收藏), 关注的便是移民与放逐的过程。为制作这幅绘 画以及相关片段, 莫莱图开始收集素描、相片、历史插图和显示人 口变化的图表。当她研究一个地域的城市规划的发展时, 她的工作 进程是在回溯过往，但同时又在空间中扩展。她的绘画与她的作为 地理学家的父亲的工作相关, 后者是利用图表来让那些人类视野之 外的各种类型的结构性变化趋势显现出来，比如时间进程中的人口 收入分配的变化。 ${ }^{28}$ 艺术家把这些视觉信息图表的概念和其他许多

America (Ithaca: Cornell University Press, 20I4); Fainstein, The Just City. 28 Joan Young and Julie Mehretu, Grey Area (New York: Guggenheim 
东西，从建筑细节的放大轮廓到从高处看到的人类集群的标记等， 层叠在一起。她将这些与类似于百年前未来主义者构想的动力线的 飞动弧线结合在一起。最终的图像则是传达了那种全球化的活力, 它让城市联系在一起，让飞机的航线遍布全球，或者是伯曼所说的 在时间进程中内爆或衰退的城市的“永恒的分裂和复兴”。

然而，莫莱图作品有时会让那些寻求人类的故事和身体的观者 感到失落，居住在约翰内斯堡的艺术家凯 - 哈思安（Kay Hassan） 的作品就致力于此。哈思安纪念碑式的拼贴与装置所赞颂的正是那 些在变化城市的艰辛日常生活的片段与瓦砾中的 “平常人”。他的 装置与纪念碑式的拼贴用广告牌的碎片制作，表达了 “被撕碎而又 重新拼合在一起” 的生命。由此，他就像垃圾箱画派艺术家一样, 将商业环境带入到了人们的日常生活。哈思安描绘的地区，就在南 非城市的郊外，其中包含了复杂的历史，牵涉到城市空间与地域体 验。他成长于一个种族隔离制度严密控制下的小镇，期间，生活空 间与公民权利都是受到限制的。从这个角度看，大都会是通过距离 和重新定位的方式来理解的：黑人与 “有色人种”仅在白天被允许 到市内工作，夜晚不许滞留在那里。每天五点，钟声就会响起，强 制他们回到自己的小镇，这些小镇通常是在 40 英里以外。随着种 族隔离制度被推翻，许多人又不得不从那些小镇重新定居到被称为 “家园” 的地方，具有讽刺意味的是，那完全就是陌生之地。他的 装置作品《地下酒吧》(Shebeen, 1997) 是受到小旅馆的启发, “在 这里, 有趣的对话常常带着绝望。”不断出现的城市交通的现代母题, 赋予哈思安作品以特殊意义。《乘坐公共汽车》(Bus Ride, 1996, High Museum, Atlanta）并没有构想孤独旅行者观望城市景象的 变换视角。而冉宁是坐在公交车内，描绘那些不断变换的人群，在 这里，那些搭乘各种非正规交通工具的工人，正从都会回到他们生 活的空间。29

Museum, 20Io); Asafa Mehretu, Regional Disparity in Sub-Saharan Africa: Structural Readjustment of Uneven Development (Boulder: Westview, 1989).

29 关于哈思安, 见 Sue Williamson, “Kay Hassan,” Artthrob 38 (October 2000); 文章见 Lindsay Bremmer, “Mobile Johannesburg," in In the Life 
从巴黎到约翰内斯堡，从纽约的中国城的人行道到底特律上空 的直升飞机, 本文探索的是城市视角的多元性以及在整个 20 世纪 的现代都会体验。这种来自摩天大楼的居高临下视角仅仅提供了这 种城市视角的多元性的一部分内容; 而街区想象也在其中占据一个 位置。 ${ }^{30}$ 我们已讨论了运动的角色，无论是穿越城市的交通系统， 还是全球范围的移民, 这会引起地域吸引力的改变, 但也并不意味 着就会消弭这种吸引力。现在全世界有超过一半人口居住在城市, 这些迥异的精神地图的共存表明, 有更为多样的现代城市经验正在 等着现代艺术家，或许还有城市理论家来开掘与表达。

（张坚、聂皓雪译校）

of Cities, ed. Mohsen Mostafavi (Zurich: Lars Muller Publishers, 20I2), 2 IO. 
像

陈瑶

I9 世纪末，纽约已经超越巴黎和伦敦，成为大都会中最耀眼的超 级明星，因此，当我们透过东北部印象派画家们的作品窥探世纪之 交美国的都市生活，纽约是毫无争议的焦点。对于美国内战前的艺 术家们而言，虽然擅长的题材各异，但大多都主要集中于风景画和 委托的肖像人物画的创作上，城市是他们展览、社交和参与教职工 作的地点而非题材的灵感来源，不过这一状况到了 19 世纪 70 年代 发生了改变。纽约的都市面貌开始疾速的发生着剧变，比奥斯曼时 期的巴黎更令人惊叹。正如威廉·豪威尔斯和西奥多·德莱赛等作 家对世纪之交美国城市生活所撰写的文学作品，纽约的都市景观在 I9 世纪末逐渐成为美国艺术家们描绘的重要题材，其中最显著的 是以查尔德 - 哈萨姆为代表的美国东北部印象派以及以约翰 · 斯隆 等为代表的垃圾箱画派。虽然这两个画派在描绘都市景象时所选择 的入画题材、技巧以及构图都颇有差异，不过这些作品都成为我们 解读和分析纽约世纪末文化历史情境的重要视觉资料。

\section{田园写实主义一一都市的阿卡迪亚}

与美国大众杂志中对海外旅行以及海外城市的描写相比，城市景象 对于镀金时代早期的美国艺术家来说依然是一个颇为罕见的题材。 对于美国本土画家而言，他们似乎还沉迷于一种农业文明的乌托邦 想象。知识界也对纽约抱有十分复杂的情绪和观点，有的将其视为 美国价值的积极象征，而另有他者将其视为隔离与无序。不过斯克

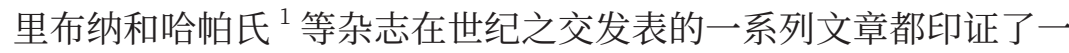

1 其中就包括 Mariana G. Van Rensselaer, “Fifth Avenue with Pictures by Childe Hassam,” Century Magazine 47 (Nov. I893); Royal Cortissoz, “Landscape of Manhattan,” Scribner's Magazine I8 (Nov. I895); H.G. Dwight, "An Impressionist's New York," Scribner's 38, no. 5 (Nov. 1905); Harrison Rhodes, "New York - City of Romance," Harper's II9, no. 7I4 
种对城市美学以及居于其中漫步乐趣的强调，而对于大多曾留学欧 洲并偶尔为杂志创作插图的印象派画家和现实主义画家而言，闲逛 者的这一身份显然并不陌生，于是，这种对都市景观的视觉记录逐 渐被他们视为创作中不可缺少的重要主题。哈特曼在 1900 年的一 篇文章中就呼吁艺术家去漫步发现城市的美，他在文中写道 : “对 于每个双眸明亮，对自己生活的时代、地点和情景都有所体验的人 而言，他只需漫步街头或搭上一辆电车就能发现在他经过的每一个 街道都有值得被描绘的画面。” 2

I9 世纪末，印象派画家们更多关注的是对城市景观的一种诗意 化的描绘，这在某种程度上与当时兴起的城市美化运动相契合。以 哈萨姆和威廉 - 蔡斯为例, 纽约被描绘为一个可供市民漫步的愉悦 而和谐的环境，一个都市的阿卡迪亚。蔡斯 I886 年搬至布鲁克林 之后成为了展望公园的常客, 他所描绘的一系列展望公园作品成为 美国印象派很重要的里程碑, 首先是对美国最主流和重要的风景画 派的一种革新，早期哈德逊河画派一直是美国艺术最具代表性的风 格，在描绘风景时无论是托马斯 - 科尔亦或是阿舍尔 - 杜兰德关注 的都是宏大风景以及在近景风景中对细节巨细无遗的描绘，这是一 种美国风景画写实主义的传统。而在纯粹风景画作之中，人物的出 现又是非常渺小而次要的, 是一种对比性的意义, 以人在大自然中 的微弱从而更加反祄在神圣造物主面前的一种卑微的性情。而蔡斯 的展望公园系列则充分展现了法国现代绘画的影响, 描绘的虽然是 公园的风景，但这种景观中人本身的意义被强调了，在这一系列画 作中常常出现的蔡斯夫人艾莉丝以及他们的女儿都在强调一种人居 的环境，而她们之间的互动以及她们与公园之间的相互关系是蔡斯 所关注的重点。当时的评论家查尔斯 ·德・凯就在《哈帕氏周刊》 上撰文赞许蔡斯的纽约公园题材的画作，称其发现了中央公园，不 是地理意义上的，而是作为一个现代的艺术意义上的。 ${ }^{3}$

( Nov. 1909); Sadakichi Hartmann, "A Plea for the Picturesqueness of New York," Camera Notes 4 (October 1900): 9I-97.

2 Sadakichi Hartmann, A Plea for the Picturesqueness of New York (1900).

3 Charles De Kay, "Mr. Chase and Central Park," Harper's Weekly 35 (May 2, I89I). 
波士顿大学荣休教授帕特里西娅・希尔斯曾经在《世纪之交的美 国》中将处理城市元素的艺术家分为了三种：“第一种是关注城市 的建筑，另一种是关注形式上的部分，第三种则是关注城市居民。” 4 哈萨姆在 I889 年秋天结束巴黎求学回到纽约定居后创作的第一个 阶段关注的更多的是城市的居民，第二个阶段则将目光聚焦到建筑 与城市整体的形式感上。对于生活在 19 世纪 70 年代纽约的艺术家 而言，城市的中心是北部从第十街到麦迪逊广场，西从第四到第六 大道，重要的艺术机构都集中在这一范围内，其中包括了 23 街和 第四大道的国家设计学院，十四街和第六大道的大都会博物馆，第 五大道西侧十街的十街画室大厦，东十五街 IO9 号的世纪俱乐部, 麦迪逊广场的联合俱乐部以及 22 街和第五大道的莲花俱乐部。 ${ }^{5}$ 和 许多留学巴黎并侨居他乡的艺术家不同, 哈萨姆始终认为纽约是世 界上最独一无二的大都会。在 1913 年的一则访谈中, 哈萨姆曾说道: “纽约是世界上最美丽的城市，在整个巴黎没有一条大道可以与我 们的第五大道相媲美，当我们在一个十月的阴霔天或一个破晓的薄 雾天从布鲁克林桥眺望时，甚至伦敦一那座我认为绝对比巴黎更有 魅力的地方，也无法与我们的曼哈顿岛相比。” 6

现收藏于纽约布鲁克林艺术博物馆的《黄昏、纽约、冬季》 (Late Afternoon, New York, Winter) 是哈萨姆新世纪的一件处于风格过 渡时期的作品。远景中摩天大楼的轮廓印证着他对这一城市新地标 的偏爱，倘若将这一件雪景与斯蒂格利茨稍早一些的摄影作品相比 可以看出哈萨姆正如何以一种抒情的色调与笔墨抹去了城市光鲜背 后的另一种真实。这件作品成为玛丽安娜 - 瑞塞勒在《世纪》杂志 撰写的一篇关于纽约一文的最佳注解，在《如画纽约》中，玛丽安 娜写道 : “当你站在 23 街的拐角处，你会发现冬天很令人愉悦，因

4 Patricia Hills, Turn of the Century America (New York: Whitney Museum of American Art, 1977), I45.

5 Linda Henefield Skalet, The Market for American Painting in New York: I870-I9I5, Ph.D. Dissertation, John Hopkins University, 1980, 9.

6 "New York, the Beauty City," The Sun, Feb. 23, 1913, Section 4, p. I6. 转引自 Ulrich W.Hiesinger, Childe Hassam American Impressionist (Munich and New York: Prestel, 1994), I8I. 
为飘落的雪花如同一条毛毯营造一个色彩的主调，这种颜色又和一 些大商场的白色门廊相呼应。这虽然算不上一个很美的景色，不过 也的确是很生动的，这种直白的、无忧无虑的和有些炫耀的生动性 正是纽约的特性。” 7 对于哈萨姆而言, 雪可以缓和纽约在世纪末尖 刻的一面从而展现了一种田园牧歌般的城市片段（图 I）。

哈萨姆从 1889 年末至 I893 年的许多纽约都市题材作品都作为插 图收录在了玛丽安娜为《世纪》杂志撰写的《第五大道》一文中 ${ }^{8}$, 其中就包括了 1890 年的《华盛顿拱门，春天》(Washington Arch, Spring，图 2)。画面表现了刚刚从寒冬后复苏的城市，远景中开始 萌芽的大树隐约地遮蔽了远处的华盛顿拱门，也作为一个隐性的间 隔划分了在街道两边的行人，右边漫步徜徉在早春街头的时尚女性 与左边的环卫工人和马车夫再一次形成了阶级上的对比。无论是早 期波士顿和巴黎亦或是定居纽约后的早期作品，哈萨姆关注的更多 的是市民在应对城区重建、改造和城市化不断推动下的一种个人体 验，处于同一视平线的近景描绘使哈萨姆将自己的身份定义为一个 身临其中的亲历者，见证着都市生活和休闲的细节。这种表现都市 漫步场景的还出现在 I890-I89I 年的《周日的第五大道》(Sunday on Fifth Avenue) 以及 I89I 年的《第五大道的华盛顿广场》 (Fifth Avenue at Washington Square）中，前者是哈萨姆表现纽约题材中 不多见的较大尺幅的水彩画。画面表现的应该是刚刚参加完周日礼 拜的人群, 左边的绅士正在摘帽行礼, 这件作品最值得关注的地方 是远景中有些模糊的教堂尖顶，那是当时纽约最著名的圣 - 帕特里 克 (St.Patrick) 教堂。“教堂通常都在同一时间关闭，于是穿着时 尚而考究的人们同时涌入街道，差不多在之后的一个小时左右，大

7 Mariana Griswold Van Rensselaer, "Picturesque New York," Century 23 (Dec I892): 169-70.

8 杂志中的插图还有 Fifth Avenue at Washington Square, A Winter Morning (Fifth Avenue and Fifteenth Street); Cabstand at Night, Madison Square; Madison Square and the Hotel Brunswick; A May Afternoon on Fifth Avenue; Delmonico's; The Manhattan Club-House; The Union League Club-House; Sunday on Fifth Avenue. 
道上将呈现一道惊艳的人群景观。” 9 在这一时期，哈萨姆将纽约描 绘成了都市的阿卡迪亚。

\section{向上的张力一摩天大楼的在场}

约书亚・ 贝尔 1876 年攀登布鲁克林大桥桥顶上所拍摄的曼哈顿全 景图中依稀可见占据天际线最高端的依然是教堂的尖顶，然而从 90 年代中后期开始, 这里的天际线开始由代表着现代性的新建筑一 一座座拔地而起的摩天大楼所主宰。从 1890 年至 1917 年，关于摩 天大楼的建立所出现的一系列美学问题是城市问题一个争论的焦 点，对于一些绅士传统体系的捍卫者，诸如亨利·詹姆斯和美国著 名的美学家乔治·桑塔耶那等都呼吁保护旧有学院的、沿袭欧洲传 统的新古典主义风格，因而将高䇯突元的摩天大楼视为对传统价值 体系的视觉革命，因为它们的建立是和不断扩张的物质和商业主义 密切相关的。桑塔耶那曾将美国的性格进行两分法：“有一半美国 人的想法还没有被俗世的事务所并吞，在闭塞的空间内安静地流动 着，而另一半美国人的想法则跳跃得如尼亚加拉的奔流。这种区分 很显著的体现在美国的建筑中，他们分别的代表是仿造殖民时期风 格优雅的建筑和高算的摩天大楼。”著名的评论家罗亚尔・科蒂索 斯曾经在《曼哈顿地标》一文中比较纽约与巴黎的城市规划后提出 了对迅速崛起的摩天大楼的担忧。 ${ }^{10}$ 蔡斯也曾明确表达过对摩天大 楼的反感 : “最令人感到失望的就是古老的建筑艺术正在一点点的 被摧毁、消失殆尽，这些冲上云霄的猛兽正在抹杀这个城市许多标 志性的美丽，包括百老汇大道的旧三一教堂，麦德逊广场的帕克赫 斯特 (Parkhurst) 的教堂。” 11

9 James D. McCabe, Lights and Shadows of New York Life (Philadelphia: National Publishing Co., I872), 446 引自 William H. Gerdts, Impressionist New York (Artabras, 1996), 48.

10 Royal Cortissoz, "Landmarks of Manhattan," Scribner's Magazine I8, no. 5, (Nov.1895): 533 .

11 转引自 The Art of William Merritt Chase, Ph.D. Dissertation, University of Pittsburgh, 1969, IOI-2. 
约翰- 凡戴克（John Van Dyke）1909 年出版的《新纽约》描 绘了自 1880 年以来纽约所发生的巨变, 他的这一论著可以说是 $\mathrm{I} 9$ 世纪 80 年代中期之后至一战之前对纽约都市文化语境分析的最优 秀的作品之一, 在此之后 “新纽约” 成为当时许多文章的标题。《新 纽约》除了文本之外, 其插图也一样值得关注, 为这本著作创作插 图的是约瑟夫 ·潘奈尔 (Joseph Pennell), 他是最早描绘现代摩天 大楼的重要人物之一。潘奈尔在面对一个崭新纽约时的情绪虽然是 复杂的，但总体上看还是乐观的，他将新证券交易所、沃尔沃斯大 厦、电话与电报公司大楼、美孚大厦等被他称之为 “商业的教堂”。

从 I9 世纪末开始, 在包括《世纪》和《斯克里布纳》等一些著 名的杂志中, 关于摩天大楼的描绘已经成为很显著的部分, 这些图 像包括一些刚刚建好的新式建筑、曼哈顿的天际线、港口的鸟瞰图 以及正在建设中的摩天大楼。另外在施蒂格利兹任主编的包括《美 国业余摄影师》(The American Amateur Photographer) 和《摄影作品》 (Camera Work) 中, 摩天大楼也是常常入镜的重要题材。 ${ }^{12} 1903$ 年斯克里布纳 (Scribner's) 刊载了著名记者阿尔文・科伯恩 (John Corbin) 的《20 世纪的城市》, 文章的插图是斯蒂格利兹的照片。 在 20 世纪初的都市摄影作品中, 1912 年科伯恩所拍摄的《章鱼》(The Octopus）开辟了一个全新的高度观察都市的新视角，这件俯拍的 作品将麦迪逊广场抽象成了一个巨大的章鱼，这件作品的问世不仅 巧妙地将原本视觉记录的复制作品提升为一种独具匠心的抽象主义 构图, 更扎实地奠定了摄影作为严肃艺术样式本身的地位, 而这样 的作品成型的前提无疑是摩天大楼拔地而起迅速地占据了人们日常 视觉的焦点。1913 年科伯恩将这一系列作品带到伦敦的古皮尔画廊 举办了 “顶峰看纽约” (New York from Its Pinnacles) 的摄影展进 一步地突出了在这一纵向垂直发展的都市环境下, 以一个全新的角 度审视纽约。他将纽约城市视为一个钢铁的荒漠, 它的摩天大楼视

12 例如在 1903 年十月刊的 Camera Work 就有包括 Hartmann 的 The FlatIron Building - An Esthetical Dissertation 以及诗歌 To the Flat-Iron, 而 对于高楼美学的部分则出现 Camera Work 里在 Roland Rood 所描写的 The Origin of Poetical Feeling. 
为其悬崖, 而它的街道则视作峡谷。 ${ }^{13}$ 尽管传统美学阵营始终存在, 针对商业化侵蚀的批驳也不绝于耳，然而，到镀金时代中期之后， 对城市发展，特别是垂直角度不断攀升的记录已经成为一股不可遏 制的势力最早在大众传媒上蔓延开来。

19 世纪 90 年代末，为了表现不断崛起的摩天大楼，美国印象派 画作中开始出现了越来越多的垂直构图，这在哈萨姆的画作中体现 的尤为突出。进入 20 世纪之后，哈萨姆的作品开始远离人群本身， 以远视角取代了街景观照。如果说哈萨姆刚定居纽约之后不就创作 的《冬天的第五大道》还是以近景角度刻画的一个冬日静烅的纽约 片段的话，那么 1919 年的《第五大道》(图 3) 和 1907 年的《曼哈 顿下城区》就暗示着城市飞速发展的背景下垂直角度不断攀升后的 一种人与建筑的强烈对比。尽管哈萨姆从未如现实主义画家们那般 明确的表达出对现代化进程的焦虑和警觉，以及阶级差异下的社会 不平等，但从他被截断的高楼和被湮没的人群中还是能体会到一丝 仿佛要居于失控状态的社会不安感和无力感，他带着一种反异化的 笔调书写着对现代城市发展的某种不适。

不过从总体上看哈萨姆还是十分热情地拥抱摩天楼这一现代题 材, 并将其视为面向未来和发展的产物和一种新的美国特性的表达。 在他的眼里 “摩天大楼比欧洲古老的城堡更壮丽，特别是在黄昏十 分的那一瞥，当那里已经有星星点点的光亮时，整个城市都笼罩在 一片融合着力量和神秘的神奇感受之中”。然而，和当时著名的摄 影师斯蒂格利兹与爱德华 ·斯泰肯对世纪之交典型的，诸如慰斗大 厦等现代建筑进行创作时，哈萨姆并没有选择任何当时代表性的高 楼建筑, 他对摩天大楼的兴趣并非是建筑个体本身, 而是一种群体 性或者说一种进步的象征性。“如果独立地看摩天楼更像一个形状 随意的建筑的异型，然而将它们视为一个整体时，那错综冲向云霄 的蜿蜒外形和慢慢消失在视线中时, 它们又是极其美丽的。” ${ }^{14}$ 在《十 月的薄雾 : 曼哈顿》中，哈萨姆将曼哈顿的天际线与威尼斯水城的

13 Alvin Coburn, "My Best Pictures and Why I Think So," Photographic News 51, no. 579 (Feb 1907): 83.

14 Archives of American Art, New York Public Library Papers on Childe Hassam, Reel NAA.I. 
河道相类比，透过一种远视角而更加强调一种颤动的反光效果，将 场景与现实脱节，从而使整个画面浸入到一种与历史交融的模糊境 界。这不由的让人想起约翰 - 凡戴克在《新纽约》中对这座城市的 解读: “远观的错觉逐渐消逝, 色彩一旦被切割成鲜明的色块, 高 楼们失去了它们的群族而呈现一种塔一般的孤立，光线变得更加锋 利, 阴影也来的更为强烈。” ${ }^{15}$ 哈萨姆后期纽约街景题材中所表现的 愈加抽象化的色彩和塑形成为我们如今重读《新纽约》时重要的视 觉想象。

尽管哈萨姆在画作中敏锐地观察着现代都市生活的脉搏，但是 他的态度, 特别是他对人的态度依然是精英主义和保守的。哈萨姆 主观地忽略了在移民浪潮涌入后城市的拥挤，而截取的纽约大多依 然是简单的、静湍的宜居环境，他对纽约动态的把握是将城市的复 杂和多样抽象化。这是他作为世纪末新英格兰后裔对待本土不可遏 制动荡趋势的应动机制，他的这种逃避心理视觉化地体现在纽约街 景中教堂作为象征形象的多次在场。然而，世纪末的纽约，一切都 在不断运动的漩浴之中，过去和未来不是一种承接的关系，而是处 于一种共时的状态。

\section{新闻写实主义一轶事性风格的发展}

I880 年亨利 - 詹姆斯曾饱含深情地写作《华盛顿广场》回忆他童年 时候的记忆，尽管与世纪中叶詹姆斯真正记忆中的样貌有了许多改 变，詹姆斯依然试图挽留曾经安静而和谐的世界，因为那些佗立的 标志性建筑代表了一种历史的延续性。于是，我们发现无论是作家 詹姆斯抑或是画家哈萨姆都在通过将纽约场景纪念碑性的冻结让一 种历史沿着理性或逻辑性的步调前行。然而，到了垃圾箱画派的画 作中，纪念碑性慢慢隐去，他们更热衷于一种轶事性来描绘。在垃 圾箱画派的纽约画作中，我们感受到的不仅仅是一幅画作，一个静 止的场景。它们更像是一部叙事电影中的一个画面，是流动场景中 画家所按下的一个定格键。而观者，则可以作为一位独立的叙述人， 继续沿着画家所提供的场景去想象故事的走向和叙事的态度。画面

15 John C. Van Dyke, The New New York (New York: Macmillan 
的现场感是为杂志和报纸做插图时所被推崇的，于是包括斯隆和希 恩在内的垃圾箱画派画家们在创作油画作品中也深谙如何通过笔法 和构图等技巧强调这样一种效果。由此, 观者在他们画作面前不仅 是观画本身，更是换身记者身份的在场者。

身为垃圾箱画派中的一员，作为年长者并扮演着亦师亦友角色 的罗伯特 ·亨利经常通过教学、演说和撰文的方式传播着自己的艺 术理念，他曾鼓励同时代的每一位艺术家都成为一个都会的记者， 这种在城市日常的琐碎生活中寻找题材的观念让人想起了波德莱尔 对康斯坦丁 · 居伊的巴黎速写的赞许。但是对于亨利而言，艺术家 的职责超越了仅仅从远观的角度是对时尚和表象的记录而是深深扎 根于都市生活本身。虽然大部分垃圾箱画派的艺术家早年有做过插 图画家的经历，不过亨利希望他们可以以油画的媒介创作超过报纸 插图之外的东西。他鼓励学生去跨越高雅艺术与流行艺术的界限, 创作出像新闻一般根深于当代生活场景之中，而在品质上又如传统 绘画那般恒久。这一点格外体现在约翰·斯隆在新世纪创作的纽约 城市题材画作中，他的这一题材画作中的大部分都与生活在都市的 女性相关。

世纪之交美国艺术中出现了对城市理想女性社会身份的热议与 塑造，这与当时的唯美主义运动相关。19 世纪 70 年代中后期至 80 年代中期是唯美主义运动在美国发展的高潮阶段，在此期间举办的 费城百年博览会是推动其发展的重要事件之一，特别是伴随着博览 会之后大规模发展的杂志出版业都通过大量插图从视觉上传达艺术 与美的生活化和日常化趋势。 ${ }^{16}$ 无论是纯粹的审美运动或是对工业 文化侵蚀的反拔，生活的审美化在美国的各大城市悄然上演，而作 为在居家生活中占据主导的女性往往是实践这种审美活动的主角。 世纪之交对女性理想美塑造的内在动力则是镀金时代至一战之前美 国文化自身对女性角色的反思。在 I893 年的芝加哥哥伦布纪念博 览会上, 女性的形象被用来赞美技术的进步。当时对女性的评价则

16 以克拉伦斯 - 库克为代表的作家开始在《斯克里布纳周刊》中撰写家庭 装饰的文章, 其中最具代表性的是 1875 至 1877 年连载的系列文章《关 于家庭装饰的连载: 床、桌子、椅子和烛台》(Beds and Tables, Stools and Candlesticks: Some Chapters on House Furnishing). 
包括了四种优秀的品行即 “虔诚、纯洁、顺从和持家” ${ }^{17}$ 。于是在美 国东北部画家诸如埃德蒙・塔贝尔 (Edmund Tarbell) 和托马斯 - 杜尹（Thomas Dewing）等画作中都有对这种理想女性的塑造。 在他们的画作中，观者被带入了一个永恒而封闭的美丽领域，画家 将一种充满诗意的美从日常世界中抽离出来, 从而自给自足了一个 平和的圣地。

而世纪之交的纽约则完全是另外一种情景，商品和商业化的不 断发展不断挑战维多利亚时期的礼仪，琳琅满目的梪窗成为女性都 市生活新的目光焦点。百货公司实际上刻意的将城市街道转化为了 一个欲望的景观。在 19 世纪末，特别是在纽约，除了有比较平常 的橛窗展示之外, 商品作为一个视觉元素还出现在各种的街道集市 和游行嘉年华中。 ${ }^{18}$ 斯隆对这些参与纽约商品景观观看的女性十分 感兴趣，他用画笔窥探记录着这些沉湎于观看的女性。在斯隆的笔 下的女性不再是绅士理想中居家和内省的形象, 而是现代都市生活 真正的参与者。斯隆这种对城市观察并寻求作画主题的手法早在他 在费城时就已经形成了，然而大都会纽约无疑给了他更多的灵感， 他的日记中保留着他漫步纽约街头并对行人与景观观察的记录。人 群、广告、驻足观看的女性形象等关键词构成了他自 1907 年左右 开始集中油画创作的重要内容。

在斯隆的《理发师的窗口》(图 4), 我们可以看到一个有趣的画 面，画家巧妙地融入了新世纪纽约街头常见的诸多现象，包括街头 广告的呈现和两性消费者的共同观看等。画面中在二楼正在进行烫 染工作的女理发师也成为画家自身的替代形象。正如迈克尔 - 弗雷 德曾经提出在库尔贝作品中画家将自身形象融入诸如《石工》和《泉》 等画作的分析，迈克尔 - 罗贝尔也曾提出《理发师的窗口》中的理

17 Barbara Welter, “The Cult of True Womanhood: I820-I860," American Quarterly I8, no. 2, pt. I (Summer, 1966): 152.

18 关于世纪末百货公司的商品展示详见，Thomas J. Schlereth, Victorian America: Transformations in Everyday Life, I876-I9IS (New York: Harper Collins, 199I), I48. Susan Porter Benson, Counter Cultures: Saleswomen, Managers, and Customers in American Department Stores, I890-1940

(Urbana: University of Illinois Press, 1986), 17-20, 38-44. 
发师是画家对自己作为画家身份的再次确认，特别是将理发师手中 的涂料与画家的颜料相比对，而染发的过程就成为了正在进行时的 绘画创作过程，那些驻足的观者也成为画作创作的见证者和欣赏 者。19

在垃圾箱画派的画作中各个阶层的人如果同时出现往往是一种 并置的关系即他们都是纽约繁忙街道勿勿的过客，而斯隆在 1907 年创作的《灰色与黄铜》则是唯一一件将不同阶级人群共同入画的 同时，直白地强调一种生活的差异与对比的作品。正如在威廉·豪 威尔斯的作品《印象与经验》中所描述的，那些驱车经过中央公园 的人们在炫耀着他们的奢华，而穷人在观看着这一举动的发生。20 这种反差虽然在斯隆的画作中并不突出，但在他日后的政治倾向中 却愈加明显，从 1910 年开始，斯隆开始更多地为纽约的左翼出版 物创作插图。

而在 19 世纪末，垃圾箱画派的另一位代表艾弗雷特·希恩就开 始在画面中强调一种都市生活的艰难。希恩 1899 年创作的《纽约 的十字路口》（图 5) 就描绘了被雪覆盖的破旧的下东区街道景象, 这里聚集着大量的外来移民以及血汗工厂的低收入人群。雪景在希 恩的纽约题材作品中占据了重要的部分，在描绘雪景时，他没有选 取哈萨姆的冬日街景那般诗意的处理，而是突出暴风雪中逆风雪而 前行的人的困境。这里出镜的有许多生活原本就宕迫的人。画面中 两边向远景延伸的破败建筑在透视的把握上并不准确，从而使得整 个被笼罩在雪景中人们步履勿忙的节奏显得更加的不稳定。这些作 品像是作家史蒂芬·克莱因的《风雪中的人们》的视觉对应，不过 无论是克莱因或是希恩，他们都是在强化视觉和想象的同时，都拒 绝任何政治性的论调。希恩并没有试图通过描绘雪景中举步维艰的 穷人而唤起公众对生活在纽约另一半人的关注，而仅仅认为 “表现 曼哈顿的受灾时，穷苦的部分使得这一种受灾更具艺术性” ${ }^{21}$ 。

19 Michael Lobel, "John Sloan: Figuring the Painter in the Crowd," The Art Bulletin 93, no. 3 (September 20II): 345-68.

20 Rebecca Zurier, Picturing the City, Urban Vision and the Ashcan School (Berkeley: University of California Press, 2006), 294.

21 Ibid., I70. 
在垃圾箱画派中，乔治·贝洛斯是对纽约城市景观刻画得最彻 底的画家之一。他 I9II 年创作的《纽约》(图 6) 和 1913 年创作的《悬 崖住客》是对摩天楼兴起的曼哈顿以及移民聚集的廉租公寓最宏观 而全景式的创作。在《纽约》一作中, 贝洛斯选择位于百老汇和 23 街交汇处的麦德逊广场作为他创作的场景，这一街区以第一个拥有 电子屏而闻名, 而那耀眼的广告牌不断地入侵着每一位路人的视觉 体验。鳞次栉比的高楼大厦被电灯勾勒出的轮廓挤满了整个天空, 几乎没有留下任何缝隙, 在光柱的偶然变换中, 它们相互融合、纠缠、 错落穿插。各种元素的丰富组合营造了一种中心与边缘含混状态而 呈现的困惑和紧张。对摩天大楼和广告牌等商业元素巨细无遗的描 绘营造了一股要被湮没的洪流, 不给人们的视觉留下丝毫喘息之地。 画面中并置了属于不同时期的交通工具，马车、电车、汽车和马都 在交通中相互盘错，不同阶级背景的男男女女熙来攘往，突出了城 市的拥堵感与混乱。摩天大楼和汽车的现代性与旧式马车的共同在 场表达了一种未来已初露端倪, 而过往依然没有迅速落幕。在这里, 贝洛斯并没有对这一座大都市流露出任何感伤的怀旧亦或是乐观的 讴歌，他笔下所呈现的完全是一种事实的堆砌。贝洛斯作品的争议 特别是纽约这件作品表现了在视觉文化的许多领域中所激发的焦虑 感。那些渴望在画作中得到短暂逃离的人们很不舒服地发现贝洛斯 显然并没有维护他对庞大而繁杂的城市题材的艺术掌控，更像是报 纸或轻歌舞剧那样将所有未经编辑的讯息一股脑地拼接在了一起。

同样拥挤的人群在《悬崖住客》中也再次出现，贝洛斯对纽约 的公寓楼题材十分感兴趣，其焦点并不在建筑，而在生活其中的人 情冷暖。这里刻画的是一个严酷夏日的诸多活动, 人们无处躲避酷 热，于是涌向街头，对于那些新移民而言，高昂的房租往往使他们 只能选择居住在多层建筑的廉价公寓中, 房间和走廊狭小, 光线黑 暗、不通风，洗手间和厨房每层公用，私人空间的拥挤导致了公共 空间的拥堵。画面中那些光着身子的顽童们正在一处公共空间作意 嬉闹，而远景中正有一辆疾驰的电车费劲地穿过层层人群。近景中 甚至还有妇女在不忌讳目光地哺乳。早在 I893 年, 亨利・布莱克· 
富勒就曾经创作过一本与贝洛斯画作同名的小说，这本小说被认为 是围绕摩天大楼的第一本小说。尽管富勒将小说的场景移到了芝加 哥而非纽约，不过小说最终强调的依然是在现代性表象之下的一个 残酷而刺痛的环境，人们逐渐退化到一种原始的状态。与文学作品 中所营造的城市想象不同，贝洛斯的画作还是承继了一种相对不涉 述评的状态，他只是针对入画的主题进行选择，而最终的情感体验 和反思则交由了观者。贝洛斯笔下的纽约充斥着新的社区人群和观 看体验。1890 年雅各布 - 里斯的《另一半人如何生活》的出版开始 激起了公众对这个城市光鲜之外另一群人生存状态的关注，我们也 在垃圾箱画派的新闻现实主义画作中感受到在绅士理想之外的人群 开始在文化和艺术中真正显现。

如果说哈萨姆的都市题材再现的只是纽约现代化的视觉表征, 那么在垃圾箱画派的现实主义画作中则蔓延着商业和商品化不断侵 蚀下的观看状态以及阶级对比的社会性记录。当前者依然努力维护 着规则性和秩序感时，斯隆、希恩和贝洛斯等垃圾箱画派艺术家开 始更加强调动态和偶然性，他们更多地着眼于人情而非建筑景观， 他们并没有去关注曼哈顿的天际线而是在街巷中探索着纽约的水平 视线，他们捕捉到了这个城市日常生活中正在显现的诸如移民、广 告、大众娱乐、性别问题和贫富差距等社会现象与趋势。他们的笔 触有了更社会学的意义而非纯粹美学上的摹写。这种在题材选择上 的变革无疑在侧面回应了当时的文学在诺里斯、德莱赛、厄普顿 . 辛克莱的作品以及凡勃伦的理论中所越来越强调的政治与社会的不 公。他们大多对社会和政治理念非常感兴趣，亨利和斯隆熟稔沃尔 特·惠特曼乐观的民族主义思想，甚至对马克思的经济和历史理论 也有所涉及。 ${ }^{22}$ 因此，当面对一个新世纪的纽约都会时，他们试图 为当时激进的社会和争执思想寻找一个视觉的对应物, 他们的作品 并非仅仅从远观的角度对时尚和表象进行记录而是深深扎根于都市 生活本身，其形式充斥着在视觉文化中常见的大规模复制和轰动性

22 亨利是无政府主义者，而斯隆也曾 经为 1910 年斯隆开始为一些左翼 出版物创作, 其中就包括 Appeal to Reason, International Socialist Review, the Coming Nation. 
效应的传播，垃圾箱画派的城市题材画作后来被学者视为是对城市 化进程一种富有创新性的回应。23 


\title{
The Urban Spectacle: New York City, Impressionist Painting, and the Ashcan School
}

\author{
Chen Yao
}

The spectacle of New York City was an important subject for American visual artists, as it was in the literary works of William Dean Howells and Theodore Dreiser about turn-of-the-century American urban life. This spectacle was best represented in the works of Childe Hassam and other American Impressionists as well as by John Sloan and his fellow artists of the Ashcan School. Even though there were considerable differences in the subject matter, techniques, and compositions of these two schools, their works provides important visual examples for our understanding of the social and cultural context of fin-de-siècle New York. I will illustrate the two artistic styles relative to representing the spectacle of a newly modernized New York City, and one emerging visual element (the skyscraper) that began to permeate these visual artworks.

\section{Pastoral Realism}

During the early days of the Progressive Era in the U.S. (I890s to I920s), in contrast to the vast number of depictions of New York City in overseas travel sketches circulating in the mass media, the urban scene was quite a rare subject for American artists who were still obsessed with an entrenched utopian idea of an agricultural society. Intellectuals held ambiguous feelings about New York City; some treated the city as a positive symbol of American values while others considered the negative effects of its social segregation and disorder. The former was demonstrated in the theories of Frederic C. Howe, while the latter was presented in the literary works of Henry James.

Numerous articles published in Scribner's and Harper's during the turn of the century began to provide literary evidence of the increasing emphasis on the beauty of the urban scene and the pleasures of promenading. Impressionist and Realist painters who once studied in Europe and worked as occasional illustrators would all have been quite familiar with the idea of the flaneur and would have also considered the visual record of the urban scene as the indispensable subject of their oeuvre. As Sadakichi Hartmann wrote in I900, "any person with his eyes open, and with sympathy for the time, place, and conditions in which he lives, has only to take a walk or to board a trolley, to find a picture worthy

I See Mariana G. Van Rensselaer, "Fifth Avenue with Pictures by Childe Hassam," Century Magazine 47 (Nov. 1893): 5-I8; Royal Cortissoz, "Landscape of Manhattan," Scribner's Magazine I8, no. 5 (Nov. I895): 53I-43; H.G. Dwight, "An Impressionist's New York," Scribner's Magazine 38, no.5 (Nov. 1905): 544-55; and Harrison Rhodes, "New York: City of Romance," Harper's Weekly i19, no. 714 (Nov. 1909): 9I4-25. 
Fig. I. William Merritt Chase, Park in Brooklyn, ca. 1887. Parrish Art Museum, Water Mill, NY, Littlejohn Collection.

of depiction almost in every block he goes," and he encouraged local artists to discover the beauty of New York. ${ }^{2}$

By the end of the I9th century, American Impressionists, as exemplified in the work of Chil-

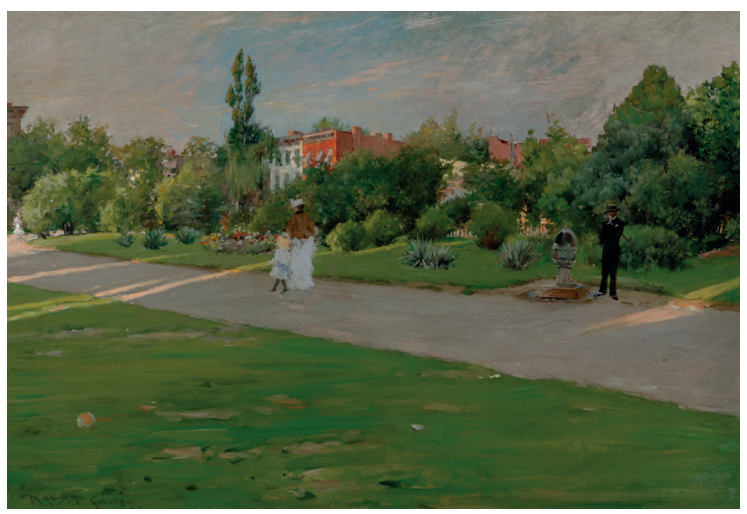
de Hassam and William Merritt Chase, preferred a poetic rendering of the urban scene, which corresponded with the burgeoning City Beautiful Movement, wherein New York City was depicted as a lovely and harmonious environment where people could stroll, as in an urbanized Arcadia. ${ }^{3}$

Chase became a frequent visitor to Prospect Park after moving to Brooklyn in I886. His series of paintings of Prospect Park were considered an important milestone for American Impressionism. Chase was also the first metropolitan artist to appreciate the hitherto almost untouched field of landscape in and about the city. The mother and child theme, with its notion of privacy and intimacy, is reminiscent of Claude Monet's pictures of his garden. As an urban environment, the "big city" park is at once public and private, but Chase stresses the privacy (Fig. I). Chase hardly included men in his images of New York's parks, so these urban landscapes were treated as domesticated nature. If Frederick Law Olmsted was the designer of Central Park, Chase's works undoubtedly endowed the park with the artistic aura of a public leisure space. Charles De Kay confirmed the innovation of Chase's effort in depicting the city park, in his I89I article "Mr. Chase and Central Park," where he wrote that he considered that Chase had succeeded in discovering Central Park, not geographically or topographically, but artistically. 4

There was no other American Impressionist more enthusiastic in depicting the cityscape of New York than Childe Hassam. In I889, when Hassam finished his studies in Paris and returned to the United States, he did not go back to his home town of Boston but settled instead in New York City. For the artist in I87os New York, the heart of the city was the area that extended north from Tenth Street to Madison Square and west from Fourth to Sixth Avenues. The most

2 Sadakichi Hartmann, "A Plea for the Picturesqueness of New York," Camera Notes 4 (October 1900): 9I-97.

3 See Childe Hassam, "New York the Beauty City," New York Morning Sun, February 23, 1913, sec. 4, 16, and Ulrich W. Hiesinger, Childe Hassam: American Impressionist (Munich and New York: Prestel, 1994), I8I.

4 Charles De Kay, "Mr. Chase and Central Park," Harper's Weekly 35 (May I89I): $327-28$. 


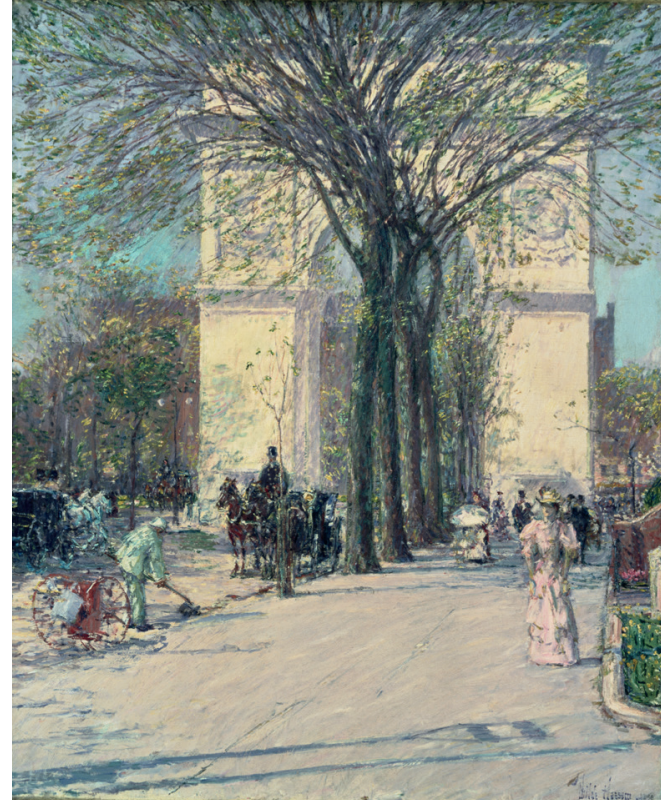

Fig. 2. Childe Hassam, Washington Arch, Spring, I890. The Phillips Collection, Washington, DC.

important landmarks of the art community located within these boundaries included the National Academy of Design at 23rd Street and Fourth Avenue, the Metropolitan Museum at I4th Street and Sixth Avenue (where it was in I879), the Ioth Street Studio Building west of Fifth Avenue, the Century Club at Io9 East I5th Street, the Union League Club on Madison Square, and the Lotos Club on Fifth Avenue at 22nd Street. Hassam's New York residence was on the corner of I7th street and Fifth Avenue, which was not far from Union Square and Madison Square. ${ }^{5}$

Many of the urban subjects that Hassam created between I889 and I893 were published to accompany Van Rensselaer's article "Fifth Avenue with Pictures by Childe Hassam" for The Century (see footnote I), which included Washington Arch, Spring (Fig. 2). The painting depicts the city awakening after a chilly winter. Trees with scattered foliage in the middle ground were applied to distinguish the high-class fashionable lady and other strollers at right from the workers and cabdrivers at left. The well-dressed woman rambling around made a striking contrast with the dustman and wagoner. In Hassam's early work in Boston and Paris, as well as in his urban scenes after settling down in New York City, we can see that the artist concentrated on the urban dweller's personal experience in the process of intense building and urbanization. The eye-level foreground description presented Hassam as a witness on the scene, observing the specific details of urban life and all its amusements. A similar scene of urban promenading is recorded in Hassam's Sunday on Fifth Avenue. We can see crowds of people flocking to the Avenue, probably just leaving church. A man on the left is doffing his hat in salute while a mother and child head toward the viewer. Interestingly, this depicted moment corresponds quite well with a literary narration of a Sunday by James D. McCabe, writing almost twenty years previously. In Lights and Shadows of New York Life, McCabe wrote: "The churches close their services near about the same hour, and then each pours

5 On the importance of urban cityscapes and industrialization in turn-of-the-century American art, see Patricia Hills, "The City, Industry, and Urban Life," in Turn-of-the-Century America: Paintings, Graphics, Photographs, I890-I9Io (New York: Whitney Museum of American Art, 1977), I45-6r. See also Linda Henefield Skalet, The Market for American Painting in New York, I870-19I5, PhD diss. (Johns Hopkins University, 1980), 9. 
Fig. 3. Childe Hassam, Late Afternoon, New York, Winter, 1900. Brooklyn Museum of Art. Dick S. Ramsay Fund.

its throng of fashionably dressed people into the avenue. The congregations of distant churchgoers all find their way to the avenue, and for about an hour after church the splendid street presents a very attractive spectacle." ${ }^{6}$ In this painting, the detail worthy of most attention is the vague church pinnacle in the distance, which can be recognized as St. Patrick's Cathedral, one of the most prestigious churches at that time. Just like Hassam's preference for including the Congregational Church in his New England scenes, religious symbolism is still reflected as an

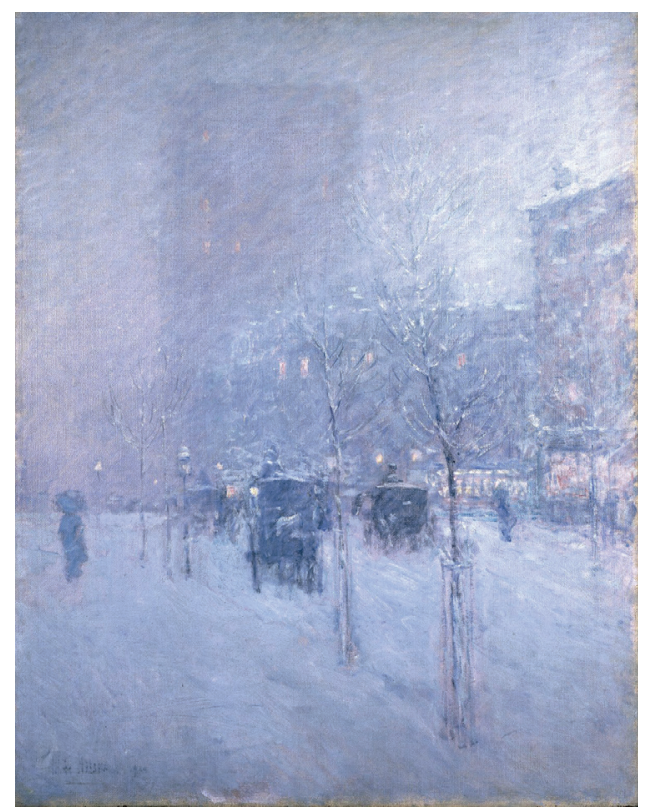
engrained Anglo-Saxon Protestant ethos that Hassam treasured quite deeply.

Hassam's Late Afternoon, New York, Winter (Fig. 3), now in the collection of the Brooklyn Museum, belongs to a series of stylistically transitional works for Hassam. The skyscraper in the distance points to his predilection for this new urban symbol. If we compare this snow scene with Alfred Stieglitz's photographs or Everett Shinn's snow scenes, we notice that Hassam somehow aestheticizes and alleviates the chilly weather by employing pale blue or pure black color against the light background, with sporadic dabs of artificial light, transforming a medley of dots and dashes into a perfect harmony. He displayed a dreamlike snowy fairyland and created an ensemble that makes a perfect visual parallel to Van Rensselaer's descriptions of the city in her essay "Picturesque New York": "You stand at the corner of Twenty-third Street. Here you will be happiest in winter, for then a carpet of snow may give a key-note of color repeated in the white fronts of certain big shops. This is not a beautiful view, but it is a picturesque one, and picturesque in a bold, careless, showy way quite characteristic of New York." 7 For Hassam, a snow scene could relieve the bleak social side during the fin-de-siècle and reveal a pastoral urban scene instead.

Both Chase and Hassam's early New York scenes were seeking a pastoral realism when depicting this metropolis. Both the inclusion of green spaces, such as parks, and the visibility of church pinnacles serve as a buffer to ameliorate the

6 James D. McCabe, Lights and Shadows of New York Life; or, The Sights and Sensations of the Great City (Philadelphia: National Publishing Co., I872), 446. See also William H. Gerdts, Impressionist New York (New York: Artabras, 1996), 48. 23, n.s. (Dec. I892): I69-70. 
potential dangers of the urban environment and provide the enclosed safety of a domestic-like urban experience. There were few lowlife denizens or threatening and bold gazes from strangers in their paintings. With the beautiful ideal of spacious urban space filled with air and sunshine, individuals could still realize their singularity and enjoy their privacy without showing any distinct alienation or social dissonance as was frequently depicted in the works of French Impressionist painters such as Edgar Degas and Gustave Caillebotte. By the end of the inth century, through an idyllic and reminiscent lens, Hassam's and Chase's treatments of New York City were an alternative to confronting the irrevocable and ceaseless transformation of the city. By ignoring the influx of immigrants and emerging social disparities, they succeeded in collecting the remnants of a poetic and picturesque New York. Combining a pastoral flavor with urban life is in itself a way of blending the idealization of agricultural nostalgia with quotidian contemporary life. Instead of highlighting forms of social detachment brought on by various processes of modernization, Hassam and Chase strove for a kind of formal and conceptual harmony which was already on the verge of collapse.

\section{Upward Thrust: The Presence of the Skyscraper}

In his Panoramic View of New York (1876), Joshua H. Beal used photography to eternalize a last impression of New York City's skyline while it was still dominated by church pinnacles. New York's first era of high rises began with the construction of the Washington Building in 1885 and the erection of the skyscraper became a visible demonstration of modernity ever after. Several debates over the aesthetic issues raised by the ascendancy of skyscrapers had become a focus of controversy relative to urban problems. Some defenders of the genteel tradition, including Henry James and George Santayana, argued for protecting the older, academic neo-classicism inherited from Europe and they saw soaring skyscrapers as a visual revolution against traditional values. They considered them to be closely related to aggressive forms of materialism and commercialism.

Santayana once described the polarities of the American character this way: "One-half of the American mind, that not occupied intensely in practical affairs,...floated gently in the backwater, while, alongside, in invention and industry and social organization, the other half of the mind was leaping down a sort of Niagara Rapids." ${ }^{8}$ The division is symbolized in American architecture, where we can see neat reproductions of the colonial mansion - with some modern comforts subtly introduced — standing beside skyscrapers. Royal Cortissoz expressed his concern, in his essay "Landmarks of Manhattan," that the burgeoning of the skyscraper would eventually make the once impressive church obscure. $\mathrm{He}$ wrote, "St. Paul's never surprises the foreigner who finds it down in the heart of busy London, the roots of the past go so deep all over that neighborhood, yet it is doubtful if many Americans can never apprehend the survival of old Trinity at

8 George Santayana, The Genteel Tradition: Nine Essays by George Santayana, ed. Douglas L. Wilson (Cambridge: Harvard University Press, 1967), 39-40. 
the head of Wall Street, in the midst of immense buildings that have sprung up like mushrooms, without thinking, if they think at all, of the utter and amazing incongruity of the church." 9 This kind of anxiety was also expressed by Chase, who was disappointed by new buildings that made an overly striking contrast in their formal styles with classical architecture. He criticized the phenomenon this way: "It is most discouraging to find one bit after another of the old architectural artistic productions wiped out of existence.... The skyscraping monsters have smothered quite out of existence as objects of beauty many of the mighty landmarks of this city."

Though the defenders of traditional architectural aesthetics held their views, and while the debate about overwhelming commercialization echoed continuously, the visual potential of the elevated viewpoints of the skyscraper became an irresistible trend, permeating mass media during the middle period of the Progressive Era. Popular periodicals established a favorable climate for the depiction of skyscrapers. Some popular magazines including The Century and Scribner's, remarked on the value of skyscrapers, including the newly constructed modern skyline of Manhattan and the panoramic views of the port and skyscrapers under construction. In addition, in the periodicals The American Amateur Photographer and Camera Work, the latter edited by Alfred Stieglitz, the skyscraper was also a frequently published subject. ${ }^{\text {II }}$

John Van Dyke's The New New York, published in 1909 and illustrated by Joseph Pennell, has long been considered one of the most interesting works illustrating the social and cultural context from I88os until the first World War. ${ }^{12} \mathrm{Al}$ though he had ambivalent feelings about modern architecture, Pennell didn't see skyscrapers as intrusions into New York's skyline. He and Hassam were among the foremost early devotees of the modern skyscraper city.

In order to fully capture the soaring skyscraper in the I89os, there were more vertical compositions in the works of Hassam during the early years of the 2oth century. He moved away from human-centered, eye-level perspectives and substituted more elevated viewpoints. In contrast to Chase's strikingly negative comments on the skyscraper, Hassam took a more ambivalent attitude toward

9 Cortissoz, "Landmarks of Manhattan," 533.

Io Quoted in Abraham David Milgrome, The Art of William Merritt Chase, PhD diss. (University of Pittsburgh, I969), IOI-2.

II See Meir Wigoder, “The 'Solar Eye' of Vision: Emergence of the Skyscraper-Viewer in the Discourse on Heights in New York City, I890-1920," Journal of the Society of Architectural Historians 61, no. 2 (June 2002): 152-69, and Alvin Coburn, "My Best Pictures and Why I Think So," Photographic News 51, no. 579 (Feb. 1907): 83. See also Sadakichi Hartmann, "The 'Flat-Iron' Building-An Esthetical Dissertation," Camera Work 4 (Oct. 1903): 36-40; reprinted in Sadakichi Hartmann, Critical Modernist: Collected Art Writings, ed. Jane Calhoun Weaver (Berkeley: University of California Press, I99I), I40-46, and Roland Rood, "The Origin of the Poetical Feeling in Landscape," Camera Work II (July I905): 2I-25. 
them. On the one hand, he admitted that they demonstrated a particularly admirable American character, while he also could not remain blind to the disjunction of people and space caused by this kind of modernization. Therefore, Hassam could explore both the formal beauty of the skyscraper as well as its effects of unrest and estrangement.

Rather than representing any particularly famous new buildings of that time, Hassam loved the formal and general spectacle that the skyscraper created. As he said: "If taken individually a skyscraper is not so much a marvel of art as a wildly formed architectural freak.... It is when taken in groups with their zig zag outlines towering against the sky and melting tenderly in the distance that the skyscraper are truly beautiful." ${ }^{13}$ This description of Manhattan's skyline was best epitomized in Hassam's painting October Haze, Manhattan (I9IO), already in William T. Evans's private collection before its first public showing at New York's Lotus Club. During an interview in I9I3, Hassam proclaimed, "New York is the most beautiful city in the world. There is no boulevard in all Paris that compares to our own Fifth Avenue... and even London, which I consider infinitely more beautiful than Paris, has nothing to compare with our own Manhattan Island when seen in an October haze or an early twilight mist from Brooklyn Bridge." ${ }^{14}$ October Haze, Manhattan was a visual representation of these descriptions of New York. In order to emphasize an aesthetic pleasure and poetic mood, Hassam abstracted himself from the Manhattan skyline and ignored any architectural exactness. His evocative, expressive, and subjective properties of color and light could be termed proto-abstract. The staccato, rippling brushstrokes along with the shadows of skyscrapers evoked the viewer's imagination of this metropolis and expressed Hassam's personal devotion to the city.

In Hassam's Lower Manhattan (1907) and Fifth Avenue in Winter (1919), the artist used the extreme vertical thrust of tall buildings and numerous disembodied pedestrians to reveal the sharp contrast between human bodies and architecture under high-speed modernization. The ant-like swarming of the crowd shows a sense of social unease and estrangement. What Hassam implied here was the impersonality and bustle of urban existence - the heedless jostling of the free-floating human atoms that endlessly surged through the streets. In consequence, the accelerated pace of the upward-thrusting skyscrapers would eventually engulf the people who lived there. At the heart of Modernism is the myth of an environment so mechanized and regularized that it mandates a dehumanized experience of the world. Though Hassam had an artistic understanding of and sensitivity to the haphazardness of the new century, and the accumulation of the commercialized spectacles that might eventually disturb the slower gentility that he valued, his attitude was still elitist and conservative. He chose to depict harmonious environments by intentionally ignoring congested urban scenes filled with immigrants. However, Chase's pictorial eclecticism was ultimately overrun

I3 Hassam, "New York the Beauty City," I6.

I4 Ibid. 
by the Ashcan artists, who eschewed any appeal to exquisite sensibility by choosing instead immersion in the vicissitudes of urban daily life.

\section{Journalistic Realism}

Since the exhibition "American Impressionism and Realism," held in 1994 at the Metropolitan Museum of Art, these two loosely defined schools have no longer been considered as wholly independent art movements. ${ }^{15}$ However, putting all of their similarities aside, I would like to discuss further the distinctive aspects of the Ashcan School relative to the spectacle of New York City in the fin-de-siècle period. ${ }^{16}$ Unlike their Impressionist counterparts, most of the Ashcan artists began their careers as illustrators rather than as serious artists. By 1900, more than 160 different newspapers were published in New York, including 56 in foreign languages and 64 dailies. When New York eclipsed other big cities as the paramount capital of publishing, Philadelphia-based artists like John Sloan and Everett Shinn found New York the place to be to continue their work depicting slices of time and place in a bustling metropolis. As Sloan wrote to Robert Henri in 1898, "A good thing done in New York is heralded abroad, a good thing done in Philadelphia is—well-done in Philadelphia." ${ }^{17}$ New York at the turn of the century became a hub suffused with the raw material of a multitude of stories and pictures. The New York scene, as depicted by the artists of the Ashcan School, was enriched by a journalist's sense of curiosity and a journalist's desire to connect with a broad public; therefore, I would categorize their works as journalistic realism.

The most well-known paintings of urban New York by the Ashcan school were created between 1897 to 1917 , when the metropolis had become the vital symbol of modernism. In contrast to the works of Impressionism and Tonalism, these realist painters were more concerned with the people who lived in the city instead of exploiting the architectural skyline, and they challenged both the aesthetic and the urban ideals associated with the Genteel Tradition and the City Beautiful Movement at the turn of the twentieth century. They captured contemporary social phenomena that included the mass influx of immigrants,

I5 H. Barbara Weinberg, Doreen Bolger, and David Curry, American Impressionism and Realism: The Painting of Modern Life, I885-19I5, (New York: Metropolitan Museum of Art and H.N. Abrams, 1994).

I6 "The Ashcan School, also called the Ash Can School, was an artistic movement in the United States during the early 2oth century that is best known for works portraying scenes of daily life in New York, often in the city's poorer neighborhoods": "Ashcan School," Wikipedia, https://en.wikipedia.org/wiki/Ashcan_ School. See also Elizabeth Kennedy, ed., The Eight and American Modernisms (Chicago: University of Chicago Press, 2009).

I7 Quoted in Bennard P. Perlman, ed., Revolutionaries of Realism: The Letters of John Sloan and Robert Henri (Princeton: Princeton University Press, 1997), 32, italics 
public advertising and consumer culture, public entertainments, gender inequality, income inequality, and so on. Their choice of subjects corresponded with the increasing awareness of political and social injustice in contemporary literature and social theories, best represented in the literary works of Theodore Dreiser and Upton Sinclair, as well as in Thorstein Veblen's theories of conspicuous consumption by the "leisure class." 18

Though Henri turned to figure painting instead of the cityscape after the end of nineteenth century, he was still an influential teacher among the Ashcan artists. Both Henri and Chase played mentor roles among the younger artists; however, a striking disparity of artistic method between the two were their attitudes toward technique. Chase encouraged his young compatriots to plunge into the dynamism of a modern city, but he still held an academic view of technique. Henri, on the other hand, abandoned the seriousness of technique and eschewed pictorial perfection. Henri encouraged every artist to be a metropolitan reporter, and the idea of the artist finding subjects amidst the daily bustle of the city recalls Charles Baudelaire's celebration of the Parisian sketch reporter Constantin Guys as the archetypal "painter of modern life." ${ }^{19}$ For Henri, the artist's task went beyond the recording of fashion and appearances from a supposedly objective distance to plunging into urban "life" itself. Yet Henri wanted his students to produce something more than newspaper illustrations rendered in oil paint. $\mathrm{He}$ encouraged them to transcend the divisions between high art and popular art and create works rooted in the contemporary scene, like the news, but enduring in their quality, like traditional paintings.

Henri's ideology was best exemplified in John Sloan's New York scenes of the I9Ios. Women constituted an important subject for Sloan's paintings, both as active spectators and as subjects with gazes of their own, resisting the gaze of male viewers. There was some enthusiastic discussion on the social role of urban ideal women, even within the framework of the Aesthetic Movement. This aesthetic is also evident in the allegorical female figures that graced the triumphant civic architecture endorsed by the City Beautiful Movement in the early decades of the twentieth century, credited to the idealization of women's roles from the Gilded Age to the dawn of World War I. Piety, purity, submissiveness, and domesticity were commonly assumed to be the four cardinal virtues for women before the Civil War. ${ }^{20}$ Although this morally-inflected opinion lost its favor during the turn of the century, idealized women were still frequently portrayed in the works of Thomas Dewing, Edmund Tarbell, Chase, and Hassam, whereas the cosmopolitan domesticity they represented in their painting was eschewed and ignored by Sloan and other Ashcan artists. Women in Sloan's work were often unescorted and susceptible to the seduction of commercial visuality.

I8 Thorstein Veblen, The Theory of the Leisure Class (New York: Macmillan, I899).

I9 Charles Baudelaire, The Painter of Modern Life and Other Essays, ed. and trans. Jonathan Mayne (London: Phaidon, 1964).

20 See Barbara Welter, "The Cult of True Womanhood, I820-1860," American Quarterly 18, no. 2, pt. I (Summer 1966): I52. 
Fig. 4. John Sloan, Hairdresser's Window, 1909. Wadsworth Athenaeum Museum of Art, Hartford, Connecticut. (C) 2019 Delaware Art Museum/Artists Rights Society (ARS), New York

Hairdresser's Window was one of Sloan's most important urban scenes, revealing a uniquely interesting perspective in the public sphere (Fig. 4). Pedestrians of different genders stop to gaze upward into an open window. Traces of commercialization fill the whole painting: window displays occupy the first floor while the performance of bleaching a customer's hair by the hairdresser becomes the live promotion of the advertisements plastered all over the brownstone building. ${ }^{2 \mathrm{I}}$ The exposure of an

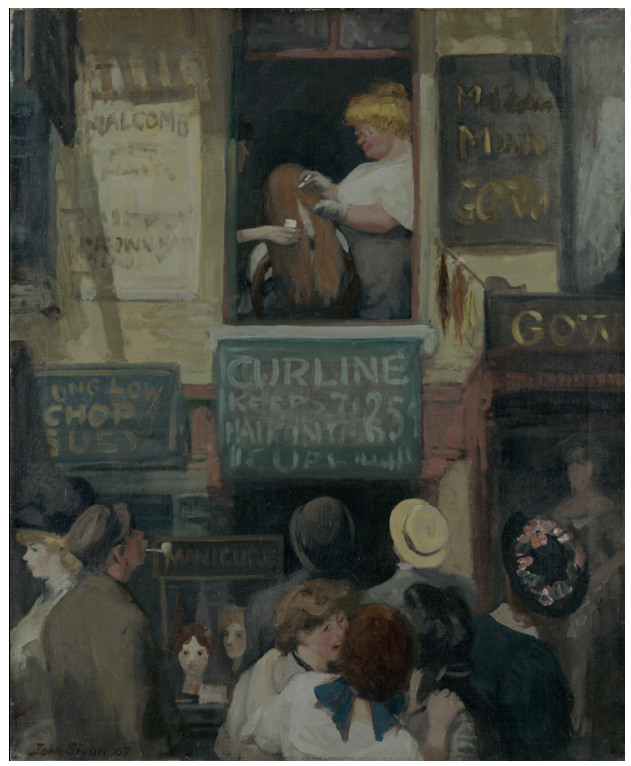
act that once belonged to the more private domestic domain showed again that boundaries were blurring between private and public life. Besides the depiction of commercial culture, there was also an artistic meta-commentary whereby the professional actions of the hairdresser echo those of the artist wielding his brush. ${ }^{22}$ The cluster of people congregating on the sidewalk suggest the focused attention of viewers at a museum or gallery. Sloan's pictures conjure a scene in which the act of painting has managed, at least for a moment, to draw a crowd's attention toward a painterly scene framed by the shop's architecture, and away from the more chaotic hustle and bustle of the urban spectacle that had come to define the viewer's experience in the new century, and the viewing of a hairdresser's work doubles as the viewing of an artwork. The attraction of art was no longer confined to the cloistered space of gallery and museum. In Picture Shop Window (1907-8), Sloan showed some critical consequences of modernization in New York: the painting depicts welldressed women who were potential art connoisseurs who paused for a moment to

2I On the hyper-commercialization of consumer culture during this time period and women's involvement in that, see Susan Porter Benson, Counter Cultures: Saleswomen, Managers, and Customers in American Department Stores, I890-1940 (Champaign: University of Illinois Press, 1986). On the relationship between the artists of the Ashcan School and an emerging consumer culture, see Rebecca Zurier, Picturing the City: Urban Vision and the Ashcan School (Berkeley: University of California Press, 2006), and also Thomas J. Schlereth, "Consuming," in Victorian America: Transformations in Everyday Life, I876-I9IS (New York: HarperCollins, 199I), I4I-68.

22 On Hairdresser's Window as a meta-commentary on painting and viewership, see Michael Lobel, "John Sloan: Figuring the Painter in the Crowd," The Art Bulletin 93, no. 3 (Sep. 20II): 345-68. 


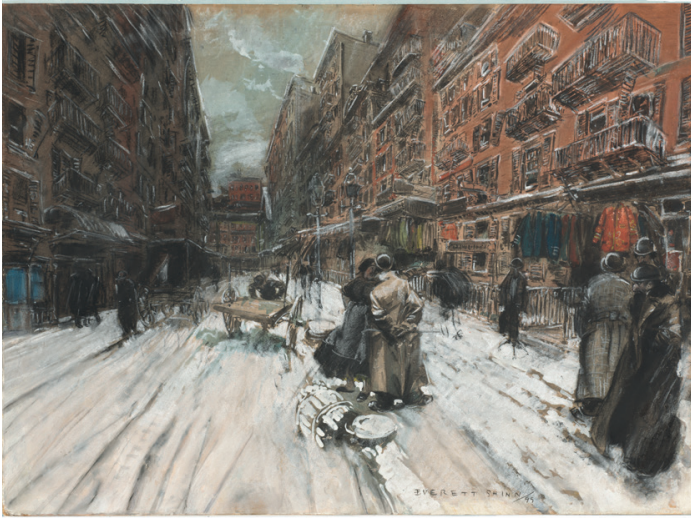

Fig. 5. Everett Shinn, Cross Streets of New York, I899. National Gallery of Art, Washington, DC. Corcoran Collection (Gift of Margaret M. Hitchcock through a Museum Exchange)

see and comment on the artworks in a gallery window display. As seen in other paintings by Ashcan artists, the gallery's glowing gaslight created a glittering spotlight for New Yorkers, attracting the public to fall prey to visual forms of commercial seduction.

Snow scenes were an essential part of Everett Shinn's New York paintings. Unlike Hassam's romanticized and poetic renderings of snowy streets, Shinn often highlighted passersby, primarily poor people, trudging against the blizzard. In his Cross Streets of New York (Fig. 5), the off-kilter, distorted perspective made the dilapidated buildings appear even more inclined to collapse. Shinn's snow scene here can be seen as a visual counterpart to Stephen Crane's article "The Men in the Storm" (I894) about the struggles of homeless men outside a soup kitchen in New York City during a snowstorm. ${ }^{23}$ Both Crane and Shinn rejected political polemics while intensifying the painterly spectacle and imaginative effects in their scenes of urban "realism." Shinn had no intention of provoking an awareness of how the other half struggled; he once claimed that "he depicted Manhattan's suffering but that only the poorer sections revealed this suffering in 'artistic' terms." ${ }^{24}$

Some scholars have doubted that the choices of subject concerned with depicting the poor and immigrants had political purposes. I do not want to argue whether these kinds of conclusions are tenable or not, but artistic differences among the Ashcan School artists should be put into consideration. Henri and Sloan were interested in social and political ideas, in the writings of Edward Bellamy and Henry George, the optimistic Americanism of Walt Whitman, the humanitarianism of Tolstoy, and the economic and historical theories of Karl Marx. They acknowledged the whole complex of late nineteenth-century idealism, which ranged from old-fashioned liberalism to socialism and communism. Hypocritically or not, their paintings did reflect social ambiguity—not statically, but in an energetic process which was also evident in the works of George Bellows.

For his encyclopedic summary statement on New York City, Bellows chose Madison Square at the crossroads of Broadway and 23rd Street as his panoramic representation of this metropolis, a site that boasted the first electric sign and other dazzling advertisements intruding upon every passerby's visual experience (Fig. 6). The painstaking effort of recording every minor detail of skyscrapers

23 Stephen Crane, "The Men in the Storm," Arena Io (Nov. 1894): 662-67.

24 Quoted in Zurier, Picturing the City, I70. 
Fig. 6. George Bellows, New York, I9I9. National Gallery of Art, Washington, DC. Collection of Mr. and Mrs. Paul Mellon.

and other commercial representations, such as billboards, created an overwhelming flux that leaves no space for the viewer to rest their eyes. The juxtaposition of horse-drawn carriages, trollies, motorcars, and horses all snarled in traf-

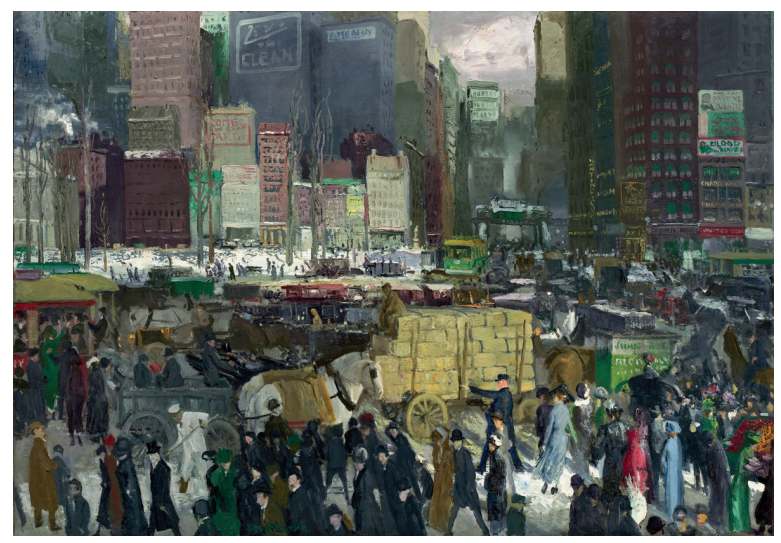
fic, and sidewalks filled with men and women of varied economic backgrounds, brings a unique focus to the modern tumult. The presence of modernity embodied in skyscrapers and motor cars, alongside old-fashioned carriages, highlights the fact that the future was blooming while the past had not yet retreated off the stage. Bellows showed neither a sentimental nostalgia nor an optimistic eulogy; what he showed instead was his observed reality. Hester Street by George Luks portrayed a similar slice of the Lower East Side, where a clutter of wagons, street urchins and people are all recorded conversing around the tenements. As with the other Ashcan realists, Luks made himself into an objective observer instead of immersing himself as a participant or insider. His over-stimulated vision responded to Guy Debord's argument in The Society of the Spectacle: the whole life of modern societies presents itself as an immense accumulation of spectacles, where the representation of life overtakes life itself. ${ }^{25}$

Bellow's The Cliff Dwellers (1913) paid attention to the highly dense urban population. Like Sloan, Bellows was also attracted to the subject of tenements and emphasized the people who lived in them instead of the architecture. Here Bellows captured the whirlwind of activities on a hot summer day in New York. The unbearable heat inside has forced the inhabitants into the street, resulting in the congestion of the public space. We can see some naked children playing in the streets, a mother nursing her infants without avoiding anyone's gaze, and a trolley fighting its way through the crowd. Interestingly, community here served as a communal identity to embrace the vicissitudes of daily life.

Henry Blake Fuller wrote a novel in I893 bearing the same title as Bellows's painting, and it was considered the first novel set among the skyscrapers. Even though the site in the novel was Chicago rather than New York City, what the author emphasized, similar to the artists of the Ashcan School, was a raw brutal environment in which, under the press of modernity, people were reduced to a relatively primitive state. Unlike the urban scenes described in some literary works, however, Bellows's paintings were non-judgmental statements: he select- 
ed his subjects, but left the ultimate emotional experience and further reflection to the viewers.

In his novel Washington Square, Henry James recalled his childhood memories with great sensitivity. Though New York City had experienced tremendous transformation by the I88os, James still strove to eternalize the tranquil slice of the rarefied, upper-class world in which he used to live. In the works of the Ashcan School, however, the classically elitist monumentality of the past has finally given way to anecdotal "slices" of a chaotic modern life. Nevertheless, both the Impressionists' eclectic and romanticized approach to urban life and the theatricality and anecdotal narration of the Ashcan School reveal the contours of a dynamic New York City at the turn of the century and give it memorable and enduring form. 


\section{进化抑或革命 : 沃尔特・帕克与 ${ }_{1913}$ 年美国军械库 艺术展}

陆豪

沃尔特-帕克是美国现代艺术史上一位极具影响并传奇的人物。他 集多重身份于一身，即是策展人、批评家，又是一位艺术家和学者， 他毕生致力于美国艺术的建构与研究之中, 其中由他参与策划的军 械库美术展已经成为世界公认的最重要的美国现代艺术展览之一。 论文的初步计划是通过对帕克作为艺术家和策展人对 20 世纪初期 美国现代艺术塑造的研究, 结合现代艺术品收藏、资助以及美国现 代主义观众的养成，找寻一种关于欧洲现代主义艺术美国化的理解 与渐进思路。

\section{I. 军械库展被遗忘的人}

1913 年 2 月 17 日至 3 月 15 日在纽约第 69 军械库举办的展览的历史 意义自不必说。从官方的角度来看, 这次展览主要的组织者是沃尔 特 ·库恩和美国画家与雕塑家协会 (The Association of American Painters and Sculptors [AAPS])，许多评论中仅仅是把帕克视为军 械库展欧洲的中介商。从 1913 年开始出版的许多报纸和期刊杂志 的文章都会谈到亚瑟 - 戴维斯, 以及库恩作为展览背后后的主要推 动者, 是如何遴选欧洲先锋派作品的。1939 年和 1963 年之间出版 的一些文章会承认帕克在军械库展中的重要角色, 但是重心依旧集 中在戴维斯和库恩的身上。在 1988 年出版的《军械库的故事》一 书中, 弥尔顿·布朗纠正了它对 1963 年版本中关于帕克角色的评价。 然而, 对于军械库而言, 帕克的角色至关重要。

军械库展览是帕克参与并组织的第一次展览。虽然帕克只是以 协助人的身份参与其中。在梳理文献的过程中发现了此次展览许多 不为人知的地方。因为帕克早期主要居住在巴黎, 熟悉欧洲许多先 锋艺术家、画商以及收藏家。而库恩和戴维斯并不十分了解欧洲现 代艺术。帕克带他们见到了当时欧洲最好和最前卫的现代艺术、参 观了许多巴黎的商业画廊、艺术家的工作室，几乎欧洲的所有参展 作品几乎都是通过帕克运往美国。因为戴维斯和库恩主要关注当代 
欧洲艺术，在最终的作品遴选中德国和俄国的先锋艺术家的作品并 被排除在外。许多评论认为这些作品的缺席是因为戴维斯和库恩认 为德国人名没有为现代艺术做出卓绝的贡献，或是准备仓促。但是 这种说法或许略显牵强，极有可能与帕克的法国品位联系更甚。这 也可以解释军械库之后为何美国现代艺术倾向趋于法国的原因。

帕克撰写现代艺术评论很早。通过阅读资料看到从 1908 年开始, 他就撰写过文章讨论雷东和杜尚·维庸的艺术作品。而军械库展时, 帕克又撰写了《一位雕塑家的建筑》《支持和反对 : 论纽约与芝加 哥的国际展》等文章，以此希望能够在美国营造一个前期潜在的观 众群体。展览还使用了帕克翻译的艾利·弗热关于塞尚和高更的文 章用作艺术评论。这在一定程度上，对美国早期对现代艺术的接受 进行了思想上的预热。

1913 年军械库展展览开幕后，帕克一直奔波于纽约、芝加哥与 波士顿之间，他希望能够最先在美国中产阶级中建立潜在的关系。 他因此成为了其中一些藏家的顾问，其中就包括约翰·奎因，他在 帕克的建议下购买了许多现代艺术作品，其中就包括杜尚，雷东， 德兰等人的作品。帕克在军械库展中还结识了沃尔特 - 奥森伯格, 他通过帕克购买了 3 件蚀刻版画以及一件素描作品。在波士顿的巡 展中，帕克同样出售了几件布朗库西，杜尚和皮卡比亚的作品给亚 瑟·杰罗姆 ·埃迪。尽管只有一小部分人能够理解或者尝试去欣赏 现代艺术作品，但是帕克对于现代艺术在美国的未来充满希望。帕 克除了建立一些潜在的现代艺术的客户关系外，帕克还在扮演着现 代艺术的公众发言人形象，帕克几乎每天都在不断的在给参观的人 们介绍和讲解现代艺术作品，这在一定程度上刺激着美国这块新大 陆未来潜在的艺术受众，也会后来美国兴起的大众艺术做了铺垫。 此次展览大约出售了 250 件艺术作品，其中有至少 50 件是美国艺 术家的作品。但是有一点引起了我的关注，就是通过帕克的艺术活 动发现，在帕克的好友约翰 - 奎因的收藏中欧洲现代艺术作品占了 大多数, 而美国本土的艺术家只有 II 幅作品, 其中约翰·马林的作 品价格也只是在 1500 美元左右。相比之下，阿尔弗雷德·斯蒂格 利茨推荐约翰-马林的作品给奎因, 没有任何文献能够说明帕克这 样做的真实目的是什么。

尽管帕克并非 AAPS 的成员，在军械库展中，他一直在艺术家、 
收藏家和欧洲画商之间进行沟通协调，帕克是军械库展历史背后被 隐藏的关键人物。

\section{2. 军械库展暗示着中产阶级的趣味}

我觉得军械库展有两个重要的作用，一个是点燃了美国国内的艺术 家、观众、画廊以及美术馆对于现代艺术的热情关注，纽约的一些 画廊开始展示现代绘画与雕塑作品。因为帕克对现代艺术上的理解 使这次展览中的许多作品脱颖而出。另一个是 1913 年的这次展览 成为区分美国两代现代艺术收藏家的节点。帕克在与美国一些收藏 家的来往活动表明了在军械库展前后两代不同的收藏趣味。早在 1913 年之前, 美国对现代艺术的兴趣仅限于少数的专业人士, 例 如阿尔弗雷德·斯蒂格利茨，约翰·奎因和亚瑟·杰罗姆·埃迪等。 这些人都对现代艺术表示出了浓厚的兴趣, 并且不断的购买现代艺 术作品, 但是由于财力有限, 他们的收藏对于美国早期的现代艺术 并没有太大的影响。而在 1913 年军械库展之后, 更多富裕的中产 阶级介入了现代艺术收藏, 尽管这一代收藏家的财富依旧无法与上 层富裕阶层相比，例如 J.P · 摩根，但是这一代藏家的趣味已经转 到了现代艺术的方向，例如，沃尔特·奥森伯格、阿尔伯特·巴恩斯、 莉莉·碧利斯、邓肯·菲利普斯等。与第一代有所不同的是, 他们 拥有更为专业的知识, 例如沃尔特. 奥森伯格是一位诗人和批评家; 巴恩斯是一位作家和艺术批评家; 帕克在与这两代收藏家的交流中, 不断鼓励和刺激着他们对现代艺术的收藏。所以，假设没有帕克的 斡旋, 很难想象此次展览的最终效果。在帕克的联动下, 军械库展 成为了 20 世纪美国艺术史上最重要的一次展览。

在考察帕克在军械库展前后的活动时, 其他一些资料, 尤其是 当时纽约对现代艺术的一些反对派评论, 引发了拓展性的思考。I 世纪末，美国各个阶层对艺术表现出来十分不同的趣味。上层富有 阶级比较青睐欧洲传统作品, 他们的趣味直接促进了美国艺术博物 馆和私人画廊的收藏。而中产阶级的趣味相对复杂, 他们既关注欧 洲艺术的发展, 又倾向于扶持本土画家 ; 中下阶层可能更倾向于美 国本土的传统化画家，例如，美国哈德逊河画派。

第一次世界大战打乱了帕克的计划, 许多参加过军械库展的画 廊纷纷关门，欧洲的艺术家更是受到了巨大的影响。在分析帕克与 
艺术家的通信中可以看出，他开始改变方法，帕克先是把纽约的一 些画廊主、藏家与美国本土的艺术家介绍给欧洲的现代艺术家，然 后帮助一些艺术家来到纽约，建立起了巴黎与纽约之间的现代艺术 商业圈，这在一定程度上把美国的收藏家、画商、博物馆以及美国 艺术家、批评家联系在了一起，在这个相对困难的时期使现代艺术 在美国仍然能够继续前行。

在面对不同阶层对艺术的不同趣味时，无论是潜在的市场利益 还是对美国本土文化展示的渴望，帕克不断的调整着他的策略，最 初，他开始在蒙特罗斯画廊，卡罗尔画廊和波日瓦等画廊与艺术家 之间频繁的活动，他一边全力帮助欧洲现代艺术进入纽约，一边不 断的鼓励纽约的画廊展示美国本土艺术家作品，例如尚伯格，斯特 拉等。帕克在与马蒂斯的信件中曾表示出美国已经不在需要进口了, 他们可以自己生产现代艺术。“美国首届当代艺术展” 是完全针对 美国艺术家作品的一次展览，分别在纽约的蒙特罗斯画廊，底特律 美术馆，辛辛那提美术馆等地方进行展出。帕克依旧负责联系机构 和作品选择。在考察资料的时候发现, 与军械库展不同的地方在于, 有几座博物馆参与了此次展览，在匹兹堡的卡耐基美术馆，有包括 戴维斯、格拉肯、库恩、尚伯格、希勒以及斯特拉等美国艺术家近 40 件作品进行展出; 底特律和辛辛那提的博物馆也展出了 76 件作 品，涉猎油画，素描，水彩等。这次展览吸引了大量的观众前往观 看，并引发了关于作品的许多公共关注。例如，《底特律新闻》刊 登了斯特拉，尚伯格等人的作品 ; 《辛辛那提商业论坛报》刊登了 戴维斯和阿伦·塔克等人的作品。

许多人关注的焦点几乎全在军械库中已经成名的欧洲艺术家反 叛传统的变革态度。尤其是法国，很多人会认为现代艺术在美国的 传播或许是为法国艺术在做广告。但是，欧美两地的画商在军械库 展之后都发现了现代艺术在美国的商机。帕克在其中更是穿针引线, 他在协通美国本土的艺术家们对于公众的教育起到了重要作用，加 速了美国艺术家将欧洲最前沿的现代艺术带回了美国 ; 在现代主义 艺术的美国本土收藏过程中，美国艺术家扮演了重要角色。当艺术 市场逐渐向现代主义转向的时候，很多艺术家也选择了现代主义。 


\section{3. 欧洲现代艺术与美国现代主义艺术的关系}

现代主义在美国是如何演变和进化?这是我前期研究帕克时，对现 代主义艺术与早期美国文化逐渐扩大思考的一个问题。从 19 世纪 末到 20 世纪初，欧洲现代主义观念传入美国后开始十分曲折的演 变过程。现代主义艺术先是在美国受到嘲笑，继而被视为欧洲的文 化入侵，受到广泛的抵制。20 世纪 30 年，美国还曾出现过大规模 的文化运动, 最终美国人似乎一夜间回到了 19 世纪末的时候。最终, 美国中产阶级精英使现代主义艺术观念成为美国了的主流思潮，而 美国也在此基础之上形成了自己的精英文化。相比帕克早期致力于 美国中产阶级对现代艺术的收藏估计也有这方面的考虑。20世纪 早期，美国通过对现代艺术的慢慢接触，消化，直到 50 年代抽象 表现主义绘画的出现，在波洛克、德库宁、罗斯科、奥基弗以及马 瑟韦尔等美国本土艺术家的画面出现的女性、天空、色点、直线、 大色块等物象，与 20 世纪前的美国本土传统并没有什么联系，甚 至也看不见欧洲的艺术传统。美国的现代艺术体现的是一个完全现 代性的特征。这也是与欧洲现代艺术最大的不同点之一。帕克只是 给美国引入了一种视觉观念, 而恰恰是这种最为直观的图像刺激了 美国人对现代化进程所带来的观念的进化。美国抽象表现主义艺术 可能只有与通过弗洛伊德的无意识心理、荣格的心理学感知才能够 解读其绘画的根本含义。

帕克的研究可能只是我这篇论文的一个发起点, 我希望能够在 此次研究计划中进一步扩充。在考察的过程也遇到了一些问题与矛 盾。比如说, 美国现代艺术的崛起与传统艺术之间是否存在联系? 欧洲对美国现代艺术发展的作用不可否认，但是如果单说真正美国 现代艺术的崛起, 是否可以被看作是如何摆脱欧洲文化影响的过程, 进而演变出有别于欧洲的本土文化。19 世纪中叶，艾默生呼吁发展 美国文化时, 希望美国摆脱欧洲传统影响: 当 19 世纪末到 20 世纪初, 当美国步欧洲之后进入工业化社会时，美国人不再把欧洲传统视为 外来文化, 而是视为自身传统的一部分。这就另一个问题, 为什么 文艺复兴的 “视觉欺骗” 风格被美国人视为传统，转而回去警惕欧 洲现代主义艺术的入侵? 最终的事实证明，美国现代艺术的形成对 于欧洲的影响恰恰来自欧洲的现代主义文化, 而非欧洲自认为传统 的欧洲古典艺术。文化与艺术并没有 “内外”之分, 有的可能是“新旧” 
之别。这就像当前世界各国对美国大众文化的抵触，担心本国文化 被 “美国化” 时，同样的场景与美国精英阶层在 20 世纪初对待现 代主义的态度十分相像，美国精英担心现代主义会影响到传统文化 和生活方式，其他各国也同样担心大众文化的兴起会威胁到自身的 文化特权。这种 “圆形” 的态度表明了 20 世纪早期对现代艺术的 接受也存在一定的精英阶层的保守态度，也就不难理解为什么沃尔 特・帕克一开始便致力建设美国中产阶级对现代艺术接受的关系。

非常感谢美国特拉基金会为我提供机会前往美国考察美国艺术。 在这次学术旅行中，在拜访了一些研究美国现代艺术的教授、策展 人以及美术馆的管理人员，使我受益匪浅。对我而言不仅仅是一次 异域之旅，更多是在对美国艺术史的梳理以及当下艺术发展的理解 上，在本身研究的基础上引发了许多对于美国过去与当下的艺术观 念的思考。 


\section{Evolution or Revolution: Walter Pach and the Armory Show in 1913}

Lu Hao

The narrative of modernism in American art is punctuated by two events, one distinctly defined and the other slightly more diffuse. The first is the "introduction" of European modernism to American artists and audiences through the Armory show of I9I3; the second is the "liberation" of American art from European domination in the years immediately after World War II, with Abstract Expressionism. While there are any number of critiques of this narrative, it is worth returning to it, since it is so deeply embedded and continues to shape our understanding of how American artists got to where they did by the mid-twentieth century. At issue are three factors. The first is the language we use: "introduction" and "liberation" are loaded terms. What happens when we use different terms to describe the interaction between European avant-garde artists and young American artists forming their careers in the I9IOs or I940s? The second is how we cast the process, which usually comes to us diadically: is it "conservative" vs. "radical"? or "native vs. foreign"? or are such divisions even useful? Or should we be thinking in terms of "evolution" or some other process? Finally, then, are these changes the result of the actions of individuals or institutions, or even forces? In this essay, I use Walter Pach (1883-1958) as an organizing figure, useful both for what he did and how he was remembered.

As an organizer of the Armory Show of 1913, Walter Pach was a key figure in driving the acceptance of European modernist art among American audiences and setting the stage for the development of America's own Abstract Expressionist movement. An analysis of Pach's activities in the early twentieth century provides a clear roadmap for the separate roles played by galleries, critics, and collectors in this process. Several important questions emerge from such an investigation of Pach's activities before and after the Armory Show. How was Walter Pach able to connect galleries, collectors, and artists in organizing the show? What was the reason behind Pach's decision to bring European modernist art to America: commercial benefits or a wish to push forward the development of a new American art movement? Why were the majority of works he marketed to American collectors by European modernists and not by Americans? Why did Pach choose to target America's middle class instead of the upper class when communicating modernist art concepts? And finally, did the American art works exhibited in the Amory Show possess broadly modernist characteristics or did they mostly feature local phenomena specific to New York? There is a larger methodological point behind these questions: to what degree can we locate the development of modernism in American art in the action of individuals and what can be ascribed to "forces." To concentrate on Pach's activities, however, is not without its ironies, since at the core of his understanding of modern art was a belief in the evolution or progression of art. Fortunately, the scholarship of 
Laurette E. McCarthy sets the stage for any investigation of Pach and his role in the development of modern art in America. ${ }^{\mathrm{T}}$

\section{The Nearly-Forgotten Man in the Armory Show}

Needless to say, the 69th Armory Show, held from February 17 to March I5, I9I3, was significant in the history of American modern art. Officially, the organizers of the exhibition were Walt Kuhn and the Association of American Painters and Sculptors (AAPS). Publically, Pach was viewed as merely an agent in most of the review articles. In the newspapers and journals published in 1913, the exhibition was mainly attributed to Arthur B. Davies and Kuhn, when talking about selecting works by the European avant-garde. Although some later articles from 1939 to 1963 drew attention to Pach playing an important role in the Armory Show, they still tended to focus on Davies and Kuhn's contributions. In the 1988 edition of The Story of the Armory Show, Milton Brown changed his view from that in the 1963 edition about Pach's role in the exhibition. ${ }^{2}$ Nevertheless, the significance of Walter Pach for the Armory Show was largely overlooked, until the authoritative scholarship of Laurette McCarthy restored Pach's role to full visibility. ${ }^{3}$

As an important milestone in American modernist art history, the Armory Show of I9I3 was also a turning point in Pach's own career. Because Pach resided for years in Paris from 1904, he was familiar with many European avant-garde artists, dealers, and collectors. In contrast, Kuhn and Davies were actually not very familiar with European modernist art. It was Pach who took them to view the best and most avant-garde modernist art in Paris at that time, visiting numerous commercial galleries, private collectors, and artists' studios in Paris, including that of Constantin Brancusi, Marcel Duchamp, and so forth. Almost all of the French works for the exhibit were shipped to the United States by Pach. ${ }^{4}$

Pach corresponded with Robert Dell and Henri Matisse, Leo and Michael Stein, and Alice B. Toklas about the loans of works from the Grafton Gallery exhibition of Post-Impressionist art in London for the exhibition in America. It was Pach who secured the loan of Matisse's Blue Nude and for securing the most notorious work of the show, Marcel Duchamp's Nude Descending a Staircase.

I Laurette E. McCarthy, Walter Pach (I883-1958): The Armory Show and the Untold Story of Modern Art in America (University Park: Pennsylvania State University Press), 20II.

2 Milton W. Brown, The Story of the Armory Show (Joseph H. Hirshhorn Foundation, 1963). The second edition is substantially revised: Milton W. Brown, The Story of the Armory Show (New York: Abbeville Press, 1988).

3 Laurette E. McCarthy, "The 'Truths' about the Armory Show: Walter Pach's Side of the Story," Archives of American Art Journal 44, nos. 3-4 (2004): 2-13. This article forms the core of McCarthy's subsequent book chapter on the same subject, but I cite the article as it is more generally available.

4 Ibid., 3-5. 
Davies and Kuhn focused on European modern art; but, in the final selection, the works by German and Russian vanguard artists had been excluded from the Armory Show. Some critics claimed that the limited contribution by German artists to modern art accounted for the absence of those works. However, as McCarthy has suggested, and I would agree even more strongly, the reason relates more to Pach's French-influenced taste and sensibility rather than lack of available art works. ${ }^{5}$

Pach began writing about Claude Monet and Cezanne as early as 1908 for American audiences, and contemporary American art for French audiences by 1910. ${ }^{6}$ The work around the Armory show, however, impelled him to write more critically about contemporary French avant-garde art, including the first essay on Duchamp-Villon in 1913. Pach wrote articles like "A Sculptor's Architecture" and "For and Against: Views on the International Exhibition held in New York and Chicago" while the Armory Show was taking place, in order to create a potential audience for modernist art in America, as well as writing about Cezanne and Cubism. These activities offered a mental warm-up to the American public for the acceptance of modernist art, as it were.

After the opening of the Armory Show in 1913, Pach was occupied in traveling to and from New York, Chicago, and Boston, in hopes of generating relationships with potential collectors. He became a consultant to some of the collectors he visited, including John Quinn who purchased many modernist art pieces, including works by Marcel Duchamp and Redon, under Pach's guidance. Through the Armory Show, Pach also connected with Walter Arensberg, who bought three lithographs and one drawing through him. During the exhibition's Chicago tour, Pach sold several works by Constantin Brancusi, Duchamp, and Francis Picabia to Arthur Jerome Eddy. Though only a few people could truly understand or try to appreciate modern artworks, Pach remained hopeful about the future of modern art in America. Other than establishing a potential buying public, Pach also served as the public spokesperson for modern art. He tirelessly introduced and explained modernist works to people who visited the shows, stimulating the creation of a future audience for modern art in America and laying a cornerstone for the rise of America's own modern art movement. At the same time, however, it should be noted that Pach's close friend and key customer, John Quinn, only possessed eleven works by American artists with the majority of his collection being made up of works by European modernists. In contrast, Alfred Stieglitz made active efforts in recommending John Marin's works to Quinn. Hence, one may infer the possibility that Pach was not so passionate in marketing American modernist works as opposed to those by European masters, although this bias is undocumented in Pach's archives. ${ }^{7}$

5 Ibid., 5 .

6 For an extended review of Pach's writings see McCarthy, Walter Pach, ch. 3 and 9. See also Sandra S. Phillips, "The Art Criticism of Walter Pach," The Art Bulletin 65, no. I (March 1983): I06-22.

2147 See McCarthy, Walter Pach, ch. 6, esp. 78-79. 


\section{The Armory Show and a Middle-Class Audience}

The Armory Show of I9I3 served several key purposes successfully, one of which was igniting the interest of American artists, viewing public, galleries, and art museums regarding modern art. Several galleries in New York began to exhibit modernist paintings and sculptures because Pach's public relations efforts allowed many of the works featured in the Armory Show to gain much attention. Furthermore, the Armory Show marked the division between two generations of American modern art collectors. Pach's interactions with certain American collectors indicated a differentiation in taste before and after the show. Before 1913, American interest in modern art was limited to a few almost-professional collectors like Alfred Stieglitz, John Quinn, and Arthur Jerome Eddy. These individuals all demonstrated a strong interest in modern art and continuously purchased modernist works; but, due to their limited financial power, their activities did not leave as great an impact on the advancement of modern art in America as it might have. However, after 1913, wealthier middle-class collectors, and a larger group of them, like Walter Arensberg, Albert C. Barnes, Lillie B. Bliss, and Duncan Phillips, began to collect modernist works. Though this new generation of collectors could not compare with extremely wealthy individuals like J. P. Morgan in terms of financial prowess, their interest in modern art became highly influential. Different from the first generation of modern art collectors, they possessed a more institutional interest in art. ${ }^{8}$ In his communications with these two generations of collectors, Pach ceaselessly encouraged and stimulated their collection of modern art. It is hard to image how much influence the Armory Show would have had without Pach's mediations.

At the end of nineteenth century, America's different social classes exhibited very distinctive tastes in art. The wealthy upper class tended to favor traditional European artworks and directly impacted the collections of American art museums and private galleries. On the other hand, the preferences of the middle class were much more variegated. These collectors not only paid close attention to the development of contemporary European art but were also inclined to support native American artists. The lower middle class was more in favor of America's own traditionalist art, such as works by the Hudson River School. ${ }^{9}$

Facing the distinctive artistic tastes of the different classes, Pach continuously adjusted his marketing strategy, whether driven by a desire for monetary gain or for presentation of America's native culture. At first, he was actively involved in negotiating between artists and galleries like Montross, Carroll, and Bourgeois Galleries. While helping European modernist art to enter the New York mar-

8 See, Yelena Furman, The Influence of Private Collections in the Public Forum: Modern Collectors and their Impact on the Art Industry, MA Thesis (Sotheby's Institute of Art, 20I3).

9 For a recent study see Michaël Vottero, "To Collect and Conquer: American Collections in the Gilded Age," Transatlantica I (2013), http://journals.openedition.org/transatlantica/6492. 
ket, he also encouraged New York galleries to exhibit works by America's own modernist artists. "The Fourteen," an exhibition held at the Montross Gallery, Detroit Museum of Art, Cincinnati Art Museum, and other important venues in I9I4, was the first exhibit to exclusively feature works by American modernists. ${ }^{\text {Io }}$ Pach was again responsible for contacting organizations and selecting participating pieces. The participation of art museums in this exhibition indicates a more widespread acceptance of modern art since the Armory Show. Pittsburgh's Carnegie Museum of Art exhibited in December 1913 nearly forty pieces by American artists like Arthur B. Davies, William Glacken, Kuhn, Morton Schamberg, Charles Sheeler, and Joseph Stella. This exhibition attracted numerous attendees nationwide and raised much public attention surrounding the works and the participating artists; for example, The Detroit News reported on works by Stella and Schamberg and the Cincinnati Commercial Tribune published works by Davies, Allen Tucker, and others. ${ }^{\text {II }}$

The Armory Show seemed to be focused on European artists' revolution against tradition. Especially in France, most believed that the development of modern art in America probably helped to promote French art. ${ }^{12}$ However, after the Armory Show, both European and American dealers saw commercial opportunities in American modern art. Acting as a go-between, Pach was crucial in the education of the public by American artists, promoting the most cutting-edge European art introduced into America by them; in turn, American artists played an important role in the process of collecting modern artworks. And many artists subsequently chose to practice modernism as the art market directed its attention to modernism.

\section{The Relationship Between European and American Modern Art}

How did modernism evolve after it reached American soil? Modernist art was first ridiculed and then viewed and rejected by many Americans as a front of a European cultural invasion. In the I930s, large-scale cultural Nativist movements brought American tastes back to the end of igth century almost overnight. In the end, however, America's middle-class elite allowed modernist art concepts to become the dominant stream of thought in American society. This

IO See Judith Zilczer, "Arthur B. Davies: The Artist as Patron," American Art Journal I9 (1987): 54-83; Laurette E. McCarthy, "Modernists on Tour: A New Look at a Historic Show," Archives of American Art Journal 37, nos. 3-4 (I997): 2-16.

II See Darcy Tell, "The Armory Show at Ioo: Primary Documents," Archives of American Art Journal 5I, nos. 3-4 (20I2): 4-I8; and Walt Kuhn scrapbook of press clippings documenting the Armory Show, vol. 2, I9I3, available at "I9I3 Armory show: the Story in Primary Sources, Archives of American Art," Archives of American Art, https://www.aaa.si.edu/collection-features/I9I3-armory-show/ timeline.

I2 See, Richard R. Brettell, Modern Art I85I-I929: Capitalism and Representation (Oxford: Oxford University Press, I999), I99. 
also provided the basis for the formation of America's own elite culture, which may have been a goal of Pach in the first place when he reached out to the middle class to promote the collection of modern art. From the early I90os, when America first came in contact with and digested modern art, until the I950s, when motifs like dripping lines, color fields, and simple geometric shapes appeared on the canvases of American artists like Jackson Pollock, Mark Rothko, and Robert Motherwell, the development of American modernism seemed to have little connection with pre-twentieth century American art traditions, or with traditional European art. American modernist art presents fully "modern" characteristics, a key difference from European modern art. Pach only introduced a new visual concept to America, and it is precisely this direct visual stimulation that brought about Americans' conceptual evolution of modernism. We might speculate that American abstract expressionist art may only be understood in the context of Sigmund Freud's theory of the unconscious mind and Carl G. Jung's psychological theories; the work of a number of scholars have explored the use of psychoanalysis by AbEx artists. ${ }^{13}$

On the other hand, while Europe undoubtedly played a crucial role in the development of modern art in America, the creation of American modernism may be viewed as a process of casting off European cultural influence and generating a distinctive American culture. In the mid-I8oos, Emerson called for the development of an American culture, hoping for America to rid itself of European bondage; in the late I80os to early I900s, when America became an industrialized society following Europe's example, Americans no longer viewed European culture as foreign but as a part of its own tradition. This raises another question: Why were Americans guarded against the invasion of European modernist art when they fully upheld traditional European art as the gold standard? As proven in the end, the formation of American modernism was brought about by Europe's modernist culture and not classical European art. In the acceptance of culture and art, perhaps the distinction between "native" and "foreign" plays less of a role than that between "old" and "new". This brings to mind contemporary negative stances toward American popular culture in many countries worried about their own cultures becoming Americanized. Their attitude toward contemporary mass media culture is similar to that held by the American elite in the early 2oth century toward modernism. The American elite was worried about modernism affecting traditional culture and lifestyle, just like countries today are worried about American popular culture threatening their cultural identity. This historically repetitive conservativeness of the elite toward new cultural influences may explain why Walter Pach devoted his efforts to pushing for the acceptance of modern art by the American middle class in the first place.

I3 See for example Ellen G. Landau's monograph, Jackson Pollock (New York: Harry N. Abrams Press, 1989); or, more provocatively, Steven Naifeh and Gregory White Smith's biography, Jackson Pollock: an American Saga (New York: C.N. Potter, 1989). 
Thus, rather than simply regarding this process as an Americanization of modern art, I prefer to think of it as foreshadowing a new trend in the evolution of human civilization, that of responding to new cultural influences and forging a unique cultural identity. 


\section{巴黎美院之往, 包豪斯之后:梁思成与“现代主义” 的镜花缘 \\ 刘晨}

1945 年，中国抗日战争胜利前夕，梁思成给当时的清华大学校长梅 贻琦写了一封信，展望中国建筑教育的发展方向，并提议创办清华 大学建筑系。梁的出发点很明确 : 他预见到抗战结束后将迎来大规 模复兴，祖国亟需建设人才，成立建筑系，首先是为这个需求服务 的, 要解决实际问题。所以建筑系先依托于工学院，教授聘建筑师。 这个起初多少有点权宜之计的举措一直延续到今天，尽管当初的建 筑系已壮大成建筑学院，但在中国特色的学科分类中仍未跳出 “理 工农医” 的框架。

另一方面，梁的提议也带出了历史问题：建筑作为一门学科, 其体系化训练在中国史无前例; 中国虽有独特的建造技术和丰厚的 建筑遗产一用梁本人的话来说，是 “世界上最古、最长寿最有新生 力的建筑体系”, 却没有学院式建筑训练和教育的传统。近现代以前, 中国的建筑史基本上是一部 “没有建筑师的建筑史”，这是与西方 建筑传统最大的不同。

梁思成是中国古建筑研究的先驱者之一，其学术成就曾在国际 学术界引起重视。1947 年美国普林斯顿大学授予他荣誉文学博士 学位。他早年留学美国宾夕法尼亚大学建筑系，该校延用的是巴 黎美术学院的训练方法，号称 “美洲的巴黎美院”。巴黎美院的历 史可追溯到 I7 世纪，当时法国的财政部长柯尔贝（Jean-Baptiste Colbert）不但在政治上很有建树，而且非常热爱文化和艺术，在 他的提议下，国王路易十四创建了一系列皇家学院，包括科学院、 绘画与雕塑学院和建筑学院。法国皇家建筑学院创立于 $\mathrm{I} 67 \mathrm{I}$ 年 ; 而直到 1927 年，中国苏州工业专科学校建筑科并入中央大学，中 国才有了第一个建筑系，那之前，建筑知识和技艺的传授，都只靠 师傅带徒弟，类似欧洲中世纪的手工作坊传统。15 世纪意大利人文 主义学者阿尔伯蒂（Leon Battista Alberti）写出《论建筑》(On the Art of Building, I443-I452)，建筑师得以跻身学者、画家和雕 塑家的名士行列，由此开启了文艺复兴建筑与艺术并驾齐驱的伟大 
时代。与此同时，明代中国的建筑师仍然只被看作匠人，虽有 “文 人画” (literati painting) 的传统, 却历来没有 “文人建筑师” 的说法。

阿尔伯蒂为整个西方建筑文化带来的影响不容小觑，他在建筑 由手工向智识领域华丽转身的过程中扮演了关键角色，催生出建筑 学的自主性和建筑师身份意识的觉醒，这实际上是为西方现代主义 建筑的隆重登场打下了 400 多年的坚实基础。现代主义在西方的 出现，绝不是一个偶然的突发事件，而是有曲折漫长的历史铺垫， 政治、经济、文化、技术等因素都在发挥作用。但中国建筑进入现 代，却没有这个铺垫的过程。晚清民国之前，中西方建筑文化交流 极少。广东、福建一带的侨乡建筑是小范围地方性的，意大利建筑 师为乾隆皇帝设计圆明园, 是独一无二的皇家案例。总的来看, 建 筑并不像绘画、雕塑、装饰和其它工艺那样与西方有更长的跨文化 交流历史。

梁是近代中国建筑教育事业的一位重要开拓者。他于 1928 年和 1945 年分别创办沈阳东北大学建筑系和北京清华大学建筑系, 也 正是在这一时期，中国开始了解西方的建筑和建筑教育。但是这里 面有时间上的错位和滞后。造成时间滞后的固然有中国自身的历史 原因, 但是从近代建筑学移植的角度看, 可以说滞后的最直接根源 在于最早一批留美的中国建筑师所受的巴黎美院式教育。从 I894 年开始，美国的学院派建筑师组织 “博扎建筑师学会” (Society of Beaux-Arts Architects) 和美国学院（American Academy）就开始 在所有美国建筑院校中实行统一课程标准，其参参照对象就是巴黎 美术学院。

20 世纪初期，大批中国学生留学美国（清华大学的前身就是清 政府利用 “庚子赔款” 而设立的留美预备学校)。“中国建筑师学会” 从 1927 年成立到 1940 年接纳的 82 名会员中, 超过半数有留学美 国的经历，而他们当中毕业于宾夕法尼亚大学的最多，共有 I4 人。 从 I9I8 年到 1927 年, 仅清华学校就有 I2 名毕业生进入宾大建筑系, 而先后在此学习过的中国学生至少有 25 人。宾大建筑系最有名气 的教师是保尔 - 克瑞（Paul Cret， I876-I945）也是当时美国极有 影响的建筑师和教育家，原籍法国，早年受业于巴黎美院，1903 年被宾大建筑系聘为教授，1938 年获美国建筑师协会 (American Institute of Architects）金奖。他指导的宾大学生从 I9II 年至 I9I4 
年连续四次获得巴黎大奖 ; 到 1930 年，博扎建筑师学会在 20 年间 所颁发的各种奖牌有四分之一被宾大学生摘得。Cret 的巴黎美院 课程因此成为美国所有建筑院校参照的经典，宾大也成为中国建筑 留学生的不二之选。按照《美国建筑大百科全书》的说法, Cret 是“一 位极有才华的折衷主义建筑师”。值得一提的是，“Beaux Arts”在 中文里通常音译为 “博扎”, 而 “博扎” 与 “折衷主义” 又常常混 为一谈。无论教学还是创作, Cret 的方法都来自地道的巴黎美院 传统；尽管他的事业与欧洲现代主义运动有时间上的交集，他本人 却不是一位革新者，也没有进入现代建筑的历史叙事。

梁 1928 年回国创建东北大学建筑系，这个时间点非常关键，之 前的一年, 他刚在 Cret 的指导下获得美国宾夕法尼亚大学建筑系 硕士学位, 梁在宾大接受的是正统而严格的学院派古典主义训练, 可谓巴黎美院根正苗红的嫡传。这样，发端于塞纳河边的巴黎美 院传统由 Cret 带到美洲大陆, 又将衣钵传给他的中国学生梁思成, 绕了地球一整圈，经过两百多年，薪火才传到中国沈阳的东北大学。 而此时欧洲的现代主义运动经过 30 年的发展壮大，已是遍地开花。 Otto Wager, Antoni Gaudí, Victor Horta, Charles Macintosh 等 欧洲建筑师和艺术家的重要代表作都已问世，并形成了 “地方版” 的现代主义: 维也纳分离派, 加泰罗尼亚现代主义, 新艺术运动, 还有德国的包豪斯学校 (Bauhaus, I919-1933)。在这幅如火如茶的 建筑革命版图上，中国乃至大部分东亚地区几乎是完全缺席的。而 美国则是姗姗来迟 : 直到 1929 年，也就是梁回国一年之后，美国 的建筑教育才逐渐摆脱巴黎美院的影响。

I933 年纳粹政权上台, 迫使包豪斯学校关门，它的两位掌门人 Walter Gropius 和 Ludwig Mies van der Rohe 移居美国，分别执 教于伊利诺伊理工学院和哈佛大学, 把 “新包豪斯” 的种子播撒在 新大陆，这才奠定了现代主义建筑教育和实践在美国的主导地位。 但此时正是清华学校因留美费用骤增而停派留学生、改办大学之际。 中国最有系统、最有组织的留学就这样与现代主义失之交臂了。

（具体到梁思成本人，他与现代主义又是怎样一种关系呢?） 1927 年 6 月他从宾大建筑系毕业, 同年 7 月又开始在哈佛大学研究生院 学习城市设计。过了 Io 年, Gropius 才到哈佛大学设计学院执教。 梁没能等到现代主义在美国落地开花。他在哈佛只读了几个月就离 
开了, 这是因为他当时在准备完成一篇关于中国建筑的博士论文, 但哈佛图书馆提供的资料十分有限，他必须回国作实地考察、收集 第一手资料。1928 年 3 月至 9 月, 新婚燕尔的梁思成和林徽因夫妇 同赴欧洲考察建筑，游历英国、瑞典、挪威、德国、瑞士、意大利、 西班牙和法国，然后横穿西伯利亚回国。按说这是了解欧洲现代主 义的绝好机会，但他的关注点似乎不在现代建筑上。他对历史建筑 更感兴趣，这是在宾大读书时埋下的种子。他在选修二年级的建筑 史课之后立刻喜欢上了建筑史, 跟教授表示 “从来不知道世界上有 这么有意思的学问”。从梁留下的西方建筑史笔记和素描中可以感 受到，他是多么喜爱那些老房子。他的蜜月之旅实际上是与向往已 久的欧洲历史建筑的一次真正的亲密接触。当然，他不可能对现代 建筑视而不见。我们今天讨论大写的 “现代主义” (Modernism), 是在说一个历史化的现象, 但 1928 年梁思成游历欧洲的时候, 它 是方兴未艾的、正在流行的新事物，法籍瑞士建筑师 LeCorbusier、 德国建筑师 Walter Gropius 和 Mies van der Rohe 这三巨头也恰是 在 20 年代声名鹊起 ; 而这些新事物与梁钟爱的历史相比, 大概不 过是旅途中一掠而过的风景。Mies 为 1929 年巴塞罗那世界博览会 设计了德国馆 (Barcelona Pavilion), Le Corbusier 于 I928-I93I 年间设计建造了萨沃伊别墅 (Villa Savoye), 两者已成为现代建筑 史上的经典案例, 梁思成当年与它们都擦边而过了。

就这样，梁不但没遇上美国的 “新包豪斯”，还有意无意间绕过 了包豪斯与现代建筑的欧洲大本营。但是 1945 年梁给梅贻琦校长 写信, 提议创办清华大学建筑系的时候, 他的想法比 17 年前创办 东北大学建筑系时已有了很大变化, 信中关于课程设置有这样一段 话: “在课程方面, 生以为国内数大学现在所用教学方法（即英美 曾沿用数十年之法国 Ecole des Beaux-Arts 之教学法）颇嫌陈旧， 过于着重派别形式，不近实际。今后课程宜参照德国 Prof. Walter Gropius 所创之 Bauhaus 方法, 着重于实际方面, 以工程地为实习 场，设计与实施并重，以养成富有创造力之实用人才。德国自纳粹 专政以还, Gropius 教授即避居美国, 任教于哈佛, 哈佛建筑学院 课程，即按 G. 教授 Bauhaus 方法改编者，为现代美国建筑学教育 之最前进者，良足供我借鉴。”可见，梁虽身在华夏，对大洋彼岸 建筑教育生态的变化却十分了解。他一语道出了巴黎美院教学法与 
包豪斯体系的本质区别, 并且洞察到后者更适用于中国的战后复兴。 但他毕竟没能亲眼目睹、亲身经历美洲的 “新包豪斯”，所以他 要去补上这一课。1946 年 IO 月，梁赴美国考察战后现代建筑教育。 次年 2 月，他代表中华民国政府，担任联合国大厦设计顾问。这里 有一张珍贵的照片，是梁在纽约与顾问团的国际建筑师们一起讨论 联合国总部的设计，用今天的话来说，这场面是 “全明星阵容” 由左至右分别是:恩斯特·考米尔 (Ernest Cormier)、勒·柯布西耶 (Le Corbusier)、符拉迪莫·包迪安斯基 (Vla-dimir Bodiansky)、梁思成。 接下来在美国逗留的几个月里，他参观了近 20 年来的新建筑，这 次他不再是走马观花，而是认真求教。他访问建筑大师沙里宁父子 (Eliel Saarinen \& Eero Saarinen)，谈建筑教原则 ; 参观 Taliesin, 跟莱特（F.Ll. Wright）切硡建筑理论，还兴致勃勃地谈中国艺术 和老子 “无以为用” 的哲学对建筑空间的启示。但是梁此行只看到 了现代主义的半壁江山，他去芝加哥的时候，Mies 在纽约，两人 正好错过。

I947 年 7 月梁回国时从美国带回了大量珍贵资料，包括建筑及 城市规划的新书, 比如瑞士历史学家和建筑评论家吉迪翁（Sigfried Giedion）的 Space, Time and Architecture。他回到清华建筑系, 尝试将一系列现代主义思潮和理念引入教学体系。他在系里举办现 代主义建筑图片展，引起了极大反响。与此同时，西方整个现代主 义运动在经历了二战之后也到了盛极而衰的转折点。很快，50 年 代的西方建筑师们将带来另一场革命 (mid-century modernism)。 而 50 年代的中国也在酝酿自己的革命，被卷入这场革命洪流的中 国建筑师注定将与西方现代建筑再次失之交臂。

I947 年从西方 “取经” 回来之后不到三年，梁思成在 1950 年 I 月的营建学研究会上发表演讲，谈 “建筑的民族形式”，他说：“在 十九世纪中，考古学的智识引诱着建筑师自觉地去仿古或集古 ; 第 一次世纪大战以后许多极端主义的建筑师却否定了一切传统。每一 个建筑师在设计的时候，都在自觉地创造他自己的形式，这是以往 所没有现象。个人自由主义使近代的建筑成为无纪律的表现。每一 座建筑物本身可能是一件很好的创作，但是事实上建筑物是不能脱 离了环境而独善其身的。结果，使得每一个城市成为一个千奇百怪 的假古董摊，成了一个建筑奇装跳舞会。请看近来英美杂志中多少 
优秀的作品，在它单独本身上的优秀作品，都是在高高的山崖上， 葱幽的密林中，或是无人的沙漠上。这充分表明了个人自由主义的 建筑之失败, 它经不起城市环境的考验，只好逃避现实，脱离群众， 单独地去寻找自己的世外桃源。” 这段话可谓意味深长，从中不难 看出，梁对一战以来西方现代建筑的态度正在发生微妙而复杂的变 化。他并没有完全否定现代建筑, 也没有提及“现代主义”, 但却以“极 端主义” 和 “个人自由主义” 这两个关键词来为现代建筑作了脚注。 “否定一切传统” 的 “极端主义建筑师” 具体指谁，我们不得而知， 但从他列举的 “优秀作品” 的具体场所来看，其评判范围有明显的 选择性，只道出了事实的一面；因为那时期的建筑师不只钟爱 “高 高的山崖”、“忽幽的密林” 或无人的沙漠”, 他们也把很多精力投 入在战后城市复兴和居住问题上，比如柯布西耶于 1947 年至 1952 年在法国马赛设计建造的“光明城” 公寓 (Radiant City)。

而梁在审视西方现代建筑时聚焦于 “极端主义” 和“个人自由 主义”，其实是为批评近代中国本土的建筑实践埋下伏笔，因为紧 接着他就说: “十九世纪以来日益发达的交通，把欧美的建筑病传 染到中国来了。在一个多世纪的长时期里，中国人完全失掉了自信 心，一切都是外国的好，养成了十足的殖民地心理。在艺术方面丧 失了鉴别的能力，一切的标准都乱了……建筑师们对于本国的建筑 毫无认识，把在外国学会的一套罗马式、文艺复兴式硬生生的搬到 中国来。这换算好的。至于无数的店铺，将原有壮丽的铺面拆掉， 改做 “洋式”门面，不能取得 “洋式”的精华，只抓了一把渣㳯， 不是在旧基础再取得营养，而是把自己的砄了又拿不到人家的好东 西。彻底地表现了殖民地的性格。这一百零九年可耻的时代，赤裸 裸地在建筑上表现了出来。” 如果把 “殖民地” 三字暂时拿掉，这 段话听着真是耳熟，像是在说今天。回过头去看，梁心里显然有一 面镜子，照得出精华与糟粕 ; 在他眼里 “洋式” 建筑不是没有好东 西, 只是我们没有把好东西学来。梁于 20 年代和 40 年代两度西游, 既受过巴黎美院传统的洗礼, 又经历了新包豪斯的现代启蒙, 见识 了西方建筑的古往今来，所以懂得 “洋式” 的好与不好，才有眼力 和底气作出以上评判。

如果说在建国伊始相对祥和的社会大环境里, 梁尚能保持对西 方建筑文化的客观评判，那么在接下来的几年中，随着二战后资本 
主义阵营与社会主义阵营之间对峙局面的形成，随着抗美援朝、土 地改革、“三反、五反”、知识分子思想改造、整风反右、“大跃进” 等一系列运动和斗争在全中国范围内展开，梁身为一名中国知识分 子，已经无法规避风云变幻的国际形势和动荡起伏的中国社会 ; 如 果梁只做个 “躲进小楼成一统” 的书生，或可排除万难，坚守 “独 立之人格，自由之思想”，可他偏偏选择了建筑这个与社会有着千 丝万缕联系的职业，他没法躲进小楼，他要关心千千万万的楼，从 理论到实践，从教育到生产，从美学到技术，无不涉及。所以与其 它领域的知识分子相比，他的言说不可避免地会打上更敏感、微妙 而复杂的时代烙印。

于是梁 50 年代对西方现代建筑的解读, 也不可避免地带上了 “中 国特色”。比如他在 $195 \mathrm{I}$ 年 8 月写给周恩来的信中说 : “最严重的是 近十余年来世界主义的反传统建筑理论十分普遍，倡所谓 '功用主 义' “忠实于材料” “唯物” 的论说（机械唯物的论说）, 其实是追 求个人自由主义的，唯心的“创造”、“现代式杰作”的思想。”进 而又检讨自己也 “受了世界主义影响，曾做过不顾环境，违反传统 的 “现代式” 建筑”。在这里，梁除了更明确地指出现代建筑反传 统的倾向，还为其增加了一个 “唯心” 的定语。再比如梁 1953 年 随中国科学院访苏代表团赴苏联考察归来后，在《新观察》杂志上 发表了一篇文章，题为 “民族的形式、社会主义的内容”，里面讲到 “在一九二五到一九三五的十年间，苏联的建筑曾一度遭受欧美资 产阶级建筑思想潮流的侵袭，在各城市造成了很大的损害”。这损 害有多严重呢? 他举了一个很形象的例子 : 访苏团来到乌兹别克首 都塔什干（Tashkent），总建筑师带大家参观部长会议大楼，梁把 这座建筑形容为 “光秃秃的结构主义方匣子”, 然后讲这位总建筑师 “以愤恨的心情指出那丑恶枯燥的形态，痛心地说，他自己的城市 遭受了这种损害的不幸。”

梁还特别提到柯布西耶在莫斯科设计的轻工业部大楼 (Tsentrosoyuz Building)，说 “那座法国 ‘现代”建筑师柯布西 耶的 “杰作” 是世界主义建筑的典型例子。它一直是莫斯科的一个 疮疤。”注意，在这里梁把 “现代” 和 “杰作” 都打上了引号，由 此可窥见他不愿、或难以正面提及现代主义的复杂心态。但他又 得给个说法，所以就用了 “世界主义建筑”，权当指鹿为马；既然 
是 “世界主义建筑的典型例子”，打上引号的 “现代” 建筑也跟着 这典型一起背黑锅了。如果它真的是莫斯科的 “疮疤”，合该是千 夫所指，但事实似乎并非如此，在构成主义（Constructivism）建 筑师 AlexanderVesnin 眼中，它乃是 “一个世纪以来笪立在莫斯科 的最棒的大楼” (“the best building to arise in Moscow for over a century”)。但戏剧性的是, 柯布西耶的瑞士同乡汉斯·迈耶 (Hannes Meyer）却毫不留情地讽刺它是 “玻璃与混凝土的放纵狂欢” (“an orgy of glass and concrete”)。迈耶是包豪斯第二位掌门人，也是 梁所谓 “功用主义” 的激进倡导者, 如此一来, 在对莫斯科 “疮 疤” 的认识上，梁与迈耶倒不谋而合。这只能说明，现代建筑有与 生具来的 “复杂性和矛盾性”。至于柯布西耶本人，他在莫斯科轻 工业部大楼设计竞赛中胜出时，是这么说的：“I shall bring to this task all that I have learned in architecture. It is with great joy that I shall contribute what knowledge I possess to a nation that is being organized in a ccordance with its new spirit.” 关于这个民族的 “新 精神” 柯布西耶的理解可能没抓住要害，但至少，他是非常真诚地 想为苏联建筑做一点贡献。大楼建成于 1933 年，梁 1947 年赴纽约 与柯布西耶共谋联合国总部方案大计的时候, 不知道两人私下里有 没有促膝谈心，敞开心扉交流过。不管怎样，1953 年访苏归国之后， 在运动和斗争的浪潮里苦苦求索中国 “新精神” 的梁，已经与西方 现代主义渐行渐远。

这一时期, 由于新的意识形态需要新的建筑, 中国古代建筑一 度被苏联风格的公寓楼和庄严礼堂所取代。中国紧随苏联 “老大 哥” 坚守在社会主义阵营里, 欧美资本主义自然是敌人，中国的建 筑艺术要走 “社会主义现实主义” 的方向，与之相反的必然是一切 “资产阶级反现实主义” 的方向 ; 批判欧美现代主义，乃是形势所 迫。梁也得跟着形势走，他写道：“以 ‘革命”姿态出现于欧洲的 这个反动的艺术理论猖狂地攻击欧洲古典建筑传统, 在美国繁殖起 来，迷惑了许许多多欧美建筑师，以 “符合现代要求” 为名，到处 建造光秃秃的玻璃方盒子式建筑。” 在这一时期发表的文章和演讲 中，梁开始运用 “阶级” 的概念和方法，他多次引用苏联建筑专家 的话 “建筑形式的斗争是激烈的阶级斗争”, 指出中国建筑领域里的 “阶级斗争” 就是 “苏联社会主义的建筑思想和欧美资产阶级的建 
筑思想” 之间的斗争，将矛头指向 “充满了资产阶级意识的，宣传 世界主义的,丝毫没有民族性的美国式玻璃方匣子的建筑”。说到“美 国式玻璃方匣子”，很容易让人联想到 Mies 的作品。而 50 年代初 期恰是 Mies 在美国一统江湖的年代。几年前梁访美时途径芝加哥, 与 Mies 缘悭一面，也没能看到 Mies 后来盖的 “玻璃方匣子”，谁 能想到这次失之交臂竟使 Mies 成为阶级斗争的靶心。1947 年之后, 梁再没有踏上美国的土地，他留下的文字里关于现代主义的最后印 象，是用 “阶级斗争” 这只照妖镜照出来的 “恶之花”。

我们知道, “阶级斗争” 是马克思在《共产党宣言》中提出 的一个重要概念 (“The history of all hitherto existing society is the history of class struggles.” -Karl Marx, The Communist Manifesto）。无独有偶，意大利著名马克思主义建筑历史学家塔夫 里（Manfredo Tafuri）也曾运用马克思的 “阶级斗争” 观点分析 现代建筑与资本主义的关系，并预言了现代主义的失败。所不同的 是，梁用的是嫁接到中国的马克思主义，而塔夫里则取自马克思主 义的本源，前者是 “外攻”，后者是 “内攻”，殊途同归。但是，身 处动荡年代的梁没来得及充分发挥他作为建筑历史学家的智慧，对 现代主义作出更为客观的评判；60 年代初期，西方正在以积极乐 观的态度面对现代建筑的创作、批评和接受，但梁专注于中国古代 建筑史的考察与研究，无睱他顾。1966 年，“文化大革命”爆发， 国门关闭，彻底阻断了中国与西方交流的渠道。与此同时，“世界 主义”风格（International Style）的建筑逐渐式微，摩天大楼间回 荡着 “现代建筑已死” (“modern architecture is dead”) 的口号; 1970 年左右，西方建筑思想正在经历微妙的变化，一个多元的新 时代即将到来。梁于 1972 年 I 月病逝。就这样，近代中国最有影 响力的建筑教育家因为种种错综复杂的历史、社会和个人原因，最 终没能将现代主义带到中国。他是一个极有远见的人，但不管是巴 黎美院传统，还是新包豪斯体系，他当年提出的建筑教育理想都未 能完全付诸实践。隔着半个多世纪看去，好比镜花水月。今日之建 筑学院，徒有巴黎美院之名，而无包豪斯之实。

但故事到这里还没有结束。中国建筑领域更富戏剧性的变革发 生在梁去世之后。“文革”结束，中国迎来改革开放，压抑良久的 建筑师们带着强烈的好奇心和求知欲，打开窗户向西方看去，沧海 
已变桑田，现代主义已是昨日黄花，取而代之的是混杂着内省、颠 覆和危机的后现代思潮, 可以说奇菂遍地。我们一方面要把落下 的 “现代主义” 功课好好补回来，一方面又要紧跟 “后现代” 的潮 流, 曕前顾后, 应接不暇。改革开放前, 中国建筑类的专业刊物极少, “文革” 后，借拨乱反正的东风办起一些建筑杂志，这时候思想已 经放开, 不用再受过去条条框框的约束, 像《建筑师》和《世界建 筑》这类专业杂志上开始涌现大量长篇介绍现代主义和后现代思潮 的文章，详细分析柯布西耶、密斯等建筑师的作品和思想，等于是 对现代主义来了一次形式上的拨乱反正。但只在理论上补课还不过 瘾。90 年代以来, 随着中国跻身世界舞台, 经济发展带来建设大潮, 中国逐渐成为 “奇怪” 建筑的新大陆。本土建筑师还没把现代主义 消化好，就打着现代主义的旗号自行其是; 外国建筑师也放开胆子， 把中国的大城市当作怪想法的实验工地。于是我们看到，半个世纪 以前梁描述的场景再次上演: 建筑师们把在外国学会的一套硬生生 地搬到中国，但是只抓了一把渣㳯，不是在旧基础再取得营养，而 是把自己的砸了又拿不到人家的好东西。

直到今日，中国的建筑师和评论家仍未逃出 “现代主义” 的如 来掌心。我们与现代主义的 “不了情”, 因理论的滞后与实践的超 速而显得格外纠结。梁在 50 年代批判现代主义，固有迫于形势而 导致的片面性，但他最关心的，乃是如何发展中国的新建筑。他认 为 “建筑是一个社会生活中最高度综合性的艺术”, 也正是站在这 个角度上，他才指出那些 “硬搬、嫁接、模仿” 而来的建筑形式没 有艺术上的价值, “对于祖国建筑是摧残而不是发展”。置文化、传统、 历史于不顾，不加判断地抄袭，这才是问题的要害。50 年代在 “社 会主义现实主义” 的语境下，抵制的对象是千篇一律的 “玻璃方匣 子”, 今天的全球化背景下, “奇奇怪怪” 的建筑是我们反对的对象一 近来政府已下达文件，禁止建造 “贪大、㜏洋、求怪，缺失特色和 文化传承” 的建筑。不管是千篇一律，还是奇奇怪怪，梁提出的问 题实质并没有解决。这里面固然有历史的、社会的和意识形态的原 因，但是否也有人文教化的原因?中国要想形成自己的现代建筑史， 就一定要追赶那个大写的 “现代主义” 乌托邦吗?这是我想借梁思 成的故事提出的两点疑问，供大家讨论。 


\section{After the École des Beaux-Arts and Bauhaus: Liang Sicheng and the Utopia of Modernism in Chinese Architecture of the Twentieth Century}

Liu Chen

In 1945, on the eve of the China's victory in the Anti-Japanese War (World War II), Liang Sicheng wrote a letter to Mei Yiqi, the president of Tsinghua University. With an eye towards the future development of architectural education in China, he proposed to establish a Department of Architecture at Tsinghua University. Liang's rationale was clear: he anticipated that after the war there would be large-scale reconstruction, and the country urgently needed talented builders (jianshe rencai). Establishing a department of architecture was first and foremost in service of this need to solve a practical problem. Therefore, the Department of Architecture initially relied on the College of Engineering to teach its architects. This rather improvisational policy from the initial period has continued to the present day. Although the original Department of Architecture has grown into the School of Architecture, it has not yet emerged from the category of "Science, Engineering, Agriculture and Medicine" within China's unique taxonomy of academic disciplines.

On the other hand, Liang's proposal also raised a historical problem: systematic architectural training as an academic discipline had no precedent in Chinese history. Although China had unique construction techniques and a rich architectural heritage - in Liang's words it is, "The world's oldest, most enduring, and most promising building system" - yet it had no tradition of academic architectural training and education. Before modern times, China's architectural history was basically a "history of architecture without architects." This is its greatest difference from the Western architectural tradition.

Liang Sicheng (190I-1972) was a pioneer in the study of ancient Chinese architecture. His academic accomplishments have attracted attention from the international academic community. In 1947, Princeton University awarded him an honorary doctorate in literature. In his early years, he studied at the University of Pennsylvania's Department of Architecture, which used the same training methods as the École des Beaux-Arts and was known as the "American École des Beaux-Arts." The history of the École des Beaux-Arts dates back to the seventeenth century. At that time Jean-Baptiste Colbert, the French Finance Minister, was not only very successful in politics, but also very passionate about art and culture. At his suggestion, King Louis XIV created a series of royal academies, including the Academy of Sciences, the Academy of Painting and Sculpture, and the Academy of Architecture. The French Royal Academy of Architecture was established in 1671, while it was not until 1927, when the architectural portion of the Suzhou Specialized Industrial College became part of the National Central University, Nanjing, that China had its first department of architecture. Before that, the transmission of architectural knowledge and techniques depended upon 
Fig. I. Monument to the People's Heroes, Beijing, designed by Liang Sicheng in 1952, and built from 1952 to 1958.

skilled masters teaching their apprentices, similar to the traditional workshops of medieval Europe. In the fifteenth century, the Italian humanist Leon Battista Alberti wrote On the Art of Building (I443-I452), and architects joined the elite ranks of scholars, painters, and sculptors. This was the beginning of a cultural and artistic renaissance, a period of parallel achievements in art and architecture. At the same time, in Ming Dynasty China architects were still seen

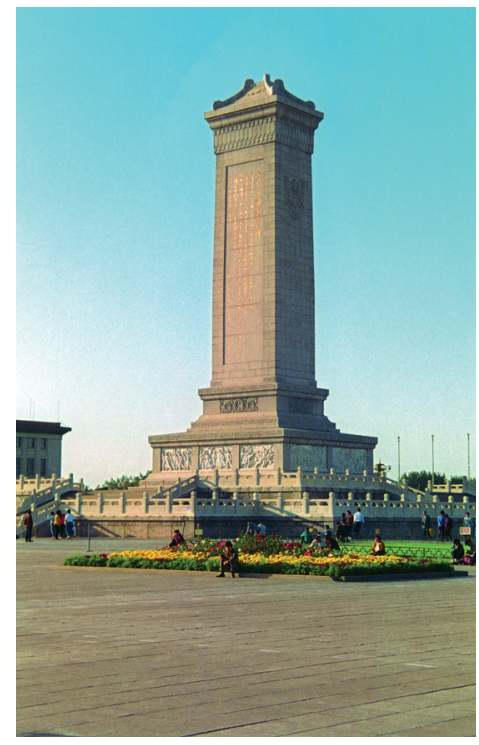
as merely craftsmen, so while there was a tradition of "literati painting," there was no such thing as "literati architecture."

The impact of Alberti's writings on Western architecture should not be underestimated. He played a pivotal role in the elevation of architecture from a form of manual labor into an intellectual domain, which gave architecture autonomy as an academic discipline and architects a newfound sense of identity. This set a solid foundation of 400-plus years of architectural history for the grand debut of Western modernist architecture. The emergence of modernism in the West was by no means an accident. Rather, it was the product of a long and winding history, in which political, economic, cultural, and technological factors all played a role in laying the groundwork. But when Chinese architecture entered modernity, there is no such process to lay the groundwork. Before the late Qing Dynasty, there was very little architectural exchange between China and the West. The architecture of overseas architects in Guangdong and Fujian was small-scale and local, while the case of the Italian architects designing the Qianlong Emperor's Summer Palace was a singular occurrence for the imperial family. On the whole, architecture was unlike painting, sculpture, and decorative arts and crafts, which had a long history of cross-cultural exchange.

Liang was an important pioneer of modern Chinese architectural professional education. In 1928 and 1945 respectively, he founded the Department of Architecture at Northeastern University in Shenyang and the Department of Architecture at Tsinghua University in Beijing. During this same period, China was beginning to understand Western architecture and architecture education. However, this understanding lacked context and lagged behind what was actually happening in the West. Although this lag was partly caused by China's own historical reasons, with respect to the transmission of modern architecture, the most immediate cause of this lag was the beaux-arts education received by the first batch of Chinese architects who studied in the United States. Beginning in I894, the Society of Beaux-Arts Architects and the American Academy, two organizations of academic architects in the United States, began to standardize 


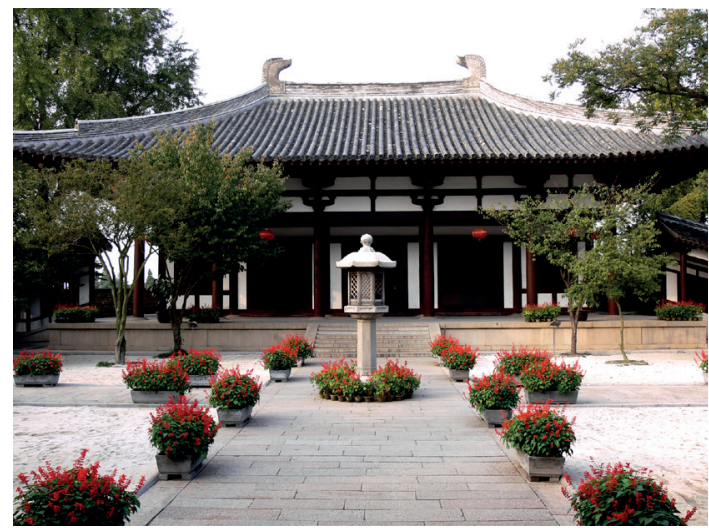

Fig. 2. Jianzhen Monk Memorial Hall in Yangzhou, designed by Liang Sicheng in 1963 , and built in 1973 .

curriculums in every school of architecture across the United States, with the École des Beaux-Arts as the standard bearer.

At the beginning of the twentieth century, a large number of Chinese students studied abroad in the United States (Tsinghua University was originally established by the Qing government as a preparatory school for students who would study in the United States, using remissions from the "Boxer Indemnity").

Of the 82 members accepted into the Architectural Society of China from when it was founded in 1927 to 1940, more than half had studied abroad in the United States. Of those, graduates of the University of Pennsylvania's Department of Architecture had the most representation, with I4 members. From I9I8 to 1927, just among graduates of Tsinghua College, I2 entered the University of Pennsylvania's Department of Architecture, and in total at least 25 Chinese students studied here. The most famous teacher in the Department of Architecture was Paul Cret (1876-1945), who was an influential architect and educator in the United States at the time. Originally from France, Cret was a graduate of the École des Beaux-Arts. In 1903 he joined the University of Pennsylvania (UPenn) Department of Architecture as a professor, and in 1938 he was awarded the Gold Medal of the American Institute of Architects. From I9II to I9I4, the Penn students that he directed won the Paris Grand Prix four times in a row, and by 1930 , a quarter of the prizes awarded by the Society of Beaux-Art Architects within a 20 year span were given to UPenn students. As a result, Cret's École des BeauxArts course became a model referenced by schools of architecture across the United States, and UPenn has become the first choice for Chinese international architecture students. According to the Encyclopedia of American Architecture, Cret was "a very talented and eclectic architect." 2 It is worth mentioning that "Beaux-Arts" is usually transliterated into boza in Chinese, and boza and "eclecticism” are often confused. In both his teaching and his works, Cret's approach (fangfa) came from the authentic (didao) tradition of the École des Beaux-Arts. Although the timespan of his career overlapped with the European modernist movement, Cret himself was not a reformist, nor has he entered the historical narrative of modern architecture.

I See Richard H. Werking, "The Boxer Indemnity Remission and Haunt Thesis," Diplomatic History 2, no. I (1978): 103-6.

2 William Dudley Hunt, Jr., Encyclopedia of American Architecture (New York: McGraw-Hill, 1980), I29. 
Liang returned to China in 1928 to establish the Department of Architecture of Northeastern University, Shenyang. This was a crucial point in time. A year earlier, he had earned a Master's degree from the University of Pennsylvania's Department of Architecture under the supervision of Cret. At UPenn, Liang was trained in strict and orthodox academic classicism, with a direct lineage to the École des Beaux-Arts. In this way, the traditions of the École des Beaux-Arts, which started on the banks of the Seine, were brought by Cret to the American continent, who then passed the mantle to his Chinese student Liang Sicheng. After a full trip around the world and more than two hundred years, this torch was finally passed to China in Northeastern University, Shenyang. By that time, the modernist movement in Europe had already developed and grown for 30 years, taking root in a number of places. The important iconic works of European architects and artists like Otto Wager, Antoni Gaudí, Victor Horta, and Charles Macintosh had all already come out and formed "local editions" of modernism: Vienna Secession, Modernisme (Catalan Modernism), Art Nouveau, and German Bauhaus (I919-1933). On the map of this rapidly spreading architectural revolution, China and most of East Asia were almost completely absent, and the United States was a late arrival—only in 1929, one year after Liang returned to China, did American architectural education begin to gradually shed the influence of the École des Beaux-Arts.

In 1933 the Nazi regime rose to power, forcing the Bauhaus school to close. Its founders, Walter Gropius and Ludwig Mies van der Rohe, moved to the United States, where they began to teach at the Illinois Institute of Technology and Harvard University respectively and to plant the seeds of "new Bauhaus" in the New World, which would finally establish modernist architectural education and practice in a position of prominence in the United States. However, at the same time, a sudden increase in the cost of sending students to the United States caused Tsinghua College to stop sending students abroad and became a university. Thus the most systematic and organized study abroad program in Chinese history missed modernism by a hair.

Concretely, what kind of relationship did Liang Sicheng himself have with modernism? In June 1927, he graduated from the UPenn Department of Architecture, and in July of that same year he began to study urban design at Harvard University's Graduate School of Arts and Sciences. It was still ten years before Gropius would arrive to teach at Harvard University's Graduate School of Design. Liang could not wait until modernism landed in the United States. He left Harvard after studying for only a few months. This is because at the time he was preparing to complete a doctoral thesis on Chinese architecture, but the materials provided by the Harvard Library were extremely limited, so he had to return to China to conduct field visits and collect primary materials.

From March to September 1928, the newlyweds Liang Sicheng and Lin Huiyin went to Europe as a couple on an architectural tour. They visited Britain, Sweden, Norway, Germany, Switzerland, Italy, Spain, and France before crossing Siberia to return home. Liang used the excuse that this was a great opportunity to understand European modernism, but his focus was not on modern architec232 ture-historical architecture interested him more. This seed was planted while 


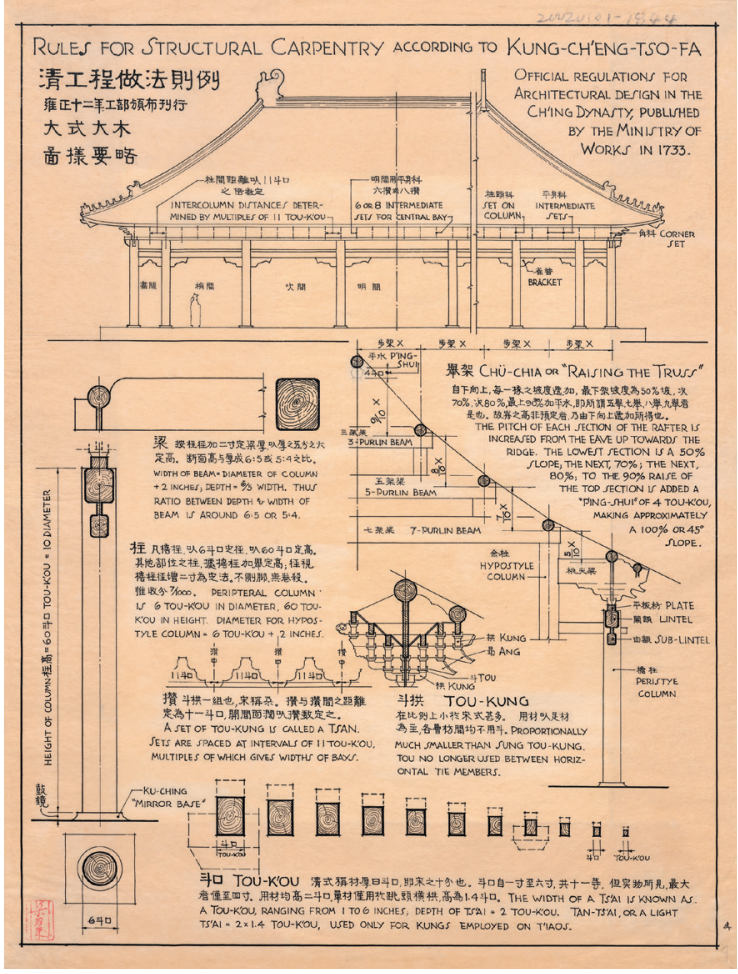

Fig. 3. "Rules for Structural Carpentry According to Kung-Ch'eng-Tso-Fa (from Qing Structural Regulations), drawn by Liang Sicheng, 1934.

he was studying at UPenn. After choosing a second-year course on architectural history, he immediately fell in love with architectural history. He told his professor: "I never knew that such an interesting academic subject existed." From the notes and sketches on Western architectural history that Liang left behind, one can feel how much he loved those old buildings. But his honeymoon trip was the first time that Liang actually came into contact with these long-awaited historic European buildings.

Of course, he could not turn a blind eye to modern architecture. Today, when we discuss "Modernism" with a capital M, we are talking about a historical phenomenon. But in 1928, when Liang Sicheng traveled to Europe, it was something new, fashionable, and in the process of unfolding. The SwissFrench architect Le Corbusier and the German architects Walter Gropius and Mies van der Rohe, three giants of modernist architecture, were building their reputations in the I920s. Compared to Liang's beloved historical architecture, these new buildings were probably just the background for his travels. In 1929 Mies designed the Barcelona Pavilion for the Barcelona World Expo. Between I928-3I, Le Corbusier designed and built the Villa Savoye. Both have become classic examples in the history of modern architecture; Liang Sicheng simply passed them by.

In this way, Liang not only missed "New Bauhaus" in the United States, but also, intentionally or unintentionally, bypassed the European headquarters of Bauhaus and modern architecture. However by 1945, when Liang wrote a letter to Tsinghua University President Mei Yiqi and proposed to establish Tsinghua University's Department of Architecture, his thinking had changed significantly from when he established Northeastern University's Department of Architecture I7 years prior. The letter contains the following passage regarding the curriculum:

With respect to the curriculum, I believe that the teaching methods currently used by a number of domestic universities (that is, the French Ecole des Beaux-Arts teaching methods that were used for decades in Britain and 
the United States) are outdated, overly concerned with stylistic schools, and not very practical. In the future, the curriculum should draw on the Bauhaus method created in Germany by Prof. Walter Gropius, which focuses on practical matters, takes the engineering site as the classroom, and equally values design and implementation, to develop creative and practical talents. Since the Nazi dictatorship in Germany, Professor Gropius has escaped to the United States and taught at Harvard. The Harvard School of Architecture's curriculum, which adapted Groupius's Bauhaus method, and is the most advanced in modern American architectural education and deserves to be studied. ${ }^{3}$

Clearly, although Liang was in China, he had an excellent grasp on changes in architectural educational of the other side of the ocean. In just one line he articulated the essential difference between the École des Beaux-Arts pedagogy and the Bauhaus system, and found that the latter was more suitable for China's post-war revival.

But since he hadn't personally seen America’s "new Bauhaus," he had to make up the curriculum. In October 1946, Liang went to the United States to observe its post-war modern architectural education. In February of the following year, he served as a representative Government of the Republic of China to consult on the design for the United Nations building. A precious photograph from this time shows Liang in New York with an international group of consulting architects, together discussing the design of the United Nations headquarters. In today's words, this was an "all-star lineup" - from left to right: Ernest Cormier, Le Corbusier, Vladimir Bodiansky, and Liang Sicheng. In his following months Liang visited new buildings in the United States from the past 20 years. This time he wasn't simply taking a cursory glance but earnestly seeking advice. He met with the father-son architects Eliel and Eero Saarinen to discuss architectural principles. He visited Taliesin, the Wisconsin estate of Frank Lloyd Wright, to exchange architectural theories and had a lively discussion on how Chinese art and the concept of the "usefulness of emptiness" from Laozi's Daoist philosophy influenced architectural space. However, on this visit Liang only saw one half of the progenitors of Bauhaus modernism in the United States-when he went to Chicago, Mies was in New York, and the two just missed each other.

In July 1947 Liang returned to China and brought back a wealth of materials from the United States, including new books on architecture and urban planning, such as Swiss historian and architectural critic Sigfried Giedion's Space, Time and Architecture. He returned to the Tsinghua Department of Architecture and tried to introduce a series of modernist concepts and ideas into the educational system. He organized a photography exhibition on modernist architecture within the department, which was met with a resounding response. Meanwhile, in the wake of World War II, the Western modernist movement had passed its Architecture and Building Press, 200I-7), 5:I-2. 
prime, with Western architects ushering in mid-century modernism. Meanwhile I950s China was fomenting its own revolution, and the Chinese architects who were caught up in this revolutionary fervor were destined to once again miss Western modernist architecture.

In January 1950, less than three years after he returned in 1947 from "studying" the West, Liang Sicheng gave a speech at the Institute of Construction Studies on the topic: "Nationalist Forms in Architecture." He said:

In the mid-I9th century, knowledge of archaeology seduced architects to self-consciously imitate the past or collect antiquities; after World War I many extremist architects rejected all of tradition. Each architect self-consciously created his own forms as he was making his designs. This had never happened before. Individualism has turned modern architecture into a form without rules. Each building may on its own be an excellent work of architecture, but buildings cannot be separated from their environments and stand on their own. As a result, cities have become like a market for fake antiques filled with every kind of curiosity, like an architectural costume ball. Look at the many outstanding works in recent English and American publications. Each of these works excels on its own, but they are all either on top of high cliffs, or in the middle of thick forests, or in unpopulated deserts. This reveals the failure of individualist architecture: it cannot stand up to the urban environment. It can only provide an escape from reality, an escape from the crowds, where one can look for a private paradise alone. ${ }^{4}$

This passage is quite profound. From its contents it is easy to see that Liang's attitude towards Western modern architecture underwent subtle and complex changes since the First World War. He did not completely reject modern architecture, nor did he explicitly mention "modernism," but rather used two key words - "extremism" and "individualism" — to comment on modernist architecture. We cannot say for certain to whom Liang was referring when he described the "extremist architect" who "rejects all of tradition," but from the specific sites that he offered as examples of "excellent buildings" he was clearly selective in the scope of his criticism. After all, architects of that time did not only love "high cliffs," "dense forests," or "unpopulated deserts," they also put a lot of energy into post-war urban renewal and housing issues. Le Corbusier's "Radiant City" apartments, which were designed to be built in Marseille, France between 1947-52, was one such example.

The reason that Liang focused on "extremism" and "individualism" in his discussion of Western modernist architecture was that he was actually foreshadowing and laying the groundwork for his criticism of practices in modern China architecture. In his next statement he said:

Since the 19th century, with the on-going developments in transportation 
and communication, the architectural diseases of Europe and the United States have infected China. In the timespan of just over a century, the Chinese have completely lost their self-confidence, believing that everything foreign is good, and developing a full-fledged colonial mindset. When it comes to art, they have lost their capacity for discernment, and all previous standards are in chaos [...]. Architects seem to have no familiarity with their own country's architecture, and have rigidly imported what they learned from abroad-Romanesque and Renaissance styles — into China. This conversation was considered good. Countless numbers of small shops demolished their magnificent original storefronts and replaced them with 'Western-style' facades. But they could not capture what was good in the 'Western style' and only grasped the dregs. Instead of getting strength from the old foundation, they destroyed what they had and could not get what the nourishing parts from others. It was a thoroughly colonial disposition. This shameful period of Io9 years was nakedly exposed in architecture. ${ }^{5}$ 


\section{决澜社艺术研究}

\section{一一作为国际艺术资源的中国现代美术}

李超

在 20 世纪 30 年代之前, 中国油画界中的现代主义风格的绘画倾向, 主要是以林风眠为代表的杭州国立艺术院和艺术运动社为标志的。 而在上海画坛仅仅属于一股支流，尽管如此，已经引起美术圈内人 士的注意。陈抱一曾撰文回忆,认为后期印象派那种发挥“表现精神” 的精神，早已在 1918 年或 I92I 年前后，为我们这些研究者所认识， 也许有过这种影响，而促进了 1920 年以后的一个发展阶段。30 年 代伊始，上海画坛形成了现代主义思潮的集中兴起。这样，在欧洲 后印象主义、野兽派、立体派等现代绘画潮流的兴起之后，时隔十 余年在中国本土已发生其效应的东方展示。

随着 20 世纪 30 年代的临近，上海的油画倾向于西方现代艺术 的画风较为明显。为此, 抗战时期曾有署名张洁的作者写了一篇《检 讨上海画坛》的文章，记述道 :

北伐以后，上海画坛上的风格，似乎又转入到后期印象主义的 一条路上去了。这虽然在前一时期刘海粟的代表作《北平前门》 上依稀可以辨别出来，然而在这时刻，陈抱一、丁衍庸、关良 等作品，会得变为多量的主观表现化，这未始不是受着这些影 响的缘故。……这一时期的上海画坛，又表现了显著的改进。 就是野兽群的叫喊，立体派的变形，达达者的神秘，超现实的 憧憬，……这一些 20 世纪巴黎画坛的热闹情况，在这号称东方 巴黎的上海再次出现，我们可以举出的代表作家，是决澜社的 庞薰琹、倪贻德与已故的张弦诸人，在这一运动中间，是有着 相当功绩的。 ${ }^{1}$

1 转引自李超 : 《上海油画史》，上海人民美术出版社，1995，第 69 页。 
自 “一二八事变” 以后，上海画坛一度出现了一段沉寂的时候，直 到 1932 年 10 月决澜社第一届画展出现，这种沉寂才被打破。决澜 社的主要成员庞薰琹、倪贻德、张弦、丘堤、阳太阳、杨秋人、周多、 段平右、刘狮、周真太等人，成为画坛现代主义画风积极参与、倡 导和实践者的代表，面对风云极盛的巴黎画坛，他们呼喊 “20世 纪的中国艺坛，也应当现出一种新兴的气象”。

在 20 世纪 20 至 30 年代的中国美术界出现一股日渐强大的现代 艺术潮流，其以上海策源地，进而全面冲击着中国的画坛。而这种 现代艺术的画风倾向，是以决澜社和中华独立美术协会为明显代表 的。在一度 “沉寂的时期”，它的出现 “犹如新花怒放似地微微显 露了一点艳色来”，“显示了较清新现代绘画的气息”2。

决澜社成立画会的设想，最初是庞薰琹和傅雷、张弦商议的。 而决澜社的成员，多来自另外两个画会：“苔蒙画会”和“摩社”。 I930 年 IO 月, 庞薰琹接受汪日章 (汪荻浪) 的邀请, 在上海成立 “苔 蒙画会”, 这个画会的中心人物是周汰 (周真太), 前后加入该画会 的还有屠乙、胡佐卿、周多、段平右、梁白波等二十余人。由于他 们在画展的前言中表现出了激进的左翼思想，为当局所不容，于 I93I 年 I 月被查封。该画会的成员后来多半加入了决澜社。I 1932 年 倪贻德任上海美专西画教授的同时，主编一份以 “摩社” 名义出版 的《艺术旬刊》。摩社是由于编辑刊物的动机而组织起来的，他们 的事业发展计划除了编辑《艺术旬刊》之外，还包括美术展览会、 公开演讲、建立研究所等。摩社成员包括: 刘海粟、王济远、张弦、 王远勃、关良、刘狮、傅雷、李宝泉、黄莹、倪贻德、吴茀之、张 辰伯、周多、段平右、张若谷、潘玉良、周瘦鹃、庞薰琹等，他们 中的一部分人也成为决澜社的成员。3

2 陈抱一 : 《洋画运动过程记略》( 续 ), 《上海艺术月刊》 1942 年第 6 期。

3 “摩社” 是以上海美专为中心的一个艺术团体，也是产生《艺术旬刊》 的编辑出版机构。“摩社” 是法文 Muse 的音译，通常译为 “缪斯”，是 希腊神话中文艺之神。“摩社” 的原本辞源，含有 “幽思”之意。该社 名除了取西文意义之外，还按中文解释。寓有 “观摩” 的意思。摩社确 立的宗旨是 “发扬固有文化, 表现时代精神”。参见张若谷: 《摩社考》, 《艺 术旬刊》第一卷第一期, 上海摩社 1932 年 9 月 $\mathrm{I}$ 日出版。 
决澜社酝酿和创办的过程，基本上是以位于当时上海法租界的 麦赛尔蒂罗路 90 号二楼的 “薰琴画室” 展开的。在上海摩社于 I932 年 IO 月出版的《艺术旬刊》第一卷第五期内, 庞薰琹发表的《决 澜社小史》中, 提到了 1932 年 4 月举行的决澜社的第三次筹备会议, 在 “麦赛尔蒂罗路 90 号” 举行; 而在本年 $\mathrm{I} 2$ 月出版的《艺术旬刊》 第一卷第十二期内，曾经刊登了关于 “薰琴画室附设绘画研究所广 告”, 在这则 “征求研究员” 的广告中, 清楚地标明了 “薰琴画室” 的地址一“麦赛尔蒂罗路 90 号二楼”。

麦赛尔蒂罗路 90 号二楼，一即是决澜社的发祥地，是一个中国 现代美术的历史纪念地。根据庞薰琹晚年对于他在上海的第一个住 所兼画室记忆犹新，他曾经回忆道 : “193I 年底，我和王济远商定， 租下吕班路和麦赛尔蒂罗路 90 号转角处的二楼作为画室，招收学 生。” “就在战火中，我和倪贻德等人商量了组织画会的事。 4 月, 在麦赛尔蒂罗 90 号商量这个工作，由倪贻德执笔写了《决澜社宣 言》, 发表在《艺术旬刊》第一卷第五期上。” 5 “麦赛尔蒂罗路 90 号, 楼下原先开了一家咖啡馆，自称 ‘文艺沙龙”，可是由于顾客稀少， 不久就关门大吉。我却是那里知道二楼房间空着。王济远和我把它 合租下来开辟一个画室，开始称济远薰琹画室，王济退出后改称薰 琹画室，但也只有一年多的历史。” 6

就在这 “只有一年多的历史” 中, 决澜社逐渐孕育成形, 显山露水。 关于决澜社的成因经过，庞薰琹的《决澜社小史》可作为重要的原 始文献史料。

薰琹自 $\times \times$ 画会会员星散后，蛰居沪上年余，观夫今日中国艺 术界精神之颓废，与中国文化之日趋堕落，辄深自痛心 ; 但自 知识浅力薄，倾一己之力，不足以稍挽颓风，乃思集合数同志， 互相讨究，一力求自我之进步，二集数人之力或能有所贡献于 世人，此组织决澜社之原由也。

20 年夏倪贻德君自武昌来沪，余与倪君谈及组织画会事，倪

4 庞薰琹：《就是这样走过来的》, 三联书店，2005，第 I29-I30 页。

5 同上，第 130 页。

6 同上，第 135 页。 
君告我渠亦蓄此意，乃草就简章，并从事征集会员焉。

是年 9 月 23 日举行初次会议于梅园酒楼，到陈澄波君周多 君倪贻德君与余五人, 议决定名为决澜社; 并议决于民国 2I 年 I 月 I 日在沪举行画展; 卒东北事起，各人心绪纷乱与经济拮据， 未能实现一切计划。然会员渐见增加，本年 I 月 6 日举行第二 次会务会议, 出席者有梁白波女士段平右君陈澄波君杨秋人君 曾志良周麇君邓云梯君周多君王济远君倪贻德君与余共十二人, 议决事项为：一修改简章。二关于第一次展览会事，决于 4 月 中举行。三选举理事，庞薰琹王济远倪贻德三个当选， I 月 28 日日军侵沪，4 月中举行画展之议案又成为泡影。4 月举行第三 次会议于麦赛而蒂罗路九十号，议决将展览会之日期延至 Io 月 中。此为决澜社成立之小史。7

自 I932 年开始，“决澜社” 的名称，逐渐在《艺术旬刊》《时代画 报》《美术生活》《申报》等报刊上出现，其 “新兴艺术团体” 开 始逐渐酰酿并显露其现代艺术艺术探索的形象。伴随着这个艺术 社团的名称的诞生, 有如其英文译名为 “Storm \& StressSociety” ${ }^{8}$ 或 “TorrentsSociety” 9 一般，这批 “负了新兴艺术使命” 的艺术家即 将在中国画坛上掀起一股“狂㚞”。

I 932 年 Io 月 Io 日, “决澜社” 中华学艺社举行第一届画展, ${ }^{10}$ 中华

7 《艺术旬刊》第一卷第五期，1932 年 Io 月出版。

8 《时代画报》第五卷第一期，上海时代图书公司 1933 年 II 月 I 日出版。

9 《美术生活》第 2I 期，I935 年 I2 月 I 日出版。

10 关于决澜社第一届和第四届展览会的展览地点, 有的称 “中华学艺社大 厦”, 有的称 “中华学艺社礼堂”, 有的称 “中华学艺社一楼”, 基本判 断为同一场所。另外, 1932 年 9 月, 决澜社的主要创办者庞薰琹的个人 画展在上海法租界爱麦虞限路的中华学艺社举办。庞薰琹曾经回忆: “个 人绘画作品展览势在必行。决定 9 月 15 日之 25 日举行画展，地点选在 爱麦虞限路的中华学艺社的礼堂。中华学艺社有宿舍，可以长期租住， 当时倪贻德，后来傅雷都曾在那里居住。爱麦虞限路在霞飞路南面，也 
学艺社在 20 世纪 30 年代以来，一直成为美术重要的展览和交流场 所。关于中华学艺社作为决澜社展览场所，其相关的背景和缘由大 致为，一是 “有熟人介绍” ; 二是 “租金便宜” ; 三是由美术界人士 在中华学艺社宿舍居住; 四是中华学艺社所在位置, 处于法租界的 南部，与东面的上海美术专科学校、新华艺术专科学校等机构距离 不远，比较方便。当决澜社初次亮相之时，“上海美术界几乎全拥 来参观画展”。“名家刘海粟刚走, 徐悲鸿大师就来了。当徐悲鸿几 次由南京到上海或由上海出国时，都赶来看决澜社的画展。在看到 庞薰琹的画后，和庞还交换过意见作过深谈。” 11

“决澜社”第一届画展展出社员和社外画家的作品，共 50 余件。 目前具有作品文献著录的有: 庞薰琴《裸体》《风景》《一阙悲曲》《藤 椅》《肖像》《如此巴黎》《慰》《咖啡店》、王济远《裸体》、倪贻德《肖 像》、阳太阳《二裸女》、杨秋人《避风堂》、周多《持花之女》、张 弦《静物》等。开幕当天他们在中华学艺社门前的集体留影，成为 了后人经常刊用和缅怀的历史画面。12

I 932 年 Io 月 Io 日开展当日, 《申报》报导 :

（此次展览作品）质量之精，为国内艺坛所创见，有倾向于新古 典者，有受野兽群之影响者，有表现东方情调者，有憧憬于超 现实的精神者。13

是一条东西向的横路，平时很少人到那里去。中华学艺社的礼堂光线不 好，举行绘画展览会，不是很合适。但是由于有熟人介绍，租金便宜。 我参加展览的作品, 一部分是从法国带回来的, 一部分是回国以后画的, 包括油画、水彩、钢笔画、白描、速写等等。作风各种各样，有写实的， 有变形的，有装饰性的。在当时来说，个人举行一个绘画作品展览，人 们觉得很新鲜。还印有一本展览作品目录, 有图片, 目录有中文与外文, 外文翻译出之于黄宝熙的主张，……展览期间我本人很少在场，一切由 曹铭熙招待。”（同注 4, 第 $132-\mathrm{I} 33$ 页。）

11 参见袁韵宜编《庞薰琹》，北京工艺美术出版社，1995，第 8I 页。

12 目前有倪贻德家属和梁锡鸿家属提供给笔者两幅相同的决澜社成员与第 一次展览会开幕期间的合影。其中倪贻德家属保存完好，梁锡鸿家属保 存者上有梁锡鸿的题字。

13 《申报》1932 年 10 月 ro 日。 
隔日，1932 年 10 月 II 日《申报》继续报导：

新兴艺术团体决澜社第一次画展，已于昨日在本埠金神父路爱 麦虞限路中华学艺社开幕，会场展出作品量虽然不多，惟精妙 绝伦，充满新鲜空气，为国内艺坛所仅见，观众踊跃。

……该会全体会员出席招待，并于下午四时请本埠文艺界 新闻界举行茶会。同时，对外发表宣言。14

这里的 “宣言”，就是后世人们所熟悉的著名的《决澜社宣言》。这 个宣言是由倪贻德执笔的，而在当天下午宣布的《决澜社宣言》， 无疑成为决澜社第一次展览会开幕仪式中最为引人注目的内容之 一。决澜社社员们，通过文艺界和新闻界的朋友们，向社会发出了 他们内心的呐喊，他们以激昂的语气宣布：

环绕我们的空气太沉寂了，平凡与庸俗包围了我们的四周。 无数低能者的蚌动, 无数浅薄者的叫器。

我们往古创造的天才到哪里去了? 我们往古光荣的历史到哪 里去了?我们现代整个的艺术界只是衰颓和病弱。

我们再不能安于这样妥协的环境中。

我们再不能任其奄奄一息以待毕。

让我们起来吧! 用了狂飙一般的激情，铁一般的理智，来创 造我们色、线、形交错的世界吧!

我们承认绘画决不是自然的模仿，也不是死板的形骸的反复， 我们要用全生命来赤裸裸地表现我们泼刺的精神。

我们以为绘画决不是宗教的奴隶, 也不是文学的说明, 我们 要自由地、综合地构成纯造型的世界。

我们厌恶一切旧的形式，旧的色彩，厌恶一切平凡的低级的 技巧。我们要用新的技法来表现新时代的精神。

二十世纪以来，欧洲的艺坛突现新与的气象，野兽群的叫喊、 
立体派的变形、Dadaism 的猛烈、超现实主义的憧憬……

二十世纪的中国艺坛，也应当现出一种新兴的气象了。

让我们起来吧!用了狂䐯一般的激情，铁一般的理智，来创 造我们色、线、形交错的世界吧! ${ }^{15}$

显见，“色、线、形交错的世界”，是决澜社中心的主旨追求，由于 传统文化的惰性和社会时局的动荡，使得他们史无前例地提出 “构 成纯造型的世界” 的口号，确实需要极大的胆识和勇气，他们的出 现，具有了浓厚的文化批判和审视的角色特质。虽然在这诗化般的 慷慨陈词之间，不乏过激和偏执的印迹，但确是近现代中国画坛的 第一次绘画本体的触及，进而扩展了洋画运动的文化效应，而这种 艺术的努力，无疑又需要矫枉而过正的过程才能实现。

作为当时西画发展中心的上海，业已表明其风格历程，已将历 时的西方绘画发展，勿勿地共时陈列和预演。出于上海独特的文化 环境，则更为敏感于世界绘画最新走向，即于近代以来以后期印象 主义和表现主义为中心的现代绘画潮流。“决澜社诸作家是接近巴 黎画坛的风气的，研究着各种风格，提炼了各国名家的真髓，而赋 以自己的乡土性，发挥着各自的才能。” ${ }^{16}$ 因而，被誉为中国有史以 来的第一个油画群体的决澜社，以其宗旨和实践的纯粹性，预示着 其将作为现代绘画在中国的最重要的历史象征。

关于决澜社的首次活动意义，在当时的活动成员看来，大多是 富于振兴画坛的浓厚使命感的，但他们的表达方式却呈现出独特的 个性化色彩。庞薰琹曾经这样写道 :

决澜社的第一次画展举办过了，宣言也发表了，究竟因为什么

15 《决澜社宣言》, 《艺术旬刊》第一卷第五期, I932 年 Io 月出版。关于《决 澜社宣言》的写作背景，庞薰琹曾经回忆：“倪贻德所写的这篇宣言， 当时只传阅了一下，没有讨论。我当时基本上同意，并且同意发表，但 是我总觉得有些话没有说出来。什么话没有说出来，当时的我也说不清 楚，中国绘画的发展前途对当时的我来说，几乎是迷迷糊糊的。” 同注 4, 第 I32 页。

16 梁锡鸿: 《中国的洋画运动》, 《大光报》1948 年 6 月 26 日。 
目的要组织决澜社? 这个问题我到现在也说不清楚, 我想大体 上有几个原因 :一，这些人都是对现实不满的，这从宣言上也 可以看得出来 ; 二, 谁都想在艺术上闯出一条路来，个人去闯， 力量究竟太单薄, 所以需要有团体; 三, 这些人都不想依附于 某种势力。在艺术思想方面, 一开始就明显, 各人有各人的看法, 不过有一点基本上是相同的：比较喜爱从西欧印象派以来的一 些绘画作风。17

王济远在他的《决澜（STORM）短喝》一文中写道 :

负了新兴艺术的使命，在风雨凄凉的慕道上，在深夜崎岖的山 路中，奔走着!狂呼着!! 不避艰辛，不问凶吉，更不计成败，向 前进，向前勇猛的进，向前不息的勇猛的进，这是艺术革命的 战士应有的常态，决澜社同人就在这种常态中奋斗着。首先起 义的是庞薰琹，薰琹由欧洲归国后，不断地在家乡制作，因为 太孤零了。偶然遇着几位同志创立画会, 旋因某种关系, 不久 即解散了。薰琹就在上海与倪贻德、周多、段平右几位同志创 决澜社，当时我由欧洲归国与几位同志赔了许多钱支持艺苑的 残局, 同时也与薰琴一样会被亲友们误解是一个无业游民, 我 们这一对游民就合组了一个画室，薰琹就邀我加入决澜社做社 员。我们觉得，画就是我们的生命，我们相依为命的就是画， 我们应该发掘自己祖先墓中的宝藏, 同时我们应当开辟大地新 鲜的宝光。尽你所有的微力去发掘, 凭你所有的精诚去开辟…… （1932.9.24 于画室） ${ }^{18}$

段平右在他的《自祝，决澜社画展》一文中写道 :

决澜社，生长在这混乱期间里，他们的希望，是想给颓败的现 代中国一个强大的波涛, 来洗一洗它的难堪的污点! 我们走的是 艰难的道路，故决澜社的同志，或是同情决澜社的人来紧握我

17 同注 4, 第 I34-I35 页。 
们强有力的手，来祝福前途的胜利吧。19

然而，从我们现在的角度观察，决澜社是一种文化现象。事实上， 以决澜社为代表的现代绘画现象，第一次走出了 “五四” 以来绘画 现象的某种误区，对 “写实主义 $=$ 入世精神 $=$ 进步艺术” 的经验模 式，实施了可贵的实践突破，虽然这种突破是在不自觉的文化意识 支配下进行，但毕竟显现了短暂而有益的端倪。

1932 年至 1934 年，决澜社的出现及其影响力，几乎涵盖了由于 画派对峙和战乱时局而一度沉寂的上海画坛，但表象的 “沉寂” 又 恰好给予洋画运动其间相应的心态调整和思想准备, 绘画上的突破, 恰似这 “沉寂”之中内在深层的酝酿和涌动，而一旦以决澜社第一 届展览为标志的艺术活动展开，其价值和意义确乎超越作品本身， 而寓示着一场艺术本体性的文化反叛态势将一发而不可收地迅猛出 现。“决澜” 的定名是其生动的形象写照，而其 “宣言” 又自然代 表着“沉寂”之中宏亮的绝响。

关于 1933 年至 1934 年决澜社第二次和第三次展览会的情况，是 相关于决澜社研究资料中最为散失的一部分。目前，我们通过新发 现的珍贵文献，了解他们当时的艺术面貌。

第二次决澜社画展是于 1933 年 Io 月 10 日在上海福开森路（今 为武康路） 393 号世界社礼堂举办的。在此地办展，“是由王济远 介绍” 的。“为的是可以不出租金，但是着地点更偏僻，所以来看 画展的人比第一次更少，来参观的人主要是上海美专、新华艺专的 学生，此外就是我们所熟悉的文艺界的朋友。” ${ }^{20}$ 目前所见最重要的 资料，是 I 933 年 II 月 I 日由上海时代图书公司出版的《时代画报》 (MODERNMISCELLANY）第五卷第一期，其中刊登了决澜社 第二回展览会的作品。其中有庞薰琹《构图》、倪贻德《人物》、周多《无 题》、段平右《风景》、张弦《人物》、阳太阳《静物》、周真太《杭 州风景》、王济远《风景》、丘堤《花》(获奖作品)。这次展览并没 有发现决澜社成员的合影，而是有《时代画报》上庞薰琹、倪贻德、 王济远、丘堤、段平右、周多、张弦和阳太阳八位画家在他们各自

19 同注 7 。

20 同注 4 , 第 137 页。 
展览作品前的留影。同时最近发现的一张决澜社第二次画展的外景 照片，展现了福开森路张挂展览横幅，世界社礼堂门口王济远、周 多、倪贻德等决澜社成员身影。 ${ }^{21}$

第三次决澜社画展是于 1934 年 Io 月在蒲石路留法同学会举行。 “这是一所双开间两层楼的普通洋房，只有朝南的房间光线好些， 但是这楼下楼上两间南房只有西墙可以挂画。前后两间房，中间是 拉门，不能挂画，举行展览会是很不合适的，但是可以免费，而且 同学会表示欢迎。这次参观的人数最多。” ${ }^{22} 1935$ 年 I2 月 I 日出版的 《美术生活》第 $2 \mathrm{I}$ 期中决澜社展览专刊, ${ }^{23}$ 成为这次展览会的珍贵 文献记录。其中发表决澜社画展出品的作品, 有: 庞薰琴《构图》(又 名《压榨》)、周真太《修机》、倪贻德《山道》、丘堤《静物》、张弦《肖像》。 其他方面的作品著录还有:庞薰琹《时代的女儿》(图 I)、《地之子》(图 2)、倪贻德《沈女士像》、杨秋人 《男像》、《羽的颜色》、阳太阳《友 人之像》、《海边裸女》、周多《黄小姐》、《持花者》、张弦《裸体》、 段平右《景》、《静物》等。其中最具有影响力的是庞薰琹《地之子》 一作。“《地之子》这幅画画面本来就暗, 挂在里间靠西的角上, 这 角上也没有什么光线, 所以更暗了, 但是观众却偏偏喜欢这幅画。” 24

在陈抱一的《洋画运动过程记略》中, 陈抱一将 “决澜社” 称为 “新 进的洋画集团”。而庞薰琹被认为是 “其中心人物”。“一一 一八 二 后，至少也经过了一段相当沉寂的时期。但在沉寂之中，犹如新花 发放似地微微显露了一点艳色来的，就是决澜社第一届画展（I932 年 IO 月)。这个集团是各方面的艺术份子集合而成的。其主要作家 为一庞薰琹、张弦、倪贻德、丘堤、阳太阳、杨秋人、周多、段平右、 刘狮、周真太，其他等等（所谓各方面者，例如作为当时的一个新 进作家的庞薰琹之外，张弦、倪贻德、刘狮等是出于上海美专的路 线，阳太阳、杨秋人等是上海艺术专科学校方面出身的）在那个时

21 该照片由倪贻德家属提供给笔者。

22 同注 4, 第 I84 页。关于此次展览会的图像资料, 目前发现的仅有由杨 秋人家属提供的历史照片。这是一张杨秋人夫人在此次展览会上的留影, 从其背景中，我们可以大约发现展览会中的部分作品和场景。

23 同注 9。 
期，决澜社画展的作品，已显示了较清新的现代绘画的气息。至于 他们个别的作家，艺术之成熟与否，是另一个问题。但就其大体而 论，都多少呈带起一点洗练的明朗的感觉。决澜社画展，很可以作 为那个新转变期的代表物之一。” 25

\section{三}

I935 年，倪贻德在《艺苑交游记》中，专题性地写作《决澜社的一 群》一文。作为决澜社的主要骨干之一，倪贻德对于决澜社活动的 意义，赋予了重新的评价：

决澜社的第四届画展又将在凉秋的季节举行了，时间过去得真 快，决澜社自从成立到现在，想不到竟过了四个年头，在一般 社会把艺术视为 “说明某种事物的手段” 的情形之下，在追求 新的技巧的决澜社，不为人们所注意或者甚至加以嘲骂，哪是 当然的事。但是，在这奄奄一息不绝如缕的中国洋画界中，还 保持着一点生气在挣扎着的，恐怕只有决澜社吧。所以，当这 第四届画展将要开幕之前，回想回想谛造的当初，再观察观察 几个同人的生活和艺术，实在也感觉到很大的兴味。 ${ }^{26}$

这种现代绘画的创造，主要的风格影响来自后印象的形式风格，在 初期的借鉴和吸收中可以窥见其中对应的痕迹。结合倪贻德的分析， 我们可以寻找到决澜社主要成员的各自的创作迹象：

庞薰琹一 “并没有一定的倾向，却显出各式各样的面目。从平 涂的到线条的，从写实的到装饰的，从变形的到抽象的……，许多 现代巴黎流行的画派，他似乎都在作新的尝试。……那时候，周多 在画着莫迪里安尼（Modigliani）风的变形的人体画，都会的色情 妇女的模特儿，狭长的颜面，细长的颈，哀娜的姿态，厚的色彩面， 神精质的线条，把那位薄命画家的作风传出几分来。但他的作风时 时在变迁着的，由莫迪里安尼而若克 fzacl，而克斯林 Kishn，而现 在是倾向到特朗的新写实的作用了。”

25 同注 2。

26 倪贻德 : 《艺苑交游记》, 《青年界》第八卷第 3 号。 
段平右一 “是出入在毕加索和特朗之间，他也一样在时时变着 新花样。他们都还年青, 他们将来还有更新的转变, 我们在很有兴 味地期待着。”

杨秋人和阳太阳一 “可说是一对广西人的伙伴。他们也是具有 清新的头脑和优秀的画才的青年作家。因为时常在共同研究, 他 们的作风是有些相近的，他们都在追求着毕加索和契里柯（De Chirico）的那种新形式，而色彩是有着南国人的明快的感觉。”

张弦一 “可说是有点憝性的。他曾两度作法兰西游，拿了他劳 作的极酬来满足他研究艺术的欲望。当他第一次回来的时候, 和其 他的留法画家一样的平凡, 是用着混浊的色彩, 在画布上点着。点 着, 而结果是往往失败的, 于是他感到苦问而再度赴法了。这次, 他是把以前的技法完全抛弃了, 而竭立往新的方面跑。从临摹德加 （Degas）塞尚（Cézanne）那些现代绘画先驱者的作品开始，而 渐渐受到马蒂斯和特朗的影响。所以当他第二次归国带回来的作品, 就尽是些带着野兽派的单纯他的东西。他时常一个人孤独地关在房 里, 研调着茜红, 粉绿, 朱标, 鹅黄等的色彩, 在画布上试验着他 的新企图。他爱好中国的民间艺术，他说在中国的民间艺术里也许 可以发现一点新的东西来。而现在, 他是在努力于用毛笔在宣纸上 画着古装仕女了。”

丘堤一 “是决澜社唯一的女作家。她的那幅杰作《花》, 是被当 时许多画报大登而特登的，而同时又被人指摘其红叶绿花的错误。 不管花草中有没有红叶绿花的一种，但画面有时为了装饰的效果， 即使是改变了自然的色彩也是无妨的。因为那幅花，完全倾向于装 饰风的。她也就因了这幅画得奖而被介绍为决澜社的社员” ${ }^{27}$ 。

确如倪贻德所指出: “洋画不仅是模仿西洋的技巧而已, 用了洋 画的材料来表现中国的, 是我们应走的道路。但是所谓表现中国的， 不仅在采取中国的题材，也不仅在采用些中国技法而已。要在一张 油画上表现出整个中国的气氛, 而同时不失洋画本来的意味一造型, 才是我们所理想的。” 28 “决澜社” 现象, 给现代的中国油画艺术第一 次提供富有创意的 “造型” 图式经验。 
之一，以庞薰琹为代表，形成一种“新构成” 样式。庞氏在决 澜社成员中以其形式探索的幅度多样而具代表性，其时常以色形的 分解、体构的重组赋予造型对象平面秩序感和装饰美，在对社会景 观、民众生活等的形象处理中，以数理和哲理的观念同构和归纳于 已有的造型格式中，确立一种音乐化的理性美感，在供鉴立体派画 风为主的表现形式和纯化本体空间结构的形象处理之间, 确立起 “构 成” 造型的艺术支点。在 I93I 年期间，庞薰琹创作了油画作品《如 此上海》《如此巴黎》（图 3) 《手掌》《无题》等, 风格基本属于 “小 幅装饰构图”，部分发表在《时代画报》《良友画报》等画报上，但 是 “原画都已经损失” ${ }^{29}$ 。

由上海中国美术刊行社于 I93I 年 2 月 I 日出版的《时代画报》 第二卷第三期，发表了庞薰琹《如此巴黎》，并进行专题的评论。 这是庞薰琹自 1930 年回国以后的第一次重要的社会媒体报道 :

繁华的巴黎是动着的：女人的笑声; 男子的烟形 ; 肉的战颤 ; 灯的摇晃。便是一光窗, 一面门, 一只缸, 也没一忽不在的变幻。 无论你的视觉怎样敏捷，你也总难得到一个静止的印象 ; 你的 笔尖正触上画面, 你的对象又不是一秒钟前所看到的那样了。动, 动着! 玻璃杯接触着嫩红的嘴唇; 手指又碰上了冷白的纸牌; 洗 净了一忽又脏污……如此巴黎!

庞薰琹先生新从巴黎回来，但他并没有把那曾使他沉醉疯狂 的巴黎丢在脑后。在半夜以后，街道上息止了一切的声音，庞 先生的眼前便又现出他热爱的巴黎，耳边便也闹忙起来。他拿 出画纸，把颜色依了当时看见的听得的一切涂上去，这张动的 画便诞生了。（文） ${ }^{30}$

1932 年，是庞薰琹艺术生涯中的极为重要的年份，是年他的第一 次个人展览和决澜社的第一届展览会先后在上海举行。上海摩社于 I 932 年 9 月 2 I 日出版《艺术旬刊》第一卷第三期, 发表庞薰琹简 介及作品《咖啡店》, 其中写道 :

29 同注 4, 第 I64 页。

30 《时代画报》第二卷第三期，上海中国美术刊行社 193 I 年 2 月 I 日出版。 
庞薰琹江苏常熟人，留法五年，一九三 $\mathrm{O}$ 年归国，仍继续创作。 现为决澜社社员。绘画之外, 兼长文学戏剧音乐等, 为现代国 内艺坛稀有之天才。本年九月十五日至二十五日，举行个人画 展于中华学艺社，引起沪上中西人士热烈之注意。上图为庞君 最近肖像, 下图为庞君作品之一, 系描写咖啡店之情景, 于构图, 形式，线条，色彩上，均有独到之处。 ${ }^{31}$

在决澜社时期，庞薰琹的得意作品之一，是油画《藤椅》。上海中 国美术刊行社于 1932 年 12 月 16 日出版《时代画报》第三卷第八期, 刊登了庞薰琹的作品《藤椅》, 并评论如下 :

庞薰琹，常熟人，留欧多年，在巴黎与常玉最相知，早夕过从， 所以他们的作品是相互影响着。薰琹更年轻，一种为中年人所 潜意识地简略掉的颜色更能使他感到莫大的兴味。因为这是一 种精神方面的获得，因此颜色便几乎会自动地飞上他的笔尖。

尤其是这张《藤椅》，他最得意的杰作：两种单纯的有黄充 分的颜色，既不相混，反而显然地分别出动的肉与静的藤来 ; 加以全画的线条，没一根不是简洁而崇高的，使我们深刻地领 悟到这世上的烦复无一非虚伪的卖弄，于是艺术便到了最满意 的境界。

薰琹苦心习艺，不参加任何名利的论争 ; 我们敬佩他艺术的 成功以外更钦佩他人格的高尚! ${ }^{32}$

在当时的画界，庞薰琹的油画之所以受到如此热切的关注，是因为 庞薰琹的形式感极富创意性，在当时的西画家群中是首屈一指的。 对于西方传统绘画和民族传统艺术的双重兴趣，导致庞氏的艺术中 将理性的色形归纳和感性的装饰变化有机结合，使得庞氏以其独有 的现代气质和才情的画家而蜚声于决澜社时期前后。傅雷先生曾评 述：“他把色彩作纬，线条作经，整个的人生作材料，织成他花色 繁多的梦。他观察、体验、分析如数学家，他又组织、归纳、综合

31 《艺术旬刊》第一卷第三期，上海摩社 1932 年 9 月 21 日出版。 
如哲学家。……他以纯物质的形和色，表现纯幻想的精神境界 : 这 是无声的音乐。形和色的和谐，章法的构成，它们本身是一种装饰 趣味，是纯粹绘画 (Peinture Pure)。”33

之二，以倪贻德为代表，形成一种 “新写实” 样式。在决澜社 时期的创作中，倪贻德多选用江南农村和城镇的一隅，衍化以线条 和色块为主的符号化的形式载体，经朴实和明快的基调，淡化对象 文学化和纪实性的知觉赋会, 在画幅本体中确立起一种 “岑寂、幽 静的秋的含蓄” 的精神投影，在借鉴野兽派画风为主的表现形式和 净化本土文化景观的形象择取之间，确立起 “情调” 造型的艺术支 点; “作为油画家，他对 17 世纪荷兰的风景画一那太空的青苍，云 影的波荡，因时间而起的光的变化及空气远近法等一有深切的领会。 对 19 世纪英国的风景画家：克罗姆的敏锐而单纯的用笔 ; 康斯太 布尔的强烈明快的色调，透纳表现大气和光线的效果 ; 到法国巴比 松派卢梭、杜比尼、柯罗等各以自己的绘画语言歌咏枫丹白露林野 的风光，都是那么兴致勃勃地进行分析鉴赏。他还批判地研究学习 印象派莫奈、西斯莱、雷诺阿闪耀着生命火焰的光色多变的作品。 但使他最感兴趣的是后期印象派创始者塞尚，对形体体积感的新探 索，还有野兽派德兰的古朴坚实的韵味，弗拉芒克豪放刚健的笔触， 以及郁特里罗市街情调的描写等。” 34

20 世纪 30 年代初期的决澜社艺术活动，是倪贻德早期艺术活 动中继上海美专之后的又一个重要阶段。“1932 年他和庞薰琹等组织 “决澜社”。集合一些敢闯新路的少壮派，替狂获一般的激情，以 表现自我的艺术新形式，向沉寂、庸俗、衰颓、病弱的画界冲击。 在 '决澜社' 前后举行三次画展中，可以看出已经到达纯熟期的倪

33 傅雷 : 《薰琹的梦》, 《艺术旬刊》第一卷第三期，1932 年 10 月出版。 34 谢海燕《倪贻德画集（序)》，载倪贻德《倪贻德画集》，上海人民美术 出版社， $198 \mathrm{I}$ 。由于倪贻德的作品大量散失，这本画集只搜集到他仅存 的近 70 幅作品, 包括油画、水彩画和素描作品。在倪贻德散失的作品中, 有《侧面人像》(油画，1930 年左右)、《花》(油画，1930 年左右)、《百 合花》(油画，1930 年左右)、《黄浦新秋》(油画，1930 年左右)、《乐器》 (水彩，1930 年)、《朝鲜声乐家高中玄》《“小猫”亚雪》《自画像》等。 
贻德艺术，具有前所未有的魅力。” 35

I934 年 IO 月 I 日出版的《美术生活》第 7 期, 刊登了倪贻德《花》 《乐器》《黄浦新秋》《百合花》《侧面》五幅油画作品, 这些作品 多为决澜社时期的创作作品。该刊为此并进行了专门的介绍：

倪贻德，浙江杭州人，现年三十岁。一九二一年开始习画，毕 业上海美专，其后曾一度热心文学创作。一九二七年东游日本， 研究现代艺术之理论与技法，归国赴华南各处旅行。一九三 o 年又往游长江各埠。一二八后返上海，任教上海美专。倪氏对 于研究艺术，具有强固之自信力与纯真之热情，自谓：此次个 展为其前期努力之结束，此后当努力于新的开展云。36

倪贻德可谓中国现代画坛上集艺术理论家和画家为一身的难得人 物。他不仅留下了一批成功的绘画作品，而且还出版了如《水彩画 概论》《艺术漫谈》《西洋画研究》《现代绘画概论》和《西画论丛》 等一批洋洋大观的艺术理论专著。倪氏多次自命为“新写实主义者”。 早在半个世纪前由他起草的 “决澜社” 宣言，就已标明了他的信仰 与追求，他渴望在日趋苏醒的中国画坛上出现一种崭新的气象，或 是 “野兽群的叫喊，立体派的变形”，或是 “达达派的猛烈，超现 实主义的憧憬”，他的目之所向不光是 19 世纪以前，更侧重于塞尚 以后的西方诸种现代画派。他对西方现代绘画的敏感和由于理论研 究而获得的清醒头脑，使他从一开始对西方绘画的选择就并不那么 狭险，以致较早地向人们揭示了刚刚兴起了不久的西方现代绘画的 面貌。他认为 “偏于空想或泯于写实”，都将失去画家自身的价值， 从西方绘画的传统 “写实” 到现代 “写意”, 都是富有开拓意义的 视觉革命。

仅从 “决澜社” 先后举办的三次展览中, 便可看出倪氏在 30 年 代就已形成的绘画特色。他推崇塞尚、毕加索、马蒂斯、德郎、弗 拉芒克、马尔盖和郁特里罗等现代画家，在他的作品中偶尔流露着 对这些画家的模仿。《黄浦新秋》的粗犷而强烈的形式感似乎很接 
近马尔盖的画风。几幅静物花卉古朴而坚实的造型又显然带有德朗 的风范, 某些人物肖像的表现更会使人联想到马蒂斯的情调。当然, 这并不意味着倪贻德个人风格的丧失，围饶着 “表现出整个中国的 气氛, 而同时不失洋画本来的意味” 的美感而构成倪氏造型的重心, 并在一系列的探求中使自己的作品特色渐趋明朗。由此形成了果断、 明快、单纯、坚实的艺术风格。不过他的 “纯造型的世界” 等艺术 主张，并未在以后的作品中得到彻底的反映。主要原因是，在其后 的艺术生涯中，他已敏感地认识到，西方现代派的某些理论在中国 画坛的社会土壤具有局限性，20 世纪 20 至 30 年代的一些 “为艺 术而艺术” 的画家们, 大多在日后出现过类似的观念转向, “决澜社” 的短暂历程便是最好的明证。

当然，在 “色、线、形交错的世界” 的艺术思想之中，决澜社 的艺术家创作侧重和审美重心各有不同，但基本求同而存异。事实 上，在决澜社宣言的措辞激烈的影响之下，人们多少会产生其为艺 术而艺术的形象，但通过其完整的前后四次的艺术创作展示，我们 可以发现其艺术的双重性, 此即一是 “接近巴黎画坛的风气” - “决 澜社诸作家是接近巴黎画坛的风气的，研究各种风格，提炼了各国 名家作品的真髓，而赋以自己的乡土性，发挥着各自的才能。他们 每年一度的大规模的画展是颇令人兴奋的，直到抗日战争开始那年 才停止举行” ${ }^{37}$; 二是 “打破单一而流俗的局面” — “总的一致性, 即欲以狂䔸运动来打破沉寂的油画画坛单一而流俗的局面”, “个别 的作家，艺术的成熟已否，是另一个问题。但就其大体而言，都多 少呈带起一点洗练的明朗的感觉。决澜社的画展，很可以作为那个 新转变期的代表物之一”。 ${ }^{38}$ 其中也不乏关注社会和人生的艺术作品 出现，以顺应当时社会时局的转变。

\section{四}

I935 年 Io 月, 决澜社第四届展览会在上海 “中华学艺社” 大厦举行, 这是该社的最后一次展览。展览的现状表明：“参观人数有限，大 致是当地的文化人士和美术学生。其观赏者范围，显然不能和当时

37 同注 I6。

38 陈抱一 : 《洋画运动过程记略》，原载《上海艺术月刊》 1942 年第 II 期。 
木刻版画展展览相比拟。”39

抑或决澜社第四届展览会，处在那个特定的历史时期，带有某 些悲剧性的色彩和气氛。庞薰琹曾经回忆道：

第四次决澜社画展是与第一次画展一样，是在在中华学艺社举 行。最后两天，参观的人很少，又是阴天。决澜社就是在这样 暗淡的情况下结束了它的历史。 40

特定的战乱时局，改变了决澜社的艺术初衷，在创作与接受之间， 渐已培植的 “纯粹造型” 化的审美导向，在民族危机日益加剧所导 致的存亡忧患意识面前，显得脆弱有余而感化不足，社会民众在当 时的思想基础和情绪心态之下，对艺术的教化功能的需要，无疑掩 蔽了艺术审美作用的感染力, 虽然期间如庞薰琹等决澜社画家也曾 创作过类于《地之子》《人生的哑谜》等触及社会时弊等力作，周 多等其它社员也涉及到一些劳工题材，并以隐晦的形式表明民众苦 难的形象和生活，但巡捕的跟踪和警局的传票即刻随展而至，迫使 会务受耽和人员离散一决澜社的时代悲剧由此萌生。

“第四次决澜社画展之后，因社员大多长期失业，靠卖画无法维 持生活，又因有人威胁：“庞薰琹必须离开上海。”同仁中又因艺术 见解不同，各有所求，经过研讨，开了一次会，发表了声明，决澜 社被迫解散了!” ${ }^{41}$ 当然，决澜社的解散，除了艺术旨趣与社会时局 不合，艺术家之间意见有别以外，还有一个不可忽视的原因，那就 是经济方面的拮据。展览期间的工作费用和广告费用，基本上是一 方面依赖于借债贷款 ; 另一方面是通过他们中间的部分画家从事广 告设计的所得报酬维持。 ${ }^{42}$ 这些综合的因素, 构成了庞薰琹所谓当时 “这样暗淡的情况”。

当时在一些批评家的眼里，决澜社的印象是多方面的。吴甲丰

39 朱伯雄、陈瑞林编《中国西画五十年（I898-1949）》，人民美术出版社， I989，第 304 页。

40 同注 4, 第 I43 页。

41 同注 II, 第 80 页。

42 同注 4, 第 I29-I44 页。 
在一篇文章中回忆了他当时参观决澜社画展时的感受，他写道: “我 当时是个不到二十岁的小青年，正在上海美专学画，亲眼看到他们 的展览。我记得清楚，他们的作品倒并不怎样激进，主要是接受本 世纪初在野兽派影响下的巴黎画派的画风，个别人模仿毕加索新古 典时期的人体造型，但风格偏于雅致，根本没有体现出他们《宣言》 中所说的 “达达派的猛烈” 等等的精神。展出的规模也不大, ” 43 孙 福熙曾着文评论决澜社的第四次展览会: “试着决澜社的第四届展 览会成绩，在当初大家认为确有狂澜溃决的意味，使人惊异的样子， 现在是大家很觉得理所当然，并不如何奇特了。这里面有两方面的 原因，第一是决澜社诸友日夕锻炼，渐臻圆熟之故，第二是展览会 教育观众，使感官渐渐形成适合于此种艺术的口味。”44

决澜社的同仁们，基于对官方学院派保守倾向的不满，充分体 现了不同的艺术风格, 庞薰琹显得尤为突出。在《人生的哑迹》《画 室内》和《地之子》等一些作品中，其画风的装饰性，表现在以构 成方法处理的构图和具体形象的塑造上。在这一幅幅理智而又颇负 哲理的作品面前，仿佛能使人们得到人生的启迪。20 世纪 30 年代 庞薰琹的艺术道路发生了转折，其已形成的画风可望给中国现代画 坛的多样性发展带来乐观的前景，但却发生了中止。就现象来看， 他是把对民族特色的追求表现在少数民族人物和静物风景画上了, 而实质上是避开了已经开辟的却又困难的艺术道路。因为在他当时 极负 “现代派” 的意味的人物画中已显露的民族性萌芽，并显现出 极大的发展潜能。他们与其被周围的环境所摧残而夭折，不如将才 能付诸在既不违背自己的艺术追求，又能为时代和社会所接受的方 面去。以致出现庞氏后半生的 “装饰之变”，其将大部分精力倾注 在装饰画的创作和研究之中，并将绘画中的装饰性引伸到属于工艺 美术范畴的装饰画之中，并作为他学术研究的重要成果。以致使今 人更多的只知道作为工艺美术设计家和教育家的庞薰琹，而淡忘了 本当可为中国现代画坛增添更多光彩的庞薰琹。

决澜社的命运，无疑成为 20 世纪前期中国油画界现代主义艺 术事件的重要写照，有关历史的结语告诉我们：“作为向西方近代

43 吴甲丰：《对西方艺术的再认识》，中国文联出版社，第 I37 页。

44 孙福熙《关于决澜社第四次展览会》，《艺风》第三卷第十一期，1935 年。 
发展道路的 “决澜社” 西画团体，由于民族危机日益严重，I937 年 “八三三事变”, 日本帝国主义进一步侵略中国以后, 它的活动便 基本上停止了。” ${ }^{45}$ 在这历史结语背后, 人们看到的是激进的现代艺 术理想与中国国难当头的社会现实时局的巨大落差 ; 看到的是中国 大地上第一个现代艺术的曙光过早地暗淡。战争和动乱, 将本源于 艺术命题中的写实和表现的艺术语言, 延伸为写实主义与表现主义 的对峙, 并且强化为艺术之外的对立, 又相应划归于进步与落后的 图解。生不逢时的命运, 使得这批献身于振兴中国美术的英才们, 不断修正和变异着他们在本土艺术活动的方式, 他们可贵的探索和 创举在那个时代显得势单而力薄一犹如流星一般, 划过 20 世纪 30 年代中国画坛的夜空，而之后即是迷失的漫漫踪迹。

\section{五}

对于决澜社这样一个具有国际影响的中国艺术群体, 本文一方面通 过对大量珍贵的史实文献的梳理, 还原决澜社艺术的丰富历史真相; 同时基于决澜社所处的文化情境，深入反思决澜社现象所引起的中 国现代主义美术演变的文化问题，并思考以决澜社艺术为代表的中 国现代主义美术，作为优质的国际艺术资源，如何在今天艺术经济 一体化的都市文化生态中，获得更好的保护和再生。

近代美术的发展是以都市化进程为驱动的，因此，都市美术资 源问题, 首先是将近代美术视为怎样的文化概念, 如何将都市的历 史记忆的视觉文献加以收藏积累和传播体现的, 一这样的学术课题 已经呈现国际化趋势，不止限于本土范围，欧美亚都有此文化战略。 因此，关于中国现代主义美术资源课题，具有国家文化战略的高度， 而且需要思考相关资源的国际化收藏和展览的布局。近现代美术在 中国为什么显得如此扑朔迷离, 未解依存, 其缘由之一正在于其资 源的严重流失，这种情况在世界范围而言算是一个特例。

众所周知的客观原因，无疑是 20 世纪前后的战火和动荡，导致 了部分作品和文献遗失或下落不明, 影响了更为完整的价值评估体 系的形成, 导致的中国现代主义美术资源呈现某种 “看不见” 现象。 
“看不见”之一，是指相关视觉文献的严重缺失。由于历史原因 所致，本土对于中国近现代美术资源，缺失集中、系统和定位收藏 基础和文化概念，因此，“看不见” 的问题就会自然出现。事实上， 通过中国现代主义美术相关展览活动, 我们已经直面触及到这些 “看 不见” 的问题，如相关中国现代主义美术的学术文献如学校丛书、 校刊、纪念册、成绩展图录与印刷性文献相关的书籍、期刊、作品 图集、展览图录、特刊、广告等，以及与非印刷性文献相关的另如 艺术家的笔记、手稿、信札、草图、速写、影视、照片、录音、视 频及其他相关用物和器具, 需要量化呈现现存与散佚的比例和现状, 并加以系统梳理和文化解读; 决澜社中的相关艺术家，除了庞薰琹、 倪贻德、杨秋人、阳太阳以外，其他艺术家如张弦、周多、段平右 等在决澜社时期的历史还原 ; 并没有完全显现了其中历史之物与艺 术之物的复合。由于相关文献没有持续性定位收藏基础，现有的社 会各方的支持只能显现其基本概貌，而无法真正思考其艺术资源的 丰富性。

“看不见”之二，是指著录量与存世量的 “反差” 问题。上海作 为中国近现代美术的发祥地，留下众多名家早期作品和文献，现在 存在的问题是, 早期他们的作品著录的数量, 要远比现存于世的作 品数量大得多，这是一个引人注目的 “反差” 现象，也就是说 “看 不见” 的多, “看见” 的少。特别是在西洋美术方面尤为明显。比如, 根据目前收集的相关文献整理，决澜社前后四次展览共发表作品有 35 幅。计为王济远 3 幅、庞薰琹 4 幅、倪贻德 4 幅、阳太阳 5 幅、 张弦 3 幅、杨秋人 3 幅、丘堤 3 幅、周多 5 幅、段平右 2 幅、周真 太 3 幅。而目前决澜社时期作品原作现存只有 2 幅, 即张弦《肖像》 (决澜社第二届展览会出品)、丘堤《静物》（决澜社第三届展览会 出品)。因此, 35 比 2 的背后, 表明自决澜社诞生至今八十年历史中, 始终没有相关系统而专题的收藏历史传统出现。由于在传统美术延 续创新和西方美术引进创造的中国近代美术两大主线之中，前者具 有收藏传统，而后者则无所谓体系可言，因此相关藏品不足导致长 期艺术资源认识的空白。

因此，在公认的客观历史原因之外，我们主观方面，也需要认 真的反思。如是问题的实质，就是我们没有一个完整的关于中国近 现代美术艺术资源的文化理念和政策机制，加以有效地保护、管理 
和推广。在艺术资源基本处于零散化的状态之下, 我们有活动有纪 念才想到要找的东西在哪里, 相关的资源怎么寻找。我们在活动之 前为什么没有长久持续性的对于资源的保护理念, 这是值得我们思 考的问题。我们没有通过相关的文化追忆, 弥补这种 “失忆” 的状态, 就是我们要把美术资源进行整合, 进行艺术之物和历史之物的复合。

认识中国现代主义美术资源的重要，是因为其是事关国家文化 战略的顶层设计, 以重振我们的文化自觉和自信, 实行国际优质文 化资源双向推进机制、实现平等对话 ; 并其公共文化资源为全民所 享用。诸如决澜社的相关历史之物与艺术之物, 皆为中国现代主义 美术资源的亮点, 需要记忆复合、经典定位、价值评估和文化再生, 使得相关艺术资源得以有效、集中的保护和转化。 


\title{
A Study of "the Storm Society": Chinese Modernism as a Resource of International Modern Art
}

\author{
Li Chao
}

I.

Before the I930s, the modernist trend of the Chinese oil painting was set by the Hangzhou National College of Art's Lin Fengmian and Art Movement Society. The Shanghai school was merely regarded as a subdivision of modern Chinese art. Nevertheless, it had caught the attention of insiders of the Chinese art world. Chen Baoyi once noted in an article that the "expressive spirit" chosen by the late Impressionism had already been known by researchers like us as early as I9I8 or I92I. Perhaps such knowledge in the academy had some influence in spawning another phase of post-I920s development. Since the '3os, the Shanghai art world became the center for the rise of modernist ideas. In this way, since its inception in the I920s, the advance of European modernist trends in painting, such as Post-Modernism, Fauvism, and Cubism, bore out its eastern manifestation on the Chinese soil in the ' 30 .

In the I930s, the oil paintings in Shanghai tended to adopt the Western approaches. Because of such tendency, during the second Sino-Japanese War, an article, titled "Examining Shanghai Painting" with the byline of Zhang Jie, commented:

Since the Northern Expedition, the style of Shanghai painting seems to have veered into the path of Post-Impressionism. Such stylistic shift could be detected as early as in Liu Haisu's Beijing Front Gate [Beijing Quianmen] of the previous period. So later when artists such as Chen Baoyi, Ting Yunyung, and Guan Liang who started to produce more works in subjective expressionist style, we can say their new style came under such influence. Shanghai painting of this period showed patent progression into the modernist direction: the cries of the Fauvism, the transformation of Cubism, the mysticism of Dada and the dreams of Surrealism could all be seen. The vibrant energy of early twentieth century Paris art scene appeared again in Shanghai, a city dubbed as "the Paris of the East." And the leading artists who contributed a great deal to the modernist art movements were ones such Pang Xunqin, Ni Yide and Zhang Xuan of the Storm Society.

After the "January 28 Incident" in 1932 there was a period of quietness in the Shanghai art scene. The subdued artistic activities weren't revived until the first art exhibitions organized by the Storm Society in October 1932. The key mem-

I Li Chao, Chinese Modern Oil Painting History (Shanghai: Shanghai Painting and Calligraphy Publishing House, 1995), 69. 
bers of the Society - Pang Xuqin, Ni Yide, Zhang Xuan, Qiu Di, Yang Taiying, Yang Qiuren, Liu Shi, and Zhou Zhengtai - became the ardent spokespeople for participating, advocating, and practicing modernist techniques in the Shanghai art world. Following the example of the Parisian booming art scene, members of the Society urged the twentieth-century Chinese art world to become vigorous as well. Between the I920s and the '30s, an increasingly powerful current of modernist arts was beginning to make waves in the Chinese art world. Such currents emerged first in Shanghai and then swept across the board. The prominent voices of such trends of modernist approaches in arts were the Storm Society and China Independent Art Association. The emergence of such art societies was likened to "the blooming of new flowerers which shows a tinge of radiant color" and which "blows a more refreshing air of modernist paintings (into Shanghai)" during "a period of silence and inactivity."

The decision to found an art society such as the Storm Society was first proposed by Pang Xunquin, Fu Lei, and Zhang Xuan. Most of the Storm Society's members came from two other art societies: Société des deux mondes (Taimeng Huahui) and the Muse Society (Moshe). In October 1930, Pang Xunqin accepted the invitation by Wang Rizhang (Wang Dilang) and founded the Société des deux mondes in Shanghai. The pivot of this Société were Zhou Tai (Zhou Zengtai) and the other 20 members who joined around that time or later were Tou Yi, Hu Zouqin, Zhou Dou, Duan Pingyou, Liang Baibou, and others. Because the Société displayed leanings towards radical left-wing thinking, they were not tolerated by the authorities. They clamped down on the Société in January I93I. Most members of the Sociéé later joined the Storm Society. In 1932, while he was working as a professor for Western painting at Shanghai Art Academy, Ni Yide also served as the chief editor for L'Art Magazine (Yishu Xunkan) published by the Muse Society. The Muse Society was founded to assume the responsibility for editing the L'Art Magazine. In addition, the Society expanded its operations into organizing art exhibitions, hosting public talks, and funding a graduate school. The Society's members include Liu Haili, Wang Jiyuan, Zhang Xuan, Wang Yunbou, Liu Shi, Fu Lei, Li Baochung, Huang Ying, Ni Yide, Wu Fuzhi, Zhang Chenbou, Zou Dou, Duan Pingyou, Zhang Ruogu, Pan Yuliang, Zhou Shoujuan, Pang Xunqin, and others. Some among this set also became the members of the Storm Society. ${ }^{3}$

2 ment," Shanghai Art Monthly 6 (1942).

3 The Muse Society (Mo She) was an arts group centered around Shanghai's art circle and also the institute which published and edited L'Art (Yishu Xunkan). Mo She is a Chinese phonographic rendition of the French word Muse, which is usually translated as $M u S e$, the goddess of arts in Greek mythology. The etymology of Mo She (the Muse Society) implied introspective "musings." Apart from deriving its meanings from its Western etymology, the name of the society in Chinese also suggests "observation." The founding mission of statement of the Society is to "advance our traditional culture and embody the zeitgeist" (Zhang 
The process of preparing for and founding the Storm Society basically took place at the "Xunqin Atelier" on the second floor of 90 rue Marcel Tillot in Shanghai's French concession and from that place it took wing. In October 1932, Pang Xunqin wrote in the Muse Society's L'Art Magazine 5, no. I, "The Concise History of the Storm Society" that the third preliminary meeting for the Storm Society scheduled in April of that year was to be held on "9o rue Marcel Tillot." Also an advertisement for "looking for researchers for the Painting Research Institute affiliated to the Xunqin Atelier" was placed in L'Art I, no. I2 of that year. The advertisement clearly points out that the address of "Xunquin Atelier" was on the second floor of 90 rue Marcel Tillot.

The address of "the second floor of 90 rue Marcel Tillot" was where the Storm Society was born and hereafter has become a memorial hall for Chinese modern art. In his later recollection of this first residence-cum-atelier, which still appears fresh in the painter's mind's eye, Pang Xunqin reminisced: "After talking the matter through with Wang Jiyuan, we decided to rent the second floor of 90 rue Marcel Tillot as an atelier for taking in students."4 "Amidst wars, along with others, Ni Yide and I put our heads together over the matters of forming an art society. In April, we discussed the preliminaries on 90 rue Marcel Tillot. Ni Yide wrote the 'Declaration of the Storm Society' and published it in the October I, 1932 issue of L'Art." "On the first floor of 90 rue Marcel Tillot there was a café, which is called 'Arts and Culture Salon.' But the café closed down because few customers set foot in the shop. But I learned that the space on the second floor was vacant. So, Wang Jiyuan and I took the lease together and made it our atelier, first named as 'Jiyun Xunqin Studio.' But later when Wang backed out, the studio was renamed as Xunqin Studio. But it lasted only a little more than one year."

But during "(the atelier's) history of a little more than one year," the Storm Society was gradually taking shape, whose capacities were known to the public. Pang Xunqin's "The Concise History of Storm Society" serves a key primary historical document on the reasons of and process of founding the Storm Society.

Ever since the members of art society had dispersed all over, Xunqin was living in seclusion in Shanghai. He felt the pangs when he witnessed that the decadence of the Chinese art world and the gradual moral decay in contemporary Chinese culture. Knowing his capacities were limited, he acknowledged that he would not be able to salvage the cultural decline by giving his all. So he put several like-minded heads together, thrashing out solutions. On the one hand, he demanded self-improvement; on the other, he understood that there was power in numbers. A united group might be able to make a meaningful contribution to the people. Such was the raison d'être for founding the Storm Society.

Rougu, "Investigating the Muse Society," L’Art I, no. I [September I, 1932]).

4 Pang Xunqin, This Is How It Happened (Jishi zheyang zouhuo laide) (Beijing: Life, Reading and New Knowledge Sanlian Bookstore, 2005), I29-30.

5 Ibid., I30.

6 Ibid., I35. 
In the summer of $1920, \mathrm{Mr} \mathrm{Ni}$ Yide came to Shanghai from Wuchang. I make my intension of forming an art society known to $\mathrm{Mr} \mathrm{Ni}$ and he in turn revealed to me he was of similar mind. Therefore we drew up a rough draft of our manifesto and immediately started on the business of assembling members.

On September 23 of the same year, we held our first meeting at Plum Garden hotel and five people showed up: Tan Ting-pho, Zhou Dou, Ni Yide, and myself. The meeting was brought to a conclusion by naming the society "The Storm Society." And we also resolved to hold an art exhibition in Shanghai on January I, I932 (2Ist of the Republic). However, it was a time of chaos and turbulence. The North-east faction was rising and we were all in a tight corner financially. Therefore the plan failed to materialize.

However, as the number of the members grew, the second meeting of the committee on membership politicies was set up and held on the January 6 of the same year. The twelve attendees included Ms Liang Baibo, Mr Duan Pingyou, Mr Tan Ting-pho, Mr Yang Qiuren, Mr Zhen Zhiliang, Mr Zhou Yijun, Mr Zhou Dou, Mr Wang Jiyuan, Mr Ni Yide, and I. The three resolutions we arrived at were: revising our charter, holding the first exhibition in April, electing Pang Xunqin, Wang Jiyuan and Ni Yide to be in the board of directors. Yet on the January 28 Japanese army invaded Shanghai and therefore the exhibition scheduled to be held in April went by the board again. We held the third meeting in April on 90 rue Marcel Tillot and settled on postponing the exhibition until mid-October. Such is the brief history of the Storm Society. ${ }^{7}$

Since 1932, the name of the "Storm \& Stress Society" started to be mentioned in pictorial magazines such as L'Art Magazine (Yishu Xunkan), Modern Miscellany (Shidai Huaboa), and Shanghai New (Shen Bao) and its reputation as an "upcoming arts society" was about to make waves and make a name for itself as an "explorer of modernist art." Along with the birth of the name of this art society, whose significance is suggested by its English name the "Storm \& Stress Society" 8 or "Torrents Society,"9 this group of artists who "bore the responsibility of new art" would soon stir up a "torrent of rage" in the Chinese art world.

II.

On October IO, 1932, the Storm Society held its first exhibition of painting at the China Society for Study of the Arts (Zhonghua Xueyishe). .' The China Society

7 L'Art I, no. 5 (1932).

8 Modern Miscellany (Shidai Huabao) I, no. 5 (1932): I.

9 The Arts and Life Pictorial Monthly Magazine 2I (1935).

Io As to the location of the Storm Society's first and fourth exhibitions, some claimed it to be the "China Society for Study of the Arts Building"; some "the Hall of China Society for Study of the Arts"; and some "the first floor of the 
for Study of the Arts had been an important locale for art exhibitions and the hub for exchanges. There are four reasons for choosing this venue for holding an exhibition by the Storm Society: introduction by friends; cheap rent; the composition of the tenants at the society dormitory consisting mainly people in the art circle; and the convenient location of the Society in close proximity to southern French concession, where colleges such as the Shanghai Art Academy and Shanghai New China Art Academy were based. When the Storm Society made its debut exhibition, "nearly the entire Shanghai art world betook themselves to the exhibition." "The minute the eminent Liu Haisu has just left the exhibition, master Xu Beihong stepped in. Whenever Xu Beihong comes to Shanghai from Nanjing or before going abroad, he would make an effort to come to the Storm Society's exhibition. After seeing Pang Xunqin's paintings, he would exchange insightful ideas with Pang."

The first Storm Society exhibition showcased 50 pieces of work by its own members and non-members. The works that have been recorded in documents are: Pang Xunqin's Nude, Landscape, A Piece of Tragedy, Wicker Chair, A Portrait, Such Is Paris, Comfort, and Café Shop, Wang Jiyuan's Nude, Ni Yide's Portrait, Yang Taiyang's Two Nude Women, Yang Qiuren's Wind Shelter, Zhou Dou's Woman Holding Flowers, and Zhang Xuan's Still Life. On the day of the opening ceremony, the artists took a group photo at the front door of the China Study

China Society for Study of the Arts." But basically these claims all point to the same location. On the other hand, in September 1932, Pang Xunqin, one of the co-founders of the Storm Society, held his solo exhibition at the China Society for Study of the Arts on rue Emmanuel III. Pang once recalled, "it was necessary for me to hold a solo exhibition. Therefore the exhibition was decided to be held between September 15 and 25 at the Hall of China Society for Study of the Arts on rue Emmanuel III. The China Society for Study of the Arts offered a longterm lease of its dormitory where Ni Yide and later Fu Lei had resided shortly. Rue Emmanuel III is a less-frequented road on the southern side of Avenue Joffre and it is oriented from east to west. The light inside the Hall of the China Society for Study of the Arts was bad and the place was ill-suited for holding a painting exhibition. However, because the location was informed by friends and the rent was cheap, it was chosen. My exhibited works consisted of works I painted in France and some since my return to China. There are oil paintings, water colors, pen and ink drawings, line drawings and sketches. And the styles of the paintings consist realism, distortion, and art deco. At that time, people found it refreshing for an artist to hold a solo exhibition. In addition, there was an exhibition catalogue with works index in both Chinese and English, reproduction of works, and a translated text of Huang Baoxi's manifesto, etc. During the exhibition period I was hardly there. Xhao Mingxi served as the overall receptionist" (Pang, This Is How It Happened, 132-33).

II Yung Yunyi, Pang Xunqin (Beijing: Beijing Arts and Crafts Publishing House, I995), 8I. 
Society. The photograph now becomes a document for historical research, usage, and memory. ${ }^{12}$

On the day of exhibition, October I0, 1932, Shanghai News reported:

The quality of the works showcased in this exhibition has been first-rate and unprecedented in the domestic art world. There are works of neo-classicism, works that reflect imprint of Fauvism, works that express Eastern moods, and works that aspire to the Surrealist spirit. ${ }^{13}$

On the following day, October IIth, 1932, Shanghai News went on to report on the exhibition:

The burgeoning art group the Storm Society held its first exhibition at the China Study Society at the intersection between rue Emmanuel III and rue Père Robert in Shanghai. Although the number of the exhibited works is small, the quality is exceptional and execution exquisite. The exhibition injected new life into the Chinese art world. Many viewers are pouring in to see this unique exhibition.

A press conference and reception will be held at four pm. All members of the Storm Society will be there to receive the Shanghai press and arts circles. Its manifesto will be released to the public. ${ }^{14}$

The "manifesto" here is what came to be known by the later generations as the "Storm Society Manifesto." The manifesto was penned by Ni Yide. And the "Storm Manifesto" announced on that afternoon no doubt became one of the most eye-catching contents at its opening ceremony of the Storm Society's first exhibition. The members of the Storm Society, through their colleagues in the arts and media circles, expressed their cri de coeur to the society. In a passionate voice, they declared:

The air surrounding us is too deadening. Mediocracies and vulgarity envelop us. Legions of morons are running about like headless chickens; countless shallow people are clamoring.

Where have the geniuses the nation used to produce been? Where have our glorious ancient history gone? What the whole of our modern art world possesses is mere decay and infirmity.

We admit that paintings are not imitation of nature nor unalterable repetition of forms. We will show our barefaced feisty spirit with all our might.

I2 I now have two identical group photographs of the Storm Society members at the opening ceremony of the first exhibition provided by Ni Yide's and Liang Xihong's families. The photography provided by the Ni family is in good condition while the one from the Liang family has his autograph and epigraph. 
We can no longer indulge ourselves in living the life of Riley.

We can no longer resign ourselves to the feeling doom and gloom.

We believe that art is no slave to religion nor footnotes to literature. We will compose a pure world of forms comprehensively and with utter abandonment.

We detest all styles and palette of the old; despise all techniques mediocre and cheap. We will demonstrate the zeitgeist of the modern with the avant-garde techniques.

Since the inception of the twentieth century, there emerged suddenly a brand new artistic climate in the European art world: the howling of les Fauves, the transformation of Cubism, and the ferocity and surrealist dreams of Dadaism....

There should also be a brand new climate in the twentieth century Chinese art world.

Let us rise up! Let us create a world woven in colors, lines and forms with stormy passion and with steely reason. ${ }^{\text {Is }}$

Apparently, to "create a world woven in colors, lines and forms" is the core mission of the Storm Society. Because of the inertia of traditional culture and the turbulence of the society of that time, the Storm Society proposed the revolutionary slogan of "composing a pure world of forms." That indeed took great daring and courage and coated the Society's existence with an air of intense culture critique and examination. Despite the imprint of radicalism and one-sidedness in their heroic rhetoric, the manifesto was in truth a first attempt at creating an ontology of art in modern Chinese art world and an effort to expand the culture of Western art movement in China. Such an effort could only be realized, no doubt, through a process of rectifying and refining the tradition.

Shanghai, as the center where "Western painting" ( $x$ i hua) developed, with its rich history and experience in displaying Western painting of various historically periods, has revealed that the city's stylistic progress had already rehearsed the West's artistic development in juxtaposition with Chinese art. Because its unique cultural environment, Shanghai was all the more sensitive to the latest art trends in the world, namely the currents of modernist art whose heart was Post-Impressionism and Expressionism: "Most of the artists at the Storm Society shared an affinity with the Parisian art world. They studied various styles and understood the essence of the masters from all countries. And then equipped themselves

I5 "The Storm Society Manifesto" was published in October of 1932, in L’Art I, no. 5. With regard to the background of creating the "Manifesto," Pang Xunqin recalled once: "We only had a quick look at the manifesto written by Ni Yide, which was only passed around among the Society members. There wasn't any discussion about it. I basically agreed to its content back then and agreed to publish it. But I somehow felt something was left unsaid. What was unsaid wasn't clear to myself at that time. The development of Chinese painting was to the me a rather vague concept" (Pang, This Is How It Happened, I32). 
with their vernacular artistic idioms, the artists all evolved their idiosyncratic talents." ${ }^{16}$ Therefore, because of purity of its mission and practice, the birth of the Storm Society, dubbed as the first art society of oil painting in the Chinese history, presaged that it would become the most significant emblem in the history of Chinese modern painting.

From its members' point of view, the significance of the Storm Society's first event lay in the sense of mission which aimed to revive the art scene. But the artistic expressions shown in the exhibition took on an idiomatic individualistic varnish. Pang Xunqin once wrote:

So now we have held the first Storm Society exhibition and published our "Manifesto," but the exact reasons for forming the Storm Society remains unclear to me. I think there might be three reasons for that: first, the members are discontented with reality, which is evident in the "Manifesto." Second, we all want to make a name of ourselves in the art world. Given one is too isolated when battling single-handedly, we need to form a group. And last, none of these people would kowtow to the authorities. Each one of the members has their own view on the meanings of art, which was apparent from the beginning. However, the group share one thing in common: they all prefer the painting styles since Western European Impressionism $[$ to guobua $] .{ }^{17}$

In his “The Storm Society's Rebuke,” Wang Jiyuan wrote:

The Storm Society has been travelling on the mission of championing the new art, hurdling headlong along the roads of proselytizing and on the rugged mountainous tracks. We advance forward regardless of the hardships, of the ups and downs, and of the failure and success. Forward we gallop with such fervor; forward we spring with unceasing courage. Such is the norm for artistic revolutionary warriors. And in such normality the comrades of the Storm Society are fighting tooth and nail. The first to revolt was Pang Xunqin. Since his return to China from Europe, Pang had been living a very lonely life as he painted all the time at home in solitude. Due to this extreme loneliness, Pang founded an oil painting society when he met a couple of allies by chance. However, one way or the other the society broke up soon.

So Xunqin founded the Storm Society in Shanghai with comrades Ni Yide, Zhou Dou, and Duan Pingyou. When I returned from Europe, along with a couple of comrades we poured our resources to rehabilitate the unprofitable wreckage of Yiyun (the Atelier). In doing so, like Xunqin, I was thought to be a tramp by my family and relatives. So we, a pair of tramps, created an atelier together. Then Xunqin invited me to join the Storm Society. We felt that this is the purpose of our life and painting is our lifeline.

I6 Liang Xihong, “The Western Painting Movement (Xihua yundong) in China," Big Light Newspaper (Da Guang Bao), June 26, 1948. 
We ought to unearth the treasure in our ancestors' tombs while exploring the refreshing sparkles in unchartered territory. Try your very personal best to explore all the new avenues and develop new skills with all your devotion.... (September 24, 1932, at the Atelier) ${ }^{18}$

Duan Pingyou wrote in his "A Tribute to the Storm Society's Exhibition":

Born in the midst of a period of chaos, the Storm Society hopes to bring a powerful wave to the decadent modern China and wash clean its embarrassing stain! The road we have chosen is a tough and rough one. So, comrades at the Storm Society and those who sympathize with our causes, come shake our strong hands and wish us the triumph that lies ahead. ${ }^{19}$

However, with the hindsight of the present day, we think that the Storm Society was (part of a wider) cultural phenomenon. In effect, since the May Fourth Movement, the phenomenon of modern painting spearheaded by the Storm Society was led back on track for the first time. And the Society made precious breakthroughs in artistic practice by breaking the habitual thinking of equating "realism" with "secular spirits" and "the progressive art." Although such a breakthrough was carried out under the unconscious cultural will, it after all gave rise to a brief but valuable initiative.

Between 1932 and 1934, the Shanghai art world, which was divided by different schools of painting and wars, was jolted out of a lull by the emergence of the Storm Society, which then swept Shanghai off its feet. But the quietened "surface" happened to make room for the society to adjust to the corresponding mindset and to get ready for the Western-style painting movement. The breakthrough in painting techniques resonated deeply with the brewing and boiling beneath the apparent surface of "lull." When we take the Storm Society's first exhibition as a benchmark for organizing artistic events, where the value and implications of the event itself exceed the works per se, we are announcing the coming of an unstoppable surge of a cultural revolutionary condition which epitomizes artistic autonomy. The name of the Storm Society reflects the vivid image of such movement and its "Manifesto" of course represents the resounding swansong in the midst of such a "lull."

The research materials concerning the conditions in which the second and third Storm Society exhibitions between 1933 and 1934 were held are mostly scattered and lost by now. Currently we can try to apprehend the then artistic environment through some precious newly-found documents.

The second Storm Society exhibition was held on 393 rue Ferguson (today's Wukang Road), in the World Society Hall on the October IO, 1933 because "Wang Jiyuan introduced us to this venue" and because "we did not need to pay rent for it." However, "the location is even more remote than the previous ven-

I8 L'Art I, no. 5 (October, I932).

I9 Ibid. 
Fig. I. Pang Xunqin, The Daughter of the Age, 1937. Oil painting. Courtesy of the Li Ching Cultural and Educational Foundation, Taipei, Taiwan.

ue, and therefore the number of the visitors of this exhibition was less than the first one. Apart from our close friends in the art and culture world, most of the visitors were the students of Shanghai Art Academy and New China Art Academy." ${ }^{20}$

The most important document we have unearthed so far is the Modern Miscellany (Shidai Huabao) 5, no. I, published by Shanghai Times Pictorial Magazine on November I, I933, in which the works exhibited

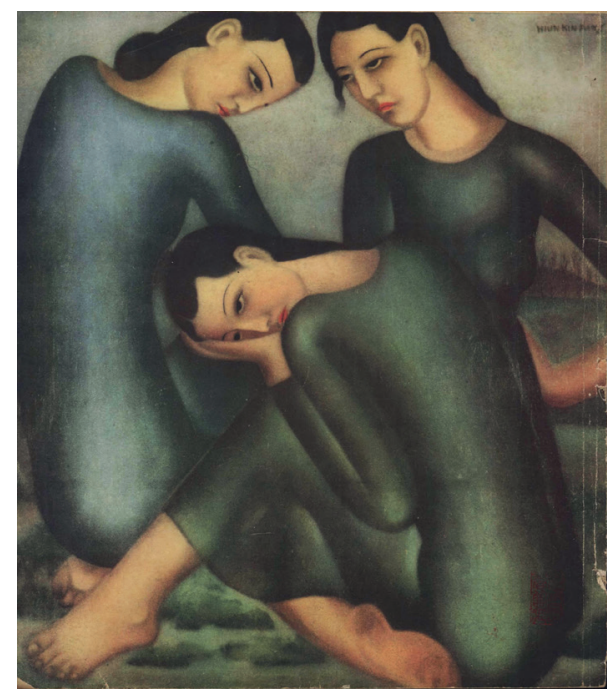
in the second Storm Society exhibition were reproduced, among which Pang Xunqin's Composition, Ni Yide's Portrait, Zhou Dou's No Title, Duan Pingyou's Landscape, Zhang Xuan's Portrait, Yang Taiyang's Still Life, Zhou Taizeng's Hangzhou Landscape, Wang Jiyuan's Landscape, and Qiu Ti's Flower (the award-winning work). We haven't discovered any group photograph of the Society's members at this exhibition but what we have are photographs of the eight painters standing in front of their exhibited works which were later printed in Modern Miscellany (the artists were Pang Xunqin, Ni Yide, Wang Jiyuan, Qiu Ti, Duan Pingyou, Zhou Dou, Zhang Xuan, and Yang Taiyang). Another photograph recently brought to the surface showed members of the Storm Society being photographed underneath the horizontal banner of the exhibition hung at the front door of the World Society Hall on rue Ferguson. ${ }^{2 \mathrm{I}}$

The third Storm Society exhibition was held on the Student Association for Studying in French on rue Bourgeat in October of 1934:

This is an ordinary two-storied semi-detached house. Only the south-facing rooms have usable lighting. But in those rooms-one upstairs and one downstairs - only on the west wall can the paintings be hung. The rooms are divided in the middle by a sliding door on which paintings can't be hung. The space is not made for the purpose of holding exhibitions but it was free. Besides, the Association welcomes it. And we are having the largest number of visitors this time. ${ }^{22}$

20 Pang, This Is How It Happened, 137.

2I This photograph is provided by Ni Yide's family to the author of this article.

22 Pang, This Is How It Happened, 184. With regard to the visual document of this exhibition, we have so far only the historical photograph provided by Yang Qiuren's family. This is a photograph of Mrs Yang at the exhibition. Judging from the background of this photograph, we can grasp most of the exhibited 


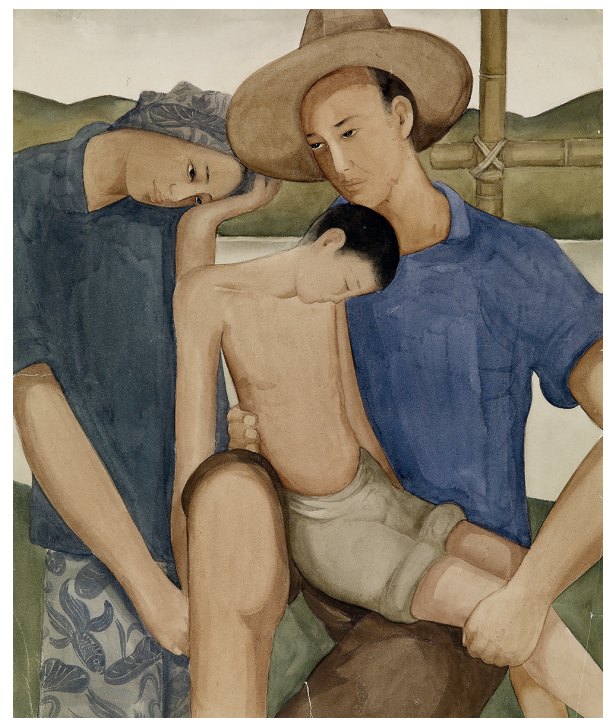

Fig. 2. Pang Xunqin, The Son of the Earth (first draft), 1934. Collection Pang Xunqin Museum of Art. Courtesy of the Li Ching Cultural and Educational Foundation, Taipei, Taiwan.

The exhibition catalogue printed in Art and Life, Pictorial Monthly Magazine (Meixu Shenhuo) 2I published on December I, I935, has become a valuable document and record of this exhibition. ${ }^{23}$ The works exhibited by the Storm Society and reproduced in Art and Life consisted of Pang Xunqin's Composition (also titled Exploitation), Zhou Zengtai's Repairing the Machine, Ni Yide's Mountain Tracks, Qiu Ti's Still Life, and Zhang Xuan's Portrait. The catalogue also includes works that were not exhibited, which included Pang Xunqin's The Daughter of Time (Fig. I), Son of the Earth (Fig. 2), Ni Yide's Portrait of Mrs Shen, Yang Qiuren's Portrait of a Man and Color of Feathers, Yang Taiyang's Portrait of a Friend, and Nude Woman by the Sea, Zhou Dou's Miss Huang and The Person Who Holds Flowers, Zhang Xuan's Nude, Duan Pingyou's Landscape and Still Life, and other works. Among the works, the most important one is Pang Xunqin's Son of the Earth: "The palette of Son of the Earth was that of a subdued and darker tone. As it was hung on the western corner of the room where lighting was bad, the painting appeared even dimmer. However, the viewers loved it." 24

In his Chronicle of the Western-style Painting Movement, Chen Baoyi called the "Storm Society" the "burgeoning Western-style painting group," with Pang Xunqin being considered to be the "key figure":

Since the January 28th Incident, there had been quite a period of lull. But amidst that lull, the Storm Society's first exhibition took place as though fresh flowers are blooming and giving out a little bit bright colors (October I932).

This group gathered force from artists of various schools. The key figures are Pang Xunqin, Zhang Xuan, Ni Yide, Qiu Ti, Yang Taiyang, Zhou Dou, Duan Pingyou, Liu Shi, Zhou Zengtai, and others. (When we say the artists belong to "all sort of schools," we mean that apart from the new-comer Pang Xunqin , artists such as Zhan Xian, Ni Yide, and Liu Shi belonged to the Shanghai school while Yang Taiyang and Yang Qiuren were trained in the Shanghai Art Academy.) During that period of time, the works exhibited by

works and the exhibition layout.

23 The Arts and Life, Pictorial Monthly Magazine 2I (December I, 1935).

24 Pang, This Is How It Happened, 143. 
the Storm Society were bringing in an invigorating air of modernist painting. However, the issue with individual artists' artistic maturity is another matter. But on the whole, these works all expressed a feel of sophisticated brightness. The Storm Society exhibitions can very well serve as an emblem for that period of new transformation. ${ }^{25}$

\section{III.}

In 1935, on the eve of the forth Storm Society exhibition, Ni Yide published a feature article titled "The Circle of the Storm Society" in Yiyun Outings. In this feature article, he revisited, as one of the key members of the Storm Society, his evaluation of the significance of the Storm Society events:

The fourth Storm Society exhibition will be held in the cooling season of autumn. Time flies. I can't believe that since its establishment the Storm Society will celebrate its fourth anniversary. In a society where art is regarded as "a means to certain ends," the fact that the Storm Society, which seeks new artistic techniques, has suffered general negligence and even mockery was quite natural. However, the Storm Society is probably the only art group that could still put up a plucky fight in the dying Chinese Western-style art scene, which is hanging by the thread. So, it is certainly fascinating to recall the moment of its foundation and to observe the lives and art of a couple of our colleagues right before the opening ceremony of the fourth exhibition. ${ }^{26}$

What led to the creation of this kind of modern art style mainly comes from the forms and styles of the Post-impressionism. At its early stage we can detect the corresponding traces of borrowing from and absorption of Post-impressionism. Combining with Ni Yide's analysis, we can trace their respective creative trajectories of the key figures of the Storm Society:

Pang Xunqin: "His works do not exhibit any particular leanings but have indicated various directions. From flat-coating to lines, from realism to art deco, from transformation to abstraction, he seems to be making attempts at the many current art schools in Paris (...). At that time, Zhou Dou was painting human bodies in Modigliani's distorted style: he painted the model of urban prostitute with a thin and long face, elongated neck, sinewy body in thick pigments and neurotic lines. He has conveyed the spirit embedded in that short-lived painter's style. But his style changes all the time: from Modigliani to George Braque to Moïse Kisling. Now he's experimenting with the effects of André Derain's new classism."

Duan Pingyou: "His style is the interplay between Picasso and Derain.

25 Chen Baoyi, "The Chronical of the Progress of Western-style Painting Movement," Shanghai Art Monthly no. 6 (1942).

27026 Ni Yide, "Yiyun Outings," New Epoch (Xinnainjie) I, no. 3. 
He too has been constantly experimenting with new styles. They are both young. We look very much forward to the new development in their art in the future."

Yang Qiuren and Yang Taiyang: "The pair are partners in art from Guangxi. The two are both young artists with creative minds and excellent painting techniques. Because they spend a lot of time comparing notes and conducting research together, the two share an affinity in their painting style. They both strive to achieve the new forms created by Picasso and Chirico while using bright colors that evoke the southern country."

Zhang Xuan: "People might think Zhuang a bit silly because he used the money he earned from selling his works for studying in France twice. When returning to China after his studying in France for the first time, his skills were fairly common like the rest of those who had studied in France. They all used the pointillist vocabulary of dotting the canvas with smudged oil paint. The pointillist results were not impressive. Out of frustration he went to study in France again. This time he unlearnt all the techniques he had previous learnt and moved into a brand new direction. Zhang began by imitating the works of modernist pioneers such as Degas and Cézanne and then came gradually under the sway of Matisse and Derain.

So the works he brought back to China from his second trip to Paris were all his own creation with some Fauvist color. He was often alone in his own room, mixing the colors such as alizarin crimson, pistachio, vermilion, and cream and experimenting his new attempts on canvas. He loves Chinese folk art. He claims that perhaps he could discover something new in Chinese folk art. Right now, he is dedicating to painting women in costume on rice paper with a Chinese brush."

Qiu Ti: "Qiu Ti is the only female artist of the Storm Society. Her masterpiece Flower was reproduced in many pictorial magazines but at the same time the piece was accused of making the mistake by painting the flowers green and leaves red. It does not matter if there exists green flowers and red leaves among the flora and fauna; what matters is that painters are free to change the colors in nature on canvas for decorative effects. And Qiu Ti's Flower was painted in a purely decorative style. Because this painting was awarded the first prize, Qiu was often introduced as a member of the Storm Society." ${ }^{27}$

Just as Ni Yide pointed out:

When we paint Western-style paintings, we do not simply imitate the techniques of Western paintings. We should take the route of expressing what is Chinese with the materials of Western paintings. But when I say 'expressing what is Chinese,' I do not mean painting Chinese subject matters nor do I mean merely adopting some techniques in traditional Chinese paintings. It is 
Fig. 3. Pang Xunqin, Such Is Paris 193I, destroyed 1937. Oil painting. Courtesy of the Li Ching Cultural and Educational Foundation, Taipei, Taiwan.

our ideal to be able to express something that spells thoroughly Chinese in an oil painting while not sacrificing the composition of Western painting. ${ }^{28}$

The phenomenon of the Storm Society for the first time offers the art of modern Chinese oil painting an experience of creatively "stylized" iconography.

First, the Storm Society, led by Pang Xunqin, formed a "new compositional" iconography. Among the Storm Society members, Pang's exploration in diverse and wide-rang-

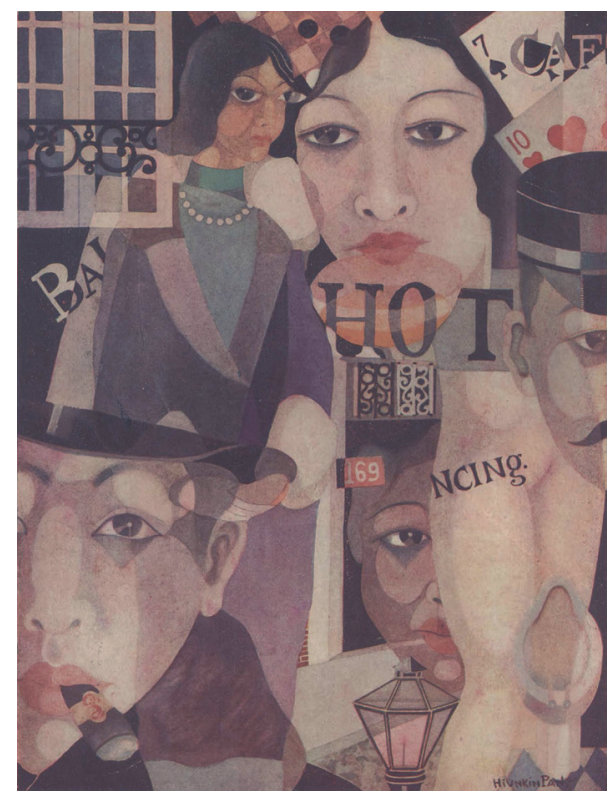
ing styles makes him the figurehead of the movement. Pang often gives his painted object an order of flatness and decorative beauty by deconstructing colors and forms and reconstructing the structure of the body. He creates a musical sense of rational beauty out of existing styles and formats to handle social-scapes and people's lives by mobilizing the mathematical and philosophical concepts of isomorphism and induction. Between referencing mainly to the Cubist techniques of expression and making stylized images by purifying the ontological compositional space, Pang makes "constructional style" his artistic fulcrum. In the year of 1931, Pang created oil paintings such as Such Is Shanghai, Such Is Paris (Fig. 3), Palm, and Untitled. These works basically belong to the category of "decorative composition on a small scale." Some of the paintings were reproduced in pictorial magazines such as Modern Miscellany (Shidai Huabao) and Young Companion (Liangyou Huabao). But "all the original paintings have been either lost or destroyed." ${ }^{29}$

The February I, I93I issue of the Modern Miscellany (published by Shanghai China Art Publishing House) reproduced Pang Xunqin's Such Is Paris and ran an art-critical feature article. This is the first time that an important media outlet reported on Pang's works since his return in 1930:

The bustling and prosperous Paris is constantly moving: the women's laughter, the men's cigarette smoke, the thrill of the flesh and the swing of the lights. Everything is constantly transmogrifying themselves: be it a slab of windowpane, a door, or a jar. No matter how alert your eyesight is, you can hardly capture a stilled impression. While the tip of your brush is on your canvas, the object of your painting is no longer what it looked like a second 
ago. Move. Moving! The glass is in contact with the soft red lips; the finger tips are touching the cold white cards. One minute it is washed clean and the next soiled in dirt.... Such is Paris!

Mr Pang Xunqin was just fresh from returning from Paris and he hadn't put the Paris that he was madly in love with behind him. In the small hours of the morning, when the streets quietened from all that clamor, the Paris that he adores again appeared in front of Mr Pang's eyes. Even the Parisian noise rang in his ears. Then he took up his canvas and created the palette of what he saw and what he heard. There the painting of movement was born. ${ }^{\circ}$

The year 1932 was an important one in Pang Xunqin's artistic career. In that year he was to hold his first solo exhibition and then the Storm Society's first exhibition in Shanghai. The Shanghai Muse Society published L'Art I, no. 3 on September 2I, 1932, in which a short biographical article on Pang Xunqin and the reproduction of his work Café were published. The article runs:

Pang Xunqin was born in Changshu, Jiangsu. He studied painting in France for 5 years, and after having returned to China in 1930, he has continued to paint. Currently he is a member of the Storm Society. Apart from painting, Pang is learned man in matters pertaining to literature, theater, and music. Such is a rare prodigy in modern Chinese art world. Between September I5 and 25 this year, Pang held his first solo exhibition at the China Society for Study of the Arts [Zhonghua Xueyishe] and became the man of the hour, capturing the attention of the Chinese and foreigners in Shanghai. The painting at the top is Pang's recent portrait and the one at the bottom is a reproduction of one of his works, which depicts the scene at a café. His application of composition, form, lines, and colors is rather unique..$^{3 \mathrm{I}}$

During his Storm Society phase, one of the works that Pang feels proud of is an oil painting Wicker Chair (Tengyi). The December 16, 1932 issue of L'Art printed the reproduction of Wicker Chair with a companion piece of criticism:

Pang Xunqin, a Changshu native, lived in Europe for many years. He met Sangyu first in Paris and hang out with him from dawn to dusk. Therefore their works inform each other. Xunqin is the younger one. So, the kind of colors that might have been omitted unconsciously by middle-age people intrigue him tremendously. Because colors offer him a spiritual reward, they leap almost automatically to the tip of his brush.

Particularly in this masterpiece Wicker Chair, of which he is proudest, there are two shades of yellows that are simple, pure, and saturated. The two shades of yellow do not get mixed-up; instead, they show the distinct movements of the flesh and the stillness of the wicker chair. Every line in

30 Modern Miscellany 2, no. 3 (February I, I93I).

3I L’Art I, no. 3 (September 2I, I932). 
the painting is painted economically and sublimely. The painting makes us see through the complexity of the phony world that is nothing but sham showoff. Such is the highest state art can reach.

Xunqin is dedicated wholeheartedly to his art and would have no truck with fame and personal politics. While we rave about his artistic success, we admire all the more his esteemed moral character. ${ }^{32}$

The reason why Pang Xunqin's oil paintings received such fervent attention in the art world back then is because Pang's forms are extremely creative and were rated the top among the Western-style painters of that time. His dual attention to the conventional Western paintings and traditional Chinese folk art led to the organic fusion of rational induction of colors and forms, and emotive transformation of the decorative in Pang's art. Such characteristics give Pang's art a unique modern temperament and patina, which made his name in the early period of the Storm Society.

Fu Lai once commented on Pang's works:

He treats colors as lines, lines as the meridian, the entire life as material and composes his kaleidoscopic dreams. He observes, experiences and analyzes like a mathematician. He also organizes, inducts, and combines like a philosopher....He expresses the spiritual state of pure fantasy with the pure materiality of forms and colors: Such is music without sound, the harmony between form and color. The constitution of the composition itself has a taste of decoration. It is peinture pure. ${ }^{33}$

Second, an iconography of "New Realism" is exemplified by Ni Yide. In his works during the Storm Society period, for example a painting of a corner of a farmer's village and a town south of the Yangtze River, objects are stylized carriers for forms composed of lines and color blocks. By employing an unembellished, bright, and crisp palette, diminishing the literary reference and dissociating realistic perception of the painted objects, $\mathrm{Ni}$ establishes a spiritual projection of "subdued and seclusive autumnal reservation and quietude" to express the subjects on canvas. Ni establishes the artistic pivot of "modish" style by straddling between the expressive forms borrowed from the Fauvism and the forms of purified native culture-scape:

As an oil painter, he has gained deep understanding of the I7th-century Dutch landscapes - the azure sky, the rolling of the shadows of the clouds, and the perspective method grew out of the changing light through time. He keenly appreciates and has analyzed works from the igth-century British landscapes: John Crome's sensitive but simple brushstrokes, John Constable's the bright and crisp palette, the effects produced by J.M.W. Turner's 
expressive atmosphere and light; to the French Barbizon School whose painters - such as Rousseau, Daubigny, and Corot-panegyrized the landscape of Forest of Fontainebleau with their distinctive painting idioms.

He also studies works by the Impressionist painters such as Monet, Sisley, and Renoir, which shone with flames of life. These painters transmogrify light and colors with an acute awareness. But what intrigues Ni most are the exploration the forms' sense of volume first explored by Cézanne, the vanguard of Post-impressionism; André Derain's Fauvist spirit of unadorned solidity; Maurice de Vlaminck's exuberant and vibrant brushstrokes; and Ultrillo's depiction of the urban street atmosphere. ${ }^{34}$

The events held by the Storm Society in the early I930s marked another salient stage for Ni Yide's early artistic development of the Shanghai period. "In 1932 Ni founded 'the Storm Society' together with Pang Xunqin. The pair summoned the younger generation of artists who dared to blaze new trails to challenge the muted, crude, declining and ailing art world with new artistic forms for self-expression. Ni Yide's art has reached such mind-blowing maturity, which was evident from the works exhibited in the three Storm Society exhibitions." ${ }^{35}$

The The Art and Life, Pictorial Monthly Magazine no. 7, published on October I, 1934, reproduced five of Ni Yide's oil paintings, which were mostly created during the Storm Society period: the works were Flower, Musical Instrument, New Autumn in Whampoa, Lilies, and Silhouette. The magazine also ran a special feature article on Ni Yide:

Ni Yide, born in Hangzhou city in the Zhejiang province, is now 30. Ni began his painting lessons in I92I and graduated from Shanghai Art Academy. After his graduation he devoted all his time to literary creation for a while. In 1927 he studied in Japan, focusing on the theories and techniques of modernist arts. On returning to China, Ni travelled around in southern China. During the I930s, he visited the cities along the Yangtze river. He returned to Shanghai and taught at his alma mater when the January 28 Incident took place. Ni has a kind of secure sense of confidence and pure passion in studying art. The artist proclaims that "this solo exhibition is the closure of my previous efforts. From now on I shall work on new development." ${ }^{36}$

34 Xie Haiyen, "Prologue" to Catalogue of Ni Yide's Paintings (Shanghai: Shanghai China Art Publishing House, 198I). Because the majority of Ni Yide's works are lost, this Catalogue contains the only surviving works of roughly 70 pieces, including oil paintings, water colors, and sketches. Among Ni's lost works there are Silhouette (oil painting, circa 1930), Flowers (oil painting, circa 1930), Lilies (oil painting, circa 1930), New Autumn in Whampoa (oil painting, circa 1930), Musical Instrument (oil painting, 1930), Korean Singer Kao Zhongxun, Yaxue the Kitten, Self-portrait, and others.

35 Ibid.

36 The Arts and Life, Pictorial Monthly Magazine 7 (October I, 1934). 
Ni Yide can be said to be an exceptional character in Chinese modern art world who married the role of an art theorist with that of the painter perfectly. Not only did he leave behind a collection of successful paintings but he published a series of books on art theories, including Introduction to Watercolor, Essays on Art, Studies of Western-style Paintings, Introduction to Modern Painting, and An Anthology of Western-style Paintings. As early as in the "Storm Society Manifesto" drafted by him half a century ago, Ni made his belief in the pursuit of art clear. He craved for in the awakening Chinese art world an utterly new spirit, the spirit as in "the cries of the Fauvism and the transformation of the Cubism," or "the ferocity of the Dada and the dreams of the Surrealism." Ni did not set his goal at recreating the pre-I9th-century Western art in China but put emphasis on the various post-Cézanne schools of modernist painting. Because of his sensitivity to Western modernist painting and his clearheadedness gained from his research on art theories, $\mathrm{Ni}$ introduced people to the face of the then nascent Western modern painting early on and his models of choices in Western paintings were not restricted. Ni believed that a painter would lose his own value if he "indulged himself in idle thinking and obliterated realism." Both the Western "Realism" and the modernist "impressionism" are visual revolutions which broaden the meanings of painting.

We can simply judge from the three Storm exhibitions that Ni's signature style in painting was formed in the I930s. Ni admired modernist painters such as Cézanne, Picasso, Matisse, Derain, Vlaminck, Albert Marquet, and Utrillo and his works at times betray traces of imitation of these painters' styles. The crude and strong forms employed in New Autumn in Whampoa have a feel of Marquet's style; the unsophisticated and firm style used in a couple of his still-lifes apparently allude to Derain's while some of the expression in his portraits recall Matisse's modes. Of course, imitating the masters' works does not imply that $\mathrm{Ni}$ Yide has nothing of his own personal style. The tenor of Ni's aestheticism and his style is "to express the overall atmosphere of China without losing touch of the authenticity of Western paintings." Hence the signature of Ni's artistic style of being resolute, bright, unsophisticated and strong. However, his artistic claim of "a world of pure form" wasn't thoroughly realized in his later works mainly because later in his artistic career, Ni sensed that certain art theories of Western modernist schools had their limitations on Chinese soil. And the facts that some of the artists who brandished the slogan of "art for art's sake" in the r920s and the I930s had similar conceptual turn later and the short-lived Storm Society are the best proof of Ni's point.

Of course, in "the world where color, line, and form intersect," each of the Storm Society artists had their own personal preference and priority in terms of aesthetics. But basically they seek similarity among their differences. As a matter of fact, the radical rhetoric of the Storm Society's "Manifesto" had created a general impression on people that the artists all believed in art for art's sake. However, having examined the entire body of works exhibited in the four Storm Society exhibitions, we realize the two sides of their art. For one, these works have "affinity to the style of Parisian art society": 
The Storm Society artists followed the styles originated from the Parisian art world closely. They studied various art styles, extracting the essence of the masters' works of various nationalities while injecting idioms of personal vernacular. They all developed their art in their capacities. The annual large-scale exhibition was stimulating and did not stop until the Second Sino-Japanese War began. ${ }^{37}$

And secondly, "shattering the monotonous and crowd-pleasing artistic phenomenon":

The overall monotony in the subdued oil painting world which aims at pleasing the crowd is about to be crashed down by the violent torrents of movements (...).(I)t's a separate issue whether individual artists' art is mature enough. On the whole, their works more or less give out a sense of sophisticated brightness. The Storm Society exhibitions could serve as an emblem of period of new paradigm shift. ${ }^{3}$

There was no shortage of works concerning social issues and life, which reflected the epochal change in the society.

\section{IV.}

In October 1935, the fourth Storm Society exhibition was held at the China Society for Study of the Art building in Shanghai. It was to be the Society's last exhibition. The exhibition made a public statement: "The number of the visitors was not big, most of which were local arts dilettantes and students. Apparently the scale of the visitors could not be compared to the exhibitions of woodcut prints at that time." ${ }^{39}$

Perhaps the forth Storm Society exhibition carried with itself an air of tragedy at that particular historical juncture. Pang Xunqin once recalled:

The forth Storm Society exhibition would take place where the first one was held at the China Society for Study of the Art. The last two days (of the exhibition) was overcast and there were very few visitors. So the history of the Storm Society came to a gloomy end..$^{4}$

This specific historical juncture of wars and social unrest resulted in the Storm Society's changed course from its point of departure. Struggling between artistic creation and its public acceptance, the growing aesthetic tendency of "pure style"

37 Liang, "China’s Western Painting Movement."

38 Chen, "The Chronicle of the Progress of Western-style Painting Movement."

39 Zhu Boxiong and Chen Railin, 50 Years of Western Paintings in China: 1898 - 1989 (Beijing: People's Fine Arts Publishing House, 1989), 304.

40 Pang, This Is How It Happened, 143. 
advocated by the Storm Society started to look feeble and ineffectual in the face of a deepening sense of national survival amidst national crisis. At a time when the underpinning historical thinking and epochal moods obliged the public to demand propaganda art forms, the contagious effects of arts' aestheticism were no doubt obscured. The Storm Society painters such as Pang Xunqin created works critiquing society, such as Son of the Earth and The Riddle of Life. Society members such as Zhou Dou also painted subjects on labors and expressed the images and life of the people's hardships. Nevertheless, the Society members were soon under police surveillance and were subpoenaed. As a result the business of the Society were put on the back burner and the members dispersed. That was the epochal tragedy of the Storm Society.

After the fourth Storm Society exhibition, most of its members faced the problems of long-term unemployment: they weren't able to live on selling paintings. Others faced menacing threats: "Pang Xunqin had to leave Shanghai." At the same time, members made different artistic demands due to conflicting aesthetic understanding. They had a meeting where ideas were thrashed out and issue a public statement to announce the disbandment of the Storm Society. ${ }^{4}$

Of course, on top of the mismatch between its artistic taste and the appetite of the wider society, and the dissonance among the artists, the dissolution of the Storm Society could be attributed to an irrefutable cause: the financial strain. The society relied on two sources to pay for the workers' wages and advertising fees: loans and the income earned from graphic design for advertisements done by some of the artists. ${ }^{42}$ These factors taken together constituted what Pang Xunqin called "such a dismal situation."

The Storm Society's arts received mixed reviews from its critics of that time. Wu Jiafong recalled how he felt about the Storm Society exhibition after his visit in an article: "I was a young man yet to be twenty. I was studying arts in Shanghai and came to see the (Storm Society) exhibition in person. I remember clearly that their works weren't so radical and were mainly schooled in the styles of Parisian art scene which were under the Fauvism's sway at the beginning of this century. Some individual works imitated Picasso's human modeling of his neo-classical period but these works tended to be on the side of elegant and devoid of the "ferocity of the Dada" claimed in their "Manifesto." Neither is the scale of the exhibition impressive." Sun Fuxi and Zheng reviewed the fourth Storm Society exhibition:

We try to give an evaluation of the fourth Storm Society exhibition. At its inception, people really expected some devastating torrents and terror stirred up by the society. Now we take (the Society's style) for granted and would not 
regard their work peculiar. There are two reasons for such change of attitudes: first, the members of the Storm Society have been honing their skills and now their techniques have matured; second, the exhibitions have trained the audience's senses to get used to such artistic taste.

Out of their dissatisfaction with the official academies' conservatism, each of the members of the Storm Society fully embodied various artistic styles in their arts. And Pang Xunqin's personal style stood out. In works such as Vestiges of Life, Painting the Interior, and Son of the Earth, is decorative style is shown in his constructivist composition and the modeling of concrete shapes. People seemed to be transfigured when they stood in front of these pieces of rational and philosophical works. Pang Xunqin's artistic course took an unexpected turn in the I930s. It was expected that his increasingly matured style could bring diversity to the development in the Chinese modern art world but such optimistic prospect was brought to a standstill. Judging from their appearance, Pang expressed his pursuit of national characteristics in his portraits of the minority peoples, in still-lifes and in landscapes. But in reality, Pang was swerving from the tough course of art which had been hacked open by himself; a burgeoning nationalism is already detectable in his "modernist" portraits and demonstrated great potentials. Instead of being crushed by their surroundings and allowing their artistic plans to be dead ducks, the artists of the Storm Society felt they might as well apply their talents to places where they did not need to forgo their own artistic pursuit but in the meantime could be accepted by their times and the wider society. Hence Pang took the "decorative turn" at the later stage of his life and devoted most of his energy to the creation of and research on decorative arts. Moreover, Pang extended the decorativeness in paintings into pieces that should come under the category of arts and crafts. Such was seen as the most prominent aspects of his academic achievements that most people today think of Pang Xunqin merely as an arts and crafts designer and educator that people have forgotten the fact that Pang was once the man who had brought a greater diversity to the Chinese modern art world.

The fate of the Storm Society no doubt epitomizes the development of modernism in the Chinese oil painting scene in the first half of the twentieth century. We can conclude the history of this period as follows "as a Xihua art group, the Storm Society paved the way for the development of Western modernity. As crisis about national security was getting out of hand - "the August I3 Incident" in 1937 and the further Japanese imperialistic incursions into China - all the Storm Society plans had to be aborted."

What lies behind such historical conclusion is that people saw the yawning gap between the ideals of radical modernist art and social reality of imminent national danger faced by China. People saw the first dawn of modernist art on Chinese soil fading prematurely. Wars and crises extended the dialectics between the realistic and expressionistic idioms which was originated in artistic pursuit into the conflict between realism and expressionism, reinforced the antagonism beyond the realm of art, and then simplified artistic styles into a dichotomy of advancement and retrogression. 
Born into the wrong time, this elite group who sought to revive Chinese art had to keep revising and altering the modes of hosting artistic events in their native land. Their precocious investigation into artistic possibilities and pioneering works appeared rather isolated and unsupported in its historical context. Like a shooting star, the Storm Society flashed across the night of the Chinese art world during the I930s but then soon vanished without a trace into the thin air.

\section{V.}

This article on the one hand restores the rich historical truth of the Storm Society, a Chinese art group with an international reach, through combing through a fair amount of precious historical documents; on the other, it reflects on the cultural issues surrounding the evolution of Chinese modernist art sparked off by the Storm Society phenomenon which grew out of its unique historical cultural context. Last, it considers the ways in which Chinese modernist art, epitomized by the Storm Society, being excellent international art resources for China, can be better protected and renovated in the urban ecosystem where art enjoys a symbiotic relationship with economy.

In recent history the development of art is driven by the process of urbanization. Therefore, when it comes to the question of urban art resources, the primary task is to clarify how we are to conceptualize the culture of art in recent history. The next one is how we collect, accumulate, and disseminate the visual documents that embody and conserve the cities' historical memories. Such academic issues have long had an international profile, not just a domestic one. Such issues have been dealt with in both European and American nations through adopting proper cultural strategies. Therefore, China should develop a top national cultural strategy to handle the problem of Chinese modernist art resources and such strategy would require an international blueprint for collecting and displaying related recourses. Chinese art of recent history often appears unfathomable to the viewers. We might hasten a guess that the reason for this public puzzlement over art has a lot to do with the hefty loss of Chinese modernist art. The scale of the loss is quite unprecedented in the world.

The wars and turbulence in the first half of the twentieth century are the two commonly known objective reasons for the loss of and mislaying of certain works and documents. Such missing parts affect the formation of a more comprehensive system of evaluation and lead to a phenomenon of "not seeing" when it comes to Chinese modernist art resources.

One kind of "not seeing" refers to the serious problem of losing relevant visual documents. Due to historical factors, our native art world lacks the infrastructure and cultural concepts for a centralized and systematic evaluation of Chinese arts resources from recent history. Therefore, we naturally have a problem of "not seeing."

In effect, through organizing exhibitions related to Chinese modernist art, we have already directly touched on the issue of "not seeing." For example, we need the evaluation and the statistics of the scale of what has been lost as opposed to what we still have. And we need to comb through the documents and artifacts 
systematically and offer them cultural interpretations. Such documents include academic ones (college publications, journals, yearbooks, graduation exhibition catalogues), printed documents (books, magazines, artists' work catalogues, exhibition catalogues, special issues of arts magazines and advertisements), nonprint documents (artists' notebooks, manuscripts, letters, drafts, sketches, visual recordings, photographs, recordings, and visual clips), and other related objects and utensils. Apart from Pang Xunqin, Ni Yide, and Yang Taiyang, the other artists who exhibited with the Storm Society such as Zhang Xuan, Zhou Dou ,and Duan Pingyou are only recovered through restoring the history of the Storm Society. However, we have not elucidated the relationship between historical objects and artistic artifacts. Because these documents lack the infrastructure to support a continuous evaluation of our collections, the current support summoned from every corner of the society could only reveal the rough outline of Chinese modernist art. Thus we cannot give full consideration to the richness of its artistic recourses.

Another kind of "not seeing" refers to the sharp contrast between the number of paintings recorded in the catalogues and the existing ones. As the birthplace of the Chinese modern art, Shanghai houses many early works and documents of the renown painters. However, the problem we have here is that there are far more catalogues of the works than the actual work existing. Such "contrast" is a conspicuously peculiar phenomenon. In other words, what "cannot be seen" exceeds "what can be seen." The problem is particularly noticeable in works of Western-style art. For example, according to the documents we have gathered so far, the Storm Society exhibited 35 paintings in total in its four exhibitions: 3 pieces by Wang Jiyuan, 4 by Pang Xunqin, 4 by Ni Yide, 5 by Yang Taiyang, 3 by Zhang Xuan, 3 by Yang Qiuren, 3 by Qiu Ti, 5 by Zhou Dou, 2 by Duan Pingyou, and 3 by Zhou Zhengtai. However, there are only two original paintings existing from the Storm Society period: they are Zhang Xuan's Portrait (exhibited in the second Storm Society exhibition) and Qiu Ti's Still Life (exhibited in the third one). What lies behind the disproportionate ratio of $35: 2$ is the fact that since the birth of the Storm Society there has never been a tradition of collecting systematically and topically in the 80 years of its history. Between the two lines of development of Chinese art of recent history-the ongoing innovation of traditional art and the transformation introduced by Western art-the former has a tradition of collection whereas the later has nothing systematic to speak of. As a result a lack of collection results in long-term deprivation of artistic resources in this regard.

However, beside the objectively acknowledged historical reasons, we need some serious subjective reflections. The fact of the matter is that we do not have an overarching cultural concept and the proper apparatus of policy regarding Chinese art of recent history for effective preservation, management, and promotion. Under the circumstances where art resources are basically scattered, we only think of locating the things we need and how to find related recourse when we hold commemorating events. We need to take it seriously why we lack the concept of long-term and continuing preservation before the events. We cannot make up with our state of "lost memories" through holding relevant cultural 
commemorations. In a nutshell, we need to integrate our art resources and restore the historical conditions by matching of the artistic artifacts and historical objects.

Identifying what are Chinese modernist art resources matters as the top priority of our national cultural strategy. Such strategy would revive our cultural consciousness and confidence, create the two-way promotional system of worthiest international cultural resources, and realize an opportunity of dialogue on equal footing. Also the resources should be regarded public, something to be shared by everyone. The historical objects and artifacts of art related to the Storm Society, for instance, are the highlights of Chinese modernist art resources. The related art resources can only be effectively preserved, integrated, and transformed when the historical memories are restored, the classical status assumed, value assessed, and culture reborn. 


\title{
Joseph Cornell at the Museum of Modern Art
}

\author{
Marci Kwon
}

"It was a real first-born, of the type of case that was to become my accepted milieu." Thus Joseph Cornell described Soap Bubble Set (I936, Fig. I), a wooden box lined with cobalt silk and divided by glass shelves. ${ }^{2}$ Soap Bubble Set was the artist's first box construction, the format for which he remains best known. The work marked a turning point in Cornell's artistic practice, signaling a growing complexity and ambition in his work, and initiating new lines of formal inquiry he would explore for the remainder of his career.

Why did the box construction appear at this particular moment, and what can we make of interconnected world arranged within? This article explores these questions by considering Soap Bubble Set alongside the exhibition for which it was created, the Museum of Modern Art's 1936 "Fantastic Art, Dada, Surrealism" (Fig. 2). Although American art of the I930s is typically associated with government-sponsored realism and regionalism, MoMA's early exhibition program was remarkably expansive and eclectic. ${ }^{3}$ During the early I930s, Barr organized exhibitions of Mexican and American murals, Persian frescoes, theater, and graphic and industrial design, and established curatorial departments devoted to film and architecture. Placing Cornell's work in dialogue with MoMA's early exhibition history complicates the familiar narrative of MoMA as a bastion of teleological formalism, while also elucidating the social and political pressures

I Joseph Cornell, draft of a letter to James Huth, July 20, 1953, box 6, folder 20, Joseph Cornell Papers, AAA.

2 Cornell often leaves his work untitled, leading to many inaccuracies in the titling of his work. I refer to this work as Soap Bubble Set because that is the title used in correspondence to Alfred Barr.Joseph Cornell to Alfred Barr, November 9, 1936, Museum of Modern Art Exhibition Records (MoMA Exhs.), folder 55.2, "Fantastic Art, Dada, and Surrealism," Museum of Modern Art Archives, New York.

3 Beginning with Sybil Kantor's indispensable volume, scholars have begun to nuance the view of Barr as a strident ideologue. See Kantor, Alfred H. Barr, Jr., and the Intellectual Origins of the Museum of Modern Art (Cambridge: MIT Press, 2002); see also Richard Meyer, What Was Contemporary Art? (Cambridge: MIT Press, 2013); Thomas A. Crow, The Long March of Pop: Art, Music, and Design, 1930-1995 (New Haven: Yale University Press, 2015); and Leah Dickerman, "An Introduction to Jere Abbott's Russian Diary 1927-1928," October 145 (Summer 2013): II5-24; Joan Saab, For the Millions: American Art and Culture between the Wars (Philadelphia: University of Pennsylvania Press, 2004); and Kristina Wilson, The Modern Eye: Stieglitz, MoMA, and the Art of the Exhibition, I925-I934 (New Haven: Yale University Press, 2009); Jennifer Jane Marshall, Machine Art, 1934 (Chicago: University of Chicago Press, 2012); Sandra Zalman, Consuming Surrealism in American Culture: Dissident Modernism (London: Routledge, 2018). 
Fig. I. Joseph Cornell, Soap Bubble Set, 1936, Hartford, CT: Wadsworth Atheneum. (C) The Joseph and Robert Cornell Memorial Foundation/Licensed by VAGA at Artists Rights Society (ARS), New York.

\section{Depression}

To apprehend the stakes of Soap Bubble Set, we must first consider the institutional context from which it arose. In an oft-cited irony, MoMA officially opened to the public just days after the stock market crash of 1929. Its first three years of operation coincided with the nadir of the Great Depression, the pre-New Deal era famously described as the "years of the locust." ${ }^{4}$ During this decade, artists worked as print makers, photographers, painters, and muralists, in a variety of styles ranging from realist to abstract, striving to create "art for the people" and engaging in impassioned yet inconclusive debates about how to do so. ${ }^{5}$

MoMA displayed a pronounced sensitivity to the fraught political debates that defined its first year of existence. As art historian Suzanne Hudson has observed, MoMA's founding charter aligned with the period's burgeoning demotic ethos, stating its mission as "encouraging and developing the study of modern arts and the application of such arts to manufacture and practical life and fur-

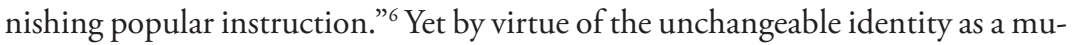
seum, an institution associated with the "sacralization of culture," MoMA found itself at odds with the decade's emergent collectivist tenor.7 In other words, the paradox facing modern art during the I930s was a part of MoMA's institutional identity: its charge was to promote modern art without alienating the public.

These contradictory aims suggest one motivation for MoMA's remarkably eclectic early exhibition program. Barr was uniquely situated to address this question; although he had done his postgraduate work with Paul Sachs at Harvard, his scholarly approach was perhaps most indebted to Princeton medievalist Charles Rufus Morey's anthropological investigation of art and culture in The Index of Christian Art. ${ }^{8}$ While Barr understood this broad array of culture as

4 Gilbert Seldes, The Years of the Locust (America, 1929-1932) (Boston: Little, Brown, 1933).

5 Isadora Anderson Helfgott, Framing the Audience: Art and the Politics of Culture in the United States, I929-45 (Philadelphia: Temple University Press, 20I5), 4.

6 Suzanne Hudson, Robert Ryman: Used Paint (Cambridge: MIT Press, 2009), 37.

7 Lawrence W. Levine, Highbrow/Lowbrow: The Emergence of Cultural Hierarchy in America (Cambridge: Harvard University Press, 1988.); see also George Lipsitz, Time Passages: Collective Memory and American Popular Culture (Minneapolis: University of Minnesota Press, 1990).

8 Charles Rufus Morey drew upon a diverse array of evidence, including liturgical metalwork, tapestries, and panel painting for classification in the Index of 


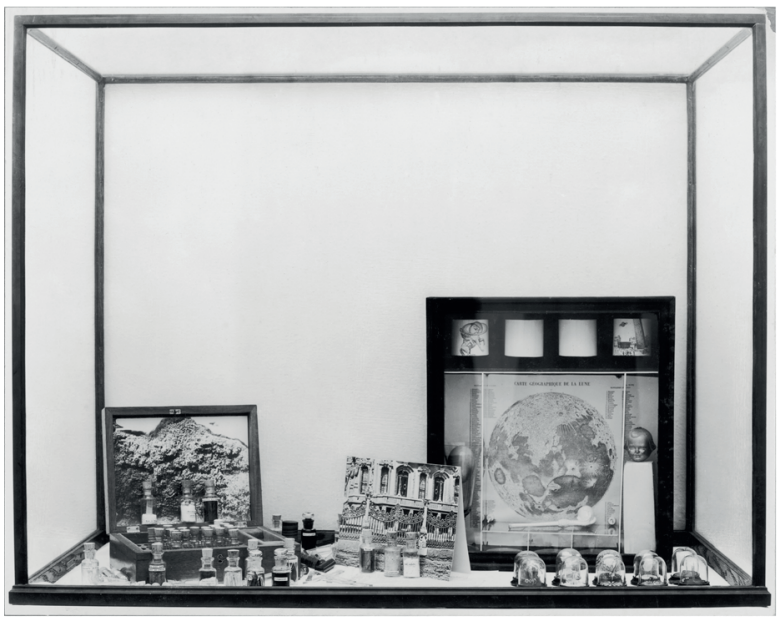

Fig. 2. Installation view of "Fantastic Art, Dada, and Surrealism," 1936, showing Joseph Cornell's Elements of Natural Philosophy, from left to right: Cabinet of Natural History (Object), 1934, 1936-40; Soap Bubble Set, 1936; and ten unidentified bell jar objects. Photographic Archive, The Museum of Modern Art Archives. Digital Image (C) The Museum of Modern Art / Licensed by SCALA / Art Resource, NY.

a crucial aspect of modernism, he also understood the museum's catholic scope as a gesture towards broad legibility. "We hope," he explained to critic Dwight Macdonald, "that showing the best in the arts and popular entertainment and of commercial and industrial design will mitigate the arcane and difficult atmosphere of painting and sculpture."

MoMA's most sustained attempts negotiate the distance between modern art and common experience was its promotion of "folk art," a crucial precedent for "Fantastic Art, Dada, Surrealism." The American vogue for folk in the I930s was descended from, but not identical to, its deployment in the $1920 .^{10}$ The I930s use of folk as a strategy of collectivity was instead aligned with the work of nineteenth-century German Romantic Johann Gottfried von Herder, who believed the national spirit of a people (Volksgeist) could be discerned from its cultural production. ${ }^{\text {II }}$ After the Crash, "folk" was suddenly described in exhibitions and publications as "the art of the common man." Accordingly, it burst into the mainstream in galleries, exhibitions, and especially in the Works Prog-

Christian Art, which he began in 1917, a year before Barr entered university. Following German historian Heinrich Wöfflin, Morey organized the Index thematically and iconographically as a means of tracing stylistic transformation over time. With the exception of Kantor, scholars have largely overlooked Morey's importance to Barr's intellectual formation, and the relationship between Morey's teachings and Barr's attentiveness to architecture, design, photograph, and film during his tenure at the Museum of Modern Art.

9 Alfred Barr to Dwight MacDonald, quoted in Kantor, Alfred H. Barr, 309.

Io As Thomas Crow has discussed, folk art's burgeoning popularity during the I930s can be understood as a form of pastoralism, in which urban elites turned to the countryside as a means of confirming the broad appeal of their values. See Crow, The Long March of Pop.

II Karl Menges, ““Particular Universals: Herder on National Literature, Popular Literature, and World Literature," in A Companion to the Works of Johann Gottfried Herder, eds. Hans Adler and Wulf Koepke (Rochester: Camden House, 2009), I89-2I4. 
ress Administration's efforts to document regional songs, oral traditions, and handicrafts. ${ }^{\text {I2 }}$

The man responsible for introducing this strand of artistic practice to the museum was Holger Cahill, who took over as MoMA's director while Barr was on sabbatical in 1932. ${ }^{13}$ Best known for his directorship of the Federal Arts Project (FAP) of the Works Progress Administration (WPA), Cahill viewed folk art as a means to reconcile the modernism's "revolution in form" and its relationship with radical politics. ${ }^{14}$ As he put it in the catalogue for his exhibition "American Folk Art: Art of the Common Man," which opened at MoMA in 1932, for him folk art was "an expression of the common people and not an expression of a small cultured class," forming a lineage of modernism distinct from cultural elitism. ${ }^{15}$

"Fantastic Art, Dada, Surrealism" encapsulated Barr's attempts to reconcile two seemingly incommensurate value systems: vernacular legibility represented by folk art, and the vanguard artistic practice of Surrealism. The show was the second of five enormous survey exhibitions intended to highlight the major tendencies of recent art. ${ }^{16}$ "Fantastic Art, Dada, Surrealism" was truly dizzying in scope, featuring over 700 objects including painting and sculpture from the fifteenth- to twentieth-centuries installed alongside Disney animation cels, folk art, and the work of children and "the insane." ${ }^{\text {17 }}$ Barr wrote in the catalogue that he considered Surrealism "a serious affair and for many it is more than an art movement: it is a philosophy, a way of life, a cause to which some of the most

I2 See Clayson, Drawing on America's Past for a description of the Index of American Design, one of the most extensive of these projects. See also Federal Writers' Project, American Stuff: An Anthology of Prose \& Verse (New York: Viking Press, 1937); and Federal Writers' Project, These Are Our Lives (Chapel Hill: University of North Carolina Press, 1939).

I3 According to Cahill, the other candidate for the job was James Johnson Sweeney, whom the board rejected for being too difficult. See Holger Cahill, "Interview with Joan Pring," I957, reel 5285, frames 214-I6, Holger Cahill Papers, AAA.

I4 Ibid.

I5 Holger Cahill, American Folk Art: Art of the Common Man (New York: Museum of Modern Art, I932), 6.

I6 The five shows in this series were Cubism and Abstract Art [MoMA Exh. \#46, March 2-April 19, 1936], "Fantastic Art, Dada, Surrealism" [MoMA Exh. \#55, December 7, 1936-January 17, 1937], "Masters of Popular Painting: Modern Primitives of Europe and America” [MoMA Exh. \#76, April 27-July 24, 1938], "Realists and Magic-Realists" [MoMA Exh. \# 217, February IO-March 2I, I943; "Romantic Painting in America”[MoMA Exh. \#246, November 17, I943-February 6, 1944].

I7 The exhibition checklist included the subject headings "Artists and Works of Art," "Art of Children," "Art of the Insane," "Folk Art," "Commercial and Journalistic Art," "Miscellaneous Objects and Pictures of a Surrealist Character," "Scientific Objects," Fantastic Architecture," and "Films" (Barr, Fantastic Art, Dada, Surrealism, 246-62). 


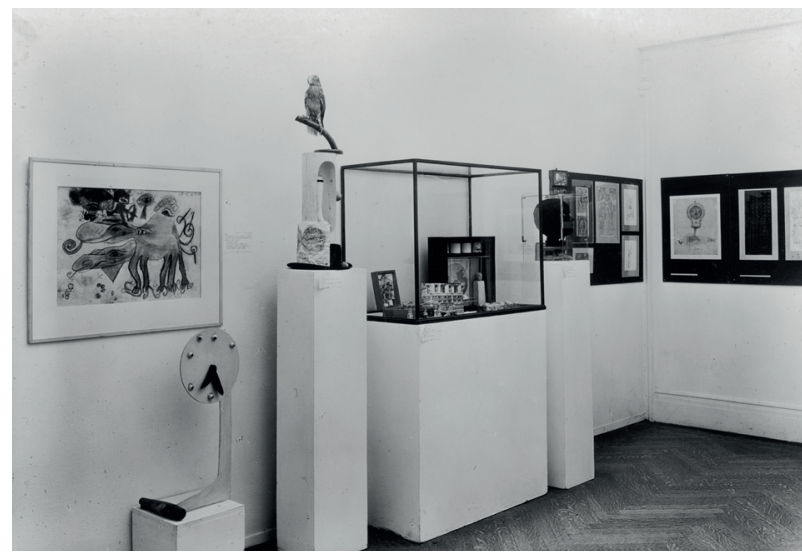

Fig. 3. Installation view of the exhibition "Fantastic Art, Dada, Surrealism," featuring (from left) work by Jean Hoisington, Wolfgang Paalen, Joan Miró, Joseph Cornell, and Marcel Jean. December 7, 1936 through January 17, 1937. Photographic Archive, The Museum of Modern Art Archives. Digital Image (C) The Museum of Modern Art / Licensed by SCALA / Art Resource, NY.

brilliant painters and poets of our age are giving themselves with consuming devotion." ${ }^{18}$ Like all primitivizing formulations, his framing of Surrealism was an argument for universality: by including work by those ostensibly unencumbered by the lessons of modern society-children, folk artists, "the insane"-Barr's construed "the fantastic" as an essential element of human nature.

Cornell became a crucial figure in Barr's attempt to answer the paradox presented by the period's populist impulse, evidenced by his description of Cornell as both an "American maker of Surrealist 'objects" and "self-taught" in the catalogue as well as the decision to install Cornell's work between a sculpture by Joan Miró and a drawing by eleven-year-old Grand Rapids native Jean Hoisington (Fig. 3). ${ }^{19}$ The artist's use of found objects, coupled with his lack of formal artistic training, allowed him to fit both categories at once, embodying the affinities between artistic sophistication and accessibility. In other words, Cornell's association with Surrealism uniquely positioned him as a bridge between folk and fine art, demonstrating the congruence of these seemingly incommensurate categories.

\section{The Fur-Lined Museum}

Soon after its debut, "Fantastic Art, Dada, Surrealism" was summarily dismissed by both cultural conservatives and defenders of the avant-garde for its willingness to elevate the work of "madmen" to art. ${ }^{20}$ Moreover, the exhibition highlighted Surrealism's growing association with commercial culture. As Thomas Crow has

I8 Ibid, 8. See Sandra Zalman, "Vernacular as Vangaurd: Alfred Barr, Salvador Dalí, and the U.S. Reception of Surrealism in the 1930s," Journal of Surrealism and the Americas I (2007): 46.

I9 According to Barr's catalogue, Hoisington's drawing was titled "A God of War Shooting Arrows to Protect the People." Alfred Barr, Fantastic Art, Dada, Surrealism, 260.

20 Sandra Zalman's Consuming Surrealism in American Culture: Dissident Modernism (New York: Routledge, 20I6). 
discussed, Surrealism's animation of objects provided a powerful new visual tool for advertising and fashion. ${ }^{2 \mathrm{I}}$ While curator Chick Austin had proposed the association between Surrealism and fashion from its first public presentation at the Wadsworth Athenaeum, it was not until "Fantastic Art, Dada, and Surrealism" that the movement began to draw attention from the mainstream fashion world. ${ }^{22}$ The exhibition's opening alone, which Russell Lynes later described as "the first truly chic event in the Museum of Modern Art's history," was attended by over 7,00o people, leading Harper's Bazaar to declare Surrealism the season's newest fashion. ${ }^{23}$

The fashion world's recognition of Surrealism was due to the ascent of two men with extensive knowledge of avant-garde art to the period's most influential mastheads. In 1936, modernist luminary Frank Crowninshield became editor-in-chief of Vogue when it merged with Vanity Fair, while Bauhaus-trained designer Alexey Brodovitch became the art director of Harper's Bazaar in 1934. Both had extensive experience presenting modernist artistic production for popular consumption: Crowninshield often featured modernist writers and poets in the pages of Vanity Fair, while Brodovitch's experience at the Bauhaus taught him to view these realms as contiguous. As art director, Brodovitch immediately transformed Harpers Bazaar's staid, illustration-based layouts with stark blackand-white photography and graphic textual experiments. ${ }^{24} \mathrm{He}$ also employed photographers with art world bona fides, including George Platt Lynes. His most extensive employment of artists came in spring 1937, when he commissioned figures such as Man Ray, Salvador Dalí, Eugene Berman, and Cornell to design layouts and covers.

Art critic Emily Genauer's notorious article "The Fur-Lined Museum," published in Harper's Magazine in 1944, pinpoints "Fantastic Art, Dada, Surrealism" as the origin of the museum's perceived decline. Méret Oppenheim's disturbingly tactile teacup, which had become synonymous with the exhibition, was for Genauer the apogee of what she described as the exhibition's "chi-chi pandering." "Fantastic Art, Dada, and Surrealism" paved the way for what she described as "stunts like the display of a tinsel-bedecked shoeshine shoe chair, of the doodlings of inmates of insane asylums, and of the pathetic efforts of frustrated amateurs." ${ }^{25}$ MoMA's focus on these works siphoned away support from "real" artists: "While serious professional artists fight for the recognition that life

2I Crow, "Modernism and Mass Culture in the Visual Arts," 36.

22 Eugene Gaddis, Magician of the Modern: Chick Austin and the Transformation of the Arts in America (New York: Knopf, 2000).

23 As the magazine stated, "One sure thing, you aren't going to find a solitary place to hide from surrealism this winter. Department stores have gone demented on the subject for their windows. Dress designers, advertising artists, and photographers, short stories in the Saturday Evening Post, everywhere, surrealism" ("The Surrealists," Harper's Bazaar, November 1936, I26).

24 Kerry William Purcell, Alexey Brodovitch (New York: Phaidon, 2002).

25 Emily Genauer, “The Fur-Lined Museum,” Harper's Magazine, July I944, I30. 
means to them, the Modern fiddles away its resources, building a precious cult around amateurism." ${ }^{26}$

Genauer's categorization of Oppenheim's object as another example of the "pathetic efforts of frustrated amateurs" suggests the success of Barr's alignment of folk and Surrealism. And she was not alone in her outrage. During the late I930s and early I940s, artists affiliated with professional associations such as the American Abstract Artists and the Federation of Modern Painters organized letter-writing campaigns and protests against they saw as MoMA's willful ignorance of abstract art. A flier advertising action against the museum excoriated it for "attempt[ing] to elevate handicrafts industrial design, and children's art to the highest forms of human endeavor; and develop[ing] the public image of the painter as a madly inspired child, rather than a human being. ${ }^{27}$ For these protesters, the museum's "precious cult of amateurism" denied material support and respect for their practice, which the Works Progress Administration had deemed valuable labor. ${ }^{28}$

MoMA curator James Thrall Soby offered a point-by-point rebuttal of Genauer's article in a remarkable sixteen-page internal museum memo. He wrote that Genauer's argument was premised on a narrow-minded definition of art that refused to recognize "allied arts" such as architecture, design, and film, as well as Romantic or Surrealist works. ${ }^{29}$ Soby also astutely pointed out that Genauer's accusation of the museum's "fashionability" was in fact accompanied by a litany of its successes, quoting her observation that "[The museum's] audiences range from kindergarteners, for whom there is a special Young People's Gallery, to soldiers who come in to see not only the painting exhibitions but also the occasional shows of sketches made at the front by their brothers-in-arms." ${ }^{\circ}$ Reaching such audiences, Soby maintained, had always been MoMA's primary aim, and by this measure "Fantastic Art, Dada, Surrealism" had been a success. What Soby and Barr had failed to account for, however, was the extreme strain such populist ideals would undergo in the subsequent years. And indeed, as Crow has discussed, in 1942 Barr was subject to ouster by trustee Stephen Clark, in part over his support for the "naïve" work of Morris Hirshfield and Sicilian immigrant Joe Milone. ${ }^{\text {I }}$

26 Ibid.

27 "Protest Against the Museum of Modern Art," April 24, n.d., Mary Ryan Gallery.

28 The W.P.A. officially closed in 1942, and it is possible that the increasing vitriol against the Museum of Modern Art for not supporting artists was due in part to the loss of this source of support. I'm grateful to Angela Miller for drawing my attention to the importance of this event.

29 James Thrall Soby, "Statement in Response to 'The Fur-Lined Museum' by Emily Genauer, Harper's Magazine, July, I944," August I8, I944, folder IV.I6, Early Museum History Administrative Records, MoMA Archives.

30 Genauer, "The Fur-Lined Museum," I29.

3I Thomas Crow, "Folk into Art: A Phenomenon of Class and Culture in Twen- 
Fig. 4. Joseph Cornell, Untitled (Mlle Faretti), I933, box construction, II $\times 8 \times 2$ in. $(28 \times 20.3 \times 5.1 \mathrm{~cm})$, private collection. Photograph: Michael Tropea, Chicago. (C) The Joseph and Robert Cornell Memorial Foundation/Licensed by VAGA at Artists Rights Society (ARS), New York.

\section{Structure and Space}

For Cornell, negotiating the period's contradictory imperatives was not only a matter of politics, but of survival. MoMa's recognition of his work could not have come at a more desperate time for the artist. Although he had been working at the Traphagen Commercial Textile Studio since 1934, the job was little more than an act of charity by his mother's friend, Ethel Traphagen. ${ }^{32}$ The difficulty of these years for

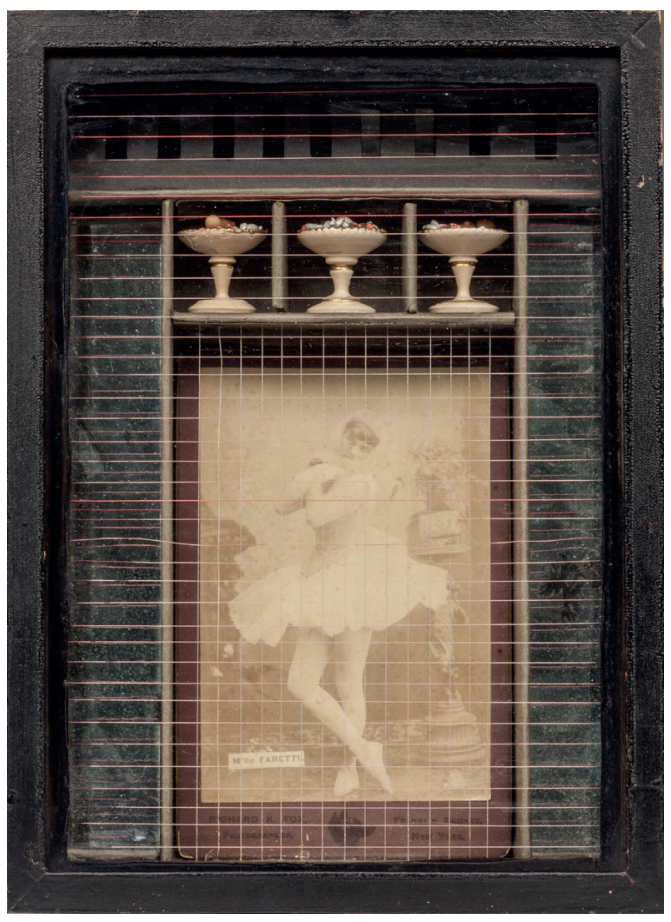
Cornell is evident in a 1954 diary entry, in which he described his compensation at Traphagen as a "starvation wage." ${ }_{33}$ When asked by Barr to participate in "Fantastic Art, Dada, Surrealism," Cornell thus found himself in the precarious position of needing Surrealism to further his public recognition as an artist, and wanting to contest its reduction of his practice to a folk-like naiveté.

Soap Bubble Set's box format can be understood as Cornell's attempt to resolve the competing pressures that defined his participation in Fantastic Art, Dada, Surrealism." Glass shelves edged in bright white paint parcel the box's interior into a grid. Cornell had already begun to explore the effects of a structuring frame in the early I930s. Like Soap Bubble Set, Untitled (Mlle Farretti) (Fig. 4) features a selection of objects arranged around a central image arranged within a frame. Its primary focus is a carte de visite of a ballerina flanked by columns of vertical mirrors. Taut pink threads run horizontally across the width of the frame, while contrasting white thread is strung vertically over the chamber containing the photograph. The resulting composition expands the shell's interior space: the mirrors reflect the pink lines to create the illusion of depth, while the gridded layer sets off the photographic centerpiece. This play of object and im-

tieth-Century America," in Harry Smith and the Avant-Garde in the American Vernacular, eds. Andrew Perchuck and Rani Singh (Los Angeles: Getty Research Institute, 20IO) 205-24.

32 Solomon, Utopia Parkway, 77-78.

33 Joseph Cornell, Diary Entry, June I2, 1954, box 6, folder 29, Joseph Cornell Papers, AAA. 
age, reflection and depth, extends to the chambers above the photograph. Three toy dishes filled with sand and fragments of color glass are arranged on the lintel, their creamy hue and trumpet shape echoing the flounce of the ballerina's tutu. These formal links allow the composition to oscillate between two and three dimensions, as if the objects and images were instantiations of the same phenomenon. While Untitled (Mlle Faretti)'s rectilinear frame and internal formal relationships cast it as a clear predecessor to Soap Bubble Set, the works differ in their wooden shells: at roughly one-third the depth of Soap Bubble Set, Untitled (Mlle Faretti) inhabits a frame rather than a box. While Cornell explored the illusion of space in this earlier work, Soap Bubble Set's additional physical depth gave him a third axis with which to work.

In Soap Bubble Set, Untitled (Mlle Faretti)'s grid is extended to the real space of the box. Ferdinand de Saussure's Course in General Linguistics illuminates the stakes of this formal innovation. In this foundational treatise on structure, Saussure explores how meaning is created from constitutive parts of language. The essay delineates two types of relational structures that impart meaning on individual words: syntagmatic and associative. ${ }^{34}$ Associative relations are created outside the confines of intelligible discourse, and are therefore untethered from the demands of coherent meaning. They are fundamentally subjective, created within memory or thought, and thus illegible to anyone but their maker. The jumbled forms pictured by Lynes's photograph are defined by associative relations: while some objects share subject matter or shape, the only concrete tie among them would seem to be the caprice of Cornell's mind. In contrast, syntagmatic relations exist within a closed system such as a sentence, wherein each word is defined by its relative position in relation to other words. Drawing on Saussure, we might see the box format as akin to a sentence: like the capitalization and punctuation that bracket this closed form, the four sides of the box create an enclosed context that allows meaning to arise from its constituent parts. ${ }^{35}$ The organizational affordances of the grid allows us to see the moon, egg, and head as inhabiting distinct yet contiguous parcels of space. Their paradoxical proximity and distance activates the play of scale: the millimeters between moon and egg stretch into the distance between heaven and earth, creating a sense of depth that is relational rather than illusionistic.

The effect of Cornell's meticulous calibration of structure becomes apparent when Soap Bubble Set is compared with a case of objects assembled by a "psychopathic patient," also included in "Fantastic Art, Dada, Surrealism" (Fig. 5). While superficially similar in composition and material, this object, lent to the exhibition by André Breton, exhibits none of the complex syntagmatic relationships that structure Cornell's work. Rather, the composition is guided by formal

34 Ferdinand de Saussure, Course in General Linguistics (New York: Columbia University Press, 20II), I23-27.

35 Hartigan identifies the shell of Soap Bubble Set as a "Chinese display case," and was the first to note the original blue color of the silk lining. Hartigan, Navigating the Imagination, 6I. 
Fig. 5. Object assembled and mounted by a psychopathic patient on a wooden panel in five small vitrines," exhibited in "Fantastic Art, Dada, and Surrealism." Collection of André Breton.

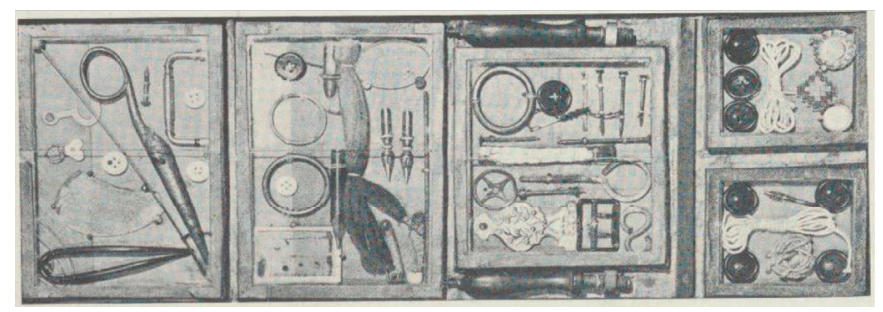

congruence alone, the size of buttons or the similar shape of a nail and pen nib, an extreme version of Lynes's illegible, associative display. Here we see the other side of perceived "amateurism": the simplistic, even instinctive connections created by a child-like or "insane" mind. To be clear, these distinctions are not intended to impose a standard of quality across a diverse field of production, but to delineate the various options open to Cornell within the exhibition. Soap Bubble Set's rectilinear structure represented the only way he could retain both complexity and legibility, a means to claim affinity with the Surrealists while maintaining separation from the movement's connotation of irrationality. The box allowed him to level just enough control over his unruly array of objects without allowing them to lapse into irrational chaos.

With their investment in the enchantment of daily life, Cornell's boxes and cinematic experiments seemed poised to resolve the tension between fine and popular art. As historian Isadora Anderson Helfgott has noted, "It is the paradox of the Depression era that art appreciation grew while the economy failed." ${ }_{36}$ Yet this paradox only became a paradox as the I930s progressed. Russia's unwillingness to intervene in the Spanish Civil War, and Stalin's purges and show trials created a growing disillusionment with Russia on the left, culminating in the signing of the German-Soviet Non-Aggression Pact on August 23, I939. With these events, the focus of the New York art world shifted from the people to the artist, from an art of the public to an art that could resist the corrupting influence of the public, and in doing so provide a bulwark against the mindless submission to a charismatic, enchanting leader. Soap Bubble Set was Cornell's attempt to create a moment of stillness, of connection, in the midst of relentless and inexorable social change. 


\section{通俗现代主义：约瑟夫・康奈尔与民粹主义文化 权玛西}

“它是真正意义上的首个盒子类作品，它也成了我被接纳的环境。” 1 约瑟夫·康奈尔 (Joseph Cornell) 如此评价他的 “肥㿝泡装置” (Soap Bubble Set，图 I）（I936），木盒子里衬着蓝色丝绸，透明架子划 分内部空间，背景是一张月球地图。2 如康奈尔所说，《肥皇泡装置》 是他的第一个盒子结构的作品，也是他最为人熟知的表达方式。一 个典型的康奈尔盒子会包括一组在复杂排布之下经过选择的物品, 日常可见的普通物品密闭在玻璃方框后面。“肥㿝泡装置”在康奈 尔创作实践中是一个转折点，标志了他逐渐增强的复杂性和雄心， 也开创了他此后的艺术生涯中对于形式的新探索。3

康奈尔的 “肥㿝泡装置” 是为参加纽约现代美术馆举办的第一 个超现实主义展览“狂想艺术、达达、超现实主义”（Fantastic Art, Dada, Surrealism）展创作的。这次展览的动因，是基于当时 纽约现代美术馆的传奇策展人阿尔弗雷德 -巴尔（Alfred Barr）希 望倡导那种可以向当时被称为 “人民” 的团结一致群众说话的艺术， 与此同时，进一步开掘这个美术馆与艺术现代主义的联系。 ${ }^{4}$ 我的 论文要探讨的是，巴尔试图将康奈尔定位为一个 “通俗超现实主义

1 Joseph Cornell, draft of a letter to James Huth, July 20, I953. Box 6, Folder 20, Joseph Cornell Papers, Archives of American Art.

2 康奈尔的作品经常是无题，这也导致了很多在作品命名时的不准确性。 我称这一作品为 “肥㿝泡装置” 是因为它曾经出现在康奈尔和巴尔的通 信中。Letter to Alfred Barr, November 9, 1936. Museum of Modern Art Exhibition Records (55.2), Museum of Modern Art Archives, New York.

3 康奈尔继续做他的盒子作品及电影直到 1972 年去世。

4 我对 “public”一词的使用受到麦克尔·华纳（Michael Warner）公众 作为社会想象讨论的影响，这些社会想象不是预先存在的实体，而是经 不断表达而产生的。正如华纳所说：“公众或许是真实而有效的，但是 它的真实性存在其反身性之中，通过这种反身性，对象被询唤出来，赋 予它话语使它存在。” Michael Warner, Publics and Counterpublics (New York: Zone Books, 2002), 67. 
者” 来弥合这个断层的意图，一位艺术家本能地觉察到这个运动的 目标，由此证实了它的普适性。就像我将要论述的，盒子模式是康 奈尔对这种限制性架构的回应，是在不脱离给他提供支持的机构的 情况下，与将他的创作实践歪曲为本能与天真的说法进行抗争的。

因此，“肥皇泡装置” 的出现在 20 世纪 30 年代纽约艺术圈提供 了一种商业主义、左翼政治、超现实主义与民粹主义间（心理）价 值转变的视角。但是, 康奈尔作品所产生的选择最终被证明是县花 一现的。到了 30 年代末，集权主义兴起破坏了这个时期的集体主 义氛围，造就了一个关于幻想与迷醉的理念的危险棺木，最终，让 康奈尔去面对一个已改头换面的文化景观。

“狂想艺术、达达与超现实主义” 展览是巴尔对 20 世纪主要艺 术潮流的系列探讨的第二个。5 第一个展览是八个月前展出的 “立 体主义与抽象艺术” (Cubism and Abstract Art)，获得了批评界的 极大赞誉。 ${ }^{6}$ 尽管巴尔将此前对抽象的研究视为一个关键的教学工 具，他也发现这个主题已成明日黄花，在向左翼批评家贾瑞木 - 克 莱恩（Jerome Klein）评价这个展览时，巴尔的说法是 “它只不过 是近期考古学意义上的一次实践”。 ${ }^{7}$ 相比之下, 巴尔将 “狂想艺术、

5 三场展览分别为立体主义和抽象艺术 (MoMA Exh. \#46, I936 年 3 月 2 日至 4 月 19 日) ; 狂想主义、达达、超现实主义（MoMA Exh. \#55, I936 年 I2 月 7 日至 I937 年 I 月 17 日）; 大众绘画大师 : 欧美早期现代 艺术家 (MoMA Exh. \#76, 1938 年 4 月 27 日至 7 月 24 日)。

6 爱德华·朱厄尔汲取了巴尔的教学目标，写下立体主义与抽象艺术的 目录，“无论如何，带着大量插图的书能帮助学生对现代艺术运动有 更清晰的认识，它应当被视作简单的既成事实，而不是被视为拥护或 是声讨的现象。” Edward Alden Jewell, “The Anatomy of Cubism and Abstract Art,” New York Times (June 7, 1936), 88. 同见 “Cubism an Abstractions,” Christian Science Monitor (March IO, 1936), I4. 展览的 负面观点，见 W.B.C. “The Cult of Ugliness,” Letter to the New York Herald Tribune (March 28, 1936), I2.

7 完整的引用 : “我十年前对立体主义与抽象艺术非常有兴趣，但是从 1927 年开始我渐渐失去了这种兴致。我向你保证我们的工作人员认为 目录的很大一部分是近期考古学意义上的一次实践。”巴尔完全承认这 个 “考古学” 是形式上的而不是社会意义上的，在信中他继续写道: “当 
达达与超现实主义” 视为揭示一种趋向于 “怪异的、梦境的、荒谬 的和神秘的” 以及 “具体化的非理性” 的现代潮流，所有这些特征 他都以“狂想”加以概括。 ${ }^{8}$

因此，“狂想艺术、达达与超现实主义”展览进一步加强了 I93I一I932 年间纽约画商朱利安·列文 (Julien Levy) 和策展人奇 科·奥斯丁（Chick Austin）把超现实主义引入美国的论题。他们 了解，这种对于非理性的投入是内在于所有人类的，而不仅仅存在 于这些先锋艺术的倡导者中间。9 列文和奥斯丁背离了布勒东众所 周知的超现实主义理论，这种理论认为震惊与裂隙是可以成为削弱 资产阶级社会压抑性的手段的。 ${ }^{10}$ 而列文与奥斯丁是将“超现实主义” 看作为所有人类生活的潜流，将之安放在艺术中，也安放在迪士尼 电影、时尚与小报的封面上。

与之前的展览一样，“狂想艺术、达达与超现实主义”在视觉上

然我们都知道迈耶・夏皮罗（Meyer Shapiro）会从社会学角度出版现代 艺术史。”尽管如此声明，巴尔决定 1936 年展出抽象艺术部分史出于社 会角度的考虑。在立体主义与抽象艺术的目录上，他注意到在整个 30 年代出访德国时，纳粹党人对抽象艺术的反感。“这篇文章以及这个展 览，”他写道，“应该献给那些在政治权力下遭受苦难的方圆之中的画家 (和那些受他们影响的建筑师)。” Alfred Barr to Jerome Klein, July 19, 1936. Alfred Barr Papers, Museum of Modern Art; Alfred Barr, Cubism and Abstract Art (New York: Museum of Modern Art, 1936), I8.

8 Alfred Barr, Fantastic Art, Dada, Surrealism (New York: Museum of Modern Art, 1936), 9.

9 这些展览是 “新超现实主义” (Newer Super-Realism), 由奇科 · 奥斯 汀策展，沃兹沃思艺术博物馆，1931 年 II 月 I5-I2 月 5 日; “超现实主义” (Surrealismé)，朱利安·莱维画廊，1932 年 I 月 9-29日。

10 超现实主义的政治含义在布列东的《第二宣言》(Second Manifesto, 1929）有所突破，《第二宣言》移除了《第一宣言》中关于自动主义 （automatism）和机会（chance）的强调。《第二宣言》的政治主张 在布列东的陈述中有所体现：“最简单的超现实主义行为包括持枪冲 入街道，盲目射击，尽可能对着拥挤的人群扣下扳机，”他希望这能 摧毁资产阶级的 “陏落和压抑”。Andre Breton, “Second Manifesto of Surrealism" reprinted in Manifestoes of Surrealism, trans. Richard Seaver and Helen R. Lane (Ann Arbor: University of Michigan, 1969), I25. 
令人晕眩, 展出了超过 700 件时间跨度从 $15-20$ 世纪的雕塑与绘 画作品，这些作品与迪斯尼的动画、民间艺术、儿童与 “疯人” 作 品放在一起。 ${ }^{11}$ 巴尔在展览目录中说，他认为，超现实主义是 “一 个严肃的事件, 而且对很多人来说, 它不仅是一个艺术运动: 它也 是一种哲学，一种生活方式，一个让我们时代最具天才艺术家与诗 人付出他们的热情的原因”。12 就像所有原始主义样式, 这种对超现 实主义的概括是一种普适性的论调, 通过那些表面上阻碍了现代社 会的人的作品来加以呈现，儿童、民俗艺术家、疯子等, 巴尔将 “狂 想” 建构为人类本性中的一种基本元素。

康奈尔敏感地适应了纽约现代艺术博物馆第一次重要的超现实 主义展览的修辞环境。在与巴尔协商他参加展览可能性的通信中, 康奈尔要求他纠正在最近一期《时尚芭莎》(Harper's Bazaar) 中 将他的作品称为 “梦境的客观化” (Objectification of dreams) 的 描述。他对这篇文章所写的 “如果我梦到将一根针刺入一个木球, 那么，我醒来后就会这么做” 有所抱怨，之后，坚定地说 : “我并 不认同超现实主义者的潜意识与梦境理论, 虽然我十分欣赏他们的 作品, 但我从来都不是一个真正的超现实主义者, 而且, 我认为, 超现实主义拥有比它业已开掘的更为健康的可能性。” ${ }^{13}$ 这封 1936 年 的信，是康奈尔最早有关超现实主义的可考的评论，表明他对将自 己的作品仅视为潜意识的表达的想法感到不适。《时尚芭莎》将他 的创作过程描述为梦境的字面转译, 这种说法遮蔽了他在研究、收 集和组织那些构成他作品的不同材料时所付出的努力。换句话说，

11 展览目录包括标题 “Artists and Works of Art,” “Art of Children,” "Art of the Insane," "Folk Art," "Commercial and Journalistic Art," "Miscellaneous Objects and Pictures of a Surrealist Character," “Scientific Object,” “Fantastic Architecture” 和 “Films”。Barr, Fantastic Art, Dada, Surrealism, 246-62.

12 Barr, Fantastic Art, Dada, Surrealism, 8. 可以预见的是, 这一构成引起 了布列东和保尔 - 艾吕雅（Paul Éluard）的不满，他们呼吁巴尔遵照他 们出版的理论, 但无济于事

13 Joseph Cornell, Letter to Alfred Barr, November 9, 1936. Exhibition File, Fantastic Art, Dada, Surrealism, Museum of Modern Art Archives. 
视他的作品为潜意识的表达就固定了他的作为超现实主义者的身 份，同时也模糊了让他的作品得以根基坚固的意图、劳作和信念， 这种对于艺术家的幼稚认识一直延续到现在。14

康奈尔对他在 “狂想艺术、达达与超现实主义”展览中的身份 担心是有充分理由的。因为长期被艺术史家脈病为目的论的形式主 义的堡垒，纽约现代艺术博物馆事实上因为表现出对充满政治议题 的讨论强烈敏感，第一年，就对展览的存在下定义。 ${ }^{15}$ 就纽约现代 艺术博物馆而言，这些问题不仅是意识形态的，还关乎生存。处在 一个遭到嘲讽氛围里, 现代艺术博物馆恰好是在 1929 年 IO 月 24 日, 也就是股市大崩盘的几天之后正式向公众开放。它头三年的运营都 伴随经济大萧条带来的低谷，前新政时代被描述成为 “破坏者的年 代”。16 考虑到它是由包括洛克菲勒（Abby Aldrich Rockefeller）在

14 认为康奈尔是一个不关心外面世界的古怪梦想家的观点在黛博拉 - 所罗 门 (Deborah Solomon) 的畅销传记《乌托邦大道》(Utopia Parkway) 中被证实。尽管近期学界试图以他广泛的网络联系以及对文化的深入 研究来反驳这一观点, 但艺术界在讨论他的艺术作品时仍旧指向他 唯一的传记。例如史蒂芬·班恩最近写到康奈尔说，“但是这种“怀 旧' 或许可以理解为康奈尔成年时期的一种特殊形式，是对童年父亲 去世前全家被迫搬离曾经温馨舒适的房子这一经历造成的对安全感 的渴望。” Stephen Bahn, “Cornell and the Tradition of Curiosity,” in Joseph Cornell and Surrealism, eds. Matthew Affron and Sylvie Raymond (Charlottesville: University of Virginia Press, 2015), 29; Deborah Solomon, Utopia Parkway: The Life and Work of Joseph Cornell (Boston: MFA Publications, 2004).

15 从西比尔 - 坎特 (Sybil Kantor) 的书开始，学者们针对巴尔的观点 展开热烈讨论。见 Sybil Gordon Kantor, Alfred H. Barr, Jr., and the Intellectual Origins of the Museum of Modern Art (Cambridge: MIT Press, 2002); Richard Meyer, What Was Contemporary Art? (Cambridge: MIT Press, 2013); Thomas E. Crow, The Long March of Pop: Art, Music, and Design, 1930-1995 (New Haven: Yale University Press, 2015); Leah Dickerman, "An Introduction to Jere Abbott's Russian Diary I927I928," October I45 (Summer 2013): II5-24.

16 关于富兰克林·罗斯福就职典礼前大萧条时期的经典论述，见 Gilbert Seldes, The Years of the Locust (Boston: Little, Brown, and Company, 
内的四位富贾一同创建，他们都希望建立一个可以同伦敦的泰特美 术馆或巴黎的卢森堡博物馆相媲美的现代艺术殿堂, 很多人将这个 博物馆视为导致大萧条的精英主义文化的象征就不奇怪了。 ${ }^{17}$ 新政 拥护者爱德华 - 布鲁斯（Edward Bruce）1933 年嘲笑道，现代艺术 博物馆被很多人认为是 “洛克菲勒家族最近奉献出来的一个势利小 丑, 这个家族将自己的死亡之手伸向了一切他们可以碰到的东西”。1 凭借这种无法变动的博物馆身份以及与洛克菲勒家族的联系, 纽约 现代艺术博物馆发现自己与 30 年代出现的集体主义呼声龃龉不合。

换句话说，30 年代面对现代艺术时的矛盾是纽约现代艺术博物 馆体制身份的一个部分：它的职责是在不脱离公众的情况下，促进 最为前卫的艺术的发展。尽管成立于 I93I 年, 惠特尼博物馆因其美 国艺术博物馆的身份，从未像现代艺术博物馆一样面对这样严峻的 身份问题。而且，格尔特鲁德·凡德比尔特（Gertrude Vanderbilt） 与格林威治村的艺术群落关系紧密。 ${ }^{19}$ 对于这个问题, 巴尔处在 一个非常特殊的位置上; 尽管他的研究生学业是在哈佛大学保罗 - 萨驰 (Paul Sachs) 指导下完成的, 但是, 他的学术研究方法也 许更多受到了普林斯顿大学中世纪研究专家鲁福斯 - 莫瑞 (Rufus Morey) 《基督教艺术索引》(The Index of Christian Art) 中对艺术 与文化的人类学研究的深刻影响。 ${ }^{20}$ 追随莫瑞开放的文化态度, 巴

1933).

17 关于更多现代艺术博物馆富贾的野心，见 Russell Lynes, Good Old Modern: An Intimate Portrait of the Museum of Modern Art (New York: Atheneum, I973), I3; 苏珊娜 ·哈德森（Suzanne Hudson）指出， 1929 年的现代艺术博物馆受纽约教育部指令 “提供大众化教学”。Suzanne Hudson, Robert Ryman: Used Paint (Cambridge: MIT Press, 2009), 37. 18 Richard D. McKinzie, The New Deal for Artists (Princeton: Princeton University Press, 1973), 43-47.

19 更多关于惠特尼博物馆, 包括它的前身惠特尼工作室以及格尔特鲁德 - 凡德比尔特·惠特尼和美国艺术家的介绍，见 Avis Berman, Rebels on Eighth Street: Juliana Force and the Whitney Museum of American Art (New York: Atheneum, 1990); Flora Miller Biddle, The Whitney Women and the Museum They Made: A Family Memoir (New York: Arcade, 1999). 
尔组织了有关墨西哥与美国壁画、波斯湿壁画、剧场、图像与工业 式设计的展览，并且成立了服务于电影与建筑的策展部门。 ${ }^{21}$ 正如 他之后对批评家德怀特 - 麦克多纳德（Dwight Macdonald）所解 释的那样，他认为，这种天主教视角对这个博物馆的观众有所禆益。 巴尔说，“我们希望这些展示艺术、大众娱乐及商业与工业设计中 的最佳作品的展览，可以缓和绘画和雕塑带给我们的神秘与艰深的 氛围”。 22 按照这个思路, 就不难看出巴尔是把超现实主义对于现成

挂毯以及《基督教艺术索引》中的版画，这一研究从 1917 年开始，即 巴尔进入大学一年前。继德国史学家海因里希·沃夫林 (Heinrich Wöfflin）后，莫瑞以主题和图像的方式整理了《基督教艺术索引》，以 此追踪随着时间变化的文体转型。除了坎特外，学者们很大程度上忽视 了莫瑞对影响巴尔知识构造产生的重要性，以及莫瑞的教学与巴尔关注 建筑、设计、摄影、在现代艺术博物馆期间任职期间的电影等方面的关系。 正如林肯 - 科尔斯坦 (Lincoln Kirstein) 后来回忆巴尔时说: “他认为 艺术是人类学, 无论对象是什么, 其本质都是属 (Genus)、种 (Species)、 目 (Order)。” Lincoln Kirstein, quoted in Kantor, Alfred H. Barr, Jr., 234 .

21 正如坎特所言, 早在 1929 年博物馆成立之初, 巴尔就希望在 MoMA 加入各种各样的媒体, 这一想法在他的 “多部门计划” (multi-department plan）中提出，该计划还包括建筑、摄影、工业设计以及电影。他的这 一建议被 MoMA 的董事会和四位 “态度坚硬” 的创始人拒绝，他们更 倾向于专注在狭义范围内的绘画和雕塑。在他第一次任职馆长期间组 织的展览包括迭戈·里维拉 (MoMA, Exh. \#I4, I93I 年 I2 月 22 日至 I932年 I 月 27 日) ; 现代建筑 : 国际展览（MoMA，Exh. \#15, 1932 年 2月9日至 3 月 23 日）; 美国画家和摄影师的壁画（MoMA，\#16，1932 年 5 月 3 日至 31 日) ; 波斯壁画 (MoMA, Exh. \#19, 1932年 Io 月 I2 日至 II 20 日)。

22 巴尔完整的引用表明他相信纯艺术与大众艺术的融合可以通过其他方式 实现，“通过同一屋檐下的展览，将（这些媒体）与当下和近期的最佳 绘画作品、雕塑等一同展示。我们已经在家具、餐具、车类等艺术设计 领域尝试了类似的事。反之亦然，我们希望这些展示艺术、大众娱乐及 商业与工业设计中的最佳作品的展览，可以缓和绘画和雕塑带给我们的 神秘与艰深的氛围。这一类非功利主义性质作品有助于强调电影及工 艺品的存在是定性基础上的事实。” Alfred Barr to Dwight MacDonald, 
品的重视理解为这一趋势的自然延伸。

因此，康奈尔成了巴尔试图展示先锋运动的普适性的关键人物。 虽然艺术家对现成品的运用显然肇始于超现实主义，康奈尔本人缺 乏艺术训练的背景，也使得他符合那种 “自学成才” 的民间艺术家 身份。在 20 世纪 30 年代的美国，“自学成才” 或 “民俗” 的说法, 因其包含的业余与本能的幼稚内涵，而成为康奈尔避之唯恐不及的 标签。尽管他求助于巴尔，“狂想艺术、达达与超现实主义” 的目 录还是给康奈尔贴上 “超现实主义器物的美国制作者” 的双重标签。 巴尔将康奈尔作品放在超现实主义雕塑家胡安・米罗（Joan Miro） 的作品与一件出自年仅十一岁的大急流村孩子简 - 霍兴顿（Jean Hoisington）之手的素描之间。 ${ }^{23}$ 那么，在目录与展览中，巴尔都 是将康奈尔定位在沟通两种此前无法调和的价值的桥梁的位置上。

对康奈尔来说，协调这种矛盾不仅是政治问题，也是生存问题。 与此同时, 他试图从一个可能让他的创作意图变得模糊的运动中来 确认自己的独立性，在给巴尔的信中，康奈尔艰难地强调他对超现 实主义的 “激赏”，这表明他并不情愿从这个运动中全然脱离出来。 毕竟，他的作品能在现代艺术博物馆及时尚杂志出现，是他同超现 实主义的联系带来的好处。当巴尔要求他参加这次展览时, 康奈尔 发现自己处在一个危险位置: 需要借助于超现实主义来扩展他的作 为一位艺术家的公共认知，同时，他也想要辩驳那种把他的艺术实 践简化为民间的天真烂漫的说法。此时的康奈尔，这种阶段性的对 于公众的关注，既是一种接纳的方式，同时也是一种边缘化。

康奈尔的第一件盒子结构的作品 “肥㿝泡装置” 可以理解为是 一种缓解或悬置那些定义 “狂想艺术、达达与超现实主义” 展览中 的相互竞争压力的尝试，坚持艺术家对于超现实主义的身份认知， 同时拒绝这个术语的原始意涵。“肥㿝泡装置” 构图的最动人之处 就是它的对称结构，是通过在一个透明玻璃隔板组成的网格中排布 各种东西而创造出来。位于中央隔间两侧的单元里，有一只放在玻 璃饮料杯中的鸡蛋, 底座上是一个玩偶的头。在 “肥㿝泡装置” 中,

quoted in Kantor, Alfred H. Barr, Jr., 309.

23 根据巴尔的目录，霍兴顿的画的名称为 “A god of war shooting arrows 
这些东西变成了由其自身形式逻辑所规范的自足世界的一部分。玩 偶的头的不同寻常的颜色，让它与对向单元空格中的鸡蛋，以及顶 部右侧角落拼贴的蔓草纹样装饰联系在一起，表现出一个类似浅绿 调的环状星球。在这件作品中，人们可以感受到这种盒子的模式是 如何让康奈尔在各种成分混杂的材料中突出这些形式关系，强调它 们之间的关联性，而非孤立状态。

康奈尔是以这些想法进行实验，作品 “无题”（Mlle Faretti, 1933）与 “肥㿝泡装置”一样，是由一系列放置在现成木质容器中 的物品组成。中央隔间，不再采用月亮，而是用了一张两侧有镜子 的芭蕾舞演员的照片。绷紧的红线水平穿过盒子，与之相对的是 垂直向度的白色线条，在照片上创造出栅，呈现出深度错觉的效 果 : 镜子反射红线，营造出盒子双重空间错觉，与此同时，照片前 面的格栅引起对中央隔间物理性退缩的关注。这种物体与图像，表 面与深度的游戏延展到照片上方的隔间，展现的是装满沙子和彩色 玻璃片的作为玩具陈设用的盘子。在这种对内在形式关系的关照方 面，“无题”（Mlle Faretti）显然是 “肥㿝泡装置” 的前身。然而， 让两件作品区别开来的，则是作为基底使用的木质外壳 : 差不多只 有 “肥㿝泡装置”三分之一的深度，“无题” 更像是在一个框架中， 而非盒子里。如果康奈尔在这件早期作品中是为了玩味空间中的错 觉，那么，“肥㿝泡装置” 所增加的物理深度，就赋予了他的作品 以第三个轴线，以此进行创作，就导致了一种戏剧性的效果。

《肥㿝泡设置》的主要隔间里，没有摆放照片，而是放了一张月 亮环形山的地图，由玻璃隔板组成的网格所框定。月亮的圆形回应 了盒子前景中圆形鸡蛋与娃娃的头。此处, 图像与物体的并置取得 的效果远超 “无题” 中的形式和谐，它们之间的毫厘之差可以延伸 至月亮与地球之间千万英里的距离，因此，是隐喻地延展了盒子的 深度。空间的延展性，不论是在形式还是图像志意义上，都被这个 白色黏土的管状物所强调，一个吹肥㿝泡的玩具，正如克尔斯滕. 霍夫因（Kirsten Hoving）指出的，球状形式是特定时期流行的宇 宙快速膨胀的比喻。 ${ }^{24}$ 如康奈尔之后的描述，这些膨胀球体从地面

24 霍夫因仔细研究了书上关于康奈尔和当代宇宙发展的联系的细节。在 她看来, 《肥㿝泡装置》是一篇逐层递进的科学探索文章，从伽利略 
漂浮到空中, 将大地和天空联系起来, 它们变成 “脆弱的发光小球, 它们又成了熠熠门伢但更具持久性的星球。” 25

是什么让康奈尔将这样一个刻板严谨结构加诸到这些物体上 呢? 费尔迪南德 - 索绪尔 (Ferdinand de Saussure) 《普通语言学 教程》(Course in General Linguistics) 是从构成要件来说明意义 的，这为理解康奈尔第一件有关盒子的作品提供了模式。索绪尔区 分了两种通过单个语词传递意义的相互关联的结构类型 : 句段关 系 (syntagamatic relations) 与联想关系 (associative relations)。 ${ }^{26}$ 句段关系基本是线性的。比如形成的，在如句子的组合结构中，每 个词是由它之前与之后的内容来定义的。相反，联想关系则是创造 话语限制之外的东西，因此，就不受连贯一致的意义要求的束缚。 它们基本是主观的，通过记忆或思考来创造，除了作者本人之外， 对任何人来说都难以辩认。通过将这些物体放在一个盒子中，康奈 尔突出了其中的特定形式关系。尽管不是严格的句段式，这个盒子 结构让我们思考在一个有内容的单元中的各物体间的关系, 那是由 一系列空间规则所掌控。某种程度上，这件作品中的木质框架就像 一个句子, 创造出一个让意义从其组成部分衍生出来的封闭语境。 27

“肥㿝泡装置”与另一个由“精神病患者”组构的物品盒子比较时, 后者也在 “狂想艺术、达达和超现实主义展览” 中展出，康奈尔对 结构细致校验的重要性就显而易见了。尽管从表面看，构图与材料 都很接近，这个由安德烈·布勒东借来的东西并没有表现出康奈尔

对月亮的研究到令人兴奋的新的宇宙扩张理论。” 其他关于《肥㿝泡 装置》的重要阐述，见 Lynda Hartigan, Joseph Cornell: Navigating the Imagination (Salem: Peabody Essex Museum; New Haven: Yale University Press, 2007); Jodi Hauptman, Joseph Cornell: Stargazing in the Cinema (New Haven: Yale University Press, 2000).

25 Joseph Cornell, I948, quoted in Dore Ashton, A Joseph Cornell Album

(New York, Viking, I974), IIo.

26 Ferdinand de Saussure, Course in General Linguistics (New York:

Columbia University Press, 2011), I23-27.

27 哈蒂根 (Hartigan) 认出《肥㿝泡装置》的外壳像一个 “中国的陈列盒”, 
的盒子装置的那种复杂的句段式的关联。其构图只是单纯地由形式 一致性所主导，诸如纽扣的尺寸或者钉子和钢笔尖的相似形状。在 这里，我们看到了“业余性” 的另一面，即出自孩童或 “疯子” 的 思想的直觉联系。需要说明的是，这些区别并不是想要把一个品质 的标准贯穿到生产的多样化的领域，而是想要在这个展览中辨析对 康奈尔作品的不同理解。“肥㿝泡装置” 的严谨结构展现出他的同 时保持复杂性与可读性的独特方法，这种方法使他既可以主张与超 现实主义的纽带，又保持了与这个运动的非理性内涵的分离。这个 盒子让他可以对那些不规则的物品进行恰当掌控，避免陷入混乱之 中。

如果康奈尔可以在艺术与手工制品的界限中创造出一个县置空 间，巴尔就不会有这样的选择了。在首次展览后，“狂想艺术，达 达和超现实主义” 展同时受文化保守主义者和先锋艺术的捍卫者的 谴责，理由是这个展览要将 “疯子” 的作品提升到艺术境界。在 一个指责的评论中，保守主义批评家托马斯·克莱文（Thomas Craven）宣称这个展览是 “国际药剂师调制的劣质艺术制剂…… 这些艺术怪胎应在帐篷里展览，与双头的牛犊，与那些纹身的俊 瓜站在一起。”正是由于这种反应，“无名艺术家协会”（Société Anonyme）元老凯瑟琳·德瑞尔（Katherine Dreier）在给巴尔写 信时, 深感恐惧, “你们好像是故意要把这些画作挂在展厅里, 聚 焦那些变态的东西”! ${ }^{28}$ 巴尔并不想消除德瑞尔的恐惧, 他回应道, “天 才就在于对童年富于想象力的才能的保持”。29德瑞尔没有被说服, 她撤出了对这个展览的后续投资。

28 她继续写道，“超现实主义艺术家试图实现创造性想象一种可以比较的 自由，但是他们与儿童和疯子一个基本的不同在于：他们可以准确分辨 想象世界与真实世界的区别，但儿童和疯子通常不行……就我个人而 言，我认为对那些没有艺术感知力的美国大众来说承担这样的费用无疑 是一件危险的事。很多离开你展览的人都会感到一头雾水!!” Katherine Dreier, letter to Alfred Barr, February 27, 1937, Exhibition Files, Fantastic Art, Dada, Surrealism, Museum of Modern Art Archives.

29 Alfred Barr, response to Katherine Dreier, Exhibition Files, Fantastic Art, Dada, Surrealism, Museum of Modern Art Archives. 
尽管两人立场截然对立，德瑞尔和克莱文都意识到巴尔的探索 是对所谓 “高雅艺术” 的神圣性的潜在威胁。毕竟，如果民间艺术 和超现实主义所提出的高雅艺术也可包括那些在没有艺术动机的情 况下创作的作品, 那么, 我们该以怎样的标准来区分艺术和艺术之 外的物质世界呢? 通过回到这些疆界和壁垒建立之前的节点, 康奈 尔的玻璃柜是在强调它们的不可分离性。巴尔并不成功的策略受到 了惩罚：“狂想艺术、达达和超现实主义” 展促成一种事态，即在 1942 年，巴尔因博物馆董事斯蒂芬·克拉克（Stephen Clark）的 操作而被罢免, 这件事的部分原因是巴尔支持了莫里斯 - 赫斯菲尔 德（Morris Hirshfield）和西西里岛移民祖马龙创作的 “天真” 作 品。30 不过, 从观众角度看, 巴尔的展览事实上是成功的: “狂想艺 术、达达和超现实主义” 展吸引了前所未有的人潮, 还有主流出版 物的巴结示好。这种矛盾状况说明, 巴尔实际上是触碰到了比这次 展览给美术所下定义更为重大的问题, 一种不久之后会在世界范围 内产生破坏性的后果。

“狂想艺术、达达与超现实主义” 展览发生在快速转换的艺术版 图的交点上，其中，走向集体主义的要求逐渐让位于一种对商业主 义与集权主义的恐惧。 ${ }^{31}$ 余下讨论将聚焦在这个故事的一个切面上,

30 Thomas Crow, "Folk into Art: A Phenomenon of Class and Culture in Twentieth-Century America," in Harry Smith and the Avant-Garde in the American Vernacular, eds. Andrew Perchuck and Rani Singh (Los Angeles: Getty Research Institute, 20I0), 205-24.

31 这些观念间的不兼容可以从美国人民阵线 (People' s Front in the United States）的命运中看出来，美国人民阵线通常被称为人民阵线 (Popular front)。为了应对国际上对欧洲日益增长的法西斯主义崛起 的担忧。人民阵线出现于 1935 年的美国作家大会 (American Writers' Congress), 急需将不稳定的左翼分子统一为一个反法西斯联盟。正如 安德鲁·海明威 (Andrew Hemingway) 所写，人民阵线文化政治的关 键层面是它对意识形态和文化多元主义的承诺 : “ “阶级反对阶级” 阵线 很大程度上已弃之，对无产阶级的豪言壮语也已不抱希望，《工人日报》 上的语言和内容也有了很大的转变。政党作家对疯狂的体育、流行音乐 和主流电影产生新的同情。” 然而，这种方式看似民主，人民阵线却被 想斯图尔特 - 戴维斯（Stuart Davis）这样的激进左翼分子视作是现代主 
审视反击民粹主义是如何改变了 20 世纪中叶对超现实主义的解读 的。的确，也就是在这样一个让人兴奋的语境中，克莱蒙特·格林 伯格的作为典范的 “前卫与媚俗” 出现了。 ${ }^{32}$ 这篇具有奠基意义的 文章讨论了很多美国现代主义的问题，而且，格林伯格有力地展现 并预示了 20 世纪后半叶的许多美国艺术的论题。 ${ }^{33}$ 从这个章节勾 画的历史视野出发，格林伯格文章以最高超的技巧而将 30 年代政 治与艺术的各种状况条分缕析地融入到一个具有强有力的道德清晰 性的表述中，这正是那个政治急剧动荡年代所稀缺的品质。对格林 伯格来说, 媚俗是一种 “仿造的艺术”, 其力量就在于它的操控能力。 与极权主义一样，它并非受制于单一意识形态（他认为，斯大林与 纳粹都利用了这一点), 可以被用来教化大众或诱骗他们进行消费 的。

令人惊讶的是，对媚俗如此不屑的格林伯格却对康奈尔的评价 十分之高。1942 年，他是这样描述康奈尔的作品 : “这些腹部填满 了鸟类、顶针、铃铛、硬纸板上的图案等等。只是意味或再现它们 自身。” ${ }^{34}$ 是什么让格林伯格肯定康奈尔的作品, 并且认为这些盒子

义实践的威胁。塞西尔·怀廷（Cécile Whiting）指出，人民阵线的重 点由集体主义向国族主义的转变概括起来就是 1937 年底更名为民族阵 线。这样的反应和“狂热主义、达达与超现实主义” 的接受形成了鲜明 的对比。Whiting, Antifascism in American Art, 38 .

32 Clement Greenberg, "Avant-Garde and Kitsch,” Partisan Review 6 (1939), 34-49.

33 更多关于克莱蒙特・格林伯格的艺术理论，特别是与 20 世纪 30 年代 政治的关系，见 T. J. Clark, “Clement Greenberg' s Theory of Art,” Critical Inquiry 9, no. I (1982): 139-56; Caroline A. Jones, Eyesight Alone: Clement Greenberg's Modernism and the Bureaucratization of the Senses (Chicago: University of Chicago Press, 2005); Fred Orton and Griselda Pollock, Avant-Gardes and Partisans Reviewed (Manchester: Manchester University Press, 1996); Susan Noyes Platt, Art and Politics in the 1930s: Modernism, Marxism, Americanism, A History of Cultural Activism during the Depression Years (New York: Midmarch Arts Press, 1999).

34 Clement Greenberg, "Review of Joint Exhibition of Joseph Cornell and Laurence Vail," first published in The Nation, December 26, 1942, 
里的东西不是媚俗而 “仅仅是它们自身” ?我们可以通过审视媚俗 这个本身就充满争议的概念来回答这个问题。这个术语让格林伯格 将宣传与商业文化放在同一个水平面上，没有将其危险性归入任何 一种意识形态，而是在再现形式的品质上面。对格林伯格来说，再 现是将虚假的民俗质朴与超现实主义的迷人品质混合在一起。因此， 媚俗就是马克思主义理论对商品拜物教的字面解读, 是把商品与危 险的控制或操控力量融合在一起。

但是, 制造这样一个重量级的敌人是要付出惨重代价的。让媚 俗与格林伯格所说的绝对力量结合起来, 这就要求相应的公众的代 理机构的缺位, 而现在被改造为消费者了。的确, 首先促使格林伯 格写作 “前卫与媚俗” 的并不是再现问题，而是观众的问题。这篇 论文的缘起，是格林伯格写给批评家德怀特- 麦克唐纳德有关《党 派评论》(Partisan Review) 上发表一系列苏联电影文章的一封信, 麦克唐纳德想要知道, 是什么让莫斯科的现代主义的西方艺术博物 馆和特列季亚科夫画廊参观者之间产生如此巨大差异，后者办的俄 罗斯学院派画家列宾的展览吸引了很多热情观众。格林伯格向唐纳 德解释道，“天平从一开始就倾向于媚俗，因为那些非常无知的农 民”。35

这封信的结尾，格林伯格在阐明他的政治观点时，“无知农民” 的形象以一种更为不光彩的形式再次出现：

我目前十分悲观，因为对我来说，在英国、法国和美国，包括 在独裁统治中, 面对左派的道德败坏, 面对无所不在的下里巴 人对所有文化的明目张胆的攻击，先锋文化开始节节败退了。 希特勒与沃旦所到之地，在这个国家，他们手持圣经而来。36

reprinted in Clement Greenberg: The Collected Essays and Criticism, Vol. I (Perceptions and Judgments, I939-1944), I3I-32.

35 Clement Greenberg, Letter to Dwight MacDonald, February 6, 1939.

Clement Greenberg Papers, Getty Research Institute, Series III, Box 24, Folder 8. 
格林伯格所鄙夷和不满的正是日益增长，并已达到巅峰的将民粹主 义视为切实可行的艺术与政治目标，以及 “普通人” 信念的逐渐丧 失，或者当他（从来不是 “她”）被其他人称为工人阶级之时。如 果卡希尔六年前曾经将民俗艺术描述为 “一个群体的观念与伤感”, 格林伯格的信则在这个年代末期代表了卡希尔设想的失败。

麦克唐纳德热情回应了格林伯格，鼓励他最终将这封信变成 “先 锋与媚俗”。在最终版本中，这篇文章重点放在媚俗的历史特点与 定义上，相对来说，几乎没有用多少篇幅去关注观众问题。但是， 正如格林伯格信中指出的，媚俗常常需要 “无知的农民”，他们头 脑简单，缺乏知识，愿意让自己处在虚无承诺的影响之下。如果媚 俗利用了这些无知者，那么，格林伯格和他的那些睿智同道看穿它 的空洞承诺也是合乎道理的。由此，格林伯格的 “乡下人” 说法就 会让他们对媚俗的迷幻有所免疫，让他们脱离当下的那些遭到诋毁 的大众。 ${ }^{37}$

在这样的历史视角下，康奈尔转向迷幻的风险就显而易见了。 迷幻世界是一个神圣意义分散在各种物体和人群中的世界。它反对 等级制，而且完全依靠一个更高级的统治力量的理念。由于他们对 日常生活的迷幻性的投入，康奈尔的盒子与电影实验，似乎倾向于 通过让世俗和精神事物重新结合，来解决美术与大众艺术间的紧张 关系。这样的实验只有在大萧条年代产生的集体精神的驱动下才有 可能。但是，在 20 世纪 30 年代，俄罗斯不想介入西班牙内战，斯 大林的清洗行动，与那些表面文章的公审，造成了对左派俄罗斯的 希望不断加剧的幻灭，其顶点是在 1939 年 8 月 23 日德国与苏联签 署互不侵犯协定。格林伯格在六个月内完成了 “前卫与媚俗” 的写 作，而且，第二次世界大战的灾难使得他的这种对抗迷幻的警告显 现出神秘的先见之明。因为这些事件，纽约艺术界的关注点从人民 转向了艺术家，从公众艺术转向了可以抵抗大众的腐蚀性影响的艺 术，而且，这种做法也为抗御盲目屈服于有魅力的领导人提供了保 护。

那么，“肥㿝泡装置” 的强烈狂想特质并非在于它古怪的主题内

37 关于文化阶级与社会阶级之间的基本考虑，见 Pierre Bourdieu,

Distinction (Cambridge: Harvard University Press, 1980). 
容。这件作品创造了一个空间，其中，历史力量暂时被悬置，这个 世界充满了意义与精神性。格林伯格的有关充斥康奈尔作品的物体 “只是意味或再现了它们本身” 的说法是不正确的。他的陈述实际 上被一种直觉所推动：即康奈尔的作品创造了一个自足的环境，这 个环境是由它自身的内在力量控制的。正如格林伯格自己说的, “康 奈尔在他的盒子的十平方英尺空间中建构了风景”。 ${ }^{38}$ 康奈尔的盒子 是这样的世界, 在其中, 那些定义了现代生活的诸种不可能的矛盾 是被悬置了的，哪怕只是一瞬间。

（聂皓雪、张坚译校）

38 Greenberg, "Review of Joint Exhibition of Joseph Cornell and Laurence Vail,” I32. 


\title{
Picturing the Good Earth: Modernism's Rural Roots in China and the United States
}

\author{
Jason Weems
}

In 1931, American author Pearl Buck published her epic novel on modern peasant life in China, The Good Earth (Fig. I). 'The dust jacket for the first edition bore the image of a horse-drawn plow resting unused before the rigid rows of a farm field. That same year, Grant Wood produced a nearly identical scene in his painting of the rural Iowa countryside, Fall Plowing (Fig. 2). That the book and the artwork share this motif is consequential. As the daughter of missionaries who had spent most of her life living in China, Buck's novel dramatized the impact of modernization on Chinese rural life. As a native son of the agrarian Midwest, Wood's painting allegorized a similar transformation of rural culture in the United States. During the first decades of the twentieth century, both nations underwent a deep and sometimes rending restructuring of cultural identity via modernization. While much of these efforts focused on the industrial city, the countryside also witnessed profound changes. Innovations in technology, economics, and social organization challenged traditional patterns of rural life. Yet the rural did not give way quietly in either nation, as artists and others turned to countryside as an anchor and antidote to modernization's many uncertainties.

My goal is to examine the artistic return to rural subject matter during the I93Os as a means to complicate our understanding of modernity - in particular to reassess art historical narratives that envision it as revolutionary, streamlined, and irresistible. Upon careful examination ruralist art discloses a more complicated negotiation between tradition and innovation; the promise of new forms weighed against the security of old practices. Though it could be nostalgic and sentimental, rural art was often subtle in content and composition, broaching the tensions between old and new that people were negotiating in their daily lives. In this way, such imagery opened a conceptual space where modernization could be reconfigured through active dialogue with the past, rather than a clean break from it. Such was the case, I will propose, in both China and the United States; two nations whose cultural modernity took shape through a long and dynamic history of rural and agrarian innovation.

Finally, while my purpose is to think in overarching terms about the importance of the rural in the history of modern art, I also want to engage with a particular agricultural motif utilized by Wood's painting and the cover of Buck's book, specifically scenery of tillage and the plow. Apropos the focus of our symposium today_China and the United States — this emblematic implement of agriculture brings forth even greater cross-cultural richness. Wood painted his image in homage to the American blacksmith John Deere's invention of the steel 
Fig. I. Cover, Pearl S. Buck, The Good Earth, John Day Company, I93I.

moldboard plow-the machine that enabled the transformation of the North American continent into Europeanized cultivated land. Yet the origins of the plow are deeper still. While the American design appeared in 1837 , the true origination of the moldboard iron plow dates to the Han Dynasty in China. In this way, the choice by American publishers to use a Grant Wood-like plow image for the cover of an American missionary's account of Chinese rural modernization seems at once uncanny, prescient, and serendipitous. There is something of the modern, I think we'll find, in this as well.

To begin unpacking the potential of rural imagery as a prism for modern transformation, I want (at least initially) to move forward in

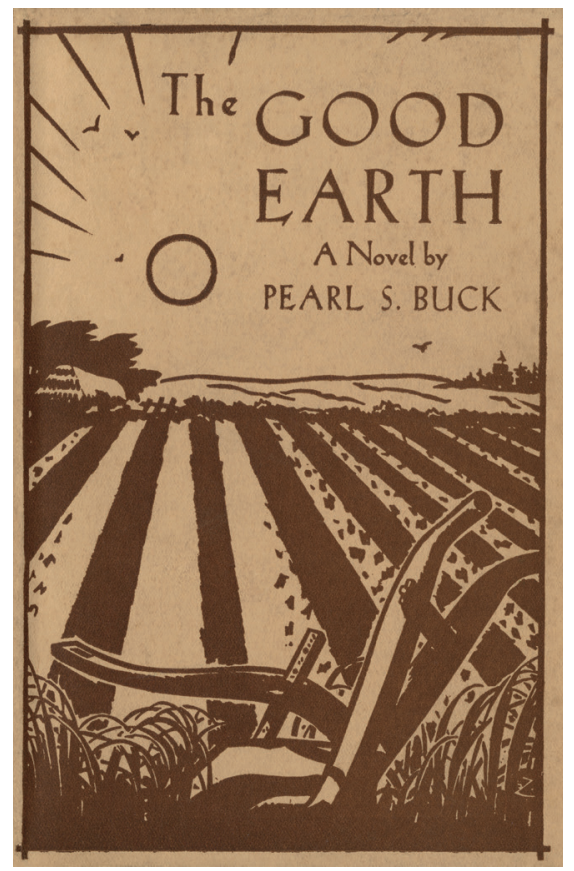
time from I93I to 1936, a moment when practices of American agriculture began to be systematically transformed. It was in that year that the US government's Department of Agriculture implemented a systematic, nationwide program of aerial survey in order to create photographs for use in the implementation of agricultural central planning. ${ }^{2}$ I936 is also the year Wood completed another, and in many ways more significant plowing painting, entitled Spring Turning (Fig. 3) Pictured from a distant and elevated viewpoint, this artwork rehearses one of the symbolic rites of rural life: the awakening of the land by the flaying action of the plow. Within their discrete contexts, each of these objects immediately affected perceptions of the American agricultural landscape. In the arena of everyday practice, the government's aerial photographs served as diagrams for the state-sponsored modernization of American agriculture. In the realm of culture, Wood's painting became an emblem in an ongoing debate regarding the place of the rural in modern America.

At first glance, the two types of images might not appear to have much in common. One emanates from high art, the other from bureaucratic culture. Moreover, suggestive of what remains a dominant—if overly simplified-understanding of I930s' rural art as nostalgic and anti-modern, Wood's painting has been understood to depict the land as a fertile body coaxed into fecundity by the Lilliputian labors of its inhabitants. By contrast, the government's synoptic aerial photography invokes a different, more abstract, visual effect. Snapped by an automatic camera from thousands of feet above the land, these images portray the

2 For a detailed account of aerial photography in US agriculture, see Jason Weems, Barnstorming the Prairies: How Aerial Vision Shaped the Midwest (Minneapolis: University of Minnesota Press, 2015). 


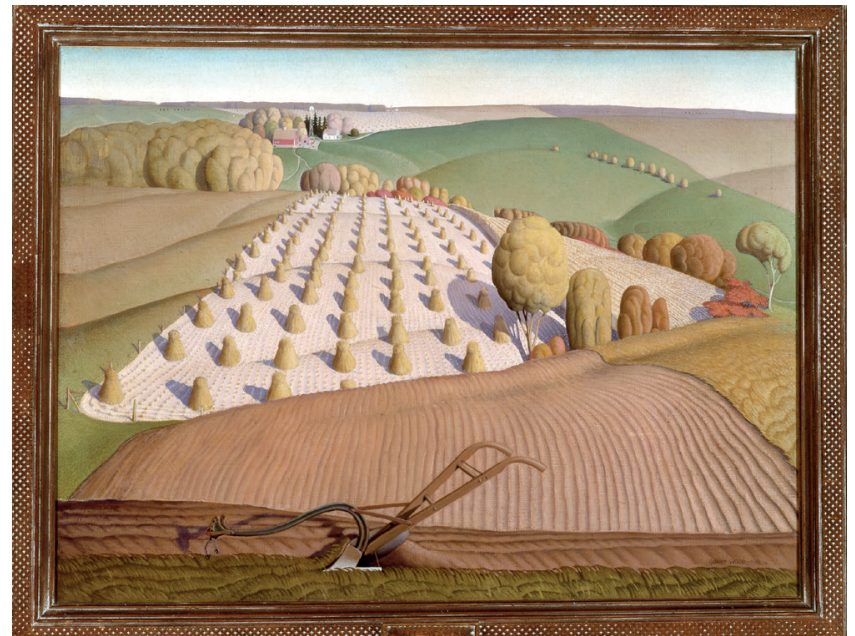

Fig. 2. Grant Wood, Fall Plowing, 1931. John Deere Art Collection. (C) Figge Art Museum, successors to the Estate of Nan Wood Graham/ Licensed by VAGA at Artists Rights Society (ARS) NY.

region as an ordered space whose rational gridwork is devoid of emotive content but filled with potential as a site for agrarian production.

Contrary to these two dominant interpretations, deep ties exist between these two kinds of landscape representations. Not only do they treat the same subject matter; they also share a common, aviation-enabled aerial perspective. First mobilized in World War I as a means of battlefield surveillance, the development of such technologically modern forms of aerial vision in the twentieth century enacted a broad, epistemic shift in the conditions of visual experience-one that opened up new possibilities for perceiving and representing the American landscape. As the simultaneous appearance of new, flight-inspired aerial gazes in both Wood's painting and the government's survey imagery suggests, the effects of this change cut across levels of visual discourse and united realms of objects whose intended uses and audiences could be quite different. Yet framed together, Wood's painting and the government's aerial photographs produce new, mutually constituted meanings - meanings that fueled a reformulated image of the rural landscape in the context of twentieth-century modernization.

Of course, the idea of representing the land from elevated prospects was not new to rural landscape painting, nor was it solely a product of technological modernity. Born in I89I on a farm in Iowa, Wood came of age amidst a culture that conditioned people to envision rural environments through imagined cartographic and bird's eye viewpoints. Beginning with the Federal Land Ordinance Act of 1785 , which organized the unsettled expanse of the U.S. continental terrain into a grid of plots and property lines, agrarian settlers were encouraged to conceive of the region not from the horizontal as an organic environment, but rather from above, as parcels of available land. This sense of the landscape as abstract and gridded space, primed for purchase and cultivation, gained its first visual form in the countless government maps, land atlases, and settlement promotions that were widely distributed to Eastern U.S. potential buyers and settlers living on the Eastern seaboard and newly arriving as immigrants from Europe. ${ }^{3}$

3 Maps, pamphlets, and guidebooks promoting land settlement were numerous. 
Fig. 3. Grant Wood, Spring

Turning, 1936. Reynolda House Museum of American Art. Gift of Barbara B. Milhouse. (C) Figge Art Museum, successors to the Estate of Nan Wood Graham/Licensed by VAGA at Artists Rights Society (ARS) NY.

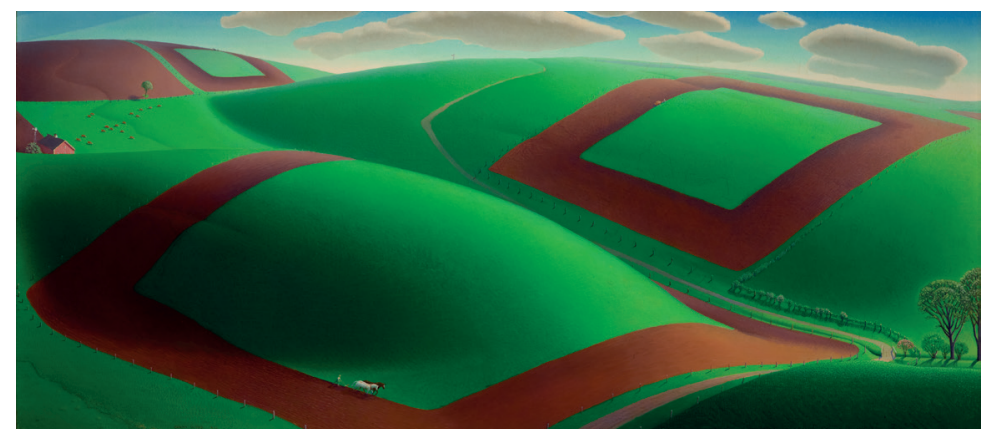

Wood's first efforts to represent the rural landscapes of the American Middle West-work that culminates in his emergence as the leading figure of the American Regionalist art movement-shared in this utilization of the elevated bird's eye vantage point as means of characterizing the region. While the artist is best known for his now famous portrait of a farmer and his daughter, American Gothic, 1930, he is also remembered for a bevy of playful and sentimentalized bird's eye paintings of rural Midwestern culture, especially as evident in its rural and small town topographies. Among the most striking features of these images is their self-aware adoption and adaptation of the elevated landscape prospect in both form and concept. ${ }^{4}$

Perhaps the most celebrated of these lyrical bird's eye landscapes is the artist's 1930 rendering of Stone City, Iowa (Fig. 4), for which Wood sought out an actual hillside location above the town in order to compose his view in a consciously elevated fashion. Looking down into the scene, the artist took advantage of his raised prospect to compress the town into a stylized, fairytale-like space of small houses, rounded trees and rolling hills. Situated at the top of such a hill, whose steep downward angle is suggested by the orthogonal rows of corn, Wood has encapsulated the town within his gaze. In doing so, he recaptured the form and sentiment of earlier rural imagery. There is a striking consonance of visual form and small town idealism shared between Wood's representation of Stone City and a similar view of the hamlet as pictured in an 1875 illustrated settlement atlas for the State of Iowa created by the publisher and entrepreneur Alfred Andreas. ${ }^{5}$ Like Wood's painting, Andreas's Iowa atlas oriented its design to the tastes of the

As two examples, see Guy H. Carleton, Sectional Map of the State of Iowa, Compiled from United States Surveys, Also Exhibiting the Internal Improvements, Distances Between Towns and Villages, Lines of Projected Railroads, Scc., I850; and The Illinois Central Rail-Road Company Offer for Sale over 2,400,00o Acres and Woodlands, in Tracts of Any Size, to Suit Purchasers... (New York: John W. Amerman, 1855). The bibliography on US landscape representation, in which bird's eye views and other forms of panoramic vision are prominent, is substantial. In particular, see Albert Boime, The Magesterial Gaze: Manifest Destiny and American Landscape Painting, I830-I865 (Washington, DC: Smithsonian Institution, 1991). 


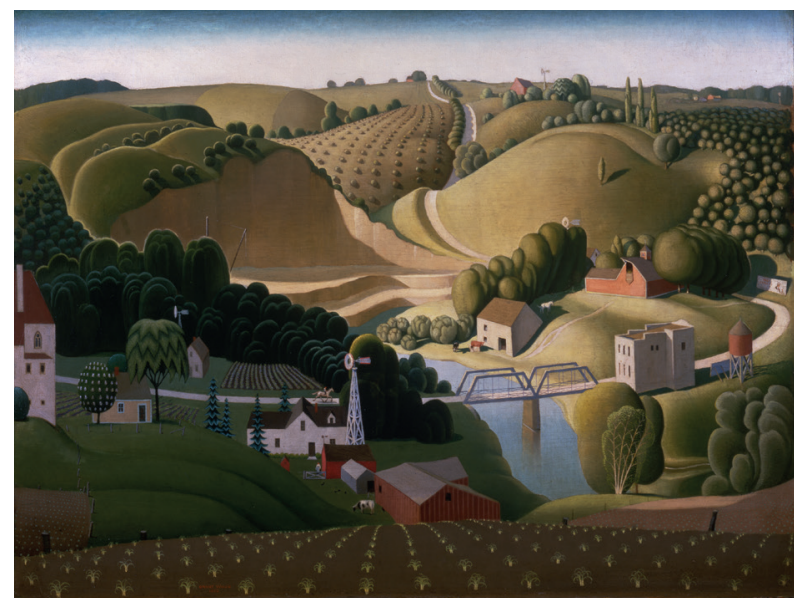

Fig. 4. Grant Wood, Stone City, 1930. Joselyn Art Museum, Omaha, Nebraska. Gift of the Art Institute of Omaha. (C) Figge Art Museum, successors to the Estate of Nan Wood Graham/Licensed by VAGA at Artists Rights Society (ARS) NY.

state's established inhabitants - the audience most connected to and thereby undoubtedly the most compelled to purchase such a work. They were also, like the Iowa-born Wood, the individuals who had the most to gain from the representation of their homesteads, countryside, and communities, in idealized ways.

Given Wood's engagement with these longstanding precepts and practices of elevated looking, it would be feasible to surmise that Wood's effort six years later in the 1936 Spring Turning would be of a piece with the nineteenth-century agrarian iconography he had adopted, mostly without complication, in prior works. Yet, viewing the 1936 painting wholly in terms of this idealizing trajectory overlooks an important shift in Wood's aerialism, and his modernity. Comparing the Stone City and Spring Turning side by side, it becomes evident that there is something different at stake for Wood in the later work, a sense of coolness and separation that is not apparent in the earlier and in many ways more tender view. Departing from the stable bird's eye view Stone City, the gaze in Spring Turning appears more distanced and dynamic_-even a bit vertiginous. Unlike the earlier landscape, Wood's perspective has become more anxious and menacing as the dark chasm in the center of the painting frustrates viewers' attempts to situate themselves in relation to the scene. Likewise, his simplification of the land into a surprisingly spare and sleek order suggests a new influence on Wood's art. This influence is both the technology aviation, and also the new visual and conceptual frameworks of modernization.

By the time that Wood painted Spring Turning, the airplane had become a dominant theme in the rural cultural imaginary. Like almost all Americans both rural and urban, Wood was an active participant in this culture of flight. As a youth, he was thrilled by a parachuting demonstration at a local fair. ${ }^{6}$ As a US army conscript during the First World War, Wood trained in a camouflage battalion where he learned in particular techniques for thwarting modern aerial

Andreas Atlas Co; Lakeside Press, i875. Chromolithographs by Chas. Shober and Co.).

6 The parachute demonstration is recounted in the unpublished autobiography "Return from Bohemia" that Wood co-authored with Park Rinard, Grant Wood Papers, Archives of American Art, Washington, DC, 252-53. 
surveillance. In the I920s, when studying in Europe, he created a postcard that pictured him, suitcase in hand, winging his way from France to Italy.7 The latter piece is especially important, as it demonstrates not only the artist's awareness of the new possibility of airplane technology and travel, but also his desire to be associated with it. For Wood and countless others, associating oneself with flight was a means to demonstrate a personal link to modernity.

The point is not simply that Wood, like so many others, fell in love with the airplane. Rather, the important thing to understand is that his encounter with aviation was visually and conceptually transformative for him. On the surface, the airplane itself symbolized modernity. More deeply, it's technological actualization of de-terrestrial prospects created new possibilities for apprehending and engaging with the world. Granted the ability to look vertically down upon the land from a position that was physically (and not merely metaphorically) discontinuous with earthly space, aerial vision inspired viewers to perceive the world from the outside - a position that enabled the implementation of new regimes of knowledge and authority. Consequently by the I930s, even as everyday audiences still delighted in the novelty of flight, a variety of image-makers were working to harness the potential of the airplane as an instrument for seeing and transforming the American landscape. Central among them was the US Department of Agriculture, which was charged with oversight of the nation's agricultural production and, more particularly, with the modernization of the rural landscape. In this capacity, the government came to depend upon aerial surveying as a means to visualize and organize a multitude of programmatic tasks including the development of soil conservation plans, the implementation of systematic agricultural regulations, and the enforcement of production quotas for individual farmers. ${ }^{8}$

Captured from airplanes traveling in high, level flight, government aerial survey images, taken in Iowa and across the nation, recorded with great accuracy the shape and size of the croplands that they depicted. From a close examination of such photographs, agricultural agents could determine, for example, the number of acres a farmer had plowed and what types of crops he had planted. Based on this knowledge, agents could discern whether a farmer was operating within the limits of the program he had developed in conjunction with government agencies. In subsequent years, the photographs served as blueprints for program enrollment as agents carried them into the countryside as visual references with which to plan the following year's crops. From kitchen tables to the hoods of Model T's, agents used the images to instruct farmers to "see" the land abstractly, as a production space. Resultantly, the views also emerged as the in-

7 Grant Wood, Christmas postcard from abroad, 1924, Grant Wood Archive, Scrapbook I8, Figge Museum Art Museum, Davenport, IA.

8 The negatives for all New Deal Era (and subsequent) government agricultural aerial survey photography are housed in Record Group I45, Records of the Farm Service Agency, National Archives and Records Administration, College Park, MD. 
struments through which farm owners could bring their new conceptualizations of rural life into practice on the ground.

In some respects, these new, high altitude aerial views probably looked familiar to rural audiences, who were used to bird's eye views of prior generations. Indeed, much its surprise, the agriculture department was quickly overwhelmed with requests from individual landowners who desired copies of the photographs for display in their homes. ${ }^{9}$ Yet unlike nineteenth-century atlas imagery, the visual autonomy and insistent indexicality of aerial photography lent itself only problematically to artistic idealization and cultural myth making. Recasting the land in a comprehensive, unadorned, and above all uniform aspect, aerial surveys exposed (or at least complicated) the often-sentimental agrarianism that suffused nineteenth-century imagery and replaced it with a powerful sense of abstraction and rationalization. Under the bureaucratic gaze of the aerial camera, the prairie was laid bare not as a picturesque patchwork of independent farmers, but rather as a vast system of homogenous landholdings geared to the production of commodities, not culture. As many farmers expressed in other letters written to the Department of Agriculture, it was discomforting for them to recognize their individual homesteads as mere components of a homogenous grid in which all farms looked alike. These farmers were also aware of what we today might call the images' surveillance overtones; it became increasingly common to hear the government's survey photographers referred to as "sky snoops."

Wood's later work suggests that he shared this ambivalence about the survey photographs, which by this time saturated not only government programming, but also rural culture. As an aviation enthusiast, Wood probably marveled at the technologies that made such images possible. As aerial view maker, he must have been fascinated by the stunning new prospects that the images offered onto his region. Indeed, in a remarkable 1935 drawing entitled Stoddard Family Lake Macbride Map (formerly Comic Relief Map of Lake McBride, Iowa, Area, Wood himself mimicked the viewpoint of the vertical photograph. ${ }^{\text {II }}$

Though fascinated by these new images, Wood also recognized the challenge that their modernity presented for those seeking to safeguard a more traditional and nostalgic vision of Midwestern agrarian life. He also seems to have understood the real peril for rural inhabitants represented by the forms of agricultural industrialization and rationalization that were both symbolized by and enacted through the government's photographs. While the agricultural transformations that the government planned "from above" may have enabled more efficient and

9 A U.S. Department of Agriculture news release from 1937 summarizes that farmers often "obtained copies of the aerial maps and had them framed." USDA News Release, May I0, 1937.

Io This term gained common use in the period, see, for example: Mark Sullivan, "The New Invasion of Farm Privacy Seen in A.A.A. 'Sky Snoopers," New York Tribune, June 20, 1938.

II Grant Wood, Stoddard Family Lake Macbride Map (formerly Comic Relief Map of Lake McBride, Iowa, Area), 1935. Pencil, ink, and chalk on paper. 
Fig. 5. Grant Wood, Death on Ridge Road, I935. Williams College Museum of Art, Williamstown, MA, Gift of Cole Porter (C) Figge Art Museum, successors to the Estate of Nan Wood Graham/Licensed by VAGA at Artists Rights Society (ARS) NY.

tightly managed production, they also favored larger scale farms at the expense of smaller, independent operations. As land was a finite commodity, the enactment of large scale agriculture meant that smaller farmers would be pushed off the land and their homesteads consolidated into more extensive landholdings. While some agricultural labor would be replaced by machinery, in other instances the farmers displaced by consolidation were compelled to return to their land as tenants. ${ }^{\text {I2 }}$

Like those farmers whose letters expressed anxiety over the new order prefigured in survey photographs, Wood's painting began to exhibit a concern over the mechanization and incorporation taking shape across the countryside. In particular, startling changes in Wood's own aerial aesthetic suggest his growing unease over the implications of modern rationalization. In his 1935 painting entitled Death on Ridge Road (Fig. 5), Wood conjured a disturbingly vertiginous aerial perspective to allegorize the threat that technology posed to traditional rural life. Rendered from an unstable and ominous oblique angle, the canvas depicts three vehicles vying for right-of-way on a curving rural highway. At center, a sleek black sedan swerves across the lanes to pass a boxy, outdated Model T. At the same time, a commercial truck lunges eagerly over the crest the hill. To the sides of the roadway, strands of barbed wire slice taut lines across the landscape. In complement to these fences, a pair of rigid power lines cut diagonal vectors across the scene, their clean linearity offering a stark contrast to the softened curve of the hillside and the rounded corner of the planted field. A darkened storm cloud in the upper corner completes the image by blocking out sunlight, while the sheet of rain that descends violently to the ground foreshadows the impact of the impending crash between truck, sedan, and farmer's flivver. Swooping down onto the sharpened point of an electrical pole, the distorted sightlines of Wood's aerial gaze transform the landscape into a violent collision not only of cars, but cultures.

Death on Ridge Road constituted Wood's most overt critique of Midwestern modernization and also in this way his most disturbing aerial prospect. What Wood captured in the image is aerial vision's potential to make once familiar spaces appear disconcerting. Indeed, if we compare the painting to a couple

I2 On the social and culture repercussions of Midwestern agrarian modernization, see, for example, David Danbom, The Resisted Revolution: Urban America and the Industrialization of Agriculture, 1900-1930 (Baltimore: Johns Hopkins University Press, 1979). 
types of aerial images - both survey views and also oblique pictures shot from swooping aircraft-we can begin to understand how Wood's image deploys the modern aerial gaze to a more defamiliarizing effect. In one instance, such oblique aerial photographs of farmsteads appeared in a the small town local newspaper, the Anamosa, Iowa Eureka, as part of a weekly feature that challenged readers to identify the owner and location of the farm depicted. ${ }^{13}$ The game, of course, was that local farms that the readers might easily and familiarly identify from their usual grounded perspectives became unrecognizable when seen from above. While the text masquerades a sort of naïve playfulness-as do Wood's paintings - the anxiety of misrecognition is painfully real. It is a picture perfect illustration of the Freudian uncanny, as the suddenly unrecognizable home space becomes the source of deeper psychological estrangement. Indeed, in one instance the Eureka editor had to publish a correction to the feature, as the newspaper writers had themselves misidentified the one of the farms illustrated-even though their own pilot photographer had captured the image. ${ }^{\text {I4 }}$ While the editor's retraction tried to strike a good natured tone, it also seems to recognize that to readers this was not a minor matter.

Similarly, Death on Ridge Road demonstrates Wood's understanding that while such uncanniness could be pleasurable for his rural subjects and audiences, it was also threatening. He then used this defamiliarizing aspect of the aerial view to allegorize the danger of modernization. Finally, it is no accident that the painting - with its fatalist iconography of cruciform electrical poles and hearse-like sedans — also marks one of the first appearances of straight lines in any Wood landscape. These lines, the electrical wires especially, are violent markers of the region's new modern look. In this sense, Death on Ridge Road might be understood at least in part in relation to survey photography-as a critique of the surging modern aesthetic that sought to reorder the region's image into a single unified geometry, but that in doing so threatened the eradication of less streamlined elements of rural tradition.

As the government's new rational vision of managed production retooled rural culture, Wood's works began to interrogate the image of the landscape invoked by modernity, and more specifically by the government's program of aerial survey photography. In 1936, the same year that the government mandated the use of agricultural survey photographs on a nationwide scale, Wood created his most modern image of the prairie landscape, Spring Turning. As mentioned earlier, the subject for the view was mythically agrarian: the yearly cycle of spring tillage. Yet in spite of its overt nostalgia for a certain ideal of rural life (few US farmers were plowing with horses in 1936), Wood's manipulation of the aerial viewpoint in Spring Turning made the image sleek and spare. Compared to earlier landscapes, Wood smoothed the contours of the hillsides, flattened the effect of paint on the canvas, decreased the amount of line and decoration, pared

I3 “Can You Identify This Farm From This Brand New Angle," Anamosa (Iowa) Eureka, September 7, 1939. Aero photograph by local pilot Art Moenck.

I4 "You're Right, It's Tobiasson's," Anamosa (Iowa) Eureka, September I4, I939. 
down the number of objects in the scene, and highlighted formal simplification, mechanical smoothness, unmodulated application of paint, and visual flatness. Certainly the painting remains somewhat sentimentalized in its rustic rendition of horse drawn tillage, but it is now also, especially in comparison to his other works, more formally modern.

Critics immediately noted the change in Wood's style. In a 1937 article that exhorted Wood to forego some of his decorative nostalgia in favor of a more "naked statement of the Iowa terrain," Regionalist champion Thomas Craven nonetheless lamented that Spring Turning embodied too great a movement from local content into modern form. The painting, Craven wrote, "has simplified the country into an abstraction, into immense and vacant and billowy protuberances which do not look like earth but like mechanical forms covered with green pigment." ${ }^{\text {Is }}$ Craven was not alone in noticing the modernism of Spring Turning; when the work was reproduced in the pages of Life magazine later in 1936, the caption heaped praise on the geometric precision of the image, implying that it was, in spite of its non-mechanized depiction of rural labor, painted in a highly modernized aesthetic. As a magazine that consciously championed modernization, Life's editors seemed to appreciate this turn in Wood's style. ${ }^{16}$

Though neither Craven nor Life's editors explicitly state the connection, it seems obvious that the modernist "look" upon which both remarked fits precisely within the abstract, distanced aesthetic of survey photography. In particular, Wood's more extreme sense of vertical disconnection, heightened as in Death on Ridge Road by the visual chasm in the immediate foreground, creates a distance between viewer and the land that is simultaneously physical and psychological. The painting demands a gaze that is depersonalized and rational rather than specific and affective- one that highlights the broad order of repetitive fields rather than the more picturesque patterns of plump trees and maternal hillsides. For the first time in his practice, the grid (in the form of aerial survey) has been injected into Wood's imagery. It is, after all, the squares of tilled land that predominate in Spring Turning-just as in the government's survey photographs. In particular, flatness has emerged to a degree unprecedented in Wood's other paintings. The sleek application of pure green across the hillsides coupled with the exacting repetition of earthen squares, for example, unites the landscape into a continuous visual field.

While Spring Turning certainly represents Wood's effort to figure into his work the visual and cultural impacts agricultural modernization, it is vital to recognize that the painting does not simply replicate (and thereby celebrate) the new sense of form and order that takes shape in the aerial survey photograph. Rather, Wood attempted to mediate the all encompassing scope and rigidity of the survey gaze by softening the edges of his rectangular spaces, reinserting a sense of form and volume into the land, and leaving open, unregimented fields

I5 Thomas Craven, "Scribner's Examines: Grant Wood," Scribner's Magazine, September 1937, 19 . 
between the squares of tilled earth. He also retained an older style, meandering roadway that resonates to some degree with the whimsically looping horse path depicted in Stone City. To complicate matters, however, it becomes evident upon careful inspection that the road in Spring Turning also conforms as much to the rectilinear dictates of the grid as it does to the natural curvature of the land. Furthermore, a look to the upper portion of the painting provides yet another iteration of Wood's engagement the new aerial survey aesthetic. Here, in this sliver of sky - the realm of government survey aircraft — the artist has marshaled the clouds themselves into configurations that mirror the geometric shape of landscape below. While this transformation of sky into puffy white grid could be seen to loosen the landscape by making it more lighthearted and sentimental, it must be read more ambivalently.

In one sense, Wood's squaring of the clouds makes all the world a grid and in that way seems to signal his acceptance of modern agriculture's new and pervasive rational reality. From another vantage, however, the artist's insistence on integrating some elements of a prior ruralist iconography, in the face of what must have seemed to him a prevailing course of modernization, proposes a more nuanced interpretation. For Wood, the choice of the modern painter (or farmer) was never one of simply embracing or rejecting the new. Instead, his paintings are dialogic; they foreground a desire to understand the condition of modernity as something shaped through constant negotiations wherein tradition and innovation are treated as fluid forms rather than set patterns. Wood's beliefs about both painting and agrarian life relied upon the possibility of such adaptation.

It is the contradictions of Wood's artistic merger of past and present conceptualizations of the land makes Spring Turning a remarkable and visually interesting work. In a broader sense, however, it is his adoption and adaptation of modernist visuality challenges us to think more carefully about rural imagery as a crucible for modern expression during the early twentieth-century. While American art historians have tended to locate the generation of artistic and cultural modernism exclusively as effects of the industrial city, what Wood shows us is that much of the real work of the modern was transacted outside these foci, in the local dialects and places of American culture. These negotiations-whether involving formal elements or cultural meanings-were complex and multi-faceted. By seeing these complexities in somewhat unexpected—rural-places, we may more fully understand the malleability of modernist pictorial strategies.

Winding back the clock from Spring Turning to Fall Plowing and the cover of The Good Earth, we may now better understand that even in 1931, picturing plowshares was no simple matter. With its blade now cutting through both soil and history, the plow invokes a particularly complicated set of tensions between flow and immobility, past and present, transformation and stasis. Without a draft animal to pull it or a farmer to grasp its wooden handles and direct it across the field, the implement at first appears strangely iconic, its refusal to move seeming to arrest change and lock the rest of Wood's vision into place as an ideal. Yet the plow's reality as an instrument of modern transformation-a means to overturn (literally) the natural surface of the earth to expose its soil as 
a productive resource — cuts against such a reading by revealing the illusion of undulating fields as fertile fantasy. A similar dualism is cultivated in the cover illustration. Buck's novel The Good Earth won the Pulitzer Prize predominantly for how it presented curious American readers with a stirring idealization of a distant and exotic China. Pressed harder, however, Buck's literary representation of China tilled the same earth as Wood's artistic vision Midwest. The novel, after all, was a tale of China's modernization: one where tradition was plowed under, but in that way became a fertile source for the new.

As yet, it's not certain whether or not Wood's painting provided the inspiration for the I93I first edition book cover, though it seems likely. Yet it was also the case that the plow motif was not the only cover used and by 1932 the plow motif had been replaced by images featuring the stock scenery of traditional Chinese rural life. The fact that these later designs became the preferred model for subsequent printings is instructive. One can surmise from this shift in imagery that the plow motif, while sufficiently agrarian proved to be inadequately Chinese in the estimation of Buck's publishers. What remains significant is the fact that for one instant in 1931, it was perceived that an American agrarian iconography might also properly emblematize — at least for US audiences—-the story of rural modernization in China. 


\section{描绘大地：中美现代主义的乡土渊源}

詹森・维姆斯

I93I 年，美国作家赛珍珠的史诗级小说《大地》(The Good Earth) 出版，内容是关于现代中国的农民生活。尘封已久的第一个版本的 封面 (图 I), 是农场内整齐排列的一排排农作物之前的马拉的犁耕。 同年, 格兰特·伍德 (Grant Wood) 在他的爱荷华乡村的绘画作品《秋 耕》（Fall Plowing，图 2) 中创作了一个相同的场景。最终，这本 书和这件作品使用了同一个母题。作为一个大部分时间生活在中国 的传教士的女儿，赛珍珠的小说夸张了现代化对中国乡土生活的影 响。作为一位美国中西部农村土著的儿子，伍德的作品将一个相似 的、在美国发生的乡土文化的转变寓言化。二十世纪的前几十年中, 中美两国都经历了一个深刻的，有时是借由现代化对文化身份之重 建的撕裂。尽管这些努力中的绝大部分集中在工业化城市，乡村仍 然见证了深刻巨大的变化。技术、经济以及社会组织方面的新变化 挑战了乡土生活的传统模式。但是，当艺术家与其他人将乡村转变 为一种应对现代化不确定性的针地与解药时, 乡土性也并没有在这 两个国家悄然沦落。

我的目标是检视 20 世纪 30 年代那些回归乡土题材的艺术创作 活动, 以此来丰富我们对现代性的理解，尤其是重新评估将之视为 革命性的、流水线生产的以及无法抗拒的艺术史叙事。在细致的研 究中，乡土主义者的艺术表达了一种传统与创新之间更为复杂的协 调过程 ; 这种新形式的前景正在威胁旧的实践的地位。尽管乡土艺 术有可能是怀旧与伤感的, 乡土艺术在内容与构图上常常是含蓄的, 在人们日常生活的平衡中，开掘新与旧的张力。这种方式中，形象 是开启了一种概念空间，现代性通过与过去展开生动对话而被重新 构建，不是完全从过去当中脱离出来。我要说的是，在中美两国， 文化的现代性是在乡村与农业的创新的漫长而充满活力的历史中得 以塑造的。

最终，我的目标是以现代艺术史普通术语来思考乡土的重要性 问题，我还想以伍德的作品和赛珍珠书籍的封面所使用的农业母题 建立更多关联，尤其是耕作与犁地的场景。就我们今天研讨会的关 
注点而言一中国和美国一这种农业的象征性工具之后，带来了更大 的跨文化丰富性。伍德创作这幅作品是为了向美国铁匠约翰- 迪尔 （John Deere）发明的钢制犁板耕地工具致敬，这个工具使得北美 洲大陆从荒野变为可耕地。但是，这种耕作有着更深刻的源头。美 国的这一设计出现于 1837 年, 不过, 铸铁犁板耕作工具早在汉代 的中国就已出现。美国出版商选择用格兰特 - 伍德式的耕作图片作 为美国传教士的中国农业现代化书籍的封面似乎有些离奇，又具有 某种预见性和机缘巧合。我相信，其中也可以找到一些现代性的蛛 丝马迹。

然而，在开掘这个作为现代转换棱镜的乡村想象的诸多潜质时， 我想将时间定格在 $193 \mathrm{I}$ 一 I936 年，这个时间段正是美国农业开始系 统变革的时候。也是在这个时候, 为拍摄照片, 美国政府农业部门 实施了一个全国范围内的空中调查项目，我们看到的爱荷华乡间的 图片（《格兰迪县》(Grundy County, I936), 就是农业部实施中心 规划时使用的。同样是在 1936 年，伍德完成了另外一幅有关耕种 的作品《春天来了》(Spring Turning, 图 3), 在很多方面, 都要比 之前的作品更重要, 画作是以远景的俯视角度创作的, 再现了乡土 生活中的一个象征性仪式: 通过耕地而让土地苏醒。画中物象, 虽 是各居其所，却即刻对美国农业风景的构想产生影响。在这个日常 活动的场所里，政府航拍图成了国家资助的美国农业现代化进程的 图表。在文化的范畴内, 伍德的绘画成了美国现代化进程中乡村居 于何种地位的争论的标志。

乍看起来，两幅图像没有太多共同点。一个源自高雅艺术，另 外一个来自官僚文化。而且, 从其主旨所暗示的一切来看, 如简单 表述, 就是将三十年代的乡村艺术理解为乡愁与反现代, 伍德作品 是把土地描绘成丰饶的躯体，栖居其间的居民以劳力而让它变得繁 茂多产。相比之下，政府概貌式的航拍照片则是展现了全然不同的 和更为抽象的视觉效果。自动摄影机在大地数千英尺之上拍摄的图 像, 是把一个地区当作富于秩序的空间来加以描绘, 沃野平畴并不 包含情感内涵，却充满了农业生产场所的潜质。

与这两种主流阐释相反, 两幅风景画实际上存在深刻的联系: 它们不仅有共同的主题；还有一个由航空技术实现的共同的俯瞰视 角。这种技术首先在第一次世界大战中运用于战地侦察, 到了 20 
世纪，这种航空视角的现代技术形式得到发展，引发了视觉经验中 的广阔的认识方式的变化，这种变化为美国风景画的构思与再现打 开了新的可能。这种飞行的俯瞰同时出现在伍德的绘画与政府土地 普查图像中，这种变化的效果跨越了视觉话语的多个层面，并把原 本功能和受众截然不同的物件的世界统一起来。但是，一旦被框定 在了一起，伍德的绘画与政府的航拍照片就产生出新的相互建构的 意义，这些意义给 20 世纪现代化语境中乡土风景画的形象的再塑 造提供了资源。

当然，从俯视角度再现土地的想法对乡土风景画来说并不新鲜, 它也不单单是现代技术的产物。I89I 年出生于爱荷华的一个农场的 伍德，就生活在一个以地图和鸟瞰方式想象和观察乡村风景的文化 中。从 1785 年菲德罗土地法令实施以来，美国的土地空间是就被 规约到一个网格分界系统当中，农业居民更多地被鼓励用空中俯瞰 的方式来规划可耕地，而不是在水平视角上，把整个区域设想为一 个有机环境。早期传推广的图像中，比如在 1850 年广泛流传的爱 荷华地图，就把农村的自然风景重塑为一个网格系统。我们也可以 在其他图像中看到这种网格。

伍德最早致力于再现美国中西部乡土风景的作品，也是美国地 方主义艺术运动的代表作，并促使该运动走向高潮，这些作品在塑 造中西部地区形象时，利用了鸟瞰视域。虽然这位艺术家最为人熟 知的作品也许是那幅著名的农民和他的女儿的肖像画，但他同时也 因为大量充满戏谑与伤感的鸟瞰视角表现美国乡土风景的作品而被 人铭记。

这其中, 最著名的抒情风景画作也许是 1930 年的《石头城, 爱荷华》 (Stone City, Iowa，图 4)，在这件作品中，伍德是站在位于小镇上 方的一座小山丘的边上，采用高视角方式来组织画面。俯瞰这片风 景，艺术家的高视角，使得镇上风景被压缩成一个风格化的和童话 般的空间，其中散布着小房子、圆树和蜿蜒起伏的山丘。山丘顶部 陡峭向下的角度，是由互相垂直成排的玉米田表现出来的，伍德在 他的凝视中，把这个小镇再次微缩化。他重获了早期乡村形象的形 式与感伤。

鉴于伍德与这些长期存在的鸟瞰视角的关联，我们推测，《春天 来了》是更早的 19 世纪农业图像志的一个部分。但是，完全以这 
种思路来看待这件作品，会忽视伍德在这种航空视角与他的现代性 中所经历的重要转变。将两件作品放在一起比较, 在我看来, 《春 天来了》，似乎有一种对伍德来说颇为不同的危险处境，一种早期 视角中不常见的冷酷与疏离感。在脱离了《石头城, 爱荷华》中的 稳定的鸟瞰视角后, 《春天来了》的凝视, 要表现得更为疏离与动感, 甚至有一点让人感到晕眩。不像之前的风景画，伍德的视角变得更 加焦虑和险恶，画中的黑色裂隙挫败了观者试图与场景建立关联的 想法，同样，他把土地简化为异常平滑的秩序，反映了伍德艺术中 的新影响。这种影响既来自航拍技术，也是新的现代化的视觉与观 念的框架。

在伍德创作《春天来了》的时候，飞机成了乡村文化形象的主 导题材。几乎与所有美国乡村与城市人一样, 伍德是这种飞行文化 的积极参与者。作为年轻人, 他对当地集市里展示的降落伞感到兴 奋。一战期间，他应征入伍，受训于一支伪装部队，学会了阻挠航 空侦察的专门技术。20 年代在欧洲学习时，他绘制的一张明信片, 上面有他手持行李箱，正从法国飞往意大利。

我的观点并不是简单地认为伍德如同其他人一样爱上了飞机。 相反, 我想要让大家理解的是, 他与飞行的相遇, 无论在视觉与观 念上都是经历了变化的。换句话说, 这种非陆地生物视角的技术化 实现, 为人们理解脚下的世界创造了新的可能, 赋予人们以鸟瞰能 力, 在这个位置上, 人与大地空间的物理联系中断了（这不仅仅是 隐喻的), 空中视角使得观者可以从外部来构想这个世界, 这样的 观看位置成就了知识与权威的新规则。到了 30 年代，尽管人们仍 然沉浸在对飞行的新奇感之中, 各类图片制作人已开始发掘飞机作 为观看和转换美国风景的工具的潜质。期间，美国农业部发挥了核 心作用, 它承担了对国家农业生产的监测, 特别是让农村地域现代 化。因为具备了这样的能力, 政府依靠航空调查的方式来组织多种 项目, 让它们视觉化, 这些项目包括推广土壤保护的计划, 强化个 体农民生产配额的执行。

那些政府的航拍监测图像, 由在高空飞行的飞机拍摄, 比如爱 荷华的格兰迪县的照片，高度精确地记录了玉米地的形状与大小。 仔细检测这些照片，农业机构既可以确定诸如一个农民耕种了多少 英亩的土地, 还可了解他种植的是那种类型的玉米。据此, 这些机 
构还可以知道个体农民是否在他与政府机构达成的协议所规定的范 围内进行耕作。在之后的几年，这些照片就作为项目注册的蓝图， 相关机构带着它们到农村，作为下一年度规划玉米种植计划的视觉 参考资料。从厨房餐桌到 $\mathrm{T}$ 型车的机罩，代理机构用这些图像来 指导农民抽象地 “观看” 这些土地，即视它们为生产的空间。

在某些方面，这些新的俯瞰视野也许对城市观者来说是司空见 惯的，他们了解之前的鸟瞰视角。让农业部感到惊讶的是，他们很 快就被那些土地拥有者期望把这些照片用作家庭展示的请求所淹 没。但是，不像 I9世纪的地图，航拍照片的视觉自足和稳定的指 代功能，使得它只是在面对艺术的理想化和制造文化神话时才显得 捉襟见肘。以一种可理解的、不加装饰的以及统一的方式来重塑大 地，航拍调查照片暴露了（或至少是复杂化了）通常的情绪性的农 业主义，它曾弥漫于 19 世纪的图像中，现在是用一种强有力的抽 象与理性秩序来代替它。在航拍摄影的官僚化的凝视中，大草原不 是作为独立农民的那种 “入画式” 的平畴而展露在天宇之下，而是 作为一个宏大的同质的土地持有系统，这个系统指向商品生产，而 不是文化。就像许多农民在写给农业部的信件里表达的那样，将自 己的住宅和田地视为同质化的农庄网格的组成部分，这让他们感到 不快。这些农民还意识到了我们今天可能称之为图像监视的问题 ; 把政府的这些调查照片称为 “天空的偷窥” 的说法开始流行起来。

伍德后期作品中可以看到他对这类调查图片也有相同的矛盾态 度，这种照片不但充斥在政府项目里，也渗透到了城市文化中。作 为一位航空爱好者，伍德也许对科学技术的进步感到惊奇。而作为 俯瞰视野的制作者，他肯定陶醉于这些引人注目的新景象。的确, 在 1935 年的一幅名为《爱荷华的麦克布莱德湖的喜剧救济基金会 地图》（Comic Relief Map of Lake McBride, Iowa, Area）的素描中, 伍德模仿了这种垂直角度的照片。

尽管对这些新图像着迷，伍德也认识到它们的现代性让传统农 业文化遭遇危险。正如那些在信中表达对航空勘察照片的新秩序深 感焦虑的农民，伍德的作品也开始表现出对遍布乡村的机械化与合 作生产的忧虑。尤其是伍德自己的航拍美学发生的令人惊讶的变 化，表明了他对现代理性带来的后果的日益增长的焦虑。1935 年创 作的《路上的死亡》(Death on Ridge Road，图 5) 中，伍德以一 
种让人不安的和充满变化的航拍角度, 将科技给传统乡土生活带来 的影响寓言化了。他采用一种不稳定和凶险的倾斜视角，画作展现 三辆在曲折乡村快速路上争夺通行权的车辆。画面中心，一辆铮亮 的黑色轿车突然转向，穿过车道，超越一辆落伍的 $\mathrm{T}$ 型车。同时， 一辆商用卡车突然冲向山丘顶部。公路两边, 紧绷的围栏铁丝网切 分了田野。与围栏相呼应的是, 一对刚劲力线形成为穿越这个场景 的斜向矢量, 它们清晰的线性特质与山丘柔和的曲线和庄稼地的圆 角形成鲜明对比。画面上方的乌云遮住了阳光，阵雨突然造访，砸 向地面，预示了即将发生的卡车、轿车和农民廉价汽车相撞的事故。 突然之间冲向电线杆的尖端，伍德的这种俯瞰的凝视，及其扭曲的 视线，让这幅风景画变成了不仅是汽车的碰撞，更是文化的冲撞。

《路上的死亡》构成了伍德对中西部现代化的最为明确的批评, 并且, 我认为, 这也是他的最困扰人心的俯瞰景象。伍德在画面中 捕捉到的是，俯瞰视野的那种让熟悉的空间变得令人不安的潜质。 的确，如果我们将这幅绘画与一些航拍图片进行比较，包括那种勘 察的图片和从俯冲飞机上拍摄的倾斜画面, 我们就可以理解伍德绘 画是如何利用现代的空中凝视来达到一种陌生化的效果的。关涉到 这种倾斜的图像，有意思的是，这幅照片第一次亮相是在爱荷华当 地的报纸上，作为一周的特色，让读者去辨认画面中的农场的位置 与主人。当然, 在这种游戏中的农场, 从平常的地面视角是容易辨 认的，但在俯瞰之下，就变得不容易识别了。这个测验是在假装玩 一种幼稚的游戏 (正如伍德的作品一样)。我认为, 对于误判的焦 虑是沉痛和真实的。这是对佛洛依德式的神秘性的完美说明（请原 谅这个双关语), 正如这种突然之间无法识别的家园空间, 成了更 深切的心理的疏离的源头。

《路上的死亡》表达了伍德的认识, 即这种神秘性可以是令人愉 悦的，但同时，也会成为一种威胁。之后，他使用这种陌生化的航 空视角来寓意现代化的危险。最终, 这幅画, 包括它的十字形的电 线杆和灵车般的轿车的宿命论图像志, 也标志了伍德的风景画作中 的直线的首次出现, 这不是偶然的。这些线条, 尤其是电线, 是这 个地区新的现代景象粗暴的制造者。在这个意义上，《路上的死亡》 至少部分是与这些勘察照片有关的, 是作为一种对凶猛的现代美学 的批判, 这种美学所寻求的是赋予这个地区的景色以统一的几何学 
的秩序，但是，这种做法造成了一种彻底根除农业传统中非现代化 因素的危险。

因为政府新的管理生产的理性视角重新利用了乡土文化，伍德 的作品便开始对由现代性所激发的，特别是那些勘察照片引发的风 景画提出质问。1936 年，也就是美国政府在全国范围内运用农业勘 察照片的那一年，伍德创作了他的牧场风景题材中最为现代的作品 《春天来了》。如我之前提到过的, 这种视角的主题是神秘化的农耕: 每年循环春耕。但是，尽管有着对某种乡土生活理想的乡愁（到了 1936 年, 几乎没有什么农民还在用马匹耕地了), 伍德在《春天来了》 中，借助航拍视角，让画面流畅而简约。与早期的风景画相比，伍 德将山丘的轮廓处理得更加光滑, 让颜色在画布变得更为平坦, 减 少线条与装饰, 削减场景中器物的数量, 更加注重形式的单纯, 机 械的光洁，采用的是不加调和的颜色，也更加突出了视觉的平面性。 当然，这幅作品在内容上保留了一定的伤感，但目前来看，特别是 与他的另外一些作品比较，这幅画在形式上要更为现代。

批评家立刻发现了伍德作品风格的变化。在 1937 年的一篇文章 中，作者劝导伍德放弃某些装饰性的乡愁，而倾心于一种更为 “直 白的对爱荷华原野的表达”，地方主义的代表人物托马斯·克雷文 （Thomas Craven）还是在嗟叹《春天来了》对从乡土到现代形式 的变化的表达过于强烈了。克雷文写道，“这件作品将乡村形象简 化为抽象形式，进入到巨大的虚空以及波浪般的起伏中，看起来并 不像土地，而是覆盖着绿色斑点的机械形式。”克雷文不是唯一注 意到《春天来了》中的现代主义倾向的人; 该作品在 1936 年《生活》 （Life）杂志上首次刊出，标引文字中，包含了大量对这件作品的 几何准确性的赞美，暗示了作品是按照一种高度现代化的美学绘制 出来的，尽管它并非是以机械方式描绘农业劳作。作为一本以推动 现代化为己任的杂志，《生活》的编辑们似乎非常欣赏伍德风格的 这次转向。

尽管克雷文和《生活》杂志编辑都没有说明这种联系, 对我来说, 现代主义 “面貌” 是与航空勘察照片抽象和疏离的美学相吻合的。 尤其是伍德对垂直方向的中断的强烈感受，这一点特别表现在《路 上的死亡》这样的作品中，通过前景视觉断裂的营造，创造了观者 与土地间的距离感，这种距离既是身体的，也是心理的。这幅画需 
要的是一种去人性化的和理性的凝视，而不是特定的与情感化的凝 视。它所关注的是纵横田地中的宽阔秩序，而不是丰饶树丛与肥沃 山丘的那种入画的效果。在他的绘画实践中，网格（航拍照片的样 式）第一次被加入到画面里。毕竟，在《春天来了》中占据主导地 位的是那些四四方方的耕地, 就好像政府的航空勘察照片中的那样。 尤其是平面性伍德的其他作品中是不曾出现的。这种贯穿整个山丘 的纯净平滑的绿色与土地的方格匹配, 将风景画融入到一个连续的 视野中。

但是，十分重要的是一《春天来了》没有简单地复制航拍照片 的审美取向。伍德试图柔化矩形空间的边缘, 以平衡航拍视角的刻 板，将一种形式和体积感重新引入大地，在耕地方块间留下开放的 和未经规划的田地。他还保留了, 蜿蜒的道路, 在某种程度上与《石 头城》中曲折回环的马道形成共鸣，仔细观察之下，《春天来了》 中的道路更多按照坐标方格进行直线排布，而没有表现土地自然的 曲线。但是, 如果我们观察这幅作品的上半部分, 就可以看到伍德 与这种新的航拍式审美取向间联系的最终证据。此处, 银色天空中, 也就是政府航拍飞机的活动领域，伍德将云彩排列成映射下半部分 风景的几何形因此布局, 让它变得更为轻松与情绪化, 天空转化为 松软的白色网格, 风景因此显得更加随意了, 不过, 还是需要以一 种模糊的方式来读解。伍德让云彩变成正方形，也让整个世界成了 一个网格, 这样一来, 现代航拍视角的那种新的理性现实就无处不 在了。但同样也整合了传统的元素，提出了一种基于传统与创新间 的适应和对话的现代性的理解。

正是伍德对土地的过往与当下概念的艺术融合矛盾，使得《春 天来了》成为重要的并且视觉上也十分有趣的作品。然而，在更广 泛意义上，我认为，这件作品对现代主义的视觉性的运用与适应， 给我们带来了挑战, 促使我们更为细致地思考 20 世纪早期作为现 代性表达的熔炉的乡土形象问题。美国艺术史家倾向于将艺术与文 化的现代主义的年代仅仅定义为工业化城市的后果，而伍德展示给 我们的是, 许多真正的现代化作业是在这些焦点之外, 也就是在美 国文化的地域性中得以实现的。这些交互作用，不论关涉到的是形 式元素，还是文化意义，都是复杂和多面的。在某些出乎意料的乡 村，可以了解到这种复杂性，由此，我们也许可以更全面地了解现 
代主义图像策略的延展性。

从《春天来了》回到《秋耕》, 我们也许能更好地理解, 甚至是 在 $193 \mathrm{I}$ 年，展现犁头也不是一件简单事情。犁刀既深耕土壤，也 切入了历史，耕种在流动与静止之间，在过去与现在之间，在转变 与停滞之间激发起一种特别复杂的张力。没有牲畜牵引犁具，也没 有农民把握犁具的木把而穿越田野，这个工具首先展现出来的是一 个陌生符号，它对移动的排斥好像阻止了变化，将伍德余下的视野 锁定在一个理想之地。但是，作为现代变革的工具，犁具的真实性， 作为颠覆（字面意义上）大地自然表面而让土壤展现为生产资源的 方法，是与这样一种读解背道而驰的，即将绵延起伏土地的景象当 作繁茂昌盛的梦想。赛珍珠小说的封面插图也助长了类似的二元主 义。《大地》赢得普利策奖的主要原因是因为它以一种搅动人心的 理想化手法，为美国读者呈现了一个遥远而有异域风情的中国。然 而, 因为用力过度, 赛珍珠的中国景象却是在耕种着与伍德的中西 部一样的大地。毕竟，这部小说是有关中国现代化的故事，那块土 地有着深厚的耕种传统，但是，采用了这样的方式，它也成了新世 界的一种丰饶的资源。

到目前为止，尽管很可能是这样，但我也并不确定伍德的绘画 是否给 193I 年该书第一版的封面提供了灵感。然而，我所知道的 是，这个犁具的主题并非唯一被采用的封面，因为其他首版采用的 是不同的图像，我们可以推测，这是出于不同意图。这个第二版的 封面设计似乎成了后续印刷的范本，这就能说明一些问题，由此， 可以推测这个犁具的主题, 至少是在赛珍珠的出版商的视野里面的, 尽管充足的耕地所证实的却是耕地并不充足的中国，不过，在 1931 年的某个时刻，美国农业的图像志也可能被用来表述中国农业现代 化的故事，至少对美国读者是这样的，这个事实倒是有点意味深长 的。

（张坚、聂皓雪译校） 


\title{
Peggy's "War Babies": Pollock, Motherwell, and Baziotes at Art of This Century
}

\author{
Ellen G. Landau
}

I believe all art to be historical. There is no such thing as an eternal art that transcends a specific historical period.

-Robert Motherwell, $1950^{\mathrm{I}}$

It was Peggy Guggenheim herself who dubbed as her "war babies" the three young Americans, Jackson Pollock, Robert Motherwell, and William Baziotes, whose initial artistic achievements she introduced to the public with solo exhibitions at her now-famous Manhattan gallery. Art of This Century, located at 30 West 57th Street, was launched in October 1942 after its wealthy American-Jewish owner's escape from occupied France along with her prized collection of blue-chip modern art, smuggled into the United States as household goods. Guggenheim's chic establishment quickly became an exile headquarters for European refugee artists (both abstract and Surrealist) to meet, exchange ideas, and exhibit. By 1943-44 during which each of her "war babies" ${ }^{2}$ was introduced in group shows and separately celebrated, Art of This Century's mission expanded, becoming more fully the "research laboratory" for artistic innovation that was her original intent. ${ }^{3}$ This essay will examine, for three U.S. artists whose careers initiated during World War II under Peggy Guggenheim's sponsorship, the subjective implications of a particular nexus between Surrealist aesthetics, artistic modernism, and the "vital and chaotic" wartime New York conditions all were forced to navigate.

Taking into account his expertise with words as well as imagery, focus will be placed on Robert Motherwell as a paradigm for studying this experience. Motherwell's early published writings, strongly inflected by his close I94I relationships in Mexico and at home with key Surrealist émigrés, provide an unprecedented window into his thinking during this all-important gestational period. Examining his wartime speculations and assertions from the point of view of what art historian Serge Guilbaut has characterized as an early '4Os "depoliticization

I Robert Motherwell, “The New York School,” Lecture at the Mid-Western Conference of the College Art Association, University of Louisville, KY, October 27, 1950. Reprinted in Stephanie Terenzio, ed., The Collected Writings of Robert Motherwell (New York: Oxford University Press, 1992), 79.

2 Peggy Guggenheim, Out of This Century: Confessions of an Art Addict (New York: Universe Books, I979), I72.

3 Press release for Art of This Century, n.d. (c. October 20, 1942); cited in Susan Davidson, "Focusing an Instinct: The Collecting of Peggy Guggenheim," in Peggy Guggenheim and Frederick Kiesler: The Story of Art of This Century (New York: Guggenheim Museum Publications, 2004), 77. 
that retained the imprint of politics," 4 Motherwell's writings and art are seen to advance the American imperative toward unrestricted personal expression in a time of "utter horror" (per the artist's own description) amidst a threat of peril unprecedented in recent human history. ${ }^{5}$

Much later Motherwell would recall the war era's mood on the home front as producing "a collective nausea from fear, not of one's own death but one's lives and beliefs." Remarking that his natural way would be to write "detachedly," Motherwell acknowledged that's not what happened then: "In the middle of a war one has to become a partisan. One cannot be a bystander, and so I wrote in a partisan way." 7 Trained in French literature and philosophy at Stanford and Harvard, Robert Motherwell's intellectual acuity and the impact of its intersection with his development of visual creativity can be nuanced by comparison to Jackson Pollock, an artist much less educated but far more intuitive and, to a somewhat slighter extent, in comparison to the ideas and works of their peer and friend, William Baziotes. Not subscribing equally to Motherwell's tragic viewpoint, theoretical bent and polemical tendencies, all three did share a similar imperative to reconcile abstraction and figuration, giving European Surrealist automatic techniques a New World wartime correction. Rejecting the use of automatism as illustrative free association, they employed it as a plastic "weapon" for formal innovation. ${ }^{8}$

Despite influential critic Clement Greenberg's promotion of originality as "art that put distance between itself and the specificities of immediate cultural influence,"9 early stages of the New York School—though not always adequately acknowledged as such-were catalyzed in varying ways by response to the current world crisis. Unlike colleagues who joined the organization Artists for Victory, participating in competitions that resulted in exhibitions such as America in the War, 1943's nation-wide print show, not many associated with the Abstract Expressionist group were willing to engage directly with visual propaganda. ${ }^{\text {Io }}$

4 Serge Guilbaut, How New York Stole the Idea of Modern Art: Abstract Expressionism, Freedom, and the Cold War (Chicago: University of Chicago Press, 1983), 79.

5 Motherwell, June 6, 1980 interview with Robert Mattison; quoted in Mattison, "Robert Motherwell's First Collages: 'All My Life I Have Been Obsessed with Death," Studies in Iconography I2 (1988): 174.

6 Robert Motherwell, "Parisian Artists in Exile: 1939-1945," Musée nationale d'art moderne, 1977, typescript, I2, Dedalus Foundation, New York.

7 Barbara Catoir, "The Artist as a 'Walking Eye': Fragen an Robert Motherwell," Bruckmanns Pantheon 38 (1980): 288.

8 Robert Motherwell, “The Modern Painter's World," Dyn 6 (November 1944), reprinted in Terenzio, The Collected Writings of Robert Motherwell, 34.

9 Greenberg's philosophy summarized by Ann Eden Gibson, Abstract Expressionism: Other Politics (New Haven: Yale University Press, 1997), xxviii.

Io See Ellen G. Landau, Artists for Victory, An Exhibition Catalog (Washington, DC: Library of Congress, 1983) and “'A Certain Rightness': Artists for Victory's 'America in the War' Exhibition of 1943," Arts Magazine 60 (February 1986): 43-54, as well as Stephen Polcari, From Omaha to Abstract Expressionism: Ameri- 
Philip Guston, Pollock's friend since their boyhood in California, was one of a few to confront the conflict head on; having included anti-Nazi themes as early as $1934-35$ in a mural painted with Reuben Kadish in Mexico, his tondo Bombardment produced at the height of the Spanish Civil War is powerfully predictive of what more was to come.

Teaching in Iowa in the early I940s, Guston participated in a War Art Workshop. There he drew Navy parachute, flotation, and physical training exercises and he also did illustrations for Fortune magazine depicting airplane construction, paratrooper training and additional Armed Service-related topics. ${ }^{\text {II }}$ While Kadish was eventually drafted, for a variety of reasons the majority of Abstract Expressionists, including our three main protagonists, were deemed unfit to fight. Rejecting the somewhat racist anti-Axis theatrics of his teacher Regionalist Thomas Hart Benton, whose 1942 Year of Peril series was widely circulated, ${ }^{12}$ Pollock did participate in a War Services project in New York around that same time. Supervised by his future wife Lee Krasner, their team engaged the fabrication of collage and photomontage store window "murals" to advertise war training courses at local municipal colleges. ${ }^{13}$

All told, as another nascent Abstract Expressionist Barnett Newman would one day expound, the history of their artistic generation began with the deceptively simple question, "what to paint." The war, Newman recalled, "made it impossible to disregard the problem of subject matter." ${ }^{14}$ This dilemma elicited substantially different solutions, with most choosing a less recognizable route than Guston to express wartime themes, incorporating by contrast indirect or encoded symbols, stories, or tropes assimilating an epoch-specific intertwined public and personal meaning. Referencing the mythic and primitive- not unlike Pollock but to a different end and degree_-during the early I940s Newman's close associates Adolph Gottlieb and Mark Rothko (the latter also shown at Art of This Century) adopted a more tragic tone. This maudlin tenor is evident in Rothko's Sacrifice of Iphigenia done in 1942 as compared with Pollock's slightly

can Artists Respond to World War II (New York: Sidney Mishkin Gallery, Baruch College, 1995).

II "Air Corps Paintings by Art Professor to Appear in Fortune," Daily Iowan, January 27, 1944; discussed in Michael Shapiro, "The Early Years, 1930-1945," Philip Guston Retrospective, ed. Michael Auping (New York: Thames and Hudson for the Modern Art Museum of Fort Worth, 2003), 29-30. Guston told the Daily Iowan, "I wasn't so much interested in portraying the appearance of the nuts and bolts of the planes as I was in showing the faces of the men, their tenseness and determination."

I2 Cecile Whiting, Antifascism in American Art (New Haven: Yale University Press, I989), II5-23.

I3 Ellen G. Landau, Lee Krasner: A Catalogue Raisonné (New York: Harry N. Abrams Inc., 1990), I8I-20I, cat. nos. 93-96.

I4 Barnett Newman in conversation with Thomas B. Hess, Solomon R. Guggenheim Museum, May I, 1966, cited in Brenda Richardson, Barnett Newman: The Complete Drawings, 1944-1969 (Baltimore: Baltimore Museum of Art, 1979), I5. 
later mid-1943 Guardians of the Secret. On occasion these war-era works hint at an underlying political viewpoint, ${ }^{\text {is }}$ Gottlieb's more aggressively. To cite one pertinent example, Gottlieb's pictographic forms included some that appear to reference saw-tooth designs painted on bombers that U.S. Colonel Claire Chennault and his Flying Tigers deployed out of China against the Japanese. ${ }^{16}$

It has already been chronicled many times over how Manhattan unexpectedly transformed from a not especially distinguished locus of provincial art production into the premier bastion (and safeguard) of cultural modernism, a direct result of the Nazi occupation of France. Arriving in the United States primarily between the fall of Paris on June I4, I940 and the following spring, some 30,000 refugees (many from the worlds of literature, art, and music) fled to a metropolis less directly "clouded by war" where free creativity still remained possible. "More than ever the home of the homeless," as Alistair Cooke of the BBC so memorably described it, New York City seemed to provide the closest alternative for continuation of even a modicum of cosmopolitan artistic life. ${ }^{17}$ By 1943, an almost wholesale relocation of the seat of the avant-garde across the Atlantic was firmly set in place; at that time, of course, no one dreamed the move was destined to become permanent.

Unsurprisingly, the above transformation also accelerated after Japan's Imperial Army Air Service attacked U.S. battleships stationed in Hawai'i in early

I5 The generally pervasive pessimism of Gottlieb and Rothko's war-era works was rooted in their self-proclaimed "recognition and acceptance of the brutality of the natural world and the eternal insecurity of life." "In times of violence, personal predilections for niceties of color and form" seemed "irrelevant." "All primitive expression reveals the constant awareness of powerful forces, the immediate presence of terror and fear," they explained, adding, "That these feelings are being experienced by many people throughout the world today is an unfortunate fact and to us an art that glosses over or evades these feelings is superficial and meaningless." "The Portrait and the Modern Artist," October I3, 1943 broadcast on radio station WNYC, transcript in the Adolph and Esther Gottlieb Foundation Archives, New York. "The war, as the Surrealists predicted, has robbed us of our hidden terror," Newman wrote in 1942. "Terror can only exist if the forces of tragedy are unknown. We now know the terror to expect. Hiroshima showed it to us." Thomas B. Hess, ed., Barnett Newman (New York: Museum of Modern Art and New York Graphic Society, 197I), 35.

I6 Stephen Polcari, Abstract Expressionism and the Modern Experience (New York: Cambridge University Press, 199I), I69-70. See also Nancy R. Versaci, "Flying Tigers," in Flying Tigers: Painting and Sculpture in New York 1939-I946 (Providence: Bell Art Gallery, 1985), 4.

I7 Cooke, quoted in Richard Goldstein, Helluva Town: The Story of New York during World War II (New York: Free Press, 2010), 92 (also source of cited statistics). New York as a "metropolis clouded by war": "Interview with Robert Motherwell by Barbaralee Diamonstein," in Inside New York's Art World (New York: Rizzoli, 1979), 228. 
Fig. I. Roberto Matta, Invasion of the Night, 194I. Collection SFMOMA. Bequest of Jacqueline Marie Onslow Ford. San Francisco Museum of Modern Art, San Francisco CA. (CArtists Rights Society (ARS), New York; ADAGP, Paris. Photograph: Katherine Du Tiel.

December 194I. This unexpected event quickly forced into virtual retreat a number

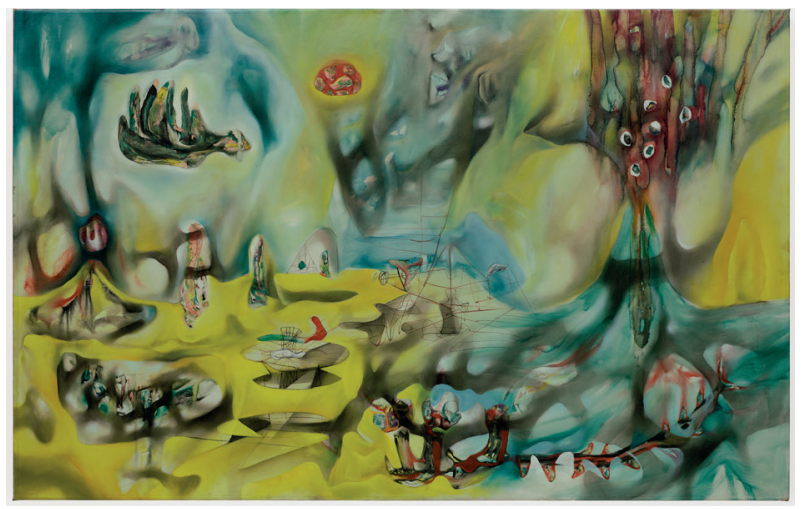
of interwar isolationist strains limiting advancement in American politics and culture, not excluding art. "Once more this struggle includes such emotional charges and is called upon to have such decisive consequences on several planes," émigré poet André Breton pronounced in the Surrealist journal View. Writing two months before Pearl Harbor, "There is no intellectual step," he predicted, "which will not find itself modified, contradicted, weakened, verified, strengthened, more or less radically." ${ }^{18}$ Lecturing at Yale the following year, Breton concluded that Surrealism (condemned as arch-degenerate by the Nazis) "can be understood historically only in relation to the war." ${ }^{19}$ By autumn 1942 with the Axis Powers in ascendance, Surrealism was eliciting both interest and controversy in its alternate home, New York. A small but powerful show at the Pierre Matisse Gallery of "Artists in Exile," followed by a larger group exhibition "First Papers of Surrealism" (held at the Whitelaw-Reid Mansion with Motherwell and Baziotes included) made a huge media splash, as did Art of This Century's inaugural presentation opening two weeks later, where works by Peggy Guggenheim's then-husband Max Ernst and his Surrealist compatriots headlined the many objects occasioning both wonder and fierce debate.

While Motherwell knew Breton, the so-called "Pope of Surrealism," and unlike other Americans could actually converse in French, it was his closer relationship with the Chilean-born painter Roberto Sebastián Antonio Matta Echaurren that precipitated an introduction to Pollock and Baziotes and led to the connection of all three with the avant-garde headquarters at Art of This Century. Referring to what these painters were doing, as well as others who also joined his workshop in winter $1942-43$, Matta recollected this group was "ready to explode." ${ }^{20}$ His own art at that time elicited, he said, from "battlegrounds of feel-

I8 “Interview with André Breton,” View I (October-November I94I), 2.

I9 André Breton, Situation du surréalisme entre les deux guerres (Paris: Editions de la Revue Fontaine, 1945), n.p.; originally a lecture delivered at Yale University, December IO, 1942. "Arch-degenerate": "Surrealists in Exile," Time 39 (April 20, I942), 48, 50 .

20 "Concerning the Beginnings of the New York School: 1939-1943. An Interview with Peter Busa and Matta, conducted by Sidney Simon in Minneapolis in 
ings and ideas, fighting to see if something would come out of these clashes." ${ }^{21}$ In pictures called "psychic morphologies," some done in Mexico where he and Motherwell had spent a recent summer, Matta imaged an ambiguous cosmic ambiance set aglow with luminescent shapes (Fig. I). By 1943 these hallucinatory "inscapes" increasingly implicated a marked political resonance. The "apocalypse of this war wreaked havoc on the emotional system," Matta wrote, "How to picture the battlefield, not the physical one, but the one inside us: fear against courage, criticism and hate, suspicion and trust?" ${ }^{22}$ In an ironic turn perhaps, Matta's self-described "internal bombardment" ${ }^{23}$ prompted visions of nature in ecstasy. ${ }^{24}$

As much as they learned from Matta's somewhat anarchic example, the as yet inexpert New Yorkers knew from the start that they were after something different, and it would not be long before their particular sense of the "most insistent" needs and values of a time_-as Motherwell described, "when men were ravenous for the human"-would lead them to conceptualize divergent formal tactics and variant thematic approaches. ${ }^{25}$ Paradoxically, the disastrous circumstances of World War II provided an ideal venue for this transformation. In particular, Art of This Century's local presence afforded these young Americans an unprecedented opportunity to mingle with world-famous modernists and study their latest output, as well as expose their own experiments to influential curators, buyers, and critics.

Peggy Guggenheim's original plan had been to develop in London what Art of This Century ultimately became. Having begun to collect modern art around I937 using her relatively modest share of the family's copper fortune, she started making plans to transform her gallery on Cork Street into something akin to a

2I Max Kozloff, "An Interview with Matta—these things were like rain catching up with a man who is running," Artforum 4 (September 1965): 25.

22 Matta quoted in Germana Ferrari, Entretiens Morphologiques, Notebook No. I, 1936-1944 (London and Lugano: Sistan, 1987), 226, n. 7. See Elizabeth A.T. Smith and Colette Dartnall, "'Crushed Jewels, Air, Even Laughter': Matta in the I940s," in Matta in America: Paintings and Drawings of the I940s (Museum of Contemporary Art Chicago and Museum of Contemporary Art Los Angeles, 200I), 17.

23 Quoted in Smith and Dartnall, "Crushed Jewels, Air, Even Laughter," 17.

24 Sidney Janis, "School of Paris Comes to U.S.," Decision 2, nos. 5-6 (NovemberDecember 194I): 95; cited in Smith and Dartnall, "Crushed Jewels, Air, Even Laughter," I8.

25 For more on Pollock's and (especially) Motherwell's artistic relationship with Matta, see Ellen G. Landau, Mexico and American Modernism (New Haven: Yale University Press, 2013), chapters 4-5. In "Notes on Mondrian and Chirico," published in the Surrealist journal $V V V$ I (June 1942), 59, Motherwell critiqued Dutch abstractionist Piet Mondrian's "loss of contact with historical reality; or more concretely loss of the sense of the most insistent needs (and thus of the most insistent values) of a given time [...] when men were ravenous for the human." Mondrian, Motherwell judged, "failed, with his restricted means, to express enough of the felt quality to deeply interest us." 
salon, fully aware that world events might frustrate this ambition. "We are going to have publications and lectures," Peggy wrote in April 1939 to a friend at home, "and [we'll] be a general living art center and of course give exhibitions of art." "I hope you will come back and see it all," she added, "before Mr. Hitler drops a bomb on it." ${ }^{26}$ Not five months later, Germany's invasion of Poland led to declarations of war by Britain and France. Guggenheim, her collection supposedly still growing by "a picture a day," hoped to wait it out in rural France, hiding her art at the Musée de Grenoble. Soon realizing this plan would not be feasible, with her ex-husband, two children, and others including Ernst (a German national) in tow, she reluctantly returned to the United States.

Because of wartime shortages it took until fall of 1942 for Art of This Century's New York launch, its mission now fully transformed with a more defiant reason for being. "Opening the gallery and its collection to the public during a time when people are fighting for their lives and freedom is a responsibility," Peggy said, of which she remained "fully conscious." "This undertaking," her press release explained, "will serve its purpose only if it succeeds in serving the future instead of recording the past." ${ }^{27}$ Her philosophy was demonstrated at Art of This Century not only through what Guggenheim chose to exhibit, but also via radical means of display. Some of Viennese architect Frederick Kiesler's more unusual (and according to one critic "faintly menacing") design ideas included hanging unframed paintings from the ceiling by strings or projecting them outward from curving gumwood walls attached to tilting baseball bats. ${ }^{28}$ To demonstrate her impartiality at the opening, Peggy famously wore one earring by abstract sculptor Alexander Calder and one by Surrealist painter Yves Tanguy.

Moving beyond her reputation as "financial angel" to the displaced Surrealists, by mid-1943 after her divorce from Ernst, Guggenheim even more eagerly consulted a well-chosen team of advisors, including such artists as Matta, Piet Mondrian, and Marcel Duchamp, plus various influential New York museum and art world luminaries. This led Art of This Century's exhibition schedule to diverge from prior concentration on the European exiles, increasing its representation of talented, but untried American fledglings. ${ }^{29}$ On the basis of successful

26 Undated letter, Peggy Guggenheim to Emily Coleman (c. early 1939). Emily Holmes Coleman Papers, Special Collections, University of Delaware Library, Newark, DE. Cited in Davidson, "Focusing an Instinct," 57.

27 Interview with Peggy Guggenheim, Trenton (New Jersey) Times, November 6, 1942. Press release: Davidson, "Focusing an Instinct," 77.

28 In Out of This Century, I03, Guggenheim quoted a critic's comment on Art of This Century's Surrealist Gallery: "It looks faintly menacing—as if in the end it might prove that the spectator would be fixed to the wall and the art would stroll around making comments, sweet or sour, as the case might be." Edward Alden Jewell, "Art of This Century," New York Times, October 25, 1942.

29 On Putzel's key role, see Melvin P. Lader, "Howard Putzel: Proponent of Surrealism and Early Abstract Expressionism in America," Arts Magazine 56 (March I982): 86-87. 
debuts by Pollock and Baziotes, its owner's acumen mostly achieved fulsome praise. Referring to their first solo shows, in late 1944 Clement Greenberg announced that two of the abstract artists Peggy recently introduced "have already placed themselves among [our] six or seven best young painters."

How did the anxious yet enervating Manhattan wartime milieu affect the content of these initial exhibitions, Jackson Pollock's in November 1943, William Baziotes in October the following year and Robert Motherwell's one month later? Seeing his entry show, Greenberg's praise for Baziotes's "unadulterated talent" was mainly effusive. "He already confronts us with big, substantial art," Greenberg wrote, "filled with real emotion and the true sense of our time." 30 Baziotes, the first of the three to meet Matta (in 1940 at a loft party), remained throughout his career the one most closely tied to the metaphoric potentiality of automatism's emphasis on unconscious imagery. ${ }^{3 \mathrm{I}}$ In his earliest published statement, originally written on stationery from Art of This Century, the artist explained that while a subject was always "uppermost" in his mind, his awareness of it could be fleeting. ${ }^{32}$

Much later Baziotes's wife confirmed that some of Bill's late I930s paintings had definitely been "war-oriented." At that time he was preoccupied with sinister-looking prehistoric reptiles in the Museum of Natural History and with a book showing photos of horribly maimed soldiers from the First World War. ${ }^{33}$ "There was one picture I kept returning to," he recalled. "It was a soldier who was decapitated at the waist and whose arms were cut off. [...] I used to draw him many times." Dwarf, painted in 1947 just after the end of World War II, reflects this fixation and more, including the impact of what Baziotes termed Picasso's "fever of death and beauty" and Spanish master Francisco Goya, whose "mixture

30 Clement Greenberg, "Art," The Nation 159 (November II, 1944): 598. Also includes comment on "six or seven best young painters" cited in text above.

3I Peter Busa, another Matta workshop participant, said about Baziotes, "Bill got us all to practice automatic drawings and he insisted on the Surrealist use of the automatic image. [...] Baziotes was always going on about aspects of Surrealism which really didn't interest me very much, but then I realized that what interested him deeply was not Surrealism, but the value of the metaphor for the experience." Transcript of interview with Jack Taylor, Peter Busa Papers, Provincetown, MA.

32 Statement published in Sidney Janis, Abstract and Surrealist Art in America (New York: Reynal \& Hitchcock, 1944), I07; discussed in Jasper Sharp, "Paintings and Drawings by Baziotes, 3-2I October 1944," in Story of Art of This Century, 308: "There is always a subject that is uppermost in my mind. Sometimes I am aware of it. Sometimes not. I work on my canvas until I think it is finished. Often I recognize my subject at completion of the picture and again I may wait a long time before I know what it is about."

33 C.R. [Cynthia Roman], "William Baziotes (1912-1963)," in Flying Tigers, 40; information from Judith Tolnick and Nancy Versaci, conversation with Ethel Baziotes, May 22, 1984 . 
Fig. 2. William Baziotes, The Parachutists, 1944. The Solomon R. Guggenheim Foundation Gift, Ethel Baziotes, 2004. (O)2020

William Baziotes/ARS, New York.

of beauty and horror" the neophyte artist also found "very exciting." 34 A few years after finishing Dwarf, Baziotes would admit that frequently "images came to him after a crisis-prostitutes with syphilis on their legs, perverts, all

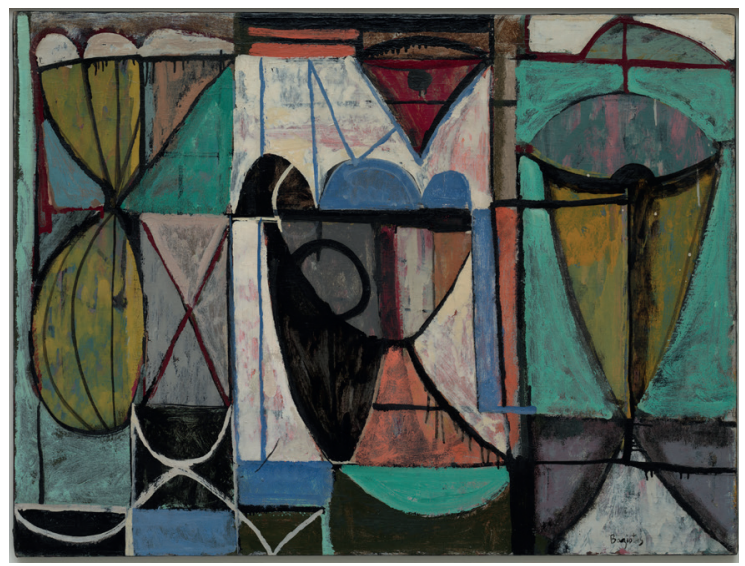
kinds of insane [...] an odalisque with a big cobra looming out of a vase, all completely unexpected." 35

In an experience Ethel Baziotes wryly described as "the blind leading the blind, an overpowering adventure in which both of them were in over their heads," ${ }_{36}$ Motherwell (himself recalling the two as "frightened and green" ${ }^{37}$ ) helped Baziotes hang his first show. Paintings and Drawings by Baziotes at Art of

34 Baziotes's letter to Barr, April 26, 1949: copy in William Baziotes Files, Museum of Modern Art Library. In this letter the artist specifically considers influences that helped him develop Dwarf. He cites not only Goya and the image of a World War I "basket baby" amputee, but also prehistoric animals, the "passive and deadly" eye of a lizard, "the grin of the crocodile which has a mixture of horror and humor" and "a feminine sexual symbol." For analysis, see Mona Hadler, "William Baziotes: Four Sources of Inspiration," in William Baziotes: A Retrospective Exhibition, ed. Michael Preble (Newport Beach: Newport Harbor Art Museum, 1978), 85-86. The artist's own face appears on a drawing of one of the World War I amputees Baziotes sent with his letter to Barr, labeling it as a study for Dwarf. On the basis of this evidence, Hadler suggests the painting had an autobiographical component. Regarding Picasso, Baziotes remarked, "I saw that the figure was not his real subject. The plasticity wasn't either-although the plasticity was great. No. Picasso had uncovered a feverishness in himself and is painting it - a feverishness of death and beauty." Quoted in Rudi Blesh, Modern Art USA (New York: Alfred A. Knopf, 1956), 268-69.

35 Quoted in Donald Paneth, "William Baziotes: A Literary Portrait," unpublished manuscript, 2I; William and Ethel Baziotes Papers 1916-1992, Archives of American Art, Smithsonian Institution; hereafter AAA.

36 Ethel Baziotes, interview with Jasper Sharp, February I3, 2004.

37 Robert Motherwell, interview with John Jones, October 25, 1965, AAA. Baziotes himself recalled of his experience at Art of This Century, "Underestimated interest of public. Not a hard-luck pioneer. Strange, most astonishing people would come and buy. Very exciting period. Fantastic. Leading a lonely life, no connection with world, thrown, thrust into it suddenly": Paneth, "A Literary Portrait." All quotes: Sharp, "Paintings and Drawings by Baziotes, 3-2I October I944," 310. 
This Century included a number of Picasso-influenced works a great deal less infatuated with expressive deformity. In one of these more classically composed I944 canvases, rejecting Matta's directives, Baziotes made thematic reference to imagery familiar from newsreels and magazines. Composing The Parachutists (Fig. 2), he translated the descent of Allied soldiers behind dangerous enemy lines into a vibrantly patterned and vividly colored Synthetic Cubist grid. Like Pollock and Motherwell, Baziotes was drawn to a painting Ernst had persuaded Peggy to buy, Picasso's The Studio of 1927-28. Here, making timely reference to "the tremors of an unstable world," ${ }^{8}$ he re-envisioned its cool rationality.

Jackson Pollock presents a somewhat different situation with regard to melding Surrealism, abstraction and the war. A more reluctant participant in Matta's workshop, Pollock did agree to participate with Krasner in playing Surrealist games with Baziotes, Motherwell, and their wives. Even more than the others, his association with Peggy Guggenheim was vitally consequent for Pollock's career. Despite considerable early reservations, Guggenheim was persuaded by her savvy assistant Howard Putzel to offer the nearly destitute artist a monthly contract. This allowed him to devote full-time to painting; in addition, she commissioned Pollock to create a mural for her townhouse that would provide a critical turning point in his artistic trajectory. As Peggy later acknowledged, after Ernst's defection, Jackson Pollock became the "central point" of Art of This Century. ${ }^{39}$

Although like his two friends, Pollock had earlier been included in group shows at the gallery (garnering critical praise), the fruits of his and Peggy's atypical arrangement were more broadly exposed at his solo debut in the hazardous year of 1943. Interestingly, in view of Pollock's distinct prior fascination with violence, apparent in 1939's Naked Man with Knife and related examples of the prewar period, by 1943 he had re-oriented his direction to greater involvement with therapeutic self-definition. Compared to Motherwell's outing twelve months later, the works included in Pollock's first one-man show were less overtly politically conscious. Indeed, "extravagantly, not to say savagely romantic" is how one critic summarized the tenor of such paintings on view as She-Wolf, Pasiphäe, and Moon Woman Cuts the Circle. In these, Pollock deeply infused archetypal identity themes with the flavor of Jungian psychology. $4^{\circ}$

38 "Symposium: Creative Process," Art Digest 28 (January 15, 1954): I6; quoted in Polcari, Abstract Expressionism and the Modern Experience, 213. For further discussion, see ibid., 216-17.

39 Out of This Century, I06. On the importance of Pollock's Mural for his career, see Francis V. O'Connor, “Jackson Pollock's Mural for Peggy Guggenheim: Its Legend, Documentation and Redefinition of Wall Painting," Story of Art of This Century, 150-69 and Ellen G. Landau, "Still Learning from Pollock," in Jackson Pollock's Mural: The Transitional Moment, eds. Yvonne Safran et al. (Los Angeles: J. Paul Getty Museum, 2014), 7-29.

40 Edward Alden Jewell, New York Times, November I4, 1943. Jewell added, "Here is obscurantism, indeed." Analysis of works in his 1943 first solo show: Ellen G. Landau, Jackson Pollock (New York: Harry N. Abrams, 1989), chapter 6. Pollock 
Fig. 3. Jackson Pollock, Burning Landscape, 1943. Yale University Art Gallery. Gift of Peggy Guggenheim. (C) 2020 The Pollock-Krasner Foundation/ARS, New York.

Pollock did once mention to Reuben Kadish that he had also done a set of "war" paintings around that time. Burning Landscape, likewise completed in 1943, is one of only two known works that intentionally references the ongoing global disaster (Fig. 3). Neither, as it turns out, was ever shown at Art of This Century. In this case, there seems little question that the title Pollock chose, while a clear echo of Matta's obsessions, also makes a specific allusion to modern warfare's incendiary tactics. Burning Landscape's Matta-like

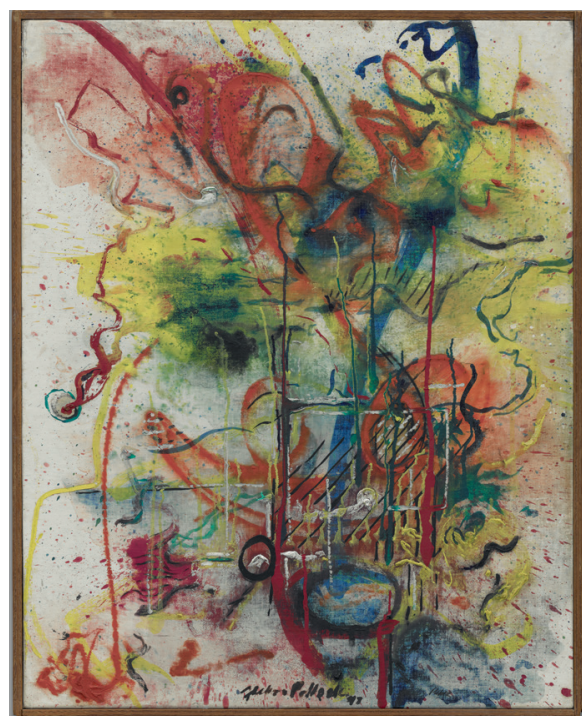
composition also resembles military photographs taken from above, the kind often reproduced by newspapers in those days. As John Sawyer points out, Pollock's inclusion of a concentric circle in red, white, and blue, a possible nod to Allied air force insignia, seems "marked with a sense of irreal intensity." ${ }^{4}$

The other identifiable WWII-related work by Pollock is an ink and colored pencil drawing, not a painting. It represents a more emotionally explosive image, depicting a pyre of human and animal bodies with a crucifixion placed over to one side. Actually titled War, its mood and imagery resonates with Picasso's 1937 anti-Fascist double print, The Dream and Lie of Franco, as well as Guernica, a work for which Pollock had great admiration. If done later in 1947 as somewhat ambiguously signed at lower right, War may represent his own recoil from postwar aftershocks, a response to detailed disclosures about the Holocaust (Krasner was Jewish) and news of the devastation wrought by atomic bombings at Hiroshima and Nagasaki. Henry McBride, critic for the New York Sun, would compare the effect of a Pollock all-over work, Number 7, 1949, to "that of a flat, war-shattered city, possibly Hiroshima, as seen from a great height in moonlight." 42 By the time Pollock painted Number 7 (now known as Out of the Web) employing his newly developed poured technique (Fig. 4), Art of This Century had closed its doors

had four exhibitions at Art of This Century; Baziotes and Motherwell each only one.

4I J.S. [John Sawyer], "Jackson Pollock, Burning Landscape 1943," in Flying Tigers, 83-84. On Pollock's "war paintings," see Stephen Polcari, interview with Reuben Kadish, October 3I, 1991. Sawyer compares forms in Burning Landscape to "the engulfment in fire of huts on small Pacific atolls."

42 Henry McBride, New York Sun, December 23, 1949. "There is sparkle to the color," he continued, "and hints of a ribbon of river holding the glimpses of the city together." 


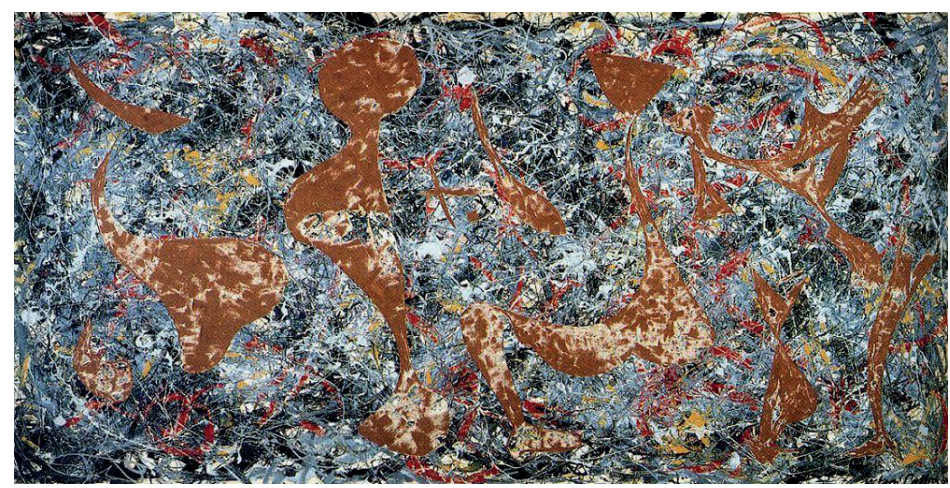

Fig. 4. Jackson Pollock, Out of the Web: Number 7 , 1949. Staatsgalerie, Stuttgart, Germany. (c) 2020 The Pollock-Krasner Foundation/ ARS, New York.

and Peggy Guggenheim moved back to Europe.

While Greenberg became Jackson Pollock's most effective champion, as evident in 1944 published remarks about his initial show, Robert Motherwell was one of the first to understand where his friend was headed and the stakes involved in getting there. ${ }^{43}$ As already established, Motherwell was highly adept at using his verbal intelligence to articulate issues not only critical to himself, but also his artistic cohort. "I believed more in words than the others," he once explained. "I'm aware of how terrible they are and also often attack them, but they're a real social weapon and anybody ignores them at their peril." 44 Because he felt unable to find "the values of our own epoch" looking at past art, during the Second World War Motherwell also sought new forms for modernism. Although his goals were roughly conversant with Pollock's aim as expressed in an undated (probably postwar) notation, "Experience of our age in terms of painting — not an illustration of - (but the equivalent)," their results were very different. ${ }^{45}$

In the words of critic Dore Ashton, Robert Motherwell became one of only a few Americans "able to salvage the germinal rather than the terminal facets of Surrealism." ${ }^{66}$ His solo presentation at Art of This Century opened alongside signed color reproductions of Picasso's latest known works, created before the war and spirited out of France. Several critics, including Greenberg, set up comparisons between the two; remarkably, none mentioned that four of Motherwell's seven oil paintings on display had an obvious Mexican connection in

43 "Since painting is [Pollock's] thought's medium," Motherwell prognosticated, his "resolution must grow out of the process of his painting itself." "Painters Objects," Partisan Review II (Winter 1944): 97.

44 Robert Motherwell, Oral History Interview Conducted by Paul Cummings, November 26, 1971, AAA.

45 Motherwell, "Modern Painter's World," reprinted in Terenzio, The Collected Writings of Robert Motherwell, 34. Pollock, handwritten statement (c. 1950?); reprinted in Pepe Karmel, ed., Jackson Pollock: Interviews, Articles and Reviews (New York: Museum of Modern Art), 1999, 24. The final words are "Concentrated. Fluid."

46 Dore Ashton, "Robert Motherwell, Passion and Transfiguration," Studio International 167 (March 1964): I02. 
Fig. 5. Robert Motherwell, Pancho Villa, Dead and Alive, 1943. The Museum of Modern Art, New York. (C) 2020 Dedalus Foundation Inc./Licensed by VAGA at Artists Rights Society (ARS), New York, NY.

title, style, or imagery. In addition to Pancho Villa, Dead and Alive, a collage that is probably his most important early ' $40 \mathrm{OS}$ work (Fig. 5), many of Motherwell's exhibited drawings also involved violence-tinged Mexican subject matter as well. For

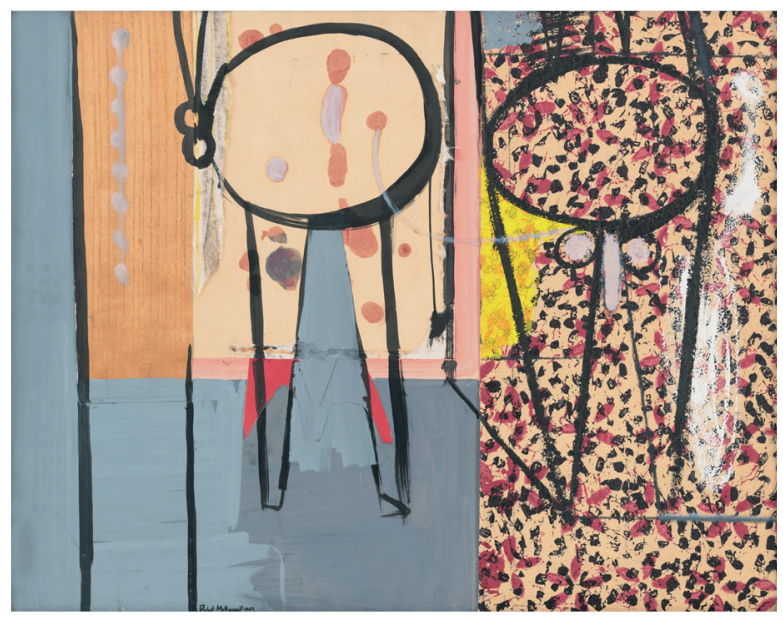
Motherwell, Pancho Villa's story (to which the family of his Mexican wife had a connection) was all about the sometimes dire consequences of making a political choice, as well as its moral implications.

Additionally included in Motherwell's Art of This Century solo show were several works on paper featuring an abstracted line of persons appearing as if shot in a street execution. All, like Pancho Villa, Dead and Alive, included splotchy red blots approximating stains of blood (Fig. 6). In 1946, the artist would designate these drawings, along with a canvas he called Little Spanish Prison, as "a kind of disasters series," referring to Goya's famous I8Io-20 antiwar prints. At the same time, Motherwell also remained cognizant that these personages shot, never identified, might equally be stand-ins for himself and his parents with whom his relationship was highly fraught. ${ }^{47}$ Three Personages Shot is inscribed June 6, I944, the date of the Allied Normandy landing.

Clearly, continuing inspiration from his summer I94I sojourn in Taxco shared with Matta and a few others, as well as a more extended experience that fall working close to Wolfgang Paalen, another Surrealist émigré living near Mexico City, had well acquainted Motherwell with a set of themes onto which he could later displace his wartime unease. Close examination of sketches Motherwell produced during his first months in Mexico indicates the extent to which he had dedicated this time to initiating a dialogue with Matta's innovations. Paalen's subsequent impact was seemimgly less formal and more related to theory. Motherwell translated Paalen's "The New Image," a lead article for the inaugural number of Dyn, a journal Paalen produced in Mexico that was also widely read in New York. Anticipating the Abstract Expressionists, Paalen considered

47 "Disasters series": Motherwell, letter to Dorothy Miller, May 22, I946; cited in Jack Flam, "Introduction: Robert Motherwell at Work," Jack Flam et al., Robert Motherwell Paintings and Collages: A Catalogue Raisonné, I94I-I99I (New Haven: Yale University Press, 20I2), vol. I, II; hereafter RMCR. "Self and parents": Jack Flam, "Paintings I94I-I944: Finding a Voice," $R M C R$, vol. I, 29, referencing a 


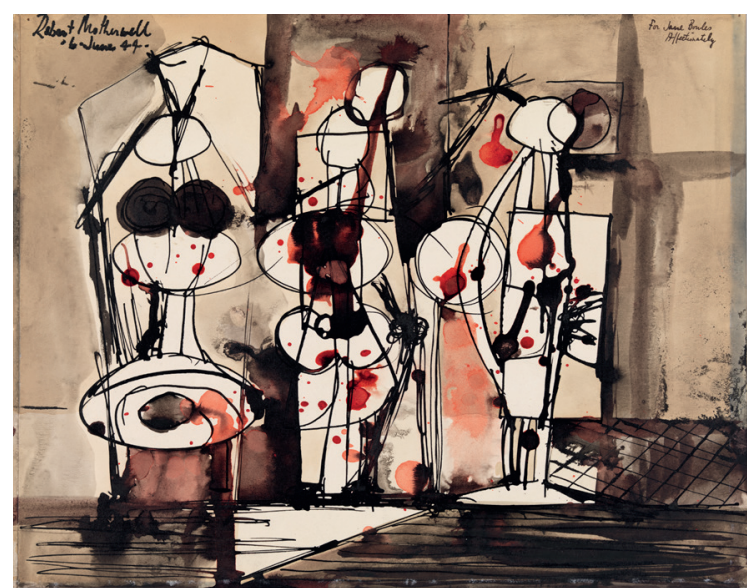

own early writings. ${ }^{48}$

Paalen lived and worked in San Angel, close to Coyoácan where exiled Communist leader Leon Trotsky was assassinated in August 1940. In September 1942 Motherwell wrote to art historian Meyer Schapiro, a recent mentor at Columbia University, about his indecision in naming a late I94I canvas, Recuerdo de Coyoácan. (Recuerdo means "remembrance" in Spanish.) He had painted that canvas, a work he associated with Trotsky's killing, soon after returning to the U.S., and other titles under consideration made even more specific reference to this politically charged event. ${ }^{49}$ One, Fear of Darkness, while generalized, had greater emotional resonance and the horizontal/vertical orientation of Recuerdo's composition demonstrates Motherwell's view of abstraction as "a process of emphasis to express feelings more clearly." ${ }^{\circ \circ}$ Much later, he would categorize this painting's overall sensibility as anxiety, considerably subjectivizing its ostensible objectivity. Prominently featured at the work's center right is a flat, ochre-lined horizontal

48 See, in particular, "The Modern Painter's World" published in 1944 in Dyn. What Motherwell gleaned from Matta and Paalen in Mexico: Landau, Mexico and American Modernism, chapters 4-5; Robert Saltonstall Mattison, Robert Motherwell: The Formative Years (Ann Arbor: UMI Research Press, 1986); varied articles and essays by Andreas Neufert, head of the Paalen Archive, Berlin.

49 Motherwell, September 25, 1942 letter, Meyer Schapiro Papers, Columbia University. Cited in Flam, "Paintings 194I-I944," $R M C R$, vol. I, 3I. In a February 22, 1946 letter to William Lee McKim, Motherwell relates this painting to "a theme I constantly recur to, of dead (and assassinated) political leaders (e.g., 'Remembrance of Coyoacan,' exhibited with French surrealists in N.Y. in '43 [sic])"; Norton Museum of Art, West Palm Beach, FL, object file for Motherwell's Personage, 1943. Cited in RMCR, vol. I, 172, n. 23. See also Megan M. Fontanella, "Bloodstains and Bullet Holes: Motherwell, Collage, and World War II," in Robert Motherwell Early Collages, ed. Susan Davidson (New York: Solomon R. Guggenheim Museum, 2013), 42-53.

50 Quoted in Robert Mattison, “A Voyage: Motherwell's Earliest Works," Arts Magazine 59 (February 1985): 92. 
"window," a device also appearing roughly mid-canvas in a number of Motherwell's concurrent early '40s paintings. Here it discloses those "blood stains" he associated with Mexico's brutalism, perhaps also providing a visual correlative for more recent global calamity. ${ }^{\text {sI }}$

Similar to Pollock, Motherwell found military maps useful for generating war-related imagery; he took this one step further by collaging remnants of an actual map into several works starting in 1943. Neither artist had ever made a pasted work when requested (as was Baziotes) to submit to Art of This Century's collage invitational in spring of that year. Pollock and Motherwell worked on theirs together; the latter recalled his friend as addressing the challenge rather violently, even burning one attempt with a match and using scorched areas to function compositionally. While Pollock's efforts did not survive, Motherwell's incongruously titled The Joy of Living ended up in the Baltimore art museum. Retaining clear vestiges of Matta's spatial illusions, Joy of Living incorporates at upper right a map fragment recently identified as Fort Benning, Georgia overlaid with names of French World War I battlefields. A related scrap was pasted onto View from a High Tower, made the following year. ${ }^{52}$ Multi-media works of $1945-$ 46 titled La Résistance and Viva provide ongoing evidence of the importance of war-generated imagery, even as the Allies were now winning. As Motherwell would later confirm, his collage practice tended toward the autobiographic, and these attempts reflect his particularly troubled wartime psyche. The tearing methods used "during some of the most tormented and exhausted years of my life" he later characterized as "equivalent to murdering, symbolically." ${ }_{33}$

Of the three discoveries Peggy Guggenheim "birthed" during World War II, Robert Motherwell became the one for whom the impetus of this extraordinarily intense foundational period would have the greatest consequence, one lasting essentially his entire career. (Indeed, as late as the I980s the artist was still describing painting as "partly war" and his use of black as a desperation "weapon.") ${ }^{54}$

5I Motherwell told Paul Cummings, AAA oral interview, that he made four friends at Oxford University on a trip to Europe in 1939: "We all knew that the war was going to start and that they would be in it. In fact all four of them were killed in that first year. Maybe it was then that I began to get some of the tragic sense that I have that was rare in America then."

52 See Fontanella, "Bloodstains and Bullet Holes," 44-45 and Gregory Gilbert, "Robert Motherwell's World War Two Collages: Signifying War as Topical Spectacle in Abstract Expressionist Art," Oxford Art Journal 27, no. 3 (2004), 3II-37. Fort Benning identification: Katy Rogers, "Collages, 1943-I949: A New Medium," RMCR, vol. I, 43.

53 "Autobiographical": Cummings Motherwell AAA oral interview. "Symbolic murder": E.A. Carmean, Jr., The Collages of Robert Motherwell (Houston: Houston Museum of Fine Arts, 1972), 63. In his May 1946 letter, Motherwell cited the more poster-like Viva as belonging to a series he called "Walls of Europe"; Rogers, "Collages, I943-1949," RMCR, vol. I, 47.

54 Grace Glueck, "The Mastery of Robert Motherwell," New York Times, December 2, 1984, sec. 6, 7I. 
There is surely little question of direct iconographic, thematic and stylistic links between 1943's Pancho Villa, Dead and Alive and Motherwell's signature Elegies to the Spanish Republic, a twenty-year series initiated in 1949. In these, the revered Spanish bullfighter Ignacio Sánchez Mejías, gored in the bullring on August I3, I934, supplanted Villa as Motherwell's male heroic lead. Using the tone of a dirge for Mejías composed by poet and playwright Federico García Lorca (a friend of Matta's assassinated by fascists) Motherwell re-interpreted the vertical/ ovoid oppositions of Pancho Villa's stick figure body into condensed phallic and scrotal (or ovular) shapes. 55 This effect replaced the tension between "control and uncontrol," that caused Pollock's painted webs to be read as signifiers for the disunity of modern life, with fragmentation, a different psycho-cultural dynamic. Also intrinsically abstract, it was likewise rooted in Surrealist practice.

Writing in 1947 even before the start of the Elegy series, Clement Greenberg noted that "Motherwell's ambition, which is to simplify and to manipulate the results of that simplification into expression, places him at the very center of all that is serious and ambitious in contemporary painting." ${ }^{66}$ With benefit of hindsight, Robert Motherwell would articulate the primary problem facing American artists during the intense period of crisis that was just coming to a conclusion as Greenberg made that flattering judgment. What had been required for Abstract Expressionism's victory over Parisian painting, the artist explained, was to "find a creative principle that was not a style, not stylistic, not an imposed aesthetic." ${ }_{57}$ A shared belief in the risky value of authenticity over perfection was central to the postwar engendering of a new, more individualist aesthetic. The astonishing originality and confidence of New York School modernism emerged from a world in shambles badly tainted, as Breton once remarked, by the predominance of a "death instinct." ${ }^{58}$ Despite or perhaps because of this circumstance American painting was enabled to come of age, transformed into an acclaimed manifestation of expanding U.S. power and influence.

55 Motherwell explained, "I suppose the Spanish Civil War was the first public event which I felt deeply emotionally involved in as did many artists and intellectuals of my generation; I suppose [it was] my first getting out of my own private narcissism into a sense of the drama of other people. It seemed to me something beautiful and marvelous died, at least temporarily, in that conflict." Interview with Bryan Robertson, December 15, 1964, I3, transcript Dedalus Foundation, New York; quoted in $R M C R$, vol. I, 174, n. 44.

56 Clement Greenberg, "Review of Exhibitions of Theo Van Doesburg and Robert Motherwell," The Nation (May 31, 1947): 665. Cited in Flam, "Paintings I944-1948," $R M C R$, vol. I, 56.

57 Diamonstein, "Interview with Robert Motherwell by Barbaralee Diamonstein," 228.

58 Authenticity over perfection": Guilbaut, 66. "Death instinct": Breton, "Three Years Ago" (1944), in Surrealism and Painting, trans. Simon Watson Taylor (New York: Harper and Row, 1972), 191. Motherwell designated originality as "the burden of modernist individualism" in Diamonstein, "Interview with Robert Motherwell by Barbaralee Diamonstein," 242. 


\section{佩吉的“战争之子” : “本世纪艺术展”上的波洛克、 马瑟韦尔和巴齐奥特 \\ 艾伦・G・兰道}

我认为，艺术必在历史之中。没有可以超越特定历史时期而存 在的永恒的艺术。

罗伯特·马瑟韦尔 (Robert Motherwell), 1950 年

佩吉·古根海姆（Peggy Guggenheim）将杰克逊·波洛克（Jackson Pollock)、罗伯特·马瑟韦尔和威廉·巴齐奥特 (William Baziotes）这三位美国青年称为她的 “战争之子” (war babies)，并 在如今已闻名于世的曼哈顿的美术馆为他们举办个展, 将他们最初 的艺术成就介绍给公众。1942 年 10 月，“本世纪艺术展” 在西 57 街 30 号开幕。这位富有的犹太裔美国人，携着她引以为豪的现代 艺术 “蓝筹股”，从被占领的法国逃离，以 “日用品” 的名义将这 些艺术品私运至美国。古根海姆这一应景的展览迅速成为欧洲流亡 艺术家（包括抽象主义和超现实主义者）互相见面、交流思想和展 览作品的场所。1943-1944 年间，随着佩吉的 “战争之子” 在群展 中为众人所知, 并各自成名, “本世纪艺术展” 的功能逐渐扩展, 彻底地成为艺术创新的 “实验室” (research laboratory) 一当然, 这正是她本意。三位美国艺术家二战期间在佩吉 - 古根海姆的资助 下投身艺术, ${ }^{1}$ 本文将要考察的是超现实主义美学、现代主义艺术与

1 Robert Motherwell, “The New York School," Lecture at the MidWestern Conference of the College Art Association (University of Louisville KY, October 27, 1950), reprinted in Stephanie Terenzio (ed.), The Collected Writings of Robert Motherwell (New York: Oxford University Press, 1992), 79. Peggy Guggenheim, "War Babies," in Out of This Century: Confessions of an Art Addict (New York: Universe Books, 1979), 172. "Research laboratory" : Press release for Art of This Century, n.d. (c. October 20, 1942); cited in Susan Davidson, "Focusing an Instinct: The Collecting of Peggy Guggenheim,” in Peggy Guggenheim 
战时纽约 “充满活力的混乱”（vital and chaotic）间独特联系的主 观意义。

马瑟韦尔的文字与形象创造功底都十分了得，我们先把目光 聚焦到他的身上，将他作为研究这种战时体验的范例。马瑟韦尔 I94I 年与墨西哥和国内的超现实主义流亡者关系密切，这对他早 年著述产生了强烈影响，他的文章为我们了解他的思想的形成打 开了一扇窗户。艺术史家瑟奇・居尔伯特（Serge Guilbaut）把生 活在 40 年代早期的人的特点概括为 “保持政治印迹的非政治化” (depoliticization that retained the imprint of politics)，从这个 观点来看，马瑟韦尔的思索与主张，他的著述与艺术作品都在坚定 地推进美国式的不受约束的个人表达，即便处在人类近代以来前所 未有危境和 “绝对恐惧” (utter-horror) 之中，也是如此。 ${ }^{2}$ 后来， 马瑟韦尔回忆道，战时大后方弥漫着一种 “对恐惧的群体性厌恶” (collective nausea)，“这不是因为恐惧个人的死亡，而是恐惧失 去人的生活和信仰”。请注意, 马瑟韦尔平常的写作风格是 “超然的” (detachedly)，但在这里，他并没有做到，他也承认这一点: “当 一个人身处战争之中，会不由自主地变得偏颇，谁也无法置身事外， 所以，我的写作方式也随之变得偏颇。” 3 马瑟韦尔在斯坦福和哈佛 接受了良好的哲学和法国文学训练，他对知性的敏锐，以及交织着 这种敏锐的视觉创作带来的冲击，与教育程度低得多的依靠直觉创

and Frederick Kiesler: The Story of Art of This Century (New York: Guggenheim Museum Publications, 2004), 77.

2 Serge Guilbaut, "Depoliticization," in How New York Stole the Idea of Modern Art: Abstract Expressionism, Freedom, and the Cold War (Chicago: University of Chicago Press, 1983), 79. Motherwell, "Utter Horror," June 6, 1980 interview with Robert Mattison; Robert Mattison, "Robert Motherwell' s First Collages: 'All My Life I Have Been Obsessed with Death," Studies in Iconography I2 (1988): 174.

3 "Collective nausea" : Robert Motherwell, "Parisian Artists in Exile: 1939-1945," Musée nationale d'art moderne, 1977, typescript, I2, Dedalus Foundation, New York. "Middle of a war": Barbara Catoir, "The Artist as a 'Walking Eye' : Fragen an Robert Motherwell,” Bruckmanns Pantheon 38 (1980): 288. 
作的杰克逊 - 波洛克相比, 要更加精微; 他的创作理念和作品，与 他的同道兼挚友威廉 -巴齐奥特相比，更为广博。除了马瑟韦尔易 悲观、喜理论、好争论外，这三位艺术家一致认为，协调好抽象与 具象十分必要。他们根据战时需求，修正了欧洲超现实主义的自动 主义技法 : 自动主义不是说明性的自由联想，而是把它当作一种形 式创新的造型 “武器” 来使用。4

尽管著名评论家克莱门特 - 格林伯格倡导要保持原创性，“艺术 应当远离当下文化的影响”，5 但早期的纽约画派一虽然大家不太承 认一正是催生于对这个世界性危机的众多回应中。一些艺术家加入 了“胜利艺术家协会” (Artist for Victory)，他们通过竞赛的形式 参与到各种展览之中, 比如, I943 年全国性的 “战时美国” (America in the War）版画展，抽象表现主义相关的艺术团体并没有多少愿 意直接投身视觉宣传。 ${ }^{6}$ 菲利普·古斯顿（Philip Guston），波洛克 在加州的总角之交, 是少数迎难而上参与的。他早在 1934 - 1935 年 就在墨西哥与鲁本 - 卡迪什（Reuben Kadish）合作，创作了反纳 粹题材的壁画 ; 墨西哥内战正酣之时，他创作的圆形壁画《轰炸》 (Bombardment)，不幸预言了未来更多的苦难。

I940 年代初，古斯顿在爱荷华州教书的同时，加入了 “战时艺 术工作室” (War Art Workshop)。他为海军绘制跳伞、漂浮和体 能训练的场景，也为《财富》(Fortune) 杂志绘制飞机制造、伞兵 训练以及其它军旅题材的插图。 ${ }^{7}$ 卡迪什最终应征入伍，但因为种

4 Robert Motherwell, “The Modern Painter' s World,” Dyn (November I944), reprinted in Terenzio, The Collected Writings of Robert Motherwell, 34.

5 Ann Eden Gibson, Abstract Expressionism: Other Politics (New Haven: Yale University Press, 1997), xxviii.

6 Ellen G. Landau, Artists for Victory: An Exhibition Catalog (Washington, D.C.: Library of Congress, 1983) and “ 'A Certain Rightness' : Artists for Victory' s 'America in the War' Exhibition of 1943," Arts Magazine 60 (February 1986): 43-54; Stephen Polcari, From Omaha to Abstract Expressionism: American Artists Respond to World War II (New York: Sidney Mishkin Gallery, Baruch College, 1995).

7 “Air Corps Paintings by Art Professor to Appear in Fortune," Daily 
种原因，大多数抽象表现主义艺术家，包括我们的三位主角，都没 有直接参战。波洛克的老师是 “地方主义艺术家” (Region-alist) 托马斯 - 本顿（Thomas Hart Benton），他的创作于 1942 年的《危 机之年》(Year of Peril) 系列流传甚广，但波洛克拒绝本顿的那 种带有种族主义反轴心色彩的戏剧性，而是在纽约参与了 “战争 服务计划” (War Services project)。在未婚妻李·克拉斯纳（Lee Krasner）的照料下，波洛克和他的团队制作拼贴装饰画，以及蒙 太奇式梪窗 “壁画”来宣传地属高校的战时训练教程。8

总体而言，正如另一位初出茅庐的抽象表现主义艺术家巴尼特 · 纽曼（Barnett Newman）所说，他们那一代艺术家的历史始于一 个看似简单的问题：“画什么”。战争，纽曼说道，“是我们不得不 面对的主题”。 ${ }^{9}$ 这种状况的解决方式有很多种，相比古斯顿，大多 数艺术家选择了一条不太好理解的方式来表现战争：利用间接对 比、象征符号、典故和比喻，整合个人与集体意义上的时代特征。 19 世纪 40 年代初，纽曼最亲密的伙伴阿道夫·戈特利布（Adolph Gottlieb）和马克 - 罗斯科（Mark Rothko）（后者也参与了 “本世 纪艺术展”)，与波洛克一样，也借用神话与原始主义，但在目的与 程度上有差别，他们采用了更具悲剧性的调子。若将罗斯科 1942 年的《伊芙琴尼亚的献祭》(Sacrifice of Iphigenia) 与波洛克 1943 年中的《秘密的守护者》(Guardians of the Secret) 进行对比，这 种悲情的基调不言自明。有些时候，这些战时作品会暗示出一些潜

Iowan (January 27, 1944); Michael Shapiro, “The Early Years, I9301945," in Philip Guston Retrospective, ed. Michael Auping (Thames and Hudson for the Modern Art Museum of Fort Worth, 2003), 29-30.

8 Year of Peril series: Cecile Whiting, Antifascism in American Art (New Haven: Yale University Press, 1989), II5-23. War Services windows: Ellen G. Landau, Lee Krasner: A Catalogue Raisonné (New York: Harry N. Abrams, I990), I8I-20I, cat. nos. 93-96.

9 巴尼特 - 纽曼与托马斯 - 赫斯 (Thomas B. Hess) 的对话，Solomon R. Guggenheim Museum (May I, I966), 引自 Brenda Richardson, Barnett Newman: The Complete Drawings, 1944-1969 (Baltimore: Baltimore Museum of Art, I979), I5. 
在的政治观点, ${ }^{10}$ 戈特利布在这方面更为激进。举一个相关的例子： 戈特利布用的图形中，有一部分明显是锯齿形图案，这种图案正是 助华抗日的美军上校陈纳德（Colonel Claire Chennault）和他的 飞虎队常绘于轰炸机之上的。 ${ }^{11}$

史书常言，曼哈顿之所以意外地从一个名不见经传的本土艺术 集聚地，摇身变为现代主义的堡垒（以及捍卫者），一个直接原因 就是法国被纳粹占领。从 1940 年 6 月 $\mathrm{I} 4$ 日巴黎沦陷到次年春，近 三万名难民流亡至美国（很多人都来自文学、艺术和音乐领域）, 逃到了这个 “战争阴云” 不那么浓郁的大都市，在这里，自由创 作仍然可能。英国广播公司 (BBC) 阿尔斯泰尔・库克（Alistair Cooke）的描述让人印象深刻：“这里越发成为无家可归者的家”, 是的，纽约似乎已成为延续大都会式艺术生活（哪怕一点点）的最 佳选择。 ${ }^{12}$ I9 43 年, 先锋艺术跨越大西洋的批量转移终于尘埃落定;

10 戈特利布与罗斯科战争时期作品中存在的悲观主义情绪根植于他们自 称 “承认和接受自然世界的残酷和生活永恒的不安感。” “在暴力时期, 对色彩和构图细节的个人偏好” 似乎是 “无关紧要的”。“所有的原始 表达都揭露了对强大力量和闪现恐惧的持续感知, ” 他们解释道, “今 天全世界许多人都在经历这些感觉，这是非常不幸的事实。对我们来 说掩饰和逃避这些感觉的艺术是肤浅又毫无意义的。” “The Portrait and the Modern Artist," October 13, 1943 broadcast on radio station WNYC, transcript in the Adolph and Esther Gottlieb Foundation Archives, New York. “如超现实主义者预言, 战争已经掠夺了我们隐藏起来的恐惧。” 纽曼在 1942 年写道。“只有悲剧的力量未知，恐惧才得以存在。现在我 们预料到了恐惧的存在, 广岛已经向我们展示了。” Thomas B. Hess (ed.), Barnett Newman (New York: Museum of Modern Art and New York Graphic Society, 197I), 35.

11 Stephen Polcari, Abstract Expressionism and the Modern Experience (New York: Cambridge University Press, 199I), I69-70. Nancy R. Versaci, "Flying Tigers," in Flying Tigers: Painting and Sculpture in New York 1939-1946 (Providence: Bell Art Gallery, 1985), 4.

12 引自 Richard Goldstein, Helluva Town: The Story of New York during World War II (New York: Free Press, 20Io), 92 (also source of cited statistics). New York as a "metropolis clouded by war" : Barbaralee 
当然，谁曾想到，这一转移，便是永远。

I94I 年 I2 月上旬，日本空军对停泊在夏威夷的美军战列舰发起 突袭。这一突发事件迅速打破了“一战” 后阻碍美国政治文化（当 然也包括艺术）进步的强烈的孤立主义，也毫无意外地加速了前 文中提到的艺术移民的进程。流亡诗人安德烈 - 布勒东在超现实主 义杂志《视野》(View) 中说，“这种斗争再一次融贯了情感力量， 在许多层面都导致了决定性后果, ”。在珍珠港事件前两个月，他还 预言说: “理智终将发现自身或多或少地激进地被修正（modified）、 抵触（contradicted）、弱化（weakened）、验证（verified），然后 得到加强（strengthened）。” 13 次年，布勒东在耶鲁任教时总结说， 超现实主义（被纳粹列入 “颓废艺术”）“只有与战争联系起来时， 才能被历史地理解。” ${ }^{14} 1942$ 年秋，正值轴心国强势之时，超现实主 义在它的新家纽约, 既激起了人们的兴趣, 也招惹了颇多争议。首先, 一场简洁有力的展览 “流亡艺术家”（Artists in Exile）, 在马蒂斯 美术馆（Pierre Matisse Gallery）举行，随后，一场规模更大的群展 “超现实主义的初始作业” (First Papers of Surrealism) 也跟着举办, 地点是在瑞得大厦（Whitelaw-Reid Mansion），马瑟韦尔和巴齐 奥特也有参展，媒体反响强烈。两周后，在 “本世纪艺术展” 的开 幕致辞上，佩吉的时任丈夫马克斯 ·恩斯特（Max Ernst）和他的 超现实主义同仁们让许多作品成为焦点, 并引发了猜想和激烈争论。

马瑟韦尔初识人称 “超现实主义教宗” 的布勒东时，还不能像 其他美国人一样可以用法语交流，当时马瑟韦尔与智利裔画家罗伯 特·马塔（Roberto Sebastián Antonio Matta）私交正密，后者把

Diamonstein, "Interview with Robert Motherwell by Barbaralee

Diamonstein,” in Inside New York's Art World (New York: Rizzoli, 1979), 228.

13 “Interview with André Breton,” View I (October-November I94I): 2.

14 André Breton, "Surrealism Understood Historically," in Situation du surréalisme entre les deux guerres (Paris: Editions de la Revue Fontaine, I945), n.p.; originally a lecture delivered at Yale University, December IO, I942. "Arch-degenerate" : "Surrealists in Exile," Time 39 (April 20, I942): 48, 50 . 
他介绍给了波洛克和巴齐奥特, 也促使了这三位与先锋艺术的总部一 “本世纪艺术展” 的结合。当谈论到这几位，以及其他一些 $1942-$ 1943 年冬加入他工作室的画家到底在干嘛时，马塔说 : 这帮人 “蓄 势待发”。 ${ }^{15}$ 关于他自己的艺术灵感, 他说, 来自 “情感与理念的战 场”, “先战斗, 然后看看能不能从冲突中迸发点什么。” 在被称为“心 理形态” (psychic morphologies) 的系列画作中（一些是在墨西哥 创作的，马塔和马瑟韦尔整个夏天都在那里)，马塔用红色的苂光 形状绘制了模糊的宇宙气氛。（图 I）I943 年, 这些迷幻的“构成要素” 逐渐引起显著的政治共鸣。“战争的浩劫给经济系统带来巨大灾难”, 马塔写道: “如何去描绘战场, 不是现实中的, 而是存在于我们内 心的战场 : 恐惧与勇气、批评与憎恨、怀疑与信任?” 17 有一个转变 挺讽刺的：马塔自述的 “心灵轰击” (Internal bombardment) 竟 促使他绘制出许多如痴如醉 (ecstasy) 的自然景观。18

他们知道马塔的无政府主义，也知道自己从一开始就走了另一 条路, 这群初出茅庐的纽约人, 不久后就意识到天命所需, 时不我待。 正如马瑟韦尔说过的：“当人渴望人性时”, 会让不同的形式策略和

15 "Concerning the Beginnings of the New York School: 1939-1943. An Interview with Peter Busa and Matta, conducted by Sidney Simon in Minneapolis in December 1966," Art International II (Summer 1967): I8.

16 Max Kozloff, "An Interview with Matta-these things were like rain catching up with a man who is running," Artforum 4 (September 1965): 25.

17 Germana Ferrari, Entretiens Morphologiques, Notebook No. I, 1936-1944 (London and Lugano: Sistan, 1987), 226, n. 7. 见 Elizabeth A. T. Smith and Colette Dartnall, “'Crushed Jewels, Air, Even Laughter' : Matta in the I940s," in Matta in America: Paintings and Drawings of the I940s (Chicago: Museum of Contemporary Art Chicago; Los Angeles: Museum of Contemporary Art Los Angeles, 200I), I7.

18 "Internal bombardment" : quoted in Smith and Dartnall, "Crushed Jewels, Air, Even Laughter," I7. Nature "in ecstasy” : Sidney Janis, "School of Paris Comes to U.S.," Decision 2, nos. 5-6 (NovemberDecember 194I): 95; cited in Smith and Dartnall, "Crushed Jewels, Air, Even Laughter," I8. 
主题探索概念化。 ${ }^{19}$ 出人意料的是，二战那个糟糕透顶的环境竟成 为这次转变的理想温床。尤其, “本世纪艺术展” 在美国本土的出现, 为这三位美国青年提供了前所未有的机遇，他们可以与世界级的现 代主义艺术家直接接触，并研习他们的新作，同时也得以将自己的 艺术展现给有名望的策展人、买家和评论家。

佩吉 ·古根海姆最初的想法是把 “本世纪艺术展” 设在伦敦。 I937 年前后，她开始将家族财力的小部分用于现代艺术品收藏，随 后意识到战争会使这一雄心付诸东流，于是开始制定计划，推动库 克街 (Cork Street) 的美术馆向沙龙的方向转型。“我们要发展出 版业务，并举办讲座”，佩吉在 1939 年 4 月写给朋友的一封信中提 到，“这里将成为一个艺术生活中心，当然也会举办艺术展览”。“真 期待你能回来一览它的全貌”, 她补充道 : “赶在希特勒同志的炸弹 之前。” 20 不出五个月，德国入侵波兰，英法被迫对德宣战。古根海 姆的藏品仍然以 “日入一幅” 的速度增加，她将藏品藏匿于格勒诺 伯美术馆（Musée de Grenoble）, 在法国的乡村巴望着战争的结束。 但不久她就意识到，事情可没那么简单。于是迫不得已，佩吉携着 前夫、两个孩子和包括恩斯特（德国国籍）在内的一些人，黯然回 到美国。

毕竟是战时, 直到 1942 年秋, “本世纪艺术展”才得以在纽约举行,

19 更多关于波洛克，（特别是）马瑟韦尔的文章与马塔的关系，见

Ellen G. Landau, Mexico and American Modernism (New Haven: Yale University Press, 20I3), chap. 4-5. 原文为 Motherwell critiqued Dutch abstractionist Piet Mondrian’ s “loss of contact with historical reality; or more concretely loss of the sense of the most insistent needs (and thus of the most insistent values) of a given time $\cdots$ when men were ravenous for the human." Mondrian, Motherwell judged, "failed, with his restricted means, to express enough of the felt quality to deeply interest us.” 见 "Notes on Mondrian and Chirico," in the Surrealist journal VVV I (June I942), 59.

20 Undated letter, Peggy Guggenheim to Emily Coleman (c. early 1939). Emily Holmes Coleman Papers, Special Collections, University of Delaware Library, Newark DE. Cited in Davidson, "Focusing an Instinct," 57. 
但此时它的功能已经全然改变, 成为一种更具挑畔性的存在。佩吉 说，她已经 “充分意识到”，“在人们为自己的生活与自由奋斗之时， 开放美术馆及其藏品，是一种责任”。“这项举措”，她在出版物中 解释说，“只有当它是面对未来而不是复述过去的时候，才会不辱 使命”。 ${ }^{21}$ 佩吉的哲学在 “本世纪艺术展” 中得到了呈现, 这不仅体 现在展品的选择上, 也体现在激进的陈列方式中。比如, 维也纳建 筑师弗莱德利克·凯斯勒 (Frederick Kiesler) 的一些异乎寻常的 (用 某评论家的话说，“略微有些危险”）设计点子，包括把未装裱的画 用绳子吊在天花板上，或将它们布置到曲面的橡木墙面上，橡木板 则粘在倾斜放置的棒球棒上作为支撑。 22 为彰显公允, 佩吉做了一 件令人瞩目的事 : 在开幕式上佩戴了两只不同的耳环，一只由抽象 主义雕塑家亚历山大·考尔德（Alexander Calder）设计，另一只 出自超现实主义画家依夫・唐吉（Yves Tanguy）之手。

1943 年中, 也就是与恩斯特离婚后不久, 古根海姆, 这个流离 失所的超现实主义者眼中的 “财神爷” (financial angel), 迫不及 待地组织了一个精选顾问团, 囊括了像马塔、蒙德里安和杜尚这样 的艺术家, 以及纽约博物馆界和艺术界的权威。这行为使得本世纪 艺术展的展览重心开始偏离欧洲流亡艺术家, 逐渐倾向于美国本 土那些天资过人但尚无建树的新人。 ${ }^{23}$ 赞助者的敏锐是波洛克和巴 齐奥特首秀成功的基础，这一点再怎么夸耀都不为过。1944 年末， 格林伯格曾这样评论他们的首秀 : 佩吉为我们带来的这两位抽象艺 术家，“能跻身（我国）最优秀的六、七位青年艺术家之列。”

21 Interview with Peggy Guggenheim, Trenton (New Jersey) Times,

November 6, 1942. Press release: Davidson, "Focusing an Instinct," 77. 22 In Out of This Century, IO3. 古根海姆引用了一位评论家对本世纪超现 实画廊的话 : “这略微有些危险——好像最后观众会被固定在墙上，而 那些艺术作品则围绕在他们周围做出评论, 或是称赞或是批判都有可 能。” Edward Alden Jewell, “Art of This Century,” New York Times (October 25, 1942).

23 霍华德 - 普策尔 (Howard Putzel) 的关键角色，见 Melvin P. Lader, "Howard Putzel: Proponent of Surrealism and Early Abstract Expressionism in America," Arts Magazine 56 (March 1982), 86-87. 
曼哈顿焦虑紧张的战时氛围是如何影响他们的处女展的呢，包 括 I943 年 II 月的杰克逊・波洛克，I944 年 IO 月的威廉·巴齐奥特 以及 1944 年 II 月的罗伯特 - 马瑟韦尔? 看完巴齐奥特的初展，格林 伯格的赞扬之情溢于言表：“简直就是个天才!” “他让我们看到了 一种响亮而充实的艺术”，格林伯格写道，“真情实感与时代精神筑 就的艺术”。 ${ }^{24}$ 巴齐奥特是这三位中第一个去见马塔的（在 1940 年 的一次阁楼派对上), 在整个职业生涯中，他都与精神自动主义所 强调的无意识图像的隐性潜能紧紧地绑定在一起。 ${ }^{25}$ 巴齐奥特在其 早期陈述中提到（最初写在本世纪艺术展的信笺上），常常，当一 个主题 “盘踞” 脑海时，意识便恍惚起来。 ${ }^{26}$

巴齐奥特的妻子后来证实：比尔 1930 年代后期的一些作品确实 是 “战争导向”（war-oriented）的。那段时日，他痴迷于研究自然 博物馆中凶狠的史前爬行动物; 还常常翻阅一本书，书中印有重伤 的一战士兵。27 “我一直想回到某张图片中的状态”, 他回忆道。“那 张图中有一名士兵，腰被斩断，臂被切除……我曾反复画他。” 战 后画于 1947 年的《侏儒》(Dwarf) 反映了他这一怪癖，也反映了

24 Clement Greenberg, “Art,” The Nation 159 (November II, 1944): 598. 包 括上文中引用的关于 “六七位最优秀的青年艺术家” 的评论。

25 马塔工作室的成员彼得 - 布萨（Peter Busa）谈到巴齐奥特时说，“比尔 要求我们练习自动绘画，他坚持超现实主义者应该运用这些自动的图像 ……齐奥特总是很关注超现实主义的各个方面, 我对此真的毫无兴趣, 但我之后意识到其实他最感兴趣的不是超现实主义，而是这一实践隐 喻的价值。” Transcript of interview with Jack Taylor, Peter Busa Papers, Provincetown MA.

26 陈述发表在 Sidney Janis, Abstract and Surrealist Art in America (New York: Reynal \& Hitchcock, 1944), I07 ; “总有一个主题盘踞在我脑海。 我时而能意识到，时而不能。我会一直专注在画布上直到它完成。通常 我在画完完成时意识到我的主题, 然后再次在我意识到它是什么之前 等待许久。” 见 Jasper Sharp, “Paintings and Drawings by Baziotes, 3-2I October 1944," in Story of Art of This Century, 308.

27 Cynthia Roman, "William Baziotes (1912-1963)," in Flying Tigers, 40; information from Judith Tolnick and Nancy Versaci, conversation with Ethel Baziotes, May 22, 1984. 
一些令这位新人艺术家 “心潮澎湃”（very exciting）的东西，包 括巴齐奥特所说的毕加索的 “死与美之狂热” (fever of death and beauty)，还有西班牙大师戈雅的 “(Francisco Goya) 恐惧与美之 交融”（mixture of beauty and horror）。28 完成《侏儒》后没几年, 巴齐奥特就承认，“危机过后，总有一些图像涌入他的脑海一腿上 长满梅毒的妓女、性变态、各种精神病……描有眼镜蛇与侍婢的花 瓶，让人猝不及防”。29

巴齐奥特第一次展览时，马瑟韦尔帮他挂画，埃塞尔 -巴齐奥 特（Ethel Baziotes）很嘲讽地描述道: “就像盲人领导盲人，进行 一场无法驾驭的探险，过程中还被两种东西占据大脑。” 马瑟韦尔 把这两者叫做 “害怕” 和 “青涩” (Frightened and green)。30 “本 世纪艺术展” 的《巴齐奥特的绘画与素描展》(Paintings and Drawings by Baziotes） 中，有很多作品深受毕加索的影响，但那些

28 Baziotes' s letter to Barr, April 26, 1949: copy in William Baziotes Files, Museum of Modern Art Library. 在信中，艺术家提到了那些帮助他创 作《侏儒》的影响。他指出, 不只是戈雅和一战 “篮子宝宝” (basket baby）截肢者的形象, 还包括史前动物, 蜥蜴 “消极又致命” 的眼睛, “鳄 鱼恐怖又幽默的笑容” 和 “一个女性的性符号”，分析见 Mona Hadler, “William Baziotes: Four Sources of Inspiration,” in William Baziotes: A Retrospective Exhibition, ed. Michael Preble (Newport Beach: Newport Harbor Art Museum, 1978), 85-86. 艺术家自己的脸出现在一战截肢者 的画作上，巴齐奥特随信一起寄给了巴尔，标注《侏儒》的一项研究。 基于这些证据，哈德勒认为这幅画有自动性绘画的成分。关于毕加索， 巴齐奥特说：“我看到了的形象不是他的真实主题。塑料也不是一一尽 管那些塑料很棒。毕加索发现了自己身上的一种狂热, 他把这种狂热注 入画中一一种死亡与美的狂热。” Rudi Blesh, Modern Art USA (New York: Alfred A. Knopf, 1956), 268-69.

29 Donald Paneth, "William Baziotes: A Literary Portrait," unpublished manuscript, 2I; William and Ethel Baziotes Papers 1916-1992, Archives of American Art, Smithsonian Institution; hereafter AAA.

30 "Blind leading the Blind" : Ethel Baziotes, interview with Jasper Sharp, February I3, 2004. "Frightened and green" : Robert Motherwell, interview with John Jones, October 25, 1965, AAA. 
作品并没有痴狂地表现残疾。巴齐奥特 $\mathrm{I} 944$ 年创作了一批构图更 典型的油画，其中一幅并没有遵循马塔的指导，而是引入了人们熟 悉的新闻短片和杂志图像。在《伞兵》(The Parachutists) 中 (图 2), 盟军士兵空降敌后，深入险境，巴齐奥特将这一场景转化为图形活 泼、色彩光鲜的综合立体主义块面。与波洛克和马瑟韦尔一样，巴 齐奥特也曾被某幅画深深吸引，这幅画便是恩斯特力劝佩吉购入的 毕加索的《画室》（The Studio, 1927-1928）。他及时引用了 “不安 世界的震颤”（the tremors of an unstable world）， ${ }^{31}$ 并重新想象其 冷冰冰的合理性。

杰克逊・波洛克以另一种方式去融合超现实主义、抽象主义和 战争。波洛克是勉为其难加入马塔的工作室的，他答应与克拉斯纳 一同加入到巴齐奥特夫妇和马瑟韦尔夫妇的超现实主义游戏中。相 比其他人，佩吉·古根海姆的帮助对波洛克事业的影响要深远的多。 尽管古根海姆起初疑心重重，但最终还是被她那颇具慧眼的助手霍 华德·普泽（Howard Putzel）说服，按月供给，资助这位几乎一 贫如洗的艺术家。这使得他可以全心全意画画，此外，她还委托波 洛克为自己的住所创作壁画，这成为他艺术轨迹的关键转折点。如 古根海姆所言，恩斯特背叛后，波洛克成了本世纪艺术展的中心。 32

尽管波洛克与他的两位朋友一样，很早就被收录到美术馆群展 之中（饱受好评），但直到 $1943 ，$ 这是危机四伏的一年，波洛克的 首次个展上，佩吉非常规的筹划与波洛克出众的设计所呈现的成果 才一览无遗。1939 年的《持刀裸男》(Naked Man with Knife) 和

31 更多讨论, 见 Polcari, Abstract Expressionism and the Modern Experience, 216-17. "Tremors of an unstable world" : "Symposium: Creative Process," Art Digest 28 (January I5, 1954): 16; quoted in Polcari, 213.

32 Out of This Century, I06. 波洛克的壁画在其职业生涯的重要性, 见 Francis V. O’ Connor, “Jackson Pollock' s Mural for Peggy Guggenheim: Its Legend, Documentation and Redefinition of Wall Painting," in Story of Art of This Century, 150-69 and Ellen G. Landau, “Still Learning from Pollock," Yvonne Safran et al., Jackson Pollock's Mural: The Transitional Moment (Los Angeles: J. Paul Getty Museum, 20I4), 7-29. 
其它一些战前作品中，波洛克明显表现出对暴力的迷恋，有趣的是， 到了 1943 年，他重新定位了自己的方向，倾全力投身于治疗性的 自我界定的活动。与马瑟韦尔 $\mathrm{I} 2$ 个月后的展览相比，波洛克处女 展作品的政治色彩并不浓郁。其实，看完他的作品后，一位评论家 是这样总结的: “大手笔，近乎狂野的浪漫主义”，这些作品包括《母 狼》(She-Wolf)、《帕西芙伊》(Pasiphäe) 和《月女断环》(Moon Woman Cuts the Circle) 等（都完成于 I943 年)。这些辨识度极 高的原型主题，有着强烈的荣格心理学色彩。33

波洛克曾提到过鲁本 ·卡迪尔 (Reuben Kadish)，他那时也创 作了战争题材的绘画。《燃烧的风景》(Burning Landscape), 同样 完成于 1943 年, 是已知刻意表现全球战乱的两幅作品中的一幅（图 3）。不过，这两幅作品都没有出现在 “本世纪艺术展”上。还有一 个小问题, 就是波洛克为何如此命名一既是对马塔疾狂的回应, 也 映射了现代战争中的火海战术。《燃烧的风景》马塔式的构图与上 述军事照片十分类似，这种照片常见于那段时日的报刊。如约翰 ·索伊尔（John Sawyer）所指出的，波洛克使用的红白蓝同心圆， 应该是引用了盟军空军的标识，表现出一种 “不真实的紧张感”。34

另一幅可确认的与二战主题相关的作品并非绘画，而是一幅墨 彩素描。该画描绘了一个由人和动物尸体以及置于一侧的十字架构 成的火葬堆，展现了更具情感爆发力的图像。其实，这幅画的标题 是《战争》(War)，它的图像与氛围，同毕加索 $\mathrm{I} 937$ 年的一些反 法西斯作品异曲同工，比如套印速写《弗朗哥的梦与谎言》(The Dream and Lie of Franco), 以及《格尔尼卡》（Guernica）这幅波

33 Edward Alden Jewell, New York Times (November I4, 1943). 朱厄尔 （Jewell）补充道，“事实上，这是一种蒙昧主义。”I943 年个人展览 的作品分析 : Ellen G. Landau, Jackson Pollock (New York: Harry N. Abrams, 1989), chap. 6. 波洛克在本世纪艺术办了四次展览; 巴齐奥特 和马瑟韦尔各办了一次。

34 John Sawyer, “Jackson Pollock, Burning Landscape 1943," in Flying Tigers, 83-84. Pollock' s “war paintings” : Stephen Polcari, interview with Reuben Kadish, October 3I, I99I. 索伊尔比较了《燃烧的风景》的 构图与 “小型太平洋环礁上的茅屋被大火吞噬的场景”。 
洛克大为欣赏的作品。此画右下角有模糊不清的签注, 标为 1947 年, 若果真作于此时，《战争》或许表现了波洛克战后的余悸，是对《兵 火之乱》(Holocaust) (克拉斯纳是犹太人) 以及广岛和长崎遭受核 打击的详细披露。《纽约太阳报》(New York Sun) 评论员亨利·麦 克布莱德 (Henry McBride), 将波洛克的《作品 7 号, I949》(Number 7, 1949）的画面效果比作 “饱受战争摧残，夷为平地的城市（或许 是广岛) 月光下的鸟瞰”。 ${ }^{35}$ 波洛克创作《作品 7 号》(Number 7 ) (现 名 [《网之外》(Out of the Web) ] 时, 使用了他新开发的倾泼法 (图 4），那时 “本世纪艺术展” 已谢幕，佩吉也返欧了。

格林伯格 $\mathrm{I} 944$ 年发表了关于波洛克首秀的一篇评论，成为他最 有力的捍卫者，而他的朋友马瑟韦尔则是第一批了解他的理想并知 晓其中利害关系的人。 ${ }^{36}$ 前文提到，马瑟韦尔极善文辞，他不仅喜 欢阐述自己的艺术观点，也乐于帮助同仁。“相比其它，我更相信 言辞。”他说：“我知道它们有多么可怕，也常常抨击；它们是真 正的社会武器，但人们常常忽视了它们的危险。” ${ }^{37}$ 因为当战时的马 瑟韦尔回首过往艺术时，怎么也找不到 “我们的时代价值”，于是 开始探寻现代主义的新形式。尽管马瑟韦尔的目标与波洛克大体 一致，正如波洛克在一则日期不明（可能是战后）的笔记中写到： “以绘画来表达我们的时代体验一不是指图解（而是完全等量齐观） …...”，它们的结果是截然不同的。 ${ }^{38}$

35 Henry McBride, New York Sun (December 23, 1949). “色彩如火花般闪 亮, ”他继续说道, “众多的河带将城市连结在一起。”

36 “由于绘画是（波洛克）思想的介质，”马瑟韦尔预测，他的 “决心 一定源自绘画的过程”。“Painters Objects,” Partisan Review II (Winter I944), 97.

37 Robert Motherwell, Oral History Interview Conducted by Paul Cummings, November 26, 1971, AAA.

38 Motherwell, “Modern Painter's World," reprinted in Terenzio, The Collected Writings of Robert Motherwell, 34. Pollock, handwritten statement (c. I950?); reprinted in Pepe Karmel (ed.), Jackson Pollock: Interviews, Articles and Reviews (New York: Museum of Modern Art, 1999), 24. 最后的话是 “Concentrated, Fluid.” 
在多尔·阿什顿（Dore Ashton）的评论中，马瑟韦尔横空出世， 成为少数“可以力挽狂澜, 而不是圊于超现实主义一隅的美国人”。39 他在 “本世纪艺术展” 的个人展览中，延续了毕加索战前在法国创 作的那些生机勃勃的作品中对颜色符号再生的使用。相当多的评论 家，包括格林伯格都会把他俩放在一起进行对比，但值得注意的是， 没有一位提到，马瑟韦尔七件参展油画中的四幅，在标题、风格和 图像上与墨西哥有着显著的联系。《潘乔·比利亚: 死与生》(Pancho Villa, Dead and Alive), 这幅拼贴画或许是马瑟韦尔 40 年代最重 要的作品（图 5), 除了这幅，一些素描也包含了墨西哥暴力主题。 对于马瑟韦尔而言，比利亚的故事（与他墨西哥妻子的家庭有关） 完全是政治站队产生的恶果，险恶至极，当然里边也有道德的暗示。

此外，马瑟韦尔在 “本世纪艺术展” 个展中，有几件纸上作品， 是以一系列抽象的人物为特点，他们的样貌如同在街头被射杀了一 般。与《潘乔 - 比利亚 : 死与生》一样, 在这些作品中, 都包括了 大量红色污点，看上去如同血渍。（图 6）1946 年，作者将这些作 品与一幅名为《西班牙小监狱》(Little Spanish Prison) 的油画一 并列入 “灾难系列”, 参照的是戈雅 I8IO-I920 反战版画。与此同时, 马瑟韦尔意识到，这些被射杀的不可名状的人物，可能就是他自己 与父母的缩影一他与他父母的关系非常不好。 ${ }^{40}$ 《三个被射杀的人物》 （Three Personages Shot） 标注的日期是 1944 年 6 月 6 日，那是盟 军登陆诺曼底的日子。

I94I 年夏，马瑟韦尔、马塔及其他一些人旅居塔斯科（Taxco）, 与沃尔夫冈・帕仑（Wolfgang Paalen）走得很近。这位久居墨西

39 Dore Ashton, "Robert Motherwell, Passion and Transfiguration," Studio International 167 (March 1964): IO2.

40 "Disasters series" : Motherwell, letter to Dorothy Miller, May 22, 1946; cited in Jack Flam, "Introduction: Robert Motherwell at Work," Jack Flam et al., Robert Motherwell Paintings and Collages: A Catalogue Raisonné, I94I-I99I (New Haven: Yale University Press, 20I2), v. I, II; hereafter RMCR. "Self and parents" : Flam, "Paintings I94I-I944: Finding a Voice,” RMCR, v. I, 29, referencing a 196I interview Motherwell gave Rudi Blesh. 
哥城的超现实主义流亡艺术家，与马瑟韦尔十分要好，向他介绍了 一些题材。马瑟韦尔深受启发，后来用这些题材替代了他的战时焦 虑感。仔细考量马瑟韦尔在墨西哥前几个月里的草稿，会发现他与 马塔就创新问题进行过深入的对话。至于帕仑的影响，形式层面较 少，理论上多一些。马瑟韦尔翻译了帕仑的《新图像》（The New Image），一篇发表于《活力》（Dyn）杂志创刊号的文章，《活力》 由帕仑创始于墨西哥，在纽约拥有众多读者。帕仑推进了抽象表现 主义，他认为，尽量减少使用可辨识主题是可以的，但并不意味着 完全放弃有意味的内容，类似的思考与相关话题在马瑟韦尔早期著 述中也时有出现。 ${ }^{4}$

帕仑生活和工作都在圣安吉尔 (San Angel)，离科约阿坎 （Coyoácan）很近，科约阿坎是 1940 年 8 月流亡共产主义领袖 里昂·托洛斯基（Leon Trotsky）遇刺的地点。1942 年 9 月，马瑟 韦尔给哥伦比亚大学的良师益友、艺术史家迈耶 - 夏皮罗 (Meyer Schapiro）写信，说自己正为一幅油画的命名问题犹豫不决，即 I94I 年末创作的《柯约坎的雷丘尔多》(Recuerdo de Coyoácan) [ 雷 丘尔多 (Recuerdo) 在西班牙语里是 “回忆” 的意思]。马瑟韦尔 画完这幅与托洛斯基遇刺相关的油画后就回美国了，其它的备选 命名对这一敏感事件的暗示则明显得多。 ${ }^{42}$ 其中一个是 “黑暗的恐

41 Motherwell, “The Modern Painter' s World.” 马瑟韦尔受马塔和帕伦 的启发 : Landau, Mexico and American Modernism, chap. 4-5; Robert Saltonstall Mattison, Robert Motherwell: The Formative Years (Ann Arbor: University of Michigan Research Press, 1986); varied articles and essays by Andreas Neufert, head of the Paalen Archive, Berlin.

42 Motherwell, September 25, 1942 letter, Meyer Schapiro Papers,

Columbia University. 引自 Flam, “Paintings I94I-I944,” RMCR, v. I, 3I. In a February 22, 1946 letter to William Lee McKim, Motherwell relates this painting to "a theme I constantly recur to, of dead (and assassinated) political leaders (e.g., 'Remembrance of Coyoacan,' exhibited with French surrealists in N.Y. in ' 43 [sic])" ; Norton Museum of Art, West Palm Beach FL, object file for Motherwell' s Personage, 1943. Cited in RMCR, v. I, I72, n. 23. Megan M. Fontanella, "Bloodstains and Bullet Holes: Motherwell, Collage, and World War II," in Robert Motherwell 
惧” (Fear of Darkness)，一般来说，这个名字更能与《雷丘多尔》 (Recuerdo）一画产生情感共鸣，其横坚交错的构图，印证了马瑟 韦尔关于抽象的观点: 抽象是 “将情感强化并明晰化的过程”。 ${ }^{43}$ 随 后，他将这幅画的整体情感归结为焦虑，把它表面的客观性大幅度 地主观化了。很明显，画作中央的左侧有一个褐线勾勒的水平 “窗 口”，这种处理方法在马瑟韦尔 40 年代早期作品中经常出现。这里 出现的 “血渍”, 与墨西哥的残暴有关, 大概也是为了在视觉上与 那时的全球性灾难相契合。44

与波洛克相同，马瑟韦尔发现，制作战争相关的图像时，军事 地图十分有用; 从 1943 年开始, 他进一步将真实地图的片断用在 一些作品中。在那年春收到 “本世纪艺术展” 的拼贴画邀请以前, 没有一位艺术家（包括巴齐奥特）创作过拼贴作品。波洛克与马瑟 韦尔一同工作，后者回忆说，这位朋友常常用暴力的手段解决问题， 甚至用火柴燃烧草稿，然后用烧过的区域进行构图。波洛克的试验 成果今已不存, 而马瑟韦尔标题与内容大相径庭的《生命的乐趣》 （The Joy of Living）则最终藏于巴尔的摩艺术博物馆。《生命的乐 趣》清晰地保持了马塔的空间错觉处理方式，在画面的右上角，有 一个地图的片断，可以辨识出是乔治亚州的班宁堡（Fort Benning, Georgia)，上面印着一战法国战场的地名。次年，相关的纸片也用 到《高塔俯视》(View from a High Tower) 之中。 ${ }^{45}$ I945-1946 年

Early Collages, ed. Susan Davidson (New York: Solomon R. Guggenheim Museum, 2013), 42-53.

43 Robert Mattison, “A Voyage: Motherwell' s Earliest Works,” Arts Magazine 59 (February 1985): 92.

44 马瑟韦尔在接受美国艺术档案馆口头采访时告诉保罗 ·卡明斯（Paul Cummings)，1939 年他在欧洲旅行中，在牛津大学交到四位朋友：“我 们都知道战争一触即发, 他们也将参与其中。事实上, 第一年他们四位 就全部遇难了。也许在那时我开始有了一些我在美国时很难感受到的悲 痛的感觉。”

45 Fontanella, "Bloodstains and Bullet Holes," 44-45; Gregory Gilbert, “Robert Motherwell' s World War Two Collages: Signifying War as Topical Spectacle in Abstract Expressionist Art," Oxford Art Journal 27, no. 3 (2004): 3II-37. 
的综合材料作品《反抗》(La Résistance) 和《万岁》(Viva) 都可 以证明，即便盟军已经获得胜利，战争题材的图像仍然十分重要。 马瑟韦尔之后也承认，他的拼贴画都带有自传性质，这些尝试反映 他战时糟糕的心理状态。他描述道: “那段让人精疲力竭受尽折磨 的日子” 所使用的痛苦方式，“等同于谋杀，象征意义上的谋杀”。46 作为佩吉 ·古根海姆在二战中 “孕育” 的三杰之一，罗伯特 -马 瑟韦尔从这个极度激烈的基础时期获益良多，并将自己毕生的事业 延续下去（事实上，直至 1980 年代，马瑟韦尔仍将绘画视为 “局 部战争”，黑色仍被视为表现绝望的 “武器”) 47 。毫无疑问，《西班 牙共和国的挽歌》(Elegies to the Spanish Republic) 这一自 1949 年 始，延续了二十年的系列作品与 1943 年的《潘乔·比利亚: 生与死》 在图像、主题和风格上有着直接的联系。在这个过程中，伊格纳西 奥·桑切斯・梅亚斯（Ignacio Sánchez Mejías），这位备受崇敬但 不幸于 1934 年 8 月 13 日死于牛角之下的西班牙斗牛士，取代了潘 乔·比利亚成为新的英雄符号。马塔的朋友，被法西斯者残忍刺杀 的费德里科·加西亚·罗卡（Federico García Lorca），曾用诗歌与 剧作为梅亚斯创作挽歌。基于罗卡作品的基调，马瑟韦尔不再用椭 圆与坚线组成潘乔·比利亚，而是将他呆板的身体重新描绘为睪丸 与阴茎形状。 ${ }^{48}$ 这种效果以别样的心理文化动力（psycho-cultural

46 “Autobiographical” : Cummings Motherwell AAA oral interview. "Symbolic murder" : E.A. Carmean, Jr., The Collages of Robert Motherwell (Houston: Houston Museum of Fine Arts, 1972), 63. 在 1946 年写给米勒的信中，马瑟韦尔引用了他称为 “欧洲之墙”（Walls of Europe）系列作品中更像拼贴画的《万岁》; Rogers, “Collages, I943I949,” RMCR, v. I, 47.

47 Grace Glueck, “The Mastery of Robert Motherwell,” New York Times (December 2, I984), sec. 6, 7I.

48 马瑟韦尔解释道，“如同很多艺术家和我这一代的知识分子，我认为西 班牙内战让我第一次有了深切的情绪参与 ; 我想我第一次从个人的自恋 情绪中走出来，开始关心他者的感受。对我来多，至少是暂时的，一些 美丽而又奇妙的东西已经死去，在那场冲突......” Interview with Bryan Robertson, December 15, 1964, I3, transcript Dedalus Foundation, New York; quoted in RMCR, v. I, I74, n. 44. 
dynamic）式断片取代了 “控制与非控制” 间的张力，正是这种张 力使得波洛克的网, 被解读为指向分裂的现代生活的能指。同样属 于内在抽象，同样源于超现实主义实践。

I947 年，在《挽歌》系列开始之前，格林伯格注意到了 “马瑟 韦尔的野心 : 简化并控制从简化到表现的结果, 这使他成为当代 绘画中一切严肃思考与雄心壮志的中心”。 ${ }^{49}$ 经过反思，罗伯特 马瑟韦尔说，战时美国艺术家所面对的主要问题已经结束了，因 为格林伯格给出了完美的判断。抽象表现主义战胜巴黎的必要条 件, 艺术家解释道, 是去 “寻找一种创作原则, 既非样式, 也非风 格, 更不是强加的审美”。 ${ }^{50}$ 纽约画派画家们普遍相信, 真实胜过 完美（authenticity overperfection），追求真实更值得冒险，这是 战后诞生出新的、更加个人化的审美观念的另一个重要原因。如 布勒东所言，这个世界被某种占据支配地位的 “死亡本能” (death instinct）所污染，而纽约画派惊人的创意和自信正是从这被污染 的世界中脱颖而出。 ${ }^{51}$ 尽管环境如此, 或许正因为如此, 美国绘画 终到及冠之年，也恰与国之兴盛相得益彰。

（王珊禄译，张坚校）

49 Clement Greenberg, "Review of Exhibitions of Theo Van Doesburg and Robert Motherwell," The Nation (May 31, 1947): 665. Cited in Flam, "Paintings I944-I948: All That is Serious and Ambitious," RMCR, v. I, 56.

50 Diamonstein, "Interview with Robert Motherwell by Barbaralee Diamonstein,” 228.

51 “Authenticity over perfection” : Guilbaut, "Depoliticization," 66. "Death instinct” : Breton, "Three Years Ago," (1944), Surrealism and Painting, trans. Simon Watson Taylor (New York: Harper and Row, I972), I9I. Motherwell designated originality as "the burden of modernist individualism" in Diamonstein, "Interview with Robert Motherwell by Barbaralee Diamonstein,” 242. 


\section{纽约画派与意识形态}

毛秋月

\section{引言}

作为美国 20 世纪最重要的绘画运动，纽约画派自萌芽初期，便受 到批评界的密切关注。2005 年, 美国学者朗多 (Ellen G. Landau) 编纂出版的论文集《阅读抽象表现主义: 语境与批评》(Reading Abstract Expressionism: Context and Critique) 以“1940 年代 : 被 神化的运动” “1950 年代:建立权威” “I960 年代: 巩固经典” “1970 年代：新兴语境与细化阅读” “1980 年代：发现新意义” “1990 年 代 : 重新定义抽象表现主义” 为副标题，收录了半个世纪以来的 六十余篇抽象表现主义经典研究文献。回顾西方对纽约画派的研 究, 其中最引人注目的, 莫过于几代学者对纽约画派与意识形态之 关系的看法。早期最为人熟知的是批评家格林纽约画派与意识形 态毛秋月伯格 (Clement Greenberg), 他将形式主义批评融入马 克思主义的文化关切之中，被普遍认为是抽象表现主义的代言人。 之后, 新艺术史研究代表学者 T.J. 克拉克 (T.J. Clark) 的学生居 尔博特 (Serge Guilbaut)、莱杰 (Michael Leja) 分别撰写了《纽 约是如何窃取现代艺术观念的》 (How New York Stole the Idea of Modern Art, 1983) 与《重构抽象表现主义》(Reframing Abstract Expressionism, 1993）两本著作，从抽象表现主义与政治、社会文 化的互动角度，探讨这一艺术成为美国资本主义文化输出范本的原 因。

回顾国内 20 世纪 80 年代以来的纽约画派研究，学者们的聚焦 点也一直是在纽约画派与美国政府之间的关系之上。其中两种观点 最具代表性：一是把美国学者赛尔热・居尔博特（Serge Guilbaut） 的观点演绎为 “阴谋论”, 认为抽象表现主义绘画之所以引起国际 关注，主要是冷战期间美国政府、美术机构合力推广的结果，绘画 的美学价值位居其次。 ${ }^{1}$ 二是其反对观点，认为抽象表现主义是在 
发展出一套成熟的前卫艺术形态、逐渐受到批评者认可之后, 才得 到政府的注意与推广, 走向世界。 ${ }^{2}$ 两种立场激烈交锋, 直至今日 余音不绝。

而笔者认为: 在对纽约画派乃至整个美国现代主义艺术的研究 之中, 由 “阴谋论” 引起的争议本不应成为一个理论热点。从某种 程度上讲，围绕 “阴谋论” 与其反题去审视纽约画派，会让我们的 眼光过多停留在它的接受过程上，从而忽略它的形成过程、它的内 在肌理, 以及它与美国本土的思想、文化和社会之间错综复杂的关 系。必须承认, 在国内的研究语境下, 只有先扫除 “阴谋论” 带来 的错觉与影响, 摆脱僵硬的政治决定论, 我们才可能进入更深层的 学术研究。需要强调指出的是: 批驳 “阴谋论” 只是要走的第一步, 而不是最终的落脚点。否则, 本为讨论艺术与意识形态关系的学术 研究，便很容易滑落到一种意识形态的 “站队”与争议之上。

那么，如何拓宽 “阴谋论” 争论之外的纽约画派研究? 我们不妨 从国内学者的论述中总结几个关键信息。其一, 学者们在论及纽约 画派与意识形态时，倾向于将艺术与政治视为两个独立领域 : 前者 或被后者利用（如 “阴谋论”)，或被后者挖掘（如反 “阴谋论”）。 可以说，这是同一视角下的两种判断。其二，学者们对纽约画派的 形成机制和美学价值存在争议, 这直接导致其对美国政府的推广行 为持有言贬不一的态度。本文认为, 艺术与意识形态并非截然分 开; 在探讨抽象表现主义的美学价值时, 当时的社会意识形态本 身就是一个重要的参考维度。在这一点上, 美国三位学者格林伯格 (Clement Greenberg)、居尔博特、莱杰（Michael Leja）的观点， 将带来一些重要启示。三位学者以西方马克思主义为立足点, 分别 从现代主义、工具主义和艺术社会史角度, 将绘画的形式要素与意 识形态结合考虑, 表达了对纽约画派的艺术属性及社会属性的看法。 三人的立意与结论, 已经在一定程度上走出政治影响论的范畴, 并 已构成一支紧密相连的学术链条。这一点, 恰恰未引起国内学界的 重视, 这不能不说是一种缺憾。因此, 后文将着重从三位学者的不

2 参见张敢:《绘画的胜利? 美国的胜利? 一一美国抽象表现主义绘画研究》, 文化艺术出版社，200I。 
同认识出发, 探索西方抽象表现主义研究的内在脉络与潜在规律, 以期为我国未来的相关研究提供全新视野。

\section{二、格林伯格的前卫艺术观}

在提到格林伯格与抽象表现主义时，国内学界更多关注着两者的亲 缘关系，将格林伯格视为抽象表现主义的 “代言人”。的确，格林 伯格在马克思主义季刊《党派评论》上发表的三篇重要文献—《前 卫与庸俗》 (I939)、《走向更新的拉奥孔》 (I940)，与之后的《“美 国式” 绘画》（1955），帮助纽约画派确立了卓越的历史地位，在客 观上为纽约画派走向世界奠定了坚实的现代主义理论基础。从表面 上看，波洛克等代表画家仿佛也正是沿着格林伯格推崇的自我批判 之路，对绘画形式不断进行革新。然而，格林伯格并非对抽象表现 主义持完全肯定的态度。即使对同一个画家，例如波洛克，格林伯 格也亦裹亦贬。因此, 格林伯格并不是一个严格意义上的“代言人”。 抽象表现主义因部分作品符合格林伯格对前卫艺术在政治批判性上 的看法，才得到他的青睐。

我们有必要仔细审视格林伯格现代主义批评中暗含的理性主义 线索。正是这条线索，导致格林伯格对现代绘画做出高下之分，并 以此为基准，表达对前卫艺术和意识形态的观点。格林伯格对理 性的坚持，受到以康德为代表的德意志哲学的影响，关于这一点， 前人之述已相对完备。 ${ }^{3}$ 同时，格林伯格还继承了美国学者白璧德 （Irving Babbitt）的新人文主义价值观。对于这一点，国内认识尚 属空白。

新人文主义是一场兴起于 20 世纪初期的美国知识分子学术运 动。它推崇旧的清教徒美德，崇尚自制、适中，并强烈反对现代主 义和浪漫主义之中的放任倾向和原始主义。作为其中的代表人物, 白璧德坚持对礼仪、节制、纪律、平衡等古典美德的培养和古典主 义的理想（普世性和崇高）。他认为，在艺术和生活中，冲动和本 能必须经历 “内心的审核”，调和感情和灵感之间的关系，最终被

3 参见张坚:《浪漫与科学的碰撞一一格林伯格艺术批评思想中的德意志 因素》, 《美术》2OII 年第 I 期，第 II2-I5。 
平和、慎重地表现出来。这种观点影响了格林伯格。格林伯格与白 璧德一样, 都把节制、平衡、标准、规则视为伟大艺术的标志。 ${ }^{4}$ 在《美 国绘画和雕塑目前的前景》一文中，格林伯格描述了自己心目中的 理想艺术。他认为，好的艺术应该 “建立在理性之上，却又不允许 自身被理性化”。 ${ }^{5}$ 在格林伯格看来，现代绘画各有千秋，但只有那 些带有理性批判精神的现代绘画才称得上是现代主义绘画, 抑或他 眼中的前卫。格林伯格如是描述现代主义的批判精神 : “现代主义 的本质就在于运用某一学科的独特方法对这门学科本身提出批判, 其目的不是去颠覆它，而是使这门学科在权限范围内处于更牢固的 地位。” ${ }^{6}$ 他认为，绘画进行自我批判的方式，就是形式简化，即对 平面的回归。他在波洛克的抽象绘画中找到了这种理想，认为波洛 克把它推向极致。所以, 格林伯格同时对波洛克作品中某些“哥特式” 元素也表示出强烈的反感一因为, 与先进的平面元素相比, 文学元 素、想象力、神秘主义, 都标志着一种倒退。从这一点出发, 格林 伯格不无遗憾地认为，纽曼（Barnett Newman）等人作品中 “象 征或 “形而上学” 的内涵” 都是一种 “在美国常见的、不甚成熟的 复旧风格”。 ${ }^{7}$ 在评点斯蒂格利兹艺术圈的作品时, 格林伯格也写道, 他们的艺术 “深奥难懂、过于感性，他们对塞尚、毕加索和布拉克 的作品一知半解”。 ${ }^{8}$ 换言之, 格林伯格觉得, 他们并没有挖掘现代 主义中形式创新与科学理性的一面。正是基于同一立场，格林伯格 对超现实主义、达达等流派中的具体艺术家亦有不同的态度。因此， 那种笼统地认为格林伯格贬低超现实主义、襄扬抽象表现主义的观

4 转引自迈克尔·莱杰 : 《重构抽象表现主义一 20 世纪 40 年代的主体 性与绘画》，毛秋月译，江苏美术出版社，2015 年，第 356 页。

5 Clement Greenberg, “The Present Prospects of American Painting and Sculpture,” in John O'Brian (ed.), Clement Greenberg: The Collected Essays and Criticism, Vol. 2, 1986, 167.

6 Clement Greenberg, “Modernist Painting,” in John O’Brian (ed.), Clement Greenberg: The Collected Essays and Criticism, Vol 4, I993, 85.

7 Clement Greenberg, “Art,” in John O’Brian (ed.), Clement Greenberg: The Collected Essays and Criticism, Vol. 2, 1986, I89.

8 Clement Greenberg, "L'art américain au XXe siècle," in Les Temps Modernes (August/September 1946): 345 . 
点都是不严谨的，甚至是错误的。

格林伯格所理解的前卫，本身便带有政治色彩。在探讨前卫与 政治的关系方面，他既是继承者，也是开拓者。英国学者保罗·伍 德（PaulWood）提出，在 I9 世纪，空想社会主义者圣西门、傅 立叶，艺术家库尔贝等人都赋予了 “前卫” 以鲜明的政治含义。随 后，这一概念 “呈现出日渐重要的审美因素 ; 重点的转移最终于 二次世界大战前夕在克莱门特 - 格林伯格的早期写作中, 具体地讲 1939 年的《前卫与庸俗》一文中完成”。 ${ }^{9}$ 格林伯格眼中的现代主义 艺术，因为与资本主义工业革命催生出的庸俗艺术形成鲜明对照， 所以构成对资本主义政治、文化的双重批判。这是他捍卫现代主义 的重要落脚点。格林伯格承认，前卫艺术不得不依附于资产阶级社 会的金钱而存在，但这并不妨碍他对前卫艺术的期待。他说：“一 旦前卫艺术成功地使自己 ‘超然” 于社会，它就会改变方向，对革 命政治和资产阶级都拒绝接受。”前卫艺术要保持在高级水平，脱 离意识形态斗争，发现一条途径，“使文化在意识形态的混乱与动 荡中 “运行””。10 针对格林伯格的早期文章，学者 T.J. 克拉克曾撰 写《格林伯格的艺术理论》, 以“艾略特式的托洛茨基主义”（Eliotic Trotskyism）一词，概括格氏的思想。克拉克提出，格氏的艺术观 兼具艾略特的进步史论维度与左派政治关怀。 ${ }^{11}$ 他的总结是比较贴 切和公允的。

综上，格林伯格对波洛克部分作品的赞赏，既出于他对形式创 新的肯定，也因其符合他对前卫艺术在社会批判功能上的看法。我 们应注意，格林伯格对抽象表现主义整体的态度是复杂的，这恰恰 取决于他对意识形态与艺术之关系的认识深度。他的理念是，在形 式上最先进、最具批判精神的艺术，即前卫艺术，才最需要坚持。 它不会有沦为庸俗艺术的危险，从而成为极权主义用以控制文化生

9 保罗·伍德：《现代主义与前卫的概念》, 秦兆凯译，《美术观察》, 2008 年第 2 期，第 122 页。

10 格林伯格：《前卫与庸俗》, 《艺术与文化》, 沈语冰译, 广西师范大学出 版社，2009，第 5 页。

11 T.J. Clark, "Clement Greenberg's Theory of Art," Critical Inquiry 9, no. I (Sept. 1982): I43. 
产的工具。在社会主义生产仍未足够发达到足以提高农民阶层等普 罗大众的文化认识时，庸俗文化就会大行其道，前卫艺术的价值就 会更加被凸显出来。一尽管后者, 这种较高级的文化未必天生就是 带有批判性的。

\section{三、居尔博特的工具论}

如果说, 格林伯格因为认识到抽象表现主义作品中出现的形式自律, 把它提升到独立于资本主义意识形态之上的高度，那么，居尔博特 则是在同时考察了纽约画派艺术家的创作动机与政治环境之后, 得 出抽象表现主义成为资本主义意识形态输出工具的看法。居尔博特 的研究隶属于 20 世纪 70 年代兴起的美国修正主义批评思潮。在 他之前, 科兹洛夫 (Max Kozloff)、 ${ }^{12}$ 考克罗芙特 (Eva Cockcroft $)^{13}$ 等学者已经探讨过纽约画派与美国政府、现代艺术博物馆等机构的 关系。从艺术史内部研究走向创作环境研究, 标志着抽象表现主义 研究的重要转折。

居尔博特的《纽约是如何窃取当代艺术观念的》以分析 20 世 纪 30 年代以降美国知识分子和思想界之中的去共产主义思潮开篇。 I 939 年, 《苏德互不侵犯协议》签订, 加之斯大林主义抬头, 动摇 了美国左翼知识分子对苏共的好感。居尔博特提出，在此环境下， 纽约画派等艺术家也纷纷转变阵营, 投身自由主义, 这种倾向恰好 迎合了美国政府文化输出、对抗苏共阵营的需要。“自由主义” 在 居尔博特的论述里，是一个关键词，它是一个既不同于保守右派， 也相异于共产主义左翼的意识形态。因为美国文化机构、美国政府 与纽约画派画家持有这样一个共同理念，才导致抽象表现主义成功 得到美国官方的关注, 成为冷战期间文化输出的范本。居尔博特在 书中写道 :

我的中心论题是，这种美国前卫艺术（即抽象表现主义）在本 国乃至国际范围中的史无前例的成功，并不像欧洲和美国的评论家

12 Max Kozloff, “American Painting during the Cold War,” Artforum (May I973): 43-54.

13 Eva Cockcroft, "Abstract Expressionism: Weapon of the ColdWar," Artforum (June 1974): 39-4I. 
仍然经常主张的那样，单单源自于审美的、风格的原因，其成功也 来自于、甚至更多地源自于这一运动的意识形态共鸣。14

在居尔博特看来，格林伯格关心的形式问题，是一种 “政治性 的非政治主义” (apoliticism)，即抽象表现主义画家走向抽象的创 新形式，虽与现代主义传统进行着对话，但更重要的，是艺术家们 为此注入了 “自由主义” 思想。将波洛克、德 - 库宁等画家在 1948 年前后走向抽象的转变, 理解为一种投身自由主义阵营的举动, 属 于居尔博特的人为建构。这是他为人诟病之处, 也是某些国内学者 缺乏系统深究而肆意发挥的地方。不过, 如果说居尔博特的立场是一 纽约画派中包裹着意识形态，那么，国内有些学者则是把此问题理 解为抽象表现主义去主动迎合、附庸意识形态。两者有微妙的不同， 我们辨析的关键，就在于对 “自由主义”一词的理解。

包括抽象表现主义画家在内的前卫艺术家们十分关注当时的左 派批评家在《党派评论》《国家》《政治学》等杂志上发表的言论。 像《前卫与庸俗》这样的重磅批评文献，就在艺术家中产生了深远 影响。居尔博特确信地写道 : “《前卫与庸俗》一文, 让许多画家原 本不甚明朗的思想立场变得正式起来，明确起来，在某种程度上理 性化起来。” ${ }^{15}$ 因此, 旨在创造前卫的艺术家开始把拒绝陷入 “图示” (illustration) 作为个人的重要关切。艺术家们认为 : 图示的对立 面一抽象 (abstraction)，使得前卫艺术能够 “与时代进行积极地 对话。让一种激进的、坚定的艺术成为可能，这种艺术既不带有政 治宣传性质, 也不会对观众卑躬屈膝” ${ }^{16}$ 。波洛克等抽象表现主义画 家是否真的彻底走向了抽象? 他们是否应该完全走向抽象?居尔博特 并不关心这一点，不过，他所肯定的是，在以波洛克为代表的前卫 艺术家作品中，出现了一种 “擦除”（ob-literation）的倾向，即一 些原本可以清晰可辨的意象，被故意描绘得支离破碎，例如波洛克 的《I948 年第 I 号》(Number I, 1948)、《第 22 号 A》(Number

14 Serge Guilbaut, How New York Stole the Idea of Modern Art, trans.

Arthur Goldhammer (Chicago: University of Chicago Press, 1983), 2, 37, 197, 169.

15 同上。

16 同上。 
22A）和《第 4 号》(Number 4)。其实，居尔博特所理解的抽象， 更接近于英国学者奥斯本（Harold Osborne）所说的语义抽象，即 “对自然外观不完全的或有限的再现”。17这种抽象可能在格林伯格 看来不算彻底，但在居尔博特看来，它代表一种拒绝社会现实主义、 革新欧洲传统，寻求独立探索的姿态。正是这种自由主义的姿态， 让持有相同意识形态的美国政府、艺术传播机构和众多艺术批评者 难以忽略纽约画派的艺术成就。格林伯格的理想是，现代主义艺术 应该像以前的艺术那样, 呆在象牙塔里, 实现我们前文提到的 “超 然”; 在现实世界, 仿佛艺术家们也是想这样做的。但居尔博特认为, 对于当代艺术家来说, 这个目标显然难以实现, 因为他们与社会环 境深深地交织在一起。

那么, 为何是自由主义形成对艺术家、知识分子和政界人士 的吸引? 对此问题, 居尔博特十分认同美国学者小亚瑟 - 施莱辛格 (Arthur Schlesinger, Jr.) 所著《生命中枢：自由的政治》(The Vital Center: The Politics of Freedom）一书中的观点。这本书所 论述的，正是自由主义在美国政治环境下抵抗苏共与斯大林集权主 义的合理性 ; 在客观上, 它也的确为冷战时期的中间派人士提供了 一套有效的行动纲领。施莱辛格认为, 自由主义将自身建立在对人 类和历史的坚定构想之上，它已经被成功实施的罗斯福新政所证实 和更新。因此, 在冷战期间, 它值得被继续坚守。他在书中提出: “与 集权主义带来的确定性有所不同的是，只有一个自由的社会才会让 现代人心中充满疏离感和不确定感。” ${ }^{18}$ 波洛克、德·库宁（William de Kooning）等人在绘画形式和创作方式上的双重独立姿态，与其 作品所传达出的某种焦虑与疏离感, 恰恰透露出, 他们是自由的个 体。这种隐形的 “范本” 让人难以忽略。居尔博特提出, 有了一个 共同意识形态的指导，即使在 1948 年前后，美国文化在整体上仍

17 哈罗德 - 奥斯本 : 《20 世纪艺术中的抽象和技巧》, 阎嘉等译，四川美术 出版社， I988，第 5页。

18 Arthur Schlesinger, Jr., The Vital Center (Boston: Houghton Mifflin, 1949), 57, quoted in Guilbaut, How New York Stole the Idea of Modern Art, 202. 
然对前卫艺术持有敌意，但后者的胜利 “只是一个时间问题”。19

对于居尔博特的观点，美国学者本雅明·布赫洛（Benjamin Buchloh）曾略带讽刺地说道：“赛尔热·居尔博特将美国文化生产 完全放在为自由资本主义民主（即美国）服务的意识形态框架中， 如果事情这样就可以澄清的话，那么……是不是也可以得出这样的 结论，认为德国的战后文化完全受制于集体性强制推行的政治和心 理健忘症?” ${ }^{20}$ 的确, 虽然居尔博特成功扭转了前期批评者的对形式 的过分关注，从一种历史唯物主义的角度展开对艺术创作机制的讨 论，不过，他带有工具主义烙印的观点是值得商榷的。在居尔博特 的书发表十年之后，其同门师弟迈克尔·莱杰在专著《重构抽象表 现主义》一书中，表达出对意识形态与绘画关系的不同看法，不仅 拓宽了居尔博特的视野，也修正了他的不足之处。

\section{四、莱杰的意识形态共谋论}

莱杰的《重构抽象表现主义》诞生之际，正是英美 “新艺术史” 研 究逐渐兴盛的时候。此时的艺术研究，越来越倾向于将艺术放在宏 大的社会背景和多元化的理论建构中考查。相比格林伯格与居尔博 特，莱杰的研究鲜明地呈现出一种研究趋势一即不再以意识形态成 分简单划分的方式, 为某一艺术运动下结论。他对格林伯格的推进, 主要从绘画形式展开，对居尔博特的批判，则是从更广义的意识形 态运作机制入手。

我们先考查莱杰的基本立意。莱杰提出，纽约画派艺术家们通 过在作品中展现 “无意识” 和 “原始性” 两大元素，建构出一个新 式的中产阶级主体形象。从客观上看，艺术家们不自觉地参与到美 国战后社会里，中产阶级重建意识形态主体的工程之中。而中产阶 级意识形态，正是当时美国整个社会的主导性意识形态。他写道 :

中产阶级的意识形态在现代遭受到了一些历史事件的重创，它

19 Serge Guilbaut, How New York Stole the Idea of Modern Art, trans. Arthur Goldhammer (Chicago: University of Chicago Press, 1983), 2, 37, 197, 169.

20 本雅明·布赫洛:《新前卫与文化工业: 1955 到 1975 年间欧美艺术评论集》, 何卫华等译，江苏美术出版社，2014，第 3 页。 
不得不从心理学层面上对这些事件构成一套解释，从而巩固自己的 统治地位; 在这个过程中, 最重要的观点, 就来自于人们对于所谓 “原 始” 人类的研究, 以及对人类无意识的研究。这种看待问题的模式 及其解决方案在 20 世纪 40 年代的美国受到广泛关注。 ${ }^{21}$

引文中的 “看待问题的模式及其解决方案”, 被莱杰统称为 “现 代人话语” (Modern Man Discourse)。这是一种探讨现代人的本质、 归属和生存状况的话语。在他的研究框架里, 纽约画派作品亦从属 于 “现代人话语”。“现代人话语” 在电影、文学、通俗哲学、美术 中均有出现。它诞生于 19 世纪的美国, 挑战着传统的乐观主义人 性模型, 又被 20 世纪的政治悲剧和文化事件所巩固, 最终, 被社 会中占据主导地位的中产阶级意识形态所吸收, 成为一种主流话语, 并逐渐渗透到人们的思想领域，包括艺术家们的思想领域之中。

这一过程看似神秘，却正是阿尔都塞意义上的 “意识形态” 发 挥作用的过程。在阿尔都塞的理论体系中, 意识形态是 “个体与其 实际生存状况的想象性关系的表现”。 ${ }^{22} 1969$ 年，阿尔都塞在《意 识形态与意识形态国家机器》(“Ideology and Ideological State Apparatuses”) 里指出, 资本主义社会中同时存在镇压性的国家机 器和意识形态国家机器, 两种机制都维持着生产关系的再生产。在 阶级社会, 意识形态具有强大的自我维护机制和传播机制, 它通过 “询唤”（interpellate）个体，与个体产生互动，从而把人塑造为 意识形态下的主体。换言之, 意识形态对个人的塑造, 以及个人对 意识形态的内化与传播, 都是在不知不觉中完成的。莱杰通过对纽 约画派作品进行抽丝剥茧式的符号学分析, 并考察纽约画派艺术家 的思想背景, 表达出这样一个观点: 纽约画派的作品在展现某种充 满原始冲动和无意识本能的主体之际, 与主导性意识形态之间形成 了一种深刻的、无意识层面的共谋关系。这就打破了格林伯格的前 卫艺术自主论，也与居尔博特的 “具论” 拉开了距离。

莱杰与格林伯格的一个重要分歧点在于 : 格林伯格及其后继者

21 Michael Leja, Reframing Abstract Expressionism: Subjectivity and Painting in the I940s (New Haven: Yale University Press, 1993), 269, 2II, 312.

22 Louis Althusser, Lenin and Philosophy and Other Essays, trans. Ben

Brewster (New York: Monthly Review Press, 197I), I62-63. 
弗雷德（Michael Fried）、鲁宾（William Rubin）认为，波洛克 的绘画创造出一个纯粹的、平面的视觉空间，这一解读构成现代主 义者展开后续论述的基本逻辑; 而莱杰则认为，其解读成立的前提， 是否认线条有任何隐喻和塑性的含义，他并不认同。他提出，波洛 克于 20 世纪 40 年代至 50 年代早期完成的绘画，一直受到具象和 抽象之间辩证关系的推动。其研究策略之一，就是把波洛克的线条 解读为 “网”，即承认其绘画中的隐喻成分。这种解释并非莱杰自 创，因为 “网” 在 20 世纪中叶的美国文化产品中，是一个非常突 出的意象，例如在黑色电影中，网就会以不同方式出现。同时，“网” 也是学者们用来解读波洛克作品的工具, 甚至格林伯格、 ${ }^{23}$ 鲁宾 ${ }^{24}$ 等 侧重形式分析的批评家也在不自觉地运用。《薰衣草之雾》(Lavender Mist)、《I948 年第 I 号》(Number I, I948) 中的网清晰自明; 而 一些尺幅较小的作品, 如《切除》(Cut Out)、《三重态》(Triad) 等, 则同时表现了网与受困的现代人意象。这样，莱杰就把对波洛克的 作品的美学解读继续纳入到现代人话语（抑或意识形态）的范畴之 中。

莱杰与居尔博特的分歧则在于：居尔博特曾区分出 “自由主 义” “保守主义” “左翼” 等不同的政治联盟意识形态，而莱杰则持 阿尔都塞的观点，认为意识形态的内涵绝不是政治层面的，甚至与 人们有意遵从的政治信仰没有任何联系。此外，居尔博特是以 “自 由主义” 为纽带，侧重于分析抽象表现主义的接受过程，莱杰则是 以意识形态的维护机制为出发点，把焦点放在抽象表现主义的创作 过程上。后者认为，抽象表现主义在诞生初始，便不自觉地参与着 主导性意识形态的传播与复制。纽约画派作品表面上的激进，掩盖 不了它们对意识形态的维护。假如它们真的彻底激进，则势必会造 成自身的边缘化。莱杰尖锐地指出：“(抽象表现主义）指出人的内 心存有理智的对立面，这并不像质疑一个人的个体经验，或质疑个 人对于自治的渴望那么难。” 25 在莱杰看来, 后两种 “质疑” 显然更 具颠覆性, 也更加棘手。例如, 当人们 “质疑一个人的个体经验” 时,

23 Leja, Reframing Abstract Expressionism, 269, 2II, 3 I2.

24 同上。

25 同上。 
可能会问：究竟有没有所谓 “个人” 这一概念? 当人们 “质疑个人 对于自治的渴望” 时，可能会问：一个人能否获得独立? 纽约画派 的作品，始终不曾试图回答这两个问题。

试举一例 : 莱杰认为, 纽曼、罗斯科等人描绘神话与原始主义 的作品，是一种不具备彻底批判性的艺术。他的分析，借鉴了阿多 诺（Theodor Adorno）在《遵命的艺术》(“Commitment”) 一文 中的美学观点。 ${ }^{26}$ 阿多诺在其论述中并没有提到纽约画派, 而是比 较了卡夫卡、贝克特与存在主义之间的区别。阿多诺写道 :

通过卸下恐惧的外壳，卡夫卡和贝克特让恐惧从艺术的内部爆 发出来，而那些遵命的艺术只能从外部征服恐惧，因此，后者 的恐惧只停留在表面上。前者的作品让人无法逃避, 它们迫使 人们不得不改变以往的观点, 而那些遵命的艺术只能要求人们 去做出改变。 ${ }^{27}$

阿多诺对卡夫卡和贝克特持赞扬观点，认为他们之所以胜人一筹， 就在于其作品中决绝的怀疑精神。换言之, 从莱杰所持的阿尔都塞 立场上看, 贝克特和卡夫卡的作品不再延续意识形态再生产, 不再 复制意识形态与生存状况的想象性关系。而存在主义这种 “遵命的 艺术”，亦即某种与政治和意识形态亦步亦趋的文学和艺术，在卡 夫卡面前相形见绌。莱杰认为，神话制造者的艺术也属于 “遵命的 艺术”。他推断，阿多诺会对此持有相同看法。

总之, 我们可以看到 : 莱杰对抽象表现主义的态度, 基本是批 判性的。因为在他看来, 清醒地认识到自身属性的艺术, 要比无意

26 阿多诺的这篇文章写于 1962 年，它主要批判了萨特、布莱希特和本 雅明等人的观点。文中频繁出现 “committed-art” 和 “committed literature”两个词语，它们指的是一种与政治和意识形态密切相关的文 学和艺术。因此, 也可以被译为 “介入的艺术” 和 “介入的文学”。现 有中文名并不统一，本文按 “遵命” 解。

27 Theodor Adorno, “Commitment” (1962), trans. Francis McDonagh, in The Essential Frankfurt School Reader, eds. Andrew Arato and Eike

Gebhardt (New York: Continuum, I982), 314-15. 
识中参与意识形态共谋的艺术更加高明。至于艺术应该以何种方式 抵抗意识形态中消极成分的渗透，同时保持先进性与独立性，莱杰 始终没有给出答案。因此，本文认为，虽然西方学者对纽约画派与 意识形态的探讨已构成不同体系，形成相对完备的结论，但仍然存 在诸多悬而未决的理论命题。

\section{结论}

前卫艺术能否独善其身，在形式创新的象牙塔里自我沉醉，以嬉笑 怒骂的姿态傲视意识形态?本文的回答是 : 不能。然而意识形态与 艺术的关系，也绝非单向度的决定与被决定、利用与被利用的关系。 要深入理解两者的互动, 需要扎根于历史唯物主义的丰厚土壤, 更 需要一种建立在综合考察艺术史实与政治环境之上的多元化理论建 构。

并且，细察三位西方马克思主义学者的研究，我们发现，“意识 形态” 的内涵在其笔下不断扩大, 逐渐超越了政治集团的信仰范畴, 变成一种宏观语境。例如，莱杰的《重构抽象表现主义》全书都在 探讨抽象表现主义与意识形态的关系，却基本没有提到政府推广抽 象表现主义的任何一种具体做法 ; 即使是被一些国内学者视为 “阴 谋论” 始祖的居尔博特，也在其书中强调 : “我的意图并不是想要 将这些前卫运动的艺术家们说成有明确的政治动机，也不是想要暗 示他们的行动是某种阴谋的产物。” 28 可见，对于纽约画派画家及其 作品背后的思想背景的关注，是西方学者探讨的重点，而这一点， 恰恰有助于我们拓宽今后的研究范围。如何理性地讨论艺术与政治 的关系，又不落入线性的、僵化的结论，尤其值得我们深思。学者 丹纳就曾提出：“要了解一件艺术品, 一个艺术家，一群艺术家, 必须正确地设想他们所属时代的精神和风情的概况。这是艺术品最 后的解释，也是决定一切的基本原因。” ${ }^{29}$ 认识到这一点，我们便可 将多学科的理论维度引入当下的艺术批评，切实关注艺术创作与意 识形态、社会语境的微妙关系。而更深远的意义则在于 : 从多元化 理论建构的角度展开西方现当代艺术研究，对于全面把握艺术运动

28 Guilbert, How New York Stole the Idea of Modern Art, 3.

29 丹纳 : 《艺术哲学》, 傅雷译, 广西师范大学出版社, 2002 年, 第 7 页。 
的发生和发展、艺术家的自主选择和政府的推广、创作与批评规律， 将产生巨大的推动作用。 


\section{The New York School and Ideology}

Mao Qiuyue

The New York School, one of the most prominent movements in the history of twentieth-century American art, has been thoroughly studied by critics ever since its formative stage. Chinese scholars began their research of the New York school by reviewing and translating Clement Greenberg's essays in the I980s. During the last 30 years, discussions of the relationship between the New York School and official ideology has become the most heated theme. There were two major positions: some scholars thought that the success and the internationalization of Abstract Expressionism mainly lay with the U.S. government's political propaganda as well as its promotion by art institutions; the aesthetic values of those paintings was secondary. Such a position was called a "conspiracy theory." Other scholars held that Abstract Expressionism could not attract the government and the attention of art galleries and thus was promoted only because it had developed a highly mature form of avant-gardism. The debate has not ended even today.

The problem with the "conspiracy theory" idea is that it neglects art's value and regards it as a subordination to politics; in addition, the controversy over this theory has become an academic hotspot. To some extent, discussions around the "conspiracy theory" and its antithesis have narrowed our attention to the process of the reception of New York School paintings, thus making us ignore its formative stage and its complex relations with U.S. modernism, culture, and society. Furthermore, it must be admitted that, in the context of Chinese domestic research, to sweep away the illusions brought about by the "conspiracy theory" and get rid of the rigid political determinism is the precondition of a deeper level of academic research. While the present discussion around the "conspiracy theory" may be necessary, it is not the final position of our art research. Otherwise, the academic study of art and ideology will easily slide into a purely ideological debate.

So how do we broaden the scope of our research on the New York School? The first step is to notice two critical messages hidden in the above positions: first, some scholars tended to regard art and politics as two separate spheres when analyzing the relationship between Abstract Expressionism and U.S. ideology; second, Chinese scholars disagreed on the forming mechanism and aesthetic values of New York School paintings, which directly led to their opposed attitudes towards the U.S. government's promotion of it during the Cold War.

This chapter argues that art and ideology are not separated. In assessing the aesthetic values of Abstract Expressionism, social ideology itself is an important dimension of reference. Therefore, Clement Greenberg, Serge Guilbaut, and Michael Leja's points of view can provide us with important enlightenment. Taking Marxism as their starting point, these three scholars combined formal elements of the New York School paintings with ideology, and thus expressed their opinions on New York School's aesthetic and social attributes. Their dis- 
cussions have formed a continuous chain which has not yet caught the attention of Chinese domestic academic circles. This paper will analyze these three scholars' mutual grounds of agreement as well as their disagreements, exploring the intrinsic logic of Western studies of Abstract Expressionism, in order to provide new perspectives for the related future research in China.

Many Chinese scholars regard Greenberg as the spokesman of Abstract Expressionism. On one hand, this attitude is reasonable. Greenberg's three major essays published in Partisan Review, namely "Avant-garde and Kitsch," "Towards A Newer Laocoon," and "American-Type Painting," not only helped Abstract Expressionism establish a distinguished historical position, but also laid a solid theoretical foundation for the internationalization of the movement. On the surface, it seems as if the New York School was progressing in a self-critical way toward flatness, just as Greenberg had argued. But Greenberg did not totally hold positive attitudes toward all Abstract Expressionist work. His feeling is complex even concerning Jackson Pollock. As far as I am concerned, Greenberg is not so much a spokesman for Abstract Expressionism, as much as a spokesman of his own modernist theories. Prior to the 1940s, he championed Abstract Expressionism because some works met his expectations for the political attributes of the avant-garde.

Underlying Greenberg's modernist theory is his rationalist attitude. It is under such guidelines that Greenberg made a distinction between good and bad among modern painting, and, furthermore, expressed his ideas on the relationship between the avant-garde and ideology. Greenberg's insistence on rationality was influenced by the German philosophy represented by Immanuel Kant. On this point, enough has been said, such as in Professor Zhang Jian's essay 《浪 漫与科学的碰撞一格林伯格艺术批评思想中的德意志因素》published in 20II. What I want to add here is a tradition that might be overlooked by Chinese scholars, namely that Greenberg also inherited the spirit of the New Humanism movement in America.

The New Humanism was a movement of intellectuals that promoted the old Puritan virtues of individual self-control, moderation, common sense, and common decency, in explicit opposition to the excesses and primitivism of Modernism and Romanticism. Its principal figure was Irving Babbitt, a literary critic and professor working at Harvard. In aesthetics, Babbitt championed a neoclassicism, insisting upon cultivation of classical virtues, such as decorum, restraint, discipline, and balance. He argued that in art, as in life, impulse and instinct must be subjected to an "inner check," tempering passion and inspiration while insuring balanced, measured expression. Such ideas influenced Greenberg, who designated control, balance, measure, and discipline as the hallmarks of greatness in art.

In his essay "The Prospects of American Painting and Sculpture," Greenberg described his ideal art. He argued that "an art, resting on rationality but without 
permitting itself to be rationalized, can adequately answer contemporary life." Greenberg thought that modern paintings differed greatly in quality, and only those with a rational critical consciousness could be called modernist paintings or, in other words, avant-garde. He wrote: "The essence of Modernism lies, as I see it, in the use of characteristic methods of a discipline to criticize the discipline itself, not in order to subvert it but in order to entrench it more firmly in its area of competence." ${ }^{2}$

Therefore, the self-criticism in modernist painting was to eliminate every effect that might be borrowed from or by the medium of any other art. Modernist painting thus displayed a tendency toward the flat surface, its unique medium. Greenberg championed some of Pollock's paintings because he thought Pollock displayed such tendencies to the full extent. Meanwhile, he also showed his distaste for the "Gothicness" in some of Pollock's other paintings. Clearly, compared to the advanced flatness, elements like literary imagination and mysticism become a symbolization of recession. By the same token, Greenberg also had reservations about the symbolic and metaphysical content of the Mythmakers' works, namely works from Barnett Newman, Mark Rothko, Clyfford Still, and Adolph Gottlieb, which were "half-baked, and revivalist, in a familiar American way." 3

Similarly, in commenting on works from the Stieglitz group, Greenberg wrote of their art that it was "esoteric, excessively emotional, and the work of Cézanne, Picasso, and Braque was still slightly understood.” 4 They didn't recognize, in other words, what Greenberg saw as the character and importance of the breakthroughs of Cézanne, Picasso, and Braque-that modernism was rational, scientific, formalist.

Such advanced form is also closely tied to a political identity. In venturing into the relationship between the avant-garde and politics, Greenberg was a successor as well as a pioneer. British scholar Paul Wood argued that in the nineteenth century, Utopian socialists such as Henri Saint-Simon, Charles Fourier, and the artist Gustave Courbet had assigned to the avant-garde a salient political identity.s And later on, such a notion increasingly incorporated factors of aes-

I Clement Greenberg, The Collected Essays and Criticism, Volume 2: Arrogant Purpose, 1945-1949, ed. John O’Brian (Chicago: University of Chicago Press, 1986), I68.

2 Clement Greenberg, "Modernist Painting" (1960), in The Collected Essays and Criticism, Volume 4: Modernism with a Vengeance, I957-I969, ed. John O'Brian (Chicago: University of Chicago Press, 1993), 85.

3 Greenberg, quoted in John P. O’Neill, ed., Barnett Newman: Selected Writings and Interviews (Berkeley: University of California Press, I992), I6I.

4 Quoted in Randall Keith Van Schepen, "American-type" Formalism: The Art Criticism of Alfred H. Barr, Jr., Clement Greenberg, and Michael Fried (Ph.D. Thesis, University of Minnesota, 1999), 225.

5 See Charles Harrison, Paul Wood, and Jason Gaiger, Art and Theory I8I5-I900: An Anthology of Changing Ideas (Malden: Blackwell, 2012). 
thetic perception. The shift of focus finally happened on the eve of World War II, in Clement Greenberg's early writings, specifically in his I939 essay, "Avant-garde and Kitsch." Greenberg maintained that the avant-garde formed a critique of the capitalist system and culture as it was in sharp contrast against kitsch, a product of capitalist industrial revolution.

In the essay, he admitted that in his day, the avant-garde was still attached to capitalist society by an umbilical cord of gold; but at the same time, he also said: "once the avant-garde had succeeded in 'detaching' itself from society, it proceeded to turn around and repudiate revolutionary as well as bourgeois politics." ${ }^{\prime}$ In other words, the avant-garde could escape the manipulation of ideological powers and "found a path along which it would be possible to keep culture moving in the midst of ideological confusion and violence." In his essay "Clement Greenberg's Theory of Art," British scholar T.J. Clark coined the term Eliotic Trotskyism to describe Greenberg's thoughts at this time. ${ }^{7}$ Clark argues that Greenberg combined T.S. Eliot's Progressivism with Trotsky's left-wing politics. Such a conclusion is appropriate.

In conclusion, it should be noted that Greenberg's attitude towards the American avant-garde is complicated. For Greenberg, the avant-garde not only carried a critical spirit, but also presented a challenge for effective propaganda for both the Fascists and the Stalinists. In a society where socialist production has not been so developed as to raise the masses' aesthetic taste, kitsch would always be popular, and thus highlighted the value of its antithesis, the avant-garde-although the latter is not "inherently a more critical culture."

Serge Guibault, after investigating both the writings and works of Abstract Expressionists and the political environment, drew a very different conclusion from Greenberg. He maintained that Abstract Expressionism was exactly a tool of propaganda of American capitalist ideology, especially during the Cold War. Guibault affiliated his research with a trend of revisionist historical study beginning from the I970s. Before him, scholars like Mark Kozloff and Eva Cockroft had discussed the interaction between the New York School and political ideology, as well as art institutions like MoMA. What matters here is that Guibault's study expanded the scope of the art historical study of Abstract Expressionism by combining the creative subjects' thoughts and writings with the environment in which they lived.

Guibault's book How New York Stole the Idea of Modern Art opens with the de-marxization of the American intelligentsia beginning in the mid-I930s. In 1939, with the signing of the Soviet-German non-aggression treaty and the rise of Stalinism, the belief in communism among left-wing intellectuals was greatly shaken. Guibault argued that influenced by such an environment, the artists of

6 Clement Greenberg, "Avant-Garde and Kitsch," in Art and Culture: Critical Essays (Boston: Beacon Press, 1965), 3-21, at 5.

7 T.J. Clark, "Clement Greenberg's Theory of Art," Critical Inquiry 9, no. I (1982): I39-56.

8 Greenberg, "Avant-Garde and Kitsch," I9. 
the New York School also switched their allegiance to the new liberalism, and this tendency catered to the needs of American cultural exports in combating the Soviet Union. In Guibault's work, "new liberalism" is a key word, and it is different from both the conservative right and the communist left. It was under the banner of such ideology that American cultural institutions, the U.S. government and the New York School painters were united, and which had finally made Abstract Expressionism an ideal model for the cold war output. Guibault wrote: "My central thesis is that the unprecedented national and international success of an American avant-grade was due not solely to aesthetic and stylistic considerations, as both European and American commentators frequently still maintain, but also, even more, to the movement's ideological resonance." 9

In the eyes of Guibault, the stylistic issues discussed by Greenberg is a kind of "political apoliticism." In other words, although the abstract tendency among the New York School artists entered into a dialogue with the modernist tradition, more important was that they injected a new liberalism into their paintings.

Guibault argued that American avant-garde artists, including the Abstract Expressionists, paid close attention to what those left-wing critics said in journals like Partisan Review, The Nation, and Politics. His groundbreaking essay, "Avant-garde and Kitsch," exerted a great influence among artists. Guibault wrote: "What 'Avant-garde and Kitsch' did, then, was to formalize, define, and in some sense rationalize an intellectual position that had been ad-opted in a confused way by many painters." ${ }^{\text {10 }}$ As a result, artists aiming at reaching the avant-garde began to embrace abstraction and resist illustration in their works. "Abstraction," Guibault wrote, "made it possible to avoid these pitfalls and to enter into an active dialogue with the age. It allowed a militant, committed art that was neither propagandistic nor condescending to its audience." Guibault found that Abstract Expressionists tended to obliterate visible images in their paintings, the most obvious example might be Pollock's Number I, 1948, Number 22A, and Number 4. In fact, the abstraction discussed by Guibault was close to what British writer Harold Osborne termed "semantic abstraction," namely an incomplete or limited abstraction of the natural world. ${ }^{12}$ To Guibault, it represented a position of resisting social realism, innovating European tradition and finding an independent path in artistic creation.

It was also a position of new liberalism. Sharing the same ideology, the U.S. government, art institutions, and art critics thus found it hard to ignore the accomplishments of those artists. And they finally had collaboration in communicating such ideology to the world. Greenberg wished that the avant-garde should escape ideological powers, while in the real world it seemed that artists

9 Serge Guibault, How New York Stole the Art World: Abstract Expressionism, Freedom, and the Cold War (Chicago: University of Illinois Press, 1985), 2.

Io Ibid, 37 .

II Ibid, 197.

I2 See Harold Osborne, Abstraction and Artifice in Twentieth-Century Art (Oxford: Oxford University Press, 1979). 
were also considering this possibility. But Guibault argued that, for modern artists, this was an impossible goal because they were closely interrelated with the social context.

Then how do we understand such new liberalism? In answering such a question, Guibault cited a noted book The Vital Center: The Politics of Freedom by American historian Arthur Schlesinger, Jr. In Guilbaut's study, Schlesinger's book stands as the quintessential articulation of the new liberalism ideology, which Abstract Expressionism came to serve, by virtue of its participation in U.S. cultural diplomacy during the I950s. Schlesinger argued that American liberalism based itself on a solid conception of man and history, which had been solidified by President Franklin D. Roosevelt's New Deal. Therefore, it was worth sticking to during the Cold War. He wrote "against totalitarian certitude, free society can only offer modern man devoured by alienation and fallibility." ${ }^{13}$

In Guibault's study, Jackson Pollock's psychological problems were but cruel tokens of the hardships of freedom. Therefore, the work of Pollock and other Abstract Expressionists was presented as representing the anxiety, alienation, and frustration that distinguished the free individual in the modern world. In other words, those artists stood out as perfect examples of liberalism. Guibault argued that although around 1948, the mainstream of American culture was still hostile to the avant-garde, the success of the latter was only a matter of time.

Commenting on Guibault's ideas, Benjamin Buchloh sarcastically said: "Serge Guibault has put the American overall cultural production under the framework of serving the American liberal capitalist democracy; if things were this clarified, then [...] isn't it possible that we could also conclude that the postwar German culture was totally under the control by a collective compelled politics and psychological amnesia?" ${ }^{4}$ Indeed, on one hand, Guibault successfully shifted the overemphasis on form issues by modernist criticism, adopting instead a materialist perspective to instigate the creative mechanism of the avant-garde; on the other hand, his view was also "instrumentalist," to use Michael Leja's term. Leja, in his study Reframing Abstract Expressionism, expressed a renewed outlook on the relation between ideology and painting which not only expanded Guibault's scope of research, but pointed out his deficiencies as well.

Leja's research was a representative of the new art history, a research method which tended to put art in a grand social context and diversified theoretical frameworks. Compared to Greenberg and Guibault, Leja's study clearly showed that his research did not designate an ideological attribute to a certain art movement. He advanced Greenberg's formalistic discussions with a different view on medium and flatness, and he also criticized Guibault's views with a broader working mechanism of the ideology.

13 Arthur M. Schlesinger, The Vital Center: The Politics of Freedom (Boston: Houghton Mifflin, 1949), 57.

I4 Benjamin Buchloh, Modernism and Modernity: The Vancouver Conference Papers (Halifax: The Press of the Nova Scotia College of Art and Design, 2004), ro. 
Framing the rationale of Leja's study, he argued that the New York School had constructed a new image of the middle class by displaying two major elements in their works, namely the unconscious and primitivism. In reality, those artists were unconsciously engaged in an ideological reconstruction of the middle-class subjectivity. He wrote: "The re-stabilization of bourgeois ideology in the face of the shock of modern historical events depended upon the construction of psychologizing explanations for those events; crucial to this project were the insights offered by the study of 'primitive' human life and the unconscious mind. This construction of the problem and its solution achieved wide currency in 1940 America." 15

"The construction of the problem and its solution" was given another name by Leja: "the modern man discourse." It is a discourse dealing with modern man's nature, status, and living conditions. The modern man discourse was born in nineteenth-century America. It appeared in many different modern cultural products, like the Hollywood movie, literature, mass philosophy, and Abstract Expressionism. It challenged traditional American optimism, and was reinforced by the tragic historical events of the 2oth century. Its development had always been guided by the dominant ideology, and then was fully recognized and incorporated by that ideology.

Mysterious as it may seem, this process was what French philosopher Louis Althusser has described as the empowerment of ideological state apparatuses. In 1969, Althusser published his famous essay, "Ideology and Ideological State Apparatuses." ${ }^{16} \mathrm{He}$ argued that there were two kinds of state apparatuses; one was the repressive state apparatus and the other the ideological state apparatus. The former functions through law, government, prison, and the latter functions through relation, education, family, and cultural agencies. Two apparatuses exist for the reproduction of the relations of production. In a class society, ideology has substantial self-preservative momentum and efficiency of transmission. It interpellates people (in Althusser's sense), interacts with people, and makes people the subjects of its influence. Through a semiotic analysis of the works from the New York School, and investigating their writings and talks, Leja expressed this idea: New York School artists formed a profound complicity with the dominant ideology, which happened on an unconscious level. Therefore, Leja departed from Greenberg's notions of art autonomy as well as Guibault's instrumentalist views.

One of the major disagreements between Leja and Greenberg was that for Greenberg, and his successors Michael Fried and William Rubin, Pollock's art created a pure, flat optical space and Pollock's lines had been freed from traditional functions of bonding and shaping. But Leja maintained that Pollock's

I5 Michael Leja, Reframing Abstract Expressionism: Subjectivity and Painting in the I940s (New Haven: Yale University Press, 1997), I6.

I6 Louis Althusser, "Ideology and Ideological State Apparatuses," in Lenin and Philosophy and Other Essays, trans. Ben Brewster (London: New Left Books, 1977), I2I-76. 
paintings throughout the I940s to the early I950s had always been guided by the interaction between abstraction and figuration. He read Pollock's lines as metaphors of webs and mazes. This kind of reading was not coined by Leja, because the web and maze was a salient image in the cultural products in mid-century America, such as in film noir. Web was also a word that had been frequently used by critics of Pollock's work, including Greenberg and Rubin. According to Leja, the image of the web was especially clear in some giant works such as Lavender Mist, and Number I, 1948. Some smaller works, such as Cut Out and Cut-Out Figure, more clearly showed images of webs and a modern man confined by webs. Thus, Leja went on to incorporate his formal analysis into the framework of this "modern man" discourse or ideology.

One difference between Leja and Guibault was that the latter regarded ideology as an explicit set of beliefs organized around a political affiliation. In his book, he mentioned the new liberalism, the conservative right, and the communist left. By contrast, Leja argued that ideology had little to do with consciously held beliefs, it is an implicit structure of belief, assumption, and disposition. Another difference was that Guibault used the new liberalism as a key concept to analyze how Abstract Expressionism was received. But Leja started from the self-preserving mechanism and focused on how it was produced. The ostensible radicalism of the New York School artists was overshadowed by the fact that they were preserving the ideology from the very beginning. Had their work been inclined to struggle against the dominant ideology, they would certainly have enforced the marginalization of their works.

Leja is also at some point in agreement with Theodor Adorno. In his essay, "Commitment," Adorno compared the differences between Franz Kafka, Samuel Beckett, and Existentialism. Adorno wrote: "Kafka and Beckett arouse the fear which existentialism merely talks about. By dismantling appearance, they explode within the art which committed proclamation subjugates from without, and hence only in appearance. The inescapability of their work compels the change of attitude which committed works merely demand." ${ }^{17}$

Adorno praised Kafka and Beckett for he thought they displayed a thorough radicalness. In other words, using Althusser's term, Kafka and Beckett no longer serve the reproduction of the relations of production, neither did they replicate an imaginative living states influenced by the dominant ideology. Existentialism, committed to politics and ideology, was comparatively inferior. Leja argued that Abstract Expressionism was also a kind of committed art. And Adorno would have had the same judgment.

Leja held a positive attitude towards the innovations made by Abstract Expressionism, but he also criticized it. Such a position reflected his expectation of art; that is, no matter how important formal innovation is, art should always display an insight, thus forming a critical, constructive power. But as to how art could possibly resist the permeation of negative elements of ideology while remaining advanced and independent, Leja did not give an answer. Therefore, 
I think that although the discussion by art historians of the West has formed a well-organized system, there is still some room left open to discussion.

From the above analysis we can see that the relationship between ideology and art is never a simple question of who uses whom, and who had been used. In order to understand their interaction, we need a solid materialist study and a comprehensive understanding based both on historical facts as well as the larger social and political context.

Exploring the study of these three scholars, we see that the connotation of ideology has been gradually expanded. It has gone beyond the beliefs of a certain political group and has become invisible. For example, the discussion of the relationship between Abstract Expressionism and the dominant ideology runs through Leja's Reframing Abstract Expressionism, but he hardly mentions a single act of the government's promotion. Even Guibault, the so-called predecessor of the conspiracy theory, emphasized this in his book.

Therefore, we should note that the discussions of the social background of New York School painting and its artists are the focus of western studies. And such concerns are helpful for broadening our horizons in future study. We need to introduce multi-perspectives into our own study, and pay close attention to the subtle relations among artistic creation, ideology, and social context. Furthermore, such methodology will not only be helpful for a comprehensive understanding of the art movements themselves, but will also improve our understanding of the creative subjects and governmental behaviors. 


\section{转义和建树 : 中美艺术交互影响的若干个案}

丁宁

中美艺术家从相互的文化和艺术影响中获益乃是有目共睹的事实, 而且, 那些超越了直接模仿的转义 ${ }^{1}$ 都无疑成了宝贵的视觉创造经 验，应该在特定的美术史上浓重地记上一笔。不过，至少在目前的 中国学界，对于中美艺术交互影响的研究却似乎才刚刚开始而已。

一方面，美国艺术家受到过中国文化和艺术的影响，虽然已是 一种不言而喻的事实，但是，对于这种影响的具体研究却少有展开， 即使有人涉及到，也大抵停留在一般史料的梳理上。然而，艺术的 交互影响的关键尤在于在转义和创造性的成就方面，因为只有在这 样的层面上才能更加清晰地了解到交互影响的实质性意义。

另一方面，有关中国艺术（尤其是当代中国艺术）所曾受到的 美国艺术的影响, 恐怕就研究得更为粗略。人们似乎习惯地认为只 有历史更为悠久的艺术才能对别的艺术产生明显的影响，而不是相 反。恰好中国的历史（包括艺术的历史）远比美国的历史要悠久得 多，因而，这种只看影响的单向效应的习惯就变得格外强大了。

当然，正如有的学者所指出的那样，美国的亚裔艺术家（甚至 连野口勇在内）也要么曾被主流社会忽略, 要么就是像曾景文那样 被人强加了一种属于成见范畴的 “中间性” (in-between-ness) ${ }^{2}$, 从 而也使得影响的研究思路多少有点程式化和简单化了。可是, 如果 对于影响研究有所忽视或无以深入，那么，对于涉及到的相关艺术 家的认识就相应地会有相应的偏差。其实，在这一领域里的影响有 时并非局部的、技巧的，而恰恰可能是普遍的、观念的，几乎实一

1 有关 “转义” 的具体含义，请参阅拙译诺曼 - 布列逊《传统与欲望一 从大卫到德拉克罗瓦》，浙江摄影出版社，2003 年。

2 See Dore Ashton, Noguchi: East and West (Berkeley: University of California Press, I992), I6; and Gordon H. Chang, "Emerging from the Shadow: The Visual Arts and Asian American History," Journal of Transnational American Studies I, no. I (2009). 
种不可忽略的界面。特别要指出的是，美国艺术对中国当代艺术的 影响在特定时期里似乎不纯粹是一种个别艺术家对于个别艺术家的 直接关联，而是一种波及面更为巨大、影响力更为长久的过程。甚 至一批有才华的中国艺术家从技巧、风格以及观念等方面获得了启 示，创作出了大量的具有深刻历史和艺术价值的作品，并被突出地 写入了当代的中国美术史，成为一个时代的重要的视觉文化记录。 毫无疑问，对于这方面的研究，尚有巨大的开掘空间。

本文通过中美艺术相互影响的一些个案，试图描述和概括其形 成的艺术实绩的若干特点。

\section{二}

美术史上曾经有过那种相对比较直接的借用, 譬如, 波提切利的《毁 谤》可能是对古希腊的画家阿佩莱斯的同名画作的直接呼应, 不过, 由于后者的作品不复存世，人们已无以知道两件作品之间的异同程 度。无疑，艺术的跨文化间的影响会呈现为更为丰富复杂的面貌。 这里，先来谈一谈中国艺术对美国艺术的影响。在这里，马克·托 贝与滕白也的交往所产生的结果堪称转义和创造的一种典型。

一般的美术史在叙述美国画家马克·托贝时，会提到他所受到 的波斯以及远东的绘画与书法的影响，甚至还提到他在日本的禅寺 中学习毛笔的经历。不过，在所有的影响中，最有助于其形成其独 特个人风格的当属中国艺术的影响。因为，一位叫做滕白也（或滕 奎）的中国艺术家不仅仅为马克·托贝教过中国画和书法，而且更 为根本的是，在艺术的观念上深刻地影响了后者。

不幸的是，在中国现代美术史上，滕白也（1900- 1980 年）本 人却是一个被埋没了的人物，或者说，是一个有意无意地被边缘化 了的艺术家。人们在通行的美术史教材中根本找不到对他的应有的 评价。尽管他在版画、中国画、雕塑以及学术研究等方面都有不俗 的记录, 而且, 他还曾经影响了像马克·托贝这样杰出的美国艺术家, 但是，却依然很少有人知道他的真正建树，仅有少量的资料不完整 地提及他和艺术生涯。即使在当今艺术拍卖会上，他的一两件作品 
虽然出自研究者的收藏, 却也被大为冷落, 其价位低估得令人吃惊。3 在中国，可以说，他是一位几乎被遗忘了的艺术家。

滕白也之所以可以影响到马克·托贝，并且令后者终身难忘，细 究起来, 是有原因可寻的。最为重要的是, 马克 - 托贝在当时是不 可能遇上一位可能比滕白也更为理想的艺术伙伴的。

第一, 滕白也酷爱中国的传统艺术, 创作过大量优秀的水墨作 品。同时, 他又有在美国的大学学习艺术的经历，从华盛顿大学获 得过艺术硕士学位, 在哈佛大学燕京学社做过专门的研究, 因而, 既有英语的表述能力，也能在结合有关西方艺术知识的基础上将中 国艺术的精粹举重若轻地凸示出来。这方面的能力有其发表的英文 论文为证。 ${ }^{4}$ 芝加哥大学的文艺复兴协会 (The Renaissance Society at the University of Chicago）曾经邀请滕白也于 I930 年 II 月 I2 日 （周三） I2 点始在该协会中就艺术家自己创作和展览的作品（主要 是指墨画）发表专门演讲。 ${ }^{5}$ 与此同时，从 1927 年到 1928 年，已经 从华盛顿大学获得了艺术硕士学位 (MFA) 的滕白也曾经留校任教, 他算是在欧美大学中任教的第一位中国艺术家。6

第二，滕白也本人殊非平庸的艺术家，相反，在同代艺术家中 成就卓越, 引人瞩目, 是西方现代美术研究文献中仅有的被人提及 的两三个中国艺术家中的一个。譬如，他有幸被美国的文艺复兴协 会选中举办过个人展，其被接受和重视的程度就非同一般。因为， 位于美国芝加哥大学内的文艺复兴协会创立于 1915 年，其实并不 是通常意义上的学术团体, 而是一个举足轻重的艺术博物馆, 虽然

3 参见上海鸿生 2009 春季大型艺术品拍卖会公布的价格 : http:// pm.findart.com.cn/350226-pm.html。

4 Teng Kwei, Art in Modern China, The Open Court, Chicago: December, I933; 收入包铭新、王瑞华《画坛遗珠一一滕白也研究》, 东 华大学出版社, 2008 年, 第 73-104 页。

5 See http://www.renaissancesociety.org/site/Exhibitions/Works.267.html.

6 参见郑逸梅，《艺坛百影》，中州书画社，1982 年; David Clarke, “Teng Baiye and Mark Tobey: Interactions between Chinese and American Art in Shanghai and Seattle," Pacific Northwest Quarterly 93 (Fall 2002): I7I-79. 
它本身并不收藏作品，但是，该博物馆对现当代艺术的推进之功有 目共睹，是美国专门倡导现当代艺术的博物馆中历史最为悠久的一 个场所，也成为现当代艺术最为牢靠的后盾之一。此馆曾经在著名 女艺术家伊娃·沃森 - 舒兹（Eva Watson-Schütze）的主导下，举 办过有勃拉克 (Braque), 阿尔普 (Arp), 布朗库西（Brancusi）, 米罗（Miró）和毕加索（Picasso）参与的现代主义展览，而历史 上在该博物馆中举办过个人展的, 也不乏非同凡响的艺术家，如亨 利 · 马蒂斯（Henri Matisse, 1930)、亚历山大 · 考尔德 (Alexander Calder, 1934)、费尔南·莱热（Fernand Léger, 1936)、拉斯洛· 莫霍利 - 纳吉 (László Moholy-Nagy, 1939)、约翰·斯隆 (John Sloan,1942)、凯绥·柯勒惠支 (Käthe Kollwitz, 1946)、保罗·克 利 (Paul Klee, 1946)、密斯· 凡德罗 (Mies van der Rohe, 1947)、 迭戈·里维拉 (Diego Rivera, I949)、乔斯 - 克莱门特 - 奥罗斯科 (Jose Clemente Orozco, 195I)、马克·夏加尔 (Marc Chagall, 1958)、雷内·马格立特 (Réné Magritte, 1964)、亨利·摩尔 (Henry Moore, 1967）……在 1930 年之前，滕白也在华盛顿、纽约和旧 金山等地都曾举办过展览。譬如，1928 年在华盛顿大学亨利美术 馆 (Henry Art Gallery Washington University) 和旧金山的东西 美术馆（East West Fine Art Gallery, San Francisco）的展览。 ${ }^{7}$ 不 过，最为值得一提的还是在芝加哥大学的文艺复兴协会举办的个 人画展。经由美国当时最孚盛名的汉学家、人类学家、东方学家、 语言学家、芝加哥菲尔德博物馆人类学部的贝托尔德 · 劳费尔博士 （Dr. Berthold Laufer， I874-1934）的介绍，文艺复兴协会以及中 国的美国友人会于 1930 年 II 月 I 日至 IO 日主办了滕白也的个人画 展 (Exhibition of the Paintings of Teng Kwei)。 ${ }^{8}$ 众所周知，劳费

7 See Clarke, "Teng Baiye and Mark Tobey," I7I.

8 Works displayed : Russian General, Landscape, Three Ducks, Lotos, Dragon Head, The Ball, Chinese Scholar, Crane, Figure Striding, Vine, Two Black Birds, Winter Evening, The Family (chickens), Contemplating Nature, The Judge (owl), After The Rain, Young Ducks, Peacock, Bamboo, Willow In Wind, and Willows. See http://www. renaissancesociety.org/site/Exhibitions/Works.267.html. 
尔博士学识淹博, 学术著述丰富, 是一位地位非凡的知名学者。滕 白也得到他的青睐，实在是难得之至。两人的交往，如果加以深究， 也一定会有值得关注的原因，只是目前尚无更多的第一手资料可供 参考和佐证。与此同时，在滕白也的画展过程中，还相应地安排了 从芝加哥艺术学院租借的中国古代艺术品以及文艺复兴协会成员的 作品展览。时任中华民国驻美芝加哥总领事叶可梁（Koliang Yih） 博士和劳费尔博士均被列为画展的嘉宾, 同时, 劳费尔博士还在画 展开幕之际举办以滕白也画展为主题的讲座，没有知音般的了解， 这是不可想象的事情。9

据现有并不完整的资料，滕白也参加过的重要展览有：布鲁 克林博物馆于 I 929 年 6 月 I 日至 IO 月 I 日举办的 “美国与国外 艺术家绘画、雕塑和素描联展” (Group Exhibition of Paintings, Sculpture and Drawings by American and Foreign Artists) ; 他的 版画作品《山景》参加过 1930 年 I2 月 4 日至 I93I 年 I 月 25 日在 芝加哥艺术学院举办的第二届平版画和木刻国际展 (The Second International Exhibition of Lithography and Wood Carving), 是 参展中仅有的两位中国艺术家中的一位。

他的平版画《雨中扬子》现藏于美国克利夫兰艺术博物馆（检 索专号：1941.528)。

雕塑是滕白也的本行，尽管我们再难看到其原作，但是，已经 有学人指出, 1935 年, 在南京举办的孙中山塑像创作竞赛中, 滕白 也曾在众多的对手中（包括李金发、江小鹣、王临乙、郎鲁蒜、刘 开渠、梁竹亭等）脱颖而出, 名列第一。由于这次竞赛吸引了当时 中国国内几乎所有重要的雕塑家, 算是民国时期雕塑水平的一次集 体亮相。滕白也能在这次竞赛中力拔头筹, 是其雕塑实力与水平的 一种证明。据说，他的雕塑在首都南京和上海一度到处可见 ......10

不能不惊讶的是，滕白也的才华甚至延伸到了设计的领域。他 的室内设计绝对不俗。1931 年, 为匹兹堡大学的寻道圣堂设计的国 际教室一一中国教室，便是滕白也的手笔，至今，仍是这类设计中

9 See "Renaissance Society Sponsors Unique Chinese Exhibition," The Hyde Park Herald XIX, 3I October 1930, 4. 
的尧楚。

第三，从 1923 年马克 · 托贝认识滕白也开始，一直到 1938 年滕 白也驰函马克 ·托贝，两人之间十多年的交往已经并非一般的朋友 应酬往来。 1923 年，马克·托贝在华盛顿州西雅图遇上滕白也，从 此迷上了对其自身绘画风格影响深远的中国书画。到了 1934 年，马 克 - 托贝从意大利那不勒斯乘船到访香港和上海。在上海，马克 · 托贝与滕白也曾一起住在当时法租界的家中，并且进一步学习中国 艺术。到了 1938 年，中国处在日本侵华战争期间，滕白也本人已 经停止画笔，投身抗战，参与桂林难民营的生产自救运动。从仅存 的一封给马克·托贝的信中，人们可以感觉到字里行间的语气绝非 一般的朋友之间的寒暄。11

事实上，马克·托贝就是从 1935 年开始他的所谓 “白色书写” 的, 也就是别出心裁地将白色的线条画满整个画面。正是在那个时候, 马克·托贝发现了传统的东方水墨中的线条的妙谛，觉得借助 “书 法的影响摆脱了形体的束缚”。12 那么，在这种影响中，马克·托贝 是如何通过转义获得自己独有的视觉印记呢?

A. 全满的构图。在传统的中国画中很少有这样的画法，往往会 强调留白，增加观者的想象余地。而且，在马克·托贝笔下，这种 全满的画法没有给画面一种通常会有的图 - 底关系，没有视觉的焦 点或重点, 只有一种可以游走而且永难停顿和重复的视线的自由性。 值得强调的是，尽管抽象绘画中全满的构图往往和波洛克联系在一 起，但是，事实上，马克·托贝在 1944 年，也就是说，比波洛克 早两年就向世人展示了没有构图中心的画面，而且这种全满的画面 还与东方的线条融合在一起。

B. 线条高于实体。滕白也不止一次地在他的演讲和论文中强调 中国艺术中线条的表现性，而马克·托贝则将这一点强调到了另一 种独特的极致，即完全不见实体的线条集合。就如马克·托贝所 说的那样 : “我刚刚在我的艺术家朋友滕奎那儿上了第一次有关中 国毛笔的课。树木就不再是大地上的实体，而分化成大地上更虚的

11 滕奎 1938 年 7 月 10 日从汉口致信马克 ·托贝。此信由美国的 Wesley Wehr 收藏，其中文译文可见于台北《雄狮美术》I99I 年第 II 期。 12 See W. Seitz, Mark Tobey (exh. cat.) (New York, I962), 50-5I. 
对象, 分解为沐浴在明暗之中更虚的事物了。在这里既有压力, 亦 有释放。每一种动态就如雪中留痕都被留存, 同时又常常自善其身 ……智性与精神元气充足。现在，一切均在动势之中 $\cdots \cdots .$. 向过去的 方向退后一步，我在西雅图画室前的树就全然是节律、升扬和腾跃 了。” ${ }^{13}$ 按照对自然的这种观感，形式被非物质化了，成了 “气” 的 构成, 即一种非恒定的宇宙能量的流动。法国的《世界报》在报道 马克 - 托贝去世的消息时特别提到，因为滕白也的指导，艺术家获 得了对远东艺术的理解，而作品也因之有了全新的格局。14 可以说， “白色书写” 风格——托贝所谓的 “书写冲动” 的特征就在于深色 背景上白色线条的图式化构成，极为自然地把画家的理性一一普遍 性思维一一带到了一种更为自由的境地。

C. 线条的连续变化。在线条的运用上，马克 - 托贝在显现出一 以贯之的执着的同时，也没有停止过对线条无穷尽的微妙变化的追 求。所以, 在其最早的白色书写构图中所传达出来的自由和力度在 像《历史的前进》这一完成于约 30 年之后的后期作品中依然显而 易见。可以这么说，在早期的《百老汇的标准》中的疯狂的线条冲 动已经变成了更为微妙而有复杂的线条网络, 其宽度、密度以及色 彩均显得千变万化了。

以上这些特征使得马克 - 托贝的作品在吸取东方的影响时，既 不同于传统中国艺术中的任何线条，也不同于他的老师滕白也的作 品，后者显然更愿意沉浸在中国传统的艺术滋养中。

尽管马克 - 托贝和滕白也的作品是谁也不像谁, 另一个令人好 奇的问题是, 作为杰出的艺术家, 滕白也从年长于自己十岁的马克 - 托贝那儿得到了相应的影响吗? 毫无疑问, 滕白也是善于吸取西方 艺术的, 他学习雕塑的经历就是一个很好的证明。但是, 他是不是 因为了解了西方艺术从而才更为坚定地认可了中国传统艺术了呢? 说实话，原始资料的匮乏，让我们对这一问题的回答显得有点力不 从心了。

13 Mark Tobey, "Reminiscence and Reverie," Magazine of Art 44 (October I95I): 230; as quoted in W.C. Seitz, Abstract Expressionist Painting in America (Cambridge: Harvard University Press, 1983), 66. 
不过，从马克 - 托贝与滕白也的交往经历看，也有助于我们理解 另一位美国艺术家野口勇 (Isamu Noguchi) 在接受中国艺术影响方 面的特殊性。根据研究文献，1930 年野口勇为什么以及如何来到中 国北京，他本人似乎总是语焉不详，成了人们心中的一个谜。更为 费解的是，他在北京生活优渥，雇有厨师、男仆和黄包车夫，甚至 还结识了张学良将军及其部下。至于在艺术方面，他在北京逗留的 8 个月， 28 年之后（1958 年）在回忆时他依然是津津乐道的，尤其 会提到是这两件事儿：一是天坛对他的震撼。他将这座建筑看作是 “古代中国人世界观的宣言，即认为大地是在一种环状轨迹中运行 的宇宙里的巨大方形。巨大的大理石方形上有圆形的平台通往一个 最终开放的平台，天坛本身就设于其上。这些方圆形在野口勇云游 四方的生涯里变成了早期许许多多的石头平台了，其象征性镌刻在 他的视觉记忆中，而最终是体现在他自己的平台创意上。方圆图形 对于野口勇刚刚离开的巴黎的现代主义运动具有特殊的审美价值, 如今却在其最为古老的辉煌中历历在目”。 ${ }^{15}$; 二是野口勇亲从中国 的著名画家，七十高龄的齐白石学习花鸟画。尽管不过初学者的水 平而已，他却异乎寻常地敏感于东方艺术中的时间因素，而与空间 因素对立的时间因素的确也是其走向抽象艺术的有效途径。 ${ }^{16}$ 应该 说，中国的影响在野口勇身上是实实在在地发生过的，但是，这些 影响在艺术家后来的作品中并不是直接的借用，而是几乎无迹可求 式的转义, 正好证明了艺术家善于吸取、提炼和转化的高超水平。

同样, 菲里普 - 库斯顿 (Philip Guston) 也是颇为独特的例子。 他对中国宋代绘画的精辟见地，令人情不自禁地猜测是来自于他的 亲眼目睹的经验与体会，而如果不是来自于他的亲眼目睹的经验与 体会，那就一定是另有高人指点了，否则，一个美国艺术家对宋画 有如此的见地简直是难以想象的事情 :

我认为, 在研究和反思以往的艺术时，我最伟大的理想就是中 国画，特别是约从 IO 世纪或 II 世纪开始的宋代绘画。宋代的 练笔是数千次地描绘某一东西一一譬如竹叶和鸟儿一一直到变

15 Ashton, Noguchi, 29.

16 See ibid., 28-30, 37, 60, 98, and 234. 
成是别的人而非你自己在画，直到有一种气韵贯彻于你的全身。 我想，这就是禅宗所谓的 satori（开悟），而我感受到了这一点。 这是双重的所为，此时你似懂非懂。17

可以说，他的觉悟甚至超过了像欧内斯特 - 芬诺洛萨（Ernest Fenollosa）那样的专家。芬诺洛萨对宋代艺术倒是倍加赞赏, 但是 却会看走了眼, 常常把明代的东西看成了宋代的东西。 ${ }^{18}$ 因而，菲 里普 - 库斯顿对于中国画的精辟观感实在是一个迷人的谜。但是, 更为重要的是，不管怎么样，对于菲里普 - 库斯顿而言, 他与其 是在直接吸收中国文化的滋养 (包括李白的诗歌 ${ }^{19}$ ), 还不如说是心 领神会之后的自由发挥。或许，这也正是他的抽象表现主义令人感 兴趣的一个潜在原因?

\section{三}

再来谈一谈美国艺术对中国艺术家的影响。在这里，没有比怀斯的 艺术更有说服力的例子了。

2009 年 $\mathrm{I}$ 月 $3 \mathrm{I}$ 日, 中国新春大年初六。国内唯一的美术周刊《美 术报》却破例报道了安德鲁 · 怀斯于 I 月 16 日与世长辞的消息, 因为 “他的作品可以说影响了我们上个世纪七八十年代乃至今天的 中国。” 20 画家杨飞云动情地说: “我估计中国很多画家对于怀斯的去 世很可能比西方艺术界对怀斯的去世还要伤感。” 21

的确，怀斯的艺术与中国文革后的艺术构成了密不可分的关联。 他在 1980 年对中国当代艺术的影响堪称一股“怀斯风”。

追究起来, 最为重要的原因是, 1976 年文革结束后, 艺术中不

17 See Dore Ashton, A Critical Study of Philip Guston (Berkeley: University of California Press, 1976), I85-86.

18 See Warren Cohen, East Asian Art and American Culture: A Study in International Relations (New York: Columbia University

Press, 1992), chap. 6.

19 See Ashton, A Critical Study of Philip Guston, I24.

20 《安德鲁 · 怀斯去世》, 《美术报》, 2009 年 I 月 3 I 日，第 4 版。

21 参见 http://art.china.cn/zixun/2009-oI/23/content_27030I7.htm。 
可抑制地浮现出一种伤感的现实主义倾向, 成为所谓的 “伤痕美术” 的一部分。它的最为温暖的部分就是一种向具有人道主义关怀的写 实精神的勇敢转换。不过，由于令人压抑的文革刚刚结束不久，艺 术中的批判倾向还只能是委婉的、间接的和温和的。当中国的艺 术家接触到安德鲁 - 怀斯的作品时，他们的心中就涌起一种强烈的 共鸣。因为，安德鲁 - 怀斯的冷峻而又伤感的情调，以及笔下的人 物与场景, 都似乎是中国艺术家心中的一种样板，尤其是其完成于 I948 年的作品《克里斯蒂娜的世界》更使得中国艺术家为之迷恋, 内中的孤独、感伤和希冀对于习惯了文革中虚假激情的中国艺术家 而言, 不仅更真实、更动人, 而且也具有在艺术上与 “红”、“光” “亮” 模式进行反叛的划时代意味。

最为突出的是当时依然是艺术学院学生的何多苓用 3 个月时间 创作的油画《春风已经䎠醒》（I98I 年），它既是体现艺术家风格的 处女作，也毫无愧色地成为文革后中国油画历史上的标志性作品。 显然，这是怀斯式的世界：一个衣着破旧的小女孩, 坐在初春长满 枯草的河滩上, 迷茫而又深情的目光遥望着远方, 春天的微风吹动 了她的黑发。同时，也有怀斯式的凄美而又充满希望的深刻寓意 : 严冬已经过去，新的生活正在走来，就像春风吹拂过荒原之后将是 绿色履盖的原野……何多荃在多处场合谈到怀斯对他的影响。他很 喜欢这位伤感的现实主义者，喜欢其严峻的思索，认为他画中那孤 独的地平线令人神往。怀斯笔下偏远的农场、荒草、孤独的人等令 年轻的何多苓为之感动不已，因为其中的那种孤寂的情调和艺术家 在 “上山下乡” 期间的感受是相似乃尔，因而一见如故，相见恨晚。 $200 \mathrm{I}$ 年 II 月 17 日，何多苓在上海接受记者采访时说：“《春风已经 䙵醒》是我的研究生毕业创作。老师……不是很赞成, 我是背着他 画的。因为画面没有情节、没有故事……我跑到成都, 躲着画。我 学的是怀斯的画法, 草都一根一根画出来, 这就背离了传统的写实 技法。据说学校给打了个不及格。后来我拿去参加北京的一个展览， 也落选了, 说是因为画面的情绪比较灰暗, 女孩子的表情比较忧郁 …… 可是，很快《春风已经生醒》在《美术》杂志 I98I 年 I2 月 
号的封面上得以发表并入选翌年的法国春季沙龙展。 ${ }^{22}$ 何多苓觉得, “我的画跟着《春风已经甦醒》而甦醒”，创作了《青春》、连环画 《雪雁》和《带阁楼的房子》等更为抒情的作品。 ${ }^{23}$ 在某种意义上说, 没有怀斯，也就没有当时的何多苓。

I985 年，何多苓访问美国，有一位观众看了其画展之后，向他 推荐了罗宾 - 杰弗斯（Robinson Jeffers）的诗集，而其中的配图则 正是温斯顿和亚当斯拍摄的荒凉、寂寞的场景, 这再次让何多苓对 怀斯的画有了新的体会, 甚至认为 “最好的油画家的话仍然是外国 的，我认为中国到目前为止还没有真正的大师，一个也没有。” 24 在 这里，何多苓再次向怀斯致以了最高的敬意。1997 年，在为自己 的画册《中国当代艺术选集（4）何多苓》写序时，画家意味深长 地说：“我的画面几乎不会出现（或保留住）一个以上的形体”。 25 这是多么怀斯式的画面啊!不过，正是在 1985 年，当何多苓有机会 在纽约的现代艺术博物馆中见到怀斯的《克里斯蒂娜的世界》时, 画家才感受到了自己与怀斯的差异所在，如他所说，“我发现《春 风已经廹醒》和它毫无共同之处。”26

不仅仅是何多苓在怀斯的影响下走向了艺术上的成功与成熟， 而且像艾轩、王沂东这样的画家也深深地迷恋于怀斯，通过画面表 达他们独有的 “诗意的忧伤”, 让普通中国人的形象显得高贵而又 有尊严。他们均在中国当代美术史上留下了杰作。以画西藏人物著 称的画家艾轩是 $198 \mathrm{I}$ 年才从陈逸飞那里听说安德鲁·怀斯的。后来, 他有机会拜访了怀斯本人，获得两本题赠的画册。 ${ }^{27}$ 他感到，在描 绘人的情绪方面，怀斯和他们那批画家有很多相似之处、共通的

221982 年，此画被中国美术馆收藏 ; 1986 年，此作品参加在日本福冈美 术馆举办的 “第二届亚洲美展” 以及其它重要的国内外展览。

23 惠蓝, 《中国油画中的写实主义一一靳尚谊、何多苓、艾轩、徐芒耀访谈录》, 《美术观察》, 2002 年第 2 期。

24 周文翰, 《何多苓: 我属于 “误读的一代》, 《新京报》, 2006 年 I 月 3 日。 25 《中国当代艺术选集 (4) 何多苓》自序, 高雄市山美术馆, 1997 年, 第 7 页。 26 钟鸣《何多苓绘画风格与伦理的形成》, 同上，第 I6 页。

27 艾轩《安德鲁 - 怀斯对我说》, 参见 http://art.china.cn/mjda/2009- 
东西, 可以在他的画面里感觉到自己想要说的话。1980 年代初期, 年轻的艾轩创作了引人注目的《牧童》《沼泽地上的晨雾》等作品。 接着，他又把怀斯式的忧伤与自己笔下的西藏题材结合起来，着意 传达出一种令人回味的诗意, 如《若尔盖的季节风》、《栏》《《也许 天还那么蓝》和《冷雨》等。2008 年, 王沂东访问纽约, 他特地 前往宾州去朝拜怀斯的故乡切斯福德 (Chadds Ford), 到那里的 博物馆观看大师的作品。确实, 在王沂东的作品中, 与怀斯依稀相 类似的情调和场景可谓比比皆是。

怀斯的意义不仅在于其绘画的技艺，而且还在于其绘画的思想 态度，他让人意识到了关注人的内心的重要性以及表达超越现实世 界的心灵追求的魅力。可以说，怀斯曾经给了中国一代艺术家如何 看世界与人生的方式。他的独特意义确实是再强调也不为过的。

\section{四}

在我们这一时代, 艺术上的转义和建树越来越成为普遍的事实, 它 意味着艺术之间的参照已经变得更加全球化了。中美艺术家之间 的交互影响的个案不过是其中的沧海一粟而已。老子已经告诉我 们: “知人者智, 自知者明。” (《老子》第三十三章) 也就是说, 所谓的 “智” 与 “明” 的结合—— “明智” ——理应包含 “知人” 和 “自知”这两个方面，缺一不可。

印度的伟大诗人泰戈尔也曾经这样说过：“我们必须为世界的所 有文化合作准备场地，在这场地上所有的人都将文化传授给别人， 又从别人那里汲取文化。这是即将到来的时代的基调。” 28 诚哉斯言!

28 Paul J. Braisted, Cultural Cooperation: Keynote of the Coming Age (New Haven: The Edward W. Hazen Foundation, 1945), 5. 


\section{Artistic Tropes: Some Cases of Mutual Chinese-American Influence}

Ding Ning

Knowledge studies others, while wisdom is self-known.

- Laozi $^{\mathrm{I}}$

1

That both Chinese and American artists benefit from each other's cultural and artistic production is a fact obvious to all, and no doubt those tropes which go beyond direct imitations have become a valuable stimulus for artistic creation which should be recognized in any art historical analysis of the works influenced by such tropes. However, at least in current Chinese academic circles, study of the interactive influence between Chinese and American art seems to have just begun.

On the one hand, although some American artists were indeed inspired by Chinese culture and art, very little in-depth research has been done concerning this specific influence, and even if it is touched upon, historical data has been compiled but no further reflection or analysis has followed. The key to the mutual influence lies in tropes and creative achievements, and only on that level can one much more clearly realize its innermost significance.

In addition, how American art has influenced Chinese art, and in particular how American art has influenced contemporary Chinese art, has been given very little attention by art historians. One seems to be more accustomed to believe that only the art with the longer history could produce an essential impact on the other younger art and not vice versa. The history of China (including the history of Chinese art) happens to be much longer than that of America, thus the inclination to observe only a one-way influence becomes particularly powerful.

As some scholars have noted, Asian American artists, including Isamu Noguchi, were either marginalized by the dominant society or, like Dong Kingman, felt an imposed stereotype of in-between-ness, which also simplifies the way influence is studied. ${ }^{2}$ If studies of this kind remain superficial and are not properly

I Witter Bynner, The Way of Life: According to Laotzu, An American Version (New York: Capricorn Books, 1962), 46. An expanded version of this essay was published by Smithsonian Research Online in East-West Interchanges in American Art: A Long and Tumultuous Relationship, edited by Cynthia Mills et al. (Washington, DC: Smithsonian Institution Scholarly Press, 2012).

2 See Dore Ashton, Noguchi: East and West (Berkeley: University of California Press, I992), I6; and Gordon H. Chang, "Emerging from the Shadow: The

$400 \quad$ Visual Arts and Asian American History," Journal of Transnational American 


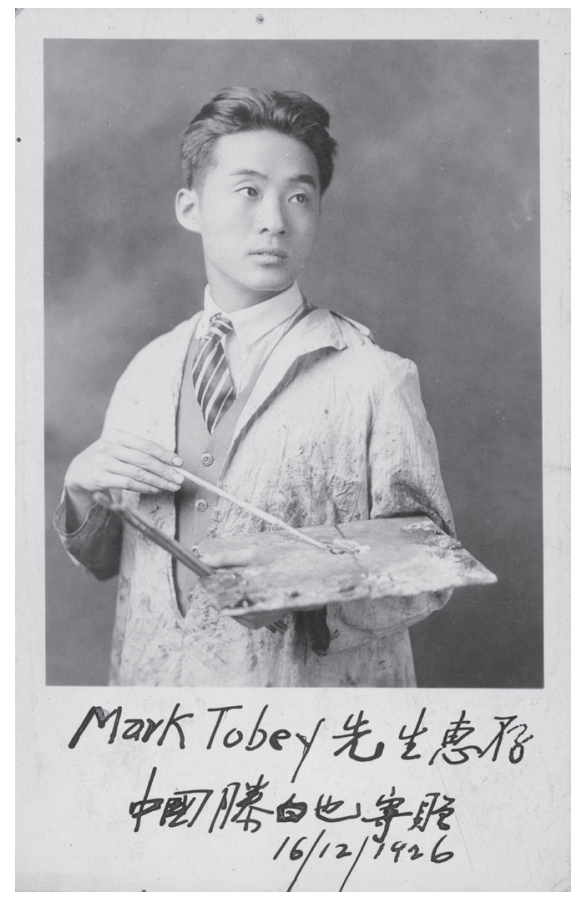

Fig. I. Portrait of Teng Kuei with dedication to Mark Tobey, 1926. University of Washington Libraries, Special Collections, neg. UW $23723 z$.

evaluated, one's understanding of certain artists will remain, accordingly, somewhat biased. Moreover, the influence involved in this area is not always partial and technical, but rather general and conceptual, so it cannot be overlooked in any sense. It is particularly important to see that within certain periods of time the influence of American art on contemporary Chinese art does not seem to have been purely an individual connection between an American artist and a Chinese counterpart, but rather to have been a far more profound and lasting process. Even a group of quite talented Chinese artists have been inspired greatly in terms of technique, style, and concept by American art. They created a large number of works with unique historical and artistic value that have become an important part of the history of contemporary Chinese art, and became a unique record of visual culture for an entire era. Studies of this topic still leave much to be explored.

In this chapter, some cases concerning the mutual influence of Chinese and American art are discussed in order that its characteristics may be described and summarized.

It is well-known that there have been relatively straightforward imitations in the history of art. For instance, Botticelli's Calumny (I494-95) was perhaps the loyal echo to the original of the same title by the ancient Greek painter, Apelles. But since the original has not survived, one cannot specify the differences between these two pieces.

No doubt, tracing artistic influence across cultures presents us with a much richer and more complex perspective. In dealing with the influence of Chinese art upon American art, the outcome of the communication and friendship between Teng Baiye and Mark Tobey can serve as a typical example (Fig. I).

Typically, art historical analyses of the American painter Mark Tobey mention that he was influenced by Persian and Far Eastern drawing and calligraphy, and that he went to Japan to study brushwork in a Zen monastery. However, among all the influences that Tobey received, the most conducive to the forma- 
tion of his own unique artistic style was undoubtedly the impact of Chinese art. The Chinese artist Teng Baiye (also called T’eng Kwei, Teng Kuei, or Kwei Dun) not only taught Chinese painting and calligraphy to Mark Tobey, but also, even more fundamentally, influenced the latter in terms of artistic concepts.

Unfortunately, in the history of modern Chinese art, Teng Baiye (1900-80) himself has occupied no place at all, as one cannot find his name and works in any available survey or art history textbooks, let alone finding him accorded the acclaim he deserves. Although a prolific artist in areas like print-making, Chinese painting, sculpture, and academic publications, and influential on important artists like Mark Tobey, few scholars today understand his real contribution to both Chinese and American art history, and only occasionally and rather briefly has his artistic career been dealt with. Sadly, even in today's art auctions, a few of his works from a scholar's collection have also been overlooked, and their value has been surprisingly underestimated. At least in China, it can be said, Teng Baiye is an almost forgotten artist.

We could ask, how could Teng Baiye have influenced Mark Tobey to such a degree that Tobey could not forget that influence during his lifetime? If examined very carefully, there are quite a few reasons we could list. Above all, Mark Tobey could not have been able to encounter a more ideal artistic partner than Teng Baiye.

Teng Baiye had studied Western art, but preferred traditional Chinese art and created a large number of excellent water-and-ink works and in particular some finger-paintings. He was well-versed in English, which was somewhat rare among Chinese artists and students, as he had studied and obtained an MFA degree at the University of Washington and had conducted a special project at Yenching Institute, Harvard University, with the recommendation of John Leighton Stuart, President of Yenching University, Beijing. So, presumably, he could feel at ease introducing Mark Tobey to the very essence of traditional Chinese art in contrast to Western art with which he was also quite familiar. His knowledge of Chinese art and his straight-to-the-point ideas concerning both Chinese and western art were further demonstrated in his English publications and lectures. ${ }^{3}$ The Renaissance Society at the University of Chicago once invited Teng to give a lecture on his own works, mainly finger-painting in water-andink, displayed at the Society. ${ }^{4}$ From 1927 to 1928, Teng taught at his Alma Mater, University of Washington, after receiving his masters degree, and very possibly he was the first Chinese artist to teach in an American or European higher educational institution. ${ }^{5}$

3 Teng Kwei, "Art in Modern China, The Open Court, Chicago: December, 1933," in Bao Mingxin and Wang Ruihua, The Lost Pearl in Painting Arena: Teng Baiye Studies [Huatan Yizhu: Tengbaiye Yanjiu] (Donghua University Press, 2008), 73-I04.

4 See https://renaissancesociety.org/publishing/5ri/paintings-by-teng-kwei-withchinese-antiques-paintings-and-mortuary-statuary-works-in-exhibition/.

4025 See Zheng Yimei, A Hundred Images of the Art Arena [Yi tan bai ying] (Zheng- 
Teng himself was among only a few modern Chinese artists who were highly acclaimed in the West. As already mentioned above, Teng was selected to hold a one -person show at the Renaissance Society at the University of Chicago, and obviously the extent to which he was accepted and appreciated was unusual. The Renaissance Society at the University of Chicago was founded in 1915, and was not an ordinary academic association. Instead, for decades, it has been a quite important museum which, while not collecting art, has made an extraordinary contribution to contemporary art. As one of the oldest American museums devoted exclusively to contemporary art, the Society has witnessed the finest of avant-garde art both from the United States and the rest of the world. Directed by the artist Eva Watson-Schütze, it held an influential exhibition in 1934, in which George Braque, Jean Arp, Constantin Brancusi, Joan Miró, and Pablo Picasso participated. Solo shows there featured the work of such artists as Henri Matisse (1930), Alexander Calder (1934), Fernand Léger (1936), László Moholy-Nagy (1939), John Sloan (1942), Käthe Kollwitz and Paul Klee (1946), Mies van der Rohe (1947), Diego Rivera (I949), José Clemente Orozco (I95I), Marc Chagall (1958), René Magritte (1964), and Henry Moore (1967). Furthermore, before 1930 Teng had held solo shows in Henry Art Gallery Washington University, New York (1928) and East West Fine Art Gallery, San Francisco. ${ }^{6}$

Teng's most important solo show was the one held at the Renaissance Society. It was Dr. Berthold Laufer who introduced Teng. As one of the most influential American sinologists, anthropologists, and linguists, Laufer was curator of Asiatic Ethnology and Anthropology at the Field Museum of Natural History, Chicago. From November I to II, 1930, the exhibition of the paintings of Teng Baiye was sponsored by the Renaissance Society and the American Friends of China. ${ }^{7}$ How Laufer met Teng Baiye and grew to appreciate his works is surely a very intriguing topic. Besides Teng's paintings, the exhibitions also showed examples of antique Chinese art loaned by the Art institute of Chicago and some members of the Renaissance Society. Presumably, the exhibition was a big event, as the Chinese consul-general Dr. Koliang Yih, Dr. Laufer, and members of the Renaissance Society were among the guests of honor. At the start of the exhibition, Laufer spoke to the public about the works of Mr. Teng Baiye. ${ }^{8}$

zhou: Zhongzhou Calligraphy and Painting Publishing House, 1982,) and David Clarke, "Teng Baiye and Mark Tobey: Interactions between Chinese and American Art in Shanghai and Seattle," Pacific Northwest Quarterly 93 (Fall 2002): 17I.

6 See Clarke, "Teng Baiye and Mark Tobey," I7I.

7 Works displayed: Russian General, Landscape, Three Ducks, Lotos, Dragon Head, The Ball, Chinese Scholar, Crane, Figure Striding, Vine, Two Black Birds, Winter Evening, The Family (chickens), Contemplating Nature, The Judge (owl), After The Rain, Young Ducks, Peacock, Bamboo, Willow In Wind, and Willows. See fn. 4 above.

8 See "Renaissance Society Sponsors Unique Chinese Exhibition," The Hyde Park Herald I9, October 3I, I930, 4. 
According to the available but incomplete data, Teng also participated in the Group Exhibition of Paintings, Sculpture and Drawings by American and Foreign Artists at The Brooklyn Museum (June I, 1929 through October I, I929); his lithograph, Rocky Landscape, was accepted at the Second International Exhibition of Lithography and Wood Carving at the Art Institute of Chicago (December 4, I930 to January 25, 193I). He was one of only two Chinese artists attending the exhibition. His Rain on the Yangtze, another lithograph, is now part of the permanent collection of the Cleveland Museum of Art (listed as by Kwai Teng).

Teng Baiye also produced sculpture, although none of his original works appear to survive. Senior historian and perhaps close friend of Teng, Zheng Yimei recalled that in 1935 there was an art competition for the best portrait sculpture of Sun Yat-sen, and Teng finally came to the fore and was listed the first among many rivals, including Li Jinfa, Jiang Xiaojian, Wang Linyi, Lang Lu Sun, Liu Kaiqu, Liang Zuting, etc. The competition drew nationwide attention and attracted almost all the major Chinese sculptors of the time; therefore, the competition amounted to a collective show of excellent sculptures of the Republican period. That Teng won first prize in such a contest indicates that his achievement in sculpture was fully recognized. It was said that for a while his sculpture could be found in the capital, Nanjing, and Shanghai. ${ }^{9}$

Teng's artistic talent was extremely far-reaching and extended even to the arena of design. In 1931, he designed the Chinese Nationality Room for the famed Nationality Rooms at the Cathedral of Learning within the University of Pittsburgh.

The relationship between Teng Baiye and Mark Tobey was not of the category of ordinary friends. In 1923, the two men met in Seattle. Tobey became fascinated by Chinese painting and calligraphy, which helped the budding artist forge his distinct style. In 1934, after his visit to Naples, Italy, and Hong Kong, Tobey made the trip by boat to see his old friend in Shanghai. Teng and probably Tobey were offered a home stay with this Chinese host in the French Concession, where Mark Tobey continued his studies of Chinese art under the instruction of his long time tutor. By 1938, China was suffering from the Japanese invasion. Teng had stopped painting and was devoting himself to the anti-Japanese war by participating in the refugee industrial movement in the camps of Guilin. One can feel rather touched by the unusual friendship conveyed between the lines of the only surviving letter to Tobey. ${ }^{\text {IO }}$

Only in 1935 did Tobey start his so-called white writing, the innovative network of white lines against a dark background that cover the surface of his work. That happened after his discovery of the traditions of ink brushwork in China and in Japan, where he found himself "freed from form by the influence of

9 See Chen Houcheng, Smile at the Lip of Death: Biography of Li Jinfa (Shanghai: Shanghai Literature and Arts Publishing House, 1996), I50-5I.

Io Teng Kwei's letter addressed to Mark Tobey from Hankou, China, was dated July IO, 1938. It is in Wesley Wehr's private collection, and its Chinese translation 404 is available at Lion Art [Xiongshi Meishu] II (I99I). 


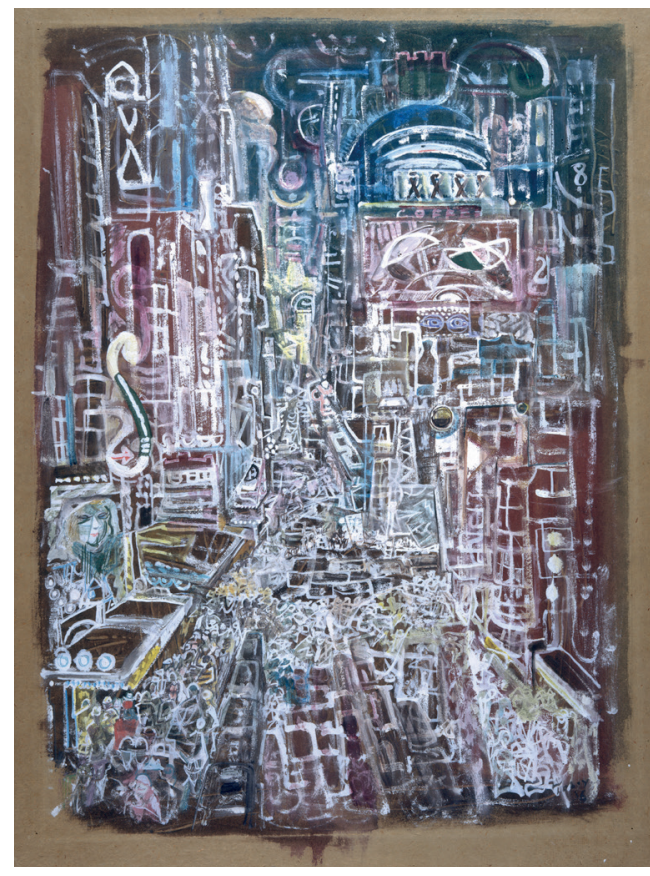

Fig. 2. Mark Tobey, Broadway, 1935-36. The Metropolitan Museum of Art. Image copyright (C) The Metropolitan Museum of Art. Image source: Art Resource, NY (C) 2019 Mark Tobey/Metropolitan Museum of Art, Artists Rights Society (ARS), New York.

the calligraphic impulse I had received in China." "I So, influenced by oriental art, how did Mark Tobey reach his own visual tropes and distinguish himself as an outstanding artist?

The first characteristic is Tobey's allover composition. This is very uncommon in traditional Chinese painting, particularly the Literati Painting, as blank space is emphasized in order to give viewers room for imagination. Tobey rejects a distinct figure-and-ground relationship within this composition, negating a visual focus or pivot but only the freedom of permitting viewers to have a wandering vision which could not easily pause and repeat. It is worth emphasizing that, despite abstract paintings with the all-over composition that are often associated with Jackson Pollock, in fact, as early as the year 1944, that is, two years earlier than Jackson Pollock, Tobey showed the world paintings without any compositional center.

Second, Tobey emphasized line above mass. Teng Baiye emphasized more than once both in his Lectures and papers the expressive quality of line in Chinese art, and Mark Tobey even went further by getting rid of any mass with a certain configuration of lines, thus reinforcing such expressiveness. Just as Mark Tobey experienced,

I have just had my first lesson in Chinese brush from my friend and artist Teng Kwei. The tree is no more solid in the earth, breaking into lesser solids in the earth, breaking into lesser solids bathed in chiaroscuro. There is pressure and release. Each movement, like tracks in the snow, is recorded and often loved for itself. The Great Dragon is breathing sky, thunder and shadow; wisdom and spirit vitalized. All is in motion now... One step backward into the past and the tree in front of my studio in Seattle is all rhythm, lifting, springing upward. ${ }^{22}$

II See W. Seitz, Mark Tobey (exh. cat.) (New York, I962), 50-5I.

I2 Mark Tobey, "Reminiscence and Reverie," Magazine of Art 44 (October 195I): 230; as quoted in W.C. Seitz, Abstract Expressionist Painting in America (Cambridge: Harvard University Press, 1983), 66. 
According to this perception of nature, form is dematerialized and composed of $q i$, the ever-changing currents of cosmic energy. This was particularly noted by Le Monde, when reporting on the death of Mark Tobey, that, owing to Teng Baiye's instruction, he had acquired an insightful perspective on Far Eastern art and reached a completely new pattern in his own work. ${ }^{13}$ Tobey's "white writing" style--what he called the "calligraphic impulse," characterized by schematized compositions of white line against a dark background--guided very naturally the artist's mind (or, more more exactly, his universalist thinking) up to a freer level.

As a corollary, Tobey persistently varied his line. He kept experimenting with lines and tried to pursue any possible subtle variations in them. The spontaneity and vitality conveyed in his early white writing compositions was still evident in his much later works like Advance of History (1964), finished about thirty years later. Arguably, the wild impulses of line in the earlier Broadway (Fig. 2), came to develop into the more delicate and intricate configuration of lines with dazzling widths, densities, directions, and colors.

All these features are more or less related to Asian art, but distinguish sufficiently Mark Tobey's works from any lines applied in traditional Chinese art, and even those of his mentor, Teng Baiye's paintings.

In spite of the similarity of work between Teng Baiye and Mark Tobey, one is still curious to know what influence Teng received from Mark Tobey, himself a promising artist and ten years senior to Teng. There is no doubt that Teng had absorbed Western art as his later achievement in sculpture convincingly proved. However, is it because he learned so much about Western art that made him more firmly endorse the traditional Chinese art? Due to the lack of first-hand data, it is difficult to tackle this truly intriguing question.

Perhaps it is always right for one to see and admire the uniqueness of mutual influences in art. Not only does the case of Tobey and Teng deserve more extensive and penetrating research, but other cases should also be more carefully examined. For example, the American sculptor and designer Isamu Noguchi seemed to have benefited greatly from Chinese art as well as from Japanese art. No one knows why and how Noguchi visited Beijing in 1930. The artist himself was reluctant to dwell on his trip to China, and the whole issue has become somehow mysterious. It is a little difficult to understand why he was so well received in Beijing, and what led to his being able to indulge in such a luxurious life style there. He employed a private cook who could speak French and cook French cuisine, a houseboy, and even a rickshaw boy. Unbelievably, despite being half-Japanese, he became acquainted with General Zhang Xueliang and his men, who hated Japan. As for the arts, Noguchi recalled, 28 years later in 1958, that his eight-month stay in Beijing two unforgettable things happened to him.

The first striking experience for him concerned the magnificent monumental Temple of Heaven (Altar of Heaven), part of an imperial complex in Beijing. According to the scholar Dore Ashton, he deemed this ancient architecture as 
a manifestation of the ancient Chinese worldview, which considered the earth to be an immense square in a universe moving in a circular orbit. The great marble square contains circular terraces leading to a final open terrace, which forms the Altar of Heaven proper. These would be the first of many stone terraces in Noguchi's wandering life whose symbolism engraved itself in his visual memory and emerged, eventually, in his own terrace inventions. The square and the circle-figures that had taken on aesthetic values specific to the modern movement in the Paris Noguchi had just left-were now perceived in their most ancient splendor. ${ }^{14}$

The second important event was his experience learning from the Chinese painting master, Qi Baishi, then seventy years old. It was said that Noguchi concentrated on flower-and-bird painting but at a neophyte's level. However, he sensitively and successfully grasped the temporal sensibility of these works, which helped his own pursuit of abstract art in both his sculpture and design. ${ }^{\mathrm{Is}}$

It should be said that China had an influence on Noguchi, but this kind of influence did not become a direct copy in his later works but instead a fairly indiscernible trope which demonstrated the artist's superb capacity for absorbing and transforming foreign art.

Philip Guston's view of Chinese painting is another fascinating case. As an Abstract Expressionist, Guston offered a pertinent and brilliant analysis of Chinese Song Dynasty painting, which makes one speculate that the artist must have had a long history of viewing the best Chinese paintings, or that there were some cognoscenti guiding him in secret. Otherwise, it is simply too hard to believe that he could have developed such an exquisite taste in Song Dynasty painting:

I think in my studies and brooding about the art of the past my greatest ideal is Chinese painting, especially Sung painting dating from about the Ioth or IIth century. Sung period training involves doing something thousands and thousands of times — bamboo shoots and birds — until someone else does it, not you, and the rhythm moves through you. I think that is what the Zen Buddhists called satori and I have had it happen to me. It is a double activity, when you know and don't know. ${ }^{16}$

To me at least, Philip Guston's response to Song painting is so much more nuanced even than that of experts like Ernest Fenollosa, who admired the art of the Song Dynasty so much; however, he would make huge mistakes by regarding more than once items of the Ming Dynasty as of the Song. ${ }^{17}$ It remains

I4 Ashton, Noguchi, 29.

Is See ibid., 28-30, 37, 60, 98, and 234.

I6 See Dore Ashton, A Critical Study of Philip Guston (Berkeley: University of California Press, 1976), i85-86.

I7 See Warren Cohen, East Asian Art and American Culture: A Study in Internation- 
Fig. 3. Andrew Wyeth, Christina's World, 1948. Museum of Modern Art, NYC. (C) 2019 Andrew Wyeth/Artists Rights Society (ARS), New York.

an intriguing question as to how Guston could have developed so refined and incisive a sensibility for Chinese painting. But, more significantly, no matter how he approached Chinese art,

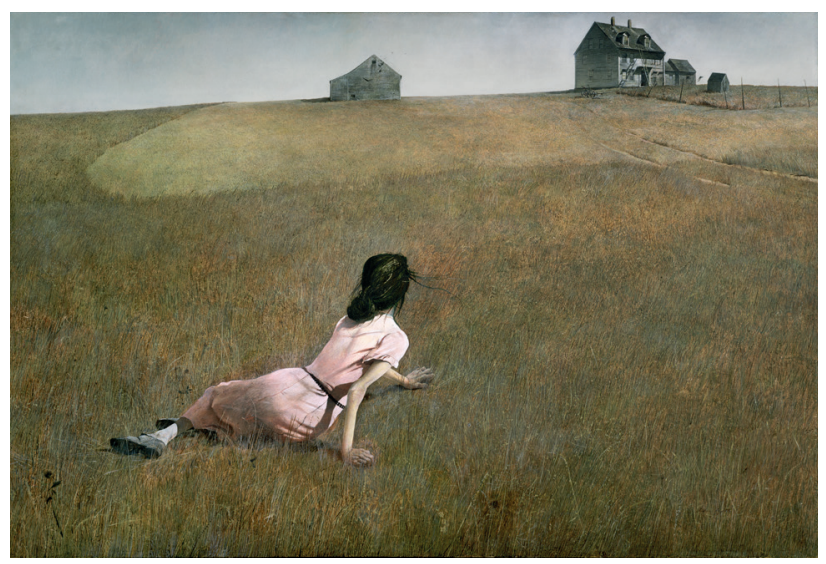
Guston aspired to express boundless and playful elaborations in his work based on his own understanding of the specific influence, rather than to take direct nourishment from Chinese culture, such as Song painting and poetry of $\mathrm{Li} \mathrm{Bai.}{ }^{18}$ In so doing, his abstract expressionist works became more bewitching.

Indeed, there is quite a lot to make one feel intrigued and even awed in the arena of Chinese artists' influence on their American counterpart.

Now, let us turn to the influence of American art upon Chinese artists. Perhaps, there is no more convincing case than the art of Andrew Wyeth.

On January 3I, 2009, the sixth day of the Chinese Spring Festival, the most important and cheerful holiday of the year, the only art weekly in China, Meishu Bao, broke with convention and reported the sad news that Andrew Wyeth passed away two weeks before. "His works can be said to have influenced our seventies to eighties of the last century and even today's China." ${ }^{19}$ Chinese oil painter Yang Feiyun put it this way: "I guess, many Chinese painters would feel much sadder than those in the West about the death of Wyeth." ${ }^{\circ}$

Indeed, the art of Andrew Wyeth resonated with Chinese art after the Cultural Revolution. His influence on contemporary Chinese art once reached a climax and blew a kind of Wyethiana across China. During the I980s and I990s, Wyeth was considered one of the most famous foreign artists, akin to Courbet, Delacroix, and Vincent van Gogh.

The reasons why Andrew Wyeth became such an influential figure for a group of Chinese oil painters in the 1980 are not complicated to list. Obviously, the top reason was that after the end of the Cultural Revolution in 1976, a more and more powerful artistic trend emerged—Sentimental Realism—which

al Relations (New York: Columbia University Press, 1992), chap. 6.

I8 See Ashton, A Critical Study of Philip Guston, I24.

I9 "Andrew Wyeth Passed Away," Art Weekly [Mei Shu Bao], January 31, 2009, 4.

20 See http://art.china.cn/huodong/2009-oI/23/content_2702910_3.htm. 
led to the production of an important part of the so-called Trauma Art. The brave transition from the Cultural Revolution art to the realistic spirit with humanistic concerns resulted in some very touching artwork. Since the depressing Io-year-long Cultural Revolution had recently concluded; however, the critical inclination in art had to be mild, indirect and suggestive. As soon as Chinese artists saw Andrew Wyeth's works_-certainly only photographic reproductions available back then - they were overwhelmed. It resonated powerfully with their experiences and feelings. No doubt, the solemn but at the same time sentimental mood, the lonely figures and isolated scenes depicted in Wyeth's works seemed the perfect models for Chinese artists to follow. In particular, Christina's World (Fig. 3) proved to be a fascinating example. The individual loneliness, sentiment, and hope emphasized in this painting looked strikingly real and moving in the eyes of Chinese painters, who had been confined so long to the false passion of the Cultural Revolution. To be closer to Wyeth's world amounted to a rebellion against the Red-Bright-Shining style that had prevailed then.

Perhaps the most brilliant response was Spring Wind Has Been Awakened by He Duoling, then a young student at Sichuan Academy of Fine Arts in Chongqing. The artist took three months to finish this work, not only bringing out his mature style for the first time but also contributing a landmark work to the history of Chinese oil painting after the Cultural Revolution. The painting looks like the typical Wyethian world: early spring, a young girl, shabbily clothed, sitting on the river bank with withered grass planted all over. She gazes into the far distance perplexedly but affectionately, and the spring breeze blows her black hair. There is also Wyethian pathos and promise: the severe winter is over and new life is coming, like the spring breeze blowing over the wilderness and the plain now turning green. He Duoling talked about Wyeth's influence on a few occasions, saying that he loved this sentimental American realist for the latter's cool meditation and lonely but enchanting horizon. In a November 200 interview with a journalist in Shanghai, he said:

Spring Wind Has Been Awakened was my MA graduation work. My supervisor [...] was not in favor of it, so I painted it in secret. Because within the painting there were no plot and narration [...]. I sneaked off to leave for Chengdu and painted secretly. I imitated the way that Wyeth painted, as blades of grass were painted one by one. This seemed a departure from the traditional realist techniques. They said my work was a marked failure. Later, I submitted it to an exhibition in Beijing and it was rejected as they said the mood embodied in the painting was rather subdued, and the girl's facial expression looked rather melancholy. ${ }^{21}$

2I See Hui Lan, "Realism in Chinese Oil Painting-Interview with Jin Shangyi, He Duol-ing, Ai Xuan, and Xu Mangyao," Art Observation 2 (2002). 
Fig. 4. He Duoling, Youth, 1984. National Art Museum of China. Courtesy of the artist.

Despite its initial rejection, however, the painting was soon published on the front cover of Fine Art (Meishu), the leading art journal in China, ${ }^{22}$ and a year later was accepted into France's Spring Salon exhibition. He Duoling said he felt, "[his] paint-

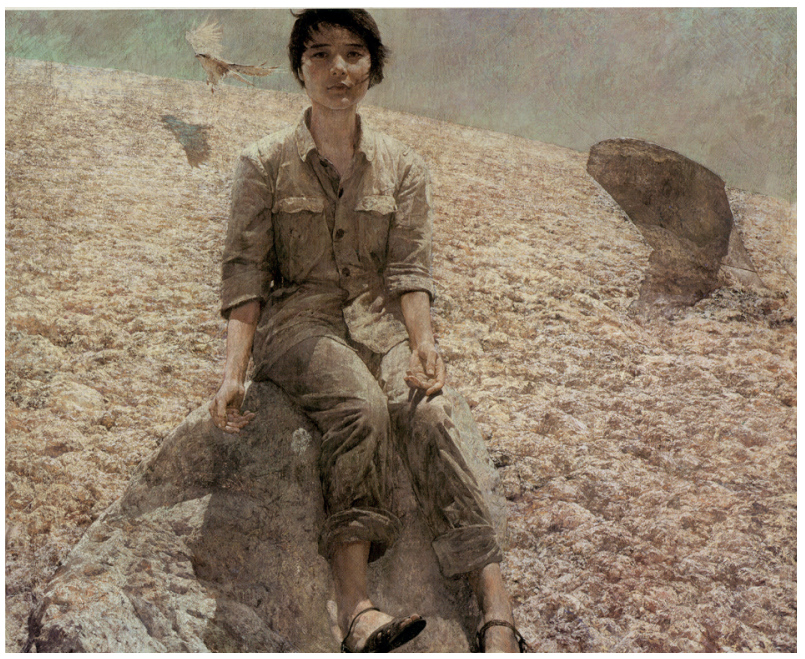
ings were awakened after the painting, Spring Wind Has Been Awakened," and he painted more lyrical and highly acclaimed works, such as Youth (Fig. 4), Snow Goose and A House with a Loft. In a sense, if there were no Wyeth, then there would be no He Duoling.

He Duoling visited the United States in 1985. After viewing He Duoling's exhibition in Boston, a visitor recommended to him a book of poetry by Robinson Jeffers that was illustrated with the desolate and lonely scenes shot by Edward Weston and Ansel Adams. ${ }^{23}$ This book offered another angle for He Duoling to experience some of the sentiments he found in Wyeth's paintings. He sighed: "[T]he best oil painters are still those foreigners and I think that so far there is no single master in China, not at all." ${ }^{24}$ This is He Duoling's special tribute to Andrew Wyeth. In 1997 in his preface to the Album of He Duolin, Contemporary Chinese Art Collection (vol. 4), he also wrote quite suggestively: "[M]y canvas is almost always having (or keeping) no more than one figure." ${ }^{25}$ What a Wyethian view! But when he finally viewed Andrew Wyeth's Christina's World at the Museum of Modern Art in New York in 1985, examining Wyeth's distinctive tempera strokes, He Duolin was able to see more clearly some of the differences between this American master and himself. ${ }^{26}$

Not only did He Duoling achieve success and became mature under the influence of Andrew Wyeth, but other talented painters such as Ai Xuan and Wang Yidong were also deeply interested in the poetic melancholy of Andrew Wyeth, and their painting depicted ordinary people of merit and dignity, contributing

22 See Meishu I2 (198I).

23 Presumably, it is Robinson Jeffers's Not Man Apart: Photographs of the Big Sur

Coast (San Francisco: Sierra Club, 1965).

24 See Zhou Wenhan, "He Duoling: I Belong to the Misreading Generation," Beijing News [Xin Jing Bao], January 3, 2006.

25 Album of He Duolin, Contemporary Chinese Art Collection, vol. 4 (Gaoxiong: Mountain Art Museum, I997), 7. 


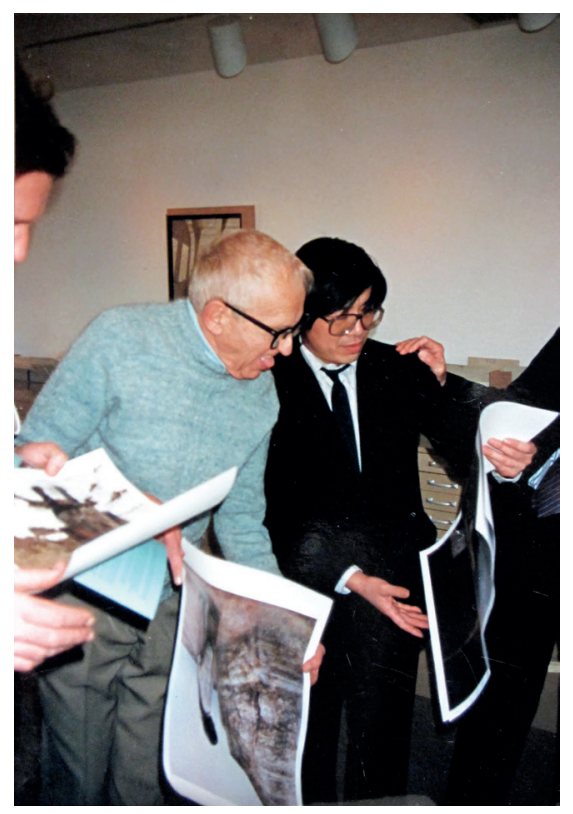
autographed exhibition catalogues, which Andrew and James Wyeth signed. ${ }^{27}$ Andrew Wyeth wrote: "To Ai Xuan: Warmest greeting from his American friend" on one and, more impressively on the other: "To Ai Xuan: With highest regard to your paintings." As Ai recalled later after returning home in Beijing, Andrew Wyeth also encouraged him by telling him: "Now there are so many artists in America [who] rely on photographs when painting, but you are different from them, as you control photographs with your emotions." ${ }^{28} \mathrm{Ai}$, even today, regards Wyeth as the greatest artist in the history of American art. He believes that Wyeth and his painter friends in China shared many similar characteristics in terms of conveying human feelings, and he was able to find much of what he wanted to say in Andrew Wyeth's paintings. In the early I980s, Ai, still very young, was inspired to paint works like the influential Shepherd, The Morning Mist over Marshes. Later, he combined Wyethian melancholy with his Tibetan subject matter and deliberately expressed a kind of poetic touch in Seasonal Wind in Zoige, Fence, Maybe the Sky Still So Blue, Cold Rain (Fig. 6).

In 2008, the painter Wang Yidong also visited New York, and made his way to Pennsylvania to pay tribute to Andrew Wyeth's hometown and to view

27 The albums Andrew Wyeth presented, An American Vision: Three Generations of Wyeth Art (New York: Corcoran Gallery of Art, 1987); and Wanda M. Corn, The Art of Andrew Wyeth (New York: Fine Arts Museums, 1973), are still carefully kept by Ai Xuan.

28 "Ai Xuan: What Wyeth Said to Me," see http://art.china.cn/mjda/2009-03/o9/ con-tent_2777I4I.htm, and "Meeting Andrew Wyeth," Fine Arts in China [Zhongguo Meishu Bao] 3 (I989), I. 
Fig. 6. Ai Xuan, Cold Rain, 1983. Private Collection. Courtesy of the artist.

his works in museums. In Wang Yidong's oil painting, Wyethian sentiment and scene are almost omnipresent.

The significance of the art of Andrew Wyeth lies not only in its realistic painting techniques but also in his aesthetic attitude. He helped Chinese painters to consider the essentiality of paying attention to one's mental universe and the aesthetic power of conveying the pursuit of one's soul-rather than secular reality. One can certainly say that Wyeth offered an inspiring way of looking at the world and life to a whole generation of Chinese artists.

In our era, artistic tropes and new achievements have become a more positive phenomenon which reminds us that references to other cultures and art should be considered on a global level. The great Indian sage Rabindranath Tagore said: "We must prepare the field for the cooperation of all the cultures of the world where all will give and take from others. This is the keynote of the coming age." ${ }^{29}$

What a foresight indeed! (New Haven: The Edward W. Hazen Foundation, 1945), 5. 


\section{塑造人民形象与认识自我 : 20 世纪 60 年代的蔡 亮和其他历史画家 \\ 张坚}

I998 年, 蔡亮油画 “延安火炬” (原名“延安地区庆祝抗日战争胜利”) 作为新中国历史画的代表作，在纽约古根海姆现代艺术博物馆举办 的题为 “世纪危机: 20 世纪中国艺术的现代性和传统” ${ }^{1}$ 展览中展出, 与这个展览配套的主题为 “中华 5000 年：艺术中的创新与变革” 2 的中国古代艺术展也同时举行，两个展览是中国和美国政府合作举 办的，当时的美国总统夫人希拉里·克林顿担任了展览的名誉主席。

蔡亮的这幅油画作品是建国后社会主义现实主义的典型画作， 以往的学者，大都从社会政治语境出发，从这幅画作激励人民的爱 国主义情感，确立中国共产党在抗日战争中的领导地位的角度来加 以阐释和定位。我的文章旨在说明，这样一种政治语境的阐释并非 是这幅画作的全部故事。事实上，通过调查和整理蔡亮在陕西省工 作时的传记资料，我们发现，这幅画作中是隐含着其他层面的真实 的，这些真实对于我们更全面地理解和认识建国以来主题创作的艺 术性问题不无裨益。

“延安火炬” 是在 1959 -I960 年间，蔡亮接受 “中国革命历史 博物馆” 委托创作的，画面采用水平构图，前景部分是举着火把庆 祝抗战胜利的游行队伍，人群从画幅右上角向左下角移动，左上角 是开阔的原野和山峦，在黑暗中显得有些模糊，不过，延安的地标 宝塔山清晰可辨，蜿蜒火把也非常引人注目。

画作的焦点是参加火炬游行的乡亲，在火把照耀下，他们的脸 上洋溢着喜悦之情，人群从左到右，分为三个组群。第一组群的领 头人物是一位咧嘴欢笑的男孩，他大约是在换牙的年龄，从他张开

1 Julia F. Andrews and Kuiyi Shen, A Century in Crisis: Modernity and Tradition in the Art of Twentieth-Century China (New York: Guggenheim Museum of Modern Art, 1998).

2 Sherman Lee, China sooo Years: Innovation and Transformation in the Arts (New York: Guggenheim Museum of Modern Art, 1998). 
的嘴，可以看到中间的门牙脱落掉了。男孩肩扛大鼓，跟在他身后 的老者正在用力擂鼓，傍边的两位村民，鼓着腮帮子，使劲地吹着 啖呐，阴影中，还有一位敲锣的老乡; 第二组群的右侧角落，是一 位抱孩子的当地妇女，她正愉快地与一位举着火把的八路军女战士 交谈。右侧后方的第三组群中，一位年轻八路军战士一只手扶着一 位老奶奶，另一只手高举火炬，跟在他身后的其他游行人群，略显 模糊，身形渐隐在背景深处。总体上，画面展现了游行队伍的欢声 笑语、鼓乐齐鸣的热烈节奏, 以及明亮耀眼的火炬创造出的抗日战 争胜利后延安人民欢欣鼓舞的情绪。

根据当时报纸报道 ${ }^{3}$, 蔡亮画作描绘的 1945 年延安人民庆祝抗日 战争胜利的火炬游行先后举行过三次, 第一次是在 1945 年 8 月 10 日, 路透社关于日本政府向盟国提出正式投降的消息传到延安后，当地 群众自发形成游行活动; 第二次游行由官方组织, 是在 8 月 15 日, 日本天皇发布终战告示的时候，新闻报道中提到，游行队伍抬着毛 主席和八路军总司令朱德的画像，八路军副总司令彭德怀到场，与 参加庆祝活动的老乡见面, 此外, 驻地美军观察团也参加了这次庆 祝活动。第三次游行是在 1945 年 9 月 5 日, 抗日战争胜利庆祝大 会之后进行的。

蔡亮本人并没有见证这一历史时刻，他通过参考这个事件的一 些历史图像和资料获得了创作思路，此外，他个人的生活经历和记 忆对这幅画的构思也起到了重要作用。比如，他提到陕西当地春节 的秧歌舞，北京五一劳动节庆祝游行以及其他一些群众庆祝活动， 都对他的构思有一定影响。他说，这幅画不是要机械地重复和记录 这个事件，而是要让这幅画成为中国人民抗日战争胜利的颂歌 4 。

而事实上，根据他 1963 年发表的一篇创作体会的文章，他决定 采纳火炬游行场景作为这幅画作的主题, 并非直接与当时延安地方 报纸上的抗日庆祝活动的新闻报道有关，而是来自于他 1958 年在 陕西省南部地区参加大炼钢铁运动时留下的印象。他说, 那是在一 个晚上, 他跟着一群老乡到一个铁矿去运炼钢用的矿石, 因为要夜

3 《解放日报》, 1945 年 8 月 16 日，以及《新华日报》，I945 年 9 月 18 日。

4 蔡亮: 《油画 “延安火炬” 创作笔记》, 载《论革命历史画创作》, 人民 美术出版社，I963，第 44-49 页。 
晚行路，每个人都举着火把，长长的队伍走向工地，在那里，有许 多小高炉建立了起来。在两座山的一个转折口，他回望队伍，看到 黑暗中移动的火把形成了一条线，当时，他感到非常震惊，回来之 后，就把这个场景用速写记录下来了 ${ }^{5}$ 。

作为体制内的艺术家，蔡亮参加了大炼钢铁运动，这个运动的 主要目标是要快速实现中国的工业化。当时的一个流行口号是 “赶 英超美”，在 “大跃进” 的狂热中，蔡亮是把这种流行于 50 年代晚 期的对理想化的共产主义社会的普遍热忱，转移到了 1945 年延安 人民庆祝抗日战争胜利的活动中。显然，画作的这个潜在的现实被 画作的标题掩盖了。

这幅画作很快在当时的主题美术创作领域里取得巨大成功，虽 然这种成功一定程度上是与这个时期特定社会氛围联系在一起，但 从艺术上讲, 蔡亮所塑造的那些活灵活现的人物形象, 他们的乐观、 欢快、自然的情绪表达，同样也是让这幅画作广受欢迎的重要原因， 并且构成了它的第二层面的真实。这幅著名的历史画作是超越了一 般的绘画叙事，而是对新中国工业化宏伟计划的热情的颂扬，对劳 动人民积极乐观的精神面貌的赞美，至于画作中所描绘的历史事件 本身的真实性倒是变得次要了。

事实上，在当时的历史画创作中，画家构想一个舞台场景是通 常做法，这种场景并不追求细节上的历史真实或纪实性。这也反映 在同时期其他一些知名历史画家那里，比如，靳尚谊油画 “毛泽东 在 I2 月会议”，主题虽然是一个历史事件，但画家是以毛泽东肖像 的形式来展现的，而没有试图再现当时开会的实际场景。画面中， 看不到听众、也没有会议室，甚至连讲话的麦克风都没有出现。这 个会议是在 1947 年 12 月 2 日在陕北地区召开的，有 I9 位中共高 级官员参加会议, 毛泽东在这个会议上对如何打败国民党军队和取 得国内革命战争在全国胜利做了一系列重要决定。

对于如何以恰当的绘画方式来展现这个会议，靳尚谊说，这幅 画的创新之处在于，成功地把一个重要政治事件的复杂叙事概括和 提炼为毛泽东讲话的一个瞬间姿态，也就是他挥动右手，向前推进 
的动作，自然地表达了当时国内战争的转折点意义，筹划人民解放 军的大反攻正是这次会议的目的 ${ }^{6}$ 。

2010 年，我和两位助手因筹备蔡亮回顾展在北京靳尚谊先生家 里对他进行专访。当时，他谈到了如何创作成功的历史画的问题。 以他的观点, 最重要的是画家要能找到表达这个历史事件的独特瞬 间，这需要画家构想各种人物的恰当姿态和脸部表情，它们形成为 有机统一的视觉表现力, 反映了时代的精神, 而不是被动和机械图 解历史内容的做法 ${ }^{7}$ 。靳尚谊是一位杰出的肖像画家, 在人物肖像中, 他力求透过对体块、空间、形式以及人物表情和姿态的精微巧妙的 调整，达到一种古典美。他想要寻找那个隐含在写实肖像背后的永 恒形式结构，他的这种对于肖像画的认识和理解，来自于在欧美美 术馆实地研究古典油画的成果, 特别是意大利文艺复兴和巴洛克时 代的绘画。维米尔和佛朗切斯卡是他最青睐的画家。安雅兰和沈揆 一在《现代中国的艺术》中, 把这类历史画作称为 “学院写实主义” , 在我看来，这是 “古典的写实主义” 这类画作的核心是以具有古典 美的人物形象来创造一种类似舞台的戏剧效果。

这个时期另一位知名的历史画家全山石油画作品 “宁死不屈” 也是一个例子。这幅画作是 I96I 年由中国革命历史博物馆委托创 作的。全山石 1960 年毕业于苏联列宁格勒美术学院，一直在杭州 的中国美术学院工作，这幅画旨在表达 1927 年 “4.I2” 国民党政 变和清洗之后，共产党不屈不挠的英雄主义精神。

画面上，一群手持武器的民兵围站在一位大屠杀罹难者周围， 尸体位于前景位置，民兵首领腰间插着一把驳壳枪，其他人手持各 式各样冷兵器。画中人物的表情和姿态都在表现愤怒情绪, 以及与 国民党反动派坚决斗争的意志。与蔡亮和靳尚谊的画作一样，这幅 画没有对历史事件本身进行详细的描绘。事实上，甚至是那些民兵

6 参见张坚、蔡汶泚、尤干:《2010 年 4 月 28 日下午靳尚谊访谈》, 载许江、 范迪安主编《历史与追怀: 蔡亮艺术文献》, 吉林美术出版社, 2010 , 第 $173-175$ 页。

7 同注 6 。

8 Julia F. Andrews, Kuiyi Shen, The Art of Modern China (Berkeley: University of California Press, 20I2), I42. 
的社会身份都是非常模糊的，观者很难从这位首领的服装打扮上推 断出他到底是一位农民还是工人，其他人物更趋概略，有些是隐退 在背景中的。

这幅画作后来也成为中共党史中的 “4.12” 政变的一种标准化视 觉阐释, 即表达政变之后共产党人坚强不屈的革命意志和斗争精神, 要比记录或复制这个历史事件的具体细节来得更加重要。

$201 \mathrm{I}$ 年，我曾访问了全山石在杭州的工作室，那时，他正在构 思和创作一幅由文化部委托的大型历史画作《国歌 : 冼星海和义勇 军进行曲》。这一个主题对写实油画而言，是比较难以视觉化的。 勾画一位音乐家埋头谱曲的历史场景显然不是一个好主意, 而最终, 他采取的是寓意方式。画面中，代表不同阶级、政治信仰、行业和 性别的人群，一字排开，站在前景，象征全中国人民团结起来，筑 成抗击日寇的长城。很明显，这种理想化的处理旨在表达中国人民 的勇敢和不屈的精神意志。

这个时期的主题创作中，也有其他方式来表现革命英雄主义的 精神。例如，有的画家采取浪漫主义手法来展现中共党史的重要事 件，比较常见的手法是，用小尺度人与高峻山峦、浩瀚辽阔海洋和 草原进行对比。比如，艾中信和吴作人所创作的两个版本的 “红军 过雪山”, 都是透过人与自然的对比，来表达红军战士的勇猛顽强 和革命乐观主义精神。画面上，行军战士的侧影背祄巨大雪山，天 际阴云密布，产生一种纪念性力量。这样的场景也让我们联想到诸 如弗里德里希的德国浪漫主义风景画。当然，后者的着眼点是在激 发一种超验的宗教情绪和体验，激发对神的信仰，这与艾中信和吴 作人的意图完全不同。

回到蔡亮 “延安火炬”，正是那些沉浸在喜悦之中的老乡才是这 幅画的真正主角，而蔡亮是当时最杰出的肖像画家之一。事实上， 他由徐悲鸿亲自推荐，进入中央美术学院，徐悲鸿赞赏他的人物素 描功底, 请他担任创作助手 9 。蔡亮在新中国历史画创作领域里取得 的成功，很大程度上来自于他的超群的人物素描能力。

9 参见张坚、蔡汶泚、尤干:《2010 年 4 月 28 日下午廖静文访谈》, 载许江、 范迪安主编《历史与追怀 : 蔡亮艺术文献》, 吉林美术出版社, 20IO, 第 $170-172$ 页。 
蔡亮的人物素描追求了形式与精神的完美结合, 其中蕴含了一 种独特的观察和提炼形象的方法，他的关注点是基于一系列特定细 节, 诸如眼帘、嘴角和脸的其他部分, 他擅长塑造脸部微妙光影细节, 人物的灵动和活泼由此得以表达，这也是他对徐悲鸿素描原则 “尽 精微、致广大” 的实践。

蔡亮作品中的人物形象，有时会与上个世纪 60 年代晚期中国流 行的所谓典型的工农兵形象, 即那些浓眉大眼、肌肉健壮的人物相 混淆，或被认为是革命人民的形象的主要来源。但实际上，两者之 间是存在差别的。蔡亮笔下的形象总是保持了一种较为丰富和鲜活 的面部表情和自然姿态，由此，观者可以感受到画家在面对当地老 乡时的那种强烈的幽默感和温情，在这一点上，与老布吕盖尔画作 的人物相近。他的素描作品，大都标明被描绘的主人公的姓名、身 份，甚至所住的村子，我们也可推断，很多情况下，蔡亮是与这些 人有个人交往的。

蔡亮对待当地老乡的幽默和温情也可从他在陕西省长期工作和 生活经历得到一定程度的解释, 特别是他因为牵连所谓的 “二流堂” 事件而被逐出北京。无论如何，蔡亮并非是这个前卫艺术家团体的 关键人物，而只是偶尔参加了一些活动，但因为这个团体在 1955 年被定性为反革命团体，他就不得不离开中央美术学院了 ${ }^{10}$ 。

从前途似锦的中央美术学院专业教师，下放到陕西省群众艺术 馆当一位主要从事群众美术教育工作的艺术家，这对蔡亮来说是职 业生涯的一次重大转折，这个转折让他失去了很多，但同时也得到 了与中国社会底层人民形成更为密切的联系的机会。事实上，在我 们为蔡亮回顾展而到西安走访他的同事和朋友时，他们讲了很多蔡 亮与当地人交往的故事，这些事情让我们意识到，他在个人生活和 艺术上是获得了一定的自由度的，而在北京，无论政治和意识形态 的管制都要更为严峻，他的幽默和乐观面对生活中的各种困难的态 度给他的同事们留下了深刻印象 ${ }^{11}$ 。他的苦中作乐的精神, 反映在他 的绘画和素描作品中, 这些作品总是表现出画家对生活百态的热情,

10 杜高 : 《蔡亮和我》，《江南》I993 年第 4 期，第 I3I 页。

11 参见杨参军 : 《蔡亮的生活与艺术》, 载许江、范迪安编《历史与追怀 : 
里面没有太多的人为造作和伪饰，特别是那种所谓的 “红光亮” 的 概念化模式。

从技术上讲，蔡亮的人物素描和速写是以他的一种对形象明暗 分界线的敏锐把握为基础的，这种方式可回溯到徐悲鸿素描的 “尽 精微、致广大” 以及 “三大面、五调子” 的原则，所有这些原则都 指向一种多样化的细节与整体构图的有机统一性的创造。

值得指出的是，蔡亮作品中的那种微妙明暗分界线是传达了对 象的诸多品质或质感的，诸如粗和细、硬与软、重和轻，引人入胜 的晕影效果，甚至产生出音乐般的运动节奏。这也是我们理解他的 作品的视觉表达特质的关键所在。对于他而言，塑造人物的头像可 以从勾画眼窝、眉骨和鼻梁等结构关系入手，这个区域的明暗分界 线最为突出，之后就可转向面项骨，过渡到嘴、双唇和下领，明暗 分界线也达到了表现力的顶点。与他的对脸部的细致描绘不同，人 物的衣服就塑造得更为松弛、自如和概略一些。总之，他的素描和 速写所揭示的是他的一种线性的理解对象的方式，这也要求观者的 一种积极的观看，甚至是参与到戏剧性的瞬间当中，这与那种对现 实的机械复制区别了开来。

在 2010 年，作为蔡亮回顾展的策展人之一，我承担了相关的文 献调研的工作, 我与两位研究生先后走访了北京、西安、杭州和上 海等四座城市, 访谈了近 30 位蔡亮的同事、朋友 ${ }^{12}$ 。值得一提的是, 许多受访者在论及蔡亮艺术创作时, 都提到了他对摄影的爱好 ${ }^{13}$, 其 中的一些人坚持认为，摄影是他的艺术创作的最重要资源。他们都

122010 年, 中国美术学院和中国美术馆策划和组织了一个蔡亮绘画的回顾 展, 这个展览先后在北京、杭州、西安和上海举行，作为这个展览的策 展人之一, 我承担了收集、整理和编辑蔡亮艺术文献的工作, 为此, 我 们带领两位研究生蔡汶泚和尤干分别采访了蔡亮在杭州、北京、西安和 上海工作的亲友、同事和学生，采访稿收录在《历史与追怀：蔡亮艺术 文献》中。

13 蔡亮在陕西的同事谌北新、王天德、高民生、耿健和党荣华等在 2010 年 I 月 22-24 日西安美术学院的座谈和访谈中, 都谈到了蔡亮喜欢摄影。 参见张坚、蔡汶泚 : 《西安美术学院蔡亮同事亲友座谈会》《西安美术 学院油画系 1977 级校友座谈会》和《谌北新、王天德访谈》，《历史与 追怀：蔡亮艺术文献》，吉林美术出版社，2010，第 209-227页。 
记得蔡亮拥有一部高级的德国相机，这在当时的中国也算是不同寻 常的事情。还有一些故事是关于他对摄影的痴迷, 尤其喜欢用照相 机捕捉当地老乡的脸部表情。

当地老乡显然不喜欢被陌生人照相，他们面对照相机镜头时， 脸部表情会变得僵硬和不自然。为了在自然状态下拍摄他们，蔡亮 采用一些小计谋，比如，把照相机藏在破草帽的里面，照相机透过 草帽上的破洞拍摄，或者让他的同伴假装与老乡聊天，而他在一旁 抓拍 ${ }^{14}$ 。他在陕西的一些同事相信, 这些照片对于他在素描中传神刻 画和表现当地老乡是起到了很大作用的。此外，他们认为，“延安 火炬” 两个版本中的人物形象塑造的差别, 很大程度上是缘于蔡亮 把照片当作创作基础素材之后 ${ }^{15}$ 。“延安火炬” 后一个版本是 1972 年 创作，现存于中国国家美术馆。

在 1972 年版本中，蔡亮在画中增加了一组抬着毛主席大幅画像 的人物, 他们取代最初版本中的那个由小男孩引导的敲锣打鼓的人 群, 另一个引人注目的改变是怀抱小孩的妇女也从前景转移到中景, 不过，他的陕西的同事坚持认为，1972 年版本中的人物表情和姿 态是要比 1960 年版本的更加自然和写实, 这应归结为蔡亮把摄影 效果吸收到了这些人物形象的塑造当中。16

在我看来，仅仅从画面上很难确认 1972 年版本的 “延安火炬” 中的人物是参考了摄影照片。如果与 1960 年版本进行比较, 可以 确认的是，画家用色彩塑造人物形象的技艺得到了发展，同时，确 实也体现了某种比较典型的当时流行的 “红光亮” 的效果。

事实上，在两个版本画作之间进行比较，倒是让我们重新思考 1960 年版本的真正主题是什么。毕竟, 就这幅画而言, 无论是 “延 安地区庆祝抗日战争胜利” 的正式名称, 还是蔡亮实际上挪用了大 炼钢铁时期的火炬游行的场景, 都不是最重要的, 这幅画作的真正 主题是那些当地老乡，尤其是民间乐手，还有节庆的民俗。从这个

14 张坚、蔡汶泚和尤干: 《谌北新、王天德访谈》, 载许江、范迪安主编《历 史与追怀：蔡亮艺术文献》，吉林美术出版社，2010，第 212 页。

15 党荣华: 《西安美术学院蔡亮同事亲友座谈会》, 载许江、范迪安主编《历 史与追怀：蔡亮艺术文献》，吉林美术出版社，2010，第 223 页。 
意义上，这幅画也应归入风俗画的类别，相形之下， 1972 年版本 倒是显示出更多的政治宣传的特点，即它的焦点从普通的农民转换 到了毛主席。我们也可以在这个时期感受到一种视觉表达样式或风 格的转换，历史画从古典写实主义转向了社会主义现实主义，这种 转变可能是与艺术家对某些中国革命史中历史事件的认识的相应改 变存在关联。

至于摄影如何以及在何种程度上有助于蔡亮绘画的创作构思, 这些问题一直以来就存在争议。确实，也有一些他的同事完全否认 蔡亮的创作依托于摄影。这是有一定道理的。蔡亮对摄影的热情和 兴趣可能更紧密地与他涃熟的写生和素描能力联系在一起, 这种能 力归根结底是一种类似于摄影快照的观察方式, 就是说, 是他的写 生和素描观察方式促使他热衷于摄影的奇妙，而不是反过来。

在这个问题上，靳尚谊特别做了澄清。他说，上个世纪 50 年代 晚期和 60 年代早期的中央美术学院，是明确反对使用照相机的， 画家需要通过写生来收集素材，常规做法是每个出现在最后完成画 作中的人物都需要事先做大量素描和油画草稿。他抱怨现在的画家 过多依靠照片，而不是他们的视觉记忆和写生技巧。其结果是，这 些画作就越发接近于照片，这是一个威胁中国当代艺术未来发展的 严重问题。对于蔡亮，他强调的是独立于摄影的艺术品质。17

靳尚谊的观点来源于他对油画的视觉自足性的信念。在他看来, 如果与传统西方油画相比, 现代中国油画远未发展到一个较高水平, 中国油画家还没有能真正理解油画的一些基本价值，即如何塑造人 物，如何达到内在结构的平衡以及人物与空间之间的和谐。他自己 的一些认识也是基于在欧美国家美术馆实地研究原作而获得的。他 还说，一些当代中国油画家迷恋印象派色彩，实际上是缺乏西方古 典油画传统的充分知识 ${ }^{18}$ 。他对于隐含在人物与空间之间的微妙平衡 的关注是关涉到诸如精神表达中的理性秩序之类的问题的，可以回 溯到发生在五四运动期间的梁启超和康有为的艺术与科学的争论。

新中国成立以来的历史画的发展进程中，来自苏联艺术家的影 响，诸如契斯恰柯夫、费钦、马克西莫夫等是无法回避的话题，蔡

17 同注 15 , 第 175 页。

18 同注 I5, 第 175 页。 
亮并没有参加过任何一个由苏联艺术家主持的学习班。事实上，蔡 亮冊宁是预示了一种把中国传统水墨画的线描模式与西方古典素描 的表现方式融合起来的新面貌，也激发了一种不同于契斯恰柯夫的 素描和写生方法。蔡亮的素描和速写，包括徐悲鸿和靳尚谊，他们 对描绘对象的线性结构的理解，现在被认为是更接近于中国传统绘 画的特点，而不同于契斯恰柯夫的那种全然依托于明暗关系经营的 素描教学观念。

当然，一些中国艺术家更加赞赏费钦素描，一种把线、面和体 块的关系有机结合到一起的风格，带有比较强烈的表现色彩，不过， 费钦喜欢用碳条在粗纹纸上作素描，创造了近似中国传统人物画， 乃至书法的视觉效果。他的素描和写生是在上个世纪 60 年代引入 中国的, 在中国美术学院, 有一些艺术家从他那里学习素描方法, 比如全山石和肖传玖，后者是雕塑家。

除了徐悲鸿和靳尚谊等倡导的古典素描体系外，也有一些画家 专注于色彩的现代观念和技术，特别是从苏联油画家马克西莫夫那 里学习外光油画, 后者于 1955 年在中央美术学院主持了一个油画 训练班。而在这之前, 对中国油画家而言, 如何创造明亮和谐的色 彩效果一直是一个大问题，正是马克西莫夫引入了新的非固有色的 色彩表现方法，一种以外光条件下的色彩关系的发现和创造为指向 的色彩语言，这也导致了国内艺术家对印象派的积极评价。

\section{结论}

蔡亮、靳尚谊和其他新中国的油画家开创了一种历史画的样式，其 中，对于历史事件的视觉阐释不是以叙事为指向的，而是侧重于表 达事件的所谓的内在真实，一种精神的、情感的乃至意识形态的真 实或真理，对事件的纪实描绘和再现是居于次要位置的。以此为目 标，画家应把写实主义与浪漫主义结合起来，形成一种社会主义现 实主义的艺术。

1959 年，著名历史画家王式廓在《美术》杂志发表一篇文章， 他写道 : 从事历史画创作的艺术家应该调查现实生活，理解现在的 人的思想感情，这会让他的绘画中的历史人物更加生动，有助于他 与古人建立密切的情感联系。因此，画家应该研究历史资料，把握 历史事件的精神，同时，他也应进入现代生活，构想过去时代的生 
活应该是怎样的, 这是创造生动的历史人物的前提条件 ${ }^{19}$ 。在段落的 结尾，他又说道，当然，画家应该站在无产阶级的立场上来观察和 理解历史事件和当代生活 ${ }^{20}$ 。

蔡亮笔下的历史人物也应看作为是一种他的确认自我的方法, 因为这些人物实际上也揭示了他自由的思想、乐观和幽默的对待日 常生活的态度。他生长在武汉的一个典型的小资产阶级家庭，在他 被迫离开北京到陕西之前，很少了解中国偏远乡村农民的生活。作 为一位艺术家，真正吸引他的注意，激发他艺术创作热情的是那些 淳朴的老乡对待生活的乐观和强健的生命意志，他们日复一日地需 要面对各种生活的艰辛和自然、社会环境的敌意，却并没有失去生 活的信心。这可能也是我们理解蔡亮为什么把这些官方定制的革命 主题的历史画成功转化成一种特殊的风俗画类型的重要线索。考虑 到蔡亮的坎坷经历，他冊宁是在乡村农民那里，而不是在像北京、 上海这样的大城市里，找到了自己的温暖家园，此种情形有点像法 国画家米勒。

正是在这样的语境中，蔡亮的历史画，还有他同时代的那些历 史画家的作品，是不能简单地称为政治的 “媚俗艺术” 的。当然， 这些作品在后来逐渐被标准化，成了政治宣传的范本，特别是在文 化大革命的时期。

值得一提的是，上个世纪 80 年代早期，蔡亮从西安调到杭州工 作之后，是表现出了对于自己在陕西的岁月的深切怀念之情的，他 不断地把自己与那些他曾经熟悉的穷乡僻壤的手工艺人相提并论, 还有他在海外旅行期间遇到的流浪艺术家，他在这个时期创作的一 些绘画，是流露了他的这种思想状态的，而最终，他发现自己的家 就是在黄土高原上生息繁衍的老乡那里。

19 王式廓 : 《题材和主题，生活与艺术形象一中央美术学院油画系创作 草图座谈会上的发言》，《美术》1959 年第 3 期，第 4 页。 


\title{
Modeling People and Identifying the Self in History Painting: Cai Liang and Others in the Early 1960s
}

\author{
Zhang Jian
}

In 1998, Cai Liang's oil painting The Torchlight Parade in Yanan (original title Celebrating the Victory of Anti-Japanese War in Yanan Town) (Fig. I), commissioned by the Museum of the Chinese Revolution between 1959 and 1960, was shown as a masterpiece of the New China history paintings at an exhibition "A Century in Crisis: Modernity and Tradition in the Art of Twentieth-Century China" held at the Guggenheim Museum of Modern Art in New York City. The exhibition, together with another exhibition, "China 5000 Years: Innovation and Transformation in the Arts," which dealt with Chinese ancient art history, was jointly organized by the governments of both China and the United States; First Lady Hillary Clinton acted as the exhibition's honorary chair.

This painting by Cai Liang is a typical work of Socialist Realism and has long been interpreted in reference to the political context in which it was painted-to "encourage patriotism" as well as to justify the leading role of the Communist Party in the anti-Japan War. This chapter will show that this interpretation, based on the painting's many political references, surely is not the whole story, and that there are other layers of meaning which may be revealed by consulting Cai's biographical materials in Shanxi Province.

Making use of an extended horizontal composition, the painting shows a celebratory parade. Torch-lights in the upper right background are continued into the lower left foreground. The parade also connects the foreground with the background, leading viewers into a foreshortened space. The open plain and hills in the upper left appear a little blurred in the darkness, but the landmark of Yanan town, the Pagoda Hill, may be recognized easily (Fig. 2).

The focal point of the painting is apparently on the exhilarated countrymen. Their faces all smiles under the light of torches, these people are divided into three groups from the left to the right. The leading figure in the first group is a grinning boy whose open mouth shows his missing front tooth. He is shouldering a big drum that is being beaten heavily by an older peasant, and beside him are two villagers blowing suona horns and another one in shadow striking a gong. In the second group at the lower right corner, a local woman carrying a baby in her arms is talking cheerfully with a female solider lifting a torch. The third group to the right and at the back includes a young soldier supporting an old woman with his arms and raising a torch high while other people follow him in the parade which begins to blur and fade into the background. Generally, these people laughing heartily from the parade, the fire-light of torches, the passionate rhythm of drum and suona horn, depict an exhilarated mood after the victory of the anti-Japan war.

It should be noted that this celebratory torch parade depicted in Cai's painting really happened in Yanan Town in 1945. According to the local newspaper's

424 reports, the torch parade had actually occurred three times. The first one was 

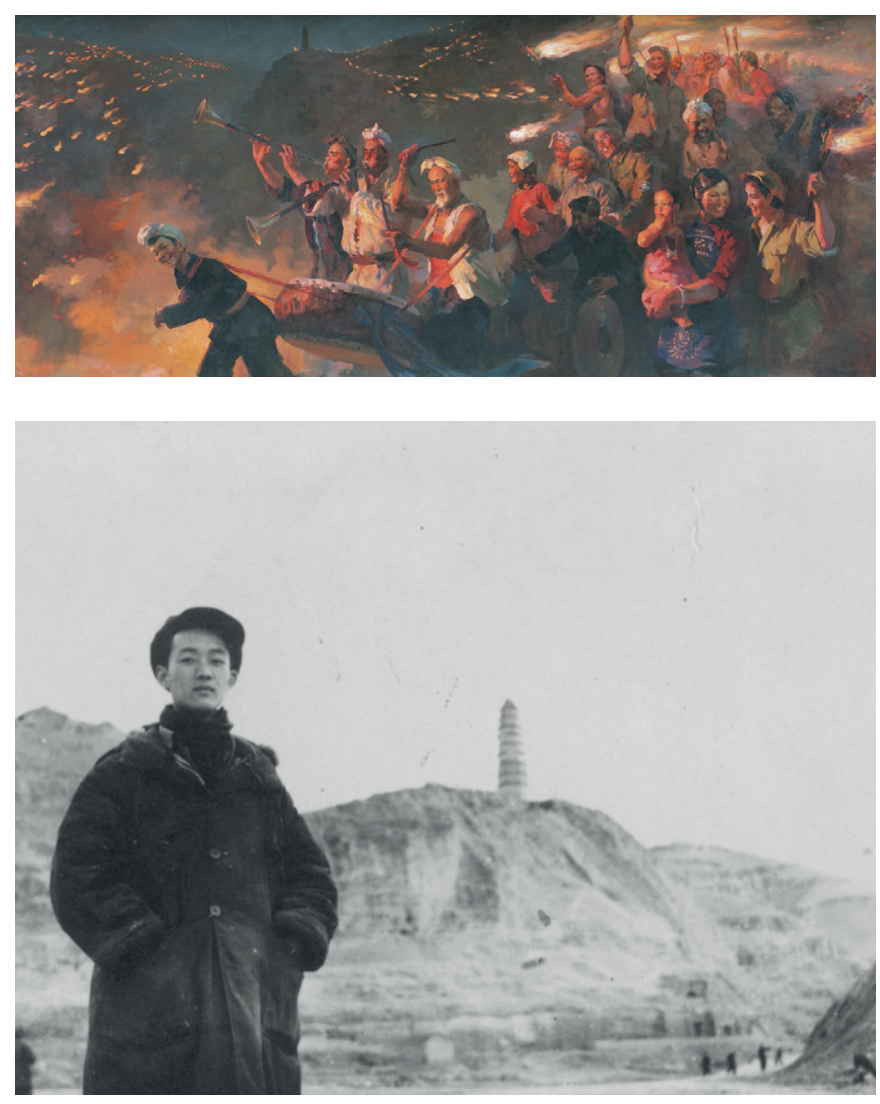

Fig. I. Cai Liang, The Torchlight Parade in Yan'an, 1959. National Museum of China, Beijing.

Fig. 2. Cai's first Visit to Yan'an in 1956. Photograph. Private Collection.

formed spontaneously on the night of August IO, I945, after the Reuters news service report that the Japanese government was presenting a formal note for surrender to the Allies had been announced at Yanan. The second was organized officially on August I5 when the Japanese Emperor's edict for "ceasing war" was released. The reports mentioned the participation of the Observation Group from the United States Army in this event, and both portraits of Chairman Mao and General Zhu De, the Commander of the Eight Route Army, were shown in public, with the Deputy Commander as well as the acting general director of the Communist Party's Army, General Peng Dehuai, favoring the local people in the parade with an interview. The third one was followed with "the Celebration Assembly of the Victory of Anti-Japan War" on September 5, 1945.

Of course, Cai Liang himself had not witnessed this historical moment and, rather, would get his idea of what the pictorial representation of this event should be through his own imagination and some memories of ordinary festivals, such as the Yangkou dancing in the Spring Festival (a special kind of folk dance popular in the northern part of Shangxi province), the celebratory parade on May Day in Beijing and others. Although this painting was not intended to be a mechanical visual recording but an anthem for this great victory, in reality he consulted many historical documents concerning this event.

And in fact, according to the article by him published in 1963 , his adoption of the scene of a torchlight parade as the motif of this painting should not be directly related to the newspaper reports from August 1945, but to the lively impressions left on him by the Movement for the Great Steel Making in 1958 
Fig. 3. Cai Liang, Small Earth Furnace for Steel-making. Watercolor, 1958. Private Collection.

in the southern Shanxi province (Fig. 3). ${ }^{1}$ He said that, one night, together with a group of local folks, he went to an iron mine to carry minerals for steel making, everybody holding a fire torch, with the long queue marching toward

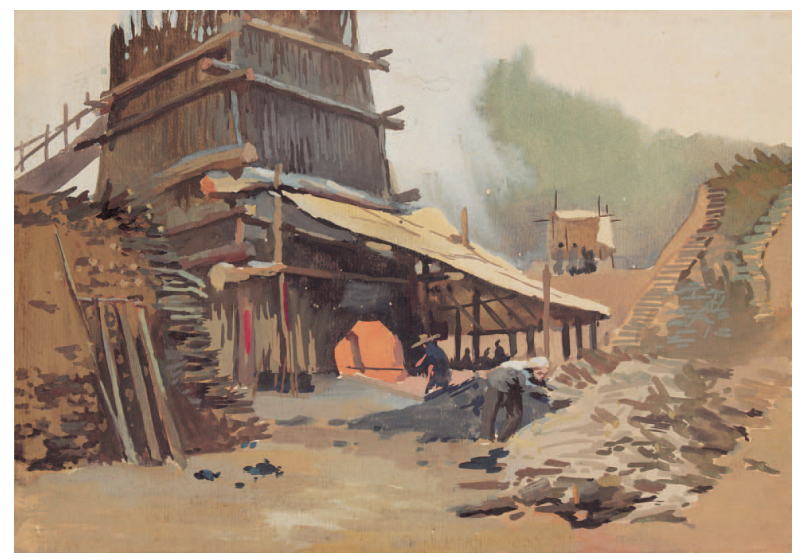
the working site where many steel-making furnaces had been built up. At a turning-point in the path between the hills, he looked back and saw a moving line of torches in the darkness. It was a forcibly strong image which he then sketched afterwards.

Cai, like most of the institutional artists in China at that time, was involved in the Movement for the Great Steel Making, with the main target to industrialize China with great speed. As a popular slogan of the Movement said, "China would catch up, even surpass England as well as the United States, in fifteen years." Under the frenzy for the great leap, Cai simply transplanted this popular fervor for an idealized communistic society to the celebration for the victory of the anti-Japan war in Yanan Town in 1945. This inherent layer of reality in the painting has always been overshadowed, however, by the celebratory parade of the painting's title.

The painting proved to be a great success, although the dramatic scene depicted was not from the actual event. In fact, what made this painting so appealing to common viewers was those lively characters with local costumes, their smiling faces lit by torches, the merry sounds of suona horn and big drum they were playing, and their cheerful chatting with soldiers, all contributing to form the second layer of reality in the painting, pointing to the local customs in festivals and going beyond the specific historical pictorial narrative. Under this perspective, it could be said that what this painting actually shows is the enthusiasm of the local people devoted to the grand project for industrializing China, together with their optimistic spirit; its narrative content was secondary.

In fact, it was the common practice in history painting at the time that a painter conceived a vision of a stage in which characters played their roles rather than create a detailed documentary depiction. For instance, Jin Shangyi's oil painting Mao Zedong at the December Meeting was simply a portrait of Mao with no reference to the actual scene of the meeting itself; there is no audience, no meeting room, and even no microphone. This meeting was held on Decem-

I Cai Liang, "Notes on the Creation of the Oil Painting 'Torchlight Parade in Yanan," in On the Creation of the Painting with the Subject of Revolutionary Histo$r y$ (Beijing: People's Fine Arts Publishing House, 1963), 44-49. 


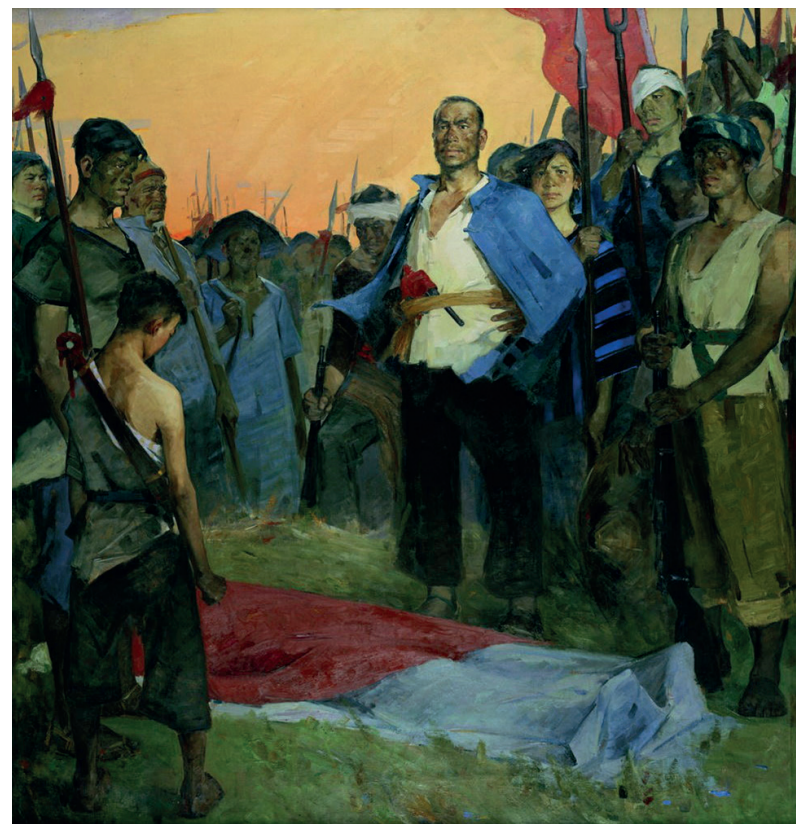

Fig. 4. Quan Shanshi, Non-yielding Heroism, 196r. Art Museum of the China Academy of Art, Hangzhou.

ber 25, 1947 in the northern Shanxi province, in which is high officials of the Communist Party participated and Mao Zedong made a series of important decisions on how to defeat the National Party's Army and win the civil war in the whole of China.

As to the pictorial representation of this meeting, Jin said that the innovation in the painting was his decision to simplify the complicated narrative of a political event into a single moment of Mao's pose in his speech; that is, his right hand waving and pushing forward naturally connoted the turning point of the civil war and the final attack of Liberating Army to the Nationalists that was the purpose of this meeting.

In 20I0, when I interviewed Jin Shangyi at his home in Beijing, he told me much about how an oil painter can create a successful history painting. In his opinion, the most important thing was to find the way of visualizing a unique or significant moment in the event depicted through the subtle designation of the poses and facial expressions of characters, of which the effect should reflect the spirit of age and not to passively illustrate documentary content. In his portrait painting, Jin has always tried his best to reach a classical beauty by his subtle and skillful management of volume, space, and form, as well as the poses and facial expressions of characters. He wanted to find the universal formal structure underlying a realistic portrait, of which he had arrived at a deep understanding or insight through his studies of classical oil paintings of Europe, especially Italian Renaissance and Baroque paintings. Vermeer and Piero della Francesca are his favorites. Julia F. Andrews and Kuiyi Shen, in their book The Art of Modern Chi$n a$, called this type of history painting "academic realism"2 and, in my opinion, the term classical realism could also be applied to them as the main characteristic is the theatrical effects produced by the characters modeled with classical style.

Quan Shanshi's oil painting Non-yielding Heroism, commissioned by the $\mathrm{Na}$ tional Museum of History in 196I, is another example (Fig. 4). Quan graduated from the Leningrad Repin Academy of Fine Arts in the Soviet Union in 1960,

2 Julia F. Andrew, Kuiyi Shen: The Art of Modern China (Berkeley: University of California Press, 2012), I42. 
and had been working at the China Academy of Art since then. The painting was intended to express the heroism of China Communist Party members after the purge within the Nationalist Party in 1927 which led to a massacre.

A group of armed militia are standing around a victim of the massacre, whose body lies in the foreground; the leader of the group holds a Mauser pistol, with others holding various other kinds of weapons. Through their facial expressions and poses, all the characters appear to be angry and show their strong will to struggle against the National Party. Just as in Cai and Jin's paintings, there is no detailed description given for the event. In fact, the social status of the characters in the painting seems to be consciously blurred as it is difficult to infer from this leader's garment whether he was a farmer or worker; other people seem to be no more than sketched in or fading into the background.

In any case, this painting became a standard visual interpretation for the April I2 Incident, in which expressing these revolutionists' strong will for struggle was much more important than merely making the painting a detailed description of this historical event.

In 20II, I visited Quan's studio in Hangzhou. At that time, he was working on a large history painting commissioned by the Cultural Department of China: the painting's subject was on the National Anthem composed by Xian Xinhai which is a difficult subject to visualize. Depicting the composer writing a piece of music in a room would not have been a good idea; he decided to depict an imaginary scene in which all the peoples in China, regardless of class, political faith or profession they belonged to, were closely united and stood together in the foreground of the painting, just like the Great Wall. Obviously, this idealized vision in the painting of all the peoples uniting as one to resist Japanese invaders aims at expressing the brave spirit and power of the Chinese people.

There were many other ways to show this kind of spirit during the period. For instance, some oil painters preferred to create a romantic vision for an event in revolutionary history. A common practice is to make contrasts between huge snowy mountains, or the vast expanses of sea, prairie, and a tiny human being: both Ai Zhongxin's Red Army Crosses the Snowy Mountains and Wu Zuoren's Crosses Snowy Mountain show the courageous and optimistic spirit of the Red Army with the silhouettes of marching soldiers against snowy mountains and chilly clouds conveying a sense of monumental power. Also, this vision reminds us of the German romantic landscape paintings by artists like Caspar David Friedrich. Of course, the latter's point is to stimulate a metaphysical mood which was the opposite of Ai and Wu's intentions.

In Cai Liang's The Torchlight Parade in Yanan, characters imbued with buoyant rhythm are the focal point and Cai was undoubtedly one of the most talented portraitists in China at the time; in fact, he was recommended to the Central Academy of Fine Arts by Xu Beihong himself. Xu admired his skillful figure drawing, and had hired him as his assistant. It should be noted that Cai's highly talented figure-drawing was the most important support for his history painting.

Cai's figure drawings are characteristic of a perfect unity of form and spirit. His observation was always based on certain selected details, such as eyelids, 428 mouth corners, and other parts of face. He was excellent at modeling these facial 


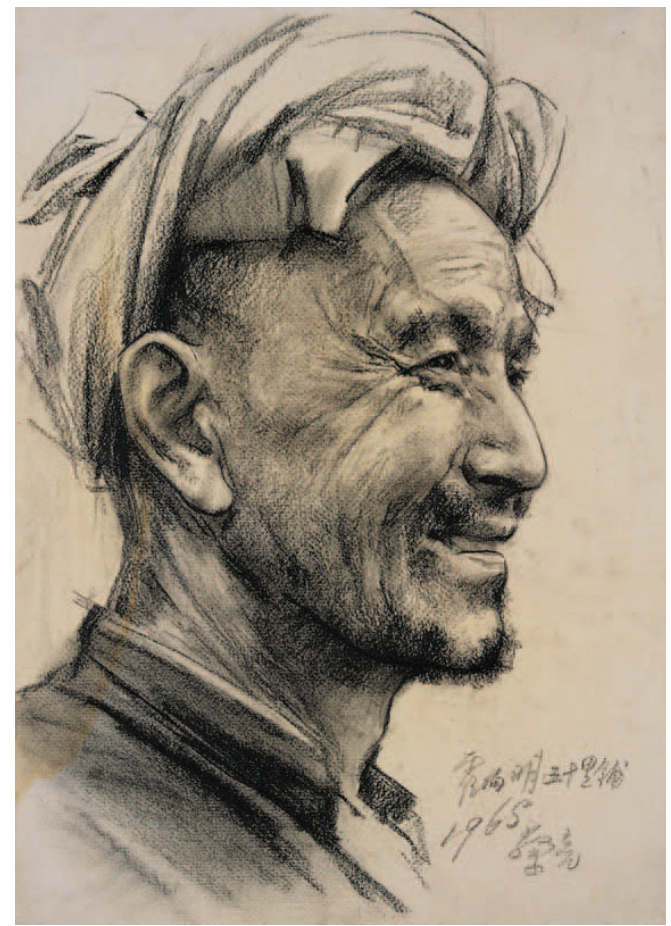

Fig. 5. Cai Liang, Huo Xiangming from San Shi Li Pu. Drawing, 1965. Private Collection.

details with subtle shadow and light; the liveliness and vigor of characters were thoroughly conveyed (Fig. 5). This can be interpreted as his personal response to $\mathrm{Xu}$ Beihong's credo for drawings: "Mastering the universal through detailed studies [jinjingwei zhiguangda]."

The figures in Cai's works are usually confused with the fashionable late I960s images of workers, peasants, and soldiers with their big eyes, heavy eyebrows, and muscular bodies, or even thought to be the main source of these revolutionary images of people. But there are fundamental differences between them. Cai's characters always keep lively facial expressions and natural poses from which viewers gain a strong sense of Cai's humor and warm attitude toward the locals, similar perhaps to the figures in Pieter Bruegel's paintings. From the inscriptions of the names of the characters in his drawing, it can be inferred that Cai was familiar with these local people personally.

His affection for the local people revealed in his paintings and drawings may be explained through his biography, especially from his expulsion from Beijing due to his involvement with a group of avant-garde artists called Erliu's Home (Erliu Tang, which means "a home of drifters"), in which Wu Zhuguang, a famous dramatist, played a leading role. Although Cai absolutely was not the key member in this artistic group, it was recognized as an anti-revolutionary community in I955, so Cai had to leave the CAFA.

The sudden fall from a comparatively high social position with a prospective future in Beijing down to a junior artist in the Shanxi Provincial Mass Art Center (Shanxishengqunzhongyishuguan) provided Cai with a unique opportunity to develop closer contact with lower social classes. In fact, there were many stories told by his colleagues about his life in Xian City which showed that he seemed to enjoy much more freedom, both in the pursuits of his personal life and artistic career, than in Beijing where political and ideological control as well as censorship was stricter. His humor and optimistic attitude towards all kinds of hardships in life also left a deep impression on many of his colleagues.

His positive spirit, finding happiness, and pleasure amidst his own sufferings, was clearly reflected in his portrait paintings, drawings, and sketches of local folk and their customs; his attention was always on those moments of cheerful chatting, laughing, working, and entertaining, depicting everybody with bright smiles on their faces, full of vigor, and in a natural state of life. There is no artifi- 
cial heroism and idealism as were fashionable in the cultural revolutionary paintings which were characteristic of "red, bright, and shining [hong guang liang]."

Technically, Cai's figure-drawings and sketches have a unique way of sensitively defining and edging the lines between shadows and lights which also may be traced back to Xu Beihong's credos for drawing, such as "Mastering the Universal through Detailed Studies" and "Three Planes and Five Values [sandamian wudiaozi]." All these credos point to an organic unity of varied details and the wholeness of composition.

It is also worthwhile to note that the subtle shadow line in Cai's work conveys varied qualities of objects, such as broad, thin, hard, soft, heavy, and light, catching chiaroscuro effects and even producing musical rhythms in movement. It provides a key for us to understand the visual essence of his artworks. To him, modeling a head of character should begin with sketching the structural relation among the eye socket, brow bone, and the bridge of nose, etc. In Cai's opinion, the shadow line in this area should be very distinctive, and then transition to firm cheek bones, then further to the cheeks which appear a little relaxed, then to the mouth and lips, and finally to the chin in which the line will be at the zenith of its expressiveness. Compared with his detailed depiction of the face, the character's clothes were modeled more freely and sketchily. In all, his drawing and sketching reveal his linear understanding of figures which also requires the viewers' active observation and even participation in dramatic moments, and not the mechanical copy of social reality.

In 20IO, as one of the curators of a retrospective exhibition for Cai Liang's art, I also undertook to survey the literature on him. I, together with two graduates, went to four cities (Beijing, Xian, Hangzhou, and Shanghai) where Cai had lived or worked, and interviewed Cai's colleagues and friends.

It is not irrelevant that many of these interviewees mentioned Cai's hobby of photography; some insisted that the photos he had taken during his stay in Shangxi province were one of the most important resources for his artworks. They still remembered his possession of a premium camera made in Germany which was an extraordinary thing at that time in China. There were also stories about his obsession with shooting pictures, especially to catch the swift facial expressions of the local inhabitants.

Considering that most of the local farmers disliked having been taken photographs by strangers, their facial expression would become stiff and unnatural when they stood in front of a camera. In order to photograph them under natural state, Cai used some intriguing tricks. For example, he would conceal his camera under a broken straw hat with a hole on the top and the camera shooting through the hole, or he would ask his friend to pretend to talk with a local person and, he himself standing nearby, took the photo of this person who was unaware of it. Indeed, his colleagues in Shangxi believed that the photos he took contributed to his creating these drawings of local folk considerably. In that regard, the distinction between the two versions of Torchlight in Yan'an, one created in Xian City in 1959, now in the China National Museum (Fig. I), and the other done in Yanan in 1972, now in the China National Art Gallery (Fig. 6), can be used as an evidence. 


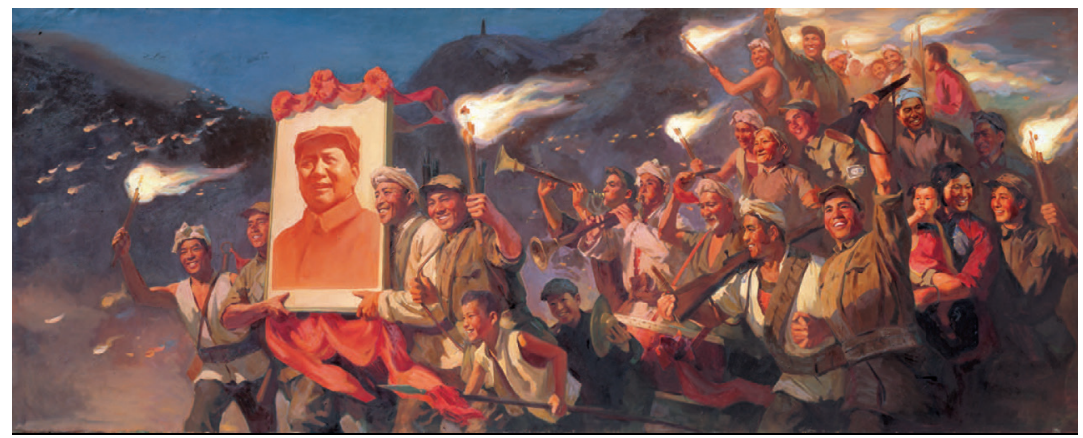

Fig. 6. Cai Liang,

Torchlight in

Yan'an Town,

1972. National Art

Museum of Art,

Beijing.

It is obvious that in the 1972 version of the painting, Cai added a group of people holding a large portrait of Mao Zedong leading the parade instead of the little boy shouldering a big drum as in the first version; he also put the woman holding the baby from the foreground into the parade. Despite that, some of his colleagues insisted that the characters' facial expressions and poses in the 1972 version were more natural and realistic than the 1959 one, which may be attributed to Cai's absorption of the photos he took into the pictorial representation of this painting.

But, in my opinion, it is hard to identify any specific evidence from the influence of photographs in the 1972 version. Compared with the 1959 one, Cai's skill for modeling characters with colors had developed, with the typical visual effects of "Red, Bright, and Shin-ing" fashionable in the early I970s.

Making the comparison between the two versions of the painting will help us to reconsider what the real subject in the I96os version might be. With its official title of Celebrations for the Victory of the Anti-Japan War in Yanan and Cai's adoption of the scenery of a torchlight parade in the movement of Great Making Steel as the pictorial motif, it could be said that the real subject of the painting was these local folk musical players as well as the customs of their ordinary life, so this painting could be classified as genre painting. In contrast, the 1972 version is overtly political propaganda, with its focus on Chairman Mao instead of the local people. From these two paintings, we can get a sense of the subtle transformations that happened in the world of history painting in China, that is from classical Realism to Socialist Realism, which may have no obvious relationship with any corresponding changes in the artist's understanding of some events in revolutionary history.

There are different opinions and even disputes as to how and to what extent photography helped Cai in the process of the formulation of his pictorial representations; some of his colleagues totally denied Cai's dependence on photography. This is partly true, in my opinion, because Cai's strong interest in photography was closely connected with his skillful drawing and sketching for local folk alive. This relationship suggests a method of observation in which photography is an additional technique, but not vice versa.

On this issue, Jin Shangyi made a clarification when he said that, during the I950s and the early I960s, the Central Academy of Fine Arts was strongly opposed to using cameras to collect visual materials for their planned artworks. Painters should make sketches from life by themselves and the normal practice 
was to do preparation studies in drawing and oil painting for every character present in the final work. He also complained that painters today depended too much on photographs and not their visual memories and manual skills for sketching figures alive. As a result, the paintings produced by them had become much closer to photographs, it would be a serious problem threatening the future development of Chinese contemporary art. In any case, he emphasized that Cai's artworks were independent of photographs.

Jin's opposition to making reference to or copying photos was based on his firm conviction of the visual autonomy of the language of oil painting. In his view, modern Chinese oil paintings had not developed to a high level up till now. Compared to traditional oil paintings of Western countries, many Chinese oil painters still had not attained a real understanding of the essential values of oil painting, of to how to model the figure and obtain inner structural balance and harmony between figure and space. He himself had insight into this problem through studying original paintings on the spot in galleries and art museums in western countries. Even more, he said that some contemporary Chinese oil painters' obsession with the colors of Impressionism could be regarded as a symptom of their lacking the knowledge of the Western classical tradition of oil paintings.

His emphasis on the values of modeling and rational structure inherent in the subtle balance between figure and space could also be referred to the issue of rational order in spiritual expression which could be traced back to the debate on the relationship between art and science that happened in the May 4th Movement between Liang Qichao and Kang Youwei.

In the history of history paintings since 1949, the influence of Soviet Union artists, such as Pavel Petrovich Chistyakov, Nicolai Ivanovich Fechin, and Konstantin Methodievich Maximov has always been an inescapable topic, although Cai himself had not participated in any of the workshops hosted by these Soviet Union artists. This history is worth exploring but the essential point is that it is Cai Liang who prefigured a new prospect for integrating the linear mode of Chinese traditional ink painting with that of western classical sketching, and that this stimulated a different way of sketching to develop that of Chistyakov. In fact, Cai's drawings and sketches, including Xu Beihong and Jin Shangyi's, together with their linear structural understanding of objects, were distinct from that of Chistyakov's teaching system which was based completely on dark and light sketching, and now have been recognized to be much closer to the characteristics of Chinese traditional painting. In other words, it is in the preliminary drawings as much as the final painting that one should look to discern the evolving relationship between Russian social realism and Chinese art.

Of course, Nicolai Ivanovich Fechin, whom some Chinese artists much admired, developed a unique style of sketching which integrated lines, planes and bodies with light and shadow containing an expressive quality; this seems to be a little like Cai's. But, Fechin preferred to sketch with charcoal on rough paper, creating a similar visual effect with that of Chinese traditional figure painting, or even calligraphy. His sketching and drawing were introduced into China in the 
I960s, in the China Academy of Art, where some artists learned from him, such as Quan Shanshi and the sculptor Xiao Chuanjiu.

Besides the classical sketching and drawing system promoted by $\mathrm{Xu}$ Beihong and Jin Shangyi, there were some other oil painters who had learned modern concepts and techniques of colors, especially in plein air, from the Soviet Union oil painter Konstantin Methodievich Maximov who hosted an oil painting workshop in the Central Academy of Fine Arts in 1955. Before that, how to create bright and harmonic effects of colors had always been a big problem for Chinese oil painters, and it was Maximov who led them to a new grasp of colors which was not based on the traditional conception of the proper colors of objects, but on colors' inner-relations in the open-air. This also led to a positive evaluation of impressionism, but that topic is beyond the scope of the paper.

In conclusion, Cai Liang, Jin Shangyi and other oil painters in New China initiated an archetype for history painting, in which the visual interpretation for commissioned subject was not aimed at detailed representation or mechanical reproduction, but at expressing so-called the inner realities of this subject; that is to say, the spiritual, emotional, and ideological meanings other than documentary facts about it. In order to reach this goal, a qualified painter should integrate realism with romanticism, that is, Socialist Realism.

In 1959, a famous history painter, Wang Shigu, published an article in Art Magazine writing as follows: "The artists engaging into history painting should investigate the realities of life and understand the feelings of modern people, which can make his historical figures in paintings be lively, and help yourselves to set up close emotional relations with ancients. So, painters should study historical materials, and grasp the spirit of the commissioned subjec; meanwhile he also should enter into modern life, and then assume what the life in past time would be. This is a precondition for producing lively figures in history." At the end of the paragraph, he added: "Of course, a painter should stand on the position of proletariat to observe and understand historical events and contemporary life." 3

In Cai's case, his characters in history painting also could be viewed as a way of self-identification that actually revealed his free-minded, optimistic, and humorous attitude towards ordinary life. Actually, he had grown up in a typical bourgeois family in Wuhan City, and had known little about remote village life before his expulsion from Beijing to Shanxi province. As an artist, what really attracted his attention and made him feel freshly, or even inspired, were these naïve villagers' optimistic spirit and strong will for life demonstrated in their facing varied kinds of hardships and hostile conditions from natural and social surroundings day after day. That should be a clue for us to understand why he could successfully transform these official commissions for history painting with revolutionary subjects into a special type of genre painting, which in some cases even

3 Wang Shigu, "Contents and Subjects, Figures in Life and Art: A Speech in a Forum on Sketches for Oil Painting Organized by the Department of Oil Painting in Central Academy of Fine Arts," Art Journal (Meishu) 3 (1959): 4. 
Fig. 7. Cai Liang, Street Artist in Paris, 1987. Private Collection.

bear no sign of the commissioned subject itself, such as The Two Sons of a Farmer, Yangge Dance Team in Garden with Red Dates Tree, and Celebrating Spring Festival with Flower Lamp. Considering Cai's tough

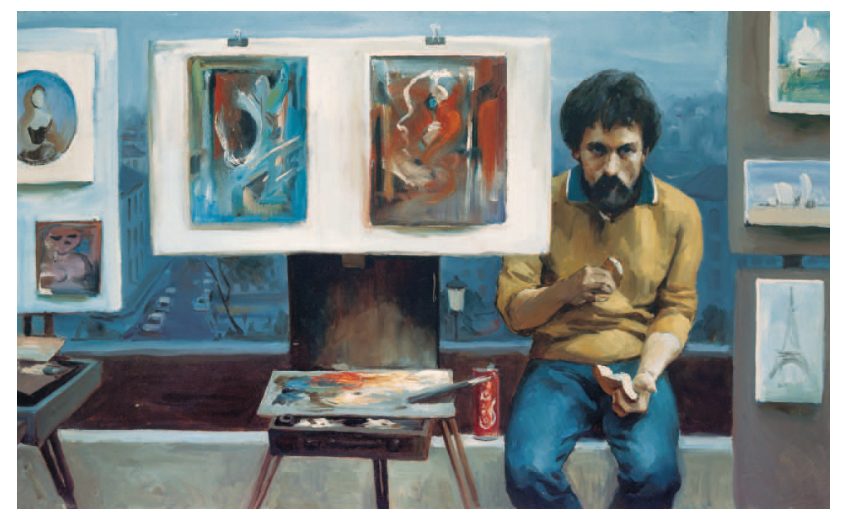
experiences as a political outcast, he would rather find his warm homeland in the countryside, in a situation similar to the French painter Jean-François Millet, than in large cities like Beijing and Shanghai.

It is in this context that Cai Liang's history paintings as well as his contemporaries' works could not be simply called "kitsch art" in the political sense. Of course, these artworks have been gradually canonized to be the model of political propaganda arts, which really degenerated into kitsch art in the Cultural Revolution.

Even more, after Cai's move from Xian to Hangzhou in the early i98os, he seemed to be nostalgic for his years in Shangxi and constantly equated himself with those traditional craftsmen with whom he had been familiar in remote villages in Shanxi province or with those foreign art drifters whom he occasionally met in his travels in the Western countries (Fig. 7). Some of his paintings produced in this period reveal the state of his mind: finally, he had found himself be at home in the world of paintings with the subject of these local people living in the remote villages on the loess plateau of Shanxi province. 


\title{
Rethinking the 1960s: The History of Art History
}

\author{
Bruce Robertson
}

The foundational narratives of modernism, as seen from an American perspective, are called into question when aligned with the interests of Chinese art historians. As we have seen, the divide between "modernism" and "post-modernism," which for Americanists occurred somewhere in the I960s, for Chinese audiences has little relevance. In this traditional story, both China and the United States are in the same relationship to modernism for the first half of the century, both being acted upon rather than originating styles and ideas when they first engage with modernist art. Then for the second part of the century, China is in a belated position in relationship to the United States, until just the last two decades. But by this point in the 2Ist century, this is an uninteresting and unproductive story, one that we can resist and make more complex.

In the United States, for example, art historians for the last generation have been looking at nativist roots for modernism: recognizing, for example, that Pollock's vision has roots in the large-scale landscape paintings of the igth century, like Frederick Church's Niagara. Or finding the roots of abstraction in the teaching of Alfred Wesley Dow, or some of the work of John Twatchman, in a lineage that extends from James McNeil Whistler. ${ }^{\mathrm{I}}$ The worldwide reactions to late capitalism must lead us to a recognition of many modernisms, internally within the United States and externally as well. As one example we may consider a group of three paintings created in San Francisco in the same month in 1926, portraits by Miki Hayakawa of an African-American man, a portrait by Yun Gee of Hayakawa painting that sitter, and a portrait of Yun Gee by their teacher Otis Oldfield. ${ }^{2}$ Miki Hayakawa (I899-1959) and Yun Gee (1906-1963) were classmates at the California School of Fine Arts in San Francisco. She had been born in Hokkaido, Japan, and immigrated to the United States at the age of 9; he had been born in Kaiping, China, and immigrated at the age of Is to join his father (who had legal status in the United States) in San Francisco. Otis Oldfield (I890-1969), who had trained in Paris, was their teacher. In this one moment, then, may be found a portrait of an African-American man by a Japanese-American woman, a portrait of Japanese-American woman by a Chinese-American man, and finally a portrait of a Chinese-American man by an Anglo-American man, cumulatively painted in a contemporary modern French manner adapted

I See Ellen Johnson, Modern Art and the Object (New York: Thames and Hudson, 1976) and Barbara Haskell, Georgia O'Keeffe and Abstraction (New York: Whitney Museum and Yale University Press, 2009).

2 See Woollin Kim, Jinmyung Kim, and Songhyuk Yang, eds. Art Across America. (Seoul: National Museum of Korea, 2013), 287. 
to local circumstances which easily cross conventional boundaries of style, race, and gender. ${ }^{3}$

The rest of this chapter proceeds by offering a cautionary tale about the ways in which art history itself distorts the history we need to discover, which lies within territory most American art historians would no longer consider "modern." I examine how the terms we use disguise and even hide the objects we look at, and ask us to consider what it means to do art history without the art history that has shaped the canonical history of modernism we all know. That is to say, to create a new art history that enlarges our sense of what modernism is.

For strategic reasons, I set this tale within the single most studied decade of the last century, the I960s, which has produced an art-historical literature in just the last quarter century almost as large as the literature on the Italian Renaissance. But much of what I say could be said of any art historical period.

What makes the I96os so important is that it embodies a paradigm shift, where the actions by artists of that decade map out the territory explored in the American art world ever since. The terms of this revolution may be listed as:

I. an expansion of the media used by artists: performance, installation, and mixed media proliferate.

2. a valuation and validation of mass media.

3. the dominance of conceptual art and a proliferation of words—by critics, artists, and art historians.

4. the emergence of identity politics and art.

5. the ascendancy of the commercial art world (and attendant art institutions) on a new, vast scale.

We deal with this complexity and simultaneity of developments by using the short hand of movements and names: Happenings, Pop, Minimalism, Fluxus, and so on. But these terms, while useful, obscure as much as they reveal. Let me focus on just one-Minimalism - to examine this problem, and question its usefulness to us as art historians.

Minimalism in most general accounts is seen as the apex of modernism-a final clarity about abstraction and the nature and use of materials and forms within the mediums of painting and sculpture, in terms that Clement Greenberg would have used. But just as frequently in recent years, it has been seen as fundamentally post-modern, allied with Pop in the rejection of affect and individuality, and arising at the same time and out of the same circumstances and with the same genealogy. ${ }_{4}$ Obviously, however, it cannot be both: that is the first problem,

3 See LACMA's online collections (https://collections.lacma.org/) and also ShiPu Wang, The Other American Moderns: Matsura, Ishigaki, Noda, Hayakawa (Pennsylvania State University Press, 2017), figs. 59, 62 and 63.

4 Rosalind E. Krauss, Passages in Modern Sculpture (New York: Viking, 1977); Michael Fried, "Art and Objecthood," Artforum 5, no. Io (Summer 1967): 12-23; 
and it is shared by other work produced in the 1960s to a degree that calls into question the value of both terms — modernism and post-modernism—as having any critical value.

One of the reasons why Minimalism has attracted such attention is that it was defended and criticized by the best critics of the day, such as Rosalind Krauss, Barbara Rose, Michael Fried, and others in a dialogue shaped as much by the artists' own writings, especially Robert Morris and Donald Judd.' A number of these artists were also trained as art historians, again particularly Robert Morris, who did a master's thesis on Brancusi. In other words, we should take seriously what these artists have to say about their own production, a point I will come back to. Second, it is a label that almost immediately taken up in adjacent fields. The choreographer Yvonne Rainer applied it to dance in 1966, and the composer Michael Nyman to music in $1968 .^{6}$ Thus it is a term that had wide, immediate, and useful currency across the arts.

At the same time, it was one that was denied by all its major figures in the visual arts, who also rejected that they had much to do with each other. Donald Judd furiously resisted the term: he preferred "specific objects," and explicitly said "the new three-dimensional work doesn't constitute a movement, school or style. The differences are greater than the similarities. The similarities are selected from the work; they aren't a movement's first principles or delimiting rules." And in the 1964 essay entitled "Specific Objects," he includes a wide range of artists whom we would not call Minimalist today, such as Jasper Johns, Lucas Samaras, Yayoi Kasuma, and Claes Oldenburg. ${ }^{8}$ Robert Morris, in his influential essay "Notes on Sculpture" in 1966, never uses the word "minimalism" and instead applies the term "literal" to his own work.9 Sol Lewitt claimed in 1967 that no artist identified with the term claimed to know anything about it and certainly hadn't agreed to be labeled as such. ${ }^{\text {I }}$

Barbara Rose, "ABC Art," Art in America 53, no. 5 (October-November 1965): 57-69, reprinted in Minimal Art: A Critical Anthology, ed. Gregory Battcock, (New York: Dutton: 1968), 290.

5 See Donald Judd, Complete Writings, I959-1975 (Eindhoven, the Netherlands: Van Abbemuseum, 1987), 197ff; and Robert Morris "Notes on Sculpture. Part I and Part II," in Minimal Art, A Critical Anthology, ed. Gregory Battcock (New York: E.P. Dutton, 1968), 222-35.

6 Yvonner Rainer, "A Quasi Survey of Some 'Minimalist' Tendencies in the Quantitatively Minimal Dance Activity Midst the Plethora, or an Analysis of Trio A," Minimal Art, A Critical Anthology, ed. Gregory Battcock, 263-73; Richard Kostelanetz and R. Fleming, Writings on Glass: Essays, Interviews, Criticism (Berkeley and Los Angeles: University of California Press, 1997), II4-I6.

7 Donald Judd, "Specific Objects," reprinted in Judd, Complete Writings, I8I.

8 Ibid., I8I-89.

9 "Notes on Sculpture. Part I," in Minimal Art, A Critical Anthology, ed. Gregory Battcock, 224.

Io See also Sol Lewitt's comments in "Paragraphs on Conceptual Art," Artforum 5 , no. Io (Summer 1967): 80: "No artist I know will own up to any part of this," 
The first exhibitions that try to deal with Minimalism are equally heterogeneous. "Black White and Gray," organized by Sam Wagstaff at the Wadsworth Atheneum in 1964, included Jim Dine and Andy Warhol along with Morris. "Primary Structures," organized at the Jewish Museum by Kynaston MacShine in 1966, included Anthony Caro and other painted sculpture, along with Morris and Judd.

Judd's inclusion of Oldenburg's Switches in his analysis of contemporary sculpture indicates that he was looking at other things than simple, geometrical form as a defining characteristic. During the run of "Primary Structures," he came under intense attack for arguing that the hand of the artist was irrelevant and that the fact that his work was fabricated by industrial specialist fabricators made no difference to its authenticity as art. ${ }^{\text {II }}$ This emphasis on industrial techniques prompted many critics to ally his work with the commercial techniques used by Warhol. And there doesn't seem to be much difference in form or technique between a stack of boxes by Warhol and one by Judd.

The articles by Judd and Morris belong to a very particular art world context, one that was both commercially and critically defined, and extremely competitive. "Pop" by 1963 had had successful exhibitions by dealers and museums on both coasts: many New York dealers were looking for the next big thing and Minimalism was a favorite choice. Leo Castelli, who had been the first to exhibit Johns and Rauschenberg, signed up both Judd and Morris in 1965 when their previous gallery folded. ${ }^{2}$ The first major museum exhibitions devoted to Minimalism were held in 1964 and 1966, as noted above. The seminal articles on Minimalism are those by Barbara Rose, "ABC Art" published in 1965, and Michael Fried's "Art and Objecthood" published in $1967 \cdot{ }^{13}$ Rose's article attempted to define the movement while Fried's article attacked it furiously for being inherently theatrical. Fried's article provoked an equally strong reaction: many critics felt Fried had erred grievously by focusing on Morris to the exclusion of Judd, a result, they felt, of his fundamental error in moving away from New York. Fried was no longer in the know, no longer had his finger on the real pulse of the New York art world. ${ }^{\text {I4 }}$ The particular issue of ArtForum that Fried's essay appeared in, also included essays by Morris on sculpture and Sol Lewitt's essay on conceptual art. In other words, this was a largely family squabble turned universal because of the peculiar power of New York City art world institutions. New Yorkers think they speak for the world, and these critics felt that the rest of the world

meaning Minimalism.

II See Mark di Suvero, Donald Judd, Kynaston McShine, Robert Morris, Barbara Rose, “Symposium on The New Sculpture,"New York, May 2, 1966, in James Meyer, Minimalism (London, New York: Phaidon, 2002), 220-22.

I2 See Anne Cohen Solel, Leo Castelli and His Circle (New York: Alfred E. Knopf, 2OIO).

I3 Michael Fried, "Art and Objecthood," Artforum 5, no. Io (Summer 1967): I2-23.

I4 See Philip Leider's comments in Amy Newman, Challenging Art: Artforum 


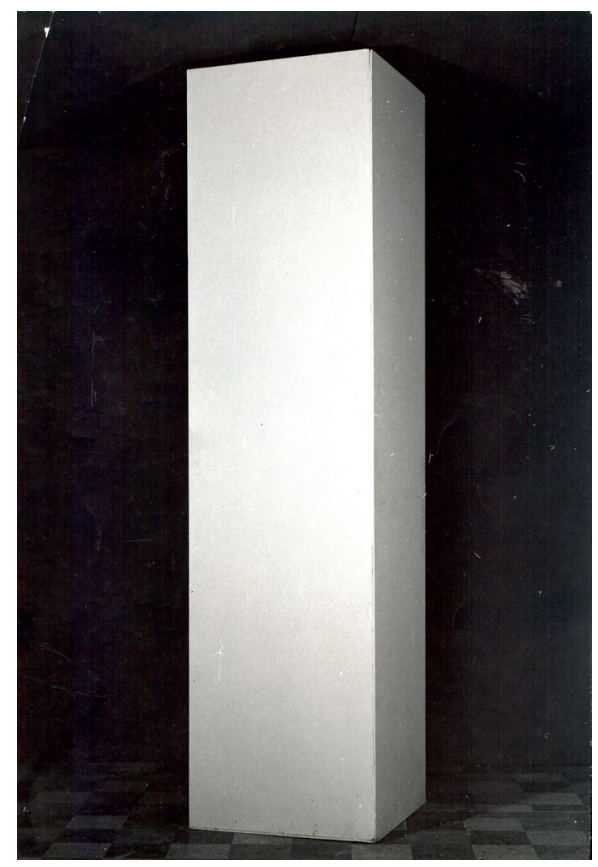

Fig. I. Robert Morris, Column, 196r. Photograph courtesy of Castelli Gallery, New York. (C) 2020 The Estate of Robert Morris / Artists Rights Society (ARS), New York

was irrelevant - and they have been successful in pushing that point of view because of the strategic and cultural power of the USA.

Moreover, Minimalism was one of a variety of terms used around 1964 to 1966 to describe what we call Minimalism today. "ABC art" was the term used by Barbara Rose in the first general article on the movement. "Literalism" was equally in play. ${ }^{15}$ Each term directs one's attention to different aspects of the work. "ABC art" suggests the basic building blocks of language and comprehension of the world. "Minimalism" invites us to inspect the visible formal aspects, as though the essential point is to carve away any excess of form to get to an irreducible core of meaning. "Literalism" points in another direction, to a one-to-one mapping of the object against some perceived reality. Morris's 196I work Column, for example, as a Minimalist object is a platonic ideal form; as a Literalist one it is a gray plywood box of a certain dimension (Fig. I).

Finally, the minute Minimalism was canonized as a certified category or art movement, younger artists reacted against it. Mel Bochner confidently saw himself, Richard Serra, Eva Hesse, and others as post-Minimalist by 1966, the year that "Primary Structures" established Minimalism publicly. In other words, Minimalism was over before it had been named. ${ }^{16}$

To examine the limits of usefulness of Minimalism, and its associated meanings, let me focus even more closely, on just one object, Robert Morris's Column of 196I, arguably the first and most iconic large-scale Minimal sculpture, what the Guggenheim Museum curator Jeffrey Weiss calls: "Morris's first, now legendary 'large form' work." ${ }^{\text {17 }}$ It is, or was, constructed out of two sheets of plywood, 4 by 8 feet, each cut in half lengthwise, assembled and painted light grey.

Generally, Column is read in terms of either Gestalt psychology or phenomenology: that is to say, it is apprehended as a whole; it exerts a presence that is equivalent to a bodily presence and exists in our space and acts on us. As Morris wrote five years later: "The better contemporary sculpture takes relationships out

I5 See James Meyer, Minimalism: Art and Polemics in the Sixties (New Haven: Yale University Press, 200I), 3.

I6 Mel Bochner quoted in Newman, Challenging Art, 26I.

I7 Jeffrey Weiss, "Eternal Return: Jeffrey Weiss on Robert Morris's Recent Work," Artforum International 52, no. 6 (February 20I4): 176. 
of the work and makes them a function of space, light and the viewer's field of vision [...]. One's awareness of oneself existing in the same space as the work is stronger [...]. One is more aware than before that he himself is establishing relationships as he apprehends the object from various positions, etc." ${ }^{18}$ In other words, Morris rejects the individual or emotional excesses of Abstract Expressionism, or even the affectlessness of Pop, and places meaning in real, kinesthetic or physiological responses. "The sculptural facts of space, light and materials have always functioned concretely and literally," Morris claims. ${ }^{19}$

But Column began its material, phenomenological presence not as a sculpture but as a dance prop, built by another sculptor, George Sugarman. Sugarman built it and painted it bright yellow, for the choreographer Yvonne Rainer's first dance concert in June 196I, a short dance, just 8 minutes long, called The Bells, in an evening of dances organized by the choreographer James Waring. ${ }^{20}$ After the evening was over, the prop was hauled backstage at the Living Theater, where Morris claimed it and took it back to the studio space he shared with his wife, Simone Forti, and Yvonne Rainer: the two dancers had the large room and he had a small room with a 7 -foot ceiling. Rainer, when she performed The Bells again (just two more times) did not use the prop-she never really understood why Sugarman insisted on building it for her in any case. And then the dance dropped out of her repertoire, and survives only in one or two photographs and a dance score.

Morris's Column has a conditional physical and documentary existence not so different from The Bells. He deployed Column in a performance, also staged for Waring at the Living Theatre, on February 8, 1962, as part of a program to raise funds for the publication of La Monte Young's An Anthology of Chance Operations. Waring gave each of the participants seven minutes and Morris's plan was to stand inside the column for three and a half minutes and then push it over, with himself in it, and let it lie there for another three and a half minutes until the curtain closed. On the day of the performance, Morris rehearsed it for the first time in the morning, splitting the skin on his forehead open when he hit an internal brace. Returning to the studio about five hours later after visiting the emergency room, he hammered a short nail at the top, attached a string to it, and during the performance, standing safely out of sight in the wings, pulled it over. ${ }^{2 I}$

Like Duchamp's Fountain, Morris's Column is a found object that is appropriated, signed, and re-presented through a different orientation and context. Unlike Fountain, however, Column did not begin existence as an anonymous,

I8 Morris, 'Notes on Sculpture. Part II,' 232.

I9 Ibid.

20 Yvonne Rainer, Feelings are Facts: A Life (Cambridge: MIT Press, 2006), 235. The existence of the prop is confirmed by Rainer's comments in "Notes on Deborah Hay," Ikon (February I967): 2-3.

2I Robert Morris's interview with Paul Cummings gives the full details. Oral histo440 ry interview with Robert Morris, March Io, 1968. Archives of American Art. 
industrial object, but as a prop by another sculptor, George Sugarman, a sculptor who the year before had pioneered the creation of large-scale sculpture that sat on the floor without a pedestal. We can see Column then, perhaps, as a collaboration among three artists: Sugarman, Rainer, and Morris. Remembering Column's origins in two performances, we should remind ourselves of the fact that the original object was constructed to stand on a stage, with a dancer in front of it and much the same size as the dancer, and to mediate the space between the dancer and the architectural frame around her, while activating the visual field with a little lively color. Morris's appropriation of the object for his performance relies on this knowledge - the perfection of its size to house his living body, now inside the piece instead of outside, static instead of moving, and transferring the action of his body to the movement of the sculpture (which was accomplished, even when he was reduced to pulling it over, by jerking his hand to produce the action of the column). Morris's performance can be seen as a negation of Rainer's, a male performance inside the column ("the transcendental phallic signifier triumphant" he ironically calls it later) instead of a female performance dancing around it. ${ }^{22} \mathrm{He}$ says of his early pieces that he needed "to make something that had a scale necessary for the body to encounter"; i.e., that a phenomenological element was crucial. ${ }^{23}$ In this case, the body encountered is both outside (Rainer) and inside (Morris) the object. We should read it not just as a grey column but also an anti-yellow column, not just as a sculpture, and not just a stage prop, but a performer in its own right.

The actuality of Column's presence and the conceptual clarity and richness of Morris's performance during Waring's benefit evening, which are self-evident to us over fifty years later, were in fact a very mixed bag of intentions and meanings: among the audience were those who thought they knew Morris was in the column, those who knew he wasn't, and those who didn't know either way. And for all the retrospective theorizing about the meaning of Column, it is curious that Morris put so little thought into how wedging his body at an angle into the box might have awkward physical consequences. Nor should one forget the humorous aspect. I bet it got a big laugh and a squeal or two of surprise when it toppled over with a bang on stage, after standing there doing nothing for three-and-ahalf interminable minutes. The "phallic signifier" had deflated. Did anyone wonder what would happen next: would it crawl off-stage? So the prop becomes an actor, the ugly duckling becomes a swan. It's not so much that the column turns into a person; it's still a column but now it's an acting column, a talking dog. It goes from background, a thing on the stage, into our lives where accidents happen and things fall over. It falls into the realm of the real, in a different sense from the phenomenological "realness" of Minimalism. Since Column is only

22 Robert Morris, Have I Reasons: Work and Writings 1993-2007 (Durham: Duke University Press, 2008), 89.

23 Benjamin Buchloh, "Conversation with Robert Morris," October 70 "Three Conversations in 1985: Claes Oldenburg, Andy Warhol, Robert Morris" (Autumn 1994): 51. 
Fig. 2. Simone Forti, Slant Board, I96I, performed at the Art, Design \& Architecture Museum, UC Santa Barbara, with Forti observing, 2017. (C) 2019 The Museum of Modern Art, New York.

intermittently material, its real existence is both performative (and hence transitory) and conceptual (and thus, seldom phenomenological), and it is called into repeat per-

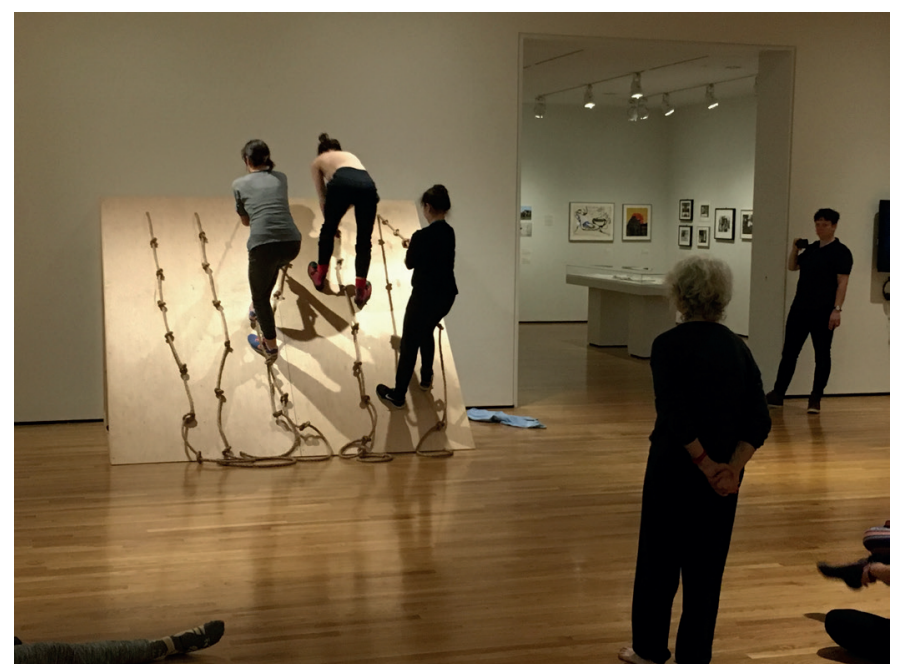
formances through the forces of market and reputation, on view always only in temporary situations.

In fact there are three more players involved in the creation of Column. Two I have mentioned already, Simone Forti, Morris's wife, and La Monte Young, a composer from the Bay Area who was actively connected to John Cage and to the musicians and artists who were part of Fluxus. Young had curated a series of evening concerts in Yoko Ono's loft in the spring of 1961, where Simone Forti had presented her second dance concert. One of the most famous of these dance constructions is Slantboard, two sheets of plywood $4 \times 8$ feet, angled against the wall, with five ropes tied to it along the top (Fig. 2). The performers work up and down and across for Io minutes or so. The structure was made by her husband, Morris, who also made several other structures, including two boxes under which the performers lay and whistled to each other. These forms resonated throughout Morris's career, an influence he has made handsome tribute to. La Monte Young also prompted a work from Morris, a conceptual piece for his Fluxus Anthology of Change Operations, entitled "Blank Form": "A column with perfectly smooth, rectangular surfaces, 2 feet by 2 feet by 8 feet, painted gray." ${ }^{24}$ This would have constituted the second public appearance of Column, if Morris had not withdrawn the piece from the publication.

The last player involved is Walter de Maria, who had known Morris and Forti in San Francisco before moving to New York in 1960, just a few months after they arrived. He had begun building boxes in California, mostly small but a few were larger, and continued to build more after coming to New York. He and Morris and Forti saw each other practically every day for the first year or two, before Morris and Forti divorced in early 1962, and de Maria realized that he and Morris were now, in his words, "competitive rather than collaborative." ${ }^{25} \mathrm{He}$ also

24 Morris withdrew the piece from An Anthology of Chance Operations, and it was not published until much later.

44225 Oral history interview with Walter De Maria, October 4, 1972, Archives of 
contributed a piece to La Monte Young's Anthology, dated February I96I (that is, well before Sugarman had built the prop for Rainer): "I have built a box eight feet high. On top place a small gold ball. Of course no one will be able to see the ball sitting up there on the box. I will just know it's there." He exhibited a few of his boxes, and perhaps this one, in July 196I, just before Rainer's performance of The Bells. So the first 8-foot tall plywood rectangular sculpture Morris saw was de Maria's. Thus, to sum up the circumstances of Column's birth, three sculptors, two choreographers, and one composer were involved, in venues as diverse as the Living Theater and a Fluxus performance. The impure state of the original (or actually, the second physical manifestation of the) object was implicitly acknowledged by Donald Judd. He recalled seeing it in the 1963 group show and disliking it so much, he and Lucas Samaras shoved it around the room to get it out of the way. ${ }^{26}$ Perhaps he was one of the people who knew that Morris was supposed to have been inside it in the first instance?

A year after Morris's performance outside the column, Column reappeared in the first exhibition of his large-scale plywood sculptures at a group show at Green Gallery in January 1963. It appeared again in Sam Wagstaffs "Black, White and Gray" exhibition at the Wadsworth Athenaeum in January 1964, and was constructed in the gallery by Morris. By the end of 1965 , Morris's large plywood pieces were being fabricated in fiberglass molded over plywood cores, so that in the 1965 exhibition at Green Gallery, the forms are composed of gray fiberglass. When Column appeared in his 1969 Corcoran show, it was still in a painted plywood version, however, and was constructed in the gallery, almost certainly by the museum's own carpenters.

By 1973 Column was paired with another column, this one lying down, recreating the two positions of the column in the initial performance, thus implying the motion in between. Morris later suggested that the "action" of Column was implicit or inspired by its position in his seven-foot ceiling studio: it lay on its side and he couldn't set it upright. ${ }^{27}$ This version of Columns (henceforth they would always be paired) appeared in an edition fabricated in aluminum. Morris recounts that he himself made the early plywood pieces whenever needed; and that if a museum or gallery "in Milwaukee say" wanted to exhibit any of them, he just got them to fabricate them and paint them the usual gray. Morris has explained that the gray-painted plywood boxes from 1964 "were competently made but not expertly made." It was easier for him to construct them for exhibitions and toss out afterward than to build permanent works. "I said at some point there are no originals of these [...]. There are only reproductions. Nobody [back then] wanted to hear that." ${ }^{28}$ One time he sent assembly instructions for

American Art.

26 Donald Judd, interview by Lucy Lippard, April I0, 1968, Lucy Lippard Papers, Archives of American Art, Smithsonian Institution, Washington, D.C.

27 Wade Guyton, “Robert Morris," Interview, January 6, 20I4, 3, http://www. interviewmagazine.com/art/robert-morris.

28 Robert Morris, interview with Jeffrey Weiss and Julia Robinson, New York Pub- 
the pieces to a museum, whose workers "built them too well—and that offended me. If you make these things too well, they look like God made them.” So Column, or its sibling Columns, was made and destroyed a number of times around the world, and not just in Morris's studio, before being immortalized in aluminum. One set of Columns is in the collection of the Tehran Museum of Contemporary Art, in aluminum, acquired in the late I970s; another, in painted plywood, was acquired in 2006 by the Museum Abteiberg in Mönchengladbach, in North Rhine-Westphalia, Germany.

The canonization of Column starts with Rosalind Krauss's game-changing 1977 monograph, Passages in Modern Sculpture, having been included (and reproduced in the catalogue but not discussed) by Annette Michelson in Morris's first major retrospective at the Corcoran in 1970). Krauss begins her discussion of "theatricality," a stringent analysis of Michael Fried's attack on Minimalism, with a description of the first appearance of Column in 1961, which she uses as the linchpin of her discussion of the sculptural involvement in theater, happenings, and kinetic art. Returning to Column at the end of the chapter, she introduces the phenomenology of Merleau-Ponty as an analytical tool. ${ }^{29}$ This discussion sets the terms for most of the critical literature about both Morris and Minimalism for decades.

Putatively, in this art history, as a large-scale Minimal sculpture, Column is a stable material object, one that produces its principal, phenomenological effect by interacting with the viewer's experience of the space in which it sits. That is what Minimal sculptures are. But in actuality, Column is many objects, most of which don't exist anymore or exist in states that make them unviewable: mostly in museum basements, with the most inaccessible probably being the basement of the Tehran Museum (over forty years by now). How they are actually experienced and talked about is on the basis of photographs. The art historian Amelia Jones makes the point that she doesn't have to see Morris's original Minimalist sculpture to be able to write about it: for her, and for most commentators, it exists only as a photograph (and the texts written about them), not so different from The Bells, the ephemeral dance that inspired its initial creation..$^{30}$ Morris has acknowledged exactly this issue: "To view the work in these [semiotic] terms we do not, needless to say, need the art. A few old photographs will do together with a few of your own old notations." ${ }^{3}$

What are we to make of Morris's purpose and intention when he recreates the piece as he does immediately? In all of the works first appearances, it is literally a new work, created for that occasion. The dimensions, construction and color remain the same, but the actual piece is new. Morris himself agreed that these first

lic Library, April 16, 20I4, https://www.nypl.org/audiovideo/object-sculpture1960-1965-robert-morris-julia-robinson-jeffrey-weiss-artist-dialogue.

29 Krauss, Passages in Modern Sculpture, 20I-3, 236-39.

30 Amelia Jones, Performing the Body/Performing the Text (London and New York:

Routledge, 1999), 47.

444 3I Morris, Have I Reasons, 87. 


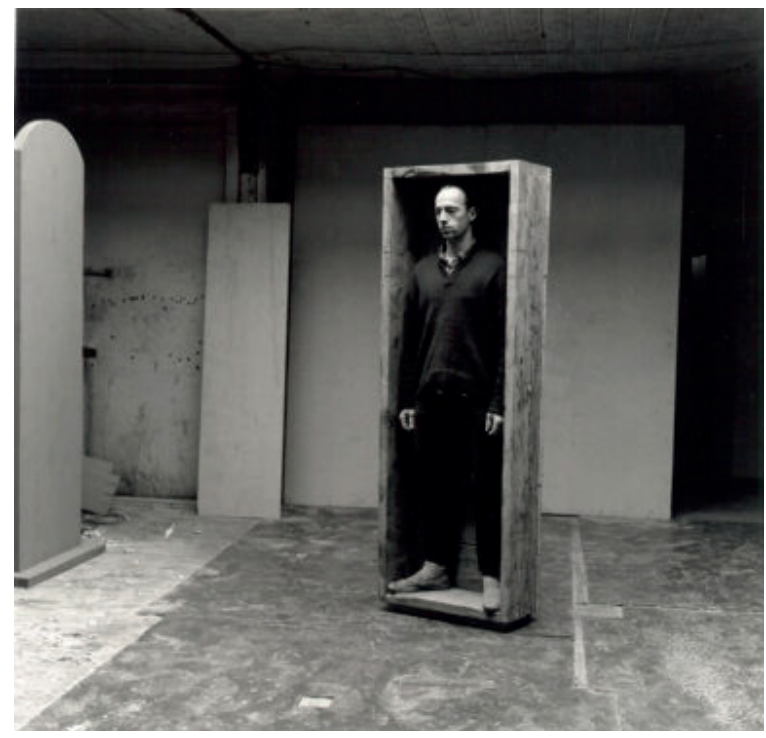

Fig. 3. Robert Morris, Box for Standing, I96r. Photograph courtesy of Castelli Gallery, New York. (C) 2020 The Estate of Robert Morris / Artists Rights Society (ARS), New York

large-scale pieces were conceptual. So they are both immaterial and material, both conceptual and phenomenological-two terms at war with each other.

Moreover, how do we understand our experience of Column when Morris recreates Box for Standing in walnut, as well as creating new Columns (Serrated, Twist, and Spiral), by hiring a professional fine carpenter, Josh Finn, for an exhibition at Sonnabend Gallery in 2013? We are certainly not reacting innocently, in the same way as a viewer in 1962. Yvonne Rainer remembers early Minimalist sculpture as humorous, as close to Dada, and regrets that the humor has been drained out of the work as it has become part of the art history canon. ${ }^{32}$ For early viewers like her, Column's first appearance, as I have suggested, must have provoked both alarm and laughter. The piece that Morris has always tied to Column as his first two mature works, Box with the Sound of its own Making, is even more explicitly Dadaist: this is a box that contains a tape of the sounds made during the three hours or more that it took Morris to make it. The history of this work, despite the fact that it has existed in a stable material form (putatively) from I96I, has its own complications: the technology of recording has changed so much (first being miniaturized and then digitized) that it is hard to say that what we hear today is what was heard when the work was first created. To ignore these complications is both to be gullible and willfully blind to the ways in which works of art evolve and degrade over time.

Morris always has had a tendency to irony, and a savage desire to dismantle the pieties of the art world, even as he partakes of it; the most recent version of Column addresses the world of art history explicitly (as Morris has done in a series of performances as early as 1964), exhibited along with other sculpture/ prop/performance pieces, such as Box for Standing, a work from 196I (Fig. 3). When a viewer encounters this Box or Column, they are not experiencing it phenomenologically_in some universal, transhistorical bodily response. It is not a minimal object but a Minimalist object; we don't react to it, we recognize it. And we recognize it through the apparatus of art history. In other words, these

32 Yvonne Rainer, interview by Connie Butler, New York, July 7, 20II, Museum of Modern Art Oral History Program Archives, New York. 
recent recreations, in Morris's sly fashion, are conceptual works that address the intersection of academic art history and the art market: they belong to the same "style" of art that Jeff Koons's work does, not Minimalist sculpture.

The real job of art history today, then, is not to certify Column's Minimalist credentials, but to attempt to deconstruct our art historical recognition of it. We cannot go back, of course, but we can recreate the context of the work's creation and reception, before it became Minimalism. To do anything else is to make us merely agents of art history, rather than art historians.

And in one last complication, we might consider work by Francesco Lo Savio, exhibited in Rome in 1960-before Morris had made a single sculpture and was still considering becoming an art historian. ${ }^{33}$ It is now celebrated as a European precursor to Minimalism, for the obvious reason to claim European priority for the movement. Is there a reason not to call it Minimalist? The two obvious reasons have nothing to do with the object in its material existence. The first is that for Lo Savio, the piece existed within a discourse on architecture and the Baroque. The second belongs the point I have been making throughout this paper: Minimalism is a retroactive construction of critics and art historians, which can be both helpful and unhelpful for us today.

In conclusion then, if we can look past received art historical narratives, and abandon the easy shorthand of art historical terms, we discover exciting and interesting harmonies and dissonances between the modernisms of China and the United States, as both nations grapple with the changing conditions of existence and the dramas of history during the last century. The relationship between Pollock and Wu Guanzhong is not just between American Abstract Expressionism and a Chinese modernist, but ultimately between two artists and two art works.

33 Germano Celant, ed., Spazio e Luce/Francesco Lo Savio (Turin: G. Einaudi, 1975). For a recent exhibition of these works see Casoli de Luca: https://www.casolideluca.com/en/rome/passate/francesco-lo-savio/. The connections between American and Italian artists in the 1950s and early 1960s were profound and rich: one can consider the effect Italy had on Cy Twombly and Robert Rauschenberg, on the 446 one hand, and Lucio Fontana's presence in New York from 1958 onwards. 


\section{反思 60 年代 : 艺术史的历史}

布鲁斯・罗伯森

以美国的角度来看，在 这次会议的背景下，重新思考一些现代主 义早期叙事是十分有用的。我们熟悉的现代主义叙事肇始于巴黎(根 据对风格或内容的不同侧重，被定位在 19 世纪中叶或 20 世纪初), 之后在全球蔓延开来。在这个叙事中，上个世纪的所有其他艺术都 变得次要，直到二次世界大战之后，这些过程，在另一个城市重新 展开一也就是纽约抽象表现主义的兴起。由此，美国艺术不再是附 属的或老派的，而是处于领先位置（而其他的现代艺术传统 实际 上已被美国人所忽略)，在 60 年代，战后艺术成了当代艺术。

在这个传统故事里，20 世纪前半叶的中国与美国与现代主义的 关系是相同的，两者初涉现代艺术，都只是因循而非开创新的风格 与观念。20 世纪后半叶，中国与美国相比，处在了落后的位置上， 直到最近的二十余年，情况才有所改变。但这是一个乏味与无趣的 故事，我们可以拒绝这种陈述方式，构建更为复杂的故事，这也是 此次会议的意图。但这是一个乏味与无趣的故事，我们可以拒绝这 种陈述方式，构建更为复杂的故事，这也是此次会议的意图。

在美国，上一代艺术史家一直在寻找现代主义的本土根源：波 洛克（画作的景象植根于 I9 世纪巨幅风景画，比如弗雷德里克· 切奇的（Frederick Church）《尼亚加拉》(Niagara)。或者从阿 尔 弗瑞德 · 卫斯理 · 道 (Alfred Wesley Dow) 的教学中以及从约 翰. 特瓦赫特曼 (John Twatchman) 的部分作 品中找到抽象的根源，这 也是从詹姆斯 - 麦克 尼尔 - 惠斯勒 (James McNeil Whistler.) 的脉 络上延续而来的。1

我们可以认定，世界范围内对晚期资本主义的反应必定将我们 引向多种现代主义的认知, 不论是美国本土还是外部世界都是如此。 举一个例子，我所展示的这三幅作品都是在 1926 年的同一个月份

1 Ellen Johnson, Modern Art and the Object (New York: Thames and Hudson, 1976); and Barbara Haskell, Georgia O'Keeffe and Abstraction (New York: Whitney Museum and Yale University Press, 2009). 
创作于旧金山，一幅是米奇 - 早川（Miki Kayakawa）的非裔美国 人肖像，一幅是华裔美国画家沅芷的哈亚卡瓦正在创作肖像画，还 有一幅由上述两位艺术家在创作肖像画，还有一幅由他们的老师奥 蒂斯·欧菲尔德 (Otis Oldfield) 创作的沅芷肖像。米奇·早川 (Miki Hayakawa I899-1959) 与沅芷 (Yun Gee 1906-I963) 在位于旧 金山 的加州艺术学院曾 是同班同学。元芷生于 日本北海道, 9岁移民 美国; 米奇- 早川生 于中国开平，I5 岁移居 美国旧金山，投靠他 的父亲 (父亲已在美国拥有合法居留身份)。奥 蒂斯·欧菲尔德 (Otis Oldfield I890-1969) 是他 们的老师, 曾在法国接受教育。在那时候, 可 以看到日裔美国女性创 作的华裔美国男性的肖像画, 华裔美国 男性创 作的日裔美国女性的肖 像画, 以及, 安哥拉裔 美国男性创 作的华裔美 国人的肖像画。这些肖像画为法式现代风格，的在日 积月累中适结合 适应了当地文化环境。 ${ }^{2}$ 这一系列的图像表达了不 同族群与风格的复杂漂泊状况以及对种族与性别的建构。

在接下来的三天中，我们建议采取一种并置的策略，而不是将 焦点集中在中国与美国艺术的显而易见的联系上，或者关注双方艺 术文化互动的特定时期。我们不会提出单一的现代主义或后现代主 义的定义, 而有可能出现多种定义。我们会进行内在意涵的分析与 讨论, 而不是一开始就进入预设前提。否则, 我们会迷失在上个世 纪以来两个国家及其历史的如此明显而又重要的诸多差别之中 : 其 中的一个国家，有着数千年的历史与传统，相对较晚才进入现代社 会 ; 另一个国家则是没有那么丰富的历史，却总是以现代化自居。 但是，我相信，我们两个国家在如何运用自己的传统，或如何通过 创新和借鉴，理解上个世纪以来所经历的社会、文化和技术的变迁 上，是可以发现很多相似之处的。

在接下来的内容中，我将以一个可资借鉴的例子，来说明艺术 史本身是如何扭曲了亟待我们去发现的历史的，并作为我们接下来 几天会议讲演的背景。我将检视我们所使用的术语如何掩饰、甚至 遮蔽了我们的研究对象, 并且会提请大家来考虑这样一个问题 : 在 艺术史尚未形成一个众所周知的现代主义历史的标准叙事时，艺术

2 Woollin Kim, Jinmyung Kim, and Songhyuk Yang, Art across America 
史又意味着什么。也即是说，要去创造一种新的艺术史，以拓宽我 们对于现代主义的感知与认识。

为更好地说明我的意图，我会致力于分析上个世纪被研究的最 多的十年一 1960 年代，也就是半个世纪以前，我们当中的很多人 都对之有着鲜活记忆，在这个世纪最后 25 年间产生的艺术史文献 数量, 几乎与意大利文艺复兴文献数量一样庞大。但是, 我所要说 的很多的内容是可以运用到任何一个艺术史的阶段中去的。

让 20 世纪 60 年代变得如此重要的原因，是在于它实现一种范 式的转换，这个时期的艺术家的活动勾勒出了美国艺术持续至今的 疆域。这个革命的术语概括如下：

I. 艺术家创作媒介的拓宽 : 演示，装置以及混合媒介的激增。

2. 对大众媒体价值的估价与确认。

3. 观念艺术的主导以及批评家、艺术家与艺术史家话语的激增。

4. 身份政治与艺术的兴起。

5. 规模庞大的新兴商业艺术世界的支配地位（以及随之而来的艺术 机构的兴起)。

我们用一些简称来处理这种艺术的诸多发展的复杂性与共时性 : 偶发艺术、波普艺术、激浪艺术等等。虽然很实用，但是，它 们在产生意义的同时，也掩盖了部分意涵。我将以“极少主义” (Minimalism) 为例来探索这个问题，质疑它对艺术史家的意义。

在一般描述中，极少主义被认为是现代主义巅峰一以克莱蒙特 格林伯格（Clement Greenberg）所使用的意涵，它是对雕塑与绘 画媒介中的抽象与自我批判性，以及物质材料与形式功用的最终明 确。但正如近年学界所论，极少主义基本被认定为后现代主义，它 与波普艺术一起，抵制情绪反应与个体性，极少主义与波普艺术同 时兴起，产生于相同的环境，并且有一样的谱系。 ${ }^{3}$ 但很显然，它

3 Rosalind E. Krauss, Passages in Modern Sculpture (New York: Viking, 1977); Michael Fried, "Art and Objecthood," Artforum 5, no. Io (Summer 1967): 12-23; Barbara Rose, "ABC Art," Art in America 53, no. 5 (October-November 1965): 57-69, reprinted in Minimal Art: A Critical 
无法同时属于现代主义与后现代主义 : 这是第一个问题，而且，在 某种程度上, 这个问题在 60 年代也存在于其他作品中, 这引发了 对现代主义与后现代主义这两个术语的价值的质疑一它是否具备批 判价值。

极少主义吸引如此多关注的原因之一，是在一次对话中, 当 时最优秀的批评家为之辩护, 比如罗莎琳德 - 克劳斯 (Rosalind Krauss)，芭芭拉·罗斯（Barbara Ross），迈克尔·弗雷德（Michael Fried）以及其他一些人，当然，也有艺术家自己撰写的文字，尤 其是罗伯特 - 莫里斯 (Robert Morris) 和唐纳德 - 贾德 (Donald Judd)。 ${ }^{4}$ 这批人中, 有相当一部分人也接受过艺术史训练, 比如罗 伯特 - 莫里斯, 他的硕士论文主题是布朗库西。换句话说, 我们应 该重视这些艺术家对于自己作品的说辞, 这个话题我后面还会提到。 第二, 这是一个在相近领域中几乎会被立刻使用的标签。编舞者伊 万诺・雷纳尔（Yvonne Rainer）于 1965 年将之引用到舞蹈中，作 曲家麦克·乃曼 (Michael Nyman) I968 年将之运用到音乐创作中。 ${ }^{5}$ 也就是说，这个术语的适用性十分宽广，即时有效地运用在艺术的 各个领域。

与此同时，它被一些视觉艺术领域中的主要人物所否定，他们 不认为这个术语与他们的艺术间有什么关联。唐纳德 - 贾德愤怒地 抵制这个术语：他更喜欢用 “特定的对象” (specific objects)，并 且, 明确指出 “这种新的三维作品并没有构建一个运动、流派或者 风格。差异要比相似大得多。这种相似性是从作品中撷取的; 它们

Anthology, ed. Gregory Battcock (New York: Dutton: 1968), 290.

4 Donald Judd, Complete Writings, 1959-1975 (Eindhoven: Van Abbemuseum, 1987), I97ff; Robert Morris, "Notes on Sculpture," in Continuous Project Altered Daily: The Writings of Robert Morris (October Books, I995).

5 Yvonner Rainer, “A Quasi Survey of Some 'Minimalist' Tendencies in the Quantitatively Minimal Dance Activity Midst the Plethora, or an Analysis of Trio A," in Minimal Art: A Critical Anthology, ed. Gregory Battcock, (New York, 1968); Richard Kostelanetz and R. Fleming, Writings on Glass: Essays, Interviews, Criticism (Berkeley and Los Angeles: University of California Press; New York: Schirmer Books, I997), II4-I6. 
不是一场运动的首要标准或限定的规则”。 ${ }^{6}$ 在 1964 年题为《特定对 象》的论文中，贾德把那些在今天不会被称为极少主义者的一大批 艺术家，比如贾斯伯 ·约翰斯（Jasper Johns）、卢卡斯·萨马拉斯 (Lucas Samaras)、草间弥生 (Yayoi Kasuma) 以及奥登伯格 (Claes Oldenburg) 等人包括进来。 ${ }^{7}$ 罗伯特·莫里斯在他 1966 年的论文《雕 塑笔记》(Notes on Sculpture) 中从头到尾没有使用 “极少主义” 这个词，而是使用 “原义性” (literal) 来描述自己的作品。 ${ }^{8}$ 索尔. 莱维特（Sol Lewitt）1967 年说，没有一个艺术家可以声称自己了 解这个术语的一切，以此来认定自己，而且也不同意被贴上这样的 标签。9

第一批试图整合极少主义的展览同样是成分混杂的。1964 年 由山姆·瓦格史大夫 (Sam Wagstaff) 在 华资沃斯雅典娜神庙 (Wadsworth Atheneum) 主办的展览《黑白灰》（图 I，Black White and Gray)，将吉姆·戴恩（Jim Dine）、安迪·沃霍尔 (Andy Warhol) 和莫里斯放在了一起。1966 年《基本结构》(Primary Structures) 则将安东尼 - 凯罗（Anthony Caro）和莫里斯与贾德 放在了一起。

贾德在他的关于当代雕塑的研究中将奥登伯格 (Oldenburg) 的 作品《开关》（Switches）包括在内，表示了他正在寻找其他简单 的几何形式作为一种可定义的特征。在《基本结构》的写作过程中, 他因为认定艺术家的手工已不再重要而受到攻击，而且，他的作品 由专业的工业制造者制作的事实，也并没有影响到其作为艺术品的 原真性。 ${ }^{10}$ 这种对于工业技术的强调促使很多批评者将他的作品与

6 Donald Judd, "Specific Objects," reprinted in Judd, Complete Writings, I8r.

7 Ibid., I8I-89.

8 "Notes on Sculpture. Part I," in Continuous Project Altered Daily: The Writings of Robert Morris (Cambridge: MIT Press, 1995).

9 Sol Lewitt' s comments in "Paragraphs on Conceptual Art," Artforum 5, no. Io (Summer 1967), 80: "No artist I know will own up to any part of this," meaning Minimalism.

10 Mark di Suvero, Donald Judd, Kynaston McShine, Robert Morris, 
安迪・沃霍尔使用的商业化技术联系在一起。而且, 安迪·沃霍尔 的一组箱子与贾德创作的箱子之间, 似乎并没有太多形式与技术上 的差别。

贾德与莫里斯的文章属于一个特定的艺术界的语境，它同时被 商业与批评所定义, 且具有强烈的竞争性。1963 年, 由画商与博 物馆策划的波普展览在东西海岸都取得了成功。很多纽约画商开始 寻找下一个令人兴奋的目标, 极少主义成为他们最好的选择。列奥 - 卡斯泰利（Leo Castelli）是第一个为约翰斯与劳申伯格策划展览 的人, 此人于 1965 年与贾德和莫里斯同时签约, 那时, 他们之前 的画廊倒闭了。 ${ }^{11}$ 如上文所示, 首批在博物馆举办的重要的极少主 义展览是在 1964 与 1966 年。关于极少主义的有创见的文章包括芭 芭拉 ·罗斯的《艺术 $A B C 》$, 以及迈克尔 - 弗雷德 1967 年的《艺术 与物性》(Art and Objecthood)。12罗斯的文章试图定义这个运动, 弗雷德则愤怒地指责它固有的剧场做作感。弗雷德的文章引发了同 样强烈的反对 : 许多批评家感到, 弗雷德仅仅关注莫里斯而排挤贾 德是犯了严重的错误, 他们认为, 这是弗雷德远离纽约所导致的根 本性错误。弗雷德不再洞悉艺术世界的变化, 不再触摸到纽约艺术 世界的真正脉搏。 ${ }^{13}$ 《艺术论坛》 (ArtForum) 特刊中出现的弗雷德 的论文, 同样包括莫里斯论雕塑以及索尔莱维特论概念艺术的文章。 换句话说，这是一个已经外化成世界性的圈子内部的风波，原因是 纽约艺术机构的强大力量。纽约人认为, 他们在为世界发声, 那些 批评者觉得, 纽约以外的世界都是不相干的, 而且由于美国战略与 文化的力量，他们成功地推销了这个观点。

极少主义只是 1964 - 1966 年前后各种用来描述我们今天称

Barbara Rose, "Symposium on The New Sculpture," New York, 2. Mai I966, in James Meyer, Minimalism (London, New York 2002), 220-22.

11 Anne Cohen-Solel, Leo Castelli and his Circle (New York: Alfred E.

Knopf, 20Io).

12 Michael Fried, "Art and Objecthood," Artforum 5, no. Io (Summer I967), I2-23.

13 Philip Leider' s comments in Amy Newman, Challenging Art: Artforum 1962-I974 (New York: Soho Press, 2003), 198. 
之为“极少主义”艺术的术语中的一个。“ABC 艺术” 是芭芭 拉. 罗斯在这个运动的第一篇概述文章中提到的术语。“原义主义” （Literalism）也同样在使用。每个术语都把关注点引向了作品的 不同方面。14 “ABC 艺术” 说明的是语言的基本建构以及对于世界 的理解。“极少主义” 让我们审视可见形式的各个方面，仿佛着眼 点是在切除冗余形式，达到原初意义的内核。“原义主义”则指向 另外一个方向，一对一的呈现，对抗某些构想的现实的目标。比如， 莫里斯 I96I 年作品《柱体》 (图 2, Column), 作为一个 “极少主义” 的器物, 是一个柏拉图式的理想形式, 而作为 “原义主义” 的器物, 则是一个特定尺寸的灰色胶合板箱子。

最终，当极少主义被确立为一种既定的标签或者艺术运动，年 轻的艺术家开始反对它。1966 年，梅尔·波切纳（Mel Bochener） 自信满满地将自己，还有理查德·塞拉（Richard Serra）和伊娃· 海斯 (Eva Hesse) 及其他人视为后极少主义者，这一年，《基本结构》 出版确立了极少主义的概念。也就是说，极少主义在被命名前就已 成为昨日黄花。15

为了研究极少主义的使用范围及其关联的意义，可把目光聚 焦在一个对象上，罗伯特·莫里斯 196I-I962 年创作的《柱体》 (Column)，毫无疑问是首个、同时也是最具标志性的极少主义 雕塑, 古根海姆艺术博物馆策展人杰弗瑞·维斯（Jeffrey Weiss） 称之为 “莫里斯第一件堪称传奇的 “宏大形式” 作品”。1 16 它由两张 $4 \times 8$ 英尺的胶合板组成, 每一张都截成两段相同长度, 组合在一起, 涂上浅灰色。

一般情况下, 《柱体》是依据格式塔心理学或现象学加以解读的: 也就是说，它被理解为一个整体，表现出一种等同于身体存在的状 态，处在我们的空间中，并且对我们施加影响。正如莫里斯 5 年后 说的：“更好的当代雕塑是从作品中提取关系，使它们发挥空间、

14 James Meyer, Minimalism: Art and Polemics in the Sixties (New Haven:

Yale University Press, 200I), 3.

15 Mel Bochner in Amy Newman, Challenging Art, 261.

16 Jeffrey Weiss, “Eternal Return: Jeffrey Weiss on Robert Morris' s Recent Work," Artforum International 52, no. 6 (February 20I4): 176. 
光和观者视域的功能，……对于自身处在一个与作品相同的空间中 的意识会更加强烈，会比之前更明确感受到自身所建构的关系，就 是那种站在不同位置上理解对象而获得的关系。” ${ }^{17}$ 换句话说, 莫里 斯拒绝抽象表现主义的个人主义或情绪的泛滥，甚至也拒绝波普艺 术的冷漠, 将意义置于真实的、动态的和社会心理学的反应中。莫 里斯提出, 空间、光与材质的雕塑性的事实总是具体而自足地发挥 功能效用的。18

然而, 《柱体》不是作为雕塑, 而是作为舞蹈的道具而形成其 物质和现象的存在的, 它被另一位雕塑家乔治- 舒格曼 (George Shugarman）所建构。舒格曼建构了它, 并施以亮黄色, 那是为 编舞家伊万诺·雷纳 I96I 年 6 月的第一次舞蹈表演, 一场仅耗时 8 分钟的舞蹈, 称为 《钟声》(The Bells), 编舞家詹姆斯·瓦灵 (James Waringin）在一个舞蹈之夜，把它组构起来。 ${ }^{19}$ 那个夜晚结束后, 道具被拖入剧场后台, 莫里斯认出了它, 并将它带回到他和妻子西 蒙尼・佛提（Simone Forti）以及雷纳共用的工作室，两位舞者占 据了大房间，莫里斯的是一个天花板只有 7 英尺高的小房间。雷纳 再次表演《钟声》的时候, 没有再使用这个道具一她从未真正理解 为什么舒格曼无论如何也要坚持为她搭这个道具。之后, 这个节目 便退出了她的节目单, 只是在一两张照片与一次舞蹈评比中留存下 来。

莫里斯《柱体》的物理与文献的存在，与《钟声》有点相似。 他也在一次表演中运用《柱体》, 还在 1962 年 2 月 8 日瓦灵的现场 剧院（The Living Theatre）中作为舞台布景，是拉蒙特·扬（La Monte Young) 为出版《偶发活动选集》(An Anthology of Chance Operations) 筹措资金的项目的一个部分。瓦灵给每个参与者 7 分 钟的表演时间, 莫里斯的计划是站在柱子内三分半钟, 然后把它推 倒, 自己在横陈柱体里面再保持三分半钟, 直到幕布落下。表演的 那一天, 莫里斯在早上进行了第一次彩排, 因为前额撞到里面的一

17 Morris. "Notes on Sculpture," Part I.

18 Ibid.

19 Yvonne Rainer, Feelings Are Facts: A Life (Cambridge: MIT Press, 2006), 
个支撑物，皮肤撕裂。去了急诊室五小时后，他重返现场，他在顶 端敲一枚短钉，把一根绳子系在上面，表演过程中，他安全地站在 两翼的视线之外, 把它推倒。 ${ }^{20}$

与杜尚《泉》一样，通过不同取向和语境，莫里斯《柱体》是 一个被挪用、标记和再造的现成物。然而, 不同于《泉》的是, 《柱体》 并不是作为一个匿名的工业化物件而存在，而是作为另外一位雕塑 家乔治·舒格曼的道具，乔治·舒格曼在此之前的一年前曾超前地 创作了置于地面的不含石亳材料的大型雕塑。我们当时看到的这件 作品, 是三位艺术家舒格曼、雷纳和莫里斯合作的结果。要知道《柱 体》源头是两次表演，我们需要记住的事实是，最初的物件是在舞 台上被建构和树立起来的，它的前面有一位舞者，其尺度与舞者相

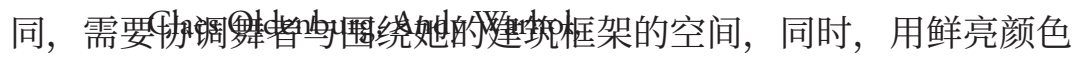
来激活这片视域。 这样一种认识, Buchlop度要正好能容纳他的身体，现在是在柱体内部 而不是外部，是处于静止而不是持续运动的状态，是将他的身体的 行动转化为雕塑的活动（这个部分已经完成，甚至是在他用手来触 发柱体活动，推倒它时就这样了)。莫里斯的表演可视为是雷纳表 演的对立面, 柱体内的男性表演（之后, 他挖苦这件作品, 称之为 “超 验的阳具标志的胜利”)，取代了一位女性围着它舞蹈的表演。 ${ }^{21}$ 他 是这样评价自己的早期作品，他需要 “为了身体的相遇而做一些必 要的事情”, 比如, 现象学因素是至关重要的。22 在这个例子中, 身 体所遭遇的同时存在于这个物件的外部（雷纳）和内部（莫里斯）。 我们不应只是将之解读为一个灰色柱体，还应视之为一个与黄色对 立的柱体，不仅作为一个雕塑和舞台道具，还是一个自足的表演者。

《柱体》实际的在场与莫里斯在瓦灵义演之夜表演的概念的明确

20 保罗 · 卡明斯对罗伯特 · 莫里斯的采访给出了全部的细节。Oral history interview with Robert Morris, March I0, 1968. Archives of American Art, Smithsonian.

21 Robert Morris, Have I Reasons: Work and Writings 1993-2007 (Durham:

Duke University Press, 2008), 89.

22 Benjamin H.D. Buchloh, "Three Conversations in 1985: Claes

Oldenburg, Andy Warhol, Robert Morris,” October 70 (1985): 50-5I. 
性和丰富性，在经历了五十五年之后，对于我们是不证自明的，事 实上，这是一个意图与意义的混合物：在这些观众中，有的人知道 莫里斯在柱体里面, 有的人认为他不在里面, 还有的则是完全不清 楚任何状况。回顾过去关于这件作品的所有理论层面的意义解读, 让人奇怪的是莫里斯对如何将自己身体从一个角度置入箱体会产生

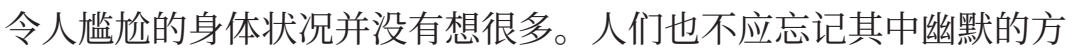
面。我打奢，它站在台上，持续三分半钟，什么动静也没有，之后， 因为一记敲击而倒下，肯定引起了笑场和惊异的尖叫。这个 “阳具 的标志” 很让人泄气。难道没有人猜想下一步会发生什么 : 它会不 会缓慢地爬出舞台? 因此，这个道具成了一个演员，这个丑小鸭变 成了天鹅。这并不是说柱体本身变成了一个人, 它仍然是一个柱子, 但是, 它是一个表演的柱子, 是一只会说话的狗。它从背景里走出 来，是舞台上的一个东西，进入到我们生活里，在这里发生了事故， 有东西跌倒了。它就㛂入了真实领域, 这是一个不同于极少主义的 现象学 “真实” 的领域。既然《柱体》并不总是实体性的，它的真 实的存在既是表演 (因此是转瞬即逝的), 也是概念的 (因此, 几 乎很少会是现象学的), 而且, 通过市场与声誉的力量, 它被要求 重复表演，因此总是在即时的语境中呈现的。

事实上, 《柱体》的创作过程中, 还有另外三位表演者。其中两 位我已经提到过，莫里斯的妻子西蒙·佛提和拉蒙特 - 扬，一位来 自旧金山湾区的作曲家，与约翰·凯奇（John Cage）和其他激浪 派音乐家过从甚密。扬于 $196 \mathrm{I}$ 年在小野洋子（Yoko Ono）的工作 室策划了一系列音乐晚会, 这也是西蒙・佛提展示她的第二场舞蹈 晚会的场所。在这些舞蹈场景构造当中, 最著名的是 “倾斜的板子” (图 3, Slantboard), 两块 4 英尺乘 8 英尺的胶合板, 对着墙面斜放, 上面系五根绳子。表演者来来回回地走上走下约十分钟左右。这个 结构是她的丈夫莫里斯制作的，包括两个箱子，表演者躺在箱子下 面, 彼此窃窃私语。这些形式在莫里斯的创作生涯中不断出现, 拉 蒙特. 扬还极为推崇莫里斯的一件作品, 一件他为激浪派《改变活 动选集》 (Anthology of Change Operations) 创作的概念作品, 题为 “空白形式”（Blank Form）: “一个表面平滑的长方形柱子， 2 英 
尺乘 2 英尺乘 8 英尺的长宽高, 是灰色的。” 23 如果莫里斯没有从出 版物中撤下这件作品，这就会是《柱体》第二次公开亮相。

最后一个参与表演的是瓦尔特 ·德 -马利 (Walter de Maria), 他在 1960 年搬到纽约之前，在旧金山认识了莫里斯和佛提。那时， 他们夫妇也刚到那里几个月。他开始在加州制作箱子，大部分是小 的，也有一些大个的，到纽约之后，做得更多了。马利和莫里斯与 佛提夫妇在头一两年中几乎每天见面，莫里斯和佛提在 1962 年初 离婚之前，德 -马利意识到，他和莫里斯现在的情况，用他的话说 就是 “彼此更像是竞争而非合作关系”。 ${ }^{24}$ 他也有一篇文章收录在拉 蒙特・扬的《选集》中，时间是 $196 \mathrm{I}$ 年 2 月，（也就是舒格曼为雷 纳搭建这个道具之前）：“我做了一个 8 英尺高的箱子。顶部放着一 个金球，当然没有人可以看见箱子上面的这个小球。我知道它就放 在那里。”他展示了几个箱子，也许就是这个箱子，那是在 $196 \mathrm{I}$ 年 7 月，正好是在雷纳《钟声》表演之前。因此，莫里斯看到的首个 八英尺高的胶合板长方形雕塑是德 - 马利的作品。总结《柱体》诞 生时的状况，三位雕塑家，两位编舞者和一位作曲家参与其中，场 所也是多样的，现场剧院和激浪派表演等。这个原初物件的混杂性 （或者实际上就是这个物件的第二种物理状态）是唐纳德·贾德默 认的。他回忆自己第一次在 1963 年 I 月群展中看到它, 非常不喜欢, 他和卢卡斯 - 萨马拉斯将这样作品在房间中推来推去, 让它离开自 己的视线。 ${ }^{25}$ 也许他就是那些在一开始就知道莫里斯应在这个柱子 里面的人中的一个?

莫里斯在柱体外表演之后的一年之后，《柱体》再次出现在他的 首个大型胶合板雕塑展览中，那是 I963 年 I 月格林画廊（Green Gallery）的一个群展。1964 年 I 月, 它又在萨姆·瓦格斯塔夫（Sam

23 莫里斯撤回了一件《改变活动选集》的作品，这件作品在之后很久才被 出版。

24 Oral history interview with Walter De Maria, October 4, 1972, Archives of American Art.

25 Donald Judd, interview by Lucy Lippard, April ıo, 1968, Lucy Lippard Papers, Archives of American Art, Smithsonian Institution, Washington, D.C. 
Wagstaff) 《黑白灰》展中出现, 这个展览是在怀斯沃斯的图书馆 举办, 莫里斯在画廊里把它搭建起来。1965 年底, 莫里斯的大型胶 合板作品是以玻璃纤维在胶合板上塑模的方式制作出来的; 所以, 在 1865 年, 格林画廊的展览中, 这些形式也是以灰色玻璃纤维组 构而成。当《柱体》出现在莫里斯 1969 年的柯尔克兰展览中, 它 仍然是那种上色的胶合板样式，不过，几乎可以肯定，它是由画廊 或博物馆自己的木工建构起来的。

1973 年, 《柱体》与另外一个立柱放置在一起, 这根柱子是平放 在地上的, 在最初的表演中重新创造了这个柱子的两个位置, 也暗 示了两者之间的活动。之后, 莫里斯指出, “柱体” 的动作是不言 自明的, 或者是因它在自己七英尺高画室中的位置而被激发 : 它躺 在一边, 无法让它直立。 ${ }^{26}$ 这个《柱体》（它们总是配对的）显示的 是一个铝质的版本。莫里斯说, 那些早年的胶合板作品只要是需要, 都由他自己制作, 而如果是密尔沃基的博物馆或画廊想要展览它们, 他会让他们的人来制作，给它们凃上通常的灰色。莫里斯解释说， 1964 年以来的灰色胶合板箱子制作得合乎要求, 但不是出自专业 人士之手。“对于他而言, 为展览制作它们, 然后, 就将它们扔掉, 这比制作一个永久作品要容易的多。我说过, 从某种角度讲, 这些 作品不存在原创性的……它们仅仅是复制品，但是（当时）没有人 愿意听这种话。 ${ }^{27}$ 有一次, 他将这些作品的组装说明寄给了一个博 物馆, 博物馆工作人员把它们组装得太好了, 以致于让我感到了冒 犯。如果你把这些东西做得太好, 它们看上去像出自上帝之手。”因此, 《柱体》或它的孪生作品在被制作成永久的铝材版本之前，在这个 世界上已被数次制作与拆毁, 并不只是在莫里斯的工作室。有一套 铝质的《柱体》 1970 年代晚期被德黑兰当代艺术博物馆收藏; 另 外一套着色胶合板作品，在 2006 年由德国的北莱茵 - 威斯特伐利

26 Wade Guyton, “Robert Morris,” Interview, January 6, 20I4, 3, http:// www.interviewmagazine.com/art/robert-morris.

27 Robert Morris, interview with Jeffrey Weiss and Julia Robinson, New York Public Library, April I6, 20I4. https://www.nypl.org/audiovideo/ object-sculpture-1960-1965-robert- morris-julia-robinson-jeffrey-weissartist-dialogue. 
亚州的门兴格拉德巴赫市的艾布泰恩伯格博物馆收藏。

《柱体》被奉为经典的转折点开始于罗莎琳德・克劳斯 1977 年 的专著《现代雕塑的进程》(Passages in Modern Sculpture), 她的 讨论从 “剧场性” 开始，是对迈克尔 - 弗雷德抨击极少主义的一次 深入分析，也对 196 I 年《柱体》的首次出现进行论述，她将这件 作品当作讨论雕塑介入剧场艺术、偶发艺术与动能艺术的关键所在, 在这一章节的末尾，又回到《柱体》这件作品，她将梅洛·庞蒂的 现象学作为分析工具。 ${ }^{28}$ 这个讨论为数十年来莫里斯与极少主义的 多数批评文献确定了术语。

在艺术史中，可以推定的是，作为一大型极少主义雕塑，《柱体》 是一个稳定的物质对象，它通过与观者对作品所处空间的体验的互 动来产生其主导的现象学效应，这就是极少主义雕塑的概念。但事 实上，如我提到的，《柱体》有许多个，其中大多数已不复存在， 或以不可见的状态存在 : 多数存放在博物馆的地下室，这当中最难 见到的也许是在德黑兰博物馆地下室（到现在已经过去了近 40 年） 的那些吧。他们实际体验与谈论的都是基于照片。艺术史家阿米莉 亚·琼斯（Amelia Jones）明确表示，她不是非要看到莫里斯极少 主义雕塑的原件才可以撰写文章 : 对于她以及多数评论者来说, 它 只是作为一张照片而存在的 (还有相关的评论文本)，与《钟声》, 那个最初激发它的创造的短促舞蹈没有大的差别。 ${ }^{29}$ 莫里斯完全承 认这个问题：“用这些符号学的术语来看待这件物品，我们无疑就 不需要艺术了。一些旧照片, 还有你自己的旧, 这些东西就够了。”30

莫里斯重新创作这件作品时，我们该如何判断他的目的和意图 呢? 在这件作品所有的初始面貌中，它实际上都是新作品，是为一 个特定场合创作的。它的空间维度、结构与颜色虽然是一样的，但 是，实际的作品却是新的。莫里斯自己也同意，这些大尺寸的初始 作品是概念性的。因此，它既是非物质的，同时也是物质的，既是 观念的，也是现象的，两个术语处于彼此交锋的状态。而且，为了

28 Krauss, Passages in Modern Sculpture, 20I-3, 236-39.

29 Amelia Jones, Performing the Body/Performing the Text (London and New

York: Routledge, 1999), 47.

30 Morris, Have I Reasons, 87. 
2013 年索纳本德画廊的一次展览, 莫里斯用抛光橡木板重新创作这 件作品时, 是雇佣了一位专业木匠嘉许·费恩（Josh Finn）的, 那么, 又该如何理解我们对于 《柱体》的经验呢? 我们的反应显然不会像 1962 年的观者那样纯洁无瑕了, 雷纳记得, 早期极少主义雕塑具 有一种近乎达达的幽默，很遗憾因其成为艺术史的标准的一部分而 丧失了这种幽默感。 ${ }^{31}$ 对于像她那样的早期观者来说, 正如我指出的, 《柱体》的首次亮相必定会激发警惕与嘲讽。这个作品, 常与《柱体》 联系在一起, 是作为他最初的两件成熟的作品, 而《箱子与它发出 的声音》(Box with the Sound of its Own) 则更加接近达达主义, 这个箱子里有一个制作好的录音带，在三个多小时的时间里，都 是莫里斯去制造的声响。尽管作品于 196 I 年左右面世，且实物保 存至今, 这件作品仍存在一些历史性的复杂问题: 录音技术大为改 变 (首先被压缩然后被电子化) 以至于我们很难保证说现在听到的 录音带就和当时作品刚被创 作出来时一模一样。忽略这些复杂性, 无异于既有意也轻信地忽视艺术品随着时间推移而发生的变化。

莫里斯常有一种讽刺倾向，以及拆解艺术世界之虔诚的粗暴愿 望, 尽管他也是其中的参与者, 《柱体》的最近一个版本表达的是 艺术史的世界 (正如莫里斯早在 1963 年系列表演中就已表现出来)。 我展示的《可以站在里面的箱子》(图 4, Box for Standing in), 以及它的最近版本 (我找不到《柱体》的图像了)。当观者与这个 箱子或者柱体相遇，他或者她并不是在现象学意义上体验它，处在 某种普世的和超历史的身体的回应中。它不是一个 “极少” 器物, 而是一个 “极少主义者” 的器物, 我们并不是对它做出回应, 而是 对它进行认知。我们从艺术史的结构中认知它。换句话说, 这些最 近的创造在莫里斯论秘的风格里, 都是概念性作品, 用以强调艺术 史学术领域与艺术市场的交集: 他们从属于和杰夫 - 昆斯的作品相 同的风格，而非极少主义雕塑。

我认为, 艺术史的工作不是去求证《柱体》作为极少主义作品 的可信度, 而是去解构我们对于它的艺术史的认知。我们当然无法 回到过去, 但我们可以在它成为极少主义之前, 在这个标签掩盖我

31 Yvonne Rainer, interview by Connie Butler, New York, July 7, 20II, 
们对它的感觉之前，来重塑作品的创作与接受语境。做其他任何事 情都只不过让我们沦为艺术史的中介机构，而非艺术史学家。

在最后一层含义中，我想要说明，这件由弗朗西斯科・萨维欧 （Francesco Lo Savio）创作的作品，1960 年，它在罗马展出，也 就是莫里斯创作出单件雕塑作品之前, 他仍在考虑成为一名艺术史 家。 ${ }^{32}$ 现在，它被当作欧洲极少主义先驱，这明显是为了申明欧洲 是这个运动先行者。那么, 有没有不把它称为极少主义者的理由呢? 有两个显而易见的理由却是与这件作品的物质存在没有关系的。第 一个理由是针对萨维欧的，这件作品是在建筑与巴洛克的话语体系 中存在的。第二个理由属于贯穿我整篇论文的观点: 极少主义是批 评家和艺术史家的一种回溯既往的建构，这个建构在今天看来既有 益也无益。

归结起来，在接下来的几天里，如果我们回望约定俗成的艺术 史叙事，抛弃那些简单历史的术语，我想我们可以在中国与美国的 现代主义之间发现令人兴奋的与有趣的协奏和异响，因为这两个国 家都在上个世纪努力地与我们的生存条件的变革以及历史的戏剧性 变化周旋。杰克逊・波洛克与吴冠中的关系并不是美国抽象表现主 义和中国现代主义者的关系，而是最终两位艺术家与两件艺术作品 之间的关系。

（张坚、聂皓雪译校）

32 Spazio e Luce and Francesco Lo Savio, a cura di Germano Celant (Turin:

G. Einaudi, I975) 


\section{Louise Nevelson's Modernisms}

Julia Bryan-Wilson

In 1972 and 1973, Louise Nevelson built a series of sculptures that she entitled

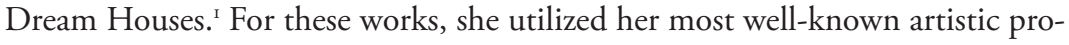
cess: she accreted small bits of wood into a larger construction that she then painted a solid, unifying color-in this case, as with most but not all of her art, black. One such piece, Dream House XXXII (1972) (Fig. I), is tall and narrow, topped with a gabled roof. Featuring small flaps mounted with metal hinges, it permeable in several ways - not only because of its variously accessible multiple entrances ("doors" or "windows" that can be open or shut), but also because its walls are shot through with apertures that make the entire enclosure riven with passages of contrasting lights and darks to create a dense, geometric visual field.

Unlike Nevelson's better known stacked-grid wall reliefs, this sculpture is displayed in the round, and its overall structure plays with the tension between rectilinear form and organic façade, as well as between protrusion and recess. Oblong shapes nestle against angular slivers, and circular cut-outs puncture rectangles, with odd jagged pieces — like shards, or fingers — fitting together to create the sense that the one might fiddle with some unexpected piece to reveal specially built compartments. Poised between a box and a column, the structure with its many accumulations and cavities issues an implied invitation to interactivity, offering itself to the viewer like a tricky puzzle to explore. But even as its dynamism is generated through its marriage of opposing forces such as concealment and revelation, Dream House XXXII does not mystify. It does not obscure or veil the evident labors that produced it; the wood's rough-cut edges and nailed together fragments are forthright about their means of making.

Nevelson's wood-based work, with its aesthetic of relationality within fields of chromatic uniformity, was in oblique dialogue with contested categories of gender, class, sexuality, and race. Dominant accounts of modernism in the US emphasize the importance of medium-specificity, truth to materials, and a rigorous formalism. Nevelson's work presented significant challenges to these prevailing theories. As she angled herself away from pure abstraction, she moved increasingly towards a sensuously suggestive art layered with allusion.

I A version of this essay appeared in Oxford Art Journal 40, no. I (March 20I7). There is no definitive catalogue raisonné of Nevelson's oeuvre, but according to Jean Lipman, there are thirty-seven total works in this series: Jean Lipman, Nevelson's World (New York: Hudson Hills Press, 1983), 65. Seven Dream House sculptures, all dated 1972, were on display at Nevelson's retrospective at the Walker Art Center in 1973; see the checklist in Martin Friedman, Nevelson: Wood Sculptures (New York: E.P. Dutton \& Co., 1973), 69-70. 

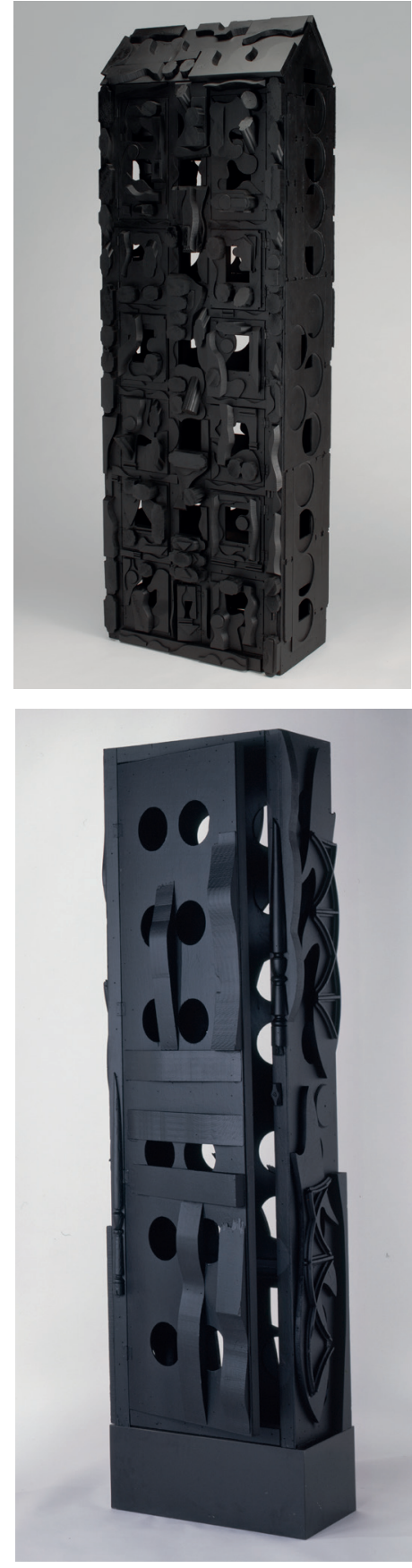

Fig. I. Louise Nevelson, Dream House XXXII, 1972. Hirshhorn Museum and Sculpture Garden, Smithsonian Institution, The Joseph H. Hirshhorn Bequest, 198r. (Photo: Lee Stalsworth) (C) 2019 Estate of Louise Nevelson/Artists Rights Society (ARS), New York.

Fig. 2. Louise Nevelson, Interior of Dream House XLIII, 1973, painted wood, $228.6 \times 66 \times 40.6 \mathrm{~cm}$. Collection Perez Art Museum Miami, gift of the American Art Foundation. (Photo: Ellen Page Wilson, courtesy Pace Gallery) (C) 2019 Estate of Louise Nevelson/Artists Rights Society (ARS), New York.

\section{Home Furnishings}

Not all of the Dream Houses are capped with peaked roofs that give a recognizable nod to the vocabulary of domestic architecture. In one flat-topped sculpture from the series, Dream House XLIII (Fig. 2), from I973, the cobbled-together feel of Dream House XXXII gives way to a highly stylized, less ornate design with curving lines and symmetrical, punched out circles that traverse the work's front and back. Instead of featuring a number of mouse-sized doors along its length, the entire structure of Dream House XLIII opens like a cabinet or armoire, with a person-sized hollow inside, segmented by shelves. And people did go inside some of Nevelson's box-like works, or, rather, at least one person did, for the purpose of posing, as evidenced by a photograph of the artist herself emerging from another sculpture swathed in a flamboyant fur coat that turns her body into an abstract, triangular shape, its striped trim echoing the notched wood on the right-hand side. ${ }^{2}$ Nevelson holds a black telephone receiver, as if interrupted in the midst of a call. With its peephole-like gaps, this "phone booth" structure could promote a voyeuristic relationship between viewer on the outside who might glimpse what lies inside, but in the photograph, Nevelson's presence blocks — or cancels_-any sense of a hidden interior, as her assertive, fully-cloaked form overflows the sculpture. A correspondence between the

2 For more on the significance of Nevelson's fashion choices, see Michael Stanislawski, "Louise Nevelson's Self-Fashioning: "The Author of her Own Life," in The Sculpture of Louise Nevelson: Constructing a Legend, ed. Brooke Kamin Rapaport (New Haven and London: Yale University Press/New York: The Jewish Museum, 2007), 27-37. 
Fig. 3. Louise Nevelson, childhood drawing, c. 1905, Louise Nevelson papers, circa 1903- 1979. Archives of American Art, Smithsonian Institution. (C) 2019 Estate of Louise Nevelson/Artists Rights Society (ARS), New York.

artist's body and the wooden container that surrounds her is suggested, then withheld.

House as female corpus, interior as gendered unconscious: these long-standing associations have famously been plumbed by oth-

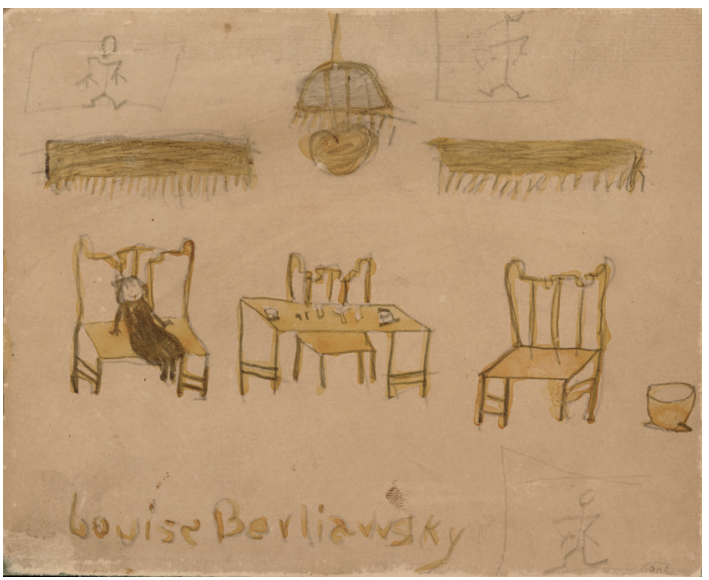
er women sculptors such as Louise Bourgeois, and Nevelson's connection to Bourgeois has been discussed in important scholarship by Elyse Speaks. ${ }^{3}$ Though many Dream Houses were built at a scale that encourages a correlation between human figure and domicile, some of the works in this series occupy a slighter footprint, with squatter, smaller dimensions. These include Dream House II from 1972; measuring about $58 \mathrm{~cm}$ by $58 \mathrm{~cm}$ by $30 \mathrm{~cm}$, it could comfortably fit on a dining-room table, like a perplexing fine-art dollhouse with its array of external knobs, openings, and scraps of moulding. ${ }^{4}$ It is not a belittlement or denigration to compare the Dream Houses to household fixtures such as wardrobe, cabinet, or toy, for integral to Nevelson's work was her deep, abiding interest in furniture, in particular the way that such objects can hold histories and activate memories. In much of her work, she recycled architectural and household elements like cornices, bannisters, bedposts, chair legs, doorknobs, packing crates, and dowels. She was compelled by the intimate bonds we forge with the things that surround us, the merging of flesh and bone with material like upholstery that can happen when one sits in a chair: both skin and fabric mutually yield. She referred to this enlivened sense of the ostensibly inanimate as "living the livingness of life, the livingness of the livingness, and using all these things to extend this awareness."s Elsewhere, she

3 Elyse Speaks, "Space, Gender, Sculpture: Bourgeois, Nevelson, and the Changing Conditions of Sculpture in the 1950s," Women's Studies: An Interdisciplinary Journal 40, no. 8 (20II): I052-9I.

4 The first Dream House "began with a store-bought doll house which she painted black and decorated with her characteristic compositions of small geometric shapes," Laurie Wilson, "Mrs. N's Palace," in Louise Nevelson: Atmospheres and Environments, I63. The toy-like scale of these smaller sculptures are a reminder that Mattel's Barbie Dream House, which was first available for purchase in 1962, provides one salient popular culture precedent for the title of Nevelson's series. I am grateful to Peggy Phelan for alerting me to this connection. Jan. I4 and undated, Archives of American Art, Smithsonian Institution. 
conjures the ways that wood in particular feels "alive" to her, as it sometimes "screams back" as she hammers into it. ${ }^{6}$ The livingness of things: here Nevelson articulates a new materialist theory far in advance of the emergence of such theories in the academy, in which human bodies interact meaningfully with, and are changed by, the lively objects they encounter.

One of her earliest known drawings, in fact, is of a little girl leaning back in a wide wooden chair or settee, her legs too short to reach the ground under her (Fig. 3). The girl's face is charmingly naïve and schematic while the furniture, including the fringed overhead lamp and the curling tops of the spindle-backed chairs, is remarkably detailed. Dated 1905 (Nevelson would have been around six years old) and signed with her birth name Berliawsky, the drawing is obviously the handiwork of a child, but one that demonstrates a precocious interest in and comprehension of interiors and perspectival spatial relations. ${ }^{7}$ Later drawings of chairs reveal her persistent interest in the precise proportions and specifics of furniture, the broken-apart components of which would, in a few decades, be integrated into her sculpture. Throughout her work, she was interested in maintaining the integrity of these domestic objects; materials like chair legs, porch spindles, and spools remain spindles and spools, repurposed, yes, but not made unrecognizable. Though Nevelson is often considered an abstract artist, works like the Dream Houses (which cohere into the recognizable form of an abode) demonstrate how frequently she stretched, and scrambled, the boundaries between abstraction and figuration.

Referring to herself as "an architect" and "a builder," Nevelson reveled in upending gendered conventions about the proper techniques for female artists. ${ }^{8}$ In her early found-object assemblages, she scavenged her materials from gutters and junkyards-reusing scraps that bore the scars of their previous lives, including their felicitous incisions and their damage. (Nevelson's thorough knowledge of wood stemmed in part from longstanding personal familiarity; both before and after her Jewish family emigrated from Kiev, Ukraine to Rockland, Maine, her father worked as a woodcutter and lumber merchant. $\left.{ }^{9}\right)$ Later in her artistic career, when her economic situation allowed, she also had wood cut to order to augment her foraged cast-offs. Often cannibalizing previous sculptures, she would dismantle some structures completely after they were displayed and harvest their parts to produce new pieces. ${ }^{\text {Io }}$ From the beginning of her mature

6 Louise Nevelson, Dawns and Dusks: Taped Conversations with Diana MacKown (New York: Charles Scribner's Sons, 1976), 78 and 8r.

7 More of her early drawings are reproduced in ibid..

8 Seckler, oral history.

9 Nevelson's biography has been amply documented. See Laurie Lisle, Louise Nevelson: A Passionate Life (New York: Summit Books, 1990) and Laurie Wilson, Louise Nevelson: Light and Shadow (London: Thames \& Hudson, 2016).

Io Nevelson's practice of "incorporating" previous works into new pieces—and the museological problems this destruction poses-is mentioned in Richard Marshall's essay in Louise Nevelson: Atmospheres and Environments, intro. Edward 
artistic life as a sculptor, she was drawn to wooden detritus and the remainders of carpentry projects, describing how, for one of her first such works she "found lumber on the street that had nails and some nail holes in it and different forms and different shapes and I just nailed them together and I knew this was art." II In other words, she did not transmute rejected scraps into art by virtue of her aesthetic choices, but recognized something in the wood that already presented itself to her as usable despite it technically being classified as garbage. What might appear at first glance to be boxes and trays of junk on a studio table are actually works in progress, their component parts strictly organized according to Nevelson's overriding formal logic, with disparate pieces crucially brought even more forcefully together as a single optical field by her consistent use of monochromatic paint.

Nevelson's appreciation of trash was tied to an acute appreciation of thrift cultivated from her days of financial hardship when she "trained [herself] not to waste." ${ }^{12}$ As Susan Strasser writes in her history of trashmaking, "trash is a dynamic category. Objects move in and out of it." ${ }^{\text {13 }}$ She elaborates that refuse cannot be defined by itself, for "nothing is inherently trash," but rather must be seen in relation to human decision-making. "Trash is created by sorting," Strasser states. "As everyday life and ordinary housework have changed over time, so has the process of defining what is rubbish, as well as the rubbish itself, the contents of the trash." ${ }^{14}$ Nevelson's sculpture was based on processes of salvaging, gathering and sorting as a complex rejection both of the category of trash and of the women's imperative to maintain the home, or what Pat Mainardi called in her 1969 feminist polemic on housework "dirty chores." Is Instead of viewing home maintenance as extrinsic to her artistic activities, Nevelson considered such procedures part of her artistic process, proclaiming that "when I clean house... I am not really cleaning house. I am building architecture. ${ }^{16}$ Nevelson's sorting rendered her home in a constant state of flux, especially as her living space and her workspace on Spring Street in lower Manhattan blurred together in the late I96os after she got rid of all of her non-essential belongings and lived surrounded by her art materials.

Though Arnold Glimcher states that at the age of sixty-six Nevelson "divested herself of all material possessions," this was not technically true; these spaces

Albee (New York: Clarkson N. Potter, Inc. in association with the Whitney Museum of American Art, 1980), 9.

II Seckler, oral history.

I2 Nevelson, Dawns and Dusks, 73.

I3 Susan Strasser, Waste and Want: A Social History of Trash (New York: Henry Holt and Company, 1999), 3.

I4 Ibid., 5.

Is Pat Mainardi, "The Politics of Housework," in Sisterhood is Powerful: An Anthology of Writings from the Women's Liberation Movement, ed. Robin Morgan (New York: Vintage, 1970), 50I-IO. 


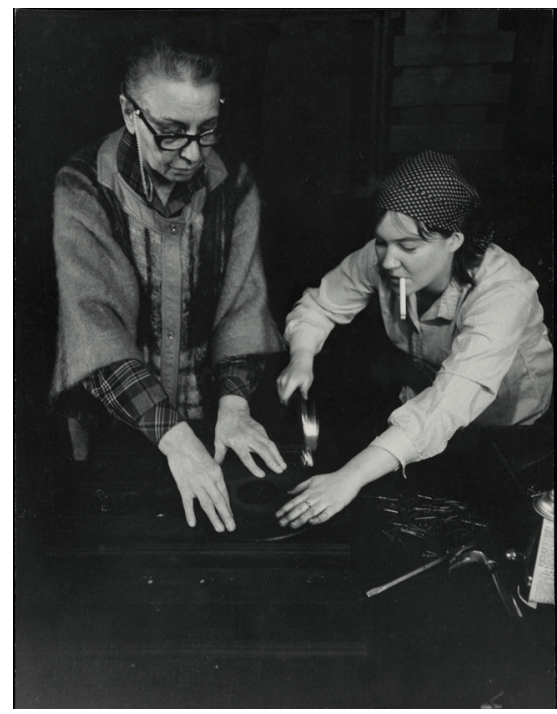

Fig. 4. Louise Nevelson at work with Diana MacKown, ca. 1965. Louise Nevelson papers, circa 1903-1979. Archives of American Art, Smithsonian Institution. (Photo: Ugo Mulas) (C) 2019 Estate of Louise Nevelson/Artists Rights Society (ARS), New York.

still teemed with stuff. But she did, just a few years before embarking on the Dream House series, purge her household of objects not directly related to her art in pursuit of some new, reconfigured relationship to things, possession, and ownership by radically altering her own living situation. ${ }^{17}$ The 1967 catalogue for her Whitney Museum of American Art retrospective noted "though it is almost entirely devoid of furniture, she nevertheless dwells among the grandeur of her own work, which crowds both studio and living areas." ${ }^{18}$ In other words, Nevelson co-habitated with her sculptures and the materials that would become her art, keeping house in an ever-changing domestic landscape of her own creation.

\section{Home Work}

Importantly, in the time in which she was creating the Dream Houses, hers was not a home inhabited solely by the artist and her work. Nevelson employed a series of helpers who were integral to her process of making, most notably her live-in studio assistant Diana MacKown (Fig. 4), who in 1962 moved in with the artist and stayed until Nevelson's death in 1988, functioning also as a companion and an archivist (she taped hours of conversation with Nevelson for the artist's book/memoir Dawns and Dusks). In photographs taken by Ugo Mulas of Nevelson in the mid-I96os, MacKown makes a number of appearances, depicted at Nevelson's side working on a piece with a can of enamel spray paint in front of her and a cigarette gripped firmly between her lips. MacKown's right hand is a blur of motion while Nevelson presses down imperiously on a piece of wood with both hands to stabilize it. In another photograph, MacKown holds brown paper bags of groceries or supplies in front of the studio, its store-front windows a jumble of objects that might be art, but might also be an aggregation of odds and ends not yet congealed into sculpture.

There are many such photos of the artist at work with MacKown at her side, which collectively add up to a portrait of their shared residence less as a space of rest and leisure than as a site of constant activity and the daily tasks

17 Arnold B. Glimcher, Louise Nevelson (New York: Praeger Publishers, 1972), I38.

I8 John Gordon, Louise Nevelson (New York: Whitney Museum of American Art, 1967), 9. 
of artmaking, which Nevelson treated like a job. In fact, starting in $1957 \mathrm{Nev-}$ elson was involved in the leadership of the Artists Equity Association (AEA), an organization founded by Yasuo Kuniyoshi that agitated for artist's rights. ${ }^{19}$ (In 1962, the same year Nevelson was included at the Venice Biennial, she was elected the national AEA's first woman president; these dual achievements mark her increased ascendency within the international art world.) With its efforts to improve the economic situation of artists and its arguments that artistic practice was a form of legitimate labor, AEA was a key forerunner to later groups like the Art Workers' Coalition, formed in 1969, which insisted that artists are workers. ${ }^{20}$

Along with highlighting the labor of artistic production, Nevelson's Dream Houses can be understood as comments about the labors of domestic care, about the never-ending and repetitive acts of making that generate and sustain a home. Dream House XLIII was recently conserved by the Pérez Art Museum Miami, in recognition that Nevelson's thin layer of black paint on wood was not gracefully weathering the test of time; a distinct and growing network of cracks, loss, and flaking began to distract from the monochromatic surface. ${ }^{21}$ A photograph taken by the conservation and crating team shows male art handlers in blue gloves maneuvering the sculpture into an upright position. Seeing a hand gently inserted into one of the circular windows helps us mentally measure the sculpture's dimensions while it also invokes the attentions, upkeep, and maintenance that attend a work like this, long after the death of the artist who brings such an object into the world with similar tendings and assistance. These almost clinical penetrations recall the invitation to and ultimate thwarting of voyeurism in the telephone-and-fur-coat photo, as these gloved hands feel less like a violation of the sculptural form than an extension of its implied protocol. The Dream House's holes and hinged flaps become orifices to be imaginatively probed, and the intermingling of bodies and wood in this photo gestures to a desirous and tactile rather than purely optical encounter with Nevelson's sculpture. The openings in Dream House series raise questions about the stability of the home as a locus of fragile privacy - constantly invited to be tested, if not violated, by the viewer. What is more, the serial nature of these sculptures places them on a continuum between repeatable (coded "feminine") chores like sorting, fixing, mending, and full-scale (coded "masculine") construction projects, moving Nevelson's work beyond any easily gendered division of labor.

19 For more on the origins of this organization, see David M. Sokol, "The Founding of Artists Equity Association after World War II," Archives of American Art Journal 39, nos. I-2 (1999): 17-29.

20 I discuss the fraught and contradictory nature of the Art Workers' Coalition in my Art Workers: Radical Practice in the Vietnam War Era (Berkeley: University of California, 2009).

2I Detailed technical information on the conservation of this piece can be found in blog posts by Stephanie Hornbeck, Rustin Levenson, Marlene Worhach, and others on the website of Caryatid Conservation Services. See https://caryatidconservation.wordpress.com/.. 
Throughout her career, Nevelson struggled with the negative impact her gender had on her career and resisted the label "woman artist." An unsigned review from her first show in 194I made the stakes of this gendered reception quite stark: "We learned that the artist is a woman, in time to check our enthusiasm. Had it been otherwise, we might have hailed these sculptural expressions as by surely a great figure among moderns." ${ }_{22}$ At the same time, she did not directly participate in the organizing efforts of I960s and I970s second wave women's liberation, and once stated, according to a widely cited quotation, "I am not a feminist. I'm an artist who happens to be a woman." ${ }^{23}$ In response to Linda Nochlin's groundbreaking 197I article "Why Have There Been No Great Women Artists?" Nevelson wrote a brief text that was published, alongside statements by seven other female artists, as a dossier in ArtNEWS. Nevelson's retort was entitled, rather sternly, "Do Your Work," and in it she rejected any assumptions about "the so-called nature of women" - an essentialism that Nochlin was not, in fact, promoting — and ends by dismissively stating: "To comment further in depth would mean a line by line analysis and that of course would interrupt my art." ${ }^{24}$ For Nevelson, constant artistic production—hard work, not feminist activism — was the only path she could envision out of entrenched sexism.

Given this rejection, it is remarkable that the Dream Houses-structures that present idealized visions of alternative homes - were created at the very same moment that feminist debates erupted around the redefinition of housework in the early I970s. Such debates focused with special intensity around questions of feminized domestic labor, epitomized by the 1972 formation of the International Wages for Housework Campaign and theorizations by the Italian feminist autonomist thinkers such as Silvia Federici that sought to make legible unremunerated, gendered household maintenance. Federici writes in her 1975 article "Wages Against Housework," "To say that we want money for housework is the first step towards refusing to do it, because the demand for a wage makes our work visible, which is the most indispensable condition to begin to struggle against it, both in its immediate aspect as housework and its more insidious character as femininity." ${ }^{25}$ Federici's argument, and the broader agitation for wages for housework as a way to defamiliarize gender roles under capitalism, marks one version of a politics of the home in 1972. The anxious repetition evidenced by the Dream House series-nearly forty such sculptures in the span of two years-indicates

22 Cue (October 4, 194I): 16, as quoted in Glimcher, Louise Nevelson, 54.

23 This quote comes to us second-hand, from Nevelson's granddaughter Maria Nevelson, rather than from any direct statement written by the artist herself; see Rapaport, The Sculpture of Louise Nevelson, 7.

24 Linda Nochlin, "Why Have There Been No Great Women Artists?" ArtNEWS 69 (January 197I): 22-29; Louise Nevelson, "Do Your Work," ArtNEWS 69 (January 197I): 4I, 43.

25 Silvia Federici, Wages against Housework (London and Bristol: Power of Women Collective/Falling Wall Press, 1975), 5. 
an almost obsessive return to a form that places the contested arenas of female art-making and home-making into direct confrontation.

As her career progressed and her visibility increased, Nevelson became more recognized as a pioneer within the women's art movement, cited as an inspiration for younger, avowedly feminist artists as a critical figure who advocated for non-typical techniques of art-making as valid avenues for women. ${ }^{26}$ How, then, might we understand Nevelson's feminism simultaneously (even paradoxically) not simply in relation to a political movement rooted in a particular time-a movement that she explicitly disavowed-but rather as an aesthetic, a method of making, and, maybe, a model of relating? Nevelson's Dream Houses, begun just one year after her response to Nochlin, coincide with the formation of the International Wages for Housework Campaign as well as with a polemically feminist version of artistic domesticity, that of Womanhouse, which was open to the public in January and February of 1972. As is well known, this was a project of the California Institute of Art's Feminist Art Program under the pedagogical guidance of Judy Chicago and Miriam Schapiro, and was realized in the context of an all-women's class as way for the students to explore collective and individual struggles with the home as a site of feminist contestation.

The hands-on renovation of a rundown house on Mariposa Avenue in Los Angeles, in which the artists utilized carpentry techniques and learned other construction skills, was considered part of Womanhouse's feminist politics. As Schapiro put it, each artist was able to "develop her own dreams and fantasies in one room of the house." ${ }^{27}$ For instance, Sandra Orgel's Linen Closet features a dark-haired, white, naked female mannequin segmented by shelves in a closet alongside neatly folded sheets and towels. The shelves slice the mannequin at her neck, below her breasts, and through her hips, and one leg is cut off at mid-thigh, but her arm reaches forward, creating an ambiguous space in which the figure appears both to be emerging from and contained within a built-in architectural element redolent of women's work. Orgel later commented that a visitor to Womanhouse told her, "This is exactly where women have always been-between the sheets and on the shelf." ${ }_{28}$ Orgel's Linen Closet offers a counter-proposition of sorts to the contemporaneous Dream Houses, a vision of domesticity in which a white female body is caught between confinement and freedom, as opposed to Nevelson's evacuation of literal figures from the home. Instead of presenting a sculptural representation of a body, the Dream Houses insist on an activation of the viewer's body (whatever color she may be) as she is invited to peer into

26 Nevelson is listed on the "Heritage Floor" of Judy Chicago's The Dinner Party (1974-1979), for instance, and figures prominently in Mary Beth Edelson's iconic feminist collage piece Some Living American Women Artists/Last Supper (1971).

27 Miriam Schapiro, "The Education of Women as Artists," Art Journal 31, no. 3 (1972): 268.

28 Sandy Orgel quoted in Arlene Raven, "Womanhouse," in The Power of Feminist Art: The American Movement of the I970s, History and Impact, eds. Norma Broude and Mary D. Garrard (New York: Harry N. Abrams, 1994), 55. 
the openings in their walls. Of course, the photograph of the artist holding a phone in her fur coat complicates this assertion, as it implies that one inhabitant of the Dream Houses might be Nevelson herself, half enclosed and half exposed, engaged in a conversation we cannot hear.

\section{Home Life}

The comparison with Orgel's Linen Closet also illustrates how Nevelson's Dream Houses are, in part, kinds of closets, spaces that contain things both real and imagined but, more crucially, complex sites of sexual secrecy and queer disclosure. Indeed, many queer artists and art historians in recent decades have attempted to claim Nevelson as one of our own, pointing to her close relationship with live-in assistant MacKown as proof of her same-sex or bisexual proclivities. (In I920, Nevelson married a man, Charles Nevelson, with whom she had a son and later divorced, but such conversion narratives are common in early twentieth-century queer life). An excerpt from Nevelson's entry in a queer artist's encyclopedia attempts to account for the artist's own resistance to any homosexual identification, while shoring up claims for her queerness at the same time:

While most of Nevelson's biographers completely skip over her twenty-sixyear-long relationship with MacKown, those who do mention it tend to accept the women's denial that their relationship was romantic. Nevelson reportedly stated, "I couldn't live with myself if I was a lesbian." However, the reality may have been more complicated. Never especially well-off and dependent on public art commissions, Nevelson may have feared the financial consequences of being exposed as a lesbian. Moreover, MacKown threatened Nevelson's estate with a palimony claim after the sculptor died in New York City on April 17, $1988 .^{29}$

Though the direct quote from Nevelson is hearsay, its phrasing is telling: what does it mean to not be able to live with oneself? What domestic splitting or psychic dislocation does that imply? When People magazine recounted MacKown's bitter battle with Nevelson's son for dozens of the artist's sculptures that the assistant argued were promised to her, it skirted the nature of their relationship, characterizing it as one of "ardent friendship," hinting at bodily ministrations in which the assistant functioned as "archivist, driver, and, finally, nurse." 30

During her lifetime, Nevelson's queer sexuality appears to have been, at least for some, an open secret. When in 1979 the Mildred Andrews Fund began to consider commissioning an artist to produce a public sculpture commemorating the Gay Liberation Movement, they first approached Nevelson "precisely be-

29 Caryn N. Neumann, "Nevelson, Louise (I899-1988)," GLBTQ Encyclopedia Project, http://www.glbtqarchive.com/arts/nevelson_1_A.pdf.

30 Patricia Freeman, "A Battle over a Legacy Pits Sculptor Louise Nevelson's Son against Her Loyal Aid," People Magazine 32, no. 3 (July I7, I989). 
cause of her sexual preference." ${ }^{31}$ According to James Saslow, she initially accepted, "remarking almost gleefully that she had grown too old and too famous for anyone to hurt her," but was later persuaded to turn it down because "acknowledging her lesbianism would hurt the career of her younger female lover." ${ }^{2}$ The commission was eventually given to the straight, white male artist George Segal; after being moved around to other locations where it was repeatedly vandalized, the monument was finally placed where it was originally intended in 1992, in Christopher Street Park, near the site of the 1969 Stonewall uprising against police harassment. Segal's sculpture blandly depicts queer desire, with paired men and women in button-down shirts and trousers expressing their physical affection for each other via a demure hand on a shoulder or knee. The monument whitewashes history, in several senses: both couples appear phenotypically as well as chromatically white, and the figures become pale stand-ins for the many working-class black and Latina/o queers (including outrageously outfitted drag queens who were a far cry from the norm-core depicted in Segal's sculpture) who participated in the Stonewall rebellion. Such an erasure of queers of color is sadly common to many representations of Stonewall; as African American lesbian feminist Rev. Irene Monroe (who witnessed the night's police brutality) reflects, "Those brown and Black LGBTQ people are not only absent from the photos of that night, but have been bleached from its written history." ${ }_{33}$

Though Nevelson was increasingly known for large-scale public sculpture throughout the I970s, it is difficult to imagine what she might have produced for the Stonewall commission, given its eyebrow-raising charge that the monument "had to be loving and caring, and show the affection that is the hallmark of gay people [...]. And it had to have equal representation of men and women." ${ }^{34}$ This proscription demands a representational or narrative solution with a very different readability —in which "men" and "women" are decipherably performing acts of affection - than Nevelson's art, an art instead occupies an in-between place that hovers at the edges of abstraction and figuration. One could argue that allowing Nevelson to pursue a more creative interpretation of the commission's request would lead to a sculpture with abundant expressions of both care (as I

3I Joseph Disponzio, "George Segal's Sculpture on a Theme of Gay Liberation and the Sexual-political Equivocation of Public Consciousness," in Critical Issues in Public Art: Content, Context, and Controversy, eds. Harriet Senie and Sally Webster (New York: Icon Editions, 1992), 7.

32 James Saslow, Pictures and Passions: A History of Homosexuality in the Visual Arts (New York: Penguin, 200I), 287; and Christopher Castiglia and Christopher Reed, If Memory Serves: Gay Men, AIDS, and the Promise of a Queer Past (Minneapolis: University of Minnesota Press, 20I2), 78.

33 Rev. Irene Monroe, "Dis-membering Stonewall," in Love, Christopher Street, eds. Thomas Keith and Bram Christopher (New York: Chelsea Station Editions, 2OI2), IOI.

34 Fore more on the official municipal history of the sculpture, see "Gay Liberation," NYC Parks, https://www.nycgovparks.org/parks/christopher-park/monu- 
have been arguing, she approached sculpture as a form of attentive housekeeping) and queerness, if it were understood that her work's liminality, her refusal to be categorized, her resistance to represent gender as a binary system, are the queerest aspects of her practice.

Queer theorist Gavin Butt has written about the theoretical import of gossip and rumour for the writing of queer histories, because we must rely on stories that are unofficial, unwritten, and off the record. ${ }^{35}$ Following his understanding about the circulation of innuendo, it is not necessary to uncover the "truth" of Nevelson's sexuality - though she did, with her abandonment of heterosexual marriage and her designation of MacKown as her primary attachment, inarguably reside within a non-standard domestic situation. That said, I do not need to know who slept in Nevelson's bed in order to claim a queerness for her work or to understand that her art, unmoored from the distinctions between abstraction and figuration, or materiality versus metaphor, has provided queer artists with a model of unconstrained opening. And regardless of biographical "proof," Nevelson has been taken up as a queer exemplar. Nevelson's exaggerated and self-conscious presentation of excessive femininity makes her an ideal drag and trans heroine. In 1983 queer video maker Jamie Walters made a short comedic tape featuring a drag version of Nevelson, starring Gregory Marcangelo in a headscarf, false eyelashes and wrinkles drawn on with eyeliner. Entitled Louise Nevelson Takes a Bath — possibly referring to a famous 1958 Life magazine spread of the artist's home in which her tub is crammed with objects- the drag character of Nevelson utters grandiose statements, some drawn directly from Dawns and Dusks: "Manhattan is a collage of sculptures" and "Ah! Cubism!" ${ }^{6}$ As she climbs into a hot bath in preparation for an art opening, she is reminded of "that one mistake I made-marriage." Walters' video was made under the auspices of a queer video collective in Washington DC, Video Free Earth; it recently re-surfaced and made the rounds in queer film festivals such as Outfest.

Another example of Nevelson's queer legacy can be found in Sharon Hayes's An Ear to the Sounds of Our History, from 20II, in which the artist installs rows of album covers that feature speeches and talks from historical figures; these form visual "sentences" in which each cover relates in some way-oblique or explicit— to those next to it. In one iteration, Hayes positions Nevelson just above Christine Jorgenson, the first publicly out trans woman in the US, thus aligning the artist spatially with a queer identification. Yet this contiguity was not always readable; one review of Hayes's piece from Art in America stated that

35 Gavin Butt, Between You and Me: Queer Disclosures in the New York Art World, 1948-1963 (Durham: Duke University Press, 2005). Nevelson was friendly with many of the gay male artists that formed a loose queer art scene in New York, including John Cage, Merce Cunningham, and Robert Indiana. See, for example, the black and white film by Anton Perich, "Cage, Cunningham, Nevelson with R. Couri Hay," 1974.

36 "Weird Woodwork of the Lunar World," Life Magazine, March 24, 1958, 70-80. 
the "recording of Louise Nevelson [is] thrown in as a wild card." ${ }^{37}$ But the presence of Nevelson in An Ear to the Sounds of Our History raises questions about the potentially queer and feminist plural possessive here about claiming this artist's history as "ours."

\section{Home Economics}

Nevelson's uptake by feminist and queer artists underscores that a capacious understanding of both the feminism and the queerness of her art need not be read through a strictly biographical framework. The narrow focus on Nevelson's life has not, ultimately, helped us gain critical purchase on the specificity and strangeness of much of her art and its manifold associations, but rather returns it, relentlessly, back onto the artist's own body. "Her work is, above all, a metaphorical story about herself, told in sculpture," claims the curator of Nevelson's 2007 retrospective at the Jewish Museum, adding that that her art is "a window into the artist's internal life." ${ }^{8}$ It is extraordinarily tedious to point out, still, again, constantly, that women's art is too often understood as limited to autobiographical pursuits in ways that do not apply to male artists, as art historians such as Anne M. Wagner have taken pains to elaborate. ${ }^{39}$ An Ad Reinhardt painting (another artist who made extensive use of the black monochrome) is not discussed within art history primarily as a "metaphorical story about himself." I do not mean to rule out of hand the circumstances of the artist's biography, which inevitably affected the production of her work and delimited its conditions of possibility, but rather, to insist that Nevelson's work was primarily an inscription of her "internal life" overlooks her considered engagement with wider concerns of materiality, the economics of housekeeping, and gendered labor.

This interpretation of her work also effaces the other world-historical issues she directly thematized. In 1964 she made two sculptures that memorialized the Holocaust, entitled Homage to 6,000,000 I and Homage to 6,000,000 II. In Homage to 6,000,000 I, the large, curving black walls of stacked boxes filled with wooden implements and identifiable furniture fragments like matching sets of turned spindles are immediately grasped as within her sculptural idiom, while they also speak to the magnitude of loss, displacement, and exile. Some of the compartments in the grid structure have a shallow composition, covered with flat wooden pieces that cover the rectangular niches like boarded-up windows. Cumulatively, the objects suggest the household goods we desperately or unwillingly discard, as well as the places one leaves behind in a hurry or the new lives one is forced to rebuild out of what is available at hand as a mechanism of survival. Its composite parts accumulate into a looming, imposing structure,

37 Paul David Young, "Time for Love: Sharon Hayes at the Whitney," Art in America (June 27, 20I2).

38 Rapaport, The Sculpture of Louise Nevelson, 3.

39 Anne M. Wagner, Three Artists (Three Women) (Berkeley: University of California Press, 1996). 
with its darkness taking on a funereal cast. Though much of our understanding of its meaning is generated via its title-and more theoretical work needs to be done on how abstract art gets tethered to meaning via titles, in Nevelson and elsewhere-the Holocaust memorials utilize her formal vocabulary to convey a sense of mourning for a shattered collective home..$^{4}$

In some images of Homage to 6,000,000 I, a completely all-black work has patches that appear pale grey, a graphic demonstration of a significant problem that has accompanied, and distorted, many of the photographic reproductions of Nevelson's sculpture. Beyond the widely discussed challenges presented when translating a three-dimensional object into a two-dimensional representationin which photography flattens sculptures that are above all volumetric interventions in space-the coloration of Nevelson's monochromatic black artwork has proven resistant to the camera and to the page. ${ }^{4 \mathrm{I}}$ Of course there are images that do justice to her works (including the photographs I chose for this essay), but in some photographs, the camera stubbornly refuses to let the details of her art register in their distinction, or her sculptures are so poorly lit that their surfaces disappear into inky shadows. And in other images, when the photographer tries to overcompensate and overexposes or uses a flash, the work's darkness is washed out, lightened, greyed; sometimes, in an astonishingly inversion, her black sculptures are turned white by the camera's glare.

Some, but not all, of this failure to depict her work adequately can be accounted for due to variations in the relative matte of the black paint she used. But film and photographic technologies have historically been calibrated to accurately depict white skin rather than darker tones, and thus the inability to adequately capture Nevelson's black work is also tied to the inherent racism of the photographic medium. ${ }^{42}$ I make these seemingly basic points about the troubled relationship between sculpture and photography because in Nevelson's case that trouble goes beyond dimensionality, raising charged questions of the very representability of blackness, which is of course not only a color but also a mutable, ever-shifting and political designation.

40 In his study on artist's responses to the Holocaust via abstract art, Mark Godfrey briefly mentions Nevelson; see Abstraction and the Holocaust (New Haven: Yale University Press, 2007), 205.

4I See, for instance, Geraldine A. Johnson, ed., Sculpture and Photography: Envisioning the Third Dimension (Cambridge: Harvard University Press, 1999).

42 Richard Dyer discusses how film technologies were invented assuming a norm of whiteness, and how nonwhite faces create "problems" for movie lighting": Richard Dyer, White (New York and London: Routledge, 1997). Other scholars have importantly insisted on making central this fundamental, and ideological, bias within the history of photography: Shawn Michelle Smith, Photography on the Color Line: W.E.B. Dubois, Race, and Visual Culture (Durham: Duke University Press, 2004). 
In many interviews and writings over the course of her career, Nevelson stated her profound attachment to blackness. This is her most direct statement on the subject:

When I fell in love with black, it contained all color. It wasn't the negation of color. It was an acceptance. Because black encompasses all colors. Black is the most aristocratic color of all. The only aristocratic color. For me this is the ultimate. You can be quiet and it contains the whole thing. There is no color that will give you the feeling of totality. Of peace. Of greatness. Of quietness. Of excitement. I have seen things that were transformed into black, that took on just greatness. I don't want to use a lesser word. ${ }^{43}$

Though it is perhaps the most frequently quoted passage by Nevelson, often appearing on wall labels next to her sculptures, that familiarity does not drain it of its lasting potency. For here the artist articulates an affirmative theory of blackness, in which black is not posited as lack or negation but rather as "the ultimate," as "totality."

As Fred Moten argues in his essay "The Case of Blackness": "The cultural and political discourse on black pathology has been so pervasive that it could be said to constitute the background against which all representations of blacks, blackness, or (the color) black take place." ${ }^{44}$ Against this background, Nevelson constellates blackness around terms of "peace," "greatness," "quietness," and "excitement." She also talks of its capacity to invoke "great sorrow, or great joy." 45 Her blackness thus insists on its multiplicity; alongside "peace" and "excitement" (which are after all arguably contradictory affects), it can also have more somber overtones, as with the Holocaust works. Moten's article circulates around his reading of a transcript of a conversation about blackness held in 1967 that included painter Reinhardt, musician Cecil Taylor, and artist Aldo Tambellini in which starkly different versions of blackness were debated; for Moten, Reinhardt's advances an almost phobic vision of "non-color." Blackness for Reinhardt is reduced to a detached "technical problem," as Tambellini puts it, and though Nevelson is not included in Moten's text, her work acts as a further retort to this construction, offering instead a dense and decades-long engagement with blackness as plentitude. ${ }^{46}$

Arthur Danto, writing about Nevelson's relation to the monochrome, speculates: "It is only natural to ask what meaning black had for her as a color: night, death, mystery, the Absolute?" 47 Danto enumerates a flawed, highly limited set

43 Nevelson, Dawns and Dusks, I26.

44 Fred Moten, "The Case of Blackness," Criticism 50, no. 2 (Spring 2008): I7I.

45 Nevelson, Dawns and Dusks, I27.

46 Tambellini, quoted in Moten, "The Case of Blackness," 198. Nevelson definitively contrasts her understanding of blackness from Reinhardt's "philosophical" version; Nevelson, Dawns and Dusks, I26.

47647 Arthur Danto, "Black, White, Gold: Monochrome and Meaning in the Art of 
of choices; in his analysis, Nevelson's blackness has no meaning at all but instead is wielded by her as an authorial device, a way to visually and assertively signal her own consistent hand, akin to a trademark or brand. Danto's inadequate accounting disregards the many meanings blackness held for Nevelson. For her, blackness suffuses space as "the only aristocratic color" - "aristocratic" meaning majestic or regal. Against narrow definitions of the adjective "aristocratic" that link it to economic elitism or class privilege, author Ralph Ellison, in a 1958 essay, describes how some women performers like Mahalia Jackson have the capacity to command a room with their presence: "indeed, we feel that if the idea of aristocracy is more than mere class conceit, then these surely are our natural queens." ${ }^{8} 8$ Nevelson's affirmative theory of the aristocratic nature of blackness places it within Ellison's - not Reinhardt's, not Danto's - realm, one of dignity, grace, and grandeur. Her sculpture's luxurious vastness swells precisely from its thrift—with her application of black paint, she produces something far bigger than the sum of its parts.

No less than queer art historians, recent critical race scholars and art historians have turned to Nevelson for her nimble interpretations of blackness, including curator Adrienne Edwards, who included the artist's sculpture in her ground-breaking exhibit "Blackness in Abstraction" at Pace Gallery, New York, in 20I6. ${ }^{49}$ Think back to the whiteness, and homo-normativity, of Segal's Christopher Street monument and imagine instead what sort of ideological statement an unapologetically black, and queerly abstract, work by Nevelson might perform its place.

Nevelson did make brief forays into other hues, namely white and gold (as well as some transparent plastic work), but these were never more than what Danto calls "temporary departures." ${ }^{\circ}$ Her first major piece in white came as an abrupt change, as she decided to shift her palette upon being invited to participate in the exhibit "I6 Americans" at the Museum of Modern Art in New York in 1959..$^{\text {I }}$ This large-scale environment, entitled Dawn's Wedding Feast, no doubt because it was by a woman, and because of its apparently nuptial white, generated a distinctly feminized review by Dore Ashton in which she described its "baroque finery-lacy and latticed like a small Victorian town with its wooden houses and daintily fenced garden." ${ }^{2}$ In other words, Ashton views this work as tidy and decorative- that is, domestic in the pejorative sense of the womanly, the limited, and the local, not the expansive or universal, confined to the sphere

Louise Nevelson," in Rapaport, The Sculpture of Louise Nevelson, 39.

48 Ralph Ellison, "As the Spirit Moves Mahalia," Saturday Review, September 27, 1958, rpt. in The Collected Essays of Ralph Ellison: Revised and Updated, ed. and intro. John F. Callahan (New York: Modern Library, 1995), 250.

49 Adrienne Edwards, Blackness in Abstraction (New York: Pace Gallery, 2016).

50 Danto, "Black, White, Gold," 39.

5I Dorothy Miller, I6 Americans (New York: Museum of Modern Art, 1959).

52 Dore Ashton, "Louise Nevelson," Cimaise 48 (April-June 1960), qtd. in Glimcher, Louise Nevelson, I07-8. 
of the family. Yet Dawn's Wedding Feast is a muscular piece, filled with assertive gestural statements that seize the room, a mix of piston-like, gravity-defying columns hanging from above and wall reliefs that resemble a mad machine, a splayed open engine with its guts and gears exposed.

As Nevelson has stated, her work creates "a completeness. It's like a marriage; you are not the total actor; you play with another actor, and my plays with the other are my materials." ${ }_{33}$ In this view, marriage is not the state-sanctified ceremonial act performed to consolidate and merge a couple's financial resourcesas one might cynically describe it in its contemporary formations-but rather an act of mutual animation that might occur between an artist and her wood, or between person and a thing. Instead of understanding this work as an oblique comment on an actual wedding (or subsequent marital discord), we might read it as a "union" of unlike elements fused together by her construction techniques and monochromatic paint. Thus such an installation might be described as a theatrical stage set or mise-en-scène, with matter such as wood not serving as a prop, but as a fellow actor playing a vital role in the preservation of memory, modeling different ways of co-existence with their human companions. That is to say, this art insists that how we live among things, and how they live in us, might tell us something about how to treat all kinds of others, not as possessions, but as possessed by or possessing of meaning and history. Moten advocates for works "that register the thingly encounter, works that are both all black and in which black is conspicuous in its absence, between blackness and chromatic saturation." ${ }_{54}$ Nevelson's all-white sculptures — no less than her all-black oneswith their insistence on a choreographed exchange, a mutuality, between body and thing, provide one concrete answer to Moten's call. The refusal of her sculpture to register accurately in photographic representation could be viewed not as failure but defiance, for it demands to be witnessed in person, insisting that the viewer be accountable to its thingliness, without mediation.

\section{Home Security}

When Nevelson heralds the "greatness" of the color black, she articulates a pointed rejoinder to those who see it as degenerate or lesser. This blackness is not only significant at the level of form, as a unifying pigment, but has implications for other interpretations around what Moten terms "social chromatism." 55 In fact, from 1974-85 (just after the Dream House series) she embarked on her Homage to Martin Luther King, Jr., a black stacked wall work in the permanent collection of the Studio Museum in Harlem, accepted as a gift in 1985 , some years before the museum rewrote its mission to include not only black artists but also art objects by non-black artists that were inspired by or in conversation with African diasporic and African American themes. Nevelson's Homage is a sculp-

53 Seckler, oral history, 1964.

54 Moten, "The Case of Blackness," 205.

$478 \quad 55$ Ibid., 200. 
ture in which an artist who is not black stands up for blackness not as "death," as Danto would have it, or abyss, or the absence of color, but as an infinite and bountiful resource. Nevelson was trumpeting the greatness and aristocratic nature of blackness through the I960s and I970s, in the years of the Civil Rights Movement and Black Power activism in the US in which African Americans proclaimed black to be beautiful (the long quote by Nevelson about "greatness" cited above was published in 1976). In the US context, in which blackness is too often a shorthand for poverty, the underclass, and debility, the formulation "black is beautiful" has an intense rhetorical force. ${ }^{56}$ At the same time, African American artists in the early I970s were nuancing this slogan, including Frank Bowling's essay "It's Not Enough to Say 'Black is Beautiful'," which called for more complex formalist language with which to approach the multiplicity of black abstraction, a language that might resist the structural, endemic racism faced by black artists. ${ }^{57}$

As a Jewish immigrant, Nevelson was not securely considered white in the context of mid-2oth century United States racial designations; she consistently pursued blackness not only as a pigment or paint but as a destabilized cultural construct that, when uncertainly solidified into dozens of abstracted forms of makeshift houses, pushes beyond the beautiful into a statement about the possibility of new habitats. What made the politics of the "home" in the US so urgent in 1972? One answer to that question, which focuses on white feminism and gendered domestic work, was on display that year in Womanhouse; another, more sharply anti-capitalist definition was formulated by the contemporaneous Wages for Housework campaign. A different answer might be found in the March 1972 Platform of the Black Panther Party for Self Defense. The platform included demands for freedom, or, in the statement's words, the "power to determine the destiny of our Black and oppressed communities," as well as full employment, the end to wars of oppression, and, significantly, "decent housing, fit for the shelter of human beings." ${ }^{8}$ The Party, which by 1969 was estimated to have a membership of at least $60 \%$ black women, recognized the importance of housing justice- the establishment of common, decent shelter-as integral to its vision of racial justice..$^{9}$

56 For more on black aesthetic theory that elaborates on this phrase, see Paul C. Taylor, Black is Beautiful: A Philosophy of Black Aesthetics (Hoboken: Wiley, 2016).

57 Frank Bowling, "It's Not Enough to Say 'Black is Beautiful," Art News, April I97I, 53-55, 82-84. Kellie Jones discusses this essay, and the circumstances of its writing, in her article, "'It's Not Enough to Say "Black is Beautiful"': Abstraction at the Whitney, 1969-1974," in Discrepant Abstraction, ed. Kobena Mercer (Cambridge: MIT Press, 2006), I54-8I.

58 Black Panther Party for Self-Defense, "March 1972 Platform," The Black Panther Intercommunal News Service, May I3, 1972, B, supplement.

59 Alondra Nelson has discussed the importance of black women's contributions to initiatives sponsored by the Party, such as its free breakfast for children 
The final plank issued in 1972 called for "an immediate end to police brutality and murder of Black people, other people of color, all oppressed people inside the United States." This demand continues to be painfully unheeded, as my own house - that is to say, my country, the fractured space of the US - is (then as now) occupied by systemically racist policing. "Domestic policy" is the contrasting phrase to "foreign policy," meaning matters of the nation, the borders of which must be fortified against any threats, internal or external, to its "safety"; this nation is filled with anger, hate, and dysfunction around questions of racism, misogyny and homophobia. There is a distinction, of course, between the purportedly atomized "home" and the social project of "housing," and the terms permit different kinds of agitation and alliance, but understanding the domestic as the State reminds us that a dream house might refer both to a discrete, familial architectural structure and to an entirely recalibrated political system.

To conclude, I want to briefly situate Nevelson alongside African American artist Noah Purifoy, in order to take seriously her art's alignment with blackness in both its aesthetic and lived formations. As mentioned, Nevelson's work has appropriately been historicized alongside sculptors like Louise Bourgeois, but there are other artistic genealogies to consider, other spaces that she jointly inhabits. Purifoy's assemblage-based works have been understood under the rubric of West Coast "junk art," and could seem geographically and art historically distant from Nevelson's New York. ${ }^{60}$ His career was catalyzed by the 1965 Watts rebellion, as he and fellow artists began salvaging burnt items in order to resignify the destruction around them into aesthetic, if still searing, creations. ${ }^{61}$ Purifoy, like Nevelson, had a keen interest in furniture, and designed and constructed elaborate wooden headboards; both evince clearly Modernist sensibilities as they reshaped recognizable objects into nonobjective works. In works like untitled (Standing Figure), from c. 1968-70, Purifoy's thingly utilization of materials harmonizes with Nevelson's own treatment of wood. This is column as personage, a vaguely anthropomorphic figure — a body merged with an architecture-consisting of a checkered gameboard as a surrogate face, rows of identical square knobs, and black, carved decorative flourishes punctuating the torso. Unlike

program and its community health centers: Alondra Nelson, Body and Soul: The Black Panther Party and the Fight against Medical Discrimination (Minneapolis: University of Minnesota Press, 20II), 96. Robyn C. Spencer further elaborates on the significant presence of black women in the Panthers and the Party's "malleable" gender politics: Robyn C. Spencer, The Revolution has Come: Black Power, Gender, and the Black Panther Party in Oakland (Durham: Duke University Press, 2016), 47.

60 The most comprehensive overview of Purifoy's work is found in Franklin Sirmans and Yael Lipshutz, Noah Purifoy: Junk Dada (Los Angeles: Los Angeles County Museum of Art, 2015). of Neon, 1966). 
Nevelson, Purifoy does not apply color over his wood, highlighting the many textured grains and carefully considering the juxtaposition of hues of brown.

What would it mean to insist that Nevelson and Purifoy be thought together, to consider their work as forged on parallel tracks via related sculptural materials and techniques? This speculative encounter does not propose that Purifoy influenced Nevelson in any direct or mappable way, or vice-versa, though their careers overlapped for several decades and they could have encountered each other's art. Instead I suggest that the two artists rhymed together in their mutual pursuit of scavenged found objects and largely wood-based work, and that both understood wood to be not only the stuff of carpentry but of aliveness and arrested, but still latent, animation. Wood has been heralded for its qualities of warmth, and in addition, it has powerful capacities to expand and contract as it adjusts to different climates — to, as it were, breathe. Both Purifoy and Nevelson use wood to hammer out and reconceive of relations as they trespassed the line between furniture and sculpture. Their "keeping house" is not as a synonym for making things neat, or corralling objects in their place, but a way to create room for new — even, we might say, queer — kinships. This is a family structure not dependent on blood, influence, or even acquaintance, but rather something like affinity that emerges and resonates across different subjects. Nevelson and Purifoy, placed side-by-side as queer kin, produce domestic sphere not as fortress or closed-off domicile but a site of possible, if conjectural, dialogue and social exchange.

In Nevelson's Dream House series-which is quite distinct from her usual idiom - the walls keep shifting as in the early I970s she compulsively makes and remakes the same basic structure. It is a repetition that suggests an anxiety but also a generosity; these houses are relatively undefended, perforated with gaps and a proliferation of entrances that encourage sightlines through and around them. Her art offers a dream-house of permeability, of traffic in and out, a queer refusal to settle. As she brings unlike shapes together and unifies them through blackness in this series, emphasizing similarities, she reveals the stakes of her commitment to the monochrome and to the act of conjoining.

I have argued that Nevelson's feminist methods of making, her queer conception of the relationality between bodies and things, and her championing of blackness are the most radical aspects of her artistic enterprise. If we take our cues from Nevelson and try to envision a "dream house," it might be a place where formal affinities indicate, give shape to, or even prefigure emerging political solidarities across multiple axes of difference-a porous dream house that lets light flood as it brings imaginative kin into affective relation, and holds them securely. 


\section{路易斯・尼维尔森的现代主义延滞性 \\ 朱丽・布莱恩 - 威尔逊}

I959 年，路易斯 - 尼维尔森（Louise Nevelson）的大型白色木构 装置作品《黎明的婚宴》(Dawn’ $s$ Wedding Feast) 在纽约现代 艺术博物馆 (MoMA) 举办的突破性展览 “十六个美国人” (Sixteen Americans) 中崭露头角，与这件作品同时展出的是一些更为年轻 的艺术家作品, 如贾斯帕·琼斯 (Jasper Johns)、弗兰克·斯特拉 (Frank Stella) 以及罗伯特·劳森伯格 (Robert Rauschenberg)。体制的认可, 确立了尼维尔森的美国艺术家身份, 这对于出生于乌克兰, 早在 20 世纪 30 年代就已成名的尼维尔森来说多少有点晚 : 参加这个展 览时, 她已 60 岁了。这个演讲主要讨论了现代主义雕塑叙事对尼 维尔森迟到的接纳, 及其在美国的后续影响; 阐述她的性别、艺术 创作过程以及媒介选择如何决定了她在 20 世纪美国艺术史进程中 的那种时而风口浪尖、时而游离滞后的位置。

我将探讨她高调的艺术面貌, 夸张或延滞的形式如何遮蔽了她 架构雕塑的精妙手法，她总是变换地借用或摒弃美国现代主义的修 辞。我认为, 由于尼维尔森所追求的 “具体的形式主义” (embodied formalism), 她对于抽象的探索, 有效延滞了现代主义 “媒介特异 性” (medium specificity) 的话语。

1972 年伊始, 艺术家路易斯- 尼维尔森创作了一系列她称为 “梦 想之屋” (Dream Houses) 的雕塑作品。为了这些作品, ${ }^{1}$ 她采用平 生最著名的艺术手法: 将小片木板装配成一个更大的结构, 之后施 以统一颜色一通常是黑色, 就像这件作品（图 I）: 形状高挑, 由一 系列可开合的小型翻板和㿋门构成。《梦想之屋》的结构具有多方 面的通透性，这不仅是因各种或开或关的入口造成的，还因为围合 这些结构的墙体被各种孔眼和缺口所打通, 使得整个围合体被光线 穿透，并创造出一个布满空洞与鼓突物的稠密的几何视阈场。

椭圆体嵌套在正方体内，圆形切面安置在矩形上，形成滑动的 
孔洞，还有一些奇怪的锯齿状物件一像昆虫的鞘翅或人的手指一此 间种种拼合在一起，创造出的效果，彷佛有人在摆弄立面上某个不 寻常组件时，让隐匿于其间的隔层显现出来。《梦想之屋》因此唤 起了一种 “隐蔽感”，就像是论谲多变的谜语，同时，也保持了制 作方式与交流的直接性。在它们赋予的谜题出现裂隙之时，并没有 走向神秘化，就是说，没有去有意模糊或掩盖制作这些雕塑的劳作， 反而是跨越了雕塑与建筑的界限。

在这件更为方正的作品中，该系列作品中那种异物的拼凑感， 被一种高度风格化的接近于 “装饰派艺术”（art-deco）的设计所取 代，婉转的曲线和通透对称圆环贯穿作品的前后。先前展示的作品 包含了一些小巧玲珑的门、凹槽和存有小物件的隔间, 相比之下, 《梦 想之屋 48》打开后的整体结构更类似于一个嘱柜，内部空间足以 容纳一人，并由两层隔板分隔开来（图 2）。

的确有人曾进入到部分作品之中，或者说，至少有人为了摆拍 而这样做过一从一张 1972 年的照片中可见，艺术家本人正从另一 件《梦想之屋》中露出身来，她将自己裹在色彩斑斓的皮毛大衣 里，大衣上的那些反差强烈的条纹图案，与雕塑抽象和严格的容 器化处理形成呼应。作为女性身体的房屋, 或是作为潜意识的室 内，其他雕塑家也执着于这些得到普遍认可的联想，如路易斯 - 布 絮瓦（Louise Bourgeois）。这类作品中，超现实主义的影响得以彰 显，同时，尼维尔森也因融合立体主义和表现主义手法而在上个世 纪 70 年代声名大噪; 但今天，我感兴趣的是她的艺术过程，也就 是她对木艺的投入一不仅把木艺视为单纯的生产方式，还是一种锤 炼或制造包含不同关系的空间的方法。

这些关系是深藏在现代主义政治学的诸多争论中的。这种政治 学特别关注二战后的诸多区隔问题。我认为，尼维尔森的木构作品 及其在统一色域中的关系美学, 是在性别、阶级、性和种族等极富 争议的范畴下进行的隐梅的对话。美国现代主义主流叙事都在强调 “媒介特异性” 诚实面对材料，保持一种严格的形式主义。而尼维 尔森的作品却对这些主流理论提出了重要挑战。当她脱离纯粹抽象 之时，就愈加走向一种隐含多重暗喻的感受性艺术。换句话说，尼 维尔森将现代主义视为一种策略性资源并为己所用, 在甚器尘上的 时尚中，以它为装扮，而后再在一种现代主义伪装的认知形式中来 
抛弃它，我称其为现代主义的 “延滞”。我要说明的是，尼维尔森 对于抽象的自如探索，对现代主义 “媒介特异性” 话语已造成了压 力, 乃至与其产生冲突, 使其延滞而成为负担, 因为她追求的是一 种 “具体化的制作模式” (an embodied mode of making)。

这个系列的部分作品是依据更为小巧、方正且隐蔽的形制建造 的，例如《梦想之屋 2》, 它的尺寸为 $4 \times 2 \times$ I 英尺, 放置在大餐桌 上绰绰有余, 就像一个带有大量球形外饰及模型的复杂精巧的玩偶 屋（图 3)。此处申明一点, 我将这个系列作品的尺寸与家具中的 衣柜、桌子甚至玩具进行对比时，并没有轻视或诋毁的意思。尼维 尔森创作理念的基础就是她对家具的浓厚兴趣，尤其是那些与使用 者建立了情感连结，还保留往日记忆的日常物件，展现了血肉之躯 与材料一如织物和木材一的独特融合，就好像一个人陷入座椅时， 肌肤和织物因重力而贴合在一起。尼维尔森最早为人所知的绘画作 品, 实际上就是右边这幅 (图 4), 描绘了一个倚靠在一张硬木长 登或长靠背椅上的小女孩，她的腿太短无法触到地面。她仅概略地 表现了小孩天真无邪的形象, 却对家具进行了细致刻画。这些档案 资料都来自史密森尼学会美国艺术档案馆 (Smithsonian Archive of American Art）一尽管没有明确的创作时间，但能明显看出是孩 童的手笔，这说明了尼维尔森很早便出对空间及其内部关系的兴趣 和理解。而在其日后的画作中，则显示了她对精确比例和特定时期 家具的热衷，多年之后，画中各部分都被她分解融合进了雕塑作品。

尼维尔森自称 “建筑工人” 及 “光影” 的建筑师, ${ }^{2}$ 她乐于颠覆大 众对 “适合女性艺术家的技艺” 的刻板印象，这体现在她从木材厂 和贫民区收集来的创作材料，并对那些残留着使用痕迹一包括精巧 的刻痕和损毁印迹的废弃物进行再利用。她还经常拆用先前雕塑上 的配件，有时甚至是将作品整体拆除，利用零部件进行再创作。当 她与建筑工人、建筑师在一起时候, 她总是提及她的木艺, 以技工 身份表明自己对下层阶级的认同，并以此来与她的原生家庭保持距 离。她的原生阶级。正如一位评论家所述：“她对犹太中产阶级生 活并不感兴趣。” 3 某种程度说, 对木艺的热衷帮助她宣告了截然不

2 Oral history, Archives of American Art, 1964.

3 Brooke Kamin Rapaport, "Louise Nevelson: A Story in Sculpture," 
同的社会从属关系。

从精神和物质环境两方面来说，“梦想之屋” 表现了一系列经过 再造、扩张后的空间，这恰恰体现在尼维尔森回收利用拾得之物和 建筑部件，如飞檐（檐部）、栏杆、床柱、门把手、钉销和锭子等 来制造家一般的氛围。尼维尔森的雕塑创作是基于废物回收利用、 整合和分类的流程，到了 20 世纪 60 年代，这种创作行为已从工 作室蔓延到了她家中，并完全占用、混淆了她的生活和工作的空 间 ; 至此，她清空了家中资产，转而全身心投入艺术媒介的研究。 为了探求某种重构之后的、崭新的物件所有权关系，她断绝了一切 与之无关的事物; 换句话说，尼维尔森和她的众多雕塑作品 “同居” 在一起，独创了一种不断变换的家庭景观。从 1967 年惠特尼展览 （Whitney exhibition）上的一张照片可以看出，她的展览理念围 绕着材料表现。那些小木箱、托盘、废弃物或零部件，根据一种主 导的美学逻辑: 即各种零部件均以尼维尔森最具代表性的黑漆喷绘, 被强有力地统一在单一视域内; 最终被规制成艺术。

这张图片是尼维尔森工作时的情景，她戴着粗项链，裹着皮毛 大衣，正在小心地进入《梦想之屋》。尼维尔森极具辨识度的穿衣 风格和服装剪裁方式一如果不说是更大的焦点的话一至少也得到 了与其雕塑作品一样多的关注。这正是她作为女性艺术家必须承 担的包袱之一：其个人身份、个性和身体常常与她的作品混为一 谈。与其完全忽略大众传媒（mass media）对尼维尔森衣着选择和 鲜明个性的痴迷宣传，我更倾向于认真研究其个人风格塑造（selffashioning）的过程, 并将其视为她建构自我形象的有效助力。她同 时颠覆了大众对性别的预期，作品中大量的附加部件及曲线风格传 达了过度的女性化特征，这再次产生了一种延滞。我认为，她的现 代主义延滞性是多元化的，这与她对装饰艺术美学的理解，以及她 如何看待自己的非典型的现代女性身份息息相关。

这些仅是尼维尔森多维艺术形象中的一面，她也是镁光灯的宠 儿。罗伯特 - 摩根（Robert Morgan）的一个经典引述提到：这位

in The Sculpture of Louise Nevelson: Constructing a Legend (New York: Jewish Museum, 2007), I2. 
艺术家 79 岁高龄时仍 “极具标志性, 化着精致的妆容, 戴着丝质 头巾，身着华丽的长袍和五彩围巾”。 ${ }^{4}$ 关于艺术家外貌的评论接踵 而至，掩盖了她在形式和观念上的成就，尤其是批评家的言论影响 更甚 ; 正如 2007 年为其策划犹太博物馆 (Jewish Museum New York）展览的策展人所说：“她的作品首先是用雕塑语言隐喻了自 己的故事”，而她的艺术则是 “可以望见艺术家内心世界的一扇窗 户”。 5 要说明女性艺术家的作品为何往往被视为只是自传式的创作, 这会十分冗长和乏味，而这种情况并不会发生在男性艺术家身上。 一幅莱因哈特（Ad Reinhardt）的绘画就不会被视为 “隐喻他自己 的故事” 及其内心世界的写照。为了避免大家认为她的性别没有影 响到她的大众接受度, 我在此引用一则来自 $\mathrm{I} 94 \mathrm{I}$ 年尼维尔森首次 展览时的佚名评论：“当我们知道这是一位女性艺术家时，高涨的 热情就仿佛被泼了冷水。若非如此, 我们本可以将这些雕塑的创作 者看作现代艺术的伟大人物。” 6 与此同时, 我想要说明, 由于尼维 尔森本人及其作品都被公众认为是兼具怪异和摩登的，故而，这种 姿态对她而言是一种非常明显且自觉的策略。

容我声明，我并非意图评判艺术家生活中那些不可控的境遇， 但这不可避免地影响到其作品的产出。我在此简述一下尼维尔森的 成长经历：她出生于乌克兰基辅的一个犹太家庭, 四岁时随家人 搬到缅因州的一个小镇, 她的父亲曾是一名樵夫，之后在当地开 了一家废品收购站。她从来没有完全适应新英格兰的生活，回忆 说: “我的童年充满不公，我们是移民家庭，对镇上的“革命女儿 会'（Daughters of the Revolution）来说是外来者。” 7 她将早早结 婚视为解脱，但很快就离婚了。1962 年, 她的助手戴安娜（Diana

4 Robert C. Morgan, "Nevelson' s Light: The Conscience in Art," in Louise Nevelson: Sculpture of the 'sos and '6os (New York: Pace Wildenstein Gallery, 2002), 6.

5 Rapaport, "Louise Nevelson," 3.

6 引自 Arnold Glimcher, Louise Nevelson (London: Secker \& Warburg, I972), 54 .

7 Louise Nevelson, Dawns and Dusks: Taped Conversations with Diana MacKown (New York: Scribner, I976), 2. 
MacKown）搬来纽约与她共同生活了数十年，直到 1988 年尼维尔 森去世。此处有两张照片：一是戴安娜带着生活用品正在离开工作 室; 其二是她在尼维尔森身旁工作的情景, 她前面放着一盒钉子（图 5)。这类拍摄于艺术家工作室的照片有很多，在戴安娜的操持下， 这些影像共同构成了她们的家园的肖像一与其说是休咊的空间，不 如说是尼维尔森日常活动和从事艺术创作的场所。

那些将尼维尔森的作品简单地视为描绘她 “个人世界” 的观点， 忽略了她在理解作品物质性及后期维护的基础上产生的更深远的 考量。将她的作品打上 “个人化” 的标签同样也抹去了自 20 世纪 60 年代起，尼维尔森作品中所直面的其他社会主题。1964 年，她 创作了两件雕塑来缅怀大屠杀受害者，定名为《六百万的礼赞 I 》 (Homage to 6 million one) 和《六百万的礼赞 II 》(Homage to 6 million 2)。这两件作品由堆砌的木箱组成蜿蜒庞大的墙体，箱 内堆满了木质工具和尼维尔森的标志性构件，如纺锤和线轴，让人 立刻辨认出她的雕塑语言。这些雕塑构件也代表大屠杀所造成的巨 大人员伤亡、充军和流离失所的现象 ; 它们象征着我们不愿放弃的 财产，仓促离去的住所或是在被迫无奈之下重建的新生活，求生之 路望尘莫及。站在这件作品前，亲眼目睹它，就能感受到它沉重的 体积感隐约环绕你，各部件共同构成了一个壮观的整体结构，而黑 色则呈现出葬礼风格。

确实，在我看来，尼维尔森对黑色的推崇是其作品中最为激进 的一个方面。我认为她作品中黑色的意义不仅体现在统一色调的形 式层面，更是具有其他复杂内涵：因为她的单色作品引发的黑色的 问题不仅是作为颜色，也是一种捉摸不透的并可能与政治指向相关。 在众多尼维尔森职业生涯的采访和著作中，她本人都宣称了自己对 黑色无法自拔的眷恋。

我爱上黑色, 是因为它包含了所有颜色。它并不是对色彩的否定, 而是一种接纳。正因为黑色包括了所有其他的颜色，它是最具 贵族气质的颜色，也是唯一具有贵族气质的颜色…不会再有其 
他颜色能给你这种完整的感受: 平和、伟大、宁静、刺激。 ${ }^{8}$

我在此仅向各位引荐几个重要概念一其一，黑色并不是对色彩的否 定，而是积极地整合、统一了所有色彩，是色彩的总和。另一个概 念则是黑色是 “唯一具有贵族气质” 的颜色一她为黑色灌输了一种 鲜明的阶级观念和崇高感。尼维尔森的黑色是一种平和、宏伟、宁 静与激情兼备的色彩, 是对那些将黑色视为堕落或更甚者的尖锐反 驳。这段引述发表于 1976 年, 此时的美国正处于几十年的激进主义 （Activism）浪潮中，美籍非裔人士开始宣称黑色应是美丽的。在 美国的社会语境中，黑色是贫穷、下层阶级和软弱无力的代名词， 而 “黑色是美丽的” 这一口号具有强烈的修辞色彩。在美国, 尼维 尔森身为一位犹太艺术家, 并不属于得到充分尊重的白种人, 她不 仅将黑色视作一种颜色或颜料来加以推广, 更是将其视为 20 世纪 50 年代以来的一种文化建构手段，在经过了动荡的 60、70 年代后 更显得具有说服力且意义非凡。

1974 至 1985 年，尼维尔森着手创作《马丁·路德 - 金的礼赞》 (Homage to Martin Luther King Jr.) : 这是一面堆叠而成的黑 色墙体, 现被永久收藏于纽约哈莱姆的 “画室博物馆” (Studio Museum)。大约就在这个时期, 博物馆不仅收藏黑人艺术家的作品, 同时也开始接收那些受非裔移民启发或与美籍非裔人士产生共鸣的 主题作品, 而这些作品, 是由非黑人艺术家创作。所以, 尼维尔森 的这件作品被博物馆视作一件礼物, 它意味着一有些人不是黑人却 拥护黑色，黑色并非威胁和地狱，而是资源和丰饶。

《梦想之屋 30》和《梦想之屋 32》图片中的尺寸都不是特别精确, 用摄影展现尼维尔森作品, 再次暴露了一些特殊难题 : 不同于一般 情况下将雕塑转换成二维或把原本圆雕作品进行平面化处理。我们 可以看到, 尼维尔森作品的黑色是如何抵御相机和页面的。尤其是 在《梦想之屋 30》的底部, 黑暗执拗地模糊了所有细节一我们只 能保留对作品外观的朦胧印象。相反, 《梦想之屋 32》已被清洗过, 整个表面的黑色经过打亮后接近灰白色，除了少数内部凹槽外，大 
部分颜色都有些发灰。

为了以不同例证来说明同一个问题, 我把这张《天空教堂》 $(S k y$ Cathedral) 的照片与她的一件最著名的作品进行对比，在后一件作 品中，因为照相机的闪光灯，一些区域看上去，接近于白色，虽然， 我可以向你保证它是全黑的。1964 年以来，这件无题的作品因为 光线不足，整件雕塑几乎消失在墨色的阴影中。目前为止，我讨论 的这些问题看似关乎雕塑与摄影纠葛的基点，但在尼维尔森的案例 中，已经超出了维度的问题一还提出了黑色的表现力问题。

《梦想之屋 48》现收藏于迈阿密的佩雷斯艺术博物馆（Perez Museum of Art）一这张照片中的一组男性工作人员戴着蓝色手套, 小心地准备装箱。它可以帮助我们判断这些作品涉及关注度和维护 保养问题时的特点 : 创作作品的艺术家去世多年后，如何依然保持 作品的关注度及同等的维护水准。尼维尔森雕塑之 “家” 是否也对 家务或永无止境的维护劳作做出评论呢?也许吧，但作品同时也提 出了家作为 “脆弱的隐居所” 的稳定性的问题一这里不时会被受邀 的参观者侵扰一当这些雕塑转化为原大的结构时，也是在测定分类、 安装、维修这类家庭琐事的边界，它们已超越了家务劳动分工的性 别范畴。

尽管尼维尔森与激进的女性主义者并无直接关系，然而事实却 是，一旦宣称自己 “并非女性主义艺术家”，更确切地说，“恰好是 女性” 的艺术家 ; 那么，其创作愈成熟，大众便愈会将她归为女性 主义的艺术活动。尼维尔森被当做更年轻的女性艺术家的灵感之源, 她是作为持续倡导非典型的艺术制作技艺的代表人物，诸如木艺， 对女性同样是有效手段。同时，我们如何理解尼维尔森的女性主义 不仅与某个特定时间的政治运动有关一这点她已明确否认一更是一 种美学、哲学、世界观、批评理论，或者一种叙述手段呢？

尼维尔森的《梦想之屋》还与《女性之屋》（Woman House）有 异曲同工之处，创作于 $197 \mathrm{I}$ 年的《女性之屋》更明确地表达了女 性主义的主张，它曾在 1972 年 $\mathrm{I}$ 至 2 月公开展示。众所周知，这 是由朱迪·芝加哥（Judy Chicago）和米里亚姆·莎佩罗（Miriam Shapiro）策划的女性主义艺术项目（Feminist Art Program）, 它让女性学习类似木艺的技术，动手翻修蝴蝶大道（Mariposa Avenue）上的破房子，被认为是《女性之屋》的女性主义争议的 
一部分。桑迪 (Sandy Orgle) 的《亚麻衣堐》(Linen Closet) 描 绘了女性人体模型被衣梪里的架子分割开, 并与叠好的毛巾放在一 起的景象。在这样一种模糊暖昧的空间环境中, 女性人体似乎想要 摆脱，但又被包容在内置的建筑元素之中。这种对比强调了《梦想 之屋》系列是如何不借助任何真实的人体，而是以一种暗示形象， 引导观者将其投射为房子的居住者。尽管尼维尔森往往被视为抽象 艺术家，但因为其作品中的各种木箱结构被明确规整成一栋房子的 形制, 《梦想之屋》只得安身于抽象的尚未解决的紧张之中。纵观 其作品, 诸如床柱之类的材料也仍旧保持为床柱样貌, 虽然有所略 微改动，但并没有变得无法辨认。

另外, 与桑迪《亚麻衣梪》的并列对比所表达的是, 尼维尔森《梦 想之屋》也类似某种衣梪，当然，不仅是用于保存真实和幻想的东 西，还包括一系列隐蔽或公开的复杂处所。近几十年来，许多同性 恋艺术家和艺术史家都期望证明尼维尔森也是他们中的一员, 并认 为她与助手戴安娜同居相伴超过 20 年, 是说明她具有双性恋或同 性恋倾向不可辩驳的证据。但我们其实并不需要求助传记细节来说 明尼维尔森的创作表达了对各类型家庭生活的想象的。

尼维尔森也确实曾试使用除黑色以外的色调, 也就是白色和 金色，但都只是浅尝则止。以《黎明的婚宴》为例，这件作品是 MoMA 举办的 “十六个美国人” 展览的一部分; 很可能是因为这 件作品出自女性艺术家之手, 女性化的标题加上雕塑呈现了婚礼标 志性的白色, 使得作品在当时的新闻报道中得到了高度性别化的回 应。包括阿什顿（Dore Ashton）在一则评论中描述到 : “巴洛克式 的华服一花边和格子纹样让人联想到维多利亚时期的小镇上的木头 房子和带围墙的精致花园。” 换句话说，她的作品是整洁且具装饰 性的一“家庭的” (domestic) 是带有贬义的受限制和地域的指向, 而不是全球的, 受限于家庭和住所。《黎明的婚宴》是一件强有力 的雕塑, 以坚定的姿态宣告了对整个空间的把控, 并通过建构技术 和统一设色将各种异类元素融合为一体。

正如尼维尔森所记, 她的作品是要创造一种 “完满。就像婚姻 一样, 你并不是唯一的演员, 而是需要和另外一位演员合作, 在我 
的剧本中，媒材就是另外一位演员。” 9 在这种视野下，婚姻并不是 发生在两人之间的正式且神圣的仪式行为，而更像是一种可能发生 在人与物之间的互动行为（mutual animation）。因此，这样的装 置可能也会被描述成剧场舞台或舞台布景（mise-en-scène），其中， 像木头这样的物体并不是作为道具，而是在保存记忆或者为它们的 人类伙伴保存不同类型的模型中发挥至关重要的作用。也就是说, 这种艺术所坚持的是我们如何在事物中间生活，它们又是如何生活 在我们中间，或许这会告诉我们如何避免将自身以外的其他事物视 为己有，而是将自身视为被意义和历史所占有。

回看《梦想之屋》系列，正因为尼维尔森反复不断地锤炼作品 中相同的基础结构，这些 “家庭” 的围墙才在不断的变化延伸中， 变得更加多元而通透。对她来说，木头不仅是木工技艺的材料，也 代表了一种延滞的潜在活力。在此，我的讨论并不限于木材的生命 力这种广为人知的特质, 而更加看重它强大的延展性和收缩性, 就 像是适应不同气候的呼吸一样。如果说我们可以从尼维尔森的木艺 和现代主义的延滞中学到什么的话，那么，它们也许可以教会我们 如何消除制作进程的性别关联，帮助我们重新构想能接纳所有类型 的关联的广阔建筑空间。

（陈涵译，张坚校） 


\title{
Because Night Time Is the Right Time: Tactics, Popular Resistance and the Formation of the Black Arts Council
}

\author{
John Vincent Decemvirale
}

In 1968 the Los Angeles County Museum of Art (LACMA) held an exhibition of West and Central African sculpture from the collection of New York collector Paul Tishman entitled "Sculpture of Black Africa: The Paul Tishman Collection." The exhibition's first opening in October 1968 was, according to multiple sources, poorly attended. ${ }^{2}$ The low attendance numbers must have been disappointing for the young LACMA, not just because it had just moved to a well-publicized campus designed by a well-known architect on Wilshire Blvd in 1965 , but also because attendance numbers have traditionally been used as measurements of success, often used to convince collectors to donate money or art objects to art museums. Considering the significance of the Watts Rebellion of three years earlier and the museum's previous location in the Exposition Park complex in South Los Angeles, it can be assumed that the exhibition was intended to address the city's Black communities. ${ }^{3}$ A demographic the museum had ignored since an early exhibition of the Black artist, Beulah Woodard, in 1935 at the Exposition Park location. "Sculpture of Black Africa" was the museum's first exhibition of African sculpture and probably also part of its larger strategy for wooing wealthy collectors to donate to the young museum, a practice that consumed the museum's early work and resources. ${ }^{4}$

According to an article in the Los Angeles Times by Sharon Fay, on a private guided tour for the museum's Black personnel, Mr. Tishman was reported to have exhorted that it was "their responsibility to get their families and friends to the museum." Confirming that there was an awareness among decision-making staff that attendance was low, particularly for Blacks. Cecil Ferguson, a long time

I Roy Seiber and Arnold Rubin, Sculpture of Black Africa: The Paul Tishman Collection (Los Angeles: Los Angeles County Museum of Art, 1968).

2 Sharon E. Fay, "Black Culture Festival: Some Firsts At the Museum of Art," Los Angeles Times, December 3I, 1968, B5; Karen Ann Mason, Interview with Cecil Fergerson, African American Artists of Los Angeles Cecil Fergerson, Center for Oral History Research, UCLA, 1996, I53.

3 LACMA Director Kenneth Donahue starts his Foreword in Sculpture of Black Africa: "With the struggle for national autonomy now in progress in Africa and the concurrent struggle of the Negro American to establish his social and cultural identity, the historic art of Africa has assumed a new importance." Seiber and Rubin, Sculpture of Black Africa, 6.

4 For an in-depth history of the museum's relationships with wealthy donors see Suzanne Muchnic, LACMA So Far: Portrait of a Museum in the Making (San Marino: Huntington Library Press, 20I5).

4925 Fay, "Black Culture Festival," B5. 
employee of the museum, remembered that Mr. Tishman castigated the museum's staff for the low attendance and LACMA's Director of Public Relations was tasked with correcting the problem. Though there is some discrepancy as to how the conversation began, decision making staff and board members worked with the museum's mostly Black security guards to see if they could rally Los Angeles' Black communities to visit the exhibition. ${ }^{6}$ Independent of who initiated the conversation, the museum guards identified an opportunity and in short order formed a temporary community around the possibility of creating an event. We know that Sgt. William Knight and seventeen other museum guards responded with what they would call a Black Culture Festival. With a small publicity budget and a small window of time to put something together, Sgt. Knight said they organized the Black Culture Festival to "commemorate the awakening of Black Culture and to encourage the Black Community to participate in more Museum activities."

Based on the Los Angeles Times' article that covered the event, oral histories and the flier and pamphlet that have survived, we know the festival consisted of Black music making, dancing, lectures, fashion shows, beauty queen hostesses, guard led tours of the exhibition and back of the house workshops, a scholarship, a film, and name badges with "Habari Gani" written on them, Swahili for "hello." It is reported that there were 4,000 visitors that attended during the hours of 7:30 PM to I:30 AM. ${ }^{8}$

If we look at this event from within the museum's narrative or within the framework of museum studies, then the festival can clearly be chalked up to a victory for the inclusion of Black culture within a public art museum and an innovative approach to outreach, all of which are important. This position, however, misses how this was accomplished. How was it that Black working class guards were able to get out from under a museological gaze that preferred traditional African sculpture to any contemporary Black artistic practices? How did non-arts professionals insinuate their reading of an African art exhibition into the museum's exhibition, when that right was and is seriously guarded by a cultural elite? How were they able to temporarily subvert the monocultural space

6 Karen A. Mason, African-American Artists of Los Angeles: Cecil Fergerson (Los Angeles: Oral History Program, University of California, Los Angeles, 1996). In his lengthy and informative oral history, Fergerson identifies Charles M. Weisenberg as the initiator and point person between decision-making staff and the museum's Black guards. In an email correspondence with the author, Mr. Weisenberg states that he became Director of Public Relations at LACMA in 1970 and in 1968 was the Director of Public Relations for the Los Angeles Public Library. This disturbs the narrative to a degree and opens up the question as to how the guards decided to organize the event.

7 Quote from Sgt. William Knight in Bridget R. Cooks, Exhibiting Blackness: African Americans and the American Art Museum (Amherst: University of Massachusetts Press, 20II), 46.

8 Fay, "Black Culture Festival"; Cooks, Exhibiting Blackness, 9I. 
Fig. I. Stanley Swinger, Black Culture Festival flyer, 1968. Balch Art Research Library, Los Angeles County Museum of Art.

and time of the museum with a plurality of practices and readings?

This festival was a unique instance of a Black working class community consuming and responding to a dominant culture's product and spaces. The guards protested against and revealed the particularity of the museum's universalized Euro-American cultural practices by re-situating the exhibition within contemporary Black artistic practices, trespassing on traditional boundaries of museum space, unprivileging sight as the dominant sense, and expanding the guards' roles. The festival proves to be an invaluable case study in disrupting the art museum's practices, standards, and boundaries, work we typically attribute to Conceptual Art and Institutional Critique. The cultural work of the guards demonstrated how the museum's individualized, disembodied, and missionary strategies are only one way of organizing and promoting culture among many.

This chapter builds on the research in Bridget Cooks's Exhibiting Blackness: African Americans and the American Art Museum, wherein Cooks observes that "the temporary change in the museum's (LACMA's) audience showed the museum how it could use its exhibition programs to expand its reach to communities that had only been acknowledged as a labor force on campus, and not as a cultural resource of potential visitors and contributors to visual arts." 9 M analysis looks at the methods and creative ways the organizers used the opportunity of the exhibition to disturb the museum's traditional ordering of space, time, and disciplined viewing. Relying on Michel de Certeau's theoretical framework of institutional strategies and everyday practices, this paper centers on the guards' artful "ways of operating" by which the museum's order was "tricked." ${ }^{\circ}$ I will highlight the guards' tactics, look at how

9 Cooks, Exhibiting Blackness, 92.

Io Michel de Certeau, The Practice of Everyday Life, trans. Steven Rendall (Berkeley:

$494 \quad$ University of California Press, 1984), 26, 30.

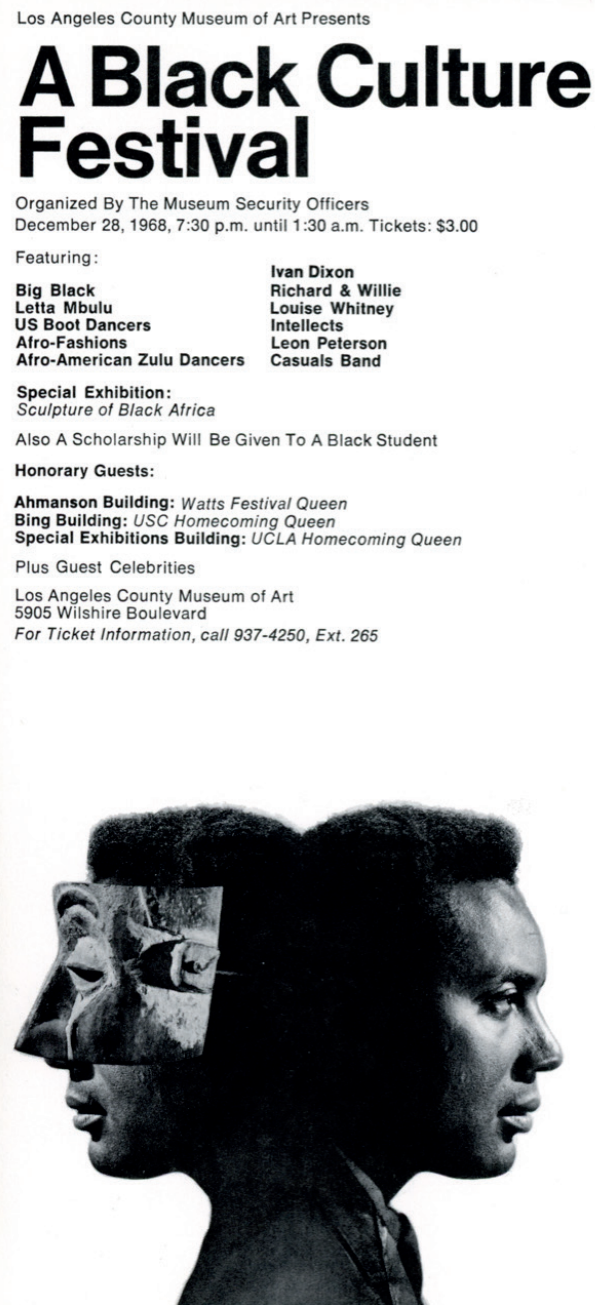

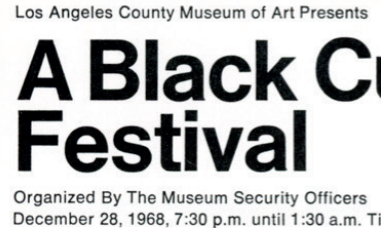

Featuring:

Afro-American

Special Exhibition:

Also A Scholarship Will Be Given To A Black Student

Plus Guest Celebrities

5905 Wilshire Bouty Musevard

For Ticket Information, call 937-4250, Ext. 265 
those tactics revealed the latent orders and values of the museum space and conclude with a look at the options this popular resistance made possible.

\section{Tactics and Disruptions}

One of the few documents we have of the work of the festival's organizers is an invitation flyer (Fig. I) designed by Stanley Swinger, one of the museum guards with a degree in graphic design. ${ }^{\text {II }}$ The flyer itself reveals some clues on how the guards envisioned the festival. I believe that we can read the flier to look for tactics and tricks that the guards relied on to destabilize the traditional museum experience.

At the top of the flier, the communal authorship of the guards is explicitly stated. Most exhibitions and events, whether on publicity materials or written on an exhibition's walls, do not run like the end credits of a movie. Instead they often hide the numerous workers that are involved in mounting an exhibition or an event. It is the museum that usually assumes authorship while the cultural workers remain anonymous. Following this, there is an indication of the event's hours, 7:30 PM to I:30 AM. The stretching into the small hours of the night is comparable to the late night hours of a jazz club or dance clubs. December 28 , I968 was a Saturday, so the festival could have taken place during the day. We do not know if this was a requirement as specified by the museum, but by staging the festival outside of the museum's normal working hours the festival was asserting or embracing that this was not business as usual. These were different operations which were to be performed during the night time. Below the numerous performers there is an indication of a scholarship that was given. Rarely do we expect our participation as museum visitors to be converted into financial assistance for those in need. This might seem like a minor observation, but part of my work here is listening for notes that are intentionally misplayed.

At the very bottom there is a Janus image of a Black man, facing both forwards and backwards. This man turns out to be Sgt. William Knight, the lead coordinator among the guards. ${ }^{2}$ If we look carefully, his iteration on the right wears his museum uniform while his backwards facing, masked counterpart does not. In the image of Sgt. Knight's body, the African mask is re-used to connect him with an African past and therein position him towards a Black American future. This is a revelatory image because it is a product of the guards' reading of the African art exhibition. We might conjecture that they used this epistemological position of doubleness as more than just a clever visual, but as a familiar

II Fay, "Black Culture Festival," B5. Stanley Swinger is a little known figure within LACMA's history. Along with the significant role he played in organizing the festival, he was also a curatorial assistant in African Art. See "The African Show at the LACMA. With Katherine Reswick, Alan Bassing, Stanley Swinger," The Sour Apple Tree, KPFK, Los Angeles, March 26, 1973, where Swinger is introduced as a curatorial assistant.

I2 Fay, "Black Culture Festival," B5. 
model by which to occupy this in-between place. One could identify this as a visual representation of how Black Americans felt living in the United States, the "double consciousness" that W.E.B. Du Bois recognized as the irreconcilable space between being American and also of African descent. ${ }^{13}$

I believe this photo-collage lays out the role the guards saw themselves as performing: as bridging two different historical moments, between the African sculpture and a living Black culture, as well as between a white art establishment and Black communities in the city. By occupying this space they made room for a heterogeneous blackness to be performed rather than to be told what it was via a static exhibition. Handed an exhibition that in many ways was in line with a racialized thinking that could not see any Black artistic production as museum worthy, the guards "turned poison into medicine." ${ }^{14}$

I have intentionally waited until the end of this section to go over the II musical and dance performances listed. Cooks explains that there was a "special focus on the musical contributions to show the evolution of African music into jazz, supporting the connection between the Tishman show and Black America." Is Deploying such an extensive presentation of Black music, the guards were asserting a tradition that was not allowed to co-exist within an exhibition space that privileged objects and silence.

I summarize here below the ethnomusicologist Christopher Small's characterization of Black music as an epistemology that subverts what he calls "modern industrial values," to add some context. African slaves were taken from different parts of Africa and on arriving in the United States they had to forge a common culture out of these numerous languages and cultures as a matter of survival. Music making became a form of common culture, a method of communication, mixing different musical traditions and values that each person brought with them. It is for this reason that Small identifies community formation, collaboration, and strong connections to vernacular sources as hallmark characteristics of both African American culture and music making. The centrality of music and dance within the festival, along with the other tactics I have specified, parallels Small's observations that Black music, from gospel music to jazz, reveals a set of values "deeply subversive of the official values of industrial society." ${ }^{16}$ These varieties of Black music have long been practiced outside of cultural and economic centers and these Black epistemologies provide alternative methods of forming community, accessing vernacular sources, as well as tactics for evading the insistent values of a dominant culture.

I3 W.E.B. Du Bois, The Souls of Black Folk (Greenwich: Fawcett Publications, I96I).

I4 See Herbie Hancock series of lectures: Harvard University, "Herbie Hancock: The Ethics of Jazz | Mahindra Humanities Center," YouTube, February I3, 20I4, https://youtu.be/EPFXC3qItTg.

I5 Cooks, Exhibiting Blackness, 9I.

I6 Christopher Small, Music of the Common Tongue: Survival and Celebration in 496 Afro-American Music (London: J. Calder, 1987), 30. 
Could we compare this musical tradition as characterized by Small with the work of the museum guards in organizing the festival? That the guards relied on Black epistemologies and ontologies based in Black music making to organize and gather the festival? While I do not want to bundle these tactics into a logic, it can be acknowledged that the festival's practices and the Black music tradition both run counter to the logic of modernity and the museum. A logic based in matrices that privilege property, objects, and authorized readings; that prefer hierarchies, exhibition, and individualized actions rather than communal thinking and doing. This festival showed that an institution, like a jazz performer, could move out of its universalized subject position of authority and let other performers play their own culture_-instead of acting as gatekeepers.

I propose that it was tactics like the flier, the change in hours, the music, the art student scholarship, and the communal authorship that temporarily changed the ontological structure and the epistemological hierarchy of the museum. Speaking of the everyday tactics of reading, Certeau says, "Autonomy of the reader depends on a transformation of the social relationships that overdetermines his relationships to texts." ${ }^{17}$ The festival disrupted the social relationships and traditional frameworks of "reading" and "viewing" in the museum. It facilitated the temporary shift from a disciplined monocultural space to a celebratory, pluriversal space, increasing the autonomy of the viewer and providing space for other ways of being with and knowing art objects. Operations that ultimately challenge what we understand the work of a museum to be.

\section{Picking Up What Was Put Down: The Black Arts Council}

The Los Angeles Times described the Black Culture Festival's slate of events as an open house, and in many ways the museum's spaces were turned inside out and its authority was disrupted. The guards led tours of restricted spaces, the museum was open very late, a majority of the audience was Black, languages other than English were introduced, Black hostesses greeted visitors. These seemingly small details, these different ways of ordering space and performing culture, were all part of the work and success of the festival. In those brief six hours the festival displayed what could be done with museum space when people were allowed to use the space on their own terms.

With most museum exhibitions of objects, there is a certain assumption that something beneficial to the community has been performed. Whether it is the opportunity to celebrate an artistic practice or revive a history, the effects are often abstract, ephemeral, counted in attendance numbers. One of the tangible outcomes of the Black Culture Festival's disruption allowed another temporary, activist community to form and pick up where the festival left off. Two art handlers, Cecil Fergerson and Claude Booker, saw another opportunity when the festival ended. The two approached the guards who had run the festival to gauge interest in organizing to pressure the museum to exhibit and collect African American 
Fig. 2. Fred Wilson, Guarded View, 1991. Whitney Museum of American Art. Gift of the Peter Norton Family Foundation. (C) Fred Wilson, courtesy Pace Gallery.

art. The guards declined. As Fergerson described it: "They had done what they had set out to do." ${ }^{\text {I8 }}$

Und eterred,

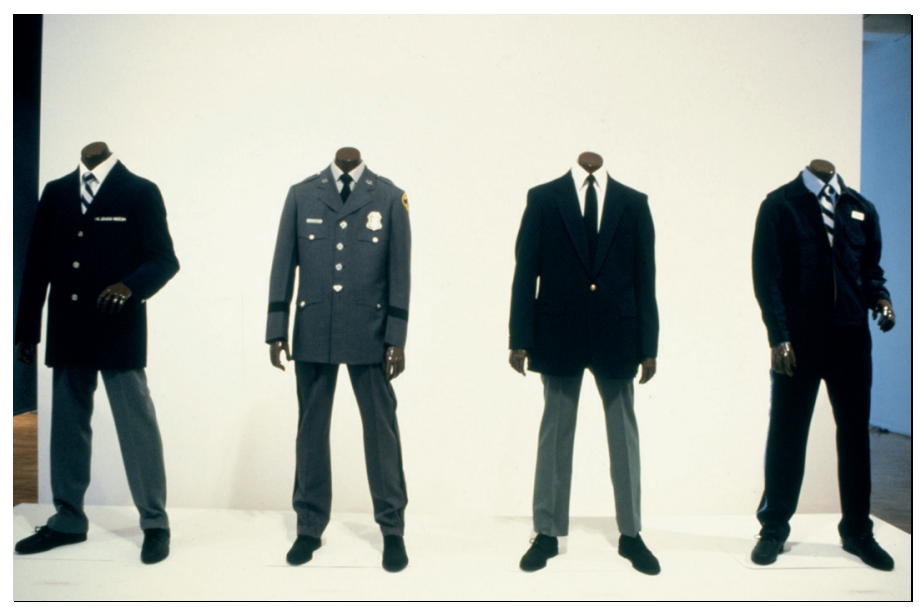
Fergerson and Booker established the Black Arts Council in 1968. Mimicking the name of other museum councils and intending to imitate their structures, the group found no support within decision-making staff or among wealthy patrons. The council took its agenda offsite and began to meet at local churches and Black run galleries, finding support in Los Angeles' Black communities. Its membership would reach 3,000 members and was responsible for numerous exhibitions around the city, protests in front of the museum and official letters to LACMA demanding more representation within the staff, the collection, and exhibition programming. Events like these went on for years and would eventually culminate in the 1976 exhibition, "Two Centuries of Black American Art." It was the first time an American museum surveyed Black creative arts within the United States.

\section{Guarding The View}

I wanted to briefly discuss Fred Wilson's Guarded View (199I) (Fig. 2). In this installation we see brown mannequins facing outwards towards the viewer, reminiscent of a display of costumed figures. These costumes, however, are actual uniforms from each of the major museums in New York City during the I980s and I990s. Headless, the guards are squarely positioned, and can be read in various states of guarding, protecting; the figures on the ends, possibly warning or cautioning

Wilson is obviously addressing the anonymity of the guards, as well as the fact that most custodial and security positions at art museums are held by people of color. According to the "Art Museum Staff and Demographic Survey," published in 2015 by the Andrew W. Mellon Foundation, American museum leadership is overwhelming white and minorities working within the museum "do not come close to representing the diversity of the American population."

I8 Mason, African-American Artists of Los Angeles, I60.

I9 See Roger Schonfeld and Mariët Westermann, "The Andrew W. Mellon Foundation: Art Museum Staff Demographic Survey," July 28, 20I5, https://mellon.org/ 
According to the study, people of color will most commonly be found in the Facilities and Security departments of most major American museums.

As recounted by the artist in an audio clip on the Whitney Museum of American Art's webpage for Guarded View, during his undergraduate years, Wilson was a guard at his college's art museum. Invited to the Whitney as part of a public program accompanying an exhibition that included his work, Wilson dressed up as a museum guard for his tour and found that museum staff that he knew did not recognize him while he was in uniform. Visitors and on-duty museum guards were bemused and taken by his performance. To quote Wilson, it was "kind of interesting for the public to see a guard speaking in art historical terms and critiquing the exhibition." ${ }^{20}$ This performance echoed the critique performed by the guards at LACMA many years earlier, when they also gave tours during the Black Culture Festival. What falls aside and what is opened up when we accept that both the guards and Wilson performed and embodied their critiques of the museum? If only momentarily and topically, they share a common position, wherein they highlighted the overlooked and unseen working bodies that police cultural spaces. Opportunities to begin reconsidering whose voices are heard, whose critiques are deemed valid and whose work supports our cultural spaces.

Guarded View makes the invisible systems of the museum visible, a practice that has been central to Wilson's work in mining the museum. But to leave it there misses the depth of what Wilson makes visible. This is not just about anonymity and racial imbalance in museum hierarchy. We are reminded that when we look at artworks in a museum setting we are always being watched while we look. That museum space is disciplined and monitored and very often that monitoring and disciplining is done by people of color.

What am I getting at here? I am concerned with the behaviors and rituals that the American art museum enforces. The demographics and Wilson's work reveal to us that these are the mechanisms and politics of our spaces. Modifying Certeau's commentary on reading: To look in a museum is to wander through an imposed system. ${ }^{21}$ What does it mean to us when those who impose the system are those we are taught to ignore?

So much scholarly and artistic work has made visible the museum's uses of space and narrative constructs. Spaces which have been constructed to tell the stories of a dominant culture in support of modern industrial values and where viewers are meant to occupy a subject position within white Euro-American history, within a timeless and universal space where viewers are expected to move

media/filer_public/ba/99/ba99e53a-48d5-4038-80eI-66f9barco2oe/awmf_museum_diversity_report_aamd_7-28-15.pdf.

20 "Audio Guide Stop for Fred Wilson, Guarded View, 1991," Whitney Museum of American Art, http://whitney.org/WatchAndListen?play_id=496.

2I "In fact, to read is to wander through an imposed system (that of the text, analogous to the constructed order of a city or of a supermarket)." Certeau, The Practice of Everyday Life, 169. 
about silently and freely as disembodied eyes. But as long as there have been guards in these spaces, this utopian space was never as pure or romantic as it was criticized for being. Guards are a silent part of the modern museum experience. Their presence in many ways disrupts the attempts at pretending that the museum is separate from the outside world. Ignoring these workers is part of looking at artworks within an art museum. Whether it is to ignore their racialized or working class bodies, it can be acknowledged that the ways of seeing are equally about what we can not see and what we are trained to ignore.

\section{Conclusion: Learning to Listen}

Museum studies and the work of Institutional Critique have shown us that the art museum, despite relentless critique, mining, and deconstruction, has gone mostly unmoved. In light of an ongoing museum crisis in engaging with communities of color, the non-traditional cultural workers discussed here show us assemblages and tactical methods for organizing culture that go against "modern industrial values." Ways for getting out from under an institution's dominant reading of whom one is. I propose that the Black Culture Festival was a rare instance of a working class culture showing how it can work within and under the authority of the museum's space and discipline. Protest and critique enacted by bodies that occupied space differently.

Public art museums in the United States continue to exhibit a majority of white, male artists. Fighting for inclusion and space have real financial and social effects on artists and communities. My paper has posited the tactical work of a group of museum guards as important to the academic discussion on how best to make the museum meaningful to as many people as possible and while inclusion on equal terms is crucial, there must equally be work towards opening up other options within the museum's methods, spaces, and epistemological hierarchies.

There is more to be said about the festival being a spontaneous, Black, working class bricolage of high and low sources than there is time for here. That it was those who do not occupy the upper echelons of the art world's hierarchy, those who are actually charged with disciplining visitor responses who would show us how to be undisciplined is an important insight for how we continue to think about the blurring boundaries between art institutions, audiences and art. The Black Culture Festival showed what other work a museum could do. It asserted that all museum employees were creative and capable of participating in cultural work and that to ignore those voices is to ignore real avenues towards reconnecting the museum's work to lived life. 


\section{夜晚好时光：策略、公众抗拒与黑人艺术委员会 的形成 \\ 约翰・文森特・德赛穆维拉}

I968 年，洛杉矶市立博物馆（LACMA）举办了一个收纽约藏家保 罗·帝斯曼 (Paul Tishman) 所藏的非洲中西部雕塑的展览, 名为 “黑 非洲雕塑 : 保罗 ·帝斯曼收藏展” (Sculpture of Black Africa: The Paul Tishman Collection)。 ${ }^{1}$ 展览于 I968 年开幕，不同来源的资 料都显示出当时参观的人数很少。 2,3 如此低的参观量肯定对年轻的 市立博物馆造成打击，不仅仅因为他们在 1965 年刚搬入了威尔舍 尔大街的一个由知名建筑师精心设计的公共园区内，也因为博物馆 参观人数在传统意义上被认为是衡量展览是否成功的标尺，常常以 此来说服收藏家为博物馆注资和捐赠艺术作品。考虑到三年之前发 生的 “沃茨暴乱” 的意义，以及这个博物馆之前位于南洛杉矶的展 览会公园的旧址，可以推断此次展览是希望同洛杉矶非裔美国人群 体产生联系。 ${ }^{4}$ 该博物馆忽略了一个统计数字，就是自 1935 年非裔 美国艺术家伍德阿德（Beulah Woodard）在展览会公园的旧址举 办展览之后，“黑非洲雕塑” 是该博物馆首个关于非洲雕塑的展览, 而且很可能隶属于这个年轻的博物馆寻求富贾收藏家向博物馆捐赠 艺术品的大战略的一部分，这个展览消耗尽了博物馆早期的运作与

1 Roy Seiber and Arnold Rubin, Sculpture of Black Africa: The Paul Tishman Collection (Los Angeles: Los Angeles County Museum of Art, I968).

2 Sharon E. Fay, "Black Culture Festival: Some Firsts At the Museum of Art," Los Angeles Times (December 3I, I968), B5.

3 Karen Ann Mason, Interview with Cecil Fergerson, African American Artists of Los Angeles Cecil Fergerson (Center for Oral History Research, UCLA, I996), I53.

4 洛杉矶市立博物馆馆长肯尼斯·多纳休（Kenneth Donahue）在黑非洲 雕塑的前言中说道 : “随着非洲国家自治斗争的进程以及非裔美国人为 建立自己的社会文化认同的不断抗争，非洲艺术史显现出新的重要性。” 
资源。 5

根据《洛杉矶时报》的一篇沙朗 - 菲 (Sharon Fay) 撰写的关于 博物馆黑人员工的私人导览的文章, 帝斯曼先生当时劝说这些保安, 认为他们 “有责任带着自己的家人和朋友前来观展”。 ${ }^{6}$ 证实了当时 的决策阶层意识到了低参观率的情况，尤其是黑人。 ${ }^{7}$ 博物馆内的 资深员工塞西尔 - 福尔古森（Cecil Ferguson）还记得蒂斯曼先生 因为观众量过少而严厉批评了博物馆工作人员，以及负责补救这个 失误的博物馆公共关系部门的领导人。尽管有关这个对话是如何展 开的说法之间还存在一些䶖齝之处，负责决策的员工、领导层与博 物馆的大部分为黑人的保安一起合作，看是否能集合洛杉矶的黑人 群体来参观此次展览。与最初引发这个对话的人不同，博物馆保安 意识到这是一次机会，并且立刻围绕着 “创造”一个事件的可能性 而组成了一个临时团体。我们知道威廉 ·奈特警长 (Sgt. William Knight）和其他十七位博物馆保安最终以我们称之为 “黑人文化节” 的活动作为回应。 ${ }^{8}$ 他们仅有少量的公共预算和一小部分时间来组 织这件事情，奈特警长说，他们组织这个黑人文化节是为了 “纪念 黑人文化的觉醒以及鼓励黑人社群更多地参与博物馆的活动”。9

5 关于博物馆与富贾捐赠者深入的历史, 见 Suzanne Muchnic, LACMA So Far: Portrait of a Museum in the Making (San Marino: Huntington Library Press, 2015).

6 Fay, "Black Culture Festival," B5.

7 Karen A. Mason, African-American Artists of Los Angeles: Cecil Fergerson (Los Angeles: Oral History Program, University of California, Los Angeles, 1996). 在他漫长且丰富的口述史中，福尔古森（Fergerson）称 查尔斯 - 魏森贝格 (Charles M. Weisenberg) 是作为决策者和博物馆黑 人保安之间的发起人和关键人物。魏森贝格称他在 1970 年担任洛杉矶 市立博物馆公共关系部的主管，1968 年是洛杉矶公共图书馆公共关系 部的主管。这在一定程度上干扰了叙事, 关于保安如何组织这次事件的 问题就此提出。

8 将列着活动的文化节小册子保留下来, 组织洛杉矶市立博物馆的员工来 参加。

9 引自 Sgt. William Knight, 见 Bridget Cooks, Exhibiting Blackness: African Americans and the American Art Museum (Amherst: University of 
根据《洛杉矶时报》对这次事件的报道，口述历史与传单和小 册子留存了下来，我们知道这个文化节包括黑人音乐的演奏，舞蹈， 讲演，时装秀，选美活动，参观展览，奖学金，保安引领参观家庭 作坊后台，电影，在徽章上题写 “Habari Gani” 的字样，那是斯 瓦希里语中 “你好” 的意思。据报道，在当天晚上七点三十分到凌 晨一点三十分，有超过 4000 名参观者来到了博物馆。 ${ }^{10}$

如果我们从博物馆叙事或在博物馆研究框架中来看待这次事件, 而不是把这个文化节记录为博物馆里的黑人文化的胜利和一种实现 超越的创新方式，那么，这些成绩就是很重要的。不过，这样的立 场也会忽略它是如何完成的问题。作为黑人劳工阶层的保安，如何 从一种博物馆学的凝视下挣脱出来, 这种凝视宁可关注传统的非洲 雕塑，而不是当代非裔美国人的艺术实践?当权力主要是由文化精 英操控时，非专业艺术人士如何让他们对一个非洲艺术展览的读解 能进入到这个博物馆的展览里，他们又如何可以在一段时间里，以 艺术实践和理解的多元性而颠覆博物馆单一的文化时间与空间?

这个节日是黑人工薪阶层消费和回应主流文化的产物与空间的 独特例子。这些保安把这个展览重新定位在当代非裔美国人的艺术 实践中，他们跨越博物馆空间的传统界限，让主流眼光非特权化， 并扩展保安角色，由此，他们抗议和揭示了博物馆世界占据主流的 欧洲 - 美国文化的实践：这个事件对于如何把博物馆实践和界限纳 入到我们通常称为概念艺术和体制批评的工作框架中是一个弥足珍 贵的案例。保安的工作证明博物馆个人化的、无形的宣传策略如何 也是诸多组织与推动文化活动的方式中的一种。

这篇文章的依据是布丽吉特-库克斯（Bridget Cooks）的研 究《展现黑人特质: 非裔美国人与美国艺术博物馆》(Exhibiting Blackness: African Americans and the American Art Museum) 上, 库克斯认为 “洛杉矶市立艺术博物馆观众的临时变化，向这个博物 馆展示了它如何以展览项目来扩大与群体的联系，但这一点仅仅被 校园中的劳动阶层意识到，而且，并不是作为一种潜在文化资源的

Massachusetts Press, 20II), 46.

10 引自 Fay, ibid., 9I. 
参观者和视觉艺术的贡献者”。 ${ }^{11}$ 我的研究关注的是组织者如何借由 这个展览机会来重新整合传统博物馆的时间、空间秩序以及专业眼 光的方式和方法。根据米歇尔 - 塞尔托 (Michel de Certeau) 体制 策略与日常实践的理论框架, 即 “弱势群体如何在主流文化策略中 运用谋略来反对它” 的观点, 论文将聚焦于保安艺术化的 “运作方 式”，而这种方式之下，博物馆的秩序如何被 “哄骗了”。12 重点是 在保安的策略上, 检视这些策略如何表现出博物馆潜在秩序与价值, 我的结论将由使这些大众化的反抗有实现之可能的诸种选择入手来 进行讨论。

\section{策略和破裂}

我们看到的有关这个节日组织者的部分文件中的一件是由斯坦利 斯威格尔（Stanley Swinger）设计的宣传单（图 I), 他是这些保安 中获得过平面设计专业学位的人。 ${ }^{13}$ 从这个宣传单本身就可以看出 这些保安是如何看待这个节日的。我认为, 我们可以通过阅读这个 宣传单来寻求他们打破传统博物馆体验所使用的策略与手段。

宣传单顶部清楚标明了这些保安的作者信息。大多数展览与活 动, 不论是有关公众宣传的材料还是展墙上撰写的内容, 都不会像 电影末尾一样详细陈述具体细节, 而常常隐匿掉了大量参与展览或 活动的工作者的名字。通常是博物馆具名, 而博物馆的文化工作者 是匿名的。

作者信息之下是活动时间和地点安排，晚上 $7: 30$ 到凌晨 $\mathrm{I}$ : 30, 在 Hit Space Bar。这个夜晚的时间段相当于爵士夜总会或舞 厅的午夜场。1968 年 12 月 28 号是星期六，因此节庆活动可能在白

11 Cooks, Exhibiting Blackness, 92.

12 Michel de Certeau, The Practice of Everyday Life, trans. Steven Rendall (Berkeley: University of California Press, I984), 26, 30.

13 Fay, “Black Culture Festival,” B5. 斯坦利 · 斯威格尔在洛杉矶市立博物 馆的历史中鲜为人知。除了组织文化节外, 他还是非洲艺术的策展助理。 见 “The African Show at the LACMA. With Katherine Reswick, Alan Bassing, Stanley Swinger," in The Sour Apple Tree (KPFK, Los Angeles, 26 Mar. 1973). 文中介绍了斯威格尔作为策展助理的内容。 
天就已经开始了。我们不知道这是否是由博物馆提出的要求, 但是, 将节庆定在平日博物馆工作时间之外，可以传达或暗示一种今时不 同以往的信息。在夜晚，是会有不同的运作方式的。

在众多表演者的下面，标明了活动资助是由奖学金提供的。通 常情况下, 博物馆的活动是不会让前来参与活动的访客提供资助的。 这有点类似于是一个不太紧要的标注，但我的部分工作就是去细致 聆听那些故意错置的标注。

宣传单的最底部是一个黑人的双面肖像，同时向着前方与后方。 这人就是奈特中士，保安的领队和协调人。 ${ }^{14}$ 仔细观察，他的右侧 形象穿着博物馆制服，同时，他的反面，带着面具的形象，却没有 穿制服。奈特中士身体形象中，非洲面具被重新使用，把他与非洲 的过往连接在一起，由此，将他自己放在了非裔美国人的未来当中。 这是一个具有启示性的形象，因为它是这些保安读解此次非洲艺术 展之后的成果。我们也许会猜想，他们使用这种双重的认识论的方 式，不仅是作为一种聪明的视觉呈现，也作为一个身处双重位置的 熟悉的范型。可以将之视为那些在美国生活的非裔美国人的生活感 触的视觉呈现，也就是杜布瓦（W.E.B Du Bois）指出的，作为一 位美国人与身为非洲后裔间的不可调和的空间的 “双重意识”。1 15

我认为，这个照片拼贴勾画出了保安对自己在此次活动中所发 挥作用的认知：作为两个不同历史时刻间的桥梁，作为非洲雕塑与 当下非裔美国文化的桥梁。通过占据这个空间，他们也就创造了一 个演示异质的黑人特性的场所，而不再是通过一个静态的展览来告 知这个内容。组织展览过程中, 许多方面都是与种族主义思想联系 在一起的，也就看不到非洲裔美国艺术家的创作的博物馆价值，而 这些保安却像 Herbie Hancock 所说的，是做到了 “妙手回春”。1 我想在这个部分论述的结尾再来讨论单子上列出的 II 个音乐与

14 Fay, "Black Culture Festival," B5.

15 W.E.B. Du Bois, The Souls of Black Folk (Greenwich: Fawcett

Publications, 196r).

16 见 Herbie Hancock 系列讲座 “Herbie Hancock: The Ethics of Jazz

| Mahindra Humanities Center,” Youtube, February 13, 20I4, https:// youtu.be/EPFXC3qItTg. 
舞蹈表演。我的论文是建立在艺术史家库克斯的论著之上的，他的 解释是， “存在一种对音乐方面的贡献的特殊关注，它展现了非洲 音乐融入爵士乐, 支撑帝斯曼收藏展与非裔美国人的纽带”。 ${ }^{17}$ 利用 黑人音乐这样一个具有延展性的呈现方式，保安主张了一种传统， 这种传统无法与赋予宁静和展品特权的展览空间共存

此处, 我的概括是在民族音乐学家克里斯托弗·斯默 (Christopher Small）的论述基础上的：他将黑人音乐视为一种颠覆 “现代工业 化价值” 的认识论, 我再加上一些背景知识。非洲奴隶来自于非洲 的不同区域，到达美国时，出于生存考虑，他们必须从大量不同的 语言和文化中创造一种共同文化，这是一个生存问题。音乐创作成 为共同文化的一个形式，一种沟通方法，融合了每个人带来的不同 音乐传统与价值。因为这个原因，斯默是把共同体的形成、合作关 系以及与民间生活源泉的强烈关联性作为非裔美国文化和音乐制作 的标志特征。在这个节日中，音乐与舞蹈的核心地位，以及我所特 别指出的其他策略，是与斯默对黑人音乐的观察类似的：从福音音 乐到爵士乐，揭示了一系列 “深刻颠覆工业化社会官方价值” 的价 值。 ${ }^{18}$ 黑人音乐的多样性很久以来在文化与经济中心之外实践的, 而且，这些黑人的认识论提供了形成共同体，获取民间资源的另类 方法，还有逃避主流文化价值的策略。

我们是否可以将斯默所定义的音乐传统与博物馆保安为组织这 次节庆活动所做的工作进行比较?也就是说，保安依靠黑人音乐制 作的认识论和本体论来组织和召集这次节庆的? 我并不想将这些策 略打包放入同一个逻辑, 可以承认，这个节庆活动和黑人音乐传统 同时遭遇了现代性与博物馆的逻辑。它们都属于财产、器物的特权 以及权威阅读的母体; 较之于群体的思考与活动, 它会更青棟等级 划分、展览和个人的行动。这个节庆表明，一个机构就像爵士乐的 表演，是可以从其一般的主题中走出来的，让其他的表演者来展现 他们自己的文化，而不是像卫道士一样固守陈规。

我认为, 正是这种类似于宣传单的策略，开放时间的变化，音乐、

17 Cooks, Exhibiting Blackness, 9I.

18 Christopher Small, Music of the Common Tongue: Survival and 
艺术学生奖学金与团队共同署名的策略等，一时之间就改变了博物 馆的本体结构以及认识的分层。论及阅读的日常策略时, 塞尔托说, “读者的自主性依靠的是多元地决定他与文本关系的社会关系的转 变”。19这个节日瓦解了博物馆中的 “阅读”与 “观看” 的社会关系 和传统框架。它促进了从严格的一元文化的空间向一个兴奋的和多 维度的空间的临时转换。增加了观者的自主性，为与艺术品相处以 及认知它们提供了更多的其他方式。他们的举动极大地挑战了我们 对博物馆工作意义的理解。

\section{朝花夕拾：黑人艺术委员会}

《洛杉矶时报》将黑人文化节的一系列事件描述为开放日，在很多 意义上，这个博物馆是将内部空间昭示于众，其权威性遭到瓦解。 保安引导参观博物馆限制区域，而且博物馆的开放到很晚，观众中 的大多数是黑人，还引入了除英语之外的其他语言，黑人迎宾小姐 招待参观者。这些看似微小的细节、不同的空间安排与文化表演的 方式，都是这次节日组织工作得以成功的一部分。在短短六个小时 内，这个节日展示的是，在人们被允许以自己方式利用博物馆空间 时，博物馆可以做什么。 ${ }^{20}$

与大多数博物馆器物展览一样 : 确定的设想使某种有益于共同 体的东西得到了展示。不论这是否是庆祝艺术实践或者重现历史的 机会，其结果常常是抽象和短暂的，以上座率来衡量。黑人文化节 实际的瓦解效应使得当时的另一个激进群体得以形成和捡拾起这个 节日遗落的部分。塞西尔・福尔格森（Cecil Fergerson）和克劳德 - 布克尔（Claude Booker）两位艺术经理人在节日落幕之时发现了 新的机会。两人试图劝说运作这个节庆的保安估测组织活动的利益, 施压博物馆举办非裔美国艺术展览以及收藏相关作品。保安拒绝了。 福尔格森说：“他们完成了自己的份内之事。”

福尔格森和布克尔没有被困难吓倒，他们在 1968 年成立了 “黑 人艺术委员会”。模仿其他博物馆委员会的名字，并且也意图模仿 其结构，这个团体并未得到决策层或者其他财团的支持。委员会将

19 Certeau, The Practice of Everyday Life, I73.

20 Mason, African-American Artists of Los Angeles, I60. 
自己计划公诸于众，与当地教堂和黑人运作的画廊会面商谈，在 洛杉矶的黑人社区中寻求帮助。其会员达到了 3000 余人, 他们负 责这个城市周围的大量展览, 在市立艺术博物馆前举办的抗议活 动, 给这家博物馆写公开信, 要求它在员工招聘、收藏与展览计划 上的更多地展现黑人份额。这样的活动持续了数年, 最终在 1976 年的展览 “两个世纪的非裔美国艺术” (Two Centuries of Black American Art）达到顶峰。这是美国境内的一家美国博物馆第一次 关注黑人的创造性艺术。

\section{监控视野}

我想要简单地讨论一下弗莱德 - 威尔森 (Fred Wilson) 的《保安 的视野》(图 2, Guarded View 199I)。在这件装置中, 我们看到 棕色模特面朝观者，使人联想到戏剧人物形象的展示。然而，这些 人物所穿的服装实际上就是 20 世纪 80 和 90 年代纽约各主要博物 馆的工作服。没有头, 这些保安的姿态十分端正, 可以解读为是各 种维持安全的工作状态; 最后的那组形象似乎是在进行警告或提醒。

威尔森显然在指涉保安的匿名化, 同时，也指涉博物馆中的大 部分维持秩序和保安类的工作岗位都是有色人种所占据的。根据安 德鲁 ·梅隆（Andrew W. Mellon）基金会 2015 年出版的 “博物馆 在职员构成调查”， ${ }^{21}$ 美国博物馆领导层中，白人占据压倒性优势， 博物馆内工作的少数族裔的状况没有能够反映出美国人口的多样 性, 根据这个研究报告, 大部分美国的重要博物馆里, 有色人种通 常都是在设备维护与保安部门。

正如这位艺术家在惠特尼美术馆网站的一段音频中对 “保安的 视野” 给出的陈述那样, 威尔森在大学本科期间就担任了他所在大 学博物馆的保安。作为包含展览的公共项目的一部分, 威尔森被惠 特尼邀请参与其中的工作, 他穿得像博物馆保安一样, 做引导工作, 发现他所认识的博物馆工作人员并没有认出穿着制服的他。参观者 和当日值班的保安都对他的行为感到困惑, 同时也被他的举动吸引。

21 见 Andrew W. Mellon Foundation: https://mellon.org/media/filer_ public/ba/99/ba99e53a-48d5-4038-80eI-66f9barco2oe/awmf_museum_ diversity_report_aamd_7-28-15.pdf 
用威尔森的话说，“对公众来说，看到一个保安用艺术史术语讲话 和评论这个展览十分有趣”。22这个举动回应了多年前洛杉矶市立艺 术博物馆保安演示评论的举动，在黑人文化节中，他们也担负了导 览工作。当我们接受保安与威尔森对博物馆展览的评点之时, 我们 搁置了什么? 同时，又开启了什么呢? 如果这种行为仅仅是短暂的和 话题性的，那么，他们就处在共同位置上，也即是说，他们聚焦在 那些被忽视和隐在的工作机制上，这些机制管制着文化空间。这是 重新思考诸如谁的声音被听到了，谁的评价被认为是有效的，以及 谁的工作在支撑我们的文化空间的机会。

“保安的视野” 使得博物馆的隐形空间显现出来，这个实践是威 尔森的作品 “开发博物馆” 的中心议题。但是，如果仅止于此，那 就忽视了威尔森拨云见日之行为的深度。这不仅与博物馆等级体制 中的匿名性和种族的不平等相关。在博物馆环境中观赏艺术作品时, 我们被提醒处于监控状态。博物馆空间是有规范要求的，是被监控 的，而且，这种监控和规范常常都由有色人种来执行。

此处, 我又得到了什么呢? 我所关注的是美国博物馆要求的行为 举止规矩和礼仪。这个人员统计和威尔森作品都向我们揭示了我们 所在空间的机制与政治学。对塞尔托关于阅读的评论的一个修正是: 博物馆中的观看，是在一个强加的系统中的漫游。 ${ }^{23}$ 那些强加系统 给我们的人恰就是那些我们被告知需要加以忽视的人，这又意味着 什么?

如此多的学术与艺术作品让博物馆空间的使用及其叙事结构浮 出水面。那些被建构起来用于讲述支持现代工业价值的主流文化的 故事的空间 ; 观者需要在欧洲 - 美国的白人历史中，占据一个主体 位置，在永恒与普遍的空间中，以纯净之眼，默然和自如地漫步， 只是一旦这些空间中出现保安，这个乌托邦空间就不会如它被评说 的那样纯洁与浪漫。保安是现代博物馆体验中一个沉默的部分。在

22 "Audio Guide Stop for Fred Wilson, Guarded View, I99I," Whitney Museum of American Art website, http://whitney.org/ WatchAndListen?play_id $=496$.

23 “事实上，阅读就像是在一个强加的系统中漫游（文中类似于城市或者 超市的建造顺序)。” Certeau, The Practice of Everyday Life, I69. 
很多层面上，他们的出现打破了博物馆与外部世界分离的假象。对 这些工作者的忽视也构成了博物馆内观赏艺术品的一部分。不论是 忽略他们种族化的还是工薪阶层的躯体, 我们都得承认, 这些观看 方式都是关乎到我们不能看什么，以及我们被训练着去忽视什么。

\section{结论：倾听业余的声音！}

博物馆研究与体制批评的工作表明，尽管有持续的批判、挖掘与解 构, 艺术博物馆多数时候是无动于衷的。这里所讨论的与有色人种 群体和非传统文化工作者相关的博物馆危机, 向我们展示了对抗 “现 代工业化价值” 的文化活动的组织安排与策略手段，从体制规约的 社会定位中解放出来的方法。我认为，黑人文化节，是工薪阶层的 文化展示它如何在博物馆的空间与规则中辗转腾挪的罕见例子。抗 议与批评是以不同方式占据了空间的躯体而被激活的。

美国公共艺术博物馆继续以白人男性艺术家的作品为主要展示 对象。对于艺术家和各种社会群体而言, 争取博物馆的接纳以及空 间是有着实际的经济与社会效应的。我的论文是把一个博物馆保安 群体的工作策略放在了重要的学术探讨的层面 : 如何能让尽可能多 的人感受博物馆的意义, 平等接纳至关重要, 而在博物馆的方法、 空间与认识的层级之内, 也必定同等存在着寻求开放其他选择的努 力。

就这个节庆是作为一个自发的和黑人工薪阶层的对高雅与世俗 资源的整合而言，自然还有很多话可以说，因为篇幅所限，不再赘 述了。那些并非属于艺术世界上层的人, 那些实际上肩负了规范参 观者行为和反应的人, 却是向我们展现了非规范化的活动如何可以 成为一种重要的认识通道，籍此，我们可以不断地思考艺术机构、 观众和艺术之间的模糊的界限。黑人文化节的启示是, 一个博物馆 可以做怎样的份外工作。它所确认的是, 所有博物馆工作人员都是 具有创造力的, 都有能力参与到文化工作中, 忽视这些人的声音, 就意味着忽视重建博物馆与生活之联系的真正途径。所有这些实际 的认识都是由业余爱好者发现的。 


\title{
Hippie Modernism
}

\author{
Lawrence Rinder
}

At first glance, few things seem to be as antithetical as hippies and Modernism. Hippies - or the stereotypical image of them-were a type of Bohemian renegade, especially common in the late I960s and early I970s in America and Europe, who were notable for their old fashioned clothing (or lack of clothing), attraction to nature and simple, rural lifestyles, embrace of mysticism and mind-expanding drugs, anti-authoritarian attitudes, and tendency to integrate art into everyday life. Modernism, on the other hand-or its stereotypical image-was a I9th- and 2oth-century philosophy and aesthetic focused on rational design, technological innovation, industrial production, and artistic autonomy. The exhibition "Hippie Modernism," which opened in 2015 at the Walker Art Center in Minneapolis and came to my own institution, the Berkeley Art Museum and Pacific Film Archive in 2017, is less an attempt to reconcile these two seemingly antithetical terms than it is a shaking loose of the terms themselves, revealing inner fractures and contradictions that allow us to see the modern in hippies and the hippie in Modernism. Neither "hippie" nor "modern," it turns out, are as simple as their stereotypical image might suggest.

One doesn't have to look very hard to notice the fractures coursing through the idea of Modernism. To begin with, as an aesthetic and social idiom, Modernism began not as an embrace of technology and industrial production but as a firm rejection of these values and effects. The igth-century Arts and Crafts Movement, from which sprang the Bauhaus, Black Mountain College, and a host of other prototypically Modernist enterprises, was envisioned by William Morris as an antidote to the pernicious effects of rapid industrialization. Morris, an ardent socialist, was appalled by the working and living conditions of the English factory workers. He proposed to address this social malaise by returning to the model of the medieval guild, including the embrace of handcrafts, and establishment of social equivalence among artists, designers, and craftspeople. It was also in the Arts and Crafts Movement that the core Modernist design principle of truth to material, structure, and function was first articulated. Ultimately, Morris's workshops and schools did less to ameliorate the lives of the working class than they did to provide a host of finely made and exquisitely tasteful products for the consumption of wealthy connoisseurs. The Arts and Crafts movement in the United States had a somewhat more progressive outcome insofar as it generated a fairly widespread, largely middle-class movement embracing a more healthful, holistic lifestyle that incorporates reverence for nature and respect for Native American traditions.

William Morris's ideas, especially concerning the embrace of handcraft and the social equivalence of art and craft, were carried through to the first iteration of the Bauhaus in Weimar, along with a holistic model of education that included yoga meditation, spirituality, and play. In this first iteration (I919-22), under the influence of the mystical guru Johannes Itten, the Bauhaus looked more like 
a hippie commune than the workshop for industrial production it later became. Itten's curriculum, the so-called Vorkurs or "preliminary course," reflected the pedagogical theories of Franz Cižek and Friedrich Froebel, who promoted the value of the imagination and free expression, especially in childhood instruction, and whose work was later highly influential in various hippie experiments in anti-authoritarian education. "Mankind is meant to enjoy a degree of knowledge and insight, of energy and efficiency of which at present we have no conception," wrote Froebel, "for who has fathomed the destiny of heaven born mankind? But these things are to be developed in each individual, growing forth in each one in the vigor and might of youth, as newly created self productions." While Itten implemented a new mode of education incorporating elements of the mystical quasi-Zoroastrian Mazdaznan cult, his Bauhaus colleague Oskar Schlemmer organized periodic festivals that were intended to break down the social boundaries between teachers and students and among the students themselves. Among these legendary festivals were the Kite and Lantern Festivals. By 1923, the Bauhaus Director Walter Gropius had evolved a new vision for the school, saying, "we want an architecture adapted to our world of machines, radios and fast cars." In 1922 Itten resigned and was replaced by László Moholy-Nagy, who shifted the school's model to reflect a core mission of developing functional designs easily adaptable to industrial, mass production.

It was the early Itten-inspired form of the Bauhaus, rather than its later incarnations, that was the model for Black Mountain College, an experimental school located in North Carolina (1933-57) that was the crucible for many of the most important artistic currents in the US in the second half of the twentieth century. Like the Bauhaus, Black Mountain College placed an exceptionally strong emphasis on innovation and unfettered individual creativity as well as on radically democratic organization. Black Mountain's curriculum—originally designed by Bauhaus alumnus Josef Albers_-was, like Itten's preliminary course, rooted in the discovery of the unique perspective and talents of each student and in the mixing of art, craft, and design. Among the many seminal artistic achievements of Black Mountain College were Buckminster Fuller's geodesic dome (based on an earlier design developed in 1926 by Walther Bauersfeld for the Zeiss corporation) and John Cage's Theater Piece Number I (considered by some to be the first Happening), both of which were also to play an important role as precursors to, and influences on, the hippie movement.

In Modernism's literary and artistic idioms, another powerful progenitor was the Symbolist movement of the late igth century. A kind of decadent Romanticism, Symbolism involved a search for truth and beauty in etheric, spiritual, and psychological realms. Like the Arts and Crafts Movement, Symbolism entailed

I Friedrich Froebel, The Education of Man, trans. W.N. Hailmann (New York: Dover Publications, 2005), 233.

2 William Curtis, "Walter Gropius, German Expressionism, and the Bauhaus," in Modern Architecture since I900, 2nd edn. (New York: Prentice-Hall, 1987), 309-I6. 


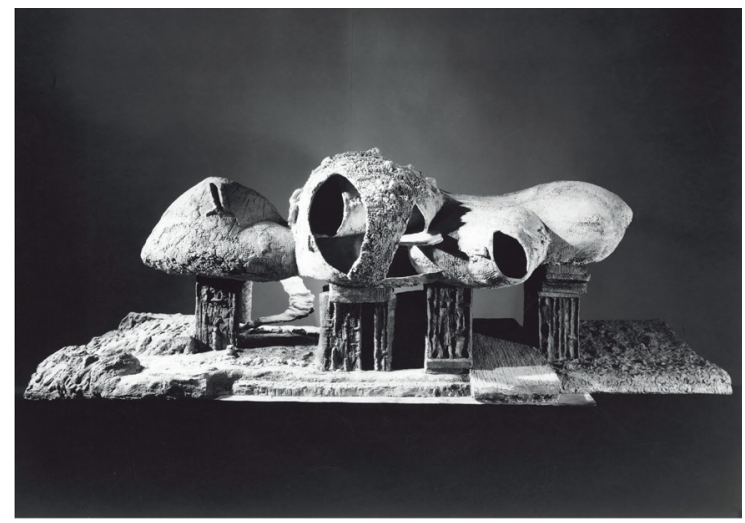

Fig. I. Frederick Kiesler, Exterior view of the Endless House Project (1950-1960), 1958. Architecture \& Design Study Center, photograph by George Barrows, Museum of Modern Art. Digital Image (C) The Museum of Modern Art/ Licensed by SCALA/Art Resource, New York.

a rejection of technology and industrialism in favor of a backward looking style as well as eccentric dandyism, and religious fervor. It was from the fertile soil of Symbolism that first grew experiments in abstraction by artists such as Piet Mondrian, Wassily Kandinsky, and Paul Klee and literary innovations from writers such as Mallarmé and Joyce. Symbolism combined with an attention to the dynamic forces and forms of nature evolved into Art Nouveau. Symbolism also laid the foundation for what was later to become Surrealism, perhaps the strongest counter-current within Modernism's putatively rationalist impulse. Finally, the peculiar movement known as Dada, which combined contempt for contemporary European society with a ludic irrationalism, can be seen as the dark heart of Modernism, emblematic of the movement's iconoclastic approach to making and being and yet irreconcilable with its socially progressive and forward thinking mindset. The influence of this thread of Modernism, from Symbolism and Art Nouveau to Surrealism and Dada, is clearly evident in the hippie's exploration of the unconscious, their fascination with nature and embrace of play and the absurd, and in the imagery and style of psychedelic art.

In the field of performance, the primal modern moment-and one that is also a precursor to hippie affect and attitude-lies in artist clubs such as the Hydropathes, Bon Bock Society, and the Incoherent Arts, which were comprised of disaffected artists and performers who congregated in the cabarets of Paris's Montmartre District in the I88os. Like the Dadaists whose embrace of negativity was a response to the horrors of World War I (or for that matter, the Hippies and their rejection of the political establishment and culture responsible for the war in Vietnam), these artist's clubs promoted a thorough disdain for the status quo as a response, in part, to France's disastrous war against Prussia in the early I870s. The most influential of these cabaret venues was the Black Cat, run by Rodolphe Solis, whose admonition, "You who pass by, be modern!" was inscribed at the door. Like so much of what has come to be called "modern," the activities of the Black Cat Cabaret combined radical new approaches with the resurrection of older forms. The performance and visual art of the Incoherents, for example, was rooted in irony and humor-their first art exhibition, titled "an exhibition of drawings by people who don't know how to draw," for example, included a cow painted in the colors of the French flag and a sculpture made of Swiss cheese; yet, these renegades were also responsible for reviving the French tradition of the shadow puppet theater. 
Fig. 2. Freeform dancing at summer music festival, San Francisco, 1967. Dennis L. Maness Summer of Love Collection, San Francisco History Center, San Francisco Public Library.

Modernism, then, has beento borrow a term from America's Republican Party-a "big tent." In architecture, it has encompassed everything from the efficiency focused, hyper-rationalist Plan Voisin of Le Corbusier to the

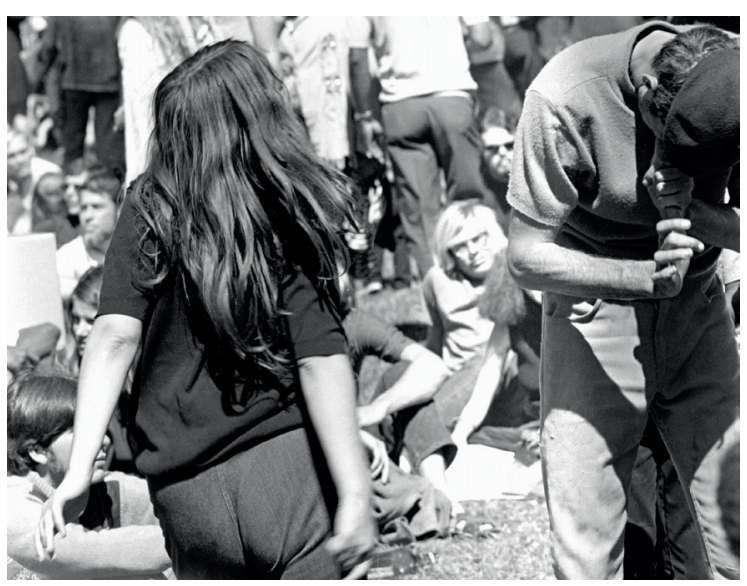
visceral, eccentric vision of Frederick Kiesler's Endless House (Fig. I). In design, it has ranged from the florid meanderings of Art Nouveau to the machine esthetic of Deco Moderne. In art, Modernism encompasses everything from Seurat's scientifically derived pointillism to Edvard Munch's emotional Scream. So, what, if anything, unites the diverse productions of the so-called Modernist project? Some have argued that Modernism has, at its heart, a utopian impulse, a drive to correct the ills of society by starting from scratch. In this way of thinking, for all of its innovatory power, Modernism has carried with it a fundamental inner negativity, an impulse to categorically reject that which has come before. However, as exemplified by the Incoherents as well as the Arts and Crafts Movement, this rejection has not always amounted to the scorched earth, condition zero that is sometimes attributed to Modernism's utopian aims. The Arts and Crafts artists and designers rejected industrialism but took as their model medieval European society. Similarly, many Modernist artists and writers from Joyce and Pound to Picasso and Malevich looked even further back to the archaic period and to non-Western cultures for formal and ideational models. To many, the project of Modernism was less a project of invention than of rediscovery.

To pose the concept of Hippie Modernism is, therefore, not simply to juxtapose two antithetical terms for the sake of dialectical frisson. Rather, within Modernism itself one can find many of the characteristics that came to define hippiedom: a rejection of the social, political, and cultural status quo; skepticism of new technology; a privileging of individual creativity and play over mass consensus and conformity; an exploration of the inner workings of the mind; and a search for models for living in pre-industrial culture and society. It's all there in Modernism, it just depends which Modernism you're looking at.

From the other end of this problematic, it appears that the idea and ethos of the hippie is just as difficult to summarize or encapsulate. Hippies were not all backward looking, drug abusing "dropouts" divorced from broad issues of social, political, and technological change. This cliché of the hippie is captured in the slogan, "Turn on, Tune in, Drop out," coined by Marshall McLuhan and popularized by the UC Berkeley-educated LSD guru Timothy Leary who used 
the phrase in his address to the Human Be-In, a gathering of 30,000 hippies in San Francisco's Golden Gate Park in the summer of 1967 (Fig. 2).

Yet in his autobiography, Leary explained:

"Turn on" meant go within to activate your neural and genetic equipment. Become sensitive to the many and various levels of consciousness and the specific triggers that engage them. Drugs were one way to accomplish this end. "Tune in" meant interact harmoniously with the world around youexternalize, materialize, express your new internal perspectives. "Drop out" suggested an active, selective, graceful process of detachment from involuntary or unconscious commitments. "Drop Out" meant self-reliance, a discovery of one's singularity, a commitment to mobility, choice, and change. Unhappily my explanations of this sequence of personal development were often misinterpreted to mean, "Get stoned and abandon all constructive activity."

Conscious social change was essential to the hippie ethos, whether undertaken in the form of self-exile for the purpose of cultivating an alternative lifestyle and mindset apart from the corrupt influences of urban culture (one thinks of the precedent of the Chinese literati scholar) or in the form of strategic engagement with the status quo that was intended to transform nodes of social power from within. Rather than fall into warring camps, hippies on the inside and those on the outside of society communicated and strategized in a shared understanding that neither approach was likely to prevail on its own but that by joining forces they might have a chance to effect social change. The hippie attitude of inclusive optimism is also exemplified by their openness to work with such diametrically opposed movements as on the one hand the Black Panthers, a Maoist, nationalist, and highly militarized movement of urban African Americans and, on the other, the research arms of the US military industrial complex in its research into Internet communications.

What hippies shared with the Panthers as well as with the early adopters of the Internet was a commitment to real-time transformation. Contrary to the stepby-step approach of progressive politics, the hippies chose to "Be Here Now," to embody the changes they proposed in real time, regardless of the possible frictions this might cause with establishment society. ${ }^{4}$ The Panthers, similarly, set out to create their image of a Black nation in real time on the streets of Oakland where they organized their own food distribution, schools, and security force. (The rapprochement between the hippies and the Panthers was memorialized in the Fall I974 issue of the hippie periodical CoEvolution Quarterly, guest edited by the Black Panther Party). It may be that the insistence on radical presence is what

3 Timothy Leary, Flashbacks: A Personal and Cultural History of an Era: An Autobiography (New York: G.P. Putnam's Sons, 1990), 253.

4 Be Here Now (197I) is the title of a popular book by Ram Dass, a.k.a. Richard Alpert, a Harvard professor whose work was profoundly influenced by psychedelic drugs and Eastern mysticism. 
most closely connects the hippie movement and Modernism broadly defined. From the Impressionist description of moments of seeing, to the Dadaists' desire to épater le bourgeoisie, to the "presence" claimed by Greenberg for monochrome painting, the avatars of Modernism have routinely returned to this central idea of the singularly important present.

The cliché image of the hippie is a near-naked, back-to-the-land, drug-addled freak. While there were plenty of hippies who fit this description, others were deeply engaged global thinkers, and some were even engaged in technological breakthroughs, including in the emerging field of computers. The connection to computing was via the concept of systems thinking, or "cybernetics," which was central to both the scientific development of computers as communications and social systems as well as to the hippie philosophy of the holistically interconnected planet. A key figure in this remarkable nexus was Stewart Brand. Brand, a graduate of Stanford University, participated in some early (and, at that time, legal) LSD experiments. He produced one of the seminal hippie festivals, the 1966 Trips Festival, which took place in San Francisco and which set the stage for the Haight-Ashbury hippie scene. In 1968, Brand founded the influential publication The Whole Earth Catalog, the cover of which featured an image of earth seen from space, which Brand (along with Buckminster Fuller among others) had campaigned for NASA to release. The Whole Earth Catalog was a key resource for the counterculture and the back to the land movement. Based on the mission to provide "access to tools," the publication, which was issued quarterly from 1968 until 1973, was much more than a tool catalog. It embodied the do-it-yourself ethos and communalist spirit of the hippie movement and was, for Brand, an exercise in systems theory and a blueprint for massive social interconnection and communication. Echoing aspects of the Bauhaus and Black Mountain curricula, the catalog promised, "intimate personal power [...] power of the individual to conduct his own education, find his own inspiration, shape his own environment, and share his adventure with whomever is interested."5 In 1968, the same year that he founded the Whole Earth Catalog, Brand assisted Douglas Engelbart (another early LSD experimenter and founder of the Stanford Research Institute's Augmented Human Intellect Research Center) in presenting a now legendary talk at the Fall Joint Computer Conference in San Francisco at which Engelbart first demonstrated the concept of a computer "Online System," including windows, hypertext, video conferencing, dynamic file linking, and collaborative real-time editing. Combining his experience with the Whole Earth Catalog and the knowledge he had gained from Engelbart and other computer scientists, Brand went on to found the WELL, an early online community that anticipated search engines and social networks such as Google and Facebook.

Brand is not the only example of the fertile relationships that existed between systems theory and the hippie counterculture. As a way of seeing interconnections and the power of feedback loops, systems theory powerfully informed the Institute, I973), I. 
emerging ecology movement. One of the key events in the ecology movement was the Freestone Gathering, which took place in March 1970 on a ranch outside of San Francisco. As Greg Castillo describes in his catalog essay, summoned by UC Berkeley professor of architecture, Sim van der Ryn, various "groups and individuals exploring communal life, ecological sustainability, alternative education, guerilla theater, and grassroots urban planning gathered 'to learn to design new social forms, new building forms, that are in harmony with life."' ${ }^{6}$ Curtis Schreier's Freestone Chart, that appeared in an article about the Freestone gathering in the July 1970 issue of Progressive Architecture embodies the inter-relational, systems-thinking approach of hippie-influenced eco-designers. This networked diagram not only shows the surprising relations among individuals and entities as disparate as Ant Farm (a hippie art collective), the San Francisco Chapter of the American Institute of Architects, and the Stanford Research Institute. A significant aspect of Schreier's diagram is its call to users to remake it on their own terms, add additional names, including their own. Hippie systems were dynamic, and radically democratic, systems.

In the words of Greg Castillo:

Sharing the modernist penchant for projecting the contours of a "new man" upon "primitive" other, hippies perceived the potential for unalienated subjectivity not in a romanticized proletarian but rather in a sentimentalized American Indian and (of more immediate concern) the unadulterated child, making schoolroom emancipation one of the counterculture's most urgent missions [...]. Rejecting assembly line processes fetishized by machine age modernism, hippies embraced recycling and bricolage as totems of post-Fordist culture. At Freestone, all these facets of hippie modernism were harnessed to an overarching ideology of "earth awareness" and its goal of restoring nature's putative balance. ${ }^{7}$

The hippie concept of design as a practice of social and ecological restoration through the creation of new systems and resurrected forms ran headlong into mainstream design concepts at the International Design Conference at Aspen, in the summer of 1970 . The conference theme, "Environment by Design," was interpreted by the organizers and most of the attendees as an extrapolation of the late-Bauhausian concept of the architectural Gesamtkunstwerk, in which "environment" is understood as the forms, spaces, and devices designed for a more productive and efficient human society. However, hoping to add a bit of modish flavor to the proceedings, the conference organizers had invited Professor Sim van der Ryn to bring along a group of his hippie design students, the very same folks who months before had coalesced a new ecological design movement at

6 Greg Castillo, "Counterculture Terroir: California’s Hippie Enterprise Zone," in Hippie Modernism: The Struggle for Utopia, ed. Andrew Blauvelt (Minneapolis: Walker Art Center, 2016), 88.

7 Ibid., 90. 
Freestone. The meeting of these two ideologically opposed camps resulted in one of the most legendary episodes in modern design history. The clash was between those, like Rayner Banham, who advocated a second "Machine Age" based on a belief in the inexhaustibility of Earth's resources and the promise of human ingenuity and technological progress and those, like the Freestone hippies, who rejected the concept of infinitely spiraling mass consumption and who believed in the need for a holistic, systems approach to solving not only design but other entrenched social and ecological problems. In retrospect, the objections of the Old Guard Modernists like Banham seem pathetically and dangerously unaware:

We will certainly have gone below the threshold of what is educationally tolerable if we produce people who think carbon dioxide is a pollutant. [...] You live on carbon dioxide; it's the key link in our life cycle. Yet we talk about it as though it were some kind of dangerous pollutant. It's no more dangerous [a] pollutant than water is. ${ }^{8}$

Worse yet, as Greg Castillo has noted, were the comments of philosopher Jean Baudrillard who attended the Aspen conference as a representative of the French New Left. In his closing remarks, Baudrillard thanked Banham for "illuminating 'the moral and technical limits and the illusions of Design and Environment practice.”

Baudrillard proclaimed that "environment, design, the fight against pollution, and so on" were "pure social manipulation" and a "new 'opium of the people" He continued: "In the mystique of Environment this blackmail toward apocalypse and toward a mythic enemy who is in us and all around [us] tends to create a false interdependence between individuals. Nothing better than a touch of ecology and catastrophe to unite the social classes, except perhaps a witch hunt (the mystique of anti-pollution being nothing but a variation of it). ${ }^{9}$

Thankfully, at least in the United States and Europe, the sentiments articulated by Banham and Baudrillard had less traction over the ensuing decades than those of the Freestone hippies. Yet, as we have seen, diametrically opposed though they were, both ways of thinking - the industrial and technocratic as well as the ecological and democratic — can be seen as facets of the complex social, cultural, and political formation known as Modernism.

In February 20I7, the exhibition Hippie Modernism opened at the UC Berkeley Art Museum and Pacific Film Archive. The San Francisco Bay Area, including Berkeley in particular, was ground zero for the theories and practices

8 Rayner Banham, "The Education of the Environmentalist," in Environment by Design; International Design Conference, Aspen, CO, June I4-I9, I970 (n.p. n.d.), 54, 56 .

5189 Castillo, "Counterculture Terroir," 99-IOO. 
that comprised the hippie counterculture. Although it has been fifty years since the Summer of Love, in many ways the values, attitudes, and even institutions that originated in the hippie movement still exist and continue to exert a powerful cultural influence today. One can see this in the Slow Food movement that grew out of the visionary work of Alice Waters and her colleagues at the restaurant Chez Panisse, where the concept of growing and consuming seasonal, locally produced food sparked a gastronomic and culinary revolution. One can see it in the landmark "Marriage Equality" legislation signed by California Governor Jerry Brown, which legalized same-sex marriage in the state. One can see it in California's 20I5 Climate Change bill that brings the state's renewable energy to 50 percent of the total by 2030 . And one can see it in the burgeoning tech innovations of Silicon Valley, where the intersection of digital technology and the hippie ideals of social interconnection, free flow of information, and ecological sustainability have resulted in the creation of a world changing industry.

Hippies were Modern not because they believed that the world could be different than it was, but because they made that difference real. 


\section{嬉皮现代主义}

劳伦斯・林德

我们的第一印象中，嬉皮士与现代主义之间似乎存在一些完全对立 的东西。嬉皮士, 或者说对他们的刻板印象, 是来自波西米亚的叛 逆者，在 20 世纪 60、70 年代的美国和欧洲特别普遍，他们的标 识是旧式的着装（或破衣烂衫），对自然和简单的乡村的生活方式 的向往，对神秘主义与让心灵放松的药物来者不拒，反权威的态度， 以及将艺术融入日常生活的倾向。而在另一方面，对现代主义的刻 板印象, 则是一种在 $19 、 20$ 世纪出现的专注于理性设计、技术发明、 工业生产和艺术自律的哲学与美学。“嬉皮现代主义”展览去年 (2015 年) 在明尼阿布利斯的 “沃克艺术中心” (Walker Art Center) 举办, 今年冬天，将要在我工作的伯克利艺术博物馆和太平洋电影档案馆 举办，这个展览并未着意于调和两个看似对立的术语，而仍然将它 们视为某种不确定的术语，以昭示其内在的破裂与矛盾，让我们可 以在嬉皮士中看到现代主义，在现代主义中看到嬉皮。事实上，不 论是 “嬉皮” 还是 “现代”,都不会是它们给人的刻板印象那么简单。

贯穿在现代主义观念中的裂隙是显而易见的。首先，作为一种 美学与社会语汇，现代主义最初并非以拥抱技术与工业生产的姿态 出现, 而是对这些价值与影响的严正拒绝。19 世纪的工艺美术运动, 孕育了包豪斯学院、黑山学院、以及其他一系列典型的现代主义企 业，那是威廉·莫里斯（William Morris）的一个愿景，以此来抵 御急速工业化带来的恶果。作为一个真诚的社会主义者，莫里斯对 英国工人的工作与生存状况感到震惊。他提出要恢复中世纪手工作 坊的方式，来诊治这种社会的疾患，他主张回归手工艺，在艺术家、 设计师与手工匠人之间建立平等的社会关系。同样是在工艺美术运 动中，忠实于材料、结构与功能等现代主义的核心设计原则也率先 得到建构。最终, 莫里斯的作坊与学校对于改善工人阶级生存状况 并没有起到多少作用，反倒是为富裕的鉴赏家提供了一系列制作精 良、品味优雅的产品。今天来看，美国的工艺美术运动产生了更为 进步的成果, 是一个影响广泛的中产阶级运动, 形成了一种更为健 康和整体的生活方式, 其中也融贯了对自然和对美国原住民的尊重。 
威廉·莫里斯的观念中，手工艺以及美术与工艺的社会平等地 位得到了特别的关注，最初是通过魏玛第一代包豪斯学校，以及一 整套包括瑜伽冥想、灵修与游戏在内的整体性的教育模式而得以实 现的。第一代包豪斯(I92I-I922) 是在神秘主义宗师伊顿 (Johannes Itten）的影响之下，包豪斯学校看起来更像一个嬉皮公社，而不是 它之后成为的工业生产的工作坊。伊顿的课程，也就是所谓的 “基 础课程” (Vorkurs)，反映了弗朗兹・齐泽克（Franz Cizek）的教 学理论和弗里德里希·福若贝尔 (Friedrich Froebel) 推崇的想象 力与自由表达的价值，尤其是在对儿童的指导中，伊顿作品在后来 的反权威主义教学的各种嬉皮实验中具有很大的影响力。“引导人 们享受那种我们现在已不了解的知识、洞察、能量以及效率所带来 的愉悦。” 福若贝尔写道 : “谁可以真正领会上天所赋予的人类的命 运? 但这些东西在每个个体中都会不断生长发展，并随着青少年智 力与力量而增长，就好像新创造出来的自我。” 1 伊顿实施这种融合 了神秘的琐罗亚斯德教的崇拜的新教育模式之时，他的包豪斯同 事奥斯卡·斯莱默（Oskar Schlemmer）组织定期庆祝活动，意在 消弭教师与学生之间以及学生与学生之间的社会界限。在这些著 名的庆祝活动中，有风筝节与灯笼节。1923 年，包豪斯校长瓦尔 特·格罗皮乌斯（Walter Gropius）为学校打开了新的愿景，他说， “我们需要一种能适应我们这个机器无线电与迅疾汽车的世界的建 筑”。 ${ }^{2}$ 伊顿在 1922 年辞职, 取代他的是拉斯洛·莫霍利 - 纳吉 (László Moholy-Nagy), 后者改变了学校的模式, 主要目标转向了发展更 能适应工业化与批量生产的功能设计。

正是早期伊顿影响下的包豪斯模式，而不是后来经过改变的包 豪斯，才是黑山学院的范型，这个位于北卡罗莱纳州的实验学校 （1933-1957）锤炼了 20 世纪后半叶美国的许多最重要的艺术潮流。 与包豪斯一样，黑山学院将重点放在了创新、不受约束的个体创造

1 Friedrich Froebel, The Education of Man, trans. W.N. Hailmann (New York: Dover Publications, 2005), 233.

2 William Curtis, "Walter Gropius, German Expressionism, and the Bauhaus," in Modern Architecture since I9oo, 2nd edn. (New York: Prentice-Hall, 1987), 309-I6. 
力以及激进的民主化上面。黑山学院课程最初是由包豪斯校友约瑟 夫 · 阿尔博斯（Josef Albers）设计的，与伊顿的基础课程一样，宗 旨是在艺术、手工与设计的结合中发现每位学生的独特视角与才 能。在黑山学院众多具有重要意义的艺术成就中, 巴克米斯特 - 福 勒（Buckminster Fuller）的球顶体育场（是基于瓦尔泽·巴尔斯 菲尔德 (Walther Bauersfeld)1926 年为蔡司公司设计的一个早期方 案）以及约翰·凯奇（John Cage）《剧场片断 I 号》（Theater Piece Number I）（有人认为这是第一件偶发艺术作品），这些人在日后 都被视为嬉皮运动重要先驱，对这个运动产生了很大影响。

在现代主义文学与艺术的语汇中, 另一个有力的先驱是 19 世纪 晚期的象征主义运动。作为一种颓废的浪漫主义, 象征主义关涉 到一种在以太的、精神的和心理学领域里探寻真实与美。就像工 艺美术运动一样，象征主义引发了对技术与工业主义的拒绝，而 青睐怀古的风格，以及一种对古怪的时髦的偏好，还有宗教狂热。 正是在象征主义的肥沃土壤中, 首先诞生了康定斯基（Wassily Kandinsky), 蒙德里安 (Piet Mondrian), 保罗 · 克里 (Paul Klee）等人的抽象实验, 还有文学领域的马拉美（Mallarmé）和 乔伊斯（Joyce）的革新。象征主义结合了一种对动态活力和自然 形式的关注，并发展成了新艺术运动。象征主义也为战后超现实主 义奠定了基础，它也许是现代主义理性脉搏中最为强大的逆动。最 终，达达主义运动是把一种顽皮的非理性与对当代欧洲社会的轻蓝 结合在一起, 可视之为现代主义的黑暗之心, 是这个运动反偶像地 探索制作与存在的象征，但同时，它与社会进步和持续发展的思想 模式存在不可调和的矛盾。这种从象征主义、新艺术到超现实主义 和达达的现代主义线索的影响，在嬉皮士对无意识世界的探索中， 在他们对自然的迷恋，对游戏与荒诞的爱好，以及在想象世界中， 在迷幻艺术的风格中，都显而易见。

在表演艺术领域里, 现代主义的重要节点, 同样也是嬉皮士式 的情感与态度的先驱，是在诸如 “水疗俱乐部” (Hydropathes)、 “烈酒协会”（Bon Bock Society）以及 “非连贯艺术”（Incoherent Arts）之类的艺术家俱乐部中的，由 19 世纪 80 年代聚集在巴黎蒙 马特街区的卡巴莱餐馆的艺术家与表演者组成。就像达达主义者认 可负面和消极的东西，那是对第一次世界大战的恐怖的反映（或者 
出于同样原因，嬉皮士对政治当权者以及文化的不满是与越战存在 关联的)，这些艺术家俱乐部倡导对现状的彻底茬视，部分也是缘 于 1870 年代早期普法战争中法国的惨败。在这些即兴歌舞表演中, 最具影响力的是 “黑猫卡巴莱特” (Black Cat Cabaret), 是由罗德 夫·索利斯（Rodolphe Solis）经营的，他给出的警示是 “只要经 过，你就是现代人!”，被镌刻在了门上。就像其他的很多被视为现 代的活动，“黑猫卡巴莱特” 的即兴表演，将全新的表演方法与再 生的古老样式结合起来。比如，“非连贯艺术” 中的表演与视觉艺 术就是根植于讽刺与幽默的，他们的第一个艺术展览取名为 “不知 如何画素描的人的素描作品展”，包括了以法国国旗颜色绘制的一 头牛，以及用瑞士奶酪做成的雕塑 ; 但是，这些反叛者同样也促使 法国皮影剧院传统恢复生机。可以将 20 世纪 60 年代嬉皮士运动 中一个叫做 “卧铺车厢” (Cockettes) 的旧金山剧团视为具有类似 的精神风貌，这尤其表现在他们对古旧样式、硬边风格以及身份特 质的融合上。那时的现代主义从美国共和党处 借了一个术语 “大 帐篷”。在建筑中，它包罗一切，从柯布西耶（Le Corbusier）关 注效率和超级理性主义的《伏瓦生计划》(Plan Voisin), 到弗雷德 里克 ·科斯勒（Freiderick Kiesler）内向而古怪的《无尽之屋》(图 I，Endless House）。在设计方面，它的范围从新艺术的华丽蜿蜒到 “现代装饰” 的机械审美。艺术上，现代主义包括了修拉（Seurat） 的源于科学的点彩主义, 爱德华·蒙克（Edvard Munch）情绪化的 《呐喊》(Scream)。由此，到底是什么把所谓的现代主义计划的多 样产物结合到一起?有些人认为，现代主义的核心是一种乌托邦的 冲动，一种期望从头开始矫正社会病态的驱动力。在这种思维方式 之下，为了它的创造力，现代主义是带有一种最基本的内在否定性 的，一种断然排斥此前发生的一切的冲动。然而，正如 “非连贯艺 术” 和工艺美术运动所表现出来的，这种排斥并不总是达到极致状 态，那种有时归诸于现代主义乌托邦目标的零起点。工艺美术运动 中的艺术家和设计者拒绝工业主义，将中世纪的欧洲社会作为他们 的典范。同样，很多现代主义艺术家和作家，从乔伊斯到庞德，再 到毕加索和马列维奇，他们回溯更古老的时代，追寻原始文化，探 求形式与理念的范型。对于很多人来说，现代主义运动更多是一种 重新发现，而不是发明。 
因此，定义 “嬉皮现代主义” 这样一个概念，就不仅是为了某 种辩证的启迪而将两个并不相关的术语放在一起。在现代主义的概 念中，可以发现很多用来定义嬉皮世界的特征：拒绝社会、政治与 文化的现状; 对新技术的怀疑, 推崇个体的创造性, 对公众舆论和 墨守成规的戏谑 ; 探索思想的内在运作 ; 以及在前工业时代文化与 社会中找寻生活的典范。所有这些在现代主义中都可以找到, 取决 于你在现代主义当中找寻什么。从问题的另一方面来说，嬉皮的理 念与精神气质似乎很难总结或概述。嬉皮并不总是在回溯过去, 药 物滥用所致的 “退隐” 使他们从广泛的社会、政治和技术变迁中脱 离出来。这种嬉皮士的陈词滥调包含在他们的口号中, 诸如 “开启, 调谐, 退隐” (Turn on, Tune in, Drop out), 是由马歇尔 - 麦克卢 汉 (Marshall McLuhan) 创造的, 加州大学伯克利分校的摇头丸 领袖蒂莫西·莱瑞（Timothy Leary）在他的嬉皮士集会的演讲中 使用了这个短语，1967 年的夏天，三万多名嬉皮士聚集在旧金山 的金门公园里。

但在自传中，莱瑞是这样解释的：

“开启” 意味着内在地激活你的神经与基因组织, 就是要对意识 的不同层级以及触发意识状态的特定机制都变得敏感，药物是 帮助你完成这个过程的一个方式。“调谐” 意味着你与周遭世界 和谐互动，具体化、外在化地表达你的全新的内在视野。“退隐” 意味着从不由自主的或无意识力量中分离出来的主动选择的和 愉快的过程。“退隐” 意味着自持, 是一种独特性的发现，是要 投身于变动、选择与变化。让人不快的是, 我的这种对于个人 发展顺序的解释常常被误解为 “一种迷乱, 摈弃了一切建设性 的活动”。3

有意识的社会变化是嬉皮士精神气质的题中之义，不论是采取自我 放逐的形式来达到建立另类生活方式的目的，或者剥离都市文化之 腐蚀影响的心态（这让人想起了中国古代的文人学者), 乃至战略

3 Timothy Leary, Flashbacks. A Personal and Cultural History of an Era: An Autobiography (New York: G.P. Putnam's Sons, 1990), 253. 
性地介入现状，意图从内部改变社会力量的节点。嬉皮士没有陷入 到相互交战的阵营中，他们在社会的内部和外部以一种共识而进行 沟通，制定战略 : 都不会以独占鳌头为目标，而是加入到那些他们 有可能影响社会变革的力量中。这种有包容的嬉皮士态度，一方面 表现在他们与反叛的 “黑色美洲豹” 这样的毛泽东主义、民族主义, 同时也是都市非裔美国人的高度军事化运动团体的公开合作 ; 另一 方面, 也体现在与美国军事工业集团的研究部门在互联网沟通研究 中的合作。

嬉皮士与黑豹团体以及早期互联网使用者的相同点是投身于实 时变化。与进步论的政治学的按部就班的方法相反，嬉皮士的选择 是 “活在当下”，实时表达他们倡议的改变，而不考虑可能引发的 与现有社会建制的摩擦。 ${ }^{4}$ 同样，黑豹群体也在奥克兰大街实时创 造了他们的黑人国家的形象。在那里，他们还组织了自己的食物分 派、学校与保安力量。（嬉皮士与黑豹组织的友好交往活动在嬉皮 士期刊《共同发展季刊》(Co-Evolution Quaterly) 1974 年秋季号 上刊发，黑色美洲豹党是作为该期刊物的客座编辑)。也许正是这 种对即时在场的坚持，才使得嬉皮运动与广义现代主义紧密联结在 一起。从印象主义对观看瞬间的描绘, 到达达主义“让资产阶级蒙差” (épater le bourgeoisie) 的企图, 再到格林伯格由单色绘画而提出 的 “在场” (presence), 这些现代主义的化身都已例行公事地回到 格外重要的现时在场的核心理念。

这个嬉皮士的陈腐形象是几乎全裸的，回归田园，因滥用药物 而变得愚蚌的怪胎。当然，很多嬉皮士是符合这个描述的，还有 一些人则与世界范围内的思想家有深入交流，甚至，他们当中的 一些人与技术变革和突破有很多互动，也包括了新兴的计算机领 域。通过系统思维概念与计算机的运作相联系，或者叫 “控制论” (Cybernetics), 这对于作为通信工具与社会系统计算机的科学发 展以及整体相互连结的星球，也包括对嬉皮士哲学来说，都是至关 重要的。在这个非凡联结中, 最重要的人物是斯坦福大学的毕业生

4 “活在当下”（Be Here Now）是哈佛教授拉姆·达斯（Ram Dass）畅 销书的书名，他的作品深受迷幻药物和东方神秘主义的影响。 
斯图尔特 - 布兰德 (Stewart Brand), 他参与了早期的部分摇头丸 的实验（这在当时是合法的），创办了其中的一个嬉皮士的节日， 也就是 1966 年在旧金山举办的旅行节，为海特·艾许伯里街区的 嬉皮场景搭建了舞台。1968 年, 布兰德创办了影响广泛的出版物《全 地球目录》(The Whole Earth Catalog), 封面是太空中看到的地 球形象，布兰德（其中也有巴克敏斯特 - 福勒）为争取美国国家宇 航局发布而竞争。《全地球目录》是反文化与 “回到大地” 运动的 主要资源。它的基本任务是提供 “开放的工具”，从 1968 到 1973 年, 每季度出版一期, 不仅是一个工具目录。它是嬉皮士运动的自 助和共产主义的精神气质的体现, 对于布兰德来说, 也是系统科学 的一次实践, 是大规模的社会联系与沟通的蓝图, 是对包豪斯与黑 山学院课程的回应, 这个目录预示这样的前景 : “......直接的个人 力量……每个个体自我教育的力量, 找到自己的灵感, 塑造自己的 环境，与同道分享自己的探险。” ${ }^{5}$ I968 年, 也就是他创办《全地球 目录》那年，布兰德协助道格拉斯·恩格巴特（Douglas Englebart） (另外一位早期摇头丸实验者以及斯坦福扩展人类智力研究中心的 创建人）在旧金山秋季联合计算机会议发表了一个现已成为传奇的 讲演，在这个讲演中，恩格巴特首次展示了计算机的 “在线联网系 统” (Online System) 的概念, 包括视窗、超文本、视频会议、动 态文档链接以及合作实时剪辑。把他在 “全地球目录” 中积累的经 验与从恩格巴特和其他计算机科学家那里获得的知识结合起来，布 兰德创立了 WELL, 这是一个早期的线上社区，预示了诸如谷歌和 脸书这样的社交媒体和搜索引擎。

布兰德并不是系统理论与嬉皮反文化间的丰富复杂关系的惟一 例子。作为一种观察交互联系和循环反馈的作用的方法, 系统理论 有力地促进了生态学运动的出现。生态学运动中的一个重要事件就 是 “福利斯通聚会” (Freestone Gathering), 那是发生在 1970 年 3 月旧金山的一个大农场外。如格雷格 ·卡斯蒂洛（Greg Castillo） 在他的目录文章中描述的那样, 在加州大学伯克利分校建筑学教授

5 Stewart Brand, The Last Whole Earth Catalog: Access to Tools (Menlo Park: Portola Institute, I973), I. 
西姆·范·德尔·瑞恩（Sim van der Ryn）的感召下，各式各样的 “族 群与个体在探索社区生活、生态的可持续性，另类教育方式、流动 剧院以及草根城市规划，他们聚集在一起，“学习创设新的与生活 合拍的社会和建筑的形式” ”。 ${ }^{6}$ 柯蒂斯·希瑞尔 (Curtis Schreier) 的“福利斯通图表” (Freestone Chart) 刊载在 1970 年 7 月号《先 锋建筑》(Progressive Architecture) 杂志的一篇有关福利斯通聚会 的文章中，具体阐明了嬉皮士精神影响下的生态设计者的交互联系 的系统思考方法。这个网络表格不仅仅表现了个体与实体间的让人 惊异关系，这就像 “蚂蚁农场” (一个嬉皮士艺术群体)、美国建筑 师学院旧金山分会和斯坦福研究院这样全然不同的组织或机构。希 瑞尔表格中的一个十分重要的方面就是呼吁使用者用他们自己的方 式重新制作它，添加额外的名字，包括他们自己的名字。嬉皮系统 充满活力，而且在根本上是一个极其民主的系统。

用格雷格·卡斯蒂洛的话说 :

与现代主义者偏爱在 “原始” 形象上加诸 “新人类” 的外形异 曲同工，嬉皮士不是以浪漫化的无产阶级方式，而是在一个伤 感的美国印第安人与（更直接的关切）纯粹孩子身上构想未 让渡的主观潜能，使得教室的解放成为反主流文化最急迫的任 务。……拒绝机器时代现代主义的对流水装配线过程的盲目崇 拜，嬉皮士欢迎循环利用，视拼装为后福特主义文化的图腾。 在福利斯通，嬉皮现代主义的所有这些面向都是被 “地球意识” 的首要意识形态以及它关于恢复自然的假定平衡的目标所规制 的。 7

设计中的嬉皮概念，是作为一种通过新的系统与诸种复活形式的创 造而使得社会与生态得以恢复的实践，在 1970 年夏在阿斯彭举办 的国际设计会议中，它迅速成为主流的设计理念。据会议组织者与

6 Greg Castillo, "Counterculture Terroir: California' s Hippie Enterprise Zone," in Hippie Modernism, The Struggle for Utopia, ed. Andrew

Blauvelt (Minneapolis: Walker Art Center, 20I6), 88.

7 Ibid., 90. 
多数与会者的解释，这次会议的主题 “设计环境”，是对晚期包豪 斯建筑学派的建筑的 “总体艺术作品” (Gesamtkunstwerk) 概念 的探索，其中，“环境” 被理解为是为建立一个更具生产力和效率 的人类社会而设计出来的形式、空间与设备。然而，为了给这次会 议的议程增加一点时髦的意味, 组织者邀请西恩教授带来了一群他 的嬉皮设计方向的学生, 也就是几个月前, 在福利斯通的新生态学 设计运动上联合起来的同一批人。这两个意识形态对立阵营的会面, 最终为现代设计历史成就了最具传奇色彩的插曲。两者之间的龃踣 之处在于，纳尔·班汉姆（Rayner Banham）的观点是，地球资源 是取之不尽用之不竭，而且相信人类的智识与技术进步，因此倡导 开启第二个 “机器时代” ; 而福利斯通的嬉皮士则拒绝无节制的不 断扩张的大众消费观念, 认为我们需要一个整体的和系统的方法, 不仅可以解决设计的问题，同时可以解决其他根深蒂固的社会与生 态问题。回顾起来，班汉姆这样的保卫现代主义的老一代卫道士的 反对是可悲的，而且危险的是，他并没有意识到：

如果我们培养出的竟是相信二氧化碳是一种污染物的人，那么， 我们的教育水平已经达到了无法容忍的临界点......我们的生存 依赖二氧化碳; 它是我们生活循环的核心链条。但是，我们却 像对待污染物一样谈论它。它并不是一个危险的污染物, 与水 无异。 ${ }^{8}$

然而，正如格雷格·卡斯蒂洛指出的那样，更糟的是法国新左 翼代表人物，阿斯彭会议的与会者哲学家让·鲍德里亚（Jean Baudrillard) 的评论。鲍德里亚在自己的结束致辞中感谢了班汉姆, 因为 “.......他点亮了 “道德与技术的界限” 以及设计与环境实践的 幻觉”。

鲍德里亚声称 “环境、设计、对抗污染的斗争等等，这些行为”

8 Rayner Banham, "The Education of the Environmentalist," (conference proceedings for "Environment by Design," International Design Conference Aspen, CO, June I4-19, I970), 54, 56. 
是 “纯粹的社会性操作”，而且是一种 “新的 “人类鸦片””，他 接着说: “正是在环境的神秘性中，这种存在于我们当中、聚集 在我们周围的面向世界毁灭及神秘敌人的勒索，造就了个体间 的一种虚假的相互依赖。对于团结社会各阶层来说，没有什么 比生态学与大灾难可以产生更好的效果了，除非巫师施展他的 法术。”（反环境污染的神秘性仅仅是它的一个变种） 9

值得庆幸的是，至少在美国与欧洲，班汉姆与鲍德里亚所建构的伤 感，在接下来的几十年里，并没有福里斯通的嬉皮士那么具有吸引 力。但是，如我们看到的，尽管他们是直接对立的，两者的思路一 工业与技术主导的和生态学的与民主的这两个路径可以被视为 “现 代主义”复杂的社会、文化与政治层面的结合体。

2017 年 2 月，嬉皮现代主义的展览将在加州大学伯克利艺术博 物馆与太平洋电影档案馆开幕。这将会是一个值得纪念的历史时刻: 首先因为它是旧金山湾区，尤其是包括伯克利在内的组成嬉皮士反 文化理论与实践的起始之地。这个展览的时机十分重要，因为这场 运动的发起者将不久于人世 : 距离 “爱之夏” (图 2, Summer of Love）活动已有五十年了。最后，也许是最为重要的一点，这个展 览对于我们的博物馆和我们所在的地区是十分重要的，因为这种价 值观、态度，甚至是起初发起嬉皮运动的机构，在今天仍然发挥强 大的影响力。人们可以从 Chez Panisse 餐厅的爱丽丝·沃特斯 (Alice Waters）以及她同事的 “慢食运动”（Slow Food movement）中看 到，种植与消费那些季节性的和本地生长的食物的概念正在触发一 个烹饪学与烹调方面的革命。人们可以将 “婚姻平权” 的主张看作 是加州州长杰瑞·布朗（Jerry Brown）的标签，他让加州同性婚姻 合法化。人们可以看到，2015 年加州气候变化法令将在 2030 年时 为这个州带来共计 50\% 的能源更新。而且, 人们可以在硅谷迅速 发展的技术创新中看到，数字化技术与社会化互相连结的嬉皮理念 的交集、信息的自由流动以及生态的可持续化已导致了一个改变世 界的工业创造。

9 Castillo, "Counterculture Terroir," 99-I00. 
嬉皮现代主义

嬉皮士之所以是现代的，并不是因为他们相信世界可以与过去 不同，而是他们让这种不同变得真实可触。

（张坚、聂皓雪译校） 


\section{建构 vs. 解构:一旅美中国当代艺术家作品中的“传 \\ 统” 困局 \\ 章锐}

\section{一、引言}

80 年代中国的改革开放开启了自 20 世纪 30 年代年以来中国公民 的首次赴海外求学、移民的热潮，这一热潮在 90 年代初期进一步 升温。出国潮的弄潮儿中，有很多艺术家的身影。与 20 世纪初中 国艺术家出国深造多选择法国或欧洲其他国家的去向不同，这批艺 术家中的多数人都选择前往美国，例如陈逸飞、艾未未、徐冰、张洹、 蔡国强、谢晓泽、杨谦、何多苓等。二十余年过去，这批艺术家中 有不少已经归国定居。与民国初期众多前往欧洲游学归国的中国艺 术家不同，这批艺术家的艺术道路与主张与他们的前辈全然不同。

民国初期，以徐悲鸿、林风眠为代表的艺术家将欧洲艺术作为 改良中国美术的源泉。这些艺术家在归国之后的创作可以被看做是 他们在民国初年的中国面对来自西方现代主义冲击的不同回应。而 这些回应，无论是决澜社的对于现代主义的接纳、还是徐悲鸿对于 欧洲学院主义的恪守，组成了贯穿 20 世纪初叶中国艺术史的一条 主线。 20 世纪 80、90 年代旅美艺术家，归国后的艺术创作中，以 艺术、文化、政治的传统为主题的作品大量出现。本文将以徐冰与 艾未未两位曾经旅居美国现回国定居中国当代艺术家为例，通过对 于他们作品中 “传统” 这一主题的分析，揭示新一代海外归国艺术 家回溯传统时不同的选择，以及这一差异中折射出的中国当代艺术 面临的挑战。

\section{二、背景}

徐冰（I955-）与艾未未（I957-），两人年龄相仿，家庭背景类似， 虽然同样生长于 “文化大革命” 中与之后的拨乱反正时期，但是如 果仔细分析，会发现从人生的起跑线开始，两人的经历迥异。徐冰 的经历中，带有强烈中国传统文人气质，他始终是好学生、好老师、 好儿子。在他人生的各个阶段，他都亦步亦趋、中规中矩。读书、 升学、毕业、留校、出国。而艾未未，则完全相反，始终是游离于 
主流外的另类。从小随父流放、成年后辍学、出国后长期在纽约街 头游荡。

徐冰 1955 年出生于重庆，父亲徐华民在民国期间曾经在上海美 专读书，后任北京大学历史系党支部书记，多年从事管理工作 ; 母 亲杨时英在北京大学图书馆学系任教学秘书。徐冰的童年与少年时 代是在 “文革” 的腥风血雨到来之前的、书香尚浓的北京大学校园 中度过的。在他儿时居住的中关园, 他的邻居中就有著名历史学家 翦伯赞。徐冰记忆中，翦伯赞还曾为年幼的他提供过绘画材料。燕 园生活的点点滴滴虽然对于徐冰之后的艺术道路没有直接的影响, 但是为他提供了最初的艺术教育的基础、与人文主义的生长环境。

艾未末 1957 年生于北京。父亲是著名诗人艾青, 与徐冰父亲早 年在上海美专读书的经历类似，艾青同样在青年时代受过美术教育。 1928 年艾青在杭州的国立艺专学习了半年之后，于 1929 年赴法国 游学，同船到达法国的还有雷圭元、孙福熙、孙伏园等人。 ${ }^{1}$ 在法 国游学三年期间，艾青深受现代派影响。回国后，加入 “中国左翼 美术家联盟” “春地美术研究所” 等进步组织, 辅导业余美术爱好 者、撰写艺术评论、从事艺术创作。1932 年, 他策划、参加了 “春 地” 画展, 并在画展上与结识了鲁迅。2 艾未未曾回忆 “我看过他 (艾 青）早期的一些画，比很多在巴黎学画的人要好得多，因为他已经 接触不少立体主义的东西，而不是巴黎美术学院的那一套。” 30 年 代中期, 艾青放下画笔成为著名诗人。1949 年新中国成立之后任《人 民文学》杂志副主编。虽然艾青早年有学习美术的经历，但是对于 1957 年出生的艾未未来说, 父亲对于他美术方面的影响是很有限的。 倒是艾青在 1949 年之后政治生涯上的起起伏伏对艾未末的幼年经 历有着极大的影响。艾青在 1957 年的 “反右运动” 中被划为右派、 开除党籍。1958 年 4 月，他先是被下放至黑龙江林场劳动，次年又 被迁至新疆生产建设兵团劳动，直至 “文革” 结束。而艾未未则从 出生后不久就随着父亲被下放。

1 骆寒超、骆蔓: 《时代的吹号者一一艾青传》, 杭州出版社, 2005, 第 I9 页。

2 同上，第 54 页。

3 艾未末 : 《IOOI 个人的现代〈童话〉》, 载《此时此地》, 广西师范大学出 版社, 20IO。 
与徐冰在充满书香的北大校园中、在父母和兄弟姐妹的呵护下 度过的童年不同，艾未未因为父亲的原因，从小随父亲下放到偏远 的黑龙江与新疆，在一种 “野蛮生长” 的状态下渡过了童年时光。 文革结束之后，两人都分别考取了艺术院校。徐冰在 1977 年考入 中央美术学院版画系。艾未未在 1978 年考入北京电影学院美术系。

\section{三、美国经历}

（一）艾未未（I98I-I993）艾未未在 “文革”结束之后，随被平反 的父亲一起回到北京。后于 1979 年参加 “星星画会” 展览，进入 北京电影学院美术系学习, 不久辍学。他于 I98I 年赴美, 1983 年 进入纽约帕森斯艺术设计学院留学, 据说因为艺术史课程不及格, 被学校取消奖学金资助而辍学。离开帕森斯学院之后他并无固定职 业, 以在街头画像、打各种零工为生。而他位于纽约市东村的东 7 街 52 号地下室的斗室，则成了众多 $80 、 90$ 年代赴美留学、访问、 旅游、工作的中国文艺界人士到美国的落脚之地一音乐家谭盾、胡 咏言，电影人顾长卫、冯小刚、姜文，画家刘小东、喻红、何多 苓、包括徐冰 ...... 都曾在那里居住。在他们的回忆中，艾未未俨 然是寄居在纽约的中国文艺界人士的精神领袖。冯小刚在自传《我 把青春献给你》一书中, 回忆 $199 \mathrm{I}$ 年作为副导演随《北京人在纽约》 剧组初到纽约时艾未未的一件趣事。那时剧组将艾未未的住处作为 男主人王启明初到美国住处的外景，“一天我们在他的地下室拍戏, 负责外联的李争争突然跑进来，对我们说，他车上的一个价值 200 美元的音响被人敲碎玻璃盗走了。未未听到后，出去转了一圈，只 花 Io 美元，就从一个黑人手里买回来了一个音响，送给了李争争。 李争争看见之后惊呼: 这就是我丢的那个。” 4

在艾未末自己的叙述中，他始终以一种玩世不恭的语气描述他 的美国经: 历 “那个时候出去, 理由太多了, 就是不想在中国待了。 去的时候本是为了要读书的, 去过几个学校, 宾州的、纽约的。我 在学校待不久, 挺烦的。真的是混了 $\mathrm{I} 2$ 年, 一边打工, 什么活都 做过。有了钱就歇了, 没钱就找份儿工作做几天。” 5 除了零工之外,

4 冯小刚 : 《我把青春献给你》, 长江文艺出版社，2003。

5 艾未末 : 《闲聊撩闲》，载《此时此地》，广西师范大学出版社，20IO。 
艾未未也从不忌讳谈起他在大西洋奢城的 2I 点牌桌的运气，甚至 一些小偷小摸的举动。而实际上，他并未全然游离在艺术之外，他 自述住在纽约期间会经常去美术馆、画廊看展览，在此期间也继续 着艺术创作。

I98I 年至 1993 年的 12 年时间, 是中国当代艺术历史上 “ 85 新潮”、 玩世现实主义、“后 89 ” 等流派风起云涌的时期，艾未未自称对这 些毫不关心，从未参与。艾未末早期以及初到美国的作品以黑白两 色的抽象绘画作品为主。1985 年他用金属衣架弯成杜尚的侧影，取 名为《挂人 / 杜尚》, 以表达他对杜尚的敬意。1988 年, 他在纽约 ArtWave 画廊举办了个展 “旧鞋一性安全”。画展上展出的作品带 有明显的杜尚现成品艺术风格的影响。除了《挂人》之外，参展的 还有约瑟夫 - 博伊斯式的雨衣, 雨衣的中部垂下一个避孕套 ; 琴颈 被改装上铲子手柄的小提琴; 一双鞋跟砍掉, 背对背缝在一起的黑 色工作靴 ; 波普式的毛泽东画像。

此外，艾未未在纽约时期养成了用相机随手拍摄照片的习惯， 这些照片中的一部分收录在在他的《艾未未 : 纽约》摄影图集中。 在这 I 万多张照片中，有日常生活的琐事、来访朋友的肖像、还有 一些突发事件。艾未未有时会将这些照片卖给纽约的报纸, 如果被 采用就会有相应的报酬。他也会在一些暴乱事件中，冲在前面，拍 摄照片。 ${ }^{6}$ 在这些照片持续的拍摄过程当中, 他已经像艺术家一样 在工作。“他花时间出去 “闲逛”，并且靠拍摄照片来 “打发时间”， 逐渐获得了作为艺术家的自信心” 7 艾未未的纽约岁月使得他无所顾 忌的生活方式和追求冲突、对抗强权的艺术态度得到充分的张扬, 也奠定了他艺术创作中使用寻常物体现对抗与冲突的风格。1993 年, 艾青患病住院，艾未未决定回国照顾年迈的父母，至此结束了他的 美国岁月。

\section{（二）徐冰（199I-2009）}

徐冰在美国的留学经历，继续秉承了他在国内一贯的模范风格。 与艾未未的经历相反一父亲病重令艾未未决定回国定居。而对于徐 冰来说，正是为了尊重父亲不同意他出国的意愿，他将美国之行推 
迟到父亲离世之后。徐冰在访谈中提到，在他于中央美术学院上学 期间，曾经受到老师古元的鼓励，打算出国留学。但是遭到了父亲 的反对，父亲认为徐冰当时的版画艺术风格更加需要吸收中国的传 统艺术的精华。 ${ }^{8} 1989$ 年徐冰的父亲因肺癌去世, 加之国内环境变化, 徐冰于 1990 年受威斯康辛大学麦迪逊分校邀请作为 “荣誉艺术家” （honorary fellow）赴美。后他曾在南达科他大学攻读艺术硕士学 位，主修现代版画、造纸和西方古典书籍装订。徐冰于 1993 年移 居纽约东村，成为职业艺术家，直至 2009 年回国。在徐冰初到美 国时，艾未未曾和中国台湾艺术家谢德庆驾车到麦迪逊看望他，那 也是这两位艺术家的初次见面。1993 年徐冰搬到纽约，正是艾未未 打算回国的时候，于是艾未未将纽约东村的公寓转租给了徐冰。徐 冰在这个公寓居住了数年。

与艾未未在美国以打各种零工为主，兼有艺术作品创作的方式 不同，徐冰在美国展览邀约、作品创作不断，并且完全以职业艺术 家的身份为生。在离开美国之前，徐冰的 “天书” 系列就已经引起 了美术界的关注。199I 年刚到美国不久，他就在威斯康辛大学麦迪 逊分校美术馆举办了《徐冰的三个装置》大型个展, 展出了《天书》、 《鬼打墙》与《五个复数系列》。之后每年徐冰都会有数个展览在 美国、中国、欧洲多地举办。一直以来，徐冰不断获得各种奖项。 1989 年，徐冰在中央美院任教期间，获得了国家教育委员会评选、 由霍英东教育基金会出资的 “年轻教员科研和教学”一等奖。在赴 美后第八年的 1999 年，他又获得美国麦克·阿瑟基金会颁发的旨 在鼓励各领域有创造力人才的 “麦克阿瑟奖”。

徐冰在美国仍旧持续着艺术，并且不断尝试新的主题与风格。 与出国之前作品中对于传统的一种自虐式的对抗不同，来到美国， 处于一个全然不同的文化当中，他的作品开始探索不同文化之间交 流的各种可能。1994, 徐冰在出国之前即开始实施 “一个转换案例 的研究” 的一系列作品就是这一转折时期的作品。

在这件行为艺术作品中，一只身上印有伪英文的公猪，和一只

8 徐冰: 《琐忆》, 载夏楠主编《家书》, 生活·读书·新知三联书店, 20I4。 
身上印有伪汉字的母猪在展厅中的猪圈生活，猪圈里面垫满了各种 各样的书。徐冰有意挑选了两只正处于发情的猪，它们会在展览期 间交配。最初艺术家担心充满 “书香” 的环境会使猪紧张或者不安, 结果在展览过程中, 两只猪神态自然, 倒是一旁参观的观众, 为它 们本能驱动下的举动而感到尴尬。徐冰解释说: “那两只完全没有 人为意识, 身上却带着 “文明痕迹” 的生灵, 以其最本能的方式 “交流” 着。这种手法处理上的直接到了一种不可思义又值得思义的程度。 这件作品给人们提供了一个反思的场所，观众看着，两头猪的行为， 想的是人的事情。” 9 正如作品题目 “一个转换案例的研究” 显示的 那样，徐冰把这件作品像一个科学实验一样对待，在不同地点以相 同的方式重现。这件作品中将不同文字、不同性别、不同物种之间 的交流以一种野蛮、原始的形式呈现, 放大了所谓 “交流” 的虚无一 在这些所谓交流中，唯有原始欲望才是在交流中被真正满足的。

赴美之后他开始创作 “新英文书法”, 开始用一种更加友好与和 解方式, 体现了不同语言与文化之间交流的可能。一个个英文单词, 外形上看似由汉字的间架结构组成，内部则是由相应的英文字母以 固定的方式组合而成。同时，作品对于 “文”与 “字”之间的结构 主义关系的探索也体现了更深层次对于中国传统象形文字的追述。 文字语言传统的承载物, 此后不断在徐冰作品中出现。并且更多地 以平和、和解、建构式的方式，呈现不同文化传统之间交流的可能 性。徐冰在美旅居期间的其它作品，例如《烟草计划》《文字风景》 等等，都充满了对于不同文化和语言之间和解式的交流。

徐冰与 2009 年接受他的母校中央美术学院的邀请, 结束旅居美 国的生活，回国任教。

\section{四、归国与传统}

\section{（一）艾未末（1993 至今）}

艾未未回国后除了创作作品之外，还以策划人、设计师、艺术 家的多重身份参与了很多展览、建筑、出版项目。例如，主持 “当 代艺术文件库” 的工作、与冯博一合作出版了《黑皮书》《灰皮书》《白

9 http://www.xubing.com/index.php/chinese/projects/year/r994/a_case_ study_of_transference_ChineseI 
皮书》, 参与了北京草场地艺术区建筑、北京奥运会主会场 “鸟巢” 建筑的设计等。同时，回国后他依旧保持着在纽约养成的即时摄影、 摄像、以及与关注社会突发事件的习惯。

从九十年代初期开始，艾未未的作品中充满了对于 “传统” 的 象征物的不屑与破坏。《摔汉代陶罐》《透视研究系列》《1994 年 6 月》 等作品是这一主题的代表。象征中国古典艺术传统的汉代陶罐不仅 被故意摔碎，整个过程以连续摄影的方式被记录下来，强调了这一 破坏的过程。在《 1994 年 6 月》中，以象征国家与权力的天安门 城楼为背景，艾未未的妻子路青站在长安街中心，向镜头掀起了自 己的裙子, 露出白色内裤。《透视研究系列》中, 世界各地著名标 志性建筑位于照片透视中心 “灭点” 的位置，而在照片近景中，同 样在 “灭点” 位置的是艾未未伸出的中指。这一作品与《I994 年 6 月》系列类似，所谓的庄严与肃穆的象征性建筑，与世俗观念中不 雅与猥琶的姿态并置一在官方语境中作为主体的神圣与庄严在这些 世俗的姿态中被解构。艾未未归国之后作品中一个明显的主题是历 史文化的传统，或者官方政治传统的象征，而它们所象征的正统性、 持续性、庄严性，则在艾未未的作品中被刻意消解。

进入新千年，艾未未作品中传统主题不断再现。在这些作品中， 他对于传统的象征物进行拆解，拆解之后它们或是被重新组合、或 是直接以碎片的形态以密集堆砌的方式进行陈列。例如，《永久自 行车》中, 社会主义时代中国百姓家庭四大件之一的永久牌自行车, 被切割成碎块, 成片地堆积在展厅的地面。有趣的是, 当这些被切 割成碎块、已经成为废物的自行车，以极大数量出现在正规艺术 展览空间的时候，在视觉上它们拥有了另一种美感，在形式上作为 “艺术品” 被 “永久” 保存下来。“永久” 虽然作为自行车并不永 久，但是作为艺术品可能进入了一个新的 “永久” 状态。人为制造 的 “废物” 在密集量化后产生了视觉冲击力一除了永久自行车之外, 中国传统瓷茶壶残留的壶嘴、象征着 IO 亿中国人的葵花籽等都在 不同作品中有所呈现。《葵花籽》由 I 亿个手工制作、上色、烧制 的陶瓷葵花籽组成。虽然每个个体都是不同的，但是当我们将它们 铺满展览空间的时候，它们形成一种密集而恐怖的同一感。这种一 个个不同个体重复叠加之后产生的千篇一律的密集视觉效果，是对 于社会主义时期忽视个性强调同一性的集体主义的一种比喻。同时, 
传统也成为被反讽的对象。在有的作品中，艾未未将传统的象征物 拆解之后, 重新组合, 或是重新组合为一个新的传统象征物（明代 庙宇拆除后组成的中国地图), 或是体量巨大充满威胁感的莫名之物 （永久自行车被首尾相连成的巨型装置）。艾未未回国后作品延续 了在美国经历中对于权力、主流话语的不屑，以对固有传统的象征 物以暴力、野蛮的方式进行拆解，从而表达对于固有意识形态概念 的解构。

\section{（二）徐冰（2009 至今）}

徐冰于 2009 年受母校中央美术学院之邀回国, 在繁忙的管理工 作之余，创作了《凤凰》《背后的故事》《桃花源》等一系列作品。 在这些作品中, 徐冰将中国传统艺术与文化作为直接灵感来源, 而 作品本身则均力图以建构的方式为中国传统赋予新的形式，以新的 语言 “激活”传统。例如，大型装置艺术作品《凤凰》。

《凤凰》由雌、雄两只凤凰组成, 总长约 45 米、宽 12 米、高 $\mathrm{IO}$ 米, 重 $\mathrm{I} 2$ 吨, 目前有两个版本, 是徐冰回国之后即着手创作的大型作品。 一雄一雌的两只凤凰，全部由建筑工地上使用的各种工具与材料组 成一红蓝白相间的围挡塑料布是凤凰的翅膀、安全帽、铁钦等组成 凤凰周身色彩斑斓的羽翼，起重机的巨臂是凤凰的脊梁。整件作品 的制作过程历时两年，中途虽然遇到赞助人撤资、苦于寻找展出场 所等诸多困难，最终仍得以完成。凤凰的形象存在于世界各民族的 神话当中, 在西方它是浴火重生的神鸟, 在中国它是象征吉祥高贵 的百鸟之王。经济高速增长的中国在 2000 年初就好像一个巨大的 建筑工地, 各种楼盘拔地而起, 混凝土车在大街小巷疾驰而过。徐 冰以凤凰这一通身由建筑材料构成的形象比喻正在经历着这样的一 个烈火烹油、鲜花着锦般繁华的中国。而根据徐冰的自述，在经历 火热的繁荣之后，这只凤凰必然有更美好的未来。“这件装置的艺 术语言不同于一般概念上的西方现代艺术作品, 而是显示出中国方 式艺术创造的魅力，如同中国这样一个发展中国家，人们集体情感 和愿望的写照。选择具有中国方式的现代性作品......有利于观众对 中国当代文化与世界文化格局的关系产生新的理解，看到中国文化 
在未来人类新文明建设中必将作出贡献的潜在寓意。” 10

凤凰在完成之后, 曾经于 2010 年在临近北京中央商务区 (CBD) 的今日美术馆展出一刻意营造出在摩天大楼的背景中，两只凤凰比 翼齐飞的景象。之后, 这件作品还曾经在上海世博会展出。2014 年初, 这件作品在美国纽约圣约翰大教堂长期展出。在圣约翰大教堂，两 只周身布满无数闪亮小灯的神鸟一前一后，面对大门，似乎正离开 圣坛，展翅飞出。《纽约时报》记者在吊装现场采访徐冰时，听到 徐冰回答助手应该如何安排两只凤凰的位置时，徐冰回答 “让女孩 上帝近些” 一在哥特式教堂中的展出显然给作品增添了庄严和神圣 的气氛。徐冰在访谈中提到, 这两只神鸟全身由建筑废料组成, “它 们伤痕累累, ’ 徐冰解释，“经历困苦，却依然保持着自尊。总的来 说，凤凰象征着未曾实现的希望与梦想, ”11

徐冰用同样的方式，创作的《背后的故事》，也是以寻常物（干 枯植物、麻丝、纸张、编织袋及各种废弃物）通过精心建构的方式， 在半透明玻璃后面反复造型，重现出了一幅幅中国古代经典山水画 作品。正面雾气氮氲、意境悠远的古典山水画形式与其背后垃圾破 烂、杂乱无章的现实场景之间构成了一种极强烈的反差性。 ${ }^{12}$ 在这 些作品中, 徐冰用寻常之物, 将艺术与文化传统的代表物（凤凰、 中国山水), 以科学实验式的理性组合方式，为传统积极建构新的 形式与意义。

\section{结语}

作为两位在国内外均享有盛名的中国当代艺术家，艾未未与徐冰的 作品中都体现出了当代艺术的 “生活化” 趋势。即，他们的作品均 取材于寻常生活之物，作品主题都切近当下。传统这一主题在两位 艺术家作品中都持续出现，两位艺术家都在回顾传统，对传统的象 征物进行挪用，都在对传统的挪用中投射中国当下的现实。徐冰在 作品中，从《新英文书法》《背后的故事》到《凤凰》，通过将古代

10 http://www.xubing.com/index.php/chinese/projects/year/2oIo/phoenix chinese.

11 http://art.china.cn/zixun/20I4-02/r9/content_6680989.htm

12 http://news.artron.net/20I5IO29/n788840.html 
文化艺术传统象征物进行外科手术式的分析, 提取其中元素进行组 合，力图建构一个 2I 世纪全球化语境中，更具有跨国界、跨文化 的国际交流能力的中国式的新语言、新传统。

而艾未未作品中被改装的客体既有象征正统文化传统的元素, 例如古建筑、古董、古代家具等，也有社会主义时期的政治传统和 文化传统，例如葵花籽、永久自行车等。而在物理拆解这些象征物 之后，艾未未很多情况下并不把它们做刻意的重建或者再创造，而 是直接以破碎的形式呈现。在艾未未的作品中，传统的被拆解状态 就是当下的现实。“你必须了解了，才能去摧毁。你只有成为行家， 才能摧毁某件东西。一个普通人无法摧毁一座桥, 只有结构工程师 才干得了。” 13

两位艺术家作品中对于传统的不同态度和解读，固然与他们的 个人经历、文化背景相关，但是他们对于传统不尽相同的借用方法 与投射的结果，也反映出中国当代艺术当下所处的所谓 “中国性” 的分裂。半个多世纪前, 徐悲鸿与林风眠所代表的不同艺术主张最 终在 1949 年之后以徐悲鸿所倡导的写实主义的推广而结束。继而 带来中国美术教育数十年以苏联学院派社会主义现实主义美学为标 准模式的确立。当下, 徐冰和艾未未两人不同的艺术主张，也分别 代表了两种中国当代艺术发展的趋势。徐冰的主张更加靠近官方主 流意识形态中对于传统复兴的号召，例如政府大力支持的保护非物 质文化遗产振兴计划等，旨在令传统在新时代将有新形式、新活力。 正如徐冰的凤凰正在离开圣坛，飞向人间。徐冰的凤凰也作为威尼 斯双年展官方中国馆的入选作品参展。而艾未未的作品则秉承了当 代艺术中批判与怀疑的姿态。他以毁灭的方式消解传统，像鲁迅所 说的那样，把有价值的东西毁灭给人看。这种充满悲剧感的创作与 呈现方式，使得他在国内官方主流话语权球化语境中回应传统时不 同的选择体现了中国当代艺术当下，处于自相矛盾中的自我身份迷 失。与民国时期海外归来艺术家共同关注中国本土艺术的未来的现 象不同，新世纪海外归来的艺术家的 “惑” 更聚焦于如何在当下的 中国安放以往文化的、艺术的、政治的传统，而在这一观点上的分 
章锐

裂，则是二十世纪后半叶至今，中国社会文化持续断裂的投射。如 果说贯穿二十世纪中国艺术史的主线之一是艺术家们对于来自西方 思潮的回应或者反抗，那么二十一世纪初中国艺术史的主线之一则 是艺术家回看中国传统时如何应对。 


\section{Construction vs. Deconstruction: Different "Chineseness" in Chinese Diaspora Artists' Works}

Zhang Rui

\section{Introduction}

The reformation and opening up in the I980s of China allowed, for the first time since the I930s, for Chinese citizens to study abroad and to immigrate. This wave of "going abroad" geared up further in the early I990s. In this growing wave of studying abroad, many of the students were artists. What distinguished this wave of studying abroad is that earlier ones in the twentieth century had France or other European countries as their destination while many of this new generation of artists chose to go to the United States, such as Chen Yifei, Ai Weiwei, Xu Bing, Zhang Huan, Cai Guoqiang Xie Xiaoze, Yang Qian, He Duoling. In the past twenty years, quite a few artists of this generation have returned to China. Unlike the older artists of the early-Republican generation who returned to China from studying in Europe, the new generation's chosen path of art and artistic claims differ completely from their predecessors.

Artists at the beginning of the Republican era, such as Xu Beihong and Lin Fengmian, used European arts as inspiration for remodeling Chinese arts. The works produced on these artists' return to China could be seen as China's artistic response to the impact brought about by Western modernism. Whether Juelang Club's acceptance of modernism or Xu Beihong's loyal observation of European academicism, these responses formed the main narrative of Chinese art history of the early twentieth century. On the other hand, a good deal of works produced by the Chinese artists of the I980s and '9os who returned from the States concerned the themes of artistic, cultural, and political tradition. This chapter will use works by two contemporary Chinese artists who stayed in the states but now reside in China - Xu Bing and Ai Weiwei- as examples to analyze the theme of "tradition" in their works. This analysis will reveal a different choice made by artists of a new generation who have studied abroad when they trace the tradition at home and the generational difference that reflects the challenge faced by contemporary Chinese arts.

\section{Historical Background}

Xu Bing (1955-) and Ai Weiwei (1957-) are similar in age and in their family backgrounds. Although both were born in the middle of the Cultural Revolution and grew up in the post-revolutionary Rectifying Period, on closer analysis, we soon realize that from the very beginning their two lives differ tremendously. Xu Bing has always lived with that strong sense of traditional Chinese literati. He has always been a good student, a good teacher, and a good son. At all stages of his life, he took things in his stride and stayed in the middle ground: he stud542 ied, advanced academically, graduated, taught at school and studied abroad. On 
the other hand, Ai Weiwei is the complete opposite type and remained all his life on the margin of the mainstream society. Ai was exiled with his grandfather to a labor camp when he was young, dropped out of school when he grew up, and was hanging out in New York streets when he studied in the US.

When he was born in 1955 , Xu Bing was critically ill. His father Xu Huaming once studied at Shanghai's American College during the Republican period and worked as a party secretary at the Department of History at Beijing University later, doing managerial work for many years. Meanwhile, Xu’s mother Yang Siying worked as a teaching secretary at the Department of Library Information of Beijing University. Xu Bing spent his childhood and teenage years on the scholarly Beijing University Campus before the blood-shedding Cultural Revolution. He grew up in an environment where the renowned historian Jen Pozan was one of his neighbors. As Xu recalls, Jen Pozan supplied his young self with painting materials. The nitty-gritty details of his childhood life on campus might not have had a direct impact on the artistic path Xu later chose, but they were certainly the cornerstone of his initial artistic education and the campus provided a humanistic environment to grow up in.

On the other hand, Ai Weiwei was born in Beijing in 1957. Ai's father Ai Qing was a famous poet and shared a similar educational background to $\mathrm{Xu}$ Bing's father's early years of studying art in Shanghai. Ai's father received an arts education in his youth. In 1928, after studying for half a year at the National Arts College in Hangzho, Ai Qing went studying in France. The same boat which took Ai Qing to France in 1929 also had Lay Guayuan, Sun Fuxi, and Sun Fuyuan on board. ${ }^{I}$ During his time in France, Ai Qing was deeply influenced by modernist art. When he returned to China, Ai Qing joined progressive arts clubs such as Chinese Leftwing Artist Alliance and Spring Land Artistic Study. Members of these arts societies supervised amateurish arts lovers, wrote arts criticism, and worked on creative arts. In 1932, Ai Qing curated the "Spring Land Exhibition" where he met and be acquainted with Lu Shun. ${ }^{2}$ Ai Weiwei recalled his earlier memories of his father's works: "I have seen his [Ai Qing's] early paintings. They are much better than the works by those who studied in Paris because of his exposure to Cubism instead of sticking with the Paris Beaux Arts." 3 In the mid-I930s, Ai Qing left painting and became a renowned poet. In 1949 when New China was founded, Ai was appointed the deputy editor of a literary magazine, People's Literature. Although Ai Qing had an arts education in his early days, for the 1957-born Ai Weiwei, the impact his father had on his arts was limited. Instead, it was Ai Qing's post-I945 turbulent political career that had a great impact on Ai Weiwei's childhood experience. Ai Qing had been labelled as "right wing" and was stripped of his party membership as a result. In April 1958,

I Cheng Guang Wei, The Epoch Maker: A Biography of Ai Qing (Beijing: Beijing October Art Publishing House, 2005), I9.

2 Ibid., 54.

3 Ai Weiwei, "The Modernity of Ioor People," in Time and Place (Guangxi: Guangxi Normal University Press, 2010), 46-49. 
he was first exiled into the forest camp in Heilongjiang for labor reformation and then in the next year to Xinjian to labor in Production and Construction Corps until the end of the Cultural Revolution. And Ai Weiwei went into these labor camps with his father soon after he was born.

Unlike Xu Bing's literary-infused childhood on the Beijing University campus, surrounded by love from his parents and siblings, Ai Weiwei spent his childhood in a state of "savage growth," as he was exiled into the remote Heilongjiang and Xinjiang regions along with his father. However, both were admitted to art colleges after the Cultural Revolution. In $1977 \mathrm{Xu}$ Bing was admitted to the department of Lithography at the Central Academy of Fine Arts, while Ai Weiei was admitted to the Arts Department of the Beijing Film Academy.

\section{American Experience}

\section{Ai Weiwei (1981-1993)}

Ai Weiwei returned to Beijing with his rehabilitated father when the Cultural Revolution ended. In 1979, Ai Weiwei took part in the Star Art Exhibition and enrolled in the Arts Department of Beijing Film Academy, but he soon dropped out. Ai went to the US in 198I and enrolled in New York's Parsons School of Design in 1982. However, it is said that Ai’s scholarship was cancelled because he failed his art history class. After leaving Parsons, Ai, without a stable job, lived on painting portraits in the streets and working odd jobs. And his basement cubbyhole at 527 th Street in New York's East Village became the stamping ground for Chinese artists set who studied, visited, travelled, and worked in the US in the I980s and I990s. The crowd who had stayed in Ai's cubbyhole included musicians such as Tang Dun and Hu Yongyan, film makers and actors such as Gu Changwen, Feng Xiaogang, and Jiang Wen, painters such as Liu Xiaodong, Yu Hong, He Duoling, and Xu Bing. To their recollection, Ai Weiwei was the spiritual leader for the Chinese artist set that stayed in New York. In his autobiography I Devote You My Youth, Feng Xiaogang recalled one particularly interesting detail about Ai Weiwei when he first went to New York as the assistant director with the film crew of the television drama A Native of Beijing in New York. Ai Weiwei's basement apartment was used as the drama's hero Wang Qiming's place in America. Feng wrote, "one day when we were shooting in the basement, our PA Li Zengzeng suddenly came over and told us that the stereo worth 200 dollars in his car was stolen and the car window smashed. When he heard this, Ai went out, brought back a stereo he bought from a black guy with io dollars and gave it to Li. When Li saw the stereo he recognized it to be his stolen one." 4

In his own account, Ai always described his American experience in a playful tone: Art Publishing House, 20I0). 
There were too many reasons for leaving the country; in a nutshell, I didn't want to stay in China. I meant to study and had studied in a couple of colleges in Pennsylvania and New York but I had trouble staying put. I was bored stiff. I was honestly taking the scenic route for I2 years. I took all sorts of odd jobs. When I had money in my pocket, I took a break; when money ran out, I did a couple of days' job.

Apart from speaking of doing odd jobs, Ai never shies away from talking about his good luck at blackjack in Las Vegas nor about some more furtive dealings. However, Ai was never entirely cut off from arts. He talked about going to the art galleries and museums for exhibitions. Meanwhile he continued to work on his art.

The I2 years between 198I and 1993 was a period in contemporary Chinese art history where new artistic movements such as the 85 New Wave Movement (Bawu yundong), "Cynical Realism," and "Post-89" surged and made waves. Yet Ai Weiwei claims that he didn't care so much about those movements and never took part in them. Ai mainly worked in black-and-white abstract paintings in his early period and during his first stay in the States. In 1985 , he made a profile of Duchamp with wire hangers, titled Hanging Man/Homage to Duchamp, as a way of paying tribute to the artist. In 1988, he had his first solo exhibition "Old Shoes, Safe Sex" in New York's Art Wave Gallery, where the Duchamp's influence was detectable in the exhibited works. Apart from "Hanging Man, there were a raincoat in the style of Joseph Beuys with a condom issuing from its waist, a violin whose neck was replaced by a shovel's arm, a pair of black work boots whose soles were sawn off and with their backs sewn together and a Mao Zedong portrait à la Andy Warhol's "Popism."

In addition, Ai made it a habit to take photos wherever he went during his New York period. Some of these photos are now collected in his Ai Weiwei: New York photography album. Among the tens of thousands of photographs, some are about the ins and outs of everyday life, some friends' portraits, and other about untoward events. Sometimes Ai sent these photos to some New York presses and earned some money if the photos were used by the news outlets. At times he would be at the firing line to take riot photos. ${ }^{6}$ During the process of taking photographs, Ai started to work like an artist. "He spent time on 'loitering in the streets' and 'killed time' by taking photos." ' Ai started to gain confidence as an artist. Ai's New York time allowed the full expression for his care-free lifestyle and the artistic tendency to look for conflicts and fight against the authorities; it set the tone for his style of deploying common objects to embody the fight and conflict. In 1993 when Ai Qing was hospitalized, Ai Weiwei decided to return to China to look after his aging parents and thereby ended his American period.

5 Ai Weiwei, "Chattering about Whiling away Time," in Time and Place, 78-83.

6 See ibid. and "Small Talk," Friends of Photography, August 7, 2008.

7 John Tancock, "The Once and Future of Ai Weiwei," NY Arts Magazine, May I4, 20I4, I4. 
Fig. I. Xu Bing, Book from the Sky (Tian Shu), 1987-1991. Installation 1991, Elvehejm Museum of Art (now Chazen Museum of Art), Wisconsin, MN. (C) Xu Bing Studio.

\section{Xu Bing (1991-2009)}

$\mathrm{Xu}$ Bing's experience of studying in the States followed the pattern of his model behavior when he was in China. Xu's American experience was quite different from Ai Weiwei's.For Xu Bing, it was out of his respect for his father's wish for him to stay in China that he postponed his plan of studying abroad until his father had passed

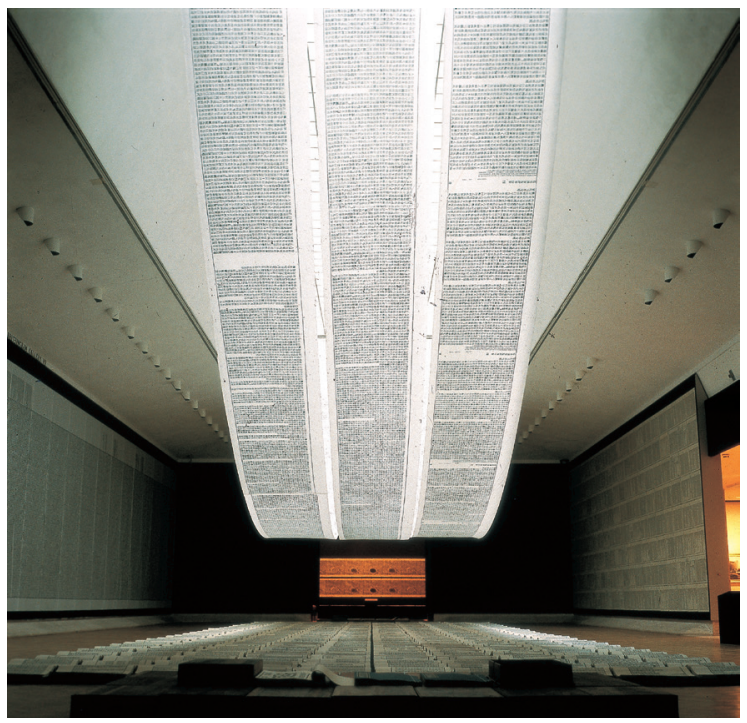
away. Xu mentioned in one of the interviews that when he was studying at the Central Academy of Fine Arts he was encouraged by his professor Gu Yuan to study abroad. But Xu's father opposed to such a plan because he was convinced that Xu's lithographical style needed to absorb more essence of traditional Chinese arts. ${ }^{8}$ In 1989 Xu's father died of lung cancer. It was also a time when the domestic situation within China was changing fast, so $\mathrm{Xu}$ accepted the invitation as an honorary fellow from the University of Wisconsin at Madison and went to the States. After that he followed a Master of Fine Arts at University of South Dakota, majoring in contemporary lithography, paper-making, and classical Western book-binding. In I993, $\mathrm{Xu}$ Bing moved to the East Village in New York and lived as a professional artist. $\mathrm{Xu}$ stayed in the States until his return to China in 2009. When Xu first went to the States, Ai Weiwei and the Taiwanese artist Hsieh Tehching drove over to visit him in Madison. It was the first time when the two artists met. When Xu moved to New York in 1993, Ai Weiwei was about to move back to China. So Ai had Xu Bing as his tenant at this East Village apartment. Xu Bing lived in that apartment for several years.

Unlike Ai Weiwei's American bohemian lifestyle of working odd jobs while creating art, Xu lived completely as a professional artist, getting endless invitations to exhibitions and commissions. Before leaving the United States, Xu Bing's Book from the Sky (Fig. I) had already caused quite a stir in the artistic scene in the States. When he first arrived in the States in I99I, Xu had a huge solo exhibition "Three Installations by Xu Bing” at the Elvehjem Museum of Art (now the Chazen Museum of Art) at the University of Wisconsin-Madison, displaying Book from the Sky, Ghost Pounding the Wall, and Five Series of Repetition. From then on, $\mathrm{Xu}$ Bing held several exhibitions in the United States, China, and Europe and won numerous awards across the globe. In 1989 when teach- 
ing at Central Academy of Fine Arts, Xu was awarded the first prize of "Young Professor Research and Teaching Award," an award judged by National Education Committee and founded by the Huo Yingdong Education Foundation. In 1999, eight years into his stay in the States, Xu received a MacArthur Fellowship, which aims to encourage creative talents in various fields.

$\mathrm{Xu}$ went on with his art-making and made attempts at new subjects and styles during his American sojourn. Exposed to a complete different culture, Xu's works in the United States, unlike the usual masochistic struggle against the tradition in his works prior to his American period, started to explore the various possibilities of exchange between different cultures. As early as 1994, before his departure for the United States, Xu started to execute A Case Study in Transference, which typifies Xu's transitional work in this period.

In this piece of performance art, a boar with pseudo-English words on him and a sow with pseudo-Chinese words lived in a hog pen in the exhibition where the floor was carpeted with all kinds of books. Xu deliberately picked two pigs in estrus, so they would mate during the exhibition. At first, the artist was concerned that the books' "smell" would put the pigs in tense and uneasy moods. As it turned out, during the period of exhibition the two pigs were in their element while the spectators were feeling awkward about the pigs' nature-driven behavior. Xu Bing explained:

The two creatures which are completely devoid of human consciousness but carry with them "traces of civilization" were "exchanging" with their most basic needs. Such method of handling art is so unthinkably direct that it is worth contemplating. This piece presents pigs' behavior but reflects human affairs. ${ }^{9}$

Just as the title of the work A Case Study in Transference indicates, Xu Bing treats this piece as though he is carrying out a scientific experiment: he re-presents it with the same methodology in different places. This piece presents the exchange between different languages, between different genders, between different species in a savage and primitive form, magnifying the emptiness of so-called "exchange" - in the acts of so-called exchange, only primitive desire is thoroughly fulfilled.

After his arrival in the States, Xu started to work on "new English calligraphy" by employing a more friendly and reconciliatory method to embody the possibilities of exchange between different languages and cultures. All the English words have the look that resemble Mandarin characters' structure but are internally structured by English alphabets. At the same time, the ways in which this piece explores the structural relationship between "meanings/texts" and "words" further embodies Xu's pursuit of traditional Chinese writing. The concept of loaded meanings embedded within linguistic traditions from then on

9 Xu Bing, "A Case Study of Transference," 1995, http://www.xubing.com/en/ work/details/395? year=1995\&type=year\#395. 
Fig. 2. Ai Weiwei, Study of Perspective - White House, 1995-2003. Acquired through the generosity of the Photography Council and the Contemporary Arts Council of The Museum of Modern Art. Courtesy of the artist.

have appeared in Xu Bing's major works and have been presented in a more peaceful, reconciliatory and constructive way to demonstrate the possibility of exchanges between different cultural traditions. The other works, such as Tobacco Project, Landscape/Landscript, are full of reconciliatory exchanges between different cultures and languages.

In $2009 \mathrm{Xu}$ Bing accepted the invitation from his alma mater, the Central Academy of Fine Arts, to teach and live in China. Thus Xu ended his sojourn in the United States.

\section{Returning and Tradition}

\section{Ai Weiwei (1993-)}

Since his return to China, apart from continuing his creative artworks, Ai Weiwei has taken part in many exhibitions, architectural and publishing projects in many capacities as curator, designer, and artist. For example, Ai hosted the Chinese Contemporary Research Paper project, co-published Black, Gray and White Cover Books with Fong Boyi, took part in the constructing the compounds in Caochangdi, the art district in which Ai Weiwei's studio was located in Beijing, and the architectural project of the Bird's Nest stadium for the 2008 Beijing Olympics. Meanwhile, even after his return to China, Ai still maintained his habits of real-time videotaping, photographing, and paying close attention to unexpected social events.

Since the early 1990s, Ai Weiwei's works are full of contempt and destruction of symbolic icons of "tradition." Works that are representative of such theme are Dropping a Hang Dynasty Urn (1995), Studies in Perspective (Fig. 2), and June 1994. A Hang dynasty urn that symbolizes the classical Chinese artistic tradition was not only deliberately smashed, but the entire process was recorded by continuous videotaping, emphasizing the process of destruction. In June I994, Ai Weiwei's wife Lu Qing stood in the middle of Chang'an Avenue against the background of Tiananmen Square tower gate, which symbolizes the State and its power, hitched up her skirt and exposed her white panties to the camera. In Studies in Perspective, famous landmark architectural buildings around the world are positioned as the vanishing point of the photograph's perspective and in the foreground of the photo, also at the vanishing point of the photo stands Ai Weiwei with his middle finger pointing out. This series of work resembles the June 1994 series in their juxtaposition of what are thought to be solemn and seri548 ous symbolic buildings with indecent and obscene gestures. One of the obvious 


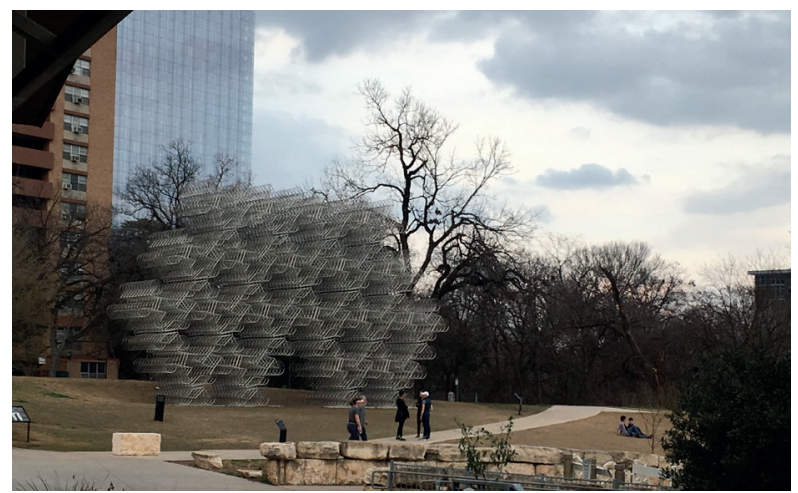

these icons were deliberately dissolved in Ai's works.

Well into the new millennium, the theme of tradition appears repeatedly in Ai's works. In these works, he goes on to deconstruct the icons of tradition, and after the deconstruction the icons are re-constructed or are exhibited in massive piles in the form of debris. For example, in Forever Bicycles (Fig. 3), Shanghai-based Forever bicycles, owned by every Chinese household, one of the must-haves during China's Socialist period, are chopped into pieces and laid on the exhibition floor in piles. What is interesting is that when the bicycles which have been chopped into bits and become rubbish appear en masse in an officially approved exhibition space, they demonstrate a different kind of aestheticism. As "artwork" they are "forever" preserved in a new form. Although they didn't stay bicycles "Forever," they might enter a new state as artwork "forever." Apart from Forever bicycles, the beaks left from the traditional Chinese porcelain teapots and the sunflower seeds that symbolize the Chinese people have appeared in various artworks. Sunflower Seeds are made up of Ioo million handmade, hand-painted, and hand-crafted porcelain sunflower seeds. Although each individual seed is unique, when they blanket wall-to-wall the entire exhibition space, forming an intense trypophobia and terrifying sense of homogeneity. This kind of intensively monotonous visual effect created by repetitively piling up identical objects is a metaphor for the Socialist period's collectivism, which over-emphasized uniformity at the expense of individuality. At the same time, tradition has become an object of irony. In all his works, Ai Weiwei reconstructs all the icons of tradition after deconstructing them; or the deconstructed objects are reconstructed into a new symbol of tradition (a map of China composed of the debris from a demolished Ming dynasty temple) or into a monumental, indescribable object that oozes a sense of threat (say, the head of the giant installation created by Forever bicycles joins its tail end). After his return from the United States, Ai Weiwei's works have inherited both the contempt he had for power and mainstream discourse he experienced in the States, and they deconstruct the existent ideological concepts embodied in the icons of tradition through violent and barbaric destruction. 
Fig. 4. Xu Bing, Book from the Sky (Phoenix), 2009-II. Sculpture. Installation at Today Art Museum, Beijing 20IO. (C) Xu Bing Studio.

\section{Xu Bing (2009-)}

$\mathrm{Xu}$ Bing returned to China on the invitation of his alma mater, Central Academy of Fine Arts, in 2009. On top of his busy schedule of administrative work, he has created a series of work such as Phoenix, Background Stories, and

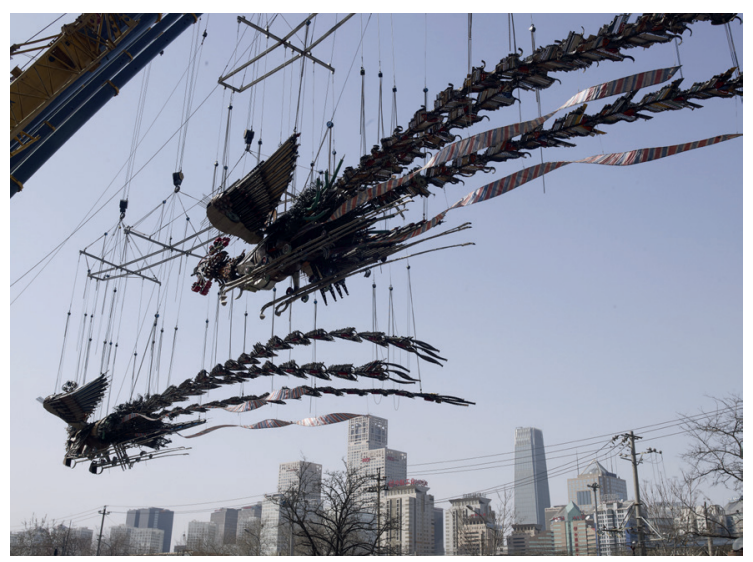
Travelling to the Wonderland. In these works, Xu Bing takes inspiration directly from traditional Chinese arts and culture and the works themselves strive to give new forms to the Chinese tradition through constructive methods and to "reinvigorate" the tradition through a new language. Take, for example, the large scale sculptural installation artwork Phoenix.

Phoenix is composed of a male and a female phoenix, about 45 meters in length, I2 meters in width, Io meters in height, I2 tons in weight. At the moment there are two versions, which were created immediately on Xu's return to China. The pair of male and female phoenixes are completely made up of all sorts of tools and material from construction sites - red-and-blue-striped plastic sheet becomes the phoenixes' wings, helmets and shovels the color-specked feathers covering their bodies, gigantic crane arms their spines. The piece took two years of assembling and creation. And despite many difficulties, such as withdrawn sponsorship and unavailable exhibition space, the piece was finished. The image of phoenix exists in myths of many peoples around the world. In the West, it is a mythical bird that arises out of ashes, while in China it is the symbol of the noble and propitious king of all birds. China's economic book at the beginning of the 2Isrt century resembled an enormous construction site where high-rises mushroomed and concrete-mixing trucks dashed about in streets and alleys. $\mathrm{Xu}$ Bing deploys the image of phoenixes comprised of construction remnants as a metaphor for the China which is in the process of fiercely burning and brilliantly blossoming. By Xu Bing's reckoning, having been through such frenzied period of prosperity, these phoenixes would definitely enjoy a better future:

The artistic language of this installation piece differs conceptually from the Western contemporary artworks: it demonstrates the charm of the Chinese ways of art-creation which reflects the collective emotion and the desire of a developing country like China. Choosing contemporary artworks created in the Chinese way [...] will make it easier for people to come to a new understanding of the connection between contemporary Chinese culture and the 
scale of world culture and see the potential contribution the Chinese culture will be able to make in the future construction of new human culture. ${ }^{\text {Io }}$

On completion, Phoenix was exhibited at Today Art Museum nearby Beijing's Central Business District (CBD), arranged such that the two phoenixes were flying sky high together against the background of skyscrapers (Fig. 4). This piece was also exhibited at Expo 20IO in Shanghai. In the beginning of 20I4, this piece was on long-term exhibition in New York's Cathedral of Saint John the Divine. In the cathedral, two divine birds, one at the front and one at the back, faced the front door with numerous twinkling fairy lights around them as though they are about to leave the altar and fly skywards. A New York Times journalist overheard $\mathrm{Xu}$ Bing's reply to his assistant as to how to arrange the position of the two phoenixes - "let the girl get closer to God" - when interviewing Xu Bing on the site of installation. In his interview, Xu Bing mentioned that these two mythical birds are completely constructed out of construction remnants from head to tail. "They are covered in scratches," explained Xu, "but have maintained their dignity despite the hardships. On the whole, phoenixes symbolize unrealized hopes and dreams." "II

With a similar methodology, Xu Bing created Background Stories, which are constructed carefully out of everyday life objects (dried plants, linen and silk, paper, woven bags, and miscellaneous discarded objects). Behind a sheet of half-translucent glass, repeated forms re-create pieces of classical ancient Chinese landscape paintings. The composition of classical landscape paintings, which foregrounds a misty, mysterious, and profound atmosphere is brought into sharp and contradictory relief with the realistic background scene of debilitated rubbles, dirt, and disorder. ${ }^{12}$ In these works, Xu Bing employs everyday objects to actively construct a new form and create new meanings for the icons in traditional arts and culture such as phoenixes and Chinese landscape through a scientifically tested and rational method of composition.

\section{Conclusion}

As two of the most renowned contemporary Chinese artists domestically and internationally, both Ai Weiwei and Xu Bing create works that embody the trend of reflecting on the "mundaneness of life." Their works are composed of found objects from everyday life and their themes reflect contemporary everyday-life concerns. The theme of tradition continues to appear in the works by both artists. Both look back at the tradition, appropriating traditional icons and projecting them onto the realities of contemporary China. In Xu Bing's works,

Io Xu Bing, "Phoenix Project," http://www.xubing.com/en/work/details/174?year=20I0\&type $=$ year $\# 174$.

II https://www.nytimes.com/20I4/o2/15/arts/design/xu-bing-installs-his-sculpturesat-st-john-the-divine.html.

I2 http://www.xubing.com/en/work/details/374?year=2004\&type=year. 
from New English Grammar, Background Stories to Phoenix, traditional icons of ancient culture and art are surgically analyzed and some elements are distilled to be made into a new construction and assembled into a fragmented representative form in the globalized context of the 2Ist century. In Ai Weiwei's works, the deconstructed state of the tradition is the reality of the contemporary: "You must understand in order to destroy. Only when you have become an expert can you destroy a certain object. A common person cannot destroy a bridge. Only structural engineers can do that." ${ }_{13}$

The different attitudes and readings of tradition in the two artists' works of course bear out their personal experience and cultural background. But the dissimilarity between their methods of appropriation and resulting projection of tradition also mirrors the fracture of so-called Chineseness in contemporary Chinese arts. Half a century ago, the different artistic claims disputed by $\mathrm{Xu}$ Beihong and Ling Fongmeng eventually ended when the brand of realism advocated by Xu Beihong prevailed after 1949. Afterwards, the aestheticism of Soviet academic Socialist Realism was introduced. It prevailed for several decades and formed the standard aestheticism in China. At the present moment, the different artistic claims by Xu Bing and Ai Weiwei also represent two developmental trends of contemporary Chinese art. Xu Bing's claim is closer to the official mainstream ideology, which calls for a renaissance of tradition, for example, the government-backed non-material cultural heritage restoration projects. These aim at injecting new form and new energy into tradition in the new age, just as $\mathrm{Xu}$ Bing's phoenixes are flying away from the altar into the secular world. On the other hand, Ai Weiwei's works inherit the critical and suspicious attitudes of contemporary arts. He dissolves the tradition through destruction the way Lu Xun would have approved of and shows the people the ashes of the valuable objects. This tragic way of representation and creation makes $\mathrm{Ai}$ an "alternative" voice with little right to speak in the Chinese officially ordained mainstream art circle. The two artists both respond to the globalized context and linguistic realities by choosing different embodiments of the lost and self-contradictory identities in contemporary Chinese art. Unlike the artists returning from abroad during the Republican period, whose common concerns focused on the future of Chinese indigenous art, the artists of the new generation focus their confusion more on how to situate the tradition of past culture, art, and politics in contemporary China. And this split of perspective offers a prognosis for the continuous fragmentation of Chinese society and culture since the second half of the twentieth century. If we say that one of the major running threads throughout 2oth-century Chinese art history is the artists' response or the fight against Western trends of thinking, then the main narrative thread of 2Ist-century Chinese art history is the ways in which artists look back and respond to Chinese tradition. 


\section{现代美术的再发现 : 回溯与借鉴一从吴冠中到“新 潮美术”运动 \\ 张坚}

2005 年，陈丹青在一篇文章中提到，上个世纪 70 年代，中国早期 的一些最重要的现代艺术家，诸如刘海粟、林风眠、吴大羽等都生 活在上海。“文化大革命”让他们惊魂未定，躲在家里不出门 ${ }^{1}$ 。根 据当时上海油画和雕塑院的魏景山回忆，他每个月都帮吴大羽把工 资带到他家里，吴甚至于自己都不敢出门，而让他的家里人透过前 门的小窗去接 ${ }^{2}$ 。1 990 年代早期, 我也曾走访过颜文樑先生在上海的 家，那是一栋老式的二层小楼，当时给我留下的印象是他家的门厅 位置上，摆了一架三角钢琴，几乎占据了房间一半的面积。

对于陈丹青那一代艺术家而言，这些中国早期的现代艺术家都 是相当陌生的。事实上，I949 年以来，他们几乎很少被人提及， 吴冠中后来抱怨说，吴大羽在上海生活了几十年，但几乎没有人知 道他，对于我们来讲，忘记这样一个伟大的现代艺术家是巨大耻

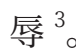

在新中国，社会主义现实主义的历史画是主流艺术，像陈丹青 那样的出生在上个世纪 50 年代的艺术家所接触和熟悉的就是这种 类型艺术。2007 年，陈丹青曾到中国美术学院做过一次讲座 ${ }^{4}$, 在 讲座中，他给出了一个上海油画家的师承谱系，其中的关键人物是 俞云阶，他是上海唯一一位参加过马克西莫夫油画训练班的画家，

1 陈丹青在一篇回忆文章中谈到上海滩 70 年代 “美术版图” : 刘海粟住 在复兴路重庆路，颜文樑住在淮海中路新康花园，关良住在永嘉路，林 风眠住在雁荡路南昌路，张充仁住在合肥路，吴大羽住在延安中路茂名 路。陈丹青：《退步集续编》，广西师范大学出版社，2007，第 45 页。

2 同上。

3 吴冠中: 《吴大羽现象》, 载《吴冠中文集》, 山东美术出版社, 20II, 第 247 页。

4 当时是经由吕澎老师介绍，陈丹青接受邀请，来中国美术学院艺术人文 学院做讲座。 
同时，也曾是徐悲鸿的学生。陈丹青显然对自己也在这个谱系当中 感到很自豪，他还为在浙江省博物馆举办的《红色记忆》展览担任 义务讲解员 ${ }^{5}$ 。

上个世纪 70 年代晚期和 80 年代早期, 中国和西方的现代艺 术如何被重新发现和定义的问题，显然是会有各种答案的，例如， 1982 年, 邵大筬就出版了一本介绍西方现代艺术的小书, 到了 I 986 年, 又发表 《西方现代艺术思潮》, 张少侠和李小山则出版了《中 国现代绘画史》，朱伯雄出版了中国西画文献集，1988 年，郎绍君 出版了《论中国现代绘画》，当然，还有许多其他涉及这个主题的 著作, 而本文将主要讨论吴冠中以及新潮美术中的一些艺术家在重 新发现和定义现代美术过程中发挥的作用 ${ }^{6}$ 。

1979-198I 年，吴冠中为艺术中的形式美和形式主义正名而发 表的一系

列文章和演讲，引发了国内对西方和中国早期现代美术（1949 年之前) 的重新发现的过程。情况正像李铸晋所说的: “文化大革命” 终于在 1976 年结束了, 这时, 国内的知识氛围与欧美国家的艺术 新思潮之间存在巨大的鸿沟, 吴冠中是当时中国唯一一位可以跨越 这个鸿沟的桥梁，许多年轻艺术家就把他视为当时新的艺术运动的 领袖。

吴冠中是杭州国立艺术专科学校中国早期现代主义艺术的传 承者之一，I936-I942 年间，他在杭州接受了系统的艺术训练， I947一I949 年, 又公派留学巴黎四年。在上个世纪的 80 年代, 他 是国内少数几个对西方现代艺术及其美学有真正的接触、理解和认 识的艺术家, 也成为了这方面的知识的启蒙者。他分别在《美术》《美 术研究》《文艺研究》 ${ }^{7}$ 等杂志发表一系列以形式美为主题的文章,

5 “红色记忆：1927-I949, 中国军事博物馆经典油画展” 是由中国军事 博物馆策划的历史画专题展览，2009 年 5 月在浙江省博物馆开展，这 个展览的目录 2009 年由长城出版社出版。陈丹青应邀为在浙江省博物 馆举办的展览担任讲解，吸引了杭州的许多艺术爱好者。

6 李铸晋 : 《吴冠中的艺术发展和理论基础》, 载吴冠中《名家翰墨 : 吴冠 中专号》，香港翰墨轩出版有限公司，I992，第 IO3 页。

7 这些文章包括 “绘画的形式美”，《美术》杂志，1979 年第五期 ; “寂寞 
激起了国内对艺术作品中的内容与形式的关系问题的广泛讨论，吸 引了艺术批评家、理论家、美学家和艺术家的积极参与, 讨论最终 还走向对艺术在政治中的作用的探讨，即艺术到底应作为政治的工 具，为现实政治服务，还是需要重新确立为艺术而艺术的原则，对 吴冠中而言，答案是清楚的，艺术的本质就是形式美，艺术应独立 于现实政治。

需要指出的是，吴冠中所引发的形式美的讨论，在当时是有一 个特殊的政治语境的，即 1970 年代晚期和 80 年代早期的思想解放 运动。在艺术和文学领域里，思想解放的一个重要信号是 1977 年 I2 月 3 I 日的《人民日报》刊发了毛主席给陈毅的一封讨论中国古 代诗词的信。毛主席的这封信也在《美术》杂志 1978 年第 I 期刊 发。吴冠中显然对此有所领悟。1978 年 3 月 17 日，吴冠中在给朋 友一封信中就说: “毛主席给陈毅的信发表, 表明中央认清文艺解放, 首先要在基础理论上奠定形象思维之根本问题，我估计形式美的问 题将被提到建国以来的空前高度，这个问题不研究，我们的文艺将 永远落后在无科学的愚昧状态中。结合建筑，又懂得点外文，情与 理双方兼顾平衡，我看你献身于这一工作是比较合适的。” 8

毛主席在给陈毅的信中, 主要是谈到了传统律诗写作的平入押 韵的规则, 以及诗歌写作需要有形象思维, 其中潜台词其实是强调 文艺创作要尊重艺术规律。而按照吴冠中的理解，视觉艺术想象力 就意味着形式想象或形式思维，当然，最终是指向形式美。

吴冠中为形式美正名的倡议自然不是一个孤立现象，在 80 年代 早期, 其他的学者也提出了类似的主张 ${ }^{9}$, 积极推进一场视觉启蒙运

耕耘六十年，怀念林风眠老师”，《文艺研究》1979 年第八期 ; “印象主 义绘画的前前后后”, 《美术研究》, I 979 年第 I 2 期; “波提切利的《春》”, 《世界美术》, 1979 年第七期 ; “关于抽象美”, 《美术》杂志，1980 年 第十期; “造型艺术离不开对人体美的研究”, 《美术》杂志, 1980 年第 四期; “梦里人间，忆夏凡纳的壁画”，《世界美术》，1980 年第七期; “梵 高”，《美术》杂志，1980 年第三期等。

8 吴冠中: 《吴冠中给邹德侬的信, no. 26, 19780118 》, 载《吴冠中文集, 卷七: 老树年轮》, 团结出版社, 2008 , 第 I48 页。

9 在 80 年代的“美学热”中, 最具影响力的学者有李泽厚、朱光潜和宗白华, 
动。但是, 需要承认的是, 他们中间, 很少有人具备类似于吴冠中 的对于现代艺术的知识视野和深切理解 ; 事实上, 这些学者的注意 力是在如何为现代艺术建构一个宏大的理论体系，与此形成对照的 是, 吴冠中宁可倡导一种形式的艺术史作为他的现代艺术的美学资 源。吴冠中的形式主义在当时不但发挥了沟通中国和西方的现代艺 术的桥梁的作用，而且也让 1930 年代中国早期现代主义与 1980 年 代的现代主义形成一种历史关联，而后者的根基可以追溯到 1930 年代杭州国立艺术专科学校以及 1940 年代晚期的巴黎国立高等美 术学院的。

用吴冠中自己的话说，1930 年代的杭州国立艺术专科学校，近 乎是法国美术院校的中国分校, 当时的学校甚至还有专门的驻欧代 表，图书馆里都是法国现代画家的画册和期刊，比如塞尚、梵高、 马蒂斯、毕加索等, 并且教法文 ${ }^{10}$ 。在巴黎四年学习期间, 他是在巴 黎高等美术学院油画系苏弗尔皮教授门下, 苏弗尔皮鼓励他用自己 的方式进行创作, 要不断地在真实的世界中去发现和表现线条和色 彩的纯粹形式美, 发展了一种唯美主义的趣味。

显然，在 “文化大革命” 之后，吴冠中成为中国最早的现代艺 术及其美学的倡导者并非偶然, 而且, 他还是当时翻译和引入西方 现代艺术的关键人物。事实上, 1980 年代, 中国最具影响力的西 方现代艺术史书籍之一, 阿纳森的《现代艺术史: 绘画、雕塑和建筑》, 其翻译和出版都与吴冠中有着紧密的关系。这本书的主要译者邹德 侬最初是 1975 年在青岛与吴冠中相识。那时，吴冠中正在为青岛 机车车辆厂的两个出口非洲的车厢创作风景画, 邹德侬刚从天津大 学建筑系毕业, 在这个厂工作, 也是一位美术爱好者, 作为建筑师, 他与吴冠中在形式美的问题上持相同见解。

在 1977 年 12 月给邹德侬的信中，吴冠中说：“你如回天大建筑 系看来甚好，此生精力当可全部奉献于形式。“建筑师成天要和抽 象的点、线、面、体、虚、实打交道，而美术界却在否定抽象美。” 11

李泽厚的著作《美的历程》在当时的艺术界广受欢迎。

10 吴冠中:《走出象牙塔: 关于前国立艺术专科学校的回忆和掌故》, 载《吴 冠中文集》, 山东美术出版社，20II，第 25 页。

11 吴冠中: 《吴冠中给邹德侬的信, no. 25, 19771210》, 载《吴冠中文集, 
阿纳森的这本书应该是在 1978 年以后就开始翻译了，邹也一直为 此事与吴冠中保持联系，吴冠中还帮助他解决了一些法文翻译的问 题。

阿纳森的书最后是在 1983 年由天津人民美术出版社出版，吴冠 中为这本书写了序言，他认为，这本书着重作品分析，文字通俗， 有助于探寻造型艺术的共同规律，改变对西方现代艺术无知的局 面 ${ }^{12}$ 。在这个时期,他自己也为一些艺术杂志和报纸写了许多介绍西 方现代艺术家的文章，诸如梵高、塞尚、夏梵纳、莫奈、马奈和图 卢兹·劳特累克等，所有这些艺术家都是他青睐的，也形成了他的 现代艺术的谱系 ${ }^{13}$ 。

与此同时，吴冠中致力于向公众介绍中国的早期现代艺术家。 对中国现代艺术的历史谱系，吴冠中有他自己的认识和记忆，他不 同意当时出版的一些中国现代艺术史著作的观点，其中也包括李小 山、张少侠《中国现代绘画史》，他称这本书是空中楼阁。他认可 的中国现代艺术史的真正先驱是林风眠、吴大羽和潘天寿 ${ }^{14}$ 。他的中 国早期现代艺术家的记忆中，有许多人是他在杭州国立艺专时的同 学，诸如朱德群、赵无极、李可染等，正是这些艺术家，构成了他 心目中的早期现代美术的历史, 他矢志不移地推崇现代美学价值 ${ }^{15}$ 。

卷七: 老树年轮》，团结出版社，2008，第 I47 页。

12 吴冠中：《阿纳森〈西方现代艺术史〉中文版前言》，1983 年 5 月，载阿 纳森《西方现代艺术史 : 绘画、雕塑和建筑》, 邹德侬、巴竹师、刘珽译, 天津人民美术 出版社，1986。

13 这些文章包括“印象主义绘画的前前后后”, 《美术研究》, 1979 年第 I2 期; “波提切利的《春》”, 《世界美术》, no. 7, 1979 年 ; “梦里人间，忆夏 凡纳的壁画”,《世界美术》no. 7, 1980; “梵高”, 《美术》, no. 3, 1980 年; “郁特里罗的风景画”, 《世界美术》, no. 7,1982 年; “读《亲爱的提奥》” 《文艺研究》，no. I2，1984 年；“没有归宿的过客，序《西方后现代艺 术流派书系》”, 《美术观察》, no. 8, 200 I 年。

14 同注 Io, 第 25 页。

15 吴冠中对中国早期现代艺术的想法反映在他发表的一系列文章中，诸如 “寂寞耕耘六十年，怀念林风眠老师”, 《文艺研究》no. 8,1979. “潘天 寿绘画的造型特色”、《新美术》, no. 4, 1981 年 ; “望尽天涯路” 《人民 文学》, no. $10 ， 1982$ 年 ; “走出象牙塔”，1985 年 ; “探望林风眠老师”， 
I980 年代初期, 国内几乎没有其他学者或艺术家, 能像他那样对 中国早期现代艺术有如此深刻的历史认识。

吴冠中的艺术和美学思想可以回溯到五四运动时期的蔡元培, 后者的艺术创造和艺术教育思想与 I8 世纪德国美学和哲学思潮, 特别是康德、威廉·洪堡特的思想有密切关系, 同时也得益于 20 世纪早期法国现代美术运动; 而在另一方面, 潘天寿承袭和发扬的 石涛和八大的中国文人画的表现主义传统, 也是他个人创作的重要 源泉。在吴冠中看来, 形式主义是沟通东西方艺术的桥梁, 杭州国 立艺专的艺术家, 诸如林风眠、吴大羽、赵无极、朱德群乃至李仲 生等人的创作，就实现了这个目标。

如果是在这样一个上下文关系里，他的 “脱离了画面效果的笔 墨等于零” ${ }^{16}$ 的说法, 也应理解为是一种尝试重述西方和中国艺术故 事的诉求，在他既不认同把社会主义现实主义视为主导标准，艺术 作品被当作文学的乃至政治的附庸的观点; 也反对把中国传统艺术 史削减为文人画史, 视 “四王” 笔墨程式被奉为最高准则认识。他 的形式主义艺术史是要跨越艺术的中与西、古与今、高雅与通俗的 分界的, 用张仃的话说, 是毕加索加城隍庙 ${ }^{17}$, 最终, 形式主义的本 质是一种对艺术作为个体经验和创造力的视觉表达的信念, 而这也 指向了个体解放，预示了一种世界艺术的观念。

吴冠中的形式主义, 以及他在积极推广现代艺术方面所做的努 力，推动了公众、官方和学界对现代艺术的接受，虽然在 1982 年, 他受到了中国美术家协会的高层领导的严厉批评 ${ }^{18}$ 。从 1990 年代到 现在, 某种程度上, 吴冠中有关形式美和现代艺术的主张不断激励

《文汇报》, 1986 年 I 月 7 日; “国美附中 65 周年笔谈”《新美术》, no. 8 , 1994 年; “吴大羽: 被遗忘、被发现的星”, 《美术观察》, no. 3，1996 年; “朱德群和我的故事” ，《文艺研究》, no. 9, 2000 年。

16 吴冠中: 《脱离了具体画面的孤立的笔墨, 其价值等于零》, 载《我负丹 青》，人民文学出版社，200，第 299 页。

17 吴冠中: 《土土洋洋、洋洋土土 : 油画民族化杂谈》, 载《文艺研究》第 I 期, 1980，第 I3工页。

18 他提到, 江丰曾激烈反对抽象画, 在讲话中多次批评他, 参见吴冠中: 《我 负丹青, 丹青负我》, 载《我负丹青》, 人民文学出版社, 2004, 第 9I-92 页。 
了多种文化和学术活动，诸如展览、研讨会、教学和研究项目 ${ }^{19}$ 等, 重新确立了现代艺术的历史地位，也促进了一种有关现代艺术的主 流叙事和话语的形成，虽然直至今天，现代艺术的地位也仍旧没有 能达到吴冠中的期望，那是他在 2010 年去世之前说的，他希望在 中国，现代艺术应与现实主义具有同等地位。

值得一提的是，吴冠中倡导现代艺术与他的一种对社会与文化 问题的关切紧密联系在一起。对于他而言，形式主义和现代艺术意 味着是一种通过解放个性和自我肯定来创造生活的独特方式，就是 说，首先要为艺术而艺术，艺术才能真正为生活。真正的艺术是依 托于具备社会责任感的个人的。吴冠中也总是以他的行动来证明自 己是一位具有强烈社会和政治责任感的艺术家。他绝对不是避世主 义者。2007 年 IO 月, 吴冠中访问中国美术学院，并把他的艺术作 品捐赠给浙江美术馆, 中国美术学院专门组织了一个向他致敬的研 讨会, 我的记忆中 ${ }^{20}$, 他在发言中说, 如果他还能有下辈子的话, 那 么，他就不选择做艺术家了，而要做政治家，用他的话说，I00 个 齐白石也比不过一个鲁迅。他明确表达了自己对于那些沉湎个人的 理想世界而与艰难社会现实保持距离的诗人和艺术家的不满。他不 认同那些仅仅因为文化课成绩不够格而选择艺术作为自己专业的学 生。对当下艺术教育规模扩大，标准降低的现状，他深感忧虑。

关于吴冠中的批判精神，陈丹青评论说，他的行事有点像五四 运动时期的文学青年 ${ }^{21}$, 确实, 在 1980 年代，陈丹青和他们那一代 艺术家最终还是发展了一种不同于吴冠中的现代主义。这些被称为 后文革时代的艺术家，特别是那些新潮美术家，宁可同步借鉴和移 植当时的西方现代和后现代艺术，也不愿意纵向梳理现代艺术的历 史。何多岺和艾轩找到了怀斯，罗中立吸纳了克洛斯的照相写实主 义，陈丹青热衷于米勒、柯罗、库尔贝和伦勃朗，而在决定借鉴和

19 有许多这样的学术项目, 赵无极 1985 年的油画训练班, 是较早的一个 项目。在 1997 年和 2000 年，潘天寿和林风眠百年大展，以及相关的国 际研讨会也分别举办，之后，一系列以 “国美之路” 为主题的展览和项 目持续举行。

20 作者参加了 2007 年 IO 月 26 日晚举行的活动，并作为嘉宾发言。

21 陈丹青: 《回忆吴冠中》, 《中国青年报》, 2010 年 6 月 30 日。 
吸纳哪一个西方现代艺术流派和风格时，他们冊宁是一种实用主义 态度，对此，吴冠中在 1979 年评论说，确实，社会给予了这些年 轻艺术家普遍的赞扬和认可，但是 “这种欢迎和关怀主要是欢迎和 关怀解放思想与打开禁区，不要就认为是作品的成就。说实在的， 其中许多画法是西方在 30 年代早就搞过了的。”22 他希望这些年轻画 家最终能从模仿中走出来，回到人民。

与吴冠中一样，邵大筬在 1983 年的时候，也表达了对这些年轻 艺术家在缺乏西方艺术和艺术史充分知识和理解情况下的移植和借 鉴的担忧。他认为，借鉴和移植相对比较容易，但是，纵向分析和 吸收就会更加困难一些，因为他们必须要选择，寻找到他们自己的 道路, 而不只是被动地追随 ${ }^{23}$ 。1 988 年, 马路在《没有新潮的新潮 美术》中写道，如果依据现代艺术史来判断，新潮美术几乎没有什 么原创性，未来的艺术，在他看来是取决于这些艺术家是否能走出 借鉴和挪用现存的艺术风格和概念，取决于他们能否在把西方现代 艺术联系到中国文化传统方面打开新空间 ${ }^{24}$ 。

概括起来，新潮美术被一些学者和艺术家视为西方现代艺术史 的运动。这种情形倒是让我想起帕诺夫斯基对早期中世纪时代艺术 家的论述，这些人在他们的作品中借用古典形式和观念来表达基督 教内容，这种形式和内容的分离成了中世纪艺术的特点，一直要到 文艺复兴时代才得以克服 ${ }^{25}$ 。但是, 也许就像艾柯所说, 我们这个时 代的文化与中世纪时代非常接近了。“新潮美术” 中的形式与内容 的分离，当然也可以说是它的优势所在。这让我想到了黄永破的作 品，他把 1980 年代由王伯敏撰写的通用教材《中国绘画简史》与 赫伯特. 里德《现代绘画简史》放到一个洗衣机里搅拌两分钟，然 后把已变成纸团的两本书拿出来作为他的作品。也许，只有通过这 样一种人为方式，形式和内容才可能结合为一个整体?

22 吴冠中 : 《我的感想和希望》，《美术》第 I 期, 1980 年 9 月。

23 邵大筬：《西方现代美术思潮》，四川美术出版社，I990，第 I4 页。

24 马路 : 《没有新潮的新潮美术运动》，《中国美术报》第 20 期，1988 年 5 月 16 日。

25 Erwin Panofsky, Renaissance and Renaissances in Western Art (Westview 
黄永破的这件作品自然包含了一种讽刺的意味，批判矛头指向 了所谓的中西艺术完美融合的理想主义。1980 年代早期，几乎没 有什么年轻艺术家有机会到西方国家实地观看原作，更不用提他们 对西方艺术家实际的工作和生活的社会和文化环境有所了解了。他 们主要是通过进口到国内的各种艺术出版物获得西方现代艺术的信 息的 ${ }^{26}$ 。

在巫鸿新近出版的《当代中国艺术》中，1970 年代之后的中国 当代艺术史是被分为了两个阶段，一是从 1970 年代到 1990 年，现 代主义时期; 之后是 1990 年代到当下，属于当代 ${ }^{27}$ 。1 1989 年后，那 种对于现代艺术的六奋和热情有所消退，对社会文化语境的关注明 显超过了对简单移植西方艺术的热情，这种情况特别反映在那些走 出国门，到西方国家学习现代艺术，同时尝试建构自己的艺术生涯 的艺术家那里。这些早期的中国移民艺术家，巨大的震撼或刺激来 自于突然之间转换到一个与他们原本在国内想象的全然不同的西方 艺术世界。

陈丹青用了 “文化错位” ${ }^{28}$ 来描述这种体验。事实上，在他到达 美国后，很快就认识到，让他的绘画在国内取得巨大成功的一切其 实早在 100 年之前的库尔贝和米勒的作品中就已经发展得很好了。 他的结论是，他在国内获得的对西方艺术作品的视觉体验，也还是 一个国内的体验，一旦到了国外，这种体验就会退化或完全丧失掉。 实际情况是, 人们的视觉体验与他们生活于其中的文化语境联系在 一起。对于他而言, 米勒总是呈现为社会主义现实主义艺术的典范, 这种感受在 1983 年他参观了波士顿的一个题为 “米勒：印象派的 先驱” 展览后，就变成了一颗印象派成长的种子。这位在中国的社

26 例如，中国美术学院在当时就非常重视采购进口的各类西方现代艺术书 籍，1979 年和 1986 年，中国美术学院图书馆分别两次全部购买了北京 举办的进口艺术图书特展上的所有书籍，极大地丰富了西方现代艺术和 艺术史的馆藏。

27 Wu Hung, Contemporary Chinese Art: A History (I970s-20oos) (London:

Thames and Hudson, 20I4), I4-I5.

28 参见陈丹青、段炼 : 《视觉经验与艺术观念》, 《美术研究》第 I 期, 1998 年 I 月, 第 49-52 页。 
会主义艺术家就此变成了一位小资产阶级艺术家，相信为艺术而艺 术的信条, 这是时间和空间的双重 “错位” ${ }^{29}$ 。移民艺术家应该承认、 表达乃至依凭这种错位，错位可以成为一种自我发现的方式。当然， 他自己也在美国找到了志同道合者，那就是马克 - 坦西，一位具象 的概念艺术家。

也许，艾未未、徐冰、谷文达和蔡国强要比陈丹青更为典型， 文化和历史的错位被他们当作了艺术创作的资源, 甚至是在欧美国 家获得成功的砝码。事实上，他们进入的这个世界，纽约已取代了 吴冠中时期的巴黎，本身就充满了各种错位，他们在艺术创作中巧 妙运用了这种错位, 由此产生的作品是可以在西方艺术的逻辑结构 中来定义的。因此, 陈丹青的结论是, 他们取得的成功基本上是属 于西方艺术史范畴里的成功, 他们因此也应被定义为是西方的艺术 家 ${ }^{30}$ 。但是, 同样现实的是, 这些艺术家, 至少其中一部分, 实际是 展现了他们与西方艺术世界隐在逻辑进行游戏的能力和智慧, 而不 只是贩卖那种穿着现代或后现代外衣的中国传统文化, 来满足西方 世界对中国的异国情调的想象。对于像艾未未这样的艺术家，现代 艺术史是没有意义的, 那不过就是一些人建构起来的神话, 在他看 来, 历史中的一切都是以零散的或碎片的形式存在, 是瞬间的, 并 没有什么历史延续性或统一性。与吴冠中不同，这些艺术家不喜欢 过多谈论艺术史, 他们关注的是艺术或艺术家在日常生活中的角色。 艺术变成了一种对待生活的态度, 或者是一种持续创新生活方式的 游戏。

约翰·戴维斯在一篇论美国艺术的学术史的文章中指出，““内 容的艺术'，从垃圾箱画派艺术家到社会现实主义，从政治卡通画 家到政府部门赞助的壁画家，这是一条介入生活的艺术的线索，现 代主义是在以关注现代生活的意义上被定义的。这样的艺术在他所 处的时代里是受到 1950 年代的抽象表现主义的挑战的，甚至被后 者所淹没” 31 。与此形成对照的是, 在中国, 社会主义现实主义遮蔽

29 陈丹青, 《纽约琐记》, 广西师范大学出版社, 2007 , 第 I49 页。

30 同上，第 325-30 页。

31 John Davis, "The End of the American Century: Current Scholarship on the Art of the United States," Art Bulletin 3 (Sep. 2003): 568. 
了现代主义和形式主义将近半个世纪，直到 1970 年代晚期和 1980 年代早期，中国和美国才都不得不面对如何重新发现他们自己的被 遮蔽的现代主义的历史，同时，也能不被任何类型的意识形态的迷 宫束缚。我是宁愿关注这些个体艺术家, 尤其是吴冠中及其追随者, 探讨他们是如何在 1970 - 1980 年代在塑造现代艺术和艺术史方面 发挥的主导作用。吴冠中的形式主义及其现代艺术家的谱系是超前 于当时中国的许多艺术批评家和史学家的认知水平的。

当然，吴冠中现代艺术和艺术史的愿景基本是以巴黎为中心的， 是唯美主义的，在这个脉络里，他也确认了美国抽象表现主义的重 要性。但是，在陈丹青和艾未未的思想中，现代艺术，特别是美国 的现代艺术，是应在关乎其文化和社会语境的情况下来进行讨论 的，他们不再把现代艺术作品视为纯粹美学产物。例如，艾未未总 是抱怨近年来中国的许多新建筑属于那种对西方范本的简单的美学 模仿，这是由于建筑师并不了解后者与中国全然不同的社会和文化 场景, 这些模仿完全是表面的, 是没有意义的 ${ }^{32}$ 。事实上, 艾未未总 是表现出他对于历史的强烈反感，在这一点上，他与陈丹青是有点 不同的，他高度评价安迪·沃霍尔，同时也热衷于以游戏的方式拆 解和重构中国的古物。

最后，吴冠中与那些后 “文革” 时期艺术家对现代艺术的态度 和认识的分别, 包括其他的一些争议, 也让我想到美国艺术史学在 很大程度上是被 $1950-1960$ 年代抽象表现主义的形式主义所塑造 的，只是到了 1970 年代，艺术史中社会和文化关照在批评的视野 之下而变得越来越重要。性别、种族和其他政治与经济的问题，拆 解了美国艺术中的那个想象特质，即所谓的 “美国艺术的美国性”。 因此, 我想说的是, 也许, 在中国和美国的现代和后现代艺术之间, 会有比我们之前所想象的更为宽广的共同点，而这会有助于我们探 索交互视野下的中国和美国的现代主义艺术史。 


\section{Rediscovering Modern Art in the 1980s: Diachronic Enquiring and Synchronic Borrowing from Wu Guanzhong to the 1985 New Wave Movement}

Zhang Jian

In 2005, Chen Danqing mentioned in his article that some of the most important early Chinese modern artists, such as Liu Haisu, Yan Wenliang, Lin Fengmian (Fig. I), and Wu Dayu, were living in Shanghai in the I970s. ${ }^{\text {T They }}$ were obviously scared out of their wits by the Cultural Revolution, and had escaped into their homes. According to Wei Jingha's recollections, an oil painter and Wu Dayu's colleague in the Shanghai Oil Painting and Sculpture Institute at the time, he had brought Wu's salary to his home monthly; Wu had not even dared to go out to fetch it, and always let his family member get it through a small window in the front door of the house. ${ }^{2}$ In the early I990s, I had visited Yan Wenliang's house which was an old fashioned two-story building; I have still remembered that there was an old grand piano in the main guest hall, which apparently occupied half of the room.

To Chen and his contemporary young artists, these early Chinese modern artists were strange and, in fact, had rarely been mentioned in the Chinese art world since 1949. Wu Guanzhong had complained that Wu Dayu (Fig. 2) had been living in Shanghai for several decades, but no one had known him there, and it was shameful for us to forget such a great modern artist. ${ }^{3}$

In New China, the style of Socialist Realism for history painting dominated, and with which the young generation of artists like Chen (born in the 1950s) were familiar. In Chen's talk at the China Academy of Art in 2007, he outlined a genealogy of Shanghai oil painters in which the key figure was Yu Yunjie who was the only Shanghai painter participating in the seminar of oil painting hosted by K.M. Maximov, an oil painter from the Soviet Union, and even he had been a student of $\mathrm{Xu}$ Beihong. Chen apparently was proud of his position in this genealogy as a successor, and in 2009, he was invited to work as a voluntary interpreter for a special exhibition of the history paintings with revolutionary

I He outlined a map of fine arts for Shanghai in the I970s as follows:"Liu Haishu's house is in Fuxingzhong Road and Chongqing Road, Yan Wenliang's located at Xinkang Garden in the middle of Huaihai Road, Guan Liang in Yongjia Road, Lin Fengmian at the Yandang Road and Nanchang Road, Wu Dayu in Yananzhong Road and Maoming Road." Chen Danqing, The Sequel for the Collected Writings of Stepping Backwards (Tuibuji xubian) (Guilin: Guanxi Normal University Press, 2007), 44.

2 Ibid.

3 Wu Guanzhong," The Phenomena of Wu Dayu," in The Collected Works of Wu Guanzhong (Jinan: Shandong Fine Arts Publishing House, 20II), 247. 

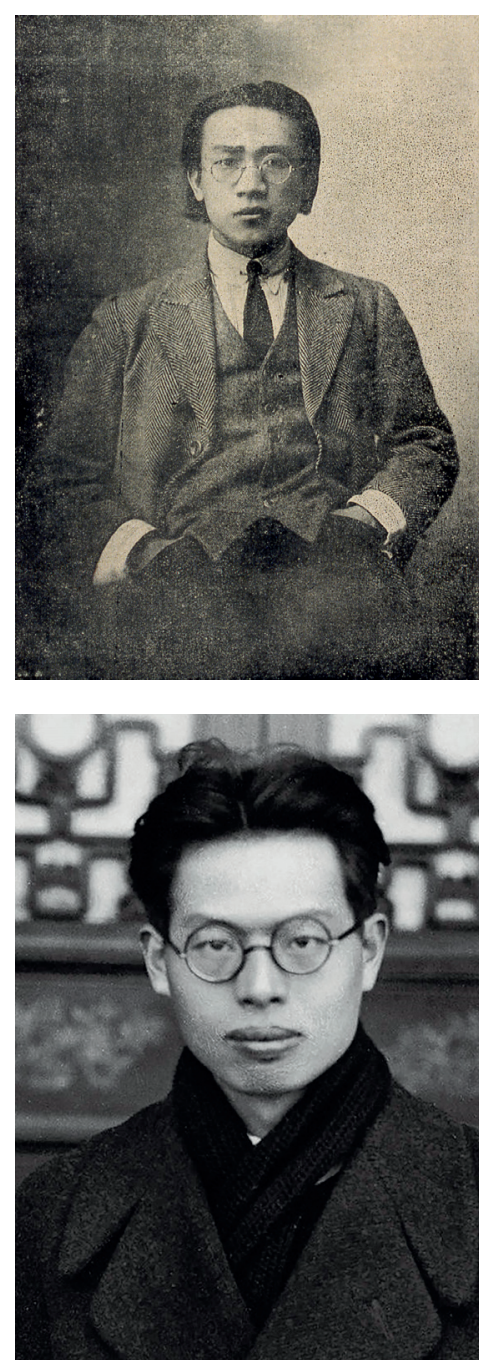

Fig. I. Lin Fengmian (1900-199I). Photograph.

Fig. 2. Wu Dayu (1903-1988). Photograph.

subjects titled "Red Memories" in the Zhejiang Provincial Museum. ${ }^{4}$

The question this essay addresses, then, is: How were Chinese and Western modern art rediscovered and redefined in the late I970s and into the I980s? There are surely many stories: for example, in 1982, Shao Dazheng published a small book on Western modern art, and then The Modern Arts Thought of Westward by him in 1986; A History of Chinese Modern Painting by Zhang Shaoxia and Li Xiaoshan was published; Zhu Boxiong, a professor from the China Academy of Art, published a documentary book on Chinese Western-style paintings; and Lang Shaojun's On Modern Chinese Painting was published in 1988. There are many other books on this subject by art historians and critics, of course; but in this essay, I will show how Wu Guanzhong (Fig. 3) and some young artists from the '85 New Wave Movement played their roles in rediscovering, or redefining modern art and then formulated their ideas on it.

It was Wu Guanzhong's justification for formal beauty and formalism in art during 1979-8I that initiated a rediscovery or reintroduction of the Western and Chinese modern arts (before 1949), of which the situation was just like what Li Zhujin wrote:

The Cultural Revolution ended finally in 1976, and there was a big gap between the domestic intellectual atmosphere and new currents of thoughts on art in European-American countries. Wu Guanzhong was the only artist in China who could be a bridge for common people to cross the gap, so many young artists turned to him and recognized him as the leader of the new art movement then. ${ }^{5}$

4 It was through the introduction by Prof. Lu Peng that Chen Danqing accepted the invitation to give a lecture at the School of Art and Humanities of the CAA in Hangzhou.

5 Li Zhujin, "The Development of Wu Guanzhong's Art and Its Theoretical Foundation," in A Magazine of Chinese Brush Art: A Special Issue for Wu Guanzhong, (Hong Kong: Han Mo Xuan Publishing Co. Ltd., 1992), I03. 
Fig. 3. Wu Guanzhong (1919-20I0). Photograph.

Wu was one of the main followers of Chinese early modernists in the Hangzhou National School of Art, and he had had his art training and education in Hangzhou from 1936 to 1942 , and then in Paris from I947 to I949. Compared with his contemporaries in the I980s in mainland China, he could work as a competent guide to the world of modern art and its aesthetics. During this period, Wu Guanzhong published a series of articles on formal beauty in Journal of Art (Meishu), A Study of Art (Meishuyanjiu), A Study of Art and Literature (Wenyiyanjiu), and stimulated a wide range of discussions on the issue of the relationship

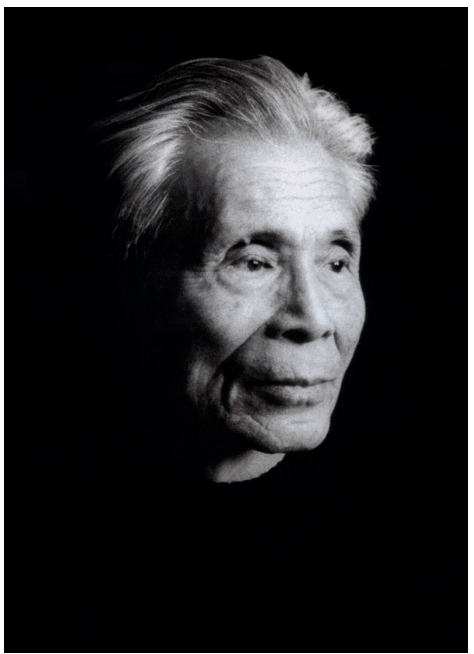
between content and form in artwork that attracted popular participation of art critics, theoreticians, aesthetes as well as artists. ${ }^{6}$ Also important was his enquiry into what the role of art should be played in politics, the question of whether art should be a tool of politics or the reverse, to reaffirm the credo of "art for art's sake." For Wu, the answer was definite: the essence of art was formal beauty; art should be independent of politics.

There was particular political situation by which Wu was inspired and even encouraged to express his personal view on formal beauty frankly, that is, the socalled "Ideological Emancipation Movement" in the late I970s and early I980s in China. One of the significant signs for this liberation of mind in the field of art and literature was the reprint of Chairman Mao's letter to Chen Yi on Chinese classical poetry in People's Daily on December 3ist, 1977. Mao's letter was also reprinted in Art Journal in its first issue of 1978. In Wu's letter to his friend on March 17, 1978, he wrote that reprinting Chairman Mao's letter to Chen Yi showed that the Party had realized ideological emancipation in art and literature should start with recognizing the importance of artistic imagination as basic theoretical issue. He added that formal beauty might be regarded as one of the most important topics in art, which had not happened since 1949, and that if we don't make a research of this issue, our art and literature will continue to be unenlightened and unscientific. ${ }^{7}$

6 These articles include “On Formal Beauty in Painting” (绘画的形式美), Art 5 (1979); “A Memory of Lin Fengmian”（寂寞耕耘六十年, 怀念林风眠老师）, Studies on Art and Literature 8 (1979); “On Impressionism” (印象主义绘画的前 前后后), Studies on Art I2 (1979); “On Botticelli’s Spring” (波提切利的《春》), World Art 7 (1979); “On the Beauty of Abstraction”(关于抽象美), Art Io (I980); “On Studies on the Beauty of Nude in Plastic Arts"(造型艺术离不开对人体美 的研究), Art 4 (1980); “In Memory of the Frescoes by Chavannes” (梦里人间, 忆夏凡纳的壁画), World Art 7 (1980); “Von Gogh”(梵高) Art 3 (1980); “On the Beauty of Oil Painting" (198I).

Wu Guanzhong, "Wu Guanzhong's Letters to Zou Denong, no.26, 19780118," 
Mao's letter to Chen Yi mainly talked about the tonal rules of rhyming for writing traditional Chinese metrical verse, but also emphasized the importance of imagination in poetry; it should be read as an official sign recognizing the legitimacy for an artist to follow artistic laws in his creations. And in Wu's understanding, imagination in visual art means the imagination of form or thinking with pure forms which aims to formal beauty.

Admittedly, Wu's call for formal beauty was not an isolated phenomenon. There were other scholars making similar claims and contributing to this movement for visual enlightenment in the early I980s. ${ }^{8}$ But it also should be acknowledged that there were few of them who had had a similar background of knowledge and insights in modern art and its history with Wu's. In fact, these scholars' main attentions were usually aimed at how to establish varied systems of theory for modern art. In contrast to that, Wu really had formed his own vision of modern art and its history which was the foundation of his aesthetics of formalism. Thus, Wu's formalism worked to bridge not only the gap between China and Western modern art, but also the early Chinese modernism of the I930s and that of the 1980s, of which the roots could be traced back to the National Hangzhou School of Art in the 1930s and the École Nationale Supérieure des Beaux-Arts in Paris in the late I940s.

In Wu's own words, in the I930s, the art school in Hangzhou seemed to be a branch of a French art school. ${ }^{9}$ In fact, there had been an agent sent by the Hangzhou school in Paris who was in charge of purchasing newly published art books in European countries, so the school's library always had kept rich collections of books, magazines and journals on Western modern art, and students were required to learn French, of which the courses were taught by Huang Jixing. ${ }^{10}$ From 1947 to 1949 , Wu studied at the Oil Painting Department of the École Nationale Supérieure des Beaux-Arts in Paris under Prof. J.M. Souverbie. Souverbie encouraged Wu to paint oil paintings in his own way, that is, to discover and express the pure formal beauty of lines and colors abstracted from outer world, and to develop a unique taste for aestheticism.

Concerning that context, it was no accident that Wu had finally became one of the earliest exponents for modern art and aesthetic in China after the Cultural Revolution, and even more, he also played a crucial role in the translation and introduction of Western modern art into China. Indeed, one of the most influ-

Collected Writings of Wu Guanzhong 7: Laoshu Nianlun (Beijing: Tuanjie Publishing House, 2008), I48.

8 The most prominent scholars of so called "aesthetic fervor" in the I980s were $\mathrm{Li}$ Zehou, Zhu Guangqian and Zong Baihua, Li's book $A$ Concise History of Chinese Aesthetic was very popular in the art world then.

9 Wu Guanzhong, "Walking out of the Tower of Ivory: Some Memories on Hangzhou National School of Art," The Collected Works of Wu Guanzhong (Jinan: Shandong Fine Arts Publishing House, 20II), 25.

Io Ding Tianque, "Some memories on Huang Jixing, a professor of French," The Cradle of Arts (Hangzhou: Zhejiang Academy of Fine Arts Press, 1988), 67. 
Fig. 4. The Chinese edition of H.H. Arnason, History of Modern Art, 1986. Tianjing People's Fine Arts Publishing House, Tianjing.

ential books on Western modern art history in China in the 1980 , H.H. Arnason's History of Modern Art: Painting, Sculpture, and Architecture (Fig. 4), of which the translation and publication were closely connected with Wu. ${ }^{\text {II }}$ The main translator of this book, Zou Denong, had first met and known Wu in Qingdao in 1975. At that time, Wu was working on two landscape paintings commissioned by local government to decorate two train carriages exported to an African country in the Qingdao Locomotive and Coach Wagon Factory. Zou had just graduated from the Architecture

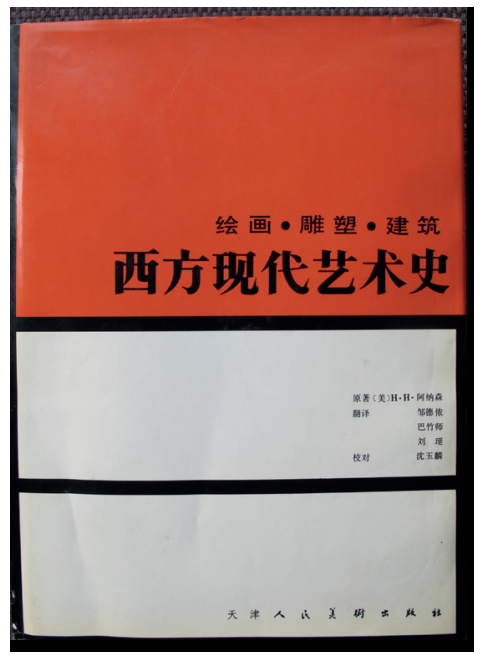
Department of Tianjing University and had worked in this factory then. Zou appeared to be an art lover, and as an architect, he shared his view on formal beauty with Wu.

In a letter to Zou in the December of 1977 , Wu wrote as follows: "If you would become a faculty member in the Architecture Department of Tianjing University, you could devote yourself to studying formal beauty." ${ }^{12}$ Architects always have to solve problems of abstract forms, such as point, line, plane, volume, space, and mass in their daily works, even when such formal abstraction was denied by fine artists. Zou's translation of Arnason's book had been started after 1978, and he had kept close contact with Wu. Wu had helped him in translating some French terms in the book.

The Chinese version of Arnason's book was published in 1986, and Wu wrote a preface for it, saying that this book focuses on formal analysis, its texts are readable, and that will be helpful to common Chinese readers to understand the inner laws of fine arts and contribute to the general education for modern art. ${ }^{13}$ During this period, he himself had written articles introducing Western modern artists, such as Van Gogh, Cézanne, Puvis de Chavannes, Monet, Manet, Toulouse-Lautrec, for art journasl, magazines, and newspapers. ${ }^{14}$ All these artists

II Wu Guanzhong, "Wu Guanzhong's Letters to Zou Denong, no. 25, I9771210," Collected Writings of Wu Guanzhong (Beijing: Tuanjie Publishing House, 2008), I47.

I2 Ibid.

I3 Wu Guanzhong, preface to H.H. Arnason, A History of Modern Art: Painting, Sculpture and Architecture, trans. Zou Denong, Ba Shizhu, and Liu Ting (Tianjing: Tianjing People's Fine Arts Publishing House, 1986).

I4 These articles include "On Impressionism"; "On Botticelli’s Spring"; "In Memory of the Frescoes by Chavannes"; "Von Gogh"; "Landscape painting of Maurice Utrillo” (郁特里罗的风景画), World Art 7 (1982); “On Dear Theo” (读 《亲爱的提奥》), A Study of Art and Literature I2 (1984); “Preface for a Series of Western Post-Modern Art Schools” (没有归宿的过客, 序《西方后现代艺术 


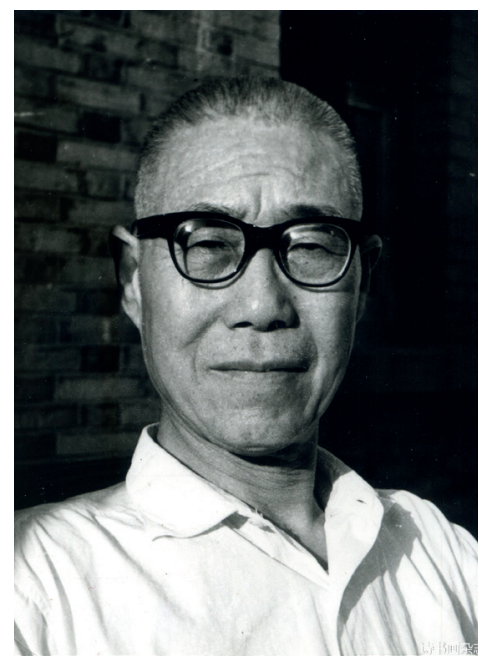

Fig. 5. Pan Tianshou (1897-197I). Photograph.

mentioned above were his favorites and formed his own genealogy of modern art history.

Meanwhile, Wu also devoted himself to reintroducing early Chinese modern artists to the public. $\mathrm{He}$ did not agree with the viewpoints held in the books newly published, including Li Xiaoshan's, simply saying Li's book is "a castle in the air, a theoretical proposition" Is Wu had his own ideas about what the history of Chinese modern art was, together with a genealogy of artists whom he recognized as real forerunners in Chinese modern art, such as Lin Fengmian, Wu Dayu, and Pan Tianshou. In fact, his memoirs on these artists, including some of his classmates in Hangzhou School, such as Zhu Dequn, Zhao Wji and Li Keran, etc., mapped out a formal history of art in Chinese early modernism, with his high valuation of it. ${ }^{16}$ It should be said that at that time, there was no other scholar or artist who had developed such a deep historical insight in early Chinese modern art.

Wu's thoughts on art and aesthetics could be traced back to Cai Yuanbei whose ideas on art and art education were influenced deeply by German aesthetics and philosophy in the eighteenth century, such as Immanuel Kant and Wilhelm von Humboldt, as well as by modern art movements in France and other European countries in the early twentieth century. On the other hand, Wu also had benefited much from the tradition of Shi Tao and Bada's expressionism, of which Pan Tianshou (Fig. 5) was an important successor. In Wu's mind, formalism could bridge Western and Chinese art which had been realized in the artworks by Lin Fengmian, Wu Dayu and other artists from the Hangzhou

流派书系》), Art Observation 8 (200I).

I5 Wu Guanzhong, "Walking out of the Tower of Ivory: Some Memories on Hangzhou National School of Art," The Collected Works of Wu Guanzhong (Jinan: Shandong Fine Arts Publishing House, 201I), 25.

I6 His vision of Chinese early modern art was reflected in a series of his articles such as “A Memory of Lin Fengmian” ( 寂寞耕耘六十年, 怀念林风眠老 师), Studies on Art and Literature 8 (1979). “The Artistic Characteristics of Pan Tianshou’s Painting” (潘天寿绘画的造型特色), New Art 4 (198I); “Seeing the End of Art Road” (望尽天涯路), People's Literature Io, (1982); “Walking out of the Tower of Ivory”; “Visiting Teacher Lin Fengmian” (探望林风眠老师), Wenhui Daily, January 7, 1986; "Memory and Expectation, 65th Anniversary of Attached Middle School of the CAA” (国美附中65周年笔谈) New Art 8, (1994); "Memories of the Hangzhou National School of Art," Art Education Io (1994); “Wu Dayu: A Re-discovered Star “ (吴大羽: 被遗忘、被发现的星), Art Observation 3 (1996); “Stories about Zhu Dequn and Me” (朱德群和我的故事) A Study of Art and Literature 9 (2000). 
school of art, such as Zhao Wuji, Zhudequn, and even Li Zhongsheng who left for Taiwan in 1949 .

In this light, Wu's famous argument, "ink and brush isolated from the pictorial effect of an artwork is zero," should be understood as an attempt to re-invent the conventional stories of Western and Chinese art. ${ }^{17}$ In the former, classicalism had worked as the dominant standard, in which artworks were regarded as the illustration of literature and even political content (socialist realism); in the latter, Chinese traditional art history was reduced into a history of literati painting, of which the formula of ink and brush summarized by "the School of Four Wangs" (Siwang) has been worshiped as the highest norm. But, Wu's vision of formalism in art history could cross the borders of Chinese and Western art, ancient and present, secular and high arts, in Zhang Ting's words, Picasso plus the Chinese temple of the City God (Chenghuanmiao).$^{18}$ In all, the essence of formalism is the belief in art as the visual expression of individual experience and creativity, so that it should be the means to be a liberation of individuality and anticipate a perspective of world art.

Wu's formalism, together with his active promotion of modern art, greatly encouraged the positive reception of modern art, and contributed much to the academic as well as official recognition of modernism, although at that time, he had been criticized bitterly by some high official in the China Artist Association in $1982 .{ }^{19}$ From the 1990 s to the present, to some extent, Wu's active promotion for formal beauty and modern art has been continually initiating varied cultural and academic events, such as exhibitions, symposiums, teaching and research programs, re-confirming the historical status of modern art and formulating an official narrative or discourses on it. Although it has to be admitted that the present status of modern art in China still has not reached Wu's expectation which he addressed before his death in 20Io; that is, modernism should be equal with realism completely.

It is worthwhile to note that Wu's promotion of modern art had been always closely related to his deep social and cultural concerns. To him, formalism and modern art are a unique way of creating life through the liberation of individuality or self-establishment. That is to say that, firstly, while art should be for art's sake, art could be for life. Art appeals to an individual with social responsibility. Wu always demonstrated himself to be an artist with social and political responsibilities; he absolutely was not an escapist. In the October of 2007, when Wu visited the China Academy of Art Hangzhou and donated his artworks to the

17 Wu Guanzhong, "Ink and Brush Isolated from the Pictorial Effect of an Artwork is Zero," in Autobiography of Wu Guanzhong (Wofudanqing) (Beijing: People's Literature Publishing House, 2004), 299.

I8 Wu Guanzhong, "Western or Chinese Style? Some Remarks on the Nationality in Oil Painting," Literature and Art Studies I (January 1980): I3I.

I9 See Wu Guanzhong, "I Shouldering Painting! Painting Shouldering Me!" He mentioned Jiang Feng was against abstract painting, and criticized him many 


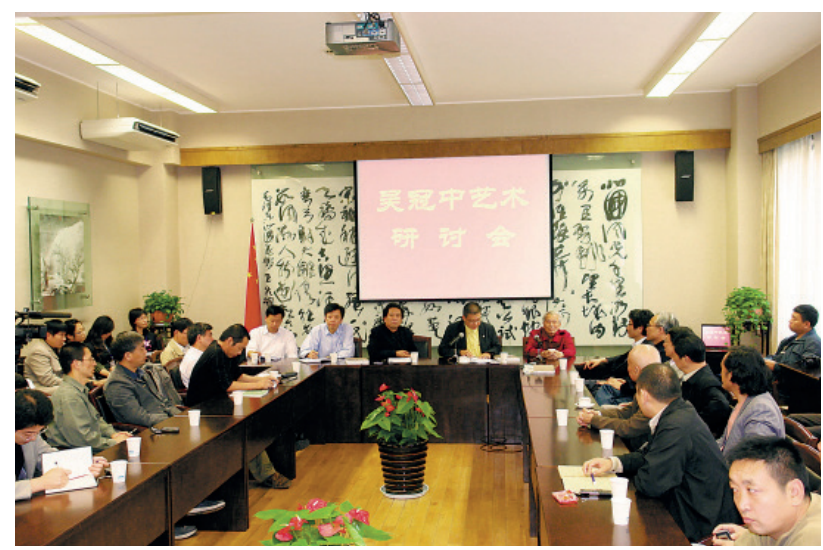

Fig. 6. A Symposium in honor of Wu Guanzhong organized by China Academy of Art in Hangzhou in October 2007. Photograph, China Academy of Art, Hangzhou.

Zhejiang Art Museum, the Academy organized a symposium in his honor (Fig. 6). ${ }^{20}$ As I recall, he said in his lecture that if he would have the next life, he would not chose to be an artist, but would be a politician. In his words, IOo Qi Baishis would not weigh much heavier than Lu Xun. He expressed his personal dislike for those poets and artists who were satisfied to indulge themselves in their idealized worlds and keep distant consciously from tough social reality. He did not think it was wise that those students who chose art as their careers only because they failed to get qualifying grades in the College Entrance Examination. He frankly acknowledged his worry about the present art education with its large scope and low standards.

As for Wu's critical spirit, Chen Danqing commented that Wu's actions were a little like those of literary youngsters from the May 4th Movement in I9I9; indeed, in the 1980 , Chen and his generation of modern artists had finally developed a different kind of modernism from Wu's. ${ }^{21}$ These so-called Post-Cultural Revolution artists, especially ones from '85 New Wave Movement, would rather borrow and transplant synchronically than to enquire diachronically into Western modern art. Now, we can see that He Duoling and Ai Xuan's discovery of Andrew Weyth, Luo Zhongli's adoption of Chuck Close's photorealism, and Chen Danqing's devotion to Millet, Corot, Courbet, and Rembrandt as well as many others, seem to have been pragmatic decisions on their parts to decide which schools or styles from Western modern art history to borrow. Wu Guanzhong had made some comments on this popular attitude in 1979, when he said that there was indeed common praise and recognition to be given to these young artists, but it should be realized that the main point of praise was given to their bravery in breaking through the forbidden realms in the minds of common people, not to their artistic achievements. Honestly, he noted, new styles with which these young painters were experimenting had been invented in the I920s and

20 The symposium was held at the Nanshan campus of CAA Hangzhou in the afternoon of October 26, 2007, in the evening of this day, Wu delivered a lecture toward the Academy's faculty members and students in the theater of CAA, and also as a special invited guest speaker, I gave a talk paying homage to him.

2I Chen Danqing, "A Memory of Wu Guanzhong," China Youth Daily, June 30, 20I0. 
Fig. 7. Huang Yongping, The History of Chinese Painting and the History of Modern Painting (Western) Washed in the Washing Machine for Two Minutes, Installation, 1987. Xiamen, China. Courtesy of the artist.

'3os. ${ }^{22}$ What Wu was waiting for was that these young painters would go out of their borrowings or imitations finally, and then root their artworks in the life of common people.

Like Wu, Shao Dazhen

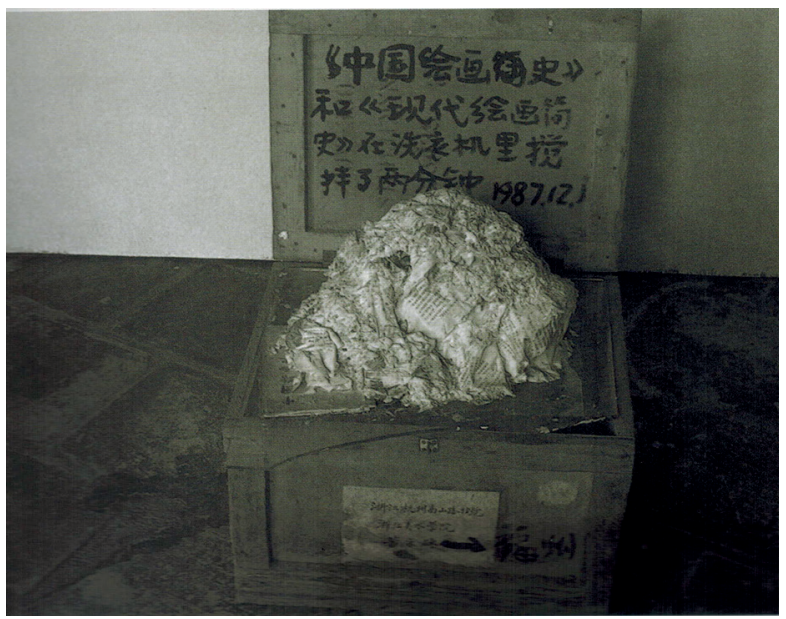
also expressed in 1983 his worries about these young artists' borrowings and transplantings without sufficient knowledge and understanding of Western modern art and art history. ${ }^{23} \mathrm{He}$ believed that borrowing and transplanting were comparatively easy, but diachronic analysis and absorption were much more difficult, because artists have to make choices and find their own ways to go, not just to be passive followers. In I988, Ma Lu wrote in an article "The New Art Wave without Newness" that the artworks of the ' 85 New Wave Movement had no originality, and the future of Chinese modern art would be dependent on whether these artists can get out of the difficult position that was to simply transplant these existing styles and conceptions of modern art, and then open new space and set up a bridge between Western modern art and Chinese traditional culture. ${ }^{24}$

In fact, some scholars and artists were inclined to regard the '85 New Wave Movement as essentially a movement of Western modern art. This special situation has reminded me of Panofsky's description of the artists in the early medieval ages who used borrowed classical forms and concepts in their works with Christian contents. This separating form from content had been characteristic of medieval art, which ended with the rising of the new mode of representation in Italian Renaissance ${ }^{25}$; but, perhaps, just as Umberto Eco said, the culture of our age is very similar to that of the medieval ages, the separation of form and content in the artwork of the '85 New Wave Movement might also have its advantages. For example, in a work by Huang Yongping, the artist put a standard

22 Wu Guanzhong, "My Thoughts and Expectations," Art Magzine I (January I980): 9 .

23 Shao Dazhen, The Modern Arts Thought of Westward (Chengdu: Sichou Fine Arts Publishing House, I990), I4.

$24 \mathrm{Ma} \mathrm{Lu}$, "A New Wave Movement without New Wave," China Art Weekly (Zhongguo meishubao) 20 (May I6, 1988).

25 Erwin Panofsky, Renaissance and Renaissances in Western Art (Stockholm: Almquist and Wiksell, 1960). 
text book, The History of Chinese Painting by Wang Bomin, and Herbert Read's A Concise History of Modern Painting into a washing machine for a two-minute cycle, and then took the paper pulp out as his work (Fig. 7). The question is whether we have to take this artificial or mechanical way to make form and content into a unity.

There was an ironical attitude in Huang's work pointing to popular idealism towards the fusion of Chinese and Western arts as well as cultures existing in Chinese intellectuals and artists. During the early I980s, young artists had few chances to go abroad to see original artworks in Western countries, not to mention to know the social and cultural contexts in which Western artists were actually working and living: they mainly got their information on modern art through varied publications imported into China.

In Wu Hong's newly published book Contemporary Chinese Art, the history of Chinese contemporary art since the I970s is divided into two phases: one from the 1970 s to 1990 which is modernism (a process of visual enlightenment); the other from the I990s to the present, which is contemporary. ${ }^{26}$ After 1989, highly exciting and stimulating atmosphere for modern art receded; concerns for social and cultural contexts of modern art apparently superseded the enthusiasm for transplanting. This happened particularly to those who went abroad to study Western modern art and also tried to establish themselves as artists. To these early Chinese immigrant artists, both a big shock and stimulation came from their sudden switch into an art world which was totally different from the one they had previously imagined in their homeland.

Chen Danqing coined the term "cultural dislocation" or "cultural time lag" ${ }_{27}$ to define this kind of experience, and in fact, after his arrival in the United States, he realized immediately that what made his paintings successful in China had been developed in the works of Courbet and Millet one hundred years ago. He concluded that his personal visual experience of Western art obtained in China mainland was fundamentally a domestic one, which would be lost or deteriorate when he was abroad. The truth is that people's visual experience is closely connected with their cultural context in which they live. To Chen, Millet had always appeared to be a model for Socialist Realism. However, in 1983, after he had seen an exhibition of "Millet: a Forerunner of Impressionism" in Boston, Millet was reduced for him to be a seed of Impressionism: Millet, a socialist artist in China, became a bourgeois artist who believed in the credo of art for art's sake. That is "dislocation," in both temporal and spatial senses. ${ }^{28}$ These immigrant artists in the United States, like Chen, should acknowledge, express, or even rely on this dislocation that would become a way of self-salvaging. Of course, Chen

26 Wu Hung, Contemporary Chinese Art: A History (I970s-2000s) (London: Thames and Hudson, 20I4), I4-I5.

27 See Chen Danqing andDuan Lian, "Visual Experience and the Conception of Art," Art Research I (January 1998): 49-52.

28 Chen Danqing, Random Notes from New York (Guilin: Guangxi Normal University Press, 2007), I49. 
Fig. 8. Wu Guanzhong, Lu Xun's Hometown, 1977. Oil painting. Zhejiang Provincial Art Museum, Hangzhou. Courtesy of the artist.

himself found his American "comrade", that is Mark Tansey, a conceptual artist engaging in figurative painting.

Perhaps, Ai Weiwei, Xu Bing, Gu Wenda, and Cai Guoqiang were much more typical than Chen, since their cultural and historical dislocations were used as the resources for their artworks and even their successes in Western art world. In fact, the world they entered, this time, was New York City instead of Paris, full of dislocations there. They might enjoy playing with these varied dislocations and produced artworks that could be defined

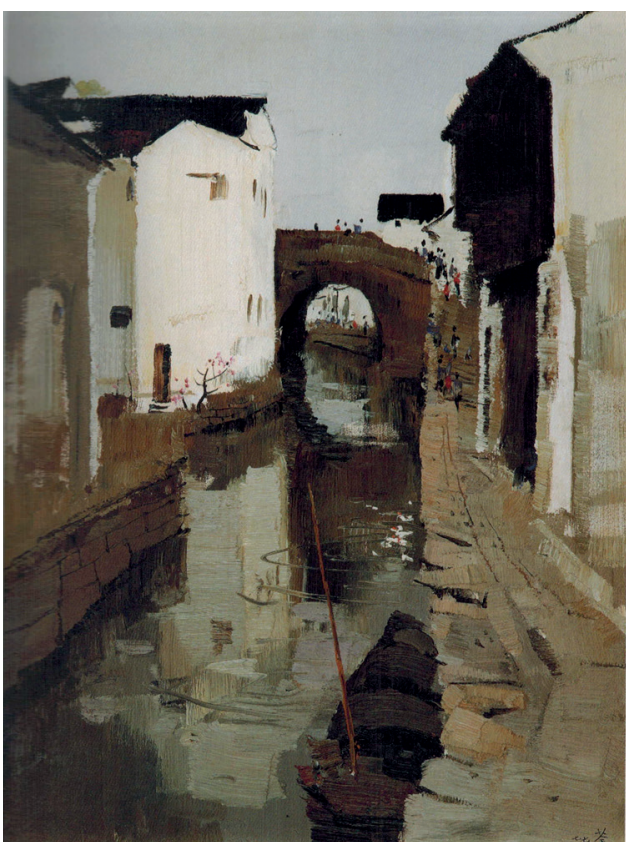
in the context of Western art. So, Chen concluded that, since the successes they achieved fundamentally were in the field of Western art history, they should be categorized as Western artists. ${ }^{29}$ But, it is also true that these artists, at least some of them, actually demonstrated their ability and wits to play games with the Western art world, not just establishing themselves through promoting Chinese traditional culture under modern or post-modern disguise to satisfy the exotic imaginations of Westerners about China. To some radical artists, such as Ai Weiwei, modern art history made no sense, it was absolutely a legend set up by someone else; to him, everything in history existed as fragments or chips, was momentary, with no such things as historical consistence or unity; unlike Wu, these artists would not like to talk much about art history in the sense that Wu had known, what they concerned with was the roles of art and artist in daily life. To them, art became an attitude towards life, or continually invented ways of playing games with life.

John Davis pointed out in an article on the scholarship of American art, that an '“art of content,' from Ashcan artists to Social Realism, from political cartoonists to government-sponsored muralists, runs as a continual strain of engaged art that is modernist primarily in the sense that it concerned itself with modern life." ${ }^{\circ}$ The value of such art was contested in the period when Davis wrote his article, overshadowed by Abstract Expressionism from the 1950s. In contrast, Chinese Socialist Realism had overshadowed modernism and formalism for nearly half a century until the late I970s and the early I980s. Perhaps,

29 Ibid., 325-30.

30 John Davis, "The End of the American Century: Current Scholarship on the Art of the United States," Art Bulletin 3 (September 2003): 568. 
both China and the United States have to face the problem of how to rediscover their own shadowed modern art history, while not being trapped into any kind of ideologically confusing labyrinth. As for me, I would rather call attention to these individual artists, especially Wu Guanzhong and his followers, to explore how they played leading roles in shaping modern art and art history in the late I970s and the early I980s in China (Fig. 8). It is obvious that Wu's formalism with his genealogy of modern artists was ahead of the knowledge of many Chinese art critics and art historians at that time.

Wu's vision of modern art and art history is fundamentally Paris-oriented. In this vein, he would like to recognize the importance of American Abstract Expressionism mainly from his perspective of formalism; but in the case of Chen Danqing and Ai Weiwei, modern art, especially American modernism, should be investigated in reference to their cultural and social contexts. They no longer treated modern artworks as purely aesthetic products. For example, Ai Weiwei always complained that the new buildings established in recent years in China were simply aesthetic imitations of varied Western models. Due to architects' blindness of the latter's totally different social or cultural context, these imitations must be superficial and make no sense. In fact, Ai showed his strong dislike for common history, which was different from Chen: he gave high praise to Andy Warhol, but also indulged in playing with antiquities of China. ${ }^{3 \mathrm{I}}$

Finally, the differences in attitude towards modern art between $\mathrm{Wu}$ and the Post-Cultural Revolution artists, such as Chen Danqing and Ai Weiwei, remind me of the way in which American art historiography has also been shaped by the formalism of Abstract Expressionism. From the mid-I96os, especially in the I970s, social and cultural concerns in art history became more and more important under varied critical perspectives. Gender, racial, and other political and economic issues dismantled the imagined identity of American art, that is the socalled "Americanness" of American art. Thus, what I want to say is that perhaps there would be much wider common ground between Chinese and American modern and post-modern art than we previously imagined, which should contribute to our complementary histories of modernisms between China and the United States.

3I Ai Weiwei, Time and Place (Guilin: Guangxi Normal University Press, 20Io), 208. 


\section{无尽的社会风景}

邵亦杨

\section{另类风景}

2010 年 IO 月，英国伦敦的泰特现代（Tate Modern）艺术馆底层 的浴旋厅铺满了一地 “葵花籽”。这些看上去无比逼真的葵花籽是 手工陶瓷制品，构成了艺术家艾未未的大型装置。在这个由废旧电 力场改建的上千平米的巨大展场上，I 亿颗 “葵花籽” 构成了一种 令人瞩目的另类风景。

伦敦的观众一下子就被眼前这道风景吸引住了，他们在铺满葵 花籽的地上走着、爬着、躺着，就象在海边的沙滩上一样，在身心 放松的过程中感受作品的内涵，这正是艺术家所期望的。可是，三 天以后，展览方阻止了观众走入其中，因为这些陶瓷制品上产生的 灰尘有可能导致肺部疾病。有趣的是，粉尘污染恰好是工业化发展 中重要问题，伦敦在曾经被称为 “雾都”，而北京的环境也越来越 被严重的雾䨪所困。馆方突然提出的限制无意中突显了这件作品所 反映的社会问题。

《葵花籽》这件作品显然与中国独特的历史、文化和政治有关。 中国人对葵花籽有着特别亲切的感受。在日常生活中，葵花子一种 在中国最常见的休闲零食; 在历史上，葵花籽也曾经有重要的政治、 经济意义。在改革开放前，中国经济困难时期，葵花籽曾经是最廉 价的营养补充来源。在政治上、葵花籽和向日葵也有特殊的象征意 义。文化大革命时期，党和毛主席就是太阳，而人民群众必须向日 葵一样面向阳光。《葵花籽》的陶瓷质地陶瓷也很中国化。在英文里, 中国（China）这个词与陶瓷同义。陶瓷这种细淢的材质及其深厚 的人文意蕴本身就包含着中国独特的历史沉淀。在中国最重要陶瓷 重镇 - 江西景德镇，陶瓷工艺上千年历史的制作、生产方式和出口 模式至今仍然存在，在全球化时代，它如何去适应新的经济运作方 式呢?

艾未未的葵花籽个个逼真。这 I 亿多枚真实大小的葵瓜子，由 I600 多名景德镇工匠花费 2 年时间运用传统的工艺技巧手工制作 而成。这样巨型的 “工程” 只可能在人口密集、劳动力低廉的地区 
完成。当观众审视这些精巧的陶瓷制品时，不由得会联想到全球化 时代“中国制造”这种现象。

英国艺术家安东尼·格姆雷 (Antony Gormley) 的作品曾经 涉及过人口资源与地缘经济的问题。他的装置《亚洲之域》(Asian Field，1989-2003）由大约 20 万手掌大小的小泥人构成。 ${ }^{1}$ 这些 小泥人并非出自能工巧匠之手，而是由格姆雷在广东的香山县雇佣 的 350 工人用当地著名的红色黏土制成。尽管做工粗糙，面目不清， 但是它们所排列的 2000 平米的巨大阵势足以令人震㨊。这种密集 型的集体呈现方式令人想起兵马俑、或是全球化的生产模式。然而， 仔细看上去，这些小人并不是整齐划一的形体，它们大小不一，从 8 厘米至 26 厘米参差不齐，没有嘴巴或者四肢，只有眼睛表明了 人的特征。展出时，所有小泥人都面向观众，令人感受到它们的凝 视所带来的震撼。

广东省南部的香山县有着密集的人口，是全球化劳动密集型加 工企业的重镇。一方面，艺术家塑造的这些小泥人反映了集体化生 产模式的总体面貌；另一方面，它也打破了这种集体化体制的一致 性和必然性。这些没有规矩、随意捏成的泥人，改变了黏土注定加 工成砖的工业生产模式, 释放了工人的个性, 强化了他们与土地和 自然的关系, 留下了个体生存的痕迹。格姆雷曾经以《英伦岛之域》 （Field for the British Isles）赢得过 1994 年的特纳奖。《亚洲之域》 延续了他的 “地域 (Field)” 系列主题，探索了人类本土的、个体的 生存方式与全球化经济生产模式之间的冲突。这件 “中国制造” 的 作品更令人联想到以中国为代表的亚洲劳动力市场的巨大力量和未 来难以估价的发展潜力。

尽管在西方人眼中，中国瓷、葵花籽都很有异国情调，然而在 实质上，艾未未的《葵花籽》与格姆雷的作品一样，反映的是当今 全球化、资本化的集体生产模式、人与自然、个体与社会的关系等 具有普遍意义的问题。与他的其它许多作品一样，艾未未作品具有 社会挑眫性，它再次提出了个体在当今社世界、特别是中国的生存

12003 年至 2004 年, 《亚洲之域》曾在广州、上海、重庆和北京展出, 还曾参加 2006 年的悉尼双年展, 参见邵亦杨，“接触的地带还是冲突 的地带? ——悉尼双年展的当代性”, 《美术观察》, 2006 年第 9 期, I2I-25。 
价值问题。在集体化社会中，我们个体的力量可能微弱的、隐形的、 无声的，但是如果凝聚在一起，就有可能成为一道亮眼的社会风景， 一股不容忽视的力量。正如那些小小的葵花籽，看上去渺小、相似 而且脆弱，但是每一个都是独特的，躲在壳子里，无声无息地成长 着，孕育着巨大的潜力，等待自然的开启。

《葵花籽》尽管看似宏大叙事，但是展示的并非集体主义的乌托 邦，相反，是个人主义的反乌托邦的行为，一种挑畔的、制造麻烦 的艺术，它挑战集体主义、专制主义对个性自由的威胁，无论这种 威胁来自于政治上的压抑、还是经济上的压榨。

\section{背后的风景}

$20 I I$ 年，在大英博物馆幽暗的灯光下，观众们被一个高约 6 米的灯 箱展现的美妙图卷所吸引。这就是徐冰的《背后的故事 7 》。在它 的侧面，同时展出的是这幅作品的灵感来源，大英博物馆的藏品 -中国清初山水画大师王时敏作于 1654 年的山水立轴。两幅作品相对, 徐冰以当代创作理念，与 300 多年前的历史经典进行了穿越时空的 对话。

徐冰自 2004 年起就开始创作《背后的故事》系列, 用同样的思路, 他还模仿过龚贤的《山水图》, 元代黄公望的《富春山居图》。透过 灯箱的磨砂玻璃，观众可以隐约看到树木与山石朦胧的轮廓。从正 面看，这是一幅经典的中国传统山水画，风景的灵魂在朦胧的光影 间跳跃。然而，转到作品背后，观众们会惊异发现其中的玄机：原 来如此优美的画面竟然是各种的垃圾废物构成的，其中有刊载威廉 王子大婚的旧报纸，也有从伦敦植物园找来的枯树枝、玉米壳、树 叶和泥土。它们被透明胶带固定在磨砂玻璃背后，在光影下的投射 下，被艺术家编织出美妙的图像，犹如中国传统水墨画在宣纸上晕 染的效果。

在展示方式上，《背后的故事 7 》回应了英国的一对年轻艺术家 提姆 - 诺贝尔（Tim Noble）和苏. 韦伯斯特（Sue Webster）的 著名作品《真正的生活是垃圾》(Real Life Is Rubbish, 1998)。他 们曾用投影机将一堆垃圾废物投射出美化的幺鱼，幽默地挑战观众 的感知，揭示出美与丑、人性的光明与阴影之间的一线之隔。

不同于英国当代艺术家的是, 徐冰的《背后的故事 7 》追溯了中 
国的艺术传统。中国传统文人画, 讲究笔墨趣味, 表现的是远离尘世、 宁静淡泊的意境，与真实的山水隔一层，因此有郑板桥依影画竹的 典故。徐冰曾解释说 “只有中国的绘画可以用这种方法复制。中国 艺术和自然的关系与西方艺术和自然的关系不一样。”2

那些树枝、树叶、棕和莳麻，不仅仅呈现出山、水、亭台、小 桥景物，还代表了晕染、勾勒、皴法等中国画的基本技法，比如 : 直接用寽麻来表现《芥子园画谱》中的榉麻皴。徐冰认为：“这种 材料之间的搭配最后所营造出来的一种节奏、一种章法和一种气势, 实际上和王时敏的笔触的节奏感是一样的。” 3

《背后的故事 7 》模仿的是王时敏 300 多年前的风景画，而王时 敏的这幅画模仿的是 300 年多前黄公望的作品。中国文人水墨画注 重模仿，画家临摹经典作品的过程，也是与前辈、传统进行对话的 过程。作为当代艺术家，徐冰与传统艺术进行了对话，正如王时敏 300 年前所做的一样。在他的作品中, 中国传统绘画的魅力再次迸 发出来，进入到我们的当代视觉经验之中，宛若新生。

中国传统文人画的是隐逸山水，画家为躲避世事烦扰，追求超 凡脱俗的意境。文人画宗师元代黄公望，生前仕途坎坷，做小官时 被诬陷入狱，出狱后看破红尘，入全真教，出家，隐居山林。王时 敏出身世宦之家，人生相对富庶平稳，明末时曾官居太常寺卿，但 身逢乱世的他看淡仕途，于崇祯五年，辞官隐居。明朝被推翻后， 继续归隐山林，潜心习画，专师黄公望。从这两位中国文人画大师 的人生经历，可以看到古代文人在皇权体制下，面对残酷的权力角 逐，被迫疏离社会，寄情于山水之间的无可奈何。但是，他们绘画 作品平淡天真、宁静高远，看不到任何人生境遇的波澜起伏。从黄 公望到王时敏，文人山水画不断师法古人，水墨技法越来越圆熟， 形式语言越来越完美，离现实世界真山真水却越来越远，社会的矛 盾和冲突、生存的挣扎都被掩盖在和谐、精致、程式化的形式之下。

不同于古代水墨大师的是，当代艺术家不再害怕揭露隐藏在完 美背后的真实。徐冰的作品不只制造形式的完美，而且破坏、拆除 这种完美。观众欣赏作品的过程，也是发现真实的过程。他们在美

2 徐冰, “不用笔墨纸砚画山水”, 新浪网, 20 II 年 IO 月 II 日。

3 徐冰, “不用笔墨纸砚画山水”, 新浪网, 201 年 IO 月 II 日。 
好的幻象背后, 最终发现了真实世界的残渣碎片。这件装置在展出 之后会被彻底拆除, 不留痕迹。艺术家甚至把创作的过程记录下来, 与观众分享艺术创作背后的故事，共同揭示幻象背后的真实。

与以往的作品一样，徐冰又一次挑战了观众习以为常的审美心 理。徐冰曾以《天书》（I988）著称，当人们看到上万个手工管刻 印成的精美书法时，没有人想得到那上面每一个精心刻制的楷体字 都是不存在的, 是艺术家发明的假字。它们彻底地挑战了观众的审 美和认知底线。徐冰的《新英文书法》也运用了同样的 “㢮计”。 那些运用中国笔墨写成的字, 表明看上去是标准的书法, 实际上却 是书法风格写成的英文字母。

柏拉图曾经说过：这个世界原本是一个洞穴, 我们所看到的事 物只不过是真实世界的影子。《背后的故事》仿佛营造了一个柏拉 图的洞穴，让观众身处其中，明白自己所看到的不过是真实世界的 影子。艺术形式的完美其实原本就是幻觉, 是艺术家对平淡无奇、 一团乱麻的现实生活的审美提炼。无论对于中国传统艺术再现方式, 还是当代世界的文化政治, 《背后的故事》都是一种反省。它提醒 人们: 事物的真实面目并不总是象看上去的那样美好, 不要被表面 现象所蒙蔽。徘徊于现实的琐碎与艺术的卓越之间, 观众在这件作 品中感受到的是真实的震撼, 同时又再次体会到艺术创造化腐朽为 神奇的力量。

艺术创造如何才能化腐朽为神奇呢? 这种神奇必须是和谐美好的 吗? 如果揭示冲突, 它会引起争议, 招致威胁吗? 《葵花籽》这类 作品容易引发争议, 而《背后的故事》看上去更和谐, 但是这种和 谐并不粉饰现实，反而揭示真实，展示现实中的矛盾和对立，是更 有深度的和谐。这两件作品都涉及传统：政治传统和文化传统，但 是它们并不怀旧, 而是展现当下的生活现实, 全球化时代无限广阔 的社会风景。 


\title{
An Imagined Utopia: Chinese Contemporary Art through the Perspective of Globalization
}

\author{
Shao Yiyang
}

"Utopia" has become a controversial concept, ranging between the belief in an ideal society and the dystopian nightmare of ideology. Contemporary art, as a form of social-critical thinking is often in some ways involved with utopian ideas. This paper aims to provide a historical review of Chinese contemporary art of the past few decades, and investigate how Chinese artists critically reassess this concept by using their artwork to construct and deconstruct political, economic or cultural states of utopia or dystopia.

\section{Dystopia: Art Causing Danger?}

Since 1985, the modern art movement in China has intensified and the Maoist ideological utopia has been deconstructed by many artists.

In the Chinese avant-garde exhibition of 1989 , Xiao Lu shot her own installation with a gun at the National Art Museum of China in Beijing. Although the artist claimed this action was triggered by her personal emotional and psychological experiences, the work entitled Dialogue, ironically, echoed the gunshots that happened later that year at Tiananmen Square. It was a symbolic gesture which revealed the endangered violence with the loss of communication between authority and ordinary people.

In the early 1990s, Fang Lijun's Yawn showed how disappointed the young generation was by the political situation after 1989, when the democratic movement was crushed, and how alienated and cynical they were towards authority (Fig. I).

Wang Guanyi’s Great Criticism: Coca-Cola (1993) is a typical political work of Pop Art. The artist used images from propaganda posters of the Chinese Cultural Revolution and commercial Western advertisements. The criticism seems to be placed on both Maoist ideology and rising consumerism.

Sui Jianguo's sculpture Legacy Mantle (1999) borrowed the imagery of the Mao suit, which is a symbol of the Maoist socialist revolution. However, the work exposes the emptiness of the Maoist utopian promise.

Zhang Xiaogang's oil painting Family Series (1995) also hearkened back to the Chinese revolutionary past (Fig. 2). The group portraits were inspired by real family photos taken during the Cultural Revolution. While the aloof look of the people suggests the ghostly memories of collectivism, the color of their faces seems to be a burning mark inherited from the passion of revolution.

Emerging under a fast-growing market economy, the younger generation of Chinese artists are more critical on globalized industrial production and consumer culture. 
Fig. I. Fang Lijun, Series II, No. 2. Oil on canvas, I992. Ludwig Museum, Cologne. Courtesy of the artist.

Fig. 2. Zhang Xiaogang, Big Family, 2007. Lithograph and screen print. Purchase with funds provided by Nancy Maron, Boulder, $\mathrm{CO}$, and CU Art Museum Benefactors. 2009.02. Photo: Jeff Wells. CU Art Museum, Boulder, Colorado, U.S.A./Art Resource, NY.

Cao Fei's video Whose Utopia? (2006) zooms into the Osram light-bulb factory in southern China, documenting the harsh reality of factory life. ${ }^{\mathrm{I}}$ In an oppressive atmosphere, some ballet-dressed dancers float into the factory. Their glamor is shadowed by the mechanical assembly line. The Surrealist dancers came out of the worker's fantasy world, which is invisible from normal life.

The film exposed the conflict between the individual dream and collective power. Globalized cor-
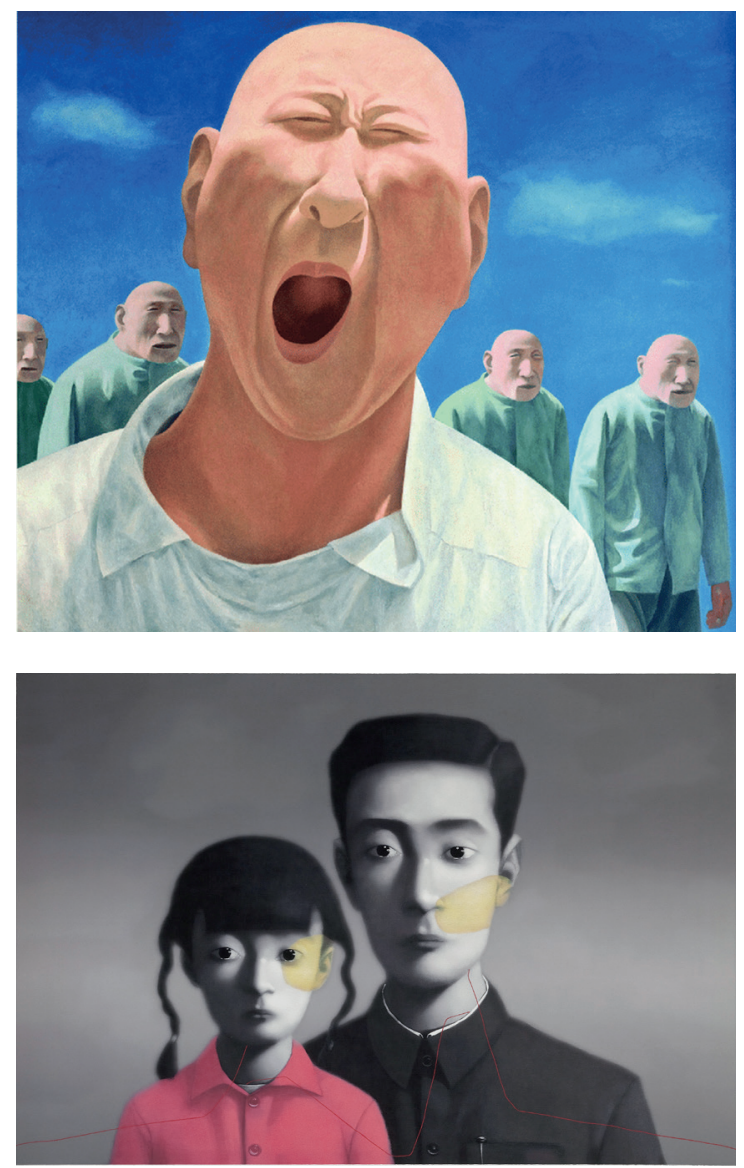
porations set up their economic dream in China based on the inexpensive resources. China's economic miracles also rely on hard-working, cheap labor. The workers, who are building the utopia for both the company and the state, however, find that their personal dream is hardly achievable. The light bulb itself may also have a symbolic meaning; such as the hope for the future and brightness of individuality against the darkness of collectivism.

$\mathrm{Xu}$ Zhen's installation, ShanghART Supermarket reconstructed a typical Chinese convenience store. The store looks fully stocked and functional, selling shiny packaged goods. But, unlike an actual supermarket, each container in

I Cao Fei's video Whose Utopia? (2006) was originally created as a part of the Siemens Art Program "What Are They Doing Here?" It is a project designed for artists to explore the social aspects of the cultural and economic change of the area. Siemens invited Chinese artists to live among the factory workers of their company at different locations in China for six months. Cao Fei volunteered to travel to Foshan, which is located in southern China and has been the heart of the manufactory industry. She stayed at the Osram lighting factory for six months. 


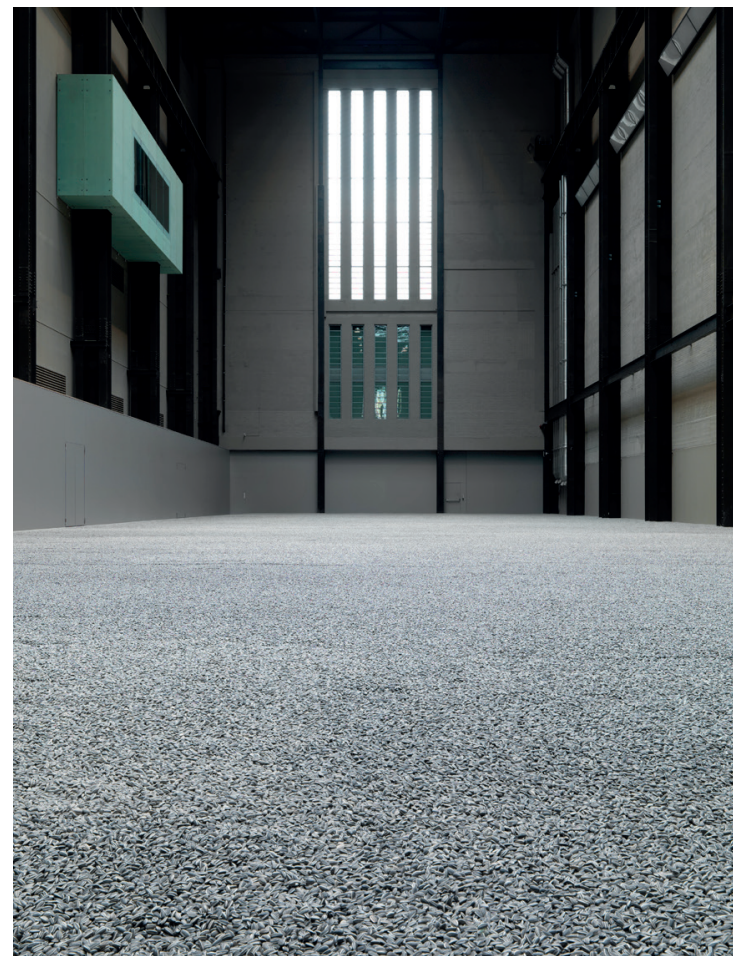

Fig. 3. Ai Weiwei, The Unilever Series: Ai Weiwei. Sunflower Seeds, 2010. Tate Modern. Sculptural installation. Photo (c) Tate. Courtesy of the artist.

this shop is empty. It recalls Guy Debord's critical description of the spectacle as "capital accumulated to the point where it becomes image?"2

The essential part of the installation is the transition from being fully stocked to empty. During the process, the rules of the game for both art and the global market have collapsed. The work reflects on the wider notions of value, and the consumer-driven utopian desire within society. It indicates that consumption is essential but also destroys.

Perhaps the strongest politically-provocative art has been made by Ai Weiwei. In October 20I0, Ai Weiwei's Sunflower Seeds was installed at the Tate Modern in London (Fig. 3). The Ioo million seeds poured onto the gallery floor formed an impressive landscape. The artist encouraged visitors to walk in the work in order to experience it. However, three days later, the Tate Modern stopped visitors from walking on the work due to health concerns over the porcelain dust created by crushing the non-organic "seeds" underfoot. Ironically, the dust problem exactly reflected the heavy environmental pollution caused during fast industrial progress experienced in China.

Sunflower Seeds actually invites the viewer to look more closely at the "Made in China" phenomenon. The image of sunflower seeds had significant meanings in modern Chinese history. During the Cultural Revolution, Chairmen Mao and the Chinese Communist Party were portrayed as the sun, and common people as faithful sunflowers gazing adoringly at the center. Meanwhile, sunflower seeds were also a humble but valued source of food for people to survive during the difficult times, as well as a snack favored by Chinese people to be consumed with friends.

However realistic they may appear, these life-sized sunflower seed were in fact hand-crafted in porcelain, made in the town of Jingdezhen - the major center for the production of fine imperial porcelain for over a thousand years. China is famous for its porcelain and, in Jingdezhen, the artisan's technique, the mode of

2 Guy Debord, The Society of the Spectacle, trans. Donald Nicholson-Smith (New York: Zone Books, 1995), 24. 
Fig. 4. Xu Bing, Background Story 7, 20II. Installation view at "An Installation by Xu Bing: Background Story 7," British Museum, 20II. (C) Xu Bing Studio.

mass production, global export, and the value invested in this cultural artifact still survive today.

To make this work, the artist manipulated traditional production methods. Each seed appeared identical, but was actually unique. It was molded, fired, and painted with three or four individual brush strokes. Sixteen hundred workers were involved in the process. This sort of work can only be achieved by the cheap labor provided by a large population.

British artist Antony Gormley approached the great labor force in a similar manner. In his installation Asian Field, he made about 200,000 hand-sized clay figures with the help of 350 people from a village in southern China.

Like Gormley's work, Ai Weiwei's Sunflower Seeds is not only a comment on China's past politics, but also a comment on today's capitalized collective production model. It is even a commentary on the relationship between man-made products and the natural world, the individual and the masses, and on global society. It continues to pose challenging questions: how could a great population be a potential source of fantastic power but not of difficult problems? What does it mean to be an individual in today's society, powerless and insignificant, or acting together to become just background scenery? Just like sunflower seeds, individual people in a collective society may appear small, identical, and vulnerable. They are all, however, unique, and full of huge potential, straining their shells and waiting for nature to take its course.

In the past decades, many Chinese contemporary artists have made efforts to challenge authoritarian power and expressed utopian ideas on individualism. Sometimes, their works are dangerously political, whether in the face of political censorship or economic repression.

Xu Bing's works always trace back to the Chinese tradition. His Background Story series consists of a dramatic, large-scale shadow and light box, giving the illusion of a traditional Chinese landscape. He has been creating installations for Background Story since 2004.

Background Story 7 was exhibited at the British Museum in London in 20II (Fig. 4). It was made in direct response to a Chinese landscape hanging scroll, dating to 1654 , by a traditional painting master-Wang Shimin. The contemporary and classic works were exhibited together in the British Museum, creating a "dialogue" between the new and past model of artistic creation. Background Story 5847 is nearly 5 meters tall and consists of a light box made with a wooden frame 
and a panel of frosted acrylic. The artist used unexpected and found materials, such as hemp fibers, dry plants, corn husks, and crumpled paper, and attached them to the back of the acrylic. From the front, the work looks like the brush strokes of a Chinese traditional landscape painting. From the back, however, the illusion is shattered by the chaotic scattering of debris. Like many of his other works, Background Story 7 is intended to challenge the way our minds perceive and question our ideas of beauty.

The same trick can also be seen in the large scale New English Calligraphy. The characters are written with ink and brush, looking much like Chinese traditional calligraphy at first glance. Again, they are in fact English letters bent into the Chinese style.

Now, do you still believe in what you first see?

This pathway of thought also could be seen in Background Story series. Standing in front of this project, the viewer occupies a contemporary version of Plato's Cave. Seeing only the front of the work, they would never suspect the chaotic contrast that lies behind it.

In a way, Background Story echoes British artists Tim Noble and Sue Webster's notable pieces made from piles of rubbish and a light projector. Their work also plays with the boundaries between beauty and the shadowy aspects of humanity. Furthermore, Xu Bing's work projects a peculiar Chinese art procedure of imitation with older masterpieces.

For Background Story 7, Xu Bing imitated Wang Shimin's I654 hanging scroll; but this is a painting that Wang Shimin had himself imitated from Huang Gongwang, another old master who lived three hundred years before him. As a contemporary artist, just as the old master Wang Shimin had done over three hundred years ago, $\mathrm{Xu}$ Bing crafted a dialogue between the old master and Chinese art history before him. In his work, the charms of Chinese traditional painting reemerged and were refreshed again to play a part in our contemporary visual experience.

The artist plays other little games with the audience, such as in the choice of hemp fiber as one of the objects used to create his shadow landscape. In traditional Chinese painting, certain brush strokes are referred to as "hemp fiber" strokes because of the texture of the ink when it is applied to the silk canvas.

Unlike Chinese old masters, Xu Bing was not afraid to reveal the ugly truth in reality that lies behind the perfection of representation. The contrast between the shabby reality and the beautiful picture reminds people that art creation always involved a physical and spiritual transformation. In Background Story, Xu Bing does not express nostalgia but exposes the illusion of perfection as messy reality, in art, as well as in life.

Drawing inspiration from the fast-changing reality in China, Xu Bing created his work Phoenix. The installation features two monumental birds: Feng is the male of the pair and the female is Huang. They measure 90 and roo feet, respectively, and are made from materials gathered from the many construction sites which dominate the Chinese landscape, including demolition debris, steel beams, tools, and remnants of the daily lives of migrant laborers. 
In 2008, Xu Bing was asked to design an art piece for a new building in Beijing's central business district. When he entered the construction site, he was struck by the shabby working conditions, cheap material, and primitive technology. The phoenixes are a tribute to the hard work and sacrifices of normal Chinese people, and critical of the fast economic growth dependent on the building industry.

The work was first exhibited outdoors at the Today Art Museum in Beijing, and perhaps the most beautiful display was at the Cathedral of St. John the Divine in New York City. The cathedral's stunning stained glass windows provided the perfect backdrop for Xu Bing's glittering and colorful installation. The phoenixes gained new meanings depending on where they were being displayed. The link with New York, which has one of the largest migrant populations in the United States, and with the United States itself seems obvious. Combining a sense of timeless fantasy with present-day materials, Phoenix adds a unique cultural component to one of New York's most spectacular spiritual venues. Out of the ashes, the phoenix rises, as the old myth goes. The myth of the phoenix casting itself into the flames, only to rise up stronger, is a powerful and monumental one, with reverberations of self-sacrifice, destruction, hope, and regeneration. What Xu Bing's phoenixes make clear is that China's quest for modernization has a price to pay, but a "rebirth" can certainly be expected.

\section{"Travelling to the Wonderland"}

A text used in the Travelling to the Wonderland installation at the Victoria and Albert Museum 2014 is quoted from "The Peach Blossom Spring" (Tao Hua Yuan), a classic Chinese fable written in the fifth century. It describes the moment when a lost fisherman discovers a wonderland hidden behind a mountain, where people, cut off from the outside world, live in harmony with nature and each other. The fisherman is fascinated by his discovery but never finds his way back when he tries to return.

Inspired by the story, Xu Bing transformed the Victoria and Albert Museum's John Madjeski Garden into an idealized landscape. Drawing elements from Chinese landscape scrolls, Xu Bing collected rocks from different places in China and made them into a magical miniature mountainscape. He created a dreamlike atmosphere with mist, light effects, and the sounds of birds and insects. Among them were placed ceramic flowers, animals and houses, each made by hand, and designed to reflect different styles of housing in the different Chinese provinces. From certain angles visitors could see hidden machines and cables. The Travelling to the Wonderland installation was especially magical after dark.

As with many of his other works, Xu Bing once again challenges the viewer to question their first impression. It also reminds us that this wonderland is ultimately un-real, just like Tao Hua Yuan is ultimately fictional. The tale about an inaccessible mountain paradise in Western tradition is called Shangri-La or Arcadia and is normally conceived of during times of imminent threat. Xu Bing's work is a warning about the dysfunctional relationship between man and nature. 
pieces," which showed a remarkable series of Chinese landscape paintings. These landscapes are not of real, but rather imagined, places symbolizing cosmic order. The art on these giant scrolls was not meant to be taken in at once but journeyed through, taken in section by section, each one revealing new landscapes.

Xu Bing used this same strategy in his work. Each of the different rocks used in "the Wonderland" represents a different style in Chinese landscape painting and it takes time to explore the whole filmic effect. The hidden LCD screens suggest that this is not an ancient fantasy but a modern utopia with cable, or perhaps that this Shangri-La is not so far away that we cannot hopefully find it someday. As Xu Bing said, "The way we live now we spend a lot of time looking for a utopia but actually this often lives within us; in our hearts and minds." ${ }^{3}$

Cai Guo-Qiang was well known for both dystopian and utopian thinking. His large- scale installations and explosive events have made him one of the most innovative figures in contemporary art. The Venice's Rent Collection Courtyard (1999), is a good example of his dystopian approach. Cai Guo-Qiang had artisans recreate the famous Socialist Realist propaganda sculpture Rent Collection Courtyard (1963) showing an evil landlord collecting rent from poor peasants, reminding people of the miserable life of the past.

Ironically, this super-realist work, made at the same time as American Pop artist Duane Hanson's Tourists, share a similar style but tell a different story. By recreating the work in Venice, Cai Guo-Qiang deconstructed the ideological message delivered in such a fabricated story, but at the same time it exposed a vivid image for the potential dark side of globalization.

One of Cai Guo-Qiang's most dramatic installations is Head On (2005). It portrays 99 life-sized stuffed wolves barreling into a glass wall. They push on relentlessly, crashing with full force against the transparent barrier. The work was first shown in Berlin, addressing social and political issues imminent to German history.

The wolves in this piece may represent Hitler and his soldiers. Hitler called himself Herr Wolf and referred to his "SS" men as his "pack of wolves." So many people blindly followed Hitler, "the big bad wolf," only to eventually charge into a Wall of Death. The piece was not only related to Berlin but also applied universally to the human condition. A lone wolf is a symbol of bravery and courage; a pack of wolves represents a collective heroism and unity. Cai Guo-Qiang uses animals to represent the human world. It exemplifies the beauty of destruction, heroism, and human blindness which has occurred throughout history.

Cai Guo-Qiang created a utopian vision in Australia in 2013. The work Heritage features 99 replicas of animals around the world, gathered together to drink from a blue lake surrounded by pristine white sand. Here, prey and predator live in harmony together. According to the artist, this installation was inspired by the beauty of Queensland. It seems to him this place could be the last paradise on earth. Both spectacular and meditative, the work presents a beautiful, thought-provoking vision of our relationship with the earth and with each other.

3 See https://www.vam.ac.uk/articles/travelling-to-the-wonderland. 
Although "utopia" as an ideological concept has fallen from grace after a series of misguided attempts to put it into practice in the 20 th century, as a mode of thinking, it can inspire us to take a break from reality and think beyond what already exists. "Utopian" artworks do not necessarily require us to take their ideas literally, but rather to trigger a question like "to what extent could idealized art be supposed to work?" "How far is it from the real world we live in?"

During the major social-economic transformation, many contemporary Chinese artists cautiously or daringly articulated the concept of utopia or dystopia in their specific visions. Some artists like Xiao Lu and Ai Weiwei took a provocative position; while others, like Xu Bing and Cai Guo-Qiang sometimes created harmony. With all the conflicts and problems in the world, it may be easy to dismiss harmonious images as an unattainable Shangri-La, but the beauty of those works and the utopian dream itself has made us hopeful for the future of humankind, raising our optimism to face the obstacles posed by the environment and society. 


\section{对中国概念艺术的几点认识 \\ 朱青生}

I980 年代，中国现代主义艺术再次起步，大量的新艺术术语从欧 美国家引进中国，用以描述新出现的艺术现象。随着中国的发展， 这些术语的意义也逐渐发生变化，有的被改造，有的被赋予新的意 义，有的甚至被误解，这一现象，十分值得研究。本文将选取这些 术语中的一个名词一 “观念艺术” (conceptual art) 展开讨论。

首先，有必要对观念艺术进行明晰的区分，将其划分为两种： 第一种是在艺术创作中注重观念，不以形式和美感作为它的诉求 ; 其二是用语言文字创作的艺术品，作品本身看上去像一个概念。这 两种观念艺术关联甚密，但差异尤存。鉴于这种差异，也是出于讨 论的需要，在本文中，我们将第一种定义为 “观念艺术”，第二种 定义为 “概念艺术”。

I969 年，约瑟夫 · 孔苏思 (Joseph Kosuth) 在其著名评论《哲学 之后的艺术》(Art after Philosophy) 写道: “一切（杜尚之后的） 艺术 (本质上) 都是观念的, 因为艺术只在观念中存在了。” 在这里, 观念艺术的两层意思重叠在一起, 基本上构成了艺术史的一次转折, 这个转折的标志正是杜尚的《泉》（Fountain, I9I7）（图 I），或者 更进一步，可以上溯到苏黎世的达达主义运动。

依照孔苏思的定义，中国目前所谓的当代艺术，都可以视为观 念艺术。在 80 年代中期，我们还会讨论吴冠中和表现主义，讨论 油画问题，但现在已经没有这个余地，目前所有正在进行的 “当代 艺术”，都不以形式美感和传统品位为作品的判断根据，而是看它 有没有想法，有没有观念。

2015 年开幕的 “中国当代艺术年鉴展 2014 ” 上的许多作品都能 反映这个现象。比如苏新平《八个东西-II 号》（图 2)，作品内容 是一幅画，同时展出的还有他画这张画所使用过的擦笔纸，这看上 去是一件墙上作品，但早已超出了架上绘画的范畴。姜杰的装置作 品《大于一吨半》(图 3), 主体是一个大型雕塑, 放置在整个房间里, 雕塑本身看上去像人体的器官，事实上是由普通的布料构成的，通 过特殊的技术悬挂起来。这件作品杂糅了很多生动的批判性的意味, 
包括女性主义对男性的抗议、对社会现状的关注和批判等等。在李 建华的作品《方》中，陶瓷被塑造成一滴水在钢板上的样子，水滴 上镀金，将水滴的豪华、奢侈和脆弱呈现出来，社会性也酝酿其中。 宋永平《金钱》（Karl Marx with dollar）（图 4）是一件装置作品, 内容是用大号的美元模型铺满整个展厅，每一张美元都是经过特殊 设计的, 其中, 把华盛顿置换成马克思的一张, 被高调地贴在了展 墙上，这其中的讽刺意味不言而喻。尚阳的《剩山图 -6》看上去是 一幅绘画，其实远非这么简单。作品表面使用的材料并不是普通颜 料, 而是一些工业废料。这些废料是农民工遗留在建筑工程中的残 迹一他们劳作、建造, 但完工之后再也没有权利踏入他们曾经工作 过的地方, 只留下少许的工业废料。因此, 这幅作品看起来是一幅画, 实际上是一件观念艺术。周洁是一位年轻的女艺术家, 在她的作品 《36 天》中, 艺术家赤裸身体, 躺在缠满铁丝、尖刺外露的床上, 持续 36 天。这是一个具有极强刺激性的行为艺术。

中国当代艺术的能量相当惊人, 仅仅是 2015 年度就有 3590 个 展览。一年 365 天只有 $\mathrm{I}$ 月 $4 、 2 \mathrm{I}$ 日，2 月9、16-25日，4 月 6 日， 5 月 28 日，6月 I5、I7、30日（共 I8 天）没有展览。展览最多的 是 3 月 $2 \mathrm{I}$ 日, 共有 6I 个展览开幕。这些数据是以 “无功利的纪实 档案” 的方式记录的，并努力达到 “全体生态档案” 的效果。

1986 年，85 美术运动的参加者与吴冠中发生了观念上的冲突, 吴认为艺术要 “美”，而我们认为 “美” 不如 “意义” 重要。在一 次会议中，吴冠中说，观念艺术作品都是 “洋垃圾”，我立即站起 来反驳: “您的表面优美的绘画已经成为艺术垃圾。” 这就造成他一 直宣称 80 年代 “老的也反对我，小的也反对我” 的情形。也正是 在这一年, 我们的行为艺术 《大地震》、徐冰《天书》以及中国第 一次公开的行为艺术 《观念 $2 \mathrm{I}$ 》相继发生。

孔苏思的定义遗留下来的三个问题在中国受到追问和质疑。

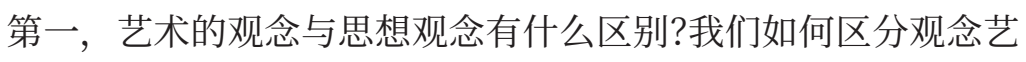
术所传达的 “观念” 与文字所传达的 “观念” ?它们之间有什么界 限和区别? 如果仅仅只将观念艺术看成是用图像和物体的形象材料 来表达一种思想和观念, 那么, 这种表达可能是粗浅的, 也因为粗 浅而变得模糊，因为模糊而变得有意味而深刻。但是其与用观念的 语言直接表达的观念之间又有哪些必要存在的意义? 抑即只有用图 
像和物体才能获得表达，而用语言则不能够获得表达，只有证明了 这一点，我们才能做出以上的区分。

第二，观念艺术的艺术传达观念，其意义是否应该是明确和清 晰的?意思如果明确的，具有针对性和逻辑因果关系，其与语言传 达信息的另外作用何在。尤其是在图像时代，今天的大多数信息和 知识，是通过照片、电视、影片和图解来进行说明的时候，观念艺 术又有什么独特存在的价值?如果不明确，观念表达的意思何在?

第三，观念艺术作为视觉艺术（作为在空间中被展示的作品） 与创作的艺术的界限和性质差异何在?其中这样的艺术与虚拟的文学 “艺术”，以小说和诗歌为主导的区别何在?与纪实或评论文字之间 观念性更强的文字创造的差别何在?

这些问题涉及了艺术与哲学的基本区别问题，也涉及了在艺术 中，作为文字的艺术和作为形象的艺术之间的根本区别何在。特别 是涉及第二种概念艺术，即直接使用语言、词句和文字符号创作的 “艺术品”，问题变得更为迫切。

而这个方向恰是孔苏思 1962 的《椅子》开辟出来的新方向。由 于中国有书法和画上题字的艺术传统，再加上文字本身保持着图画 性, 所以, 对于这个问题, 我们就有必要继续追问。孔苏思的《椅子》 总共包含三个内容: 真实的椅子、椅子的图像以及关于椅子的文字。 在这件作品中，文字是必不可少的，如果缺失了这段文字，这件作 品便不可能成立。那么, 这个文字究竟蕴含怎样的意义? 是文字本 身的内涵, 还是观念艺术中的某一种观念?这些文字在整个环境之 中如何发挥作用，又如何避免邽落和滑落为其它的部分? 只有理清 了观念艺术的概念，我们才能将观念艺术与符号、标语以及美学意 义上的文字区分开来，尤其是中国的传统书写艺术一书法。

必须要指出的是，概念艺术仍然是视觉艺术，应当被观看，而 不是被阅读。文字作为观念艺术的形式诚然可以被阅读，但只能作 为观看的辅助形式，在艺术语境中，没有观看的阅读是没有意义的。 因此诗歌、符号、书法都不是概念艺术。

马格利特的《这不是一个烟斗》是概念艺术的典型例子。烟斗 的图像，和 “这不是一个烟斗” 的文字，都是作品不可或缺的成分， 因为这不是一件绘画作品，更不是一件文字作品，而是观念艺术， 图像与文字共同构成了艺术作品的意义。概念艺术应当是一个悖论, 
马格利特的作品就是悖论，但正是这悖论将图像与文字相连，它的 意义无法在解读的过程中被理解。当观看成为理解的障碍之时, 文 字也就变成了概念艺术。概念艺术不是概念，而是概念的表达。

而另一方面，观念艺术并不会因为意义的破解而消逝。因此， 这是一个悖论，也就是说，意义只有在特定的场合特定的时间才能 得到认可, 否则, 意义也随之丧失。比如, 如果孔苏思作品中物体 椅子和图像椅子都不存在, 文字椅子则只得沦为说明的信息, 这件 作品的意义不可能脱离前两种椅子的形态而存在。

为了讨论何为概念艺术，我曾做过一个实验。1993 年，一场关 于中国前卫艺术的展览在柏林的德国文化博物馆（Haus der Welt Kulturen）举行。我由于同时受到美国观念艺术和中国特殊的观念 艺术传统的影响, 不由得想要探索观念艺术的内涵。因此我制作了 一块牌子，上面写着 “这个展览中所有作品都不是朱青生的”，委 托参展的另一位艺术家吴山专递交给策展人汉斯 - 凡 - 戴杰 (Hans van Dije）。这时展方将面对一个悖论 : 如果不予以展出, 他们就 剽窃了我的作品, 因为他们使展览中没有朱青生作品这一概念已经 形成，作品的目的已经达到; 若展出了这件作品，则同时破坏了它， 因为一旦出展, 需要表达的概念也会随之消亡。最终展委会决定, 这件作品一定要被展出，但不可进入展览厅，只能放置在展览之外。 于是，这一悖论会始终缠绕其中。

我做的这个实验的目的, 是要把概念艺术中最为极端的问题揭 露出来, 把它放在真实的场合中进行尝试, 来讨论概念艺术是否可 以成为一种艺术。通过这次实验，以及后续的对概念艺术的观察， 我们发现，概念艺术必需满足三个条件 :

首先，概念艺术虽然是一些文字，但这些文字是被看的，有被 观看的形式感。

其次，概念艺术的文字并不是可以被阅读替代的概念，它必须 与它所处的情景构成不可取消的关系, 如果作品脱离了它所处的特 殊地点和特殊关系（不仅指语境，而且指它所处空间位置的关系和 面对它的人之间的关系), 就无法成立（这就是说概念艺术是不能 通过转换空间和形式就能被媒体传播的)。

最后, 概念艺术中的概念应该是一个悖论, 它才能够消除对它 的理解和追随, 它不是一个标语或一个概念的传播, 它在语言上必 
须构成消减逻辑的悖论关系, 也就是说它是不能理解的, 一旦能被 理解, 就是一个无意义的形式框架。它应该是一种搅动人的感觉、 激发人的创造性的遭遇。而这种遭遇是每一个人在面对它时所得到 的 “感受”，每人每次遭遇都会有所不同的感悟。 


\section{Some Remarks on Conceptual Art in China}

\section{Zhu Qingsheng}

In the 1980s, Chinese modernist art began the re-emerge, and many new art terms from Europe and the United States entered China to describe these new artistic phenomena. As China developed, the meanings of these terms also gradually changed. Some were altered, some were given new meaning, and some were even misunderstood. This phenomenon deserves to be studied. This article will select one name from among these terms- "conceptual art" as the starting point for our discussion.

First, we must clearly define conceptual art. We can divide it into two types: the first emphasizes concepts during artistic creation instead of pursuing form and beauty; the second uses language and writing to create artworks, so that the work itself looks like a concept. These two kinds of conceptual art are closely related yet contain important differences. Given these differences, and the needs of this discussion, in this paper we will call the first one "idea-based art" (guannian yishu) and the second "conceptual art" (gainian yishu).

In 1969, Joseph Kosuth wrote in his seminal text Art after Philosophy: "All art (after Duchamp) is conceptual (in nature), because art only exists conceptually." Here, the two meanings of conceptual art overlap with one another to fundamentally create a turning point in art history. The symbol of this turning point is Duchamp's Fountain (1917). Or we could take it a step further and trace it back to the Dada movement in Zurich.

According to Kosuth's definition, all of China's contemporary art can be considered conceptual, idea-based art. In the mid-r980s, we were still discussing the early-2oth-century modernist painter Wu Guanzhong, expressionism, and issues of oil painting, but now there is no room for that kind of talk. These days, all the "contemporary art" that is being made rejects formal aesthetics and traditional taste as a basis for judgement, and instead looks at whether or not it has an idea, whether or not there is a concept.

Many works from the Annual Exhibition of Contemporary Art of China 20I4, which opened in 2015, reflected this phenomenon. For example, in Su Xinping's No. II (Series: Eight Things) (Fig. I), the work consists of a painting, but it was exhibited with the paper that Su used to clean his brush while painting this painting. This work looked like a mural, and had far exceeded the scope of a painting in a frame. Jiang Jie's installation More than One and a HalfTons (Fig. 2) is a large-scale sculpture that takes up an entire room. The sculpture itself looks like a human organ, though it is actually composed of ordinary fabrics suspended by a special technique. This work combined a number of lively and critical implications, including feminism's opposition to masculinity, and attention to

I Joseph Kosuth, “Art after Philosophy," Studio International 178, no. 915 (October 1969): 135 . 


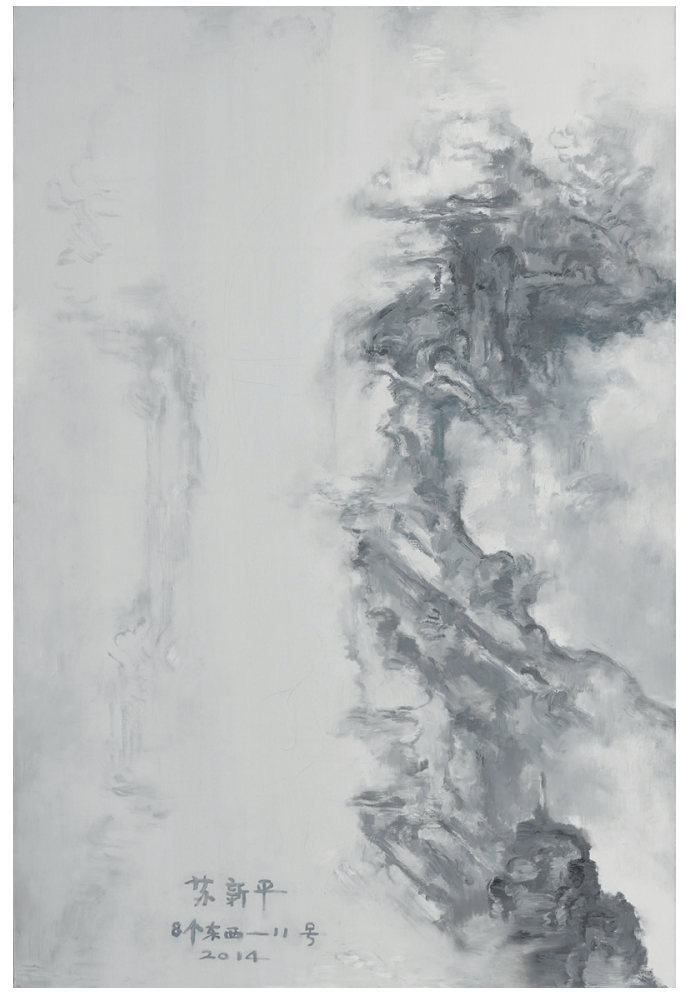

Fig. I. Su Xinping, No. II (from the Series: Eight

Things), 20I5. Courtesy Today Art Museum, Beijing, and the artist.

and criticism of social conditions. In Liu Jianhua’s Square, ceramic forms are shaped to look like drops of water on a steel plate. These water droplets are covered in gold leaf, revealing the luxuriousness, extravagance, and fragility of water droplets, while also brewing sociality. Song Yongping's Karl Marx on a Dollar (Fig. 3) is a work of installation art that uses large US dollars to wallpaper an entire exhibition hall. Each dollar was specifically designed, including one on which George Washington was replaced by a picture of Karl Marx, which was prominently displayed on the wall of the exhibition. The irony of this work speaks for itself. Shang Yang's Mountain looks like a painting, but in reality it's not that simple. The materials used on the surface of the work are not ordinary paints but rather industrial detritus. These are the traces left by migrant workers at their construction sitethey work, they build, but after they are finished, they no longer have any right to step into the places where they used work. All that's left is a small amount of industrial detritus. Therefore, while this work looks like a painting, it is actually a work of conceptual art. In Zhou Jie's work 36 Days, the artist lies naked on a bed filled with tangled iron wires and exposed spikes and endures for 36 days. This is a very provocative piece of performance art.

The amount of energy behind Chinese contemporary art surprises people. In 2015 alone there were 3,590 exhibitions. In the entire year there were only i8 days without exhibitions: January 4, 21; February 9, I6-25; April 6; May 28; and June I5, I7, and 30. March 2I had the most exhibitions, with a total of 6I exhibitions open. These data are recorded in the form of "non-profit documentary files" and strive to achieve the effect of "all-environmental archive."

In 1986, the participants of the ' 85 New Wave art movement participants had a conceptual conflict with Wu Guanzhong. Wu believed that art should be "beautiful," while we believed that "beauty" was not as important as "meaning." At one conference, Wu Guanzhong said that all conceptual art was "foreign garbage." I immediately stood up and rebutted: "Respectfully, your superficially beautiful paintings have already become art garbage." This led him to claim that in the '8os, "The old were against me, and the young were also against 
Fig. 2. Jiang Jie, More than One and a Half Tons, 20I4. Courtesy Sichang Art Museum, Beijing, and the artist.

Fig. 3. Song Yongping, Money Hostage: Karl Marx on a Dollar, 20I8. (C) WhiteBox, New York and Song Yongping.

me." ${ }^{2}$ That was also the year of our performance piece The Great Earthquake, Xu Bing's Book from the Sky, and China's first public work performance art Concept 2I-Art before Your Eyes.

The three questions defined by Kosuth's legacy continue to be pondered and pursued in China.

First, what is the difference
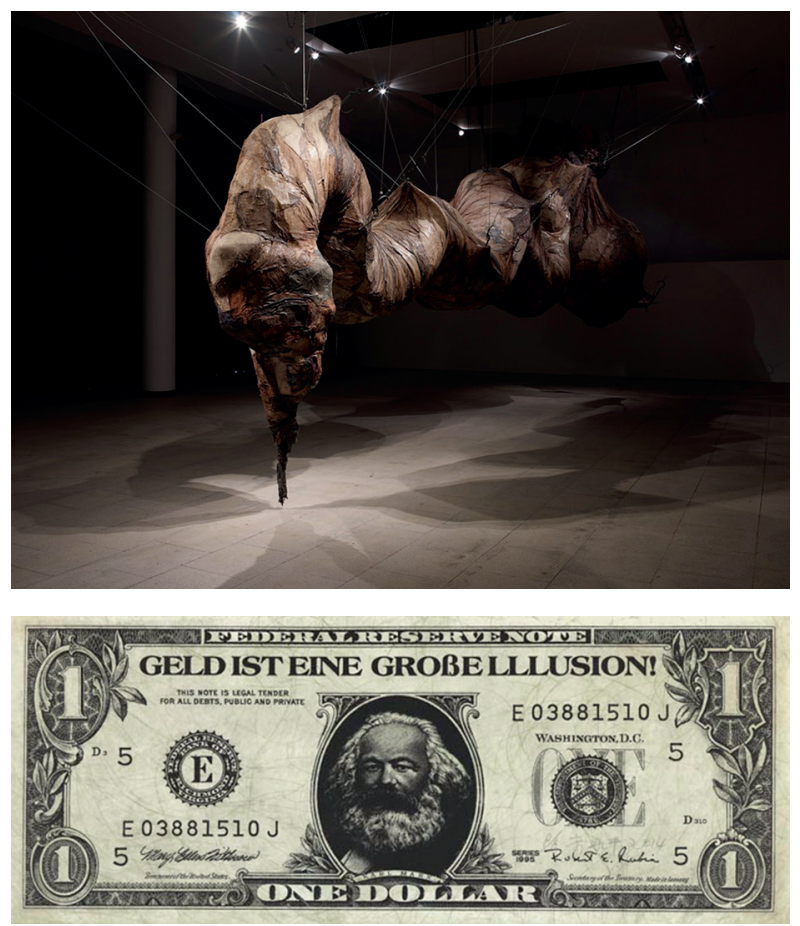
between concepts in art and concepts in thought? How do we make a distinction between "concepts" expressed through conceptual art and "concepts" expressed through written language? Where is the boundary between them and what are the differences? If we see conceptual art exclusively as art that uses images and material objects to express a certain kind of idea or concept, then it is possible that the expression is shallow or superficial. And because it is superficial, it becomes unclear. And because it is unclear, it becomes meaningful and profound. But is there any essential existential meaning in between this and concepts that are directly expressed through conceptual language? That is, only by using images on material objects can one achieve expression; language alone is not sufficient. Only after we've proven this point can we make the above distinction.

Second, when it comes to conceptual art, should the concepts that art conveys be clear and distinct? If its meaning is clear, with focus and a logical cause and effect, then how is that effectively different from using language to convey information? Especially in today's era of images, when the vast majority of information and knowledge is communicated through photography, television, film,

2 Editor's note: Wu Guanzhong is referring here to how in the pre-reform era, "formal beauty" was persecuted by the older generation for being too bourgeois and not political enough in content, while after the art movements of the I980s, formal beauty was criticized by the younger generation for being too conventional. 
and graphic design, what special intrinsic value does conceptual art offer? And if it's not clear, then what is the meaning of conceptual expression?

Third, where is the boundary and what is the categorical difference between conceptual art as a visual art (as work that can be exhibited in space) and the creative arts? What is the distinction between such art and the intangible literary "arts," led by novels and poetry? How is conceptual art different from literary works such expository or argumentative writing, which are even more conceptual?

These questions touch on the issue of the fundamental difference between art and philosophy, as well as the fundamental difference between art that uses language and art that uses images. They are especially relevant and urgent when considering the second type of conceptual art, which directly uses language, words, and symbols to create "artworks."

This line of questioning is precisely that which Kosuth's One and Three Chairs opened in 1962. And since China has the artistic traditions of calligraphy and painting inscriptions, combined with the pictographic nature of Chinese characters, so we must continue to pursue these questions. Kosuth's One and Three Chairs contains a total of three elements: a real chair, an image of a chair, and some text about a chair. In this work the text is indispensable-if the text were missing then the piece would not work. But exactly what kind of meaning does this text contain? Is it the meaning of the text itself, or is it some sort of concept within conceptual art? How does this text work within its context? And how does it avoid falling or slipping into other categories? Only by clarifying the idea of conceptual art we can differentiate between conceptual art and symbols, slogans, and aesthetically meaningful texts, and especially the traditional Chinese art of writing — calligraphy.

It must be pointed out that conceptual art is still visual art and should be seen, not read. Of course, words within conceptual art can be read, but reading can only operate as a supplementary form of looking. In artistic terms, if there is nothing to look at, then reading is pointless. Therefore, poetry, symbols, and calligraphy are all not conceptual art.

Rene Magritte's This Is Not a Pipe (The Treachery of Images) is a classic example of conceptual art. The image of a pipe and the words "This is not a pipe" are both essential components of the work. Because it isn't a painting or a work of literature, but rather a work of conceptual art, image and text together create the work's meaning. Conceptual art should be a paradox. Magritte's work is a paradox, but it is this paradox that connects images and words, and its meaning cannot be understood just by the process of reading. When looking at it becomes an obstacle to understanding, then text turns into conceptual art. Conceptual art is not a concept, but the expression of a concept.

On the other hand, conceptual art doesn't fade away after its meaning has been cracked. Therefore, this is a paradox, which is to say, its meaning can only be confirmed within a particular time and context; otherwise its meaning will be lost. For example, if Kosuth's work did not have the material chair and the pictorial chair, then the textual chair only succeeds in offering information. The meaning of the work cannot exist in the absence of the other two forms of chairs. 
In order to discuss what is conceptual art, I conducted an experiment. In 1993, an exhibition of Chinese avant-garde art took place in Berlin's Haus der Kulturen der Welt. Because I was simultaneously influenced by American conceptual art and China's unique conceptual art tradition, I could not help but explore the meaning of conceptual art. So I made a plaque that said: "The works in this exhibition are not Zhu Qingsheng's," and asked another exhibiting artist, Wu Shan, to deliver it to the curator Hans van Dije. At this point the exhibitors faced a paradox: if they did not agree to display it, they would have plagiarized my work.

My purpose for doing this experiment was to expose the most extreme questions in conceptual art and test them out in a real world situation, in order to discuss whether or not conceptual art can considered a type of art. Through this experiment, and subsequent observations of conceptual art, we found that conceptual art must meet three conditions:

First, although conceptual art is a bunch of words, these words are visual, they are looked at from a formal sense.

Second, the text in concept art is not an idea that can be replaced by reading. It must form an inseparable relationship with the situation in which it is located. If a work is detached from its unique place and relationships (this isn't limited to its context, but also includes its relation to its spatial position and the relationship between the people in the audience), then it is untenable (that is to say, one cannot change the space and form of conceptual art and broadcast it via media).

Finally, conceptual art ought to be a paradox, because only then can it shake off those who try to comprehend or follow it. It is not a slogan or the transmission of a concept. Its language must create a paradoxical relationship that defies logic and cannot be comprehended. Once it is comprehensible, it is a meaningless formal framework. It should be creative encounter that provokes people's feelings and inspires their creativity. And this kind of encounter is every individual's "feeling" while looking at it, every person and every encounter will result in a different feeling. 


\section{替罪的肉身一中国行为艺术的意义 \\ 王端廷}

行为艺术 (Action art) 是艺术家直接以自己的身体为媒介，在特 定的空间场所通过表情、姿态、动作和过程，抑或借助道具来表达 思想观念的创作方式。行为艺术又称身体艺术 (Body art) 或表演 艺术 (Performance art)，它属于观念艺术范畴，肇始于 20 世纪 20 年代的达达艺术，兴盛于 20 世纪 60 年代。值得注意的是，进 入当代艺术时期之后，也就是自 20 世纪 90 年代开始，国际当代 艺坛出现了艺术家只是充当导演而让他人出场的表演艺术样式，这 就使得行为艺术与表演艺术之间出现了差异，而且，行为艺术发展 到后来产生了分化，在表演艺术中甚至出现了形式化和审美化的新 倾向。

\section{一、蹒跚学步}

中国的行为艺术发端于 20 世纪 80 年代中期, 也就是 85 新潮美术 运动时期，但哪一个是中国第一个行为艺术作品，或者说中国第一 件行为艺术作品究竟出自何人何时何地，似乎还有待确认，但确定 无疑的是行为艺术这样一种创作方式源于对西方现代和后现代艺术 观念和形式的学习、模仿和借鉴。改革开放后西方出版物的引进以 及我国学术界对西方现代艺术史论的翻译和介绍打开了中国当代艺 术家的国际视野，浙江美术学院编辑的《美术译丛》和中央美术学 院编辑的《世界美术》成为许多艺术家获取国外最新艺术信息的主 要窗口。根据鲁虹和孙振华著《异化的肉身：中国行为艺术》（河 北美术出版社，2006 年 6 月第 I 版）一书记载，中国行为艺术出 现在 1986 年，当年浙江杭州 “池社” 的耿建翌、宋陵、张培力和 王强，广东广州 “南方艺术家沙龙” 的王度和林一林，山西太原的 宋永平和宋永红兄弟，上海的丁乙、张国梁和秦一峰等人在他们举 办的艺术展览中开始了中国行为艺术的最早尝试。在随后的整个 80 年代后期，行为艺术不断涌现，愈演愈烈。然而，这些地方性 的展览因为规模小、时间短、观众少，且缺乏媒体的充足报道，在 当时产生的社会和学术影响相当有限。 
1989 年 2 月 5 日至 19 日在中国美术馆举行的 “中国现代艺术展” 是中国行为艺术第一次大规模集中亮相, 该展览也是对 85 新潮美 术运动中的行为艺术的全面回顾, 因为上面提到的此前在全国各地 发生的行为艺术作品都以照片的形式陈列在展览中, 而展览现场创 作的行为艺术更是成为观众关注的焦点。“中国现代艺术展” 现场 上的行为艺术集中出现在开幕式那天。吴山专以《大生意》为名在 开幕式上出售对虾，价格为 9.5 元一斤，比市场上便宜很多，而他 的第一位顾客竟是中国美术馆馆长刘开渠，他买了 30 元钱的对虾。 王仁德则在从一楼到三楼所有展出作品的前面撒上避孕套。在二楼 展厅，李山一身红装坐在椅子上用一个贴有许多里根头像照片的木 盆洗脚。张念则在一个用稻草席子铺成的鸡窝里 “孵蛋”, 他头戴 蓝布帽, 身披纸披肩, 上书 “孵蛋期间, 拒绝理论, 以免打扰下一代”, 他的身边散放着 I8 个鸡蛋, 面前的地板上还铺有一张写着六个 “等 待” 字样的白纸。比起展厅墙壁上那些架上绘画, 这些中国美术馆 此前从未有过的行为艺术作品更能吸引观众的注意力。该展览上更 令人震惊的行为是参展艺术家肖鲁和唐宋用左轮手枪朝他们自己的 装置作品 《对话》打了两枪, 这一《枪击》行为超出了艺术的极限 而成为治安事件，导致展览被警方停展 4 天。这些行为艺术随即成 为国内外新闻媒体报道的主要内容, 在展览开幕的次日, 美国《时 代周刊》就对展览做了报道，其封面大标题就是 “孵蛋、枪击、避 孕套”。

披览包括 1989 年中国现代艺术展相关作品在内的整个 80 年代 的中国行为艺术, 我们可以看到, 作为起步阶段, 当时的行为艺术 呈现出随机性和简单化倾向。大多数行为艺术作品都是把日常行为 进行简单的场地置换, 准确地说, 就是给日常行为贴上艺术的标签, 这类作品不仅缺少语法和修辞等语言学上的完善和严谨性, 更缺乏 意义上的明确和深刻性。不过，这不仅符合事物发展的客观规律， 亦即任何新生事物都必定要经过一个由初级到高级、由幼稚到成熟 的成长过程, 而且符合行为艺术产生的原初动机和目的, 也就是说, 这类行为艺术的意义不在作品的形式，而在于行为本身的寓意，即 它们是对既定社会规则、艺术概念和审美标准的反叛。 


\section{二、步入成熟}

进入 20 世纪 90 年代, 中国行为艺术开始步入成熟和繁荣期。此时, 不仅参与行为艺术创作的艺术家及其作品的数量急剧增长, 而且出 现了主要甚至专门从事行为艺术创作的艺术家。更重要的是，此时 的行为艺术已经变成了一 种独立而完善的艺术语言，它不仅有表 达上的深思熟虑，更有主题上的明确和丰富性。对于不计其数、林 林总总的中国行为艺术作品，艺术史论家给予了各种各样的分类与 归纳，它们被划归到千差万别的主题之下。在我看来，作为由艺术 家本人亲自出场，尤其是以艺术家的身体作为媒介的行为艺术，艺 术家是作品的主体，而所有主题不外乎艺术家与自我、艺术家与社 会、艺术家与自然之间的关系。而在绝大多数情况下，艺术家与自 我的矛盾、艺术家与社会的对立、艺术家与自然的冲突成为行为艺 术作品的主题。正是由于艺术家的身体是行为艺术的媒介，而自己 的身体又是自己最了解、最容易支配的对象，因而大多数行为艺术 家热衷于探究精神（或主观意志）与肉体（或生命存在）的关系。 值得一提的是，行为艺术家在表现自己的精神与肉体的矛盾时，往 往采用裸体的形式和自虐、自伤和自残等手段，这类作品往往最引 人注目，通常也最饱受争议。在表现艺术家与社会的对立关系时， 除了对等级、性别和贫富等社会不平等现象的揭示和批判之外，历 史的反思和文化的冲突也成为行为艺术表现的对象。

虽然我们可以对行为艺术作品进行主题上的分类，但每个艺术 家的创作并不限于单一的主题，甚至一件作品的含义也可能是含混 不清、模棱两可的。另外，即使艺术家想要表达的是非社会学的主 题，但如果采取的是裸体形式，也会被看作是对社会行为准则亦即 法律和道德的背叛而受到警方的干预和社会的抵制。因为在中国社 会习俗和文化传统中，裸体始终是被严格禁止的。相对于西方行为 艺术家，这是中国行为艺术家额外背负的枷锁。

20 世纪 90 年代以来，参与行为艺术创作的中国当代艺术家数 量众多, 作品宏富, 限于篇幅, 这里只能挑选极少数最具代表性、 最有影响力的艺术家及其作品做一简要介绍。

张洹是专门以行为艺术跻身中国当代艺坛的艺术家，也是一位 以裸体进行行为艺术创作的艺术家, 并且主要是以自虐的方式表达 自己的生命感受。1994 年 5 月他给自己的身体涂满蜂蜜和鱼油后在 
北京东村的一个肮脏的公共则所里静坐一个小时, 让苍蝇爬满全身, 依据则所的面积, 他给这件作品命名为《 $\mathrm{I} 2$ 平方米》 (图 $\mathrm{I}$ )。同年 6 月张洹又在东村自己的工作室创作了行为艺术 《65 公斤》 $($ 他自 己的身体重量), 他用 Io 条铁链将自己赤裸的身体吊在房顶上，并 让医生在 60 分钟内从他身上抽出 250 毫升血, 这些血通过导管慢 慢滴落在地面上一个烧热的白瓷盘中，散发出刺鼻的气味。1998 年 张洹在美国纽约 PSI 当代艺术中心完成了行为艺术作品 《风和水 纽约》 (又称《卧冰》), 他以赤裸之身在一张冰床上俯卧了 10 分钟 (图 2)。张洹的行为艺术通过对自己身体的伤害，表达了人类自我主宰 的意志。艺术家以超越视觉的痛苦体验, 揭示了意志与肉体、自我 生命与外在世界之间的尖锐对立。虽然自我伤害的行为艺术在西方 现代艺术史上早有先例并且不胜枚举、五花八门，但张洹的自虐似 乎给了其他中国行为艺术家以直接的示范性影响, 以至此后伤害性 行为艺术变本加厉, 不断触及道德和法律的底线, 引起艺术界和社 会的强烈反对。

马六明也是最早采取裸体形式进行行为艺术创作的艺术家之一。 年轻时的马六明相貌俊秀，身材苗条，具有极强的女性外形特征。 I993 年底他非常偶然地意识到自己 “亦男亦女、雌雄同体” 的混合 外貌可以作为行为艺术创作的条件, 于是他开始了一个名为《芬. 马六明》的行为艺术系列作品的创作。该系列作品最初是女妆表演, 很快就转换为裸体并与观众互动的行为艺术方式。1994 年 6 月马 六明在北京东村因创作《芬.马六明的午餐》遭警方逮捕，并以 “打 着艺术的名义进行淫秽表演” 的罪名被拘禁两个月后遣返回原籍。 1996 年之后，马六明相继在日本、荷兰、加拿大、美国、德国和 瑞士等国美术馆和画廊以 《芬.马六明在 XXX》为题进行现场互 动行为表演。他邀请各种不同性别、年龄、国籍和种族的人与他合 影, 以至服用大剂量的安眠药使自己处于完全无意识状态而任由现 场观众随意摆布。马六明的行为艺术以其异化的身体对认识论中的 普遍现象一即表象与本质的背离, 抑或假象对真实的遮蔽一进行了 艺术的表达，也对人生的荒诞、困惑和不确定性进行了深刻的揭示。 在中国行为艺术中, 《为无名山增高一米》是一件知名度极高的 作品（图 3), 它是 1995 年 5 月由张洹、马六明、马忠仁、王世华、 602 朱昱、苍金金、张彬涁、段英梅、高炀和诅咒等 IO 人在北京门头沟 
区妙峰山区一座无名山头上完成的，他们以赤裸的身体分五层叠出 一个一米高的人丘。这件作品对 “人是大地之子” 和 “天人合一” 的世界观做了直观而形象化的演绎，也为现代工业文明时代人们如 何思考、面对与处理人与自然的关系问题进行了巧妙的提示。张洹 后来完成的另一著名行为艺术创作《为鱼塘增高水位》（1997 年夏） 算得上是这一作品的姐妹作。值得一提的是，作为一件集体创作的 作品, 《为无名山增高一米》还是东村作为一个短期存在的行为艺 术家群落的证明，事实上，这个群体中的多位艺术家后来成了中国 行为艺术界的主要人物。

随着 1989 年柏林墙倒塌，经济全球化时代的来临，特别是 1992 年邓小平南巡之后，中国进入市场经济高速发展时期，与此相关， 商业化和消费主义观念迅速在社会中膨胀蔓延。当时许多中国当代 艺术家敏感地意识到这一社会现象并以行为艺术的方式表达出自己 的批判立场。

朱发东 1994 年在北京实施了一个为期一年的行为艺术创作，他 手提一个黑色公文包，身穿一套蓝色中山装，后背缝有 “此人出售 价格面议” 的布标，行走于北京的大街小巷。正如鲁虹所言 : “这 是一件具有明确、直观、有效的大众焦点的艺术作品，表达了艺术 家对什么都被物化、什么都被商品化现象的批判。”

I996 年 I 月 28 日王晋、姜波和郭景涵在河南郑州创作了一件 大型装置 - 行为艺术作品《冰·96 中原》 (图 4), 他们利用市中心 二七广场天然商厦开业典礼之机，在商场门前垒起一堵长 30 米、 厚 I 米、高 2.5 米的冰墙，冰墙中埋有近 300 件商品。数以万计的 顾客参加了开业典礼。仪式结束后，顾客被允许用任何方式砸开冰 墙取走商品，一时间群情激奋，场面火爆，冰墙很快化为乌有。这 是一个有大量观众参与的大规模行为艺术作品，它给消费主义时代 人们膨胀的物欲提供了一个疯狂释放的舞台，使人性的贪婪得到了 真实而充分的暴露。

改革开放后中国社会发生着日新月异的变化，而个人身份的差 异和个人地位的变换是给每个社会成员的精神和物质生活带来直接 影响的重要因素，因而社会身份也是人们最关心的问题。这样的问 题也成为许多行为艺术家创作的主题。罗子丹在 1996 年创作的《白 领系列》行为艺术作品通过一人同时装扮两种角色、形象与行为的 
反差等形式则将身份的重合、分裂和变换的社会现象做了直观的呈 现。苍金金于 2000 年开始实施的行为艺术作品《互换身份系列》则 是与教授、厨师、演员、白领、农民和拾荒者等各种社会人物互换 服装并在这些人的工作场地合影。

如果说身份的变化反映的是社会的变迁，那么席卷城乡且日益 剧烈的建筑拆迁之风则是中华大地物质世界和人文景观巨变的集中 体现。张大力自 1998 年 2 月在北京大街小巷那些写有 “拆” 的墙 上，喷上几千个涂鸦式的侧面人头像，并写上 $\mathrm{AK} 47$ 或 $\mathrm{I} 8 \mathrm{~K}$ 字样。 $\mathrm{AK} 47$ 是一种枪的名称，用以表示工业化和城市化进程中的暴力; I $8 \mathrm{~K}$ 是黄金成色，象征繁荣背后的物欲。他有时也会在正待拆毁的 墙体上丵出镂空的头像。这些头像和文字随着旧房屋拆除、新建筑 动工而消失。这个名为《对话》的行为艺术系列作品试图在新旧之 间、历史记忆与现实存在之间、过去、现在和未来之间建立起永恒 的纽带。

\section{三、暴力美学}

2000 年是中国行为艺术史上一个重要的节点, 不仅因为这一年先 后举办了一系列包含有大量行为艺术的大型当代艺术群展, 更因为 这些展览上出现了大量极端暴力化的行为艺术作品, 引起社会各界 的极大争议, 最终导致政府出台了相关管理规定, 从而严重影响了 后来的行为艺术的发展。

这年 4 月 22 日由栗宪庭策划的 “对伤害的迷恋” 行为艺术展在 北京朝阳区中央美术学院雕塑创作工作室举行, 孙原、彭禹、琴嘎、 朱昱、张涵子、肖昱和大张等 6 位艺术家参展。该展览展出了大量 使用人体标本和动物尸体作为创作媒材以及严重伤害的行为艺术作 品。朱昱的参展作品叫《植皮》, 创作过程和情形是这样的: 一个 月前的 3 月 22 日，朱昱在北京某医院让大夫动手术从自己下腹部 割下一块长 $\mathrm{I} 2$ 厘米、宽 4.5 厘米的菱形皮肉, 经生理盐水浸泡后保 存在零下 $\mathrm{IO}$ 度的冰箱里。展览开幕当天, 他在展厅拿出手术器械, 将那块皮肉一针一针地缝合在一块新鲜的猪肉上，与此同时，他还 将从自己身上抽取的 220 毫升血液输入到猪肉里。孙原和彭禹则展 出了他们利用胎儿和婴儿尸体标本做道具的行为艺术作品《连体婴 儿》和《人油》。在第一件作品中, 他们将一个连体婴儿的标本屈 
腿树立在白色矮台上一个医用磁盘里，两人则分坐两旁并让专业护 士将从他们血管里各抽出的 100 毫升血液直接输入到死胎标本的嘴 里，由于死胎标本容量有限，大量鲜血流到死婴的体表，场面十分 恐怖。《人油》则更加骇人，表演中，彭禹席地而坐，怀中抱着一 具小孩的干尸，手里拿着一根连接一个大瓶子的管子往这个死婴嘴 里喂着流质的东西，这种流体物质正是人油。在旁边墙上屏幕上播 放的视频里呈现了两人切割、下锅和翻搅这样一个完整的謷炼人油 的过程。

同年 II 月 4 日至 II 日由艾未未和冯博一策划的 “不合作方式” 艺术展在上海东廊画廊举行，48 位艺术家参展，杨志超、王楚禹、 何云昌、朱冥和冯卫东等人实施了行为艺术作品。杨志超在展览现 场实施了《植》行为艺术作品, 在不打麻药的情况下，他让医生在 他的肩背上种了两颗草，可想而知的疼痛令其在场的妻子仍不禁失 声痛哭。在此一个月前，他还完成了一个同样具有严重自我伤害性 质的作品《烙》，将一个刻有自己身份证号码的金属模具烧红，让 人在没有麻醉的情况下烙印在自己的后肩上。这个行为艺术的照片 陈列在展场上。朱昱的行为艺术作品《晚餐 : 食人》由于暴力色彩 过于强烈，以致图片都未被允许在展览上展示，而只是刊登在展览 图录中。这组图片展示了他把一个 6 个月大的死婴从清洗、烹饪到 食用的全过程，其场景之恐怖令人不寒而栗。

除此之外，这一年还出现了一些以行为艺术的名义虐杀动物的 事件。

大量出现的极端暴力化行为艺术严重触犯了道德乃至法律的底 线, 激起了包括学术界在内社会各界的强烈反对。200I 年 I 月 28 日 《文艺报》刊发了署名杨盎的文章《以艺术的名义：中国前卫艺术 的穷途末路》, 对此前出现的自虐、喂人油、吃死婴和虐杀动物等 极端行为艺术给予了猛烈抨击。作者指出 : “不管行为艺术的行为 如何前卫，都应该在一定的底线范围之内，这个底线就是艺术的命 根，是艺术和非艺术的界限，包括不能超越社会道德和法律，不能 超越人性和公共利益，不能仅以艺术的名义。”随后，《中国社会导 刊》和《美术》等杂志也相继发表了系列讨论文章，对这类艺术创 作进行了分析和批评，各方观点趋于一致，也就是说批评者大多对 极端行为艺术持否定立场。 
由于社会各界的强烈反应，200I 年 4 月 3 日文化部下发了《文 化部关于坚决制止以 “艺术” 的名义表演或展示血腥残暴或淫秽场 面的通知》，这是我国政府出台的为数不多关于艺术创作的管理规 定之一。毫无疑问, 这一文件对于遏制行为艺术暴力化现象的蔓延 和升级起到了一定作用。

除了来自社会舆论和政府政策的压力之外，2005 年之后汹涌而 来的艺术市场化和商品化潮流也对行为艺术的发展带来了巨大影 响。在艺术市场大力追捧架上艺术且绘画作品价格急剧暯升的情况 下，因为缺乏商品价值，或者说由于这类艺术的市场尚未形成，行 为艺术遭到了冷遇。

在第一代行为艺术家纷纷退场的情况下，何云昌堪称一位执著 的行为艺术坚守者。从 1999 年的《与水对话》开始，他便开始了 矢志不渝的行为艺术创作。何云昌的行为艺术始终以各种自我伤害 的形式表达不同的主题，2008 年 8 月 8 日他借助医学手术取出了 自己的一根胁骨, 2009 年他将这根胁骨和四百多克黄金组合制成 一根项链，取名《夜光》。2013 年何云昌参加了第 55 届威尼斯国际 艺术双年展中国馆的展出, 虽然参展作品《威尼斯的海水》是一个 温和的互动行为艺术, 但他是第一个代表参加威尼斯双年展国家馆 展览的行为艺术家。

2I 世纪以来的中国行为艺术日渐疲软, 虽然仍有大量行为艺术 出现, 但作品的力度和社会影响大为减弱。在数量庞大的行为艺术 创作中，能给人留下深刻印象的作品越来越少。

艾未末 2007 年借 “第 12 届卡塞尔文献展” 实施了名为《童话》 的艺术项目，算得上是新世纪最著名的行为艺术作品。他从当年 2 月起开始在自己的博客上发布招募 “童话军团” 公告, 至 7 月 17 日组织起一个 IOOI 人的队伍去德国格林童话的故乡卡塞尔参加文 献展，所有成员的食宿和往返交通费用由他承担，总投入 300 万欧 元。如此耗费高昂的团体旅行与其说是一次时空转换的行为艺术, 不如说是一个含义浅显的日常事件。

厉槟源是最近两年出现的行为艺术新人, 2013 年 3 月 20 日他开 始在深夜的北京街头抱着充气人偶及十字架裸奔, 前后共跑了 IO 次。由于微博的高效传播, 厉槟源一时爆红网络, 被网友称为 “裸 奔哥”。相对于前辈的创作，这位 “80 后” 年轻艺术家的《裸奔》 
只能算是行为艺术中稀松平常的普及样式和轻松无害的 “小清新” 版本。应该说，厉槟源的行为艺术也反映了中国当代艺术随着代际 的更替而产生的风潮和趣味的改变。

\section{四、价值反思}

披览 20 世纪 90 年代以来行为艺术的发展历程，我们可以窥见中 国当代行为艺术的特点和本质。

在西方，行为艺术原本兼有背叛既定艺术规范、反抗现行社会 制度的双重使命，但在我国，这类创作在艺术内部没有具体的反对 对象，因此几乎没有产生类似伊夫 ·克莱因（Yves Klein）的《人 体测量》和约瑟夫 ·博伊斯 (JosephBeuys) 的《如何向死兔子解 释绘画》那样针对艺术自身的行为艺术作品。黄永硳 1987 年创作 的《〈中国绘画史〉和〈现代绘画简史〉在洗衣机里搅拌了两分钟》 行为艺术作品（1989 年 “中国现代艺术展” 以装置作品形式参展）、 黄岩将传统山水画画在人体皮肤上的《中国山水》（I995一 I 999 年） 和张强的人体书法《踪迹》（1996-2002 年）勉强可以算作针对艺 术本体的行为艺术创作，但它们与中国现当代艺术之间均缺乏直接 的上下文关系。事实上，中国行为艺术主要挑战的对象是伦理、道 德和法律等社会规范，于是，行为艺术与社会规则之间天然形成了 相反相成的对立关系。我们看到，中国行为艺术产生的动机和目的 就是反抗社会规则，与此对应，我国社会和政府从一开始就对行为 艺术采取了压制的态度。至关重要的是，行为艺术家对社会的反抗 往往通过自我伤害的手段来实现，这样的反抗之所以能够生效是由 于人是社会动物，而个体又是社会的一员，所以对自我的伤害就是 对整个社会的伤害。从某种角度上看, 行为艺术暴力程度的不断升 级也是艺术家与社会之间对抗程度不断加剧及其恶性循环的结果。 无论是宣泄心灵的痛苦，还是抗议社会的禁锢，在行为艺术作品中 都变成了对身体的伤害。换言之，在行为艺术家那里，身体成了代 罪的羔羊。

由于社会的抵制，行为艺术在我国始终未能获得宽松的生存和 发展环境。从一定意义上说，中国行为艺术的畸形状态与其逼入和 严酷的生存空间密切相关。我们看到, 长期以来在国内举办的大量 当代艺术展览中很少出现现场实施的行为艺术，行为艺术作品大多 
是以照片和影像的形式与观众见面，这在很大程度上损害了这种艺 术的现场感受性，因为观众的在场乃至与观众的互动不仅是行为艺 术的组成部分，也是它生效的首要条件。对于观众而言，参观行为 艺术的照片如同观看电影的剧照, 因而对作品的认识是局部和片面 的。行为艺术只有借助摄影和影像这些载体才能呈现, 或者说摄影 艺术和影像艺术变成了行为艺术的必要依托, 这是行为艺术生存艰 难的体现。

在行为艺术生效的过程中媒体扮演了举足轻重的角色，但是， 媒体宣传对于行为艺术既有正面作用也有负面效应。人们知道，行 为艺术家需要借助媒体宣传产生社会影响，而媒体往往喜欢通过报 道那种 “人咬狗” 式的非正常社会新闻来吸引读者的好奇心。事实 上, 许多极端行为艺术也正是经过网络媒体的大规模宣传而放大了 恶劣影响。相反，对于那些形式温和甚或内含深刻的行为艺术，媒 体却漠不关心、熟视无睹。客观地说, 非暴力行为艺术占行为艺术 的多数, 但媒体对行为艺术的片面宣传却给公众造成这样一个印象, 即所有的行为艺术都是暴力行为。

无论是什么艺术作品，手段只是艺术价值构成要素的次要部分， 评价艺术的最终标准是作品的内涵。同样是行为艺术，不同作品之 间同样存在着表达和含义上的高低优劣之别。像其他所有领域一样, 中国行为艺术界也并非一片纯洁的净土。毫无疑问，对于这样一个 新兴的艺术创作领域，鱼龙混杂、良莠不齐更是它的正常生态。在 这个领域有很多富有才华的严肃认真的艺术探索者，但不可否认， 其中也有一些哗众取宠、沽名钓誉的投机者。媒体和公众对反常事 物的追逐也诱惑着那些渴望成名的艺术投机者, 使得他们处心积虑、 挖空心思地制造事端，以求产生轰动效应。对于那些不谙表达深刻、 积极而善良的人文精神，而一味张扬人性的卑劣、阴暗和邪恶，并 希望借此博取名声的伪艺术家，学术界还是具有鉴别能力的。大浪 淘沙，时间终将冲掉没有价值的沙粒，留下闪光的金子。

我们知道, 在行为艺术反对的清单中还包括既定展览、收藏和 商品化模式，也就是说行为艺术原本是反对商品化的。事实上，中 国行为艺术产生和发展的最好时期也正是中国当代艺术的市场化和 商品化浪潮尚未来临的时代。这一历史事实告诉我们，早期行为艺 术家从一开始就没有把赚钱获利作为创作的目的。相反，正是由于 
艺术市场化和商品化现象的产生使得许多行为艺术家回到或改行进 入到架上艺术的行列，从而严重损害了行为艺术的发展势头，以致 今天这一领域出现了后继无人的局面。

20 世纪 90 年代之后中国行为艺术由兴旺逐渐变为平淡，这一 转变既有社会政治经济等外部原因, 也是艺术自身规律作用的结果。 这期间无数艺术家及其创作的大量艺术作品都向世人证明了行为艺 术取得的巨大成就。人们公认，在中国当代艺术发展史上，相对于 其他艺术门类，行为艺术在捍卫艺术自由、拓展艺术边界方面是走 得最远、影响最大的一脉。无论如何，行为艺术家对中国当代艺术 的发展进步做出了巨大贡献。 


\title{
Redemption of Sins through the Human Body: Meanings of Action Art in China
}

\author{
Wang Duanting
}

Action art is a creative method with which the artist directly uses their body as a medium and expresses their thoughts and concepts, perhaps with the help of props, through facial expressions, body gestures, actions, and the process in a given space. Action art is also called body art or performance art; it belongs to the realm of conceptual art, beginning with Dadaism in the 1920 and reached its peak in the I96os. What is worth noting is that on the cusp of the period of contemporary art, that is around I990s, the artistic form emerged where artists only act as a director while others perform on international art scenes, and that has created a gap between action arts and performance art. Besides, action art starts to ramify into various branches after a long period of development. In performance art there even appear new tendencies of formalization and anesthetization.

\section{Initial Steps}

Action art in China began during the mid-8os of the 2oth century, that is during the ' 85 New Wave movement. But it is not possible to pin down who created the first action art in China, or where and when it appeared. What is beyond doubt is action art as a method of artistic creativity originated from Western modernist and postmodernist concepts, and the learning, modeling, and appropriation of Western forms. When China opened herself up again after the Reformation, the introduction of Western publications into China and scholarly efforts to translate and introduce Western modern art history and theories into Chinese broadened the horizon of Chinese contemporary artists. The Translated Arts, edited by the China Academy of Art, and World Arts, edited by the Central Academy of Fine Arts have offered many artists the main access to the latest arts news from the international art world. According to Lu Hong and Sun Zenghua's Alienated Body: Chinese Action Art, action art first occurred in China in 1986. ${ }^{1}$ Artists all over China_-Ge Genyi, Song Ling, Zhang Peili, and Wang Chan of the "Pool Society" of Hanghou in Zhejiang, the Wang Du and Ling Yiling of the "Southern Artist Salon" of Guangzhou in Guangdong, the Song Yongping and Song Yongqing brothers of Taiyuan in Shanxi, and Yi Ding, Zhang Guoliang, and Qing Yifong of Shanghai-started to make attempts at creating Chinese action art at the art exhibitions they held. Then throughout the 1980s, action art popped up continuously and started to gain significant ground in the Chinese art world. However, these local exhibitions had rather limited impact on the so- 
ciety and the academy at that time because of their limited scale, short duration, small audience and lack of media attention.

The 89 China/Avant-Garde Exhibition, held between February 5-19, I989, was the first time when large-scale Chinese action art saw the world. That exhibition also serves as a comprehensive retrospect of the '85 New Wave movement because the action art pieces that occurred all over China were exhibited here in the form of photos. Meanwhile, the action art performed impromptu at the exhibition was the center of attraction. The performances mostly took place during the opening ceremony of the 89 China/Avant-Garde Exhibition. Wu Sanzhouan was selling Chinese white shrimps at the price of 9.5 RMB/kilo, which is much lower than the market price, in the name of "Big Business." His first customer was the director of China Academy of Art, Liu Kaiqu, who bought 30 RMB worth of shrimps, while Wang Rende scattered condoms across the exhibited works from the ground floor to the second floor. In the exhibition hall on the first floor, Li San sat on a chair, dressed all in bright red, washing his feet in a wooden bowl plastered with Reagan's portrait photos. Zhang Nain was hatching eggs on a straw matted chicken coop. Zhang wore a blue beret, draping a paper shawl around himself on which was written "No discussion while hatching so that the next generation would not be disturbed." There were I8 eggs scattering around him with 6 pieces of white paper on which was written 'waiting' on the floor in front of him. As opposed to the exhibited paintings on the wall, these unprecedented action artworks at the China Academy of Art drew more of the audience's attention. The more daring acts were carried out by Xiao Lu and Tang Song, whose works were on exhibition. The pair took a revolver and shot their own installation Dialogue twice. The "gun-shooting" act went beyond the limit of being art and was turned into a violent event which led to a 4-day suspension of the exhibition by the police. These action artworks soon hit the international and Chinese headlines. On the second day of the exhibition, the Times magazine of the United States titled its piece on the exhibition "Hatching, Gun Shots and Condoms."

If we survey the oeuvres of related works of Chinese action art throughout the eighties, we can see that action art back then, still at its incipient stage, showed the tendency of randomness and simplicity. Most of the action art pieces simply transported an everyday life action to another context. To be precise, action art back then meant no more than labeling everyday behavior as art. This type of artwork not only lacked linguistic and rhetoric completeness and the rigor of linguistics but was also short of precise meanings and depth. However, these characteristics were simply the logical corollary of how things developed according to their objective laws, meaning that all nascent things will experience the whole gamut of growth from the rudimentary to the complex, from being immature to being mature. In other words, the meanings of this kind of action art lie not in the forms of the work but in the implied meanings of the action. That is, they embody rebellion against received social rules, artistic conceptions, and aesthetic standards. 
Fig. I. Zhang Huan, $I 2 m^{2}$, I994, Performance, Beijing, China. Courtesy Zhang Huan Studio.

\section{Coming to Maturity}

On moving into the I990s, Chinese action art also marched into a stage of maturity and blossoming. Not only the number of the participating action artists and their works were growing thick and fast but there appeared artists who focus their energies entirely on action art. What is more important is that action art during this period developed its own system of independent and complete artistic language. Not only were the meanings conveyed through profound and thoughtful expressions, but the subjects themselves became articulate and rich. The numerous and various Chinese action artworks have been classified and summarized

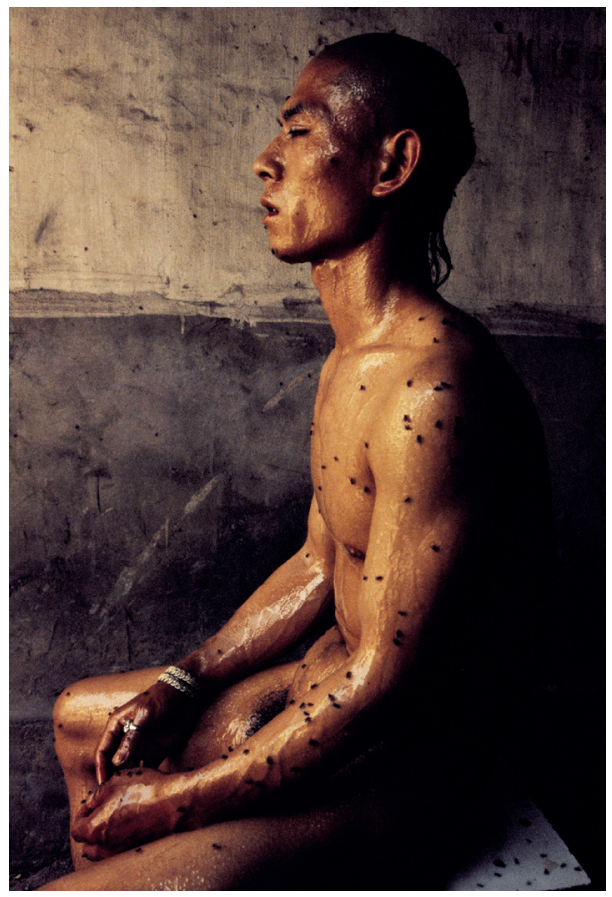
by art historians according to different criteria and pigeonholed into multiple themes. In my opinion, artists are the subjects of their work when they themselves participate in the performance, particularly when the artist's body is the medium of their action art, while all subjects inevitably explore the relationships between the artist and their identity, the artist and society, and the artist and nature. Under most circumstances, the themes of action art concern the contradiction between the artist and their identity, the clash between the artist and their society, and the conflict between the artist and nature. It is precisely because the artist's body is the medium of action art while one's own body is the object one knows best and can most easily control that most action artists are keen to explore the relationship between the spiritual (or the subjective will) and the physical (or the existence of life). What is worth mentioning is that when the artist is expressing the paradox between their spirit and their physical body, they tend to adopt the form of a naked body and deploy the means of self-abuse, self-injuring, and self-harm. Therefore this type of work tends to be most noticeable but also controversial. When expressing the oppositional relationship between the artist and the society, the artist not only reveals and criticizes the class, gender, and wealth inequality in a society but make reflection on history and cultural conflicts the subject of their action art.

Although we can classify the subjects of action artworks, the works created by each artist cannot be confined to one single subject. Sometimes the meanings of one particular piece can be vague and ambivalent. Besides, even if what the artist is trying to convey is a non-sociological subject, the form of performing naked will certainly be regarded as breaking the rules of socially acceptable behavior, meaning that the form violates the law and morality of the given society and the 612 artistic act will therefore be stopped by the police and sanctioned by society. The 


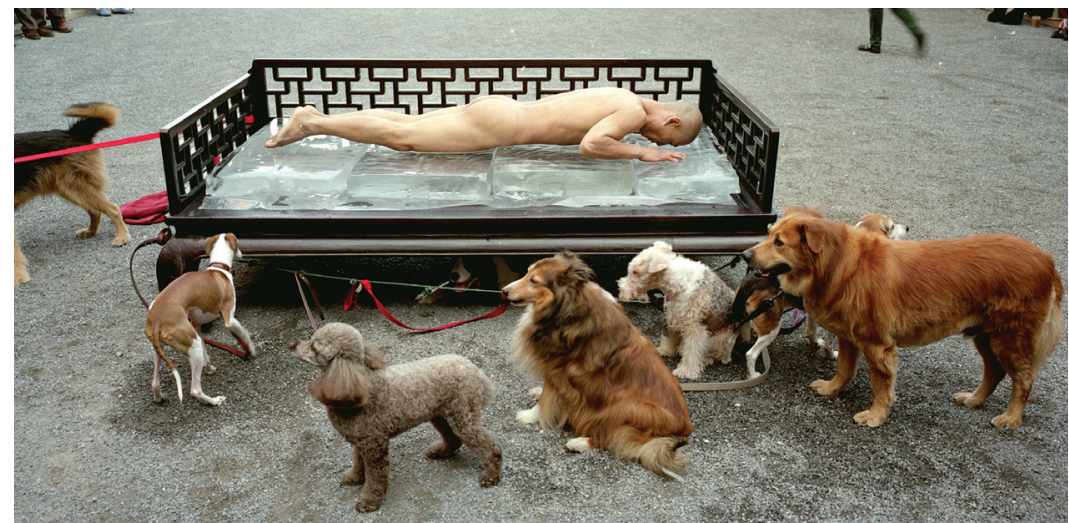

Fig. 2. Zhang

Huan, Pilgrim-

age-Wind and

Water in New York, I998, Performance, P.S.I, USA. Courtesy Zhang Huan Studio.

customs of Chinese society and traditional culture strictly prohibit the public demonstration of naked bodies. As opposed to their Western counterparts, this is the extra moral and legal shackle that the Chinese action artists have to deal with.

Since the I990s, the number of contemporary Chinese artists who have taken part in action art has multiplied several fold. Given the limitations of this chapter, one has to sacrifice the richness and vastness of their works and make brief introduction to a couple of seminal artists whose works are the most representative and influential in the field.

Zhang Yuan is an artist who has come to be regarded as one of the most important contemporary Chinese artists specifically through his action art. $\mathrm{He}$ is also an artist who performs in the nude and expresses his perception of life through self-abusive means. In May 1994, he slathered honey and fish oil all over his body and sat stock still for an hour in a dirty public latrine in the East Village of Beijing, during which flies crawled all over him. He named the piece $I 2 \mathrm{~m}^{2}$ (Fig. I) in accordance with the size of the latrine. In June of the same year, Zhang made another action art piece 65 Kilograms (his own body weight) in his studio in East Village. He hung himself naked from his roof with ten iron chains and asked a doctor to draw 250 millimeter's blood, which dripped through a tube into a boiling white porcelain pot on the ground. The blood gave out an offensive odor. In 1998 Zhang Huan made Pilgrimage_Wind and Water in New York (also titled Lying on Ice) by lying naked on an ice bed for Io minutes in the courtyard of New York's PSI Contemporary Art Center (Fig. 2). Zhang's action art expresses the human will to self-dominance and to control through doing harm to one's one body. The artist exposes the acute opposition between the will and the physical body, and between one's existence and external world. Although there had long been numerous precedents of self-harm action arts, which differ in kinds and forms, in Western modern art history, Zhang Huan's masochism seems to have a direct impact on all the rest of Chinese action artists as he shows up the possibility of being one. From that point on, Chinese action artists simply stepped up their harmful performance several notches, constantly corroding the moral and legal baseline and drawing severe criticism from the art world and the society alike. 
Fig. 3. Zhang Huan, To Add One Meter to an Anonymous Mountain, 1995, Performance, Beijing, China. Courtesy Zhang Huan Studio. (Zhang Huan, Ma Liuming, Ma Zhongren, Wang Shihua, Zhu Xi, Cang Xin, Zhang Binbin, Duan Yingmei, Gao Wei, and Curse)

Ma Liuming was also one of the earliest artists who performed action art naked. As a young man,

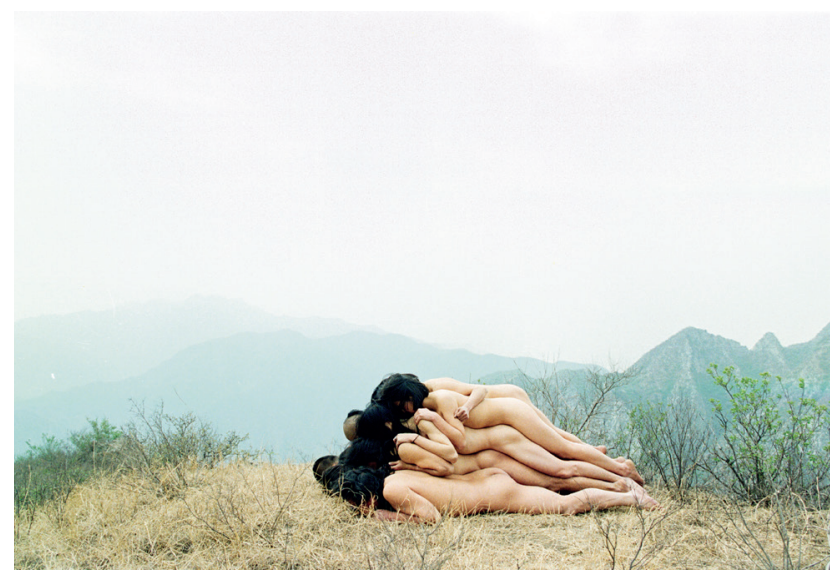
Ma had a strong "feminine" appearance: he had a clean-shaven, elegantly lined face and a lithe body. At the end of 1993 he suddenly became aware that his "androgynous, both man and woman" appearance could work as a condition for his action art creativity. So he began a series of action acts titled Fen-Ma Liuming's Lunch, which began as cross-dressing performance and soon evolved into Ma interacting with the audience in the nude. In June 1994, because of Fen-Ma Liuming's Lunch, Ma was arrested by the police and charged with the crime of "performing obscenity in the name of art" in Beijing East Village and sent back to where he was originally from after being banned from performing for two months. After 1996 Ma started to perform impromptu actions titled Fen-Ma Liuming in __ in museums and galleries in Japan, the Netherlands, Canada, the United States, Germany, and Switzerland. He invited people of various genders, ages, nationalities and races to take a photograph with him. And when he performed, he took huge doses of sleeping pills so that he was completely unconscious and his body could be manipulated by the audience at will. Ma's action art explores an epistemological phenomenon-appearance at variance with essence, or illusion shadowing truth—with his alienated body and it reveals the profound absurdity, confusion, and uncertainty of life.

To Add One Meter to an Anonymous Mountain is one of the most well-known Chinese action artworks (Fig. 3). It was performed in May 1995 by a group of ten artists—Zhang Huan, Ma Liuming, Ma Zongyin, Wang Shihua, Zhu Ming, Cang Xin, Zhang Binbin, Duan Yingmei, Gao Yang, and Zu Zhou-who lay on top of one another nakedly to create a 5 -layered one-meter human hill on an anonymous peak of the Maofongshan Mountain in Beijing's Mentou Ditch area. This piece gives a direct and stylized interpretation to the cosmic concept of "humans being the offspring of the earth" and "the unison between heaven and humans," while giving a hint as to the questions of how one thinks in the age of modern industrial civilization and of how to face the relationship between humans and nature. Another famous piece by Zhang Huan titled To Raise the Water Level in a Fishpond (summer 1997) can be seen as a companion piece to Mountain. What is worth mentioning is that as a piece of collaboration, To Add

614 One Meter to an Anonymous Mountain bears witness to the short-lived action art 


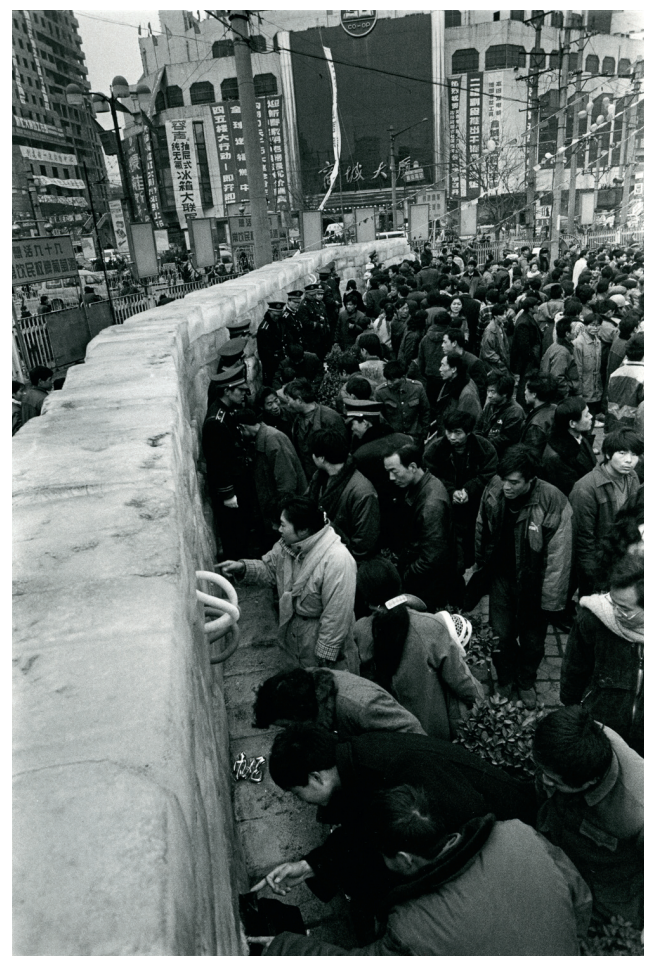

Fig. 4. Wang Jin, Ice - 96 Central Plains, 1996. Performance and installation. Courtesy of the artist.

community in East Village, Beijing. In effect, most of the artists in this community have gone on to be the major players in the Chinese art world.

With the fall of the Berlin Wall in I989 and the arrival of globalized economy era, China entered a period of rapid development of market economy, particularly after Deng Xiaoping's 1992 southern tour. At the same time, commercialization and consumerism dominated the Chinese society. Many of the contemporary Chinese artists were sensitive to and conscious of such a social phenomenon and started to express their critical stance through action art.

In 1994, Zhu Fadong performed a year-long action art piece in Beijing. During that period of time Zhu rambled around the streets and alleys in Beijing, carrying a black attaché case, clad in a blue Chinese tunic suit with a banner saying "this man is for sale, prices to be negotiated" sewn on his back. As Lu Hong says, "This is a piece of artwork with precise, direct and effective focus for the public. It expresses the artist's critique of the phenomenon in which everything is objectified and commercialized."2

On January 28, 1996, Wang Jin, Jiang Bo, and Guo Ginghen collaborated on an installation piece, Ice . 96 Central Plains (Fig. 4) in Zhengzhou, Henan. The quartet took the opportunity of the opening ceremony of Natural Commercial Building at the 27 Square to build an ice wall of 30-meters long, I-meter thick, and 2.5-meter high in front of a shopping mall with nearly 300 consumer goods embedded in the wall. Tens of thousands of customers took part in the opening ceremony and when it ended the customers were allowed to take the frozen goods away by any means. In the blink of an eye the crowd grew agitated and the scene became violent; soon the ice wall was gone. This is a large-scale action art installation with the participation of a great number of audience members. It offered a platform for releasing people's inflated desire for goods in a consumer age while fully revealing the true nature of human greed.

The post-revolution Chinese society was changing day in and day out. What impacts most directly on the spiritual and material life of each member of the society is the gap between individual positions and displacement of individual

2 Lu Hong, Illustrated Handbook to Contemporary Chinese Art [Zhongguo dangdai meishu tujian 1979-1999], vol. 5 (Wuhan: Hubei Education Press, 200I), 23. 
social status. As a result, social status has become what people concern themselves with most. This issue also features heavily in many action artists' works. Through dressing up to play two contrasting roles, presenting two split images and conducting contradictory behaviors, Luo Zidan's Half White-Collar/Half Peasant directly presents the social phenomenon of regrouping, splitting, and exchanging identities. In his Identity Exchange series, which started in 2000, Cing Xin donned the clothes of people in various social standings-professors, chefs, actors, white-collar workers, farmers, and litter-pickers—and was photographed with these people at their workplaces.

If we say that the change of identities reflects the change of a given society, the massive-scale and quickening demolition that were happening across the cities and the countryside in China must be the epitome of the colossal transformation done to the great material world of the Chinese landscape and the cultural spaces. Since February 1998 Zhang Dali has been spraying, graffiti-style, thousands of images of human profiles on the walls written with "demolition" in the streets of Beijing and sprayed AK47 or $18 \mathrm{~K}$ on top of the walls. "AK47" is the name of a machine gun and is used to represent the violence that happened during the process of industrialization and urbanization while " $18 \mathrm{~K}$ " is the number to indicate the percentage of gold, and the sign is used to represent the coveting for objects underneath the booming economic prosperity. At times Zhang paints bold portraits on those walls to be knocked down. These portraits and words dissipated into thin air along with the demolition of old houses and raising of new buildings. This series of action artwork titled Dialogue is an attempt to establish a permanent link between the past, the present and the future that exist between the old and the new, between historical memories and reality.

"Money talks" and indifference are the diseases of commercial society; and one of missions of contemporary artists is to resist the material corrosion of humanity. In 2000 the Gao brothers (Gao Zhen and Gao Qiang) created a series of action art pieces titled The Utopia of 20 Minutes Embrace. Embracing is a common socializing behavior in Western societies, but this behavior is heavily loaded with deep emotions in the Chinese society. For the Chinese people, particularly men and women who are strangers to one other, embracing is a taboo. The Gao brothers called for roughly I50 young men and women who volunteered to hug each other at all sorts places and in different locations, for example, along the Yellow River bank, Old Yellow Railway Bridge and within highrises in the middle of construction. The volunteers can choose who they want to hug for $15 \mathrm{~min}$ utes and then hug collectively for 5 minutes so that they would experience the friendship and human warmth that has been worn out by a utilitarian society.

\section{Aesthetics of Violence}

The year 2000 is a seminal year in Chinese action art history not just because there have been series of large-scale exhibitions that included many extremely violent actions artworks, but because these works became extraordinarily controversial from all sectors of the community, which eventually led to the govern- 
ment laying down regulations on action arts. The regulations seriously affected the development of action art from then on.

On April 22, 2000, "The Obsessions with Harm," an action art exhibition curated by Li Xianting, was held at the Sculpture studio of the Central Academy of Fine Art in Beijing Chaoyang district, with six other artists' participation: Sun Yuan, Peng Yu, Qin Qin, Zhu Yu, Zhang Henzhi, Xiao Yu, and Da Zhang. That exhibition mobilized quantities of human specimen and animal carcass as creative materials and displayed action art works that involved with serious bodily harm. The creative process of Zhu Yu's exhibited work titled Skin Graft goes like this: On March 22, a month before the exhibition, Zhu Yu cut off a patch of skin (a diamond shape in I2 millimeters' long and 4.5 millimeters' width) on his lower abdomen at an unspecified hospital in Beijing and the skin was kept in saline and in a freezer at minus ten degrees centigrade. On the opening day of the exhibition, Zhu sewed his own skin onto a chunk of fresh pork with surgical instruments. At the same time, he transfused 220 milliliters of his own blood to the pork. On the other hand, Sun Yuan and Peng Yu performed their works Siamese Twins and Human Oil with the props made out of babies and baby corpses. In the former piece, the pair respectively injected Ioo milliliters of their own blood into the mouth of a specimen of Siamese twins, which was propped up in between the two artists, with its knees bent in a medical porcelain plate on a white low table. Because the specimen wasn't able to take in much blood, much of the injected blood dripped all over the specimen's body. The scene was stomach-churning. Human Oil presented an even more blood-curdling performance: during the performance, Peng Yu sat on the floor, holding a baby's corpse in one his arms and suckling the baby with the other arm with a tube that was connected to a huge bottle. And what the baby was suckling was human oil. In a screen attached to the wall shows the process in which the two artists cut, boiled and stirred the human oil in a sizzling pot.

Between the November 4 and II of the same year, a controversial contemporary art exhibition "Fuck Off 2000" ("Uncooperative Attitude" in Chinese), curated by Ai Weiwei and Feng Boyi at the Eastlink Gallery in Shanghai. 48 artists took part in it with Yang Zhichao, Wang Chuyu, He Yunchang, Zhu Ming, and Feng Weidong performed action art impromptu. Yang Zhichao performed Planting in which he had a doctor plant grass on his shoulder blades without anesthesia. He must have endured such excruciating pain that his wife burst into tears while watching him perform. Just a month before, he had just performed another piece Branding with the same degree of self-harm. In Branding, Yang heated the branding iron with his ID number red hot and applied the brand to his back without anesthesia. The piece was documented with photographs which were exhibited at the exhibition. As to Zhu Yu's piece Eating People was deemed far too violent to exhibit in any form and can only be listed in the exhibition catalogue. The series of photographs document the entire process in which the corpse of a 6-month-old baby was seen to be cleaned, cooked, and eaten by Zhu Yu. The work is unappetizingly distasteful.

Apart from these, in the same year, cases of animal abuse were done in the name of action art. 
The sudden emergence of extreme violent action art had crossed the moral and legal line the Chinese society could tolerate and fueled furious antagonist criticism from all sides of the society, including the academic world. On January 28, 200I, an article "In the Name of Art: Endgame of Chinese Contemporary Art," byline by Yang Yan, appeared in Wen Yi Bao (usually translated as Literature and Art Newspaper or China Literature and Arts Gazette), in which drastic and violent performances such as self-harm, sucking human oil, eating dead babies, and animal abuse are condemned. The author points out: "No matter how progressive the action art is, it should not cross a certain line, which is the ground rule of arts, the borderline between art and non-art. Of course the lines of socially-accepted morality, of laws, of humanity and of public interest shouldn't be crossed in the name of art either." Later on, magazines such as China Society and Art, following in Wen Yi Bao's footsteps, published a series of articles to analyze and criticize this type of action art. Most critics unanimously took the stand against pieces that had gone into the extreme violent end.

Due to the strong backlash from all fronts, in April 200I the Ministry of Culture issued an official announcement which was the first and one of the few official injunctions against artistic creativity. sternly forbidding the performance or exhibition of scenes of gore, violence and obscenity in the name of art. Undoubtedly this announcement worked and put, to a degree, the prevalence of increasingly violent action artworks to a stop.

Apart from the pressure from social criticism and governmental policies, action art has been under the unstoppable sway of commercialization of and commodification of artworks. When the art market continues to venerate works that have been on the market and paintings' prices have skyrocketed while action artworks lack market value, the fever for action art at this junction has been cooled off.

While the first generation action artists were backing out one by one, $\mathrm{He}$ Yunchang can be said to be headstrong in standing his ground. Since his 1999 piece Dialogue with Water, He began his steadfast devotion to action art, whose themes are invariably expressed in all forms of self-harm. On August 8, 2009, he surgically took out a rib of his own; in 2009 the rib was made into a necklace laced with 400 milligrams of gold, titled One Rib (Night Light). And in 2013 He's work The Sea Water of Venice was exhibited at the China Pavilion of the 55th Venice Biennale. Although The Sea Water is a relatively moderate piece of interactive action artwork, He Yunchang is the first Chinese action artist whose work was shown at the Venice Art Biennale.

Chinese action art appeared on the wane as the 2ist century marched in. Although not lacking in number, this type of art form has weakened in its force and reduced its impact on the society. Therefore, among the great number of works, merely a handful has made an impression on the audience.

In $2007 \mathrm{Ai}$ Weiwei executed his piece Fairytale at the I2th Documenta exhibit, which is probably one of the most well-known piece of action art in the new millennium. Ai started to recruit a "fairytale army" by posting announcement on his own blog from February of that year. And on July 17 of the same year Ai ar-

618 ranged to fly this IooI-strong team to attend the art exhibition in the birthplace 
of the Grimm fairytales and footed all the bills that included accommodation, food, and transportation. The bills ran up to 3 million euros. However, such expensive group journey is more of a shallow everyday event than action art which is supposed to transform people's temporal-spatial existence.

Li Binyuan is a new kid of the Chinese art block in recent years. On March 20, 20I3, he initiated a performance where he ran naked around streets of Beijing with an inflated doll and a cross in the wee hours, which he repeated ten times. Because the video went viral on Wechat, Li Binyuan became an overnight sensation on internet and was dubbed "Naked Runner Bro" by the Chinese netizens. As opposed to the works by the previous generation action artists, this post-' 80 young artist's Running Naked can only be seen as something rather mundane, formulaic, and harmlessly "refreshing." In other words, Li Binyuan's action art reflects the change in trend and in taste as Chinese contemporary art is going through a paradigm shift.

\section{Values and Reflections}

When we survey the history of action art's development since 1990, we grasp the characteristics and the essence of contemporary Chinese action art.

In the West, action art is on the dual mission of subverting the received rules of art and challenging the existent social systems. However, in China action art does not have a concrete, specific antagonist and therefore there hasn't been the likes of Yves Klein's Anthropometry: Princess Helena and Joseph Beuys's How to Explain Paintings to a Dead Hare, the kind of action art that reflects upon art's inherent nature. Only if we stretch a point can works such as Huang Yongbin's 1987 action artwork, The History of Chinese Painting and the History of Modern Western Art Washed in the Washing Machine for Two Minutes (exhibited in the form of installation at China/Avant-Garde Exhibition), Huang Yan's Chinese Landscape Tattoo (1995-1999), which covered the artist's entire torso and arms with traditional Chinese landscape painting, and Zhang Chan's human calligraphy in Marvelous Traces (1996-2002) be considered works that examine the ontology of art. However, these works do not fit directly into the context of contemporary Chinese art. In effect, the main issues with which the Chinese action art is confronting are ethical, moral, and legal regulations. Therefore, action art naturally forms a system that opposes the established social rules. We see that the motivation and purpose for the birth of Chinese action art is to subvert the orthodox rules; such attitude of Chinese action art is met accordingly with the Chinese government's suppressing management. The matter of utmost importance is that action artists tend to square off against the establishment through means of self-harm and the effectiveness of such means comes down to the social nature of human beings and individuals being members of the given society, thereby harming the self implies harming the society at large. Judged from a certain perspective, the greater intensity of violence seen in action art is the direct outcome of the increasing division between the artists and their society. That division has formed a vicious circle. Whether the artistic action works as a means to give expression to some spiritual angst or the struggle against social 
confinement, the artistic expressions all end up being an end to injuring oneself in action art. In other words, for the Chinese action artists, the body has become a scapegoat.

Action art hasn't really been allowed an easy condition for its existence and development in China because of social opposition. To a certain degree, the distorted condition of Chinese action art ties in with its stringent and harsh environment in which it strives to survive. We see that for the longest time only a handful of action artworks have been performed impromptu at most of the contemporary art exhibitions held at home. Instead, most of the action art has been presented to the audience in the form of photographs. Such an exhibition form to a degree dampens the sense of immediacy of the art form because the presence of as well as the interaction with the audience is not just part and parcel of action art but also a requisite for its effectiveness. For the audience, seeing the photographs of action art is like seeing film stills; they can glimpse at a partial and fragmentary picture of the entire work. The fact that action art can only be presented through the aid of photography and videotaping, or the symbiotic relationship between the arts of photography and video and action art, reveals the struggle of action art's survival.

The media plays a critical role in action art's effectiveness. However, the publicity generated by media is a double-edged sword for action art. People are aware of the fact that action artists cannot have held sway without the media publicity; however, the media tends to report only on the cheap, sensational, and scandalous side of the art to grab the readers' attention. In truth, some of the extreme behaviors are the blown-up upshot of the media's wide publicity. On the other hand, the kind of action artworks which look deeply inwards in a relatively moderate form are cold-shouldered by the media. Objectively speaking, non-violent action artworks take up the bigger proportion of the art from but the media consistently reports only on one end of the spectrum, which leaves the public an impression that all action artworks comprise of violent behaviors.

Regardless the forms in which art takes, the means are merely a secondary component of the artistic value. The final judgement of art lies in the work's content. Even when we compare different action artworks together, not all pieces are equally praiseworthy in their artistic expression and meanings. Like other fields, Chinese action art is not exactly a place of utopia, pure and simple. Undoubtedly, being an uncharted artistic territory, the norms of action art can be a mixed bag of the good and the bad, the superior and the inadequate. There are many talented artists in this field who are serious about their art as well as opportune crowd-pleasers who go for fame and success. Those fame-hungry opportunists are courted by the media and the public who are after the abnormal, and bend over backwards to create sensational scandals. However, the academy is capable of distinguishing those who actively search for the good and the spirits of humanism without courting fame from those who aspire to fame through rapping only about the mean, the dark, and the evil side of humanity. Eventually time will testify to the true value of good works and separate the wheat from the chaff.

We know that action art is up against officially decreed exhibitions, the prac620 tice of art collection, and the economic model of commodification. In other 
words, action art is supposed to challenge the process of commercialization. In effect, the high point of Chinese action art's production and development is also the period before the waves of marketization and commodification of Chinese artworks. This historical fact reveals that the early generation of artists didn't aim to make a profit out of their creativity. Instead, it is the emerging phenomenon of marketing and commodifying artworks that drives many action artists back to putting their works on the market. This trend further brings the development of action art to a standstill. And very few artists have seen themselves to be heir of action art.

After the 1990s, the development of Chinese action art has been arrested from this previous blossoming. This shift can be the corollary of external factors of the given socio-economic and political conditions but is also the natural upshot of art's internal laws. During this period of time, numerous artists and the quantity of their artworks have proved their prestige to the world. People now recognize it in opposition to other forms of art. In the development of Chinese contemporary art history, action art is a tradition that goes farthest and has the most profound impact when it comes to fighting for artistic freedom and broadening the artistic border. No matter what, action artists have made a tremendous contribution to the development of Chinese contemporary art. 


\section{艺术史 : 趣味、图像与身份一从何多苓 VS 怀斯到 王广义 VS 沃霍尔两对个案看艺术的出发点与针对 性对艺术史书写的作用 \\ 吕澎}

\section{前言}

对于今天的美国人来说，I607 年 5 月 14 日和 1776 年是两个关键的 时间点, 前一个时间在美洲出现了 I8O 名移民者, 后一个时间是《独 立宣言》的诞生, 尽管之前就存在着印第安或者土著美洲人的艺术, 但是, 我们今天所说的美国文化, 或者美国艺术, 产生于这两个时 间之后。可是，基于第二次世界大战之前美国艺术家深深地受着欧 洲艺术的影响（风格、语言、手法等等）从最初用新古典主义的 手法描绘历史绘画来宣传美国社会的政治文化到接续欧洲现代主义 用抽象艺术风格表现自由的美国社会，因此，在什么是美国艺术史? 或者如何评估美国艺术的历史身份与价值上，能够为我们书写 20 世纪中国艺术史遭遇的问题提供参考。的确，中国拥有五千年的文 化历史，但是， 1500 年之后，不断有欧洲人到达亚洲和中国沿海 地区，进而进入中国内陆，以致在 19 世纪后半叶，欧洲艺术对中 国的影响涵盖宫廷和民间，在 20 世纪的初期和后期，欧洲（文艺 复兴以来的和现代主义及其之后的）与美国艺术（主要是二战之后 的）对中国艺术影响不断，这也给中国近现代艺术史研究者提出了 挑战: 新艺术与几千年的传统艺术之间具有什么样的历史关系?什 么是中国的 (而不是欧洲的) 现代艺术或者当代艺术 (不是美国的)? 如何把握 20 世纪中国艺术的历史书写所遭遇的影响与身份问题。

文明之间产生相互影响的原因是复杂的，尽管形式、语言或视 觉方式是艺术史研究中极为重要的部分一在 80 年代很长一段时间, 里德 (Herbert Read) 的《现代绘画简史》 ( $A$ Concise History of Modern Painting) 对视觉方式的阐述给中国艺术家和批评家以深 刻的印象和影响 ${ }^{1}$, 但是, 90 年代后现代主义和新史学观念的影响, 
改变了人们的历史观和艺术史观，趣味以及图像所唤起的相似性和 差异构成了艺术史书写的一个重要部分。的确，发生在特定时期的 相似性通常有其自身的原因，艺术家的出发点与问题的针对性往往 构成了趣味与图像的差异和自己的文化身份，并影响着我们对趣味 和图像体制中的差异性解释。由于不同国家与地区的历史状况，艺 术史的写作远远不应该局限于图像传统与体制的分析，所谓风格、 语言、视觉方式，在不同的语境下因出发点和问题的针对性会构成 完全不同的文化身份，并应该是今天更为富于学科性的全球艺术史 书写中需要关注的。

在 20 世纪不同时期，我们都能够找到中国艺术家与美国艺术家 之间有艺术史价值的案例，例如早期的李铁夫、冯钢百，这两位世 纪初的中国画家在美国的艺术经历以及归国后的影响可以看成是 19 世纪末以来中国大陆艺术家向西方学习西画的早期范例。在 20 世纪的后端，美国艺术与中国 1978 年之后发生的艺术现象有更为 复杂的关系，例如 80 年代中期，劳申伯（Robert Rauschenberg, I925-）在北京中国美术馆举办了自己的展览，对中国当代艺术产 生了直接的影响。

本文选择了两位在中国当代艺术史中具有不同艺术特征和历史 影响的艺术家何多苓与王广义, 将他们分别与怀斯和沃霍尔进行分 析，讨论基于影响、语境、图式、文化背景之上不同的艺术出发点

第一章“现代艺术的起源” (The Origins of Modern Art) 里, 作者写道: “整 个艺术史是一部关于视觉方式的历史。关于人类观看世界所采用的各 种不同方法的历史。” (The whole history of art is a history of modes of visual perception: of the various ways in which man has seen the world.) 在中国读者来说，这句话有两个角度的启发，一是我们要改变曾经观看 世界的方式，二是我们的艺术语言的形式必须发生改变。基于特定的历 史语境，这种启示是很容易理解的。可是，人们不断地问 : 继续使用那 些已经被欧洲现代主义者（古典主义者）创造出来的语言形式，究竟是 否意味着 “视觉方式” 的改变?中国艺术家难道没有自己的 “独创” ?到 了 80 年代后期, 贡布里希 (E. H. Gombrich) 的著作《艺术的故事》(The Story of Art ) 开始对这个时期的现代主义艺术家产生影响一参见后面 “王 广义VS 沃霍尔”。进入 90 年代, 艺术家和批评家开始理解后现代的复制、 挪用等手法的作用。 
和复杂的问题针对性，找出发生在 20 世纪不同国家与地区表面近 似而目标不同的艺术价值, 为全球艺术史书写的出发点和视野提供 研究案例。

\section{何多苓与怀斯}

“《春风已苏醒》（图 I）是我研究生的毕业创作，开始时我并没有打 算那样画, 草地先有了, 里面主要人物一开始是知青, 后来变成农 民，决定最终画法的是，当时《世界美术》封底一幅安德鲁 - 怀斯 的画《克里斯蒂娜的世界》(图 2), 那张画让我一看就有一见如故 的感觉，我觉得我就应该这么画。当时，油画是没有那么画的，但 是我没管这个，不仅用了怀斯的笔法，而且画面改成农村小女孩衣 服的细节等等，这在当时是带有颠覆性的。它奠定了我最初的绘画 风格，这种风格对中国新美术的发展也带来很大的影响。”

何多苓提及的《世界美术》是 $198 \mathrm{I}$ 年第 I 期，该期刊登了赵毅 衡介绍美国画家安德鲁·怀斯 (Andrew Wyeth) 的文章, 配图中有 《克里斯蒂娜的世界》这件作品: 这是一幅高视点构图的作品, 描 绘了一位残疾的女孩一他的邻居，半卧在倾斜的草地上，仰望着山 坡上的房子。无论画家最初的意图是什么, 主题也许就是茫茫荒草 上的孤独。笔法细淢，气氛忧伤……但是杂志中的图像印刷质量非 常低劣, 与今天的画册比较起来, 那不过是一个色彩不准确的图像 信息，却引起了中国画家何多苓的 “震撼”。

何多苓在成都画院绘制《青春》（I984 年）期间, 我曾拜访过他 的画室, 在沾满颜料的椅子上放着一本印刷精良的怀斯画册, 不过, 经过无数次翻阅，画册上也滴上了油画颜料和应该是沾有颜料的手 触摸翻阅的痕迹, 显然, 这是何一边绘制作品一边不断翻看画册的 结果, 的确, 直至这时, 怀斯还是何多苓完成自己的绘画风格的参考。

早在进入四川美术学院学习之前, 何多苓已经是成都这个西南 中心城市里具有光芒的画家, 年轻的艺术爱好者与朋友经常围绕着 他, 他一边拉着手风琴, 一边谈论绘画、音乐与文学。1 977 年之前, 如果不是特殊的原因, 人们对 “国外” 的文学艺术大致限于俄罗斯, 限于契科夫、托尔斯泰、列宾、苏里科夫等等，直至 1978 年之后， 
虽然已经可以翻阅巴尔扎克、雨果和狄根斯的小说 ${ }^{2}$, 相互转录巴哈、 贝多芬、拉赫玛尼诺夫、德彪西的音乐，但是，能够通过印刷精良 的画册看到印象主义及其之后的西方绘画，却是在 1979 年之后的 事情。不过，对文学、绘画与音乐的天赋理解，在这时已经将何多 苓训练为无需学院教师的教授就能够画得一手好画的年轻人，他提 前进入研究生的学习也正是这个原因。

在《春风已经苏醒》（1982 年）之前, 何多苓画了一幅《追穷寇》 (1976 年)，一位在国共内战期间的中共士兵正在墙上写下 “打过 长江去” 这个标语。这幅画用微妙的黄色调子一士兵的军服与黄色 的土墙以及整个构图的调子非常吻合一和细淢的笔触描绘了一个并 非战场中的战争情景。何多苓理解此时的官方艺术标准 : 主题没有 任何政治问题，在构思上 “以小见大”一个局部可以感受到千军 万马的存在，符合此时的艺术标准。可是，画家关心的是正被刷上 白色口号凹凸不平的土墙肌理、战士身上被烟火和时间蹂躏过的旧 军服以及地上四处都能见到的子弹壳，那些到处可见的真实细节所 唤起的逼真 “趣味” 引起了观众的兴趣。陈述这个事实想说明的是, 在十年 “文革” 的尾声，何多苓没有顾及 “红光亮” 的标准，他将 构图的整个调子控制在黄色上，不过是满足自己的色彩趣味而尽量 躲避官方的风格要求。 ${ }^{3}$ 实际上, 之前他对国外和西方文艺有了 “鬼 鬼崇崇” 的了解，在他的艺术能力上已经培育了对真实的关注，一 旦有机会，这种关注就会通过具体的形式表现出来。何的个性不允 许被无关于自己的内心需要而被强加任何要求一 1976 年中国政治 局面的变化刚好给予了他这种个性发展的可能。早年，何多苓的绘 画技法主要受俄罗斯巡回画派的影响，也许他朋友保留的不少画册

2 何多苓说他是在进入成都师范学校美术班之后阅读雨果、巴尔扎克、狄 更斯、契科夫和托尔斯泰的 (参见何多苓:《在绘画上我从来没有撒过谎》, 载《天生是个审美的人》，三联书店，20II，第 I55 页)。

3 为了表现真实的视觉效果, 何多苓甚至找了一面土墙, 将 “打过长江去” 的字写在墙上，照着临摹，以便可以将刷在墙上的字在最后完成的创作 中画得很真实。而这样的画法是不同于 “文革” 要求的，属于资产阶级 的 “自然主义”，因为画家没有将日常生活的内容提高到一个符合标准 即所谓 “革命的现实主义与革命的浪漫主义相结合”一的层次。 
或者还没有被 “文革” 毁掉的印刷品使他多少了解一些欧洲绘画 ${ }^{4}$, 无论如何, 对画册的翻阅所唤起的天赋能力, 使得何多苓很早就能 够驾驭油画的趣味，保持对绘画的敏感性。

人们谈及怀斯对何多苓的影响, 的确, 按照何多苓的说法, 也 许是怀斯作品中的草地成为《春风已经苏醒》的诱因，I988 年，当 日本福冈美术馆为何多苓举办个人展览 “中国一现实主义的深层” 时，艺术家本人写了一篇回顾性的自述，其中，他提及到了他早年 在大凉山的经历 :

1969 年冬天, 在四川西南部大凉山无边无际的群峰之间, 我躺 在一片即使在严寒季节也不调零的枯草地上，仰望天空。十年后我 才意识到, 就在那无所事事、随波逐流的岁月中, 我的生命已被不 知不觉地织入那一片草地。

他承认 “那片草地被我画在《春风已经苏醒》这幅最初的作品中, 在被一种盲目的狂热所驱使的苦心经营中，我逐渐找到了自己。 5

4 尽管 1949 年以来在历次政治运动中都会不同程度地出现对欧洲和民国 时期的文化艺术的批判和对实物的销毁, 但是, 一些旧的印刷品和书籍 仍然藏于私人家庭。何多苓谈了他早年在朋友朱成家里看到的画册和散 落的印刷品，其中，前苏联的《艺术家》杂志介绍了不少欧洲艺术，其 中包括东欧社会主义国家例如罗马尼亚、捷克斯洛伐克, 也有欧洲从中 世纪艺术到法国的古典艺术和印象派画家的介绍。在西方音乐方面的知 识也是如此：但是真正喜欢上可以称之为 “音乐” 的还是在 “文革” 期 间。那时我还住在川大, 我们一些半大的孩子经常在一起玩, 有一个同 学的母亲是音乐学院的, 他们家里有大量的唱片, 是当时所谓的 “密纹” 唱片，78 转的，还有一个唱机。那时他的父母都到 “五七” 干校去了, 所以我们就经常去他们家听那些唱片。在那个时代, 你知道, 听唱片基 本上属于非法, 因为那属于资产阶级艺术, 如果被抓到的话, 至少是被 没收唱片。我们当时对此完全不管, 当然也不敢把声音开得太大, 就觉 得跟在搞地下活动一样, 很有趣。那时听的音乐, 确实给我留下了非常 深刻的印象，比如莫扎特的《弦乐四重奏》、贝多芬的几个著名交响曲、 里姆斯特 - 科萨科夫的 《天方夜谭》, 还有德沃夏克的《自新大陆交响曲》 等等 (参见何多苓 : 《在绘画上我从来没有撒过谎》, 载《天生是个审美 的人》，三联书店，201I，第 165-166 页)。

5 何多苓 : 《关于我所热爱的艺术》, 载《天生是个审美的人》, 三联书店, 
显然，怀斯的《克里斯蒂娜的世界》画中的草地本身成为何多苓早 年记忆的诱因，那片草地本身是早年情绪与感受的象征，因为它是 在 “无所事事、随波逐流的岁月” 中被无意识织入何多苓的内心的， 草地连同情绪基因一直深深地隐藏在何多苓的潜意识里，等待着某 个时候的唤起，再次浮现于可视的世界。“找到了自己” 是一个非 常关键的句子，这个表述具有普遍性，从 70 年代末开始，整个 80 年代的年轻人的共同愿望之一就是 “寻找自己”。所以, “寻找自己” 是这个时期普遍的内心需求，既然在已经有的艺术样式和表现中难 以找到自己，所以，从 1979 年以来的西方艺术任何风格与语言在 中国的出现仅仅是不同的 “自己” 试图从无意识的大海底跃出海面 在趣味与图像上的 “艺术” 诱因。就在 $\mathrm{I} 98 \mathrm{I}$ 年的某一天，当《克 里斯蒂娜的世界》出现在何多苓的眼前时，使得他恢复了记忆，他 改变了一开始的草图设计，直至他准备完成的作品接近他朦胧而充 满欲望的感受。可是，什么是自己要在画中实现的感受?正如艺术 家坦然承认的那样，“那张画让我一看就有一见如故的感觉，我觉 得我就应该这么画”。“草地” 在没有出现于构图中之前，不过是个 概念而不是艺术形象，最多是还没有语言化的想象与记忆这类精神 活动。事实上，是怀斯细淢的技法使得作品里的草地唤起了何多苓 感受和记忆中的草地，至少怀斯画中的草地与早年记忆中的草地多 少有些相仿, 而最重要的是, 这个草地带动了 “仰望天空” 的感受, 进而无疑带动了对那个由时间与环境和经历构成的岁月的记忆。为 了呼应这样的感受，防止被具体的对象干扰，他甚至将当初设置为 “知青” 的人物改成一个小女孩, 人物的历史身份被尽可能地弱化一 艺术家仅仅想保留他记忆中的一种抽象的感受。可以说, 将 “知青” 改为小女孩，是何多苓最早的抽象意识的表现，他从一开始就强调 的是内心感受而不是像他的同学高小华、程丛林那样的方便叙述的 历史事实。

无论是怀斯还是何多苓，他们都没有否认自己作品中情绪的重 要性，对于生活在中国内地城市的何多苓，“安静”与 “冷漠” 的 感受首先来自自己的经历。在 1969 年到 $197 \mathrm{I}$ 年期间，对一个出生 
于普通知识分子家庭的年轻人来说，大凉山既意味着枯燥与贫痊， 也意味着安静与冷漠，在这个时代，他的经历与大多数 “知青” 一 样没有任何特殊性。1972 年，何多苓回到成都开始了对绘画的认 真学习 (成都师范学院), 天赋与敏感性被专业训练进一步诱发出来, 这就是为什么他能够在 1976 年完成一开始就给人深刻印象的《追 穷寇》的原因。从 1972 年全国美术展览得以恢复，由 1966 年开始 的严酷的无产阶级 “文化大革命” 所带来的放弃技术甚至智性的绘 画倾向开始停息，艺术界的 “文艺工作者” 似乎有条件表达对油画 技法的兴趣与实践。所以, 当何多苓进入成都师范学院学习绘画时, 他多少获得了研习技法的可能，这为四年后完成《追穷寇》提供了 技术上的条件。可是，无论是俄罗斯绘画还是苏联绘画在中国的影 响, 都表现出并不精细的笔触, 而苏联绘画的方块笔触一马克西莫

61972 年 5 月 23 日，“纪念毛主席 “在延安文艺晚会座谈会上的讲话” 发 表三十周年全国美术作品展览”在北京中国美术馆开幕。这是自 1964 年最后一次全国美术展览以来所举办的第一次官方展览，这个为时两个 月的展览有包括国画、油画、版画、年画、宣传画、水彩画、剪纸等多 种艺术形式的 270 多件作品。展览中, 唐小禾的《在大风大浪中前进》( I97I 年)、陈衍宁的《毛主席视察广东农村》、张自嶷、蔡亮、湛北新合作的 《毛主席在大生产运动中》、吴云华表现工矿环境的《毛主席视察抚顺》 作品中都表现出对造型与技法的重视。这个时期，尽管存在着符合政治 意图的艺术标准, 但是, 人们能够看到, 画家因自己的思想与感受的特 殊性，总是在绘画趣味上也不时表现出个人的特征，尽管这样的表现通 常是微妙的和不宜宣扬的。例如 “辽宁省宣传馆美术创作组”（实际作 者是吴云华）的《虎口夺铜》因为其对细节和逼真性的强调获得了评委 的一致认同，这件以 “抓革命，促生产” 为主题的画具有明显的政治基 调。但是, 观众总是要被发光的安全帽、结实的脸庞以及从石㖓落下的 水滴所吸引。潘家峻的《我是海燕》给观众的印象是接近逼真的风雨和 湿透的军服体现出来的人体。汤小铭的油画《永不休战》正是因其技巧 上的表现和色彩上的灰调子的运用给人留下深刻印象。在普遍采用过分 强烈的色彩和模式化构图的作品泛滥的时期，他们在汤小铭的 “鲁迅” 中看到了更加符合人性的色彩与气质。70 年代中期，广东画家的技法 构成了一个微妙的美学倾向 : 涃熟的造型、波酒的笔触、接近真实的色 调以及退出重大题材的构思，例如陈衍宁于 1974 年完成的《渔港新医》 中特殊的构图和衣褶的笔触趣味成为不少年轻的画家模仿的典范。 
夫 50 年代在中国的教学强化了这个表现手法一在很长一段时间里 构成了画家们追求的方法与趣味。在《追穷寇》里，流行的方块笔 触虽然仍然存在，不过，为了追求视觉真实的效果，何多苓不仅将 他的方块笔触弱化一以便塑造更为符合视觉感受的形象与细节，还 将笔触的面积降低到尽可能小的程度。那时，在成都学习绘画的年 轻人经常会从他们的老师那里听到 “宁方不圆”（最早是徐悲鸿给 他的学生们的口诀之一) 的教导, 以致 “方笔触” 本身就是一个普 遍重视的趣味一在何的同学周春芽曾经就读的成都五・七艺术学校 里, 即便是石膏素描也讲究排线构成的一个小块面, 这些小块面透 气而充满活力, 以致成为学生中间流行的趣味。可是对于何多苓来 说，这个趣味或者方法难以表现出他的感受，直至他从怀斯那里看 到了另一种技法、这种技法的视觉效果以及由此感受到的情绪。图 像对心灵的影响或者对人的大脑皮层的刺激究竟会怎样地因人而 异，至少对于何多苓来说，怀斯的技法让他产生了趣味上的共鸣。 这个共鸣的结果是 : 十多年前的感受和记忆在突然出现的图像面前 于内心复活了，同时，他有能力去理解那位美国画家的技法，最终 完成了一件符合自己当初意图的作品。之前, 尽管他已经有了草图, 但是，还缺乏具体的表现方法，现在，怀斯作品的趣味以及产生的 心理效果，在何多苓内心诱发了一个唤起，一旦这个趣味得到了内 心的认可，剩下的就仅仅是技法的运用与效果的实现，而这对于天 赋足够的何多苓来说，通过学习一种新的技法来达到自己的目的并 不困难。但是显然，何多苓仅仅是遭遇了一个契机，他的目的不是 复制怀斯，当然更不是想描绘一种异国情调，而是 “潜意识中被青 春时代固定下来的力量如此顽强地控制了手（而不是大脑），使绘 画的过程身不由已” (何多苓)，为了完成心中的效果，画家使用了 中国的小楷毛笔去富有耐心与天赋地勾勒那些无尽繁杂的小草，最 后产生了一幅让那个时代的人普遍受到感动的绘画。也许出生于 $70 、 80$ 年代之后的人难以产生他们前辈那样的感动, 那是因为他 们已经远远脱离了彼时的语境: 就在昨天，人们还相互怀疑、厮杀， 人性已经被政治和意识形态的概念完全掏空，感情也完全被涂上了 阶级的色彩，如果不同意这样的标准，艺术家肉身的存在都会成为 问题。在 1979 年的一组题为《枫》的连环画里，就描绘了一对恋 人因非人性的政治理论而最终成为 “敌人” 并死在恋人的枪下的故 
事。因此，当 1978 年之后官方允许人们对之前的 “文革” 给予控 诉的时候, 就出现了像何多苓的同学高小华的《为什么》、程丛林的 《I 968 年 $\times$ 月 $\times$ 日雪》等等一批对刚刚过去的历史的质疑与控 诉的作品。只是, 对于何多苓来说, 俄罗斯和苏联绘画的文学性也 许并不重要, 因为艺术家要讲述的是感受本身, 而不是触动感受的 事件。因此，何多苓选择的构图就既不是描述俄罗斯画家那样的文 学故事一就像程丛林的 $《 1968$ 年 $\times$ 月 $\times$ 日雪》对苏里科夫的效仿, 也不是表现库尔贝 (Gustave Coubert) 所说的 “眼睛看到的” 就像陈丹青的 “西藏组画” 对法国 19 世纪画家的效仿，而是像怀 斯那样提供一幅难以理解其内涵的图像世界, 尽管画中有时间、空 间、人物以及环境，但是，观众并不能够知道画的具体意图，或者 艺术家就没有给出任何意图, 仅仅是他的感受与工作结果而已一而 这样的出发点与现代主义是一致的。再次强调, 何多苓将最初考虑 的知青改为农民女孩, 就是他尽可能地消除绘画的说明性和故事性, 将感受放在首位的一次努力。的确，标题 “春风已经苏醒” 让人们 倾向于理解政治气候的变化, 可是, 女孩含糊的表情与整个构图的 感伤空气究竟意味着什么?这样的处理方法将何多苓与他的同学们 区别开来了。

的确, 有人说何多苓是怀斯的模仿者, 何是这样回复这个判断的:

一点也不错, 我的确很喜欢这位 “伤感的现实主义者”, 并且试 图模仿他。我喜欢怀斯那严峻的思索, 他那孤独的地平线使我 神往。此外, 虽然评论赋予他以浪漫情调, 但他却是更加理性 和哲理化的，他的手法更为客观、精确。 ${ }^{7}$

80 年代是西方现代主义在中国大行其道的时期，批评界习惯于用 “在短短的十多年里将西方现代主义各个风格流派都实验了一遍” 来评价这十年中的艺术现象。然而, 至少对于何多苓来说, 西方现 代主义提示的艺术语言或者形式的变化本身根本不是他关注的目

7 何多苓: 《关于〈春风已经苏醒》》, 载《天生是个审美的人》, 三联书店, 2OII，第33 页。 
标，相反，他对选择的过分自由给予了警惕。I 988 年，他明确表示 了自己如何在创作的过程中找到自己的艺术的边界，而不被太多的 可能性所诱惑。斯特拉文斯基关于艺术自由来自限制的看法让何多 苓倍感赞同，他说：“对 “自由”的滥用正是当代艺术贬值的原因 之一，而严格的自我限制是使一个真正的艺术家获得真正自由的唯 一手段。” 8 简单地说，与其他一些现代主义热衷者不同，形式并不 是何多苓的出发点。

也许我们可以把何多苓视为一位绘画原教旨主义者，不过对于 艺术家为什么要坚持绘画艺术的思想，我们需要厘清。作为一位敏 感的艺术家，何多苓显然会根据自己的气质对现代主义的不同风格 进行研究，他甚至对库尔贝以来的西方不同流派的绘画都进行过分 析。在 “关于我所热爱的艺术” 一文里, 他说现实主义 “繁琐不堪”, 超现实主义是 “廉价的罗列”，波普艺术是 “业余的游戏”。在 1989 年写的一篇文字 “信念一人的自然与自然的人” 里，他干脆认真阐 述了对印象派以来的绘画的看法。他有一个基本的判断：“绘画没 落了。最有悲剧性的是，它是在这样一个充满狂暯式的革命动力和 具有前所未有的多样流派的时代走向灭亡的。” 9

何多苓对印象主义及其之后的现 代绘画的分析与评估所使用的 语言和具有的洞察力，超越了同时代不少中国批评家，这里我们可 以通过引用画家的文字来了解他的艺术思想究竟关注的是什么：例 如针对印象主义，他这样写道 :

20 世纪最伟大的变革始于一幅叫做《日出印象》的画。作为几 个世纪神圣艺术工厂的画室崩坉了。艺术涌向表象世界，在画 布上集聚起不可抑制的光的洪流。在这热情、贪婪、划时代的 淘金热中，古典主义的庄重晦暗的宗教被废除了，情欲取代了 理智。在雷诺阿笔下，艺术成为真正的享乐主义。

印象主义是带着香槟酒和大块的肥肉，乘着火车到自然中去的。他

8 同注 5, 第 I4-I5 页。

9 同上，第 I9 页。 
们是鲁茾的不速之客, 而不是园丁; 他们的践踏使乐园渐渐荒芜。 印象主义由于过度的感官享受和纵情狂欢耗尽了精力, 感觉因为经 常处于最敏感的状态而疲崽不堪。10

可是, 作为一位绘画的实践者, 何多苓可以非常具体地从绘画 的基本特征与要素去分析现代主义绘画与自己内心需要之间的关 系。他当然知道色彩之于印象主义者的重要性, 他清楚色彩 “似乎 纯粹为视觉存在的”, 可是, “对于我的艺术, 色彩, 是一个陷阱。 我越是被它吸引, 理智就越强烈地要求远离它” 11 。于是, 当他的同 学例如张晓刚、周春芽正在对印象主义和表现主义充满激情的时候, 何多苓对色彩采取了非常谨慎的态度一他并不选择节日般的色彩, 他甚至认为印象主义的色彩比古典主义更加物质性, 而物质性是何 多苓一开始就试图避免的。 80 年代, 塞尚、凡·高、高更成为启示 年轻艺术家的范例, 何多苓当然是这些重要艺术家的研究者之一, 可是, 他在分析的过程中, 发现的是自己的需求, 是与这些艺术家 之间的差异以及他仅仅需要的那部分 :

他（塞尚一引者）为他的理想牺牲了印象主义色彩的清新和视 觉上的亲切感, 并没有获得色彩的宗教式表情一古典的特征之一。 他的静物画是真正的光色生理解剖, 他却无法把肢解的面缝合起来; 他的山像摇摇欲坠的纪念碑, 一面宣告他的崇高理想的失败, 另一 面预示了更肆意屠杀一立体主义的到来，尽管塞尚本人是不同意那 后果的。

高更完成了色彩的浪漫主义升华。他把印象主义色彩从实证的 光学中解放, 从而宣告了新古典主义到象征主义色彩时代的开始, 这个时代的信念是, 色彩不仅仅服从于外部光源, 更接受内在的光 源, 即心灵的指引; 色彩的狂热并未在他那里冷却, 但已具备了某 些暗示、象征的规定性因素。12

实际上，在讨论这些艺术家的时候，他将他们视为印象主义色 彩的整理者, 基于这个论题, 他也将人们开始熟悉的马蒂斯引入了 讨论, 他说 :

10 同注 5, 第 19 页。

11 同注 5, 第 23 页。 
与高更一样, 马蒂斯在色彩中建立了秩序, 削弱了表面的紧张度, 在静态的平衡中建立了和谐。但这种和谐仍然是感官式的，只 不过更精致，是冰冷的瓷一般的表面 ; 他约束了印象主义的野 性的色彩分子，只是做成了一个适用于资产阶级市民懒洋洋的 审美目光的玩偶。 ${ }^{13}$

在讨论了那些西方艺术家的色彩之后，何多苓很坦率地说 :

我固执地对抗如下的教条（尽管这教条甚至来自我的内心），即 色彩是以 “强烈的” 和 “灰暗的” 来评定其价值的。我坚信, 与浓艳相比，苍白也是同样辉煌的色，正如黑夜之于白昼具有 同样的审美力度一只要它符合某种表现的话。 ${ }^{14}$

无论西方批评家是如何解释的，了解 80 年代中国现代主义运动的 人知道 : 这也正是不少艺术家用表现主义色彩的强烈与灰暗去覆盖 “文革” 艺术的鲜艳色彩的时期, 人们, 至少习惯于符号化地理解 “变 迁” 和 “革命” 的人们对 “强烈的” 色彩，或者 “灰暗的” 色彩运 用非常敏感，然而，这个时候的何多苓关心的却是自己更为微妙的 内心色彩，在他看来，对色彩的控制一避免大红大绿或者过分的强 烈以致影响了人们对构图整体和情绪的感受一是实现自己绘画的至 关重要的工作。与大多数现代主义的热心人一样，何多苓当然关注 了更多的艺术问题，他显然注意到了未来主义的口号 : 赛跑的汽车 比女神更美。但是 :

这种“画”出运动的努力不外乎：在具象绘画中，把画面复化 为数个相并列、可移动、可重叠的画面，它们以观者的视点为 轴心移动，运动中形体各部分在移动中被分解、叠加、相互渗 透和分离，实际上把视觉对运动的联想过程表象化了。在画面 上可以看到同一形体在梦游般的状态中的各个局部的痕迹 ; 这

13 同注 5, 第 23 页。

14 同注 5 , 第 24 页。 
种对运动外模仿的最直率的表现是一只八条腿的狗。15

何多苓分析了抽象画的形式特征，也提及到了 “光效应” 艺术所具 有的运动特质。不过，他还是说 “光效应” 艺术 “不过是装饰功能 的一个新花招罢了。” ${ }^{16}$ 对这些形式没有太多的兴趣，在详细地分析 了抽象主义不同特征之后，他表达了自己的形式立场：“我奉行一 种在抽象主义指导下的具象主义, 或者说是有具象外观与物质表现 的抽象主义。” ${ }^{17}$ 从何多苓的作品中我们可以看到画家的抽象含义究 竟是什么, 他通过无论是人物还是自然的轮廓线, 控制住构图的基 本结构，保持着不让观众掉进视错觉的空间里，在尽可能降低强度 的色彩呼应下，完成一种具象外观的抽象主义。

我累赘地引用何多苓的文字, 目的是想突出一个事实 : 即便在 上个世纪 80 年代, 中国才刚刚打开国门, 西方的思想与艺术像万 花筒一样展现在中国年轻艺术家的面前, 但是, 至少对于何多苓来 说，艺术语言的丰富性必须听从内心的安排，基于自己的经验的思 考、立场与出发点选择语言才是艺术家最关注的。 I98I 年 I 月，当 怀斯的印刷品（印刷的效果与原作相去甚远）出现在何多苓的眼前 时，这只是一个契机，不过是唤起了这位中国艺术家自己的个人经 验与绘画的出发点。正如艺术家很早就告诉我们：“四川省地形的 多样化与总体的封闭性构成了符合我的宇宙观的因素，在很长的时 间里, 我大部分作品的主题将来自在这片土地上的沉思, 或者不如 说，这片土地是我的观念赖以寄存的表现。” ${ }^{18} 1985$ 年，他到美国去 讲学，去看了怀斯的《克里斯蒂娜的世界》原作，“我发现《春风 已经苏醒》和它毫无共同之处”。尽管他于多年后图 3 何多苓《克 里斯蒂娜以后的世界》2010 的 2008 年以《克里斯蒂娜以后的世界》 （图 3）这幅作品向怀斯给与了有礼貌的致敬 ${ }^{19}$ 。

15 何多苓 : 《信念一人的自然与自然的人》, 载《天生是个审美的人》三 联书店，20II，第 26 页。

16 同上，第 26 页。

17 同注 15 , 第 29 页。

18 同注 5, 第 16 页。

19 在这幅 $150 \mathrm{~mm} \times 200 \mathrm{~mm}$ 的画里, 何多苓保持了怀斯的构图, 但更加 
我们知道，怀斯的艺术在他那个时代也饱受质疑，原因是与现 代潮流或者国际潮流缺乏联系。怀斯出生的时间是 1917 年，对生 活的体验与认识正好是联系着两次世界大战之间的 30 与 40 年代, 经济萧条与战争的到来，构成了这个时期美国的基本状况，人们的 心情受着艰难与悲剧空气的笼罩。在艺术领域，美国的艺术明显受 着欧洲风格的影响，立体主义和表现主义的风格仍然是一些艺术家 的范本。不过，用 Regionalism（地方主义）这个词概括的美国艺 术家虽然没有使用现代主义的语汇，却在欧洲风格的影响下开始了 美国风格的塑造。“地方主义”这个词汇多少让人觉得不入艺术史 的潮流，但是，正是这个时候的地方主义者，开始了真正的美国艺 术。这里的确涉及到了艺术史的观念与视角问题，按照语言和视觉 方式的判断逻辑，怀斯遭到不少同时期的批评家的否定或者嘲笑显 然是欧洲标准的结果。可是，之后的美国艺术史让人们看到：正是 托马斯·本顿（Thomas Benton）、约翰·居里（John Curry）、格 兰特·伍德（Grant Wood）这样的艺术家，创造出了美国的面貌一 自然、历史与人。因此，这些画家使用的写实手法因没有成为欧 洲现代主义影响下的一部分而在美国艺术界 “不入流”，不少采用 现实主义手法的艺术家甚至退回到格列柯（El Greco）、丁托莱托 (Tintoretto)、鲁本斯 (Rubens)，至于怀斯，则向丢勒（Albrecht Dürer，I47I-I528）、伦勃朗（Rembrandt, I606-I669）寻求艺 术的深刻的表现力，但是，他们为之后的美国艺术开启了可能性， 他们知道 : 对永恒的追求需要考虑自己的出发点, 欧洲大陆现代主 义所表现出来的形式诉求与此时的美国精神并不合拍。在很大程度 上讲, 正是对 “地方” 使用一种更为深入和细致的真实观察与感受, 使得美国的气质真正为艺术家表现出来并为人们所看到，进而让美 国的艺术家们渐渐意识到自己的发展路线究竟是什么 ${ }^{20}$ 。正如怀斯所

具有梦幻般的气氛，他在克里斯蒂娜原有的位置上画了一位站立的中国 女孩，她似乎是在寻找那位让人们不断追念的克里斯蒂娜。

20 事实上，在 19 世纪中期开始的对美国地貌与自然的关注并产生的风景 画，应该看成是最早的美国艺术，尽管像科尔（Thomas Cole, I80II848)、丘奇（Frederic Edwin Church, I826-1900）这样的画家使用的是 欧洲绘画传统，但是，他们描绘的哈德逊河（Hudson River）沿岸的 
说：是他熟悉的环境所呈现出来的 “虚无” 而不是大海, 构成了他 的艺术的主题。这样，怀斯从一开始就脱离了自然的物理外貌而表 现出抽象的精神。这呈现出当代艺术的一个重要的特点: 艺术的出 发点产生于对语境及其相关历史要素的感受与洞察之后。而确立自 己特殊的出发点，也正是何多苓这代中国艺术家的关键，尽管他像 怀斯一样，完全清楚欧洲现代主义的面貌，但是，从开始到最终， 他们都将艺术的目标指向自己的内心，按照 “内心需要”（康定斯 基 W.Kandinsky）来确定自己的艺术语言和样式。

的确，何多苓与怀斯一样，不是对物理世界的表面感兴趣，他 们同样是为了探究表现对象下面的问题, 是时代的精神气候一至少

风景（科尔）和类似《尼亚加拉瀑布》(Niagara Falls) 的壮观风景, 受 到了人们的关注与赞誉, 并带动了人们对美国疆土所持有的民族主义情 绪和相应的国家意识。显然，手法并不是美国画家创造的，但是题材与 对主题的宏伟渲染却是美国的。以后，霍默（Winslow Homer, I836I9IO）的绘画具有典型而鲜明的美国主题，虽然带有法国元素，却让人 们能够一眼就看出那就是美国人的气质。在 19 世纪最后的时光, 美国 人可以凭借蒸汽轮船任意航行, 很多画家可以在纽约、伦敦和巴黎来来 回回，尽管像萨金特 (John Singer Sargent)、卡萨特（Mary Cassatt， 1844-I926)、伊肯斯（Thomas Eakins, I844-I916）这些画家已经非常 熟悉欧洲的风格，不过，他们将注意力和关注点更多地是放在美国的生 活与特殊性上。我们不能因为萨金特使用了印象派的手法, 伊肯斯的语 言让人们想起库尔贝，就认为这些艺术家的艺术仅仅是对欧洲的拷贝。 实际上，美国 19 世纪晚期和之后的艺术家尽管深受欧洲艺术的影响， 但是，他们的艺术出发点和针对性与欧洲的艺术家完全不同。如果我们 关注到了这个时期的美国在工业与技术各个方面的成就，注意到了美国 资本的扩张与财富的渗透, 就不难了解到, 正是日新月异的美国生活本 身引导着画家们使用他们从欧洲学习而来的手法, 他们不仅与欧洲的艺 术保持着同步，也在试图通过自己的实践来深究美国的艺术。正是美国 艺术家对生活和内心的真实态度, 使得他们即便是采用了印象派的手法, 也经常表现出对写实主义手法的借用, 在 20 世纪初开始活跃的所谓 “垃 圾箱派” (Ashcan School) 的那些画家就是如此。之后的艺术史家不会 将这样的历史现象简单地表述为对欧洲的拷贝。在中国的 20、30 年代, 从欧洲回到国内的画家例如徐悲鸿、颜文樑与之相似, 即便对印象派的 方法颇为入迷的颜文樑，也是小心翼翼地控制着他的色彩运用。 
是艺术家自己以为的精神气候。为了实现这个目标，怀斯总是将构 图与空间处理抽象化，视角不是由下而上，就是由上而下，使得构 图陌生化，完全不同于一般写实主义的构图，以达到一种抽象的结 构。同时，他总是简化描绘的对象细节，例如《克里斯蒂娜的世界》 中房子与仓库之间的距离的调整，鸡笼和琐碎的树木被删去，怀斯 只保留他需要的对象，使构图简洁而不被物理世界所干扰，在并不 响亮、往往是灰色沉着的色彩帮助下，营造出一种迷茫与总是伤感 的气氛，这正好是怀斯的表现所针对的目标：世界的虚无。这样的 艺术态度与方法显然接受了现代风格比如说抽象主义的影响，琐碎 的现实被剔除和打扫干净，天空、大地、人以及仅有的现实象征物， 它们之间构成了一种并不是空洞的形式关系，这正是怀斯和何多苓 都想要的。1989 年，何多苓归纳出他的艺术创作的基本构思逻辑 :

我想画一个彝族少女站在雪原上。我需表现出她与这个原野之 间的来自同一本源的不可分割性。除此之外我什么也不知道, 我无须知道，譬如说她为什么站在那里，也许在等待，这一类 情节我是不需要的。我只需表现出那神秘。为了这个目的，我 使她的头转动着, 直到那一瞬来临我感觉到和谐产生了, 于是 我把这一瞬固定下来。我也无须说明这一和谐的定义以及它产 生的原因。我只知道，我叙述了一个无人知晓的故事，这个秘 密就包含在画面的寂静中。我将乐于和我的观众一起去寻找那 秘密，而且我知道，我们的答案永远不是同一个。难道还有比 这更令人欣慰的结果吗 ${ }^{21}$

所以，与怀斯一样，何多苓了解现代主义的手法与意义，但是，他 希望通过分析与归纳，在看上去熟悉的世界中找寻世界的抽象性， 他们从可视世界中希望获得的不是物理性的特征，而是潜藏于之后 的情绪。最终, 他们都想表现这个世界表层下深深的谜。在这方面, 何多苓与早年到美国学习的李铁夫和冯钢百的出发点和确立的目标 完全不同。22

21 同注 15 , 第 30 页。

22 李铁夫（1869-1952）出走异乡一开始是为了谋生, 就像那些早年留学 
需要简洁地归纳 : 正是感受与趣味的出发点, 使得何多苓在怀 斯的作品中找到了自己的开始; 正是语境与文化的差异, 让何多苓 与怀斯拉开了距离。有趣的是，在仅仅能够看到印刷质量不高的西 方作品的中国，何多苓似乎距怀斯很近；在能够看到怀斯原作的美 国，何多苓却发现了与后者明显的距离。而他们的共同点在于 : 尊 重各自的社会变化、文化背景以及内心的真实感受，这使得他们都 是成为艺术史特定历史时期章节的范例。

\section{王广义与沃霍尔}

的确，20 世纪初的美国艺术圈对欧洲现代主义推崇备至，但是， 美国人开始了他们雄心勃勃的创新计划。1913 年 2 月举办的军械 库展览成为美国在世界范围内的宣示: 在文化与政治方面, 美国 都具有及时的先锋性。1000 多件作品大多为美国艺术家创作的, 但是，欧洲的大师高更（Gauguin）、塞尚（Cezanne）、马蒂斯 (Matisse)、布朗库西 (Brancusi) 以及杜桑 (Marcel Duchamp, I887一I968）的作品仍然是人们好奇的焦点。三年后，在安德逊画 廊 (Anderson Galleries) 举办的美国现代画家论坛暨展览（Forum Exhibition of Modern American Painters）强化了美国艺术的重 要性, 就像展览目录说的, 展览的目的就是 “将公众当前对欧洲

幼童的初衷不过是寻求一个饭碗而已。大约是 1896 年, 李铁夫到了美 国。按照画家自己的说法，他在 1905 年至 1925 年期间是美国著名画家 切斯 (William Merritt Chase)、萨金特的 “门人”。从切斯 1916 年离世 到萨金特 1925 年去世的时间并不短暂，画家在学校不断获得各类奖项 以及对重要艺术活动和组织的参与表明他对油画的理解与掌握达到了炉 火纯青的程度。作为李铁夫在纽约美术学院的同学, 冯钢百 (I883-1984) 同样是在谋生的过程中获得机会留学的。冯钢百对光与色彩的理解让人 联想到伦勃朗。在美国，他看到过太多的西方作品与复制品 : 伊肯斯、 切斯和萨金特，而这些画家的真正背景是欧洲的写实主义传统。在那个 中国人还不熟悉写实绘画的时期，冯对他的中国学生强调的是物理空间 的真实描绘，他甚至对 “皮肤里面好像有血液在流动” 这样的视觉现象 更有兴趣。无论如何, 这两位早期油画先驱从美国画家那里学到的是如 何再现眼睛看到的世界，这样，绘画的方法与结果之缺乏特殊性是可以 想象的。 
艺术的注意力引导到对美国自己精彩作品的关注上来”一美国的 抽象绘画开始了，尽管这些美国艺术家显然受到巴黎潮流的影 响，但他们还是尽力说明对色彩与音符的理解是独立发生的, 例 如怀特（Stanton Macdonald-Wright, I890-1973）就声称色彩交 响主义（Synchronism）是美国艺术家创造的。抽象绘画引起了 不少的争论一中国 80 年代有关艺术的讨论也有许多相似之处，可 是，这种风格的出现意味着，在视觉艺术领域，是 “塑造” 而不 是 “反映” 美国社会的时代的到来。 40 年代，格林伯格（Clement Greenberg）在他的《论抽象艺术》里强调了绘画的纯粹性，然而， 正是塑造独特性的国家，使得我们认为关于语言形式的纯粹性的表 述显得太单薄，历史说明，即便是同样的图像体制一传统艺术史的 分析基础，基于出发点和针对性以及语境的不同，一种语言形式的 历史差异就有可能明显地反映出来。的确，30 年代的美国因为大 萧条而引发人们对现实的不满与质疑，人们对现实主义的叙述与批 判性手法产生了需求。正如本顿的绘画成为极具争议的对象一样, 批评界也警惕着左派批评产生的艺术导向。可是，大萧条的结束与 二战期间美国的发展，为世纪初开始的现代艺术提供了接续和充分 发展的机会，抽象表现主义出现了，不过，随着商品与消费的社会 发展，以及人们对抽象表现主义玄学的困惑，让人们一目了然，开 始以 “新现实”，之后很快以 “POP ART”之名的新艺术出现了, 主要成员有利希滕斯坦（Roy Lichtenstein, 1923-1997)、罗森奎 斯特（James v Rosenquist, I933-)、奥登贝格 (Claes Oldenburg, I929-）等，他们迅速让人们去拥抱和浸淫现实的物质生活，而不 是对神秘的概念或者来自日本的禅意一抽象表现主义的热衷一的冥 思苦想，这是我们了解沃霍尔的基本历史背景。

中国大陆的情形也有类似：当 80 年代初期对过去的历史给予质 疑，并以写实图像体制展开对历史和现实的批判，以及在对人性的 复苏提供美学陈述的可能性之后，如何进一步反映和塑造从 1978 年开始的改革时代的精神状况，就成为中国艺术家的课题。 80 年 代中期的 “新潮美术” 的风格与手法尽管来自西方，但是，那些出 现在不同城市里的 “前锋” 与 “前卫” 分子的目的是重树新文化。 这与战后的抽象表现主义重树美国文化的雄心多少有相似之处，差 异是，中国官方（艺术）机构对各地发生的现代主义运动没有任何 
呼应与支持，并根据中央的政治意志对新潮艺术不时有一些干预。 这种背景提示出在建立自己的新文化的过程中, 中国艺术家面临困 难，国家意志与艺术家的努力方向并不一致，人们通常将这种现象 视为价值观混乱。如果说何多苓的艺术更多地是那个时期人们普遍 需要的对人性的唤起, 那么王广义的艺术就参与到了更为复杂的价 值争论中，尽管在美国沃霍尔的艺术也受到过人们的指责，但是几 乎很少人不认为他的艺术就是美国艺术。

与怀斯相反, 沃霍尔热衷于消费主义的都市生活, 他甚至根本 就没有将商业与艺术视为两件事。在他看来，赚钱本身就是艺术， 这类艺术家与那种感伤主义的低调者大相径庭。人们一开始对波普 艺术虽之以鼻, 可是, 对于从卡内基学院一毕业就冲进纽约的沃霍 尔来说，根本就没有时间去应付艺术圈对他的愤怒。更为迎合潮流 的批评家当然把沃霍尔视为真正的美国艺术家，并认为抽象表现主 义不过是欧洲现代主义观念的延续。

沃霍尔出生的时间是 1928 年 8 月, 他从小喜欢画画, 这也许是 母亲的爱好感染与帮助的结果, 至少, 沃霍尔拥有绘画的基因, 也 正是常常保护他的母亲唤起了他对艺术的内在性。以后他的哥哥约 翰回忆说: “他就是喜欢画画, 我想他就是为了画画而来到人间的。” 他还回忆过母亲为安迪购买幻灯机让安迪看《米老鼠》和《孤儿安 妮》, 然后把其中的内容画出来。 23

安迪最早接受的美术教育是设计，尽管老师也教授一些基本的 东西例如构图、透视与色彩。但是学校里那些工商业的设计专家加 强了他对商业美术的兴趣与理解，以后沃霍尔干脆将美国文化理解

23 沃霍尔的另一个与艺术相关的基因在儿童时期表现出来, 在小孩们经常 玩要的时候, 他总爱选择女孩, 但这并不表明安迪很早暴露出喜欢异性, 相反, 他在女性身上能够感受到自己的内在特质一一他经常表现出差怯 而不是过分好强，在早年要好的女孩回忆中，他甚至 “是我的跟屁虫”。 正是在与女孩一道周期性地看电影的那些日子, 安迪收藏了大量从电影 院获得的明星照片的印刷品——正是这些明星照成为若干年后他的肖像 画的重要主题。种种记录表明, 他很小的时候就对好莱坞发生了实质性 的兴趣, 他甚至给好莱坞的明星写信索要照片并模仿他们的腔调、姿势 以及舞蹈。当然，之后安迪保持了对女人持久的关注与兴趣。 
为电影、广播、报纸与广告。无论如何，流行文化构成了沃霍尔的 艺术基因，但他对流行文化本身在人类文化概念中的价值高低一这 是知识分子圈子经常质疑的问题一没有特别的兴趣，不过是顺手接 纳而已。以后他在《美国》书中写道 :

我喜爱去看电影，也许我希望电影能告诉我们生活是什么样的， 但实际上不是那么回事。电影中的生活和我了解的生活大有出入, 我是决不相信的。虽然也许把此当真是很美的，或许将来有一天会 发生在我身上，但电影自从发明出来以后确实对美国影响很大，它 们引导你做什么, 怎么做, 何时做, 怎样感觉, 怎样看待自己的感觉。

这样的态度表明了沃霍尔对顺应流行文化的赞同。事实上，他 毕业后的第一份工作就是为百货商场画梪窗布景，在商业社会里获 得的成功构成了他从事艺术创作的基本欲望。

尽管沃霍尔还没有获得成功，但他还是说抽象表现主义是 “狗 屎”，这表明了他对如何创作出自己的艺术的意识非常强烈，直到 他将母亲的厨房中他从小就熟悉的 Campbell 汤罐作为绘画的对象, 他完成了波普艺术标志性的作品。1962 年 7 月，安迪在洛杉矶的 FerusGallery 举办了他的展览，人们看到了三十二幅汤罐绘画。日 常用品、重复性以及作品消除意义的面貌标志着美国的当代艺术进 入了一个崭新时期。任何熟悉 50,60 年代美国生活的人都能够理解, 为什么沃霍尔的艺术能够代表这个时期的艺术，尽管一开始他仍然 遭受过嘲笑与批评。

当沃霍尔于 1982 年在北京天安门前拍下自己的照片时，王广义 才从浙江美术学院毕业。这时，中国新艺术的代表性潮流是四川的 “伤痕美术”。无论如何，特定的社会生活与创造性的个人气质总 能够找到吻合，王广义的出生时间也与何多苓相差近十年，就像沃 霍尔与怀斯相差十岁而青春是在 30、40 年代的艰难岁月之后的 50 年代度过的一样，他们各自分享着不同的时代空气与社会语境的特 殊性。1978 年 12 月, 中共十一届三中全会将发展经济确定为全党 全国人民首要的任务一之前这个国家还在 “以阶级斗争为纲” 的严 酷政治环境里，这从很大程度上改变了中国社会单调的政治空气， 自由与商业的元素开始渗透到社会的各个领域。

无论如何，刚刚开放的中国在商业与消费领域还处于低级的阶 段，在这方面，与 “纸醉金迷”、“眼花缭乱” 的美国社会没有任何 
可比性。整个 80 年代，王广义的大部分时间都用于对西方哲学概 念和艺术史的了解与思考。与远在西南地区成都生活的何多苓不 同，王广义似乎具有本能地回避感伤与抒怀的倾向。他在包括 80 年代中期之前的作品确立了 “北方” 地域的特征，他的 “北方极 地” 系列构成了他早期试图超越地方性却又依赖于地方特征的努 力, 总之, 他试图摆脱毕业时期的那种温情很足的自然主义, 他与 他的朋友舒群等人提出了 “寒带文明”, 不过是一个抵御假设的 “温 带文明” 的措施，目的是在那个现代主义运动时期划出与其他艺术 倾向的界限。在构图上，人物与环境的描绘非常概括，与西南地区 的表现主义潮流比较, 王广义的绘画是理性而缺乏情感因素的一这 为以后批评家高名潞编制 “理想绘画” 和 “生命流” 这对概念提供 了形式上的依据。我们无需细致地罗列王广义的艺术历程，可以 清楚的是, 在 1987 年左右的时间, 王广义的艺术理念已经从黑格尔 (Georg Wilhelm Friedrich Hegel) 或者尼采（Friedrich Wilhelm Nietzsche) 的思想转换到了波普尔 (Karl Popper) 这类哲学家的 逻辑, 贡布里希 (E. H. Gombrich) 的艺术史分析使他发现 : 所 谓的原创在很大程度上讲并不存在, 试图与其他团体的艺术家划分 界限的方法不能够从绝对理念中去寻找, 世界没有这样的东西, 因 此, 王广义在 80 年代后期开始摆脱本质主义的哲学思考, 而认定 类似“世界 3”这样的概念可以使自己的艺术获得解放, “后古典主义” 系列是他试图摆脱概念化自然主义的最早尝试。

对贡布里希概念的任意使用，将王广义引向了对艺术史的理解， 他在 1987 年第 39 期《中国美术报》中的一篇文字中说 : “贡布里 希给了我一点图式一文化修正和延续性方面的启示。”正是这样的 启示，王广义发现意义的生成不是对客观的挖掘，而是赋予，这是 他的艺术观念的一个很大转变。“北方极地” 系列是对 “向上” “形 而上” 或者 “崇高” 甚至 “绝对理念” 的一种图像象征, 至少艺术 家本人将其视为追求真理的形象化。可是, 无论是图像、技法还是 观念, 他发现都没有达到理想的目的, 至少他与他的朋友们希望建 立起来的 “终极理想” 根本就没有实现, 我们来读一读他之前在黑 格尔和尼采的思想影响下试图获得意大利文艺复兴时期那样的梦 想 : 
生命的内趋力一这一文化背后力量在今天真正到了高扬的时刻 了。我们渴望并 “高兴地看待生命的各种形态，建树起一个新 的更为人本的精神形式，使生命的进化过程更为有序。我们仅 反对那些病态的、未梢的、罗可可式的艺术，以及一切不健康 的对生命进化不利的东西。因为这些东西将助长人类弱的方面, 它使人远离健康、远离生命。正是从这种意义上讲，“ 85 美术 运动” 的参与者们所从事的并不是作为艺术的艺术创作，而是 在进行一种不是哲学的哲学观念和行为过程，这一点正像欧洲 文艺复兴初期的艺术所具有的那种不确定性的特质一样，文艺 复兴时期的艺术之所以具有历史价值，重要的并不是作为艺术 模式的完善程度如何，而是作为不是哲学的哲学观念表述所具 有的启示性而引发了人文主义思想兴起，使欧洲走出了中世纪 的困扰，发现了人和作为人的人性价值。24

可是很快，王广义觉悟到，艺术是基于艺术史的，这就正如文明是 基于文明的一样，本质论的要害就是追求绝对真理，而王广义从波 普尔、贡布里希的启发中很快就知道了：绝对真理根本就不存在。

“后古典” 系列首先表现为从形而上的哲学企图转向了求助于艺 术史, 从思想的层面上讲, 王广义开始了形而上学的“下降”。“古典” 艺术一主要是欧洲的一在王广义看来是艺术史的基础与最重要的部 分，他甚至将形而上的心理情结也继续挂在具体的古典艺术上一例 如伦勃朗，但是，他用自己理解的 “图像修正” 来指导自己的行动， 将伦勃朗、大卫（David）以及其他一些文艺复兴时期以来欧洲大 师的作品作为他 “修正” 的母题，以便顾及到如何走出陈旧艺术的 陷阱而又保持着稳定的步伐。新的策略产生了效果，从事艺术史研 究的同学洪再新这样评价“后古典” :

《后古典一大悲爱的复归》和 《后古典一大天使》是最引起我兴 趣的，它们从精神上、也从视觉感受上给我以庄严静穆和高伟 俊雄的向上感，它让我想到你很早在一篇发言中所讲的，理性

24 王广义:《我们—— 85 美术运动的参与者》, 载《王广义 : 艺术与人民》, 四川美术出版社，2006。 
的彼岸世界要比感性好。换句话说, 你真的不是在画渺小个人 的感觉，而是希图弘扬 “大人类” 的旨意。难怪乎大家要感叹， 没有一个新潮人物像你这么成功地为自己建立了一种图式。 ${ }^{25}$

洪再新的理解与王广义尝试 “修正” 的初衷是不吻合的，“理性的 彼岸世界要比感性好” 只是从前的理想, 而这时, 王广义试图摆脱 的就是形而上学的哲学情结，尽管他对古典 “图式” 依依不舍。

1987 年，艺术界的基本状况是这样 : 从 1984 年开始的现代主义 运动似乎因为频繁的宣言和不同风格流派的语言实验而暂告段落, 这年党发动的 “反对资产阶级自由化” 政治运动显然为现代主义运 动的抵触者提供了政治资源，毕竟，任何流派的现代主义艺术都是 资产阶级形式主义的艺术, 只要政治需要, 这样的艺术将受到压制, 至少要控制其扩张。然而, 在批评领域, 还存在着一种继续推动学 术思考的声音, 这个声音针对现代主义艺术的语言问题, 而提出需 要 “纯化艺术语言”, 在一些批评家看来, 现代主义运动一尤其是 表现主义倾向一存在着 “粗制滥造” 的语言问题。的确，直至 1989 年，大多数现代主义艺术家缺乏充分的物质条件，他们的画布来自 洗旧的床单或者其他低劣的织品, 颜料是国内生产的, 非常容易变 色和干后脱落，有人用 “观念大于实践” 来对艺术家过分关心哲学 问题提出质疑，大多数年轻艺术家的作品在物理质量上讲也都是简 陃和勉强的。物理意义上的问题显然不是 “纯化语言” 的依据，部 分批评家认为: 如果要推进现代艺术的发展, 必须 “纯化” 艺术语 言。这场讨论很快就结束了，因为 “纯化语言” 是一个本质论的伪 命题，不过是形式和内容一壳与核一的批评范式的另一种表述，内 容被理解为一种有价值的精神, 而形式应该是“精致的”和“准确的”。 不过这时，中央美术学院不少教师的古典风格的作品（例如靳尚谊、 孙为民、杨飞云等）连同浙江美术学院青年教师的 “新学院主义” 口号将 “纯化语言” 的试图给迅速融化了，前卫批评家根本就不认 可这样的 “纯化”一这是一种显而易见的回头路。到了 1989 年 “现 代艺术展”，大多数艺术家还没有来得及认真思考 “纯化语言” 这 
类问题，就感受到了一个时代的结束，尽管他们是在 1990 年之后 才陆续理解了新的时代空气为什么被命名为 “后现代主义”, 发现 了对本质主义态度的普遍放弃，以及对意义的彻底消除或者完全开 放。

在 1988 年完成，并于 1989 年现代艺术展中展出的《毛泽东 AC》 是王广义的关注焦点从艺术史向社会生活转变的一个重要例子，他 也许是本能地意识到现实问题的重要性。不过，他从一开始就厌恶 使用写实或者表现主义的方法去表达对现实的看法与感受一但他说 表现主义是一种病态的看法与沃霍尔说抽象表现主义是 “狗屎” 没 有什么相似之处，所以他必须沿着自己的路线寻找可能性。《毛泽 东 $\mathrm{AC}$ 》在展览期间引起轰动和质疑是可以想象的。1988 年的社会 生活表现出普遍的焦躁不安, 商品经济的发展在不相匹配的政治体 制的背景下开始明显扭曲人们的心理状态，这个时期的杂志不时报 道社会中的混乱现象 : 数以千万计的农村人口拋弃农业生产流入他 们渴望的大城市 ; 部分工厂的倒闭、开工不足以及在不久之内很可 能产生千百万失业大军的说法让人们恐慌 ; 失业队伍的剧增在 1988 年构成了一个让各地政府高度紧张的危机，所谓 “盲流” 开始成为 滚滚之势，进而，交通铁路方面因为流动人口和管理难以应对不断 发生恶性事件; 加之通货膨胀，“官倒” 盛行 ${ }^{26}$, 官员腐败，这一切， 在人们心中构成了难以承受的精神负担和心理压力。因此，曾经的 平均主义领袖毛泽东成为人们怀念的对象，这样的社会心理也辅助 着观众对作品的理解，或者唤起人们对历史的联想。不过，这样的 新闻效应对部分批评家来说与艺术无关，不过是一种正好对位的现 实需求，而不是现代主义艺术自身的逻辑发展。这时的王广义对作 品产生的效应感到暗暗高兴，前不久他提出过一个口号 “清理人文 热情”，这是针对表现主义倾向而去的，可是，《毛泽东 AC》产生 的影响让他意识到人们的 “人文热情” 被他的作品更多地调动起来, 这并没有让他感到不适。他带着矛盾的心情给批评家朋友严善錞写 了一封信（I989年 4 月 I8 日）：

26 指国家机关、团体、企事业单位官员，在价格双轨制下，利用手中权力， 违法使用平价和市场价（议价）两个杜杆牟利，俗称 “官倒”。 
……我当时很担心，很担心人们只是把我的《毛泽东 AC》看作 是一种抢新闻的工具。《毛泽东 $A C$ 》在当时一定会产生新闻效 应，这是毫无疑问，但只这是问题的表面。我真正要做的是把 人们那种具有新闻嫌疑的文化心态用艺术的方式中性地、恰到 好处地揭示出来。现在看来，我的这一理想实现了。它不仅揭 示了一工人、农民、士兵、知识分子对毛泽东这位往日领袖的 一种特殊的文化心态，也是我的艺术图式的一个必然逻辑，《毛 泽东 AC》问世后所激发的这种 “人文热情”, 正表明我在去年 提出的那个 “清理人文热情” 的观点是有先见之明的。

将王广义这样的看法与沃霍尔比较, 他们在艺术的出发点完全不同, 王广义仍然保持了寻求作品内在含义的努力, 只是, 他也感觉到了 图像的意图或象征性是否应该更加隐藏起来，“把人们那种具有新 闻嫌疑的文化心态用艺术的方式中性地、恰到好处地揭示出来”。 然而, 对于沃霍尔来说, 艺术就是应该创造新闻效应, 而不简单是 “新 闻嫌疑”。不过，之后不久，王广义在他的《艺术笔记》中很清楚 地表达了一个看法 :

在当代艺术中，“创造” 并不像人们所想的那么重要。昨天，人 们就已经创造了所有的语言, 我们今天所要做的、所能做的也 就是赋予这些语言以什么新的意义。 ${ }^{27}$

在《毛泽东 $A C 》$ 里, 王广义进一步降低了手的功能, 他不过是将 毛泽东标准肖像复制一遍，如果可能，他甚至希望放弃绘制一他的 确也做过一些印刷品的小稿子 ${ }^{28}$ 。他的确希望用现成的 (而不是 “创 造” 的）图像来构成他的作品。这样的艺术思想和制图逻辑自然会

27 转引自王俊艺编: 《王广义的艺术与思想 : 批评与访谈文集》, 中国青年 出版社, 2015 , 第31 页。

28 直到 90 年代末，王广义也没有条件建立自己的工厂来完成类似丝网印 制作品，所以他以后的 “大批判” 系列的作品统统都是手绘。当然, 手 绘是艺术家的个人趣味的最后机会, 不过已经不像表现主义那样成为必 须。 
发展到“大批判”系列。

I99I 年 I 月，第一期《艺术·市场》采访了王广义。当记者问道: “你认为中国当代艺术在世界艺术工业中的地位如何?”王广义这 样回答：

就目前来看，中国的当代艺术还没有获得与它本身所达到的学 术高度相对等的地位，这里面的原因是很复杂的，其中主要的 一点是没有强大的国家集团来做后盾，战后美国艺术的成功， 实质上是国家集团的成功，否则，像波洛克、德库宁、琼斯这 些艺术家将不会是今天的样子了。

王广义对美国当代艺术的发展的看法并不具体，但是，他已经非常 清楚地意识到任何国家背景对当代艺术的重要性。事实上，正是中 国经济的高速发展这个事实，为 1993 年之后中国当代艺术在国际 社会上的影响力提供了基本的国家背景，尽管这个国家的艺术主管 机构并没有为那些流散在社会而不是画院或政府艺术机构里工作的 艺术家提供任何帮助，部分西方人也没有去区分一也许根本就不清 楚一中国大陆体制内与体制外的实际情形，而是把中国当代艺术与 整个中国看成一个整体。的确，在回答如何看待金钱问题的时候， 王广义已经能够非常清楚而不太差涩地直接讨论人们过去差于谈论 的金钱问题：

我作为艺术家，我想金钱和艺术都是好东西，人类干了几千年 才发现只有艺术和金钱才能带来欣喜和冥想。作为一个艺术家像普 通人一样热爱金钱，不同的是普通人用钱来过豪华的生活，而艺术 家则用钱来维持神话的形象。一个艺术家的神话魅力越大，他的作 品就越值钱，这里边有一个神话的形而上向神话的世俗转换规律在 发生作用，这两方面互为关系才能推进艺术的进程，应当说在当代 艺术中是 “马太效应” 的正题和发题现象左右着艺术家、评论家和 艺术市场的神话的诞生和消亡。

作为美国人的沃霍尔也许认为这样的表述有些啰嗦，他对金钱 的表述没有丝毫玄学成分。可是，在刚刚启开市场的中国，王广义 的这些看法已经达到了遭受攻击的临界点，因为在这个时候，艺术 界的大多数人还认为：艺术与金钱不应该扯上关系，金钱更不应该 
成为艺术的裁判。然而，远在美国的沃霍尔早已将美元作为绘画的 主题。

有趣的对比是，正如王广义也注意到的，从 40 年代开始，被称 之为 “抽象表现主义” 的绘画大当其道，波洛克（Jackson Pollock, I9I2-1956)、德库宁 (Willem de Kooning, I904-I997)、罗斯 科（Mark Rothko,1903-1970）的艺术流行一时。然而沃霍尔对 之不以为然，他也不愿意去接近劳申伯或者琼斯（Jasper Johns, 1930一）这样一些在手法上与抽象表现主义者不同的艺术家，倒是 利希滕斯坦（Roy Lichtenstein, 1923-1997）的艺术提示了一种可 能性, 使得沃霍尔能够安心地利用现成的商业图像和符号制作作 品一这是他 1962 年的 32 幅色彩不同的汤罐绘画的前因。无论是否 真的有 Muriel Latow 对沃霍尔的那次有趣而重要的告诫, 作为在 茫茫商海里游泳的安迪，一定是在与朋友们的讨论中和自己的思考 中, 得出来结论: 必须表现人们最司空见惯的东西, 并且不能再使 用那些含含糊糊的手法，例如滴落颜料在画布上。

王广义的逻辑是趋向尽可能地利用现成图像，与沃霍尔不同的 是，人们熟悉的图像也许一部分来自历史，而另一部分是来自现实。 那些来自历史的图像不是艺术家的回忆的记录，而是这个国家的制 度以及相应的意识形态编制的结果, 无论市场经济的术语有多么地 丰富，这个国家的口号与之前的历史是一致的：这是一个以工人、 农民和士兵为主体的社会主义国家。在 1989 年之后, 这个概念（口 号）被官方以国家机器的力量再次给予加固。

然而，在大街小巷，人们已经熟悉了来自西方国家的商品符号， Coca Cola, Nestle Caffè, Marlboro 如此等等。在新兴的市场国家, 这些符号随着消费而迅速流行，构成了人们对市场的普遍印象和视 觉惯习。在 90 年代的中国, 人们习惯于认为国外商品的品质高于 国内，消费的标准应该看齐这些西方产品，这多少有点类似 80 年 代越来越多的年轻人接受西方思想一样, 总之, 这是一个整体性的 涌入与影响一从精神到物质，对中国人构成的全面冲击可以想象。 王广义当然敏感于这些外来的流行符号, 不过他几乎是本能地发现: 具有历史与意识形态功能的工农兵形象与西方商品符号的并置显然 是中国此时的奇观。之前, 他使用毛泽东的符号产生了迅速的影响, 这使得他也几乎是本能地意识到与现实有关的形象和符号而不是艺 
术史的经典图式更有利于迅速传播，何况作品的针对性是如此地与 此刻的中国接近一社会主义制度下的市场经济。一天，他发现 “文 革” 四处可见的 “工农兵” 大批判图像具有一种极为简单的历史与 现实的提示，两罐可口可乐放在他刚刚完成的 “大批判” 的面前, 他发现了仅仅是将可口可乐的商标符号直接放进图中，就能够产生 一种强烈而戏谑的张力，这就是中国的现实一仍在进行中的意识形 态教条与资本主义商品的并置。“大批判” 最初发表在 I99I 年 3 月 22 日的《北京青年报》，艺术家本人与编辑王友身和批评家吕澎共 同策划了一期专版，他们试图通过媒体将 “大批判” 的图式传播出 去。1992 年 $\mathrm{IO}$ 月, 在轰动全国的广州双年展上, 王广义的《大批判一 万宝路》获得最高奖，这个事件导致了从 I99I 年开始的波普艺术 迅速流行，人们开始关注出现在不同城市里不同语言形式的波普艺 术 (上海有李山、余友涵、刘大鸿)。

在广州双年展的评选会议上，批评家们对此时出现的 POP 艺术 充满喜悦，尽管参与评委的批评家们才刚刚从本质主义的现代艺术 理论中苏醒过来，但是，简明的符号和作品与社会现实的呼应，让 他们感受到了 POP 艺术在中国的兴起具有真实的背景。与生活在 60 年代美国的沃霍尔关于日常生活中的用品被作为艺术表现对象 适应了对美国生活的赞美主题的看法不同，发生在中国的 POP 艺 术有其特殊的出发点与针对性。事实上，没有一位 POP 艺术家对 商品社会有多少赞美，90 年代初期，当代艺术家的生活仍然非常 严峻，甚至对 “消费” 这个词的使用还远远没有 2000 年之后那样 随意，面对大街小巷的商品与市场空气，他们在 “无所适从” 的精 神状态下多少表示出一丝对市场的质疑。批评家们认为这些 POP 作品与美国的 POP 艺术不同，艺术家们表现出对历史与现实问题 的思考，不过是采取了通俗易懂的语言形式而已，所以，批评家皮 道坚使用了 “文化波普” 和 “社会 POP” 这样的词汇，试图说明： 这些出现在中国的 POP 艺术与美国的 POP 艺术在出发点和问题 的针对性上完全不同 : 中国艺术家们在内心仍然潜存着对这种含含 糊糊的制度形态和意识形态冲突状况的茫然和不知所措，以致采取 
了一种调㑆的态度 ${ }^{29}$ 。

王广义没有表述他的 “大批判” 系列产生的初因, 他不断翻阅 “文 革” 时期的报头图册，进一步尝试着将 “工农兵” 复制在尺寸不大 的画布上, 将不同的西方商品符号放进作品, 基于 “文革” 时期的 “大 批判” 宣传画往往都有被置于铁锤、拳头、钢笔以及步枪之下的政 治人物，现在，这些被 “批判” 的对象换成了资本主义的商品符号， 这既满足了艺术家对历史莫名其妙的好奇心，也对应了他对现实的 敏感性。这种看上去是简单的并置, 构成了历史、社会以及现实 问题的强烈张力一从 1992 年春天邓小平巡游中国南方并发出对何为 “社会主义”与何为 “资本主义” 不要争论的政治意见之后，西方 商品及其意识形态随着中国的市场经济发展汹涌而入。的确，“市 场经济” 在 90 年代的中国获得了合法性，然而，没有人宣布这个 国家的性质有任何改变，官方不过是用 “社会主义市场经济” 这样 的句子来说明政治制度与经济发展没有什么绝对的对立。然而，西 方国家的市场经济所匹配的制度与伦理法则并没有充分地在中国取 得相应的建设, 这无疑将催生导致未来政治、社会与经济危机的基 因一这些危机统统都在新世纪的高速发展之后开始一一暴露出来。 90 年代的艺术家的质疑和茫然，都与这些问题有关。

某种类似沃霍尔早年冲进纽约的心态出现了。在特定的历史时 期，王广义自信 “大批判” 是一次对艺术界的冲击，他采取了一个 策略，在 I99I 年的《北京青年报》专版里，他这样回答记者关于

29 皮道坚在 “双年展” 作品的基本估计” 中分析说 : 本届展览中的探索 性作品所显示的特征和动向 “必将引起批评家和艺术史家们的注意” : ……艺术家们的创作心态显然较 85 时期放松。调㑆、嘲讽、游戏的创 作态度成为一种新的时尚。这在 “湖北波普” 和所谓 “新生代” 艺术家 群的作品中均有鲜明的反映。“湖北波普”从过去的历史文化中引用图式, 或将流行的大众消费品转换为艺术的做法, 无疑具有深刻的文化或社会 的含义，以致批评家可以将其大致划分为 “文化波普” “社会波普” 这 样一些不同的类型。然而这些作品中的相互冲突、互不连贯、错综复杂 的多重意义, 却是经由幽默与机智的艺术想象, 耐人玩味的技术性制作, 轻松而酒脱地自然溢出, 绝少刻意为之的痕迹。生活意识的加强, 与公 众距离的切近，则使之更加富于中国当下文化的浓郁气息（转引自吕澎 主编:《广州双年展: 20 周年文献》, 四川美术出版社, 2013 , 第 227 页 )。 
他是 “毁誉参半的人物” 的提问 :

有些事情是不能以个人意志来决定的，我的作品和我所说的话 一经离开我，就成为一个 POP（波普）产物了，也许，正因为这 样才使得当代艺术逼近每一个人的生活，以此引起人们的兴趣。就 中国当代艺术的状况而言，我以为 “经院” 味的语言纯化，以及个 人情绪的表达倾向是有危险的，前者是贵族艺术，后者是贫民艺术。 其实就当代艺术来讲，它似乎应当是一种公众共时性经验的一种重 组的实现，它涉及到所有人，它是一场大型的 “游戏”，它迫使公 众参加进去。从表面上看，公众似乎弄不清楚这个游戏的真面目， 这有点像公众在晚间观看电视新闻节目一样。有一点是清楚的，那 就是当代艺术总是在提醒公众注意一个最基本的问题 : 新闻和游戏 引导我们走向真实的生活。

的确，沃霍尔比王广义的话更为简洁明快。纵然王广义 “真实 的生活” 的潜在意图就是要过 “好日子” 一中国人对财富生活的一 种表述，可是，他的 POP 意图仍然包裹了一种 “思想的外衣”，他 必须采用一种历史过渡性的语言来表述一个可能非常简单的问题。 实际上，直到 90 年代中期，中国的艺术圈才敢于无所顾忌地正面 谈论金钱与艺术的关系。而对于沃霍尔来说，金钱是可以直接画出 来的东西。正如王广义评价的：“沃霍尔是把平常的事物变得更平 常。”但是终究，王广义的早期思想情结似乎决定了他的艺术倾向： 让艺术尽可能地大众化但保留一层思想的薄纱。而沃霍尔则创造了 这样的名言：

Being good in business is the most fascinating kind of art. Making money is art and working is art and good business is the best art.

王广义所处的语境完全不同于 60 年代美国，可是，商业与消费 社会的因素一旦进入了新的环境，定将对人们的大脑产生影响。不 过, 将王广义的艺术视为对消费社会的拥抱是文不对题的。事实上， 在内心深处，王广义始终保留着一种属于形而上的质疑态度。在 80 年代，黑格尔的 “绝对理念” 唤起了他和朋友们的 “绝对原则”, 尽管他在 80 年代后期（1988 年黄山会议上）提出了 “清理人文热 
情” 的口号，不过，艺术圈里的聪明人仍然认为这位风头主义艺术 家一定是在 “要花枪”，他一定在玩弄什么策略。“毛泽东” 系列被 认为是他玩弄策略的一次努力, 不过, 批评家们认为 1989 年 “现 代艺术展” 中的枪声将展厅里所有作品的影响力给大大削弱了。但 是, 展览中的《毛泽东 AC》仍然成为媒体关注的重点, 这件作品 显然与历史和现实政治有关，而不可能成为商品社会中的艺术噱头。 1990 年下半年，王广义开始了他的 “大批判” 系列的实验，他在 多少有些犹豫的心情下同时也在继续他的 “工业油漆覆盖的名画” 系列。到了 1992 年, “广州双年展” 即将在 Io 月举办, 王广义送 交了 “工业油漆覆盖的名画” 和 “大批判” 两个系列的作品，他试 图让评委的成员在两者中必须选其一。王广义如愿以偿, 由十四位 批评家组成的 “鉴定委员会” 与 “评审委员会” 最终认定了 “大批 判”的重要性，评委在最后的意见书中这样写道：

在《大批判》（图 4）中，人们熟悉的历史形象与当下流行符号 的不可协调却一目了然的拼接，使纠缠不清的形而上问题被悬 置起来，艺术家用流行艺术的语言启开了这样一个当代问题： 所谓历史，就是与当代生活发生关系的语言提示。而《大批判》 正是九十年代初这种语言提示的最佳范例之一。

尽管在评委的文章里使用了“文化波普” “社会波普”这样的概念， 但是很快, 由于 “大批判” 系列显而易见具有意识形态冲突的符号, 批评家栗宪庭在他的文章里使用了“政治波普”这样的概念。人们 毫不犹豫地接纳了这个概念, 它再简单不过地提示了这个时期的特 征, 认同艺术家通过两种不同意识形态符号的并置带来的、可以无 限解释的盲点。王广义不止一次地否认 “大批判”与政治无关, 可是, 产生 “大批判” 系列的这个时期一进入 “社会主义市场经济” 的中 国成为 “大批判” 系列的有效注释 ${ }^{30}$ 。

30 在《芭莎艺术》（2012 年）里他写道 : 媒体和批评家曾对我的 “大批判” 做了各种各样的解释, 开始我并没有说什么。但我想事实上, 我是潜在 地在放任这种公众的解读, 你爱怎么想就怎么想, 当公众形成一个比较 明确的认识的时候, 然后我说, 我不是这样想的, 我是无立场的、我是 
王广义之后的作品涉及国际政治、身份以及中国当代政治史方 面的主题，我们很难将他看成是沃霍尔在中国的翻版（图 5)。王 广义使用波普的语言，不过是他的艺术思想的一个逻辑结果，并且 较之表现主义来说，更容易处理他涉及的艺术问题。的确，在 “思 想的薄纱” 这方面，博伊斯（Joseph Beuys）显然是他的一个基因。 很多年后，王广义谈到了他对沃霍尔和博伊斯的看法。在《沃霍尔 和博伊斯，我更喜欢谁?》里，王广义说：“博伊斯是一个炼金术士， 而沃霍尔是把平常的事物变得更平常。” “博伊斯喜欢制造谜团，沃 霍尔把自己彻底放在阳光下。” ${ }^{31}$ 而对于一个事实上在性格方面非常 差澀的东北人来说，王广义既不希望成为一个彻底的神秘主义者， 也不愿意像沃霍尔一样暴露自己的一切。他对制造谜团和完成大众 能够理解的艺术同样都感兴趣 ${ }^{32}$, 王广义的这个特点表现在他 90 年

中性的。而对我而言，我自己也真是不知道我有没有态度。我倒不是故 意说我是这样，我是真的不知道。只是人们在问我的时候，我确实可以 回答一些问题，在一些特定的谈话中我会谈一些问题。但当平静下来我 再想的时候, 我自己也不知道。

31 《芭莎艺术》这篇文章主要是讨论他对沃霍尔和博伊斯的看法 : 沃霍尔 和博伊斯是美术史上的两个伟人，这两个人曾经在我年幼无知的时候， 几乎同时站在我的面前。我第一次看到了博伊斯的作品是在一本国外的 杂志上，那上面有博伊斯的东西。当然文字我也看不懂，就是那些图片 特别诱惑我，还真是有点不像艺术的东西，或者说像 “炼金术” 的一些 记录。应当说当时他的东西是让我挺困惑的，这种困惑是因为我不知道 他要表达什么。当然后来我看到一本简装的翻译过来的介绍博伊斯的资 料, 才知道博伊斯是怎么回事。现在我更愿意把博伊斯视为带点玄学 色彩的这么一个艺术家。他可以给任何一个普通的物体赋予一个图腾的 意象。博伊斯最早的一个我印象最深的作品是《钢琴的均质渗透》，也 有的翻译为《战后欧洲》。这是一件我最难忘的作品。而我第一次看到 沃霍尔的作品是《玛丽莲 · 梦露》, 它如此简单, 如此没有人工的痕迹, 没有任何绘画的感觉，这让我很困惑。但在内心深处，我却感觉我是喜 欢《梦露》的。

32 他在这篇文章中写道: 博伊斯是一个喜欢制造谜团的艺术家，他一直在 制造一层层的迷雾。像在《如何对一只死兔子解释绘画》这件作品中, 他所提供的思想是非常模糊的。如何给死兔子讲解艺术是一个很难的问 题。这种难度，可能博伊斯自己都不知道。我之所以喜欢博伊斯，和他 
代及其之后的所有作品中。

一开始，纽约文化圈将琼斯、劳申伯等人的艺术称之为 $\mathrm{New}$ Realists, 到了 1962 年底，人们将这种与思想和感情没有干系的流 行艺术称之为 “PopArt”。这是这些艺术家绘制日常消费品的结果, 而沃霍尔的确毫无顾忌地声称：人们喜欢的、物美价廉的东西就是 他要去歌颂的和表现的。

至于王广义, 他始终处在悖论性的心理状态之中 : 在复杂的思 想作用下尽可能地实现通俗意义上的社会影响。无论他对实现自己 设置的目标究竟有多大程度上的把握始终无从知晓，他唯一感到庆 幸的是，他知道，也许任何人都对自己的命运缺乏终极的把握。 ${ }^{3} 3$

有趣的是, 沃霍尔在 58 岁时画了 “最后的晚餐” 系列, 王广义 也在他 57 岁时展出了他的《最后的晚餐》; 当人们问及为什么要创 作达芬奇的主题?沃霍尔回答： “哇，意大利文化一我只知道意大利

所呈现出来的这些神秘的因素有关系。他有时候好像很认真地在想一些 问题, 但这所有的这些问题又不具有事实的可能性, 都是站在一个玄学 的立场来说艺术。他等于把自己置于一个永远不可证伪的位置。而安迪 沃霍尔则把自己彻底地放在阳光下，看起来是赤裸裸的，什么都没有。 我想这个往深的说还是德国的文化传统和美国的文化传统的不一样。德 国还是有对一个事物理性地追根问底的这样一种传统，这一点在博伊斯 身上体现得挺明确的。而沃霍尔推崇的是彻底的大众，彻底的通俗。

33 在思想的层面上, 博伊斯对我的影响更大, 我也更愿意用不确定的话语 来解释我的作品。在我身上有些很复杂、很悖反的东西, 就是在思想的 层面上, 我更喜欢晦涩难懂、不确定、具有模糊性和指鹿为马式的思维 方式。观念类艺术这种样式的东西, 它的尺度是模糊的, 就像我们说思想, 思想是看不见摸不着的一些东西。沃霍尔的因素在我身上更多地体现为 社会对我的期待, 而博伊斯的因素更多体现为我作为艺术家对自己更深 层的期待。从更深层而言, 我很喜欢博伊斯的东西, 但是一个艺术家也 会有一个很社会化的自我期待, 这是沃霍尔的附体。从公众的角度, 可 能人们更容易喜欢安迪沃霍尔。因为沃霍尔为大众提供和呈现了一个非 常通俗易懂的假象一虽然他的本意也许我们并不知道。所以有时候我 甚至在想, 沃霍尔说出的所有的话, 是否具有真实都是很难说的。也许 对他而言，探讨艺术或者谈论艺术，是没有真实性的。德国艺术评论家 克劳斯·霍内夫 (Klaus Honnef) 对沃霍尔和博伊斯两个人的比喻很准确: “他们俩一个是手心，一个是手背” (《芭莎艺术》2012 年)。 
吕澎

实心面条令人称道!”王广义的回答是 : “在我看来，达芬奇的《最 后的晚餐》是一幅风景画。”事实上，王广义再一次回到了对玄学 的迷恋，20II 年开始的 “新宗教” 系列不过是艺术家长期存在着的 心理悖论在新的时期里的表现，这与沃霍尔消费主义的艺术观念大 相径庭。 


\section{Taste, Image, and Identity: He Duoling and Andrew Wyeth; Wang Guangyi and Andy Warhol. A Comparative Analysis of the Role of Artistic Approaches and Directions in Art History}

Lu Peng

\section{Prelude}

For America today, the day May I4, I607 and the year 1776 mark two watershed moments in its history. On the former date, I8o immigrants arrived on the American shore while the latter year saw the birth of the Declaration of Independence of the United States. Although indigenous arts or arts by Native Americans existed before the arrival of European immigrants, American culture or art as we generally think of it took shape within this time frame. Before World War II, American artists were mostly deeply influenced by European art (forms, languages, and styles, etc.); the artistic languages employed ranged from deploying the earliest neoclassical historical paintings for promulgating the political culture of the American society, to inheriting European modernist abstract styles for expressing a liberal American society.

That history propels us to ask the question: what is a history of American art? Perhaps, the way in which we assess the historical identity and judge the values of American arts can shed some light on similar questions that twentieth-century Chinese art is facing. On the one hand, it is true that China boasts a 5000-year culture and history. On the other, since 1500 , Europeans have been coming to Asia and the coastal areas of China; later, they moved inland. So, in the later part of the igth century, the influence of European arts on China can be seen in the imperial court and across the civil society. During the twentieth century, European (modernism and post-modernist artist trends) and American art (post-World War II) continued to hold sway in the Chinese art world. Such historical facts present the researchers of contemporary Chinese art history several challenges: what is the historical relationship between new art and the thousands-year-old art tradition? What is Chinese (not European) modernist art or contemporary art (instead of American)? How do we nail down the issue of the influence and the question of identity in writing the history of twentieth-century Chinese art?

The issue of mutual influence between cultures is a complicated one. Visual forms, languages and styles are the crucial elements of art historical research as can be testified by the long-enduring and profound impact on Chinese artists 
and critics, particularly in the I980s, by the ways in which Herbert Read illustrates visual presentation in his A Concise History of Modern Paintings. ${ }^{1}$

But since the I990s, in the wake of modernism and the new historicism, people's sense of history and art history, of taste and of image have changed. Indeed, there usually is an inherent reason for the similarities among these cultural trends during a specific historical period. Individual artists' points of departure and perspectives on issues are often responsible for the differences between taste, images, and our own cultural identities and thereby influence how we explain the differences between the systems of taste and images. Because of national and regional historical conditions, historical writing should not be limited to analysis of imagery tradition and system. So-called taste, language, and visual style would construct a completely different cultural identity because the points of departure and inquiry perspective would be different in a different context. Such different perspectives should be noted when it comes to writing a global art history which should employ scientific methodologies.

In different periods of the twentieth century, we can find connections between Chinese and American artists; and such links are worthy of art historians' attention. For example, the American experience that two turn-of-the century Chinese painters Li Tiefu and Feng Gangabi had and the impact of that experience on their art when they returned to China can be seen as an early example of how Chinese artists have learned from the Western painting tradition since the end of the nineteenth century. ${ }^{2}$ By the end of the twentieth century, American art has a more complex relationship with the Chinese post-I978 art scene. For example, Robert Rauschenberg (I925-2008) held a solo exhibition at Beijing's National Art Museum of China, which had a direct impact on Chinese contemporary art.

This chapter focuses on two Chinese artists with distinct artistic characteristics and historical impact in contemporary Chinese art history-He Duoling

I The Chinese edition of Herbert Read's A Concise History of Modern Paintings was translated by Liu Pingjun and published by Shanghai People's Fine Arts Publishing House in 1979 .

2 Li Tiefu (I869-1952) first went abroad to make a living around I896, to the United States. According the painter's own words, he was a protégé of the renowned American painters William Merritt Chase and Sargent between 1905 and 1925. The fact that Li kept winning various awards at school and participating in important artist events and organization prove that he had good understanding of oil painting and had mastered its techniques. Feng Gangbai (I883-I984), who went to New York Academy of Art with Li, also gained the opportunity to study aboard while looking for a job. Feng's application of light and colors remind people of Rembrandt. During the period when Realism was still foreign to the Chinese people, Feng's teaching to his students stressed the authentic depiction of the physical space. He was even more keen on expressing the visual phenomenon as though "the blood is flowing under the skin." Regardless, what the earliest two oil painting vanguards learnt from the American painters is how to represent the world seen through our eyes. 
Fig. I. He Duoling, Spring Breeze Has Awakened, 1982. Courtesy of the artist.

and Wang Guanyi. I will compare the pair with American artists Andrew Wyeth and Andy Warhol for their different artistic points of departure, as well as historical contexts, imageries, and cultural backgrounds. By doing so this essay aims to analyze the artistic values found in

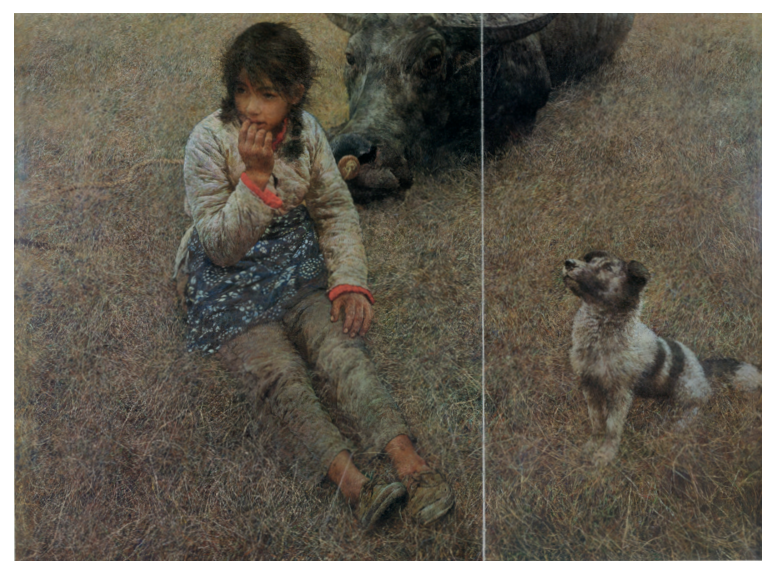
different countries and regions in the twentieth century while looking into the differences in the aims of seemingly shared values. Thus, this article serves as a case study for writing about artistic points of departure and perspectives of global art history.

\section{He Duoling and Wyeth}

Spring Breeze Has Awakened [Fig. I] is my graduation work. At first I intended to paint it differently. The grass was there from the beginning. But the main character was meant to be a public intellectual but then was changed to be a civilian. What decided how I eventually painted it was my sense of affinity with Andrew Wyeth's Christina's World, which I first saw on the back cover of an issue of World Art. I then felt that that's how I should paint my painting. Of course, no one paints oil paintings that way but I simply went my own way. Not only did I paint the way Wyeth paints but changed the details of the village farmer girl's clothes. That was pretty subversive then. It set the tone of my early painting style, which further influenced greatly the development of Chinese new art. $^{3}$

The issue of World Art He Duoling mentioned (198I, vol. I) in which Chao Yihen published an article on American painter Andrew Wyeth and features Christina's World (Fig .2). Painted from a high viewpoint, the painting depicts a girl with polio — a neighbor of the painter's_ reclining on a sloping grass, looking up to the house of the hill top. Regardless of the painter's initial intention, the theme of the painting is the loneliness emanating from that barren grass. The painting's brushstrokes are meticulous and create a dejected atmosphere. But the print quality of the reproduced painting in the World Art magazine is very poor. As opposed to most of the painting catalogues we have today, the painting looks more like a painted message with an inaccurate color scheme. However, the 


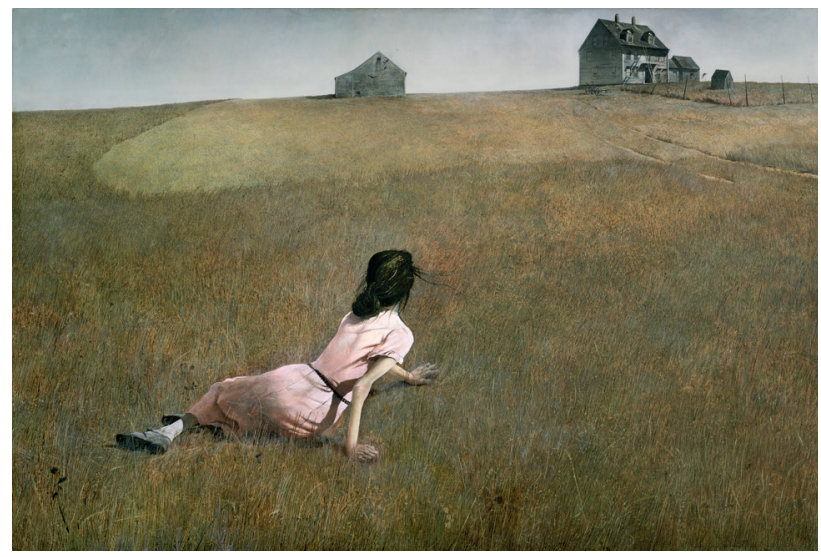

Fig. 2. Andrew Wyeth, Christina's World, 1948. Oil painting. Museum of Modern Art, NYC. (C) 2019 Andrew Wyeth/Artists Rights Society (ARS), New York.

message chimed aggressively with something within the Chinese painter He Duoling.

When he was working on his commissioned work Youth for Chengdu Art Academy (in 1984), I visited his studio once. On a chair stained with paint lay a Wyeth catalogue of good print quality. However, after being referred to numerous times, the catalogue was soiled with oil paint and traces of being thumbed through with paint-stained hand. Obviously that resulted from He's constant consultation with the catalogue while he was in the process of creating Youth. Indeed, still today, Wyeth remains a point of reference even when He has achieved his own painting style.

Well before his admission to Sichuan's Chengdu Art Academy, He Duoling had been recognized as one of the brightest painters in Chengdu, the central city in Sichuan Province. He was often surrounded by a group of art lovers and friends while talking about art, music and literature and playing an accordion. Before 1977, most Chinese people's understanding of "foreign" literature and art was largely limited to Russian authors and artists such as Chekhov, Tolstoy, Lenin, and Surikov. In 1978, although novels by Balzac, Hugo, and Dickens were being read ${ }^{4}$ and recordings of Bach, Beethoven, Rachmaninoff, and Debussy were being exchanged, high-quality painting catalogues of Western paintings of Impressionism and schools that came after that were rare. However, with his exceptionally gifted understanding for literature, painting and music, $\mathrm{He}$ Duoling had long been trained to be able to paint well without the guidance of teachers in academic institutions. That was the reason for his early admission to the post-graduate program.

Before he painted Spring Breeze Has Awakened (1982), He Duoling painted Chasing after the Enemies (1976), in which, against the background of Chinese Civil War, a Chinese communist soldier was writing a slogan "Battle over Yangzi River" on a wall. This painting employs a subtle scheme of yellow-the soldier's uniform and the yellow mud wall match perfectly the tone of the painting's entire composition - and exacting brushstrokes to depict a non-fighting scene in a battle. He understood the officially decreed art standard of that time: non-polit-

4 He Duoling says that he started to read Hugo, Balzac, and Dickens after he enrolled in the arts class at Chengdu Teachers College. He Duoling, "I Never Lie in Painting," in Born to be an Aesthetic Person (Beijing: Joint Publishing, 20II), I55. 
ical themes and ideas need to reveal the bigger picture through minor subjects. That a small detail about a soldier's life reveals the story of a mighty army fits perfectly the artistic standard of that time. However, what the state wanted was precisely the jagged textile of the mud wall which is plastered with white slogan, the soldier's uniform which has been ravaged by gun fires and time, and the bullet shells scattered all over the ground. These authentic details that evoked the "realistic taste" attracted the audience's attention. What I'm trying to say by relating this fact is that towards the end of the ten-year Cultural Revolution, He Duoling discarded the standard requirement for "Bright Red" bannering. Instead, he focused the entire composition on the color yellow. By doing so, He was fulfilling his own artist taste for colors and deflecting the official requirement for style. ${ }^{5}$ In effect, he had some surreptitious understanding of foreign and Western art; his artistic ability had nurtured in him a concern for the authentic. Whenever there was a chance, such concern would be shown through concrete forms. He's personality did not allow his internal demand to be overridden by any externally forced demands that were not relevant to his art. The 1976 political dynamics in China offered a perfect opportunity for He's personality to prevail. In his earlier days, He's painting techniques were mainly guided by the impact of Russian Peredvizhiki (the "Itinerants" or "Wanderers"). As well, some of the painting catalogues preserved by his friends or prints saved from the Cultural Revolution's destruction may have allowed He some understanding of European paintings. ${ }^{6}$

5 In order to achieve a realistic visual effect, He Duoling went to great length to find a mud wall, painted the slogan "Battle of the Yangtze River" on it and copied the slogan from the writing on the wall so that both would look authentic in the painting. Such a method of painting differs from the bourgeois "naturalism" demanded by the Cultural Revolution standard because the painter did not elevate the contents of everyday life to the level which meets the criterion of "the combination of revolutionary realism and the revolutionary romanticism."

6 Despite the fact that the cultures and art of Europe and of the Republican era have often been denounced and the artifacts destroyed with various degrees in several waves of political movements since 1949, some old prints and book were still hidden away in private households. He Duoling talked about having seen painting catalogues and scattered prints at his friend Zhu Chengzhou's place: "Among these reproductions, the former Soviet magazine Artist introduced art traditions from several European countries, including socialist countries of the Eastern Bloc-Romania and Czechoslovakia—the art history from European medieval art to French classical art, and the Impressionist artists. It was the same with music. But it wasn't until the Cultural Revolution period that I truly enjoyed what can be called "music." Back then I still lived on the campus of Sichuan University and often hung out with other youths. The mother of one of our classmates worked at the Music College and they had a huge collection of vinyl records at home. They were the so-called long playing records of 78 rpm discs. They also had a record player. Back then their parents were sent to the May 7 th Cadre school, so we frequented their house to listen to the records. 
No matter what, his gift, evoked through browsing over the catalogues, enabled He Duoling to acquire a sensitivity to oil painting.

When people speak of Wyeth's influence on He Duoling, they think of the grass in Wyeth's works. Indeed, according to He's own statement, the grass may be seen as the trigger for Spring Breeze Has Awakened. In He Duoling's solo exhibition, "China-The Depth of Realism," in Japan's Fukuoka Art Museum—-the artist himself wrote an article on self-retrospection in which he mentions his early experience in Daliang Mountains:

In the winter of 1969, among Shichuan's Daliang Mountains' connecting peaks I lay on a patch of tawny grass and looked up to the sky. The grass grew despite the harsh winter and seemed to suspend in the borderless and limitless sky. It wasn't until ten years after when I realized that it was in those years of loitering about and doing nothing that my life has been unconsciously woven into that piece of grass. ${ }^{7}$

He admitted, "That patch of grass was painted in one of my earliest works, Spring Breeze Has Awakened. In the hard work driven by a kind of blind frenzy, I gradually found myself." Obviously, the grass in Wyeth's Christina's World served as a trigger for He Duoling's memories of his earlier experience. The grass itself became a symbol for the emotions and feelings of the earlier years because it was unconsciously woven into He's internal world "in those years of loitering about and doing nothing." ${ }^{8}$ The grass together with the emotional seeds had been lying dormant deeply in He Duoling's unconsciousness, waiting for the right moment to be awakened and become visible in the conscious world. "Found myself" is the key phrase here. The phrase states something universal of that time. Since the late I970s, one of the shared wishes of the young throughout the '8os was to "find oneself." Given that the existent art forms and expressions did not satisfy that desire, since 1979 any artistic styles or languages of the West that appeared in China pointed to the possibility of a different self and could serve as the artistic trigger for style and image to surface from the bottom of the unconscious sea. So when Christina's World appeared in front of him on a certain day in I98I, He Duoling's buried memory was stirred up. He then changed his initial composition until the completed work captured his ambivalent feelings which were brimming with desire.

we were caught, the least punishment would be confiscating the records. But we felt insouciant then. Of course, we wouldn't turn the volume up. So the whole thing had the exhilarating feel of underground activities. The music we listened to back then left a deep impression on me, say, Mozart's string quartets, Beethoven's famous symphonies, Rimsky-Korsakov's Scheherazade and Dvořák's Symphony No. 9, 'From the New World."' Ibid., I65-66.

7 He Duoling, "About the Art I Love," in Born to be an Aesthetic Person, I4.

8 Ibid. 
However, what were the feelings that he desired to realize in painting? As the artist confessed, "I had a sense of déjà vu when I first saw [Christina's World]. I felt that I should paint this way." Before it appeared in the composition, "grass" is nothing more than an idea, not an artistic image. At best, it existed as imagination without language and as a mental activity such as remembering. In fact, it was Wyeth's meticulous painting techniques that enabled the grass in his painting to evoke He Duoling's feelings and the patch of grass in his memory. Most importantly, that grass summons up the sensation of "looking up to the sky" and further induces the memory of a bygone age which is composed of time, environment and experience. To echo such feelings and to prevent them from being interfered with by a specific character, He changed the intended figure of a public intellectual to a young girl. In doing so, the historical identity of the character might be disguised, but it allowed the artist to preserve the abstract feelings in his memory. We can venture to say that the switch from a public intellectual figure to a young girl produces or makes visible He Duoling's abstract expression. From the beginning He stressed that it was his internal feelings that he was painting but not the conveniently narrated historical facts such as the work of his classmates such as Gao Xiaohua or Chen Zongling.

Be it Wyeth or He Duoling, neither has never denied the importance of emotions in their works. For He, who lives in Chengdu, an inland city of China, the feelings of "quietness" and "indifference" first came from his own experience. Between 1969 and I97I, for a young man from an educated household, the Daliang Mountains meant boredom and barrenness but also quietness and indifference. At that time, He's experience differed in no way from "that of the public intellectuals." When he returned to Chengdu to study painting seriously at Chengdu Teachers College in 1972, his talents and sensitivity were further brought out by professional training. That is why he was able to finish an impressive painting Chasing after the Enemies from the beginning. At that point, the tendency for art to abandon craft and even intelligence brought about by the harsh Cultural Revolution of the proletarian class, which began in 1966, was ebbing away and the National Art Exhibition was reinstated in 1972. The "artistic workers" in China's art world seemed to be taking an interest in oil painting techniques and to a degree practicing it. ${ }^{\text {ro }}$ So, when he was admitted to Chengdu Teachers Col-

9 Ibid.

Io On the May 23, 1972, "the I3th National Art Exhibition to commemorate the 3oth anniversary of Reform and Chairman Mao's 'Talks at the Yenan Forum on Art and Literature"' opened at the National Art Museum of China in Beijing, the first official exhibition since the last National Art Exhibition in 1946. The exhibition which lasted two months included 270 pieces of various art forms: Chinese paintings, oil paintings, lithographs, New Year paintings, propaganda posters, watercolor paintings, and papercutting. In the exhibition, works such as Tang Xiaohe's Advancing in Tempest and among Crushing Waves (1971), Chen Yanning's Chairman Mao Inspects A Guandong Farming Village, Zhang Zizhen, 
lege to learn painting, He Duoling more or less had some opportunity to learn the craft; such learning laid the technical foundation for his completing Chasing after the Enemies four years later.

Nevertheless, regardless of the impact of Russian or Soviet paintings on the Chinese art scene, neither tradition would have helped produce the refined brushworks in Chasing after the Enemies. For a long period, the block brushstrokes championed in Soviet paintings-Konstantin Maksimov's teaching in China during the I950s reinforced the trend for such expressive technique-was the de facto method and the standard style sought after by Chinese painters. In Chasing after the Enemies traces of block brushstrokes can still be seen. However, to look for more realistic visual effects in Spring Awakening, He Duoling not only diminished the block brushstrokes in order to produce images and details that fit better the kind of perception the grass required, but he reduced the space between each brushstroke to the minimum. At that time, the young artists who studied painting in Chengdu often heard the teaching formula "rather square than round" from their teachers (at first passing down from Xu Beihung to his disciples). As a result, "block brushstrokes" itself was a taste that received widespread attention in Chinese art teaching. At the 5.7 Art School, which He's classmate Chou Chunya attended, even a modeling sketch was required to be composed of small blocks of short strokes. These small blocks are airy and vi-

the Big Production Movement, and Wu Yunhua's Chairman Mao Inspects Fushun, which depicts the factory's environment, all expressed an emphasis on forms and techniques. At that time, although there existed art that applied to the artistic standards political tendentiousness, people could still see that artists always expressed their individual uniqueness in taste because of their own peculiar thoughts and perceptions, despite the fact that such expressions were often subtle and concealed. For example, the Art Division of Liaoning Province's Propaganda Department's Tiger's Copper (but the real author of the work is Wu Yunhua) won the unanimous praise from the judging committee because of its stress on details and authenticity. This painting on the subject of "catching up with revolution and promoting production" is painted with an ostensible political cast but the audience's attention was invariably drawn to the polished helmets, the taut faces and the droplets falling from the cracks in stones. Pan Jiajun's $I$ Am a Sea Swallow gives the viewers an impression of authentic storm and rain and the body clothed in soaked soldier's uniform. Tang Xiaoming's oil painting Never Cease the Fire left a strong impression on viewers because of its techniques and the application of gray. In an era that abounded with works that commonly abused ultra-bright colors and standardized composition, the painters found colors and temperaments that are more human in Tang Xiaoming's Lu Xun. In the mid-I970s the Guandong School of painters developed a technique that formed a subtle aesthetic tendency: skillful forms and handsome brushworks, realistic palette and thoughts that avoid grand subjects. For example, the particular composition and the brushworks of the clothes folding in Chen Yanning's New Doctor of the Fishing Port have become the paradigm for many young painters to imitate. 
brant and had become a popular artistic taste among art students. However, for He Duoling, such taste or even method was limited in expressing his feelings until he saw another technique in Wyeth, the emotions triggered by such technique and its visual effects. How images would affect the mental state or stimulate the cerebral cortex differs from person to person. For He Duoling, at least, Wyeth's technique resonated with his artistic taste. Such resonance led to reviving the perception and memories of more than a decade ago, when a similar image suddenly appeared in front of him. At the same time, He was capable of understanding the American painter's technique and eventually completed a piece that lived up to his initial intention.

For a gifted artist such as He Duoling, it wasn't difficult to achieve his goal through learning a new technique. Obviously, He still encountered another kind of challenge. His goal was not merely to copy Wyeth let alone to portray a kind of exoticism. However, "the unconscious force having been laid down from youth so obdurately controls the hands (not the mind) that the process of painting was not in the conscious control." In order to achieve the effects seen in the mind's eye, the painter employed the small and stiff writing brushes for Chinese calligraphy to painstakingly paint those endless grass in great detail. Eventually He created the painting that universally moves the people of that generation. Perhaps it would be difficult for the post-I970s and post-' 8 os generations to be moved the same way as had the previous generation because they are already out of the historical context of the painting. It had been only yesterday when people still suspected and killed each other because humanity had been completely erased by political and ideological ideas and having emotions been branded as classist. If an artist disagreed with such a standard, they would find it difficult even to secure their physical existence. For example, in a series of comics titled Maple in 1979, a couple ended up being enemies to each other and killed by each other lover's guns because of inhuman political ideas.

Thus, when the Government permitted people to criticize the Cultural Revolution in 1978, there appeared works which interrogated recent history, such as Why by He Duoling's classmate Gao Xiaohua, Cheng Junglin's $1968 \times$ Month $x$ Sun Snow. However, for He Duoling, the overt subject matter in Russian and Soviet paintings was not so important because, for He, artists concern themselves with the perceptions, not the event that sparks off the feelings. Therefore, the composition that He chose does not narrate a literary story as the Russian painters do, or pays homage to Surikov by way of imitation which Cheng Junglin did in his $1968 \times$ Month $x$ Sun Snow. Nor does He's composition express Gustav Courbet's "what the eyes see" in the way Chen Danqing's Tibetan Group Paintings model themselves on the nineteenth-century French painter. Instead, He's painting presents itself as a world of inscrutable images. Although there is discernible time, space, character, and environment, the specific intentions of the painting remain impenetrable to the spectators. Or, the painting is merely the end result of the artist's perceptions and labor, without any artistic intentions. Such a point of departure is consistent with modernism. To emphasize again, the fact that He Duoling replaced the public intellectual figure with a farmer 664 girl illustrates his effort to place perception as the top priority and to eliminate 
the explanatory and story-telling nature in paintings. Indeed, the painting's title Spring Breeze Has Awakened makes people think of the change of political climate. But what do the girl's ambiguous facial expression and the composition's sentimental air try to signal? It is such a way of handling the composition that distinguishes He Duoling from his classmates.

When some people say that He Duoling copied from Wyeth, He replied:

That's right. I do love this "sentimental realist" and try to imitate him. I love Wyeth's stringent thinking; his lonely line of horizon mesmerizes me. Moreover, although critics have him as a romantic, he is rational and philosophical and his methods objective and precise. ${ }^{\text {II }}$

The eighties were the period when Western modernism was making waves in China. When critics evaluate this artistic phenomenon, they tend to formulate the period as a time when all schools and styles of Western modernisms were experimented with in China within a short space of a decade. However, at least for He Duoling, the artistic languages inspired by Western modernism or the change in artistic forms are not his concerns. On the contrary, he warns against the excessive freedom of choice. In 1988, he clearly expressed the ways in which he found his artistic parameters in the process of creation. He strongly endorsed the composer Igor Stravinsky's view of artistic freedom being attained by limitation. He says: "The abuse of freedom is precisely one of the reasons why contemporary art is devaluated. And the strict self-imposed limitation is the only means for real artists to obtain real freedom." ${ }^{12}$ To put it simply, as opposed to other eclectic modernists, form is not He Duoling's point of departure.

Perhaps we can regard He Duoling as a fundamentalist painter. However, we also need to clarify why artists' insist on certain ideas about art and painting. $\mathrm{He}$ has analyzed different modernist styles in accordance with his own personality. He has even explored different schools of Western painting since Courbet. In his article "About the Art I Love," He says, "Realism is 'tedious'; surrealism is a 'display of cheapness'; pop art is an 'amateurs' game'." In a 1989 essay, "FaithHuman's Nature and Natural Humans," He elaborates on his views on paintings since Impressionism. He made a fundamental judgement: "Painting is in decline. The most tragic part about this is that it is going into its grave in an era crowded with frantic revolutionary drives and unprecedented artistic schools." ${ }^{13}$

He's analysis of modernist paintings after Impressionism, his assessment of their artistic language and his perceptiveness about modernist art surpass those of the Chinese art critics that were his contemporaries. Here we can understand what exactly his artistic ideas are concerned with through quoting the painter's words. For example, on Impressionism, He wrote:

II Duoling, "Spring Breeze Has Awakened," in Born to Be an Aesthetic Person (Beijing: Joint Publishing, 20II), 33.

I2 Duoling, "About the Art I Love," I4-I5.

I3 Ibid, I9. 
One of the greatest transformations of the twentieth century began with a painting titled Impression: Sunrise. The painter's studio as the sacred factory of arts over the centuries had collapsed. Art surged towards the surface world and converges on the canvas to form an irresistible torrent of light. In this passionate, greedy and momentous heat of gold-digging, the solemnity of classicism and the grimness of its religiosity were brushed off. Desire replaced reason. In Renoir's paintings, art has become real Epicureanism.

Impressionism brings its picnic basket brimming with champagne and hunks of fatty meat to Nature on a train ride. The Impressionists are uninvited guests, not gardeners; their trampling sterilizes the paradise bit by bit. Impressionism eventually runs out of steam because of excessive sensual pleasure and hedonic indulgence; the school seems to peter out because it stays constantly in the most sensitive state..$^{14}$

However, as a practitioner of painting, He Duoling can analyze the relationship between modernist paintings and his internal needs with very tangible expression. Of course he knows the importance of color to Impressionists; he knows by heart that color "seems to exist purely for vision." However, "for my art, color is a trap. The more I'm drawn to it, the more my reason demands me to stay away from it." Is As a result, when his classmates such as Zhang Xiaogang and Chou Chunya were passionately championing Impressionism and Expressionism, $\mathrm{He}$ Duoling adopted a very cautious attitude - he did not go for festive colors; he even thought that the Impressionist colors are more materialistic than those of Classicism. Materiality was what He Duoling was managing to avoid from the very beginning. In the 1980 os Cézanne, Van Gogh, and Gauguin served as inspiring role models for the young Chinese artists. He Duoling of course researched on these seminal artists. However, during the process of analysis, what He discovered were his own needs, his difference from these artists and the components he needed to express himself.

Cézanne sacrificed Impressionism's refreshing colors and visual accessibility for his ideal without achieving a kind of scrupulous sanctity in the colors--one of Classicism's characteristics. His still-lives perform an exact autopsy of light and colors without being able to sew the dissected planes back together. His mountains look like faltering monuments: on the one hand they announce the failure of his lofty ideality; on the other, pronounce the upcoming free-falling slaughter--the arrival of Cubism.

Gauguin perfects the Romantic sublimation of colors. He liberates Impressionist colors from empirical optics and thereby announcing the beginning of a paradigm shift from Neo-classicist to Symbolist color scheme. The motto of this era is that colors do not simply follow the external light source but also the spir- 
itual direction. The passion for colors does not cool off in Gauguin's paintings but his use of colors begins to hint at some prescriptive aspects of symbolism. ${ }^{16}$

In actuality, when discussing these artists, He treated them as organizers of Impressionist colors. Because of the subject, He introduced Matisse in his discussion, who was beginning to become a well-known artist to the Chinese public. He says:

Just as Gauguin, Matisse establishes order among colors and diminishes the surface intensity, thereby creating harmony in a quiet state of balance. But such harmony is still of a sensuous kind, only more refined, like the icy cold surface of porcelain. He restrains the feral color atoms of Impressionism while making them into a custom-made play thing for the bourgeois class's lazy aesthetics. ${ }^{17}$

When discussing the Western artists' employment of colors, He Duoling was frank about it:

I defy obstinately the following doctrines (despite the fact that such doctrines even come from within): that colors are to be judged according to their being "strong" or "opaque." I believe that in contrast to a "rich and loud" palette, a "pale and opaque" one is a equally glorious. Just as the darkness of the night can possess the same aesthetic force as the brightness of the day-as long as it fits in certain expressive language..$^{18}$

No matter how Western critics explain such a period in China, those who understand the modernist movements in the I980s in China know that this is precisely a period when many artists deployed Expressionism's strong and dark colors to cover up the bright colors that dominated the arts of the Cultural Revolution. People, at least those who are used to think of "transformation" and "revolution" in terms of symbols, tend to be very sensitive about the use of "strong" or "dark" colors. However, what He Duoling was concerned most then was the subtle color palette of his internal world. For him, the manipulation of colors-to avoid bright red or green or excessive strong colors so as not to affect people's overall and emotional perceptions of the composition-is the most important task in realizing his own painting. Like most of the modernist enthusiasts, He Duoling concerned himself with aesthetic matters; he took heed of the Futurist slogan: "A race car $[\ldots]$ is more beautiful that the Victory of Samothrace." But:

Such efforts to "paint" the movement include: in a concrete painting, multiply the painting plane into planes which can be juxtaposed together, shifted, and overlapped. These planes move along the axis of the viewer's perspec-

I6 Ibid.

I7 Ibid, 24 .

I8 Ibid. 
Fig. 3. He Duoling, The World after

Christina, 20Io. Courtesy of the artist.

tive and all the parts of a moving object would be disintegrated, accumulated, intersected and separated. In effect, such process flattens the connection between vision and movement. On the canvas one can see the traces of all parts of the same object in a daydreaming state. The bluntest expression of such imitation of external movement is a dog with 8 legs. ${ }^{19}$

He Duoling has analysed the formal properties of abstract paintings and also mentioned the qualities of movement in the "optical art." However, he maintained that "op art" is "nothing more than a new trick of the decorative function of art." ${ }^{20}$ Without being too keen on these forms, He, after analysing different characteristics of abstract art in great detail, expresses his take on form: "I abide by the kind of concretism under the guidance of abstraction, or, the abstraction expressed in concrete appearance and materiality." ${ }^{21}$ We can tell what the painter means by abstraction in He Duoling's works. He controls the basic structure of composition through the lines of the objects' silhouette while preventing the audience from mistaking the canvas as an illusionary space. The composition echoes the low-intensity palette and thus achieves a kind of abstraction with a palpable appearance.

The reason why I have quoted He Duoling's words verbatim is that I want to emphasize a fact: even in the 1980 os of the last century when China had just opened its door to the West, Western thinking and arts were immediately displayed as a kaleidoscope in front of young Chinese artists. However, for $\mathrm{He}$ Duoling, the richness of artistic language must follow the heart; and what the artist is concerned with most is choosing that language according to their thinking based on experience, the artist's own perspective and their own point of departure. In January, I98I, when Wyeth's print (whose quality is a poor imitation of the original work) appeared in front of He Duoling, it proffered an opportunity for this Chinese artist to evoke the memory of his personal experience and trigger the point of departure of his painting. As the artist informs us, much

I9 He Duoling, "Faith: Human's Nature and Natural Humans," in Born to Be an Aesthetic Person, 26. 
earlier "Sichuan's geographical diversity and the seclusion of the entire space constitutes elements that are fit for my world view. For a very long period of time, most of the subjects of my works come from my meditation on this land. Or, one can say that the land is the embodiment of my thinking." ${ }^{22}$ In 1995 when He gave lectures in the United States, he saw Wyeth's original Christina's World. He recalled, "I realized that Spring Breeze Has Awakened has nothing in common with [Christina's World]," regardless of the fact that he paid a courteous homage to Wyeth with The World after Christina in 2008 (Fig. 3). ${ }^{23}$

Wyeth's art was questioned by critics in his own time because his art wasn't associated with modernist or international trends. Wyeth was born in 1917 and his experience and understanding of life fell between the two World Wars, including the Great Depression, spanning across the I930s and the I940s. American art was under the influence of modernist European art. Although American artists who were labelled Regionalists did not employ modernist language in their art, they nonetheless created an art shaped by European influence. While the label "regionalism" doesn't invite itself to being part of an artistic trend, it is precisely the regionalists of this period who really began to consciously create American art. Wyeth was denied consideration as a serious artist or sneered at by many contemporary critics in part because he was judged against European standards. However, it is the artists who came just before Wyeth-Thomas Benton, John Curry, and Grant Wood-who allowed people to see the face of America during this period-nature, history, and people. For this very reason, the realistic idioms deployed by these painters were dismissed by mainstream American art world because they did not appear to demonstrate the reliance of American art on European art. At the same time, quite a few artists who adopted realistic methods even went back to the artistic influence of El Greco, Tintoretto, and Rubens. As to Wyeth, he looked to Albrecht Dürer (I47I-I528) and Rembrandt (I606-I669) for their profound artistic expressions.

These Regionalists and realist artists opened up possibilities for American artists who came after them for an authentic "regionality" that could be expressed by artists and seen by people. Wyeth's audiences have felt that it is the emptiness suggested by the environment with which he is familiar that constitutes the theme of his art. At the same time, from the beginning Wyeth departed from the constraint of the physical appearance of the nature and expressed the spirit of an abstract idea. This exemplifies one of the important characteristics of contemporary art: the artistic point of departure is generated after the artist has perceived and formed an insight into the context and related historical factors. And so, confirming one's unique point of departure is the key for Chinese artists of He Duoling's generation. Although, like Wyeth, He comprehends the whole

22 He Duoling, "About the Art I Love," I6.

23 In this $150 \mathrm{~mm} \times 200 \mathrm{~mm}$ painting, He Duoling maintains Wyeth's composition but adds a dreamy atmosphere to it. He places a Chinese girl where Christina stands in Wyeth's painting and the Chinese girl appears to be looking for the Christina, whom people cannot stop searching for. 
picture of European modernism, both from the beginning to the end of their artist careers have always directed their artistic goals internally, and validated their own artistic idioms and styles in accordance to their "internal needs" as Kandinsky insisted. ${ }^{24}$

Indeed, like Wyeth, He Duoling isn't interested fundamentally in the appearance of the physical world. They both dedicate themselves to investigating and expressing the issues beneath the phenomenal that is the spiritual zeitgeist of their age - at least, the spiritual zeitgeist that the artists themselves believe in. In order to realize such a goal, Wyeth always makes the composition and space of his painting abstract, taking either a high or low perspective, thereby alienating the composition. Such composition deviates from the usual realist norms so that its structure has become abstract. At the same time, he always simplifies the details of the objects he depicts. For example, the distance between the house and the barn in Christina's World has been adjusted, and chicken coops and superfluous trees were omitted from the composition. Wyeth only keeps the objects he needs so that the composition is neat without the interference of the physical world. The use of an opaque, usually grey and solemn palette intensifies the atmosphere of confusion and perpetual sentimentality. That is exactly what Wyeth aims to express: the emptiness of the world. Such artistic attitude and techniques obviously have been under the influence of abstraction: superfluous reality is eliminated and cleared up, and its elements form a formal system is full of meanings. In 1989, He Duoling summarized the basic compositional logic of his artistic creation:

I want to paint a teenage girl of the Yi people on a snowy plateau. I need to express the undividedness between her and the wilderness, both originated from the same root. Apart from that, I know nothing and need not to know anything. For example, why did she stand there? Perhaps she was waiting for someone or something. I don't need such scenario. All I need is to express the mystery. In order to achieve this goal, I keep turning her head to the moment so I can feel the creation of harmony. Then I pin down such a moment. Nor do I need to explain the definition of such harmony and the reason of its creation. I only know that I've narrated an unknown story and the secret is contained in the stillness of the canvas. I will start to search for that secret along with the viewers. And I know that our answers to that inquiry will not be the same. Would any realization be more consolatory than this?25

So, as with Wyeth, He Duoling understands modernist techniques and artistic intentions, but he wishes to search for abstraction in the seemingly familiar physical world through analysis and induction. They hope to abstract from the

24 Vassily Kandinsky, On the Spiritual in Art (New York: Guggenheim Museum, I946), 55 .

25 He Duoling, "Faith: Human's Nature and Natural Humans," in Born to Be an Aesthetic Person, 30. 
world which is visible to our eyes not its physical attributes but the emotions stored away behind the appearance. In the end, they both want to express the deep mystery beneath the surface of physical world. In this regard, He Duoling sets himself completely apart from the points of departure and confirmed goals of the earlier artists who studied in the US such as Li Tiefu and Feng Gangbai.

To summarize, it is precisely the points of departure in perception and taste that allow He Duoling to have discovered his own beginning in Wyeth's work; it is precisely the gap between contexts and cultures that sets He Duoling apart from Wyeth. What is interesting is that in the China where high-quality prints of Western artworks were rare He Duoling seems to have affinities with Wyeth while in the United States where the authentic Wyeth are available to viewers, He Duoling discovered the yawning gap between the former and himself. The two still share some common ground which lies in their respective respect for social changes, cultural backgrounds and genuine internal perceptions. That makes the pair exemplary models for a specific art historical period.

\section{Wang Guangyi and Warhol}

Abstraction has had a varied history in the United States, both accepted and rejected. By the end of the Great Depression and the Second World War, abstraction had a second chance, with the appearance of Abstract Expressionism. But along with the social development of extreme commodity consumerism, and audiences' confusion about Abstract Expressionism's aestheticism, a new art form which was easy for ordinary people to understand quickly took shape, as "new reality," in the name of "Pop Art." The key first players of Pop Art were Roy Lichtenstein (1923-1997), James Rosenquist (1933-), and Claes Oldenburg (I929-), as well as Warhol. Instead of conveying some mysterious concepts or meditative thoughts derived from Zen Buddhism, which was an important aspect of Abstract Expressionism, Pop Art allowed people to embrace the material life. This is the basic historical background for us to understand Warhol.

The situation in Mainland China was similar: in the early I980s the recent past was being questioned and there developed a critique of history and reality based on realism's system of imagery. After being given the opportunity to make aesthetic statements valuing the restoration of human relations, it had become a major issue for Chinese artists to reflect on and create a spiritual state for the reformation period after 1978. In the mid-I980s, although the style and approaches of '85 New Wave were derived from the Western art, the name of the game for the vanguard and avant-garde artists was to construct a new culture. Such emphasis mirrors the post-war Abstract Expressionists' artistic ambition to reconstruct American culture. Where the two movements part company lies in the fact that the Chinese officially decreed art institutions did not echo or back any modernist movements taking place anywhere in China. Moreover, from time to time these institutes, singing from the same Communist Party hymn sheet, would intervene with the '85 New Wave movements. When such background intervention appeared in the process of constructing a new culture, Chinese artists faced a difficulty, namely that their efforts were out of sync with the state's will. 
People tended to view such phenomena as a confusion of values. If we say that He Duoling's art invokes people's common need for humanity during a specific historical period, Wang Guangyi's art takes part in a more complicated debate on values. Although Warhol's art was condemned by some critics in the United States, very few would agree that his art isn't the American art.

Contrary to Wyeth, Warhol was enthusiastic about the urban life of consumerism. He didn't even consider art as something wildly different from commercialism. In his view, making money itself is art. The two types of artists are like chalk and cheese. Andy Warhol, who succeeded in New York the moment he graduated from Carnegie Institute of Technology, didn't pay attention to negative commentary directed at him from the art world. Indeed the artists who followed him naturally saw Warhol as a true American artist and regarded Abstract Expressionism as an extension of European modernism.

Warhol was born in August 1928. He was drawing from a very early age, an inclination that may be attributed to his mother's preference and assistance; indeed, she bought a slide projector for Warhol to see Mickey Mouse and Annie, which Warhol would draw later. Andy Warhol's earliest art education concentrated on commercial design although his teachers taught some basic painting techniques. Later Warhol would regard Hollywood films, television, newspapers, and commercials as essential American culture. In any case, popular culture constitutes Warhol's artistic genealogy. But he was not particularly concerned with how popular culture was perceived in the grander human value system, which was the issue for intellectual circles; he simply inherited that American culture. He later wrote in America:

I love going to the movie theatre. Perhaps I wish the movies can tell us what life is like but in reality that's not the case. The life in the movies and the one I know differ a great deal and I wouldn't believe in the movies. Although believing the life portrayed in the movies to be real is a beautiful thing, perhaps that will happen to me one day. It's the movies that have really been running things in America since they were invented. They show you what to do, how to do it, when to do it, how to feel about it, and how to look how you feel about it. ${ }^{26}$

Such an attitude illustrates Warhol's approval of going with the popular cultural flow. As a matter of fact, the first job Warhol got after graduation was to decorate department store windows. To achieve success in a commercial society constitutes his underlying desire for artistic creation.

Even before Warhol achieved fame, he knew that Abstract Expressionism was "shit," which points to his strong will to create his own art. ${ }^{27}$ It was not until he used the Campbell soup cans as the object of creation, which he was

26 Andy Warhol, America (New York: HarperCollins, 1985), 5.

27 See Arthur C. Danto, Andy Warhol (New Haven: Yale University Press, 2009), I6. 


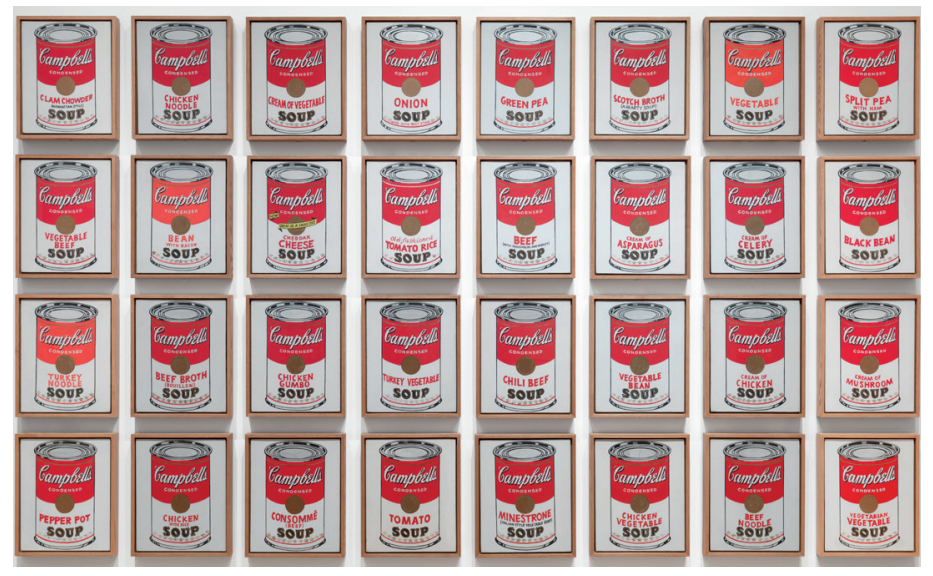

Fig. 4. Andy Warhol, Camp-

bell's Soup Cans, 1962. Museum of Modern Art, NYC. (C) 2019

The Andy Warhol Foundation for the Visual Arts, Inc./ Licensed by Artists Rights Society (ARS), New York.

familiar with since childhood from his mother's kitchen, that he completed a landmark work of pop art. In July 1962, Warhol held his solo exhibition at the Ferus Gallery, Los Angeles, where people saw 32 paintings of Soup Cans (Fig. 4). Art works showing daily utilities, composed of repetitions and devoid of meanings heralded a new era for American contemporary art. Anyone who is familiar with American life in the I950s and the '6os would understand why Warhol's art could represent the art of this period in spite of the fact that he was criticized at first.

When Warhol took his own photo at Tiananmen Square in Beijing in 1982, Wang Guangyi had just graduated from the China Academy of Art. Wang Guangyi was born some ten years after He Duoling, just as Warhol and Wyeth were a little more than a decade apart. Those who spent their youth in the I930s and '4Os and those who spent their formative years in the post-austerity 'sos respectively took in the different atmosphere of the era and each era's unique context. In December, 1978, the Third Plenary Session of the Eleventh Central Committee of the Communist Party of China made sure that the top priority of the entire nation and of the Party was economic reform. This declaration changed the monotonous political atmosphere of the Chinese society, making a sharp contrast with a nation deeply seeped in the cruel political environment of the "Class Struggle Outline," while elements of freedom and commercialization start to trickled into every fold of society.

Whatever the situation, Chinese society, which was at the initial phase of commercialization and consumerism, stood in no comparison to its glitzy-ritzy, sumptuous and voluptuous American counterpart. Throughout the entire I980s, Wang Guangyi spent most of his time learning and contemplating the philosophical concepts and art history of the West. Unlike He Duoling, who lives in southwestern China, Wang seems to have an innate tendency to avoid sentimentality and lyricism, a kind of "northern" regional signature style. His North Pole series constitute his earliest attempt at going beyond regionality while relying on it. In any case, he tried to get rid of the kind of mellow naturalism of his graduation period. He, along with his friend Xu Chung, proposed "Frigid Zone Civilization," which is an initiative to counter the "Temperate Zone Civilization" and aims to draw a line between them and other forms of modernism adopted in China. In terms of composition, the depiction of characters and 
their environment is very generalized. As opposed to the southwestern trend of expressionism, Wang Guangyi's paintings are rational and lack emotional factors. Such artistic contrast provided art critic Minglu Gao a stylistic basis for his pair of concepts of "ideal painting" and "life stream." There is no need for us to document all of Wang Guangyi's artistic journey in great detail; but what is clear is that Wang changed camps from being a Hegelian or Nietzschean to thinking along Karl Popper's philosophical lines. E.H. Gombrich's analysis of art history allows him to realize that the so-called originality to a great degree does not exist. One cannot distinguish one's art from artists in other camps through pure ideas. There are no such things in the world. Therefore, in the later part of the 1980 s, Wang freed himself from materialistic philosophical thoughts and he was convinced that concepts embodied in the computer simulation The World 3 could liberate his art. The Post-Classicism series is the earliest attempt to relieve his art of conceptualized naturalism.

As Wang wrote in an article published in volume 39 of The China Art Newspaper in 1987: "Gombrich offers me a certain iconography-cultural correction and revelation on continuity." It is such revelation that leads Wang to discover that the production of meanings does not happen in the excavation of the objective world but in the giving of meaning. That is a turning point for his conceptualization of art. The North Pole series is an "upward" symbolic iconography of "metaphysics," or of "sublimity," and "absolute idea." At least the artist himself views such iconography as stylizing the pursuit of truth. However, whether it was iconography, techniques, or concepts, Wang realized that none of these got close to the ideal goal. At least the "ultimate ideal" that Wang and his friends wished to establish was not realized.

Imagining himself in a period akin to the Italian Renaissance period when he was still under the spell of Hegel and Nietzsche, Wang wrote:

The Übermensch of life-such driving force of culture has reached its zenith today. We desire to "treat various forms of life gladly, establish a new and more humanistic spiritual form, and to create a more orderly evolution of life." But we're only against those art forms of the pathological, of the trivial, of Rococo, and all those unhealthy things which impede the evolution of life. Because these things breed human weakness, they make people run away from health and from life. From this perspective, the art that "'85 New Wave Movement" participants created is not art. Instead, they were realizing a kind of philosophical concept and behavioral procedure that is not philosophy. In this regard, '85 New Wave Movement resembles the beginning of Renaissance when art is characteristic of a sense of uncertainty. The reason why Renaissance art is valuable has nothing to do with its degree of perfection as an artistic model but with the revelation stated in the unphilosophical philosophical concepts. The revelation triggered the rise of humanist thinking, 
led Europe out of the Medieval predicament, and discovered the humanistic values of human beings and being human. ${ }^{28}$

But Wang Guangyi soon realized that art is based on art history just as civilization is based on the progress of civilization. The shortcoming of essentialism is the pursuit of absolute truth. And Wang Guangyi soon learned from Popper and Gombrich that absolute truth does not even exist.

The Post-Classical series first demonstrates Wang's turning away from his metaphysical attempt to seek help from art history. Conceptually speaking, Wang was beginning his "descent" from the higher metaphysics. In Wang's opinion, "classical" art - mainly the European strain—is the basic and the most important part of art history. But he guided his own action with an "iconography correction" of his own understanding, taking works by Europeans masters since Renaissance such as Rembrandt and David as his motifs for "correction." In the opinion of art critic Wang's classmate, the art historian Hong Zaixin:

The pieces-Post-Classical: The Return of Compassion and Love and Post-Classical: Arch Angel — are the two that hold my attention. They trigger a visual and spiritual sense of solemn and magnificent elevation in me. They remind me of something you said: "the underworld of rationality is better than sentimentality.” In other words, you really aren't painting personal feelings but celebrating the mission of Übermensch. No wonder people moan and comment that no single artist of the New Wave has established a successful iconography as you have done. ${ }^{29}$

Although, it should be pointed out, Hong Zaixin's understanding doesn't square with Wang Guangyi's initial attempt at "correction:" "The underworld of rationality is better than sentimentality" is merely an ideal of the past. At that time, despite his reluctance to let go of classical "iconography," Wang Guangyi was making attempts to get rid of his philosophical relationship towards metaphysics.

By 1989, in the Chinese art world, the modernist movements that had begun in 1984 had run out of steam because of the sheer volume of manifestos and the constant linguistic experiments of various styles and schools. The political campaign slogan "anti-bourgeoisie class liberalization" initiated by the Communist Party provided political ammunition to opponents of modernism. After all, all schools of modernist art are a formalization of bourgeois art. As long as the slogan remained politically correct, that type of art would be suppressed, or at least kept on a short leash. However, in the field of art criticism, there still existed a voice which continued academic thinking. This voice proposed the need to "purify

28 "Us—-the Participants of '85 New Art Movement," Zhongguo Meishu Bao (Fine Arts in China) (1986): 35-42.

29 Hong Zaixin, "The Iconography of Critique and the Critique of Iconography," Arts 3 (1988): 53-56. 
artistic language" apropos of the language problem of modernism. In the eyes of a certain critics, there exists in the modernist movements-particularly those of the Expressionist leanings_ - issues of a "rough and ready" artistic language. Indeed, before 1989 most of the modernist artists in China suffered from poor material conditions: they had to make do with threadbare bedsheets or low-quality textile for painting canvas and to produce paint domestically, which is prone to discoloration and peeling when dried. One can judge the artists' overt concern with philosophical questions in their works to be "accomplished more conceptually than in practice." Most of the works by young artists were rough around the edges and ineffective in terms of their material conditions and quality. Of course, the "purity of language" cannot be judged upon the questions of materiality. Some critics are convinced that in order to promote the development of modern art, the artistic language has to be "purified." Such discussion tapered off quickly because "pure language" is an essentialist pseudo-proposition. It simply is another paradigm of formulating criticism on form and content-the exterior and its core-when the content is understood to be valorized ideas while the forms are supposed to be "exquisite" and "precise." However, at the same time, quite a few classically styled works by the teachers at Central Academy of Fine Arts (such as Jin Shangyi, Sun Weimin, and Yang Feiyun), along with the New Academicism proposed by the young teachers at China Art Academy, soon broke down the efforts to "purify language." Critics of the avant-garde simply refused to accept such "purification," an unmistakable "regression." In the 1989 China/Avant-Garde Exhibition, before catching up with the modernist issue of "pure language," most artists had sensed the end of an era. Although the group of artists went on to learn the rationale for naming the new artistic trend "Postmodernism," they realized the universal abandonment of essentialism and the total acceptance of the dissolution of meanings.

Mao Zedong: $A C$, a triptych finished in 1988 and exhibited at the 1989 China/ Avant-Garde Exhibition, is a seminal case in point where Wang Guangyi shifted his focus from art history to the change of social life. Perhaps Wang was only aware of the importance of real life problems instinctively. However, he resented the realistic or expressionist approaches to express his views and perceptions of reality. When Wang said that Expressionism is pathological, he differed from Warhol's view of Abstract Expressionism being shit. Given the dissimilarity between the two artists' views, Wang had to search for possibilities for his art of his own accord.

One can imagine the commotion and speculation caused by Mao Zedong: $A C$ during the exhibition period. The social life in 1989 appeared to be restless and in a state of agitation. The commodity economy developing in a mismatched background of an incongruous political system started to distort people's psychological state. The news magazines during this period often reported on the chaotic social situations: tens of thousands of people from the farming communities abandoned agricultural production and rushed to the big cities of their dreams. Rumors about factory closures in certain places, decline in production, and millions of job losses in a short span of time fanned people's panic. The dramatic increase of unemployment in 1988 created a crisis that caused all local government 
officials to sit up and take notice when rural migration became an unstoppable trend. Yet, the sheer number of migrants paralyzed the railway networks, and the demanding crowd management in transportation caused social disturbances. To cap it off, inflation was on the rise. Profiteering in government was widespread ${ }^{30}$ and government officials were corrupt. All this became an unbearable psychological burden and mental stress for the nation. Therefore, people started to immortalize Mao Zedong, who had advocated for egalitarianism, into a legendary hero. Understanding such social mindset helps the viewers comprehend the works or remind them of the past. However, for some critics the ripples stirred up by such news stories were irrelevant to art. They were merely repercussions of the demand for reality, not the logical progression of modernism.

At this point, Wang Guangyi was secretly pleased with the waves made by his work. It wasn't long when he put forward a slogan "clearing up humanistic passion," which was leveled at Expressionist leanings. But the reverberations Mao Zedong: $A C$ sent allowed him to be aware that people's "humanistic passion" was fueled by his work. That did not perturb him. On April I8, 1989, he wrote to his critic friend Yan Shanchun with mixed feelings:

I was concerned, very concerned that people treated my Mao Zedong: $A C$ as a mere attention-grabbing tool. Mao Zedong: $A C$ was guaranteed to make news headlines, without a doubt. But that is only looking at the surface of things. What I had in mind was to reveal the cultural attitude where art is treated suspiciously as newsworthy with artistic means neutrally and squarely. With hindsight, I think I realized my intentions. Not only did the work revealed people's peculiar cultural nostalgia for Mao Zedong, our leader of the pastfolks such as laborers, farmers, soldiers, and intellectuals alike-but it is the logical corollary of my artistic iconography. The question posed by the piece to posterity and the inspired "humanist passion" in all respects prove my insight in having proposed to "clear up humanist passion."

So when we put side by side Wang's perspective and Warhol's, we can tell that their artistic points of departure are poles apart. Wang Gaungyi still strives to seek the internal meanings of art while deliberating whether he should conceal the intent of his iconography or symbolism: to "reveal the cultural attitude where art is treated suspiciously as newsworthy in artistic means neutrally and squarely." On the other hand, for Warhol, art is supposed to be grabbing news headlines and not just "newsworthy." But, soon, Wang clearly points out in his book Art Notes:

30 Guan dao (official profiteering) refers to the officials in the state institutions, organizations, and state-owned enterprises who abuse the power they have and profit through leveraging the state-set price against the free-market price (sale price) in China's dual-track pricing system (shuangguizhi). 
In contemporary art, "creation" doesn't hold much sway as people think. Yesteryear, people had created all possible artistic languages. What we want to and can only achieve today is to give the languages some new meanings. ${ }^{31}$

In Mao Zedong: $A C$, Wang Guangyi further reduces the function of hands. He merely reproduced the standard Mao Zedong portrait. If possible, he would even give up painting - indeed, he made some pamphlets. ${ }^{32}$ He preferred using ready-made portraits (not "created" ones) to compose his works. He then developed such artistic ideas and painting logic into the Great Criticism series.

In January 1991, the first issue of Arts \& Market magazine interviewed Wang Guangyi. When the journalist asked him, "How is Chinese contemporary art situated in the world arts industry in your opinion?" Wang replied:

For the time being, Chinese contemporary art hasn't been at the same peak that it has been accredited in the academic world. The reasons for this are complicated. And one of the reasons is that we lack a strong public institution to back it up. The success of post-War American art is in fact the success of the public institutions. Otherwise, artists such as Pollock, de Kooning, and Johns could not have been where they are.

Wang Guangyi's opinion on the development of American contemporary art is rather vague. But he sees clearly that state power remains an important background factor for the development of contemporary arts. In effect, China's rapid economic development since 1993 provides a basic backdrop for the sway Chinese contemporary art has held in the international society, despite the fact that the arts-supervising institutes in China do not provide any help for artists who are dispersed in the private sectors instead of serving at the arts colleges or the public arts institutes. Some Westerners do not distinguish-perhaps they do not understand at all — the real conditions within and without the public institutions in China. Instead, Chinese contemporary art is usually seen as a homogenous whole. Indeed, when relating the question of money, Wang Guangyi can speak of the subject in a lucid and straight forward manner, without shying away from the topic of finances which has been avoided by people out of shame:

Being an artist, I think money and art are both good things. It has taken people thousands of years to realize that only arts and money can bring joy and meditation. The artist loves money the way common people do. What

3I Wang Junyi, ed., Wang Guangyi's Art and Thought: An Anthology of Criticism and Interviews (Beijing: China Youth Publishing Corporation, 2015), $3 \mathrm{I}$.

32 Even till the late 1990s, Wang Guangyi still had no resources to construct his own workshop to produce screen prints or similar types of work. So his works since the Great Criticism series have all been handmade. Of course, handmade production gives the artist the last chance to express personal taste but it is not a "necessary artistic means" as it was for Expressionism. 
is different is that the rank and file usually spend money on luxuries while artists use money to sustain a myth of image. The more mysterious an artist appears, the more value his works can pitch. Here the metaphysics of myth is exchanging values with the myth of the secular world. Only when the two mythical systems reinforce each other can art develop. We should say that in the world of contemporary art, the issues and illustrations of the "Matthew effect" control the birth and death of the myths of artists, critics, and art markets. $^{33}$

As an American, Warhol might have found such a manifesto long-winded; his own on money has nothing mystical about it. However, in China where the market economy was just at its nascent stage, Wang Guangyi's opinions on money and art faced harsh condemnation because at this moment most of the people in the Chinese art scene still believed that art should not have anything to do with money and money should not be the arbitrator of art. However, Warhol in the States had long used the dollars as a subject for painting.

Around 1960, artists such as Jackson Pollock (1912-1956), Willem de Kooning (1904-997) and Mark Rothko (1903-1970) were the men of the hour. Yet Warhol did not care so much about Abstract Expressionism and would have no truck with artists such as Robert Rauschenberg (1925-2008) or Jasper Johns (1930-). Instead it was Roy Lichtenstein's cartoon art that indicated the possibility that Warhol could make use of ready-made commercial images and signs to create works - this is the precondition for Warhol's 1962 Campell's Soup Cans in 32 different colors. No matter if the gallerist Muriel Latow had given Warhol the important advice to look at Lichtenstein's work, Warhol, who was swimming in the vast seas of commerce, must have concluded from the discussions with his friends and from his thinking that he has to express the commonest objects in people's daily life without resorting to the vague approaches such as dripping paints on canvas. ${ }^{34}$

Wang Guangyi's logic drives to make use of ready-made images. Where Wang differs from Warhol is that some of the images familiar to people come from history and some from reality. The images that have come down from history are not the records of the artist's memories but the logical conclusions from the state's systems and the corresponding ideological construction. In spite of the rich jargon of the market economy, the slogans of the state accord well with the earlier history: this is a Socialist country where laborers, farmers, and soldiers are the mainstay of the nation. Since 1989 this concept has been reinforced officially by the power of the state apparatus.

However, in their everyday life people have long been accustomed to the commercial signs from the West, such as Coca Cola, Nestle Coffee, Marlboro, etc. In emergent market economies, such signs gain fast popularity along with

33 Wang Junyi, Wang Guangyi's Art and Thought, 28.

34 For a summary of the origin stories, see Gary Comenas, "The Origin of Andy Warhol's Soupcans," https://warholstars.org/andy_warhol_soup_can.html. 
Fig. 5. Wang Guangyi, Great Criticism-Coca Cola, I992. Oil painting.

consumerism and constitute people's general impression of the market's stock images. In the I990s, the Chinese people habitually believed that imported goods were of better quality than domestic ones and people treated the Western consumer products as a benchmark for consumer standards. This phenomenon hearkens back to the '8os trend when more and more of the younger generation started to regard Western thoughts as gospel. Of course, Wang Guangyi was sensitive to these popular imported signs, and he almost intuitively discovered the unique spectacle created by the juxtaposition of the images of laborers,

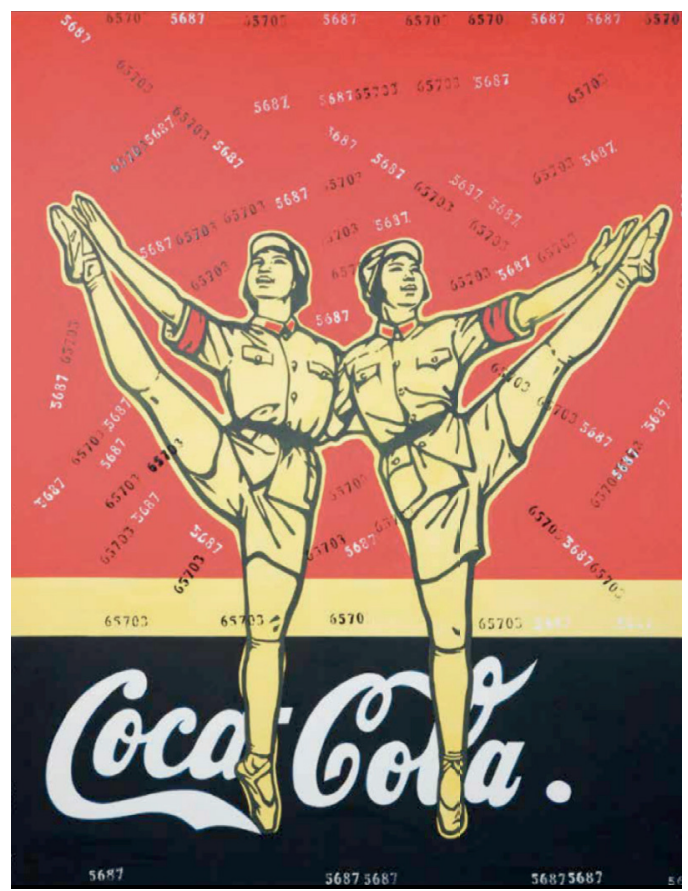

historical and ideological functions and Western commercial signs in the Chinese context. His previous appropriation of Mao Zedong's sign had had an immediate impact. And that success allowed him to be aware that images and signs connoting reality are better for fast transmission than classical iconography in art history. Besides, the contents of the works were pertinent to contemporary China - the market economy underlying a Socialist system. One day, he caught the simplest glimpses of the history and facts of the Cultural Revolution: he put two cans of Coca Cola in front of the Great Criticism he had just completed. By simply inserting Coca Cola's commercial logo in his painting Wang could create an intense and playful tension. Such is China's reality-the juxtaposition of ongoing ideological doctrines and capitalist commodities. The Great Criticism (Fig. 5) was first published in the Beijing Youth Daily of the March 22, 1991. The artist himself, with the editor Wang Yoshen and critic Lu Peng, co-curated a special edition in which the trio attempted to disseminate The Great Criticism's iconography via the media. In October of the next year, Wang Guangyi's The Great Criticism-Marlboro was awarded the first prize in the 1992 Guangzhou Biennial Art Fair. This event led to the quick popularization of Pop Art of I99I. People started to pay attention to Pop Art of various linguistic contexts in various cities (for example, Li Sang, Yu Youhan, and Liu Dahong in Shanghai).

The critics who were on the judging committee of the Guangzhou Biennial Art Fair had just woken up from the essentialism of modernist theories, and they were thrilled with the Pop Art emerging at that time. The straightforward signs and works resonated with social reality. This made them feel that Pop Art in China rose against some authentic backdrop. Spending his formative years 680 in the I96os United States, Warhol made objects of everyday life into the ob- 
jects of artistic expression, thereby in effect granting approval for the adaptation of American lifestyle. In contrast, Pop Art in China had a different point of departure and pertinence; no Chinese Pop artists would wax lyrical about the commodity society. In the early '9os, contemporary artists were still living in an impoverished condition and weren't able to command the term "consumption" as freely as the ones who came after the new millennium. Feeling spiritually ill at ease with the commodity-swamped society, the artists were suspicious of the market. Critics therefore hold that these works of Chinese Pop Art differ from that of the American brand, arguing that in order to express their reflections on history and reality, Chinese artists simply adopted an accessible and common artistic language. So, art critic Pi Daojian sets out to explain the difference between Chinese and American Pop Art by coining the terms such as "cultural pop" and "socialistic pop": they differ in their artistic points of departure and sense of pertinence. Unlike their American peers, the Chinese artists were still feeling so confused and overwhelmed by the artistic conflicts between a vague sense of institutional mode and new ideologies that they unanimously adopted a mocking attitude. ${ }^{35}$

Wang Guangyi never stated his reasons for creating the Great Criticism series. He simply skimmed through the headers of the newspaper and of the books published during the Cultural Revolution period and tried to reproduce "laborers, farmers, and soldiers" on canvas of various sizes, inserting different commodity signs from the West. The "Great Criticism" propaganda billboards of the Cultural Revolution period tend to place the images of political figures under the images of hammers, fists and fountain pens. Now the objects of "criticism" are replaced by the signs of capitalist commodities. Such displacement satisfies

35 Pi Daojian analyzes the situations of contemporary Chinese arts in "Basic Estimate of the 'Biennale' Works": "The investigative works in this year's Biennale have demonstrated characteristics and trends that 'will definitely capture the critics' and the art historians' attention' [...]. The artists have shown a more relaxed creative mentality than those of the '85 New Wave. The creative attitudes of ridicule, mockery, and playfulness have become the new trends, which can be clearly seen in the works by 'Hubei Pop' and 'new generation' artists. 'Hubei Pop' cites iconography from the culture of the past and from history or transforms popular mass consumer goods into arts. Such approaches no doubt suggest something more profoundly cultural and social and allow the critics to sub-divide the works into categories of 'Cultural Pop' and 'Social Pop'. The manifold meanings suggested in these works can be mutually conflicting, disrupted and labyrinthine. Yet these contradicting ideas spring naturally out of humorous and witty artistic imagination and captivating technique accomplishment, with a sense of reckless abandon and ease. There are hardly any trances of deliberateness. With heightened consciousness of everyday life and a shortened distance to the public, works at the Biennale are rich in of contemporary culture of modern China." In Lu Peng, ed., Guangzhou Biennale: Collection of 2oth Anniversary (Sichuan: Sichuan Publishing Group Company, Limited and Sichuan Fine Arts Publishing House, 2013), 227. 
the artist's curiosity about history and resonates with his sensitivity to social reality. This seemingly simple juxtaposition creates an intense tension between history, society, and issues of reality. Deng Xiaoping expressed his political opinion during his 1992 Southern Tour, putting a stop to the dispute over "why socialism" and "why capitalism." Since then, Western commodities and their ideologies flooded China as China was developing its market economy. Indeed, the "market economy" has become legitimate in China in the '9os. However, no one had proclaimed any change in the nation's nature. The government was merely making a case that there is no absolute opposition between the political system and economic development by coining a new phrase: "socialist market economy." However, the social system and its ethical principles governed by the market economy in Western countries failed to gain similar ground in China. And such failure no doubt would be a recipe for future political, social, and economic disaster. These crises have since been exposed at the beginning of the rapid development of the new millennium. The doubt and sense of loss felt by the artists of the 'gos have everything to do with these problems.

So Wang exhibited an attitude similar to Warhol's when Warhol first broke into New York's art world. Wang Guangyi was confident that under that specific historical condition, the Great Criticism was on a collision course with the artistic establishments. In answering the journalist's question as to his being "a figure of controversy" for the special issue of Beijing Youth Daily in I99I, Wang adopted the following strategy:

Some things cannot be determined by the will of a single individual. My works and words have become products of Pop once they leave me. Perhaps that is precisely what pushes contemporary art to zero in on everyone's life and thereby catching people's attention. Judging from the state of Chinese contemporary art, I think the purification of academic language and the tendency to express personal emotions are dangerous. The former makes art aristocratic and the latter the underclass. But when it comes to contemporary art, it should be better treated as a realization of the reformulation of the public's synchronic experience; it involves everyone; it is a game of a grand scale that forces the public to participate in. To all appearances, the public do not seem to see the true color of such a game, which resembles the state when the public are watching the evening news on television. One thing is clear is that the contemporary art always reminds us of one basic question: both the news and games lead us to the real life.

Indeed, Warhol's words were punchier and more vivacious than Wang Guangyi's. However, the underlying message of Wang's "real life" was to "live prosperously" - the Chinese expression for wealth and life. But his Pop intention was still clothed with the "appearance of thought." Wang needed to borrow a language of historical transition to ask a question which might have been rather simple. In effect, it was not until the mid '9os that the Chinese art world dared to discuss the relationship between money and art without scruples. For Warhol, money was something he could paint on his canvas directly; and Wang com- 
ments on such attitude, "Warhol makes ordinary objects even more ordinary." But eventually Wang's early philosophical complex might have determined his artistic tendency: let art be as public as possible but still shrouded by a thin veil of philosophy. Meanwhile Warhol declared the following famous aphorism:

Being good at business is the most fascinating kind of art. Making money is art and working is art and good business is the best art. ${ }^{36}$

The context in which Wang speaks differs completely from i96os America. But once the factors of the commercial and consumerist society enter a new environment, they definitely make tremendous impact on human minds. However, regarding Wang Guangyi's art as an embrace of consumerist society is barking up the wrong tree. In truth, in Wang's heart of hearts, he still preserves the questioning attitude of metaphysics. Although he proposed the slogan of "cleaning up humanistic passion" in the late '80s (during the 1988 Huang Mountains Convention), Hegel's "absolute concept" had brought into being the "absolute concepts" Wang created with his friends. However, thought leaders in the Chinese art world still believed that this opportunistic artist was "playing tricks" or someone's game. The Mao Zedong series is seen as an attempt at advancing his plans. Critics in general believed that the gunshot ${ }^{37}$ at the 1989 China/ Avant-Garde Exhibition greatly overshadowed the impact of the rest of the exhibited works. But the Mao Zedong A/C was still the talk of the town and the focus of the media attention. That piece obviously has something to do with history and real politics and therefore cannot possibly be a publicity stunt of the commodity society. In the latter half of the I990s, Wang began his experiment with his Great Criticism series and meanwhile continued his Masterpieces Covered by Industrial Quick-Drying Paint series with some hesitation. In 1992, before the Guangzhou Biennial Art Fair opened in October, Wang Guangyi submitted the Masterpieces Covered by Industrial Paint series and the Great Criticism series. The members of the jury were put in a difficult position of having to choose between the two series. Wang got what he wished for. The Appraisal Panel and the Judge Panel composed of I4 art critics made the final judgment on the significance of the Great Criticism series. The members of the committees wrote in their final recommendations that:

The Great Criticism series are collages of incongruous but self-evident historical images that people are familiar with and the contemporary popular signs. The series has put the tangled metaphysical questions on the back burner. The artist applies the language of Pop art to open the doors to contemporary issues such as "what is history?" History is the verbal cues that are closely tied

36 Andy Warhol, The Philosophy of Andy Warhol: From A to B and Back Again (New York: Harcourt Brace Jovanovich, 1977), 92.

37 The artist Xiao Lu shot her own painting with a pellet gun, and shut the exhibition down. 
up with contemporary life. And The Great Criticism is one of the best examples of such verbal cues of the early '9os. ${ }^{38}$

Although the judging committee's article uses concepts such as "Cultural Pop" and "Social Pop" in reference to Wang's art, critic Li Xianting still refers to Wang's works with the concept of "Political Pop" because of the conspicuous signs of ideological conflicts in the Great Criticism series. And such concept immediately gains traction, pointing unambiguously to the understanding that the artist has pinpointed a blind spot which can be annotated ad infinitum and brought on by the juxtaposition of two different ideologies. Despite Wang's repeated denial of the relationship between the Great Criticism series and politics, the series has been best explicated by the year which produced the series, when China was about to enter "socialist market economy." 39

After the Great Criticism series Wang Guangyi's works tended to concern themselves with subjects such as international politics, identity, and contemporary Chinese political history. Therefore, it is difficult for us to see him merely as the Andy Warhol of China (Fig. 5). Wang's appropriation of Pop Art's language is simply the logical conclusion of his artistic thoughts. In contrast, Expressionism can be better fit for tackling the artistic issues Wang takes. And Joseph Beuys is part of the make-up of Wang's "thin veil of thought." When, years later, talking about his opinions on Warhol and Beuys, in "Who do I prefer: Warhol or Beuys?" Wang said, "Beuys is an alchemist while Warhol makes what's ordinary more ordinary." And "Beuys loves to create mysteries while Warhol lays everything bare under the sun." ${ }^{40}$ For a shy northeasterner like Wang Guangyi, he

38 Ideals and Operations-The first Iggos Biennial Art Fair (Oil Painting Section) Guangzhou China [Lixiang yu Caozuo] (Sichuan: Sichuan Fine Arts Publishing House, October 1992), I03.

39 In "Bazaar Art" (2012), Wang Guangyi writes, "the media and the critics have made all sorts of comments on my Great Criticism series. At first I didn't say a thing. But I think I might have unconsciously allowed this kind of public reading. You can think whatever you prefer. When the public has formed a more concrete consciousness, I would then say, 'that's not what I think. I have no specific stance and I am neutral. For me, I am not quite sure if I hold no attitudes toward my own works. I didn't mean to say this is how I am. I really have no ideas. But when people are asking me questions, I can answer some. In some specific conversations, I would talk about certain issues. But when look back at calmer moments, I normally have no definite answers." "Wang Guangyi Talks about Warhol and Beuys," Bazaar Art (20II): 4. See also Wang Guangyi, "On Andy Warhol: Perhaps Simplicity Outshines Complexity," Post: Notes on Modern \&. Contemporary Art around the Globe, October 9, 2013, https://post.at.moma. $\mathrm{org} /$ sources/I2/publications/243.

40 "Warhol and Beuys are two legends of the art history. The pair stood in front of me almost at the same time when I young and ignorant. I first saw Beuys's works in a foreign magazine; it reprinted Beuys' works. Of course I couldn't read the language but those photos grabbed my attention. They don't look quite like 
wishes neither to be a downright mystic nor someone like Warhol who puts everything about himself on display. He is equally interested in creating art works that are at once mysterious and comprehensible by the public. ${ }^{4 r}$ And both traits are present in all his works of the I990s and after that.

From the beginning, the New York culture world dubbed works by Johns and Rauschenberg "New Realists." When it came to the end of 1962, people called the kind of art that has nothing to do with thoughts and feelings "Pop Art." Such labeling is the outcome when artists start to paint everyday consumer goods. So Warhol claimed unabashedly: he wanted to wax lyrical about and paint things that people love and buy for a song.

As to Wang Guangyi, he remains in that perpetual paradoxical psychological state: straining to realize the social impact of the popular idioms while being affected by complex thoughts. We would never know for sure if he is confident in realizing the goal he sets for himself. The only thing he feels fortunate enough is that he knows that perhaps no one has the full control one's ultimate fate. ${ }^{42}$

art. Or, perhaps, they are records of "alchemy." Or, perhaps I should say that I was puzzled by what he was trying to convey at that time. It wasn't until I read some translated materials on Beuys in a paperback did I grasped what went on. Until now I still want to see Beuys as an artist with somewhat mystic aura. He can attach meanings of a totem to any ordinary objects. One of Beuys's earliest works that has impressed me most is Homogeneous Infiltration for Piano (1966), also translated as Post-War Europe in Chinese. This piece left a lasting impression on me. And the first Warhol piece I saw was Marilyn Monroe. It is so simple, so artless, so un-painting-like. That confuses me. But in my heart of hearts, I feel that I like Marilyn Monroe." Ibid.

4I Wang writes: "Beuys is an artist who loves to create mystery. He has been creating layers and layers of fog. For example, in the piece How to Explain Pictures to a Dead Hare, the ideas offered by Beuys are very vague. How to explain arts to dead hare is a thorny question. Beuys himself might not have realized how thorny the question is. The reason why I like Beuys has something to do with these mysterious elements. At times he seems to be thinking about the questions seriously. But none of these questions have possibly factual answers. He in effect puts himself over an impossible barrel.

Meanwhile, Andy Warhol displays himself thoroughly publicly. He seems naked, with nothing on. I was wondering if the difference between the two artists has anything to do with the gap between German tradition of culture and the American tradition. Germany has the tradition of going to the bottom of things in a rational matter. And we can see that spirit manifest in Beuys. Meanwhile, Warhol worships everything thoroughly popular and thoroughly commercial." Quoted in Wang Guangyi, "On Andy Warhol."

42 "On the level of thoughts, Beuys has a greater impact on me [than Warhol], and I also prefer use phrase of uncertainty to explain my works. There is something very complicated, very rebellious in me. On the level of thoughts, I prefer ways obscure and abstruse, indeterminate and ambivalent ways of thinking that might 'mix a deer up with a horse' as the Chinese idiom goes. This type of thinking has a vague dimension like the way we describe 'thoughts', which are intangible. The 
What is interesting is that Warhol painted the Last Supper series at the age of 58 while Wang exhibited his Last Supper at age 57. When people ask him why he painted Da Vinci's subject, Warhol answered, "Wow, Italian culture-I only know that Italian spaghetti is very good." And to a similar question Wang replies, "In my opinion, Da Vinci's The Last Supper is a landscape painting." In fact, during this period Wang again has returned to his fascination with mysticism. The New Religion series, beginning from 20II, expresses nothing more than the artist's long-term psychological paradox in a new historical era, which does not bear comparison with Warhol's artistic concept of consumerism.

Warhol elements manifest themselves in me as what the society expects of me while the Beuys elements manifest as what I as an artist expect of myself. In a very profound sense, I love Beuys's works. But an artist also has a very socialized self-expectation and this is where I'm possessed by Warhol because Warhol offers and presents an accessible and popular illusion for the public_-although we might not even know his real intentions. So at times I would be thinking if what Warhol meant everything he said. Perhaps to him, there's nothing authentic in examining or discussing art. The metaphor that the German critic Klaus Honnef uses to describe Warhol and Beuys is very accurate: 'one of them is the palm of the hand and the other the back.'” Ibid. 


\section{抽象或视觉逼真：历史画创作的新趋向—“国家 重大历史题材美术创作工程” 中的视觉表达问题 张坚}

2005 年，国家重大历史题材美术创作工程启动，该项工程由文化 部和财政部共同资助，来自中国社会科学院和其他机构的历史学家 和文化官员从 1840 年至当下的历史中，选出了 106 个事件作为创 作主题。全国共有超过 1000 名艺术家向这项工程提交了他们的设 计和构思方案，最终，来自 IIS 位艺术家或工作团队的 IO6 件创作 方案获得资助。承担创作任务的艺术家用了将近 4 年时间来完成 所有这些主题美术创作的定件。2009年 9 月，IO2 件完成的作品， 其中包括 5I 件油画、33 件水墨画和 I8 件雕塑作品，在中国美术馆 举办了专题展览，之后又在国内各省区做巡回展览。资助这个创作 工程项目的总金额为 1.05 亿元，所有这些完成的作品都由国家或 省区艺术和文化机构收藏，诸如中国国家博物馆、中国美术馆、中 华艺术宫（上海）等。

新中国成立以来，第一轮国家层面的主题创作热潮是从 1957 年 持续到 1962 年的历史画创作。从 1970 年代晚期改革开放到 2000 年中期，国内的大型主题创作项目一度有所沉寂，相形之下，I980 年代以来的” 新潮美术以及其他前卫艺术运动成为最为引人瞩目的 艺术现象。也正是在这种语境之下，2005 年，国家重大历史题材 美术创作工程的启动可以看作为恢复 50、60 年代主题创作的国家 定件传统的一项举措。用这个项目组织者的话说，就要建构和确立 视觉艺术中的民族精神和国家形象。

但是，正如赫拉克里特所言，一个人不可能两次踏进同一条河， 历史主题的艺术创作的社会、政治和文化语境经历了巨大变化, 2005 年的国家定件项目，显然不会是之前简单重复。这篇文章将 说明的是，那些在经历了文化大革命之后的学院艺术家，是如何接 纳和吸收西方现代和后现代的艺术观念和视觉形式，重新塑造社会 主义现实主义的传统，把一种新的时代精神引入到他们的作品中， 同时，也让自己的表现方法的革新能为定件的机构所接纳。 
作为中国美术学院入选这项美术创作工程 ${ }^{1}$ 的油画作品 “戊戌六 君子” 是由杨参军创作的，他是蔡亮 $\mathrm{I} 98 \mathrm{I}$ 年调到中国美术学院油 画系后指导的第一位硕士研究生，这幅画作的主题是关于晚清时期 的一场失败的政治改革运动，这场改革由康有为和梁启超领导，试 图在中国建立一个现代君主立宪制的国家。由于慈禧太后的反对, 六位改革家谭嗣同、康广仁、林夕、杨深秀、杨锐、刘光弟等被清 政府逮捕，在菜市口处决。

画作意图表现处决六位改革殉难者的场景，谭嗣同，作为其中 最具影响力的人物，站在画面的中央，其他的五位殉难者，有三位 站在右侧，二位在左边，身后为深色的背景。他们的表情坚毅的脸， 渲染了画面的悲剧气质，深度空间是经由这些人物的相互交叠暗示 的，并无统一灭点，画家有意识地通过在绘画表面安置旧报纸和书 刊的断片来形成拼贴的效果，使得深度空间模糊，同时也揭示了这 场悲剧性的政治变革的复杂社会与历史意义。这张画不再以戏剧性 的主题再现为目标，而是现代主义与写实主义的一种结合体，虽然 画家确实显示了他的作为娴熟的肖像画家的能力。

事实上，他在构思这幅画作的过程表现出了透过抽象形式来强 化单纯有力的表现的倾向。这幅画的最初草图试图再现真实的历史 场景，其中，六位改革者分别是站在木构囚车上，贝车沿画面中轴 线向深处退缩，谭嗣同的囚车处在前景，他被绑在十字木架上，整 个场景有点类似于《基督受难》。

有关这幅画作的历史真实感问题，在专家评审会上，一些历史 学家坚持认为, 画面上出现的囚车样式在晚清时代并不存在, 并且, 整体效果因类似于基督受难，容易引导观者做错误联想。当然，画 家本人并不同意这些历史学家的意见，他说，他的目标并非是要达 到历史纪实的效果, 而是要表现这个重大事件中隐含的那种悲壮和

1 中国美术学院共 15 件作品入选 2007 年国家重大历史题材美术创作工程, 2009 年 4 月, 按照学校安排, 我组织了工作团队对承担入选作品创作 任务的艺术家或艺术创作小组进行采访, 所有这些采访的文字报道都汇 编成《中国美术学院国家重大历史题材美术创作工程 15 个项目创作小 组采访汇编》, 2009 年 6 月 25 日。 
惨烈气氛，也就是要表达这个事件的精神的真实 ${ }^{2}$ 。

在对历史主题的所谓精神真实的表达上，杨参军也许是继承了 蔡亮的传统，不过，他在创作过程中，并不排斥参考一些历史档案 照片，比如，谭嗣同、刘光弟和杨深秀都是留下了影像照片的。蔡 亮画中的人物大多来自于他所熟悉的老乡的素描和速写稿，而杨参 军的人物塑造，确实更多地需要依靠照片，因此，在某些方面存在 概念化的问题。在这幅画中，那些站在抽象的空间中的人物，不是 作为实际刑场处决的再现，视觉表现力来自于这些人物坚实体魄营 造的严峻仪式感，来自于他们坚毅不屈的表情，虽然他们中间只有 两位面对观者，其他四位，有的是在阴影里，有的是以侧影或背影 方式呈现，通过这种方式，画家也在一定程度避免因塑造那些完全 没有视觉资料留存下来的历史人物的尴尬

当然，对于许多历史画家来讲，要塑造一个从未见过、也没有 任何视觉资料可以参考的人物形象，无疑是一个挑战。历史画中的 人物形象的概念化处理是比较常见的现象, 如果是以宣传为目的, 那么，这种概念化可能是必须的。就这幅画的作者而言，他还是表 现出想要克服这种概念化诉求。

比如，他在 2007 年创作的油画《白居易在杭州》和《哲学家黄 宗羲》就是这方面的例子。白居易这位唐代大诗人曾担任过杭州的 地方首长，他发起了疏浚西湖的工程，对于杭州地方经济和文化的 发展做出了贡献。当然，白居易是没有什么可信的视觉资料留存下 来的，画家只能通过想象来展现这位诗人的形象。事实上，画家笔 下的白居易的脸部表情是显得有些模糊的。

后一幅画中的哲学家黄宗羲，是明代思想启蒙运动的创始人， 画家虽然找到了诸如祖宗像之类资料，但对于构想和刻画一个鲜活 的历史人物还是远远不够的，特别是如何透过脸部表情和姿态的描 绘来把握主人公的个性气质。有趣的是，画家实际上是依据他在油 画系的一位同事，一位退休教授为原型来构想这个人物的，这位教

2 张坚: 《百日维新传世纪, 廿载绘事系戊戌 : 记国家重大历史题材创作 之〈戊戌六君子喋血菜市口〉》, 载《中国美术学院国家重大历史题材 美术创作工程 15 个项目创作小组采访汇编》, 中国美术学院艺术人文学 院，2009，第 96 页。 
授以针砭时弊而闻名，在画家的思想中，黄宗羲的性格应该是类似 于他的这位同事的吧 ${ }^{3}$ 。显然, 这种替代让画中的主角变得更加具体 和真实了。

相对于蔡亮的那种对于老乡的乐观向上的生活态度的表达，更 多表现出一种客观和冷静地面对他所描绘的人物的态度, 其中, 没 有温情和幽默，而是保持一种显著的疏离感，一种生命存在的荒诞 感, 这种感觉当然更多地出现在他的那些非主题创作的绘画作品中。

对于形式抽象或形式美的热情, 以及透过现成物进行拼贴的实 验在 1980 年代在中国现代艺术家中相当流行，《戊戌六君子》也是 以平面抽象形式关系的经营来提升叙事场景的表现力的。在这个展 览中，有很多类似例子，特别是在水墨画当中，比如大尺幅的水墨 画作品《皖南事变》 ${ }^{4}$, 采用正方形构图方式, 其中充满各种片断的 图像，画面中央是一位牺牲的新四军战士，他伸展手臂，头向后方 倾斜，嘴巴痛苦张开，围绕他的身体周围的是其他一些表情痛苦的 战士形象, 还有各种武器、象征和平的鸽子以及其他物件, 这幅画 作并非意在叙事再现, 而是要创造一种永恒的视觉纪念性, 这种纪 念性通过各种与这个不幸事件相关的图像和符号组构而成。确实, 我们在画面中可以发现一些奇怪的东西，比如一只伸长脖子的我、 香烟、马灯, 当然也包括和平鸽, 类似这样的西方文化符号出现在《皖 南事变》的场景中，看上去有些奇怪。

水墨画《太行山的战斗》 ${ }^{5}$ 也没有采取出现在统一空间中再现戏 剧场景的传统做法, 而把行军、侦察、战斗和后勤支援等片段展现 在多块面的空间中，其视觉效果有点类似于立体主义。他许多水墨 画作品也都采取这种表现方式, 比如《井冈山会师》 ${ }^{6}\left\langle\right.$ 虎门销烟》 ${ }^{7} 《$ 末

3 本文作者 2014 年 12 月与杨参军的对谈, 杭州, 文中提到的这位退休教 授是中国美术学院油画系的徐永祥教授, 他是一位知名油画家, 也经常 撰写一些美术批评文章，2008 年 5 月 2 日去世。

4 施大畏、施晓颕, 《永生 : 皖南事变 I94I.I.I4》, 国画, $404 \mathrm{~cm} \times 452$ $\mathrm{cm}_{\circ}$ 国家重大历史题材美术创作工程作品目录，2009 年。

5 王迎春、杨力舟, 《太行烽火》, 国画, $407 \mathrm{~cm} \times 640 \mathrm{~cm}$ 。

6 刘大为, 苗再新《会师井冈山》, 国画, $293 \mathrm{~cm} \times 6 \mathrm{I} 2 \mathrm{~cm}$ 。 
代皇帝溥仪离开紫禁城》 ${ }^{8} 《$ 二 $\cdot$ 七铁路工人大罢工 $\rangle^{9}$ 等。另外, 还有 一些历史画作品是以会议、仪式、文化事件为主题的，这类作品中， 画家更多采取一般的群体肖像模式，与此同时，也更加注重画面的 形式构成感。水墨画《陈独秀创办新青年杂志》 ${ }^{10}$ 就展现为一个带有 抽象形式构成感的群体肖像。水墨画 《南昌起义》 ${ }^{11}$ 《第一次国共合 作》 ${ }^{12}\langle\text { 开国大典》 }\rangle^{13}$ 等作品都具有类似特点。还有的作品采用文献照 片、旗帜、报纸片段和手迹等元素的拼贴，来表达的主题内涵。

在这次创作工程中，有相当一部分画作是以战争为主题的，这 类作品通常都采用大尺幅和宽视域方式，背景深远，同时也包含了 许多人物的特写式的表达，战场的全景视野，产生一种包围的视觉 效果，把观者引入到一个虚拟世界中，让他们产生实际见证战场的 景象。

当然，在历史画中制造某种虚拟真实是可以回溯到 19 世纪晚期 的西方绘画的，诸如籍罗姆等人的作品，这些画家的工作有点像现 代的电影导演，寻求视觉地重现历史事件。不过，上个世纪 50 年 代的历史画中，画家构架的场景基本是以舞台的戏剧效果的经营为 导向的，其中不太有纪实细节，而侧重于揭示人物之间的思想和情 感联系，与此形成对比的是，当下的历史画作，往往有意无意追求 一种电影效果。

比较 $195 \mathrm{I}$ 年和 2009 年由两位不同画家创作的两个版本的油画 《地道战》也许能说明一些问题。第一个版本是由罗工柳创作的, 展现一个马厩的内景，两位女游击队员中，一位拿着驳壳枪，刚从 隐蔽在马槽下的地道中露出身来，她们前面，是一位男游击队员， 手持长枪，正透过墙上的孔洞观察敌情，画面左侧，有一把梯子通 向屋顶，两位年轻游击队员站在梯子上，正向屋顶运送武器。整个 场景是一个相对封闭的地道战的戏剧片段。

8 赵奇，《溥仪出宫，民国十三年》，国画，267 cm × $600 \mathrm{~cm}$ 。

9 刘健、黄骏、花俊, 《二七风暴》, 国画, $370 \mathrm{~cm} \times 87 \mathrm{I} \mathrm{cm}$ 。

10 胡伟, 《陈独秀与〈新青年》》, 国画, $246 \mathrm{~cm} \times 617 \mathrm{~cm}$ 。

11 韩硕，《南昌起义》，国画，294 cm × $640 \mathrm{~cm}$ 。

12 赵建成, 《1924 年的国共合作》, 国画, $310 \mathrm{~cm} \times 685 \mathrm{~cm}$ 。

13 唐勇力, 《新中国诞生》, 国画, $203 \mathrm{~cm} \times 816 \mathrm{~cm}$ 。 
后一个版本中 ${ }^{14}$ ，一个村庄全景视野铺展开来，当地的那些带有 立方体块特征的建筑物分布在不同水平面上，透过坍塌的墙壁，破 窗、打开的门，以及瞭望塔等，可以看到各种战斗场景，画面效果 有点类似于宽银幕电影，创造出一种视觉奇观的效果，而不是基于 画中人物间的情感和思想的内在联系的视觉表达。

更为重要的是, 在两个版本的油画作品的比较中, 我们可以看 到不同历史时期历史画创作中隐含的视觉模式的转换, 即从传统绘 画的观看模式，转向一种更契合于电影和摄影的凝视，从前者对观 者与画中主人公的感同身受的期许，转向后者寓含的一种面对视觉 奇观时的置身事外的心理疏离状态。事实上，为强化绘画的类似于 电影的视觉感染力和逼真度, 一些画家还特地租用电影拍摄场, 来 搭建战场布景, 雇佣演员扮演战士角色 ${ }^{15}$ 。宽银幕电影的构图也在这 类战争主题的作品中得到广泛运用。所有这些画作都是大尺度的， 力图以奇观的景象而给观者带来视觉震撼。在这方面，一些画家是 从美国的一些以第二次世界大战为主题的电影中借鉴了很多手法。

值得一提的是，一些艺术家也尝试在他们的主题创作中，移植 西方后现代艺术的观念和手法，诸如波普、概念艺术和超级写实主 义等。雕塑 “重庆, I945, 毛泽东和蒋介石” 16 就是一件带有某些后 现代色彩的作品，看起来，几乎就是这两位政治人物在重庆谈判时 留下的合影的 $3 \mathrm{D}$ 翻版。当然，这次会议并没有取得任何成果。

在历史画中，毛泽东的图像是形成为一种理想化视觉程式的， 这件雕塑作品表现出来的那种忠实于历史文献照片的视觉表达，其 实隐含了一种对待这两位政治领袖的客观态度。在超过半个世纪的 时间里，这两个政治对手现在是站在了同一个水平面上，他们看上 去与 1945 年的那张著名照片几乎完全一样, 超级写实的风格消减 了这个主题原本的那种严峻色彩，不过，观者也仍旧能够感觉到这 两个人物在政治上的互不妥协的态度。

14 王国斌、周景伦、徐冰，《华北地道战》，油画， $200 \mathrm{~cm} \times 500 \mathrm{~cm}$ 。

15 徐青峰, 油画《血战台儿庄》作者, 租用解放军电影制片厂的一个拍摄 工作室，来搭建战场的场景。www.qingdaonews.com, 2006-I2-8.

16 梁明诚, 《重庆, I945: 毛泽东和蒋介石》, 雕塑, $250 \mathrm{~cm} \times 160 \mathrm{~cm} \times$ 
油画《毛泽东和尼克松》 ${ }^{17}$ 也是基于 1973 年拍摄的一张文献照片, 虽然画作表面色块肌理形成一种模糊效果，有点类似于格哈特-里 希特的作品，但就场景本身而言，与原本的照片相比，是包含了一 些微妙调整的, 例如, 毛泽东和尼克松交谈的姿态, 经过重新设计, 画作中的毛泽东显然处在支配位置，尼克松则显得被动，当然，总 体上仍旧保持了文献照片的特质，而不是理想化的再现或人为拔高。

雕塑《中国加入世界贸易组织》 ${ }^{18}$ 在这次展览中也显得有些不同 寻常，这件作品由一系列的流行商品、市场图像或商标构成，诸如 汽车、电视机、家乐福超市、沃尔玛超市、麦当劳以及北京与上海 一些著名摩天大楼和地标建筑，还有来自世界各地的商人、穿时髦 服装的普通消费者等。所有这些元素堆砌在一起, 形成一个图腾柱, 意图表明加入世界贸易组织之后对中国都市生活缤纷多彩的预期, 但同时也包含了对于城市生活物质主义讽刺的意味，这种物质主义 在 1990 年代以来的所谓 “媚俗艺术” 或 “艳俗艺术”, 诸如王庆松、 刘利国和罗氏兄弟的作品中是要表现得更为典型，也更负面一些。

油画《义乌小商品市场》 ${ }^{19}$ 虽然是以浙江省的一个小商品市场为 主题的，但画家并没有去再现市场喧器热闹的交易场景，而是力图 表达他个人在这个市场中感受到的巨大的视觉震撼，那些廉价的机 器复制的小商品堆积如山, 它们才是这个业已成为中国经济奇迹之 一的义乌小商品市场的秘密所在。

历史画的问题从根本上讲是与画家如何视觉地阐释官方确定的 主题联系在一起的。上个世纪 $50 、 60$ 年代的历史画家大多是一些 娴熟的肖像画家，历史画也可被视为一种肖像画的特殊类型，其中 的人物和场景都是经过了理想化处理，展现为一个浪漫主义与现实 主义的结合体，一个英雄主义的情感或精神的统一体。1980 年代 以来，年轻一代艺术家发展了新的历史画表达方式，开始关注形式 抽象，发掘拼贴以及波普、超级写实主义语汇，这些来自西方现代 和后现代艺术的风格和流派，激发了他们突破传统历史画的社会主 义现实主义的一元状态, 把他们的作品重塑为更复杂的视觉结合体,

17 马刚, 《毛泽东会见尼克松》, 油画, $190 \mathrm{~cm} \times 270 \mathrm{~cm}$ 。

18 王少军、孙璐，《中国加入世贸》, 雕塑, $314 \mathrm{~cm} \times \mathrm{I} 35 \mathrm{~cm} \times \mathrm{I} 23 \mathrm{~cm}$ 。

19 常青, 《义乌小商品市场》, 油画。 
当然，这些作品应该在一种视觉文化的视野下来加以调查的。

与 19 世纪 50-60 年代以来的传统历史画家相比, 80 年代以来 的历史画家更愿意表现出一种对他们所描绘的历史主题的客观态 度，而非个人情感的介入。因此，在创作过程中，他们表现出对于 那些未公开的历史材料的收集和研究的兴趣，这常常导致他们形成 一种与官方标准叙事有所不同的对特定历史事件的真相的理解和认 识。当然, 具体到视觉表达上, 也是保持在一种可以被定件方所接 纳的范围之内的。

从这个展览中，我们可以看到，传统的社会主义现实主义风格 仍旧得到了延续和发展。事实上，那些在表现手法和气质面貌上更 接近于 50 、60 年代的历史画是得到了充分认可的，油画《启航》 20 就是一个例子。这件作品表现的是在嘉兴南湖举行的中国共产党第 一次会议，这幅画作中，大小两条船的交汇构成画面构图的主体， 毛泽东站在两条船的汇合点上, 其他人分为两个群组, 在大船前甲 板上, 站着五位代表, 小的接驳船上有四位代表, 他们正想要登上 大船。

画家巧妙设计了这些人物的姿态和表情，他们是中国共产党的 创立者, 不过, 在党史中的地位有所不同。画面上, 他们形象的清 晰程度与他们的历史地位相关。至于那些后来放弃了最初的共产主 义信仰的人，则是被安排在了阴影里，或呈现为背影的状态。总体 上，整个画面构图设计显得比较自然，尽管里面包含了政治的信息， 但是, 所有人物的表情和姿态都被统一到一个戏剧性瞬间，毛泽东 处在中心位置，但是，他的体型大小还是基本保持了与其他人物的 一致。事实上，这幅画作倒是让我想起伦勃朗《杜尔普教授的解剖 学课程》以及《夜巡》, 这两幅画也同样是把一个群体肖像转变为 故事的场景，其中的每个人物都被设计到了一个戏剧的瞬间，同时， 画家也坚持传统油画的基本价值，即那种叙事和塑造人物的能力。

从上个世纪 50-60 年代到现在, 中国的历史画创作经历了复杂 变化，这种变化一定程度上可定义为艺术家对待历史主题的态度的 变化。第一代艺术家对创作主题的视觉阐释往往表现出一种浪漫主 
义与现实主义相结合的主观情感的介入, 而在 2009 年的国家重大 历史题材美术创作工程中, 艺术家的视觉表达, 更多地保持了一种 客观态度, 他们的注意力放在了如何让画作产生视觉的震撼, 许多 现代和后现代艺术的观念和手法被引入到他们的创作中。更为重要 的是，在接受的层面，凝视代替了观看，视觉文化的视野对于我们 认识和理解这些作品就变得非常重要了。 


\title{
Abstract or Optical Fidelity: New Trends in History Painting after the 1980s
}

\author{
Zhang Jian
}

In 2005, a national commission for artworks with historical subjects (Guojia zhongda lishi ticai meishu chuangzuo gongcheng) was initiated and funded by the Department of Culture and the Department of Finance of China. One hundred and six historical events from 1840 to the present were selected by a special committee consisting of historians and cultural officials from the China Academy of Social Sciences and other institutes. More than I,Ooo artists submitted their designs and proposed drafts for these commissioned subjects and, in the end, Io6 proposals by IIs individuals and working teams obtained financial support.

Completing all these commissioned artworks took nearly four years, and it was not until September 2009 that IO2 artworks were finished; among them, 5I oil paintings, 33 ink paintings, and I8 sculptures. A special exhibition was organized to show these artworks in the China National Gallery of Art in Beijing, followed by an exhibition tour through the whole of China. The total supporting funds for this project reached I.05 billion CNY (about 17.5 million US dollars), and all the artworks were collected by the official art and cultural institutions, such as the China National Museum, National Art Gallery, and China Arts Museum in Shanghai.

The first wave of large-scale national commissions for artworks with historical subjects dates from 1957 to 1962, and then in the Cultural Revolution nearly all artworks were politically oriented and regarded as propaganda tools. The years from the Reform and Opening-up in the late-1970s to the middle-200os have witnessed a break in the projects of officially commissioned historical artworks. In contrast, the rise of modern art movements, such as New Art Wave and other avant-garde movements in the I980s, became the most significant phenomena in the Chinese art world. In this context, the national commission for historical artworks in 2005 could be regarded as an important measure to renew the I950s and I960s tradition of officially commissioned historical artworks and, in the words of an organizer of this program, to establish and confirm the national identity as well as the image of China in the visual arts.

But, as Heraclitus said, people can't step into the same river twice: the social, political, and cultural situations in which historical artworks were commissioned and produced had changed greatly, and compared with these of the I950s and I960s, this national commission for historical artworks in 2005 certainly was no simple repetition. This paper will show how these new academic artists after the Cultural Revolution adopted the ideas and visual forms from Western modern and postmodern arts to re-shape the tradition of Socialist Realism and, on one hand, bring the new spirit of the times for their artworks while, on the other, make their renovations be acceptable to the official censorship.

The oil painting Six Martyrs of the Political Reform in I898 (Wuxuliujunzi) 696 was produced by Yang Chanjun who had been Cai Liang's graduate student 


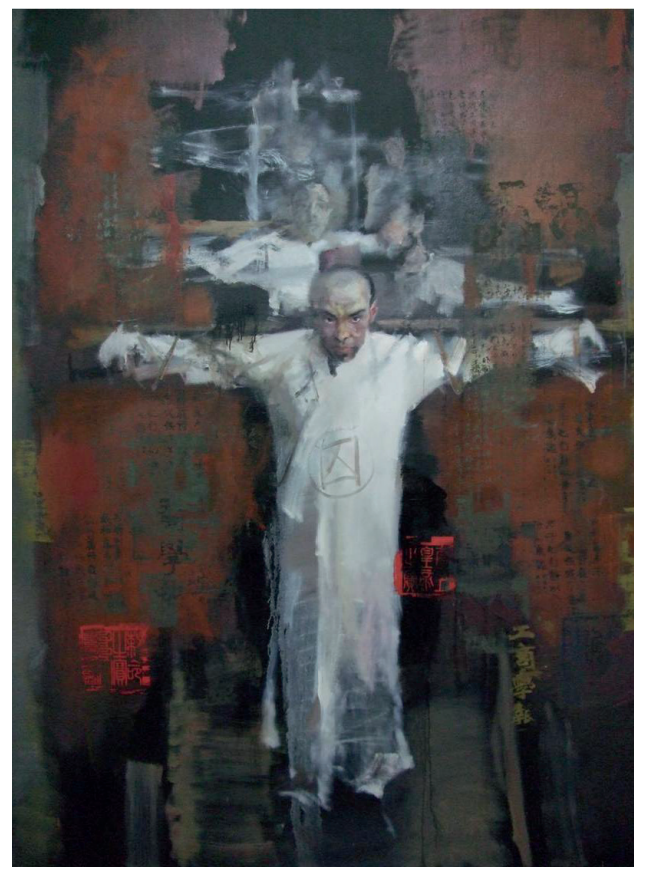

Fig. I. Yang Chanjun, Six Martyrs of the

Political Reform in I898. Oil painting, 2009.

National Art Museum of Art, Beijing.

in the early I980s when Cai left Xian for Hangzhou and joined the faculty of the Department of Oil Painting in the China Academy of Art in 198I (Fig. I). The subject of this painting is a political reform movement which occurred in the late Qing Dynasty aimed at setting up a modern constitutional monarchy, and was led by Kang Youwei and Liang Qichao. The reform met with total failure from the Empress Dowager, and six reformists, Tang Shitong, Kang Guangren, Linxi, Yang Shenxiu, Yang Rui, and Liu Guangdi, were arrested and executed in the public market by the Qing government.

The painting was intended to show the scene of the execution of the six martyrs. Tang Shitong, the most influential one among them, stands at the center, with three other people to his left side, and two to his right. Against the dark background, the martyrs' highlighted bodies, with their strong-willed facial expressions, produce dramatic contrasts. The deep space in the painting is indicated by these overlapping bodies, not unified into one disappearing point. The painter has consciously blurred the sense of depth by putting some fragments of pages cut from old newspapers and books on the painting's surface, to create a visual effect similar to that of collage, and to reveal the complicated layers of historical and social meanings in this tragic political reform movement. The painting is no longer the kind of traditional history painting of Socialist Realism with its dramatic representation of the subject, but a mixture of Realism and modernism, although the painter still shows himself as a competent portraitist, a little like his teacher Cai Liang.

A survey of Yang's creative process for this painting reveals a transformation from detailed depiction into simplified expression with abstract formal patterns. His initial draft for the painting appears to be a fact-based scene in which the six martyrs, standing on separate wooden cages - a special instrument of torture - line up and recede into the central distance. Tan Sitong was tied to a wooden cross with his arms stretching on both sides; the scene is similar to that of the crucifixion of Christ, which is a compelling image to many viewers. Meanwhile, its central foreshortening makes the other five martyrs hidden by Tan Shitong in the front.

In a special review meeting for the painting, some historians insisted that there was no such instrument of torture as the standing cage depicted in the painting in the late Qing Dynasty and, even more, the whole visual effects of the proposed draft was similar to that of the Crucifixion, which might lead viewers 
Fig. 2. Tan Shitong (1865-I898). Photograph.

to equate this tragic political reform movement with the Crucifixion. The painter did not agree with these historians' opinions, and he said that his aim absolutely was not to make a realistic or documentary depiction for this event but to express the tragic and solemn mood in it as well as its spiritual reality.

As Cai's student, to some extent, Yang inherited his teacher's history painting tradition where the focus is on revealing the unified spiritual reality among the characters and not depict documentary facts of the historical event. Meanwhile, he had also consulted rare photos of Tan Shitong

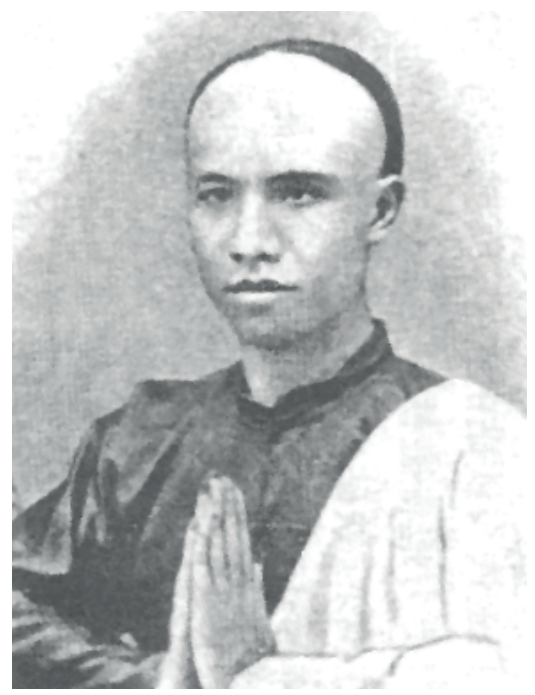
(Fig. 2), Liu Guangdi, and Yang Shenxiu. Cai's characters usually were drawn live from local folks with whom he was familiar while, in contrast, Yang's are mainly photo-based, appearing to be more conceptually modeled. In this painting, the characters who stand in an unrealistic space were not intended to show the actual scene of execution. Its visual impact comes from the solemn ceremony produced by these six martyrs' firm mass, not from the detailed recordings of the scene. As for their facial expressions, only two of them face the viewers while the other four are in the shadows, in profile or turning their backs to the viewer. In this way, the painter avoids the awkwardness of modeling the people who had left no visual clues to their features.

It is puzzling as well as challenging for a painter to conceive people in the past whom he or she had never met or for whom there are no visual materials surviving. The conceptualization of characters in history painting have always been a common practice among painters, which could make their paintings work for the needs of political propaganda. But, it should be said that both Cai and Yang showed their ambitions to get beyond this issue and endow their artworks with artistic interest through new ways.

Both oil paintings of Poet Bai Juyi and Hangzhou and Philosopher Huang Zongxi were produced by Yang in 2007. Bai Juyi, the main character in the former painting, was a famous poet from the Tang Dynasty who had been the mayor of Hangzhou and initiated a project for dredging the West Lake. There are no visual materials left for Bai Juyi's appearance so the painter had to imagine what the poet would look like according to the ancient literature. In order to cover up the awkwardness inherent in this process, the painter consciously blurred Bai's facial expression.

In the latter painting, Philosopher Huang Zongxi, who was the founder of the enlightenment movement in the Ming Dynasty, left some visual materials which could be consulted, such as ancestor portraits. But this was not enough for Yang to conceive a lively history painting, especially to get an accurate grasp of the character's personality through the depiction of his facial expression and pose. 698 Interestingly, the painter actually conceived Huang's portrait based on his col- 


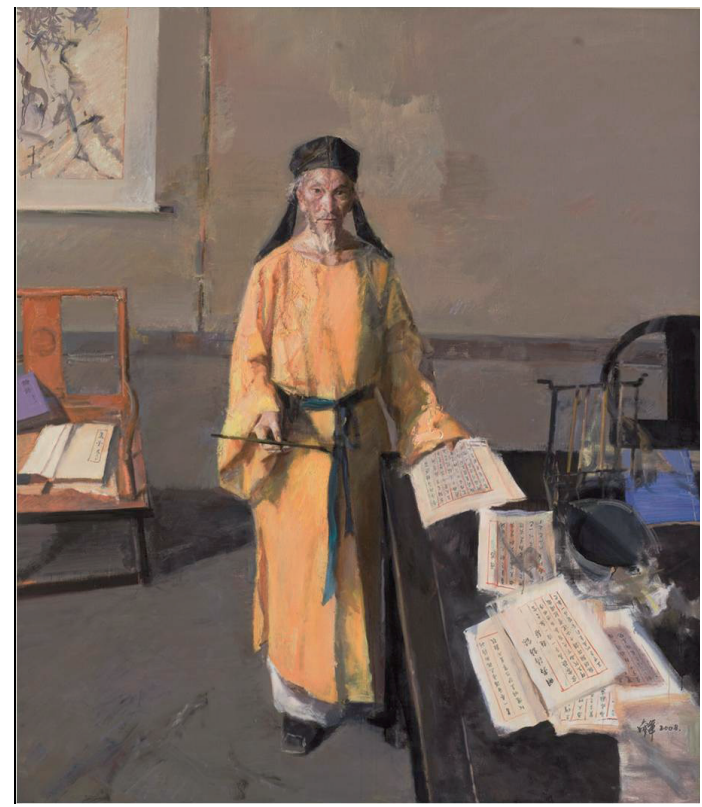

Fig. 3. Yan Chanjun, Philosopher and Political

Thinker Huang Zhongxi. Oil painting, 2009. Zhejiang Provincial Art Museum, Hangzhou.

league, a retired professor of the Oil painting Department of the Academy, who always exhibited a strong critical spirit and social concern in his daily life. In Yang's mind, Huang's temperament must have been a little like that of this colleague. The substitution really made the main character in the painting more concrete than "Poet Bai Juyi and Hangzhou" which had no reference to any living person (Fig. 3).

It could be said that both Cai and Yang did their best to endow the characters with vitality and lively expressions. In contrast with Cai's forceful revelation of the positive aspects in local peoples' daily life, Yang would rather keep an objective and calm attitude toward the people he depicted in which there is no warmth, happiness, and humor, but an obvious alienation that stimulates a strong sense of absurdity and boredom, characteristics that often appeared in his regular portrait paintings.

Enthusiasm for informal abstraction or formal beauty as well as experiments with collage from ready-made objects were quite popular among Chinese modern artists in the I980s. In Yang's Six Martyrs of the Political Reform in I898, we can see that the painter paid great attention to planar formal abstraction which was used to enhance the expressiveness of the narrative scene.

There were many similar examples in this exhibition. For instance, the ink painting Forever: Southern Anhui Incident on January I4, I94I depicts a military conflict between the Army of the National Party and the New Fourth Route Army led by the Communist Party during the Anti-Japanese War. The painting is a square composition full of fragmented and confusing images: in the middle is a dead soldier stretching his arms, with his head leaning back and his mouth open; around him are other soldiers' faces with their anguished expressions, weapons, and other items. The painting obviously was not intended to be a story-telling representation but a visual monument with a quality of timelessness that was arrived at through the assemblage of images and signs related to this tragic event. Also, there are some strange things in the painting, such as the head of a goose with its long neck, as well as cigarettes, a lamp, and even pigeons symbolizing the desire for peace from the Communist Party side which is a little weird in this context.

The ink painting The Struggles in Taihang Mountains is about anti-Japanese fights led by the Communist Party. It also does not exhibit a dramatic scene 
Fig. 4. Shun Zhixi and Zhang Yuan, Tunnel Warfare. Oil painting, 2009. National Art Museum of China, Beijing. in a unified space but shows fragmented scenes of marching, scouting, fighting and logistic support in a multi-faceted space, with a visual effect that resembles Cubism. A number of of ink paintings adopt similar methods in the exhibition, such as Joining Forces in Jinggang Mountain, Burning Opium in Hu Gate in Guangdong Province, The Last Emperor of Qing Dynasty Leaving Royal Palace, The Strike of Railroad Worker in 1927. In addition, there are a group of history paintings on meeting, ceremony, and cultural events that are difficult to visualize; in this case, painters have adopted the conventional modes for a group portrait and simultaneously put much weight on the planar pattern. The ink painting

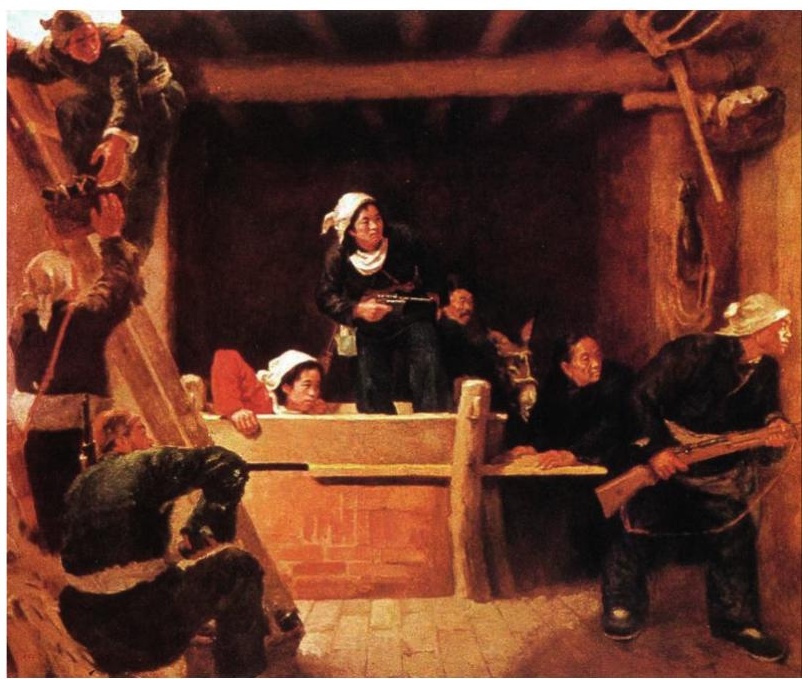
Chen Duxiu, the Founder of China Communist Party, Initiating New Youth Magazine is a group portrait with an imposed abstract formal pattern. The ink paintings Uprising of Nanchang City, The First Co-operation of CCP and KMT, and Founding Ceremony of New China are similar. Even more, a print-work Student Strike of Zhejiang University in 1949, which memorialized student activist Yu Zhishan who was killed by the Nationalist Party, is simply a collage of documentary photos, flags, newspaper pages and Yu's handwritings, and all these items, together with varied signs in the background, produce the historical implications of this painting.

In the new national commission for history paintings, a large number of paintings were intended to show battles and fights. These contain, within the large canvas, a broad horizon with its far-reaching background extending into deep space as well as some close shots of the characters, producing a panoramic view of the battlefield while embracing visual effects that induct the average viewer into a virtual world to witness what actually happened in the war.

Of course, making a certain kind of virtual reality in history painting could be traced back to late-nineteenth-century Western European paintings, such as those by Jean-Léon Gérôme. These painters worked just like a director of modern movies would to visually recover the historical event visually and obtain a factual immediacy. In the I950s, however, the actual settings in history paintings were more like a theater stage, not a movie set, with few documentary details. The main point of these 1950s paintings was on the revelation of emotional and spiritual interactions among characters.

Comparing two versions of the oil paintings for Tunnel Warfare, produced in $195 \mathrm{I}$ and in 2009, is revealing. The first painting by Luo Gongliu presents an interior of a stable in which two female guerrillas, one armed with a pistol, have just emerged from a tunnel concealed under a manger (Fig. 4). In front of them is another male guerrilla holding a rifle watching the passing enemy outside through a hole in the wall; on the left side, two young guerrillas are sending weapons up a ladder to the roof. It is a close-up view showing a moment of tunnel warfare. 

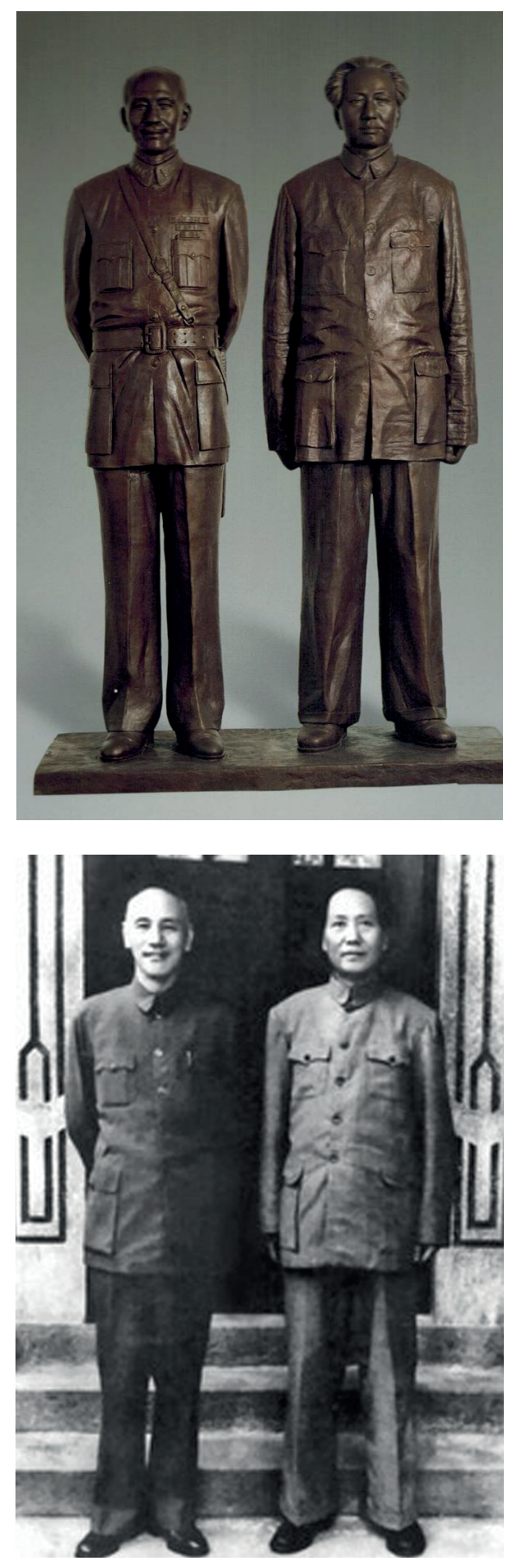

Fig. 5. Qu Chengming, Chongqing Negotiation. Sculpture, 2009. National Art Museum of China, Beijing.

Fig. 6. Mao Zendong and Chiang Kai-shek, 1945. Photographed by $\mathrm{Hu}$ Chongxian.

By contrast, in the later painting, a panoramic view of the village with a broad horizon is presented. Around local buildings, with cubic shapes placed on different levels, a battlefield unfolds. Varied fighting scenes are seen through collapsed walls, broken windows, opened gates, and a watchtower; an obvious imitation of the verisimilitude of movies. The painting sets up a visual compelling spectacle rather than expressing emotional interactions among characters, which was the primary stimulus of this later painting.

Even more significant and revealing for the comparison between these two paintings is the transformation of their visual modes, from the mode of "seeing" for traditional painting to the "gazing" at movies and photos, from the former's anticipation of a viewer's emotional and spiritual identification with the characters in the painting to the latter's implying the position of onlooker to the visual spectacle from which one is psychologically distanced or alienated. In fact, in order to strengthen a painting's compelling visual effects and filmlike optical fidelity, some painters even hired a film studio in order to set up a battle field and employed actors playing the roles of fighters. Also, a wide-screen format like that of film was commonly adopted in the oil paintings, such as The Lugou Bridge Incident in 1937, Chinese Expeditionary Army in 1944, The Battle of Liaoshen, Attack to Jingzhou City in Civil War in 1947, The Battle of Shanggan Hill in Korea War, Anti-Japanese Struggles in Ali Mountain in Taiwan, Nanjing under the Deformed Sun, and The

Earthquake of Tangshan. All these paintings are large-scale and mainly intended to attract viewers with visually shocking imagery and spectacle, not the spirit of heroism in their characters. It seems that screen-shots from American films about the second World War, such as Saving Private Ryan, Enemy at the Gate, and others, influenced these history painters. 
Fig. 7. Ma Gang, Meeting of Mao

Zedong and Nixon. Oil painting, 2009. National Art Museum of

China, Beijing.

Some artists also made interesting attempts to transplant ideas and methods from post-modernism, such as Pop Art, Conceptual Art, and Super-realism into their

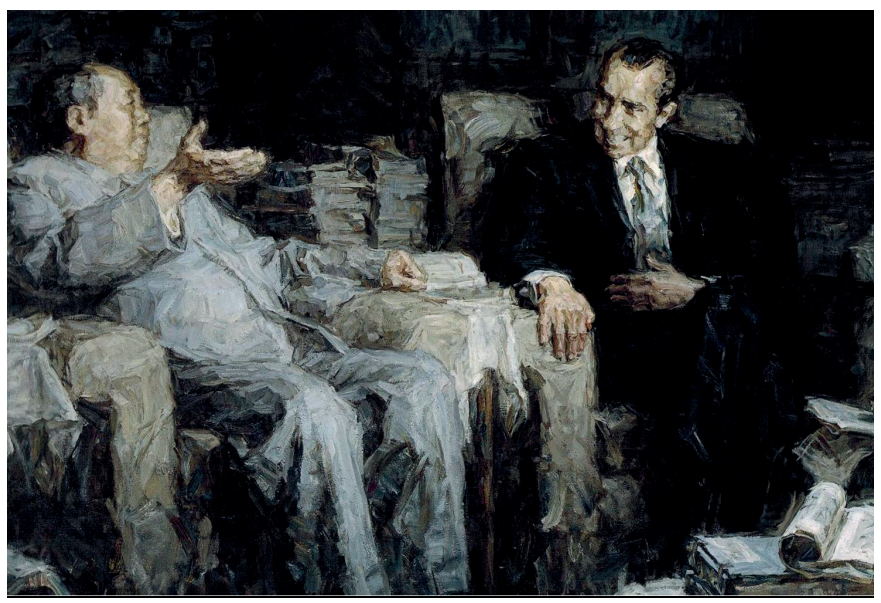
works. The sculpture

Chongqing in 1945: Mao Zedong and Chiang Kai-shek is a work with the symptoms of post-modernism (Fig. 5). It seems to be a $3 \mathrm{D}$ copy of the photo taken of these two VIPs in their meeting in Chongqin in 1946 (Fig. 6). Although General Marshall from the United States acted as a coordinator and special envoy of the President of the United States, Franklin Roosevelt, for this meeting between the Communist Party and the National Party, the meeting was not fruitful.

The audience in mainland China who were used to seeing the conventional images of Mao Zedong and Chiang Kai-shek in history paintings or other artworks of political propaganda since 1949 would feel surprised or even a little puzzled. Because there is no idealization, the sculpture presents an objective recording of visual facts from the documentary photo, revealing a neutral position and distanced attitude toward these two political leaders.

And even more, in the sculpture, these two political opponents from more than half a century ago are standing on the same level and they look exactly as they appeared in the photo taken in 1945. The style of Super-realism brings to this work a subtle amusement, thereby reducing the seriousness of the subject. Yet viewers still get an idea of these two figures' uncompromising determination in political issues. Perhaps, this is the reason that this work passed official censorship.

The oil painting Mao Zedong and Nixon was also based on a documentary photo taken in 1973, although its color patches as well as blurring are similar to Gerhart Richter's work (Fig. 7). There are adjustments or refinements made to the actual scene; for instance, the corresponding gestures between Mao and Nixon were re-designed so that in the painting, Mao was in a dominating position, while Nixon obviously appeared to be a passive role. It should be noted that the painting still shows some features of documentary photographs so that it was not developed into the kind of idealized representation of Socialist Realism fashionable in the i950s and i96os.

The sculpture China Joining the World Trade Organization was an unusual work in this exhibition (Fig. 8). It consists of a series of images and brands of popular commodities and markets, such as mobiles, TV sets, Carrefour, 702 Walmart, McDonald's, as well as landmark skyscrapers in Shanghai and Beijing, 


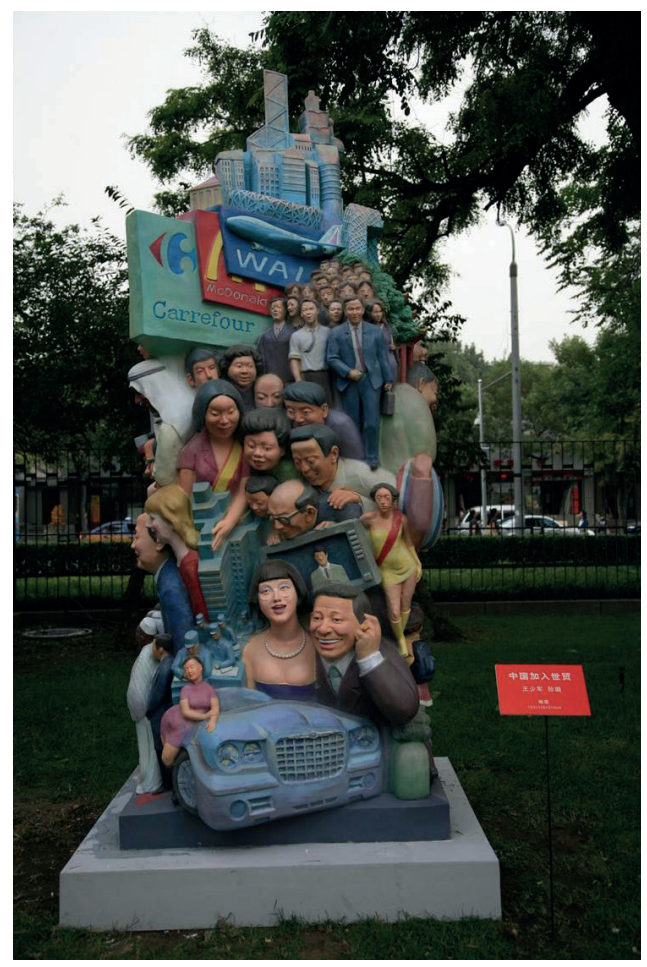

Fig. 8. Wang Shaojun, China Joining the World Trade Organization. Sculpture, 2009. National Art Museum of China, Beijing.

and people including businessmen from around the world, common customers wearing fashionable clothes, and hurrying commuters in their daily life. All the figures, signs, and images are piled together into a totem pole, as a positive and bright anticipation of urban life in China after joining in the World Trade Organization; but it also contains a little irony about the artificial and materialistic aspects of city life reflected or revealed more typically in the so called "kitsch arts" or "gaudy arts" in the I990s. The artworks by kitsch artists, such as Wang Qingsong, Liu Liguo, and his Luo brothers would appear to be much more negative and in conflict with official requirements for the visual arts. Obviously, in this sculpture, the revelation of the negative aspects in city life is restricted to a limited extent and does not lead to any serious social criticism.

An oil painting Yiwu Small Commodity Market, commissioned by the Zhejiang provincial project for artworks with historical subjects, also contains a subtle irony. The painter did not represent the noisy scene of trading activities and the businessmen or customers wandering everywhere in Yiwu, a small commodity market located in the central part of Zhejiang province and the largest exporting base for small commodities. Instead, he conveys his personal visual shock from the tremendous amount of mechanical repetitions of small cheap items, such as toys, stationery, hats, socks, and ties. For the artist, all these trivial things revealed the inner truth of this world-famous market, and maybe a part of the truth of the Chinese economy.

The issues in history painting are fundamentally connected with how a painter makes his visual interpretation of the subjects officially commissioned. In the I950s, history painters were always skillful portraitists. History painting could be regarded as a special type of portrait painting in which characters and settings were idealized and shown as an emotional and spiritual unity of heroism, a combination of romanticism and realism. After the I980s, a young generation of artists developed new ways of visual expression for history painting, such as formal abstraction, assemblage, collage, and Super-realism from Western modern and post-modern arts which stimulated them to break through the monopoly of Socialist Realism in traditional history painting, and re-shaped their artworks into more complicated visual compounds which should be investigated under the perspective of visual culture. 
Compared with traditional history painters in the 1950s-60s, the new generation of painters in the I980s and afterwards would rather keep an objective attitude than create a personal emotional involvement with the historical events they painted. Thus they appeared to be much more interested in unpublished historical materials on the commissioned events which always demonstrate different realities from what the public was familiar with. As a result, some of their works really stimulated much freer visual interpretations of these officially commissioned subjects.

Of course, we still can find artworks with traditional socialist realism in this exhibition. In fact, these artworks, akin to the masterpieces of the 1950s-6os, obtained praise from the organizing committee. The oil painting Set Sail by $\mathrm{He}$ Hongzhou is an example. The painting's subject is the "South Lake Meeting in Jiaxing," that is, the First Congress of the Chinese Communist Party. In the painting, one large boat meets the small one at a ninety degree angle, forming the main compositional structure of the painting. Mao Zedong stands at the meeting point of the two boats, with everyone else divided into two groups: on the front deck of the large boat there are five people, and in the small boat, four people are just about to step into the larger one.

The painter tactically designed the poses and expressions of the actors in the painting. Those who were recognized as the founders of the Party in the official version of the revolutionary history are shown clearly, with the extent of the clarity dependent on their historical status defined by the official narrative of the history of the Party; and those who abandoned or changed their initial belief in Communism were assigned to the shadows, or only shown with their backs to the viewer. Generally, the pictorial design of the painting is natural, and all the poses and facial expressions of characters were integrated into a dramatic moment. Although Mao Zedong occupies the central position, he is equal with other people in size.

In fact, this painting reminds one of Rembrandt's The Anatomy Lesson of Dr. Tulp and The Nightwatch, in which both turn a group portrait into a story-telling scene where the characters were organized into a dramatic moment. At the same time, the painter kept his insistence on the value of oil painting by modeling figures in such a painterly manner.

In addition, one should remember that there were older artists whose artworks appeared to continue the tradition of history painting in the 1950s, such as the oil painting The Chorus of Huang He River by Zan Jianjun, and Quan Shanshi's National Anthem of China, March of the Volunteers.

From the 1950s-6os to the present, history paintings in China have gone through the complicated changes defined by the changes of these artist's basic attitudes toward history. The first generation of artists tended to visualize the commissioned historical subjects with emotional involvement that anticipated a combination of romanticism and realism. After thirty years, in the exhibition of 2009, artists tended to interpret the commissioned subjects visually with an objective attitude and paid attention to how to make the paintings be visually shocking to an audience, while using ideas and methods from modern and 704 post-modern art. And even more important is the fact that "gazing" rather than 
"seeing" was required when the audience is facing these paintings, a change that places the investigation of these works under the perspective of visual culture. 



\section{Author Biographies}

Julia Bryan-Wilson is the Doris and Clarence Malo Professor of Modern and Contemporary Art at UC Berkeley, where she also directs the Arts Research Center. She is also an adjunct curator at the Museu de Arte de São Paulo.

Julia Bryan-Wilson 为美国加州大学伯克利分校的现当代艺术史教授, 同时主持艺术研究中心。她也是圣保罗艺术博物馆的兼任策展人。

Chen Yao teaches in the College of Architecture and Art at Hefei University of Technology. Chen researches and teaches French and American Impressionism.

陈瑶: 合肥工业大学建筑与艺术学院教师, 致力于法国和美国印象派 研究和教学。

J.V. Decemvirale is finishing his $\mathrm{PhD}$ in the History of Art and Architecture Department at University of California, Santa Barbara. Specializing in contemporary art history, he is working towards the completion of his dissertation: "Knowing Your Place and Making Do: Radical Arts Activism in Black and Latino Los Angeles, I968-1985."

J.V. Decemvirale 即将获得美国加州大学圣巴巴拉分校的艺术与建筑 史博士学位。他主修当代艺术史, 并即将完成博士论文《非裔与拉丁 裔美国人在洛杉矶的激进艺术行动, 1968-1985》。

Ding Ning is a Professor in the School of Art at Peking University who researches and teaches aesthetics, psychology of art, and Western art history.

丁宁: 北京大学艺术学院教授, 博士生导师, 致力于美学、艺术心理学 和西方美术史研究和教学。

Kou Huaiyu is the Chinese translator of Andy Warhol's POPism: The Warhol Sixties. He has a B.A. in Chinese History from Peking University and a M.A. in Anthropology from the Chinese University of Hong Kong. Trapped by his interest in too many things, his future is quite obscure.

寇淮禹独立选题并翻译了安迪·沃霍尔《波普主义》一书。先后毕业于 北京大学历史学系和香港中文大学人类学系的他, 因为对事物抱有 过于宽泛的兴趣而前途渺范。 
Marci Kwon is Assistant Professor of Art \& Art History at Stanford University. Her research interests include the intersection of fine art and vernacular practice; theories of modernism; Asian American art; critical race theory; and "folk" and "self-taught" art. Kwon's first book, Enchantments: Joseph Cornell and American Modernism is forthcoming from Princeton University Press.

Marci Kwon 为美国史丹佛大学艺术与艺术史系助理教授。她的研究 兴趣包涵艺术与风俗实践的互动、现代主义理论、亚裔美国艺术、批 判种族理论、以及“民间”与“自学”艺术。Kwon的第一本书《摄魄: 约瑟 夫・康奈尔与美国现代主义》即将由普林斯顿大学出版社出版。

Ellen G. Landau, Andrew W. Mellon Professor Emerita in the Humanities at Case Western Reserve University, is the author of Jackson Pollock (1989), Lee Krasner: A Catalogue Raisonne (1995), Abstract Expressionism: Context and Critique (2005), and Mexico and American Modernism (2013). Select recent projects include catalogue essays on Krasner, Hans Hofmann, and Michael West, as well as articles on Pollock's Mural for Peggy Guggenheim and Robert Motherwell's relationship to Surrealism.

Ellen G. Landau为美国凯斯西储大学荣誉退休教授, 著有《杰克逊・波 洛克》(1989)、《李・克拉斯纳:艺术家作品全集》(1995)、《抽象表现主 义: 情境与批判》(2005) 和《墨西哥与美国的现代主义》(2013)。近期的 研究包括撰写李 - 克拉斯纳、汉斯 - 霍夫曼和蜜雪儿・韦斯特的图录论 文, 也有关于杰克逊・波洛克为佩姬.古根汉创作的《壁画》、罗伯特・ 马哲威尔与超现实主义的研究专文。

Li Chao is a Vice Chair and Professor in the Shanghai Academy of Fine Arts at Shanghai University. He is also a Vice Director of the Liu Haisu Art Museum. He researches urban art resources, Chinese modern and contemporary art, Chinese oil painting, urban cultural heritage, and art museum studies.

李超: 上海大学上海美术学院副院长、教授、博士生导师, 刘海粟美术 馆副馆长。致力于都市美术资源、中国近现代美术、中国油画、城市文 化遗产和艺术博物馆学研究。

Liu Chen is a lecturer in the School of Architecture at Tsinghua University, Beijing, Visiting Professor at Beijing Film Academy, and at Tongji University in Shanghai. Prof. Liu researches and teaches visual art history, Baroque culture and art, decorative arts, and architecture.

刘晨: 清华大学建筑学院讲师, 北京电影学院和上海同济大学客座教 授, 致力于视觉艺术史、巴洛克文化与艺术、手工艺与建筑的研究和 教学。 
Lu Hao teaches in the School of Arts and Humanities at Guangzhou Academy of Fine Arts. He researches and teaches modern art and museum studies.

陆豪: 广州美术学院艺术与人文学院教师; 致力于现代主义艺术、美 术馆及现代艺术机制的研究和教学。

Lu Peng is an Associate Professor at the School of Arts and Humanities at China Academy of Art, Beijing, and President of L-Art University. He researches and teaches Chinese modern and contemporary art.

吕澎: 中国美术学院艺术人文学院副教授, 那特艺术学院院长, 致力 于中国现当代艺术史的写作、研究和教学。

Mao Qiuyue teaches in the College of Humanities at Tongji University, Shanghai. She researches and teaches American art and art criticism.

毛秋月: 同济大学人文学院教师, 致力于美国艺术史和艺术批评研究 和教学。

Lawrence Rinder is Director and Chief Curator of the UC Berkeley Art Museum and Pacific Film Archive. Previously, he served as the Curator of Contemporary Art at the Whitney Museum of American Art and Dean of the College at the California College of the Arts.

Lawrence Rinder 为美国加州大学伯克利分校艺术博物馆及太平洋电 影资料馆的馆长与主要策展人, 他也曾是惠特尼美术馆的当代艺术 策展人与加州艺术学院的学院院长。

Bruce Robertson is Professor Emeritus of the History of Art and Architecture, and Director Emeritus of the Art, Design \& Architecture Museum, University of California, Santa Barbara. He is the author/curator of many books and exhibitions on American art, from the early I8th-century to the present.

Bruce Robertson 为美国加州大学圣巴巴拉分校荣誉退休教授, 以及校 内“艺术、设计与建筑博物馆”馆长。同时他也是诸多关于十八世纪早 期至现代美国艺术史研究的专书作者与展览策展人。

Shao Yiyang is a Professor in the School of Arts and Humanities, Vice Chair of the School of Arts and Humanities, and Director of Teaching and Research Center for Foreign Art History at Central Academy of Fine Arts, Beijing. She researches and teaches Western art history and Western contemporary art.

邵亦杨: 中央美术学院人文艺术学院教授, 人文艺术学院副院长, 外 国美术史教研室主任, 致力于西方美术史、西方现当代艺术研究和教 学。 
Shen Yubing is a Professor in the School of Philosophy at Fudan University, Shanghai. He researches and teaches Western modern aesthetics, modern art history, and art theories and criticism.

沈语冰:复旦大学哲学学院教授, 博士生导师, 致力于西方现代美学、 现代艺术史、艺术理论与艺术批评研究和教学。

Wang Duanting is a researcher and Director of the Foreign Art Center at the Institute of Arts at Chinese National Academy of Arts, Beijing. He is also a Professor in the Department of Art at the Graduate School of Chinese National Academy of Arts. He researches and teaches Western art history and Chinese contemporary art criticism.

王端廷: 中国艺术研究院美术研究所外国美术研究室主任, 研究员。 中国艺术研究院研究生院美术系教授, 博士生导师, 致力于西方美术 史、当代中国艺术评论的写作、研究和教学。

Jason Weems is Associate Professor and Chair of the History of Art Department at the University of California, Riverside. He is author of Barnstorming the Prairies: How Aerial Vision Shaped the Midwest (University of Minnesota Press, 2015), along with numerous articles on the art and visual culture of the United States and the Americas.

Jasom Weems 为美国加州大学河滨分校艺术史所所长。他的研究专长 为摄影与区域主义, 著有《草原上的暴风雨: 苍空视野如何形塑美国 中西部》(2015)。

Reva Wolf is Professor of Art History at the State University of New York at New Paltz, where she teaches courses on art of the eighteenth century to the present and on art historical methodology. She is an expert on the art of Goya and Warhol, has published widely on historiographical topics, and is co-editor of Freemasonry and the Visual Arts (Bloomsbury, 2020).

Reva Wolf 是美国纽约州立大学纽柏兹分校的艺术史教授, 她在该 校教授十八世纪至现代艺术史以及艺术史方法论。她是研究哥雅与 沃荷艺术的专家, 并出版了许多相关书籍, 也《共济会与视觉艺术》 (2020) 的共同编者。

Zhang Jian is a Professor in the School of Arts and Humanities at the China Academy of Art, Hangzhou, and was a Fulbright scholar in 20I3-20I4. He researches and teaches modern and contemporary art history and theory of historiography.

张坚: 中国美术学院艺术人文学院教授, 博士生导师, 图书馆馆长, 中 美富布赖特研究学者(2013-2014年), 致力于近现代美术史和史学理论 710 研究和教学。 
Zhang Rui is Associate Professor in the Academy of Art and Design at Tsinghua University, Beijing, Academic Principal of a cooperation project with Sotheby's Institute of Art, the Academy of Art and Design and the School of Economics and Management at Tsinghua University. Her research interests are the contemporary art market and art management.

章锐: 清华大学美术学院艺术史论系副教授, 苏富比学院与清华大学 艺术管理合作项目学术负责人, 研究方向为当代艺术市场与艺术管 理。

Zhu Qingsheng is a Professor in the Department of History at Peking University, Chair of CIHA (Comité International d'Histoire de l'Art), Director of the Center for Visual Studies at Peking University, Chair of the Han Art Institute at Peking University, and the editor of Annual of Contemporary Art of China. He researches and teaches art theory, art history, and Han dynasty painting; he also engages in practicing modern art.

朱青生: 北京大学历史系教授, 国际艺术史学会主席, 北京大学视觉 与图像研究中心主任、北京大学汉画研究所所长、《中国当代艺术年 鉴》主编, 致力于艺术学、艺术史和汉画研究和教学, 亦从事现代艺术 创作。

Rebecca Zurier is Associate Professor of the History of Art and Faculty Associate in the Program in American Culture at the University of Michigan. Her research and teaching focus on American art with a special interest in urban culture and representation, national identity and the perception of American art abroad, and concepts of race, realism and representation.

Rebecca Zurier 为美国密西根大学教授。他是“垃圾筒画派”的研究权 威, 也对此议题出版相关的书籍与策展。 


